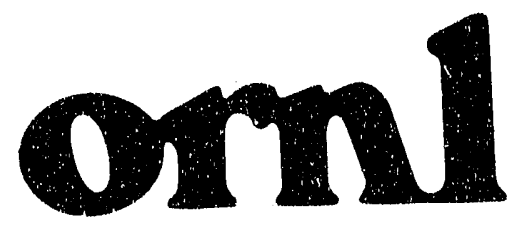

OAK RIDGE

NATIONAL

LABORATORY

MARTINALLETRA

\section{PHASE I ENVIRONMENTAL REPORT FOR THE ADVANCED NEUTRON SOURCE AT OAK RIDGE NATIONAL LABORATORY}

February 1992

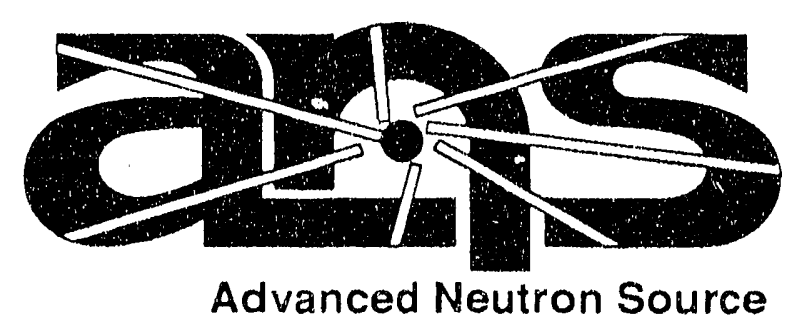

MANAGED BY

MARTIN MARIETTA ENERGY SYSTEMS, INC.

FOR THE UNITED STATES

DEPARTMENT OF ENEPGY 
This report has been reproduced directly from the best available copy.

Avallable to DOE and DOE contractors from the Office of Scientific and Technical Information, P.O. Box 62, Oak Rldge, TN 37831; prices available from (615) $576 \cdot 8401$, FTS $626 \cdot 8401$.

Available to the pubiic from the National Technical information Service, U.S. Department of Commerce, 5285 Port Royal Rd., Springfield, VA 22161.

This report was prepared as an account of work sponsored by an agency of the United States Government. Neither the United States Government nor any agency thereot, nor any of their employees, makes any warranty, express or Implied, or assumes any legal liability or responsibility for the accuracy, completeness, or usefulness of any information, apparatus, product, or process disclosed, or represents that its use would not infringe privately owned rights. Reference herein to any specific commercial product, process, or service by trade name, trademark, manufacturer, or otherwise, does not necessarily constltute or imply its endorsement, recommendation, or favoring by the United States Government or any agency thereof. The views and opinions of authors expressed herein do not necessarily state or reflect those of the United States Government or any agency thereof. 


\section{PHASE I ENVIRONMENTAL REPORT FOR THE ADVANCED NEUTRON SOURCE AT OAK RIDGE NATIONAL LABORATORY}
T. J. Blasing
R. H. Ketelle
R. A. Brown
R. L. Kroodsma
G. F. Cada
C. Easterly
D. L. Feldman
C. W. Hagan
R. M. Harrington
R. 'O. Johnson
L. N. McCold
W. J. Reich
P. A. Scofield
M. L. Socolof
R. P. Taleyarkhan
J. W. Van Dyke

February 1992

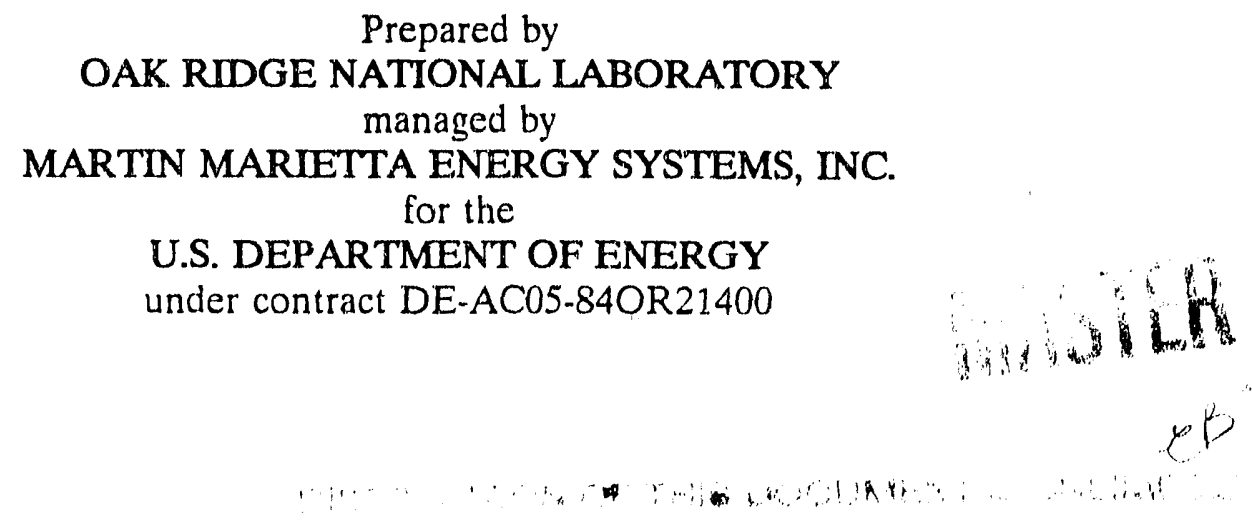




\section{TABLE OF CONTENTS}

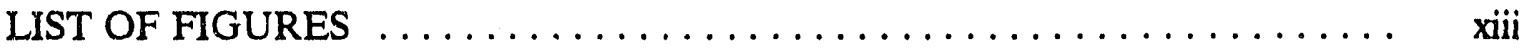

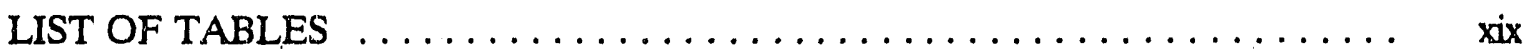

ABBREVIATIONS, ACRONYMS, AND INITILLISMS $\ldots \ldots \ldots \ldots \ldots \ldots$ xxv

EXECUTTVE SUMMARY $\ldots \ldots \ldots \ldots \ldots \ldots \ldots \ldots \ldots \ldots \ldots \ldots \ldots \ldots \ldots$

1. THE PROPOSED FACILITY $\ldots \ldots \ldots \ldots \ldots \ldots \ldots \ldots \ldots \ldots \ldots \ldots$ 1-1

1.1 PURPOSE OF THE ADVANCED NEUTRON SOURCE . . . . . . . 1 1-1

1.2 NEED FOR THE ADVANCED NEUTRON SOURCE . . . . . . . . . 1-1

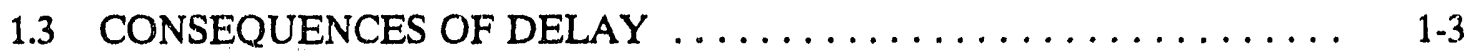

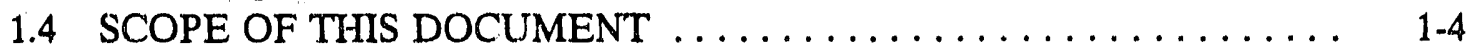

2. THE SITE AND ENVIRONMENTAL INTERFACES $\ldots \ldots \ldots \ldots \ldots \ldots .2-1$

2.1 GEOGRAPHY AND DEMOGRAPHY $\ldots \ldots \ldots \ldots \ldots \ldots \ldots \ldots . \ldots \ldots \ldots$

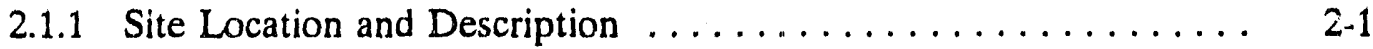

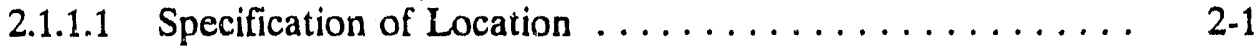

2.1.1.2 Site Area Map ................... 2-1

2.1.1.3 Boundaries for Establishing Effluent Releases ....... 2-6

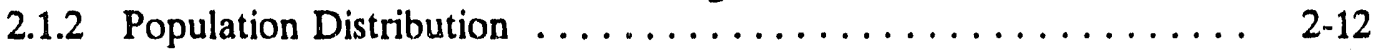

2.1.2.1 Population Within $80.5 \mathrm{~km}$ (50 Miles) $\ldots \ldots \ldots \ldots \ldots . \ldots 2-12$

2.1.2.2 Transient Population .................. 2-12

2.1.3 Uses of Nearby Lands and Waters . . . . . . . . . . . . . 2-29

2.1.4 Nearby Industrial, Transportation, Military, and

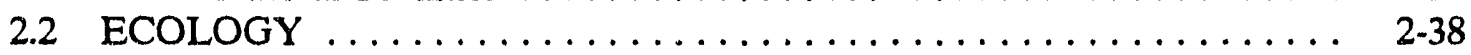

2.2.1 Terrestrial Ecology ...................... 2-38

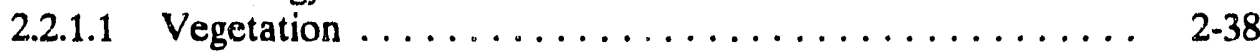

2.2.1.2 Wetlands ......................... 2.46

2.2.1.3 Wildlife ........................ 2.49

2.2 .2 Aquatic Ecology . . . . . . . . . . . . . . . . . 2-55

2.2.2.1 Inventory of Aquatic Species ............. 2-55

2.2.2.2 Preexisting Stresses to Aquatic Biota $\ldots \ldots \ldots \ldots \ldots$ 2-63

2.2.3 Threatened or Endangered Species $\ldots \ldots \ldots \ldots \ldots \ldots \ldots \ldots$ 2-64

2.2.3.1 Plants .......................... 2-64

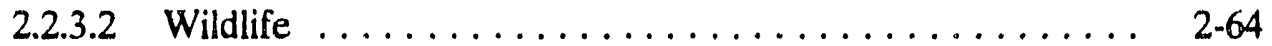

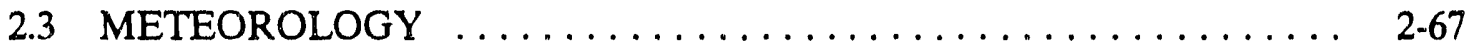

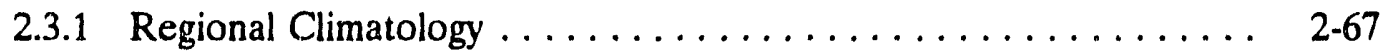

2.3.1.1 Data Sources .................... 2-68

2.3.1.2 Description of the Regional Climate .......... 2-68

2.3.2 Specific Meteorological Phenomena ................ 2-74

2.3.2.1 Hurricanes ........................ 2-74

2.3.2.2 Tornadoes and Waterspouts ............... 2-75

2.3.2.3 Thunderstorms and Lightning $\ldots \ldots \ldots \ldots \ldots \ldots \ldots . \ldots \ldots$

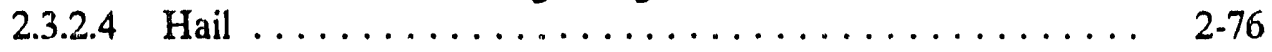

2.3.2.5 High Air-Pollution Potential . . . . . . . . . . . 2-76

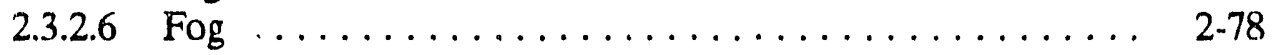

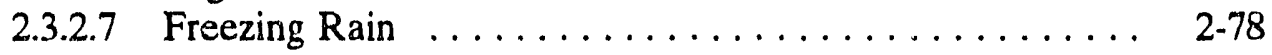

2.3.2.8 Snowstorms . . . . . . . . . . . . . . . 2-80

2.3.2.9 Wind Speed and Direction by Stability Class . . . . . . . 2-80 
Table of Contents (continued)

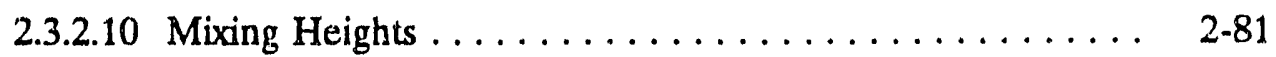

2.3.3 Representativeness of Meteorological Data . . . . . . . . . 2-81

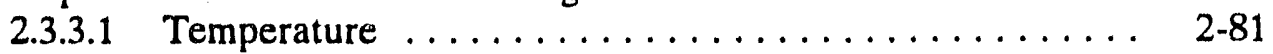

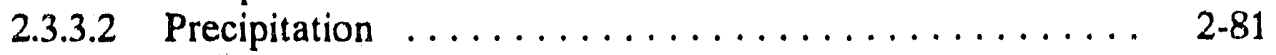

2.3.3.3 Wind ......................... 2-90

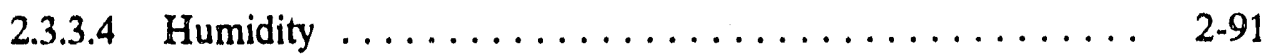

2.3.3.5 Atmospheric Stability and Mixing Heights ........ 2-92

2.3.4 Local Air Quality and Emissions Sources ... . . . . . . . . . 2-92

2.3.4.1 Tennessee Ambient Air Quality Standards ... . . . . . . 2-92

2.3.4.2 Existing Air Quality ................... 2-92

2.3.4.3 Local Emissions Sources .................. 2-93

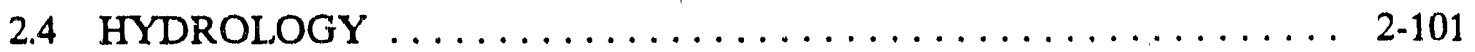

2.4.1 Surface Water Hydrology . . . . . . . . . . . . . . . . 2-101

2.4.1.1 Regional Surface Water Hydrology . . . . . . . . . . 2-102

2.4.1.2 Local Surface Water Hydrology .............. 2-118

2.4 .2 Groundwater Hydrology . . . . . . . . . . . . . . . 2-122

2.4.2.1 Groundwater Occurrence ................. 2-122

2.4.2.2 Groundwater Use . . . . . . . . . . . . . . . . 2-125

2.4.2.3 Regional Groundwater ................. 2-130

2.5 GEOLOGY ............................. 2-133

2.5.1 Regional Setting ..................... 2-133

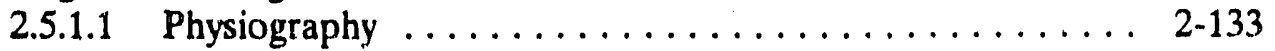

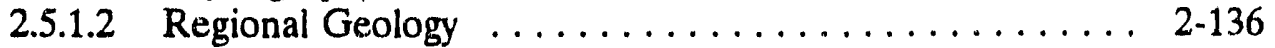

2.5.2 Geology of the ANS Site . . . . . . . . . . . . . . . 2-155

2.5.2.1 Topography and Geomorphology of the ANS Site ..... 2-155

2.5.2.2 Bedrock Stratigraphy in the ANS Site Vicinity ....... 2-157

2.5.2.3 Areal Geology of Meiton Valley ............... 2-166

2.5.2.4 Structural Geology of Melton Valley ............. 2-166

2.5 .3 Soils . . . . . . . . . . . . . . . . . . . . . . . 2-172

2.5.3.1 Soils Mapped at the Proposed ANS Sit. . . . . . . 2-172

2.5.3.2 Conasauga Group ................... 2.172

2.6 REGIONAL HISTORIC, ARCHITECTURAL, SCENIC, CULTURAL,

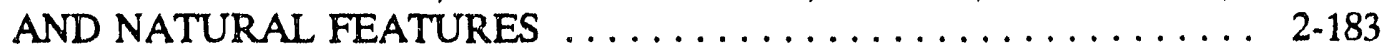

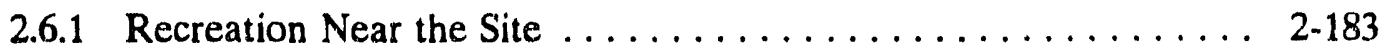

2.6 .2 Cultural Resources . . . . . . . . . . . . . . . . . 2-183

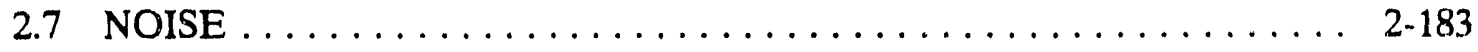

2.8 RADIOLOGICAL AND CHEMICAL DOSE TO THE PUBLIC . . . . 2 2-184

2.8.1 Background Radiation Sources and Doses . . . . . . . . . . . 2-184

2.8.2 Historical Radiological Effluents . . . . . . . . . . . . 2-186

2.8.3 Radiological Effluents for the Most Recent Year . . . . . . . . . . 2-186

2.8.3.1 Airborne Emissions Sampling . . . . . . . . . . . . 2 2-190

2.8.3.2 Radioactive Airborne Emissions . . . . . . . . . . 2-192

2.8.3.3 Liquid Discharges . . . . . . . . . . . . . . . 2-192

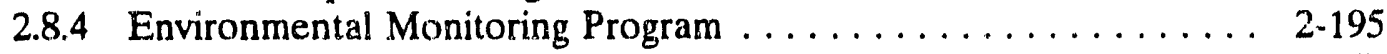

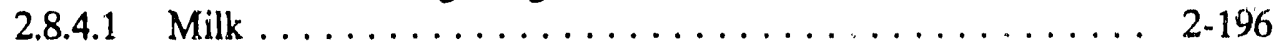

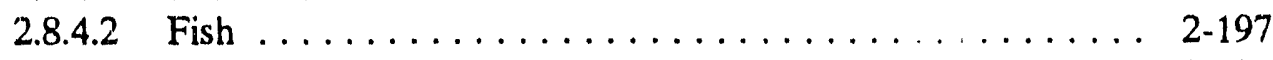

2.8.4.3 ORR Deer Population ................ 2-199 
2.8.4.4 Vegetation ..................... 2-200

2.8.5 Potential Radiation Dose to the Public . . . . . . . . . . . 2-200

2.8.5.1 Radiation Dose to Humans . . . . . . . . . . . . 2-200

2.8.5.2 Doses to Aquatic Biota ................ 2-204

2.8 .6 Chemical Dose . . . . . . . . . . . . . . . . . . . . 2-204

2.9 REFERENCES FOR SECTION $2 \ldots \ldots \ldots \ldots \ldots \ldots \ldots \ldots \ldots \ldots . \ldots \ldots$

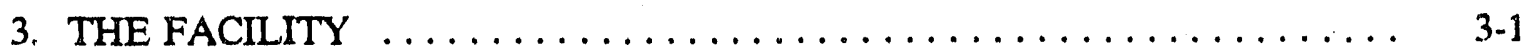

3.1 FUNCTIONAL DESCRIPTIONS $\ldots \ldots \ldots \ldots \ldots \ldots \ldots \ldots \ldots \ldots \ldots . \ldots \ldots \ldots$

3.1.1 The Reactor Building . . . . . . . . . .

3.1.1.1 Overall Building Structure ............... 3-9

3.1.1.2 Central Reactor Pool, Shield, and Associated Structures .. 3-12

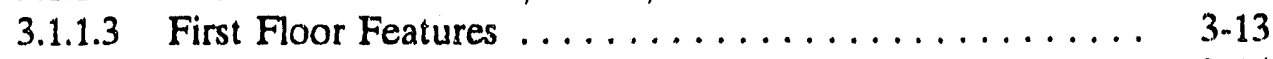

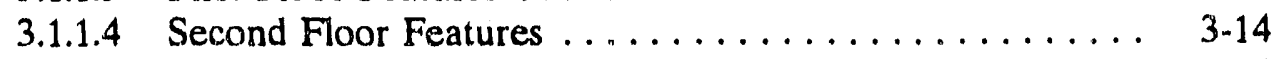

3.1.1.5 Third Floor Features $\ldots \ldots \ldots \ldots \ldots \ldots \ldots \ldots \ldots$ 3-14

3.1.1.6 Subpile Room Features $\ldots \ldots \ldots \ldots \ldots \ldots \ldots \ldots \ldots$ 3-15

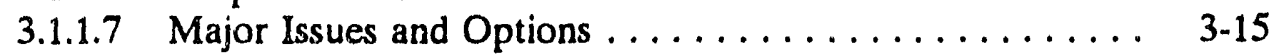

3.1.2 Reactor Support Building .................. 3-15

3.1.2.1 General Description .................. 3-15

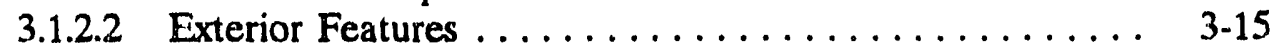

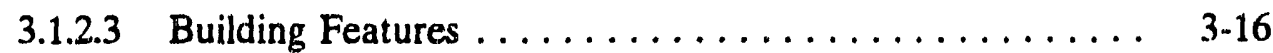

3.1.3 Operations Support Building $\ldots \ldots \ldots \ldots \ldots \ldots \ldots \ldots \ldots . \ldots \ldots$ 3-16

3.1.4 Guide Hall Building and Research Support Building $\ldots \ldots \ldots$ 3-16

3.1.4.1 General Building Description .............. 3-16

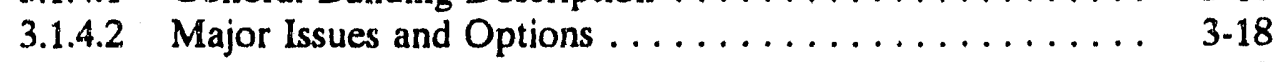

3.1.5 Office Building and Interface Building $\ldots \ldots \ldots \ldots \ldots \ldots \ldots . \ldots \ldots$

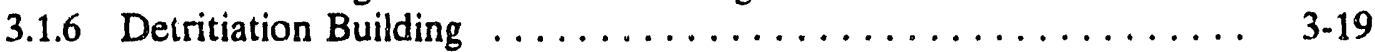

3.1.7 Other Structures $\ldots \ldots \ldots \ldots \ldots \ldots \ldots \ldots \ldots \ldots \ldots \ldots$ 3-19

3.1.7.1 Reactor Secondary Cooling System Cooling Towers .... 3- 3-20

3.1.7.2 Essential Cooling Water System Cooling Tower ....... 3-20

3.1.7.3 Nonessential Cooling Water System Cooling Tower .... . 3-20

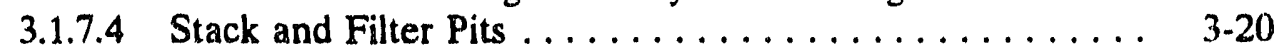

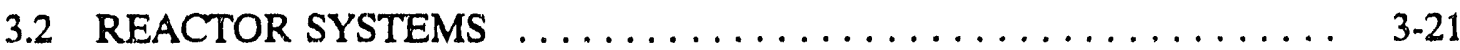

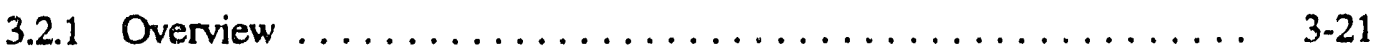

3.2 .2 Reactor Assembly ...................... 3-25

3.2.2.1 Reactor Core Assembly . . . . . . . . . . . . 3-25

3.2.2.2 Reactor Coolant Pressure Boundary System . . . . . . . . 3-27

3.2.2.3 Reflector Vessel Assembly . . . . . . . . . . . . . . . 3-29

3.2.2.4 In-Core Irradiation Facilities $\ldots \ldots \ldots \ldots \ldots \ldots \ldots \ldots .3 .30$

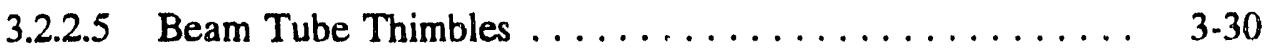

3.2.3 Refueling System $\ldots \ldots \ldots \ldots \ldots \ldots \ldots \ldots \ldots \ldots \ldots \ldots \ldots \ldots$ 3-30

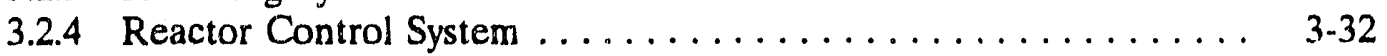

3.2 .5 Cold Source Assemblies $\ldots \ldots \ldots \ldots \ldots \ldots \ldots \ldots \ldots \ldots \ldots$ 3-32

3.2.6 Hot Source Assembly . . . . . . . . . . . . . . . . . 3-33

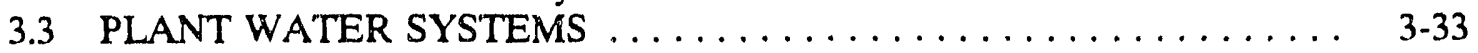

3.3.1 Essential Cooling Water System $\ldots \ldots \ldots \ldots \ldots \ldots \ldots \ldots \ldots \ldots$ 3-33

3.3.2 Demineralized Water System $\ldots \ldots \ldots \ldots \ldots \ldots \ldots \ldots \ldots$ 3-33 
3.3.3 Cooling Tower Blowdown and Makeup System $\ldots \ldots \ldots \ldots \ldots$ 3-34

3.3.4 Nonessential Cooling Water System . . . . . . . . . . . . . . . . 3. 34

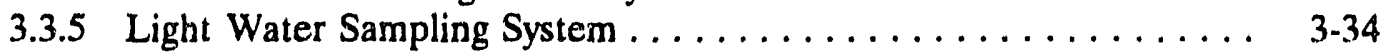

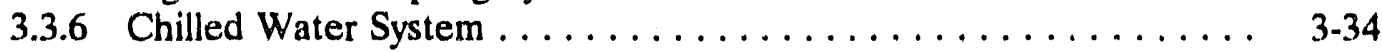

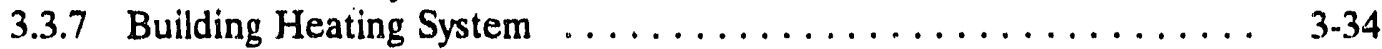

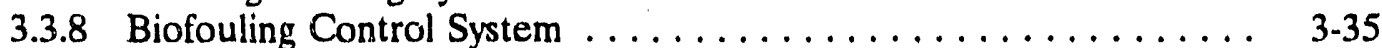

3.3.9 Process Water System . . . . . . . . . . . . . . . . 3-35

3.3.10 Light Water Pools and Spent Fuel Pool Cooling and Cleanup System ........................... 3-35

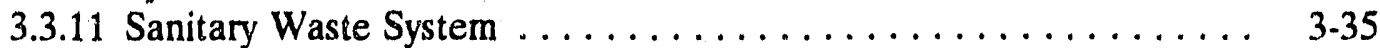

3.3.12 Potable Water System ..................... 3-35

3.4 REACTOR HEAT DISSIPATION SYSTEM $\ldots \ldots \ldots \ldots \ldots \ldots \ldots \ldots .3 .36$

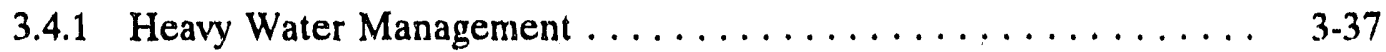

3.4.2 Primary Heavy Water Cooling System . . . . . . . . . . . . 3 3-38

3.5 ANS RADIOACTIVE WASTE SYSTEMS AND SOURCE TERMS . . . 3.40

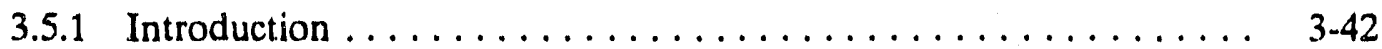

3.5.2 Methodology ........................ 3-43

3.5.2.1 Comparison with HFIR Experience $\ldots \ldots \ldots \ldots \ldots \ldots .3-43$

3.5.2.2 Tritium Management at DOE and non-DOE Reactors ... 3-43

3.5.2.3 Waste-Management Scenarios at the ORNL Host Site . . . 3-44

3.5.3 LLLW Management . . . . . . . . . . . . . . . . . 3-44

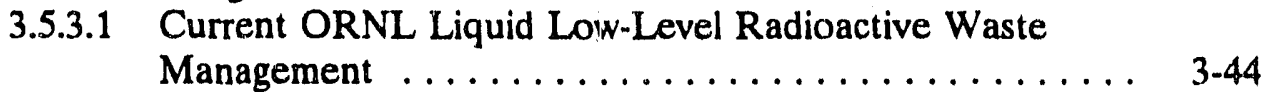

3.5.3.2 ANS LLLW and Its Management . . . . . . . . . . 3-46

3.5.3.3 Planned ORNL LLLW Management ... . . . . . . . 3-47

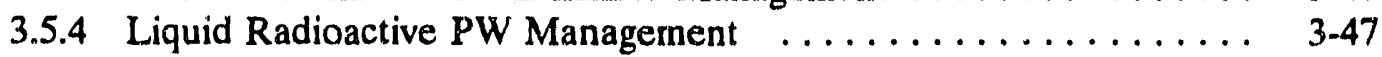

3.5.4.1 Current ORNL Liquid Radioactive PW Management . . . . 3-47

3.5.4.2 ANS Radioactive PWs and Their Management ........ . 3-49

3.5.4.3 Planned ORNL Radioactive PW Management . . . . . . . 3-49

3.5.5 Solid Radioactive Waste Management at ANS ........... 3.50

3.5.5.1 Overview of Current ORNL TRU Waste Management .. 3-50

3.5.5.2 Overview of High-Level Incidental Waste . . . . . . . . 3-56

3.5.5.3 Overview of Spent Fuel Management .......... 3-56

3.5.5.4 Overview of Greater-than-Class-C Waste Management ... 3-58

3.5.5.5 Overview of Solid Low-Level Radioactive Waste

Management at ORNL ................ 3.58

3.5.6 Overview of Radioactive Gaseous Waste Management ....... . 3. 3-63

3.5.6.1 Current ORNL Radioactive Gaseous Waste

Management ..................... 3-63

3.5.6.2 ANS Gaseous Radioactive Wastes and Their Management ................... 3-65

3.5.6.3 Planned ORNL Radioactive Gaseous Waste Management ...................... 3-65

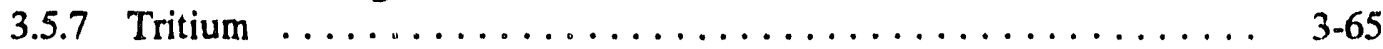

3.5.7.1 Current Tritium Management at ORNL .......... 3-65

3.5.7.2 ANS Tritium Sources and Their Management ....... 3-67

3.5.7.3 Planned Tritium Management at ORNL ......... 3-68 
Table of Contents (continued)

3.5.8 Mixed Waste $\ldots \ldots \ldots \ldots \ldots \ldots \ldots \ldots \ldots \ldots \ldots \ldots . \ldots \ldots$ 3-68

3.5.8.1 Current Liquid Mixed Waste Management at ORNL . . . 3 3-68

3.5.8.2 Current Solid Mixed Waste Management at ORNL . . . . 3.68

3.5.8.3 ANS Liquid and Solid Mixed Wastes ............. 3-70

3.5.8.4 Planned Liquid and Solid Mixed Waste Management at

ORNL ......................... 3.70

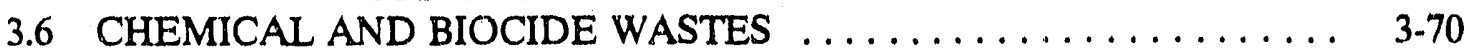

3.7 ANS SANITARY AND OTHER WASTE SYSTEMS $\ldots \ldots \ldots \ldots \ldots \ldots .3-71$

3.7.1 Current ORNL Sanitary Waste Management . . . . . . . . . . 3-71

3.7 .2 ANS Sanitary Wastes . . . . . . . . . . . . . . . . .

3.7.3 Future ORNL Sanitary Waste Management ............ 3.73

3.7.4 Current ORNL Conventional Liquid Waste

(Effluents) Management ...................... 3-73

3.7.5 ANS Conventional Liquid Waste Management . . . . . . . . . 3-73

3.7.6 Planned ORNL Conventional Liquid Waste

(Effluents) Management . . . . . . . . . . . . . . 3-73

3.7.7 Current ORNL Conventional Solid Waste Management ........ 3.73

3.7.8 ANS Conventional Solid Wastes . . . . . . . . . . . . . 3-74

3.7.9 Planned ORNL Conventional Solid Waste Management ....... 3.74

3.7.10 Current Conventional Gaseous Waste Management at ORNL . . . 3 3-74

3.7.11 ANS Conventional Gaseous Wastes .............. 3.74

3.7.12 Planned Conventional Gaseous Waste Management at ORNL . . . 3.74

3.7.13 Current Hazardous Liquid Waste Management at ORNL . . . . . . 3.74

3.7.14 ANS Hazardous Liquid Wastes .................. 3.75

3.7.15 Planned Hazardous Liquid Waste Management at ORNL ..... 3. 35

3.7.16 Current Hazardous Solid Waste Management at ORNL . . . . . . 3-75

3.7.17 ANS Hazardous Solid Wastes . . . . . . . . . . . . . . . 3-77

3.7.18 Planned Hazardous Solid Waste Management at ORNL ... . . . 3. 3-77

3.7.19 Current Management of Hazardous Gases at ORNL . . . . . . . . 3-77

3.7.20 ANS Hazardous Gases . . . . . . . . . . . . . . . . . . 3-77

3.7.21 Planned Management of Hazardous Gases at ORNL . . . . . . . . 3.77

3.8 REPORTING OF RADIOACTIVE MATERIAL MOVEMENT . . . . . 3 3-78

3.8.1 Current Reporting of Radioactive Material Movement ....... . 3-78

3.8.2 ANS Radioactive Material Movement Reporting . . . . . . . . . . . 3-78

3.8.3 Planned Radioactive Material Movement Reporting . . . . . . . . . . 3-78

3.8.4 Transportation Risk Assessment for the ANS Reactor . . . . . . . . 3.78

3.8.4.1 Transportation Routes ................. 3.80

3.8.4.2 Characterization of Radioactive Materials . . . . . . . 3 3-81

3.8.4.3 Transportation Risk Assessment .............. 3-83

3.8.4.4 Summary of Transportation Risks from Incident-

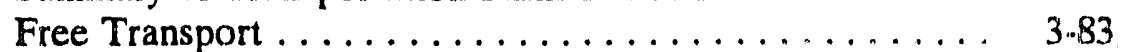

3.9 REFERENCES FOR SECTION $3 \ldots \ldots \ldots \ldots \ldots \ldots \ldots \ldots \ldots \ldots$

4. ENVIRONMENTAL EFFECTS OF SITE PREPARATION AND FACILITY

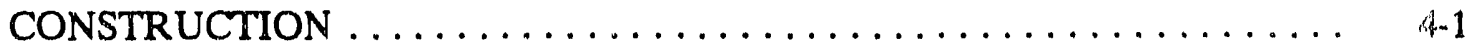

4.1 SITE PREPARATION AND FACILITY CONSTRUCTION ........ 4-1

4.1.1 Effects on Terrestrial Biota $\ldots \ldots \ldots \ldots \ldots \ldots \ldots \ldots \ldots \ldots . \ldots . \ldots \ldots$

4.1.1.1 Vegetation .................... 4.1 


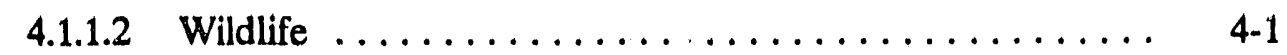

4.1.1.3 Wetlands ........................ 4-1

4.1.1.4 Threatened and Endangered Species ............ 4-2

4.1.1.5 Mitigation ...................... $4-2$

4.1.2 Effects on Water Quality and Aquatic Biota ........... 4-2

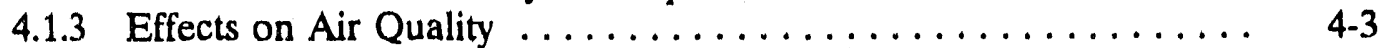

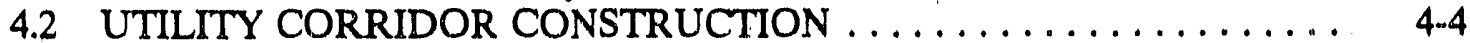

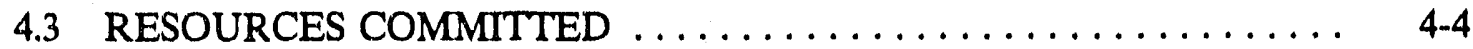

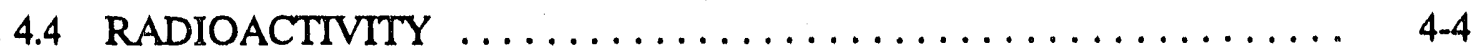

4.5 CONSTRUCTION IMPACT CONTROL PROGRAM $\ldots \ldots \ldots \ldots \ldots .4 .5$

4.5.1 Dust Suppression Measures . ................ 4.5

4.6 REFERENCES FOR SECTION $4 \ldots \ldots \ldots \ldots \ldots \ldots \ldots \ldots \ldots \ldots$. 4 .6

5. ENVIRONMENTAL EFFECTS OF FACILITY OPERATION $\ldots \ldots \ldots \ldots$ 5-1

5.1 EFFECTS OF THE HEAT DISSIPATION SYSTEM $\ldots \ldots \ldots \ldots \ldots \ldots .5-1$

5.1 .1 Effluent Limitations and Water Quality Standards .......... $5-1$

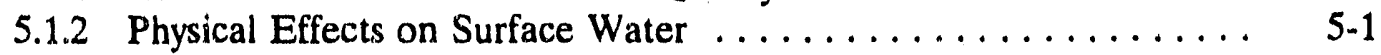

5.1 .3 Biological Effects . . . . . . . . . . . . . . . . . .

5.1.4 Potential Influence of the Proposed ANS Facility on Local

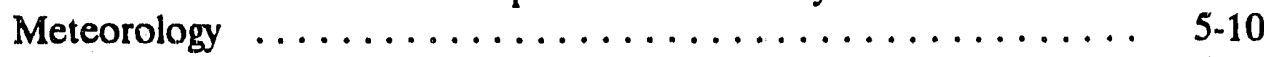

5.1.5 Impacts on Terrestrial Biota $\ldots \ldots \ldots \ldots \ldots \ldots \ldots \ldots \ldots \ldots .5 .10$

5.2 RADIATION DOSE TO THE PUBLIC FROM ROUTINE

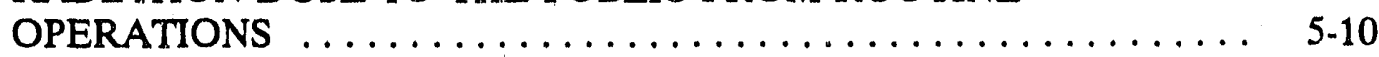

5.2 .1 Exposure Pathways ....................... $5-11$

5.2 .2 Calculational Parameters and Assumptions ............ 5-11

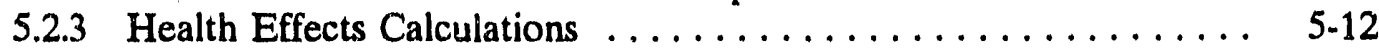

5.2 .4 Source Terms ......................... $5-12$

5.2.5 Results of Dose Calculations ................ 5-12

5.3 EFFECTS OF CHEMICAL AND BIOCIDE DISCHARGES . . . . . 5.13

5.4 EFFECTS OF SANITARY WASTE DISCHARGES ........... $5-14$

5.5 EFFECTS OF OPERATION AND MAINTENANCE OF UTILITY

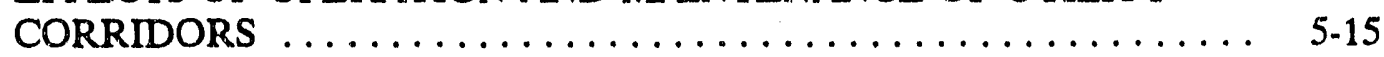

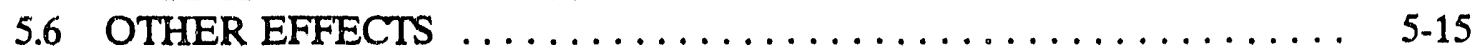

5.6 .1 Noise ........................... 5-15

5.6.2 Dispersion Estimates for Routine Operations . . . . . . . . . 5-16

5.7 RESOURCES COMMITTED ..................... $5-17$

5.8 DECOMMISSIONING AND DISMANTLING $\ldots \ldots \ldots \ldots \ldots \ldots \ldots$ 5-18

5.9 THE URANIUM FUEL CYCLE $\ldots \ldots \ldots \ldots \ldots \ldots \ldots \ldots \ldots \ldots$. 5.18

5.10 WORKER HEALTH AND SAFETY $\ldots \ldots \ldots \ldots \ldots \ldots \ldots \ldots \ldots$ 5-18

5.10 .1 Experience at Other Facilities . . . . . . . . . . . . . . 5-19

5.10.1.1 High Flux Isotope Reactor at Oak Ridge National

Laboratory ....................... 5 5-19

5.10.1.2 Experience from the Savannah River Plant . . . . . . . 5-20

5.10.1.3 Institut Laue Langevin, Grenoble, France . . . . . . . . 5-20

5.10.1.4 National Institute of Standards and Technology

Reactor ....................... 5-20

5.10.1.5 Canadian Heavy Water Reactors $\ldots \ldots \ldots \ldots \ldots \ldots . . \ldots$ 5-21 
Table of Contents (continued)

5.10.1.6 Occupational Doses Anticipated at ANS ........ 5-21

5.10.2 The Biological Effectiveness of Neutrons ........... . 5-25

5.10.3 ORNL As Low As Reasonably Achievable Program . . . . . . . . . 5 5-27

5.10 .4 Hazardous Chemicals at ANS . . . . . . . . . . . . . . . 5-32

5.11 WASTE MANAGEMENT IMPACTS OF ADVANCED NEUTRON

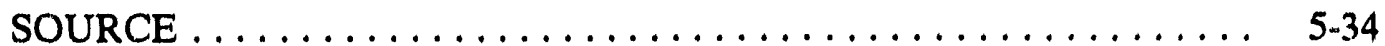

5.11 .1 Scenario-Driven Impact Analysis $\ldots \ldots \ldots \ldots \ldots \ldots \ldots \ldots .5 .34$

5.11.2 Impacts of Liquid Low-Level Radioactive Wastes . . . . . . . . . . 5-35

5.11.2.1 Impacts of Radioactive Process Waste $\ldots \ldots \ldots \ldots \ldots$ 5-37

5.11.3 Impacts of Solid Radioactive Wastes ............... 5-37

5.11.3.1 Transuranic Waste Impacts . . . . . . . . . . . . . 5-37

5.11.3.2 High-Level Incidental Waste Impacts . . . . . . . . . 5.39

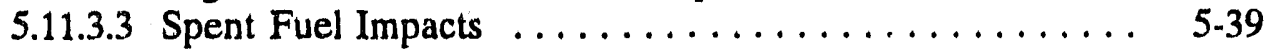

5.11.3.4 Greater-than-Class- $C$ Waste Impacts $\ldots \ldots \ldots \ldots \ldots . .5-40$

5.11.3.5 Solid Low-Level Radioactive Waste Impacts . . . . . . . . 5-40

5.11.4 Gaseous Radioactive Waste Impacts and Tritium Vapor Impacts .. 5-43

5.11 .5 Impacts of Tritiated Liquids and Solids ............. 5.45

5.11 .6 Mixed Waste Impacts . . . . . . . . . . . . . . . . . 5.45

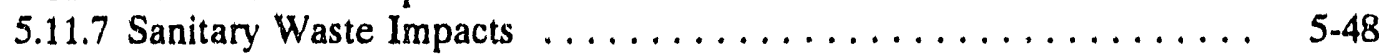

5.11 .8 Conventional Waste Impacts ................ 5.48

5.11.8.1 Conventional Liquid Waste (Effluent) Impacts ....... $5-48$

5.11 .8 .2 Conventional Solid Waste Impacts ............ 5.48

5.11.8.3 Conventional Gaseous Waste Impacts . . . . . . . . . . 5 5-49

5.11 .9 Hazardous Waste Impacts . . . . . . . . . . . . . . . . . . 5-49

5.11.9.1 Impacts of Hazardous Liquids $\ldots \ldots \ldots \ldots \ldots \ldots \ldots$ 5.49

5.11 .9 .2 Impacts of Hazardous Solids . . . . . . . . . . . 5.50

5.11.9.3 Impacts of Hazardous Gases . . . . . . . . . . . 5-50

5.12 REFERENCES FOR SECTION $5 \ldots \ldots \ldots \ldots \ldots \ldots \ldots \ldots \ldots \ldots$. $5-50$

6. EFFLUENT AND ENVIRONMENTAL MEASUREMENTS AND

MONITORING PROGRAMS $\ldots \ldots \ldots \ldots \ldots \ldots \ldots \ldots \ldots \ldots \ldots \ldots \ldots \ldots$ 6-1

6.1 PREOPERATIONAL MONITORING PROGRAM .......... 6-1

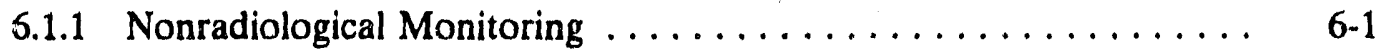

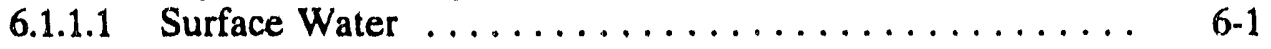

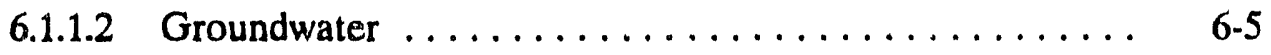

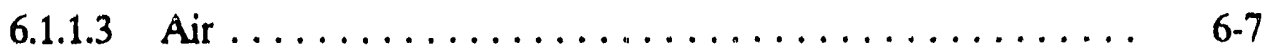

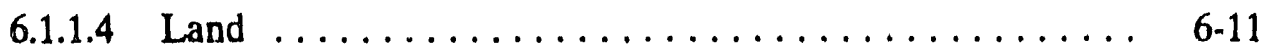

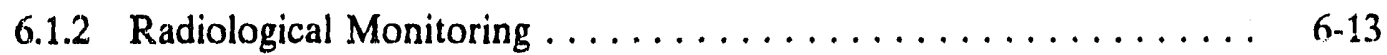

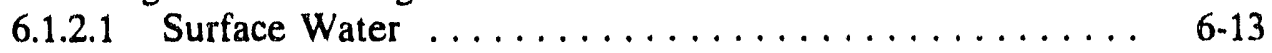

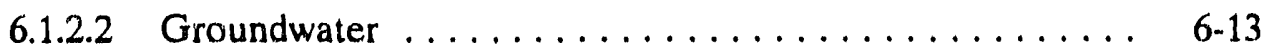

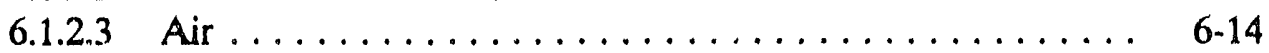

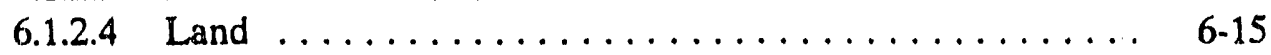

6.2 PROPOSED MONITORING PROGRAMS $\ldots \ldots \ldots \ldots \ldots \ldots \ldots 6$ 6-16

6.3 REFERENCES FOR SECTION $6 \ldots \ldots \ldots \ldots \ldots \ldots \ldots \ldots \ldots . \ldots \ldots$ 6-17

7. ENVIRONMENTAL EFFECTS OF ACCIDENTS $\ldots \ldots \ldots \ldots \ldots \ldots \ldots$ 7-1

7.1 FACILITY ACCIDENTS INVOLVING RADIOACTIVITY . . . . . . . 7-1 
7.1.1 Source Terms and Radiological Consequences from Reactor Severe

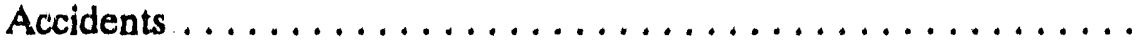

7.1.1.1 Source Terms . . . . . . . . . . . . . . . . .

7.1.1.2 Off-Site Consequences .................

7.1.2.1 Radioactive Waste System Failures ............. 7-36

7.1.2.2 Fission Products to Primary and Secondary Systems .... . 7-38

7.1.2.3 Refueling Accidents . . . . . . . . . . . . . . 7-42

7.1.2.4 Spent Fuel Handling Accident .............. 7-44

7.1.2.5 Accident Initiation Events Considered in Design Basis

Evaluation in the Safety Analysis Report-Loss of

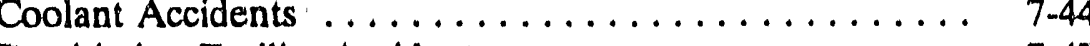

7.1.2.6 Detritiation Facility Accidents ............. 7-47

7.1.2.7 Radiological Impacts of Postulated Nonsevere

Accidents ...................... $7-49$

7.2 TRANSPORTATION ACCIDENTS INVOLVING RADIOACTIVITY . $\quad 7.50$

7.2.1 Transportation Risk Assessment ................. 7.50

7.2.2 Summary of Transportation Risks from Accidents $\ldots \ldots \ldots \ldots .7-52$

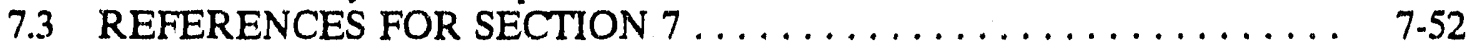

8. SOCIOECONOMIC EFFECTS $\ldots \ldots \ldots \ldots \ldots \ldots \ldots \ldots \ldots \ldots \ldots \ldots$ 8-1

8.1 EMPLOYMENT AND INCOME $\ldots \ldots \ldots \ldots \ldots \ldots \ldots \ldots \ldots . \ldots \ldots$

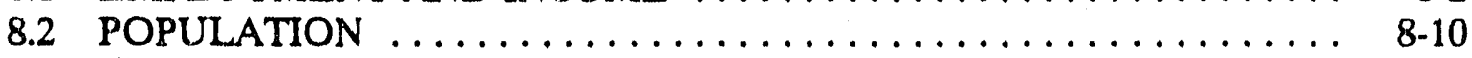

8.3 HOUSING AND PUBLIC SERVICES $\ldots \ldots \ldots \ldots \ldots \ldots \ldots \ldots . \ldots \ldots$

8.4 FISCAL AND TAX EFFECTS $\ldots \ldots \ldots \ldots \ldots \ldots \ldots \ldots \ldots \ldots . \ldots \ldots$

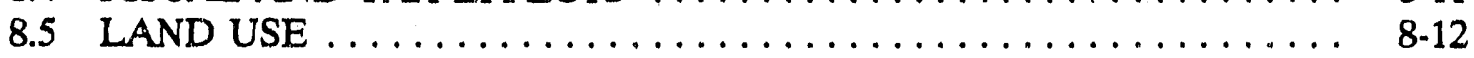

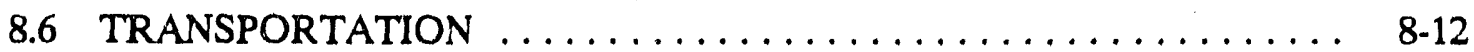

8.7 EMERGENCY PREPAREDNESS $\ldots \ldots \ldots \ldots \ldots \ldots \ldots \ldots \ldots \ldots . \ldots . \ldots \ldots$

8.8 REFERENCES FOR SECTION $8 \ldots \ldots \ldots \ldots \ldots \ldots \ldots \ldots \ldots \ldots \ldots$

9. TECHNOLOGIES AND SITES $\ldots \ldots \ldots \ldots \ldots \ldots \ldots \ldots \ldots \ldots \ldots$ 9.1

10. FACILITY DESIGN ALTERNATTVES $\ldots \ldots \ldots \ldots \ldots \ldots \ldots \ldots \ldots \ldots$ 10-1

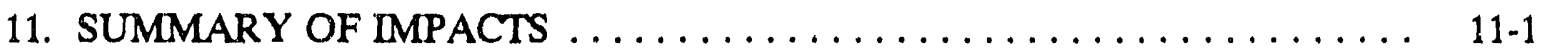

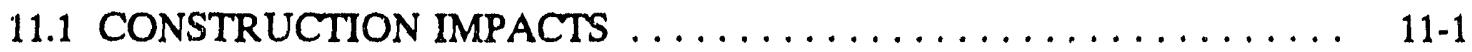

11.1.1 Terrestrial Biota . . . . . . . . . . . . . . . . . . 11-1

11.1.2 Water Quality and Aquatic Biota ............... 11-1

11.1.3 Air Quality ............................ 11-1

11.2 RESOURCES COMMITTED $\ldots \ldots \ldots \ldots \ldots \ldots \ldots \ldots \ldots \ldots \ldots$ 11-1

11.3 HEAT DISSIPATION SYSTEM EFFECTS $\ldots \ldots \ldots \ldots \ldots \ldots \ldots \ldots$. $11-2$

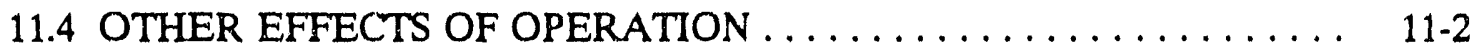

11.4.1 Sanitary, Chemical, and Biocide Discharges ............ 11-2

11.4 .2 Noise ............................. 11-3

11.5 RADIATION DOSE TO THE PUBLIC $\ldots \ldots \ldots \ldots \ldots \ldots \ldots \ldots \ldots . \ldots \ldots$

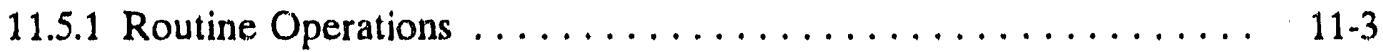

11.5.2 Routine Transportation of Radioactive Materials . . . . . . . . 11-3 
Table of Contents (continued)

11.5.3 Nonsevere Accidents . . . . . . . . . . . . . . . . . . . . . 11-4

11.5.4 Severe Accidents . . . ....................... 11-4

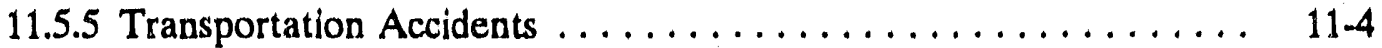

11.6 WORKER HEALTH AND SAFETY $\ldots \ldots \ldots \ldots \ldots \ldots \ldots \ldots \ldots \ldots \ldots$

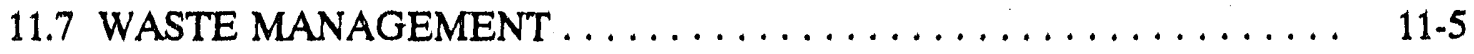

11.8 SOCIOECONOMIC EFFECTS $\ldots \ldots \ldots \ldots \ldots \ldots \ldots \ldots \ldots \ldots \ldots \ldots \ldots$

12. ENVIRONMENTAL, HEALTH, AND SAFETY REGULATORY

REQUIREMENTS . . . . . . . . . . . . . . . . . . . . . . . . $12-1$

12.1 GENERAL REQUIREMENTS . . . . . . . . . . . . . . . . . . . $12-1$

12.2 AIR QUALITY REQUIREMENTS $\ldots \ldots \ldots \ldots \ldots \ldots \ldots \ldots \ldots \ldots \ldots$

12.2.1 Clean Air Act . . . . . . . . . . . . . . . . . . . . . . 12-9

12.2.2 Impact of Clean Air Act Amendments . . . . . . . . . . . . . . . 12-9

12.2.3 Regulation of Radionuclide Emissions Under NESHAP . . . . . . . 12-10

12.2.4 Air Quality Requirements for Tennessee .............. 12-10

12.3 WATER QUALITY AND WATER RESOURCE

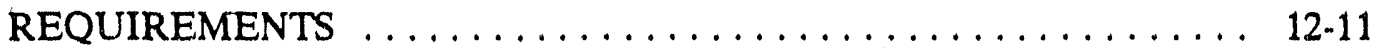

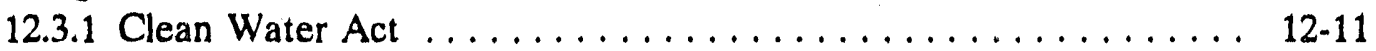

12.3.2 Clean Water Act Requirements for Tennessee . . . . . . . . . . . 12-11

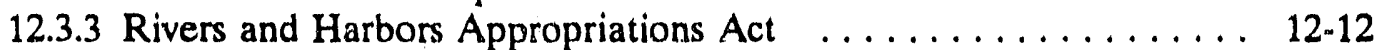

12.3.4 Safe Drinking Water Act $\ldots \ldots \ldots \ldots \ldots \ldots \ldots \ldots \ldots \ldots$ 12-13

12.3.5 Executive Order 11988, Floodplain Management

Executive Order 11990, Protection of Wetlands . . . . . . . 12-13

12.4 BIOTIC RESOURCES . . . . . . . . . . . . . . . . . . 12-14

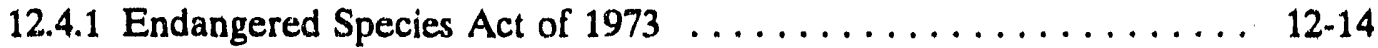

12.4.2 Bald and Golden Eagle Protection Act $\ldots \ldots \ldots \ldots \ldots \ldots \ldots$ 12-14

12.4.3 Fish and Wildlife Coordination Act . . . . . . . . . . . 12-15

12.5 HISTORICAL, ARCHAEOLOGICAL, AND CULTURAL

RESOURCE REQUIREMENTS . . . . . . . . . . . . . . . . . . . 12-15

12.5.1 National Historic Preservation Act . . . . . . . . . . . . 12-15

12.5.2 Archaeological and Historic Preservation Act $\ldots \ldots \ldots \ldots \ldots$. . . . . . . . . . .

12.5.3 American Indian Religious Freedom Act $\ldots \ldots \ldots \ldots \ldots \ldots . \ldots 12-16$

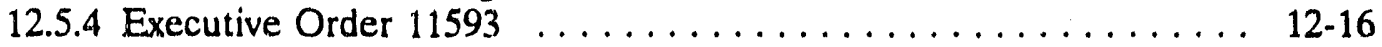

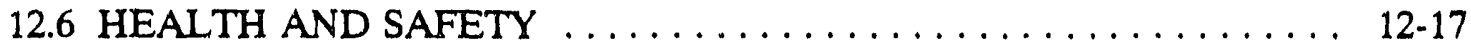

12.6.1 Worker Health and Safety . . . . . . . . . . . . . . 12-17

12.6.2 General Public Health and Safety . . . . . . . . . . . . 12-18

12.7 MANAGEMENT OF WASTES AND HAZARDOUS MATERIALS . . 12-20

12.7.1 Resource Conservation and Recovery Act of $1976 \ldots \ldots \ldots \ldots$. . . . . .

12.7.2 Tennessee RCRA Program ................... 12-21

12.7.3 Comprehensive Environmental Response, Compensation,

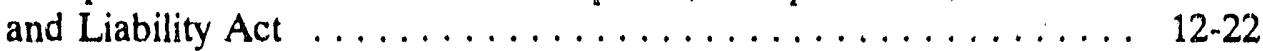

12.7.4 Radioactive Waste . . . . . . . . . . . . . . . . 12-23

12.7.5 Emergency and Spill Prevention Control Planning . . . . . . . . . 12-24

12.7.5.1 National Oil and Hazardous Substances Pollution

Contingency Plan .................. 12-24 
Table of Contents (continued)

12.7.5.2 Spill Prevention Control and Countermeasures

Plan . . . . . . . . . . . . . . . . . . . . . 12-24

12.8 REFERENCES FOR SECTION $12 \ldots \ldots \ldots \ldots \ldots \ldots \ldots \ldots \ldots \ldots$ 


\section{LIST OF FIGURES}

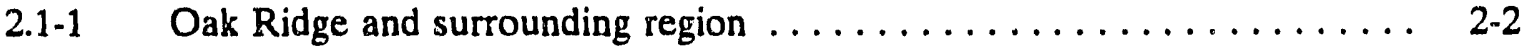

2.1-2 Communities, bodies of water, and major transportation routes

near the proposed Advanced Neutron Source site . . . . . . . . . . . . 2-3

2.1.3 The Oak Ridge Reservation ..................... 2-4

2.1-4 Topographical map of the proposed Advanced Neutron Source site showing the site boundary security area $\ldots \ldots \ldots \ldots \ldots \ldots \ldots . \ldots .5$

2.1-5 Primary industries and industrial parks in the proposed Advanced Neutron Source area ........................ 2-7

2.1-6 Industrial, recreational, and public areas on the Oak Ridge Reservation .............................. 2-8

2.1-7 Highways and roads within $16.4 \mathrm{~km}$ (10 miles) of the proposed Advanced Neutron Source site . . . . . . . . . . . . . . . . . . .

2.1-8 Transportation system for the area near the proposed Advanced Neutron Source site ........................ 2.10

2.1-9 Location map of Oak Ridge Reservation tributaries ............ 2-11

2.1-10 Significantly populated residential areas nearest the proposed Advanced Neutron Source sire . . . . . . . . . . . . . . . 2-14

2.1-11 County borders and towns within $16.4 \mathrm{~km}$ (10 miles) of the proposed Advanced Neutron Source site . . . . . . . . . . . . . . 2-15

2.1-12 Population count for 1990 by sectors and annuli between 0 and $8.2 \mathrm{~km}$ ( 5 miles) from the center of the proposed Advanced Neutron

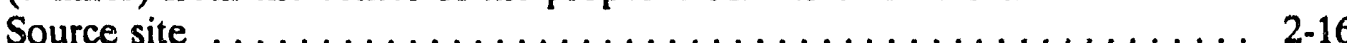

2.1-13 Population counts by sectors and annuli for 1990 within $80.5 \mathrm{~km}$ (50 miles) of the proposed Advanced Neutron Source site . . . . . . . 2-21

2.1-14 Schools closest to the proposed Advanced Neutron Source site . . . . . . 2-26

2.1-15 Hospitals and nursing homes closest to the proposed Advanced Neutron Source site . . . . . . . . . . . . . . . . . . . . 2-28

2.1-16 Highways and roads close to the proposed Advanced Neutron Source site . . ............................

2.1-17 Major Tennessee Valley Authority power-generating facilities near the proposed Advanced Neutron Source site . . . . . . . . . . . . .

2.1-18 Natural gas pipelines and valve stations on the Oak Ridge Reservation ............................ 2-39

2.1-19 Raw and treated waterlines on the Oak Ridge Reservation ... . . . . . 2 2-40

2.1-20 Rail, road, and water facilities in the proposed Advanced Neutron Source area ........................... 2-41

2.2-1 Vegetation map of the proposed Advanced Neutron Source site .................................... 2-45

2.2-2 Location of potential jurisdictional wetlands and rare plants on the proposed Advanced Neutron Source site . . . . . . . . . . . . . . 2-47

2.2-3 Map showing surface waters in the vicinity of the proposed Advanced Neutron Source site, streamflow gauging weirs, monitoring sites for water quality and aquatic biota, and major Oak Ridge

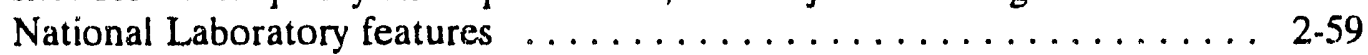

2.3-1 Meteorological towers on the Oak Ridge Reservation ... . . . . . . . 2-69

2.3-2 Locations of meteorological towers 2, 3, and 4 in relation to the proposed Advanced Neutron Source site ........... 2-70 
2.3-3 Wind rose (1986-1990) for the 30-m (98-ft) anemometer on

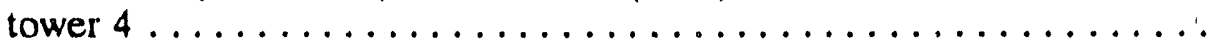

2.3-4 Wind rose for stability class A (1986-1990) for the 30-m (98-ft)

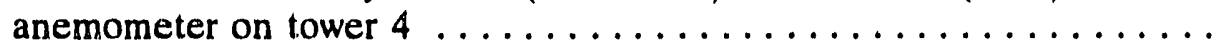

2.3-5 Wind rose for stability class B (1986-1990) for the 30-m (98-ft)

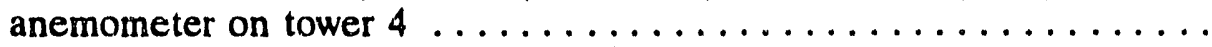

2.3-6 Wind rose for stability class C (1986-1990) for the 30-m (98-ft)

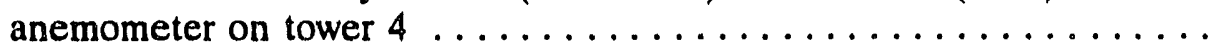

2.3-7 Wind rose for stability class $D(1986-1990)$ for the $30-\mathrm{m}(98-\mathrm{ft})$ anemometer on tower $4 \ldots \ldots \ldots \ldots \ldots \ldots \ldots \ldots$

2.3-8 Wind rose for stability class E (1986-1990) for the 30-m (98-ft)

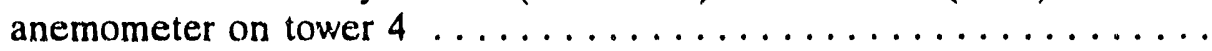

2.3-9 Wind rose for stability class $F(1986-1990)$ for the $30-\mathrm{m}$ (98-ft) anemometer on tower 4

2.3-10 Wind rose for stability class G (1986-1990) for the 30-m (98-ft)

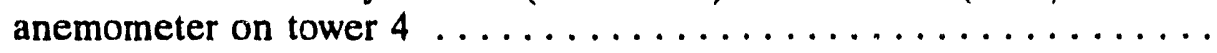

2.3-11 Western part of Oak Ridge National Laboratory, looking south, with the steam plant and the coal yard in the upper-central part

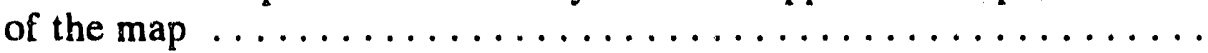

2.4-1 Location of the proposed Advanced Neutron Source site in the Tennessee River Basin

2.4-2 Hydraulic regime in the vicinity of the proposed Advanced Neutron Source site during normal conditions (not drawn to scale) .........

2.4-3 Major rivers and streams in the immediate vicinity of the proposed Advanced Neutron Source site . . . . . . . . . . . . . . . .

2.4-4 Map illustrating general depth to groundwater in the White Oak

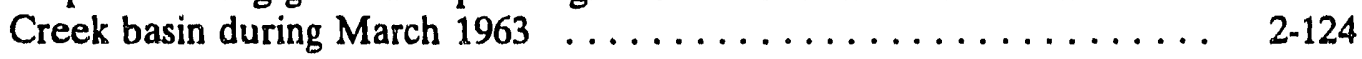

2.4-5 Location of water wells in the Oak Ridge vicinity ............

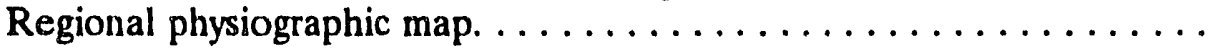

2.5-2 Stratigraphic column for the Valley and Ridge Province Paleozoic bedrock formations in the Oak Ridge Reservation vicinity ..........

2.5-3 A regional surface and subsurface geologic map modified after the Watts Bar Nuclear Plant Final Safety Analysis Report ............

2.5-4 A tectonic map showing extensive structural deformation in the

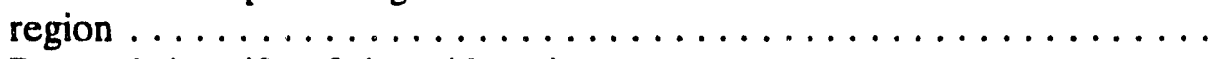

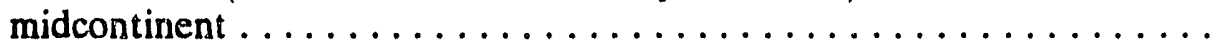
ancient rift zones (basement structures) in the southeastern 
2.5-10 Comparison between Electric Power Research Institute, Seismicity Organizational Group, and Lawrence Livermore National Laboratory seismic hazard curves for the High Flux Isotope Reactor site (Risk Engineering, Inc., 1991) and Coats and Murray's (1984) "best estimate" hazard curve for the Oak Ridge Reservation . . . . . . . 2-156

2.5-11 Location of the proposed ANS site near Oak Ridge National Laboratory . . . . . . . . . . 2.158

2.5-12 Stratigraphic column for the Valley and Ridge Province Paleozoic bedrock formations in the Oak Ridge Reservation vicinity . . . . . . . . 2-159

2.5-13 Generalized geologic map of the Oak Ridge area showing the proposed ANS site location ....................... 2-167

2.5-14 Geologic cross section of the Melton Valley area ............. 2-168

2.5-15 Lower hemisphere equal area projections of poles to joint planes from measurements of joints at three separate sites within Solid Waste Storage Area 7, located approximately $610 \mathrm{~m}(2000 \mathrm{ft})$ along strike to the southwest of the ANS site ..............

2.5-16. Soils map of the proposed Advanced Neutron Source site .... . . . . 2-173

2.8-1 Locations of major stacks at Oak Ridge National Laboratory . . . . . . . 2 2-189

2.8-2 Map showing milk-sampling stations $\ldots \ldots \ldots \ldots \ldots \ldots \ldots \ldots \ldots \ldots$

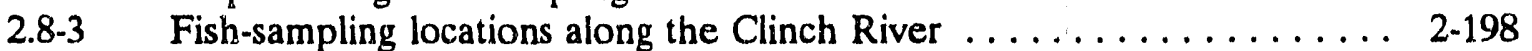

3.1-1 Conceptual site plan of the Advanced Neutron Source facility. . . . . . 3-2

3.1-2 Principal facilities of the Advanced Neutron Source buildings; tloor elevation, $76 \mathrm{ft}(23.3 \mathrm{~m}) \quad \ldots \ldots \ldots \ldots \ldots \ldots \ldots \ldots \ldots \ldots . \ldots \ldots$

3.1-3 Principal facilities of the Advanced Neutron Source buildings; floor elevations, $96 \mathrm{ft}(29.3 \mathrm{~m})$ and $103 \mathrm{ft}(33.2 \mathrm{~m}) \ldots \ldots \ldots \ldots \ldots . \ldots .4$

3.1-4 Principal facilities of the Advanced Neutron Source buildings; floor elevation, $133 \mathrm{ft}(40.5 \mathrm{~m}) \ldots \ldots \ldots \ldots \ldots \ldots \ldots \ldots \ldots \ldots \ldots \ldots .5$

3.1-5 Principal facilities of the Advanced Neutron Source buildings;

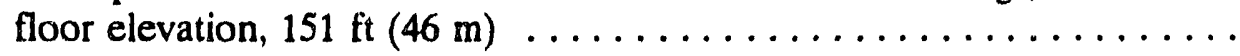

3.1-6 Principal facilities of the Advanced Neutron Source buildings;

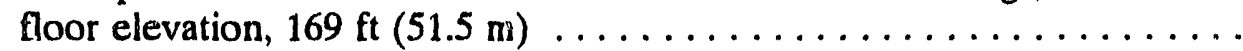

3.1-7 Principal facilities of the Advanced Neutron Source buildings;

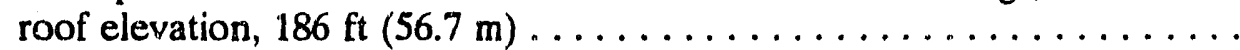

3.1-8 Cross-section of the reactor building and reactor support building . . . . . . Elevation view of the reactor building $\ldots \ldots \ldots \ldots \ldots \ldots \ldots \ldots$

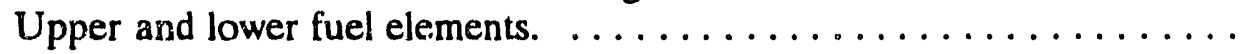
The core pressure boundary tube $\ldots \ldots \ldots \ldots \ldots \ldots \ldots \ldots$ Principal components of the Advanced Neutron Source reactor. . . . . . . The two-element offset core. $\ldots \ldots \ldots \ldots \ldots \ldots \ldots \ldots \ldots$

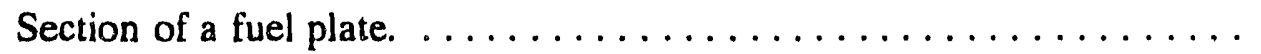
Flowsheet of reactor coding system . . . . . . . . . . . . . . Proposed management of liquid low-level waste from Advanced Neutron Source Reactor at Oak Ridge National Laboratory . . . . . . . . . Management of Advanced Neutron Source radioactive process waste at Oak Ridge National Laboratory $\ldots \ldots \ldots \ldots \ldots \ldots \ldots \ldots$ 
List of Figures (continued)

3.5-3 Management of contact-handled/remote handled-transuranic waste from Advanced Neutron Source at Oak Ridge National Laboratory . . . . 3.53

3.5-4 Management of solid low-level radioactive waste from Advanced Neutron Source site at Oak Ridge National Laboratory . . . . . . . . . . 3-60

3.5-5 Proposed management of radioactive and nonradioactive gaseous emissions from Advanced Neutron Source site at Oak Ridge National Laboratory ............................ 3-64

3.5-6 Management of mixed waste from Advanced Neutron Source at Oak Ridge National Laboratory . . . . . . . . . . . . . . . . . . . 3-69

3.7-1 Proposed management of conventional wastes from Advanced Neutron Source at Oak Ridge National Laboratory . . . . . . . . . . . . . 3-72

3.7-2 Proposed management of hazardous wastes from the Advanced Neutron Source at Oak Ridge National Laboratory . . . . . . . . . . . . . 3-76

5.1-1 The four tributaries of Melton Branch in relation to the Advanced Neutron Source and the High Flux Isotope Reactor . . . . . . . . . . . 5-4

6.1-1 Oak Ridge National Laboratory surface water and reference sampling locations . . . . . . . . . . . . . . . . . . . . . . . 6-4

6.1-2 Oak Ridge National Laboratory waste area groupings ........... 6.9

6.1-3 The Oak Ridge Reservation and Oak Ridge National Laboratory perimeter

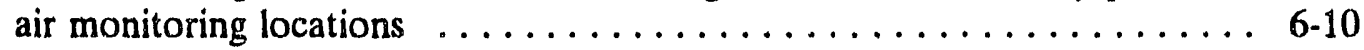

6.1-4 The Oak Ridge Reservation meteorological monitoring network . . . . . . 6-12

7.1.1 Partial core-melt progression event tree for environmental report

7.1-2 Advanced Neutron Source containmerat representation for environmental report. ...................... 7-6

7.1-3 Total decay power variation with time for Advanced Neutron Source

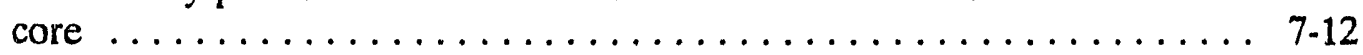

7.1-4 Variation of control volume pressures with time $\ldots \ldots \ldots \ldots \ldots \ldots$ 7-12

7.1-5 Variation of reactor pool water inventory with time $\ldots \ldots \ldots \ldots \ldots$ 7-13

7.1.6 Distribution of aerosol masses in various control volumes with time . . . 7-13

7.1-7 Distribution of vapors (noble gases and halogens) in various control

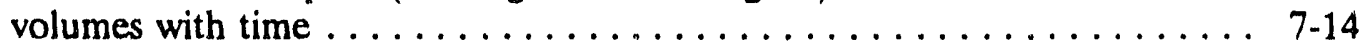

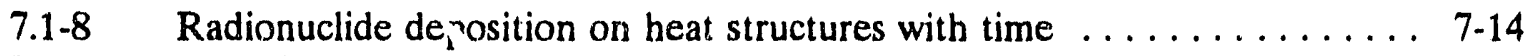

7.1.9 Variation of radionuclide masses in reactor pad with time $\ldots \ldots \ldots \ldots$ 7-15

7.1-10 Variation of radionuclide masses in reactor pool with time ........ 7-15

7.1-11 Variation of radionuclide masses in reactor pool with time $\ldots \ldots \ldots \ldots$ 7-16

7.1-12 Radionuclide masses entering environment with time ........... 7-16

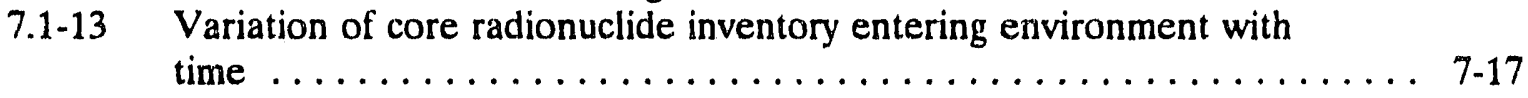

7.1-14 Variation of control volume pressures with time $\ldots \ldots \ldots \ldots \ldots \ldots$ 7-17

7.1-15 Variation of control volume temperatures with time $\ldots \ldots \ldots \ldots \ldots \ldots$ 7-19

7.1-16 Variation of hydrogen mole fractions in various control volumes . . . . . 7-19

7.1-17 Variation of various gas mole fractions in subpile room $\ldots \ldots \ldots \ldots \ldots$ 7-20

7.1-18 Variation of total radionuclide aerosol mass in control volume

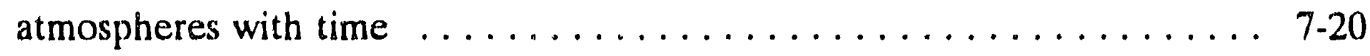




\section{List of Figures (continued)}

7.1-19 Variation of total radionuclide vapor mass in control volume atmospheres with time $\ldots \ldots \ldots \ldots \ldots \ldots \ldots \ldots \ldots \ldots \ldots \ldots$ 7-21

7.1-20 Variation of total radionuclide mass deposited on heat structures with

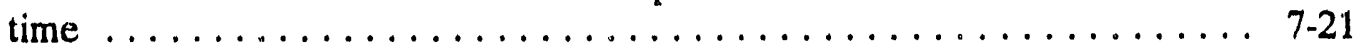

7.1-21 Radionuclide masses entering environment with time $\ldots \ldots \ldots \ldots \ldots$ 7-22

7.1-22 Variation of fraction of core radionuclide inventory entering the environment with time over $400 \mathrm{~s} \ldots \ldots \ldots \ldots \ldots \ldots \ldots \ldots \ldots \ldots . \ldots \ldots+22$

7.1-23 Variation of fraction of core radionuclide inventory entering the environment with time over $72 \mathrm{~h} \ldots \ldots \ldots \ldots \ldots \ldots \ldots \ldots \ldots . \ldots \ldots$ 7-23

7.1-24 Schematic representation for radiological consequence calculations . . . . 7 7-23

7.1-25 Cumulative complementary distribution functions for cancer fatality estimates from scenario $1 \ldots \ldots \ldots \ldots \ldots \ldots \ldots \ldots \ldots \ldots .31$

7.1-26 Cumulative complementary distribution functions of populationweighted risk cancer fatality estimates from scenario $1 \ldots \ldots \ldots \ldots$ 7-31

7.1-27 Cumulative complementary distribution functions for early fatality

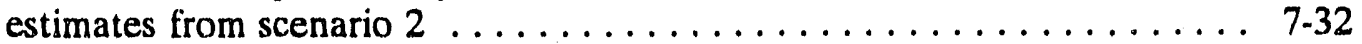

7.1-28 Cumulative complementary distribution functions for cancer fatality

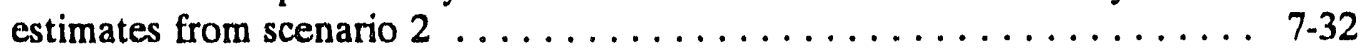

7.1-29 Cumulative complementary distribution functions of population weighted risk for early fatality estimates from scenario $2 \ldots \ldots \ldots \ldots \ldots \ldots$ 7-33

7.1-30 Cumulative complementary distribution functions of population weighted risk for cancer fatality estimates from scenario $2 \ldots \ldots \ldots \ldots \ldots \ldots 7-33$

8.6-1 Area highways leading to the Advanced Neutron Source site. . . . . . . 8 8-15

8.6-2 Local area roads leading to the Advanced Neutron Source site . . . . . . 8-16 


\section{LIST OF TABLES}

2.1-1 Approximate distance from the center of the of proposed Advanced Neutron Source site to Oak Ridge Reservation boundary . . . . . . . . . 2-13

2.1-2 Population estimates for 1990 within an $80.5-\mathrm{km}$ (50-mile) radius, incremental data . . . . . . . . . . . . . . . . . . . 2-17

2.1-3 Year 2000 population projections within an $80.5-\mathrm{km}(50$-mile) radius, incremental data ......................... 2-18

2.1-4 Year 2010 population projections within an $80.5-\mathrm{km}(50-$ mile) radius, incremental data . . . . . . . . . . . . . . . . . . . . . . 2-19

2.1-5 Year 2020 population projections within an $80.5-\mathrm{km}(50-$ mile $)$ radius, incremental data . ....................... 2-20

2.1-6 Industries in the Advanced Neutron Source area . . . . . . . . . . . . 2-22

2.1-7 City and county schools within a $16.4-\mathrm{km}$ (10-mile) radius of the proposed Advanced Neutron Source site . . . . . . . . . . . . . 2-25

2.1-8 Major recreational facilities within $16.4 \mathrm{~km}$ (10 miles) of the proposed Advanced Neutron Source site . . . . . . . . . . . . 2-30

2.1-9 Roads and highways nearest the proposed Advanced Neutron Source

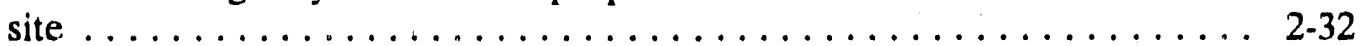

2.1-10 Oak Ridge National Laboratory waste generation summary for $1990 \ldots \ldots$. . 2-34

2.1-11 Oak Ridge National Laboratory waste in storage at the end of $1990 \ldots \ldots$ 2-35

2.1-12 K-25 Site waste in storage at the end of $1990 \ldots \ldots \ldots \ldots \ldots \ldots . \ldots \ldots$

2.1-13 Y-12 Plant waste generation summary for $1990 \ldots \ldots \ldots \ldots \ldots \ldots . . \ldots \ldots$

2.1-14 Y-12 Plant waste in storage at the end of $1990 \ldots \ldots \ldots \ldots \ldots \ldots \ldots 2-38$

2.2-1 Estimates of the abundance of various habitats on the Oak Ridge

Reservation ......................... 2-43

2.2-2 Species composition (percent frequency) of trees, saplings, and shrubs at three sites in the possible wetlands in the draw at the southern boundary of the Advanced Neutron Source site . . . . . . . . 2-48

2.2-3 Amphibians, reptiles, birds, and mammals characteristic of or dependent on various habitats of the Oak Ridge Reservation . . . . . . 2-50

2.2-4 Bird species of the Oak Ridge Reservation and the proposed Advanced Neutron Source site . . . . . . . . . . . . . . . . 2-51

2.2-5 Mammal species and their habitat preferences on the Oak Ridge Reservation .......................... 2-56

2.2-6 Amphibian and reptilian species and their habitat preferences on the Oak Ridge Reservation and Advanced Neutron Source site . . . . 2.57

2.2-7 Checklist of the benthic macroinvertebrates collected from upper Melton Branch [above kilometer 2.1 (mile 1.31) and Friendship Creek on June 30 and July 5,1989 , respectively $\ldots \ldots \ldots \ldots \ldots \ldots \ldots \ldots$

2.2-8 Status of threatened and endangered species on the Oak Ridge Reservation ........................... 2-65

2.2-9 Threatened, endangered, and in-need-of management species on the Oak Ridge Reservation . . . . . . . . . . . . . . . . . . . . 2-67

2.3-1 Average wind speed, by month, at McGhee-Tyson Airport in Knoxville, Tennessee ........................ 2-72

2.3.2 Temperature data for Oak Ridge, Tennessee $\ldots \ldots \ldots \ldots \ldots \ldots \ldots$. . . . . . . . .

2.3-3 Precipitation data for Oak Ridge, Tennessee ................ 2.73 
List of Tables (continued)

2.3-4 Relative humidity data for Knoxville, Tennessee ..............

2.3-5 Record fastest $1.609 \mathrm{~km}$ (1 mile) of wind for Knoxville and

Chattanooga, Tennessee ....................... 2-76

2.3-6 Average numbers of thunderstorm days at Oak Ridge and Knoxville, Tennessee . . . . . . . . . . . . . . . . . . . . . . . 2-77

2.3-7 Number of Korshover stagnation episodes, by month, during the 40-year period $1936-1975 \ldots \ldots \ldots \ldots \ldots \ldots \ldots \ldots \ldots \ldots . \ldots \ldots$ 2-78

2.3-8 Mean number of days per year with fog and visibility $402 \mathrm{~m}$

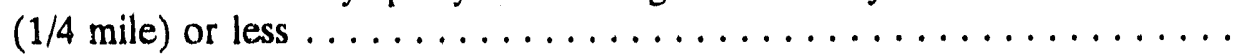

2.3-9 Snowfall records for Oak Ridge and Knoxville ..............

2.3-10 Mixing height and wind speed data for the Knoxville-Oak Ridge

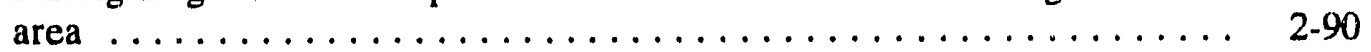

2.3-11 Monthly morning and afternoon mixing heights for Knoxville,

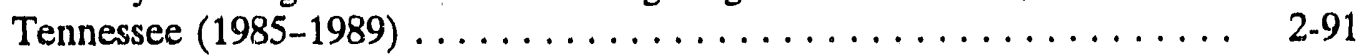

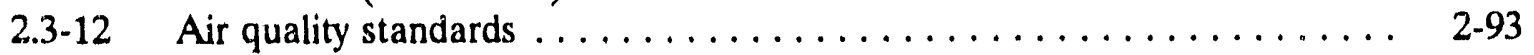

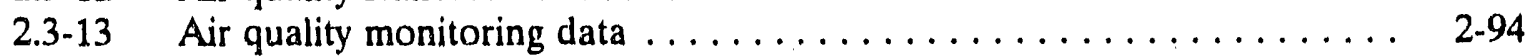

2.3-14 Average emissions from boilers 1-4 at the Oak Ridge National

Laboratory Steam Plant, based on actual coal consumption data for

1987-1989 and peak emissions, based on the maximum design capacity

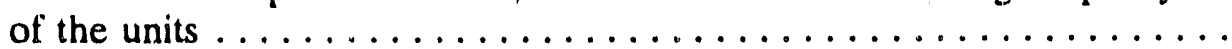

2.3-15 Average emissions from (gas-fired) boiler 5 at Oak Ridge National

Laboratory Steam Plant based on actual gas consumption data for

1987-1989 and peak emissions, based on the maximum design capacity

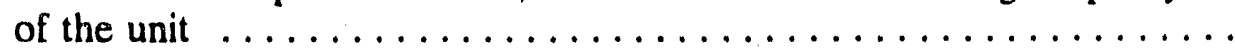

Stack parameters corresponding to boilers $1-4$ at the Oak Ridge

National Laboratory Steam Plant

2.3-17 Stack parameters and Universal Transverse Mercator coordinates corresponding to boiler 5 at the Oak Ridge National Laboratory

Location of the Bull Run Steam Plant $\ldots \ldots \ldots \ldots \ldots \ldots \ldots . \ldots \ldots$. . . . . . . . . . . . . .

2.3-19

Emissions inventory (1990) for the Bull Run Steam Plant . . . . . . . .

Stack parameters for the Bull Steam Plant ... . . . . . . . . . . 2-99

2.3-20

Location of the Kingston Steam Plant . . . . . . . . . . . . . . 2-99

2.3-21

Emissions inventory (1990) for the Kingston Steam Plant . . . . . . . 2-100

2.3-22

Stack parameters for the Kingston Steam Plant . . . . . . . . . . . . 2-100

2.3-24

Location of the $\mathrm{Y}-12$ Plant $\ldots \ldots \ldots \ldots \ldots \ldots \ldots \ldots \ldots \ldots$

$2-100$

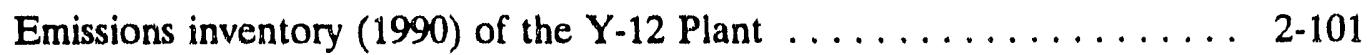

Stack parameters of the $\mathrm{Y}-12$ Plant . . . . . . . . . . . . . 2-101

2.3-26

2.4-1

Turbine discharges from Melton Hill Dam for the years 1963

through $1978 \ldots \ldots \ldots \ldots \ldots \ldots \ldots \ldots \ldots \ldots \ldots$. . . . . . . . . . . . . . . . . .

2.4-2 Average daily flow duration at Watts Bar Dam for the years 1960

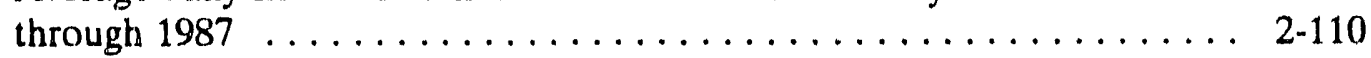

2.4-3 Periods of zero release from Melton Hill Dam from May 1963 to

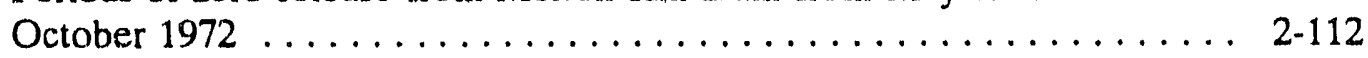

2.4-4 Measured water quality of the Clinch and Tennessee rivers $\ldots \ldots \ldots$ 2-115 
List of Tables (continued)

2.4-5 Public supply surface water withdrawals within approximately $32 \mathrm{~km}$ ( 20 miles) of the proposed Advanced Neutron Source site . . . . 2-117

2.4-6 Industrial water withdrawals from the Clinch-Tennessee Rjver system in the vicinity of the proposed Advanced Neutron Source site . . 2 2-119

2.4-7 Flow characteristics of White Oak Creek and Melton Branch . . . . . . 2. 2-121

2.4-8 Characteristics of some domestic wells and springs near the city of Oak Ridge and south of the Clinch River in the vicinity of Oak Ridge National Laboratory . . . . . . . . . . . . . 2-126

2.4-9 Industrial groundwater supplies within about $32 \mathrm{~km}$ (20 miles) of Oak Ridge National Laboratory . . . . . . . . . . . . . . . . . . 2-129

2.4-10 Public groundwater supplies within about $32 \mathrm{~km}$ (20 miles) of Oak Ridge National Laboratory . . . . . . . . . . . . . . . . 2 2-131

2.4-11 Groundwater quality in the Valley and Ridge Physiographic Province in the Tennessee Valley Region . . . . . . . . . . . . . . 2-132

2.5-1 Historic earthquakes probably felt at the Clinch River Breeder Reactor Site . . . . . . . . . . . . . . . . . . . 2-148

2.5-2 Maximum expected earthquakes and their associated peak ground accelerations at the Oak Ridge Reservation for nearby tectonic provinces . . . . . . . . . . . . . . . . . . . . . . 2-151

2.5-3 Oak Ridge Reservation Soil Coding Systems as applicable to the proposed ANS Site . . . . . . . . . . . . . . . . . . . . . . . . . 2-174

2.5-4 Classification of soils mapped at the proposed ANS site ......... 2-176

2.8-1 Average annual effective dose equivalent of ionizing radiation to a member of the U.S. population $\ldots \ldots \ldots \ldots \ldots \ldots \ldots \ldots \ldots$ 2-185

2.8-2 Annual discharges of radionuclides from White Oak Creek to the Clinch River, 1944 to 1989 . . . . . . . . . . . . . . . . . . . . . . 2-187

2.8-3 Estimated atmospheric releases of radioactivity at Oak Ridge National Laboratory . . . . . . . . . . . . . . . . . . 2-188

2.8-4 Oak Ridge National Laboratory radioactive airborne emissions

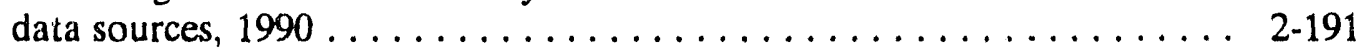

2.8-5 Oak Ridge National Laboratory annual airborne radionuclide

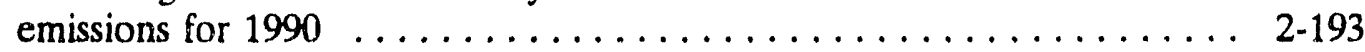

2.8-6 Oak Ridge National Laboratory liquid radioactive discharges measured at White Oak Dam for $1990 \ldots \ldots \ldots \ldots$. . . . . . . . . . 2-195

2.8-7 Radionuclide concentrations in raw milk in $1990 \ldots \ldots \ldots \ldots \ldots$. . . . . 2-197

2.8-8 Tissue concentrations of Clinch River bluegill in $1990 \ldots \ldots \ldots \ldots \ldots$. . 2-199

2.8-9 Release point parameters and receptor locations used in the dose calculations . . . . . . . . . . . . . . . . . . . 2-202

2.8-10 Potential radiation dose equivalents from external exposures at locations on and near the Oak Ridge Reservation . . . . . . . . . 2-205

2.8-11 Potential dose rates to aquatic biota . . . . . . . . . . . . . . . 2-206

2.8-12 Acceptable daily intakes for chemicals found above detection limits at Oak Ridge Reservation facilities . . . . . . . . . . . . 2-208

3.4-1 Primary and secondary coolant parameters .............. 3-39

3.5-1 Maximum allowable concentrations of specific wastewater contaminants for discharge to the process waste treatment plant ..... 3-51 
3.5-2 Solid radioactive waste generated at Oak Ridge National Laboratory in 1989: all sources . . . . . . . . . . . . . . . . . . . 3-52

3.5-3 Current status of Oak Ridge National Laboratory solid transuranic waste facilities ............................ 3-54

3.5-4 Summary of Department of Energy and university research reactor spent fuel shipments, $1983-1989 \ldots \ldots \ldots \ldots \ldots \ldots$. . . . . . . . . . . 3-57

3.5-5 Greater-than-Class- $\mathrm{C}$ radionuclides commonly found in solid radioactive waste . . . . . . . . . . . . . . . . . . . . . . 3-59

3.5-6 Preliminary on-site disposal capacity scenarios for Oak Ridge National Laboratory wastes . . . . . . . . . . . . . . . . . . . . . 3-63

3.5-7 Principai gaseous waste management systems for the proposed

Advanced Neutron Source and their features . . . . . . . . . . . . . 3-66

3.8-1 Annual Advanced Neutron Source waste volumes . . . . . . . . . . . . 3.79

3.8-2 Transportation route analysis from HIGHWAY model . . . . . . . . . 3-82

3.8-3 RADTRAN IV assumptions for the Advanced Neutron Source transportation risk assessment . .................. 3-84

3.8-4 Summary of Advanced Neutron Source transportation risks from incident-free transport . . . . . . . . . . . . . . . . . . 3-86

3.8-5 Summary of Advanced Neutron Source transportation risks due to accidents . . . . . . . . . . . . . . . . . . . . . . . . . . . . . . . 3-87

5.1-1 Concentrations of water quality constituents of upper Melton Branch, Oak Ridge National Laboratory potable water, and projected Advanced Neutron Source cooling tower blowdown. . . . . . . . . . . . . . .

5.1-2 Measured inean monthly discharges and daily temperatures in the tributaries forming Melton Branch ...................

5.1.3 Calculated water tenperatures in the east fork of Melton Branch downstream from the Advanced Neutron Source that consider effects from the cooling tower blowdown heat load and flow ............

5.1.4 Calculated water temperatures in the main channel of Melton Branch, upstream from the High Flux Isotope Reactor $\ldots \ldots \ldots \ldots \ldots \ldots$

5.1-5 Calculated water temperatures in Melton Branch, downstream from the High Flux Isotope Reactor (combined Advanced Neutron Source and High Flux Isotope Reactor discharges) $\ldots \ldots \ldots \ldots \ldots \ldots$

5.6-1 Simulated concentrations of a neutrally buoyant pollutant at selected receptors on a radial grid centered at the proposed Advanced Neutron Source site . . . . . . . . . . . . . . . 5.17

5.10-1 Cumulative doses at the High Flux Isotope Reactor . . . . . . . . . 5-20

5.10-2 Occupational doses at the Institut Laue-Langevin Research Reactor, Grenoble, France ......................... 5-21

5.10-3 National institute of Standards and Technology Reactor radiation workers annual dose: $1985-1989 \ldots \ldots \ldots \ldots \ldots \ldots \ldots \ldots$. . . . . . . .

5.10-4 National Institute of Standards and T'echnology person-codes and license work areas for radiation workers, assigned dose equivalents

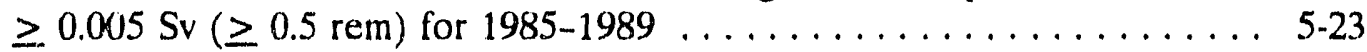

5.10-5 Annual tritium dose by work group averaged over period 1978-1982 . . . . 5-2.4 
5.10-6 Estimated values of relative biological effectiveness for fission neutrons relative to gamma rays for several biological

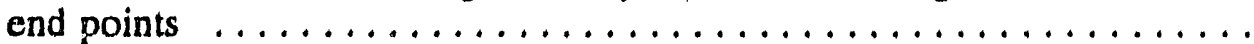

5.10-7 Radiation weighting factors, $\mathrm{W}_{\mathrm{R}}$, recommended by the International

Commission on Radiological Protection . . . . . . . . . . . . . . 5-27

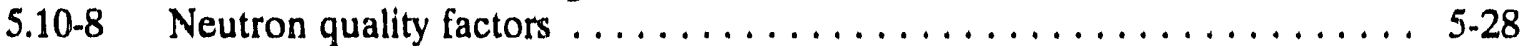

$5.10-9$ Quality factor as a function of neutron energy $\ldots \ldots \ldots \ldots \ldots \ldots \ldots$. 28

5.10-10 Hazardous chemicals inventory for the High Flux Isotope Reactor . . . . . 5-33

5.11-1 Predicted generation of liquid low-level waste from the Advanced

Neutron Source . . . . . . . . . . . . . . . . . . . . . . . 5-36

5.11-2 Predicted generation of liquid radiological process waste from the Advanced Neutron Source . . . . . . . . . . . . . . . . . . . . . 5-38

5.11-3 Predicted generation of solid contact- and remote-handled low-level radioactive waste from the Advanced Neutron Source . . . . . . . . . . . . . 5-54

5.11-4 Predicted gaseous radiological emissions from the Advanced Neutron Source reactor facility and adjacent buildings .............. 5.44

5.11-5 Predicted generation of tritiated aqueous liquids and tritiated solid wastes from the Advanced Neutron Source

5.11-6 Predicted hazardous and mixed waste generation at the Advanced Neutron Source . . . . . . . . . . . . . . . . . . . . . . . . 5-47

5.11-7 Predicted conventional waste generation at the Advanced Neutron Source ................................... 5-49

6.1-1 1990 National Pollutant Discharge Elimination System permit (TN 0002941) points and effluent parameters at Oak Ridge National Laboratory . . . . . 6-3

6.1-2 Groundwater monitoring parameters for the Oak Ridge Reservation ... . 6-6

6.1-3 Oak Ridge National Laboratory waste area groupings, $1990 \ldots \ldots \ldots$. . . 6-8

6.1-4 National Pollutant Discharge Elimination System outfalls at Oak Ridge National Laboratory and radionuclide parameters monitored . . . . . . . . . 6-14

7.1-1 Radionuclide mass inventory predicted by ORIGEN2 for Advanced Neutron Source core (end-of-cycle) $\ldots \ldots \ldots \ldots \ldots \ldots$. . . . . . . . 7-8

7.1-2 Activity levels of important radionuclides at end-of-cycle for Advarced Neutron Source core . . . . . . . . . . . . . . . . . . . . . . . 7-9

7.1-3 Population distribution around the Advanced Neutron Source . . . . . . 7-25

7.1-4 Mean values for estimates of prompt fatalities and latent cancer

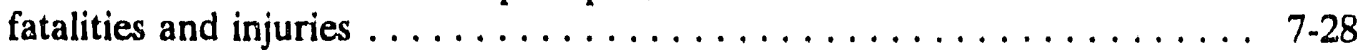

7.1-5 Numbers of persons receiving dose exceeding specified values . . . . . . . 7-29

7.1-6 Population and average doses by distance from the site . . . . . . . . 7-29

7.1-7 Variation of average individual risk from postulated severe accidents . . . 7-30

7.1-8 Radiological accident risk limitation goals for the Advanced Neutron

Source .............................. 7-35

7.1-9 Reactor core end-of-cycle inventory of noble gas and halogen fission

7.1-10 High Flux Isotope Reactor and Advanced Neutron Source coolant activity concentrations . . . . . . . . . . . . . . . . . . . . 7-37

7.1-11 Source term calculation sheet for heat exchanger tube leak ........ 7.39

7.1-12 Source term calculation sheet for heat exchanger tube rupture $\ldots \ldots \ldots .7-41$ 
List of Tables (continued)

7.1-13 Source term calculation sheet for end-of-cycle off-design event inducing $0.02 \%$ fuel failure $\ldots \ldots \ldots \ldots \ldots \ldots \ldots \ldots \ldots . \ldots \ldots . . \ldots \ldots$

7.1-14 Source term calculation sheet for refueling accident with $100 \%$ damage to one element ..................... $7-45$

7.1-15 Source term calculation sheet for small pipe break into limited volume cell ..................................

7.1-16 Source term calculation sheet for large pipe break accident with

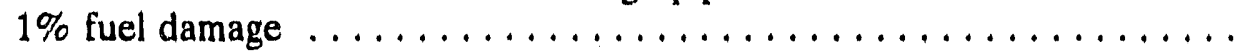

7.1-17 Inhalation dose to nearest offsite resident from postulated

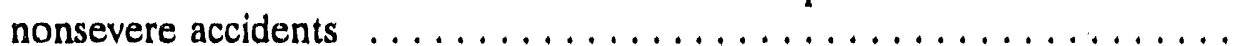

8-1 Department of Energy local payroll distribution ..............

8-2 Numbers of Oak Ridge National Laboratory employees living in

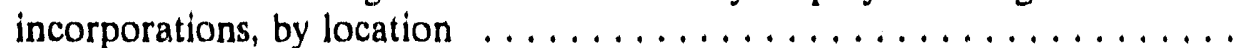

8-3 Demographic and economic characteristics in 1990 for Advanced Neutron Source region of interest $\ldots \ldots \ldots \ldots \ldots \ldots \ldots \ldots$

$\begin{array}{ll}8.1-1 & \text { Annual projected direct local expenditures } \ldots \ldots \ldots \ldots \ldots \ldots \ldots \ldots \ldots\end{array}$

8.1-3 Projected annual direct Advanced Neutron Source employment allocated to counties within the region of interest .............

8.1-4 Projected craft employment during construction of Advanced Neutron Source .................................

8.1-5 Estimated local employment and expenditures resulting from Advanced

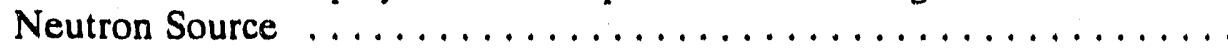

8.1-6 Projected total local earnings including secondary effects resulting from Advanced Neutron Source in the region of interest $\ldots . \ldots \ldots \ldots$

8.1-7 Projected total local employment including secondary employment resulting from Advanced Neutron Source in the region of interest .....

8.4-1 Projected increase in sales tax collections for counties in region of interest $\ldots \ldots \ldots \ldots \ldots \ldots \ldots \ldots \ldots \ldots \ldots \ldots \ldots \ldots . \ldots \ldots \ldots . \ldots \ldots$

8.5-1 Distribution of land use by area and percentage $\ldots \ldots \ldots \ldots \ldots \ldots$ 8-14

8.6-1 Present and projected average daily traffic flows $\ldots \ldots \ldots \ldots \ldots \ldots$ 8-18

8.6.2 Present and future levels of service $\ldots \ldots \ldots \ldots \ldots \ldots \ldots \ldots \ldots$ 8.19

8.6-3 Data/assumptions for level of service calculations ........... 8-20

8.\%-1 Advanced Neutron Source emergency zone characteristics and planning criteria for dose impacts under hypothetical maximum credible severe accident conditions . . . . . . . . . . . . . $8-23$

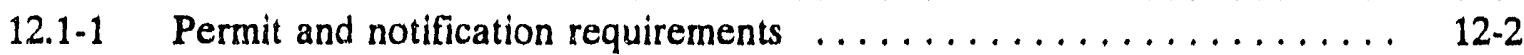

12.1-2 Consultation requirements for the Advanced Neutron Source . . . . . . . 12-6

12.6-1 U.S. Department of Energy orders applicable to the Advanced Neutron Source project $\ldots \ldots \ldots \ldots \ldots \ldots \ldots \ldots \ldots$

12.6-2 U.S. Environmental Protection Agency public protection regulations applicable to the Advanced Neutron Source project ............ 
ADI

AEA

AEC

ALARA

AMAD

ANS

ASME

at.

ATDD

AVLIS

BMAP

BPJ

$\mathrm{Bq}$

B\&W

C

CAA

CANDU

CAT

CDE

CDI

CERCLA

CFC

CFR

$\mathrm{CH}$

CH/RH-LLW

$\mathrm{Ci}$

$\mathrm{cm}$

COE

CPBT

CRBR

CRK

CRM

CSLF

CSLF II

CWA

CY

d

$d B(A)$

DCF

DCG

DDT

diam

DOC

DOE

DOE-OR acceptable daily intake

Atomic Energy Act

Atomic Energy Commission

as low as reasonably achievable

activity median aerodynamic diameter

Advanced Neutron Source

American Society of Mechanical Engineers

atomic

Atmospheric Turbulence and Diffusion Division

atomic vapor laser isotope separation

Biological Monitoring and Abatement Program

best professional judgement

becquerel

Babcock and Wilcox

Celsius

Clean Air Act

Canadian Deuterium Uranium Reactor

collection and transfer

collective dose equivalent

calculated daily intake

Comprehensive Environmental Response, Compensation, and Liability Act of 1980

chlorofluorocarbons

Code of Federal Regulations

contact handled

contact handled/remotely handled low-level waste

curie

centimeter

(U.S. Army) Corps of Engineers

core pressure boundary tube

Clinch River Breeder Reactor

Clinch River kilometer

Clinch River mile

Centralized Sanitary Landfill

Centralized Sanitary Landfill II

Clean Water Act

calendar year

day

decibel, A-weighted scale

dose conversion factor

Derived Concentration Guide

dichlorodiphenyl-trichloroethane

diameter

U.S. Department of Commerce

U.S. Department of Energy

Department of Energy Oak Ridge Field Office 
Abbreviations, Acronyms, and Initialisms (continued)

DOE-ORO
DOI
DOT
DTO
D\&D
EDE
EIS
EOC
EPA
EPRI
ER
ETNG
F
Fed. Regist.
FFA
FSAR
ft
ft
tt
FTE
FWCA
FWS
FY
g
gal
GCD
GTCC
h
ha
HDPE
HEPA
HFBR
HFIR
HIC
HLW
HPRR
HSWA
HTO
HVAC
HWUDB
ICRP
ICRU
ILL
in.
INM

U.S. Department of Energy - Oak Ridge Operations

U.S. Department of the Interior

U.S. Department of Transportation

deuterium tritium oxygen

decontamination and decommissioning

effective dose equivalent

environmental impact statement

end-of-cycle

U.S. Environmental Protection Agency

Electric Power Research institute

environmental report

East Tennessee Natural Gas

Fahrenheit

Federal Register

Federal Facilities Agreement

Final Safety Analysis Report

foot

square feet

cubic feet

full-time equivalent

Fish and Wildlife Coordination Act

U.S. Fish and Wildlife Service

fiscal year

gram

acceleration due to gravity

gallon

greater confinement disposal

Greater-than-Class-C

hour

hectare

high-density polyethylene

tigh-efficiency particulate air

High Flux Beam Reactor

High Flux Isotope Reactor

high-integrity container

high-level waste

Health Physics Research Reactor

Hazardous and Solid Waste Amendments of 1984

tritiated water

heating, ventilating, and air-conditioning

Heavy Water Upgrading and Detritiation Building

International Commission on Radiological Protection

International Commission on Radiation Units and

Measurements

Institut Laue-Langevin (Grenoble, France)

inch

in need of management

xxvi 
Abbreviations, Acronyms, and Initialisms (continued)

\begin{tabular}{|c|c|}
\hline $\begin{array}{l}\text { INPO } \\
\text { INZ }\end{array}$ & Institute of Nuclear Power Operations \\
\hline $\begin{array}{l}\text { INZ } \\
\text { IRIS }\end{array}$ & immediate notification zone \\
\hline IRIS & Integrated Risk Information System \\
\hline IWMF & Interim Waste Management Facility \\
\hline $1 \& \mathrm{C}$ & Instrumentation and Controls Division \\
\hline $\mathrm{J}$ & joule \\
\hline K & kelvin \\
\hline keV & kiloelectronvolt \\
\hline $\mathrm{kg}$ & kilogram \\
\hline $\mathrm{km}$ & kilometer \\
\hline $\mathrm{kPa}$ & kilopascal \\
\hline L & liter \\
\hline Ib & pound \\
\hline LCF & latent cancer fatality \\
\hline LET & linear energy transfer \\
\hline LLLW & liquid low-level radioactive waste \\
\hline LLNL & Lawrence Livermore National Laboratory \\
\hline LLW & low-level radioactive waste \\
\hline LOS & level of service \\
\hline LPCE & liquid phase catalytic exchange \\
\hline m & meter \\
\hline $\mathrm{m}^{2}$ & square meter \\
\hline $\mathrm{m}^{3}$ & cubic meter \\
\hline $\mathrm{m}_{\mathrm{b}}$ & body wave magnitude \\
\hline MAACS & MELCOR Accident Consequence Code System \\
\hline MBK & Melton Branch kilometer \\
\hline MBM & Melton Branch mile \\
\hline $\mathrm{MBq}$ & megabecquerel \\
\hline $\mathrm{MCA}$ & maximum credible accident \\
\hline MCCI & molten-core-concrete-interaction \\
\hline $\mathrm{MCL}$ & maximum contaminant level \\
\hline $\mathrm{MeV}$ & megaelectronvolt \\
\hline MCS & model conservation standards \\
\hline $\mathrm{Mg}$ & megagram \\
\hline $\mathrm{mg}$ & milligram \\
\hline $\min$ & minute \\
\hline $\mathrm{mL}$ & milliliter \\
\hline MMC & Methodist Medical Center \\
\hline MMI & Modified Mercalli Index \\
\hline $\mathrm{MPa}$ & megapascal \\
\hline $\mathrm{mph}$ & miles per hour \\
\hline mrem & millirem \\
\hline msl & mean sea level \\
\hline $\mathrm{mSv}$ & millisievert \\
\hline MTU & metric tons uranium \\
\hline MVST & Melton Valley Storage Tank \\
\hline MW & megawatt \\
\hline
\end{tabular}


Abbreviations, Acronyms, and Initialisms (continued)

$M W(f)$

$M W(t)$

$\mu \mathrm{Ci}$

$\mu \mathrm{g}$

NAAQS

NAS

$\mathrm{nCi}$

NCRP

NEPA

NESHAP

NHPA

NIST

NOAA

NPDES

NRC

NRHP

NRWTF

NRWTP

OBE

ORMWI

ORNL

ORR

$\mathrm{Pa}$

PAG

PCB

$\mathrm{pCi}$

PGA

PHF

$\mathrm{PM}_{10}$

PMC

PMF

ppb

ppm

PSD

psi

psia

psig

Pub. L.

PW

PWTP

P\&E

$\mathrm{R}$

rad

RBE

RBOF megawatt fission

megawatt thermal

microcurie

microgram

National Ambient Air Quality Standards

National Academy of Sciences

nanocurie

National Council on Radiation Protection and

Measurements

National Environmental Policy Act of 1969

National Emission Standards for Hazardous Air Pollutants

National Historic Preservation Act

National Institute of Standards and Technology

National Oceanic and Atmospheric Administration

National Pollutant Discharge Elimination System

Nuclear Regulatory Commission

National Register of Historic Places

Nonradiological Wastewater Treatment Facility

Nonradiological Wastewater Treatment Plant

operating basis earthquake

Oak Ridge Mixed Waste Incinerator

Oak Ridge National Laboratory

Oak Ridge Reservation

pascal

Protective Action Guide

polychlorinated biphenyl

picocurie

peak ground acceleration

peak hour factors

particulate matter with a diameter of less than

10 microns

Project Management Corporation

probable maximum flood

parts per billion

parts per million

prevention of significant deterioration

pounds per square inch

pounds per square inch, absolute

pounds per square inch, gage

Public Law

process waste

Process Waste Treatment Plant

Plant and Equipment Division

roentgen

radiation absorbed dose

relative biological effectiveness

Receiving Basin for Off-site Fuels 
Abbreviations, Acronyms, and Initialisms (continued)

\begin{tabular}{|c|c|}
\hline $\begin{array}{l}\text { RCRA } \\
\text { REDC } \\
\text { rem }\end{array}$ & $\begin{array}{l}\text { Resource Conservation and Recovery Act of } 1976 \\
\text { Radiochemical Engineering Development Center } \\
\text { roentgen equivalent man }\end{array}$ \\
\hline RERTR & $\begin{array}{l}\text { roentgen equivalent man } \\
\text { Reduced Enrichment Research and Test Reactor }\end{array}$ \\
\hline RfD & reference dose \\
\hline RH & remote handled \\
\hline RIMS & Regional Industrial Multiplier System \\
\hline ROI & region of influence \\
\hline RQ & reportable quantities \\
\hline RRD & Research Reactor Division \\
\hline RSS & Reactor Safety Study \\
\hline R\&D & research and development \\
\hline $\mathbf{s}$ & second \\
\hline SAR & Safety Analysis Review \\
\hline SC-GTCC & special case greater-than-class- $C$ waste \\
\hline SDWA & Safe Drinking Water Act \\
\hline SF & slope factor \\
\hline SHPO & State Historic Preservation Officer \\
\hline SLLW & solid low-level waste \\
\hline SMCL & secondary maximum contaminant level \\
\hline SPCC & spill prevention control and countermeasures \\
\hline SR & State Route(s) \\
\hline SSD & Solid State Division \\
\hline SSE & safe shutdown design earthquake \\
\hline SSE/DBE & safe shutdown/design basis earthquake \\
\hline STP & Sewage Treatment Plant \\
\hline SWSA & solid waste storage area \\
\hline Sv & sievert \\
\hline $\mathrm{t}$ & ton \\
\hline TCA & Tennessee Code Annotated \\
\hline TDEC & Tennessee Department of Environment and Conservation \\
\hline TDHE & Tennessee Department of Health and Environment \\
\hline TEMA & Tennessee Emergency Management Agency \\
\hline Tenn. Comp. R. \& Regs. & Tennessee Compilation of Rules and Regulations \\
\hline THWMA & Tennessee Hazardous Waste Management Act of 1975 \\
\hline TRB & $\begin{array}{l}\text { Transportation Research Board (National Research } \\
\text { Council) }\end{array}$ \\
\hline TRF & Tritium Removal Facility \\
\hline TRM & Tennessee River mile \\
\hline TRU & transuranic waste \\
\hline TRUPACT & transuranium packaging transportation \\
\hline TSCA & Toxic Substances Control Act of 1976 \\
\hline TSF & Tower Shielding Facility \\
\hline TSPO & Tennessee State Planning Office \\
\hline TVA & Tennessee Valley Authority \\
\hline TWRA & Tennessee Wildlife Resources Agency \\
\hline U.S.C. & United States Code \\
\hline
\end{tabular}


Abbreviations, Acronyms, and Initialisms (continued)

USGS

UST

W

WAC

WEAF

WHPP

WIPP

WOCK

WOCM
U.S. Geological Survey

underground storage tanks

watt

waste acceptance criteria

Waste Examination Assay Facility

Waste Handling and Packaging Plant

Waste Isolation Pilot Plant

White Oak Creek kilometer

White Oak Creek mile 


\section{EXECUTIVE SUMMARY}

The U.S. Department of Energy (DOE) has proposed the construction and operation of the Advanced Neutron Source (ANS), a 330-MW(f) reactor, at Oak Ridge National Laboratory (ORNL) to support neutron scattering and nuclear physics experiments. ANS would provide a steady-state source of neutrons that are thermalized to produce sources of hot, cold, and very cold neutrons. The use of these neutrons in ANS experiment facilities would be an essential component of national research efforts in basic materials science. Additionally, ANS capabilities would include production of transplutonium isotopes, irradiation of potential fusion and fission reactor materials, activation analysis, and production of medical and industrial isotopes such as ${ }^{252} \mathrm{Cf}$.

Although ANS would not require licensing by the U.S. Nuclear Regulatory Commission (NRC), DOE regards the design, construction, and operation of ANS as activities that would produce a licensable facility; that is, DOE is following the regulatory guidelines that NRC would apply if NRC were licensing the facility. Those guidelines include instructions for the preparation of an environmental report (ER), a compilation of available data and preliminary analyses regarding the environmental impacts of nuclear facility construction and operation. The ER, described and outlined in NRC Regulatory Guide 4.2, serves as a background document to facilitate the preparation of environmental impact statements (EISs). Using Regulatory Guide 4.2 as a model, this ANS ER provides analyses and information specific to the ANS site and area that can be adopted (and modified, if necessary) for the ANS EIS.

The ER is being prepared in two phases. This Phase I ER includes many of the data and analyses needed to prepare the EIS but does not include data or analyses of alternate sites or alternate technologies, because no such alternatives have yet been identified. The Phase II ER will include the additional data and analyses stipulated by Regulatory Guide 4.2 and will be initiated after the completion of Phase I. Section 1 of this ER discusses the scope of the document, the need for the facility, and the consequences of delaying the project.

Section 2 describes the site and environmental interfaces for the ANS facility; it gives detailed background information about the proposed site, the ORNL area, and the surrounding environs. Included in the discussion are (1) geography and demography (e.g., ANS site location and description, residential and transient population statistics, and nearby facilities), (2) ecology (terrestrial, aquatic, and threatened or endangered species), (3) meteorology (climate and air quality), (4) hydrology (surface water and groundwater), (5) geology (geology of the proposed site, local area, and region); (6) scenic and cultural resources, (7) noise, and (8) radiological and chemical dose to the public (background levels, ORNL sources, and nonradiological chemical doses).

Section 3 begins with a description of the ANS facility, including functional descriptions of ANS buildings, the reactor, water systems, and heat dissipation systems. Because the ANS design has not been finalized, the latest available ciata regarding process specifics were used, but they are subject to modification in the Phase II ER. ANS radioactive waste systems and source terms also are discussed in Sect. 3. Liquid, solid, and gaseous radioactive wastes at ORNL are described, providing a baseline for predicting how laboratorywide radioactive waste management systems would be affected by the operation of ANS. Radioactive waste management systems for ANS and their interface with ORNL waste systems also are characterized, as are chemical, biocide, sanitary, and other nonradiological waste systems. Section 3 concludes with a discussion of radioactive 
material transport and in. 3eses a projection of ANS waste volumes, an analysis of transport risks, and a characterization of the radioactive materials.

Section 4 describes the environmental effects of site preparation and facility construction, such as effects on vegetation, wildlife, wetlands, and air quality. Other subjects considered are utility corridor construction, resources committed, site radioactivity, and a construction impact control program.

Section 5 analyzes the environmental effects of facility operation. As a significant driver of nuclear facility impacts, the effects (both physical and biological) of the heat dissipation system are discussed in detail. Other important areas include radiation dose to the public from routine operations, chemical and biocide discharges, sanitary waste discharges, operation and maintenance of utility corridors, noise, stack emissions (generic calculations), resources committed, worker health and safety, and waste management. Discussions of ANS decommissioning and the uranium fuel cycle are deferred to the Phase II ER, in which more complete information will be available.

Section 6 gives an overview of current effluent and environmental monitoring programs on the Oak Ridge Reservation (ORR), the proposed site for ANS. The discussion emphasizes the ORNL area and provides more summary information for the K-25 Site and Y-12 Plant areas. ANS operational monitoring programs have not been developed yet, but descriptions of these programs will be included in the Phase II ER. Section 6 offers some preliminary comments about wastes and surface water monitoring.

Section 7 analyzes the environmental effects of potential accidents. For severe reactor accidents involving radioactivity, a computer-based model is used to predict the transport of fission product nuclides and their release from containment, and another model is used to determine subsequent atmospheric dispersion and radiation exposures. A discussion of modeling methodology and assumptions is included. Potential nonsevere accidents and transportation accidents involving radioactivity also are evaluated.

Section 8, socioeconomic effects, examines changes in local employment, income, population, housing and public services, fiscal and tax effects, land use, transportation, and emergency preparedness that would result from ANS construction and operation.

Sections 9 (technologies and sites) and 10 (facility design alternatives) are deferred to the Phase II ER. Section 12 of the ER identifies the major environmental and health and safety statutes, regulations, Executive Orders, and DOE Orders applicable to the proposed construction and operation of ANS. In particular, Sect. 12 addresses the various federal and state statutes that impose environmental, health, and safety protection and compliance requirements on DOE.

Section 11 gives a summary of the impacts predicted by the analyses in the ER; these impacts are described below.

\section{Construction Impacts}

Terrestrial biota. The construction of ANS would require clearing 25-35 ha (60-90 acres) of second-growth hardwood forests for facilities and laydown areas, and $6-10$ ha (15-25 acres) of forest would be cleared for power line right-of-ways. These clearings would benefit animal species that thrive in cleared areas and adversely affect animal species dependent on relatively undisturbed forest conditions.

A number of possible wetland areas are found on the ANS site. About 4 ha (10 acres) of these would be destroyed or damaged by the construction of ANS. The exact extent and legal status of these areas is being pursued but is not yet clear. The site has been surveyed for threatened or endangered plant and animal species. The only 
threatened or endangered plant or animal found on the site is ginseng, but it is located in an area that would not be disturbed by ANS as currently planned.

Water quality and aquatic biota. The construction of ANS could adversely affect water quality and aquatic biota in Friendship Creek and in the Melton Branch-White Oak Creek system. Standard mitigative techniques should be adequate to prevent significant adverse effects on water quality and aquatic biota.

Air quality. The exhaust from construction equipment would increase local levels of carbon monoxide, nitrogen oxides, volatile organic compounds, and particulate matter. These emissions would not have appreciable effects on regional ambient air quality. Excavation and earthwork could appreciably increase local concentrations of inhalable particulate matter with a diameter of less than 10 microns. To avoid violations of the national air quality standards during the construction period, a combination of limiting the amount of area disturbed at one time and using diligent dust suppression measures may be required.

\section{Resources Committed}

Construction of ANS would involve the irretrievable commitment of land, energy, and material resources. The 30-45 ha (75-115 acres) of land committed to the facilities and the power lines most likely would not be available for other uses in the foreseeable future. The material and energy used in the construction of ANS facilities (for which estimates are not presently available) would be essentially unavailable for any future uses.

The operation of ANS would result in the use of about $7,200 \mathrm{~kg}(16,000 \mathrm{lb})$ of highly enriched uranium fuel over the 25 -year life of the facility. About $17 \mathrm{~kg}(37 \mathrm{lb})$ of $95 \%$ enriched uranium fuel is used each time the reactor is refueled. Spent fuel contains only about $10.3 \mathrm{~kg}(22.7 \mathrm{lb})$ of ${ }^{235} \mathrm{U}$. Spent fuel is expected to be reprocessed, so the amount of ${ }^{235} \mathrm{U}$ consumed over the life of ANS would be about $2200 \mathrm{~kg}(4800 \mathrm{lb})$. Reprocessing the spent fuel would produce substantial quantities of high- and low-level radioactive wastes that would require permanent disposal. The amounts of these wastes produced in reprocessing presently are unknown, but they would be generated at the Savannah River Site, where reprocessing would occur.

ANS also would consume substantial quantities of electricity, natural gas, and steam from the ORNL Steam Plant. Over the life of the facility, ANS would consume about $6 \times 10^{16} \mathrm{~J}\left(6 \times 10^{13} \mathrm{Btu}\right)$ of primary energy in various forms.

\section{Heat Dissipation System Effects}

Blowdown from the cooling towers would be discharged to upper Melton Branch. These discharges would change the flow regime in upper Melton Branch from intermittent to perennial. The temperature of the blowdown will increase the temperature of the water in much of the upper reaches of Melton Branch during most of the yea:. This increased flow will support warm-water-tolerant aquatic life where little aquatic life currently is found and discourage aquatic life that prefers colder water and more variable stream flows. 
The plume from the cooling towers may cause fog and icing during certain weather conditions. Because no roads (except access roads) are located near the ANS site, fog and icing would not cause a public safety hazard. Normal operation of the ANS cooling towers would not be expected to have any significant effects on terrestrial biota, although vegetation in the immediate vicinity could be damaged slightly.

\section{Other Effects of Operation}

Sanitary, chemical, and biocide discharges. Sanitary wastewaters would be piped to the Sewage Treatment Plant. After treatment, this wastewater would be discharged to White Oak Creek, resulting in an increase of about $1 \%$ in the average annual flow in the creek but no significant alteration of the aquatic communities in the creek.

Process water would be piped to the Nonradiological Wastewater Treatment Facility, treated, and discharged to White Oak Creek a short distance upstream of the Sewage Treatment Plant outfall. The chemical composition of process waters from ANS has not been determined yet but would be nontoxic after treatment. Process water from ANS would increase flows in White Oak Creek by aboui $1 \%$, which is not expected to significantly affect aquatic communities.

Storm water runoff from the ANS site would be collected in detention basins and monitored before being released to Friendship Creek and Upper Melton Branch. If treatment were necessary, storm water could be piped to the Process Waste Treatment Plant. The discharge of collected runoff from the detention basins must be controlled to minimize alteration of the receiving streams.

Noise. During operation, the principal noise from the ANS site would be from the mechanical-draft cooling towers. Because the nearest is about $2.4 \mathrm{~km}$ (1.5 miles) away and would be separated from the nearest humans by intervening hills, no significant noise impacts to humans would exist.

\section{Radiation Dose to the Public}

Routine operations. Because of meteorological conditions, the closest individual, assumed to be at Shoreline Estates, $2.8 \mathrm{~km}$ (1.7 miles) southeast of the site, is estimated to receive $1.7 \mu$ Sv/year $(0.17 \mathrm{mrem} / \mathrm{year})$, while an individual at Gallaher Bend, $2.9 \mathrm{~km}$ (1.8 miles) east-northeast of the site, would receive the greatest radiation dose of $12.4 \mu \mathrm{Sv} /$ year (1.24 mrem/year). For this maximally exposed individual, tritium contributes $97 \%$ of the dose and ${ }^{133} \mathrm{Xe}$ contributes $2.7 \%$. These individual doses are below the applicable federal limit of $100 \mu \mathrm{Sv} /$ year (10 mrem/year) specified in $10 \mathrm{CFR} 16$. Current ORR radioactive material releases to the atmosphere result in a 50-year committed effective dose of $20 \mu \mathrm{Sv}(2 \mathrm{mrem}$ ) to the hypothetical, maximally exposed individual (near the Y-12 Plant). Releases from ANS would contribute to a negligibly small increase in this maximally exposed individual's dose.

The operation of ANS is estimated to result in a collective effective dose to persons within $80 \mathrm{~km}$ ( 50 miles) of ANS of 0.0418 person-Sv/year (4.18 person-rem/year) and a collective effective dose to the gonads of 0.0416 person-Sv/year (4.16 personmrem/year). Tritium accounts for $91 \%$ of this dose and ${ }^{133} \mathrm{Xe}$ accounts for $8.7 \%$. These doses are small compared with natural doses. They would increase the populationwide 
chance of fatal cancer by less than 1 in $1,000,000$ and the chance of birth defects by less than 3 in $1,000,000$.

Routine transportation of radioactive materials. The transport of spent fuel to the Savannah River Site would be the dominant source of radiation exposure to the public, but the dose from that activity would result in less than a 3-in-10,000 chance per year of inducing a latent cancer facility. Other transportation activities would carry less than onethousandth the risk of inducing cancer fatalities.

Nonsevere accidents. Radiation dose calculations for atmospheric pathways (the most rapid pathway) of the seven nonsevere accident scenarios were evaluated using computer-assisted modeling. The evaluation indicates that all doses are below $0.01 \mathrm{~Sv}$ (1 rem), whether for effective whole body or organ (thyroid), except for the detritiation facility accident. A dose of $0.013 \mathrm{~Sv}(1.3 \mathrm{rem})$ would result from the detritiation facility accident. Doses from postulated accidents other than the detritiation facility accident are below the 0.01 Sv (1 rem) level at which the U.S. Environmental Protection Agency (EPA) has recommended protective actions. In the case of the $0.013 \mathrm{~Sv}$ (1.3 rem) estimate, the recommended actions are to at least seek shelter, consider evacuation, or evacuate, unless constraints make it impractical.

For nonsevere accidents with liquid pathways, a maximum dose of $8.2 \times 10^{-6} \mathrm{~Sv}$ $\left(8.2 \times 10^{-4} \mathrm{rem}\right)$ is estimated to result from drinking contaminated water; this dose is equivalent to about $1 \%$ of natural annual external background radiation dose in Tennessee.

Severe accidents. ANS is being designed to ensure that severe accidents are very unlikely. ANS is being designed to a 1 -in 100,000 per year probability of a core damage accident and a containment failure probability goal of less than 1-in-100 per core damage accident. However, in the unlikely event of a severe accident, the consequences could be severe. Two potential severe accidents were examined using pessimistic assumptions. For the more severe of the two, about five on-site workers would be expected to die within a few weeks of radiation exposure. Another 17 workers would be expected to die of radiation-induced cancers. About another 33 persons within $80 \mathrm{~km}$ (50 miles) would be expected to die of radiation induced-cancer caused by the accident.

Transportation accidents. The risks of transporting radioactive materials to and from ANS would be very low. The chance of inducing a latent cancer fatality for any postulated accident is estimated to be less than 5 in 10,000. For any postulated accident, the dose to a maximally exposed individual would be $<6 \times 10^{-8} \mathrm{mSv}\left(6 \times 10^{-3} \mathrm{mrem}\right)$.

\section{Worker Health and Safety}

Because the design of ANS is currently conceptual, occupational radiation doses cannot be predicted with any certainty. However, experience from other reactors with similar features and from ORNL's program to minimize occupational exposure suggest that typical doses will be less than $5 \mathrm{mSv} /$ year $(500 \mathrm{mrem} / \mathrm{year})$. A few operators and experimentalists might experience up to $1 \mathrm{mSv} / \mathrm{year}$ (1 rem/year). (While not expected to be significant, the possible contributions from skyshine have not been evaluated.) 


\section{Waste Management}

Waste management procedures and techniques are being upgraded on ORR and throughout DOE. Many types of waste are being stored on-site while permanent storage disposal facilities are being developed. The analysis of waste management impacts considers two scenarios: (1) permanent waste disposal and improved waste treatment facilities will be available by the time ANS becomes operational, and (2) permanent disposal and improved waste treatment facilities will not be available by the time ANS becomes operational, so most wastes will continue to go to interim storage on ORR.

The potential impacts of ANS wastes on the ORR waste management system are summarized as follows:

- Without upgrades, liquid lownlevel radioactive wastes (LLLW) from ANS would exceed the capacity of the ORNL LLLW system.

- Without upgrades, the ORNL radioactive process waste (PW) system may not be able to accommodate additional PW from ANS.

- If the Waste Isolation Pilot Plant becomes operational in 2007 as planned, transuranic wastes from ANS could be accommodated easily; if not, transuranic waste storage facilities must be constructed on ORR.

- High-level incidental radioactive wastes would not be generated during normal ANS operations.

- Spent fuel from ANS could be accommodated by the proposed deep-geologic storage facility or the Receiving Basin for Offsite Fuels at the Savannah River Site.

- DOE has responsibility for developing disposal facilities for greater-than-class-C (GTCC) low-level radioactive waste. Until such facilities are developed, GTCC wastes will be stored on ORR. Because the volume of GTCC waste generated by ANS would be small, it could be accommodated by interim storage facilities at ORNL or the K-25 Site until permanent disposal facilities become available.

- If planned and proposed solid low-level waste disposal facilities (on and off ORR) do not become available, additional interim storage capacity on ORR would be needed.

- About $2.7 \times 10^{14} \mathrm{~Bq} /$ year (7200 Ci/year) of tritium would be released to the atmosphere; these releases are not expected to cause any serious problems. Tritium would permeate most solid and liquid radioactive wastes generated by ANS. The waste management organization is concerned that additional tritium releases to White Oak Creek may not be acceptable because of the $9 \times 10^{13}$ to $11 \times 10^{13} \mathrm{~Bq} /$ year $(2500$ to $2900 \mathrm{Ci} /$ year) currently leaking into White Oak Creek from Solid Waste Storage Area 5.

- Mixed wastes from ANS could be readily accommodated by the Oak Ridge Mixed Waste Incinerator.

- Sanitary wastes from ANS could be readily accommodated by the ORNL Sanitary Waste Treatment System.

- The disposal of conventional solid, liquid, or gaseous wastes would not cause any particular problems; however, waste water discharges to upper Melton Branch or Friendship Creek would require modification of the ORR National Pollutant Discharge Elimination System permit.

- Nonradioactive hazardous wastes generated at ANS would be disposed off-site at EPA-permitted treatment and disposal facilities. 


\section{Socioeconomic Effects}

The net economic effect of ANS would be positive; however, because ANS would involve less than $1 \%$ of the labor force in the region of influence (ROI), it would not induce significant changes in the local economy. Immigration would modestly increase the populations of communities in the ROI, with the largest effect in Oak Ridge being about 100 persons or $0.3 \%$ of the current population. Public services and housing in the surrounding communities are expected to easily support the additional people who come to the community because of ANS. ANS would have small but beneficial fiscal and tax effects on local communities. ANS would increase the fraction of ORR committed to facilities by about $0.5 \%$ but would have no appreciable effect outside ORR. Additional workers traveling on Bethel Valley Road and State Road 62 could reduce the level of service (LOS) from $D$ to $E$ during rush hour periods; however, staggering work hours would allow these roads to accommodate the ANS workers without reducing LOS on these highways. ANS design objectives would protect public safety to the extent that ANS would not increase demands on the existing emergency preparedness systems. 


\section{THE PROPOSED FACILTTY}

The U.S. Department of Energy (DOE) has proposed the construction and operation of the Advanced Neutron Source (ANS), a $330 \cdot \mathrm{MW}(\mathrm{f})$ reactor, at Oak Ridge National Laboratory (ORNL) to support neutron scattering research and to produce transplutonium isotopes. This section describes the purpose of ANS, the need for the facility, the consequences of delaying the project, and the scope of this environmental report, which has been prepared to facilitate the preparation of the environmental impact statement for ANS.

\subsection{PURPOSE OF THE ADVANCED NEUTRON SOURCE}

The purpose of an Advanced Neutron Source (ANS) facillty (described in Sects. 3.1-3.4) would be to support neutron scattering and nuclear physics experiments by providing a steady-state source of neutrons that are thermalized to produce sources of hot, cold, and very cold neutrons. The proposed facility would be an essential component of national research efforts in basic materials science and would be designed to provide an effective user-oriented environment.

In addition to neutron scaltering and nuclear physics experiments, the capabilities of ANS would include production of transplutonium isotopes, irradiation of potential fusion and fission reactor materials, activation analysis, and production of medical and industrial isotopes. For example, ANS is being designed to produce $1.5 \mathrm{~g} /$ year of ${ }^{252} \mathrm{Cf}$ and $40 \mu \mathrm{g} /$ year of ${ }^{254} \mathrm{Es}$, which have industrial, medical, and research applications. These capabilities are being incorporated into the ANS design without compromising the facility's ability to support neutron scattering and nuclear physics experiments. ANS is also being designed to allow placement of materials samples on high-flux zones of the reactor in order to measure the physical characteristics of materials exposed to high neutron fluxes (e.g., in a fission reactor).

\subsection{NEED FOR THE ADVANCED NEUTRON SOURCE}

Many of the research data that form the basis for U.S. materials technology are gathered by probing matter with three types of radiation: electromagnetic (e.g., light or X rays); charged particle (e.go, electrons), or neutral particle (neutrons). Although the three types of information thus obtained are complementary, certain research areas may be weighted more heavily towards one or the other. In the past few decades, the equipment required to obtain information about materials has become increasingly complex, and the cost of providing research facilities has exceeded the reach of most industries. In response to this need, the federal government has provided access to the necessary equipment through the DOE national laboratories. Neutron research at DOE laboratories provides unique information needed to maintain high-technology research and development (R\&D) endeavors in several important fields. The proposed ANS facility is needed to help the

United States stay competitive in these R\&D fields. Although it is difficult to quantify the value of neutrons to industrial $R \& D$, there are several indicators that industrial neutron research is cost effective. For example, industry has often preferred to pay full cost recovery for neutron scattering experiments at the High Flux Isotope Reactor (HFIR) at ORNL, even for basic research, rather than operate under the policy of free access in return for publishing the results. Another indicator is that industries that began to use neutron data many years ago are still doing so (e.g. Exxon and Rolls Royce Aerospace). 
Although many U.S. corporations have found neutron research necessary to their operations, they have had to use overseas facillties to gain access to the best equipment. This is complicated by the fact that currently, overseas facilities are heavily over-subscribed (by a factor of two to five, for example, at the Institut Laue-Langevin in Grenoble, France), and priority is given to researchers from member nations. Furthermore, proprietary research by U.S. companies is generally not possible at such facilities.

Neutron scattering research has developed into an important tool for understanding the structure and behavior of solid and liquid structures. Thermalized neutrons have properties that make them uniquely valuable for probing the structure of condensed matter. Many of the properties of materials are determined by structures that are 100 to $100($ ) times the size of atoms. Thermalized neutrons have wavelengths in a range suitable for probing these structures. Because they have no electric charge, neutrons can penetrate materials that charged particles cannot; consequently, neutrons can be used to determine the bulk properties of materials. The ability of neutrons to penetraie large items enables large manufactured articles to be examined for defects and allows deiails of operations to be studied.

The AN's neutron scattering capabilities will have multidisciplinary applications in physics, astroph/sics, nuclear physics, condensed matter (solid and liquid state) physics, surfaces and interfaces, biochemistry, structural biology, materials science and engineering, archaeology, materials irradiation and analysis, and isotope research. For example, neutron scattering has been used to study fluid-flow properties under operating conditions in jet engines and can be used to study fluid flow in other situations. Neutron scattering can also be used to measure stress patterns in manufactured objects, and, because it yields important information about the microscopic structure of polymers, it can be used in the design of new polymers. Cold neutron scattering has been used to measure magnetic flux lattices in high-temperature superconductors and is expected to play a critical role in the development of materials that are superconducting at higher temperatures.

ANS would also provide defense-related capabilities. Defense uses of ANS would include production of isotopes for aircraft and other radiography and for explosives detection in counterterrorism; testing of materials under irradiation bombardment; and nondestructive testing of critical engineering components. In this context, the most important task for ANS would probably be to take over from HFIR the production of ${ }^{252} \mathrm{Cf}$, a portable neutron source, thus enabling neutror, radiographic inspection to take place in the field.

Although the primary purpose of the ANS facility would be basic research, a secondary function would be the production of isotopes with commercial applications. There are more than 300 radioactive isotopes with half-lives varying from about $1 \mathrm{~d}$ to 10,000 years or more. The widely varying physical, chemical, and biochemical properties of these radioisotopes can be applied to many uses in food technology, agriculture, energy supply, aerospace, public health, medicine, industrial technology, and national security. In the United States alone, about 40,000 medical procedures each day make use of radioisotopes, and about $45 \%$ of all single-use medical supplies (syringes, surgical gloves, etc.) are sterilized by radioisotope irradiation.

In assessing the need for ANS as an isotope production facility, it is important to bear in mind that it would also be the only source in the United States for the transplutonium isotopes, as HFIR is now. These isotopes have a variety of uses, including medical diagnosis, cancer therapy, and radiography of aircraft wings. A strong case can also be made for the continued production of these isotopes as research materials for basic studies in nuclear physics, chemistry, and solid state physics. The large volume of very high thermal tlux in the ANS reflector would also allow production of high specific 
activity isotopes of lower mass number, as programmatic needs arise. ANS would operate isotope loan agreements and sales in line with existing, well-established DOE policies.

Commerclal production accounts for most radioisotopes in general use. The role of DOE has been to fill gaps where no commercial source exists. Often, this requires facilities unique to DOE. The HFIR in particular is the only source in the United States of transuranic isotopes such as ${ }^{252} \mathrm{Cf}$, which undergoes spontaneous fission with a half of 2.64 years. One gram of ${ }^{252} \mathrm{Cf}$ will produce $2.3 \times 10^{12}$ neutrons/s. It is a strong, portable source of neutrons, and this property has led to many applications. At present, DOE has 109 loan agreements with 82 institutions for HFIR produced ${ }^{252} \mathrm{Cf}$.

Therapy based on neutron bombardment from ${ }^{252} \mathrm{Cf}$ has been shown to be effective in the treatment of cervical cancer. Sources are also being developed for in vivo neutron activation analysis to be used in clinical diagnosis and monitoring and medical conditions involving abnormal amounts of lithium, aluminum, or nitrogen. In addition, the U.S. Fond and Drug Administration has ordered $200 \mathrm{mg}$ of ${ }^{252} \mathrm{Cf}$ (a large fraction of the current national supply) to be used in neutron activation analysis of certain foods. The commercial power industry uses ${ }^{252} \mathrm{Cl}$ as the industry standard method for startup of pressurized water reactors and as a source for neutron radiography of power reactor fuei rods. There are also growing commercial uses of ${ }^{25} \mathrm{Cf}$ as a source for neutron activation analysis and as a standard source for dosimeter calibration. One of the newest applications of ${ }^{252} \mathrm{Cf}$ is detecting hidden explosives in airline passenger luggage. Monitors have already been installed at airports in New York, San Francisco, Los Angeles, and Miami; and installations of similar devices are planned for London, Atlanta, Frankfurt, and Rome.

Finally, the Naval Ocean Systems Center uses neutrons from ${ }^{252} \mathrm{Cf}$ to test infrared devices for resistance to neutron damage, and the Mound Laboratory uses ${ }^{252} \mathrm{Cf}$ neutron radiography for nondestructive inspection of explosive fill in detonators. Production reactors at the Savannah River Site require ${ }^{252} \mathrm{Cf}$ for startup, and there are some classified uses.

In addition to the production of transplutonium isotopes, ANS would also be used to prepare the many other neutron-produced radioisotopes that are used in industry and medicine. For example, certain isotopes, such as very high specific activity ${ }^{60} \mathrm{Co}$ that is used in medical therapy, sterilization, and radiography, can be produced only in facilities that provide a very intense neutron flux, such as HFIR or the proposed ANS.

\subsection{CONSEQUENCES OF DELAY}

The neutron scattering capability of facilities in the United States is being eroded by the aging of current research reactors. This capability will be essentially eliminated by their eventual shutdown. With more instruments than exist cumulatively on all U.S. reactors, ILL is the world leader in neutron research; however, thermal flux at the proposed ANS would be about $10^{20}$ neutrons $\cdot \mathrm{m}^{-2} \cdot \mathrm{s}^{-1}$ at a thermal power level of approximately $330 \mathrm{MW}$, which would be five to ten times greater than any current research reactor's capability, exceeding the capabilities of facilities in any other country. If the proposed ANS is not operational before HFIR is shut down, U.S. neutron researchers will be totally dependent on foreign research facilities. As a result, delaying the ANS project could have scientific and technological consequences in the United States. For example, the two high-flux reactors in the United States, are more than 25 years old and will soon be retired. In many fields of research, these reactors are no longer competitive 
with Japanese and European facilities. ANS could help restore the United States to a position of leadership in the field of neutron research.

Retiring the HFIR facility and delaying ANS construction and operation would also have economic implications. The immediate impact could be a loss of direct scientific and technical jobs at ORNL because of the HFIR shutdown, followed quickly by a loss of corollary jobs that have been created as the result of off-site support of HFIR (e.g., the industrial, medical, and research use of the production capability of HFIR). As a consequence, with the loss of domestic production capability for medical and industrial isotopes, the R\&D work in those fields would be lost to foreign research reactor facilities.

Critical issues of quality control would arise because programs that evaluate the effects of radiation on components in varying radiation fields would also not continue. Without this safeguard, the result could be unanticipated failure of expensive components in, for example, space hardware, reactors, and fusion applications.

Fi:illy, if ANS were delayed, the loss of HFIR capabilities would lead to the simple logistical problem of access. There would be a severe reduction in the time experimenters could spend on a reactor because the available time on the remaining reactors would be in much greater demand and thus more difficult to schedule.

\subsection{SCOPE OF THIS DOCUMENT}

An environmental report (ER) is a document that was developed by the Nuclear Regulatory Commission (NRC) to facilitate preparation of environmental impact statements (EISs) for nuclear power plant licensing. An ER is prepared by license applicants following NRC's Regulatory Guide 4.2. Although this ER is not part of an NRC license application, the outline of ER contents in Regulatory Guide 4.2 serves as an appropriate basis for the organization of this report.

An ER typically includes analyses that would normally be included in an EIS, along with any supplemental information necessary to ensure that EIS preparers have all the data they need to perform their analyses. This approach minimizes the effort required by EIS preparers. Reasonable alternatives to the proposed action are considered in EISs, including the no-action alternative. The no-action alternative is not directly addressed in this ER because it would have no impacts. Reasonable alternate sites and alternative technologies may also be considered in EISs; however, this ER addresses only the impacts of the proposed technology at the proposed site. Some of the data and analyses called for by Regulatory Guide 4.2 also support NRC's regulatory role.

DOE regulates itself but is committed to having ANS be a licensable facility. To ensure that the facility will be licensable and that the EIS preparation proceeds as quickly as possible, this ER is being prepared in two phases. Phase I includes those data and analyses needed to prepare the EIS. However, the Phase I ER does not include data or analyses of alternate sites or alternate technologies, because no such alternatives have been identified to date. Phase II will include the additional data and analyses called for by Regulatory Guide 4.2 and will be initiated after completion of Phase I. 


\section{THE SITE AND ENVIRONMENTAL INTERFACES}

\subsection{GEOGRAPHY AND DEMOGRAPHY}

The following sections discuss a proposed Advanced Neutron Source (ANS) site location and describe the population distribution near the site.

\subsection{Site Location and Description}

It is expected that the ANS facility would be constructed near Oak Ridge National Laboratory (ORNL), which is one of three major facilities on the U.S. Department of Energy's (DOE's) Oak Ridge Reservation (ORR). The other two facilities are the Y-12 Plant to the northeast of the proposed ANS site and the K-25 Site to the northwest of the ANS site (Chance and Frye 1989, pp. 1-3 to 1-4).

\subsubsection{Specification of Location}

The specific location of the reactor at the ANS site would be latitude $35^{\circ} 55^{\prime} 30^{\prime \prime}$ and longitude $84^{\circ} 17^{\prime} 40^{\prime \prime}$. The Universal Transverse Mercator coordinates are N $3978.9 \mathrm{~km}$ and E $744.25 \mathrm{~km}$. The site, as well as the entire ORR, is located within the corporate limits of the city of Oak Ridge, which straddles Anderson and Roane counties in upper East Tennessee. Oak Ridge and the surrounding area are shown in Fig. 2.1-1. The region is known as the Great Valley of Tennessee, lying between the Cumberland and Southern Appalachian mountains (DOE 1989, p. 2-3), and is characterized by ridges and valleys that follow a northeast to southwest direction. Elevation in the reservation ranges from a low of $230 \mathrm{~m}$ (750 ft) above mean sea level (msl) along the Clinch River to a high of $385 \mathrm{~m}$ (1260 ft) above msl along Pine Ridge (DOE 1989, p. 3-7). The ANS site lies in Melton Valley and is bordered by Haw and Copper ridges. The ORR is bordered on the south and east by the Clinch River (also referred to as Melton Hill Lake).

The ANS site is approximately $8 \mathrm{~km}$ ( 5 miles) southwest of central Oak Ridge and $35.2 \mathrm{~km}$ ( 22 miles) west of Knoxville, the nearest major urban center. The 1990 population of Oak Ridge is 27,310; of Knoxville, 165,121. Knox County, which includes Knoxville, has a population of 335,749 (TSPO 1991, n.p.); the 1990 estimated population of the Knoxville metropolitan area is 605,000 (DOC 1991, p. 30). Other incorporated areas near ANS include Lenoir City, approximately $16 \mathrm{~km}$ (10 miles) south (population 6147); Oliver Springs, approximately $14.4 \mathrm{~km}$ (9 miles) north northwest (population 3433); Farragut, approximately $15.2 \mathrm{~km}$ (9.5 miles) east southeast (population 12,793); and Kingston, approximately $20.8 \mathrm{~km}$ (13 miles) west (population 4552) (TSPO 1991, n.p.). Figure 2.1-2 shows prominent features of these areas.

\subsubsection{Site Area Map}

Figure 2.1-3 shows the ORR property boundary and the location of the proposed ANS site. The ORR consists of about 14,266 ha $(35,252$ acres) of federally owned lands (DOE 1989, p. 2-3). The ANS exclusion area boundary is tentatively defined as a 1-km (0.62-mile) radius around the site. A topographical map of the proposed ANS site is presented in Fig. 2.1-4.

The following facilities would be within the limited access area, to be enclosed by a security fence: the main building, which houses the reactor complex; utility buildings; a 


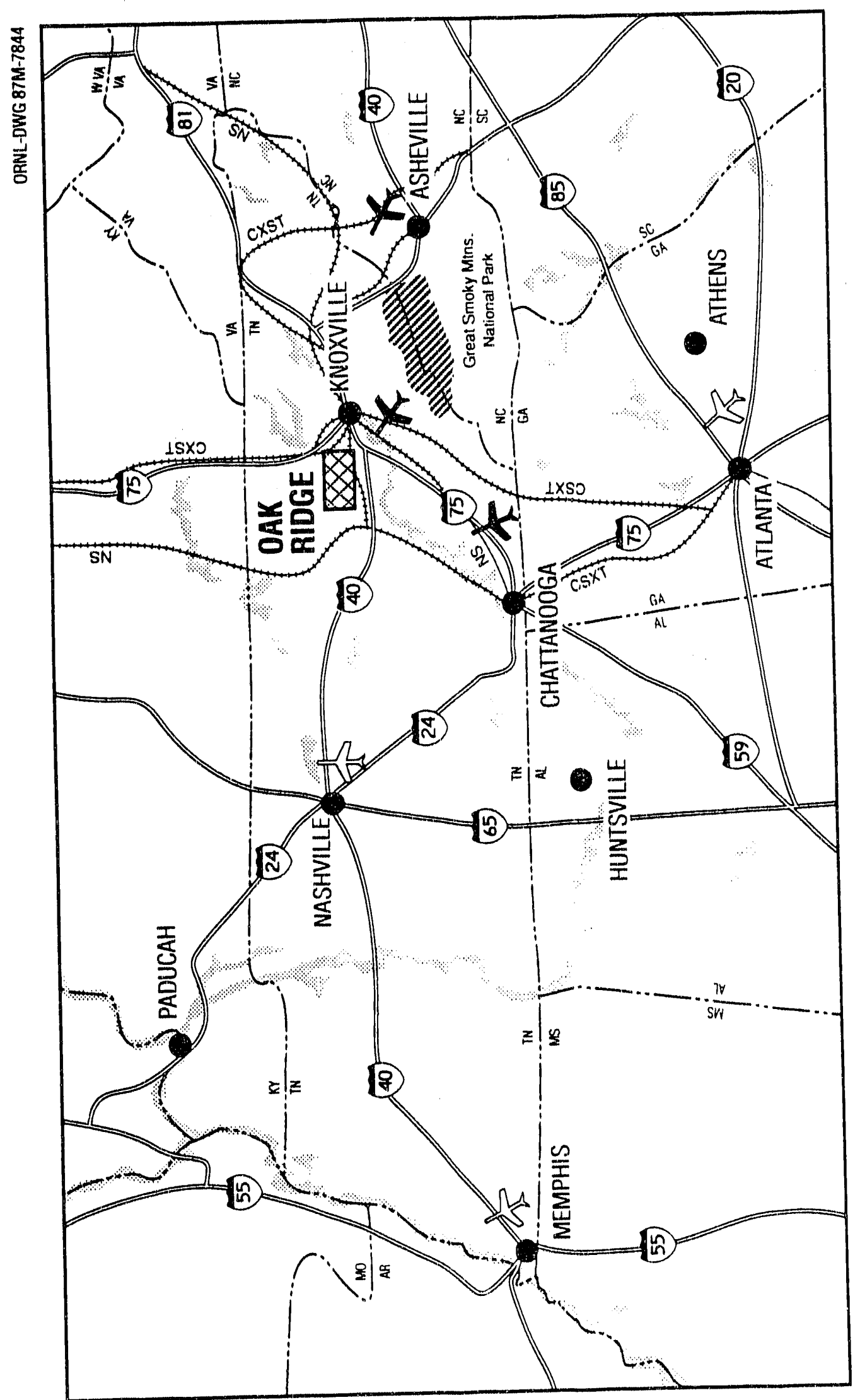

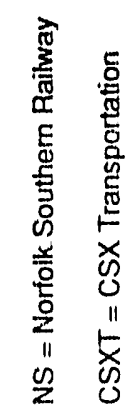
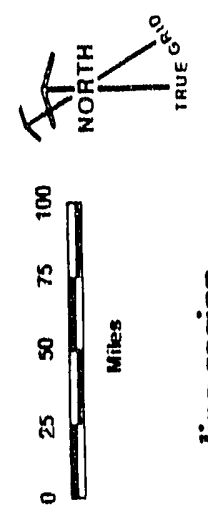

.

I

些

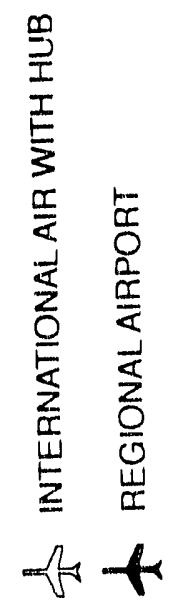




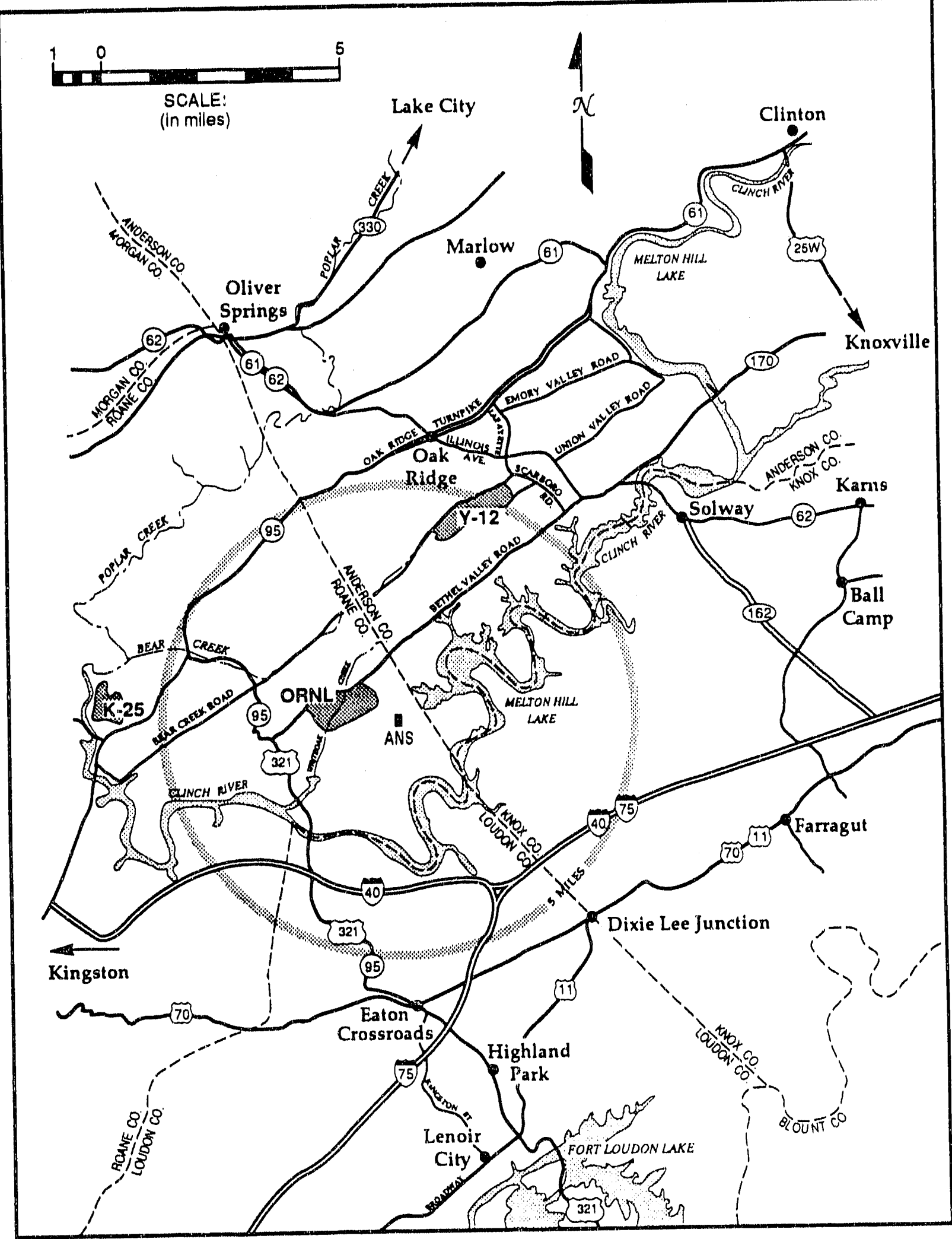

Fig. 2.1-2 Communities, bodies of water, and major transportation routes near the proposed Advanced Neutron Source (ANS) site. 


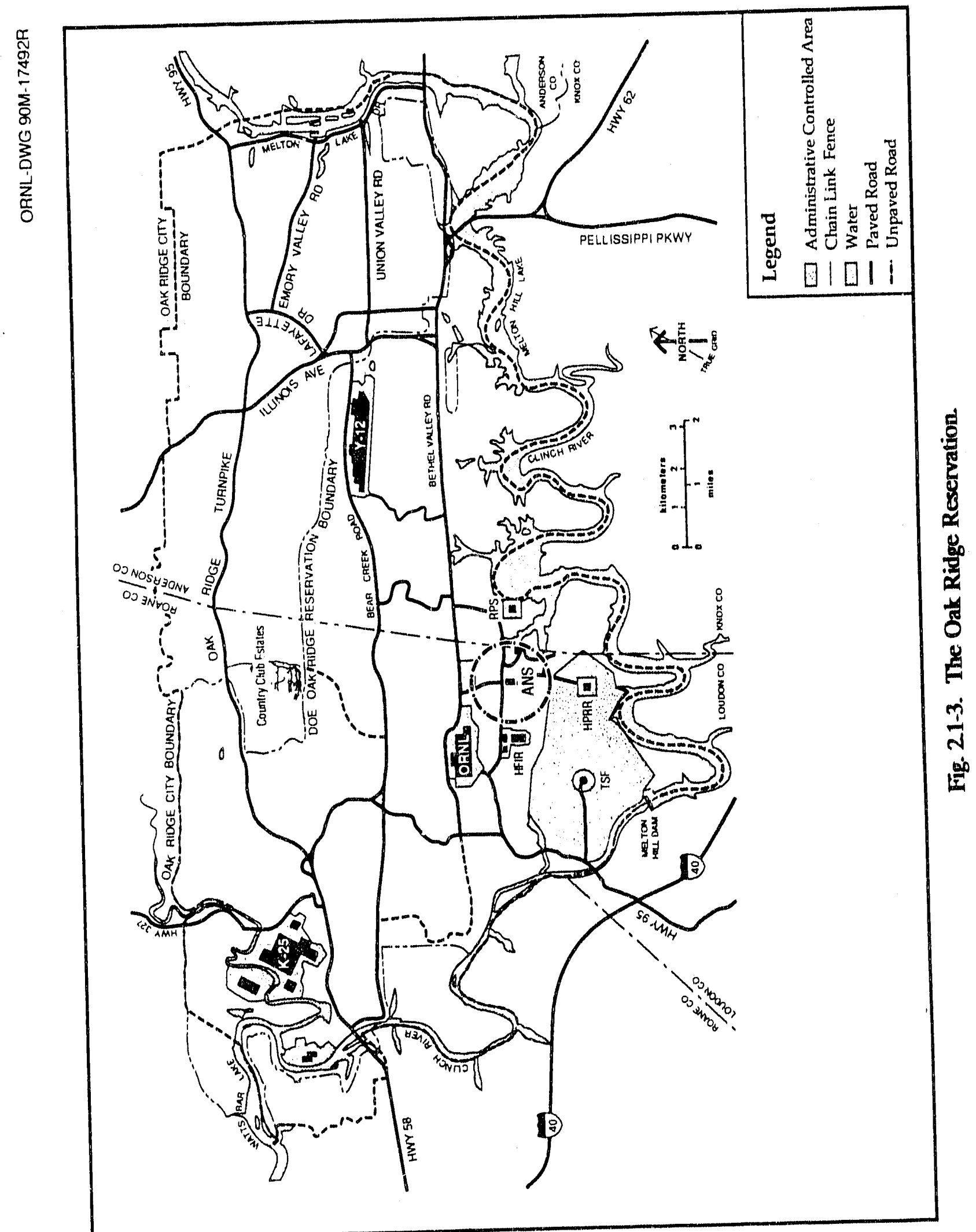



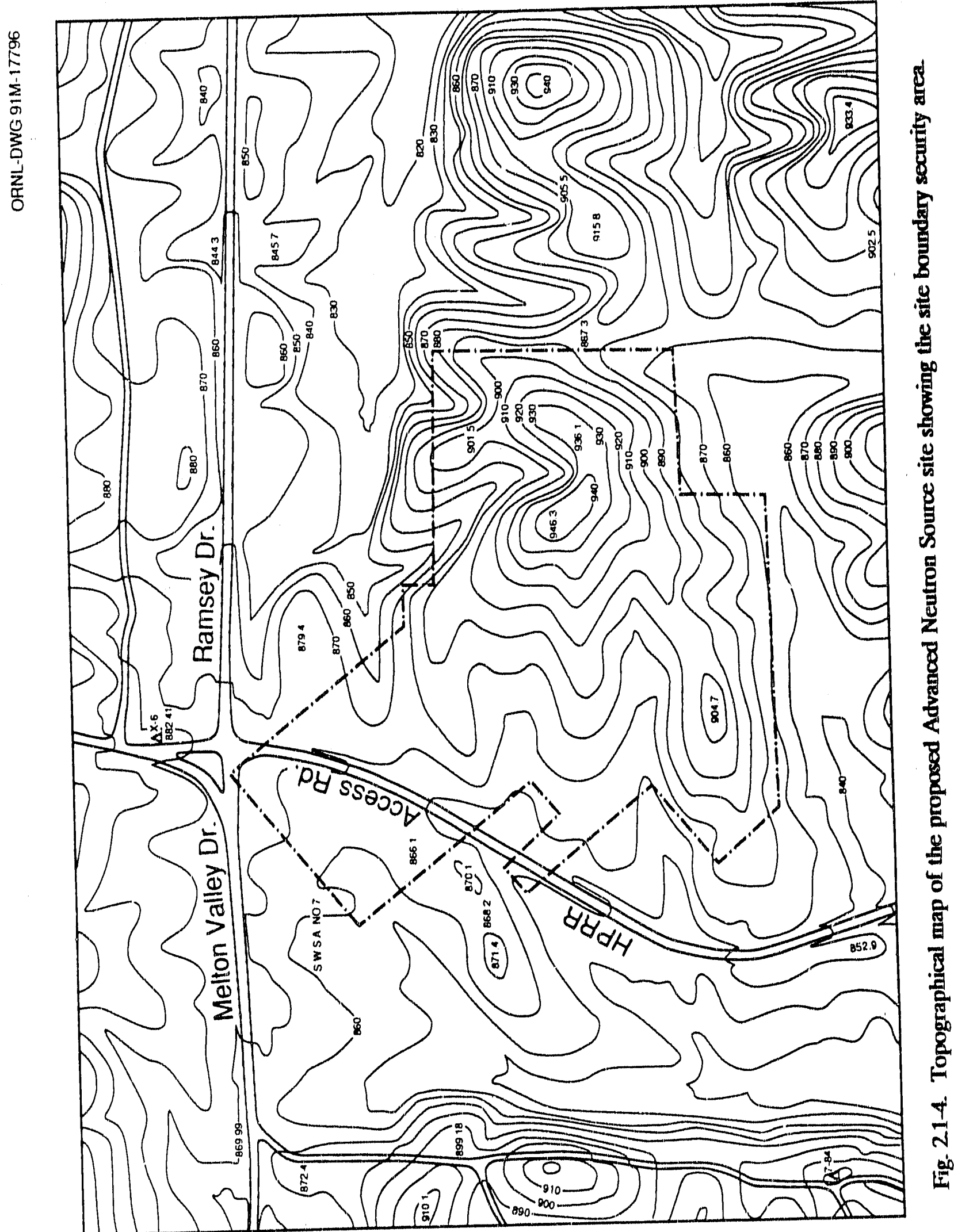
waste management facility; plant maintenance; storage; and a detritiation facility. A parking lot and user housing would also be part of the site structures but are outside of the limited access area.

There are no structures within the ANS site area. Within the ORR boundary there are the structures associated with the three major ORR sites. The primary function of ORNL is research and development; the Y-12 Plant is a weapons fabrication facility; and the K-25 Site, which was once a uranium enrichment facility, is now used for developing uranium enrichment technology and storing and processing waste. These facilities are described in greater detail in Sect. 2.1.4.

Near the Y-12 Plant are several industrial parks, including Bethel Valley Industrial Park, Commerce Industrial Park, Valley Industrial Park, Boeing Aerospace, the Midway and Mitchell roads area, Municipal Industrial Park, and the East Oak Ridge Turnpike area. The Clinch River Industrial Park is on Bear Creek Road near the K-25 Site. The industries in these areas are presented in Sect. 2.1.4, and their locations are presented in Fig. 2.1-5.

Public access areas on the ORR include the Clark Center Recreation Park, the ORNL Overlook, the K-25 Overlook, the ORNL Graphite Reactor, and cemeteries (Fig. 2.1-6). The Freels Bend Education Center, which is run by the ORNL education office, is used as a public education facility.

State Highways 58,61, 62, and 162 provide direct access to the ORR. Bethel Valley and Bear Creek roads are the primary ones on the ORR. The main access road to ANS is Melton Valley Road, which intersects Bethel Valley Road. The proposed ANS site is at the intersection of Melton Valley Road, Melton Valley Drive, Ramsey Drive, and the Health Physics Research Reactor (HPRR) Access Road (Fig. 2.1-7). Melton Valley Road will be rerouted to the west and then will reconnect to the HPRR Access Road, which runs south of the facility.

There is no rail service to the proposed ANS site or ORNL. Norfolk Southern Railway services the K-25 Site, and CSX Transportation (Seaboard System Railway, Inc.) provides service to the Y-12 Plant. DOE owns and maintains spurs at each of these facilities that total $27.2 \mathrm{~km}$ (16.9 miles) of railroad (Chance 1986, p. 97). These areas are shown in Fig. 2.1-8.

The surface hydrology of the ORR is shown in Fig. 2.1-9. The Clinch River forms the boundary of the ORR to the south and west. The ANS area is topographically divided so that the eastern side of the site drains to Bearden Creek and on to Melton Hill Lake. The western side, which would contain the majority of the site and the reactor, drains to Melton Branch, a tributary of White Oak Creek that flows to the Clinch River. Before flowing into the Clinch River, White Oak Creek flows into White Oak Lake, an impoundment that serves as a final settling pond for waste-water drainage from ORNL chemical and radioactive waste disposal areas. Water quality monitoring occurs at the White Oak Dam, 0.5 mile upstream of Clinch River.

\subsubsection{Boundaries for Establishing Effluent Releases}

The site boundary for effluent releases from the proposed ANS site is the ORR boundary (Fig. 2.1-3), which demarcates the controlled access area. DOE (or its prime contractor) has control over the entire ORR regarding public use and other activities. 


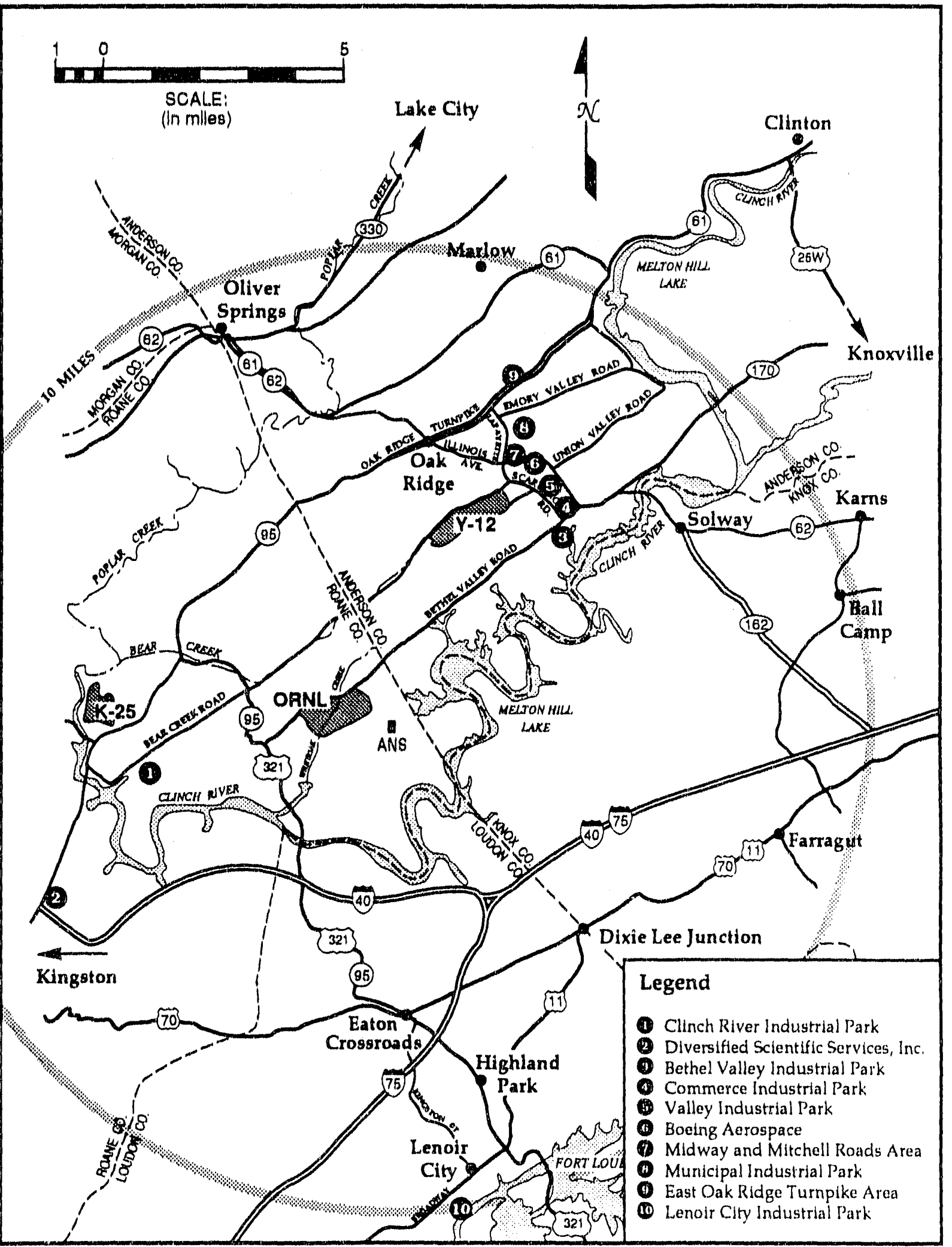

Fig. 21-5. Primary industries and industrial parks in the proposed Advanced Neutron Source (ANS) area. 
ORNL. DWG 91.1779

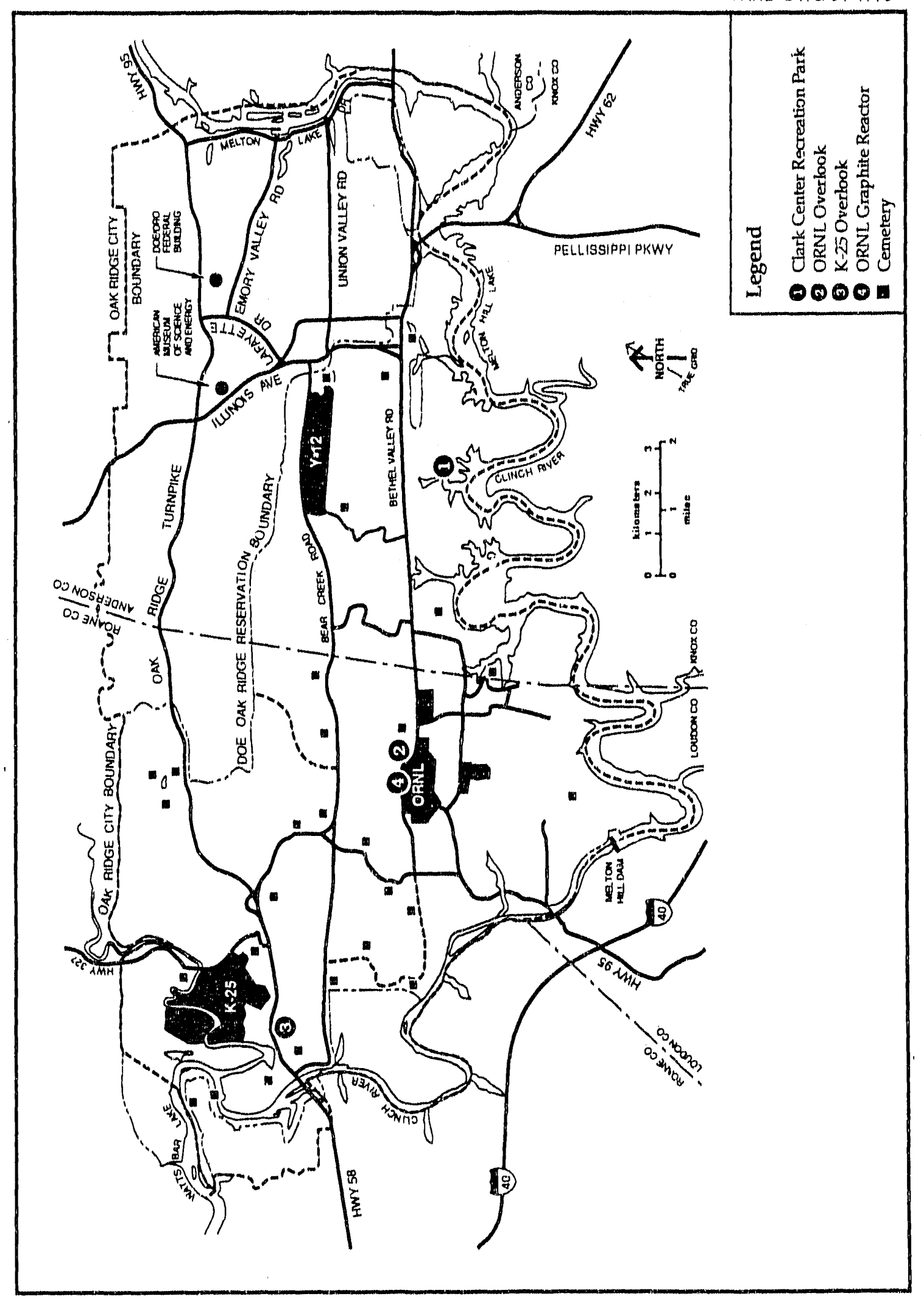

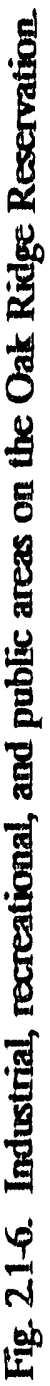




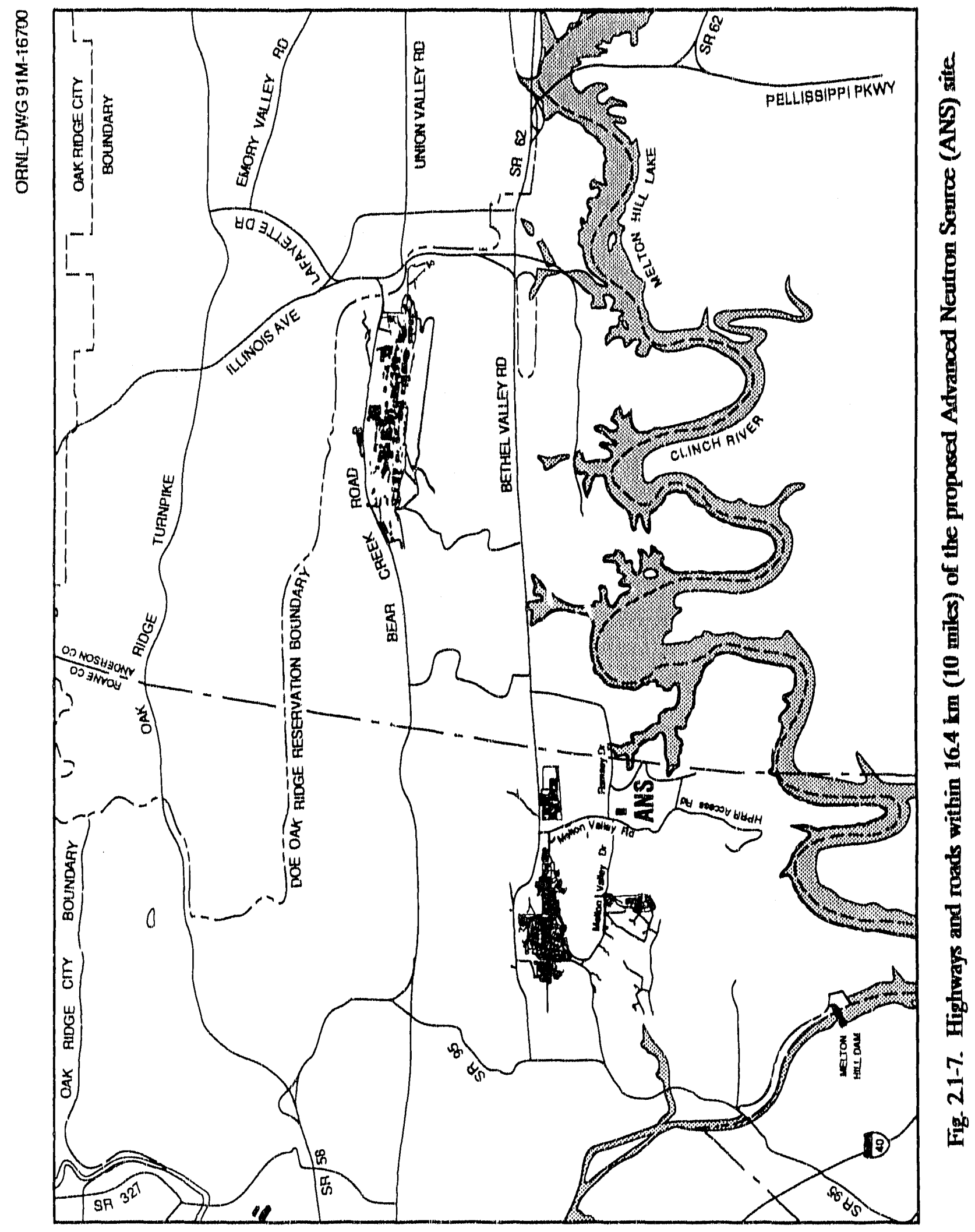




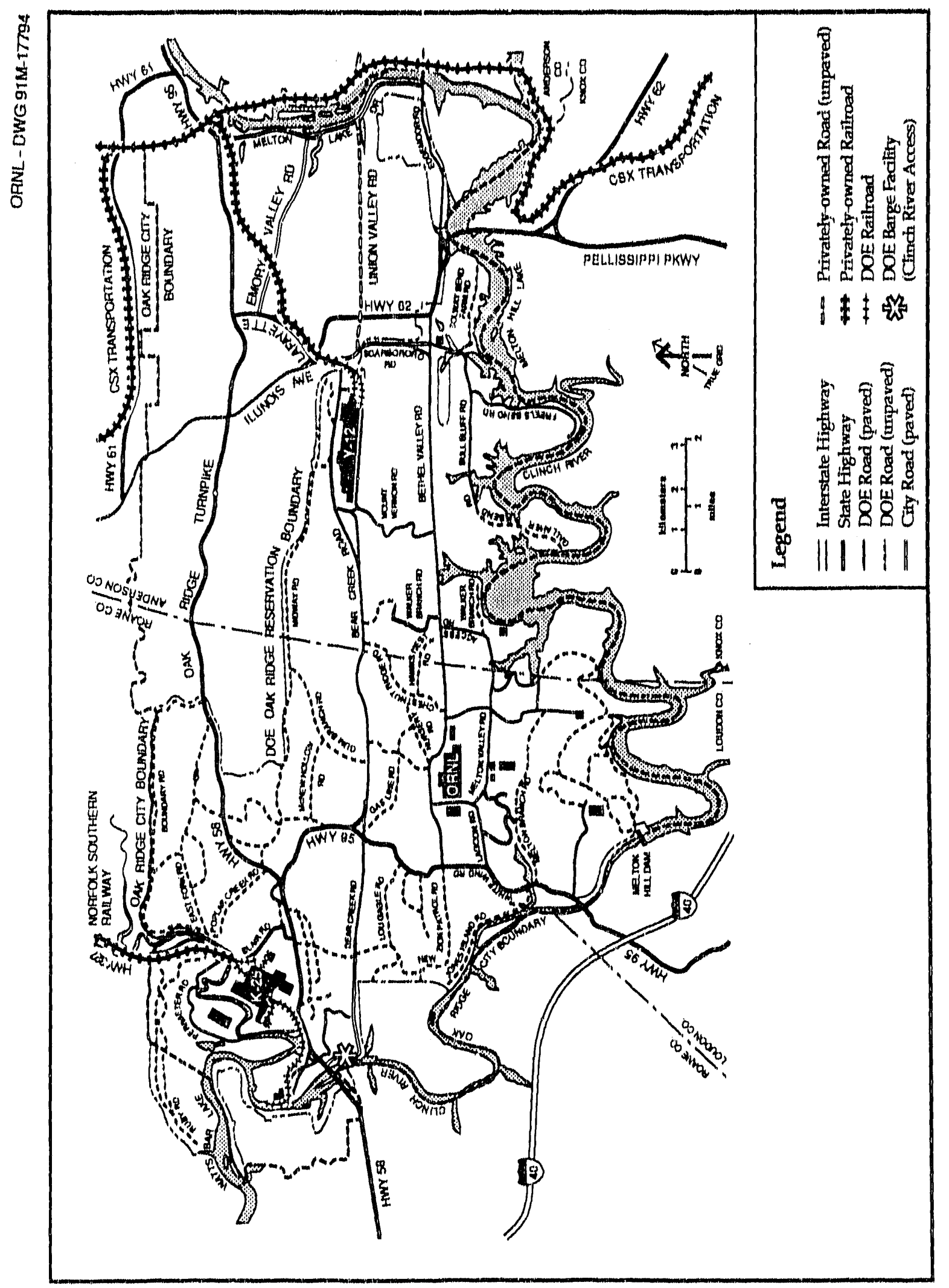

告 


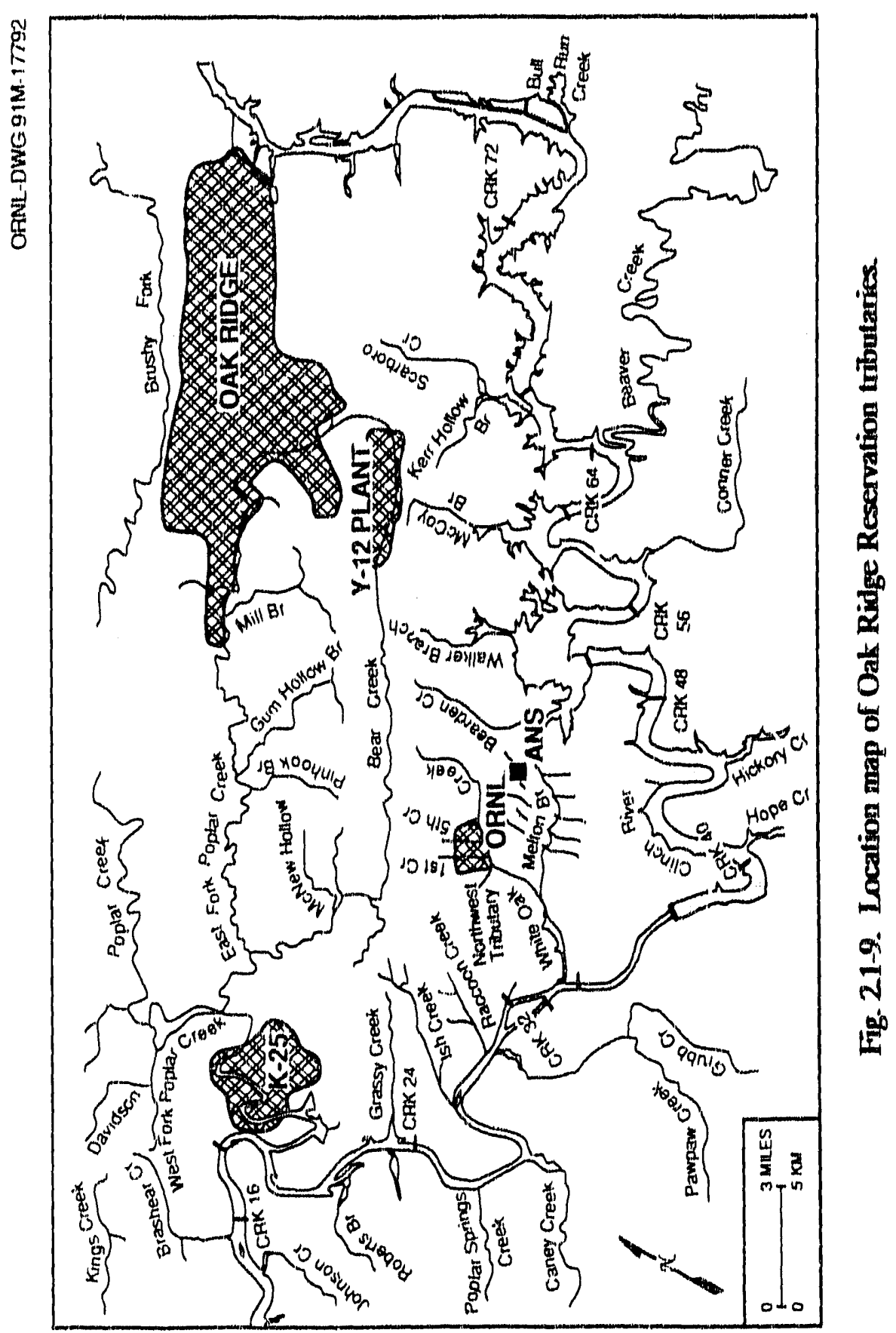


The effluent release point has not been determined; therefore, the exact distance from that point to the ORR boundary cannot yet be determined. The distance to the ORR boundary from the approximate center of the proposed ANS site, is, however, piesented in Table 2.1-1.

\subsubsection{Population Distribution}

In this section, current and projected population within $16.4-\mathrm{km}(10-\mathrm{mile})$ and $80.5-\mathrm{km}(50-\mathrm{mile})$ radil are given. Places of high population density, (l.e., nearby cities) are identified.

\subsection{Population Within $80.5 \mathrm{~km}$ (50 miles)}

Estimated 1990 population within $16.4 \mathrm{~km}$ (10 miles) of the ANS site is 77,277 . The estimated population in 2020, during the mid-life of the ANS project, is 81,787. Although ORR is within the boundaries of the city of Oak Ridge, the nearest significantly populated residential area of Oak Ridge (Country Club Estates) lies approximately $5.12 \mathrm{~km}$ (3.2 miles) northwest of the ANS site (Fig. 2.1-10). Figure 2.1-11 shows the jurisdictional boundaries of the counties and the locations of the cities and towns within $16.4 \mathrm{~km}$ (10 miles). Figure 2.1-12 shows the 1990 population counts in concentric circles at distances of $1.6,3.2,4.8,6.4$, and $8.0 \mathrm{~km}(1,2,3,4$, and 5 miles) from the site. Refer to Fig. 2.1.13 for population within $80.5 \mathrm{~km}$ (50 miles). The same 1990 population counts are presented in Table 2.1-2; the 2000,2010, and 2020 population counts in each sector are presented in Tables 2.1-3, 2.1-4, and 2.1-5, respectively. The estimated 1950 residential population between 16.4 and $80.5 \mathrm{~km}$ (10 and 50 miles) of the ANS site is approximately 815,780 , and the total estimated 1990 population within $80.5 \mathrm{~km}$ ( 50 miles) is $893,05 \%$. Figure $2.1-13$ presents the 1990 population counts of each directional sector between $8.2 \mathrm{~km}$ and $80.5 \mathrm{~km}$ (5 and 50 miles). A considerable portion of this population is in Knoxville, which lies to the east of the site. The estimated population between 16.4 and $80.5 \mathrm{~km}$ (10 and 50 miles) at the mid-life of ANS (2020) is 1,026,727, and the estimated total population within 50 miles in 2020 is 1,108,514. Tables 2.1-2, 2.1-3, 2.1-4, and $2.1-5$ also list the $16.4-$ and $80.5 \mathrm{~km}$-radius (10- and 50-mile-radius) populations for $1990,2000,2010$, and 2020, respectively.

\subsubsection{Transient Population}

Relevant transient populations include persons at nearby industries, schools, medical facilities, and recreational and public use areas. The population at the ANS facility during normal operations, after construction is completed, is estimated to be 449 full-time equivalents (FTEs) (beyond the year 2004), including operations support workers, users, and visitors (R. Brown, Advanced Neutron Source, Oak Ridge National Laboratory, personal communication with M. L. Socolof, Oak Ridge National Laboratory, Oct. 31, 1991). In 1990, employment at the three ORR facilities totalled 15,146, including 5,524 OR:IL employees, 3,019 K-25 Site employees, and 6,603 Y-12. Plant employees. At ORNL, 1958 guest assignments brought the total ORNL population to 7482 . At the Y-12 Plant, the primary construction and maintenance subcontractor employs 1135 persons. In addition, ORNL received more than 30,000 visitors in 1989.

There are many industrial facilities in the area (within 10 miles) of ANS. These facilities and the number of employees at each are listed in Table 2.1-6. 
Table 21-1. Approximate distunce from the center of the of proposed ANS site to Oak Ridge Reservation boundary

\begin{tabular}{cc}
\hline Direction & $\begin{array}{c}\text { Distance } \\
{[\mathrm{km} \text { (miles) }]}\end{array}$ \\
\hline N & $6.23(3.88)$ \\
NNE & $7.69(4.78)$ \\
NE & $11.8(7.34)$ \\
ENE & $2.25(1.40)$ \\
E & $3.50(2.18)$ \\
ESE & $2.86(1.78)$ \\
SE & $2.67(1.66)$ \\
SSE & $2.98(1.85)$ \\
S & $4.67(2.90)$ \\
SSW & $5.27(3.15)$ \\
SW & $4.99(3.10)$ \\
WSW & $6.76(4.20)$ \\
W & $12.2(7.57)$ \\
WNW & $8.99(5.59)$ \\
NW & $8.66(5.38)$ \\
NNW & $5.04(3.13)$ \\
\hline
\end{tabular}

Oak Ridge, Loudon County, Roane County, Anderson County, and Knox County all have schools within a $16.4-\mathrm{km}$ (10-mile) radius of the ANS site. The fall 1991 enrollments of the schools are listed in Table 2.1-7. Total enrollment of all city and county schools within the $16.4-\mathrm{km}$ (10-mile) radius is 16,101 . Also located within a 16.4-km (10-mile) radius are the two Oak Ridge campuses of Roane State Community College, with a total enrollment of 2053 in 1991 (O. Fern, Roan State Community College, personal communication with Maria Socolof, Oak Ridge National Laboratory, Nov. 14, 1991), and Pellissippi State Technical Community College in Knox County, with 7236 enrolled in 1991 (H. Moeller, Pellissippi State Technical Community College, personal communication with Maria Socolof, Oak Ridge National Laboratory, Nov. 14, 1991). The locations of schools within $16.4 \mathrm{~km}$ (10 miles) are shown in Fig. 2.1-14.

The nearest hospital is the 301-bed Methodist Medical Center (MMC) of Oak Ridge (TDHE 1989a, p. 1). Near MMC is the Ridgeview Psychiatric Hospital, which has 43 inpatient beds and also provides outpatient services. In addition, three institutions in 


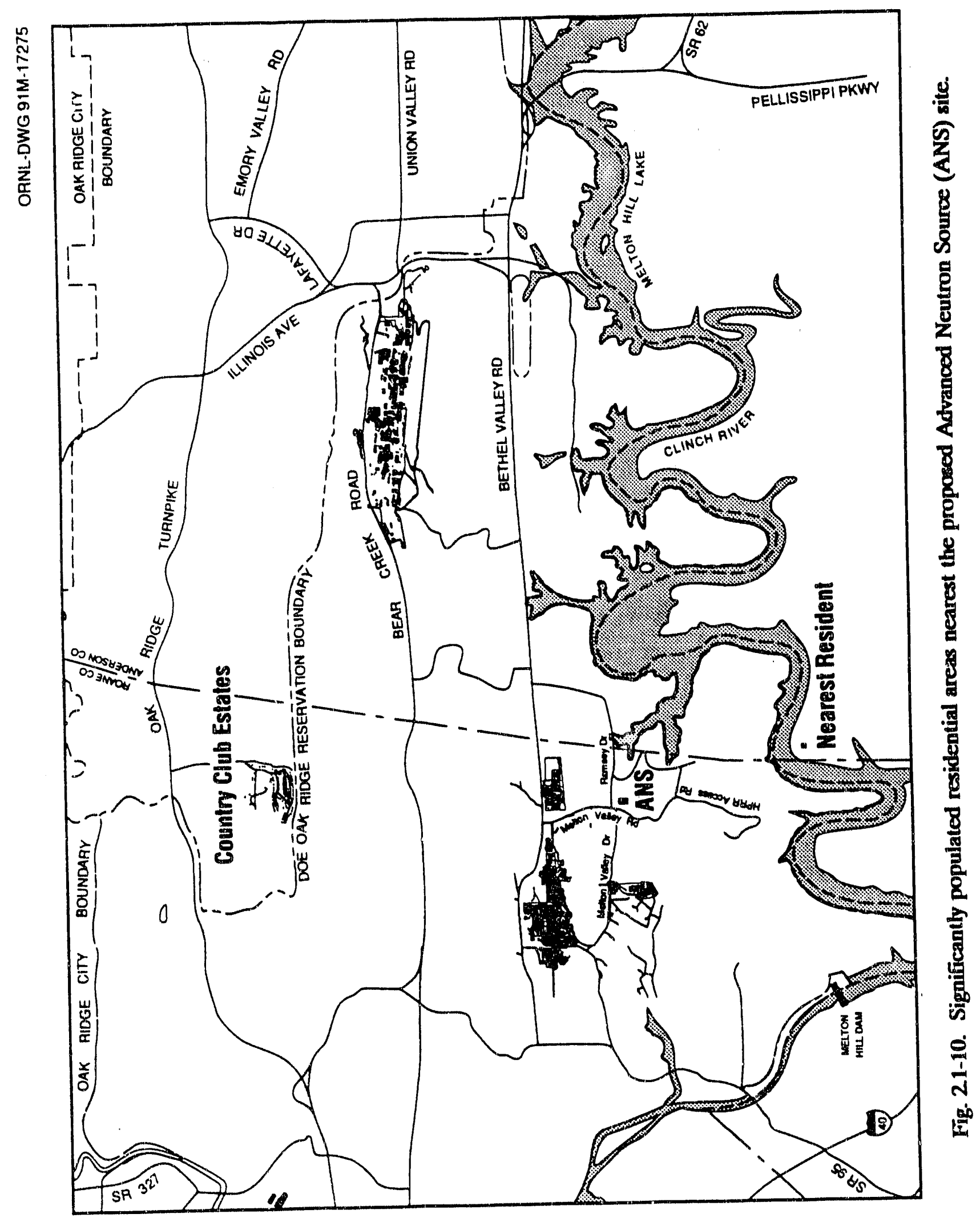


ORNL-DWG $92 \cdot 2124$

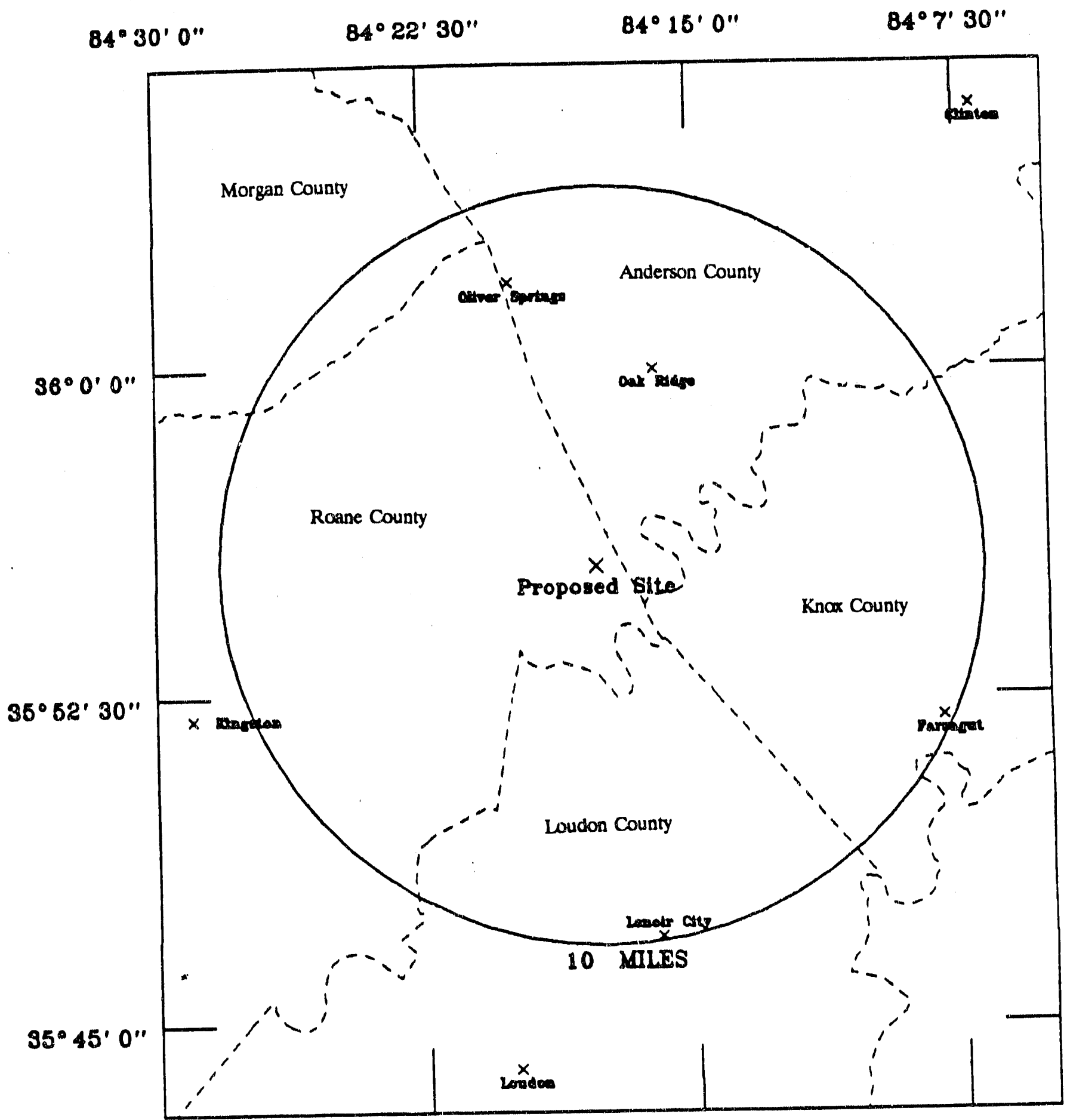

Fig. 2.1-11. County borders and towns within $16.4 \mathrm{~km}$ (10 miles) of the proposed Advanced Neutron Source site. 
ORNL-DWG 92-2125

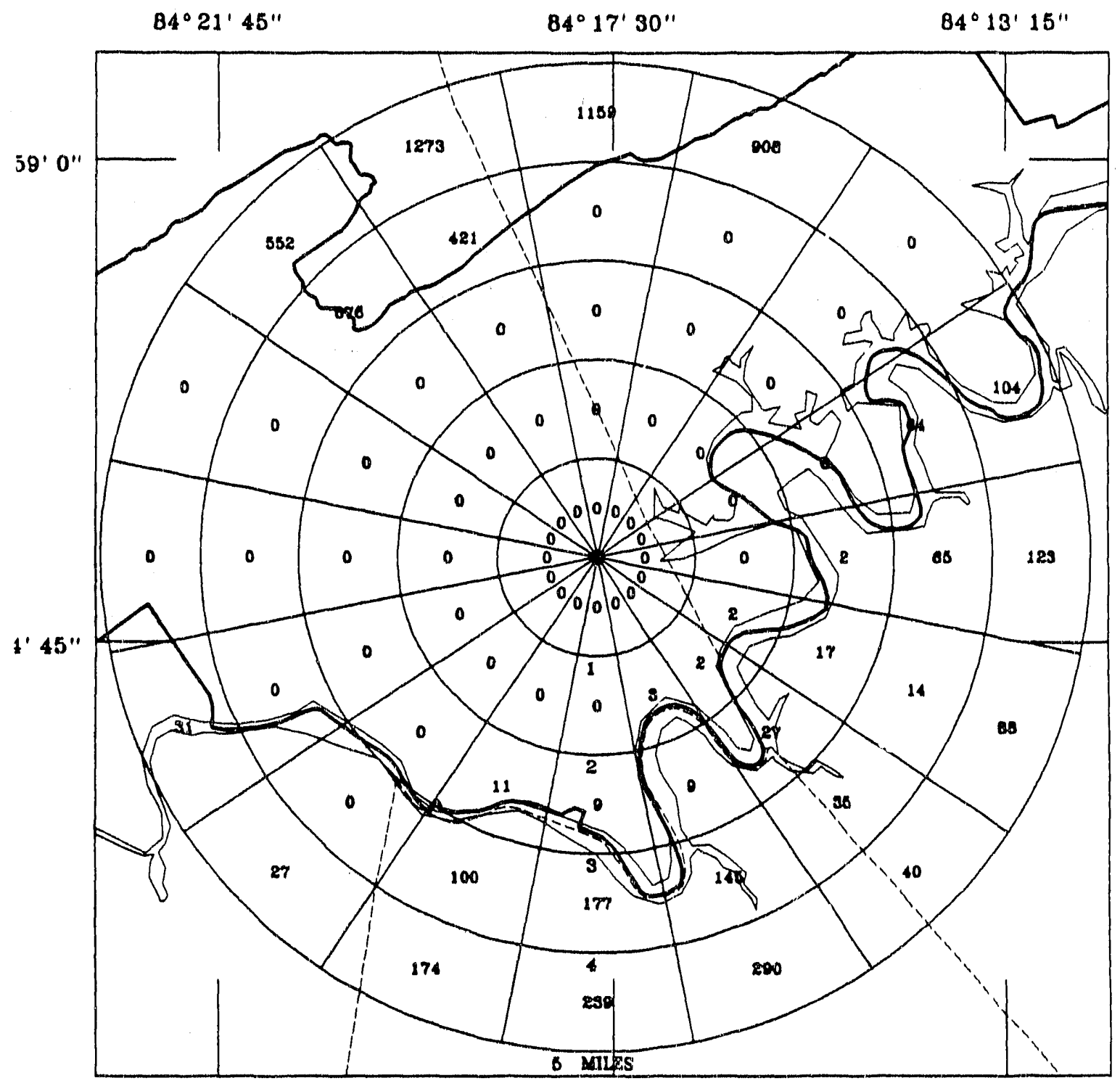

Fig. 21-12 Population count for 1990 by sectors and annuli between 0 and $8.2 \mathrm{~km}$ ( 5 miles) from the center of the proposed Advanced Neutron Site. Source: Department of Commerce 1991. Bureau of the Census, 1990 Census of Population and Housing [computer database]. 


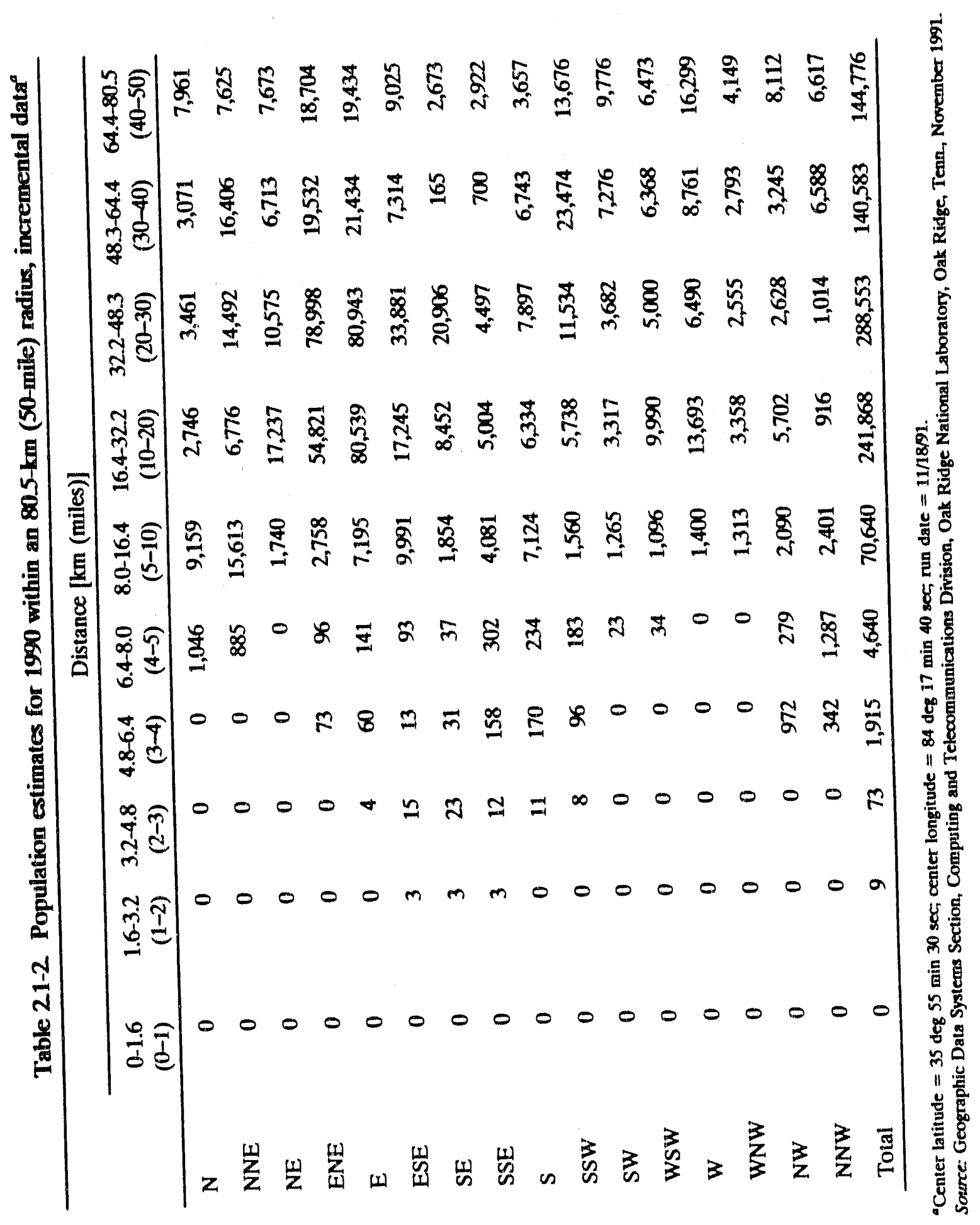




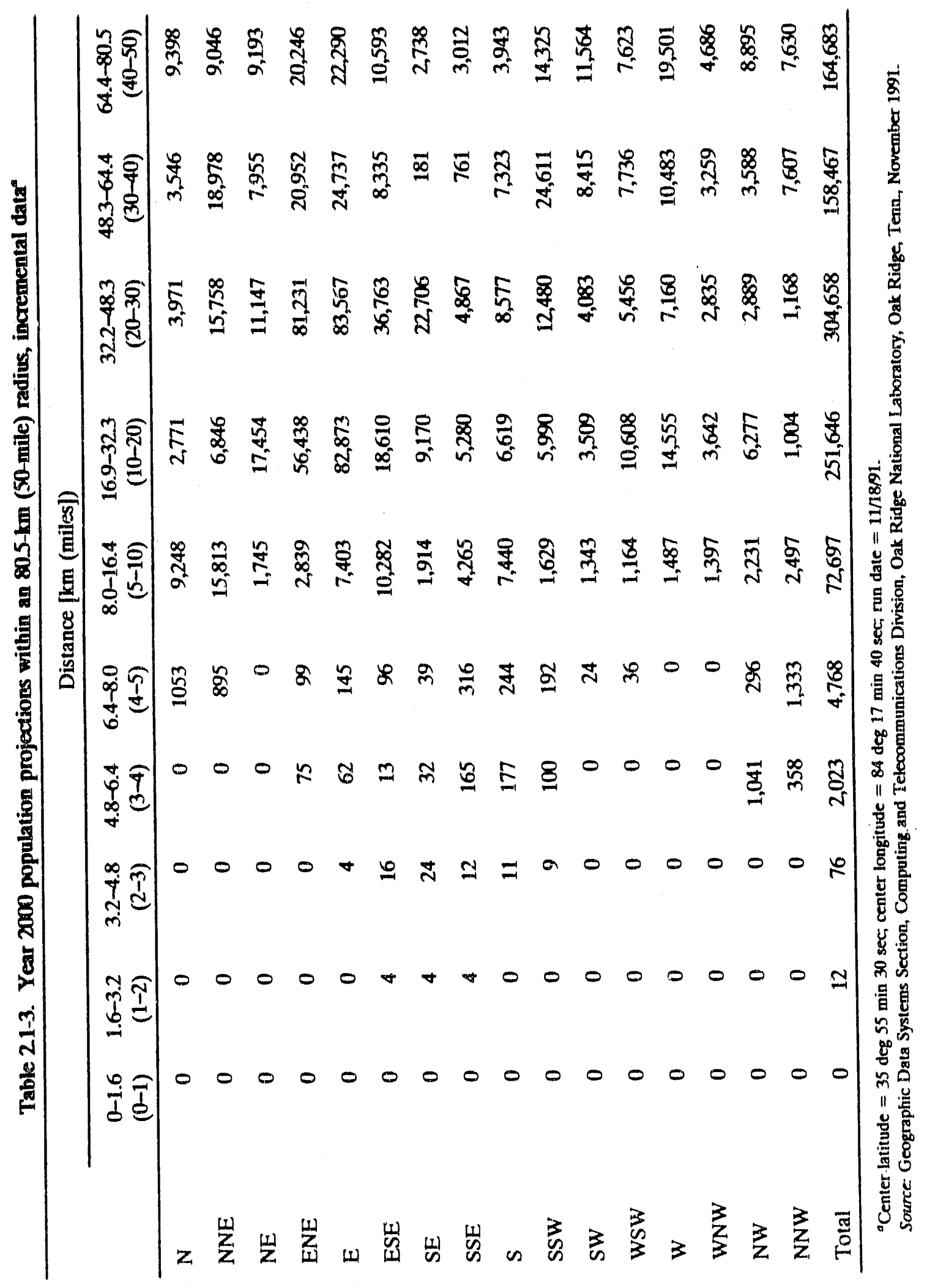




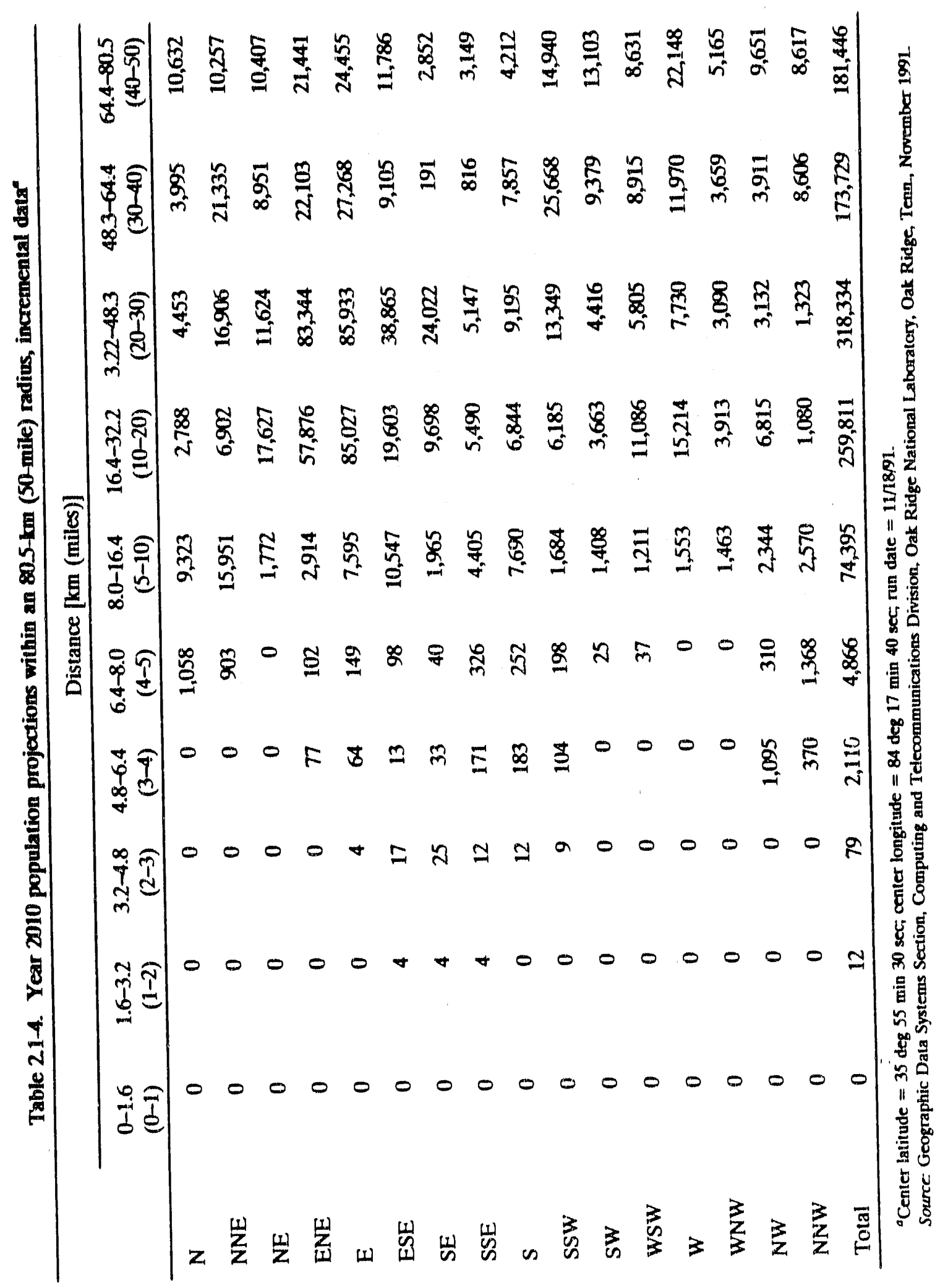




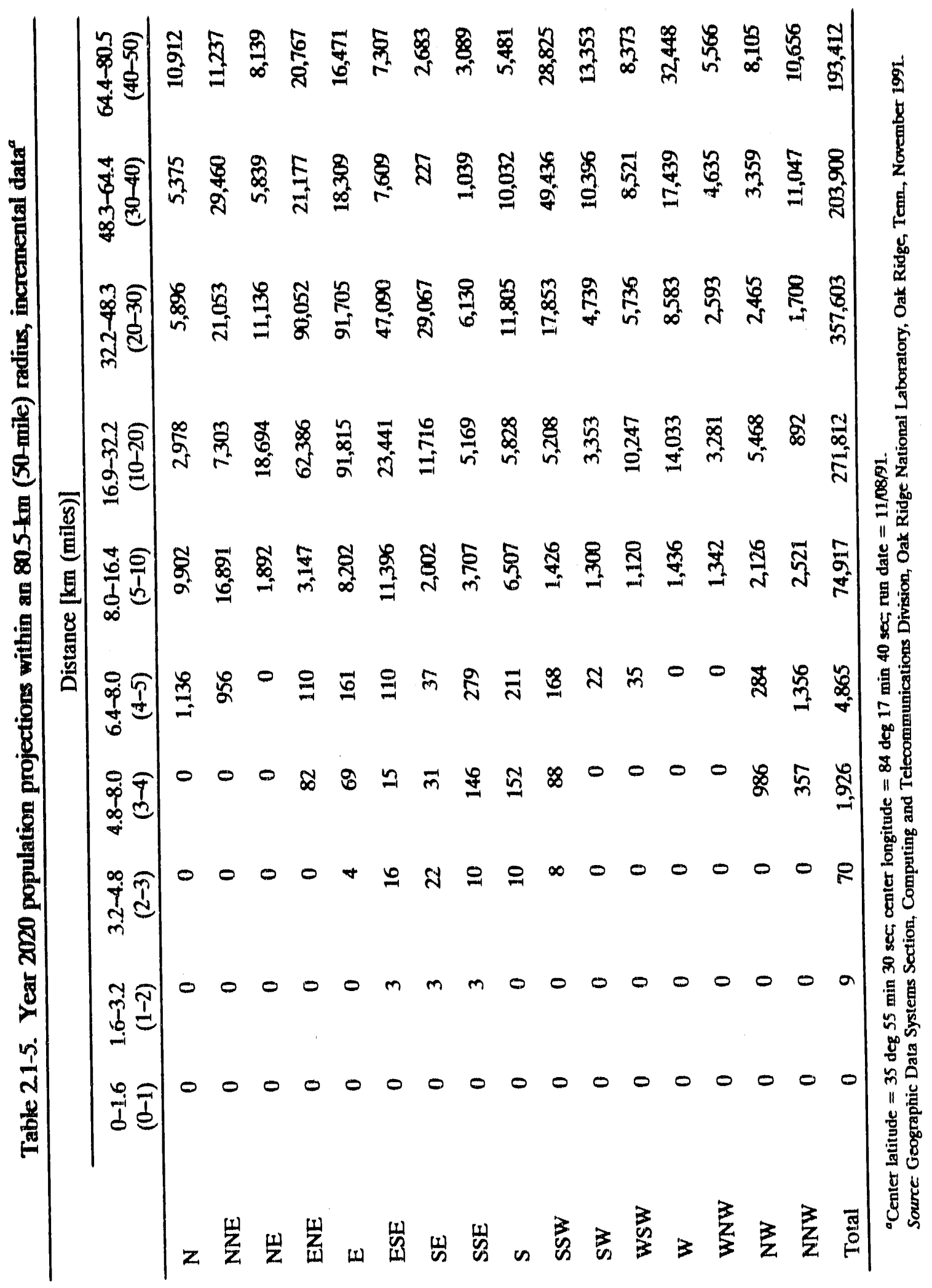


ORNL-DWG 92-2126



Fig. 21-13. Population counts by sectors and annuli for 1990 within $80.5 \mathrm{~km}$ (50 miles) of the proposed Advanced Neutron Source site. Source: Department of Commerce 1991. Bureau of the Census, 1990 Census of Population and Housing [computer database]. 
Table 21-6. Industries in the Advanced Neutron Source area

\begin{tabular}{ccc}
\hline Industry & Product description & $\begin{array}{c}\text { Number of } \\
\text { employees }\end{array}$ \\
$\begin{array}{c}\text { materials } \\
\text { licensec }\end{array}$ \\
\hline
\end{tabular}

Within $8 \mathrm{~km}$ ( 5 miles) of ANS

Clinch River Industrial Park:

International
Technology Corporation

Scientific Ecology

Group, Inc.

Kingston (see Fig. 2.1-5)

Diversified Scientific

Services, Inc.

Oak Ridge (see Fig. 2.1-5):

Boeing Aerospace

Bethel Valley Industrial Park:

Comstock, Inc.

HNU X-ray

Phyton Technologies

$\mathrm{R} \& \mathrm{D}$ Tectonics

Municipal Industrial Park:

Acroloc

American Magnetics

Aardvark Printing

Chambers Tool \& Machining

Cryomagnetic, Inc.
Mbxed waste analysis, radlochemistry, health physies assessments, bloassay, and environmental analysis and surveys

Hazardous waste Incineration and low-level waste compaction and shipping

$$
>8 \mathrm{~km} \text { (5 miles) from ANS }
$$

Mixed waste processing

20

Yes

Advanced aerospace parts

600

Yes

Electrostatic energy analyzers and charged particle detectors

Manufacture of X-ray fluorescents and
75

Plant geneties and propagation

Gencral Machine Shop

Design and build food packaging systems, precision gauges, fixtures, dies, and jigs

Superconducting magnets and cryogenic instrumentation

Printed materials $\quad 4$

General machine shop 5

Superconducting magnets and cryogenic 12 instrumentation 
Table 21.6. (continued)

\begin{tabular}{|c|c|c|c|}
\hline Industry & Product description & $\begin{array}{l}\text { Number of } \\
\text { employees }\end{array}$ & $\begin{array}{l}\text { Nuclear } \\
\text { materlals } \\
\text { llconsec }\end{array}$ \\
\hline \multicolumn{4}{|c|}{ Municipal Industrial Park (continued); } \\
\hline $\begin{array}{l}\text { CSEC Sholtered } \\
\text { Workshop }\end{array}$ & $\begin{array}{l}\text { Bulk mall service; manuffoture survey } \\
\text { stakes, core boxes, and wooden crates }\end{array}$ & 162 & \\
\hline Hilltop Muffler & Muffler installatlon & 15 & \\
\hline Industrlal Hardware & Wholesale distrlbutor of tools & 7 & \\
\hline The Nucleus & $\begin{array}{l}\text { Nuclear radiation dotectors, radiolsotopes, } \\
\text { and nuclear medicine instruments }\end{array}$ & 150 & Yes \\
\hline Oak Ridge Tool-Engineoring & Tooling clles & 45 & \\
\hline Pathway Bellows & $\begin{array}{l}\text { Duct systems, metal and fabric expansion } \\
\text { jolnts, dampers, and closures }\end{array}$ & 214 & \\
\hline Pic-Alr & Precision dlecast components & 90 & \\
\hline Quadrex Corporation & Radlation decontamination and waste processing & 110 & Yes \\
\hline Ridge Metals, Inc. & Tool and dies; precision machining & 25 & \\
\hline Roden Electric & Wholesale electric parts and wiring & 4 & \\
\hline $\begin{array}{l}\text { Tennessee Tool \& } \\
\text { Engineering }\end{array}$ & Tool and dies; precision machining & 39 & \\
\hline \multicolumn{4}{|l|}{ Valley Industrial Park: } \\
\hline Bechtel Service Center & $\begin{array}{l}\text { Maintenance and storage of decontamination } \\
\text { equipment }\end{array}$ & 20 & Yes \\
\hline Conny's Custom Cabinets & Cabinets & 2 & \\
\hline Dixie Electronics & Electronics Components Distributor & 9 & \\
\hline Ebasco & Waste Characterization Contractor & 75 & \\
\hline Industrial Development & Incubator program for fledgling industries & varies & \\
\hline Jamerson Construction & Construction & 6 & \\
\hline Lewts Electric & Electrical contracting & 27 & \\
\hline $\begin{array}{l}\text { Manufacturing Sciences } \\
\text { Corporation }\end{array}$ & $\begin{array}{l}\text { Rolling of depleted uranium; fabrication } \\
\text { of depleted uranium products }\end{array}$ & 41 & \\
\hline $\begin{array}{l}\text { Materials Engineering \& } \\
\text { Testing }\end{array}$ & $\begin{array}{l}\text { Analytical chemistry, metallurgical testing, } \\
\text { fallure analysis, and technical consulting }\end{array}$ & 4 & \\
\hline Maxima & Information management services and products & 100 & \\
\hline
\end{tabular}


Table 2.1-6. (continued)

\begin{tabular}{|c|c|c|c|}
\hline Industry & P'rocluat descriptlon & $\begin{array}{l}\text { Number of } \\
\text { employecs }\end{array}$ & $\begin{array}{l}\text { Nuclear } \\
\text { matorials } \\
\text { licenseo }\end{array}$ \\
\hline \multicolumn{4}{|l|}{ Valley Industrial Park (contlesued): } \\
\hline Miduncliy Tool Co. & T'ool and dies; precision mohining & 4 & \\
\hline Oak Ridge Researoh Instlute & $\begin{array}{l}\text { Environmental montioring and blomedical research; } \\
\text { blologleal waste treatment systems }\end{array}$ & 30 & \\
\hline Oak Ridge Utility Distriat & Propane gas storaga & & \\
\hline Ordela, Inc. & Electranic and electrical equipment and instruments & 5 & Yes \\
\hline Remotec & Moblle robots and manlpulators & 1.5 & \\
\hline Zyp Coatings & High temperature paints, coatlings, and marking inks & 9 & \\
\hline \multicolumn{4}{|l|}{ Commerce Parki } \\
\hline Coors Ceramics & $\begin{array}{l}\text { High-precision complex configurations of } \\
\text { advanced cerarnle material }\end{array}$ & 50 & \\
\hline Tennessee Innovation Center & Incubation center for fledgling industries & varies & \\
\hline Hertel Cutting Technologies & Carbicle and cerainic tools and wear purts & 60 & \\
\hline \multicolumn{4}{|l|}{ Fast Oak Ridge Turnplke Area: } \\
\hline NUS Corporation & $\begin{array}{l}\text { Environmental engineering; waste management } \\
\text { services and environmental control equipment }\end{array}$ & 40 & Yes \\
\hline Tennelec, Inc. & $\begin{array}{l}\text { Charged particle and germanium detectors, and } \\
\text { alpha and beta low background counters }\end{array}$ & 107 & Yes \\
\hline TMA/Eberline & $\begin{array}{l}\text { Callbration of nuclear detection instruments; } \\
\text { health physics services }\end{array}$ & 7 & Yes \\
\hline \multicolumn{4}{|l|}{ Midway and Mitchell Road Area: } \\
\hline EG \& G Ortec, Inc. & $\begin{array}{l}\text { Instrumentation, detectors, and } \\
\text { systems for nuclear radiation measurement }\end{array}$ & 350 & Yes \\
\hline
\end{tabular}

Sources: J, Crider, Diverslfied Sclentific Services, Inc., KIngston, Tenn., personal communication with S. M. Schexnayder, Oak Ridge National Laboratory, Oak Ridge, Tenn., Jan. 9, 1991. Cox, W. C. 1991. "Site Description, Y-12 Plant Bullding 9215," pp, 1-226, O-Wing Final Safety Analysir Report, Oak Ridge National Laboratory, Oak Ridge, Tenn. S. Thompson. Scientific Ecolngy Group, personal communication with S. M. Schexnayder, Oak Ridge National Laboratory, Oak Ridge, Tenn., Jan. 9, 1991. S. Tremain. International Technology Corporation, Oak Ridge, Tenn., personal communication with S, M. Schexnayder, Oak Rldge National Laboratory, Tenn., Jan, 9, 1991, White, J, L. (ed.) 1990. Directory of Tenriessee Mamufucturers, M. L. Smith, Nashville, Tenn. W. Brown, City of Oak Ridge office of business llcensing, personal communication with S. M. Schexnayder, Oak Ridge National Laboratory, Oak Ridge, Tenn., Jan. 8, 1992. L. Young, 1991. Oak Ridge Chamber of Commerce office of Industrial Development, persorial communication with S. M. Schexnayder, Oak Ridge National Laboratory, Jan. 8, 1991. 
Table 21-7. City and county schools within a $16.4 \mathrm{~km}$ (10-mile) radius of the propoesed Advanced Noutron Source site

\begin{tabular}{lcc}
\multicolumn{1}{c}{$\begin{array}{c}\text { Jurisdiction and } \\
\text { schoola }\end{array}$} & Enrollment & Totals \\
\hline $\begin{array}{l}\text { Oak Ridge } \\
\text { 1. Oak Ridge High }\end{array}$ & 1,019 & \\
2. Jefferson Junior High & 6842 \\
3. Robertsville Jurtor High & 733 & \\
4. Linden Elementary & 643 & \\
5. Clenwood & 465 & \\
6. Willowbrook & 501 & \\
7. Woodland & 595 & \\
Anderson County & & \\
8. Norwood Elementary & 334 & \\
9. Norwood Middle & 274 & \\
10. Graxid Oaks Elementary & 362 & \\
Roane County & & \\
11. Oliver Springs High & 433 & \\
12. Oliver Springs Elementary & 632 & \\
13. Dyllis Elementary & 171 & \\
Kuox County & & \\
14. Farragut Primary & 1,061 & \\
15. Farragut Intermediate & 1,096 & \\
16. Farragut Middle & 1,434 & \\
17. Farragut High & 2,309 & \\
Loudon County & & \\
18. Eaton Elementary & 682 & \\
19. North Middle & 493 & \\
20. Highland Park & 326 & \\
Lenoir City & & \\
21. Lenoir City Elementary & 555 & \\
22. Lenoir City Middle & 336 & \\
23. Lenoir City High & & \\
Total & & \\
\hline
\end{tabular}

"Numbers preceding schools correspond to locations on Fig. 2.1-14.

Sources: Robert Martow, supervisor of student services, Anderwon County Schools, Clinton, Tenn, personal cornmunication with M. Ln Socolof, Oak Ridge National Laboratory, Oak Ridge, Tenn., Now. 13, 1991; S. Carroll, Secretary to the Superintendent of Attendance, Oak Ridge City Schools, personal comimunication with M. L. Socolof, Oak Ridge Nalional Laboratory, Oak Ridge, Tenn, Now, 13, 1991; E. Headlee, Loudon County Schools, Loudon, Tenn, personal cornmunication with M. L. Socolof, Oak Ridge National Laboratory, Oak Ridge, Tenn., Now, 14, 1991; M. Price, Knox County Schools, Knoxville, Tenn., personal communication with M. L. Socolof, Oak Ridge National Laboratory, Oak Ridge, Tenn., Nov. 14, 1991; B. Ruffner, Oltver Springs High School, Oltver Springs, Tenn., personal communication with M. L. Socolof, Oak Ridge National Laboratory, Oak Riage, Tenn., Nov. 13, 1991;

T. 1, Russell, Oltver Springs Elementary School, Oltver Springs, Tenn, personal communication with M. L. Socolof, Oak Ridge National laboratory, Oak Ridge, Tenn., Now, 23, 
ORNL. DWWGHA-1632A

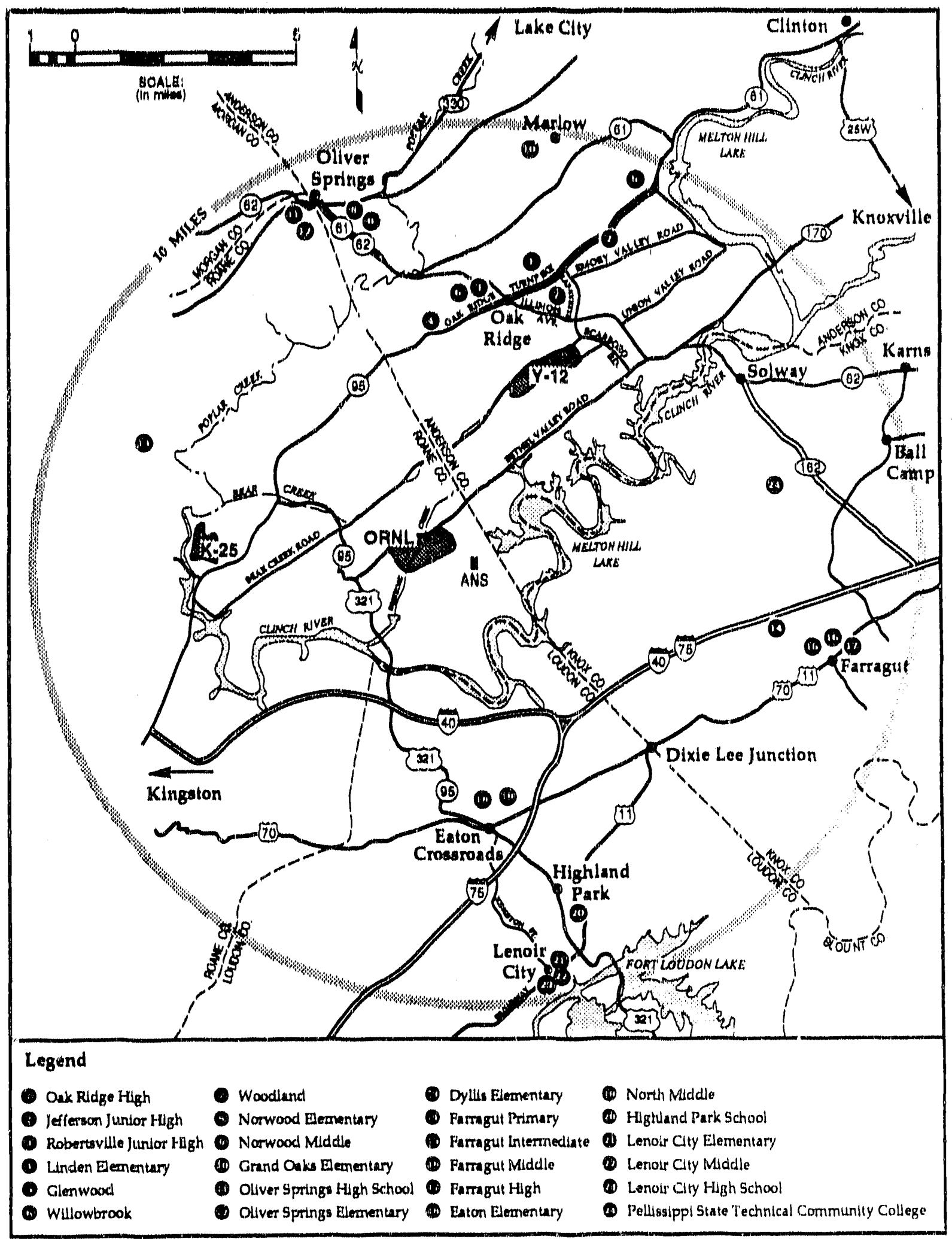

Fig. 21-14. Schools closest to the proposed Adtvanced Neutron Source (ANS) site. 
Oak Ridge provide residential care for the elderly and are located within $16.4 \mathrm{~km}$ (10 miles) of the facility: the Oak Ridge Senior House, with 21 beds; the Oak Ridge Health Care Center, with 130 beds; and the Oak Ridge Retirement Center, with 50 beds (TDHE 1989b, p. 1-25). The Baptist Health Care Center, near Eaton Crcssroads, provides 104 beds for the elderly. Locations of these medical facilities are presented in Fig. 2.1.15.

Four recreational and public areas on ORR attract visitors: the Clark Center Recreational Park, the ORNL Graphite Reactor, the ORNL Overlook, and the K-25 Site Overlook. The Freels Bend Education Center, used as a teaching facility, is also on ORR. Also, 28 cemeteries within the reservation attract visitors (Fig. 2.1-6).

Clark Center Recreational Park is a 134-ha (330-acre) DOE-operated site located on Melton Hill Lake, approximately $5.6 \mathrm{~km}$ (3.5 miles) east of the ANS site. The park has areas and facillties for playing team sports, picnicking, swimming, and launching boats. Softball games held from May through August attract as many as 300 people per night, players and spectators comblined. Four games are held on each of the two fields on Mondays through Thursdays from $4: 15 \mathrm{p} . \mathrm{m}$. to $10 \mathrm{p} . \mathrm{m}$. Two picnic shelters are used by as many as 100 people per day during weekdays from mid-April through October. On weekends, as many as 1000 people attend picnics sponsored by various local companies and organizations. The picnics are usually several hours long, and attendance is staggered throughout this period. The swimming area is open from Memorial Day through Labor Day and is most heavily used on July 4 , when as many as 1000 people use the area; normal usage is from 50 to 75 people on weekdays and from 200 to 500 on weekends. On weekends, more than 50 boats per day are launched at the park; weekday usage is approximately 20 boats per day (C. Jones, Clark Center Recreational Park, ORNL, personal communication with S. M. Schexnayder, ORNL, Sept. 21, 1991).

The Graphite Reactor is a National Historical Landmark at ORNL. In past years, annual visitation to the Graphite Reactor ranged from 13,500 to 15,000 people. In 1991, the reactor was closed a substantial amount of time; however, visitation is expected to return to normal in the future. No estimates are available of the number of visitors to the ORNL Overlook, the K-25 Site Overlook, or the cemeteries. Approximately 19,000 people per year visit Freels Bend Education Center.

Deer hunts are held on OKR and managed by DOE in conjunction with the Tennessee Wildlife Resources Agency (TWRA) (Kornegay et al. 1991, p. 168). The controlled hunts are designed to regulate the deer population on the reservation and to reduce the number of deer-and-vehicle collisions. In 1991, as in the past few years, three hunts will be held: one archery and two shotgun or muzzle-loaded rifle hunts. (Before 1989, four hunts per year were held.) The hunts occur on Saturdays and Sundays in October, November, and December. In 1989, 1990, and 1991, the quota for archery permits was 1850 ; for gun permits, 1000 . It is estimated that $75 \%$ of the permitted hunters are present for the hunts. Guards are stationed along roads to prevent access to restricted areas. No uccess is allowed to administrative control areas.

Bordering the ORR on the south and east sides is the Clinch River-Melton Hill Lake, which is dammed and maintained by the Tennessee Valley Authority (TVA). Numerous access points and recreational areas are along the lake. Total estimated visitation to the entire Melton Hill Lake area is approximately 800,000 visits annually 


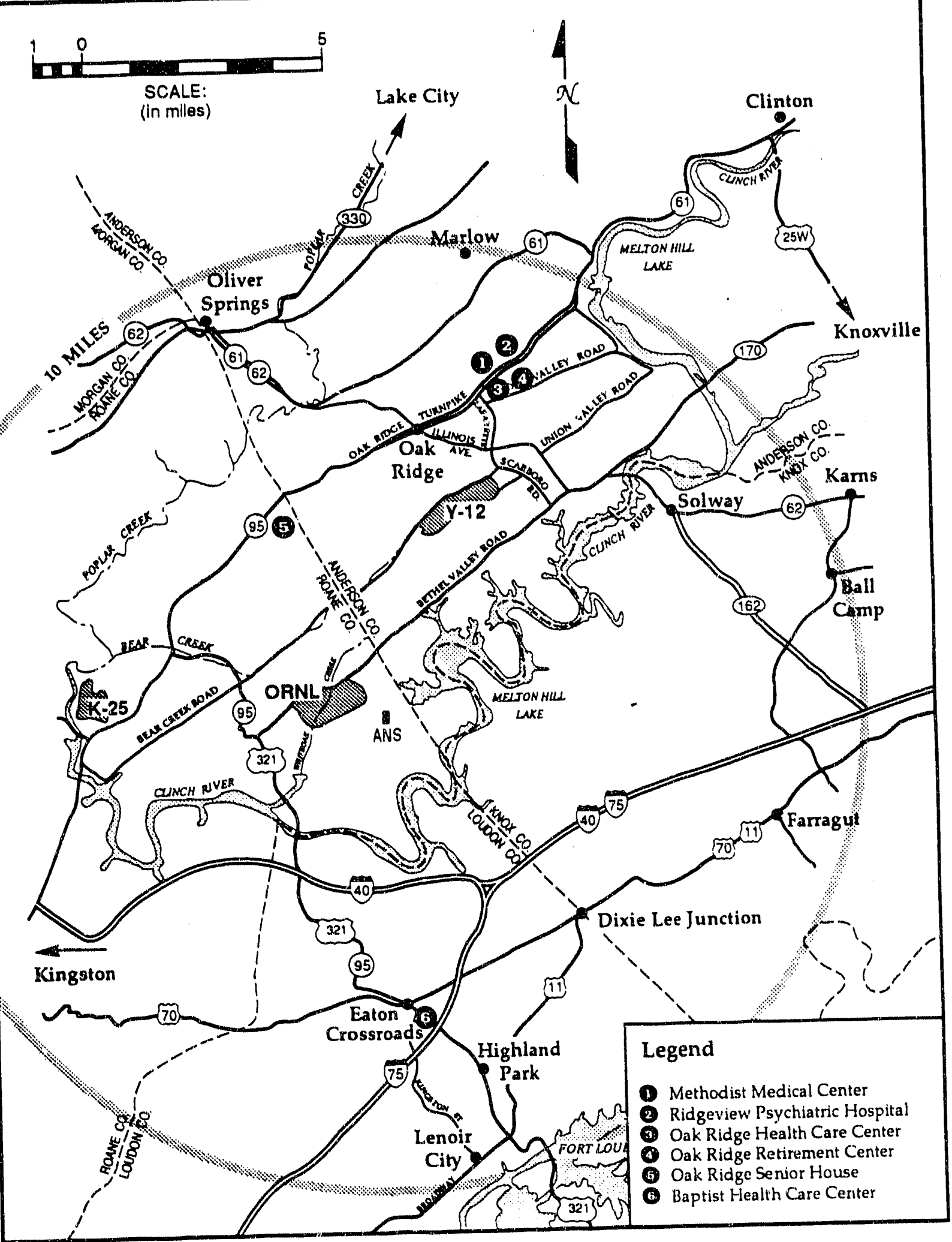

Fig. 21-15. Hospitals and nursing homes closest to the proposed Advanced Neutron Source (ÁNS) site. 
(R. Farrell, TVA, personal communication with B. D. Lasley, ORNL, Jan. 14, 1991). About 300,000 of these visits occur at the Melton Hill Dam Reservation, approximately $4.8 \mathrm{~km}$ (3 miles) southwest of the ANS site.

Other major recreational facilities or public use areas, their approximate distances from the ANS site, and estimates of visitations are presented in Table 2.1-8, including Melton Hill Dam and Visitors' Overlook, Atomic Speedway, Melton Hill Community Club, Melton Hill Park, Oak Ridge Golf and Country Club, South Hills Golf Course, Willow Creek Golf Course, and Haw Ridge Park. Several other small parks available for public use are scattered throughout the area encompassing the $16.4-\mathrm{km}(10$-mile) radius.

\subsection{Uses of Nearby Lands and Waters}

Within an $80.5-\mathrm{km}$ (50-mile) radius, the land surrounding the proposed ANS site is used for industrial, recreational, residential, and small-scale agricultural purposes. It includes a portion of the Great Smoky Mountains National Park, the city of Knoxville, and several other population centers. The National Park, located on the Tennessee-North Carolina border, attracted more than 8.3 million visitors in 1989 (NPS 1989, n.p.). Use of the park peaks in the fall, but visitation is also heavy in spring and summer.

Nine public water supply systems, which serve approximately 91,500 people, withdraw surface water within a 32.4-km (20-mile) radius of ORR. Of these nine supply systems, only the city of Kingston and the K-25 Site Water Treatment Plant are downstream of the ORR. The intake for Kingston is about $592 \mathrm{~km}(0.37$ mile) above the confluence of the Clinch and Tennessee rivers and $33.7 \mathrm{~km}$ (21.1 miles) below the mouth of Poplar Creek. Kingston withdraws approximately $9 \%$ of its average daily public water supply from the Tennessee River. The K-25 Site Water Treatment Plant intake is located $4 \mathrm{~km}$ (2.5 miles) above the mouth of Poplar Creek and provides all of the water for the K-25 Site (Kornegay et al., p. 13).

The nearest residence is approximately $2.8 \mathrm{~km}(1.7$ miles) southeast of the site (Fig. 2.1-10) on the opposite bank of the Clinch River from the ORR. Note that the projected populations estimated in Section 2.1.2.1 may not accurately reflect the future population of this local development because the projections are based on general population growth for the area.

Agricultural activity in the area is limited, consisting of peach and apple orchards and some small farms. Milk is monitored for radionuclides at four small farms and the Broadacre Dairy. The closest location for milk monitoring is Solway, $14.4 \mathrm{~km}$ (9 miles) to the northeast. The dairy is approximately $25.6 \mathrm{~km}$ (16 miles) east-northeast from the site and is a processing plant that does not keep cattle.

Bethel Valley and Bear Creek roads are the major roads nearest the site. Figure 2.1-16 shows several highways that also run close to the site, including Interstates 40 and 75; U.S. Highways 11, 70, and 25W; and State Routes 95, 62, 58, and 162. Bethel Valley Road is the closest, at 0.75 mile to the northwest. The distances and directions from the ANS site to other major roads and highways are listed in Table 2.1-9.

\subsection{Nearby Industrial, Transportation, Military, and Nuclear Facilities}

This section identifies and describes nearby non-ANS activities that might pose a hazard to the safe operation of the ANS facility. At the three major facilities on ORR (ORNL, the K-25 Site, and the Y-12 Plant), radioactive and hazardous materials are stored and handled. Three major TVA facilities-Watts Barr Nuclear Power Plant, Bull Run Steam Plant, and Kingston Steam Plani-are withiñ an $80.5-\mathrm{kmn}(50$-mile) radius of the 
Table 21-8. Major recreational facilities within $16.4 \mathrm{~km}$ (10 miles) of the proposed Advanced Neutron Source site

\begin{tabular}{|c|c|c|c|}
\hline Facility & Location & $\begin{array}{c}\text { Distance and } \\
\text { direction from } \\
\text { ANS } \\
\text { [km (miles)] }\end{array}$ & $\begin{array}{c}\text { Annual } \\
\text { visitation }\end{array}$ \\
\hline Melton Hill Dam and Visitors' Overlook & Roane County & $4.8(3.0) \mathrm{SSW}$ & 300,000 \\
\hline Atomic Speedway & Roane County & $6.4(4.0) \mathrm{SW}$ & $\mathrm{NA}^{a}$ \\
\hline Willow Creek Golf Club & Farragut & $11.84(7.4) \mathrm{SE}$ & 35,000 \\
\hline Melton Hill Community Club & Loudon County & $4.8(3.0) \mathrm{SE}$ & $\sim 1,900^{b}$ \\
\hline Melton Hill Park & Knox County & $5.76(3.6) \mathrm{NE}$ & NA \\
\hline Haw Ridge Park & $\begin{array}{l}\text { City of Oak } \\
\text { Ridge }\end{array}$ & $\begin{array}{l}14.08(8.8) \\
\mathrm{NE}\end{array}$ & NA \\
\hline Oak Ridge Golf and Country Club & Roane County & $\begin{array}{l}6.4(4.0) \\
\text { NNW }\end{array}$ & 32,000 \\
\hline South Hills Golf Course & $\begin{array}{l}\text { City of Oak } \\
\text { Ridge }\end{array}$ & $\begin{array}{l}7.04(4.4) \\
\text { NNE }\end{array}$ & 20,563 \\
\hline Oak Ridge Sportman's Association & $\begin{array}{l}\text { City of Oak } \\
\text { Ridge }\end{array}$ & NA (NA) & NA \\
\hline 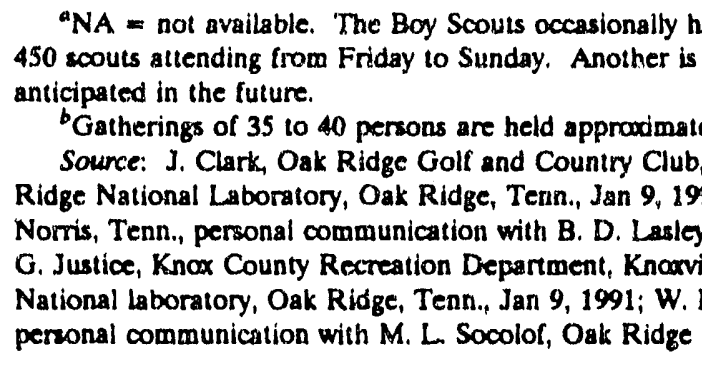 & $\begin{array}{l}\text { ur times per mon } \\
\text { Ridge, Tenn., pe } \\
\text { G. Farrell, Recr } \\
\text { Ridge National } \\
\text { enn., peroonal co } \\
\text { General Manag } \\
\text { Gal Laboratory, }\end{array}$ & $\begin{array}{l}\text { The last one was in } \\
\text { er, use for this purn } \\
\text { rily on weekends. } \\
\text { mmunication with } \\
\text { anner, Tennessee } \\
\text { ry, Oak Ridge, Ter } \\
\text { tion with B. D. Las } \\
\text { w. Creek Golf Clut } \\
\text { e, Tenn., Jan. 9, 19 }\end{array}$ & $\begin{array}{l}\text { Lasley, Oak } \\
\text { y Authority, } \\
\text { lan. 14, 1991; } \\
\text { Oak Ridge } \\
\text { magut, Tenn., }\end{array}$ \\
\hline
\end{tabular}

ANS site. These locations are depicted in Fig. 2.1-17. Other industrial facilities or industrial park areas are shown in Fig. 2.1-5.

At the three primary facilities on ORR, a variety of hazardous chemicals and radioactive materials, including wastes, are generated, stored, and transported during normal operations. At ORNL, diverse programs involve the production and shipment of radioactive materials; among these programs is the production of stable isotopes through an electromagnetic separation process. Isotope shipments leave ORNL by truck, but $90 \%$ are then shipped to their ultimate destination by air; the remaining $10 \%$ are trucked to their buyers (Fitzpatrick 1982, p. 2-63). Hazardous and mixed wastes are generated by both research projects and facility operations at ORNL. Table 2.1-10 surnmarizes wastes generated at ORNL in 1990, and Table 2.1-11 summarizes waste storage at ORNL in 1990. 


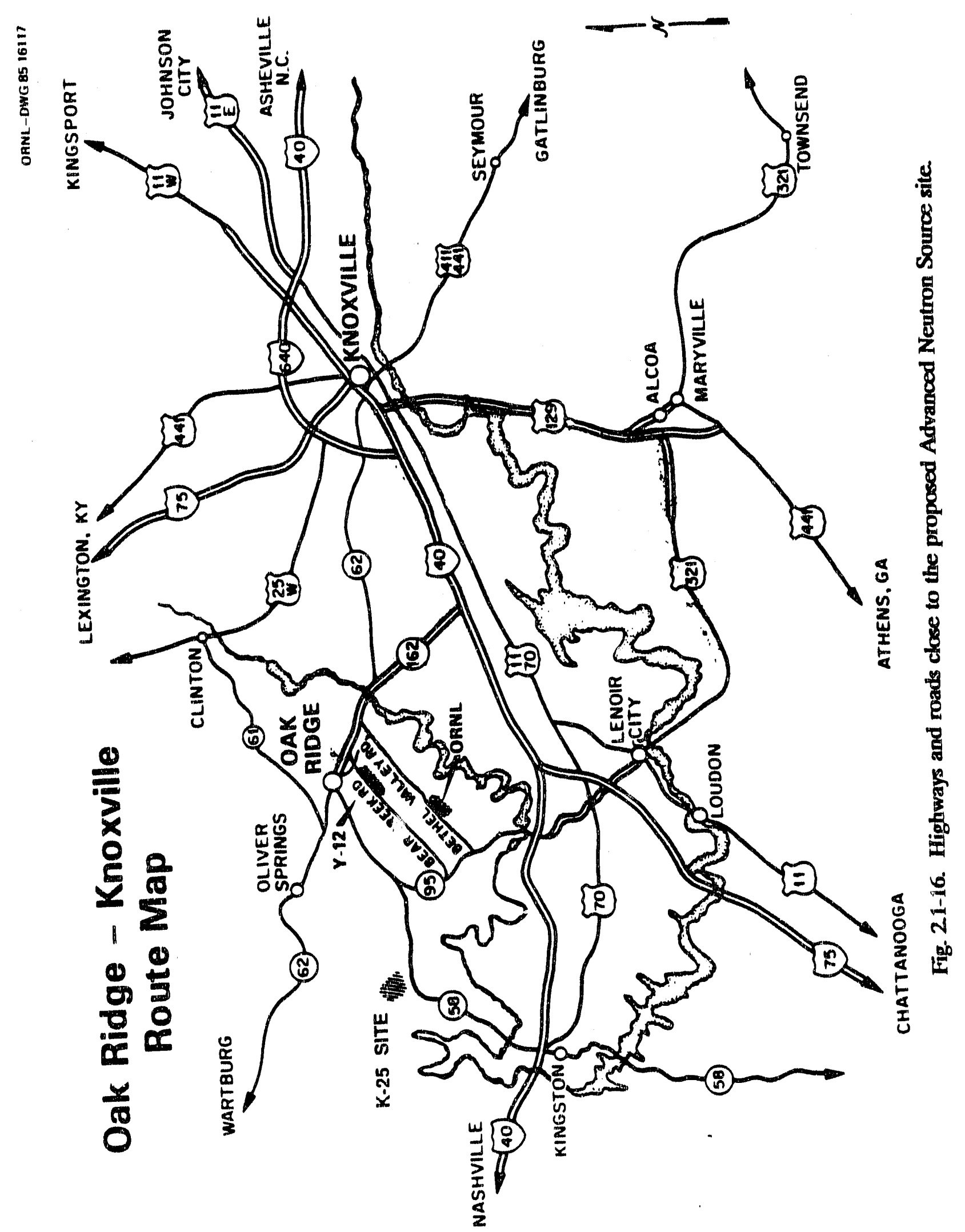


Table 21-9. Roads and highways nearest the proposed Advanced Neutron Source site

\begin{tabular}{lc}
\hline Roads and highways & $\begin{array}{c}\text { Shortest distance and } \\
\text { direction from ANS } \\
{[\mathrm{km} \text { (miles)] }}\end{array}$ \\
\hline Bethel Valley Road & $1.06(0.667) \mathrm{NW}$ \\
Bear Creek Road & $3.07(1.89) \mathrm{NW}$ \\
SR-95 & $3.95(2.44) \mathrm{SW}$ \\
I-40/I-70 & $5.78(3.57) \mathrm{S}$ \\
US-70/US-11 & $8.97(5.54) \mathrm{SW}$ \\
SR-58 & $7.01(4.33) \mathrm{WNW}$ \\
SR-62 & $9.54(5.89) \mathrm{NE}$ \\
SR-162 & $11.69(7.22) \mathrm{ENE}$ \\
US-25W & $21.06(13.0) \mathrm{NE}$ \\
\hline
\end{tabular}

Until August 1985, the primary function of the K-25 Site was the enrichment of uranium in the ${ }^{235} \mathrm{U}$ isotope. The plant currently provides storage of radioactive, hazardous, and mixed waste produced at five DOE facilities: ORNL, the Y-12 Plant, the Portsmouth and Paducah gaseous diffusion plants, and Westinghouse Material Company of Ohio (Cox 1991 p. 71). Solidified depleted uranium hexafluoride is also stored at the K-25 Site in 9,000- and $12,600-\mathrm{kg}$ (10- and 14-ton) cylinders. The types and quantities of waste stored on-site are summarized in Table 2.1-12. The Sludge Fixation Facility (K-1419) at the K-25 Site mixes hazardous and inorganic wastes with concrete to form a solid mixture that can be stored above ground. The Toxic Substances Control Act (TSCA) Incinerator at the K-25 Site, which began full operation in 1991, disposes of oils, solvents, chemicals, sludges, aqueous waste, and solids.

The principal function of the Y-12 Plant is the fabrication of nuclear weapons components. Enriched and depleted uranium, thorium, beryllium, and lithium are processed at the plant (Fitzpatrick 1982, p. 2-61). The transportation of acids, chemicals, helium, mercury, metals, uranium, and thorium is essential to the operation of the Y-12 Plant. Waste generation at the Y-12 Plant during 1990 is summarized in Table 2.1-13. Waste storage at the end of 1990 is presented in Table 2.1-14.

Of the ten facilities on ORR that at one time served as reactors, only five can become operational and are thus classified as nuclear reactors. Only two of these reactors, the Tower Shielding Facility (TSF) and the High Flux Isotope Reactor (HFIR), are currently operating. The other three reactors have been defueled: the Health Physics Research Reactor, which was disassembled and moved to X-12 for storage on December 6, 1990, is not expected to become operational; the Bulk Shielding Reactor, which is in standby and on which no decision has been made regarding future operations; and the Oak Ridge Research Reactor, which is awaiting decontamination and 


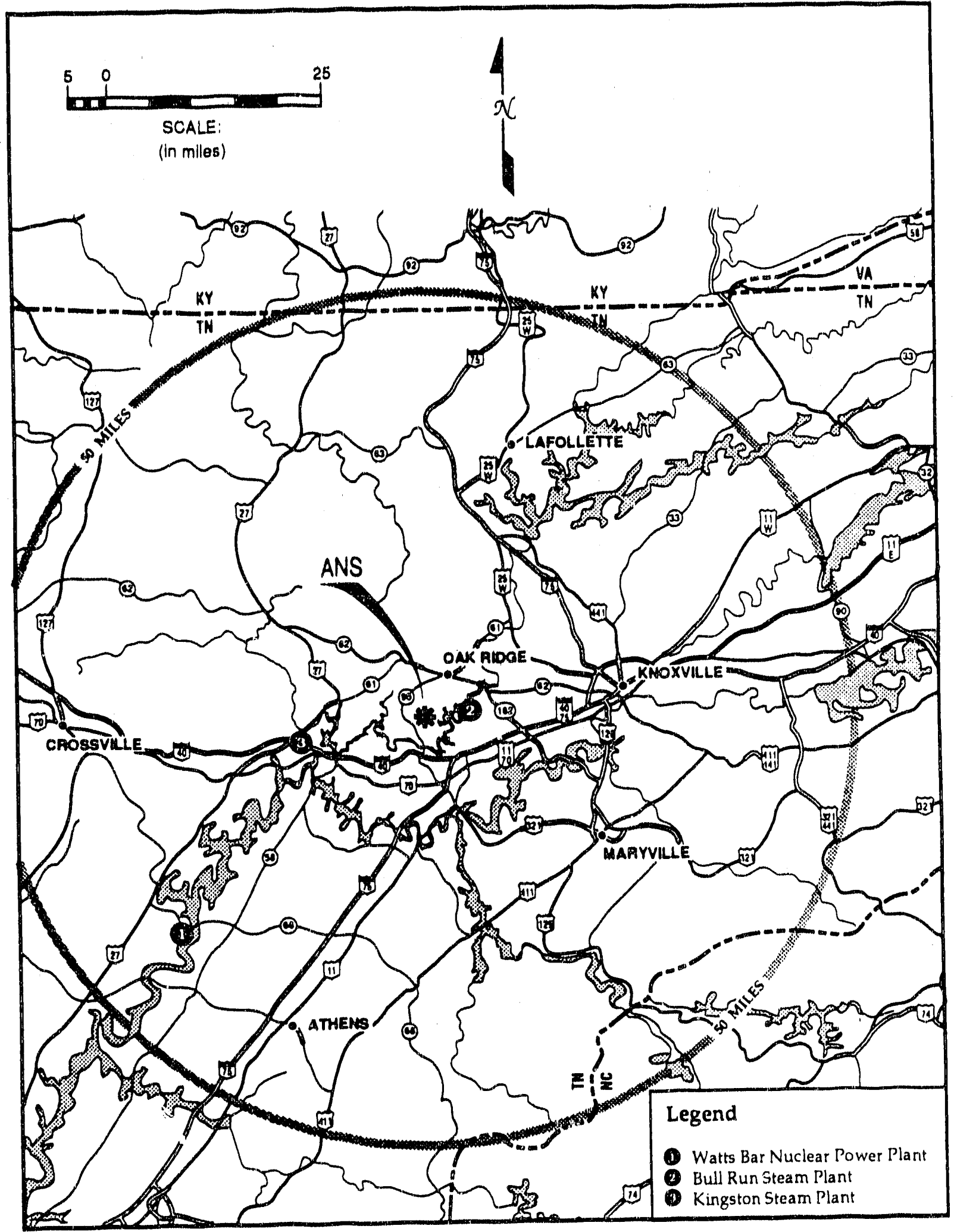

Fig. 21-17. Major Tennessee Valley Authority power-generating facilities near the proposed Advanced Neutron Source (ANS) site. 
Table 21-10. Oak Ridge National Laboratory waste generation summary for 1990

\begin{tabular}{|c|c|c|}
\hline Waste & $\begin{array}{c}\text { Volume } \\
{\left[\mathrm{m}^{3}\left(\mathrm{ft}^{3}\right)\right]}\end{array}$ & $\begin{array}{l}\text { Weight } \\
{[\mathrm{kg}(\mathrm{lb})]}\end{array}$ \\
\hline Hazardous & & $71,000(156,555)$ \\
\hline Sanitary & $12,200(430,782)$ & $3,400(7,497)$ \\
\hline \multicolumn{3}{|l|}{ Industrial } \\
\hline Mixed & & $4,900(10,805)$ \\
\hline $\begin{array}{l}\text { Polychlorinated biphenyla } \\
\text { Radiological } \\
\text { Nonradiological }\end{array}$ & & $\begin{array}{r}22(48.5) \\
12,000(26,460)\end{array}$ \\
\hline $\begin{array}{l}\text { Transuranic } \\
\text { Contact handled } \\
\text { Remote handled }\end{array}$ & $\begin{array}{r}5.5(194) \\
0\end{array}$ & \\
\hline Low-level wastewater & $1,590(56,145)$ & \\
\hline $\begin{array}{l}\text { Asbestos } \\
\quad \text { Radiological } \\
\text { Nonradiological }\end{array}$ & $28(988)$ & $\begin{array}{r}6,600(14,553) \\
15,237(33,598)\end{array}$ \\
\hline $\begin{array}{l}\text { Scrap metal } \\
\text { Radiological } \\
\text { Nonradiological }\end{array}$ & & $\begin{array}{r}24,000(52,920) \\
416,340(918,030)\end{array}$ \\
\hline Miscellaneous nonhazardous & & $1,535(3,385)$ \\
\hline Miscellaneous radiological & & 0 \\
\hline
\end{tabular}

'Martin Marietta Energy Systems policy defines any material with polychlorinated biphenyl (PCB) contamination greater than 20 ppm as PCB waste.

Source: Kornegay, F. C., et al. 1991, Oak Ridge Reservation Environmental Report for 1989, ORNL/ES/ESH-18/N1, Oak Ridge National Laboratory, Oak Ridge, Tenn., p. 213.

decommissioning, (J. Sims, Research Reactor Division, Oak Ridge National Laboratory, personal communication with B. D. Lasley, Oak Ridge National Laboratory, Jan. 4, 1991).

Table 2.1-6 lists other industrial facilities in the area and the products they manufacture. Industrial growth in the area is expected to occur in the Clinch River Industrial Park and the Bethel Valley Industrial Park. On the ORR, the Atomic Vapor Laser Isotope Separation (AVLIS) Plant project is in the development stage. The K-25 Site is one of three DOE facilities being considered as a location for the AVLIS facility (the other two are Portsmouth and Paducah). It is planned that the decision on the location be made by November 1992. Construction of the facility is not expected to begin until 1994 or 1995. 
Table 21-11. Oak Ridge National Laboratory waste in storage at the end of 1990

\begin{tabular}{|c|c|}
\hline Waste description & Quantity \\
\hline Hazardous, kg (lb) & $71,000(156,555)$ \\
\hline Mixed, kg (lb) & $4,900(10,805)$ \\
\hline $\begin{array}{l}\text { Polychlorinated biphenyls, } \mathrm{kg} \text { (lb) } \\
\text { Nonradiological } \\
\text { Radiological }\end{array}$ & $\begin{array}{r}12,000(26,460) \\
22(48.5)\end{array}$ \\
\hline $\begin{array}{r}\text { Transuranic, } \mathrm{m}^{3}\left(\mathrm{ft}^{3}\right) \\
\text { Contact handled } \\
\text { Remote handled }\end{array}$ & $\begin{array}{r}5.5(194) \\
0\end{array}$ \\
\hline Radiological asbestos, $\mathrm{kg}$ (lb) & $6,600(14,553)$ \\
\hline Low-level ${ }^{a}, \mathrm{~m}^{3}\left(\mathrm{ft}^{3}\right)$ & $33(1,165)$ \\
\hline Radiological scrap metal, kg (lb) & $24,000(52,920)$ \\
\hline
\end{tabular}

East Tennessee Natural Gas Company (ETNGC) supplies natural gas to ORR. A 55.8-cm (22-in.) main enters ORR from Knox County, crosses the Clinch River, and proceeds to Valve Station C located along Bethel Valley Road (Chance 1986, p. 85) (Fig. 2.1-18). Two other valve stations are located on ORR. Pipelines that carry gas to the various facilities are smaller in size, ranging from 15.24 to $35.56 \mathrm{~cm}$ (6 to 14 in.), with the exception of the abandoned $56-\mathrm{cm}(22-\mathrm{in}$.) line that served the old powerhouse area south of the K-25 Site. ETNGC mainline pressure ranges from $4.0 \times 10^{6}$ to $5.4 \times 10^{7} \mathrm{~Pa}$ ( 450 to $600 \mathrm{psig}$ ), but the pressure is reduced to $2.2 \times 10^{6} \mathrm{~Pa}(250 \mathrm{psig})$ for Valve Stations $\mathrm{A}$ and $\mathrm{C}$. The pressure is further reduced to $5.8 \times 10^{5}$ and $1.1 \times 10^{5} \mathrm{~Pa}$ (65 and $125 \mathrm{psig}$ ) for distribution to the K-25 Site and the Y-12 Plant, respectively, and to $8.9 \times 10^{5} \mathrm{~Pa}$ (100 psig) for distribution to ORNL. Additional pressure reductions, to as low as $4.5 \times$ $10^{4} \mathrm{~Pa}(5 \mathrm{psig})$, will be made for distribution to points of special use at each facility (Chance 1986, p. 5-86). The location and size of the pipelines are also shown in Fig. 2.1-18.

The water supply to ORNL is provided by the pumping station at the Clinch River, about $1.2 \mathrm{~km}$ (2 miles) southwest of the Y-12 Plant. Raw water is pumped from this station to the DOE water treatment plant located north of the Y-12 Plant on Pine Ridge. This treatment facility provides sanitary water through two storage reservoirs with a combined capacity of 26.6 million L ( 7 million gal). A $69-\mathrm{cm}$ (24-in.) main provides sanitary water to ORNL from the treatment facility. Two 11.4-million-L (3-million-gal) storage reservoirs hold the water before it is distributed through ORNL's distribution system. Figure 2.1-19 shows the location of the raw and sanitary waterlines and the holding reservoirs. 
Table 2.1-12 K-25 Site waste in storage at the end of 1990

\begin{tabular}{|c|c|c|}
\hline $\begin{array}{c}\text { Waste } \\
\text { description }\end{array}$ & Quantity & $\begin{array}{l}\text { Ultimate } \\
\text { disposal }\end{array}$ \\
\hline K-25 low-level waste, $\mathrm{m}^{3}$ & 687 & Incineration \\
\hline K-1420 nitric acid (mixed), $\mathrm{kg}$ & 8,850 & Under review \\
\hline K-1420 electro-less nickel solution (mixed), $\mathrm{kg}$ & 830 & Under review \\
\hline $\begin{array}{l}\text { Spent solvents oils, and Polychlorinated biphenyls (PCB) } \\
\text { liquids (mixed), L }\end{array}$ & 628,351 & Incineration \\
\hline Paint waste, $\mathrm{kg}$ & 40,869 & Incineration \\
\hline K-1232 spent carbon filter agent (mixed), $\mathrm{kg}$ & 25,284 & Under review \\
\hline PCB sollds and liquids (PCB radiological), $\mathrm{L}$ & 1,326 & Incineration \\
\hline Portsmouth PCB-contaminated soll, $\mathrm{kg}$ & 909,000 & Under review \\
\hline Incineration ash/sludge, $\mathrm{kg}$ & 199,841 & Under review \\
\hline $\mathrm{K}-1407 \mathrm{~B} / \mathrm{C}$ pond sludge (mixed), $\mathrm{kg}$ & $14,883,190$ & $\begin{array}{l}\text { To be fixed in } \\
\text { concrete }\end{array}$ \\
\hline $\mathrm{K} \cdot 1407 \mathrm{~B} / \mathrm{C}$ pond sludge (mixed), $\mathrm{kg}$ & $24,982,170$ & Stabilized \\
\hline $\begin{array}{l}\text { Reactive Metals, Inc. (RMI), lead } \\
\text { contaminated liquid (mixed), } \mathrm{kg}\end{array}$ & 23,843 & Under review \\
\hline $\begin{array}{l}\text { Westinghouse Materials Company of } \\
\text { Ohio (WMCO) hazardous waste } \\
\text { liquid (mixed), kg }\end{array}$ & 79,067 & Incineration \\
\hline WMCO hazardous waste solld (mixed), $\mathrm{kg}$ & 9,728 & Under review \\
\hline Y-12 low-level waste (LLW), $\mathrm{m}^{3}$ & 4,628 & Under review \\
\hline ORNL LLW, $\mathrm{m}^{3}$ & 783 & Under review \\
\hline $\mathrm{Y} \cdot 12$ hazardous liquids, $\mathrm{kg}$ & 134,623 & Under review \\
\hline Portsmouth (PORTS) hazardous solids, $\mathrm{kg}$ & $7,84.5$ & Under review \\
\hline PORTS hazardous liqulds, $\mathrm{kg}$ & 25,263 & Under review \\
\hline RMI spent solvents (mixed), $\mathrm{kg}$ & 1,245 & Under review \\
\hline ORNL hazardous liquids, $\mathrm{L}$ & 440 & Under review \\
\hline Lab pack chemicals, $\mathrm{kg}$ & 1,531 & Incineration \\
\hline Centrifuge expoxies/resins, $\mathrm{kg}$ & 7,581 & Under review \\
\hline $\begin{array}{l}\text { Central Neutralization Facility centrifuge } \\
\text { sludge, } \mathrm{kg}\end{array}$ & 595,495 & Under review \\
\hline Laboratory Best Management Practices solutions, $\mathrm{kg}$ & 140,725 & Under review \\
\hline Photo wastes, $\mathrm{kg}$ & 33,924 & Under review \\
\hline Metallic mercury, $\mathrm{kg}$ & 1,177 & Under review \\
\hline Rags contaminated with solvents, $\mathrm{kg}$ & 2,409 & Under review \\
\hline Test burn materials, $\mathrm{kg}$ & 32,081 & Under review \\
\hline Metal shavings/lead, $\mathrm{kg}$ & 68 & Under review \\
\hline Hazardous waste liquids, $\mathrm{kg}$ & 77,565 & Under review \\
\hline Asbestos-covered lead pipe, $\mathrm{kg}$ & 2,318 & Under review \\
\hline Hazardous waste solids, kg & 54,339 & Under review \\
\hline Gases/cylinders, $\mathrm{kg}$ & 648 & Under review \\
\hline $\begin{array}{l}\text { Toxic Substance Control Act and Ionized } \\
\text { Wet Scrubbers sludge, } \mathrm{kg}\end{array}$ & 129,129 & Under review \\
\hline Laundry sludge, $\mathrm{kg}$ & 35,193 & Under review \\
\hline $\begin{array}{l}\text { Waste from treatment of WMCO } \\
\text { hazardous waste liquid, } \mathrm{kg}\end{array}$ & 57,821 & Under review \\
\hline
\end{tabular}

Source: Kornegay, F. C., et al., 1991. Oak Ridge National Laboratory, Oak Ridge, Tenn., Oak Ridge Reservation Environmental Report for 1990, ORNL ES/ESH-18/N2, p. 212. 
Table 21-13. Y-12 Plant waste generation summary for 1990

\begin{tabular}{lr}
\multicolumn{1}{c}{ Waste description } & \multicolumn{1}{c}{$\begin{array}{c}\text { Quantity } \\
{[\mathrm{kg}(\mathrm{lb})]}\end{array}$} \\
\hline Sanitary and industrial ${ }^{a}$ & $10,756,145(23,717,300)$ \\
Asbestos and BeO & \\
Uncontaminated & $217,270(479,080)$ \\
Contaminated & $84,638(186,627)$ \\
Hazardous ${ }^{b}$ & $2,136,440(4,710,850)$ \\
Mixed & $3,880,486(8,556,472)$ \\
Polychlorinated biphenyls (PCBs) & $81,888(180,563)$ \\
PCBs and uranium & $10,661(23,508)$ \\
Low-level contaminated waste ${ }^{\circ}$ & $1,960,042(4,321,893)$ \\
Scrap metal & \\
Uncontaminated & $1,209,297(2,666,500)$ \\
Contaminated & $587,865(1,296,242)$ \\
Classified & $44,387(97,873)$ \\
Nonhazardous liquids ${ }^{d}$ & $554,701(1,223,116)$ \\
\hline
\end{tabular}

The major transportation routes, including highways, waterways, railways, and the barge facility on ORR, are identified in Fig. 2.1-20. The Oak Ridge and Knoxville areas are connected by navigable waterways, primarily the Clinch and Tennessee rivers, that are maintained by TVA and the Army Corps of Engineers. The depth of the channel of both waterways is $2.7 \mathrm{~m}$ (9 ft) (TDECD 1989, n.p.). Using these waterways, barge traffic can connect with ports on the Mississippi and Ohio Rivers. The only water transportation facility located on ORR is a barge facility on the east bank of the Clinch River south of Highway 58. The facility is rarely used but is maintained in operable condition.

The McGhee Tyson Airport, located 56 road km (35 road miles) or 28.8 air km (18 air miles) east-southeast of the ANS site, provides the nearest available scheduled commercial air service. The airport is served by 10 airlines offering 110 flights (arrivals and departures) daily (TDECD 1989, n.p.). No areas of restricted airspace exist over ORR; however, FAA has recently proposed restricting air space over the Y-12 Plant (Fed. Register., Vol. 55, No. 30). The minimum altitude currently allowed is $910 \mathrm{~m}(3000 \mathrm{ft}) \mathrm{msl}$ or $610 \mathrm{~m}(2000 \mathrm{ft})$ above ground level. Other small airports or airfields in the area that 
Table 21-14. Y-12 Plant waste in storage at the end of 1990

\begin{tabular}{|c|c|}
\hline Waste & $\begin{array}{l}\text { Quantity } \\
{[\mathrm{kg}(\mathrm{lb})]}\end{array}$ \\
\hline Low level & $1,074,582(2,369,4,53)$ \\
\hline Mixed & $677,661(1,494,293)$ \\
\hline Hazardous & $88,112(194,287)$ \\
\hline Polychlorinated biphenyls (PCBs) & $116,573(357,043)$ \\
\hline PCBs and uranium & $106,594(23,504)$ \\
\hline Noncontaminated olls and solvents & $113,269(249,758)$ \\
\hline Roofing materials & $3,109,000(6,855,345)$ \\
\hline $\begin{array}{l}\text { Scrap metal } \\
\text { Clean } \\
\text { Uranium contaminated }\end{array}$ & $\begin{array}{r}0 \\
2,919,056(6,436,518)\end{array}$ \\
\hline Mercury-contaminated soll & 0 \\
\hline
\end{tabular}

serve private aircraft include the Downtown Island Airport in Knoxville, Rockwood Municipal Airport in Rockwood, and a grass-runway airfield in Oliver Springs.

No large military facilities are nearby; however, the military reserve and National Guard have installations in Oak Ridge, Elza, Lenoir City, Knoxville, Harriman, and Clinton (Fitzpatrick 1982, p. 2-58).

\section{ECOLOGY}

The following sections discuss the ecology of the proposed ANS site.

\section{Terrestrial Ecology}

This section examines the terrestrial ecology of the site.

\subsubsection{Vegetation}

\section{Vegetation of Oak Ridge Reservation}

General Description. The following general description of vegetation was obtained from Dahlman, Kitchings, and Elwood 1977 (p. 1-83), Kitchings and Mann 1976 (p. 1-58), and DOE and is representative of the proposed ANS site as well as the entire ORR. 

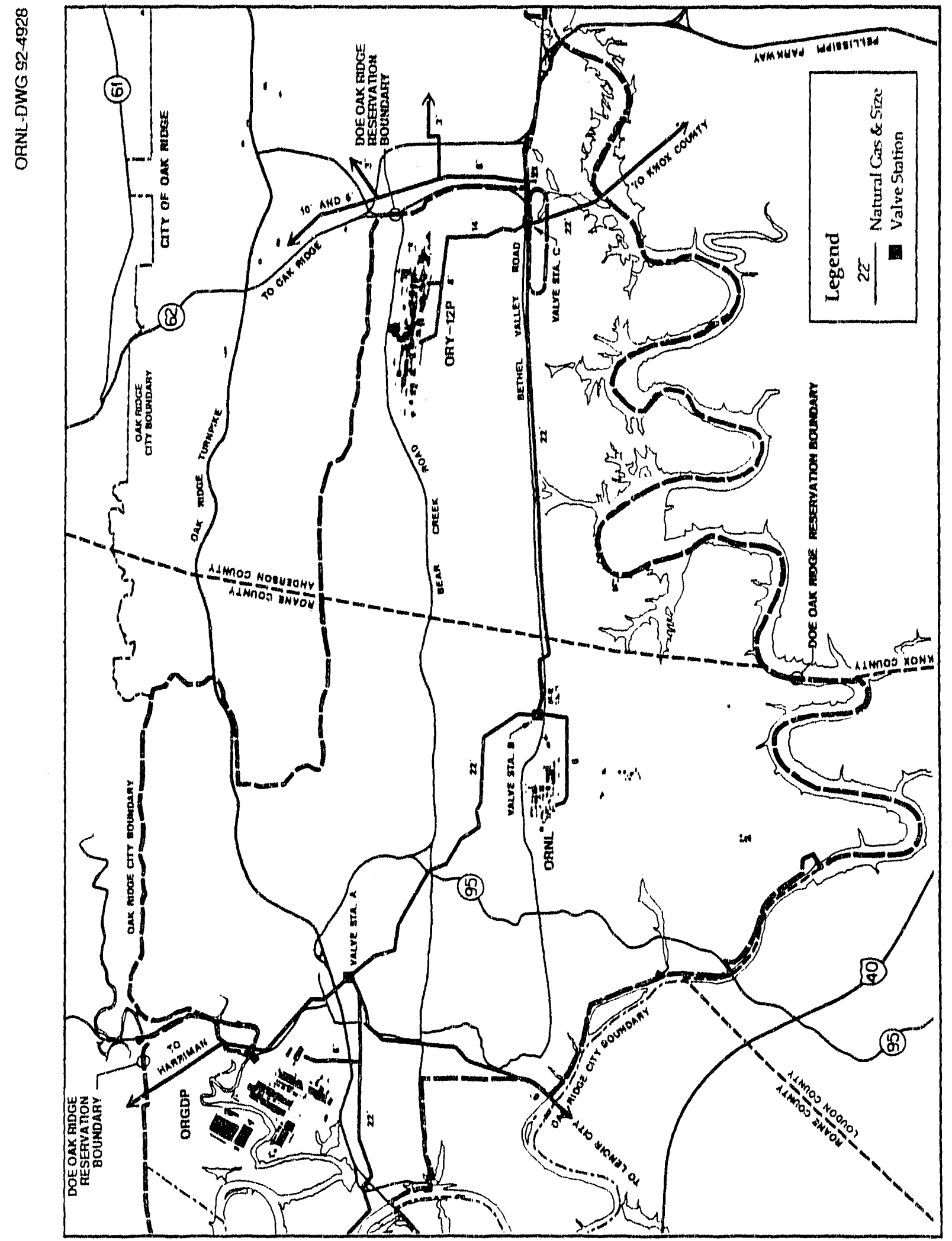

量 







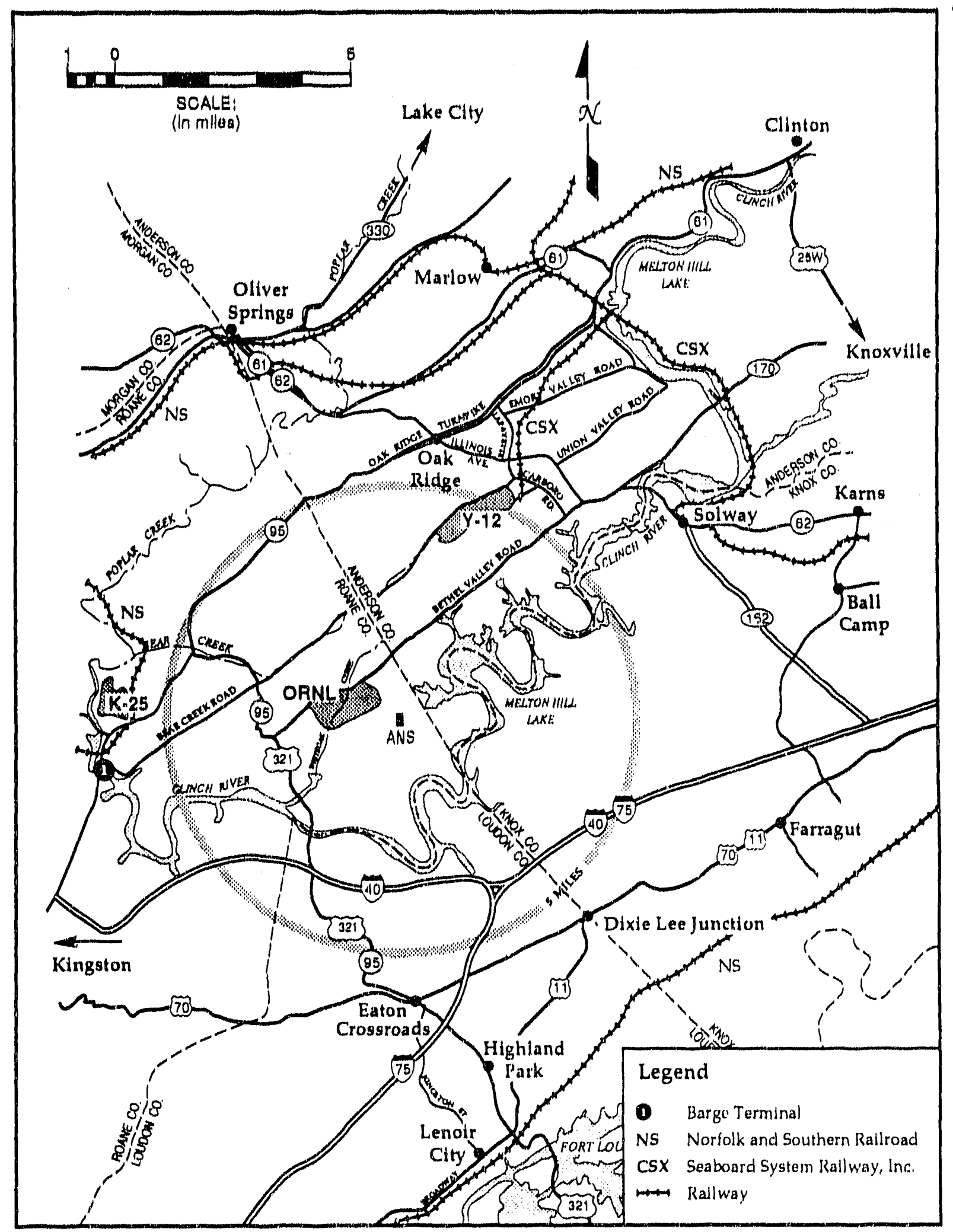

Fig. 21-20. Rail, road, and water facilities in the proposed Advanced Neutron Source (ANS) area. 
Plant communities of ORR are characteristic of those found in the intermountain regions of Appalachia from the Allegheny Mountains in southern Pennsyivania to the southern extension of the Cumberland Mountains in northern Alabama. The dominant association is oak-hickory (Quercus-Carya) forest, although elements of the mixed mesophytic forest commonly found in the Cumberland Mountains are also present in scattered areas. Within all the community types on ORR, 1370 plant species have been identified and listed (Mann and Bierner 1975, p. 1-141).

Oak-hickory forest is extensive on the ORR and ANS sites and, in addition to the dominant oaks and hickories, has many subdominant hardwood species. In these forests, scattered pines and small natural stands dominated by pines are also present. Yellow poplar (Liriodendron tulipifera) often forms nearly pure stands on well-drained bottomlands and lower slopes. Willow (Salix discolor), sycamore (Platanus occidentalis), and box elder (Acer negundo) border streams and are dominant on poorly drained floodplains.

Species more commonly found in the mixed mesophytic association, such as beech (Fagus grandifolia), sugar maple (Acer saccharum), magnolia (Mangolia acuminata), buckeye (Aesculus spp.), and basswood (Tilia americana), often occur in the coves and on the sheltered slopes. In addition, about 1740 ha (4300 acres) of ORR were planted in loblolly pine (Pinus taeda) between 1947 and 1960; smaller areas have since been planted in loblolly pine, black walnut (Juglans nigra), river birch (Betula nigra), sycamore, and yollow poplar (Bradburn 1977, p. 1-64). None of these pine or hardwood plantings are located on the ANS site.

Major plant community types. The major plant communities of ORR have been grouped into seven major categories (Dahlman, Kitchings, and Elwood 1977, pp. 26-29). These are described in the following paragraphs, and their relative abundance on ORR is given in Table 2.2-1.

Pine and pine-handwood. This furest type includes plantations, mostly of loblolly pine (Pinus taeda), and natural forest stands dominated by shortleaf pine (Pinus echinata) and Virginia pine (Pinus virginiana). The plantations are monocultures, whereas the natural pine-dominated forests include oaks (Quercus spp.), hickories (Carya spp.), and yellow poplar. Once, the natural pine-dominated stands occupied relatively large areas (see the vegetation map in Dahlman, Kitchings, and Elwood 1977, p. 27); however, because of natural succession and selective harvesting of pine in this original pinehardwood forest, most areas are now dominated by hardwood species, with small stands of natural pine scattered among the hardwoods. Also, some of the original pine-hardwood forest was cleared and converted to pine plantations during the 1960s and 1970s.

Hemlock, white pine, and hardwood This forest type represents a Southern Appalachian extension of a more northern, higher-elevation forest type. Small stands are present in scattered areas in the western half of the ORR. Hern lock (Tsuga canadensis) and white pine (Pinus strobus) are dominant.

Cedar, cedar-pine, and cedar-hardwood. This vegetation type is extensive in ite southern half of ORR but nearly absent north of Bear Creek Road. It characteristically occurs on shallow limestone (or dolomite) and appears rapidly in nonforested areas following disturbance. Eastern red cedar (Juniperus virginiana) is the predominant species; also present are shortleaf and Virginia pine, yellow poplar, oaks, hickories, redbud (Cercis canadensis), sassafras (Sassafras albidum), and other hardwoods.

Upland hamiwonds. This forest type originally occupied roughly $20 \%$ of ORR's land area. The largest concentrations occurred on Black Oak, East Fork, Pine, Chestnut, and Copper ridges. Because pines were selectively harvested in the original 
Table 22-1. Estimates of the abundance of various habitats on the Oak Ridge Reservation

\begin{tabular}{lc}
\multicolumn{1}{c}{ Habitat $^{\natural}$} & Percent $^{b}$ \\
\hline Pine and pine hardwood & 29.8 \\
Plantations & 14.8 \\
Natural stands & 15.0 \\
Hemlock, white pine, and & 0.3 \\
hardwood & \\
Cedar and open scrub & 3.7 \\
Upland hardwoods & 48.1 \\
Bottomland hardwoods & 2.5 \\
Northern hardwoods & $>1.0$ \\
Nonforest & \\
Fields, old fields, & 7.6 \\
pastures, lawns & 2.6 \\
Roads & 5.3 \\
Rights-of-way & \\
\hline aOther habitats include swamp or marsh (0.1\%) and scrub \\
hardwoods (0.4\%). \\
bFacility areas within fences are not included. There are no facility \\
areas on the proposed Advanced Neutron Source site. \\
Source: Mann, L. K. 1985. Unpublished data, August.
\end{tabular}

pine-hardwood forests, upland forests dominated by hardwoods now occupy a greater percentage (about $48 \%$ ) of ORR. The upland hardwoods type consists primarily of an oak-hickory complex and is the climax type in this region of the eastern United States. Important species include chestnut oak (Quercus prinus), white oak (Quercus alba), black oak (Quercus velutina), northern red oak (Quercus rubra), scarlet oak (Quercus coccinea), post oak (Quercus stellata), various hickories, ash (Fraxinus spp.), yellow poplar, red maple (Acer rubrum), black gum (Nyssa sylvatica), dogwood (Cornus florida), beech, and others. The dominance of white oak is a characteristic feature of the forest communities in this area of the Ridge and Valley Physiographic Province, especially $i$ । valley floors (Braun 1950 , p. 237). On the ridges, black oak increases in abundance, and the forest is a white oak-black oak-hickory type.

Northern hardwoods. Another type of upland hardwood forest is the northern hardwood, which occurs only in very small areas on Blackoak and Copper ridges in the northwestern and southwestern parts, respectively, of ORR. Northern hardwood species composition is similar to upland hardwood forest, with admixtures of gar maple, hemlock, basswood, and buckeye. 
Bottomland handwoods. Bottomland hardwood forest is restricted to floodplains along creek bottoms. It occurs principally along Gum Hollow Creek, Bear Creek, Grassy Creek, White Oak Creek, and Eası Fork Poplar Creek. Dominant species include cottonwood (Populus deltoiaes), sycamore, elm (Ulmus americana), ash, willow, silver maple (Acer saccharinum), and river birch.

Nonforest. Nonforest includes grasslands, devegetated areas, and cultural features. Of two types of grasslands present on ORR, one is uncultivated grassland that is either reverting to forest or is maintained (e.g., under power transmission lines). Dominants are primarily native species, including bluestem (Andropogon spp.), fescue (Festuca spp.), and bluegrass (Poa spp.). The second type is cultivated grassland (lawns and pastures) around the three plant areas (ORNL, the Y-12 Plant, and the K-25 Site) and on lands of the former Comparative Animal Research Laboratory in the eastern half of ORR. Fescues, bluegrass, and orchard grass (Dactylis glomerata) are the predominant giasses.

\section{Vegetation of the proposed Advanced Neutron Source site}

The plant communities of the proposed site are mapped in Fig. 2.2-1.

Area west of the Health Physics Research Reactor (HPRR) access road. There is little topographical variation here, and three drainages join together in the lower areas (Fig. 2.2-1). The vegetation in the low sites is characterized by an overstory of mainly sweet gum (Liquidambar styraziflua), red maple, and green ash (Fraxinus pennsylvanica). The ground cover is primarily Nepal microstegium (Microstegium vimineum) and sedges (Carex $s p$.$) . The more upland sites support immature forests dominated by shortleaf pine$ and virginia pine, with sweet gum, white oak, and blackjack oak (Quercus marilandica) also present. The understury is almost exclusively hardwood, including sweet gum, white oak, hickories, and dogwood. Ground cover consists of Nepal microstegium, panic grass (Panicum sp.), beggar's-lice (Desmodium sp.), and snakeroot (Sanicula sp.). A stand of large, mature white oak is present near the center of this area.

Area east of the HPRR access road. The topography in this area is much more varied and includes some fairly steep slopes. In general, an oak-hickory forest is present, with white oak being the duminant species. Northern red oak and black oak are also common on low and north-facing slop 's; blackjack oak and post oak are common on ridge tops and south-facing slopes. Other important canopy species include shagbark hickory (Carya ovata), mockernut hickory (Carya tomentosa), shortleaf pine, tulip poplar, and sweetgum. Common herbaceous and woody ground cover plants include Nepal microstegium, Panicum sp., pipissewa or spotted wintergreen (Chimaphila maculata), rattlesnake plantain (Goodyera pubescens), wild ginger (Asarum canadense), Christmas fern (Polystichum acrostichoides), poison ivy (Rhus taxicodendron), and Japanese honeysuckle (Lonicera japonica).

The highest ridge on the site supports a forest dominated by pine (Virginia and shortleaf), eastern red cedar, and hickory. Part of this ridge has been cut, resulting in a 

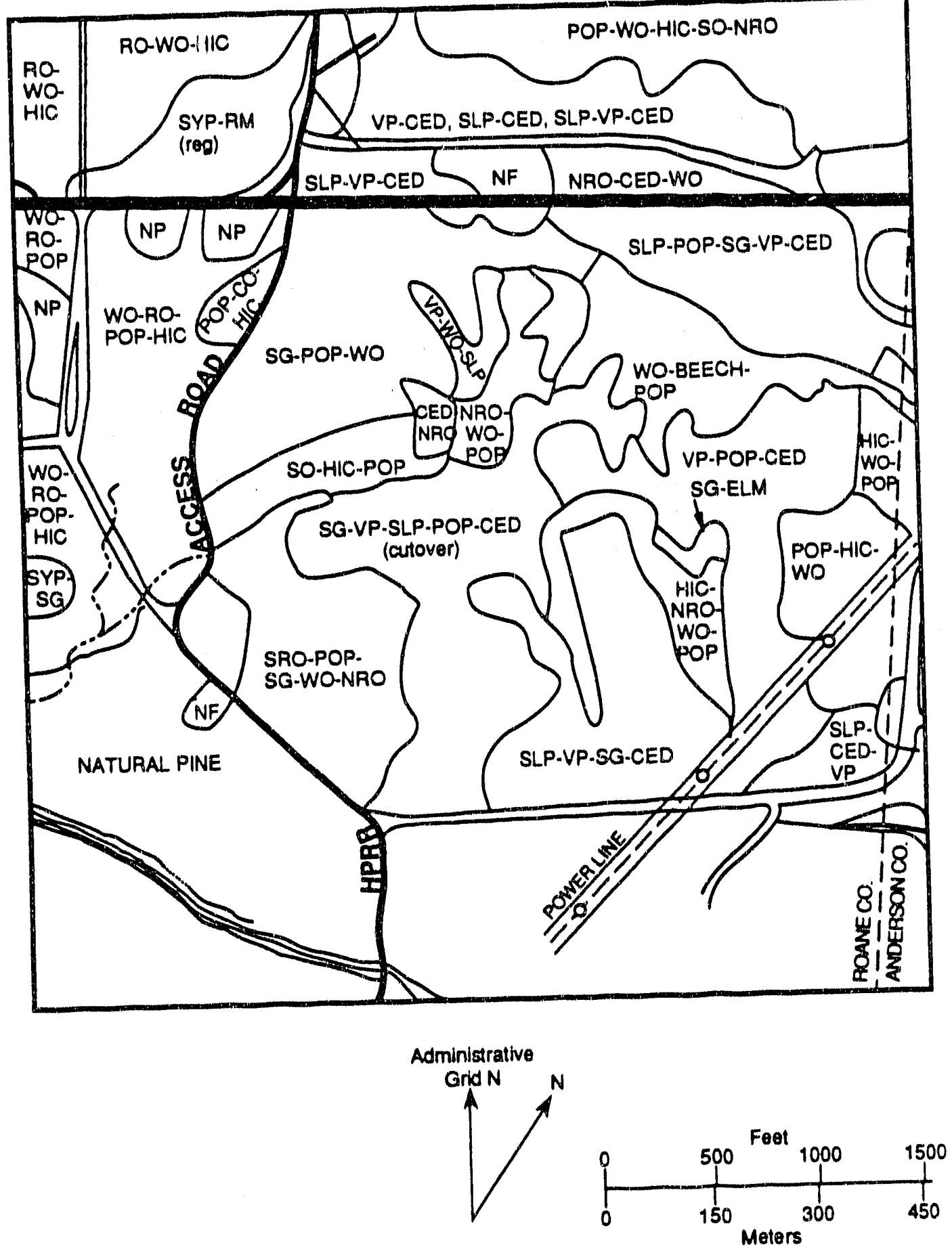

Fig. 22-1. Vegetation map of the proposed Advanced Neutron Source site $\mathrm{CED}=$ cedar, HIC = hickory, NF = nonforested, NP = natural pine, $\mathrm{NRO}=$ northern red oak, $\mathrm{POP}=$ yellow poplar, $\mathrm{RM}=$ red maple, $R O=$ red oak, $S G=$ sweet gum, $S L P=$ short leaf pine, $S R O=$ southern red oak, SYP = southern yellow pine, VP = Virginia pine, WO = white oak. Source: Oak Ridge Reservation Timber Compartment Maps. 
mixture of tree species [hickories, sourwood (Oxydendrum arboreum), eastern red cedar, Virginia pine, etc.] with no clear dominants. Herbaceous ground cover is sparse. On the northfacing slope of this ridge, white oak, northern red oak, and hickories are dominant, along with American beech. The sheltered draws also support eastern hemlock (Tsuga canadensis). The understory includes paw (Asimina triloba), white oak, American beech, and eastern hemlock. Herbaceous ground cover is varied and consists of such species as Christmas fern, wild ginger, and ebony spleenwort (Asplenium platyneuron). The sheltered draws support additional species such as broad beech fern (Thelypteris hexagonoptera), cranefly orchid (Tipularia discolor), foam flower (Tiarella cordifolia), and liverleaf (Hepatica acutiloba).

Other slopes on this ridge are dominated by white oak, chinquapin oak (Quercus muehlenbergii), northern red oak, shortleaf pine, and hickories. The understory consists of the same overstory trees, plus red maple, sweet gum, and tulip poplar. Herbaceous ground cover includes Japanese honeysuckle, poison ivy, panic grass, and cinquefoil (Potentilla sp.).

Two ridge spurs branch off from the main ridge. White oak, hickory spp., and sweetgum are the dominant overstory tree species. The understory is similar to the overstory, with the addition of red maple. Between the ridge spurs runs a small stream. Along this valley, sweetgum and red maple are the dominant overstory and understory tree species, with the addition of American hornbeam (Carpinus caroliniana) in the understory. The herbaceous ground cover is dominated by Nepal microstegium and sedges.

Rare plants. No rare plants have been found on the ANS site, although ginseng (Panax quinquefolia), which is listed as threatened by the state of Tennessee (Sect. 2.2.3), occurs near the site (Fig. 2.2-2).

\subsection{Wetlands}

Various areas along the ephemeral streams on and near the proposed ANS site exhibit wet-site conditions and may be wetlands according to the Federal Manual for Identifying Wetlands (COE et al. 1989, p. 1-86). A review of the soils, hydrology, and vegetation is necessary to determine if the sites are wetlands. The soil and hydrology information is currently being reviewed, and that information will be incorporated when complete. The vegetation is described in the following paragraphs.

West of the HPRR access road. Some intermittent wetland vegetation exists along the three connecting drainages. The overstory vegetation is dominated (greater than $50 \%$ ) by red maple, sweetgum, and green ash, the last two of which are classified as facultative wetland species (Reed 1988, p. 1-124). Herbaceous ground cover consists primarily of Nepal microstegium (facultative), and scattered sedges and reeds (Juncus sp.) (both obligate and facultative wetland).

East of the HPRR access road. Of two possible wetland areas one is less than 0.1 ha $(0.25$ acre) and is located near the access road along a small stream. The construction of the HPRR access road may have caused this wetland. Sweetgum and red maple dominate this site; ground cover consists of Nepal microstegium, with scattered sedges and wetland grasses (Leersia). 

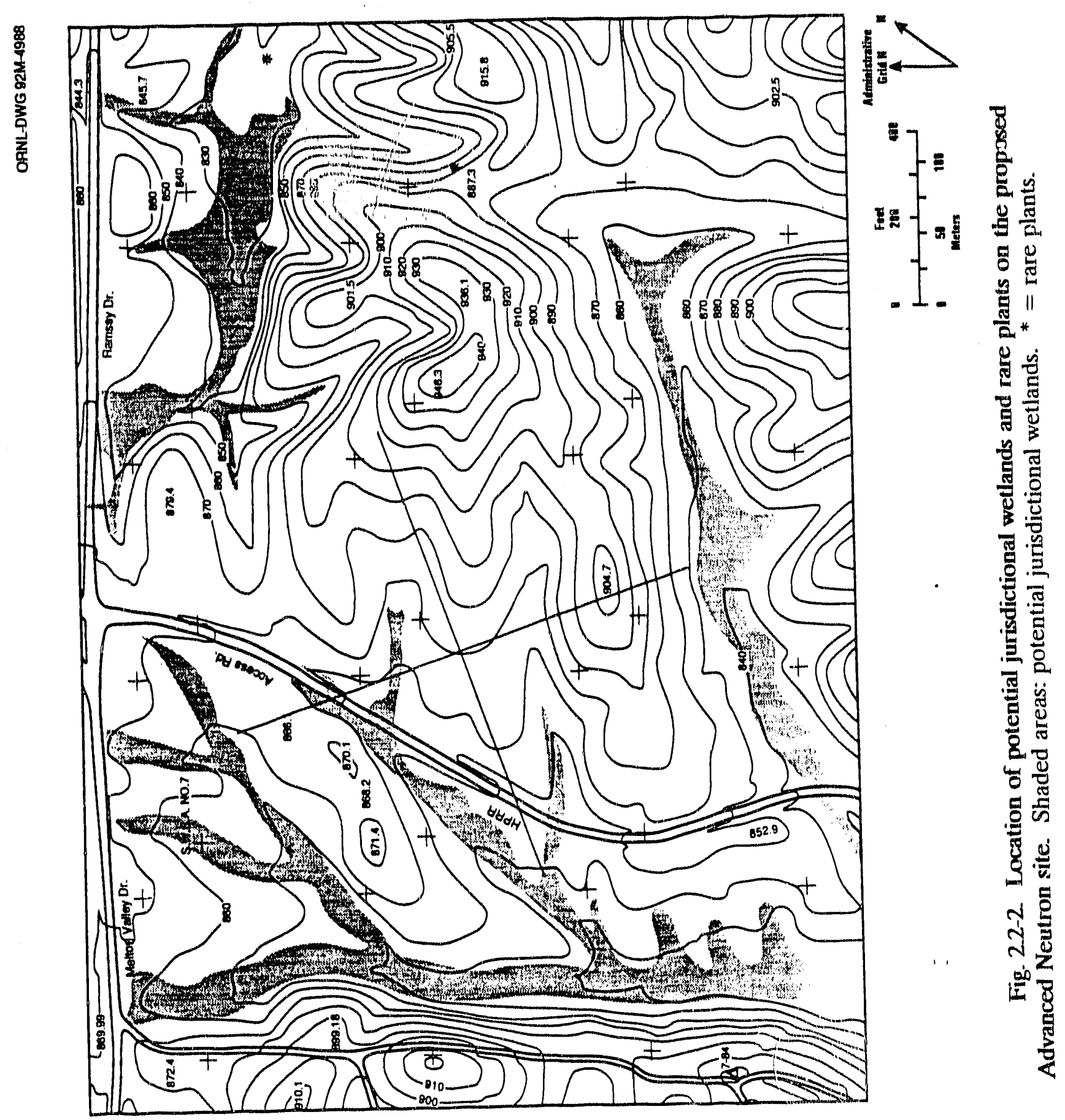
The other possible wetland is along the ephemeral stream in the draw bordering the south side of the ANS site (Fig. 2.2-2). The vegetation of this possible wetland was surveyed at three sites in 1991, and the results are presented in Table 2.2-2. Red maple and sweet gum dominate the overstory vegetation, with slippery elm, American hornbeam, green ash, and dogwood also being common in the midstory. Ground cover consists of microstegium, Japanese honeysuckle (facultative), Lycopus spp. (obligate), poison ivy (not on wetland plant list), Aster spp. (obligate to facultative upland), Juncus spp. (probably obligate, facultative wetland, or facultative), Carex frankii (obligate), and various species of wetland or nonwetland grasses. The herbaceous ground cover is similar to that of the other small wetland site.

Table 22-2. Species composition (percent frequency) of trees, saplings, and shrubs at three sites in the possible wetlands in the draw at the southern boundary of the Advanced Neutron Source site

\begin{tabular}{|c|c|c|c|c|}
\hline $\begin{array}{l}\text { Common } \\
\text { name }\end{array}$ & $\begin{array}{l}\text { Wetland } \\
\text { indicator } \\
\text { status }^{\circ}\end{array}$ & Site 1 & Site 2 & Site 3 \\
\hline Red maple ${ }^{b}$ & & 27 & 37 & 36 \\
\hline Sweet gum & fact & 31 & 14 & 8 \\
\hline Slippery elm & $\mathrm{fac}$ & & 24 & 4 \\
\hline American hornbeam & fac & 9 & 1 & 12 \\
\hline Green ash & facw & 12 & 4 & 6 \\
\hline Flowering dogwood & facu & 8 & 4 & 15 \\
\hline Oak spp. & & 5 & 1 & 3 \\
\hline American sycarnore & facw- & 2 & 1 & 1 \\
\hline Tulip tree & $\mathrm{fac}$ & 1 & 7 & \\
\hline Northern spicebush & facw & & 1 & 11 \\
\hline Pine spp. & & 2 & & \\
\hline Hickory spp. & & 1 & & 1 \\
\hline Eastern redbud & facu & 1 & & \\
\hline Carolina buckthorn & facu & 1 & & \\
\hline Eastern red cedar & facu- & & 5 & \\
\hline Black gum & $\mathrm{fac}$ & & 1 & 1 \\
\hline Black cherry & facu & & & 2 \\
\hline
\end{tabular}

"Common names and wetland indicator status follow Reed, P. R., Jr. 1988. National List of Plants Species that Occur in Wetlands: Southeast Region 2, Biological Report 88 (262), U.S. Department of Interior, Fish and Wildife Service Research and Development, p. $1-124$; fact $=$ a tendency toward more wetland, facw $=$ facultative wetland, facu $=$ facultative upland, facw. $=$ a tendency toward less wetland, and facu $-=$ a tendency toward less upland.

'Acer rubrum could include red maple (facultative), Drummond red maple (obligate), or trident red maple (obligate). 


\subsubsection{Wildlife}

\section{The Oak Ridge Reservation}

Animals whose geographic ranges include the ORR and ANS sites include 70 species of reptiles and amphibians (Conant 1958, p. 366), 140 species of breeding birds (Cook 1969, pp. 63-84), and 70 species of mammals (Simpson 1964, pp. 57-73). Not all of these species would be expected to occur on ORR, however, because not all the habitats required by these species are present. Fauna that have been recorded on ORR include about 60 species of reptiles and amphibians, more than 120 species of migrant and resident birds (excluding 32 species of waterfowl, wading birds, and shorebirds), and about 40 species of mammals. Some of these occur on the ANS site. Species characteristic of various habitats on ORR are listed in Table 2.2-3, and more complete lists of species are given in Tables 2.2-4, 2.2-5, and 2.2-6.

The wildlife information provided in this ER is based on many population surveys of wildlife in certain areas of ORR. These studies were typically limited in scope to small study sites and to certain taxonomic or ecologic groups of species. General overviews of these past surveys are presented by Kitchings and Story 1984 (p. 1-44), Dahlman, Kitchings, and Elwood 1977 (p. 1-83), NRC 1977, Exxon Nuclear Co., Inc. 1976, Kitchings and Mann 1976 (p. 1-58), and Project Management Corporation 1975. Additional research projects involving wildlife surveys include Anderson and Shugart 1974 (pp. 828-837), Anderson, Mann, and Shugart 1977 (pp. 216-221), Kroodsma 1982 (pp. 79-94), Kroodsma 1984a (pp. 426-436), Kroodsma 1984b (pp. 418-425), and Johnson 1964 (p. 1-28). Reconnaissance-level surveys of wildlife habitat on the ANS site were conducted in 1989 and 1991.

Habitats supporting the greatest number of species are those dominated by hardwood tree species, followed by wetlands, old fields, fields (e.g., pastures and cultivated fields), and pine plantations. Hardwoods are required by most species occurring in hardwood-dominated or pine-dominated forests. Of all the reptile, bird, and mammal species that breed on the reservation, only the pine warbler requires pine. Bird species characteristic of old fields require the presence of brushy vegetation such as shrubs, saplings, and blackberry (Rubus).

Most of the species (e.g., wild turkey, red-tailed hawk, red fox, and white-tailed deer) that use more than one habitat type (e.g., forest and fields, Table 2.2-3) are more dependent on the presence of trees, forest, or brush than on the presence of fields. However, limited amounts of cultivated or old fields are beneficial to most of these species. Populations of such species are often densest in predominantly forested areas with small fields interspersed among the forest. Species that require extensive forests and are negatively affected by forest fragmentation may find much suitable habitat on ORR, where forests are less fragmented than in the surrounding countryside.

The Advanced Neutron Source site. The proposed ANS site consists of relatively young, second-growh hardwood forest with an open or sparse understory. The site's wildlife habitat, which is relatively undisturbed, is typical of many forested areas on ORR and supports many spucies of amphibians, reptiles, birds, and mammals. Wildlife diversity and abundance in this relatively young, somewhat even-aged forest would be expected to increase as the forest ages, thus developing greater structural heterogeneity both horizontally and vertically. Important species that occur on the site include the whitetailed deer, bobcat, gray fox, wild turkey, and red-tailed hawk. Although the forest floor includes several small, occasionally wet areas along small streams, these areas do not 


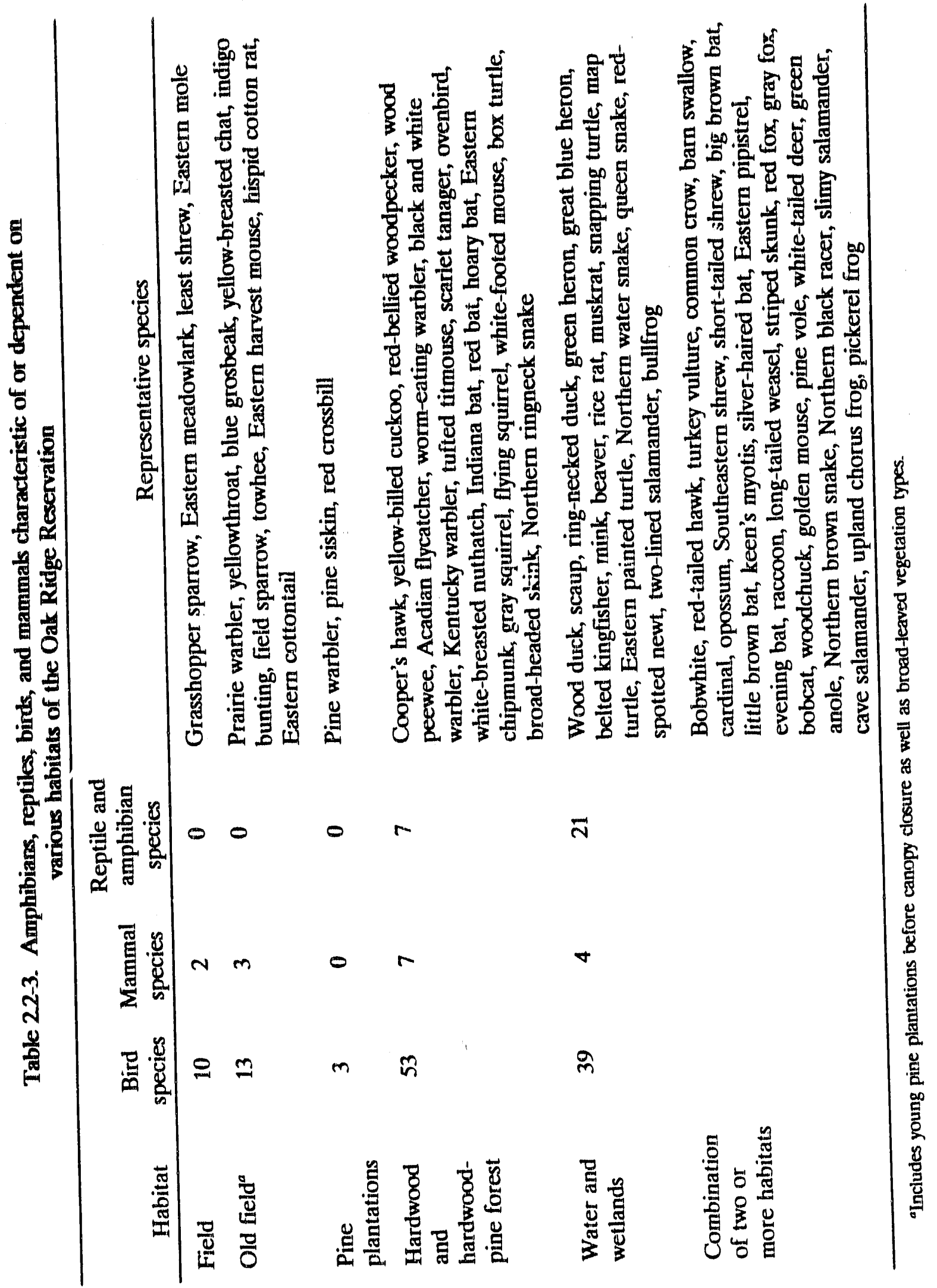


Table 22-4. Bird species of the Oak Ridge Reservation and the proposed Advanced Neutron Source site"

Species

Status

in Oak

Ridge

area
Abundance on

Oak Ridge

Reservation
Breeding density

[pairs/40 ha

(pairs/100 acres),

summer \& perma.

Abundance

nent residents

at ANS site
Wood duck

Black vulture

Turkey vulture

Northern harrier

Sharp-shinned hawk

Cooper's hawk

Northern goshawk.

Red-shouldered hawk

Broad-winged hawk

Red-tailed hawk

American kestrel

Ruffed grouse

Wild turkey

American woodcock

Northern bobwhite

Mourning dove

Black-billed cuckoo

Yellow-billed cuckoo

Common barn-owl

Eastern screech-owl

Great horned owl

Barred owl

Long-eared owl

Short-eared owl

Northern saw-whet owl

Common nighthawk

Chuck-will's-widow

Whippoorwill

Ruby-throated hummingbird

Belted kingfisher

Red-heacled woodpecker

Red-bellied woodpecker

Yellow-hellied sapsucker

Downy woodpecker

Hairy woodpecker

Noi thern flicker

Pileated woodpecker

Olive-sided flycatcher
PR

PR

PR

WV

PR

PR

WV

PR

SR

PR

PR

PR

PR

PR

PR

PR

M

SR

PR

PR

PR

PR

WV

WV

WV

SR

SR

SR

SR

SR

PR

PR

WV

PR

PR

PR

PR

M
C

C

C

R

E

R

R

U

U

C

U

U

C

U

C

C

$\mathrm{N}$

C

$\mathrm{N}$

C

C

C

R

$\mathbf{R}$

R

$\mathbf{R}^{\mathrm{c}}$

$\mathrm{U}^{\mathrm{c}}$

C

C

C

R

A

$\mathrm{U}$

A.

C

C

C

$\mathrm{R}$
R

C

C

E

E

R

R

U

U

C

E

U

R

R

E

E

N

C

E

C

C

C

R

E

R

R

U

U

C

E

E

A

U

C

C

U

C

R

\section{0}

0

0

N/A

0

0

N/A

0

0

0

0

0

0

0

0

0

N/A

5.7

0

$+$

$+$

0.4

N/A

N/A

N/A

0

0.4

0

0.9

0

0

2.2

N/A

0.4

1.1

0.2

0.7

N/A 
Table 22-4. (continued)

\begin{tabular}{|c|c|c|c|c|}
\hline Species & $\begin{array}{l}\text { Status } \\
\text { in Oak } \\
\text { Ridge } \\
\text { area }\end{array}$ & $\begin{array}{l}\text { Abundance on } \\
\text { Oak Ridge } \\
\text { Reservation }\end{array}$ & $\begin{array}{l}\text { Abundance } \\
\text { at ANS site }\end{array}$ & $\begin{array}{l}\text { Breeding density } \\
\text { [pairs } / 40 \text { ha } \\
\text { (pairs } / 100 \text { acres), } \\
\text { summer \& perma. } \\
\text { nent residents } \\
\text { only], SWSA.7 site }\end{array}$ \\
\hline Eastern wood-peewee & SR & $U^{c}$ & $U$ & 0 \\
\hline Yellow-bellied flycatcher & $\mathrm{M}$ & $\mathrm{N}$ & $\mathrm{N}$ & $\mathrm{N} / \mathrm{A}$ \\
\hline Acadian flycatcher & SR & $\mathrm{C}$ & $\mathrm{C}$ & 1.5 \\
\hline Alder flycatcher & $\mathrm{M}$ & $\mathrm{N}$ & $\mathrm{N}$ & N/A \\
\hline Willow flycatcher & SR & $\mathbf{R}$ & $E$ & 0 \\
\hline Least flycatcher & $M$ & $\mathbf{N}$ & $\mathbf{N}$ & N/A \\
\hline Eastern phoebe & PR & $\mathrm{C}$ & $\mathrm{E}$ & 0 \\
\hline Great-crested flycatcher & SR & $\mathrm{C}$ & $\mathrm{U}$ & V \\
\hline Eastern kingbird & SR & $\mathrm{C}^{r}$ & $\mathrm{E}$ & 0 \\
\hline Blue jay & PR & $\mathrm{C}$ & $\mathrm{C}$ & 1.1 \\
\hline American crow & PR & $\mathrm{C}$ & $\mathrm{C}$ & 0.7 \\
\hline Carolina chickadee & PR & A & A & 4.4 \\
\hline Tufted titmouse & PR & C & $\mathrm{C}$ & 3.2 \\
\hline Red-breasted nuthatch & WV & $U$ & U & N/A \\
\hline White-breasted nuthatch & PR & $\mathrm{C}$ & $\mathrm{C}$ & 1.3 \\
\hline Brown creeper & WV & $\mathrm{U}$ & $\mathrm{U}$ & N/A \\
\hline Carolina wren & PR & $\mathrm{C}$ & $\mathrm{C}$ & 1.2 \\
\hline Bewick's wren & PR & $\mathrm{E}$ & $E$ & 0 \\
\hline House wren & SR & $\mathrm{R}^{c}$ & $\mathrm{E}$ & 0 \\
\hline Winter wren & WV & $\mathrm{U}$ & $U$ & N/A \\
\hline Sedge wren & $\mathrm{M}$ & $\mathbf{R}$ & $\mathrm{E}$ & $N / A$ \\
\hline Golden-crowned kinglet & WV & $\mathrm{C}$ & $\mathrm{C}$ & N/A \\
\hline Ruby-crowned kinglet & WV & $\mathrm{C}$ & $\mathrm{C}$ & N/A \\
\hline Blue-gray gnatcatcher & SR & $\mathrm{C}$ & A & 4.4 \\
\hline Eastern bluebird & PR & $\mathrm{C}$ & U & V \\
\hline Veery & M & $\mathrm{N}$ & $\mathrm{N}$ & N/A \\
\hline Gray-cheeked thrush & M & $\mathrm{C}$ & $\mathrm{C}$ & $\mathbf{N} / \mathbf{A}$ \\
\hline Swainson's thrush & M & A & A & N/A \\
\hline Hermit thrush & WV & $\mathrm{C}$ & $C$ & N/A \\
\hline Wood thrush & SR & A & $\mathrm{C}$ & 0.9 \\
\hline American robin & PR & $U^{d}$ & U & 0.2 \\
\hline Gray catbird & SR & $\mathrm{U}^{c}$ & U & 0 \\
\hline Northern mockingbird & PR & $\mathrm{C}^{\bullet}$ & $\mathrm{U}$ & 0 \\
\hline Brown thrasher & PR & $U^{c}$ & U & 0 \\
\hline Cedar waxwing & PR & $U^{c}$ & $\mathrm{E}$ & 0 \\
\hline Loggerhead shrike & PR & $\mathbf{R}$ & $\mathrm{E}$ & 0 \\
\hline European starling & PR & $C^{*}$ & $\mathbf{R}$ & 0 \\
\hline Red-eyed vireo & SR & A & A & 7.5 \\
\hline White-eyed vireo & SR & $\mathrm{C}$ & $U$ & 0 \\
\hline
\end{tabular}


Table 22-4. (continued)

\begin{tabular}{|c|c|c|c|c|}
\hline Species & $\begin{array}{l}\text { Status } \\
\text { in Oak } \\
\text { Ridge } \\
\text { area }\end{array}$ & $\begin{array}{l}\text { Abundance on } \\
\text { Oak Ridge } \\
\text { Reservation }\end{array}$ & $\begin{array}{l}\text { Abundance } \\
\text { at ANS site }\end{array}$ & $\begin{array}{l}\text { (pairs/100 acres), } \\
\text { summer \& perma- } \\
\text { nent residents } \\
\text { only], SWSA-7 site }\end{array}$ \\
\hline Solitary vireo & $M$ & $U$ & $U$ & $N / A$ \\
\hline Yellow-throated vireo & SR & $U$ & $U$ & 0.9 \\
\hline Warbling vireo & M & $\mathrm{N}$ & $N$ & N/A \\
\hline Philadelphia vireo & M & $N$ & $\mathrm{~N}$ & $\mathrm{~N} / \mathrm{A}$ \\
\hline Blue-winged warbler & SR & $\mathrm{R}$ & $\mathrm{E}$ & 0 \\
\hline Golden-winged warbler & M & $N$ & $\mathrm{~N}$ & N/A \\
\hline Tennessee warbler & M & $\mathrm{C}$ & $\mathrm{C}$ & $\mathrm{N} / \mathrm{A}$ \\
\hline Orange-crowned warbler & M & $N$ & $\mathrm{~N}$ & $N / A$ \\
\hline Nashville warbler & M & $\mathrm{N}$ & $\mathrm{N}$ & N/A \\
\hline Northern parula & SR & $U^{d}$ & $\mathrm{C}$ & 3.9 \\
\hline Yellow warbler & SR & $U$ & $\mathrm{E}$ & 0 \\
\hline Chestnut-sided warbler & $\mathbf{M}$ & $N$ & $\mathrm{~N}$ & $\mathrm{~N} / \mathrm{A}$ \\
\hline Magnolia warbler & $M$ & $\mathrm{~N}$ & $\mathrm{~N}$ & $N / A$ \\
\hline Cape May warbler & M & $\mathrm{C}$ & $\mathrm{N}$ & N/A \\
\hline Black-throated blue warbler & - $M$ & $N$ & $\mathrm{~N}$ & N/A \\
\hline Yellow-rumped warbler & WV & $\mathrm{C}$ & $\mathrm{C}$ & $\mathrm{N} / \mathrm{A}$ \\
\hline Black-throated green & & & & \\
\hline warbler & M & $\mathrm{C}$ & C & N/A \\
\hline Blackburnian warbler & M & $\mathrm{N}$ & $\mathrm{N}$ & N/A \\
\hline Yellow-throated warbler & SR & $U^{c}$ & $\mathrm{C}$ & 1.8 \\
\hline Pine warbler & SR & $\mathrm{C}$ & $\mathrm{U}$ & 0.9 \\
\hline Prairie warbler & SR & A & $E$ & 0 \\
\hline Palm warbler & M & $N$ & $N$ & $\mathrm{~N} / \mathrm{A}$ \\
\hline Bay-breasted warbler & M & $\mathrm{C}$ & $\mathrm{C}$ & N/A \\
\hline Cerulean warbler & SR & $U^{d}$ & $\mathrm{E}$ & 0 \\
\hline Black-and-white warbler & $\mathrm{SR}$ & $\mathrm{U}$ & $\mathrm{U}$ & 0 \\
\hline American redstart & $\mathrm{M}$ & $\mathbb{N}$ & $N$ & $\mathrm{~N} / \mathrm{A}$ \\
\hline Prothonotary warbler & SR & $U^{c}$ & $\mathrm{E}$ & 0 \\
\hline Worm-eating warbler & SR & $U$ & $\vec{E}$ & 0 \\
\hline Swainson's warbler & SR & $E$ & $\bar{E}$ & 0 \\
\hline Ovenbird & SR & $\mathrm{C}$ & $\bar{C}$ & 4.4 \\
\hline Northern waterthrush & $\mathrm{M}$ & $\mathrm{N}$ & $\mathrm{N}$ & $\mathrm{N} / \mathrm{A}$ \\
\hline Louisiana waterthrush & SR & $U$ & $\mathrm{U}$ & 0.4 \\
\hline Kentucky warbler & SR & $\mathrm{C}$ & $U$ & 0.9 \\
\hline Connecticut warbler & $M$ & $\mathrm{~N}$ & $\mathrm{E}$ & N/A \\
\hline Mourning warbler & $\mathrm{M}$ & $N$ & $\mathrm{E}$ & $\mathrm{N} / \mathrm{A}$ \\
\hline Common yellowthroat & SR & $\mathrm{C}$ & $\mathrm{E}$ & 0 \\
\hline Hooded warbler & $\mathrm{SR}$ & $\mathrm{C}$ & $\mathrm{U}$ & 0 \\
\hline Wilson's warbler & $\mathrm{M}$ & $N$ & $\mathrm{~N}$ & N/A \\
\hline
\end{tabular}

Breeding density Ipairs/40 ha (pairs/100 acres), summer \& perma. nent residents only], SWSA-7 site

Solitary vireo

Yellow-throated vireo

Tennessee warbler

Orange-crowned warbler

Chestnut-sided warbler

Magnolia warbler

Cape May warbler

Black-throated blue warbler

Yellow-rumped warbler

Black-throated green

warbler

Blackburnian warbler

Yellow-throated warbler

Pine warbler

Prairie warble

Palm warbler

Bay-breasted warble

Swainson's warbler

Ovenbird

Northern waterthrush

Louisiana waterthrush

Kentucky warbler

Connecticut warbler

Mourning warbler

Hooded warbler

Wilson's warbler

M

Oak Ridge

at ANS site
N/A

N/A

N/A

$N / A$

$N / A$

N/A

3.9

N/A

$N / A$

N/A

N/A

N/A

N/A

0.9

N/A

$\mathrm{N} / \mathrm{A}$

N/A

N/A

0.4

$\mathrm{N} / \mathrm{A}$

N/A

0 
Table 22-4. (continued)

\begin{tabular}{|c|c|c|c|c|}
\hline Species & $\begin{array}{l}\text { Status } \\
\text { in Oak } \\
\text { Ridge } \\
\text { area }\end{array}$ & $\begin{array}{l}\text { Abundance on } \\
\text { Oak Ridge } \\
\text { Reservation }\end{array}$ & $\begin{array}{l}\text { Abundance } \\
\text { at ANS site }\end{array}$ & $\begin{array}{l}\text { Breeding density } \\
\text { [pairs/40 ha) } \\
\text { (pairs } / 100 \text { acres), } \\
\text { summer \& perma. } \\
\text { nent residents } \\
\text { only], SWSA-7 site }\end{array}$ \\
\hline Canada warbler & $M$ & $\mathrm{~N}$ & $\mathbf{N}$ & $\mathbf{N} / \mathbf{A}$ \\
\hline Yellow-breasted chat & SR & $\mathrm{C}$ & U & 0 \\
\hline Summer tanager & SR & $\mathrm{C}$ & $U$ & 0.2 \\
\hline Scarlet tanager & SR & $\mathrm{C}$ & $\mathrm{C}$ & 0.4 \\
\hline Northern cardinal & PR & $\mathrm{C}$ & $\mathrm{C}$ & 1.8 \\
\hline Rose-breasted grosbeak & $\mathrm{M}$ & $\mathrm{C}$ & $\mathrm{C}$ & N/A \\
\hline Blue grosbeak & SR & $\mathrm{C}$ & $\mathbf{E}$ & 0 \\
\hline Indigo bunting & SR & A & A & 3.7 \\
\hline Dickcissel & M & $\mathbf{N}$ & $E$ & $N / A$ \\
\hline Rufous-sided towhee & PR & $\mathrm{C}$ & $U$ & 0 \\
\hline Bachman's sparrow & SR & $\mathbf{R}$ & $\mathrm{E}$ & 0 \\
\hline Chipping sparrow & SR & $\mathrm{U}^{\mathrm{c}}$ & $\mathbf{R}$ & 0 \\
\hline Field sparrow & PR & $\mathrm{C}$ & $\mathrm{E}$ & 0 \\
\hline Vesper sparrow & WV & $\mathbf{N}$ & $\bar{N}$ & N/A \\
\hline Lark sparrow & $\mathrm{M}$ & $\mathbf{R}$ & $\mathrm{E}$ & N/A \\
\hline Savannah sparrow & WV & $\ddot{U}$ & $\mathbf{E}$ & $\mathrm{N} / \mathrm{A}$ \\
\hline Grasshopper sparrow & SR & $\mathrm{U}^{d}$ & $\mathrm{E}$ & 0 \\
\hline Henslow's sparrow & $M$ & $\mathrm{R}$ & $\bar{E}$ & N/A \\
\hline Le Conte's sparrow & $\mathbf{M}$ & $\mathbf{N}$ & $\mathrm{E}$ & N/A \\
\hline Sharp-tailed sparrow & $\mathrm{M}$ & $\mathbf{N}$ & $\mathrm{E}$ & $\mathrm{N} / \mathrm{A}$ \\
\hline Fox sparrow & WV & $\mathbf{R}$ & $\bar{R}$ & $\mathrm{~N} / \mathrm{A}$ \\
\hline Song sparrow & WV & $\vec{R}$ & $\vec{R}$ & $\mathrm{~N} / \mathrm{A}$ \\
\hline Lincoln's sparrow & $\mathrm{M}$ & $\mathbf{N}$ & $\mathrm{N}$ & $\mathrm{N} / \mathrm{A}$ \\
\hline Swamp sparrow & WV & U & $E$ & N/A \\
\hline White-throated sparrow & WV & $\mathrm{C}$ & $\mathrm{C}$ & N/A \\
\hline White-crowned sparrow & WV & $\mathrm{U}$ & $\mathrm{E}$ & N/A \\
\hline Dark-eyed junco & WV & $\mathrm{C}$ & $\bar{U}$ & $\mathrm{~N} / \mathrm{A}$ \\
\hline Red-winged blackbird & PR & $C^{\circ}$ & $\mathrm{E}$ & 0 \\
\hline Eastern meadowlark & PR & $\mathrm{C}$ & $E$ & 0 \\
\hline Rusty blackbird & WV & $\mathbf{R}$ & $\overrightarrow{\mathbf{R}}$ & $\mathrm{N} / \mathrm{A}$ \\
\hline Brewer's blackbird & WV & $\mathbf{R}$ & $\ddot{R}$ & $\mathrm{~N} / \mathrm{A}$ \\
\hline Common grackle & PR & $\mathrm{C}$ & $\dot{U}$ & $\mathrm{~V}$ \\
\hline Brown-headed cowbird & PR & $\mathrm{C}$ & $\mathrm{C}$ & V \\
\hline Orchard oriole & SR & $C^{c}$ & $E$ & 0 \\
\hline Northern oriole & SR & $\mathbf{R}$ & $\mathrm{E}$ & 0 \\
\hline Purple finch & WV & $\mathrm{C}$ & $\mathrm{U}$ & $\mathrm{N} / \mathrm{A}$ \\
\hline House finch & PR & $\mathrm{U}$ & $E$ & 0 \\
\hline Red crossbill & WV & $\mathbf{R}$ & $\mathrm{R}$ & $N / A$ \\
\hline Pine siskin & WV & U & $\mathrm{U}$ & N/A \\
\hline
\end{tabular}


Table 22-4. (continued)

\begin{tabular}{lllll} 
Species & $\begin{array}{l}\text { Status } \\
\text { in Oak } \\
\text { Ridge } \\
\text { area }\end{array}$ & $\begin{array}{l}\text { Abundance on } \\
\text { Oak Ridge } \\
\text { Reservation }\end{array}$ & $\begin{array}{l}\text { Abundance } \\
\text { at ANS site }\end{array}$ & $\begin{array}{l}\text { (pairs/100 acres), } \\
\text { dummer \& perma. } \\
\text { nent residents } \\
\text { only], SWSA.7 site }\end{array}$ \\
\hline $\begin{array}{l}\text { American goldfinch } \\
\text { Evening grosbeak }\end{array}$ & PR & C & E & 0 \\
\hline
\end{tabular}

Breeding density (pairs/40 ha) (pairs $/ 100$ acres), in Oak Abundance on Ridge Oak Ridge Abundance nent residents only], SWSA-7 site

\footnotetext{
"Explanation: Only those species for which sultable habitat may be present on the site are included. For summer and permanent residents, the abundance notation for the ANS site reflects abundance only during the breeding season and does not apply to fall, spring, or winter seasons. No swallows or swifts are included, although they regularty occur overhead at the site. $P R=$ permanent resident, $S R=$ summer resident, $W V=$ winter visitor, $M=$ occurs exclustvely or almost exclustvely during inigration, $A=$ abundant, $C=$ common, $U=$ uncommon, $R=$ rare, $V=$ visitor, $N=$ no information but probably uncommon or rare, $\mathrm{E}=$ probably absent as a breeder at the site $+=$ probably present but missed during 1985 surveys. $0=$ birds present on ORR but not recorded on SWSA.7. N/A $=$ not applicable. Common names of spectes are according to the 34th Supplement to the American Ornithologist's Unlon Check-list of North American Birds, Supplement to The Auk, Vol, 99, No. 3, July 1982.

The Solld Waste Storage Area 7 (SWSA-7) site is adjacent to the ANS site, and a 198.5 survey of birds on the SWSA.7 site (Krondsma, R. L. 1985, Ecological Characterization of Terrestrial Biota of the Proposed Solld Waste Storage Area (SWSA) 7, unpublished report, Oak Ridge Natlonal Laboratory, Oak Ridge, Tenn., p. 1-A4) is considered approxdmately representative of bird populations on the ANS site.

Locally common in region.

"Locally uncommon in region.

Tocalty abundant in region.
}

provide suitable habitat for wildlife that are typically thought of as wildlife species of marshes or swamps (e.g., herons, muskrats, or ducks). No significant stresses on wildlife (e.g., clearcutting and industrial facilities) exist on the site.

\subsection{Aquatic Ecology}

Surface water runoff during construction and operation of the ANS facility could affect aquatic biota in two small streams: the upper reaches of Melton Branch and Friendship Creek, a tributary to Bearden Creek. (Fig. 2.2-3). In addition, cooling tower blowdown may be discharged into Melton Branch. Process and sanitary wastewaters gencrated by the ANS are expected to be treated by existing ORNL treatment facilities (e.g., the CRNL Sewage Treatment Plant and the Nonradiological Wastewater Treatment Facility) and discharged to White Oak Creek.

\subsubsection{Inventory of Aquatic Species}

The following sections describe the aquatic communities of the three streams that could be impacted by construction and operation of ANS. 
Table 22-5. Mammal species and their habitat preferences on the Oak Ridge Reservation ${ }^{a}$

\begin{tabular}{|c|c|c|c|c|c|}
\hline Species & Abundance & Wetlands & $\begin{array}{l}\text { Old } \\
\text { fields }\end{array}$ & $\begin{array}{l}\text { Hardwood } \\
\text { forest }\end{array}$ & $\begin{array}{l}\text { Pine } \\
\text { forest }\end{array}$ \\
\hline Opossum & $\mathrm{C}$ & & $\mathrm{x}$ & $\mathrm{x}$ & $\mathrm{x}$ \\
\hline Short-tailed shrew & C & & & $x$ & \\
\hline Least shrew & $\mathbf{R}$ & & $\mathrm{x}$ & & \\
\hline Eastern mole & $\vec{R}$ & & $\mathrm{x}$ & & \\
\hline Southeastern shrew & R & & & $\mathbf{x}$ & \\
\hline Big brown bat & $\mathrm{N}$ & $\mathrm{X}$ & $\mathrm{x}$ & $\mathrm{X}$ & \\
\hline Silver-haired bat & C & $\mathrm{x}$ & $\mathrm{x}$ & $\mathrm{x}$ & \\
\hline Red bat & C & $\mathrm{X}$ & $\mathrm{x}$ & $\mathrm{x}$ & \\
\hline Hoary Bat & $\mathrm{U}$ & $\mathrm{x}$ & $\mathbf{x}$ & $\mathrm{x}$ & \\
\hline Keen's myotis & $\mathbf{R}$ & $\mathrm{x}$ & $\mathbf{X}$ & $\mathrm{x}$ & \\
\hline Little brown bat & C & $\mathbf{x}$ & $\mathbf{x}$ & $\mathbf{x}$ & \\
\hline Indiana myotis & $\mathrm{E}$ & $\mathrm{X}$ & $\mathrm{x}$ & $\mathrm{x}$ & \\
\hline Evening bat & C & $\mathbf{x}$ & $\mathbf{x}$ & $\mathbf{x}$ & \\
\hline Eastern pipistrel & C & $\mathbf{x}$ & $\mathrm{x}$ & $\mathbf{x}$ & \\
\hline Eastern cottontail & C & & $\mathbf{x}$ & $\mathrm{x}$ & $\mathrm{X}$ \\
\hline Beaver & E & $\mathbf{x}$ & & & \\
\hline Southern flying squirrel & $\mathrm{C}$ & & & $\mathbf{x}$ & \\
\hline Woodchuck & C & & $\mathbf{x}$ & $\mathbf{x}$ & $\mathbf{x}$ \\
\hline Pine vole & $\mathrm{C}$ & & $\mathbf{x}$ & & \\
\hline House mouse & $\mathrm{U}$ & & $\mathbf{x}$ & & \\
\hline Golden mouse & C & & & $\mathrm{x}$ & $\mathbf{x}$ \\
\hline Muskrat & C & $\mathrm{x}$ & & & \\
\hline Marsh rice rat & $\mathrm{U}$ & $\mathbf{x}$ & $\mathrm{x}$ & & \\
\hline White-footed mouse & C & & & $\mathrm{x}$ & \\
\hline Norway rat & $\mathrm{U}$ & & $\mathbf{x}$ & & \\
\hline Eastern harvest mouse & $\mathrm{U}$ & & $\mathbf{x}$ & & \\
\hline Gray squirrel & C & & & $\mathbf{x}$ & \\
\hline Hispid cotton rat & $\mathrm{C}$ & $\mathbf{x}$ & $\mathbf{x}$ & & \\
\hline Eastern chipmunk & C & & & $\mathrm{x}$ & \\
\hline Bobcat & $\mathbf{U}$ & $\mathrm{x}$ & $\mathrm{x}$ & $\mathbf{x}$ & $\mathbf{x}$ \\
\hline Striped skunk & $\mathrm{C}$ & $\mathrm{x}$ & $\mathbf{X}$ & $\mathbf{x}$ & \\
\hline Long-tailed weasel & $U$ & $\mathrm{x}$ & $\mathbf{X}$ & $\mathrm{x}$ & \\
\hline Mink & $\mathrm{U}$ & $\mathrm{x}$ & & & \\
\hline Raccoon & U & $\mathrm{x}$ & $\mathbf{x}$ & $\mathrm{x}$ & \\
\hline Gray fox & C & $\mathrm{x}$ & $\mathbf{X}$ & $\mathrm{x}$ & $\mathrm{X}$ \\
\hline Red fox & $\mathrm{C}$ & $\mathrm{x}$ & $\mathrm{x}$ & $\mathrm{x}$ & $\mathrm{x}$ \\
\hline White-tailed deer & C & $\mathrm{x}$ & $\mathrm{x}$ & $\mathrm{x}$ & $\mathrm{x}$ \\
\hline
\end{tabular}

Explanation: $\mathrm{C}=$ common, $\mathrm{U}=$ uncommon, $\mathrm{R}=$ rare, $\mathrm{N}=$ no information but probably uncommon or rare, $E=$ probably absent at the site, $X=$ preferred habitat.

Source: Modified from Dahiman, R. C., et al. 1977. Land and Water Resources for Environmental Research on the Oak Ridge Reservation, ORNL/TM-5352, Oak Ridge National Laboratory, Oak Ridge, Tenn., p. 1-83. 
Table 22-6. Amphibian and reptilian species and their habitat preferences on the Oak Ridge Reservation and Advanced Neutron Source site"

\begin{tabular}{|c|c|c|}
\hline Species & $\begin{array}{l}\text { Number } \\
\text { collected }\end{array}$ & Habitat \\
\hline Spotted salamander & $1^{b}$ & Pond, pool, spring branch, marsh \\
\hline Red-spotted newt & $\begin{array}{c}1^{c} \\
25^{d}\end{array}$ & $\begin{array}{l}\text { Upland and floodplain forest (left), pond } \\
\text { (adult and larvae) }\end{array}$ \\
\hline Dusky salamander & $\begin{array}{l}34^{b} \\
14^{d}\end{array}$ & $\begin{array}{l}\text { Spring, spring branch, spring seep, stream, } \\
\text { marsh }\end{array}$ \\
\hline Slimy salamander & $4^{b}$ & Upland and floodplain forest, cave \\
\hline Northern red salamander & $\begin{array}{l}2^{b} \\
1^{d}\end{array}$ & Spring, spring seep, marsh, pool \\
\hline Two-lined salamander & $\begin{array}{c}4^{e} \\
12^{d}\end{array}$ & Spring, spring seep and branch, pool, marsh \\
\hline Cave salamander & $6^{b}$ & Caves \\
\hline Eastern spadefoot toad & 15 & Pools in ruderous areas and old fields \\
\hline American toad & 9 & $\begin{array}{l}\text { Upland and floodplain forest, old field, } \\
\text { ruderous area }\end{array}$ \\
\hline Fowler's toad & 10 & $\begin{array}{l}\text { Upland and floodplain forest, old field, } \\
\text { ruderous area }\end{array}$ \\
\hline Northern cricket frog & 16 & Pond, marsh, stream, embayment \\
\hline Spring peeper & heard & Pool, pond, marsh \\
\hline Gray treefrog & 23 & Pool, pond, marsh, forest \\
\hline Chorus frog & heard & Pool, pond, spring seep, marsh \\
\hline $\begin{array}{l}\text { Eastern narrow-mouthed } \\
\text { toad }\end{array}$ & 58 & Pond, pool, old field, ruderous area \\
\hline Bullfrog & 3 & Pond, stream \\
\hline Green frog & 8 & Pond, stream \\
\hline Leopard frog & 22 & $\begin{array}{l}\text { Pond, pool, marsh, spring seep, floodplain } \\
\text { forest }\end{array}$ \\
\hline Pickerel frog & 4 & $\begin{array}{l}\text { Pond, pool, stream, spring branch, } \\
\text { floodplain forest }\end{array}$ \\
\hline Box turtle & 6 & $\begin{array}{l}\text { Floodplain and upland forest, old field, } \\
\text { ruderous area }\end{array}$ \\
\hline Northern fence lizard & 6 & Upland forest, old field, ruderous area \\
\hline Six-lined racerunner & 5 & Ruderous area, old field-transition, old field \\
\hline Ground skink & 3 & $\begin{array}{l}\text { Upland and floodplain forest, old field- } \\
\text { transition }\end{array}$ \\
\hline Five-lined skink & 6 & $\begin{array}{l}\text { Floodplain and upland forest, old field- } \\
\text { transition, mixed hardwood and pine }\end{array}$ \\
\hline Broad-headed skink & 1 & Floodplain and upland forest \\
\hline Queen snake & 6 & Stream, fluvial \\
\hline Water snake & 7 & Stream, fluvial, spring branch, pond, marsh \\
\hline Brown snake & 1 & $\begin{array}{l}\text { Old field, upland forest, mixed hardwood } \\
\text { and pine }\end{array}$ \\
\hline Red-bellied snake & 1 & Upland forest, old field \\
\hline
\end{tabular}


Table 22-6. (continued)

\begin{tabular}{|c|c|c|}
\hline Species & $\begin{array}{l}\text { Number } \\
\text { collected }\end{array}$ & Habitat \\
\hline Eastern garter snake & 9 & Old field, floodplain forest, pond \\
\hline Eastern earth snake & 1 & $\begin{array}{l}\text { Old field, upland forest, mixed hardwood } \\
\text { and pine }\end{array}$ \\
\hline Northern ringneck snake & 6 & Upland and floodplain forest, spring seep \\
\hline Worm snake & 14 & Upland and floodplain forest, old field \\
\hline Black racer & 7 & $\begin{array}{l}\text { Old field, upland and floodplain forest, } \\
\text { mixed hardwood and pine, ruderous area }\end{array}$ \\
\hline Rough green snake & 2 & Old field \\
\hline Corn snake & 4 & Old field, upland and floodplain forest \\
\hline Rat snake & 5 & Old field, upland and floodplain forest \\
\hline Mole snake & 1 & Old field, mixed hardwood and pine \\
\hline Black kingsnake & 3 & $\begin{array}{l}\text { Old field, mixed hardwood and pine, upland } \\
\text { forest }\end{array}$ \\
\hline Eastern milksnake & 3 & Upland forest, mixed hardwood and pine \\
\hline Scarlet snake & 1 & Upland forest, mixed hardwood and pine \\
\hline Northern copperhead & 5 & $\begin{array}{l}\text { Upland and floodplain forest, mixed } \\
\text { hardwood and pine, old field }\end{array}$ \\
\hline
\end{tabular}

"Species and number of specimens were collected at the Oak Ridge Reservation by Johnson (1964, p. 1-28); species that were not collected but which Johnson expected to occur in the area are red-backed salamander, spring salamander, long-tailed salamander, green anole, slender glass lizard, hognose snake, and crowned snake.

Adult(s).

Eft.

Larvac.

"Subadults.

\section{Friendship Creek}

The fish and benthic macroinvertebrate communities of this small stream were surveyed in June and July 1989 (Smith and Ryon 1989, pp. 1-6). Electrofishing of approximately $250 \mathrm{~m}(825 \mathrm{ft})$ of stream near the proposed ANS site failed to produce any fish, although numerous salamander larvae (principally Desmognathus and Gyrinophilus) were observed. Qualitative sampling of benthic macroinvertebrates indicated a relatively diverse fauna characteristic of undisturbed or only moderately disturbed streams on ORR. Insect taxa that are usually associated with good water quality (e.g., mayflies and the caddis fly Diplectrona) were collected (Table 2.2-7). Fish and aquatic invertebrates are probably most limited by the seasonally intermittent flows of this small tributary stream. 
2.59

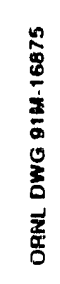
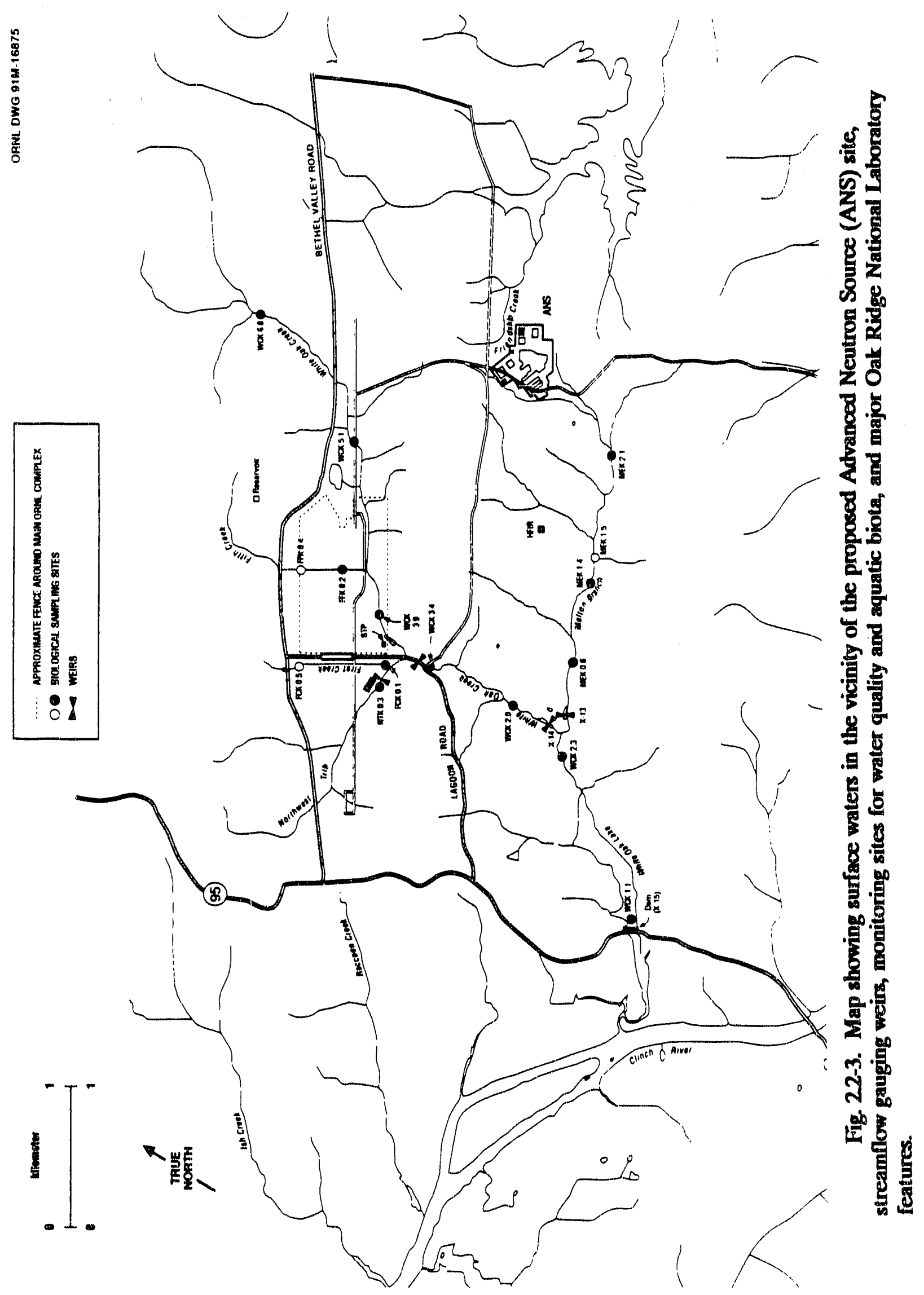

คำ है है

줄 
Table 22-7. Checklist of the benthic macroinvertebrates collected from upper Melton Branch [above kilometer 21 (mile 1.31) and Friendship Creek on June 30 and July 5, 1989, respectively

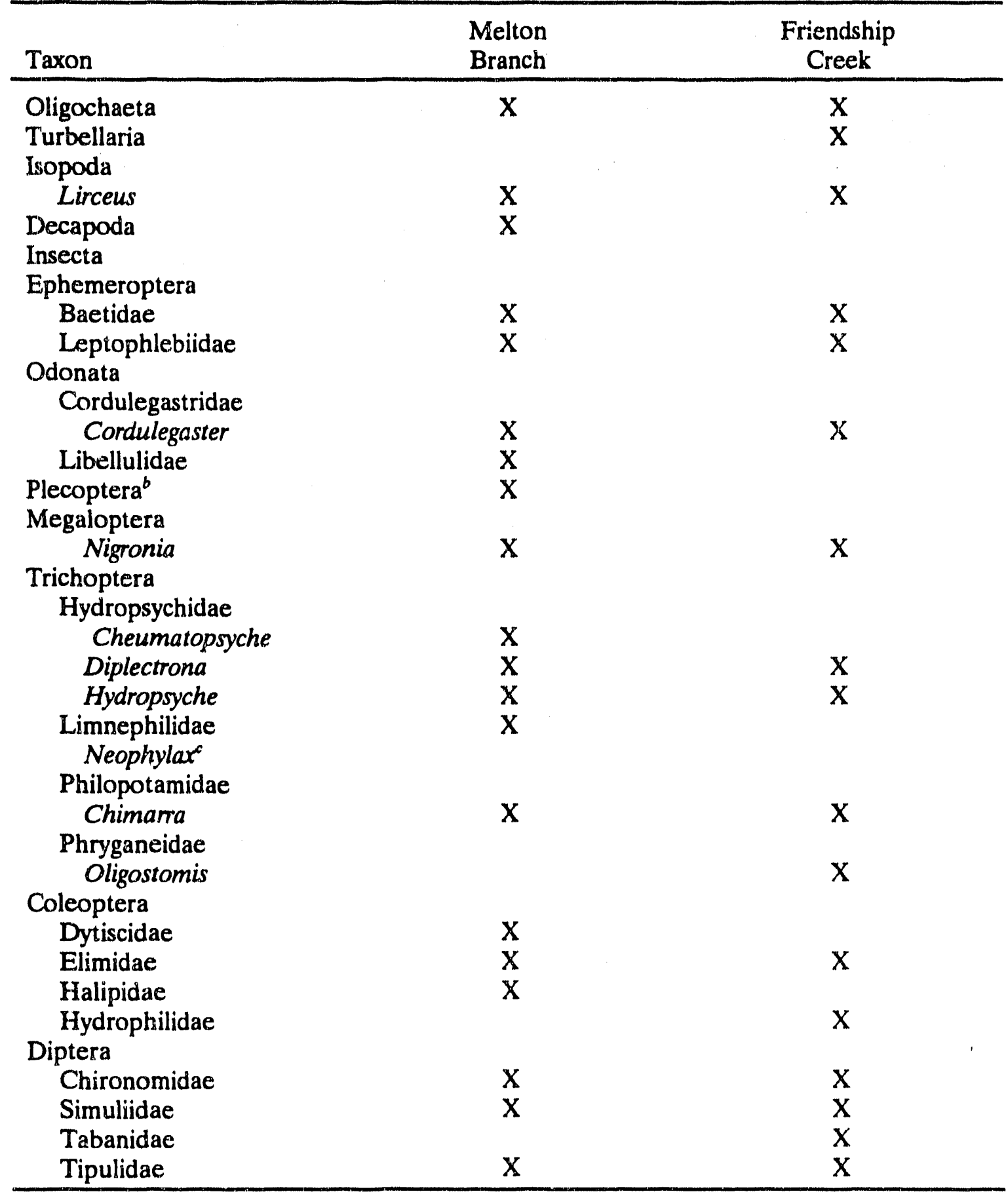

"An "X" indicates the taxon was collected at the respective site. Source: J. G. Smith and M. G. Ryon, Oak Ridge National Laboratory, memorandum to J. M. Loar, Oak Ridge National Laboratory, Oak Ridge, Tenn., July 21, 1989.

${ }^{b} \mathrm{~A}$ single adult was collected at streamside; thus, actual occurrence within the stream is implied but not confirmed.

'Onty the case of this taxon was collected within the creek; however, its occurrence is an indication that this taxon is a periodic member of the benthic community within this stream. 


\section{Melton Branch}

Melton Branch is also seasonally intermittent in the vicinity of the proposed ANS facility, with flow ceasing for days or weeks during the summer months (Loar 1991, Table 2.1). However, sufficient flows exist during the non-summer months to establish relatively diverse benthic macroinvertebrate community and small fish populations (Loar 1988, pp. 164-249). Early reports on the aquatic biota of lower Melton Branch have been summarized in Loar et al. 1981 (pp. 1-198).

A survey of fish at four sampling sites in the middle reaches of Melton Branch (Cada 1986, pp. 1-15) collected two species of fish: creek chub (Semotilus atromaculatus) and blacknose dace (Rhinichthys atratulus). Both of these species are minnows commonly found in ORR streams. Creek chub densities ranged from 0 to $1.7 / \mathrm{m}^{2}$; highest densities were found at the uppermost sites and in summer, when large numbers of juveniles were present. Standing crops of creek chubs ranged from 0 to $1.74 \mathrm{~g} / \mathrm{m}^{2}$; highest values also occurred in summer at the uppermost site. Variations in these population parameters were rarely as much as an order of magnitude among sites, although large increases in standing crops and especially numbers per unit area occurred between May and August 1985 , reflecting springtime spawning of this species. Subsequent mortality gradually reduced the densities of creek chubs at these sites in December 1985 and May 1986. Total lengths of individual creek chubs ranged from 1.9 to $12.4 \mathrm{~cm}(.76$ to $4.96 \mathrm{in}$.), whereas weights ranged from 0.1 to $19.0 \mathrm{~g}$.

Blacknose dace had densities and standing crops similar to those of creek chubs at these sampling sites in the middle reach of Melton Branch (Cada 1986, pp. 1-15). Blacknose dace densities ranged from 0 to $4.29 / \mathrm{m}^{2}$, and standing crops ranged from 0 to $148 \mathrm{~g} / \mathrm{m}^{2}$; values were generally highest at the uppermost sites. Spring spawning resulted in large increases in densities between May and August 1985. As w' $h$ creek chubs, differences in densities or standing crops between sites were generally smaller than seasonal differences at a given site. Total lengths of individual blacknose dace ranged from 1.6 to $9.0 \mathrm{~cm}$ (0.6 to $3.5 \mathrm{in}$.), and weights ranged from 0.1 to $6.8 \mathrm{~g}$.

An electrofishing survey of upper Melton Branch on June 30, 1989 (J. G. Smith and M. G. Ryon, Oak Ridge National Laboratory, personal communication to J. M. Loar, Oak Ridge National Laboratory, Oak Ridge, Tenn., July 21, 1989) also revealed large numbers of blacknose dace and especially creek chubs. A water-discharge weir at approximately Melton Branch kilometer (MBK) 2.2 (mile 1.3) (Fig. 2.2-3) constituted a

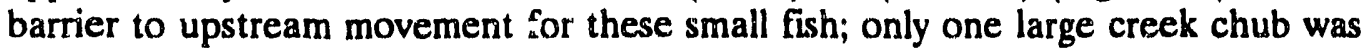
collected in a $100-\mathrm{m}$ (328-ft) reach of upper Melton Branch above the weir.

Like Friendship Creek, upper Melton Branch supported a relatively diverse benthic macroinvertebrate community (Table 2.2-10), with some taxa indicative of relatively undisturbed conditions (J. G. Smith and M. G. Ryon, ORNL, personal communication to J. M. Lyon, ORNL, Oak Ridge, Tenn., July 21, 1989, pp. 1-6).

Extensive studies of Melton Branch have been conducted under the ORNL Biological Monitoring and Abatement Program (BMAP), including instream ecological monitoring, studies of the periphyton communities, toxicity testing, radioecological studies, and bioaccumulation of nonradiological contaminants. Results of the studies from March 1986 through 1990 have been reported in a series of annual reports (Loar et al. 1987, pp. 1-354; Loar 1988 pp. 1-475; 1989 pp. 1-298; 1990 pp. 1-289; 1991 p. 1-317). Semiannual monitoring of Melton Branch will continue under the ORNL BMAP.

The annual reports for the ORNL BMAP provide periodic estimates of densities, standing crops, condition factors, ages, growth rates, and annual production of fish at three sites on Melton Branch. The most recently reported BMAP fish surveys of Melton 
Branch (April and October-November 1990) found only creek chubs and blacknose dace in the uppermost Melton Branch sampling sites [Melton Branch kilometers 1.4 and 2.1 (miles 0.86 and 1.30) (Fig. 2.2-3)]. Samples in lower Melton Branch [0.6 km (0.4 mile) above its confluence with White Oak Creek] contained creek chub, blacknose dace, and redbreast sunfish (Loar 1991 pp. 1-317). Densities and standing crops in lower Melton Branch varied considerably among dates but were comparable to values from 13 other sites sampled in the White Oak Creek watershed (Loar 1991, Table 6.7).

Mean densities of benthic invertebrates in Melton Branch ranged from 72.5 to 528.8 organisms $/ 0.1 \mathrm{~m}^{2}\left(67.4\right.$ to $\left.491.4 / \mathrm{ft}^{2}\right)$; average biomass ranged from 79.2 to $587.0 \mathrm{mg} / 0.1 \mathrm{~m}^{2}\left(67.4\right.$ to $545.5 \mathrm{mg} / \mathrm{ft}^{2}$ ) (Loar 1991, Table 6-1). Densities were highest at the site farthest downstream [Melton Branch kilometer 0.6 (mile 0.37)] and lowest at the site farthest upstream [Melton Branch kilometer 2.1 (mile 1.3) (Fig. 2.2-3)]. The benthic macroinvertebrate density and biomass values were comparable to those for 12 other sites sampled in the White Oak Creek watershed. A total of 81 benthic invertebrate taxa were collected at the three Melton Branch sites, but the taxonomic list was dominated by chironomidae (midge) larvae and contained relatively few examples of "clean water" insects, (e.g., mayflies and stoneflies) (Loar 1990, Appendix C).

In summary, the fish community in the sampled reaches of Melton Branch appears to be typical of small headwater streams in the area. The two minnow species collected near the proposed ANS site are common and locally abundant throughout the region and have been found in studies of other streams on ORR. Densities and standing crops of fish are probably limited at the upper reaches of Melton Branch by discharge; flows in this part of the stream can be low or zero during the summer, and fish habitat becomes restricted to isolated pools. On the other hand, streamflows in the lower portion of Melton Branch have been more reliable due to the discharges from the High Flux Isotope Reactor (HFIR) (see Sect. 2.2.2.2), but other factors (most likely excessive water temperatures) have restricted fish production. Lengths and weights were typical for these species and exhibited normal seasonal variations due to the changing age structure of the populations. Frequent or extended periods of no flow, which have been common in upper Melton Branch near the proposed ANS site, may also prevent or reduce successful colonization of many macroinvertebrate taxa, including many species of mayflies, stoneflies, and caddistlies that require 6 months or more to complete their life cycle (Loar 1991, pp. 1-317).

\section{White Oak Creek}

Early reports on the aquatic biota of White Oak Creek have been summarized in Loar et al. 1981 (pp. 1-198). Most recently, extensive studies of this stream have been conducted as part of the ORNL BMAP, including instream ecological monitoring, studies of the periphyton communities, toxicity testing, radioecological studies, and bioaccumulation of nonradiological contaminants. Results of the studies from March 1986 through 1990 have been reported in a series of annual reports (Loar et al. 1987, pp. 1-354; Loar 1988, pp. 1-475; Loar 1989, pp. 1-298; Loar 1990, pp. 1-289; Loar 1991, pp. 1-317). Semiannual monitoring of White Oak Creek will continue under the ORNL BMAP.

The annual reports for the ORNL BMAP provide periodic estimates of densities, standing crops, condition factors, ages, growth rates, and annual production of fish at six sites on White Oak Creek. Recent quantitative surveys of White Oak Creek collected 14 species of fish, of which 7 were sunfishes and 4 were minnows (Loar 1991, pp. 1-317). Densities estimated on two dates in 1990 at White Oak Creek kilorneter 3.4 (mile 2.11), 
downstream from the ORNL sewage treatment plant (Fig. 2.2-3), were 0.02 and $0.06 \mathrm{fish} / \mathrm{m}^{2}\left(0.01^{\mathrm{n}} 5\right.$ and $\left.0.0278 \mathrm{fish} / \mathrm{ft}^{2}\right)$; biomass estimates were 5.7 and $6.2 \mathrm{~g} / \mathrm{m}^{2}(0.5$ and $\left.0.6 \mathrm{~g} / \mathrm{ft}^{2}\right)$. These values were near the middle of the ranges for 15 other sites in the White Oak Creek watershed.

Estimated densities of benthic macroinvertebrates at White Oak Creek kilometer 3.4 (mile 2.11) were 61.4 and 729.0 organisms $/ 0.1 \mathrm{~m}^{2}\left(57.1\right.$ and 677.5 organisms/ft ${ }^{2}$ ) in 1986 and 1987 , respectively; biomass estimates were 11.5 and $633.6 \mathrm{mg} / 0.1 \mathrm{~m}^{2}$ (10.7 and $588.8 \mathrm{mg} / \mathrm{ft}^{2}$ ) (Loar 1991, Table 6.1, pp. 6-4 and 6-5). These values were near the middle of the range for the 15 sites sampled in White Oak Creek watershed. Like Melton Branch downstream from HFIR, 116 taxa were collected at 6 sites, but the samples were numerically dominated by midge larvae and had relatively few mayflies or stoneflies (Loar 1990, Appendix C, pp. C-3-C-9).

\subsubsection{Preexisting Strrsses to Aquatic Biota}

There are no known anthropogenic stresses to aquatic biota in Friendship Creek or the upper reaches of Melton Branch nearest the proposed ANS site. Aquatic communities in these reaches appear to be structured in response to the intermittent nature of the natural flow regimes (Sect. 2.2.2.1).

The lower reaches of Melton Branch are affected by discharges of cooling tower blowdown fiom the HFIR. The HFIR discharges are a source of heat and chemical contamination to lower Melton Branch. For example, mean daily water temperatures in lower Melton Branch below the HFIR tributary occasionally exceeded $30^{\circ} \mathrm{C}\left(86^{\circ} \mathrm{F}\right)$, and maximum daily temperatures approached $38^{\circ} \mathrm{C}\left(100^{\circ} \mathrm{F}\right)$ during the summer of 1986 (Loar et al. 1987, pp. 1-354). However, the HFIR discharges ensure stream flow at times when the upper reaches are reduced to a series of isolated pools. Stream flow in Melton Branch at MBK 0.16 (Melton Branch mile 0.09) (below the HFIR tributary input) between 1955 and 1963 averaged $0.07 \mathrm{~m}^{3} / \mathrm{s}\left(2.5 \mathrm{ft}^{3} / \mathrm{s}\right)$; maximum flow during that period was $6.85 \mathrm{~m}^{3} / \mathrm{s}\left(241.87 \mathrm{ft}^{3} / \mathrm{s}\right)$, although this may underestimate actual flood flows (Boyle et al. 1982, pp. 1-185).

Cada (1986, pp. 1-15) sampled fish populations of Melton Branch at sites both above and within the reach heated by the HFIR tributary (Sect. 2.2.2.1). Upper lethal temperatures for the two species found in Melton Branch, creek chubs and blacknose dace, are around $31.5^{\circ} \mathrm{C}$ and $29.3^{\circ} \mathrm{C}\left(88.7^{\circ} \mathrm{F}\right.$ and $84.7^{\circ} \mathrm{F}$ ), respectively (NAS 1972 , pp. 410-419). Creek chubs and blacknose dace were found above the tributary, but were absent from the sampling site below the tributary on all but a single sampling date in December. On this date, water temperature was $28.9^{\circ} \mathrm{C}\left(84^{\circ} \mathrm{F}\right)$, below the upper lethal temperatures of both species, and large numbers of both creek chubs and blacknose dace were collected. Recent surveys (Loar et al. 1987, pp. 1-354; Loar 1990, pp. 1-289; Loar 1991, pp. 1-317) suggest that both fish and benthic invertebrate communities of lower Melton Branch continue to be influenced by HFIR discharges.

The aquatic communities in White Oak Creek downstream from ORNL are moderately impacted, probably by a variety of stresses including chemical discharges, nutrient enrichment, elevated temperatures, altered flow regimes, and siltation. Effluents from ORNL treatment facilities and other point source discharges to White Oak Creek are described by Loar 1991 (pp. 1-317). Toxicity monitoring (bioassays of water samples) indicates that chlorine is likely a major toxicant in White Oak Creek below the ORNL sewage treatment plant, although some toxicity remained in the water samples even after the chlorine was removed (Loar 1990, pp. 1-289). Discharges of total residual chlorine are believed responsible for low densities and biomass of fish (and a 1989 fish kill) in this 
stream reach (Loar 1991, pp. 1-317). The invertebrate communities at White Oak Creek sampling sites are composed primarily of chironomids (midges) and other taxa with short generation times, probably reflecting episodic discharges of toxicants. Farther downstream, water quality improves through dilution, volatilization, and other chemical and physical processes; as a result, longer-lived, moderately pollution-tolerant invertebrate taxa become established (Loar 1991, pp. 1-317).

\section{Threatened or Endangered Species} examined.

In this section the presence of threatened or endangered species on ORR is

\subsection{Plants}

No plant species listed as threatened or endangered by the U.S. Fish and Wildlife Service is known to occur on or near ORR. However, many species listed by the state of Tennessee as rare, threatened, or endangered occur on ORR (Parr 1984, p. 1-24). None of these species has been found on the ANS site. Ginseng (threatened) is the only statelisted plant that is known to occur near the ANS site, where it has been found in two locations (Fig. 2.2-2). Potential impacts of ANS construction on these two ginseng locations are discussed in Sect. 4.1.1.

\subsection{Wildife}

The potential occurrence of threatened or endangered wildlife species in the Oak Ridge area is discussed in detail in Kroodsma 1987 (p. 1-24). That report's list of threatened or endangered species is provided here as Table $2.2-8$, which has been updated to incorporate several changes in threatened or endangered species status that have occurred since that report was published. Information was obtained from the U.S. Fish and Wildlife Service (FWS) and the state of Tennessee to comply with the Endangered Species Act. FWS provided letters addressing the status of threatened or endangered species on ORR (Bay 1991, p. 1-2; Barclay 1990, p. 1-2). The state of Tennessee also lists many wildlife species as "in need of management" (INM) and provides them with legal protection; no one may knowingly destroy the habitat of state-listed threatener or endangered and INM species without a permit.

Table 2.2-9 shows the ORR habitats for T\&E and INM species that are known to occur or have a relatively high probability of occurring on ORR (Bay 1991, p. 1-2; Barclay 1990, p. 1-2; Hatcher 1990, pp. 16-20; TWRC 1990, p. 1-4). No threatened or endangered species or critical habitat listed, or proposed to be listed, by FWS is known to be present on ORR. However, the Indiana bat and gray bat are possible summer residents on ORR, particularly along East Fork Poplar Creek and the Clinch River, respectively. Several species listed by the state of Tennessee occur on ORR, as shown in Table 2.2-9. Of these species, only the black vulture and Cooper's hawk probably occur regularly on the proposed ANS site. No nesting of these two species, however, is known to occur on or near the site. 
Taible 22-8. Status of threatened and endangered species on the Oak Ridge Reservation ${ }^{a}$

\begin{tabular}{|c|c|c|c|c|}
\hline \multirow{2}{*}{ Species } & \multicolumn{2}{|c|}{ Legal status } & \multirow{2}{*}{ ORR status } & \multirow{2}{*}{$\begin{array}{l}\text { Recommended } \\
\text { action }\end{array}$} \\
\hline & Federal & $\overline{\text { State }}$ & & \\
\hline \multicolumn{5}{|c|}{ Inveriebrates } \\
\hline $\begin{array}{l}\text { Birdwing pearly niussel } \\
\text { (Conradilla caellasa) }\end{array}$ & E & E & County & None \\
\hline $\begin{array}{l}\text { Dromedary pearty mussel } \\
\text { (Dromus dromais) }\end{array}$ & $\mathrm{E}$ & E & County & None \\
\hline $\begin{array}{l}\text { Yellow-blassom pearly mussel } \\
\text { (Epioblasma flarentina) }\end{array}$ & $\mathrm{E}$ & E & County & None \\
\hline $\begin{array}{l}\text { Tubercled-blossom or green blossom } \\
\text { pearty mussel (Epioblasniza torulosa) }\end{array}$ & $\mathrm{E}$ & $\mathrm{E}$ & County & None \\
\hline $\begin{array}{l}\text { Turgid-blossom pearly mulssel } \\
\text { (Epioblasma mirgidula) }\end{array}$ & $\mathrm{E}$ & $\mathrm{E}$ & County & None \\
\hline $\begin{array}{l}\text { Tan riffle shell pearty mussel } \\
\text { (Epioblasma walkeri) }\end{array}$ & E & $\mathrm{E}$ & County & None \\
\hline $\begin{array}{l}\text { Fine-rayed pigtce pearly inussel } \\
\text { (Fusconais curreolus) }\end{array}$ & E & E & County & None \\
\hline $\begin{array}{l}\text { Shiny pigtoe pearty mussult } \\
\text { (Fusconaia edgariana) }\end{array}$ & E & E & County & None \\
\hline $\begin{array}{l}\text { Pink mucket pearty mussel } \\
\text { (Lampsilis orticulata) }\end{array}$ & $\mathbf{E}$ & $\mathbf{E}$ & County & None \\
\hline $\begin{array}{l}\text { Alabama lamp pearly mussel } \\
\text { (Lampsilis vinescens) }\end{array}$ & $\mathbf{E}$ & $\mathbf{E}$ & County & None \\
\hline $\begin{array}{l}\text { White warty back pearty mussel } \\
\text { (Plethobasus ciarricosus) }\end{array}$ & $\mathbf{E}$ & $\mathbf{E}$ & County & None \\
\hline $\begin{array}{l}\text { Orange-footed pearly mussel } \\
\text { (Plethobasus cooperianus) }\end{array}$ & E & $\mathrm{E}$ & County & None \\
\hline $\begin{array}{l}\text { Rough pigtoe pearly mussel } \\
\text { (Pleurobema plenum) }\end{array}$ & $\mathbf{E}$ & E & County & None \\
\hline $\begin{array}{l}\text { Cumberland monkeyface pearty mussel } \\
\text { (Quadrula intermedia) }\end{array}$ & E & $\mathrm{E}$ & Range & None \\
\hline $\begin{array}{l}\text { Appalachian m.onkeyface pearty mussel } \\
\text { (Quadrula sparsa) }\end{array}$ & E & $\mathbf{E}$ & Range & None \\
\hline $\begin{array}{l}\text { Pale lilliput pearly mussel } \\
\text { (Taxolasma cylineirellus) }\end{array}$ & $\mathrm{E}$ & $\mathbf{E}$ & Range & None \\
\hline $\begin{array}{l}\text { Cumberland bean pearly mussel } \\
\text { (Villosa trabalis, } V \text {. perpurpurea) }\end{array}$ & $\mathbf{E}$ & $\mathbf{E}$ & County & None \\
\hline $\begin{array}{l}\text { Painted snake coiled forest snail } \\
\text { (Anguispira picta) }\end{array}$ & $\mathbf{T}$ & $\mathrm{E}$ & Range & None \\
\hline $\begin{array}{l}\text { Chittenango ovate amber snail } \\
\text { (Succinea chittenangoensis) }\end{array}$ & $T$ & $\mathrm{~T}$ & Range & None \\
\hline
\end{tabular}


Table 22-8. (continued)

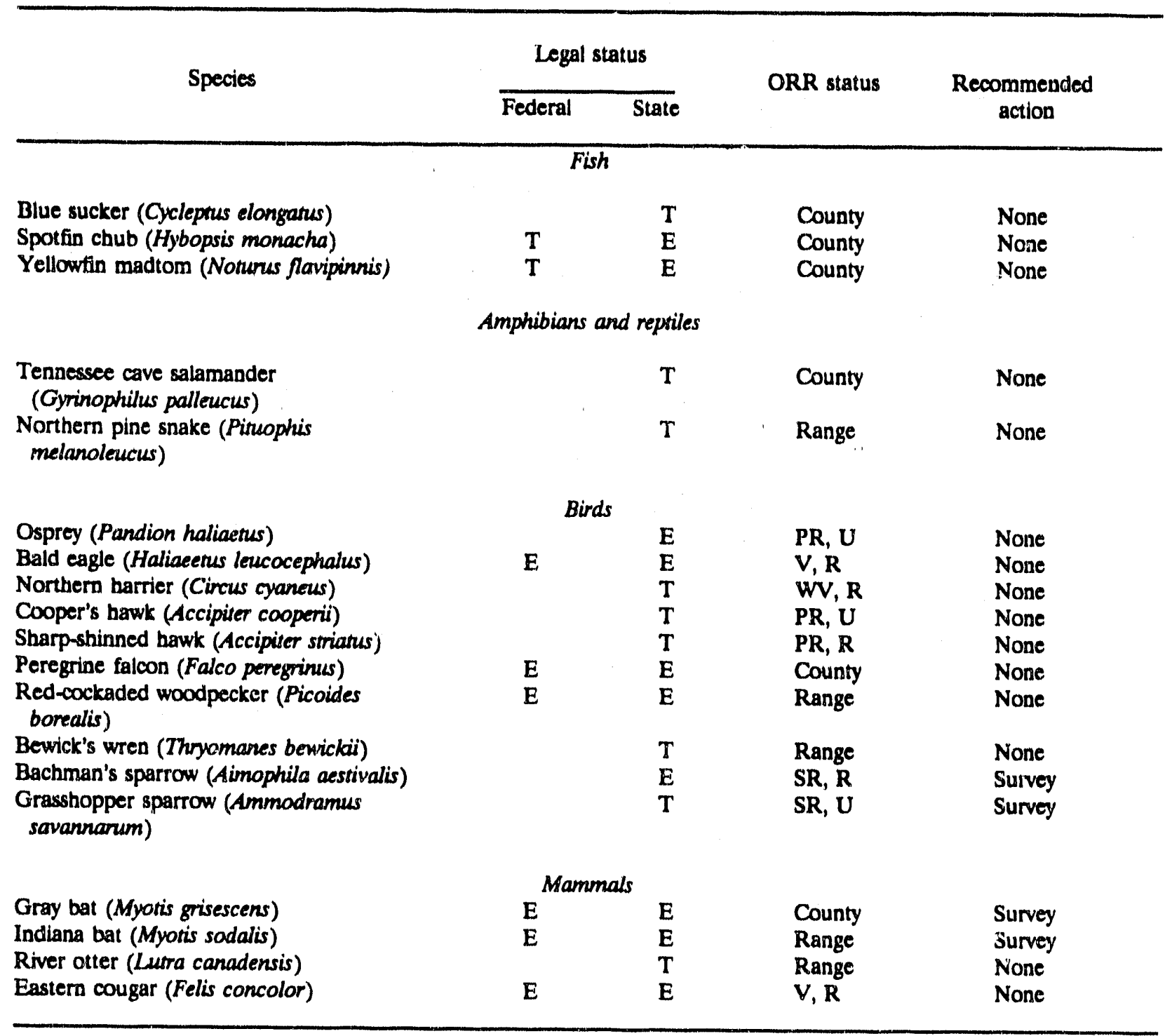

'Legend: County-The species has occurred in Anderson or Roane counties, according to the records of the Tenneasee Heritage Program. Range-ORR lies within the geographic range of the species, but occurrence records on ORR and in Anderson and Roane countics are lacking. None-No sysiematic population surveys are recommended apecifically for the species at this time. Manage-Habitat management to promote the apecies population is recommended. Survey-Syatematic population surveys are recommended. E-Endangered, PR-Permanent (year-round) resident, R-Rare, SR-Summer resident (does not occur in winter), T-Threatened, U-Uncommon (more aumerous than rare speciea), V-Visitor (nonbreeding individuals occur sporadicalty or occasionalty), WV-Winter visitor (does not occur in summer).

Source: Kroodsms, R. L. 1987. Resounce Managemens Plan for the Oak Ridge Reservation Vol. 24: Threatened and Endangered Animal Species, ORNL/ESH-1/N24, Oak Ridge National Laboratory, Osk Ridge, Tenn. 
Table 22-9. Threatened (T), endangered (E), and in-need-of-management (INM) species on the Oak Ridge Reservation

\begin{tabular}{|c|c|c|}
\hline Species & Status & Location \\
\hline \multicolumn{3}{|c|}{ U.S. Fish and Wildlife Service } \\
\hline Indiana bat & $\mathrm{E}$ & $\begin{array}{l}\text { Possibly present in vicinity of East Fork } \\
\text { Poplar Creek }\end{array}$ \\
\hline \multicolumn{3}{|c|}{ State of Tennessee } \\
\hline Tennessee dace & INM & $\begin{array}{l}\text { Bear Creek drainage, Ish Creek, and tributaries } \\
\text { of East Fork Poplar Creek (siltation due to } \\
\text { erosion in vicinity of the creeks must be } \\
\text { avoided) }\end{array}$ \\
\hline Osprey & $\mathbf{E}$ & Vicinity of Melton Hill Lake and Clinch River \\
\hline Sharp-shinned hawk & $\mathbf{E}$ & $\begin{array}{l}\text { Area between Jones Island, Grubb Island, and } \\
500-\mathrm{Kv} \text { power line }\end{array}$ \\
\hline Cooper's hawk & $\mathrm{T}$ & Entire Oak Ridge Reservation \\
\hline Grasshopper sparrow & $\mathrm{T}$ & Large grassy fields \\
\hline $\begin{array}{l}\text { Black-crowned } \\
\text { night heron }\end{array}$ & INM & Clinch River \\
\hline Black vulture & INM & $\begin{array}{l}\text { Entire Oak Ridge Reservation; an active nest } \\
\text { site is located on Chestnut Ridge between } \\
\text { Highway } 95 \text { and New Zion Patrol Road }\end{array}$ \\
\hline Red-shouldered hawk & INM & $\begin{array}{l}\text { Forests and fields along the Clinch River and } \\
\text { relatively large streams }\end{array}$ \\
\hline Common barn owl & INM & Freel's Bend and vicinity \\
\hline
\end{tabular}

\section{METEOROLOGY}

This section discusses regional climatology, specific meteorological phenomena, representativeness of meteorological data, local air quality and emission sources, and diffusion estimates.

\subsection{Regional Climatology}

This section reviews briefly the data sources used for establishing the meteorological record in the region around ORNL. The general climate of the region is described with respect to large-scale synoptic features (high- and low-pressure systems, air masses, fronts, etc.) that provide the context for localized weather phenomena. Localized features (e.g., temperature, humidity, precipitation) are discussed in relation to the larger scale patterns. 


\subsubsection{Data Sources}

ORR currently has six active meteorological monitoring towers (Fig. 2.3-1). The tower nearest to the proposed ANS site is Tower 4, located in the same valley (Melton Valley) as the proposed ANS site and about $1.3 \mathrm{~km}(0.8$ mile) southwest of it. Tower 4 is the principal source of site-specific climatology for the ANS site. This tower has instrumentation to measure temperature, humidity, wind speed, and wind direction at $10 \mathrm{~m}$ $(33 \mathrm{ft})$ and $30 \mathrm{~m}(98 \mathrm{ft})$.

Towers 1 and 6, located in Bear Creek Valley, have instruments at 10 and $60 \mathrm{~m}$ ( 33 and $98 \mathrm{ft}$ ); Towers 2 and 5 have instruments at 10,30 , and $100 \mathrm{~m}(33,98$ and $330 \mathrm{ft})$; and Towers 3 and 4 have instruments at 10 and $30 \mathrm{~m}$ (33 and $98 \mathrm{ft}$ ). Wind speed, wind direction, and temperature are measured at all instrument heights on all six towers.

Information obtained by thuse instruments is transferred, stored, edited, and formatted using a central proccissor sonnected to remote data loggers. Wind velocity vector averages of $1 \mathrm{~min}$ are calculated and retained for $24 \mathrm{~h}$. These velocities are processed into 15-min averages using the unit-vector method described in EPA 1987 (pp. 6-7-6-8); that same method is then used to convert the 15-min averages to hourly averages. Stabilities are also calculated using the standard deviation of the wind direction (sigma theta), corrected by wind speed and time of day per EPA 1987, pp. 6-20 and 6-32.

The instruments at the ORNL towers (Towers 2, 3, and 4) are all checked for accuracy and maintained quarterly; the instruments are currently under contract to Environmental Services Corporation, Knoxville, Tennessee. Locations of these towers are shown on a topographic map of the immediate vicinity in Fig. 2.3-2.

The Atmospheric Turbulence and Diffusion Division (ATDD) of the National Oceanic and Atmospheric Administration (NOAA) maintains a meteorological station along Illinois Avenue in the city of Oak Ridge, about $9.3 \mathrm{~km}$ (5.8 miles) north-northeast of the proposed ANS site. The most complete set of meteorological data from a nearby station comes from the McGhee-Tyson Airport (Knoxville airport), located just south of Knoxville and about $32 \mathrm{~km}$ (20 miles) east-southeast of the proposed ANS site. Data from these stations (DOC 1977a, pp. 1-4; DOC 1977b, pp. 1-4; DOC 1989a, pp. 1-8; DOC 1989b, pp. 1-8) and from Chattanooga (DOC 1977c, pp. 1-4) were used for describing precipitation features and other aspects of the regional and local climatology. General information on the climate of Tennessee is available in Climates of the States (Gale Research Company 1985, pp. 1021-1041.)

\subsubsection{Description of the Regional Climate}

The proposed ANS site is located in Melton Valley in Roane County in eastern Tennessee, between the Cumberland Mountains to the northwest and the Great Smoky Mountains to the southeast. Local terrain is mostly ridges and valleys, with ridge elevations generally between about 275 and $365 \mathrm{~m}(900$ and $1200 \mathrm{ft}$ ) and with valley floors extending to the Clinch River, which, below the Melton Hill Dam, is at an elevation of $226 \mathrm{~m}(741 \mathrm{ft})$. Orientation of the ridges and valleys is generally southwest-northeast, and the near-surface winds generally follow the orientation of the local topography. Elevation also influences temperature and precipitation patterns over the region, with cooler temperatures and greater precipitation generally occurring at the higher elevations, especially in the Great Smoky and Cumberland Mountains. Severe storms are relatively rare because the region lies east of the tornado belt, south and east of most blizzard occurrences, and too far inland to be much affected by hurricanes (Gale Research Company 1985, p. 1024). 


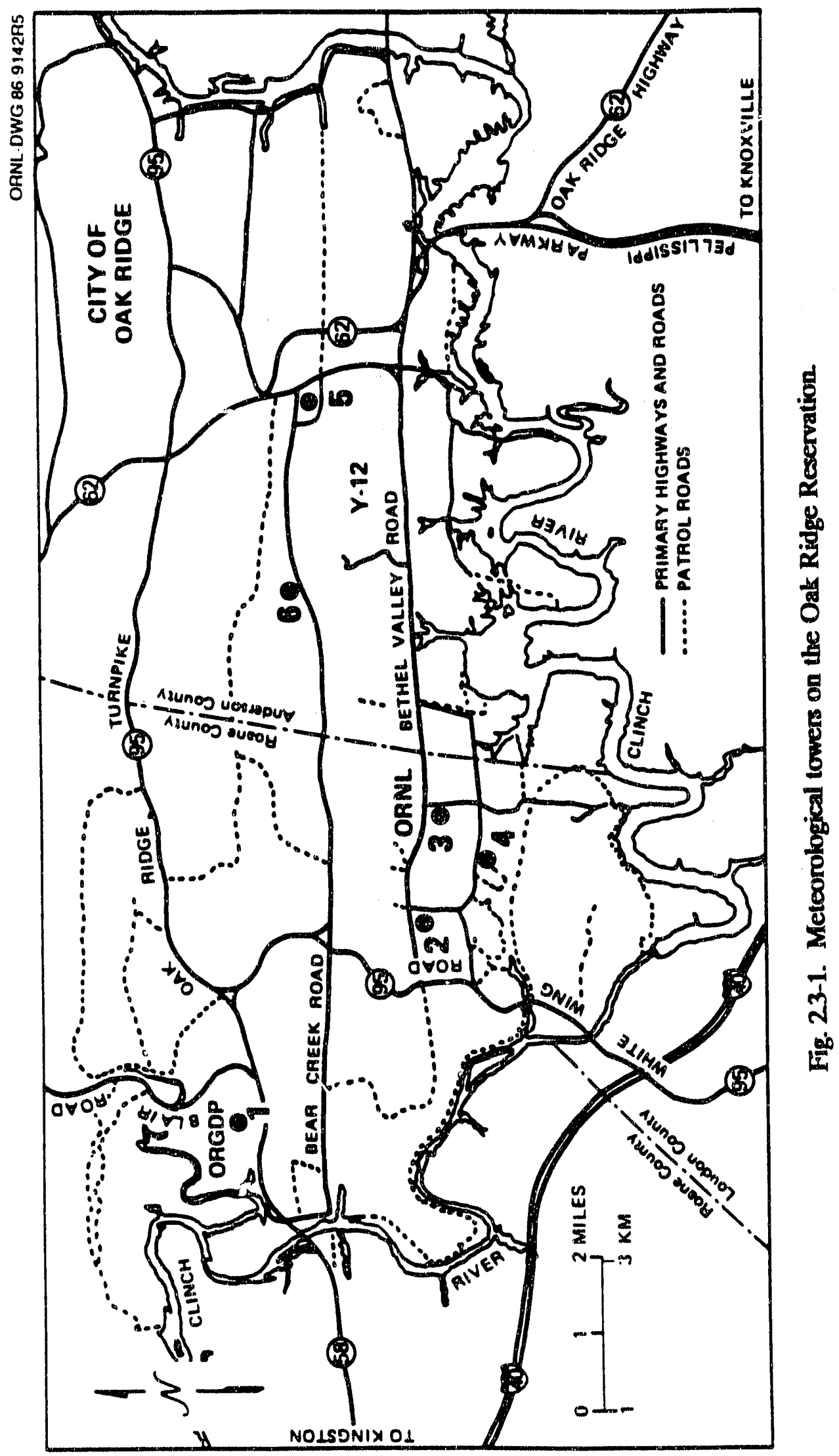




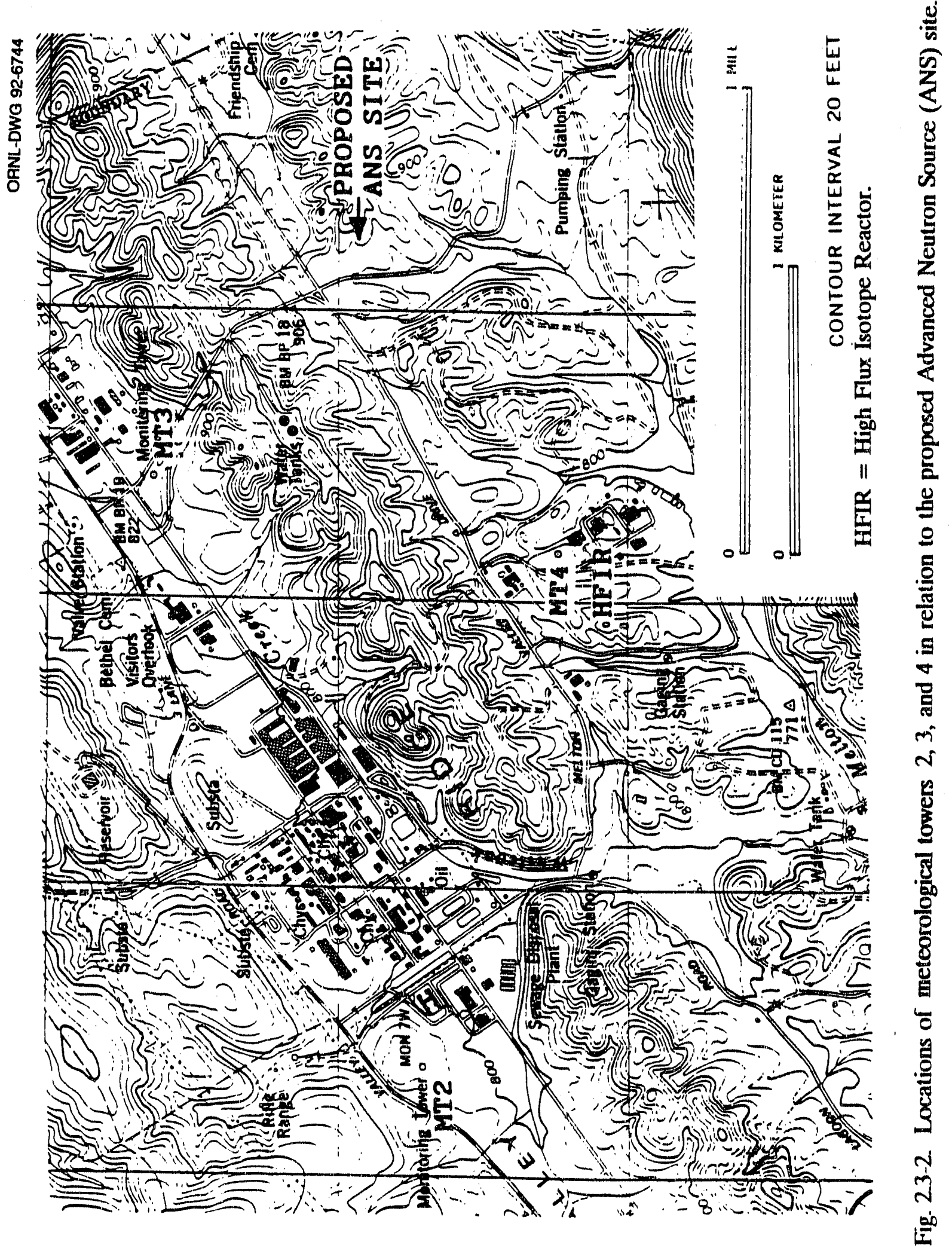


The climate of the region may be classified as humid continental. The Cumberland Mountains to the northwest help shield the region from cold air masses that frequently penetrate far south over the plains and prairies in the central United States during the winter months. During the summer, tropical air masses from the south provide warm and humid conditions that often produce thunderstorms. However, anticyclonic circulation around high-pressure systems centered in the western Gulf of Mexico can bring dry air from the southwestern United States into the region, leading to occasional periods of drought. Air stagnation is relatively common in eastern Tennessee. About two multiday air stagnation episodes occur each year, covering an average of about $8 \mathrm{~d} /$ year (Korshover 1976, p. 10).

Wind speeds are not currently recorded at the Oak Ridge weather station. The average annual wind speed at McGhee-Tyson Airport, at 6.7 to $9.1 \mathrm{~m}(22$ to $30 \mathrm{ft}$ ) above

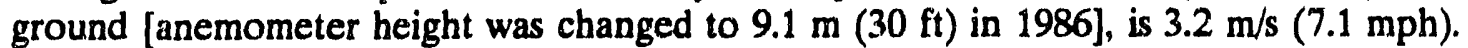
The prevailing wind directions are from the northeast and southwest, reflecting the influences of the local ridge-and-valley topography. The fastest monthly average winds are $3.9 \mathrm{~m} / \mathrm{s}(8.8 \mathrm{mph}$ ) in March (DOC 1989a). Average wind speeds, by month, are given in Table 2.3-1. Most tornadoes in the state occur in the areas of relatively low relief, to the west of the Cumberland Mountains.

Average annual temperature in Oak Ridge is $14.2^{\circ} \mathrm{C}\left(57.5^{\circ} \mathrm{F}\right)$. The coldest month is January, averaging $2.6^{\circ} \mathrm{C}\left(36.7^{\circ} \mathrm{F}\right)$, and the warmest month is July, averaging $24.8^{\circ} \mathrm{C}$ $\left(76.6^{\circ} \mathrm{F}\right)$ (DOC $\left.1989 \mathrm{~b}\right)$. Extremes were $-27.2^{\circ} \mathrm{C}\left(-17^{\circ} \mathrm{F}\right)$ in January 1985 and $40.6^{\circ} \mathrm{C}$ $\left(105^{\circ} \mathrm{F}\right)$ in July 1952 (DOC $\left.1989 \mathrm{~b}\right)$. Temperatures above $32.2^{\circ} \mathrm{C}\left(90^{\circ} \mathrm{F}\right)$ occur on an average of $31 \mathrm{~d} /$ year, with about two-thirds of those days in July and August.

Temperatures below freezing occur on an average of $88 \mathrm{~d} / \mathrm{year}$, with more than threefourths of those days in December through February (DOC 1989b, pp. 1-8). A temperature summary for Oak Ridge is given in Table 2.3-2.

Precipitation in Oak Ridge averages about $139 \mathrm{~cm}$ (54.7 in.) per year. Precipitation in amounts of $0.25 \mathrm{~mm}(0.01 \mathrm{in}$.) or more occurs on an average of $128 \mathrm{~d} /$ year (DOC 1989b, pp. 1-8). Precipitation in the region is greatest in the winter months (December through March) due to the frequent passage of large-scale cyclonic systems and associated fronts. A secondary peak occurs in July due to summer thunderstorm activity that is particularly evident in the mountainous regions. Lightest precipitation generally occurs in the fall when anticyclonic (high-pressure) systems are most frequent (Gale Research Company 1985, p. 1023). Average annual snowfall is $262 \mathrm{~mm}$ (10.3 in.). The record of $1050 \mathrm{~mm}$ (41.4 in.) of snow fell during the winter of 1959-60, which included the monthly record of $533 \mathrm{~mm}$ (21 in.) in March 1960 (DOC 1977b, pp. 1-4; $1989 \mathrm{~b}, \mathrm{pp} .1-8)$. It is unusual for the snow to remain on the ground for longer than a week.

Maximum precipitation at Oak Ridge in a 24-h period was $190 \mathrm{~mm}(7.48 \mathrm{in}$.) in August 1960 (DOC 1977b, pp. 1-4;1989b, pp. 1-8). At the Knoxville airport, the highest amount of precipitation in a 24-h period was $129 \mathrm{~mm}$ (5.08 in.), in September 1944. The record precipitation for Knoxville in one month was $298 \mathrm{~mm}$ (11.74 in.) in January 1954. In that same month, Oak Ridge experienced $337 \mathrm{~mm}$ (13.27 in.) of precipitation, which is the second-highest monthly value for that station. However, $489 \mathrm{~mm}$ (19.27 in.) of precipitation fell in Oak Ridge in July 1967 (Gale Research Company 1985, pp. 1037-1038). These statistics reflect the intensity and localized nature of summer shower activity that can occur in the region. A precipitation summary for Oak Ridge is given in Table 2.3-3.

The average number of thunderstorm days per year is 47 in Knoxville and 53 in Oak Ridge. These storms may sometimes be severe with damaging winds. More than 
Table 23-1. Average wind speed by month at McGhee-Tyson Airport in Knoxville, Tennessee

\begin{tabular}{lc||lc}
\hline Month & $\begin{array}{c}\text { Wind speed } \\
{[\mathrm{m} / \mathrm{s}(\mathrm{mph})]}\end{array}$ & Month & $\begin{array}{c}\text { Wind speed } \\
{[\mathrm{m} / \mathrm{s}(\mathrm{mph})]}\end{array}$ \\
\hline January & $3.5(7.9)$ & August & $2.5(5.6)$ \\
February & $3.8(8.3)$ & September & $2.6(5.8)$ \\
March & $4.0(8.7)$ & October & $2.6(5.8)$ \\
April & $4.0(8.7)$ & November & $3.1(6.9)$ \\
May & $3.2(7.0)$ & December & $3.4(7.4)$ \\
June & $3.0(6.5)$ & Annual & $3.2(7.1)$ \\
July & $2.8(6.1)$ & & \\
\hline
\end{tabular}

Source: U.S. Department of Commerce 1989. Local Climatological Data with Comparative Data, 1989, Knowville, Tennessee, National Climatic Data Center, Asheville, N.C.

Table 23-2 Temperature data for Oak Ridge, Tennessee

$\left[{ }^{\circ} \mathrm{C}\left({ }^{\circ} \mathrm{F}\right)\right]$

\begin{tabular}{lrrrrr}
\hline \multicolumn{1}{c}{ Month } & $\begin{array}{c}\text { Mean } \\
\text { monthly }\end{array}$ & $\begin{array}{c}\text { Daily } \\
\text { maximum }\end{array}$ & $\begin{array}{c}\text { Daily } \\
\text { minimum }\end{array}$ & $\begin{array}{c}\text { Record } \\
\text { highest }\end{array}$ & $\begin{array}{c}\text { Record } \\
\text { lowest }\end{array}$ \\
\hline January & $2.6(36.7)$ & $7.6(45.7)$ & $-2.4(27.7)$ & $24.0(75)$ & $-27.0(-17)$ \\
February & $4.3(39.8)$ & $10.1(50.2)$ & $-1.5(29.3)$ & $26.0(79)$ & $-17.0(1)$ \\
March & $8.8(47.9)$ & $15.0(59.0)$ & $2.6(36.7)$ & $29.0(85)$ & $-17.0(1)$ \\
April & $14.5(58.1)$ & $21.4(70.5)$ & $7.6(45.6)$ & $33.0(92)$ & $-7.0(20)$ \\
May & $18.9(66.1)$ & $25.6(78.1)$ & $12.3(54.1)$ & $34.0(93)$ & $-1.0(30)$ \\
June & $22.9(73.2)$ & $29.2(84.6)$ & $16.6(61.8)$ & $38.0(101)$ & $4.0(39)$ \\
July & $24.8(76.6)$ & $30.7(87.2)$ & $18.8(65.9)$ & $41.0(105)$ & $9.0(49)$ \\
August & $24.4(76.0)$ & $30.4(86.7)$ & $18.4(65.2)$ & $39.0(103)$ & $10.0(50)$ \\
September & $21.2(70.2)$ & $27.4(81.3)$ & $15.1(59.1)$ & $38.0(102)$ & $1.0(33)$ \\
October & $14.6(58.3)$ & $21.3(70.4)$ & $7.8(46.0)$ & $32.0(90)$ & $-6.0(21)$ \\
November & $8.4(47.2)$ & $14.5(58.1)$ & $2.4(36.3)$ & $28.0(83)$ & $-18.0(0)$ \\
December & $4.2(39.6)$ & $9.4(48.9)$ & $-1.0(30.2)$ & $26.0(78)$ & $-22.0(-7)$ \\
Annual & $14.2(57.5)$ & $20.2(68.4)$ & $8.1(46.5)$ & $41.0(105)$ & $-27.0(-17)$ \\
\hline
\end{tabular}

- Mean monthly values are the climatic normals for the 30-year period 1951-1980. Extremes are based on the 42-year record at Oak Ridge (1948-1989).

Sounce: U.S. Department of Commerce 1989. Local Climatological Data with Comparative Data, 1989, Oat Ridgr, Tennessee, National Climatic Data Center, Asheville, N.C. 
Table 23-3. Precipitation data for Oak Ridge, Tennessee [mm (in.)]

\begin{tabular}{lcccc}
\hline \multicolumn{1}{c}{ Month } & \multicolumn{1}{c}{ Mean $^{a}$} & Maximum $^{b}$ & Minimum $^{b}$ & $\begin{array}{c}\text { Maximum in } \\
24 \mathrm{~h}\end{array}$ \\
\hline January & $133.4(5.25)$ & $337.1(13.27)$ & $23.6(0.93)$ & $108.0(4.25)$ \\
February & $116.8(4.60)$ & $265.9(10.47)$ & $23.1(0.84)$ & $74.7(2.94)$ \\
March & $157.7(6.21)$ & $310.9(12.24)$ & $54.1(2.13)$ & $120.4(4.74)$ \\
April & $112.0(4.41)$ & $246.6(9.71)$ & $22.4(0.88)$ & $158.5(6.24)$ \\
May & $107.4(4.23)$ & $271.8(10.70)$ & $20.3(0.80)$ & $112.0(4.41)$ \\
June & $108.2(4.26)$ & $283.0(11.14)$ & $13.5(0.53)$ & $94.0(3.70)$ \\
July & $132.3(5.21)$ & $489.5(19.27)$ & $39.4(1.55)$ & $124.7(4.91)$ \\
August & $95.3(3.75)$ & $265.0(10.46)$ & $13.7(0.54)$ & $190.0(7.48)$ \\
September & $96.5(3.80)$ & $231.1(9.10)$ & $10.4(0.41)$ & $95.5(3.76)$ \\
October & $73.4(2.89)$ & $176.5(6.95)$ & 0 & $67.6(2.66)$ \\
November & $114.3(4.50)$ & $310.4(12.22)$ & $34.8(1.37)$ & $134.9(5.29)$ \\
December & $143.5(5.65)$ & $261.9(10.31)$ & $17.0(0.67)$ & $130.0(512)$ \\
Annual & $1390.9(54.76)^{c}$ & $489.5(19.27)^{d}$ & $0^{d}$ & $190.0(7.48)$ \\
\hline
\end{tabular}

"Mean monthly values are the climatic normals for the 30-year period 1951-1980.

${ }^{b}$ Extremes are based on the 42-year record at Oak Ridge (1948-1989).

Mean annual precipitation is the annual average total precipitation.

'Annual extremes are for particular months.

Source: U.S. Department of Commerce 1989. Local Climatological Data with Comparative Data, 1989, Oak Ridge, Tennessee, National Climatic Data Center, Asheville, N.C.

$50 \%$ of the thunderstorms occur in June, July, and August (Gale Research Company 1985, pp. 1037-1038). Hailstorms are typically observed in the region two or three times a year (Eagleman 1985, p. 235), and a damaging ice storm occurs in Tennessee about one year in five, on average, with considerable variation (U. S. Army 1959, pp. 60-61). Freezing rain is not uncommon during the winter months, especially when cold air is trapped in the valley and relatively lighter (warm and moist) air from the Gulf of Mexico occurs at higher elevations. Under these conditions, the rain may be freezing in the valley but not in the surrounding mountains.

Relative humidity in Knoxville averages about 72\% (DOC 1989a, pp. 1-8), which is about the average for the eastern United States. In general, relative humidity is highest early in the morning, during the cooler hours, and lowest during the afternoons. The nearest long records of relative hurnidity come from the Knoxville airport. These data are summarized in Table 2.3-4. 
Table 23-4. Relative humidity data for Knoxville, Tennessee

\begin{tabular}{lccccc}
\hline & \multicolumn{5}{c}{ Mean monthly relative humidity $(\%)$ at specified times of day } \\
\cline { 2 - 6 } Month & 1 a.m. & 7 a.m. & 1 p.m. & 7 p.m. & Average \\
\hline January & 77 & 80 & 64 & 66 & 72 \\
February & 72 & 78 & 59 & 59 & 67 \\
March & 71 & 79 & 55 & 56 & 65 \\
April & 71 & 80 & 51 & 52 & 64 \\
May & 81 & 85 & 57 & 60 & 71 \\
June & 85 & 88 & 60 & 63 & 74 \\
July & 87 & 90 & 62 & 66 & 76 \\
August & 87 & 91 & 61 & 66 & 76 \\
September & 87 & 92 & 60 & 67 & 77 \\
October & 84 & 89 & 56 & 64 & 73 \\
November & 79 & 84 & 59 & 66 & 72 \\
December & 77 & 81 & 63 & 67 & 72 \\
Annual & 80 & 85 & 59 & 63 & 72 \\
\hline
\end{tabular}

Source: Gale Research Company 1985. Climates of the States, Vol. 2, 3d ed., Gale Research Company, Detroit.

\subsection{Specific Meteorological Phenomena}

This section provides information about specific meteorological phenomena and their effects in the area around Oak Ridge. The following items are addressed: hurricanes, tornadoes and waterspouts, thunderstorms and lightning, hail, high air pollution potential, fog, freezing rain, snowstorms, wind speed and direction by stability class, and mixing heights.

\subsection{Hurricanes}

ORR is more than $483 \mathrm{~km}$ ( 300 miles) from the Atlantic Ocean and is separated from it by the Appalachian Mountains. The Gulf of Mexico is more than $644 \mathrm{~km}$ (400 miles) away. Therefore, hurricanes are not observed in the Oak Ridge area. However, effects of a hurricane can sometimes be seen (for example, in the form of heavy rain) if a hurricane is sufficiently strong and landfall is sufficiently close. Hurricane Hugo, for example, was a strong hurricane that made landfall near Charleston, South Ca: $\lrcorner$ lina, on September 22, 1989. Charleston is about the nearest coastal point to Oak Ridge. The Oak Ridge area received heavy rain caused by the remnants of the hurricane. The 
weather station at ATDD reported $44.9 \mathrm{~mm}$ (1.77 in) of rain on September 22 and $20.8 \mathrm{~mm}$ ( $0.82 \mathrm{in})$ more on September 23. This is far from the record 24-h precipitation amounts, most of which are not associated with hurricanes.

\subsection{Tornadoes and Waterspouts}

Eastern Tennessee is infrequently subjected to tornadoes and waterspouts.

Tornadoes tend to be larger and more frequent in the areas of relatively low relief to the west of the Cumberland Mountains. Tornado frequencies have been calculated by Thom (1963, pp. 730-736) for each $1^{\circ}$ square of latitude and longitude in the United States for the period 1953-1962. Kelly et al. (1978, pp. 1172-83) have made similar calculations using an increased data base (1950-1976) with additional quality assurance procedures for tornado reporting.

The annual probability that a tornado will strike any location in a gridsquare may be estimated by multiplying the number of tornadoes per year per square kilometer (in that particular gridsquare) by the path area of a tornado. The result of such a calculation is greatly affected by the assumption of the size of the path area of a tornado. The data and assumptions of Thom (1963) suggest that the probability of a "typical" tornado striking a specific site on ORR in any particular year is $3.63 \times 10^{-4}$, which is a return period of 2752 years. These figures are based on tornado occurrences from 1953-1962. Applying the same assumptions to the (Innger) data base of Kelly et al. (1978, pp. 1172-83) suggests a return period of about 2000 years. Because of the nature of the local terrain, the probability that an extremely large or violent tornado will occur on ORR is extremely small. The American Nuclear Society (1983, Fig. 3.2-3) and Coats and Murray (1985, p. 54) indicate that tornadic wind speeds of close to $67 \mathrm{~m} / \mathrm{s}(150 \mathrm{mph})$ would be expected at a particular location in eastern Tennessee about once in 100,000 years.

Sustained high winds not associated with tornadoes can cause damage to buildings and other structures. Maximum sustained winds were traditionally quantified as the "fastest 1 mile $(1.6 \mathrm{~km})$ " of wind [the highest average wind speed over a $1.6-\mathrm{km}$ (1-mile) long column of passing air]. The maximum fastest $1.6 \mathrm{~km}$ (1 mile) of wind values recorded at Knoxville and Chattanooga are indicated in Table 2.3.5. These data are taken from older summaries because of longer record lengths in those summaries. The records for Knoxville, given by DOC 1977a (pp. 1-4) go back to 1947, and the records for Chattanooga, given by DOC 1977c (pp. 1-4), go back to 1943. The all-time maximum value for Knoxville has not been exceeded as of 1989 (Gale Research Company 1985, p. 1037; DOC 1989a, pp. 1-8). For comparison, fastest 1.6-km (1-mile) winds range from about 20-30 m/s (45-65 mph) in southern California and the lower Mississippi Valley (away from the Gulf Coast) to more than $45 \mathrm{~m} / \mathrm{s}(101 \mathrm{mph})$ in southern Florida, southern Texas, and parts of the Midwest (DOC 1968, p. 74).

Waterspouts could occur on the Clinch River, but the nearest point on the Clinch River is about $1 \mathrm{~km}(0.6$ mile), over hilly terrain, from the proposed ANS site. Waterspouts would therefore pose no problems or hazards at the proposed ANS site.

\subsection{Thunderstorms and Lightning}

On the average, thunderstorms and associated lightning occur in the region about 50 days per year, with about 10 thunderstorm days occurring in July. From 30 to 40 thunderstorm days typically occur during the 4-month period from May through August, 
Table 23-5. Record fastest $1.609 \mathrm{~km}$ (1 mile) of wind for Knoxville and Chattanooga, Tennessce

\begin{tabular}{lcccc}
\hline Location & $\begin{array}{c}\text { Speed } \\
{[\mathrm{km} / \mathrm{h}(\mathrm{mph})]}\end{array}$ & $\begin{array}{c}\text { Direction } \\
\text { (wind from) }\end{array}$ & Year & $\begin{array}{c}\text { Length of } \\
\text { record (years) }\end{array}$ \\
\hline Knoxville & $117(73)$ & SW & 1961 & 31 \\
Chattanooga & $131(82)$ & W & 1947 & 35 \\
\hline
\end{tabular}

The anemometer heights at the time of the record fastest mile were $17.4 \mathrm{~m}(57 \mathrm{ft})$ for Chattanooga and $6.7 \mathrm{~m}(22 \mathrm{ft})$ for Knawille.

Sources: U.S. Department of Commerce 1977a, Local Climatological Data with Comparative Data, 1989, Knowville, Tennessee, National Climatic Data Center, Asheville, N.C., p. 2; U.S. Department of Commerce 1977c. Local Climatological Data with Comparative Data, 1977, Chattanooga, Tennessee, National Climatic Data Center, Asheville, N.C., p. 2.

and less than 20 thunderstorm days are normally scattered over the remaining 8 months. Monthly and annual average numbers of thunderstorm days are given in Table 2.3-6.

\subsubsection{Hail}

Hail usually occurs during thunderstorms associated with cold fronts. Hailstorms at a given locality in Tennessee may typically occur two or three times a year (Gale Research Company 1985, p. 1024; Eagleman 1985, p. 235). For comparison with extreme values in the United States, an average of less than one-half hail day per year occurs near the coast of the Gulf of Mexico and about 8 hail days per year occur near Cheyenne, Wyoming (Eagleman 1985, p. 235). On an index of potential hail damage to residential property calculated for $1^{\circ}$ squares of latitude and longitude, eastern Tennessee averages about 5 , which is relatively low. Values of this index are as high as 50 in northwestern Kansas and as low as 1 or less in the Florida peninsula and in a broad area centered roughly where the Arizona-Utah border meets the Nevada state line (Changnon 1972, Fig. 4). Therefore, on a geographical basis, the proposed ANS site is in an area of relatively low potential risk from hail damage.

\subsection{High Air-Pollution Potential}

Days of high air-pollution potential, or stagnation days, over the eastern United States have been studied by Korshover (1976) and Korshover and Angell (1982). Stagnation days for a particular area or location were defined for those studies as days on which the surface geostrophic wind" is less than $8 \mathrm{~m} / \mathrm{s}(18 \mathrm{mph})$, no fronts are in the region, no precipitation occurs, and the wind speed at $7.3 \mathrm{~Pa}$ (500 millibars) [about $5.5 \mathrm{~km}$ ( 3.4 miles) altitude] does not exceed $13 \mathrm{~m} / \mathrm{s}(29 \mathrm{mph}$ ) (Korshover and Angell 1982, p. 1515). A sequence of four such days in a row is termed an air-stagnation episode. From interpolation of Fig. 3 in Korshover 1976 (pp. 1-28), 70 incidents of stagnation covering about 330 days occurred near the proposed ANS site during the 40-year period

\footnotetext{
"The geostrophic wind is defined as the horizontal wind velocity for which the coriolis force exactly balances the pressure gradient force. This approximation overestimates the actual wind speed at the surface because the effects of friction and turbulence, which reduce wind speed, are not considered.
} 
Table 23-6. Average numbers of thunderstorm days at Oak Ridge and Knowille, Tennessee

\begin{tabular}{|c|c|c|}
\hline Month & Knoxville & Oak Ridge \\
\hline January & 1 & 1 \\
\hline February & 1 & 2 \\
\hline March & 3 & 3 \\
\hline April & 4 & 5 \\
\hline May & 6 & 8 \\
\hline June & 8 & 9 \\
\hline July & 10 & 11 \\
\hline August & 7 & 9 \\
\hline September & 3 & 3 \\
\hline October & 1 & 1 \\
\hline November & 1 & 1 \\
\hline December & $a$ & 1 \\
\hline Total $^{a}$ & 47 & 53 \\
\hline
\end{tabular}

The average is less than $0.5 \mathrm{~d}$ for December in Knowville. Differences between the column sums and annual totals are due to roundoff in the numbers given in the source.

Source: Gale Research Company 1985, Climates of the States, Vol. 2, 3d ed., Detrolt, pp. 1037-1038.

from 1936 through 1975. This works out to an average of 1.75 episodes per year, covering an average of $8.25 \mathrm{~d} /$ year. More than half (39) these stagnation episodes occurred during August, September, or October (Table 2.3-7).

Holzworth (1972, p. 118) has studied air-pollution potential throughout the entire contiguous United States. His definition of air pollution potential is more conservative than that given by Korshover (1976, pp. 4-7) or Korshover and Angell (1982, pp. 15-75) in the sense that more days qualify as having meteorological conditions favorable for air pollution. An episode of conditions favorable for air pollution is defined as occurring when, for a period of $2 \mathrm{~d}$, the mixing height is less than $1500 \mathrm{~m}(4922 \mathrm{ft})$, the actual surface wind speed (not the geostrophic wind speed, which is greater) is less than $4.0 \mathrm{~m} / \mathrm{s}$ (9 mph), and there is no precipitation (Holzworth 1972, pp. 21-22). Interpolating from the map on page 83 of Holzworth 1972, the area around Oak Ridge experiences about 5 pollution episodes annually, covering an average of 11 to 12 days per year. Note that Holzworth's 1972 conclusions are based on only 5 years of data and may not be as rigorous as Korshover's 1976 conclusions, which are based on 40 years of data. 
Table 23-7. Number of Korshover stagnation episodes, by month, during the 40-year period 1936-1975

\begin{tabular}{lcc}
\hline \multicolumn{1}{r}{ Month } & Number by month & Cumulative number by month \\
\hline January & 0 & 0 \\
February & 0 & 0 \\
March & 0 & 0 \\
April & 3 & 3 \\
May & 8 & 11 \\
June & 8 & 19 \\
July & 5 & 24 \\
August & 12 & 36 \\
September & 9 & 45 \\
October & 18 & 63 \\
November & 6 & 69 \\
December & 1 & 70 \\
\hline
\end{tabular}

Source: Korshover, J. 1976. Climatology of Stagnating Anticyclones East of the Rocky Mountains, 1936-1975, NOAA Technical Memorandum ERL ARL.S5, U.S. Department of Commerce, NOAA, Washington, D.C.

Other combinations of wind speed and mixing height (on occasions when no precipitation occurred) are summarized by Holzworth (1972). The most restrictive combination during a 2-d period [mixing height less than $500 \mathrm{~m}(1640 \mathrm{ft})$ and winds less than $2 \mathrm{~m} / \mathrm{s}(4.5 \mathrm{mph})$ ] did not occur in eastern Tennessee during the 5 years studied by Holzworth (1972, p. 76).

The Korshover and Holzworth studies both indicate that the southeastern United States has a greater trequency of potential air pollution days than does the northeastern United States or the Great Plains and that the area around the proposed ANS site is above average for the eastern United States in terms of frequency of meteorological conditions favoring air pollution.

\subsubsection{Fog}

Fog occurs on ORR about $1 \mathrm{~d}$ in 11 each year, but the frequency is concentrated in the autumn months, when fog occurs on about $1 d$ in 6 . Fog in the area is usually caused by the advection of cold air across a warm surface during the previous night. This fog is often referred to as "valley fog" because it occurs mainly in river valleys, particularly in autumn when cold air passes over rivers that have retained heat from the summer. The fog usually disappears by mid-morning. The frequency of fog days at the Oak Ridge and Knoxville weather stations (DOC 1989a, pp. 1-8; DOC 1989b, p. 1-8) is shown in Table 2.3-8.

\subsubsection{Freexing Rain}

Freezing rain, sometimes called glaze, is supercooled liquid rain that freezes upon impact with an object that has a temperature near or below the freezing point. This can occur when rain falls from a warm (above freezing) layer of air through a cold (below freezing) layer sufficiently shallow so that the rain does not freeze until it makes contact with highways, trees, telephone wires, and other surfaces. 
Table 23-8. Mean number of days per year with fog and visibility $402 \mathrm{~m}$ (1/4 mile) or less

\begin{tabular}{lcc}
\hline \multicolumn{1}{c}{ Month } & Knoxville $^{a}$ & Oak Ridge $^{b}$ \\
\hline January & 3 & 1 \\
February & 2 & 1 \\
March & 2 & 1 \\
April & 1 & 1 \\
May & 2 & 2 \\
June & 2 & 1 \\
July & 2 & 3 \\
August & 3 & 4 \\
September & 4 & 4 \\
October & 5 & 8 \\
November & 3 & 6 \\
Decernber & 3 & 2 \\
Total & 32 & 34 \\
\hline
\end{tabular}

-Based on a 47-year record.

based on a 15-year record.

Sources: U.S. Department of Commerce 1989. Local Climnasological Data with Comparative Data, 1989, Knoxville, Tennessee, National Climatic Data Conter, Asheville, N.C.; U.S. Department of Commerce 1989, Local Climatological Data with Comparative Data, 1989, Oak Ridyz, Tennessee, National Climatio Data Center, Asheville, N.C.

Freezing rain in the Oak Ridge area is not uncommon during the winter months, especially when cold air is trapped in the valley and relatively lighter (warm and moist) air from the Gulf of Mexico is present at higher elevations. Under these conditions, glaze may occur in the valley but not in the surrounding mountains. Conditions favoring freezing rain in the Oak Ridge area are most likely to occur during the cooler months, from December through March. Typically, the freezing rain only lasts for a few hours, until meteorological conditions change. The affected surfaces may, on occasion, remain frozen for a few more hours, depending on the time of day and related factors such as temperature and traffic patterns (on roads).

According to a study by the U.S. Weather Bureau (now the National Weather Service) of a 28-year period ending with the winter of 1952-53 (U.S. Army 1959, pp. 59-62), most of eastern Tennessee experienced from three to six ice storms, or an average recurrence of about one storm per 5 to 9 years. Because some storms probably went unrecorded in the earlier years, this tigure may be low. Other studies of shorter periods by parties with particular interests in the subject suggest a greater frequency of ice storms in eastern Tennessee. Data summaries made by the American Telephone and Telegraph Company (covering the winters of 1917-18 through 1924-25) and by the 
Association of American Railroads (covering the winters of 1928-29 through 1936-37) are presented in a U.S. Army report (1959, pp. 59-62). These data suggest a frequency of about one ice storm every 2 years, with glaze nore than 0.25 in. thick forming in about two-thirds of these cases, or about once every 3 years. However, these data summaries each cover less than 10 years and may represent periods of particularly high ice-storm frequencies. Further, Tennessee's climate may have changed somewhat since these shortterm studies were conducted. A more recent climatic summary of Tennessee presented by the Gale Research Company (1985, p. 1024) states that "damaging ice storms occur in the State every 5 or 6 years."

\subsection{Sncowstorms}

Snowfall in Oak Ridge averages about $254.0 \mathrm{~mm}(10 \mathrm{in.}$ ) per year. Some snowfall records for Oak Ridge and Knoxville are given in Table 2.3-9.

Table 2.3-9. Snowfall records for Oak Ridge and Knoxville

\begin{tabular}{|c|c|c|c|}
\hline Period & Station & $\begin{array}{l}\text { Record snowfall } \\
\text { [mm (in.)] }\end{array}$ & Date \\
\hline $12 \mathrm{~h}$ & $\begin{array}{l}\text { Knoxville } \\
\text { Oak Ridge }\end{array}$ & $\begin{array}{l}462.0(18.2) \\
304.0(12.0)\end{array}$ & $\begin{array}{l}\text { November } 1952 \\
\text { March } 1960\end{array}$ \\
\hline 1 month & $\begin{array}{l}\text { Knoxville } \\
\text { Oak Ridge }\end{array}$ & $\begin{array}{l}591.0(23.3) \\
533.0(21.0)\end{array}$ & $\begin{array}{l}\text { February } 1960 \\
\text { March } 1960\end{array}$ \\
\hline Annual & $\begin{array}{l}\text { Knoxville } \\
\text { Oak Ridge }\end{array}$ & $\begin{array}{l}1440.0(56.7) \\
1051.0(41.4)\end{array}$ & $\begin{array}{l}1959-60 \\
1959-60\end{array}$ \\
\hline
\end{tabular}

Sources: U.S. Department of Commerce 1977. Local Climatological Data with Comparative Data. 1977, Knowille, Tennessee, National Climatic Data Center, Asheville, N.C., Pp. 1-4; U.S. Department of Commerce 1989. Lacal Climasological Dasa with Comparative Data, 1989, Knoxville, Tennessee, National Climatic Data Center, Asheville, N.C., pp. 1-8; and Gale Research Company 1985. Climates of the States, Vol. 2, 3d ed., Gale Research Company, Detroit, pp. 1037-1038.

The winter of 1959-60 was clearly the snowiest year on record in Knoxville and Oak Ridge. Since that time, not even three-quarters as much snow has fallen during any other winter on record.

\subsubsection{Wind Speed and Direction by Stability Class}

Figure 2.3-3 shows the wind rose (the distribution of wind speed and wind direction) for Tower 4 at $30 \mathrm{~m}$ (98 ft) above ground level for 1986-1990. Wind roses for the same period, for each atmospheric stability class, are given in Figs. 2.3-4-2.3-10. The stability classes range from extremely unstable (A) to extremely stable (G). Flow of cold air from the north-northeast at night is prominent under the most stable conditions (stability category $\mathrm{G}$ ) and is not evident in very uasiable conditions (stability category A), which occur mostly in the early afternoon. 


\subsection{Mixing Heights}

Mixing height is related to the volume of air available for the dispersion of atmospheric contaminants. Mixing-height data are usually obtained from upper-air data available from only a few selected stations; the closest one to Oak Ridge is Nashville, Tennessee, which is about $237 \mathrm{~km}$ (135 miles) west of Oak Ridge. A first approximation of the diurnal and annual distribution of mixing heights may be interpolated from the maps in Holzworth 1972 (pp. 27-35). Table 2.3-10 shows the results of such an interpolation. Table 2.3-11 summarizes mixing heights calculated from upper-air data from Nashville.

\subsection{Representativeness of Meteorological Data}

This section is included to examine the representativeness of local meteorological data in space and time. Spatial representativeness is important because it allows inferences about climatic parameters at local sites to be made from data for surrounding stations with similar exposure characteristics and elevations. Temporal representativeness ensures that a short record is characteristic of longer-term conditions. Temporal representativeness throughout periods greater than two or three decades also indicates that the climate of the region is not changing in ways that might be relevant to the cnvironmental effects of the proposed action.

\subsubsection{Temperature}

Temperature does not vary appreciably over horizontal distances of a few kilometers unless corresponding differences exist in elevation, in distance to a large body of water, or in some other feature that obviously influences temperature. No large bodies of water are present in the vicinity of ORR. Temperature varies with elevation in the area, but the elevation of the proposed ANS site ( $268 \mathrm{~m}$, or $880 \mathrm{ft}$ above sea level) is the same as the elevation of the Oak Ridge NOAA weather station at ATDD and is close to the elevation of the weather station at McGhee-Tyson Airport $(276 \mathrm{~m}$, or $905 \mathrm{ft}$ above sea level). The annual average temperature at the airport is $14.94^{\circ} \mathrm{C}\left(58.9^{\circ} \mathrm{F}\right)$; in Oak Ridge, it is $14.17^{\circ} \mathrm{C}\left(57.5^{\circ} \mathrm{F}\right)$. Short temperature records (mid-1940s through 1952) from three stations several kilometers apart on ORR were compared by the U.S. Atomic Energy Commission (1953, p. 248). The average annual temperatures at the sites were all between $14.11^{\circ} \mathrm{C}\left(57.4^{\circ} \mathrm{F}\right)$ and $14.72^{\circ} \mathrm{C}\left(58.5^{\circ} \mathrm{F}\right)$. Taken collectively, these data show that the temperatures in the Oak Ridge area do not vary appreciably from one site to the next, nor have temperatures :hanged through time, at least during the last 50 years or so.

\subsubsection{Precipitation}

Precipitation for short time periods can vary greatly over distances of only a few kilometers during summer thunderstorm activity. On longer time scales (e.g., monthly or annual averages), precipitation in the Oak Ridge area can vary appreciably with elevation. The Oak Ridge and Knoxville weather stations are at similar elevations and receive average annual amounts of $1392 \mathrm{~mm}$ (54.8 in.) and $1201 \mathrm{~mm}$ (47.3 in.), respectively. The higher average in Oak Ridge may result from its proximity to the Cumberland Mountains. 







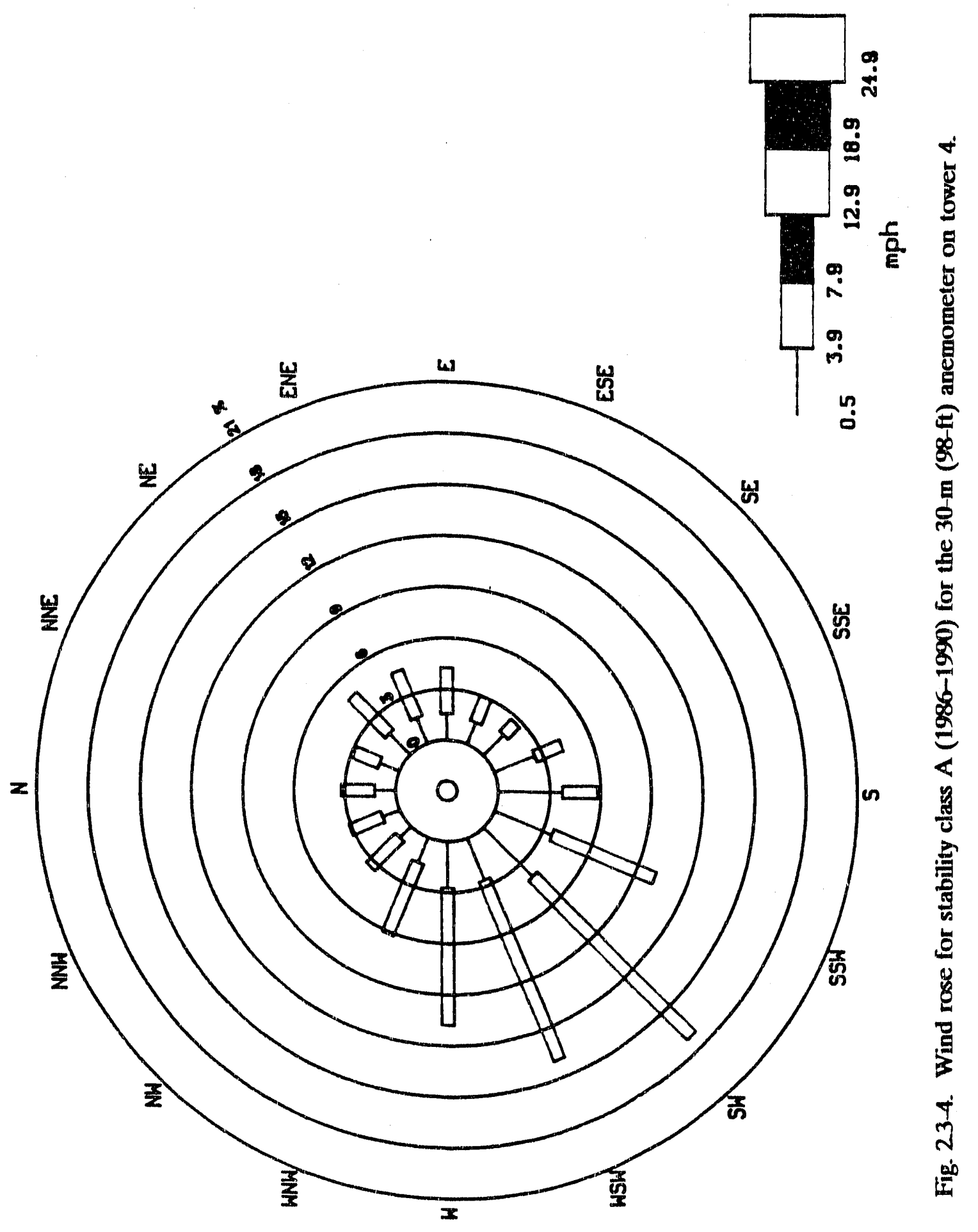




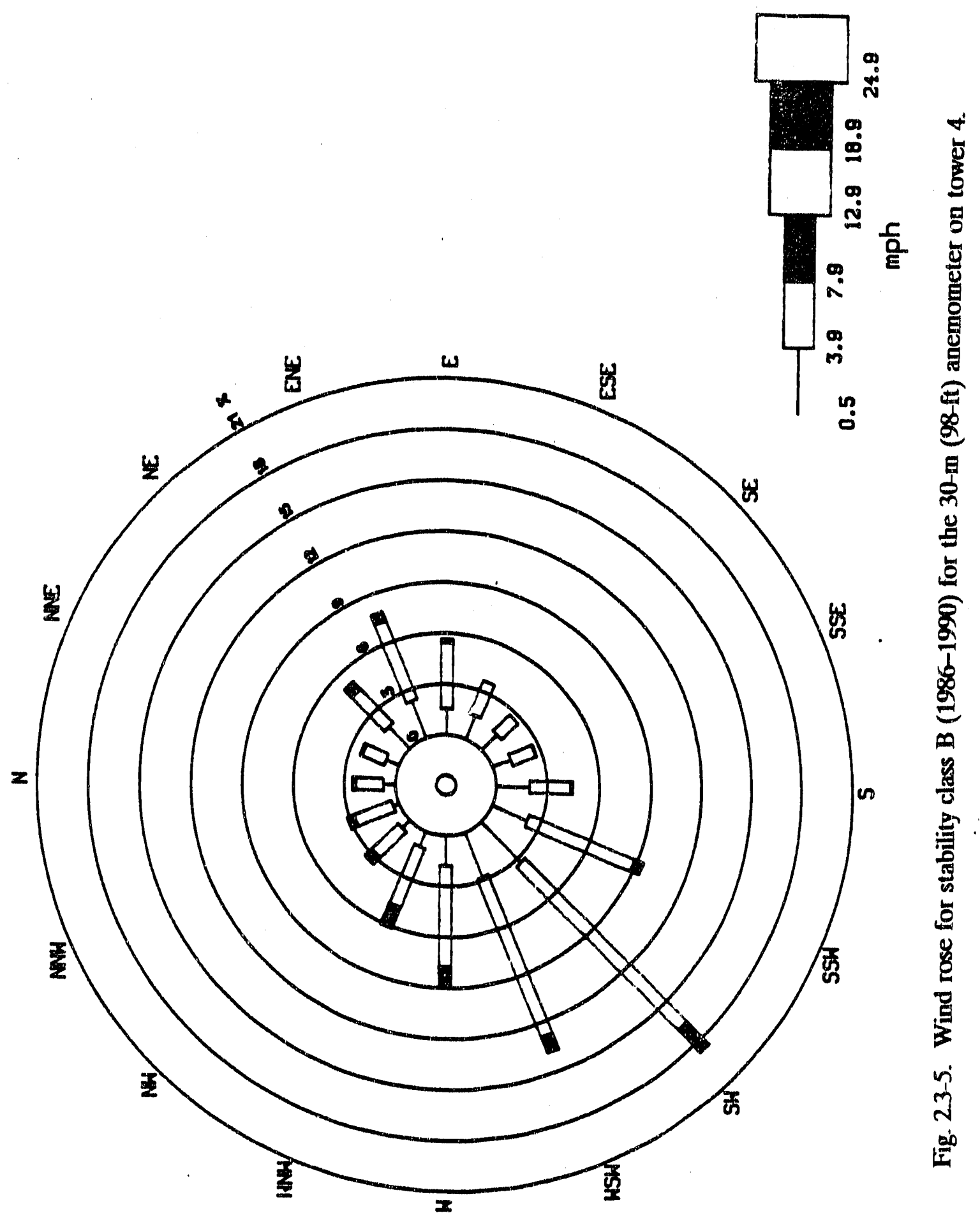




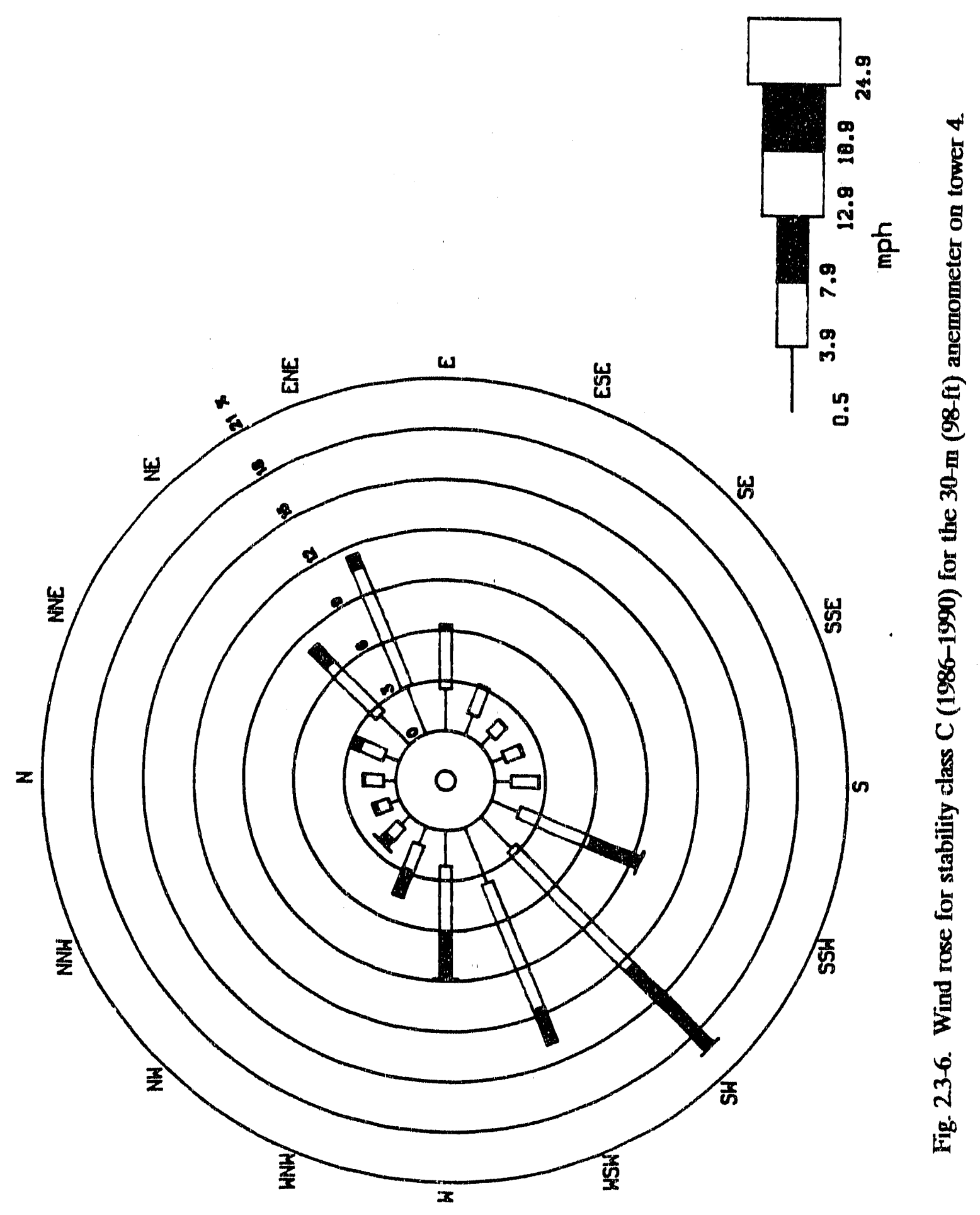




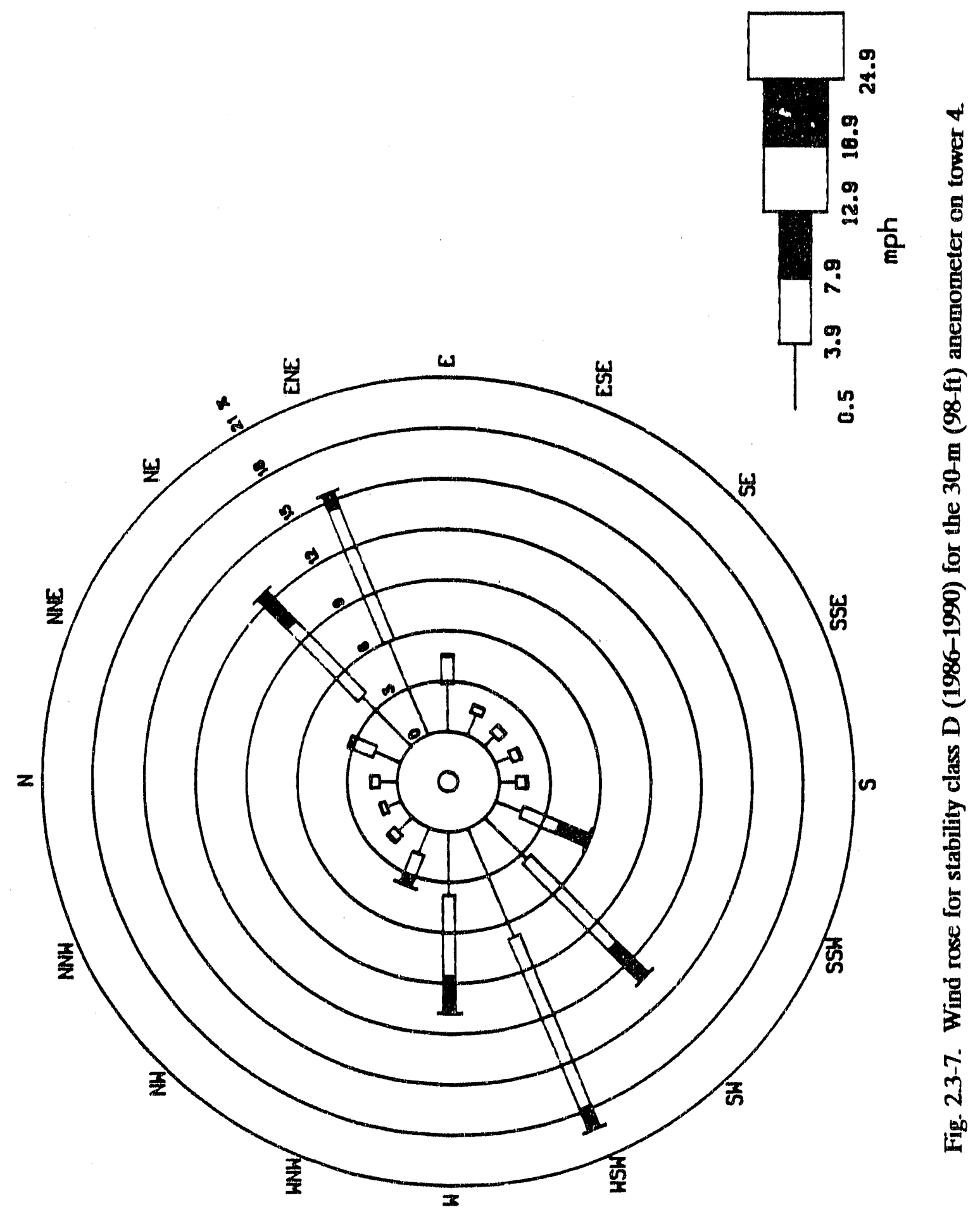




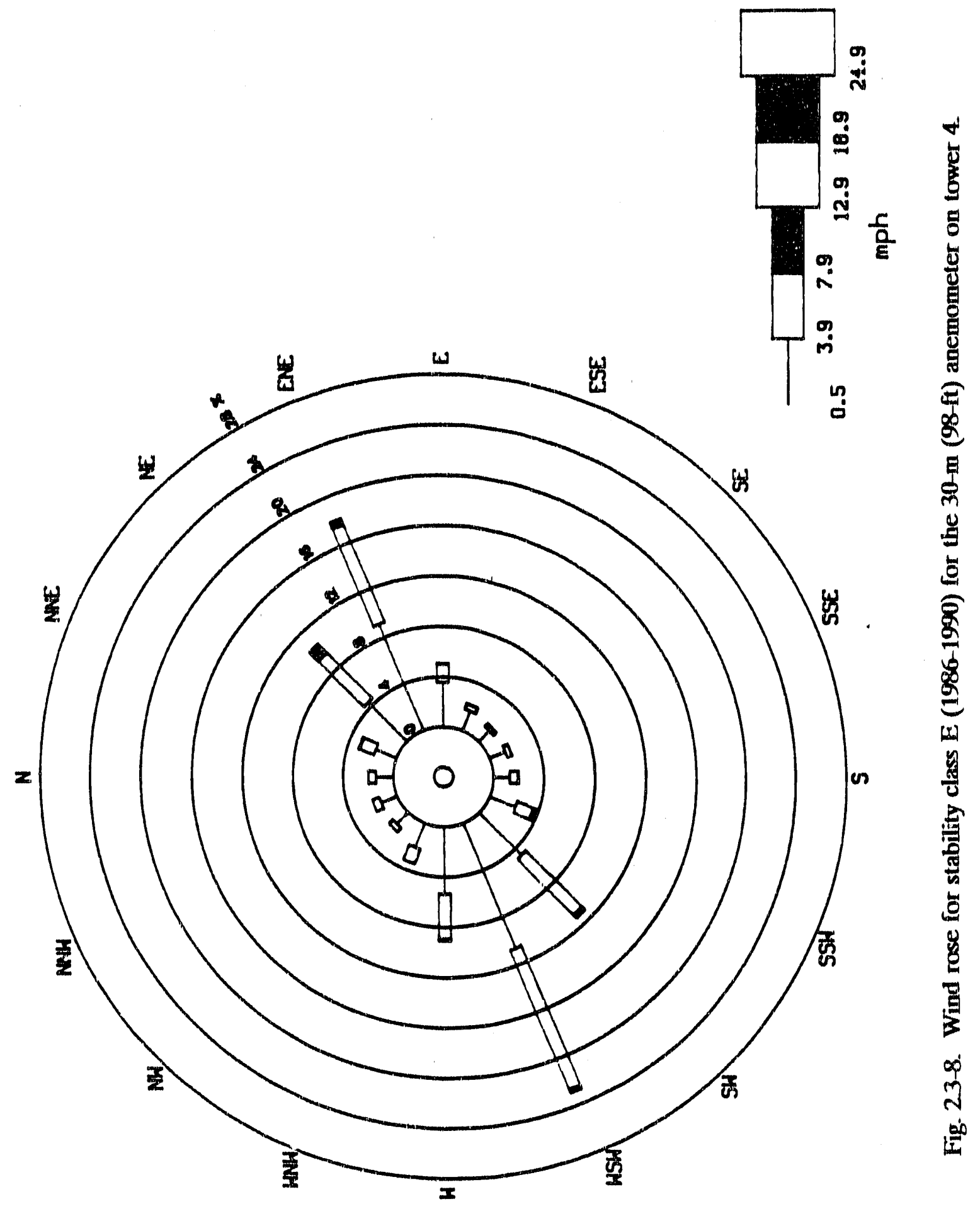




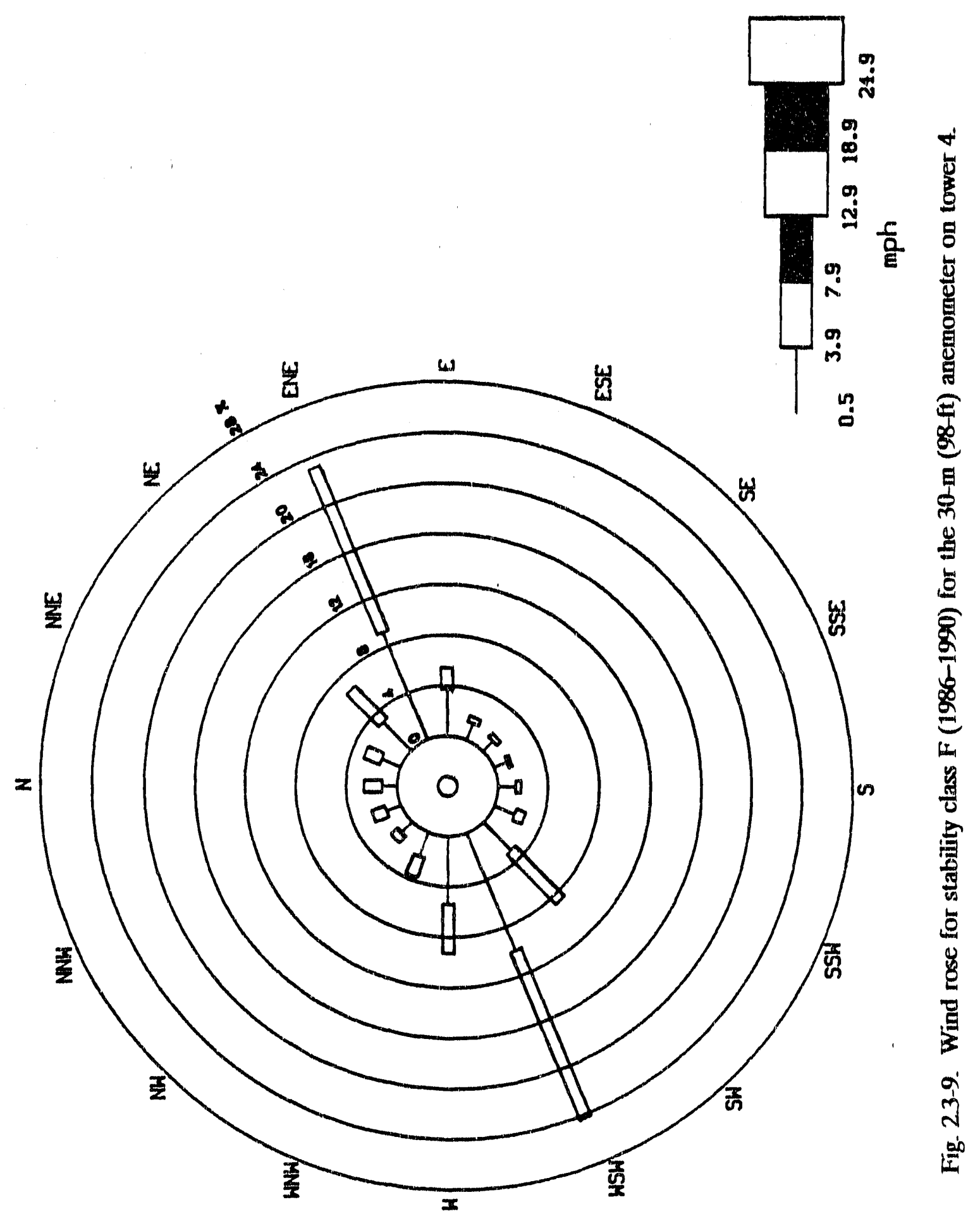




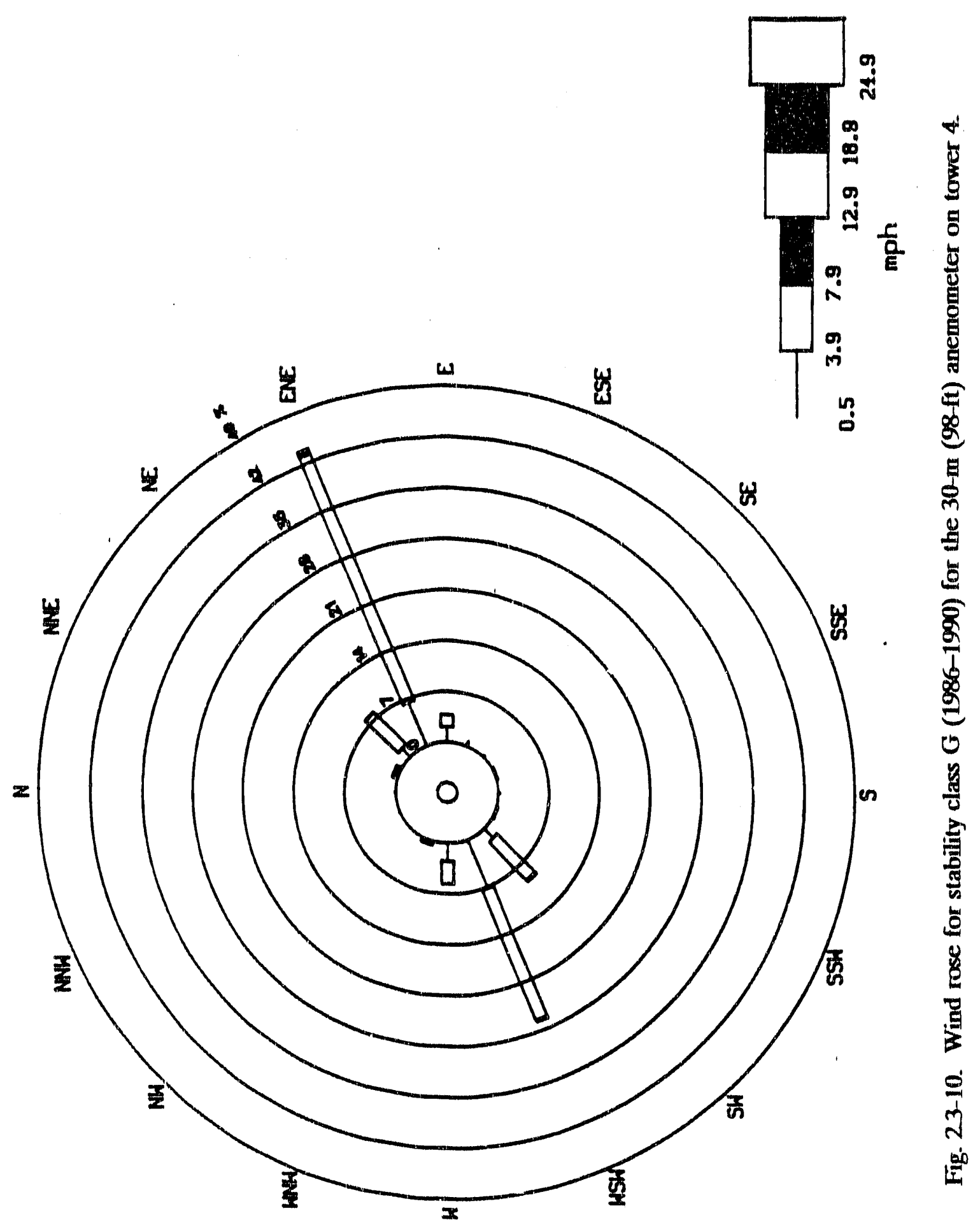


Table 23-10. Mixing beight and wind speed data for the Knowville-Oak Ridge area

\begin{tabular}{|c|c|c|c|c|}
\hline & $\begin{array}{c}\text { Morning mixing } \\
\text { height } \\
{[\mathrm{m}(\mathrm{ft})]}\end{array}$ & $\begin{array}{l}\text { Morning } \\
\text { wind speed } \\
\text { [m/s (mph)] }\end{array}$ & $\begin{array}{l}\text { Afternoon } \\
\text { mixing height } \\
{[\mathrm{m}(\mathrm{ft})]}\end{array}$ & $\begin{array}{l}\text { Afternoon } \\
\text { wind speed } \\
{[\mathrm{m} / \mathrm{s} \text { (mph)] }}\end{array}$ \\
\hline Winter & $500-600(1640-1968)$ & $5-6(11.2-13.4)$ & $\begin{array}{l}1000-1200 \\
(3280-3936)\end{array}$ & $\begin{array}{l}6-7 \\
(13.4-15.6)\end{array}$ \\
\hline Spring & $500-600(1640-1968)$ & $5-6(11.2-13.4)$ & $\begin{array}{l}1800-1900 \\
(5905-6233)\end{array}$ & $\begin{array}{l}6-7 \\
(13.4-15.6)\end{array}$ \\
\hline Summer & $400-500(1312-1640)$ & $3-4(6.72-8.9)$ & $\begin{array}{l}1800-2000 \\
(5905-6561)\end{array}$ & $\begin{array}{l}4-5 \\
(8.9-11.2)\end{array}$ \\
\hline Fall & $300-400(984-1312)$ & $3-4(6.72-8.9)$ & $\begin{array}{l}1400-1600 \\
(4593-5249)\end{array}$ & $\begin{array}{l}5-6 \\
(11.2-13.4)\end{array}$ \\
\hline Annual & $400-500(1312-1640)$ & $4-5(8.9-11.2)$ & $\begin{array}{l}1600-1700 \\
(5249-5577)\end{array}$ & $\begin{array}{l}5-6 \\
(11.2-13.4)\end{array}$ \\
\hline
\end{tabular}

Source: G. C. Holzworth, 1972. Mixing Heights, Wind Speeds, and Potential for Urban Air Pollution Throughout the Contiguous United States, Ap-101 (NTIS No. PB 207-103), U.S, Environmental Protection Agency, Research Triangle Park, N.C.

According to a map of average annual precipitation (for 1948-1951) presented by the U.S. Atomic Energy Commission (AEC) (1953, p. 380), Knoxville received about $1400 \mathrm{~mm}(55 \mathrm{in}$.) per year; locations in the Great Smoky Mountains, southeast of Knoxville, received as much as $2290 \mathrm{~mm}$ ( $90 \mathrm{in}$.) per year. The annual average for that period near McGhee-Tyson Airport, just south of Knoxville, was 1270 to $1400 \mathrm{~mm}$ (50 to $55 \mathrm{in}$.). This average, based on 4 years of data, was about $150 \mathrm{~mm}$ (6 in.) above the longterm normal for that location at the time (AEC 1953, p. 381), indicating that the longterm normal at that time was about 1120 to $1240 \mathrm{~mm}$ (44-49 in.). This brackets the current (1951-1980) long-term annual average precipitation of $1201 \mathrm{~mm}(47.3 \mathrm{in.}$ ) at McGhee-Tyson Airport.

\subsubsection{Wind}

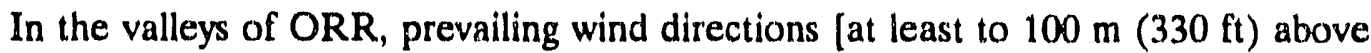
ground level] parallel the nearest ridge. This tendency is evident in the wind roses based on recent measurements from the six existing meteorological monitoring towers (Kornegay et al. 1990, Vol. 2, pp. 11-17) and is also evident in the wind roses from an earlier period and a different network of sites (AEC 1953, pp. 465-472). Wind patterns are therefore similar from one location to the next within a particular valley, as long as the wind. measuring instruments are not influenced by local structures or other obstacles. The wind data presented in this report are based on measurements $30 \mathrm{~m}(98 \mathrm{ft})$ above-ground at Tower $4,1.3 \mathrm{~km}$ ( 0.8 mile) southwest of the proposed ANS site, in the same valley and about the same distance from Haw Ridge as the proposed site. Therefore, these data represent winds at a similar altitude (and equally free of the effects of local obstacles) at the proposed ANS site. 
Table 23-11. Monthly morning and afternoon mixing beights for Knoxville, Tennessee (1985-1989)

\begin{tabular}{lccccc}
\hline & \multicolumn{2}{c}{ Average heights [m(ft)] } & & \multicolumn{2}{c}{ Extremes [m(ft)] } \\
\cline { 2 - 3 } \cline { 5 - 6 } \multicolumn{1}{c}{ Month } & Morning & Afternoon & & Minimum & Maximum \\
\hline January & $748(2454)$ & $829(2719)$ & $7(22.9)$ & $2472(8110)$ \\
February & $707(2319)$ & $948(3110)$ & & $2(6.56)$ & $2271(7450)$ \\
March & $685(22.47)$ & $1290(4232)$ & & $2(6.56)$ & $3143(10311)$ \\
April & $528(1732)$ & $1648(5406)$ & & $1(3.28)$ & $3053(10016)$ \\
May & $372(1220)$ & $1612(5288)$ & & $4(13.1)$ & $3240(10629)$ \\
June & $321(1053)$ & $1700(5577)$ & & $4(13.1)$ & $3401(11158)$ \\
July & $334(1095)$ & $1680(5511)$ & & $5(16.4)$ & $3162(10373)$ \\
August & $344(1128)$ & $1582(5190)$ & & $14(45.9)$ & $2925(9596)$ \\
September & $408(1338)$ & $1447(4747)$ & & $8(26.2)$ & $2872(9422)$ \\
October & $513(1638)$ & $1184(3884)$ & & $3(9.84)$ & $2364(7755)$ \\
November & $664(2178)$ & $901(2956)$ & $6(19.6)$ & $2477(8126)$ \\
December & $689(2260)$ & $814(2670)$ & $5(16.4)$ & $1876(6154)$ \\
Annual & $507(1663)$ & $1309(4294)$ & $1(3.28)$ & $3401(11158)$ \\
\hline
\end{tabular}

Sources: Mixing height tapes were obtained from the National Climatic Data Center, Federal Building, Asheville, N.C. 28801. Surface data are taken from the Knoxville airport. Upper air data are from Nashville.

AEC studied wind patterns on ORR in detail during the 1940s and early 1950s. Maps of wind patterns for 1948-1952 (AEC 1953, pp. 465-472) can be compared with more recent wind patterns at various locations on ORR (Kornegay et. al, 1990, Vol. 2 , pp. 11-17). One of the wind-measurement locations in the earlier study was in Melton Valley, about $200 \mathrm{~m}$ (about $650 \mathrm{ft}$ ) north of the present location of Tower 4 . As could be expected from the preceding discussion, the wind patterns were similar. Such comparisons confirm that the wind patterns in the area have not changed since the first instruments were installed in the late 1940s; therefore, recent wind data represent long-term conditions at the site. Because surface wind patterns in the region are determined primarily by topography, slight climatic fluctuations should not alter wind patterns.

\subsubsection{Humidity}

Because values of relative and absolute humidity are primarily determined by the time of day and by the large-scale weather pattern in the area, humidity measurements at weather stations will be representative of conditions at nearby locations. Humidity in eastern Tennessee has not changed detectably during the last 50 years or so. 


\subsubsection{Atmospheric Stability and Mixing Heights}

Atmospheric stability influences the dispersion rate of contaminants in the atmosphere. Stability for a particular hour is classified in one of seven categories ranging from extremely unstable (A) to extremely stable (G). Because stability is determined largely by the time of day and the large-scale weather features in a region at the time, it tends to be of the same category for a particular hour at all sites of the same elevation in the region. The fact that other climatic parameters related to stability (e.g., temperature and wind speed) have not changed during the period of record indicates that the diurnal and annual distributions of atmospheric stability have not changed.

Mixing heights are related to the volume of air through which contaminants may be dispersed. Mixing heights in eastern Tennessee may range from zero (ground-lovel Inversion) to more than $3000 \mathrm{~m}(9843 \mathrm{ft}$ ) (Table 2.3-11). Upper-air data from Nashville, Tennessee, wero used in conjunction with surface data from the Knoxville airport to obtain the mixing-height data summarized in Table 2.3.-11. The maps of Holzworth (1972, pp. 27-35) indicate that the diurnal and annual distri'sutions of mixing helghts at Nashville are not much different than those at Knoxville. Berause otherr climatic parameters related to mixing height (e.g., temperature and wind speed) have not changed during the period of record, it can be inferred that the diurnal and annual distributions of mixing height have not changed noticeably during the same period.

\subsection{Local Air Quality and Emissions Sources}

This section discusses applicable state and national ambient air quality standards, the quality of the local ambient air as compared with those standards, and major sources of pollution emissions to the atmosphere on and around ORR.

\subsubsection{Tennessee Ambient Air Quality Standards}

The state of Tennessee has adopted the National Ambient Air Quality Standards (NAAQS) and standards for fluoricle expressed as hydrogen fluoride (HF). These standards are set to protect human health and welfare. Federal standards also exist for the prevention of significant deterioration (PSD) of air quality. A set of PSD standards exists for Class II areas that cover most of the United States. A much more stringent set of PSD standards exists for Class I areas, which include national parks and wilderness areas. All of these standards are summarized in Table 2.3.12. The nearest PSD Class I area is the Great Smoky Mountains National Park. The nearest boundary of this area is about $50 \mathrm{~km}$ (31 miles) southeast of the proposed ANS site. Because of the distance from the site to the park and the small amounts of emissions expected from ANS, the effects of ANS on the park are expected to be negligible.

\subsubsection{Existing Air Quality}

Roane County is in attainment of all state and local air quality standards (Chuck Northington, Tennessee Air Pollution Control, Nashville, Tennessee, personal communication with T. J. Blasing, Oak Ridge National Laboratory, Oak Ridge, Tenn., May 20, 1991). Knox County, immediately east of Roane County and about $1.5 \mathrm{~km}$ (.93 miles) east of the proposed ANS site, was designated as a marginal nonattainment area for ozone on November 6, 1991 (Fed. Regist. 56, p. 56694). Because of a 60-d waiting period, this designation became effective January 6, 1991. The nonattainment 
Table 23-12. Air quality staudards"

\begin{tabular}{|c|c|c|c|c|c|}
\hline \multirow[b]{2}{*}{ Pollutant } & \multirow[b]{2}{*}{$\begin{array}{c}\text { Averaging } \\
\text { period }\end{array}$} & \multicolumn{2}{|c|}{$\begin{array}{l}\text { National ambient air } \\
\text { quality standard }\end{array}$} & \multicolumn{2}{|c|}{$\begin{array}{l}\text { Prevention of } \\
\text { significant } \\
\text { deterioration }\end{array}$} \\
\hline & & Primary & Secondary & Class I & Class II \\
\hline Sulfur dioxide & $\begin{array}{l}\text { Annual } \\
24 \mathrm{~h}^{b} \\
3 \mathrm{~h}^{b}\end{array}$ & $\begin{array}{r}80 \\
365\end{array}$ & $130 \overline{0}$ & $\begin{array}{r}2 \\
5 \\
25\end{array}$ & $\begin{array}{r}20 \\
91 \\
512\end{array}$ \\
\hline Nitrogen dioxide & Arnual & 100 & 100 & 2.5 & 25 \\
\hline Carbon monoxide & $\begin{array}{l}8 \mathrm{~h}^{b} \\
1 \mathrm{~h}^{b}\end{array}$ & $\begin{array}{l}10,000 \\
40,000\end{array}$ & - & - & $\overline{-}$ \\
\hline Ozone & $1 \mathrm{~h}^{b}$ & 235 & 235 & - & - \\
\hline Inhalable particles ${ }^{c}$ & $\begin{array}{l}\text { Annual } \\
24 \mathrm{~h}^{b}\end{array}$ & $\begin{array}{r}50 \\
150\end{array}$ & $\begin{array}{r}50 \\
150\end{array}$ & $\begin{array}{l}4^{d} \\
8^{d}\end{array}$ & $\begin{array}{l}17^{d} \\
30^{d}\end{array}$ \\
\hline Lead & 3 months" & 1.5 & 1.5 & - & - \\
\hline \multicolumn{6}{|c|}{ State of Tennessee Standards } \\
\hline Fluorides' & $\begin{array}{l}30 \mathrm{~d}^{b} \\
7 \mathrm{~d}^{b} \\
24 \mathrm{~h}^{b} \\
12 \mathrm{~h}^{b}\end{array}$ & $\begin{array}{l}1.2 \\
1.6 \\
2.9 \\
3.7\end{array}$ & & & \\
\hline
\end{tabular}

"All concentrations are in $\mu \mathrm{g} / \mathrm{m}^{3},-2$ No standurd.

${ }^{b} \mathrm{Not}$ to be exceeded more than once per year (for ozone, on more than $1 \mathrm{~d} / \mathrm{year}$ ).

TPartlculate matter less that 10 microns in dlameter.

"Proposed standard.

"Calendar quarter.

'Gaseous fluorides expressed as hydrogen fluoride.

Source: Fed. Reg, as updated.

status is based on exceedances during 1988 at the Rutledge Pike monitoring station, located in the eastern part of Knoxville, about $40 \mathrm{~km}$ ( 25 miles) east of the proposed ANS site. Otherwise, the region around the ANS site is in attainment of all state and local standards. Table 2.3-13 lists air quality monitoring data.

\subsubsection{Local Emissions Sources}

Emissions of particulate matter and nonradiological chemicals from particular sources at ORNL are very low, except for the steam plant. Therefore, the permits issued by the Tennessee Department of Health and Environment (TDHE), Air Pollution Control Board, do not require sampling or monitoring at any of the permitted emission points except the steam plant (Kornegay, et al. 1990, Vol. 1, p. 39). Permit No. 02802\% covers air emissions from the five boilers (four coal-fired and one gas-fired) at the steam plant. 
Table 23-13. Air quality monitoring data $a^{a, b}$

\begin{tabular}{|c|c|c|c|c|c|}
\hline \multirow[b]{2}{*}{ Pollutant } & \multirow[b]{2}{*}{$\begin{array}{c}\text { Monitoring } \\
\text { location }\end{array}$} & \multirow[b]{2}{*}{ Year } & \multirow[b]{2}{*}{$\begin{array}{c}\text { Averaging } \\
\text { time }\end{array}$} & \multicolumn{2}{|c|}{ Maximum } \\
\hline & & & & First & Second \\
\hline \multirow[t]{6}{*}{ Sulfur dioxide } & Kingston & 1990 & $\begin{array}{l}\text { Annual } \\
24 \mathrm{~h} \\
3 \mathrm{~h}\end{array}$ & $\begin{array}{r}11 \\
107 \\
538\end{array}$ & $\begin{array}{r}d \\
75 \\
267\end{array}$ \\
\hline & & 1989 & $\begin{array}{l}\text { Annual } \\
24 \mathrm{~h} \\
3 \mathrm{~h}\end{array}$ & $\begin{array}{r}13 \\
61 \\
227\end{array}$ & $\begin{array}{r}58 \\
220\end{array}$ \\
\hline & Y-12 East & 1990 & $\begin{array}{l}\text { Annual } \\
24 \mathrm{~h} \\
3 \mathrm{~h}\end{array}$ & $\begin{array}{r}28 \\
69 \\
218\end{array}$ & $\begin{array}{r}61 \\
192\end{array}$ \\
\hline & & 1989 & $\begin{array}{l}\text { Annual } \\
24 \mathrm{~h} \\
3 \mathrm{~h}\end{array}$ & $\begin{array}{r}33 \\
150 \\
966\end{array}$ & $\begin{array}{r}134 \\
444\end{array}$ \\
\hline & Bull Run & 1990 & $\begin{array}{l}\text { Annual } \\
24 \mathrm{~h} \\
3 \mathrm{~h}\end{array}$ & $\begin{array}{r}11 \\
85 \\
562\end{array}$ & $\begin{array}{r}- \\
61 \\
292\end{array}$ \\
\hline & & 1989 & $\begin{array}{l}\text { Annual } \\
24 \mathrm{~h} \\
3 \mathrm{~h}\end{array}$ & $\begin{array}{r}12 \\
67 \\
313\end{array}$ & $\begin{array}{r}64 \\
218\end{array}$ \\
\hline \multirow[t]{2}{*}{ Nitrogen dioxido } & McMinn Co. & 1990 & Annual & 23 & - \\
\hline & & 1989 & Annual & 24 & - \\
\hline \multirow[t]{2}{*}{ Carbon monoxide } & Knoxville & 1990 & $\begin{array}{l}8 \mathrm{~h} \\
1 \mathrm{~h}\end{array}$ & $\begin{array}{r}5,900 \\
11,750\end{array}$ & $\begin{array}{r}5900 \\
10500\end{array}$ \\
\hline & & 1989 & $\begin{array}{l}8 \mathrm{~h} \\
1 \mathrm{~h}\end{array}$ & $\begin{array}{r}9,430 \\
14,030\end{array}$ & $\begin{array}{r}7705 \\
13570\end{array}$ \\
\hline \multirow[t]{6}{*}{ Oxone } & Blount Co. & 1990 & $1 \mathrm{~h}$ & 211 & 210 \\
\hline & & 1989 & $1 \mathrm{~h}$ & 192 & 190 \\
\hline & Knoxville & 1990 & $1 \mathrm{~h}$ & 265 & 241 \\
\hline & & 1989 & $1 \mathrm{~h}$ & 186 & 186 \\
\hline & Sevier Co. & 1990 & $1 \mathrm{~h}$ & 200 & 198 \\
\hline & & 1989 & $1 \mathrm{~h}$ & 182 & 172 \\
\hline
\end{tabular}


Table 23-13. (continued)

\begin{tabular}{|c|c|c|c|c|c|}
\hline \multirow[b]{2}{*}{ Pollutant } & \multirow[b]{2}{*}{$\begin{array}{c}\text { Monitoring } \\
\text { location }\end{array}$} & \multirow[b]{2}{*}{ Year } & \multirow[b]{2}{*}{$\begin{array}{c}\text { Averaging } \\
\text { time }\end{array}$} & \multicolumn{2}{|c|}{ Maximum } \\
\hline & & & & First & Second \\
\hline \multirow[t]{5}{*}{ Inhalable particles" } & Maryville & 1990 & $\begin{array}{l}\text { Annual } \\
24 \mathrm{~h}\end{array}$ & $\begin{array}{l}27 \\
65\end{array}$ & $\overline{64}$ \\
\hline & & 1989 & $\begin{array}{l}\text { Annual } \\
24 \mathrm{~h}\end{array}$ & $\begin{array}{l}27 \\
50\end{array}$ & $\overline{49}$ \\
\hline & Loudon & 1990 & $\begin{array}{l}\text { Annual } \\
24 \mathrm{~h}\end{array}$ & $\begin{array}{l}31 \\
61\end{array}$ & 52 \\
\hline & Knoxville & 1990 & $\begin{array}{l}\text { Annual } \\
24 \mathrm{~h}\end{array}$ & $\begin{array}{l}38 \\
75\end{array}$ & $\overline{73}$ \\
\hline & & 1989 & $\begin{array}{l}\text { Annual } \\
24 \mathrm{~h}\end{array}$ & $\begin{array}{r}38 \\
873\end{array}$ & $6 \overline{7}$ \\
\hline \multirow[t]{2}{*}{ Lead } & Nashville & 1990 & 3 months & 0.13 & 0.12 \\
\hline & & 1989 & 3 monthof & 0.16 & 0.16 \\
\hline
\end{tabular}

Units are $\mu g / \mathrm{m}^{3}$.

bWhen data from more than one monitoring station are available for a particular ctty, the highest values are presented.

'Approdimate distances from the proposed Advanced Neutron Source site: Kingston, $24 \mathrm{~km}$ (15 milles) west; Y.12,6 km (4 miles) northeast; Bull Run, $16 \mathrm{~km}$ (10 miles) northeast; McMinn County, $60 \mathrm{~km}$ (37 miles) south; Knowville (Rutledge Pike), $40 \mathrm{~km}$ (25 miles) east; Maryville (and Blount County), $40 \mathrm{~km}$ (25 miles) southeast; Sevier County, $60 \mathrm{~km}$ (37 milles) east; Loudon, $25 \mathrm{~km}$ (16 miles) south; Nashville, $217 \mathrm{~km}$ (135 miles) west.

There is only one annual average per year, no second highest value per year is given.

Particles less than 10 microns in diameter.

'Calendar quarter.

Emissions from the steam plant are from the stacks connected to Building 2519 , on White Oak Avenue just west of Third Street on the map in Fig. 2.3-11. Emissions estimates for the steam plant are presented in Tables 2.3-14 and 2.3-15. Associated stack parameters are given in Tables 2.3-16 and 2.3-17.

In addition to the ORNL steam plant, three major emissions sources near ORNL could contribute noticeably to cumulative effects on local ambient air quality: the Y-12 Plant near Oak Ridge, about $6.8 \mathrm{~km}$ (4.2 miles) northeast of the proposed ANS site; the Bull Run Steam Plant, about $16.1 \mathrm{~km}$ (10 miles) northeast of ANS; and the Kingston Steam Plant, about $20.8 \mathrm{~km}$ (12.9 miles) west of ANS. Emission rates and stack parameters for each of these sources are listed in Tables 2.3-18-2.3-26. 


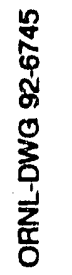

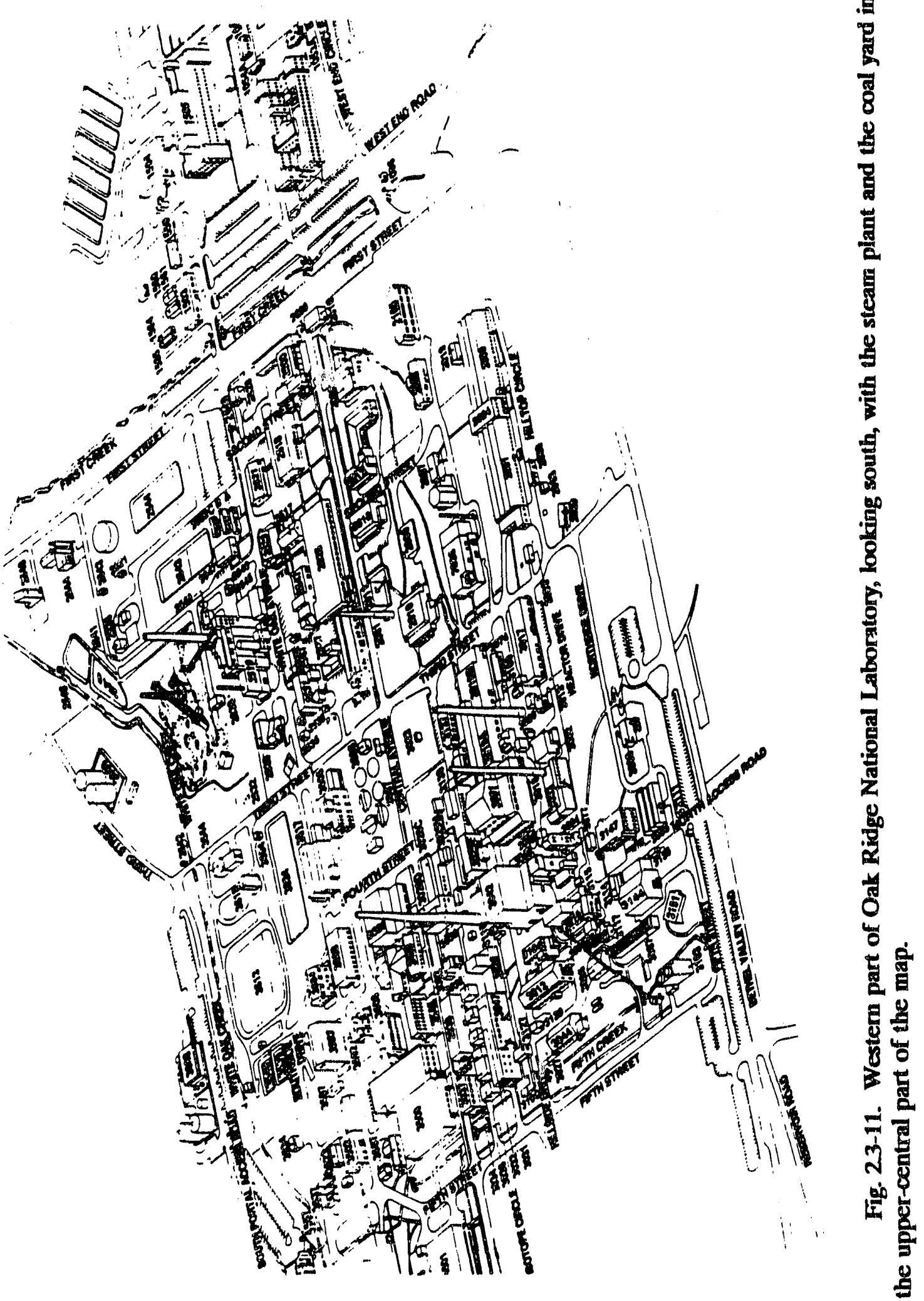


Table 23-14. Average emissions from Boilers $1-4$ at the Oak Ridge National

Laboratory Steam Plant, based on actual coal consumption data for 1987-1989 and peak emissions (in parentheses), based on the maximum design capacity of the units

\begin{tabular}{|c|c|c|c|}
\hline \multirow[b]{2}{*}{ Pollutant } & \multicolumn{3}{|c|}{ Emissions rates } \\
\hline & $\mathrm{g} / \mathrm{s}$ & $\mathrm{lb} / \mathrm{h}$ & tons/year \\
\hline Sulfur dioxide & $33.5(122.1)$ & $266.0(969)$ & 1164 \\
\hline Nitrogen dioxide & $5.2(19.0)$ & $42.0(151)$ & 182 \\
\hline Carbon monoxide & $1.9(6.8)$ & $15.0(54)$ & 65 \\
\hline Total particulate matter & $0.23(0.8)$ & $2.0(7)$ & 8 \\
\hline Non-methane $\mathrm{VOCs}^{b}$ & $0.03(0.1)$ & $0.2(0.8)$ & 1 \\
\hline Methane & $0.01(0.04)$ & $0.1(0.3)$ & 0.4 \\
\hline Carbon dioxide (est) ${ }^{c}$ & 1865.1 & & 64,880 \\
\hline
\end{tabular}

${ }^{\circ}$ An average of 23,550 metric tons $(25,952$ tons) of coal per year was burned during this period. The sulfur content of the purchased coal is given as $2.3 \%$.

Volatile organic compounds.

Calculated as $2.5 \mathrm{~kg}(5.51 \mathrm{lb})$ of carbon dicxide per $1 \mathrm{~kg}(2.204 \mathrm{lb})$ of coal burned.

Table 23-15. Average emissions from (gas-fired) Boiler 5 at the

Oak Ridge National Laboratory Steam Plant based on actual gas consumption data for $1987-1989^{\circ}$ and peak emissions

(in parentheses), based on the maximum design capacity of the unit

\begin{tabular}{lllc}
\hline & \multicolumn{3}{c}{ Emissions rates } \\
\cline { 2 - 4 } \multicolumn{1}{c}{ Pollutant } & \multicolumn{1}{c}{$\mathrm{g} / \mathrm{s}$} & \multicolumn{1}{c}{$\mathrm{lb} / \mathrm{h}$} & tons/year \\
\hline Sulfur dioxide & $0.002(0.013)$ & $0.011(0.1)$ & 0.05 \\
Nitrogen dioxide & $1.4(9.1)$ & $11.4(72)$ & 50 \\
Carbon monoxide & $0.1(0.7)$ & $0.8(5.2)$ & 3.5 \\
Total particulate matter & $0.01(0.1)$ & $0.1(1)$ & $0.4 \varsigma$ \\
Methane & $0.0006(0.006)$ & $0.005(0.05)$ & 0.02 \\
Non-methane VOCs ${ }^{b}$ & $0.004(0.03)$ & $0.03(0.2)$ & 0.13 \\
Carbon dioxide (est) & & & 11,053 \\
\hline
\end{tabular}

An average of $5.13 \times 10^{6} \mathrm{~m}^{3}\left(181.2 \times 10^{6} \mathrm{ft}^{3}\right)$ of gas was burned during this period.

Wolatile organic compounds.

Calculated as $4.309 \mathrm{~kg}(9.5 \mathrm{lb})$ of carbon diaxide per cubic meter $\left(35.32 \mathrm{ft}^{3}\right)$ of gas burned. 
Table 23-16. Stack parameters corresponding to Boilers 1-4 at the Oak Ridge National Laboratory Steam Plant

\begin{tabular}{lll}
\hline Height of stack & $49 \mathrm{~m}$ & $(160 \mathrm{ft})$ \\
Inside diameter of stack & $2.74 \mathrm{~m}$ & $(9 \mathrm{ft})$ \\
Gas exit velocity & $9.8 \mathrm{~m} / \mathrm{s}$ & $(32 \mathrm{ft} / \mathrm{s})$ \\
Gas exit temperature & $433-450 \mathrm{~K}$ & $\left(320-350^{\circ} \mathrm{F}\right)$ \\
& $160-177^{\circ} \mathrm{C}$ & \\
\hline
\end{tabular}

Table 23-17. Stack parameters and Universal Transverse Mercator coordinates correspondiuxg to Boiler 5 at the Oak Ridge National Laboratory Steam Plant

\begin{tabular}{|c|c|c|c|}
\hline Height of stack & $22 \mathrm{~m}$ & $(72 \mathrm{ft})$ & \\
\hline Inside diameter of stack & $1.58 \mathrm{~m}$ & $(5.17 \mathrm{ft})$ & \\
\hline Gas exit velocity & $4.7 \mathrm{~m} / \mathrm{s}$ & $(15.4 \mathrm{ft} / \mathrm{s})$ & \\
\hline Gas exit temperature & $\begin{array}{l}405 \mathrm{~K} \\
132^{\circ} \mathrm{C}\end{array}$ & $\left(270^{\circ} \mathrm{F}\right)$ & \\
\hline \multicolumn{4}{|c|}{ UTM Coordinates for boilers $1-5$} \\
\hline $\begin{array}{l}\text { UTM }^{a} \text { Advanced Neutron } \\
\text { Source }\end{array}$ & $3979000 \mathrm{~N}$ & $744300 \mathrm{E}$ & Zone 16 \\
\hline UTM ORNL ${ }^{b}$ Steam Plant & $3978700 \mathrm{~N}$ & $742000 \mathrm{E}$ & Zone 16 \\
\hline Difference & 300 & 2300 & \\
\hline
\end{tabular}

- UTM = Universal Transverse Mercator.

${ }^{b}$ ORNL = Oak Ridge National Laboratory.

Table 23-18. Location of the Bull Run Steam Plant

\begin{tabular}{cc}
$\begin{array}{c}\text { Distance and direction from } \\
\text { proposed ANS site }\end{array}$ & $\begin{array}{c}\text { Approximate UTM } \\
\text { coordinates }\end{array}$ \\
\hline $10.8 \mathrm{~km}(6.7$ miles) & $3989800 \mathrm{~N}$ \\
$11.9 \mathrm{~km}(7.3$ miles) & $756200 \mathrm{~W}$ \\
$16.1 \mathrm{~km}(10$ miles)NE & Zone 16 \\
\hline
\end{tabular}

"UTM = Universal Transverse Mercator. 
Table 23-19. Emissions inventory (1990) for the Bull Run Steam Plant

\begin{tabular}{lcc}
\hline \multicolumn{1}{c}{ Pollutant } & $\begin{array}{c}\text { Average annual } \\
\text { emissions } \\
{[\mathrm{g} / \mathrm{s}(\mathrm{lb} / \mathrm{h})]}\end{array}$ & $\begin{array}{c}\text { Maximum rate based } \\
\text { on permit limit } \\
{[\mathrm{g} / \mathrm{s}(\mathrm{lb} / \mathrm{h})]}\end{array}$ \\
\hline Sulfur dioxide & $1353(10,730)$ & $4171(33,080)$ \\
Oxides of nitrogen & $542(4298)$ & No data \\
Particulate matter & $8(63)$ & $109(868)$ \\
Carbon monoxide & $22(174)$ & No data \\
VOC emissions & $3(24)$ & No data \\
\hline
\end{tabular}

Table 23-20. Stack parameters for the Bull Steam Plant

\begin{tabular}{lr}
\hline \multicolumn{1}{c}{ Parameter } & \multicolumn{1}{c}{ Value } \\
\hline Stack height & $243.8 \mathrm{~m}(800 \mathrm{ft})$ \\
Stack diameter & $8.5 \mathrm{~m}(28 \mathrm{ft})$ \\
Exit velocity & $21.8 \mathrm{~m} / \mathrm{s}(48.8 \mathrm{ft} / \mathrm{s})$ \\
Exit temperature & $385 \mathrm{~K}\left(233^{\circ} \mathrm{F}\right)$ \\
\hline
\end{tabular}

Table 23-21. Location of the Kingston Steam Plant

\begin{tabular}{lc}
\hline $\begin{array}{c}\text { Distance and direction } \\
\text { from proposed ANS site }\end{array}$ & $\begin{array}{c}\text { Approximate UTM } \\
\text { coordinates }\end{array}$ \\
\hline $3.6 \mathrm{~km}$ (2.2 miles) S & $3975400 \mathrm{~N}$ \\
$20.5 \mathrm{~km}$ (12.8 miles) W & $723800 \mathrm{~W}$ \\
$20.8 \mathrm{~km}$ (13.0 miles) W & Zone 16 \\
\hline
\end{tabular}

UTM = Universal Transverse Mercator. 
Table 23-22. Emissions inventory (1990) for the Kingston Steam Plant

\begin{tabular}{lcc}
\hline \multicolumn{1}{c}{ Pollutant } & $\begin{array}{c}\text { Average annual } \\
\text { emissions } \\
{[\mathrm{g} / \mathrm{s}(\mathrm{lb} / \mathrm{h})]}\end{array}$ & $\begin{array}{c}\text { Maximum rate based } \\
\text { on permit limit } \\
{[\mathrm{g} / \mathrm{s}(\mathrm{lb} / \mathrm{h})]}\end{array}$ \\
\hline Sulfur dioxide & $2660(21,094)$ & $5475(43,418)$ \\
Oxides of nitrogen & $811(64,31)$ & No data \\
Particulate matter & $14(111)$ & $196(1,554)$ \\
Carbon monoxide & $32(254)$ & No data \\
VOC & $4(31.7)$ & No data \\
\hline
\end{tabular}

VOCs = volatile organic compounds.

Table 2.3-23. Stack parameters for the Kingston Steam Plant ${ }^{\circ}$

\begin{tabular}{llr}
\hline & \multicolumn{2}{c}{ Value } \\
\cline { 2 - 3 } \multicolumn{1}{c}{ Parameter } & \multicolumn{1}{c}{ Stack 1 } & \multicolumn{1}{c}{ Stack 2 } \\
\hline Stack height & $304.8 \mathrm{~m}(1000 \mathrm{ft})$ & $304.8 \mathrm{~m}(1000 \mathrm{ft})$ \\
Stack diameter & $7.9 \mathrm{~m}(25.9 \mathrm{ft})$ & $7.9 \mathrm{~m}(25.9 \mathrm{ft})$ \\
Exit velocity & $27.2 \mathrm{~m} / \mathrm{s}(61 \mathrm{ft} / \mathrm{s})$ & $29.9 \mathrm{~m} / \mathrm{s}(61 \mathrm{ft} / \mathrm{s})$ \\
Exit temperature & $422 \mathrm{~K}\left(300^{\circ} \mathrm{F}\right)$ & $430 \mathrm{~K}\left(315^{\circ} \mathrm{F}\right)$ \\
\hline
\end{tabular}

There are two large stacks; to be conservative, assume all emissions come from stack 1. Simulated concentrations will be close to the more precise modeling with two stacks.

Table 23-24. Location of the Y-12 Plant

\begin{tabular}{lc}
\hline $\begin{array}{c}\text { Distance and direction } \\
\text { from proposed ANS site }\end{array}$ & $\begin{array}{c}\text { Approximate UTM } \\
\text { coordinates }\end{array}$ \\
\hline $6.3 \mathrm{~km}$ (3.9 miles) N & $3985300 \mathrm{~N}$ \\
$2.5 \mathrm{~km}$ (1.5 miles) E & $746900 \mathrm{~W}$ \\
$6.8 \mathrm{~km}$ (4.2 miles) NE & Zone 16 \\
\hline
\end{tabular}

UTM = Universal Transverse Mercator. 
Table 23-25. Emissions inventory (1990) of the Y-12 Plant

\begin{tabular}{lcc}
\hline \multicolumn{1}{c}{ Pollutant } & $\begin{array}{c}\text { Average annual } \\
\text { emissions } \\
{[\mathrm{g} / \mathrm{s}(\mathrm{lb} / \mathrm{h})]}\end{array}$ & $\begin{array}{c}\text { Maximum rate based } \\
\text { on stack tests } \\
{[\mathrm{g} / \mathrm{s}(\mathrm{lb} / \mathrm{h})]}\end{array}$ \\
\hline Sulfur dioxide & $19(151)$ & $395(3132)$ \\
Oxides of nitrogen & $25(198)$ & No data \\
Particulate matter & $0.2(1.6)$ & $2(15.9)$ \\
Carbon monoxide & $1(7.9)$ & No data \\
\hline
\end{tabular}

aStack tests were conducted in 1984 when fuel for the steam plant was $100 \%$ coal.

Table 23-26. Stack parameters of the Y-12 Plant ${ }^{a}$

\begin{tabular}{lrr}
\hline & \multicolumn{2}{c}{ Value } \\
\cline { 2 - 3 } \multicolumn{1}{c}{ Parameter } & \multicolumn{1}{c}{ Stack 1 } & \multicolumn{1}{c}{ Stack 2 } \\
\hline Stack height & $58 \mathrm{~m}(190 \mathrm{ft})$ & $58 \mathrm{~m}(190 \mathrm{ft})$ \\
Stack diameter & $3.8 \mathrm{~m}(12.5 \mathrm{ft})$ & $4.6 \mathrm{~m}(15 \mathrm{ft})$ \\
Exit velocity & $4.5 \mathrm{~m} / \mathrm{s}(10 \mathrm{ft} / \mathrm{s})$ & $3.0 \mathrm{~m} / \mathrm{s}(6.7 \mathrm{ft} / \mathrm{s})$ \\
Exit temperature & $430 \mathrm{~K}\left(315^{\circ} \mathrm{F}\right)$ & $428 \mathrm{~K}\left(311^{\circ} \mathrm{F}\right)$ \\
\hline
\end{tabular}

There are two large stacks; to be conservative, assume all emissions come from stack 1 . Simulated concentrations will be close to the more precise modeling with two stacks.

\section{HYDROLOGY}

This section describes the surface and groundwater hydrology of the regional and local areas around the proposed ANS site.

\subsection{Surface Water Hydrology}

This section describes the regional and local surface water hydrology in the vicinity of the ANS site. Regional climatology is discussed in Sect. 2.3.1. Precipitation records are summarized in Sect. 2.3.1.2 and evaluated in Sect. 2.3.3.2. 


\subsubsection{Regional Surface Water Hydrology}

\section{Watershed description}

Water that drains from the proposed ANS site enters the Clinch River by Melton Branch and White Oak Creek (Sect. 2.4.1.2) and then flows into the Tennessee River (Fig. 2.4-1). The Tennessee River is the seventh largest in the United States, and drains a basin of $105,000 \mathrm{~km}^{2}\left(40,900\right.$ mile $^{2}$ ) (Boyle et al. 1982, p. 3-11). Flow in the Tennessee River watershed is regulated by TVA using nine multipurpose impoundments on the Tennessee River and 26 dams on tributaries.

The Clinch River originates in southwestern Virginia near Tazewell and flows $560 \mathrm{~km}$ ( 350 miles) to join the Tennessee River at Kingston, Tennessee. The Clinch River watershed drains a basin of $11,340 \mathrm{~km}^{2}\left(4,410 \mathrm{mile}^{2}\right)$. The confluence of the Emory and Clinch Rivers occurs above Kingston and downstream from ANS at Clinch River mile (CRM) 4.4. The Emory River drains a basin of $2,240 \mathrm{~km}^{2}\left(865 \mathrm{mile}^{2}\right)$ and is the second largest Clinch River tributary. The Powell River is the largest Clinch River tributary and joins the Clinch above Norris Dam (upstream from and northeast of ANS).

The flow of the Clinch River in the vicinity of ANS (Fig. 2.4-2) is controlled by three dams: Norris Dam, $129 \mathrm{~km}$ (80 miles) upstream from the mouth at CRM 79.9; Melton Hill Dam, $37 \mathrm{~km}$ (23 miles) from the mouth at CRM 23.1; and Watts Bar Dam on the Tennessee River, $61 \mathrm{~km}$ ( 38 miles) downstream from the mouth of the Clinch River at Tennessee River mile (TRM) 529.8 .

Norris Dam, built in 1936, is approximately $81 \mathrm{~km}$ (50 miles) upstream from ANS. The dam provides flood control and regulates water flow. It has a head of $81 \mathrm{~m}(265 \mathrm{ft})$ and a generating cinpacity of $100 \mathrm{MW}$. Norris Dam creates one of TVA's largest storage reservoirs with a useful storage volume of $2.37 \times 10^{9} \mathrm{~m}^{3}\left(1.92 \times 10^{6}\right.$ acre-ft).

Melton Hill Dam has a head of approximately $15 \mathrm{~m}(50 \mathrm{ft})$ and creates a reservoir that extends $71 \mathrm{~km}$ (44 miles) upstream. The dam was completed in 1963 and provides power production $(72 \mathrm{MW}$ ), navigation, recreation, and some low-flow regulation. Melton Hill Dam provides little flood protection, however. Melton Hill Reservoir has a useful controlled storage of $3.9 \times 10^{7} \mathrm{~m}^{3}\left(3.2 \times 10^{4}\right.$ acre- $\left.\mathrm{ft}\right)$ which is approximately $2 \%$ of the storage capacity of Norris Reservoir. Minimum normal pool elevation in Melton Hill Reservoir is $241 \mathrm{~m} \mathrm{(790} \mathrm{ft),} \mathrm{although} \mathrm{it} \mathrm{is} \mathrm{possible} \mathrm{to} \mathrm{lower} \mathrm{the} \mathrm{water} \mathrm{level} \mathrm{to} \mathrm{an} \mathrm{elevation}$ of approximately $230 \mathrm{~m}(754 \mathrm{ft})$. ANS is located somewhat inland from Melton Hill Dam in the White Oak Creek watershed, which drains into the Clinch River (see inset in lower right corner of Fig. 2.4-3).

Hydroelectric power is not generated constantly at Melton Hill Dam (ORNL 1986, p. 17). Flow in the Clinch River downstream from the dam is pulsed, varying from periods of zero flow to hours of flow reaching $560 \mathrm{~m}^{3} / \mathrm{s}\left(20,000 \mathrm{ft}^{3} / \mathrm{s}\right)$. These pulsations affect the flow of White Oak Creek (Sect. 2.4.1.2), which empties into the Clinch River approximately $3 \mathrm{~km}$ ( 2 miles) downstream from Melton Hill Dam.

Watts Bar Dam on the Tennessee River creates backwaters on the Clinch River that extend upstream to Melton Hill Dam. The dam has a head of $34 \mathrm{~m}(112 \mathrm{ft})$ and a generating capacity of $72 \mathrm{MW}$. Watts Bar Dam was completed by TVA in 1942. Pool elevations are maintained from 225.5 to $225.8 \mathrm{~m}$ (740 to $741 \mathrm{ft}$ ) from mid-April through September. Corresponding winter water level elevations, which are lower, range from 224 to $224.6 \mathrm{~m}(735$ to $737 \mathrm{ft}$ ). 







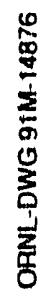

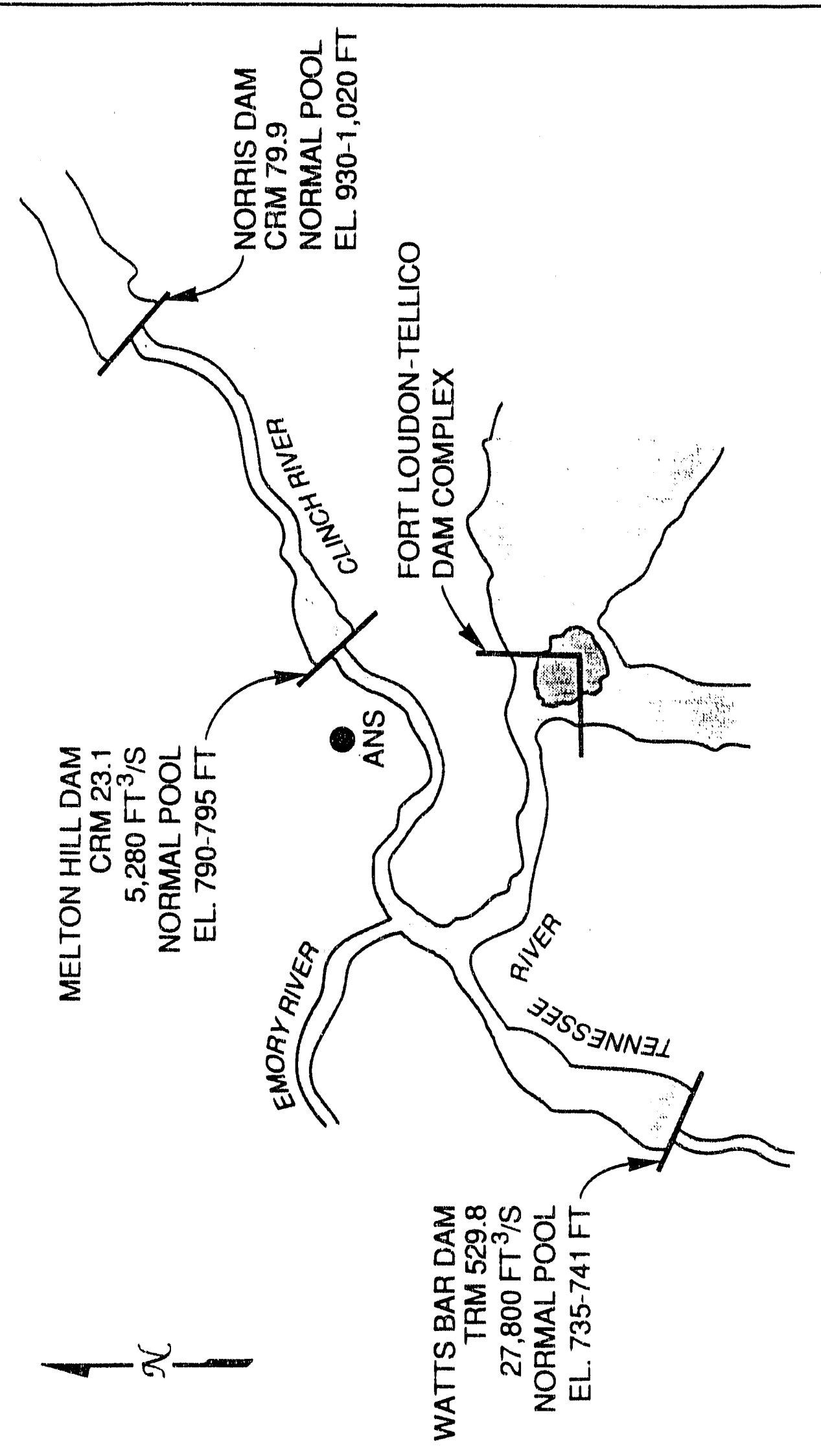

告

88

s

를

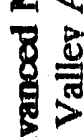

8

8

8

兘

牙

茨

刍.

马

.

党

包它至

気 9

년

I

용

㘳

.

8 논 


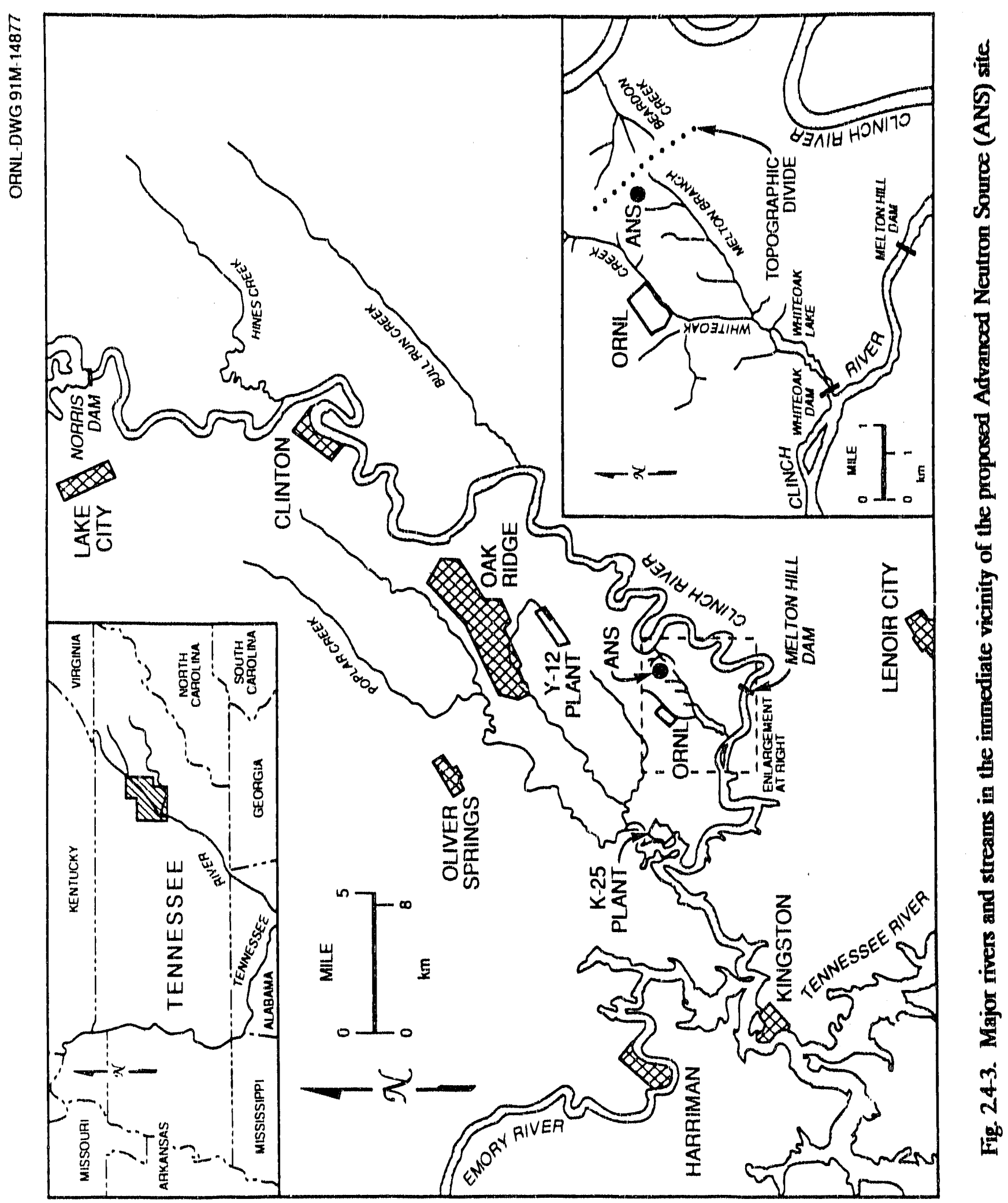


Flow characteristics

The average discharge through Melton Hill Dam from 1963 to 1979 was $150 \mathrm{~m}^{3} / \mathrm{s}$ $\left(5280 \mathrm{ft}^{3} / \mathrm{s}\right)$ (Boyle et al. 1982, p. 3-15). Average summer discharge (June through September) was $134 \mathrm{~m}^{3} / \mathrm{s}\left(4720 \mathrm{ft}^{3} / \mathrm{s}\right)$. Except during periods of heavy rainfall, the discharge through Melton Hill Dam results mostly from hydroelectric power generation. Two turbines exist in the Melton Hill Dam powerhouse that are used primarily to help supply peak demands for electricity. Flow through a single turbine at normal pool elevation results in a discharge of approximately $283 \mathrm{~m}^{3} / \mathrm{s}\left(10,000 \mathrm{ft}^{3} / \mathrm{s}\right)$. Depending on the demand for electricity, which is seasonal, and the availability of flow in the Clinch River, power may be generated during mid-morning, afternoon, or early evening. Thus, the Clinch River below Melton Hill Dam typically has periods of zero flow followed by one or more hours of flow at 283 to $566 \mathrm{~m}^{3} / \mathrm{s}\left(10,000\right.$ to $\left.20,000 \mathrm{ft}^{3} / \mathrm{s}\right)$. Table $2.4-1$ summarizes monthly turbine discharges from Melton Hill Dam from the time of its construction in 1963 through 1978. The figures clearly exhibit the pulsating nature of the flow through the dam.

The influx of water from the Emory, Clinch, and Tennessee Rivers causes increased flows to occur at Watts Bar Dam downstrearn from ANS. The average daily stream flow since completion of Watts Bar Dam in 1942 has been $787 \mathrm{~m}^{3} / \mathrm{s}\left(27,800 \mathrm{ft}^{3} / \mathrm{s}\right)$. (TVA 1976, n.p.). The maximum daily discharge of $5,290 \mathrm{~m}^{3} / \mathrm{s}\left(187,000 \mathrm{ft}^{3} / \mathrm{s}\right)$ occurred on December 30, 1941, before construction of Watts Bar Dam. Daily average releases of zero flow were recorded on seven occasions during a 28-year period. Flow data for water years 1960-1987 indicate an average summer (May-October) discharge through Watts Bar Dam of $671 \mathrm{~m}^{3} / \mathrm{s}\left(23,700 \mathrm{ft}^{3} / \mathrm{s}\right)$. The corresponding winter (November-April) discharge through the dam was $903 \mathrm{~m}^{3} / \mathrm{s}\left(31,900 \mathrm{ft}^{3} / \mathrm{s}\right)$. Average daily flow durations based on Watts Bar Dam discharge records are tabulated in Table 2.4-2.

Figure 2.4-2 displays the systems of dams in the vicinity of ANS during normal pool and average flow conditions. The average Tennessee River flow, which is five times larger than the average Clinch River flow, substantially dilutes undesirable constituents that migrate past the confluence of the two rivers. The flow of the Emory River also supplements this dilution process.

\section{Floods}

A gauging station has been maintained near Wheat, located at CRM 14.5 several miles downstream from ANS. Stage and discharge records are available for the years 1937-1963 and for the 1967-1968 water year. Stage records have been maintained farther downstream at Kingston near the mouth of the Clinch River since 1874, excluding the years from 1877 to 1882 . Mixed stage and discharge records have been maintained upstream from ANS at Clinton since 1883, excluding the years from 1949 to 1964. Discharge records for the Clinch River also are available for various periods of time at Scarboro and Lake City, Tennessee, as well as at Norris Dam, which all are upstream from ANS.

The greatest known flood on the Clinch River (based on a review of available gauging station records, newspapers, and other historical accounts) occurred in March 1886 (TVA 1959, Plate 12). This flood reached an elevation of $234 \mathrm{~m}(767.5 \mathrm{ft}$ ) at the mouth of White Oak Creek downstream from ANS at CRM 20.8. Upstream from ANS at the mouth of Bearden Creek, CRM 32, the 1886 flood crested at an elevation of $238.7 \mathrm{~m}$ 


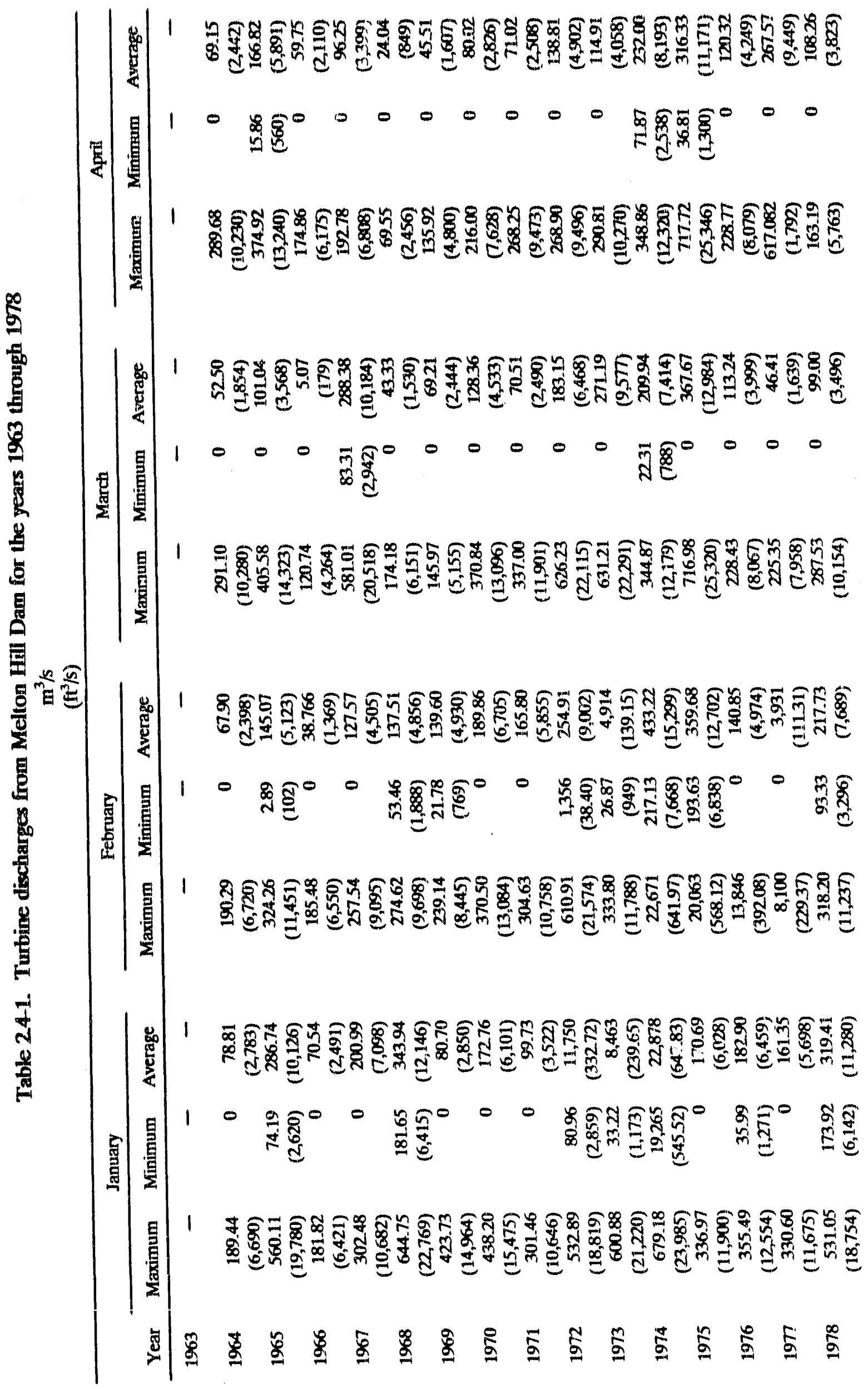




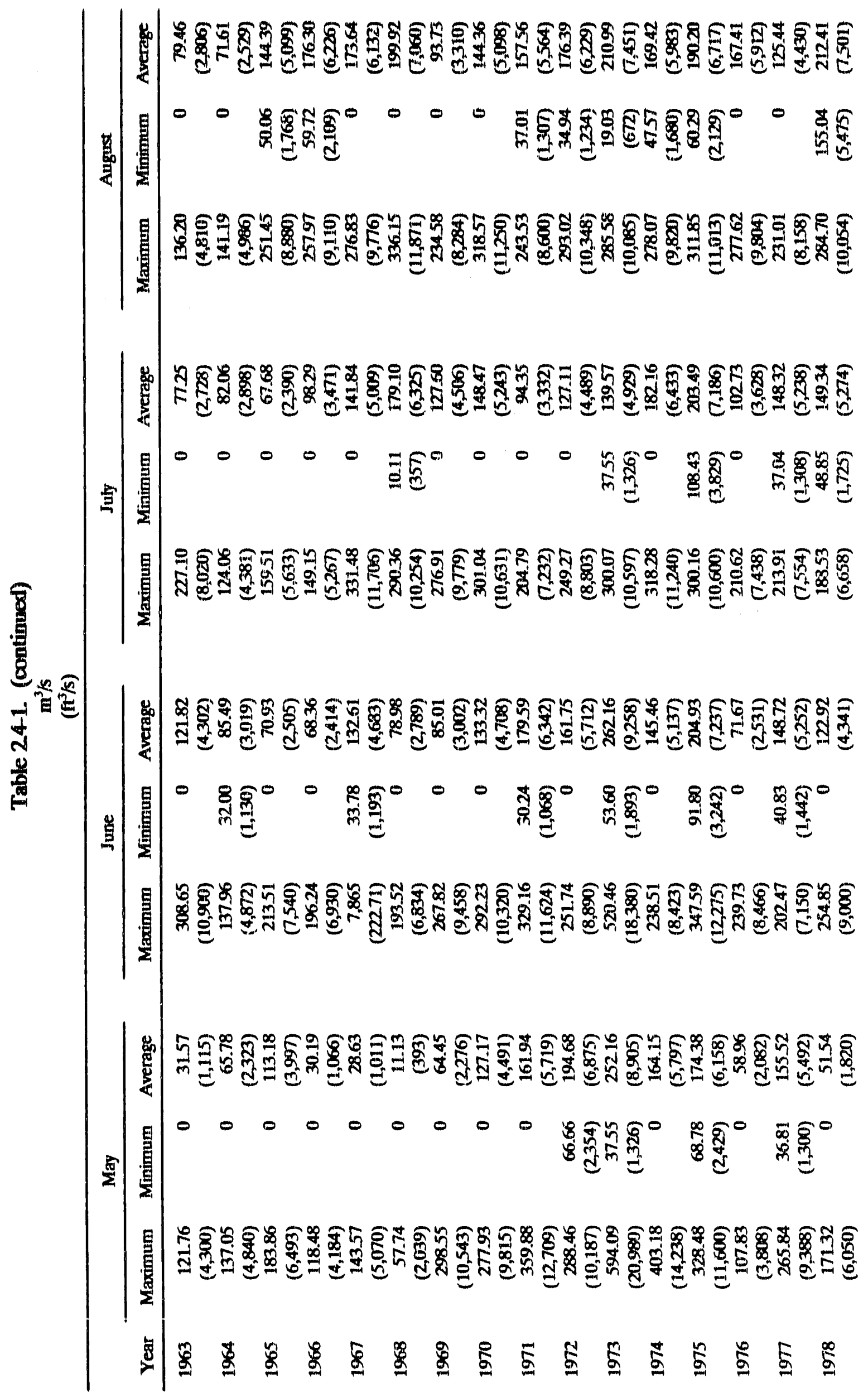


Table 24-2. Average daily flow duration at Watts Bar Dam for the years 1960 through 1987

\begin{tabular}{cc}
$\begin{array}{c}\text { Average daily discha.ge } \\
\mathrm{m}^{3} / \mathrm{s}\left(\mathrm{ft}^{3} / \mathrm{s}\right)\end{array}$ & $\begin{array}{c}\text { Percent of time equaled } \\
\text { or exceeded }\end{array}$ \\
\hline $141(5,000)$ & 98.8 \\
$283(10,000)$ & 93.2 \\
$425(15,000)$ & 83.3 \\
$566(20,000)$ & 69.1 \\
$708(25,000)$ & 50.6 \\
$849(30,000)$ & 32.9 \\
$991(35,000)$ & 20.1 \\
\hline
\end{tabular}

Source: Tennessee Valley Authority, 1976. Warts Bar Nuclear Plant Unis Numbers 1 and 2 , Final Safety Analysis Report, Docket Numbers 50-390 and 50-391, Knowville, Tennessee, p. WENP-63.

$(783 \mathrm{ft})$. There is anecdotal evidence of a March 1826 flood that had been $1 \mathrm{~m}(3.3 \mathrm{ft})$ higher than the 1886 flood. The 1826 flood is the highest flood in the vicinity of Clinton for which any historical documentation or physical evidence exists.

Backwater from the Tennessee and Emory Rivers has also caused floods along the lower portion of the Clinch River in the vicinity of ANS. The maximum known flood along the Tennessee River occurred in 1867. A record-breaking flood along the Emory River took place in March 1929. Both floods caused water levels essentially equal to those of the 1886 Clinch River flood up to approximately CRM 18. Further upstream in the vicinity of ANS, the flood stages caused by backwater effects from the Tennessee and Emory Rivers were lower than the 1886 Clinch River flood levels.

\section{Regulation of reservoirs during Dloods}

Since the installation of Norris Dam, the backwater effect caused by Watts Bar Dam is the dominant factor that determines flood levels along the lower Clinch River in the vicinity of ANS. Repetition of the 1929 Emory River flood would result in higher stages on the lower $37 \mathrm{~km}$ ( 23 miles) of the Clinch River than would the repetition of any of the large headwater floods, which would be regulated by Norris Dam (TVA 1959, Plate 12). Repetition of the 1929 Emory River flood would cause a 229-m (751-ft) water level elevation in Watts Bar Reservoir that would extend back to Melton Hill Dam. The maximum Clinch River flood level of 1886 would be reduced to an elevation of approximately $228 \mathrm{~m}(748 \mathrm{ft}$ ) by flow regulation at Norris Dam (including any backwater effects from Watts Bar Dam). 
The largest flood since completion of the present TVA system of locks and dams occurred in March of 1973 . The water level slightly downstream from Melton Hill Dam crested at an elevation of $228.54 \mathrm{~m}(749.6 \mathrm{ft})$.

\section{Floodplains}

TVA has performed probable maximum flood (PMF) studies along the Clinch River. PMF is the flood that can be expected from the most severe combination of critical hydrometeorological conditions that are reasonably possibly over the entire Clinch River watershed. PMF has a long but finite recurrence interval with a value ranging from thousands to billions of years. The PMF recurrence interval exceeds the 100-to-500 year recurrence interval of $10 \mathrm{CFR} 1022$. Results from these analyses were obtained from TVA to assess PMF levels along the Clinch River near ANS (Louis E. Buck, TVA, personal communication to Robert O. Johnson, ORNL, Nov. 19, 1990). Further information, such as the assumptions and methods utilized to determine the PMF levels, is available on request from TVA.

The PMF levels along the Clinch River at the mouth of Bearden Creek, CRM 32 , and at the mouth of White Oak Creek, CRM 20.8, occurred at elevations $248.4 \mathrm{~m}$ $(814.7 \mathrm{ft})$ and $237.6 \mathrm{~m}(779.3 \mathrm{ft})$, respectively. Elevations at the ANS site range from 259 to $286 \mathrm{~m}$ ( 850 to $940 \mathrm{ft}$ ) (USGS 1988, n.p.). The ANS site is located above the PMF floodplain of the nearby Clinch River. ANS could not be affected by the occurrence of a PMF on the Clinch River.

\section{Droughts}

Stream gauge records for the Tennessee River at Chattanooga, which extend back to 1874 , indicate that periods of extreme drought occurred in 1881,1883 , and 1925. Flows in the Tennessee River during these years reached minimum recorded values. The years of 1881,1883 , and 1925 were presumably years of relatively low flows in the Clinch River, which feeds into the Tennessee River.

Since the 1940s, the flows of the Clinch and Tennessee Rivers have been controlled by the series of dams built by TVA such that the unavailability of water (as exhibited by low river flows) associated with periods of extended drought has been mitigated. Norris and Watts Bar Dams have been in place for approximately 50 years, while Melton Hill Dam has been in operation for over 25 years. Norris, Melton Hill, and Watts Bar Reservoirs store large volumes of water, and the controlled relcases through these dams greatly alter natural flow patterns in the river system. Historical low flows along the Clinch River have resulted from regulated rather than natural flows. Thus, low water levels and corresponding low flows in the vicinity of ANS must be evaluated in terms of the operating policies of Melton Hill Dam, which controls the water level in Melton Hill Reservoir.

Since the completion of Melton Hill Dam in 1963, there has been an average of approximately $13 \mathrm{~d} /$ /year during which no water was released through the dam (ORNL 1986, pp. 17-19). The longest period of no release was 29 consecutive days during February and March 1966 (Table 2.4-3). The second-longest period was 11 consecutive days during April and May 1967. Both of these extended periods of no release resulted from operations to control aquatic weed growth in Melton Hill Reservoir and not from periods of extreme drought. Periods of drought since 1963 have caused shorter periods of no release relative to the duration of zero release periods for control of aquatic weed growth. 
Table 243. Periods of zero release from Melton Hill Dam from May 1963 to October 1972

\begin{tabular}{ccc}
\hline $\begin{array}{c}\text { Consecutive days } \\
\text { of zero release }\end{array}$ & $\begin{array}{c}\text { Number of } \\
\text { occurrences }\end{array}$ & $\begin{array}{c}\text { Percentage of total } \\
\text { number of occurrences }\end{array}$ \\
\hline 1 & 114 & 50.7 \\
2 & 73 & 32.4 \\
3 & 22 & 9.8 \\
4 & 9 & 4.0 \\
5 & 2 & 0.9 \\
6 & $\mathrm{~N} / \mathrm{O}^{\circ}$ & $\mathrm{N} / \mathrm{O}$ \\
7 & 2 & 0.9 \\
8 & 1 & 0.4 \\
9 & $\mathrm{~N} / \mathrm{O}$ & $\mathrm{N} / \mathrm{O}$ \\
10 & $\mathrm{~N} / \mathrm{O}$ & $\mathrm{N} / \mathrm{O}$ \\
11 & 1 & 0.4 \\
29 & 1 & 0.4 \\
\hline Total occurrences & 225 & \\
\hline
\end{tabular}

$\mathrm{N} / \mathrm{O}=$ not observed.

Source: Tennessee Valley Authority, Hydraulic Data Branch Files, Knowville, Tennessee.

\section{Regulation of reservoirs during droughts}

The mouth of White Oak Creek (Sect. 2.4.1.2) is located on an arm of Watts Bar Reservoir that extends up the Clinch River. The water surface elevation at the mouth of White Oak Creek is strongly influenced by the operation of Watts Bar Dam. TVA maintains a pool elevation between 225.5 and $225.8 \mathrm{~m}$ ( 740 and $741 \mathrm{ft}$ ) during the spring and summer months (mid-April through September) and a normal winter-pool elevation between 224.0 and $224.6 \mathrm{~m}$ (735 and $737 \mathrm{ft}$ ) during the months of December through March. Flow from summer-ponl level $[225.8 \mathrm{~m}(741 \mathrm{ft})]$ is allowed to begin as early as July 1 during dry weather to provide downstream flow augmentation or power generation.

Since the initial filling of Watts Bar Reservoir, TVA has been able to closely follow the aforementioned plan of normal operation (Project Management Corporation 1982, pp. 24-38). Sufficient inflow has been available each year to raise the reservoir from winter level to summer level on schedule, and no extended period of drought has forced a significant lowering of the lake level below either the normal summer or winter operating levels. The normal minimum operating elevation of Watts Bar Reservoir is $224.0 \mathrm{~m}$ (735 ft) based upon navigation considerations. Watts Bar Reservoir may be drawn down temporarily at the dam to elevation $223.4 \mathrm{~m} \mathrm{(733} \mathrm{ft)} \mathrm{provided} \mathrm{that} \mathrm{a}$ minimum tailwater elevation of $224.0 \mathrm{~m}(735 \mathrm{ft})$ can be maintained upstream at Melton Hill Dam and Fort Loudon Dam (located on the Tennessce River). These minimium 
elevations have been maintained since the filling of Watts Bar Reservoir. It is possible to lower Watts Bar Reservoir to about $217.3 \mathrm{~m}$ (713 ft) by opening the gated spillway at the dam. More than $12 \mathrm{~h}$ would be required to lower the reservoir from elevation $224.0 \mathrm{~m}$ $(735 \mathrm{ft})$ to elevation $221.0 \mathrm{~m}$ (725 ft). TVA policy requires that Watts Bar Reservoir be maintained at a minimum level of $224.0 \mathrm{~m}(735 \mathrm{ft})$. There is no reason to lower Watts Bar Reservoir below elevation $224.0 \mathrm{~m}$ ( $735 \mathrm{ft}$ ).

In addition, releases from Norris and Melton Hill Dams can be used to regulate flows and water levels at the mouth of White Oak Creek. The operation of Melton Hill Dam contributes to low flows at the mouth of White Oak Creek, which is immediately downstream. The days of zero release from Melton Hill Dam result in essentially zero velocities below the dam at the mouth of White Oak Creek. During the longest period of no release from Melton Hill Dam, the minimum elevation of Watts Bar Reservoir was $224.115 \mathrm{~m}(735.32 \mathrm{ft})$. Such extended periods of zero flow from Melton Hill Dam are not anticipated, as was discussed in the preceding paragraph. The drainage area between Melton Hill Dam and the mouth of White Oak Creek is small. Thus, the incremental flow in the Clinch River between Melton Hill Dam and the mouth of White Oak Creek is also small during periods of low flow. It is possible to lower Melton Hill Reservoir to about elevation $229.8 \mathrm{~m}$ ( $754 \mathrm{ft}$ ) by use of the spillway. The total volume of storage in Melton Hill Reservoir between elevations $240.8 \mathrm{~m}$ (790 ft) (normal minimum pool elevation) and $229.8 \mathrm{~m}(754 \mathrm{ft})$ is $1.04 \times 10^{8} \mathrm{~m}^{3}\left(8.45 \times 10^{4}\right.$ acre-ft).

Releases from Norris Reservoir, located on the Clinch River 91.5 river km (56.7 river miles) upstream from Melton Hill Dam, are discharged into Melton Hill Reservoir and flow past ANS. These releases eventually flow through Melton Hill Dam and pass by the mouth of White Oak Creek. Norris Reservoir is a multipurpose reservoir providing power generation and flood control. The normal minimum pool elevation is $292.6 \mathrm{~m}$ (960 ft). Power generation at Norris Dam can be maintained to a minimum pool elevation of approximately $274.3 \mathrm{~m}(900 \mathrm{ft})$. Stored water between elevations $292.6 \mathrm{~m}$ $(960 \mathrm{ft})$ and $274.3 \mathrm{~m}(900 \mathrm{ft})$ is available for low-flow augmentation during periods of drought, although this is not its primary purpose. However, minimum levels will not be violated without specific TVA Board of Directors' action. The total volume of storage in Norris Reservoir between elevations $292.6 \mathrm{~m}(960 \mathrm{ft})$ and $274.3 \mathrm{~m}(900 \mathrm{ft})$ is $6.38 \times 10^{8} \mathrm{~m}^{3}$ $\left(5.17 \times 10^{5}\right.$ acre-ft $)$. This volume of water represents an average discharge of approximately $20 \mathrm{~m}^{3} / \mathrm{s}\left(710 \mathrm{ft}^{3} / \mathrm{s}\right.$ or $\left.320,000 \mathrm{gal} / \mathrm{min}\right)$ for a period of 1 year. It is possible to lower Norris Reservoir to about elevation $262.1 \mathrm{~m}$ ( $860 \mathrm{ft}$ ) using the slide gates. The total storage volume in Norris Reservoir between elevations $274.3 \mathrm{~m}(900 \mathrm{ft})$ and $262.1 \mathrm{~m}$ $(860 \mathrm{ft})$ is $1.15 \times 10^{8} \mathrm{~m}^{3}\left(9.31 \times 10^{4}\right.$ acre-ft $)$.

In the Clinch River above Melton Hill Dam near ANS, periods of no flow reaching $30 \mathrm{~d}$ could be mitigated by increasing the discharge upstream at Norris Dam if water level declines became excessive in Melton Hill Reservoir. Likewise, Melton Hill Dam could be opened to allow the discharges through Norris Dam to alleviate low water conditions on Watts Bar Reservoir near the mouth of White Oak Creek.

The water elevation in Melton Hill Reservoir is controlled by Norris and Melton Hill Dams. Sufficient water is available in storage in Norris Reservoir to provide an average flow in the Clinch River of more than $20 \mathrm{~m}^{3} / \mathrm{s}\left(710 \mathrm{ft}^{3} / \mathrm{s}\right.$ or $\left.320,000 \mathrm{gal} / \mathrm{min}\right)$ for a period of 12 months, assuming available storage between water level elevations between 292.7 and $274.4 \mathrm{~m}$ ( 960 and $900 \mathrm{ft}$ ) and assuming no inflow into Norris Reservoir during the 1-year duration of the drought. Adequate flow would be available from Melton Hill Reservoir to meet the demands of ANS without starving the water supply system. 
Water quality

The waters of the Clinch and Tennessee Rivers are moderately hard and slightly basic (Boyle et al. 1982, p. 3-28; Evaldi and Lewis 1986, p. 25). Calcium and magnesium are the principal cations. The abundance of limestone and dolomite underlying much of the river basins causes anionic composition to be dominated by bicarbonate and carbonate. Coal mining activities have caused increased sulfate levels in some portions of the watershed (such as the Emory River) that drain from the Cumberland Plateau.

Water quality measurements recorded at Melton Hill and Watts Bar Dams on the Clinch and Tennessee Rivers, respectively, are in Table 2.4-4 (Evaldi and Lewis 1986, Tables 9 and 10). Water quality at these two locations is generally favorable. Except for $\mathrm{pH}$ and fecal coliform, the measured constituent concentrations listed in Table 2.4-4 comply with federal drinking water standards. Total dissolved solids exhibit a slight decrease between Melton Hill and Watts Bar Dams, while total nitrite plus nitrate nitrogen (as $\mathrm{N}$ ) shows a slight increase.

Except for fecal coliform bacteria, the differences between species concentrations measured at the two dams are small. The measured $\mathrm{pH}$ and fecal coliform levels are within acceptable limits for sources of raw water [5.0 to 9.0 and $2,000 / 100 \mathrm{~mL}$ to $20,000 / 100 \mathrm{~mL}$, respectively (NAOS 1973, pp. 58 and 80)] and are treatable to achieve compliance with the drinking water standards quoted in Table 2.4-4. The elevated fecal coliform levels at Watts Bar Dam are related to occasional releases of raw sewage into Fort Loudon Lake further upstream on the Tennessee River at Knoxville, Tennessee (Evaldi and Lewis 1986, p. 43). Daily releases of raw sewage have bypassed the water treatment plant during wet weather.

Summaries of radioactivities measured at Melton Hill Dam are available in Oak Ridge Reservation Environmental Surveillance Reports (ORNL 1986, Oakes et al. 1987, Daniels et. al. 1988, Rogers et al. 1988, Kornegay et al. 1990). Measured radioactivity levels were less than $28 \%$ of the EPA drinking water limit, which recommends a maximum dose at the outlet of a public water distribution system of $0.04 \mathrm{~Sv} /$ year ( 4 mrem/year) based upon $2 \mathrm{~L} / \mathrm{d}$ of water consumption (Kornegay 1990, Vol. 1, p. 68).

\section{Consumption}

About 91,500 people are served by the nine public water supply systems that withdraw surface water within a 32-km (20-mile) radius of ANS as listed in Table 2.4-5. Of these nine supply systems, only the city of Kingston, which is located downstream from White Oak Dam (Sest. 2.4.1.2), receives a portion of its flow from Melton Branch (Boyle et al. 1982, p. 3-20, ORNL 1986, p. 24). The intake for Kingston is located at TRM 568.2, approximately 0.6 river $\mathrm{km}$ ( 0.4 river mile) above the confluence of the Clinch and Tennessee Rivers and 34.1 river km (21.2 river miles) below White Oak Dam. The Kingston intake is located in an area of backflow of Clinch River water. As indicated in Table 2.4-5, Kingston withdraws approximately $9 \%$ of its average daily supply from the Tennessee River. In a worst-case scenario, the Kingston water supply could be affected by activities at ANS because of its close proximity to the confluence of the Clinch and Tennessee Rivers. The intakes for Lenoir City and the city of Loudon are located farther upstream on the Tennessee River; backwater effects from the Clinch River could not impact thern.

The city of Rockwood withdraws about $1 \%$ of its average daily supply from Watts Bar Reservoir. The Rockwood intake is located $2 \mathrm{~km}$ (1.3 miles) upstream from the mouth of King Creek Embayment near TRM 553 and would not be affected by activities at ANS. Likewise, the city of Harriman withdraws water from the Emory River upstream 


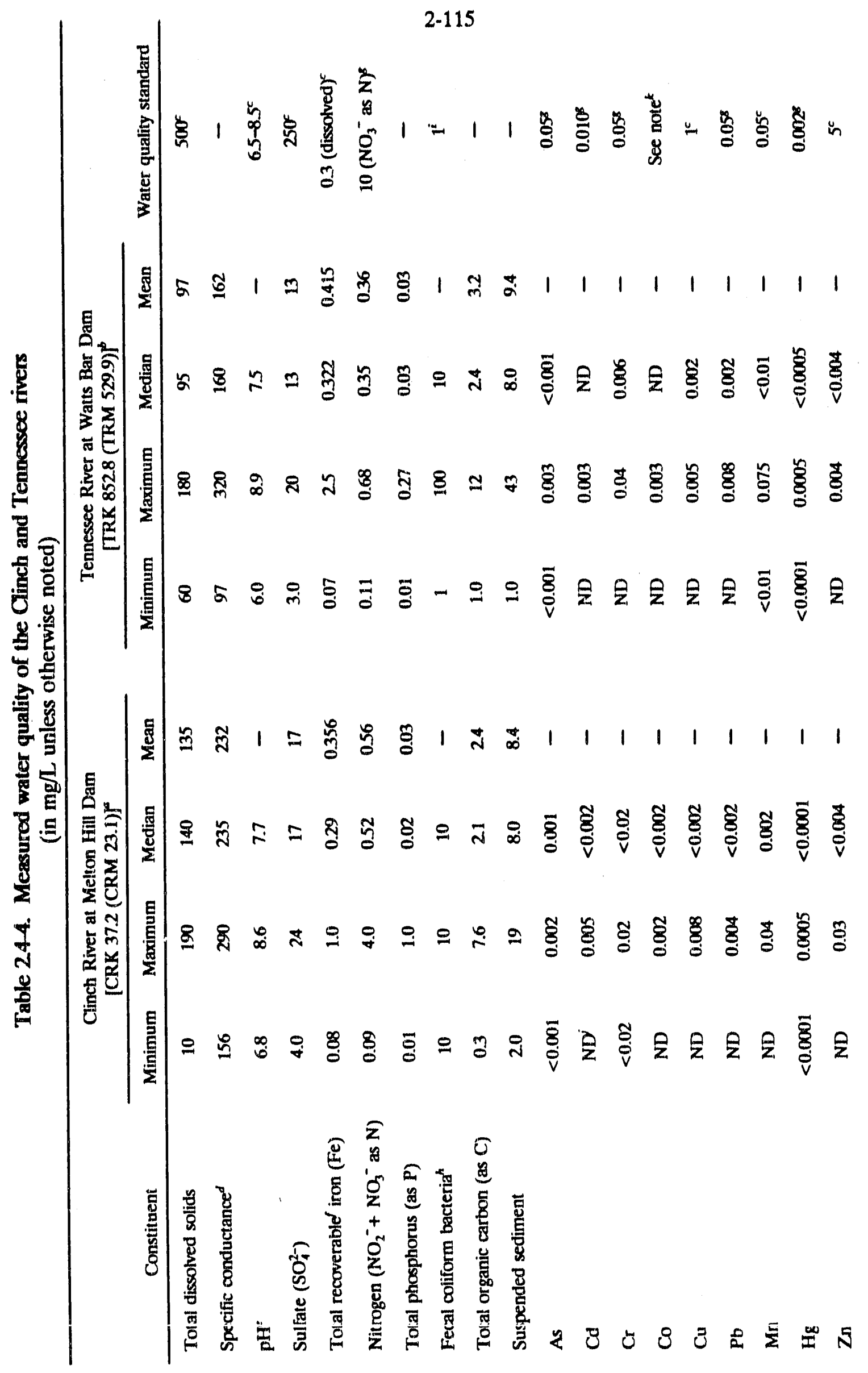




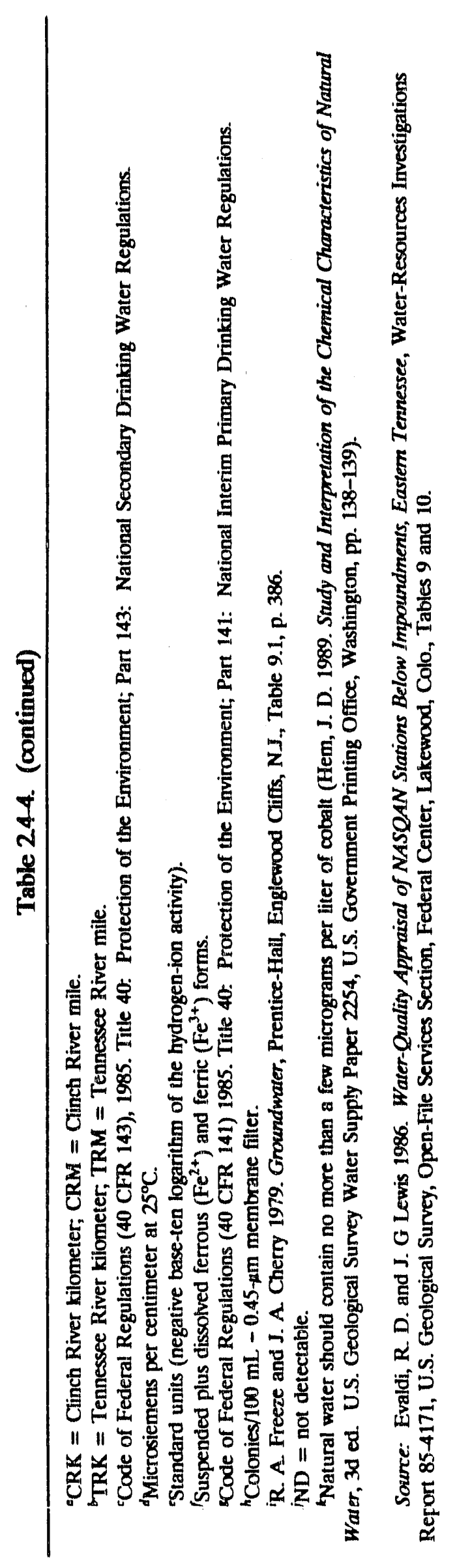


Table 24-5. Public supply surface water withdrawals within approximately $32 \mathrm{~km}(20 \mathrm{miles})$ of the proposed Advanced Neutron Source site

\begin{tabular}{|c|c|c|c|c|}
\hline Public supply system & $\begin{array}{c}\text { Population } \\
\text { served } \\
\text { (thousands) } \\
\end{array}$ & $\begin{array}{c}\text { Average } \\
\text { withdrawal rate } \\
{\left[\mathrm{m}^{3} / \mathrm{s}(\mathrm{million}\right.} \\
\mathrm{gal} / \mathrm{d})]\end{array}$ & $\begin{array}{l}\text { Withdrawal source and } \\
\text { location [river } \mathrm{km} \text { (river } \\
\text { mile)] }\end{array}$ & $\begin{array}{l}\text { Distance from } \\
\text { ANS [km } \\
\text { (miles)] }\end{array}$ \\
\hline Clinton & 6.2 & $0.03(0.7)$ & CRK 106.7 (CRM 66.3)" & $25.1(15.6)$ \\
\hline Harriman & 10.0 & $0.10(2.3)$ & ERK 20.8 (ERM 12.9) & $21.7(13.5)$ \\
\hline Kingston & 5.0 & $0.014(0.32)^{c}$ & TRK $914.2($ TRM 568.2) & $20.9(13.0)$ \\
\hline Lenoir City & 6.6 & $0.04(0.9)$ & TRK 967.5 (TRM 601.2) & $16.6(10.3)$ \\
\hline Loudon & 5.2 & $0.03(0.7)^{e}$ & TRK 953.0 (TRM 592.2) & $21.7(13.5)$ \\
\hline $\begin{array}{l}\text { Anderson County } \\
\text { Utility Board }\end{array}$ & 8 & $0.03(0.7)$ & CRK 89.3 (CRM 55.5) & $14.5(9.0)$ \\
\hline $\begin{array}{l}\text { Cumberland Utility } \\
\text { District of Roane } \\
\text { and Morgan counties }\end{array}$ & 4.3 & $0.008(0.18)^{\prime}$ & LEREK 3.5 (LEREM $2.2 \beta$ & $14.0(8.7)$ \\
\hline $\begin{array}{l}\text { First Utility District of } \\
\text { Knox County }\end{array}$ & 10.5 & $0.05(1.1)$ & SCEK $2.7($ SCEM 1.7) & $18.7(11.6)$ \\
\hline $\begin{array}{l}\text { Hallsdale-Powell } \\
\text { Utility District }\end{array}$ & 28.7 & $0.07(1.6)^{\prime}$ & BRCEK 2.1 (BRCEM 1.3) & $18.2(11.3)$ \\
\hline $\begin{array}{l}\text { West Knox County } \\
\text { Utility District }\end{array}$ & 15.0 & $0.06(1.4)^{k}$ & CRK 74.2 (CRM 46.1) & $16.3(10.1)$ \\
\hline
\end{tabular}

${ }^{\circ} \mathrm{CRK}=$ Clinch River kilometer; $\mathrm{CRM}=$ Clinch River mile.

${ }^{b} \mathrm{ERK}=$ Emory River kilometer; ERM = Emory River mile.

'Secondary source 9\%; spring, $91 \%$.

TRK = Tennessee River kilometer; TRM = Tennessee River mile.

"Half source 50\%; spring, 50\%.

'Secondary source 5\%; spring, $95 \%$.

ILEREK = Little Emory River Embayment kilorneter; LEREM = Little Emory River Embayment mile.

nSCEK = Sinking Creek Embayment kilometer; SCEM = Sinking Creek Embayment mile (Tennessee River tributary).

'Primary source 70\%; spring, $30 \%$.

BRCEK = Bull Run Creek Embayment kilometer; BRCEM = Bull Riun Creek Embayment mile (Clinch River tributary).

${ }^{k}$ Primary source $90 \%$; well, $10 \%$.

Source: Environmental Safety and Health Division 1986. Environmental Surveillance of the Oak Ridge Reservation and Surrounding Environs During 1985. ORNL-6271/ESH, Oak Ridge National Laboratory, Oak Ridge, Tenn., p. 25. 
from the Clinch River and would not be affected by ANS activities. The total population served by the public water systems, using surface water supplies in the area within a $32-\mathrm{km}$ (20-mile) radius of ANS and from the Tennessee River outside that area down to the city of Chattanooga, exceeds 370,000. Additional municipal water supply intakes are located farther downstream along the Tennessee, Ohio, and Mississippi rivers.

Table 2.4-6 lists major industrial water withdrawals from the Clinch and Tennessee rivers in the vicinity of ANS. The K-25 Site (formerly the Oak Ridge Gaseous Diffusion Plant) withdraws $0.13 \mathrm{~m}^{3} / \mathrm{s}\left(3 \times 10^{6} \mathrm{gal} / \mathrm{d}\right)$ at CRM 14.5 for potable and process uses. This intake, which also supplies the city of Oak Ridge Industrial Park, is located $10.4 \mathrm{~km}$ (6.5 miles) downstream from White Oak Dam. A second K-25 Site intake slightly upstream from the first, at CRM 11.5 , supplies $0.54 \mathrm{~m}^{3} / \mathrm{s}\left(12 \times 10^{6} \mathrm{gal} / \mathrm{d}\right)$ of makeup to the recirculating cooling system. None of this cooling water is used for potable purposes. Major withdrawals of water for industrial consumption occur farther downstream on the Emory River at the TVA Kingston Steam Plant and on the Tennessee River at the TVA Watts Bar Dam and Watts Bar steam and nuclear plants. Major industrial water withdrawals also occur along the Clinch River upstream from the mouth of White Oak Creek and are presented in Table 2.4-6.

Consumers located downstream from ANS that could be impacted by activities at the facility include the municipal intake for Kingston and the two intakes for the K-25 Site. Consumers located farther downstream are relatively distant from ANS, and upstream consumers are above Melton Hill Dam. The dam serves as a barrier to flow reversals in the Clinch River near the mouth of White Oak Creek.

Both Melton Hill and Watts Bar Reservoirs receive considerable recreational use in the vicinity of ANS. Boating and fishing occur on both reservoirs. Melton Hill Reservoir is also used for waterskiing and swimming. Public facilities are provided on Melton Hill Reservoir within $8 \mathrm{~km}$ ( 5 miles) of ANS. A concrete boat launching ramp and a parking area are provided that open to the public off Tennessee, State Highway 95 immediately below Melton Hill Dam and allow access to the headwaters of Watts Bar Reservoir.

\subsubsection{Local Surface Water Hydrology}

The proposed ANS site is located on the south side of Haw Ridge overlooking the headwaters of Melton Branch, a tributary of the White Oak Creek watershed (Fig. 2.4-3). Elevations at the proposed ANS site rise to $268 \mathrm{~m}(880 \mathrm{ft})$, sloping downward at a grade of approximately $10 \%$. Storm water originating as surface runoff would discharge directly into Melton Branch. Rapid runoff would be promoted by the clayey, poorly drained, relatively impervious soils characteristic of East Tennessee. Approximately $30 \%$ of the incident rainfall impinging on unpaved, grassy surfaces would flow overland into Melton Branch (Binford, Cole, and Cramer 1968, p. 2-13). Drainage from roofs, structures, and pavement would be discharged into Melton Branch through a storm sewer system having an appropriate retention basin for surge and contamination control.

The majority of the northeast-to-southwest-trending valley between Haw and Copper ridges is drained in a southwesterly direction by White Oak Creek and Melton Branch (Fig. 2.4-3). The confluence of White Oak Creek with the Clinch River occurs downstream from Melton Hill Dam at CRM 20.8. The upper portions of the valley between Haw and Copper ridges are drained in the northeasterly direction by unnamed tributaries of Bearden Creek. The confluence of Bearden Creek and the Clinch River occurs at CRM 32 upstream of both ANS and Melton Hill Dam. A north-to-south-

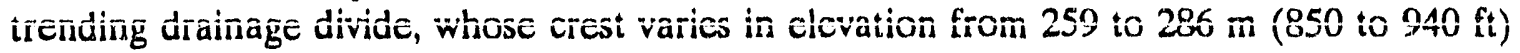


Table 24-6. Industrial water withdrawals from the Clinch-Tennessee River system in the vicinity of the proposed Advanced Neutron Source site

\begin{tabular}{|c|c|c|c|}
\hline Industrial water user & $\begin{array}{l}\text { Average withdrawal } \\
\text { rate } \\
\left.\left[\mathrm{m}^{3} / \mathrm{s} \text { (million gal } / \mathrm{d}\right)\right]\end{array}$ & $\begin{array}{l}\text { Withdrawal source and } \\
\text { location [river } \mathrm{km} \text { (river } \\
\text { mile)] }\end{array}$ & $\begin{array}{l}\text { River distance from } \\
\text { mouth of White Oak } \\
\text { Creek [km (miles)] }\end{array}$ \\
\hline \multicolumn{4}{|c|}{ Withdrawals above White Oak Creek (mouth located at CRK 33.5 (CRM 20.8) } \\
\hline Modine Manufacturing Co. & $0.05(1.1)$ & CRK 103.7 (CRM 64.4) & $71.2(44.2)$ \\
\hline $\begin{array}{l}\text { Tennessee Valley Authority } \\
\text { Bull Run Steam Plant }\end{array}$ & $25.0(570)$ & CRK 77.2 (CRM 48) & $43.7(27.2)$ \\
\hline $\begin{array}{l}\text { U.S. Department of Energy } \\
\text { Oak Ridge National } \\
\text { Laboratory, Y.12 Plant, } \\
\text { Scarboro Facility, and } \\
\text { City of Oak Ridge }\end{array}$ & $0.96(22)^{b}$ & CRK 66.8 (CRM 41.5) & $33.3(20.7)$ \\
\hline \multicolumn{4}{|c|}{ Withdrawals below White Oak Creek } \\
\hline $\begin{array}{l}\text { K-25 Site and City of } \\
\text { Oak Ridge Industrial Park }\end{array}$ & $0.13(3)^{6}$ & CRK 23.3 (CRM 14.5) & $10.2(6.3)$ \\
\hline K-25 Site & $0.54(12)^{c}$ & CRK 18.5 (CRM 11.5) & $15.0(9.3)$ \\
\hline $\begin{array}{l}\text { Tennessee Valley Authority } \\
\text { Kingston Steam Plant }\end{array}$ & $61.3(1,400)$ & ERK $2.9(\text { ERM } 1.8)^{d}$ & $29.6(18.4)$ \\
\hline $\begin{array}{l}\text { Watts Bar hydro plant, } \\
\text { lock, and steam plant }\end{array}$ & $0.02(0.7)$ & TRK $851.5($ TRM 529.1) & $94.5(58.7)$ \\
\hline
\end{tabular}

${ }^{a} \mathrm{CRK}=$ Clinch River kilometer; CRM = Clinch River mile.

${ }^{b}$ Process and potable water.

'Cooling water makeup onty.

${ }^{d}$ ERK $=$ Emory River kilometer; ERM = Emory River mile.

TRK $=$ Tennessee River kilometer; TRM $=$ Tennessee River mille.

Source: Environmental Safety and Heaith Division 1986. Environmental Surveillance of the Oak Ridge Reservation and Surrounding Environs During 1985. ORNL,6271/ESH, Oak Ridge National Laboratory, Oak Ridge, Tenn., p. 26.

(USGS 1988, n.p.), separates the headwaters of Melton Branch and the unnamed Bearden Creek tributaries. ANS is located on the Melton Branch (e.g., western) side of this drainage divide slightly below the crest.

The White Oak Creek watershed drains an area of $16.4 \mathrm{~km}^{2}\left(6.37 \mathrm{mile}^{2}\right)$. The headwaters of White Oak Creek form along the crest of Chestnut Ridge at elevation $372 \mathrm{~m}(1220 \mathrm{ft})$ north of the ANS site, dropping to elevation $226 \mathrm{~m}(741 \mathrm{ft})$ at the mouth of the creek where it joins the Clinch River at CRM 20.8. Melton Branch, the primary tributary of White Oak Creek, joins the main stem at White Oak Creek Mile (WOCM) 
1.55 and has a drainage area of $3.83 \mathrm{~km}^{2}\left(1.48 \mathrm{mile}^{2}\right)$ above the confluence. The headwaters of Melton Branch form along Haw Ridge in the immediate vicinity of ANS.

White Oak Dain, located at WOCM 0.6 above the stream mouth, impounds the waters of White Oak Creek and Melton Branch. The dam's sluiceway has a design capacity of $56.6 \mathrm{~m}^{3} / \mathrm{s}\left(2000 \mathrm{ft}^{3} / \mathrm{s}\right)$ and can accommodate the discharge calculated as the maximum possible flood (Boyle et al. 1982, p. 3-16). This sluiceway has a dual system of weirs that allows accurate flow measurement and sample collection over the full range of discharge. Floodgates allow temporary impoundment of the flow from White Oak Creek and Melton Branch should contaminants be accidentally released upstream. White Oak Lake, the small shallow impoundment behind White Oak Dam, has an approximate surface area of 5 to 10 ha (12 to 24 acres). The water level in White Oak Lake is strongly influenced by storms, prolonged rainfall, and operations at the White Oak Dam, which are strongly influenced by activities at ORNL.

The portion of White Oak Creek between White Oak Dam and the confluence of the creek with the Clinch River is known as the White Oak Creek Embayment. The White Oak Creek watershed is generally considered to be the $15.5-\mathrm{km}^{2}\left(5.98-\mathrm{mill}^{2}\right)$ drainage area above White Oak Dam because flow in the embayment is regulated externally by Melton Hill and Watts Bar Dams. The White Oak Creek Embayment resembles a large mudflat during the winter. During the summer, daily water level fluctuations, which do not exceed $0.5 \mathrm{~m}(1.5 \mathrm{ft})$, occur, as do flow reversals caused by releases through Melton Hill Dam. Upstream flow velocities as high as $30 \mathrm{~cm} / \mathrm{s}(1 \mathrm{ft} / \mathrm{s})$ and lasting as long as $15 \mathrm{~min}$, followed by downstream currents of similar magnitude and duration, have been observed in the embayment.

Discharges in Melton Branch are monitored with a small weir located approximately $0.16 \mathrm{~km}(0.1$ mile) upstream from the confluence of Melton Branch and White Oak Creek. The average discharge across the weir for the periut of record from 1955 to 1963 was $0.07 \mathrm{~m}^{3} / \mathrm{s}\left(2.5 \mathrm{ft}^{3} / \mathrm{s}\right.$ ) (Table 2.4-7) (Boyle et al. 1982, p. 3-17). The discharge varies from a minimum of zero to a maximum of $6.85 \mathrm{~m}^{3} / \mathrm{s} \quad\left(242 \mathrm{ft}^{3} / \mathrm{s}\right)$. Peak discharges and corresponding stage measurements are not reliable because the capacity of the weir is exceeded. There is no record of flooding near the ANS site during extreme flows along Melton Branch or Bearden Creek. The north-to-south-trending drainage divide disallows hydraulic communication between ANS and the occurrence of flooding along Bearden Creek. Extreme flooding along Bearden Creek would not inundate ANS. Fitzpatrick (1982, pp. 2-166 and 2-175) has performed a PMF analysis along Melton Branch. The ANS site is located above the Melton Branch PMF floodplain described by Fitzpatrick (1982). The flood plain requirements of 10 CFR 1022 are satisfied because the PMF recurrence interval exceeds 100 and 500 years.

Liquid releases from ORNL enter the White Oak Creek watershed. The water quality of White Oak Creek and Melton Branch is monitored just upstrearn of their confluence. Both of these locations are designated National Pollution Discharge Elimination System (NPDES) permitted discharge points. White Oak Creek was dammed to form White Oak Lake, which serves as a settling basin to inhibit the off-site dispersion of radionuclides and chemical pollutants discharged into the White Oak Creek watershed by ORNL, facilities. Further information on radiological and nonradiological constituent concentrations measured in the White Oak Creek watershed is available in Oak Ridge Reservation Environmental Surveillance Reports (ORNL 1986; Oakes et al. 1987; Daniels et al. 1988; Rogers et al. 1988; Kornegay et al. 1990).

Melton Branch and White Oak Creek do not serve as municipal or industrial water supplies. Melton Branch and White Oak Creek are not suitable for contact recreation, and tishing is prohibited. The White Oak Creek watershed, which includes Melton 


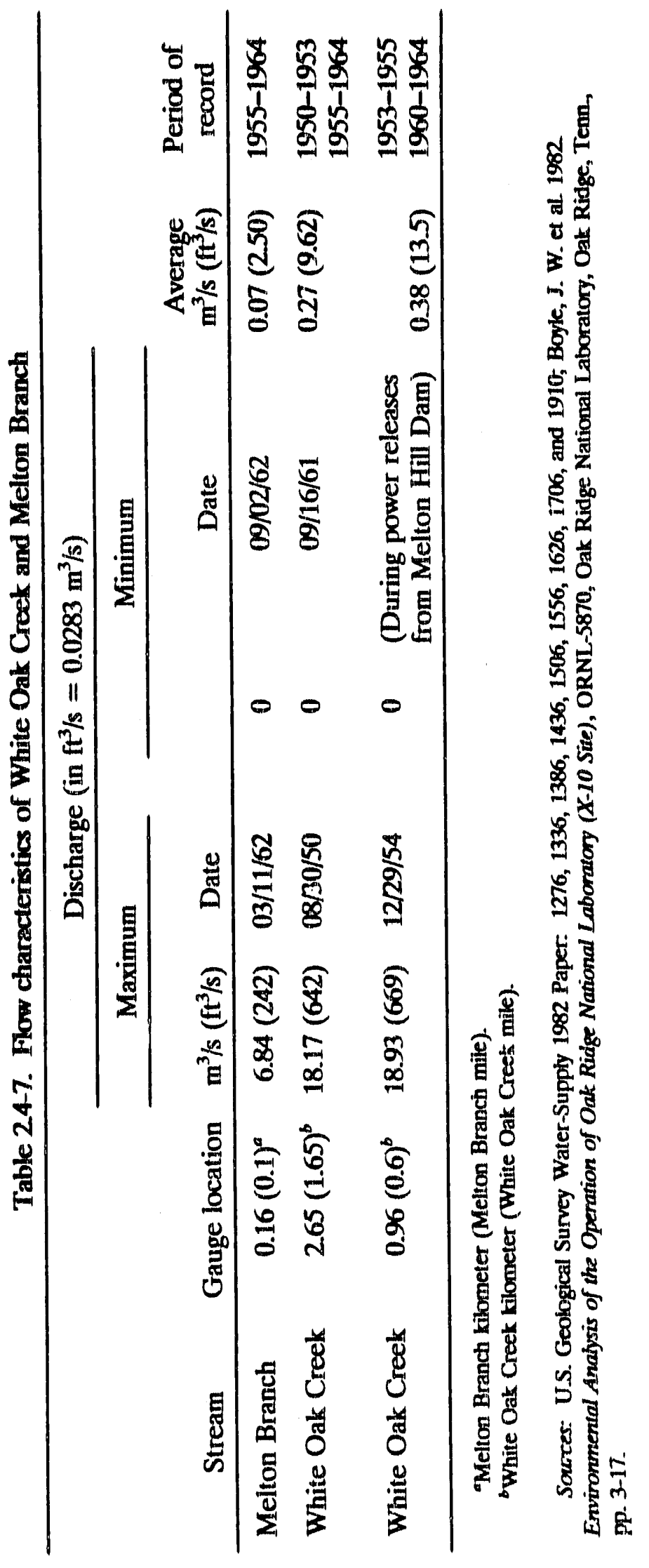


Branch, is located within the confines of the ORR. Access to this DOE fenced area in which ANS would be located is restricted and not open to the public.

\subsubsection{Groundwater Hydrology}

Groundwater in the Tennessee Valley Region supplies water to many rural residences for domestic use and supplies the base flow to streams and rivers. This section includes discussions of groundwater occurrence in the region, local groundwater use, and geohydrologic conditions at waste disposal facilities.

\subsubsection{Groundwater Occurrence}

In the Valley and Ridge Physiographic Province of Tennessee, groundwater generally occurs in bedrock formations or in residual soil accumulations near the bedrock surface. Alluvial aquifers are of minor importance in the region. Porosity in the shales and carbonate rocks that predominate in the region is attributed to fractures and solution cavities.

ORR is underlain by nine geologic formations or groups (Sect. 2.5) ranging in age from Early Cambrian to Early Mississippian. The formations are of sedimentary origin, both chemical (limestone and dolomite) and clastic (sandstone and shale). From the standpoint of occurrence in the area, the most important formations are the Rome Formation, the Conasauga Group, the Knox Group, and the Chickamauga Group. Other formations occupy relatively small parts of the area.

Information on the groundwater capacity in the sandstone and shale of the Rome formation is sparse because few wells have been drilled into the formation. Although limited in number, existing road cuts and water gaps indicate that this stratigraphic unit has very little capacity for receiving, storing, and transmitting water (Fitzpatrick 1982, as referenced in Boyle et al. 1982, p. 3-2.1). In weathered bedrock the occurrence of water is largely limited to small openings that occur along joints and bedding planes. The steep terrain underlain by the Rome increases surface runoff and reduces recharge. The thin mantle of residual clay and the near-surface weathered bedrock zones having slightly enlarged openings probably account for the greater part of water movement in the Rome (McMaster 1967, as referenced in Boyle et al. 1982, p. 3-21).

Because of its heterogeneous composition, the hydrologic properties of the Conasauga Group are somewhat variable. Generally, the ability of this group to transmit water increases with the thickness of the limestone strata. Formations below the Maynardville Limestone in this geologic unit are practically devoid of permeability below a depth of $35 \mathrm{~m}$ (100 ft) (Project Management Corporation 1975, as referenced in Boyle et al. 1982, p. 3-21). In these instances groundwater occurs principally in the weathered zone where openings along joints and bedding planes are enlarged. Because thesc enlarged openings occur primarily at shallow depths, the total capacity for water storage is small (McMaster 1967, as referenced in Boyle et al. 1982, p. 3-21). When recharge is limited in summer by evaporation and transpiration losses, discharges from this groundwater reservoir are severely depleted. The more calcareous members of this formation that provide bedrock for Bear Creek Valley often contain cavities that are several meters wide and extend for at least $35 \mathrm{~m}(100 \mathrm{ft})$ below the surface (Fitzpatrick 1982, as referenced in Boyle et al. 1982, p. 3-21). The capacity to transmit water is facilitated by these numerous large solution openings, and springs are particularly common at the Knox and Conasauga interface (Pecora 1978 , as referenced in Poylc ot ail, 1982, p. 3-21). 
The Knox Group is the principal aquifer of the Oak Ridge area and of East Tennessee. The extensive water-storage capacity of this geologic unit is due to fractures of bedrock enlarged by dissolution of the soluble dolomite (Fitzpatrick 1982, as referenced in Boyle et al. 1982, p. 3-22). Some of these openings can attain cavernous proportions. Sinkholes occur frequently in the outcrop belts, and many sizable springs arise from the bases of the ridges. Depths to the water table reach $39 \mathrm{~m}(125 \mathrm{ft})$ at the ridge tops (McMaster 1967, as referenced in Boyle et al. 1982, p. 3-22). Water table position commonly coincides with the interface between bedrock and residual clay overburden. Residual material, which is the thickest soil mantle in the area and varies in depth from 9 to $38 \mathrm{~m} \mathrm{(30}$ to $125 \mathrm{ft}$ ), actually provides the major basin for this unit's groundwater storage. This huge expanse of overburden has a high infiltration capacity, which also tends to minimize overland runoff while maximizing recharge (Pecora 1978, as referenced in Boyle et al. 1982, p. 3-22). In most instances, ridges underlain by the Knox also define the watershed divides of the area. The mean yield of springs and wells in the Knox Group used for public and industrial water supplies is $1.7 \times 10^{.2} \mathrm{~m}^{3} / \mathrm{s}(268 \mathrm{gpm})(\mathrm{see}$

Sect. 2.4.2.2.). No estimate is available for mean well yield of domestic water wells in the Knox Group.

Because it contains so much shale and siltstone, the Chickamauga Group is a poor aquifer. The rocks are practically devoid of any large solution cavities, and the only water derived probably permeates along the bedding planes and joint partings (Fitzpatrick 1982, as referenced in Boyle et al. 1982, p. 3-22). Although numerous small openings may occur within the Chickamauga Group, but rarely beyond $30 \mathrm{~m}(100 \mathrm{ft})$ of the surface, rates and quantity of water transport are small. Recharge is further restricted by the high clay content of the overburden (Pecora 1978, as referenced in Boyle et al. 1982, p. 3-22). The residual material is typically less than $3 \mathrm{~m}$ (10 ft) thick; therefore, most is diverted to surface runoff.

Although local, semi-confined, artesian conditions exist, groundwater flow on ORR basically follows water table conditions. Hence, groundwater levels parallel topographic contours, and the water movement is from areas of high elevation to areas of low elevation. Recharge is derived primarily from precipitation, and groundwater discharge is through evapotranspiration, springs, and streams. Extensive clay subsoils channel much of the hydrological input into surface flow (Fitzpatrick 1982, as referenced in Boyle et al. 1982, p. 3-22).

Groundwater discharge contributes to the base flow of surface streams that ultimately augment the Clinch River water supply. The Clinch River is a major drainage feature of the area, and its base flow is determined by groundwater discharges to the surface water system. The low water table elevation in areas near the river is expected to be controlled by the river level elevation. It is unlikely that significant groundwater flow could pass beneath the Clinch River except for the case of extensive well pumping on one side, which may lower the local water table.

Depth to the water table varies both spatially and temporally. At a given location, depth to water is generally greatest during the October-December quarter and least during the January-March quarter (Pecora 1978, as referenced in Boyle et al. 1982, p. 3-22).

In Bethel Valley, depth to the water table ranges from 0.3 to $11 \mathrm{~m}$ ( 1 to $35 \mathrm{ft}$ ), whereas in Melton Valley the range is from 0.3 to $20 \mathrm{~m}$ (1 to $67 \mathrm{ft}$ ), Seasonal fluctuations tend to be greatest beneath hillsides and near groundwater divides. A seasonal variation of as much as $4.5 \mathrm{~m}$ (15 ft) was reported for Melton Valley. A generalized map showing the range in depth to groundwater in White Oak Creek (WOC) watershed during March 1963 is given in Fig. 2.4-4. 


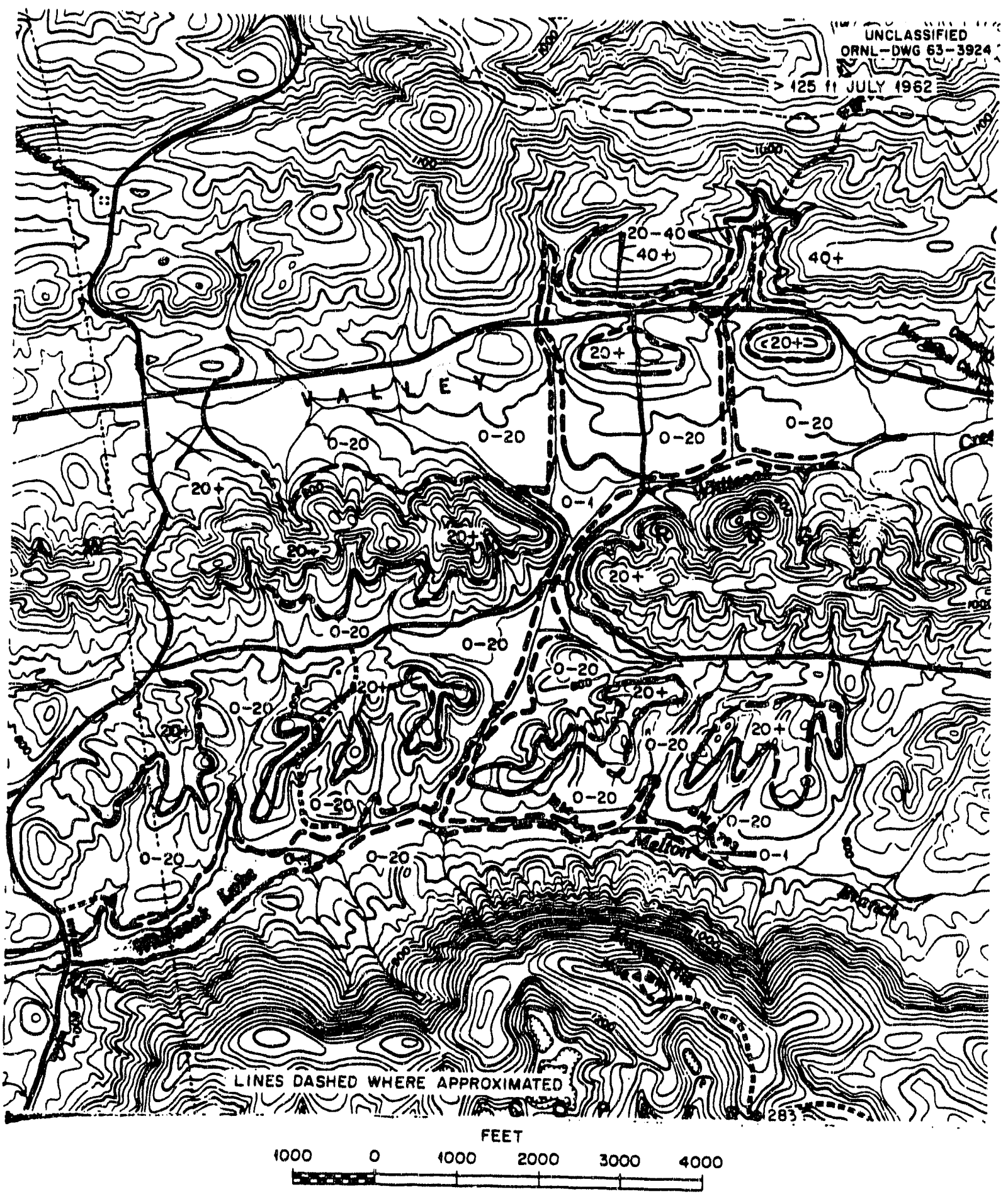

Fig. 24-4. Map illustrating general depth to groundwater in the White Oak Creek basin during March 1963. Source: Health Physics Division Annual Progress Report for Period Ending June 30, 1963, ORNL-3492, Oak Ridge National Laboratory, Oak Ridge,
Tenn., Sept. 23. 
Water table contour maps are useful, in a general way, for estimating the direction of groundwater movement, especially in the weathered residual soil or unconsolidated materials overlying bedrock. However, the direction of movement in the underlying bedrock is influenced more strongly by directional variations in permeability.

Groundwater flow in the residual soil is generally toward the individual streams of the surface-drainage network. In Bethel Valley, groundwater in the Chickamauga limestone moves through small solution channels. Although the rate of groundwater flow in the area is not known, the direction and pattern of this flow on the Bethel Valley site is essentially a subdued replica of the topography. Thus, water flows from areas of high elevation to those of low elevation, and the principal movement is in directions normal to the contour lines. The lay of the land is such that drainage at and below the surface of the Bethel Valley site apparently converges to feed WOC and White Oak Lake. An exception to this situation occurs in the western end of the Bethel Valley site where the groundwater west of a groundwater divide flows west into the Raccoon Creek drainage basin rather than into WOC.

Groundwater movement in the Conasauga shales of Melton Valley has been considered in four separate investigations and reviewed by Webster (1976, as referenced in Boyle et al. 1982, p. 3-24). Each investigation concluded that, within the study area, the primary direction of groundwater movement in the Conasauga is parallel to the strike. This observation suggests that greatest permeability in unweathered bedrock is associated with partings between beds and perhaps with residue of more soluble units. However, Webster reported that factors controlling fluid movement within the Conasauga vary with depth. He concluded that in the uppermost portion of the saturated zone, the slope of the water table (hydraulic gradient) is the primary factor controlling movement. With increasing depth, there is a change in control from the areal hydraulic gradient to control by local hydraulic head distribution within the partings, joints, fractures, or other more permeable zones within the rock. Webster also reported that the rate of movement in limes'one beneath Bethel Valley is relatively slow because of the small size of solution cavities observed in drill cores and the slow recovery of wells after pumping. The best current estimate of movement rate in the Conasauga under natural conditions is about 0.17 to $1.8 \mathrm{~m} / \mathrm{d}(0.5$ to $6 \mathrm{ft} / \mathrm{d})$ based on tracer tests performed in Solid Waste Storage Area (SWSA) 6 (Cooper 1981, as referenced in Boyle et al. 1982, p. 3-24).

\subsection{Groundwater Use}

The major portion of the industrial and drinking water supplies in the Oak Ridge area is taken from surface water sources. However, single-family wells are common in adjacent rural areas not served by the public water supply system. As in most of East Tennessee, groundwater areas adjacent to ORR occur primarily in fractures in the underlying rocks. Other than those adjacent to the city of Oak Ridge, most of the residential wells in the immediate area are south of the Clinch River. The characteristics of some domestic wells and springs in areas adjacent to the city of Oak Ridge and ORNL are given in Table 2.4-8. The locations of some water wells in the Oak Ridge vicinity are shown in Fig. 2.4-5. Wells shown are those for which the Tennessee Department of Water Resources has well logs including well location, elevation, and depth to water. Additional wells exist within the regions shown, but they either have not been reported to the state or were incompletely reported. 


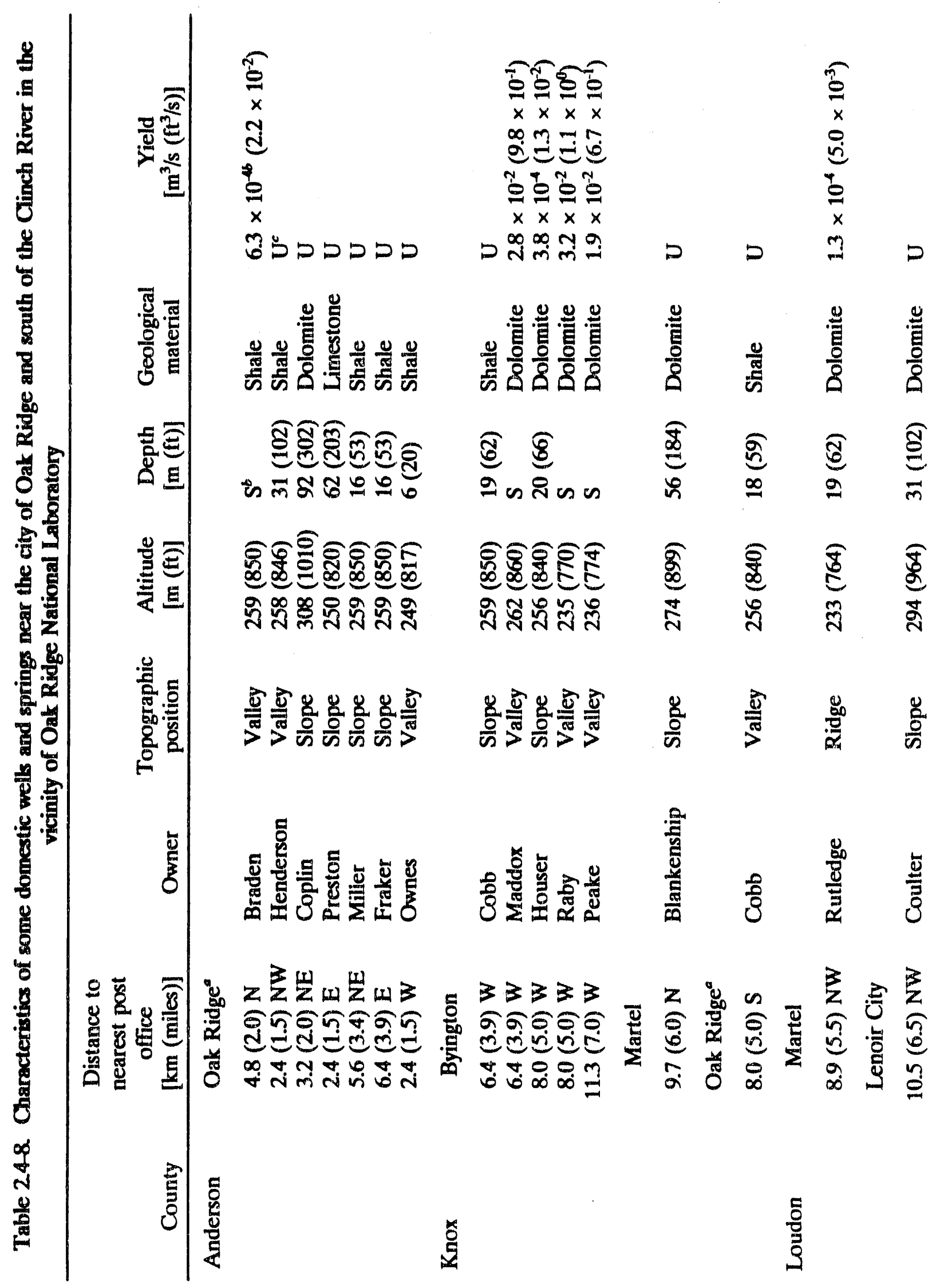







ORNL-DWG 82-11900

$36.125^{\circ}$

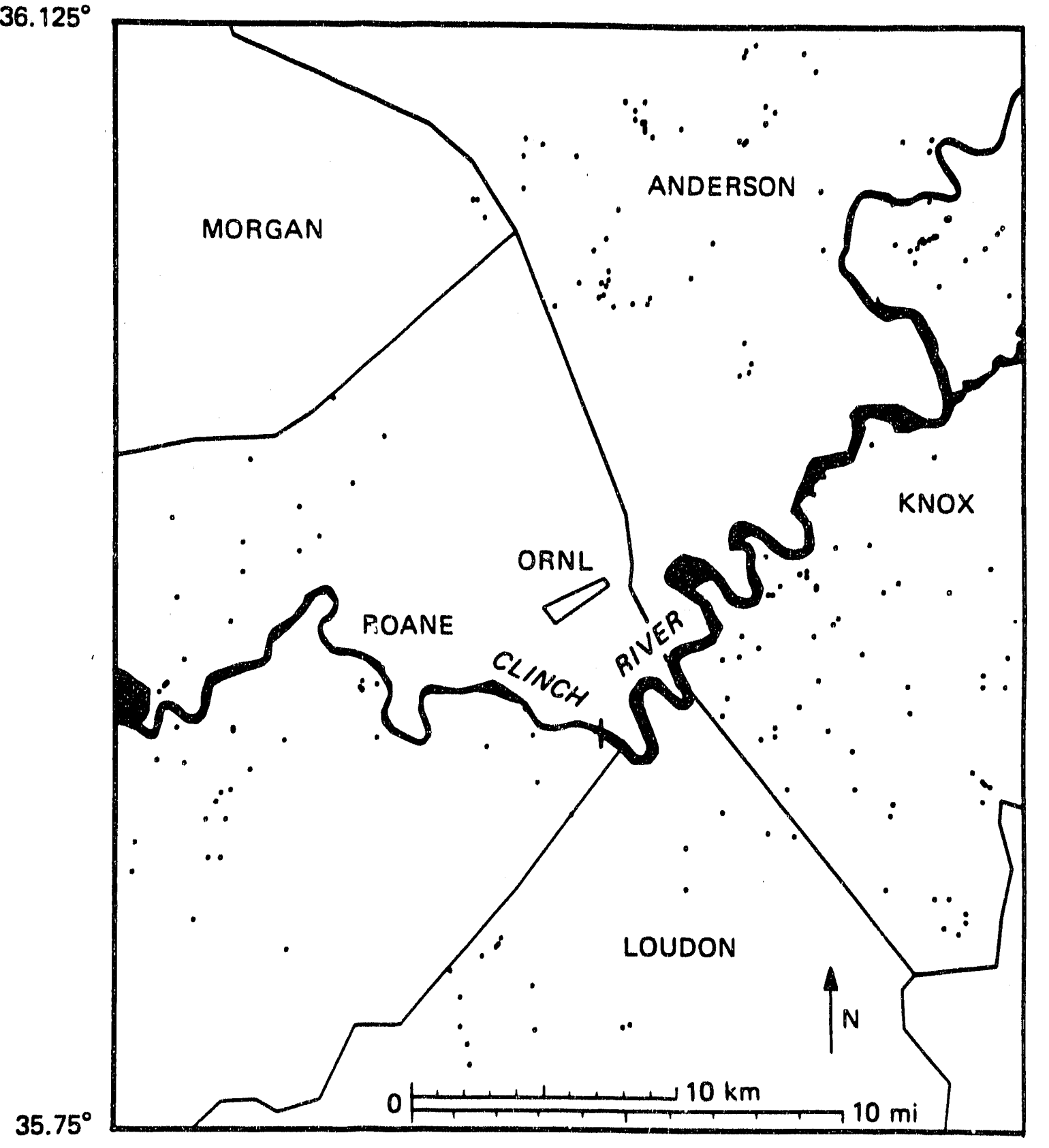

$84.500^{\circ}$

$84.125^{\circ}$

Fig. 24-5. Location of water wells in the Oak Ridge vicinity. Source: Tennessee Department of Conservation, Division of Water Resources, Computerized Master File of Tennessee's Water Wells, Nashville, Tenn., 1981. 
More than 100 wells and springs are located within $16 \mathrm{~km}$ (10 miles) of ORNL, and all are south of the Clinch River. Studies have indicated that the incised meander of the river in bedrock represents a major topographic feature that prevents any groundwater flow from passing beneath the river (Exxon 1976, as referenced in Boyle et al. 1982, p. 3-24).

Eight industrial groundwater supplies exist within about $32 \mathrm{~km}$ (20 miles) of ORNL (Exxon 1976, as referenced in Boyle et al. 1982, p. 3-24) as indicated by the data in Table 2.4-9. Three of these supplies are about $14.5 \mathrm{~km}$ (9 miles) from ORNL and the nearest is at the Charles $H$. Bacon Company in Lenoir City, Tennessee. An estimated average of $320 \mathrm{~m}^{3}(85,000 \mathrm{gal})$ is obtained daily from this supply, (Exxon 1976, as referenced in Boyle et al. 1982, p. 3-24) which is located about $14.5 \mathrm{~km}$ (9 miles) southsoutheast of ORNL. A daily average of about $38 \mathrm{~m}^{3}(10,000 \mathrm{gal})$ is obtained from the well supplying the Lenoir City Car Works, which is about $14.9 \mathrm{~km}$ (9.3 miles) south of ORNL, as well as the one supplying the Ralph Rogers company, which is approximately $15 \mathrm{~km}$ (9.4 miles) northeast of ORNL. The other five industrial groundwater supplies are farther from ORNL.

Table 249. Industrial groundwater supplies wilhin about $32 \mathrm{~km}$ (20 milcs) of Oak Ridge National Laboratory

\begin{tabular}{|c|c|c|c|c|}
\hline $\begin{array}{l}\text { Industrial } \\
\text { water user }\end{array}$ & $\begin{array}{l}\text { Yield } \\
{\left[\mathrm{m}^{3} / \mathrm{s}\right.} \\
\left.\left(\mathrm{ft}^{3} / \mathrm{s}\right)\right]\end{array}$ & Source & $\begin{array}{l}\text { Probable } \\
\text { water- } \\
\text { bearing } \\
\text { formation }\end{array}$ & $\begin{array}{c}\text { Distance from ORNL } \\
{[\mathrm{km} \text { (miles) }] \text { and }} \\
\text { direction }\end{array}$ \\
\hline $\begin{array}{l}\text { Charles H. Bacon } \\
\text { Co. (Lenior City) }\end{array}$ & $\begin{array}{c}3.7 \times 10^{.3} \\
\left(1.3 \times 10^{-1}\right)\end{array}$ & Well & Knox & $14.5(9.0) \mathrm{SSE}$ \\
\hline $\begin{array}{l}\text { Lenoir City Car } \\
\text { Works }\end{array}$ & $\begin{array}{c}4.4 \times 10^{-4} \\
\left(1.5 \times 10^{-2}\right)\end{array}$ & Well & Chickamauga & $15.0(9.3) \mathrm{S}$ \\
\hline Ralph Rogers Co. & $\begin{array}{c}4.4 \times 10^{-4} \\
\left(1.5 \times 10^{.2}\right)\end{array}$ & Well & Conasauga & $15.1(9.3) \mathrm{NE}$ \\
\hline $\begin{array}{c}\text { Charles H. Bacon } \\
\text { Co. (Loudon) }\end{array}$ & $\begin{array}{c}1.5 \times 10^{-2} \\
\left(5.2 \times 10^{-1}\right)\end{array}$ & Spring & Knox & $20.4(12.6) \mathrm{S}$ \\
\hline $\begin{array}{l}\text { Union Carbide Co. } \\
\text { (Loudon) }\end{array}$ & $\begin{array}{c}1.4 \times 10^{-1} \\
\left(4.9 \times 10^{0}\right)\end{array}$ & Spring $^{b}$ & Chickamauga & $21.2(13.0) \mathrm{S}$ \\
\hline John J. Craig Co. & $\begin{array}{c}5.7 \times 10^{-4} \\
\left(2.0 \times 10^{-2}\right)\end{array}$ & $\begin{array}{l}\text { Well } \\
\text { Spring }\end{array}$ & Knox & 24.9 (15.4) SSE \\
\hline $\begin{array}{l}\text { Tennessee Forging } \\
\text { Steel }\end{array}$ & $\begin{array}{c}1.1 \times 10^{.3} \\
(3.9 \times 10)^{.2}\end{array}$ & $\begin{array}{l}\text { Well } \\
\text { Pond }\end{array}$ & Knox & $30.6(19.0) \mathrm{W}$ \\
\hline $\begin{array}{l}\text { Morgan Apparel } \\
\text { Co. }\end{array}$ & $\begin{array}{r}1.3 \times 10^{-4} \\
\left(4.6 \times 10^{.3}\right)\end{array}$ & Well & Unknown & $30.7(19.0) \mathrm{NW}$ \\
\hline
\end{tabular}

APrimary source.

'Secondary source.

Source: Exxon Nuclear Co., Inc., 1970. Nuclear Fuel Recovery and Recycling Center, Preliminnary Safenty Analysis Report, Report XN-FR.32, Docket No. 50-564. 
There are 16 public groundwater supplies located within a $32-\mathrm{km}$ (20-mile) radius of ORNL, and a seventeenth supply, for the city of Rockwood, is about $34.6 \mathrm{~km}$ (21.5 miles) from ORNL. These 17 public groundwater supplies, their sources, and their distances from ORNL are given in Table 2.4-10. Of these sources, the closest to ORNL is the Allen Fine Spring supplying the Dixie-Lee Utility District in Loudon County. This groundwater source is about $10.9 \mathrm{~km}$ (6.8 miles) southeast of ORNL, and it serves approximately 6700 people with an average of about $1500 \mathrm{~m}^{3}(400,000 \mathrm{gal})$ of water per day. The well that serves the Edgewood Center in Roane County is about $12.2 \mathrm{~km}$ (7.6 miles) southwest of ORNL, and the spring that supplies the Cumberland Utility District of Roane and Morgan counties is approximately $12.9 \mathrm{~km}$ (8 miles) west of ORNL.

Because of the stratigraphic and structural control of groundwater flow in the region, groundwater beneath $O R R$ is expected to migrate along strike and discharge to surface water bodies. There is a low probability of groundwater migration from ORR to offsite wells.

The importance of the Knox Group as a regional aquifer is apparent from its wide use among the public and industrial groundwater users. The mean Knox spring and well yield estimated from water use figures included in Tables 2.4-9-2.4-10 is about $1.7 \times 10^{-2} \mathrm{~m}^{3} / \mathrm{s}$ (268 $\left.\mathrm{gal} / \mathrm{min}\right)$. Reliable estimates of the mean yield to domestic wells in the Knox group are not available. Yields are expected to vary widely depending on the size and extent of cavity systems encountered by individual wells.

\subsection{Regional groundwater}

A previous study conducted by the USGS (Zurawski 1978, as referenced in Boyle et al. 1982, p. 3-36) presented summary appraisals of the groundwater resources in the Tennessee Valley Region. The region lies mainly in Tennessee, Alabama, and North Carolina but includes small parts of Virginia, Georgia, Kentucky, and Mississippi. The six distinctive physiographic provinces in the Tennessee Valley Region are the Coastal Plain, Highland Rim, Central Basin, Cumberland Plateau, Valley and Ridge (within which the ORNL site is located), and Blue Ridge. The natural quality of groundwater in the Tennessee Valley Region depends on many factors but mainly on the chemical composition of the rock in which the water occurs. A summary of the median chemical quality of the groundwater in the Valley and Ridge Physiographic Province is presented in Table 2.4-11.

In the Tennessee Valley region, the quality of groundwater from a particular aquifer at any one place tends to be relatively constant with time. Most of the groundwater in the region is chemically suitable for public drinking water supplies. As shown in Table 2.4-11, median values for iron, sulfate, fluoride, chloride, and nitrate concentrations observed in the Valley and Ridge Physiographic Province are well below the maximum concentrations for drinking water recommended by the EPA. However, well-developed openings and highly porous material, less than about $30 \mathrm{~m}(100 \mathrm{ft})$ below land surface, are very susceptible to pollution. Strong protective measures are needed to ensure that the groundwater quality remains unimpaired.

In general, the groundwater quality at the CRBR site is comparable with the regional groundwater quality with the exception of total hardness, conductivity, bicarbonate, and iron concentrations, which have proven to be somewhat higher at the site than is typical of the region. Groundwater at the CRBR site is chemically suitable for human consumption, although the hardness of the water may be troublesome for some uses. 
Table 24-10. Public groundwater supplies within about $32 \mathrm{~km}$ (20 miles) of Oak Ridge National Laboratory

\begin{tabular}{|c|c|c|c|c|c|}
\hline Public water user & $\begin{array}{l}\text { People } \\
\text { served }\end{array}$ & $\begin{array}{c}\text { Yield } \\
{\left[\mathrm{m}^{3} / \mathrm{s}\left(\mathrm{ft}^{3} / \mathrm{s}\right)\right]}\end{array}$ & Source & $\begin{array}{l}\text { Probable } \\
\text { water-bearing } \\
\text { formation }\end{array}$ & $\begin{array}{c}\text { Distance } \\
\text { from ORNL } \\
{[\mathrm{km} \text { (miles) }] \text { and }} \\
\text { direction }\end{array}$ \\
\hline Oliver Springs & 4,000 & $\begin{array}{l}1.3 \times 10^{-2} \\
\left(4.5 \times 10^{-1}\right)\end{array}$ & Spring & Knox & 16.9 (10.5) NNE \\
\hline $\begin{array}{l}\text { Dutch Valley } \\
\text { Elementary School }\end{array}$ & 140 & $\begin{array}{l}1.2 \times 10^{-4} \\
\left(4.2 \times 10^{-3}\right)\end{array}$ & Well & Rome & 22.5 (13.9) NNE \\
\hline $\begin{array}{l}\text { First Utility District } \\
\text { of Anderson County }\end{array}$ & 3,600 & $\begin{array}{l}1.2 \times 10^{.2} \\
\left(4.2 \times 10^{.1}\right)\end{array}$ & Spring & Conasauga & $21.4(13.3) \mathrm{NE}$ \\
\hline $\begin{array}{l}\text { West Knox Utility } \\
\text { District }\end{array}$ & 15,000 & $\begin{array}{l}5.7 \times 10^{.2} \\
(2.0)\end{array}$ & Well $^{a}$ & Knox & $22.5(13.9) \mathrm{E}$ \\
\hline $\begin{array}{l}\text { Dixie-Lee Utility } \\
\text { District }\end{array}$ & $6,700^{b}$ & $\begin{array}{c}1.8 \times 10^{.2} \\
\left(6.3 \times 10^{.1}\right)\end{array}$ & Spring & Knox & $10.9(6.7) \mathrm{SE}$ \\
\hline Piney Utility District & 2,000 & $\begin{array}{l}3.3 \times 10^{-3} \\
\left(1.1 \times 10^{-1}\right)\end{array}$ & Spring & Knox & $23.2(14.4) \mathrm{S}$ \\
\hline Loudon & 5,200 & $\begin{array}{l}2.5 \times 10^{.2} \\
\left(8.8 \times 10^{-1}\right)\end{array}$ & Spring $^{c}$ & Knox & 23.5 (14.6) SSW \\
\hline Philadelphia & 300 & $\begin{array}{l}2.6 \times 10^{-4} \\
\left(9.1 \times 10^{-8}\right)\end{array}$ & Well & Knox & $28.2(17.5) \mathrm{SSW}$ \\
\hline $\begin{array}{l}\text { Edgewood SE } \\
\text { Center }\end{array}$ & 100 & $\begin{array}{r}1.7 \times 10^{-4} \\
\left(6.0 \times 10^{-3}\right)\end{array}$ & Well & Knox & $12.2(7.5) \mathrm{SW}$ \\
\hline $\begin{array}{l}\text { Paint Rock } \\
\text { Elementary } \\
\text { School }\end{array}$ & 250 & $\begin{array}{r}2.2 \times 10^{-4} \\
\left(7.8 \times 10^{-3}\right)\end{array}$ & Well & Rome & $26.9(16.7) \mathrm{SW}$ \\
\hline Midway High School & 500 & $\begin{array}{l}5.7 \times 10^{-4} \\
\left(2.0 \times 10^{-2}\right)\end{array}$ & Spring & Chickamauga & $27.0(16.7) \mathrm{SW}$ \\
\hline Kingston & 5,000 & $\begin{array}{l}1.4 \times 10^{.2} \\
\left(4.9 \times 10^{-1}\right)\end{array}$ & Spring & Conasauga & 18.8 (11.6) WSW \\
\hline Rockwood & 10,000 & $\begin{array}{l}6.2 \times 10^{.2} \\
(2.1)\end{array}$ & Springd & Knox & 34.6 (21.5) WSW \\
\hline $\begin{array}{l}\text { Cumberland Utility } \\
\text { District of Roane \& } \\
\text { Morgan Cos. }\end{array}$ & 4,300 & $\begin{array}{l}7.8 \times 10^{.3} \\
\left(2.7 \times 10^{-1}\right)\end{array}$ & Spring $^{d}$ & Knox & $12.9(8.0) \mathrm{W}$ \\
\hline Midtown & 2,500 & $\begin{array}{c}4.7 \times 10^{.3} \\
\left(1.6 \times 10^{-1}\right)\end{array}$ & Well & Rome & $26.4(16.4) W$ \\
\hline
\end{tabular}


Table 24-10. (continued)

\begin{tabular}{lccccc}
\hline & $\begin{array}{c}\text { People } \\
\text { served }\end{array}$ & $\begin{array}{l}\text { Yield } \\
\left.\mathrm{m}^{3} / \mathrm{s}^{3} \mathrm{ft}^{3} / \mathrm{s}\right)\end{array}$ & Source & $\begin{array}{c}\text { Probable } \\
\text { water-bearing } \\
\text { formation }\end{array}$ & $\begin{array}{c}\text { Distance } \\
\text { from ORNL } \\
{[\mathrm{km} \text { (miles) }} \\
\text { and direction }\end{array}$ \\
\hline $\begin{array}{l}\text { Brushy Mountain } \\
\text { State }\end{array}$ & 200 & $\begin{array}{c}8.8 \times 10^{-6} \\
\left(3.3 \times 10^{-4}\right)\end{array}$ & Well & Unknown & $27.7(17.2) \mathrm{NW}$ \\
$\begin{array}{l}\text { Honor Farm } \\
\begin{array}{l}\text { Plateau Utility } \\
\text { District }\end{array}\end{array}$ & 2300 & $\begin{array}{l}9.0 \times 10^{-3} \\
\left(3.1 \times 10^{-1}\right)\end{array}$ & Well & Unknown & $28.2(17.5) \mathrm{NW}$ \\
\hline
\end{tabular}

"Secondary source.

${ }^{b}$ Includes Martel Utility District.

'Half supply.

'Primary source.

Source: Exxon Nuclear Co., Inc. 1976. Nuclear Fuei Recovery and Recycling Center, Preliminary Safety Analysis Report, Report XN.FR-32, Docket No. 50-564.

Table 24-11. Groundwater quality in the Valley and

Ridge Physiographic Province in the Tennessee

Valley Region

\begin{tabular}{lc}
\hline Constituent & $\begin{array}{c}\text { Concentration } \\
(\mathrm{mg} / \mathrm{L})\end{array}$ \\
\hline Silica & 10.0 \\
Iron & 0.09 \\
Calcium & 38.0 \\
Magnesium & 12.0 \\
Sodium & 4.5 \\
Potassium & 4.5 \\
Bicarbonate & 178.0 \\
Sulfate & 5.0 \\
Chloride & 3.5 \\
Fluoride & 0.0 \\
Nitrate & 3.9 \\
\hline
\end{tabular}

Source: Zurawskd, A. 1978. Summary Appraisals of the Nation's

Ground Water Resources - Tennessee Region, U.S. Geological Survey

Professional Paper 813-L. 


\section{GEOLOGY}

This section describes geologic conditions in the region surrounding ORR and the proposed ANS site. The information provides a regional physiogeologic and geologic framework for the site. The discussion of regional geology is based on review of available data, published reports, and maps, and relies heavily on existing safety analysis reports performed for the CRBR (Project Management Corporation 1975), the High Flux Isotope Reactor (HFIR) (CRNL 1991) and the Watts Bar Nuclear Plant (TVA 1976, Chapter 3). In most cases, the region includes the area within $322 \mathrm{~km}$ (200 miles) of ORR, with major emphasis on the Valley and Ridge Physiographic Province, in which the ANS site is located.

\subsubsection{Regional Setting}

This section describes regional geologic conditions within the area previously defined including physiography, historical geology, regional structural geology and tectonics, and seismicity.

\subsubsection{Physiography}

Physiographic characteristics have a strong influence on local and regional climate and drainage patterns. Physiographic provinces are defined by geographic areas of similar geomorphic history, lithology, stratigraphy, and geologic structure. While defined on the basis of topographic expression, physiographic provinces are a reflection of underlying bedrock lithology and structure. Brief descriptions of geologic conditions that contribute to geomorphic and physiographic characteristics are included for the Valley and Ridge and surrounding physiographic provinces. The physiographic provinces within an approximate $322-\mathrm{km}$ (200-mile) radius of ORR include the Interior Low Plateaus of the Interior Plains Divisior, Axpalachian Plateaus (Cumberland and Allegheny Plateau), Valley and Ridge, Blue Jlidge, and Piedmont of the Appalachian Highlands Division, as shown in Fig. 2.5-1.

The Interior Low Plateaus Physiographic Province includes areas in Tennessee's Cencral thasin and the Bluegrass Region of Kentucky. This province is about $483 \mathrm{~km}$ (300 miles) long and $483 \mathrm{~km}$ (300 miles) wide with land surface elevations ranging between 100 and $300 \mathrm{~m}$ ( 328 and $984 \mathrm{ft}$ ) msl. It is the province farthest northwest of those described in the region surrounding ORR. The topography of the province is defined by tise structure and lithology of Paleozoic rocks and is characterized generally as mature and well-rounded with areas of karst (Seaber, Brahama, and Hollyday 1988, p. 193). Weathering of the gently dipping bedrock that underlies the area results in generally flat topography. The presence of resistant sandstones creates rough topography or elevated terrain locally, and depressions mark areas underlain by less resistant limestone and shale (Baxter, Desborough and Shaw 1967, p. 2). The eastern and southern boundaries of the Interior Low Plateaus are formed by the Highland Rim, the western boundary by the eastern boundary of the Coastal Plain Province, and the northern boundary by the southern limit of significant Pleistocene glaciation. The bedrock of the Interior Low Platealss is mostly limestone of Ordovician and Mississippian age with lesser amounts of sandstone and shale of Pennsylvanian age. The strata are gently inclined over the Cincinnati Arch, which includes the Nashville and Jessamine Domes. Surface drainage is dendritic with major drainages exhibiting little preferred directional trend. 


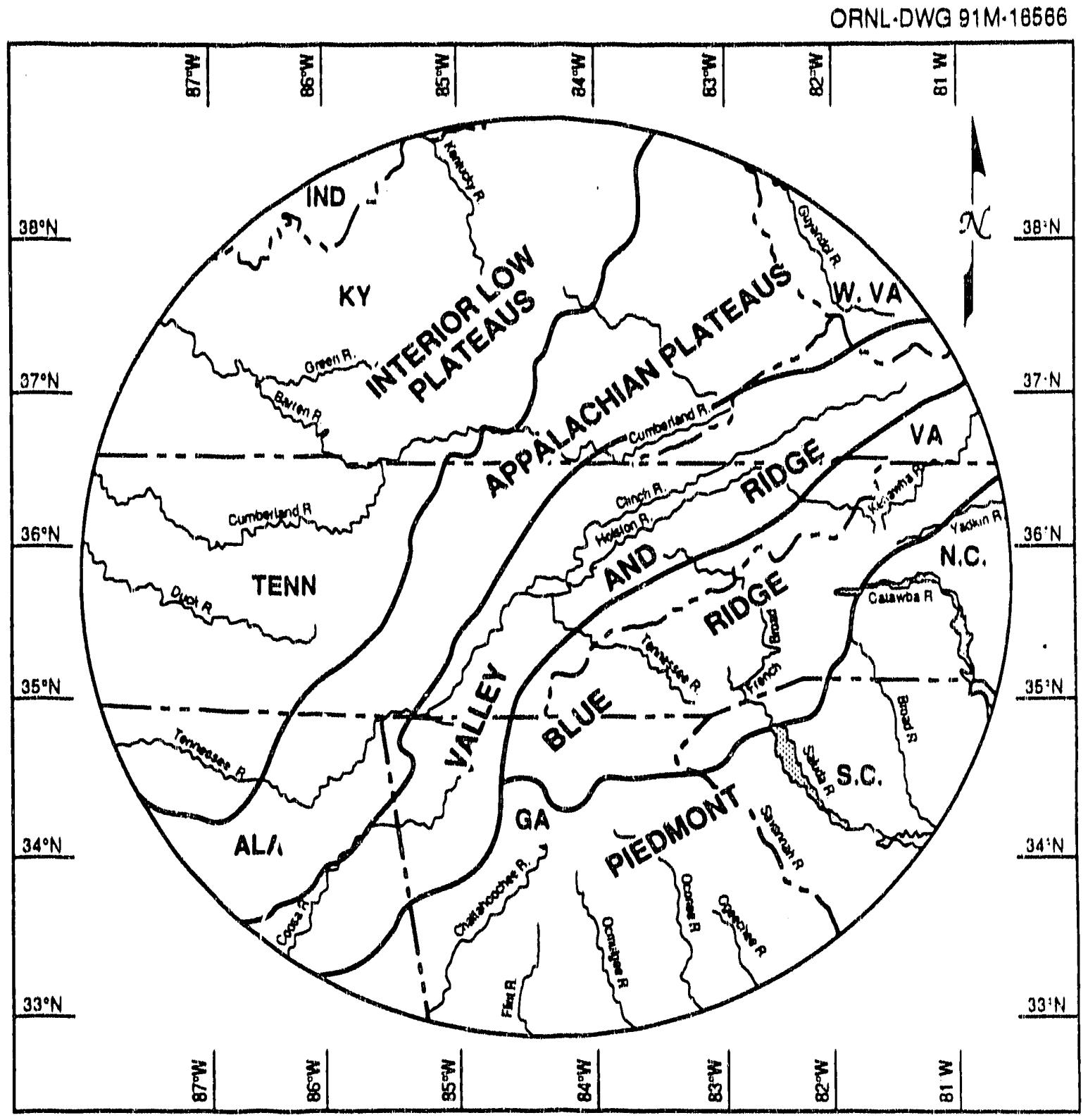

Fig, 2.5-1. Regional physiographic map. Source: Hunt, C. B. 1967. Physiography of the United States. W. H. Freeman, San Francisco. 


\section{$2 \cdot 135$}

The Appalachian Plateaus Physiographic Province borders the Valley and Ridge to the northwest and is about 32 to $322 \mathrm{~km}$ (20 to 200 miles) wide and $1610 \mathrm{~km}$ (1000 miles) long, extending from Alabama to New York. Two physiographic subdivisions of the Applachian Plateaus lie within $322 \mathrm{~km}$ (200 miles) of ORR. The Allegheny Plateau of Virginia, West Virginia, and northern Kentucky and the Cumberland Plateau of southern Kentucky and Tennessee are synonymous with the central and southern segments of the Appalachian Plateau, respectively. The Appalachian Plateaus Province is an area characterized by rugged terrain that varies from rolling hills to mountains. Its southeastern border with the Valley and Ridge is an abrupt topographic rise known as the Allegheny Front in Virginia and the Cumberland Escarpment in Tennessee. The Cumberland Escarpment lies about $8 \mathrm{~km}$ (5 miles) northwest of ORR. Surface elevations range from about 305 to $914 \mathrm{~m}(1000$ to $3000 \mathrm{ft}) \mathrm{msl}$. The topography is gently sloping to undulating, with localized mountainous areas. Most of the Appalachian Plateaus Province is underlain by alternating Pennsylvanian-age sandstone and shale. The strata are gently folded in a broad symcline. Surface drainage is dendritic; major surface drainages exhibit no preferred directional trend.

The proposed ANS site is located on ORR, which is in the southwestern portion of the Valley and Ridge Province that extends more than $800 \mathrm{~km}$ (500 miles) from Alabama northeastward into Virginia. The southwestern portion of the Valley and Ridge Province ranges from about 40 to $80 \mathrm{~km}$ (25 to $50 \mathrm{miles}$ ) wide. The province is characterized by a series of narrow, elongate ridges and slightly broader intervening valleys. The trend of these features is northeast-southwest, reflecting the regional orientation of the underlying, deformed bedrock that was intensely folded and faulted by compressional forces from the southeast during the late Paleozoic Appalachian Orogeny (Beavers et al. 1982, p. 5; Spencer 1977, pp. 449-466). In the vicinity of ORR, ridges are fairly evenly crested and are developed on underlying sandstone (comparatively resistant to weathering), and siliceous limestone and dolostone form thick residual soils with chert armored soil (comparatively resistant to erosion). Valleys are typically broader than ridges and are underlain by more readily eroded siltstones and shales. Topographic relief varies from about $245 \mathrm{~m}(800 \mathrm{ft}) \mathrm{msl}$ in valleys to more than $335 \mathrm{~m}(1100 \mathrm{ft}) \mathrm{msl}$ on ridge crests. Surface drainage is modified trellis; major surface drainages generally follow the northeastsouthwest trend of the province.

The Blue Ridge and Piedmont Physiographic Provinces border the Valley and Ridge to the southeast including portions of Georgia, South Carolina, Tennessee, North Carolina, and Virginia. Southeast of ORR, the Blue Ridge is about $120 \mathrm{~km}$ (75 miles) wide. The province is about $965 \mathrm{~km}$ (600 miles) long, extending from Pennsylvania to Georgia, and encompasses the most rugged terrain and highest elevations in the eastern United States, reflecting the erosion resistant character of the underlying metamorphic bedrock. Surface elevations vary from 457 to $1524 \mathrm{~m}$ (1500 to $5000 \mathrm{ft}$ ) mis! with the highest elevation being $2037 \mathrm{~m}(6684 \mathrm{ft}) \mathrm{msl}$. Generally, closely spaced ridges in the province trend in a northeasterly direction (Project Management Corporation 1975, as referenced in the HFIR SAR 1991, p. 2-329). Rock units in the Blue Ridge Province predominantly consist of slate, phyllite, schist, gneiss, granite, pegmatite, and quartzite. These are Precarnbrian and Lower Paleozoic metamorphic rocks ranging from chlorite to amphibolite grade morphism. The schist and gneiss are considered the oldest rocks of the region. The Blue Ridge is highly deformed, and its northwestern boundary generally coincides with major thrust faults (border faults) along which metamorphic rocks have been thrust to the northwest over the younger unmetamorphosed sedimentary rocks of the Valley and Ridge. In Tennessee this boundary is marked by the location of the Great 
Smokies Fault, which passes through Monroe, Blount, Sevier, and Cocke Counties about $50 \mathrm{~km}$ (30 miles) east and southeast of ORR.

The Piedmont Province is about 65 to $200 \mathrm{~km}$ ( 40 to 125 miles) wide and about $1610 \mathrm{~km}$ (1000 miles) long. It extends from Alabama to New York. Surface elevations in the Pledmont are about $305 \mathrm{~m}(1000 \mathrm{ft}) \mathrm{msl}$ near the Blue Ridge and decrease to about $152 \mathrm{~m}(500 \mathrm{ft}) \mathrm{msl}$ near the southeastern border of the province (the Fall Line). Elevations generally decrease to the northeast and are about 30 to $152 \mathrm{~m}$ (100 to $500 \mathrm{ft}$ ) mal near the northeastern terminus of the province. The devolopment and subsequent erosion of saprolitic soils give the province a smooth, rolling landscape. Rocks of the Piedmont are mostly metamorphics, such as gneiss and schist, with some marble and quartzite. The Carolina Slate Belt, which occurs along the eastern part of the province and extends from southern Virginia to Georgia, contains less intensively metamorphosed slate. The Slate Belt makes up about $20 \%$ of the province. Another $20 \%$ of the province is granite or granite gneiss.

\subsubsection{Regional Geology}

This section describes the geologic conditions for the region defined within a $322-\mathrm{km}(200-\mathrm{mile})$ radius of ORR. Information presented in the following subsections includes discussion of geologic history as it affected the region, stratigraphy, areal geology, geologic structure and tectonics, and seismicity.

\section{Regional geologic history}

ORR is located near the western edge of the Valley and Ridge Physiographic Province, part of the Appalachian Highland Physiographic Division of the eastern United States. To the east of the Vallcy and Ridge lies the Blue Ridge Province, which consists of Precambrian age rocks that were intensely folded and subjected to metamorphism during late Precambrian time. These Precambrian structures were subsequently greatly modified by middle and late Paleozoic tectonic pressures resulting in the crystalline rocks currently developed in the province. The Cumberland Plateau, part of the Appalachinn Plateaus Physiographic Province, lies west of the Valley and Ridge Province. The Cumberland Plateau is an area of nearly flat-lying Paleozoic sedimentary rocks that have been deeply dissected by erosion (Beavers, Manrod, and Stoddart 1982, pp. 5- 7 ).

Early in the Paleozoic era (600 million years ago), the location of the present Appalachian Highlands Physiographic Division was a depocenter for terrigenous clastic and carbonate sediments deposited within an epeiric sea. Up to $12,190 \mathrm{~m}(40,000 \mathrm{ft})$ of sediments accumulated on top of a subsiding sea floor, a tectonic feature known as the Appalachian Basin. At the same time, highlands adjacent to the depocenter continued to rise. The present Blue Ridge Physiographic Province coincides with the previous boundary between the deeper southern seas and the shallower, northwestern part of the depocenter. In earliest Paleozoic time, the Piedmont Province was part of the depocenter but eventually became a source area for sediments deposited in the basin.

During middle and late Paleozoic time, several episodes of tectonism occurred in the region. The sediments southeast of the present Blue Ridge Province were altered in composition, subjected to intrusive igneous processes, and severely deformed.

Deformation of sediments north of the Blue Ridge was restricted to folding and major thrust faulting with no extensive metamorphism occurring. These tectonic episodes resuited in the present distribution of regional faults (Sect. 2.5 .4 ) and the present bedrock configuration. Toward the end of the Paleozoic, the whole region underwent uplift and 
since that time has remained an emergent area, except for the formation of localized basins in the Pledmont province that developed during the 'Triassic Period (180 million years ago). During the Mesozoic (230 to 63 million years ago) and the Cenozoic eras (63 million years ago to present), erosion of the present. Appalachian Highlands supplied the sediments of which the Coastal Plain Formations are comprised.

\section{Regional stratigraphy}

Because of the numerous bedrock units that accur in the ORR region, more detailed descriptions of units other than those given previously is beyond the scope of this document. Only those principal rock units occurring on ORR are provided. More complete stratigraphic descriptions are provided for the formations that occur on ORR in Sect. 2.5.2. The majority of the bedrock in the Valley and Ridge Province consists of the Rorne Formation and the Conasauga, Knox, and Chickamauga Groups, Figure 2.5-2 depicts a stratigraphic column of Paleozoic bedrock formations which are recognized in the vicinity of ORR in the Valley and Ridge Province. These bedrock units torm repetitious northeast-southwest trending bands as a result of thrust faulting during the Aileghenian Orogeny (see Sect. 2.5.2.).

The Rome Formation is Middle Cambrian in age and is $366-457 \mathrm{~m}(1200-1500 \mathrm{ft})$ thick. It is generally divisible into upper and lower parts. The lower Rome is characterized by maroon to greenish-gray shale with subordinate shaley siltstone and sandstone beds. The shales are fissile and generally variegated. Because of lithology and regional structure, few exposures of the typical lower Rome occur in ORR. The upper Rome is generally characterized by interbedded sandstone and shale. The Rome is considered the basal sedimentary formation in the Valley and Ridge, and at or near its base lies the sole fault from which the major thrust faults emerge and surface. Beneath the Rome is the Precambrian basement.

The Conasauga Group is as much as $610 \mathrm{~m}(2000 \mathrm{ft})$ thick regionally and about $520 \mathrm{~m}(1700 \mathrm{ft})$ thick on ORR. On ORR the Conasauga Group is divided into the Pumpkin Valley Shale, Rutledge Limestone, Rogersville Shale, Maryville Limestone, Nolichucky Shale, and Maynardville Limestone. As the formation names imply, these formations consist of nearly alternating limestone and shale-dominated lithologies that outcrop in an alternating, banded pattern producing the alternating valleys and ridges of the Valley and Ridge Province.

The Knox Group is an Upper Cambrian-Lower Ordovician dolomite and limestone sequence that is divisible into five formations: late Cambrian Copper Ridge Dolomite, early Ordovician Chepultepec Dolomite, Longview Dolomite, Kingsport Formation, and Mascot Dolomite. Total thickness ranges from 700 to $1000 \mathrm{~m}$ (2000 to $3000 \mathrm{ft}$ ) in East Tennessee with the Copper Ridge Dolomite being approximately onethird of the total. The Knox Group is the principal strong unit that supported the folding and thrust faulting that occurred throughout the Valley and Ridge and the Cumberland Plateau.

The Chickamauga Group represents deposition on a regionally extensive disconformity on the top of the Knox. Relief on the disconformity accounts for locally variable stratigraphic thicknesses in the lower Chickamauga. The Chickamauga Group is among the most variable rock units in the Valley and Ridge. Major thickness and lithologic differences occur across strike belts such that only a generalized regional description can be made. The Chickamauga is Middle Ordovician in age and ranges in thickness from about $610 \mathrm{~m}$ ( $2000 \hat{f} \mathrm{f} i)$ in the northwestern part of the region to more $2400 \mathrm{~m}(8000 \mathrm{ft})$ in the southeastern part. In general, the Chickamauga Group is 
ORNL-DWG 91M-16567

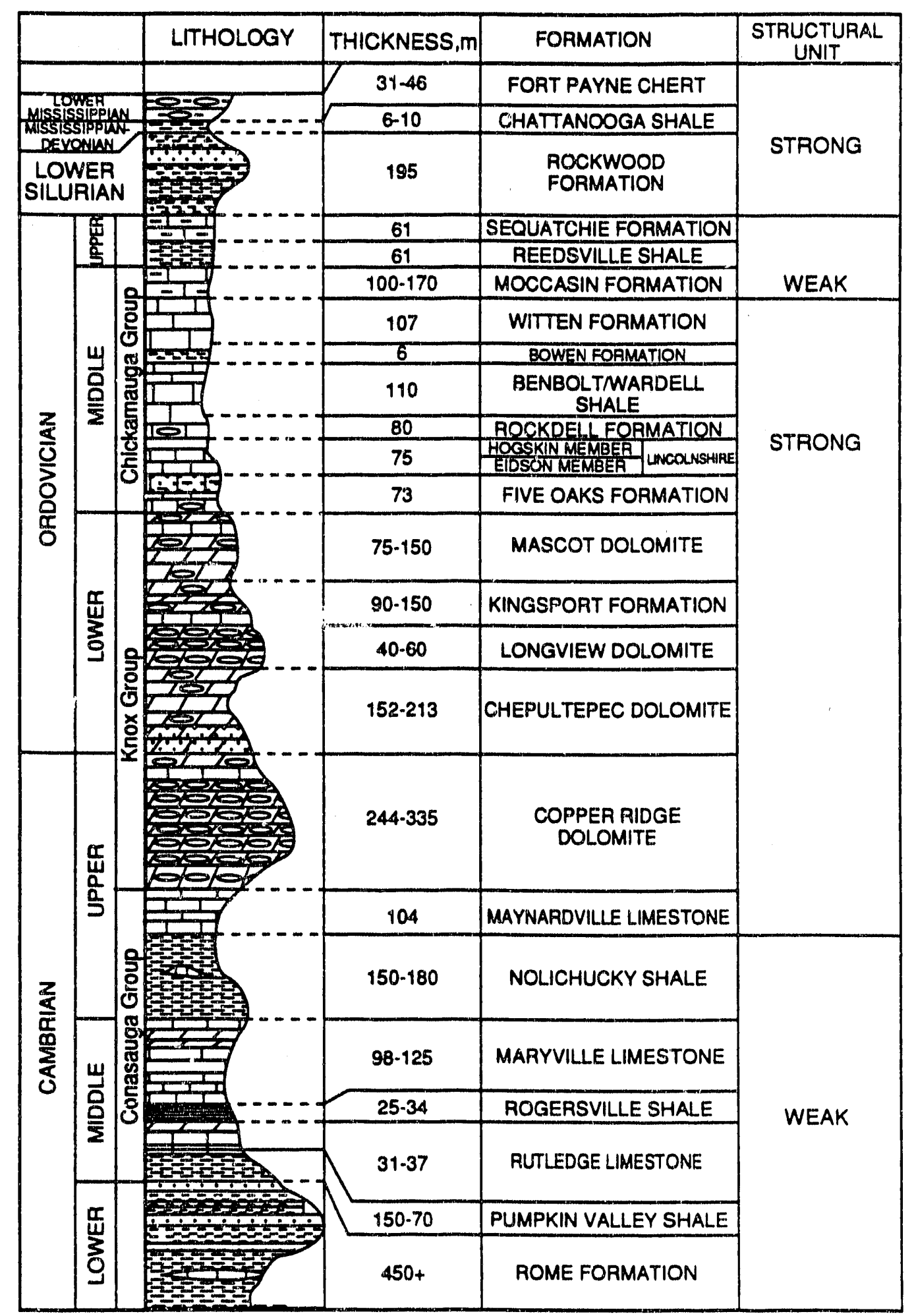

Fig. 25-2 Stratigraphic column for the Valley and Ridge Province Paleozoic bedrock formations in the Oak Ridge Reservation vicinity. 
composed of alternating layers of gray and maroon limestone, calcareous siltstone, and shale in varying thicknesses. Other rock units with limited exposure in the Valley and Ridge include the Rockwood Formation, the Chattanooga Shale, and the Fort Payne Chert.

\section{Regional structural geology and tectonic features}

ORR is located in the complexly folded and faulted Valley and Ridge Province of the Appalachian Highlands Division. Figure 2.5-3 is a regional surface and subsurface geologic map modified after the Watts Bar Nuclear Plant Final Safety Analysis Report (TVA 1976, Chapter 3). This section describes the major structural features in the region that possess surface and near-surface expression and deeper structural features that lack surface expression. The surface and near-surface structures are remnants of Paleozoic structural deformation in the eastern continental margin and are generally considered to be tectonically inactive features. Basement structures that lack surface expression are not as well identified but are considered to be related to historic seismicity. Near-surface geologic structures are discussed in this section and basement structures are discussed in the following section.

Figure $2.5-4$ is a tectonic map showing the extensive structural deformation in the region. Faults exposed at the land surface, and major folds, domes, and basins are shown. During the Paleozoic era, tectonic forces directed toward the northwest deformed the rocks of the Appalachian Highlands paleobasin. Deformation was greatest in the southeastern part of the basin (Piedmont and Blue Ridge Provinces) where the rocks were metamorphosed and subjected to intrusive igneous processes. These rocks were thrust to the northwest along a series of boundary faults. Rocks for several miles to the northwest of the boundary between the Blue Ridge and the Valley and Ridge were broken into a series of thrust-block fault traces trending generally from northeast to southwest. The thrusting abruptly diminished toward the northwest, where a broad syncline was developed (Appalachian Plateaus Province).

The geologic structure of the Valley and Ridge is characterized by elongate folds and thrust fauits that trend northeast-southwest. The strata dip to the southeast to varying degrees. On ORR, bedding dip generally varies from less than $10^{\circ}$ to more than $45^{\circ}$. Detailed descriptions and analyses of the structural setting of the Appalachians can be found in Hatcher et al. 1989.

Thrust faults in the Valley and Ridge do not extend to the basement, which is at a depth of about $3962 \mathrm{~m}(13,000 \mathrm{ft})$ below ground surface in the region. These structures overlie a decollement in the Rome Formation at a depth of about $4.0 \mathrm{~km}(13,000 \mathrm{ft})$ beneath the surface in the vicinity of ORR (Stockdale 1951, as referenced in the HFIR SAR 1991, p. 2-327; Rodgers 1970, p. 271; Hatcher 1972, pp. 2735-2760). Two such thrust faults (the Whiteoak. Mountain Fault and the Copper Creek Fault) occur on ORR. The ANS site is located approximately $0.5 \mathrm{~km}$ ( 0.31 mile) southeast of the Copper Creek Fault outcrop zone.

There were several episodes of tectonism during the Paleozoic Era; however, one episode caused the major deformation of the rock strata in the vicinity of ORR. This event is referred to as the Allegheny Orogeny, which occurred during either the Pennsylvanian or Permian period, or at least 230 million years ago (Rodgers 1970, p. 271). Northwest of the Annalachian paleobasin. the strata were gently folded to form the Cincinnati Arch. This feature was formed during the Paleozoic era by downwarping along its margins. 
$\overline{5}$
$\frac{5}{1}$
$\frac{9}{0}$
$\frac{5}{5}$
$\frac{1}{2}$
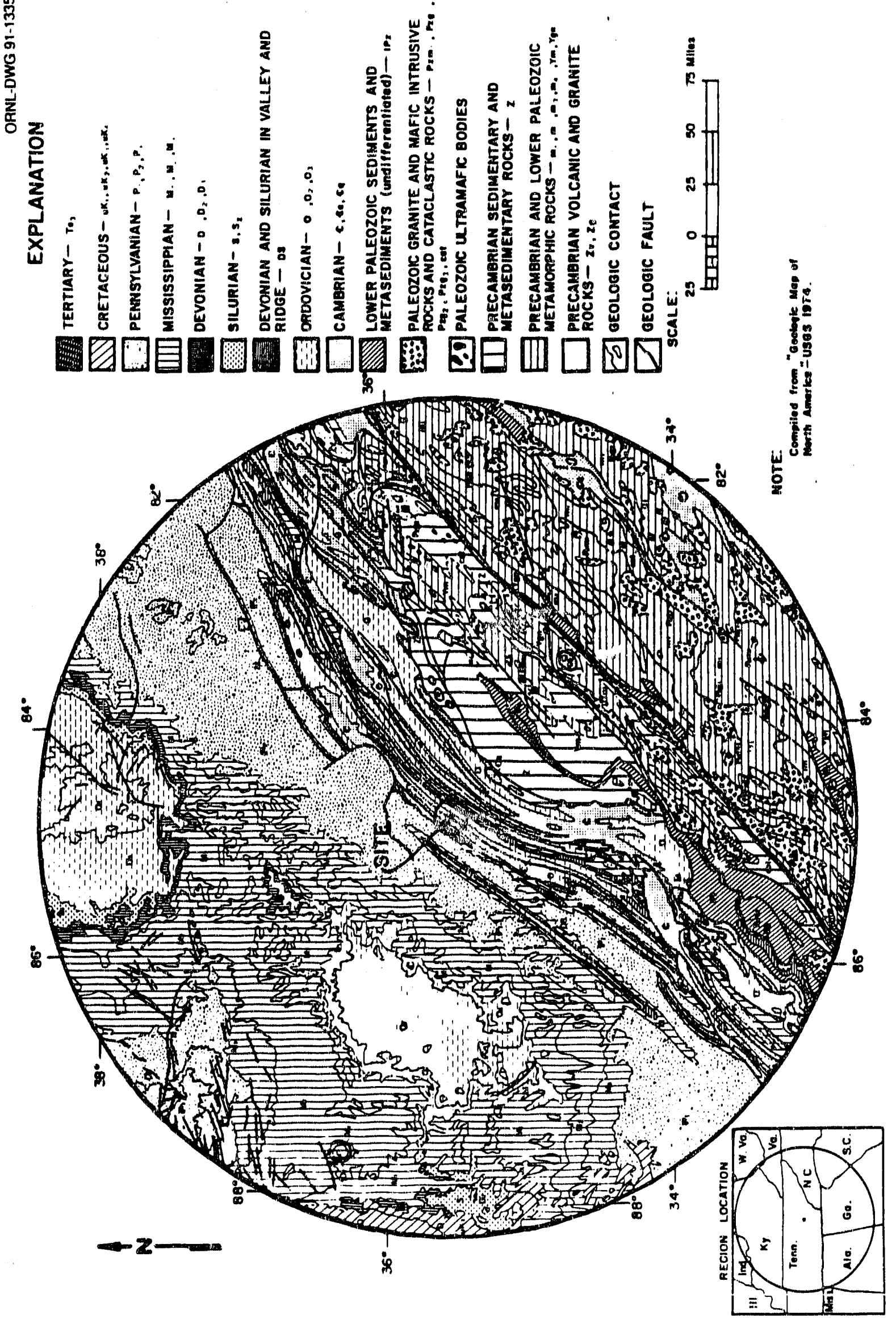

焉

로

这

8

है

需 㤩

ㅇํㅇ

更

8 蛋立

总

슬

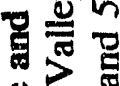

8 \&

붑 它

造之

क्ष

$<$ 造

ทें

ํㅝㄹ

玨

會 
$2-141$
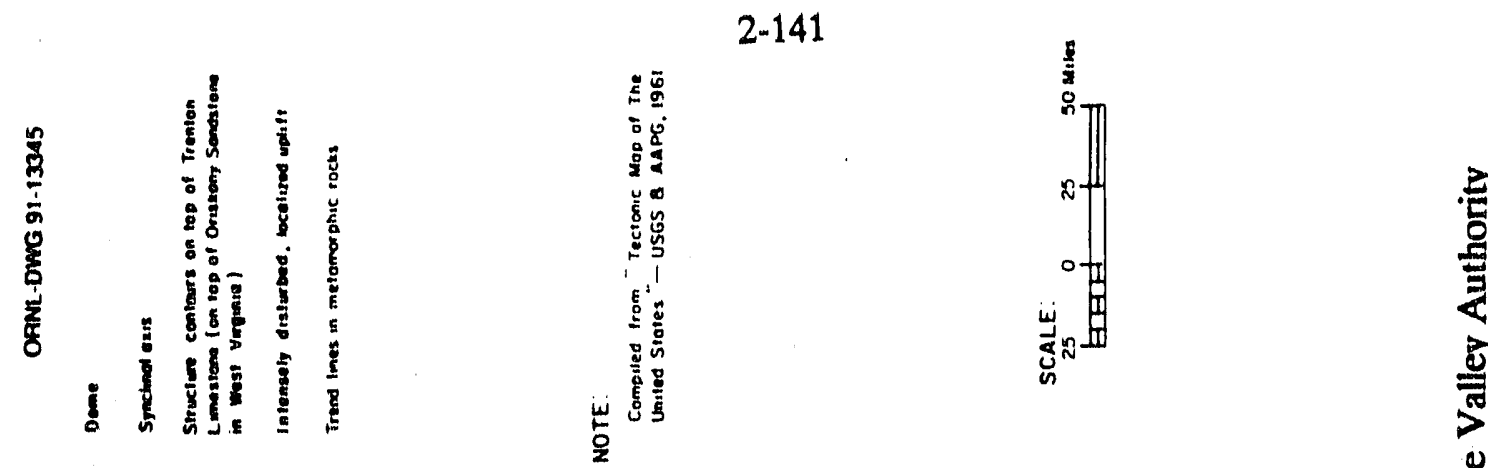

由因图 0 圈

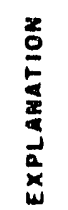
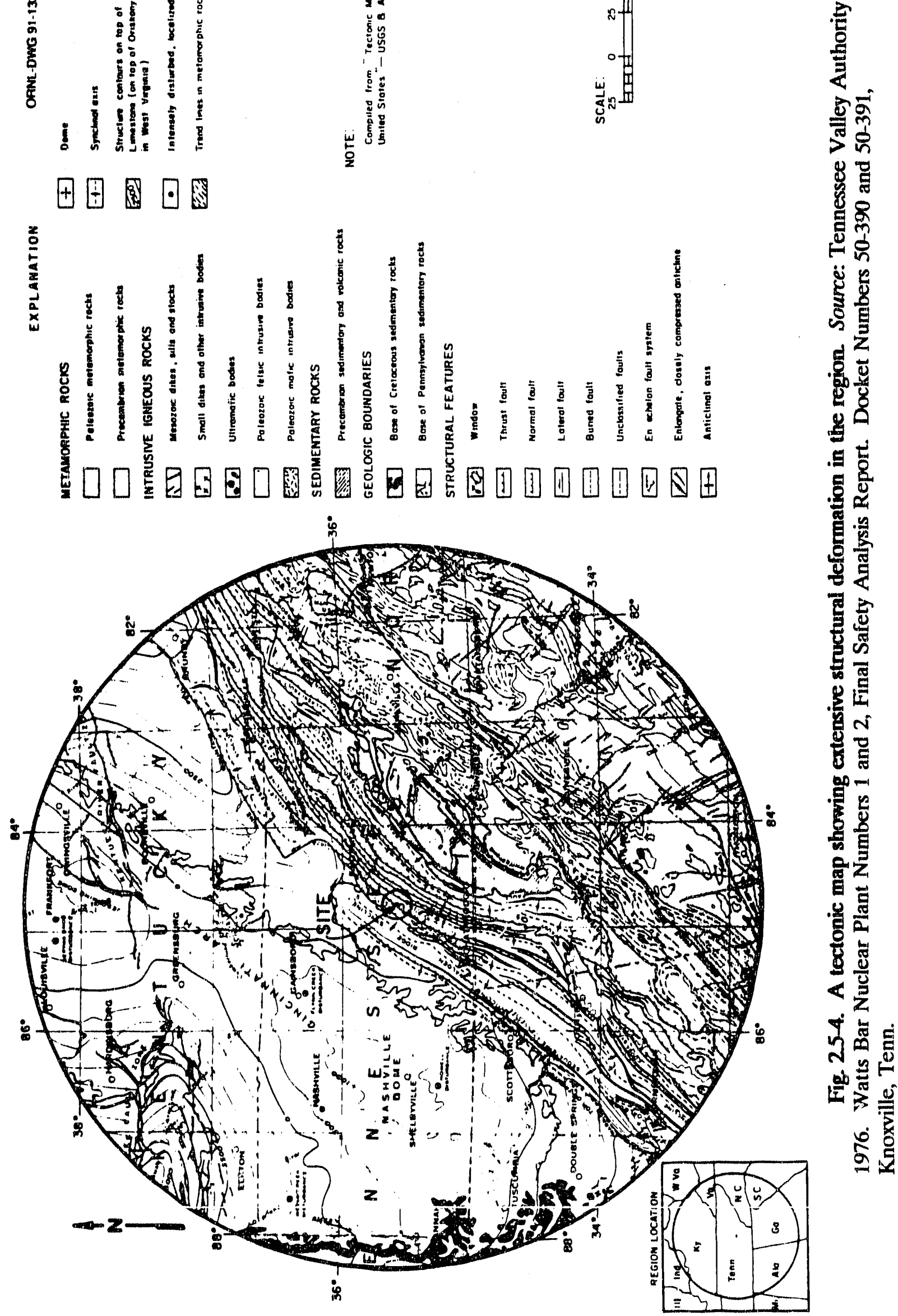
Deep-seated fault systems developed further west of the Valley and Ridge during the Paleozoic era (e.g. the Kentucky River and Rough Creek Fault zones). The Kentucky River Fault zone trends east-west from eastern Kentucky westward across the Cincinnati Arch and dies out on the western flank of the arch. The fault zone has a total length of about $241 \mathrm{~km}$ (150 miles) and a width of about $40 \mathrm{~km}$ ( 25 miles). The closest fauit to ORR in the Kentucky River Fault zone is more than $145 \mathrm{~km}$ (90 miles) to the north. Faults in the Kentucky River Fault zone are mostly steep, en echelon normal faults. The maximum displacement along the Kentucky River Fault zone is approximately $183 \mathrm{~m}$ $(600 \mathrm{ft})$ (Eardley 1951, p. 235). Underlying basement rocks within this zone are faulted with movement that began in early Paleozoic time (Rogers 1970, as referenced in the HFIR SAR 1991, p. 3-328). Active movement within this fault system ceased after the Pennsylvanian period, approximately 310 million years before the present (Sutton 1971, pp. 391-412). The Rome Trough (located just beyond the $322-\mathrm{km}$ regional boundary from ORR) is an eastward extension of the Kentucky River Fault zone into West Virginia. Keller et al. (1983, pp. 69-78) describe the Rome Trough as an Eocambrian failed rift zone.

The Rough Creek Fault zone begins west of the Cincinnati Arch and extends across western Kentucky into southern Illinois. This fault system has an east-west trend similar to that of the Kentucky River Fault zone. Near Shawneetown, Illinois, the Rough Creek Fault zone curves southwestward around Hicks Dome and merges with the New Madrid Fault zone, an ancient Eocambrian failed rift zone (Keller et al. 1983, p. 398). The Rough Creek Fault zone is approximately $193 \mathrm{~km}$ (120 miles) long and about $40 \mathrm{~km}$ (25 miles) wide. At its closest point, the Rough Creek Fault zone is about $193 \mathrm{~km}$ (120 miles) northwest of ORR.

Seismicity

Underlying tectonic structures. Basement structural features that lack surface expression and are generally unrelated to structural features in the overlying Paleozoic sedimentary rock veneer occur in the eastern midcontinent of the United States. While data to infer the presence of basement structures are generally limited to gravity, magnetic, and geophysical, much has been learned about such features within the past decade. Keller et al. (1983, pp. 391-412) drscribed these basement features in the United States midcontinent within a plate tectonic framework as follows.

Regional mapping of magnetic and gravity anomalies has been used to infer the location of Precambrian paleo-rifts (Fig. 2.5-5). One example of such an inferred paleorift is a discontinuous, arcuate structure extending for approximately $2000 \mathrm{~km}$ (1240 miles) from Lake Superior to Kansas. This rift, the Midcontinent Rift System, is overlain by Paleozoic rocks except where it is exposed in the Lake Superior region. Its location is primarily known from its limited exposure, interpretations of geophysical data, and extrapolations from limited basement drill holes. It is interpreted that the feature originated in a major thermo-tectonic event, involving primarily extensional stresses, that culminated in the extrusion and intrusion of vast quantities of largely mafic rocks during a short time span from approximately 1200 to 1100 million years ago. In the ORR region, the presence of a north-trending magnetic and gravity high extending from the Cumberland Plateau in Tennessee into Kentucky is similarly interpreted to represent a precambrian paleo-rift. 


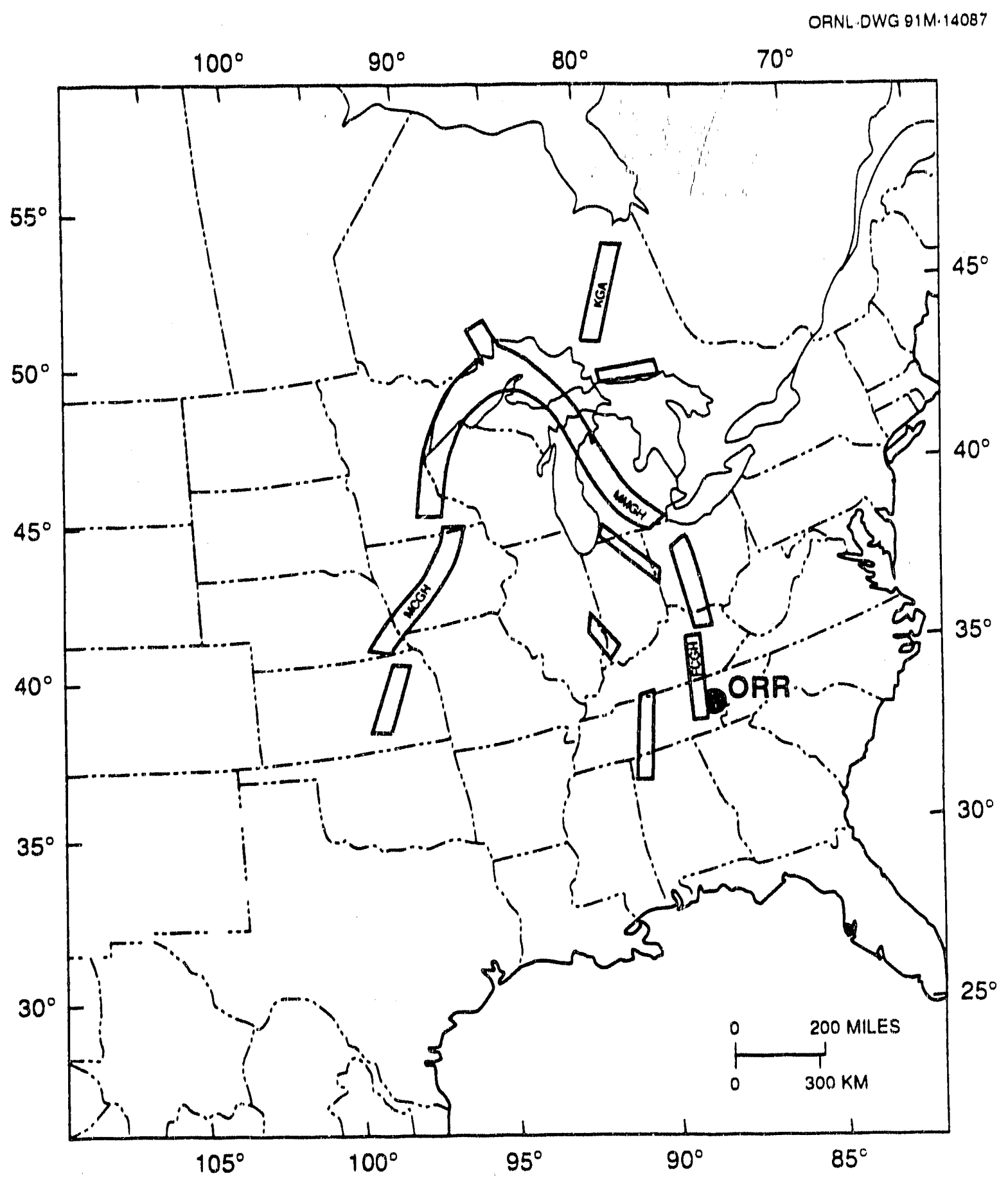

Fig. 25-5. Precambrian rifts of the midcontinent. MCGH = Midcontinent gravity high (Midcontinent rift system); $\mathrm{MMGH}=$ Mid-Michigan gravity high; ECGH = East continent gravity high. Source: modified from Keller, G. R. et al. 1983. "The Role of Rifting in the Tectonic Development of the Midcontinent, U.S.A.," Tectonophysics, 94, 391-412. 
Eocambrian (Late Precambrian to Early Cambrian) continental breakup that occurred during formation of the Proto-Atlantic Ocean formed a series of failed-arm rifts extending into the continent (Fig. 2.5-6). The successful rift arm that formed parallel to the continental margin may have been obliterated by Paleozoic orogenic activity. This complex of basement rifts is similar to the one that formed during the Mesozoic breakup of Africa and South America. One of the Eocambrian rifts of significance to ORR is the Reelfoot Rift located about $480 \mathrm{~km}$ (300 miles) west of ORR. The Reelfoot Rift underlies the Mississippi Embayment and is relatively well known from geophysical data. Little direct evidence exists to date the Reelfoot Rift.

The final period of continental extension in the early Mesozoic resulted in the formation of a rifted margin all along the Atlantic coastal region of North America (Fig. 2.5-7). The Triassic grabens of this reglon delineate the inland extent of this rifting event. These grabens apparently extend to the Gulf Coast although uncertainties remain regarding the tectonic history of this region.

Evidence to date suggests that Paleozoic structures are not related to historical seismicity in the Appalachian Basin. Scattered earthquakes in the Appalachian Basin have focal depths of greater than $10 \mathrm{~km}$, well within the basement (Bollinger 1973, pp. 1785-1808; Bollinger and Wheeler 1988, p. 23). The depth of focus has often been cited as evidence in support of a relationship between historical earthquakes and basement, rather than Paleozoic, structures. Based on data provided by Bonilla 1982 (p. 43) there is no evidence of Pleistocene or Holocene surface rupture related to earthquakes in the Appalachian Basin, and, according to TVA 1976 (p. 2.5-54-2.5-64), traces of local thrust faults (the White Oak Mountain and Copper Creek faults) are covered with residual soil and colluvitum that has not been displaced.

At present, details of the proposed relationship between historical seismicity and basement structures in the Appalachilan Basin are unknown. Several basement structures beneath the Appalachian Basin have: been documented by Keller et al. (1983, pp. 391-412). These structures have: many of the same characteristics as well known rift zones. Like the Reelfoot Rift zone, they are elongate basins with unusual thicknesses of Late Precambrian to Cambrian stratil and elongate trends of unusually dense and strongly magnetic basement rocks (based on yravity and aeromagnetic surveys and a few boreholes that penetrate into the basement). Dense and highly magnetic rocks infer the presence of shallow oceanic crust as would be expected where continental rifting has taken place. However, the historical earthquake record is too short and the details of basement structures are not known well enough to establish a firm cause-and-effect relationship between them.

Bollinger and Wheeler (1988, p. 1) provide evidence of a relationship between instrumentally recorded earthquakes and a basement structure underlying the Appalachian Basin. They propose that recent earthquakes (precisely located by a network of portable. earthquake seismometers) occurred along an Eocambrian (late Precambrian to early Paleozoic) rift zone beneath the Appalachian Basin. Twelve instrumentally recorded earthquakes occurred along a linear trend within the basement at focal depths ranging from 5 to $26 \mathrm{~km}$ (mean value $=14 \mathrm{~km}$ ). This linear trend is oriented at an acute angle with outcropping Paleozoic structures and passes beneath Giles County, Virginia, the site of the largest historical earthquake in the Appalachian Basin (May 31, 1897). By inference, Bollinger and Wheeler suggest that the Giles County earthquake of 1897 occurred along the same basement structure. Bollinger and Wheeler also believe that this basement structure is not unique in the Appalachian Basin and that similar structures may be present elsewhere in the basin. 
ORNL.DWG $91 M \cdot 14088$

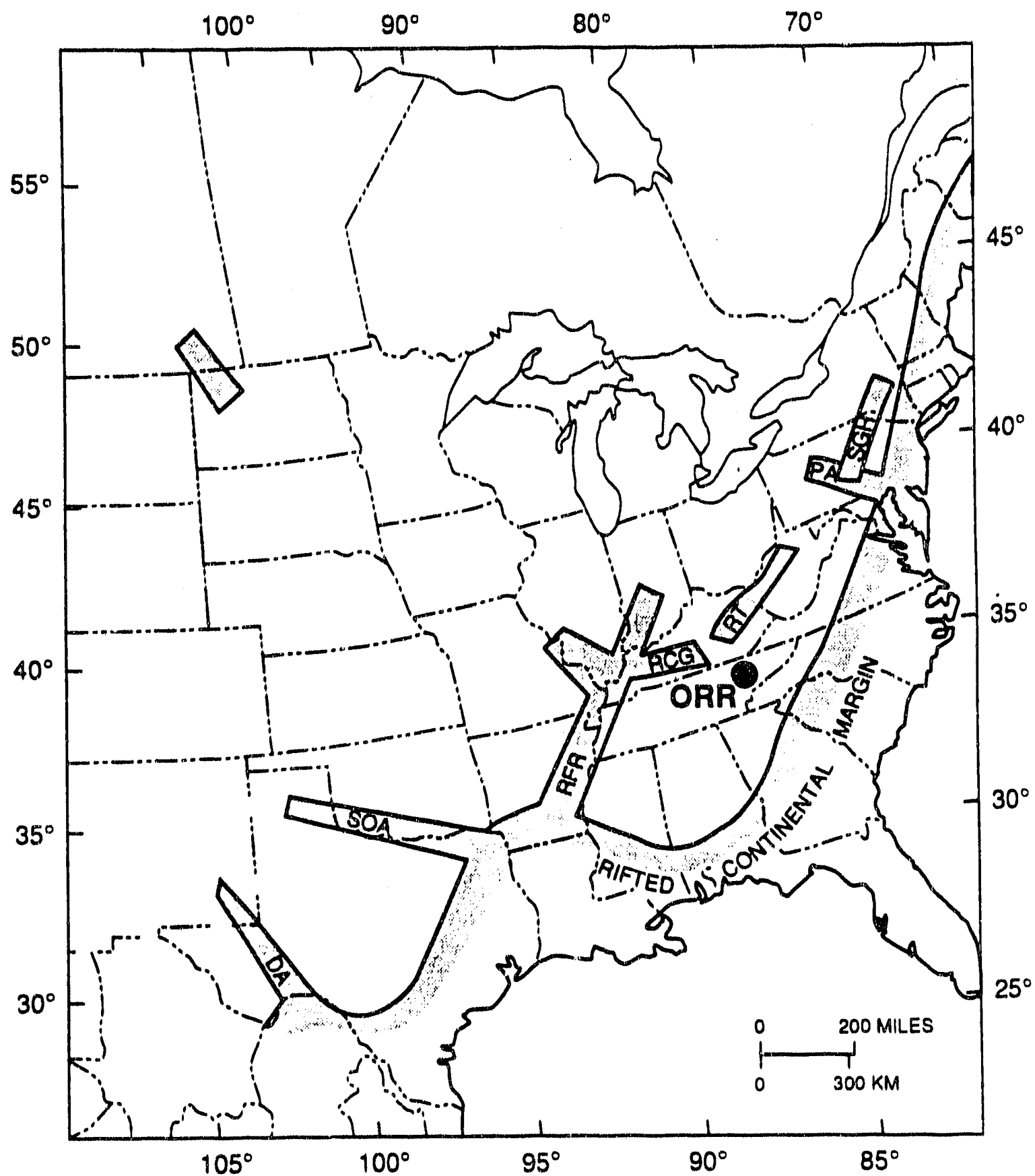

Fig. 25-6. Eocambrian (Late Precambrian to Early Cambrian) rifts of the midcontinent. $\mathrm{RFR}=$ Reelfoot $\mathrm{Rift} ; \mathrm{DA}=$ Delaware aulacogen; $\mathrm{RCG}=$ Rough Creek Graben; RT = Rome Trough; PA = Pennsylvanian aulacogen; SGH = Scranton gravity high. Source: modified from Keller, R. G. et al. 1983. "The Role of Rifting in the Tectonic Development of the Midcontinent, U.S.A.,"

Tectonophysics, 94, 391-412. 


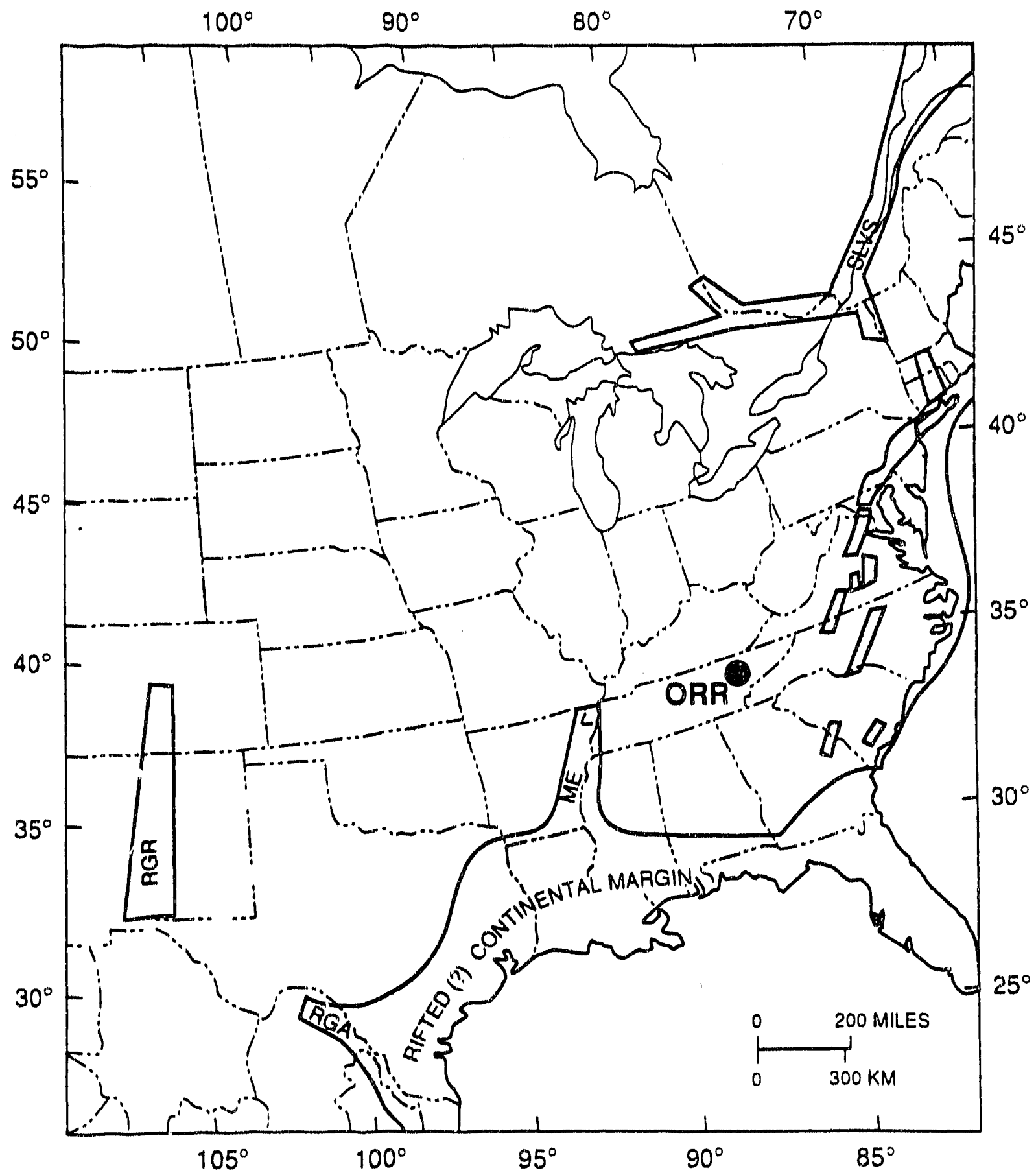

Fig. 25-7. Mesozoic and Cenozoic rifts of the midcontinent. $R G R=$ Rio Grande rift; RGA = Rio Grande aulacogen; ME = Mississippi Embayment; SLVS = St. Lawrence Valley system. Source: modified from Keller, R. G. et al. 1983. "The Role of Rifting in the Tectonic Development of the Midcontinent, U.S.A.," Tectonophysics, 94, 391-412. 
Johnston and Kanter (1990, pp. 68-75) hypothesize that most strong-motion intraplate earthquakes occur along reactivated rift zones within the basement and along passive continental margins containing rift structures (deep Triassic and Cretaceous basins) associated with the early opening of the Atlantic Ocean basin. The series of New Madrid earthquakes in 1811-1812 is an example of reactivation of an ancient rift zone [the Reelfoot Rift zone of Ervin and McGinnis 1975 (pp. 1287-1295)]. The Charleston, South Carolina, earthquake of August 31,1886, is an example of reactivation of a rift structure along a passive continental margin. Johnston and Kanter's conclusions are based on a world-wide study of large intraplate earthquakes and ancient rift zones.

Earthquake history. Historic earthquakes that have occurred since 1942 and may have been felt at the ANS site are listed in Table 2.5-1. Although the Maryville-Alcoa earthquake of November 30,1973, may have been large enough and close enough to cause minor damage on $O R R$, there are no earthquake-related damage reports for the local DOE facilities.

Five tectonic provinces have experienced significant historical strong-motion earthquakes relevant to ORR. These provinces are the Appalachian Basin, Piedmont, and Interior Low Plateaus (discussed previously), the Mississippi Embayment, and the Atlantic Coastal Plain. Locations of provinces with borders within $320 \mathrm{~km}$ (200 miles) of ORR and strong-motion earthquakes $\left[\mathrm{m}_{b} \geq 5.5\right.$ and/or Modified Mercalli Intensity (MMI) 2 VIII] within them are shown in Fig. 2.5-8. Tectonic province boundaries are based on maps provided by Bayer (1983, p. 1) and by Frezon and Finn (1988, p. 1). Earthquake locations were provided by NOAA's Geophysical Data Center in Boulder, Colorado. Salient information about the largest earthquakes in each of these provinces are presented in Table 2.5-2.

The three largest historical earthquakes in the southeastern United States occurred in northeastern Arkansas and southeastern Missouri on December 16, 1811; January 23, 1812; and February 7, 1812. They were all located in the Mississippi Embayment between Marked Tree, Arkansas, and New Madrid, Missouri, as shown in Fig. 2.5-8. For each of these earthquakes the MMIs = XI to XII in their epicentral areas and nearby villages were nearly totally destroyed. By the estimate of Mitchell et al. (in press), the $m_{b}=7.4$ for the largest of these earthquakes (the February 7, 1812, event). Moderate damage was reported as far away as Cincinnati, Ohio, and these earthquakes were felt on the eastern seaboard as far north as Boston, Massachusetts. These earthquakes were comparable to the March 28, 1913 earthquake in Upper East Tennessee producing the largest historical MMIs in eastern Tennessee (VI-VII in Knoxville).

The second strongest earth quake in the southeastern United States occurred near Charleston, South Carolina, on A sgust 31, 1886. Bollinger (1973, pp. 1785-1808) estimates that this earthquake's $\Omega_{b}=6.8$ and its MMIs $=X$ and IV to VI in the epicentral region and in eastera Tennessee, respectively. The epicenter was located on the Atlantic Coastal Plain.

The strungest earthquake in the Appalachian Basin (the tectonic province where ORR is located) was the Giles County, Virginia, earthquake of May 31, 1897. Bollinger and Wheeler $(1988, p .1)$ estimate the size of this earthquake as $m_{b}=5.8$ and the strength as MMIs = VIII and IV-VI in the epicentral region and eastern Tennessee, respectively. As previously stated, the Giles County earthquake is believed to be associated with an Eocambrian rift zone in the basement beneath Appalachian Basin structures. 


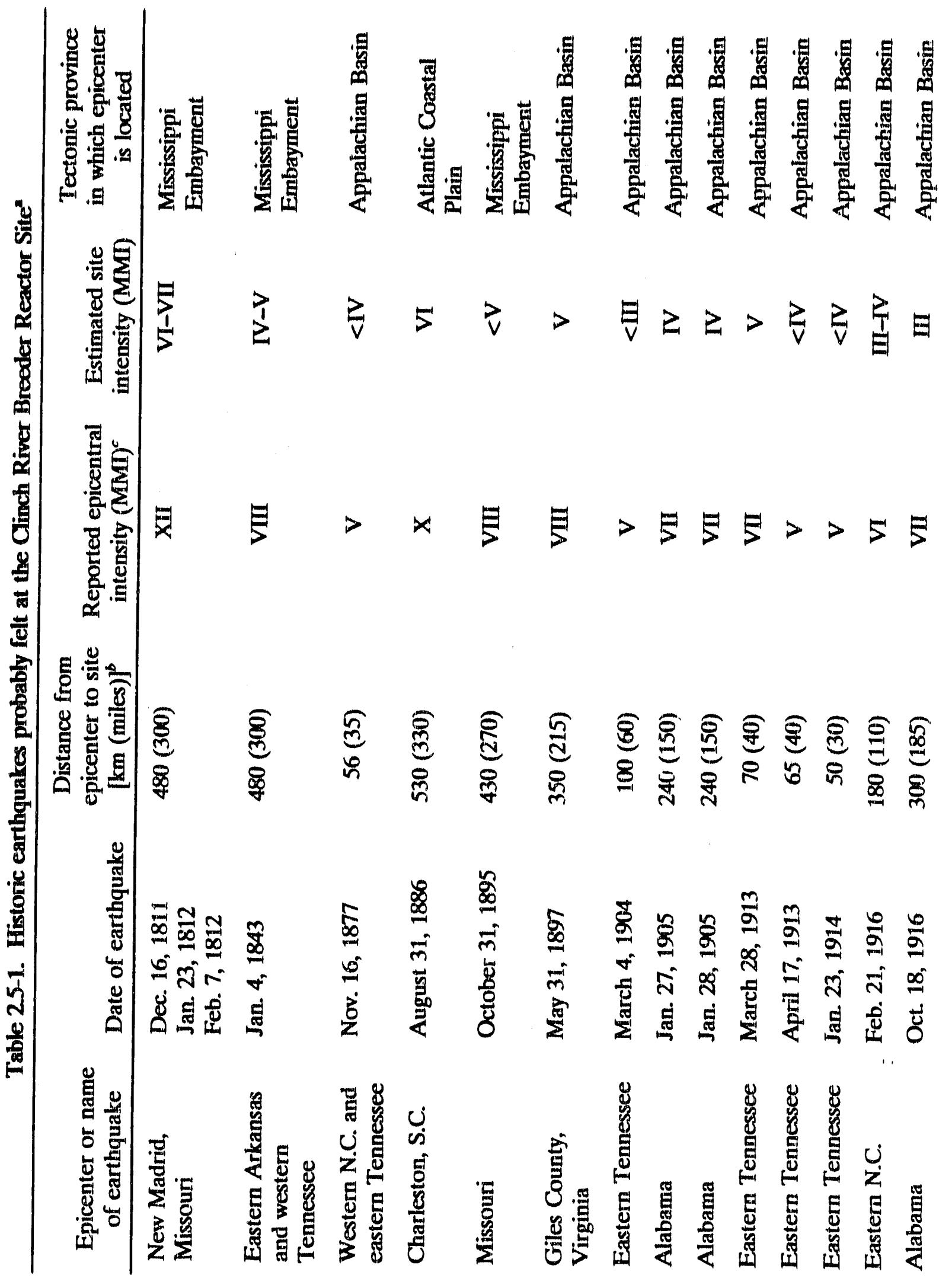




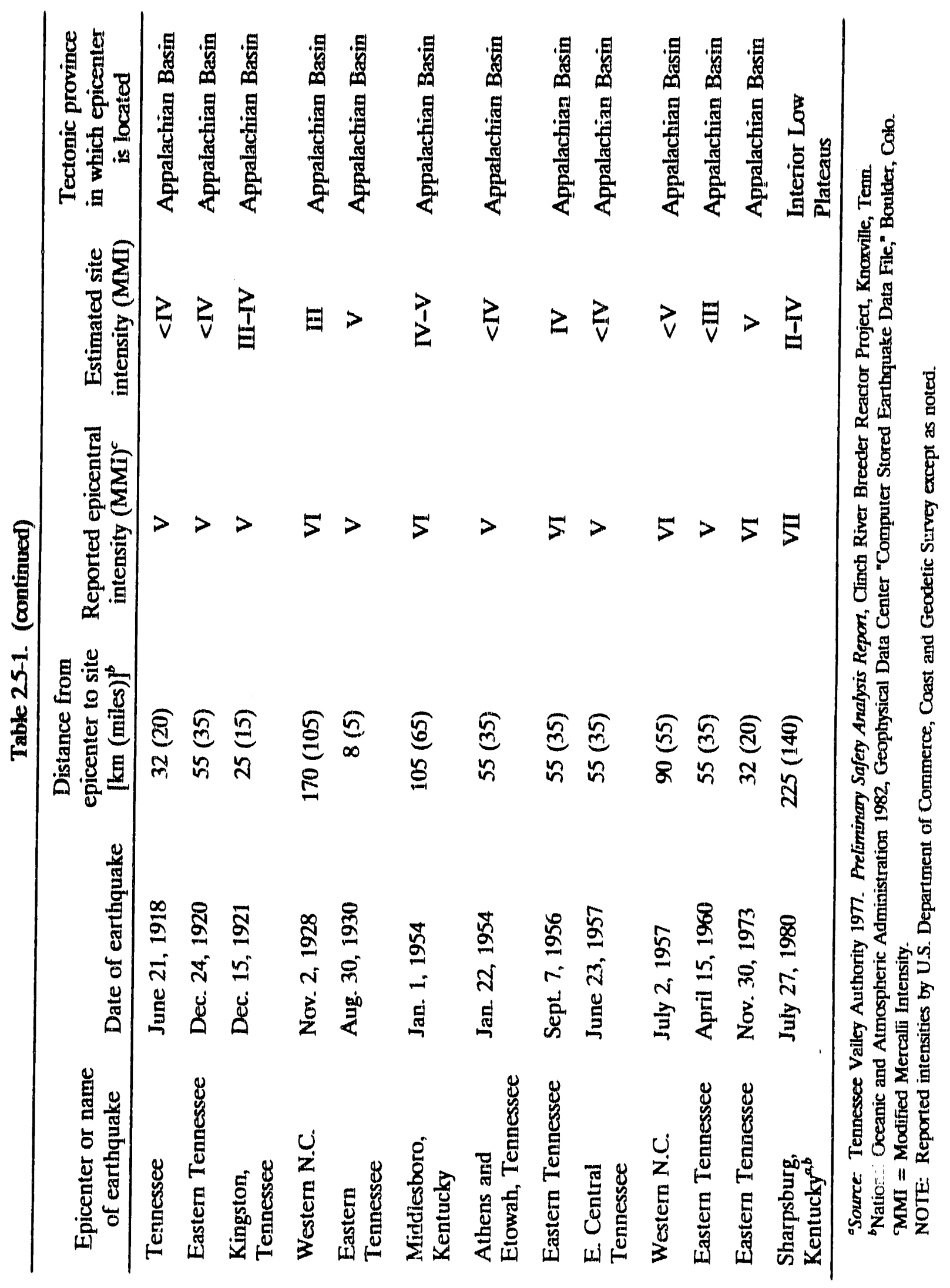




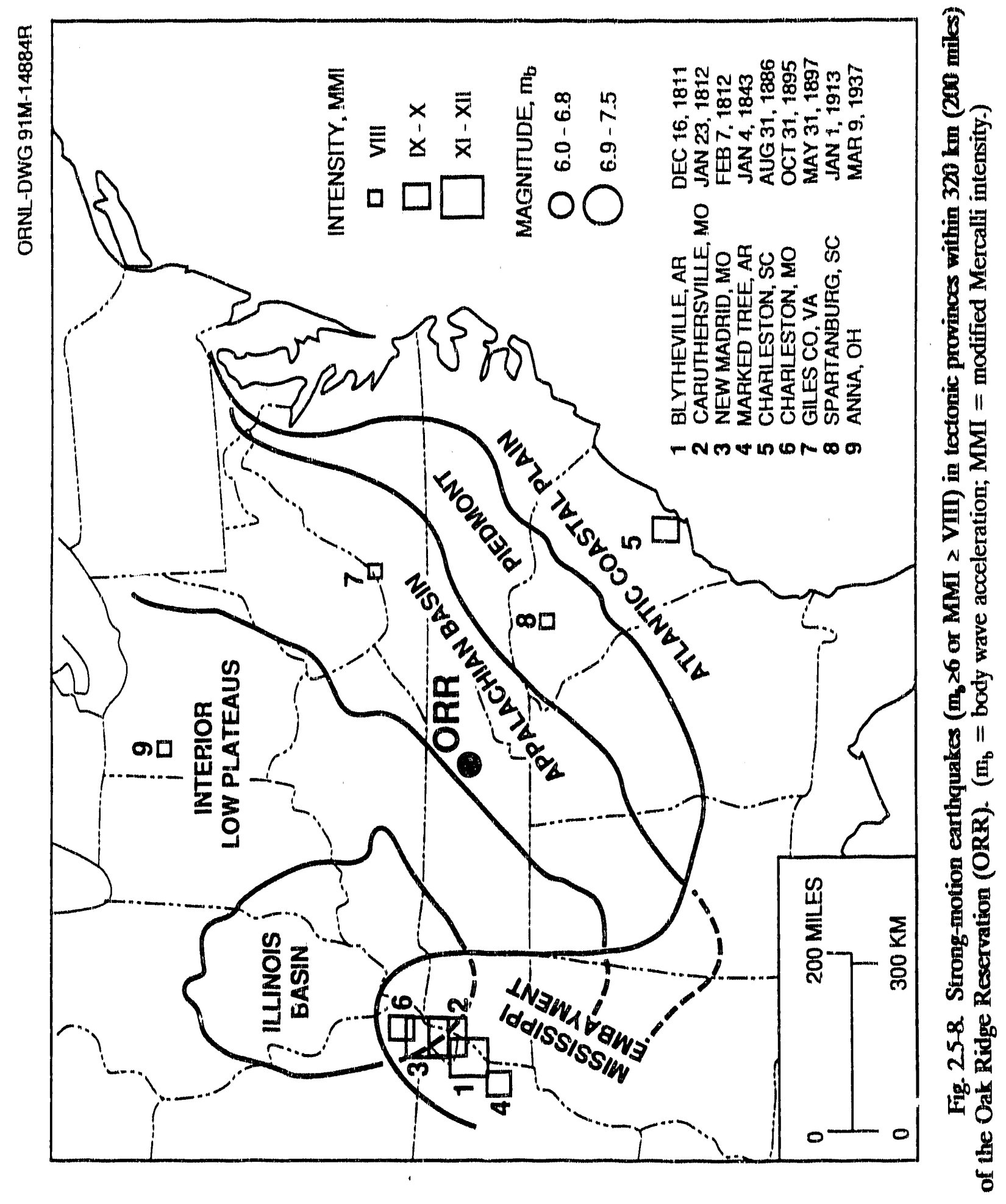




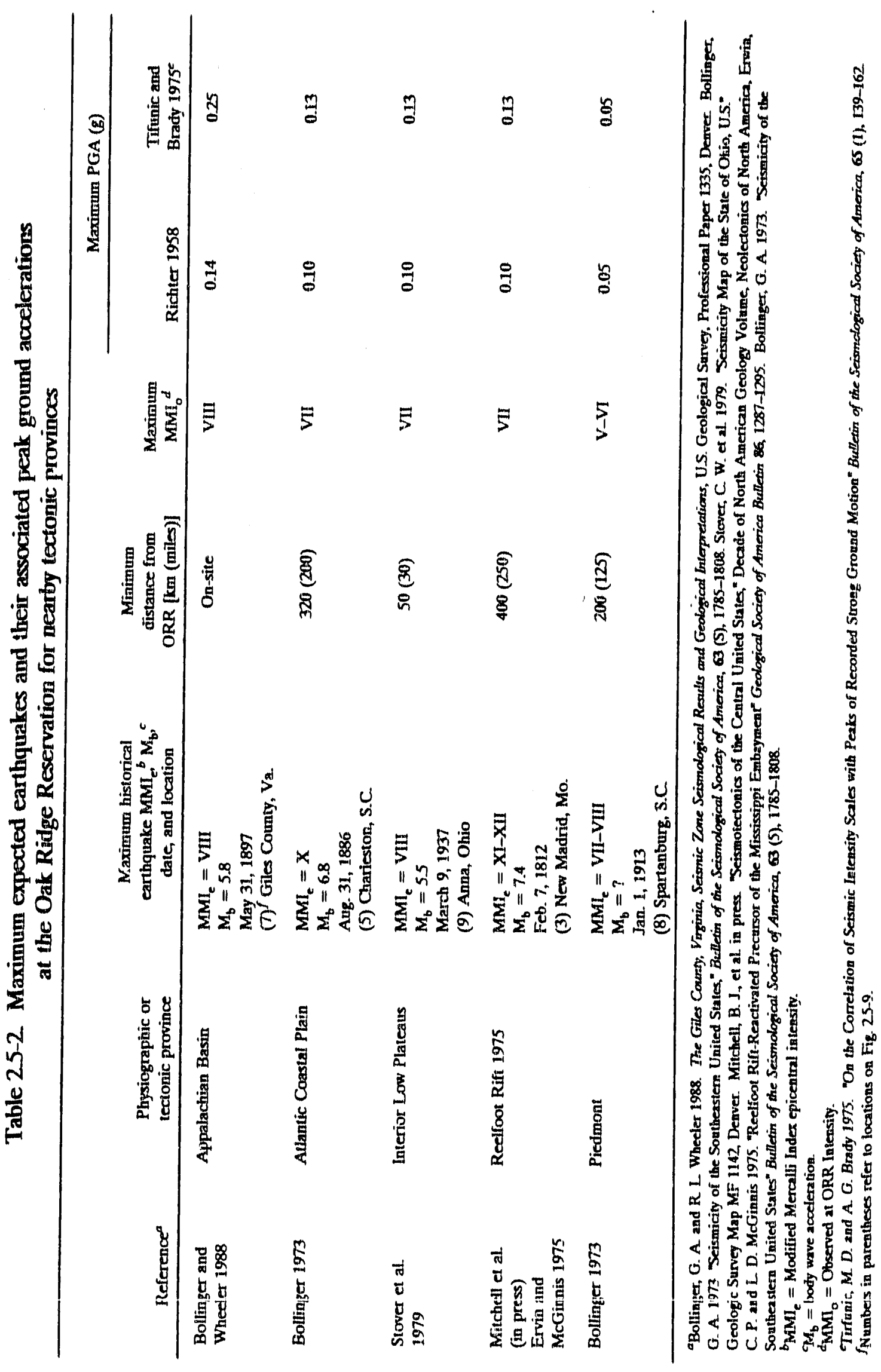


The strorgest earthquake in the Interior Low Plateaus (its border with the Appalachian Basin is nearest to ORR) was the Anna, Ohio, earthquake of March 9, 1937. This earthquake's MMI was VII to VIII in its epicentral area (Stover et al. 1979, p. 1), but it was apparently not felt in eastern Tennessee.

The strongest earthquake in the Piedmont (adjacent to the Appalachian Basin and southeast of ORR) was the Spartanburg, South Carolina, event of January 1, 1913.

According to Bollinger (1973, p. 1790), the MMI of this earthquake was VII to VIII in the epicentral area, but it was not felt at Knoxville, Tennessee.

The strongest earthquake $\left(m_{b}=4.6\right.$, Bollinger et al. 1976, p. 531) within $100 \mathrm{~km}$ (60 miles) of ORR was the Maryville-Alcoa, Tennessee, event of November 30, 1973. The epicentral $\mathrm{MMI}=\mathrm{VI}$ for this earthquake, and the $\mathrm{MMI}=\mathrm{V}$ in the region that includes ORR, based on data provided by Bollinger.

Correlation of epicenters with geologic structures. Historical seismicity in the southeastern United States has been traditionally correlated with surficial or shallow geologic features as expressed by physiographic and tectonic provinces. However, some large earthquakes in the southeastern United States are apparently associated with basement structures (ancient rift zones) and others have not been correlated with any specific geologic structures. Little is known about the precise relationship between earthquakes and basement structures because the historical record of seismicity is too short and the location and nature of basement structures is not well known. The following discussion provides a brief summary of what is known about the relationship between basement structures and large $\left(m_{b} \geq 5.5\right.$ or MMI 2 VIII) historical earthquakes in the southeastern United States. Figure 2.5-9 is a map of known and suspected basement structures (compiled by Keller et al. 1983, pp. 391-412) as well as large earthquakes in the southeastern United States. One additional basement structure is described by Bollinger and Wheeler (1988, p. 38).

The New Madrid earthquakes occurred along the New Madrid Fault in the Reelfoot Rift zone [Mitchell et al. (in press); Johnston and Kanter 1990, pp. 68-75; Ervin and McGinnis 1975, pp. 1287-1295]. The New Madrid Fault is believed to be a reactivated basement fault within the ancient rift zone. This fault offsets Holocene sediments as well as basement rocks (Russ 1979, p. 1). The southeastern boundary of the Reelfoot Rift zone is about $480 \mathrm{~km}$ ( 300 miles) from ORR.

The epicenter of the Charleston, South Carolina, earthquake was near the rifted continental margin. Rift structures associated with the early (Triassic) opening of the Atlantic Ocean basin are buried beneath the Atlantic Coastal Plain in Georgia and South Carolina, exposed at the surface in the Piedmont of North Carolina and Virginia, and exposed in the Appalachian Basin from Maryland to Connecticut (based on data provided by Bayer 1983, p. 1; Keller et al. 1983, pp. 391-412 and Frezon and Finn 1988, p. 1). Oliver and Issaks (1971, p. 30) suggest that South Carolina earthquakes may be taking place along reactivated Triassic basin faults. The northwestern limit of Triassic basin faults in North and South Carolina is in the southeastern part of the Piedmont physiographic province near its boundary with the Atlantic Coastal Plain, based on data provided by Frezon and Finn (1988, p. 1) and Bayer (1983, p. 1). The nearest Triassic basin is about $320 \mathrm{~km}$ (200 miles) from ORR.

The epicenter of the Giles County, Virginia, earthquake was located on an Eocambrian basement rift zone beneath Paleozoic Appalachian Basin structures as described by Bollinger and Wheeler (1988, p. 1). ORR is in the Appalachian Basin. 


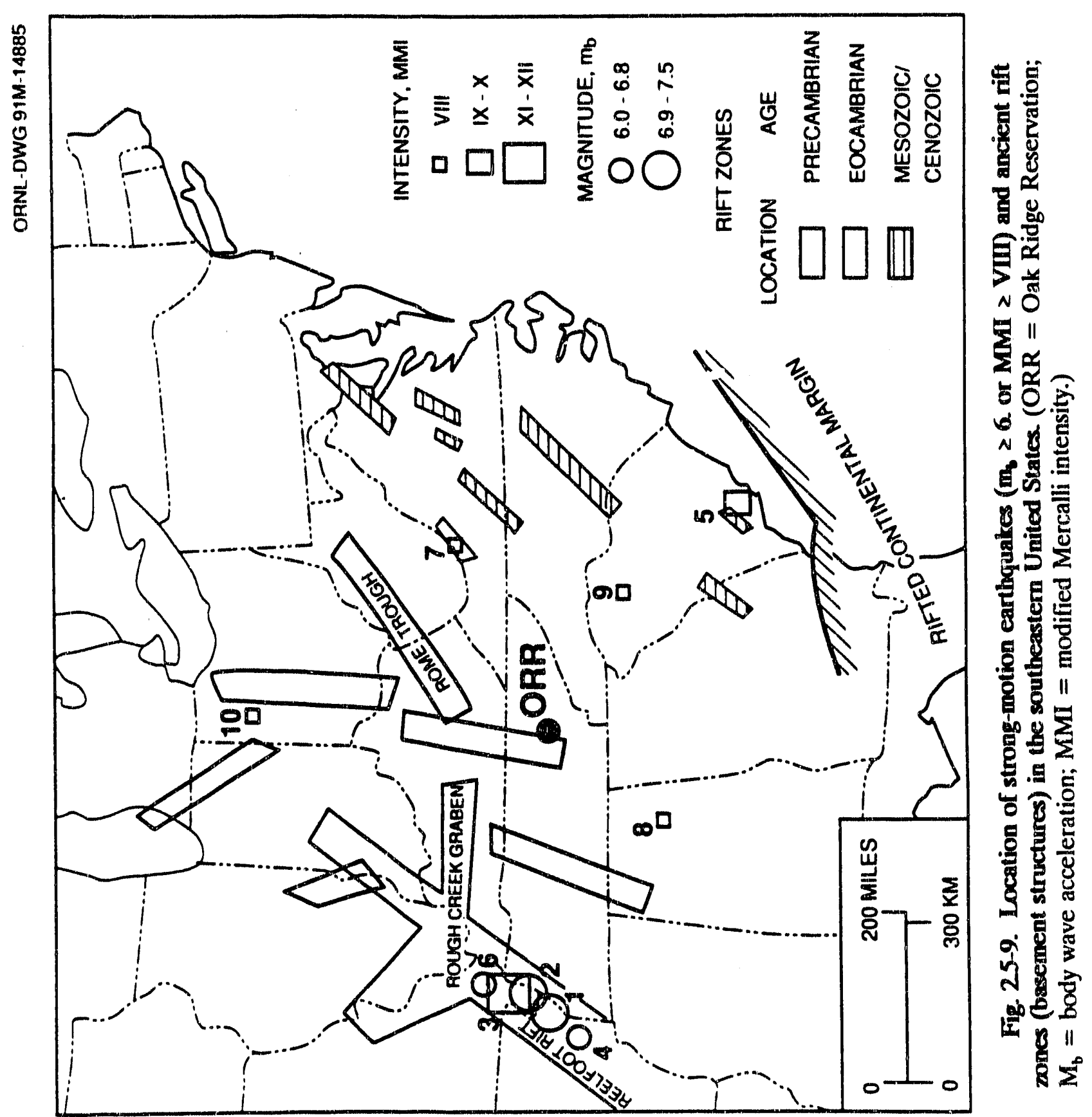


The epicenter of the Anna, Ohio, earthquake was in the Interior Low Plateaus Province. This earthquake has not been identified with any specific surficial or basement faults. However, the Anna earthquake's epicenter is near the junction of two Precambrian rift zones. The southeastern boundary of the Interior Low Plateaus Province is a minimum of $95 \mathrm{~km}$ ( 60 miles) from ORR.

Epicenters of smaller earthquakes are concentrated in the Reelfoot Rift zone, the Appalachian Basin, and parts of the Piedmont and Atlantic Coastal Plain. There are fewer small earthquakes scattered throughout the Interior Low Plateaus. Small earthquakes in the Reelfoot Rift zone often occur along distinct linear trends associated with the New Madrid Fault zone (Stauder et al. 1976, pp. 1453-1964). No other small earthquakes within $640 \mathrm{~km}$ ( 400 miles) have been identified with either Paleozoic or basement faults and no linear trends among these earthquakes are apparent.

Identification of capable faults. The ncarest capable faults are in the New Madrid Fault zone, approximately $480 \mathrm{~km}$ (300 miles) northwest of ORR. An exhaustive literature search in the preparation of TVA Safety Analysis Reviews (SARs) revealed no evidence of capable faults in the Appalachian Basin where ORR is located. The Nuclear Regulatory Commission reached the conclusion (based upon the preponderance of evidence cited in various TVA SARs) that there are no capable faults in the Appalachian Basin within $320 \mathrm{~km}$ (200 miles) of the proposed CRBR (NRC 1983, p. 2-20). The CRBR site is immediately adjacent to ORR. The depth of focus is generally greater than $10 \mathrm{~km}$ (6.2 miles) for instrumentally recorded earthquakes in the Appalachian Basin. Neither earthquake nor outcrop data support the hypothesis that Paleozoic faults exposed at the surface have been reactivated during Holocene (modern) time.

Maximum earthquake. Maximum expected earthquakes are the basis for deterministic seismic analysis used in earthquake design of commercial nuclear power stations under the regulatory authority of NRC. Previous sections discussed the largest historical earthquakes in tectonic (physiographic) provinces close enough to ORR to produce significant ground motions there. Body-wave magnitudes $\left(\mathrm{m}_{\mathrm{b}}\right)$, epicentral and predicted maximum MMIs on ORR ( $\mathrm{MMI}_{c}$ and $\mathrm{MMI}_{\mathrm{o}}$, respectively), and peak horizontal ground accelerations (PGAs) at the rock surface on ORR are presented in terms of these earthquakes. It is assumed that epicenters of similar earthquakes in the future are located nearest ORR in their tectonic provinces of origin as discussed previously. Table 2.5-2 provides salient facts pertaining to these earthquakes.

An earthquake similar in size to the 1897 event in Giles County, Virginia, but with its epicenter on-site, was designated as the safe shutdown design earthquake (SSE) for all of TVA's nuclear power stations located in the Appalachian Basin. TVA's Final Safety Analysis Report (FSAR) for Watts Bar Nuclear Plant (1976) recommended a design PGA of 0.14 gravity, based on the MMI-PGA relationship of Richter 1958 (p. 140) and an $\mathrm{MMI}_{e}$ of VIII. However, TVA and NRC eventually agreed on a PGA of 0.18 gravity for the SSE for power plants in the Appalachian Basin (AEC 1974, p. 3-12). More recently, NRC increased the SSE design PGA to 0.25 gravity in support of the construction permit for the CRBR, based on the MMI-PGA relationship of Trifunic and Brady (1975) (NRC 1983, p. 7).

The operating basis earthquake (OBE) for TVA's nuclear power stations is generally assigned a design PGA onc-haili that of the SSE. Therefore, the design $\mathrm{PGA}=0.13 \mathrm{~g}$ and $0.09 \mathrm{~g}$ for the OBE at the CRBR and at other TVA power stations, respectively, in the Appalachian Basin.

Safe shutdown (design basis) earthquake/evaluation basis earthquake. The safe shutdown/design basis earthquake (SSE/DBE) is prescribed by Kennedy et al. (1990. 
p. A-5). Design PGAs for the SSE are based on the hazard classification of given facilities and probabilistically based seismic hazard curves.

Three hazard classes are described by Kennedy et al. (1990, p. 2-4). The least stringent design standard PGA is prescribed for low hazard/general purpose structures. Successively more stringent standards are set for moderate and high hazard facilities. Low hazard/general purpose structures are designed to shut down safely in the event of earthquake generated PGAs with return periods of $\leq 500$ years, corresponding to probabilities of $22 \times 10^{-3}$ annual events. Moderate and high hazard facilities are designed to shut down safely in the event of PGAs with return periods of $\leq 1000$ and 5000 years, corresponding to probabilities of $\geq 1 \times 10^{-3}$ and $2 \times 10^{-4}$ annual events, respectively.

Currently, Kennedy et al. 1990 (p. 4-9) recommends the "best estimate" seismic hazard curves for selecting SSE design PGAs. The seismic hazard curve for ORR is represented by the heavy line shown in Fig. 2.5-10. Design PGAs for low, moderate, and high hazard facilities on ORR are $0.15 \mathrm{~g}, 0.19 \mathrm{~g}$, and $0.32 \mathrm{~g}$, respectively.

More recent seismic hazard curves for ORR have been provided by Risk Engineering (1991, pp. 3-16-3-17). Median, 15th, and 85th percentile curves are presented in Fig. 2.5-10 for comparison with Kennedy's "best estimate" seismic hazard curve for ORR. These curves are based on seismic hazard methodologies developed by the Electric Power Research Institute (EPRI 1988, pp. 2-1-2-9) and Lawrence Livermore National Laboratory (LLNL 1989, p. 9-16). Results express the range of opinions and analyse provided by five teams of EPRI seismic experts and 16 individual LLNL seismic experts. Kennedy's "best estimate" curve is about midway between LLNL's median and 85th percentile curves and is above EPRI's 85th percentile curve. Therefore, Kennedy's results are more conservative than those of most experts participating in the EPRI and LLNL analyses. Recommendations by Kennedy et al. (1990, p. 4-9) are currently being reviewed in response to the EPRI and LLNL analyses.

Design response spectra at the free ground surface is facility specific for those structures that are not anchored to rock, and they are not necessary for an environmental analysis. These are factors considered in the safety analysis report. Buildings resting on insitu soil fill will experience a different ground motion earthquake than structures sited on rock. Site specific soil studies will be required if structures are supported on soil.

\subsection{Geology of the ANS Site}

This section describes the topography, geomorphology, stratigraphy, areal geology, and structural geology of the ANS site and surrounding areas.

\subsection{Topography and Geomorphology of the ANS Site}

ORR encompasses 14,266 (35,252 acres) of typical Valley and Ridge land. Valleys are underlain by bedrock formations predominated by calcareous siltstones and limestones (Conasauga Group and Chickamauga Group), and ridges are underlain by bedrock formations predominated either by weathering resistant sandstones and siliceous shales and siltstones (Rome Formation and Rockwood Formation) or by the Knox Group, which comprises a thick sequence of siliceous dolostones that weather to form thick, residual, silty clay soils rich in chert that are resistant to erosion.

From northwest to southeast the major valleys of ORR include the East Fork Valley, Bear Creek Valley, Bethel Valley, and Melton Valley. Major ridges of ORR include Blackoak Ridge, East Fork Ridge (discontinuous), Pine Ridge, Chestnut Ridge, 


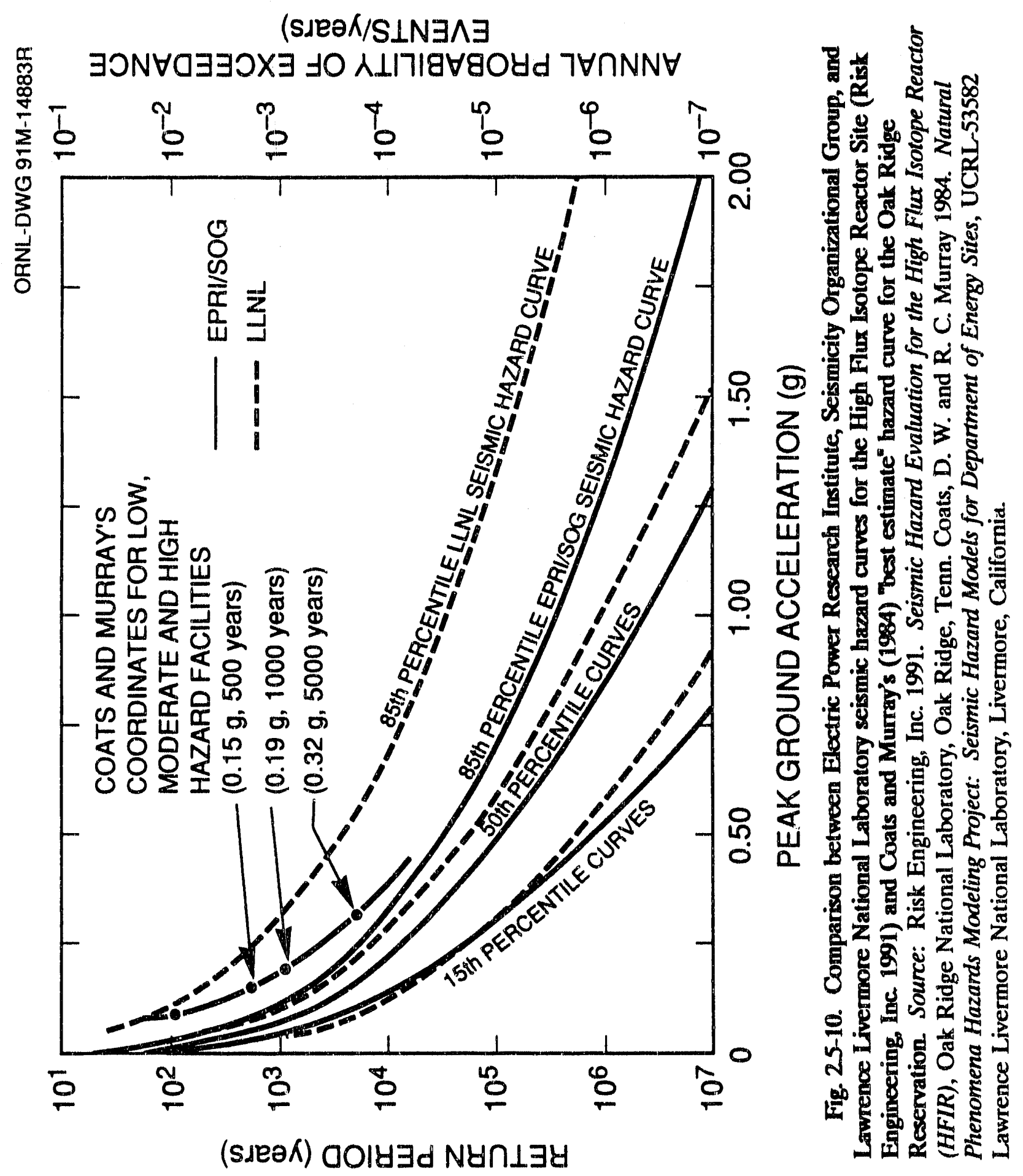


Haw Ridge, and Copper Ridge. With the exception of the East Fork Ridge, these valleys and ridges extend beyond the limits of ORR because their configurations are determined by geologic structures that extend for tens of kilometers in the northwest/southeast pattern of the Valley and Ridge Province. The width of valleys and ridges in this area is determined by geologic factors, such as the dip angle and formation thickening due to thrust faulting of underlying geologic formations, that determine the outcrop width. For example, though East Fork Valley and Bethel Valley are both underlain by the Chickamauga Group, the East Fork Valley is, wider because of a wider Chickamauga Group outcrop band. Similarly, although Copper Ridge, Blackoak Ridge, and Chestnut Ridge are all underlain by the Knox Group, Copper Ridge is much broader than the other two because bedrock dip in that area is only about $10^{\circ}$ in contrast to the $30^{\circ}$ to $45^{\circ}$ dips observed for the other ridges.

Topographic relief between valley floors and ridge crests in ORR is generally about $100 \mathrm{~m}$ ( 300 to $350 \mathrm{ft}$ ). Landforms in the Valley and Ridge Province and at ORR have formed primarily as a result of bedrock weathering, which forms residual soils and saprolite, and subsequent erosion and colluvial slope movement of soils. Weathering and erosion processes coupled with the general dipping attitude of bedrock underlying the area result in rather steep (commonly steeper than $45^{\circ}$ ) northwest-facing slopes (scarp slopes), while southeast facing slopes (dip slopes) are commonly gentler with inclinations of 5 to 25\%. Floodplain areas along streams contain small zones of alluvial soils with colluvial soils along valley walls resulting from downslope soil movement from adjacent hillsides. The surface water drainage system has a trellis to modified trellis pattern common to the region.

The proposed ANS site is located in Melton Valley about $2 \mathrm{~km}$ (1.5 miles) east of the main ORNL facilities (Fig. 2.5-11). Topography in and around Melton Valley is typical of that in the northwestern portion of the Valley and Ridge Province of East Tennessee. The valley is about $2 \mathrm{~km}$ (1.2 miles) wide and trends northeast/southwest. Haw Ridge lies about $1 \mathrm{~km}(0.6$ mile) northwest of Melton Valley with crest elevations of approximately $305 \mathrm{~m}$ (1000 ft). Melton Hill, with a high crest of $413 \mathrm{~m}$ (1356 ft) on Copper Ridge, lies about $1 \mathrm{~km}(0.6$ mile) southeast of the axis of Melton Valley and is about $1 \mathrm{~km}$ ( 0.6 mile) south of the ANS site. A line of low knobs with crest elevations of about $260 \mathrm{~m}$ ( $850 \mathrm{ft})$ occurs near the center of Melton Valley. The ANS site lies on the southwest facing slope of such a knob at the headwaters of Melton Branch. The lowest topography in the vicinity of the ANS site is at the mouth of White Cak Creek at its confluence with the Clinch River arm of Watts Bar Reservoir [normal pool elevation $226 \mathrm{~m} \mathrm{(742} \mathrm{ft)].} \mathrm{Maximum} \mathrm{topographic} \mathrm{relief} \mathrm{in} \mathrm{Melton} \mathrm{Valley} \mathrm{is} 187 \mathrm{~m}(614 \mathrm{ft})$, and relief between the ANS site and the mouth of White Oak Creek is about $50 \mathrm{~m}(150 \mathrm{ft})$.

\subsection{Bedrock Stratigraphy in the ANS Site Vicinity}

As described in the previous paragraph about regional stratigraphy, bedrock at ORR is of Paleozoic age including strata as old as the Early Cambrian Rome Formation and as young as the Devonian Chattanooga Shale. Figure 2.5-12 depicts a stratigraphic column of bedrock formations recognized on ORR with typical thicknesses determined from core drilling or estimated based on surface geologic mapping. Descriptions of the major stratigraphic units present on ORR with emphasis on characteristics relevant to interpreting the stratigraphic contributions to geomorphology and hydrogeology follow. 

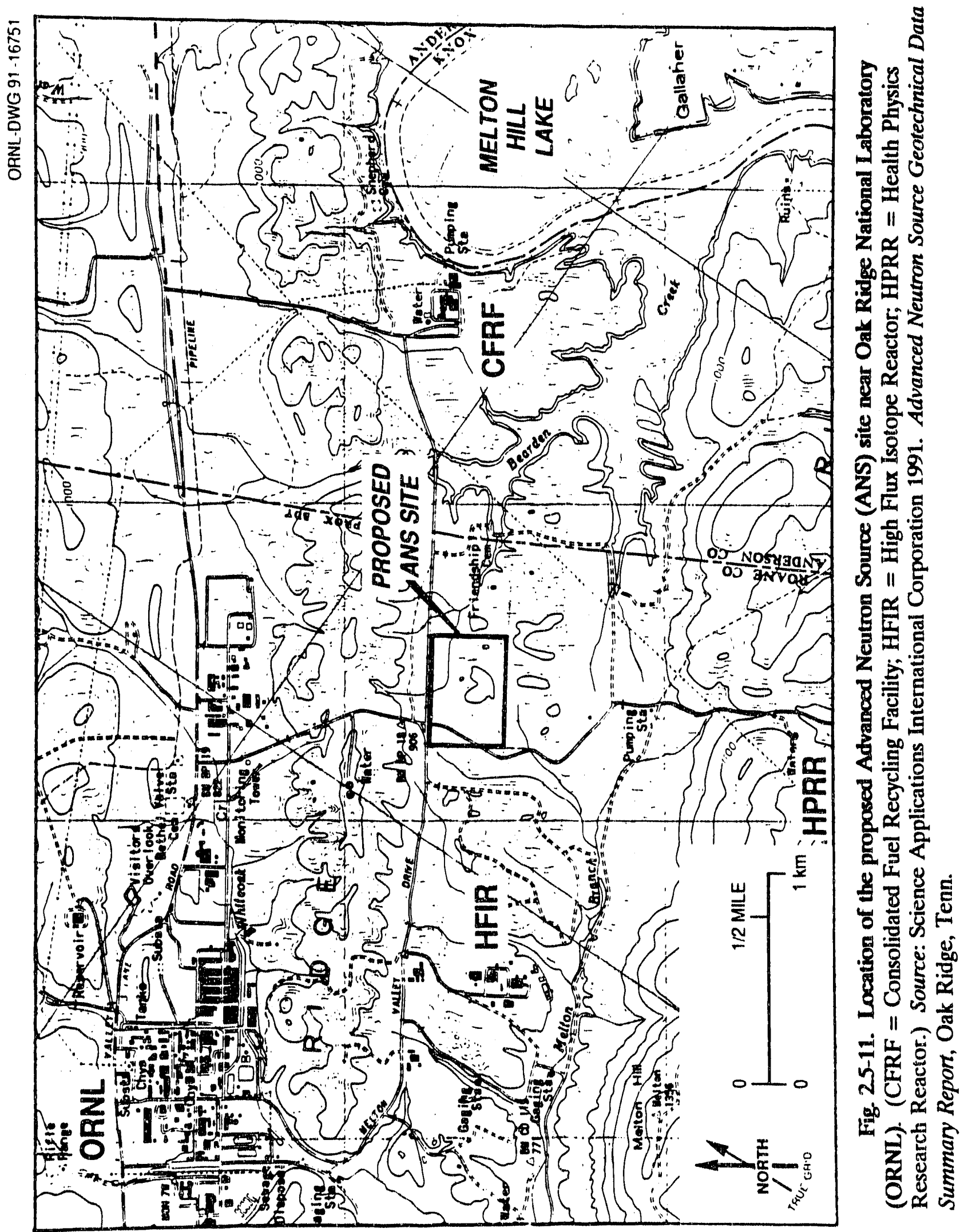
ORNL-DWG $91 M-16567 R$

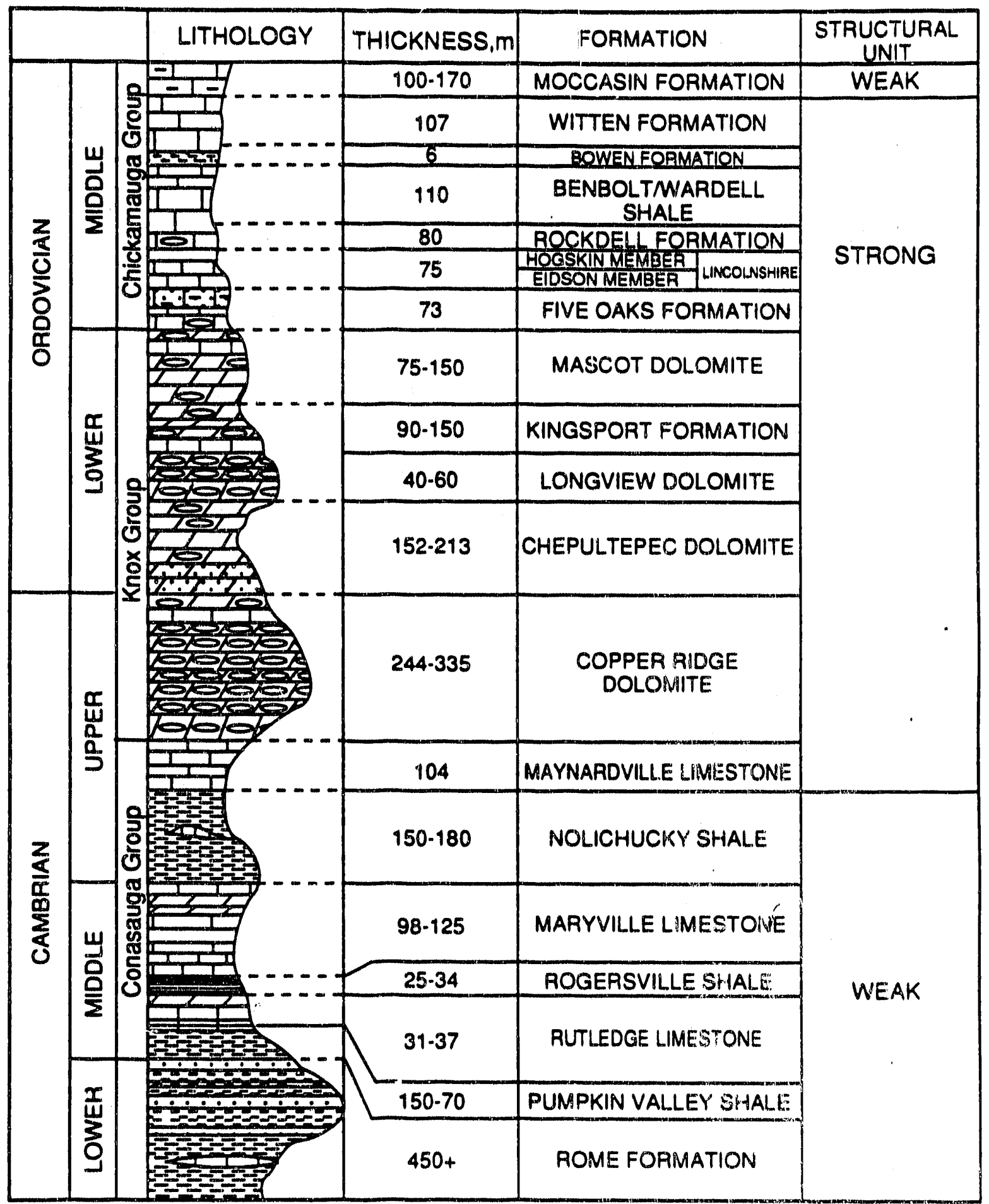

Fig. 2.5-12. Stratigrapic column for the Valley ant Ridge Provisuce Paleozoic bedrock formations in the Oak Ridge Reservation vicinity. 


\section{Rome Formation (the Rome)}

The Rome includes more than $450 \mathrm{~m}$ (1475 ft) of variegated shales, siltstones, sandstones, and subordinate carbonates. Sediments of the Rome were deposited in a tidal flat environment and are predominantly cast materials distributed in an interbedded tidal channel and tidal flat complex. For mapping purposes the Rome is divided into upper and lower portions. Where observed, the lower portion is dominated by shales and siltstones, but because the Rome is the decollement zone for regional thrust faults that carry the upper portion of the formation to the surface, the lower portion of the Rome is rarely, and incompletely exposed. The upper portion of the Rome contains sequences of clean orthoquartzitic sandstone, maroon and green siliceous shale and siltstone, and sporadically distributed carbonate rocks in thick, reef-like masses. The carbonates develop local karst. Soils that develop on the Rome are thin. The sandstones are erosion resistant; consequently, the upper portion of the Rome formation holds up the crests of prominent ridges such as Pine Ridge and Haw Ridge. Thickness and character of the upper sands vary, and in places the contact between the Rome sands and the bioturbated sandy lower Pumpkin Valley Shale is gradation. The Rome forms a dipping sole beneath each regional thrust sheet on ORR and elsewhere in the northwestern Valley and Ridge Province.

\section{Conasauga Group}

The Conasauga Group is a rock sequence characterized by interlayered shale, limestone, and limestone-rich shales. The group lies conformably over the Rome, and, because of the aforementioned weathering and erosion characteristics of Conasauga bedrock lithologies, this unit underlies valleys. Detailed descriptions of the lithologic characteristics of the Conasauga from examination of core are available in Haase, Walls, and Farmer 1985 (as referenced in the HFIR SAR 1991, p. 2-333) and Lee and Ketelle 1989 (as referenced in the HFIR SAR 1991, p. 2-333). The Conasauga Group is roughly $520 \mathrm{~m}(1700 \mathrm{ft})$ thick on ORR and is divisible into six formations recognizable in rork core, in saprolite exposures, and as mappable soil types. In ascending stratigraphic order the six formations of the Conasauga Group include the Pumpkin Valley Shale, Rutledge Limestone, Rogersville Shale, Maryville Limestone, Nolichucky Shale, and Maynardville Limestone. Characteristics of each of these formations are described below.

Pumpkin Valley Shale. The Pumpkin Valley Shale is a clastic dominated formation deposited in a transitional environment from shallow water in the lower portiou to somewhat deeper quiescent water in the upper portion. The lower portion of the Pumpkin Valley is composed of reddish-brown to greenish-gray interbedded fine-grained sandstone, siltstone, and shale. The lithologic character of the lower Pumpkin Valley varies locally depending on paleodepositional conditions, and the sand/shale ratio in this zone is quite variable. The lower portion of the Pumpkin Valley is somewhat more erosion resistant than the upper portion and frequently holds up a topographic shoulder at its outcrop location on the southeast crest of the Rome ridges (Pine Ridge and Haw Ridge). The upper portion of the Pumpkin Valley is a laminated to thin-bedded shale with variegated colors including reddish-brown, reddish-gray, greenish, and greenish-gray. Thin beds and laminations of fine-grained glauconite pellets are ubiquitous in the upper Purnpkin Valley. The upper Pumpkin Valley has outcrops on the steeply sloping southeast faces of Pine Ridge and Haw Ridge. 
Rutledge Limestone. On ORR, the Rutledge Limestone is quite clastic and consists of light gray, micritic to coarse-grained, thin- to medium-bedded limestone, ciontaining shale partings interbedded with dark gray or maroon thin-bedded shale beds. Cilauconite occurs as fine grains incorporated in the limestone beds of the Rutledge in contrast to the distinct laminae and beds of glauconite observed in the upper Pumpkin Valley. Weathering and erosion of the Rutledge creates an alignment of topographic saddles and valley heads in its outcrop band. The Rutledge outcrop band occurs at the southeastern base of Pine Ridge and Haw Ridge.

Rogersville Shale. The Rogersville Shale is dominated by noncalcareous shale and silitstone with minor amounts of limestone (the locally recognized Craig member) in the Iupper part of the formation. The lower portion of the Rogersville is predominantly dark Igray mudstone while the upper portion is predominantly maroon shale with variable content of thin-bedded argillaceous limestone. The Rogersville Shale frequently has outcrops on the northwest slope (scarp slope) of the low knobs crested by the overlying Maryville Limestone. In some areas the Rogersville has outcrops in the discontinuous saddle and valley zone described in the outcrop band of the Rutledge.

Maryville Limestone. The Maryville Limestone is a clastic dominated (60 to $70 \%$ clastic sediments) carbonate formation. In the ORR area the formation i, dominated by thin-bedded gray calcareous siltstones with thin-bedded silty.limestones and isolated medium-bedded clean limestone and intraclastic limestones. The Maryville weathers to form a saprolitic soil zone that is thin to nonexistent along streams and thickens to as much as $20 \mathrm{~m}$ ( $65 \mathrm{ft}$ ) beneath the crest of mid-valley knobs underlain by the formation. Outcrops of siltstone and limestone of the Maryville are visible in cross-cutting stream channels. As mentioned previously, the Maryville holds up the crest of a discontinuous line of low knobs that occur in the northwestern half of Bear Creek and Melton Valleys. The ANS site is located on the southwest facing slope of such a knob.

Nolichucky Shale. The Nolichucky Shale is dorninated by gray, olive-gray, and maroon shales with subordinate amounts of medium-bedded oolitic, glauconitic, and intraclastic limestone. In some areas the formation is subdivided into three units that are discriminated by the presence of a middle member known as the Bradley Creek member, which is a limestone-rich zone. The Nolichucky occupies different topographic settings in its two outcrop bands on ORR. In Bear Creek Valley the Nolichucky lies northwest of Bear Creek and forms an area of gentle, hill and swale terrain. In Melton Valley the Nolichucky underlies the axis of the valley and the lower slopes of Copper Ridge. In both settings the topographic expression is that of a soft, erodible formation.

Maynardville Limestone. The Maynardville Limestone is a fine- to mediumgrained dolomitic limestone with oolitic and algal lamellar zones. Stylolitic bedding planes are common. The Maynardville has a low clastic content and tends to be karstic. In Bear Creek Valley the Maynardville underlies the valley axis, and mixing of surface water and ground water flow occurs in reaches of stream subsidence and resurgence. In Melton Valley the Maynardville occurs on the midslope of the northwest face of Copper Ridge. In this setting the Maynardville occurs on a steep slope, and limestone pinnacles and bluffs are common. 


\section{Knox Group}

The Knox Group includes approximately $900 \mathrm{~m}(3000 \mathrm{ft})$ of dolostone of varying texture and color with minor zones containing limestone and sandstone. Chert of various types and textures is common in the Knox Group and is significant both for recognizing stratigraphic divisions of the group and for its near-surface hydrologic role. The Knox Group is divisible into five mappable bedrock formations at the surface. In ascending stratigraphic order these formations include the Copper Ridge Dolomite of late Cambrian age, and the Chepultepec, Longview, Kingsport, and Mascot Dolomites, all of early Ordovician age. In the vicinity of ORR the Knox Group bedrock underlies broad ridges of complex morphology. The Knox Group underlies Blackoak Ridge, Chestnut Ridge, and Copper Ridge on ORR. Differentiation of the Knox Group is based primarily on the characteristics of the residuum and on occurrence of distinct chert types. Even though the Knox weathers rather deeply and residual soil thicknesses exceeding $30 \mathrm{~m}(100 \mathrm{ft})$ are common, relationships exist between stratigraphic formation and overlying topography in thr Knox Group outcrop belts. The bases for these relationships are not thoroughly understood; however, differences in insoluble mineral content (silt and clay in addition to chert) and differences in limestone content may contribute to the topographic expression of the Knox formations.

Copper Ridge Dolomite. The Copper Ridge contains thin-bedded to massively bedded dolostones that range from light to dark gray. Massively bedded dolostones tend to be dark, are usually porous to vuggy, and often emit a petroliferous odor from freshly broken surfaces. Chert sections in the middle and lower portion of the formation tend to be replacements of algal mats (cryptozoon) that have a "waffle iron" appearance when observed in the soil zone. In the upper portion of the Copper Ridge, cherts become pronouncedly oolitic with ooids that are concentrically banded with alternating light tan and dark-brown-to-black rings. Near the contact of the Copper Ridge with the overlying Chepultepec, bedded oolitic cherts become intermingled with thin beds of quartz sand. The relatively high silica content of the Copper Ridge results in development of a thick residual soil mass upon weathering of this formation. The high chert content provides abundant gravel and cobble-sized rocks in the soil mass, which are left on the surface as an erosional lag. This gravel layer may be several inches thick on steep slopes and promotes shallow lateral shedding of infiltrating rainfall while protecting underlying fine grained soils from erosion. The topographic prominence of the Copper Ridge outcrop band as the highest crest of ridges underlain by the Copper Ridge Dolomite is attributed largely to this "chert armoring" of the residual soil mass. Dolines are observed in some portions of the Copper Ridge. Alignments of dolines along strike indicates that certain stratigraphic zones are susceptible to preferential weathering and development of cavity systems beneath the thick residual soils. Such strike-parallel alignments of karst features are common in the upper Copper Ridge, and closely spaced dolines are observed over distances of several thousand feet in some localities on Chestnut Ridge.

Chepultepec Dolomite. The Chepultepec Dolomite is less siliceous than the Copper Ridge, tends to weather more deeply, and occupies a topographic setting characterized by adddles and valley heads. The base of the Chepultepec is recognized by the presence of a zone of sandstone of variable prominence. The sandstone tends to be medium-grained and is observed as float blocks in the soil or, where the sandstone is quite prominent, as a discontinuous sandstone outcrop. The Chepultepec/Copper Ridge contact marks the Cambro-Ordovician boundary in East Tennessee. Dolomite in the Chepultepec 
tends to be light gray, fine-grained, and medium bedded. Chert is less abundant in the Chepultepec than in the Copper Ridge, and it tends to be light gray, cream, tan, and white. Locally, large boulders of porous chert are observed in the lower portion of the Chepultepec. Comparatively low insoluble residue content and possibly higher solubility due to a finer grain size combine to result in deep weathering of the Chepultepec with accompanying development of karst features, internal drainage, and weak topographic landforms. In the outcrop band of the Chepultepec on Blackoak and Chestnut Ridges the dipping bedrock attitude interacts with deep weathering to form strike-parallel valley heads and topographic saddles between the ridge crest and knobs upheld by the Copper Ridge and Longview Dolomites.

Longview Dolomite. The Longview Dolomite is recognized as a mappable formation in surface geologic mapping; however, the Longview is not recognized as a subsurface formation in the East Tennessee zinc mining district. The Longview is a cherty zone that separates the Chepultepec from the Kingsport Dolomites. The chert tends to be bedded and light gray to cream in color, and frequently contains the molds of small [ $<1$ $\mathrm{mm}$ (.04 in.)] weathered dolomite thombohedra leading to the description "dolomoldic" texture. Because of its high chert content, the Longview is an upland landformer and holds up a line of knobs in the outcrop belts on Blackoak and Chestnut ridges. These knobs are discontinuous because the Longview is relatively thin and would only hold up a narrow hogback ridge, and ephemeral streams that head in the Chepultepec outcrop belt cross the Longview as they flow southeastward off the upland area, breaching the Longview terrain. Dolines occasionally form in the Longview and they may find their origin in the underlying, deep-weathering Chepultepec, only finding surface expression in the Longview as a result of vertical development of subsidence basins through the residual soil column.

Kingsport Dolomite. The Kingsport Dolomite contains light to medium gray, fineto medium-grained, medium- to thick-bedded dolomite, with nodular chert and medium to bluish gray, thick bedded limestone near its base. Pinkish gray dolornite occurs near the top of the Kingsport. Limestone is also observed scattered through the middle portion of the formation in some areas. The Kingsport apparently has a lower insoluble residue content than the Copper Ridge and the Longview, because upon weathering the Kingsport forms a discontinuous line of valleys and saddles between the knobs upheld by the underlying Longview and the overlying Mascot and lower Chickamauga bedrock. Preferential weathering leads to development of strike-parallel doline alignments. Since the Kingsport tends to be a valley former, and it lies near the southeast edge of the Knox outcrop band, seasonal streams are observed in deeply incised valleys where the water table rises seasonally to the ground surface.

Mascot Dolomite The Mascot Dolomite contains light gray and pinkish gray dolomite similar to that observed in the Kingsport; however, the Mascot is much chertier. Nodular jasperoid chert and bedded chert are c smmon in the Mascot. Chert matrix sandstone occurs locally in the Mascot, and the lowest of such sandstones ooserved is used to define the contact between the Kingsport and Mascot Dolomites. Where chert matrix sandstones are not present, the formations are combined and termed the Newala Formation. Soil development is usually thin in the Mascot outcrop belt, and exposed pinnacles are common. The chert and sand content of the Mascot Dolomite helps it hold up the ridge line where it outcrops. The top of the Mascot Dolomite is an erosional 
unconformity. Paleokarst development on this surface has been observed with local relief of at least $60 \mathrm{~m}(200 \mathrm{ft})$.

Chickamauga Group. Bedrock of the Chickamauga Group is of middle Ordovician age and contains an interfingering complex of fine-grained clastic sediments and shallow water carbonate deposited in a coastal margin, shallow basin environment. Rock types present range from bedded chert and calcareous siltstone in the lower part of the group, through calcareous maroon to gray mudstone, to interbedded thin-bedded light gray limestone and dark gray shale, to massive clean light gray limestone. Variability in bedrock lithologies leads to variations in the overlying landforms; however, the general topographic expression of the Chickamauga is formation of broad strike-parallel valleys with rolling, hilly topography within the valleys. Two such broad valleys occur in the outcrop belts of the Chickamauga Group on ORR (East Fork Valley and Bethel Valley).

Because the Chickamauga Group bedrock was deposited in an environment with abundant facies variability, nomenclature used in stratigraphic unit designations varies widely depending on locality. Stratigraphic nomenclature adopted for use in the Bethel Valley outcrop belt of the Chickamauga on ORR includes the Five Oaks, Lincolnshire (divided into Eidson and Fleanor members), Rockdell, Benbolt, Bowen, Witten, and Moccasin formations (Hatcher et al. 1991, pp. 3-35-3-38). Bethel Valley stratigraphic nomenclature is used in this report because the Bethel Valley is the occurrence of the Chickamauga Group nearest the ANS site.

Five Oaks Formation. The Five Oaks Formation consists of a thin [1-m (3.3-ft) thick] purplish maroon dolomitic limestone overlying a thin bed of pale olive limestone that in turn is overlain by a thick sequence of purplish to maroon siltstone. Total formation thickness is approximately $55 \mathrm{~m}$ (180 ft). The bulk of the Five Oaks Formation is a readily mappable unit in the lowermost Chickamauga Group. It consists of thick sections of purplish to dark maroon and olive gray calcareous siltstone interbedded with suioordinate amounts of dark and light gray calcarenite. Dark maroon to purple, 5- to 10-cm (2 -to 4-in.) thick, bedded and blocky chert is diagnostic of the Five Oaks in the field. Upon erosion of the siltstones and limestones in outcrop or as float, the size and color of these cherts resemble bricks. The Five Oaks occurs on the crest and southeast slope of knobs that form the boundary between Chestnut Ridge and Bethel Valley. The presence of abundant chert beds and siltstones in the Five Oaks probably contributes to its ability to hold up this landform.

Lincolnshire Formation. In Virginia and elsewhere in East Tennessee, the Lincolnshire Formation is divisible into three members. In ascending order these are the Eidson, the Fleanor, and the Hogskin members. Presumably because of lateral facies changes regionally, only the Eidson and Fleanor Members are recognized on ORR. Both are readily mappable.

Eidson Member. The Eidson Member of the Lincolnshire Formation is a relatively minor limestone unit on ORR. With limited outcrop exposure, it provides a sharp contrast to the maroon siltstones of the underlying Five Oaks Formation. In core

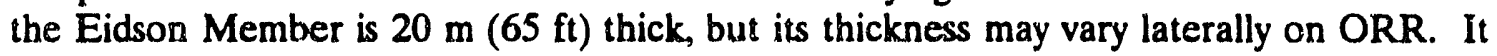
consists of massive to nodular limestone with bedded and nodular chert occurring near the top. The Five Oaks and Eidson constitute Unit A in Stockdale's nomenclature. The Eidson typically occurs on sloping terrain or through saddles between the Five Oaks/Mascot knobs and a secondary line of low knobs. This secondary line is underlain by 
the Rockdell Formation of the Chickamauga Group and occurs near the northwestern side of Bethel Valley.

Fleanor Member. The Fleanor Member of the Lincolnshire Formation is a thick accumulation [53 $\mathrm{m}(175 \mathrm{ft})$ ] of maroon, calcareous, and shaly siltstone with numerous light gray limestone beds. Vertical burrows and general bioturbation are commonly recognized. The lowermost and uppermost portions of the Fleanor consist of thick, olivegray calcareous siltstone in contrast to the overall maroon siltstone that characterizes the unit. The occurrence of thicker limestones and subordinate maroon siltstones higher in the section that would constitute the Hogskin Member of the Lincolnshire Formation is not recognizable on ORR, and the entire maroon siltstone section is therefore referred to as the Fleanor. The Fleanor corresponds to Unit B in Stockdale's nomenclature. The Fleanor, like the Eidson, is not very erosion-resistant and tends to occur in topographic lows or saddles between the Five Oaks/Mascot knobs and the Rockdell knobs.

Rockdell Formation. A thick section of limestone, the Rockdell Formation, overlies the Fleanor. The Rockdell underlies the discontinuous line of knobs near the northwest edge of Bethel Valley. The lower portion of the Rockdell contains light gray calcarenite, dark gray calcareous siltstone, fossiliferous nodular limestone, and birdseye micritic limestone. Small chert nodules are common, and evidence of vertical burrowing is seen occasionally. This lower lithology grades upward to dense calcarenite with subordinate amounts of birdseye micrite and nodular limestone lithologies. The frequent occurrence of bedded and nodular chert is distinctive of the upper portion of the Rockdell. The lower and upper lithologies are of nearly equal thickness. The cleaner limestones of the upper Rockdell develop local karst in Bethel Valley. The Rockdell Limestone can be seen in old Rogers Quarry on ORR. The lower and upper lithologies of the Rockdell were formerly referred to as Units C and D, respectively, in Stockdale's nomenclature.

Benbolt Formation. The Benbolt Formation is a relatively heterogeneous formation that underlies much of ORNL. The Benbolt consists of thick interbeds of fossiliferous nodular limestone, unfossiliferous amorphous micrite within a dark gray siltstone matriy, dark gray siltstone, and unfossiliferous calcarenite. Because of its greater siltstone content compared with the underlying Rockdell, the Benbolt occupies topographic lows. A pale buff color is characteristic of weathered Benbolt rock fragments, which are seen in vegetatively barren areas. While limestone content increases in the upper $23 \mathrm{~m} \mathrm{(76ft)} \mathrm{of} \mathrm{the} \mathrm{Benbolt} \mathrm{as} \mathrm{shown} \mathrm{in} \mathrm{rock} \mathrm{core} \mathrm{and} \mathrm{geophysical} \mathrm{logs,} \mathrm{which} \mathrm{is}$ indicative of the overlying Wardell Formation, the increased limestone content is insufficient to allow reliable mapping of the Wardell on ORR. Therefore, while the "Nardell may be present on ORR, it is not included in field mapping. The Benbolt corresponds to Unit $\mathrm{E}$ of Stockdale.

Bowen Formation. A minor maroon unit (the Bowen Formation) overlies the lower thick limestone of the Benbolt and is a reliable marker for field mapping and subsurface exploration. The Bowen is 5 to $7 \mathrm{~m}(15$ to $20 \mathrm{ft}$ ) thick and consists of maroon calcareous and shaly siltstone, and thin beds of light gray to olive-gray limestone and argillaceous limestone. Vertical and horizontal burrows are prevalent throughout sie unit. The Bowen underlies a very minor, discontinuous ridge in the southern portion of Bethel Valley, and it is mappable in numerous locations along the valley. Stockdale referred to the Bowen as Unit F. 
Witten Formation. The uppermost limestone-dominated unit in the Chickamauga Group in Bethel Valley is the Witten Formation. In many respects, the lower Witten resembles the upper Benbolt, and without the presence of the maroon Bowen, the Witten and Benbolt might otherwise not be separated on ORR. The Witten consists of nodular limestone; calcarenite; amorphous, thin-bedded limestone and siltstone; and wavy interbedded limestone. Extensively bioturbated beds and beds with numerous bryozoa are distinctive of the upper Witten. The Witten has outcrops near the southeast edge of Bethel Valley and usually occupies the lowest topography in the valley. Much of the Witten is exposed along the interchange roadcut connecting Bethel Valley Drive with Edgemoor Road. The Witten constitutes Unit G of Stockdale.

Moccasin Formation. Because it was largely removed by the Copper Creek Fault, the youngest Chickamauga unit (the Moccasin Formation) is not fully represented on ORR. For the same reason, its thickness is also likely to be variable. While Stockdale reported $104 \mathrm{~m}$ (340 ft) of the Moccasin on ORR, subsurface investigations have not turned up a complete section of the formation. The Moccasin is recognized as olive to light gray and pale maroon calcareous siltstone interbedded with light gray, fine-grained limestone. Haase, Walls, and Farmer (1985, p. 3-38) describe the upper $24.8 \mathrm{~m}(80 \mathrm{ft})$ of the Moccasin as interbedded maroon-gray calcareous siltstones, gray to maroon-gray shaley limestones, and maroon mudistones. Weiss $(1981$, p. 32) described as much as $64 \mathrm{~m}$ $(210 \mathrm{ft})$ of the Moccasin along the roadcut on the southwest corner of Solway Bridge. The Moccasin represents Unit $\mathrm{H}$ of Stockdale.

\subsection{Areal Geology of Melton Valley}

A simplified geologic map of ORR is shown in Fig. 2.5-13, and a geologic cross section perpendicular to the axis of Melton Valley and Haw Ridge is shown in Fig. 2.5-14. The principal significant geologic structures on ORR are regional-scale thrust faults that result in the bedrock orientations and outcrop patterns observed. Superimposed on the structure imposed by these regional-scale faults is a multitude of local fractures, small folds, and local-scale faults that affect near-field geology and hydrogeology. Bedrock fracturing is ubiquitous on ORR with variation in the degree of fracturing based on local bedrock type and proximity to local- or regional-scale folds and/or faults. Two regionally important thrust faults cross ORR in a northeast/southwest direction. These faults are the White Oak Mountain Fault zone, which lies several miles northwest of the ANS site, and the Copper Creek Fault, which has outcrops on the northwest slope of Haw Ridge about $1 \mathrm{~km}(0.6 \mathrm{mile})$ northwest of the ANS site.

The Copper Creek Fault underlies the ANS site at a depth of about $250 \mathrm{~m}$ $(800 \mathrm{ft})$ below the land surface. Motion of bedrock above the Copper Creek Fault during the Appalachian Orogeny carried the Upper Rome Formation, the Conasauga Group, and the overlying Knox Group strata to their present orientations. At the end of the Paleozoic era the rocks that outcrop at the land surface were buried deeply beneath a mountainous deformation belt. The present regional terrain is the result of weathering and erosion of bedrock and soils over the millennia since the Appalachian Orogeny.

\subsection{Structural Geology of Melton Valley}

This discussion of the structural geology of Meiton Valley is excerpted from the HFIR SAR 1991. 


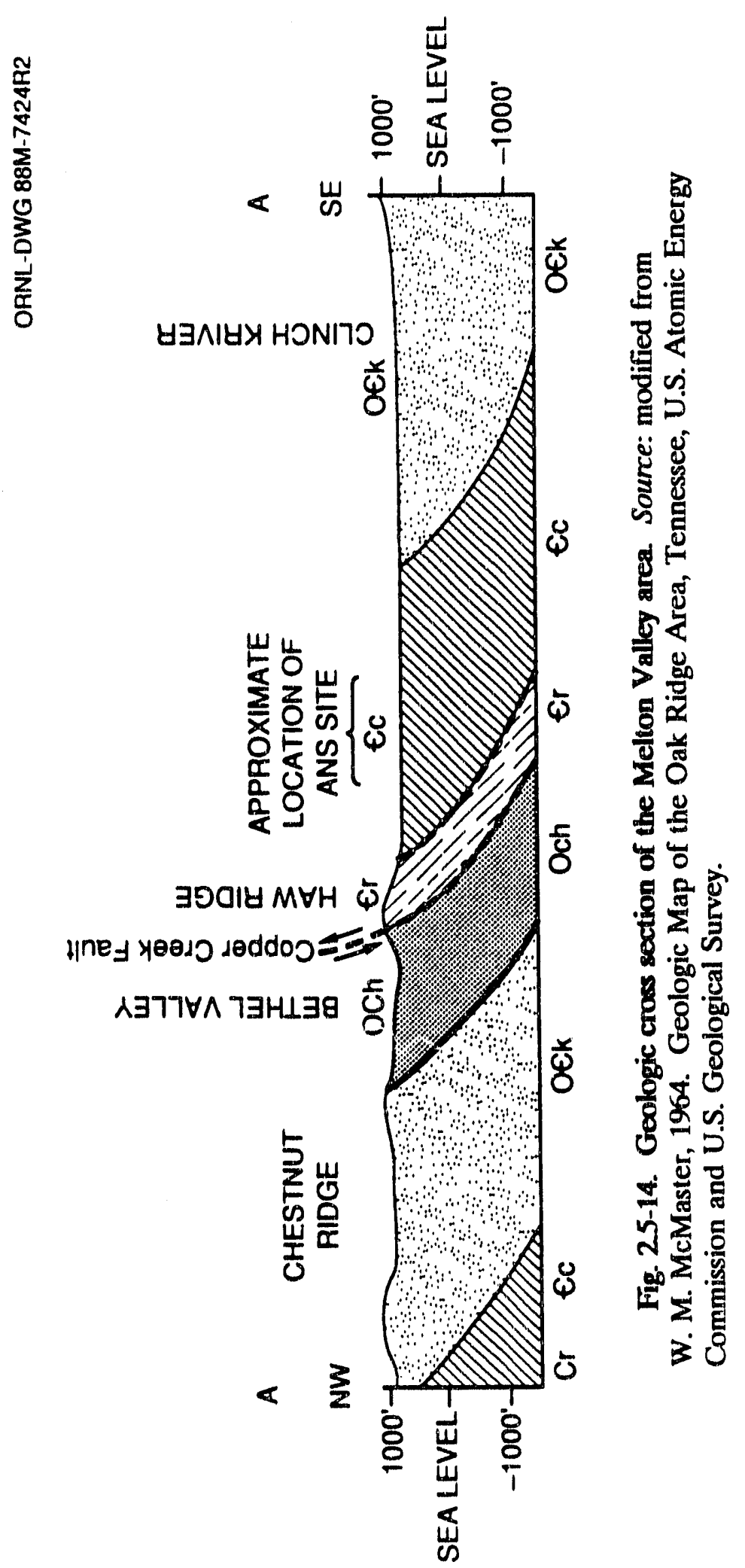




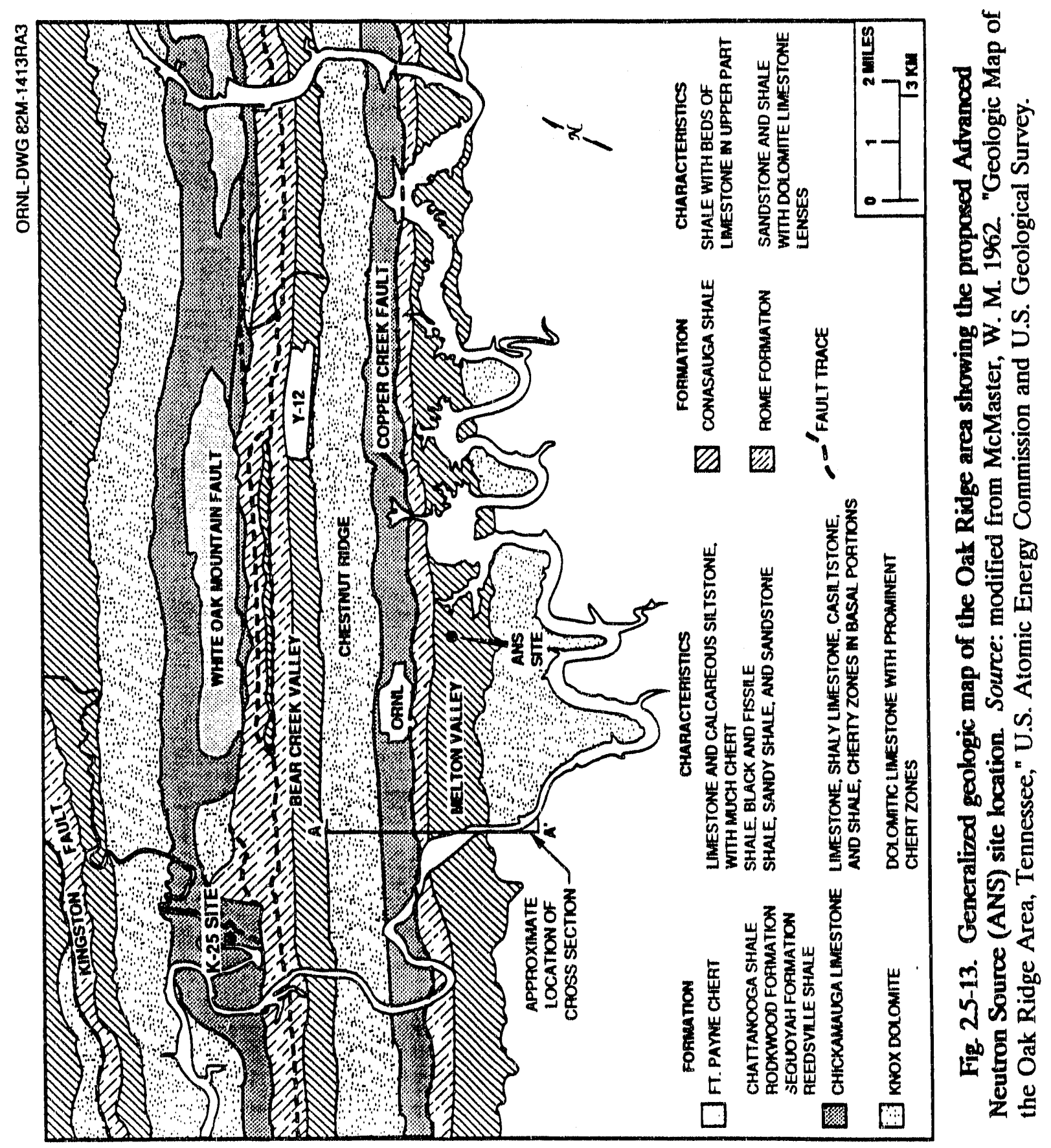


Structural features within Melton Valley are related to motion along the Copper Creek Fault, a regionally significant noncapable thrust fault that strikes $\mathrm{N} 50^{\circ} \mathrm{E}$ to $\mathrm{N} 60^{\circ} \mathrm{E}$ and dips to the southeast at gener ally a shallow angle $\left(0-25^{\circ}\right)$. Significant mesoscale deformational features within the Conasauga Group, particularly the upper part of the Maryville Limestone and the lower part of the Nolichucky Shale, include numerous lowamplitude folds, thrust faults, bedding-plane faults, and high-angle reverse faults, and several sets of pervasive joint sets (Rothschild et al. 1984, p. 26; Rogers et al. 1989, as referenced in the HFIR SAR 1991, p. 2-349).

\section{Bedding orientation}

In Melton Valley, geologic strike averages about $\mathrm{N} 55^{\circ} \mathrm{E}$, and the dip of the rock units is highly variable due to the highly deformed character of the Conasauga Group. The deformed character of the Conasauga Group, particularly the upper part of the Maryville Limestone and the lower part of the Nolichucky Shale, was noted in the 1950s, when large trenches were being excavated for disposal of ORNL's liquid radioactive waste in what is known as the "Pits and Trenches Area" of ORNL. Photographs taken of the excavations show numerous folds that exhibit complex geometries. Some of the folds appear to have been broken by intraformational thrust faults but exhibit only minor offset along the faults. Within this deformed interval, the most intensely deformed strata were mapped as a "zone of crumpled beds" that is continuous up and down Melton Valley.

Twenty-two boreholes were drilled and logged and cores of bedrock were taken during the preconstruction site investigation for the HFIR facilities. The HFIR facilities lie approximately $1.6 \mathrm{~km}$ (1 mile) northeast of the "Pits and Trenches Area" in Melton Valley and directly along strike. Boring logs, on file at ORNL Central Engineering, show that the dip of the upper Maryville and lower Nolichucky at the HFIR site is highly variable between localities. Dip may vary between $30^{\circ}$ and $70^{\circ}$ in the same borehole (e.g., boring C-2) and may change from essentially horizontal beds to $30^{\circ}$ in within $1 \mathrm{~m}$ ( $3 \mathrm{ft}$ ) (e.g., boring C-4). Such variability in the dip of strata suggests the presence of significant geologic structure in the subsurface and supports the idea that the Maryville and Nolichucky are highly deformed throughout Melion Valley.

Photographs taken during the excavation and construction of the HFIR facilities confirm the contorted nature of the Maryville and Nolichucky bedrock and overlying saprolitic materials. These photographs show numerous mesoscale tight to broad synclines and anticlines that have been faulted (shear dislocations) and in some cases refolded. The mesoscale folds and faults at the HFIR site were not investigated in detail to determine orientations before HFIR construction and have not been investigated in detail elsewhere on ORR. These features are difficult to map because their geometry is complex (they plunge into the ground where they typically die out or are transacted by other structures) and they are generally small-tens of meters or feet across in the visible dimensions. The significance of the geologic structure at the HFIR site is that fractures associated with such intense deformation have been shown to be the primary pathway of groundwater and contaminant movement on ORR. The complex geologic character of the site makes understanding groundwater movement beneath the HFIR facilities extremely difficult. At present, remedial investigations being cond inted in SWSA 6, located approximately $2.4 \mathrm{~km}$ (1.5 miles) southwest of the HFIR site, are focusing on the effects of this intensely deformed zone on groundwater and contaminant movement at the site. The work performed in SWSA 6 may provide information that can be used to support a similar investigation at the HFIR site. 
Jointing

Joint and fracture orientations have not been investigated in detail at the ANS site, although fracturing was observed in core from preliminary boreholes drilled at the site. Recent studies on ORR have illustrated the presence of ubiquitous joints and fractures joints in the bedrock. Joint spacing is highly variable. Studies to date have generally agreed that at least one major joint set roughly parallels the geologic strike of the area and dips at $\sim 40^{\circ}$ to the northwest. A second steeply dipping joint set strikes about $\mathrm{N} 12^{\circ} \mathrm{W}$ (Geraghty and Miller 1989, pp. 3-8). These joint sets were formed by extensional forces. However, an orthogonal joint set resulting from shear forces is also recognizable.

In Melton Valley, fracturing and jointing in Conasauga Group rock is extensive and several pervasive joint set orientations have been identified. Data obtained from the Conasauga Group at three sites within SWSA 7, an area located about $610 \mathrm{~m}(2000 \mathrm{ft})$ along strike to the northeast of HFIR, show joint set orientations similar to joint sets measured elsewhere on ORR. At site A, two joint sets predominate, a set that strikes between $\mathrm{N} 70^{\circ} \mathrm{W}$ and $\mathrm{N} 90^{\circ} \mathrm{W}$ and a set that strikes about $\mathrm{N} 20^{\circ} \mathrm{W}$. The set striking $\mathrm{N} 20^{\circ} \mathrm{W}$ dips at a high angle to the northeast (about $80^{\circ}$ ); the second set dips about $50^{\circ}$ to the northeast. The approximate strike and dip of bedding at site $\mathrm{A}$ are $\mathrm{N} 55^{\circ} \mathrm{E}$ and $35^{\circ} \mathrm{SE}$, respcctively. At site $B$, two joint sets were recognized, one striking about $N 30^{\circ} \mathrm{W}$ and dipping at a high angle, and the second striking between $\mathrm{N} 70^{\circ} \mathrm{W}$ and $\mathrm{N} 90^{\circ} \mathrm{W}$ and dipping $26^{\circ} \mathrm{SE}$. The orientation of bedding at site $B$ averages a strike of $N 40^{\circ} \mathrm{E}$ with a dip of $26^{\circ} \mathrm{SE}$. At site $\mathrm{C}$, two joint sets were identified, one striking about $\mathrm{N} 20^{\circ} \mathrm{W}$ to $\mathrm{N} 40^{\circ} \mathrm{W}$ and the other $\mathrm{N} 20^{\circ} \mathrm{E}$ to $\mathrm{N} 30^{\circ} \mathrm{E}$, with dips of $66^{\circ} \mathrm{NE}$ and $74^{\circ} \mathrm{NW}$, respectively. Data from the three sites are shown graphically on equal area projections of poles to joint planes in Fig. 2.5-15 (Rothschild et al. 1984a, p. 27).

At each of the three localities within SWSA 7, the joint sets form an approximate angle of $120^{\circ}$ between their strike directions. This angle is approximately bisected by the orientation of bedding at each respective location. Such a relationship indicates an orthogonal joint set at each site that formed under shearing stresses. Data from SWSA 7 are consistent with data obtained elsewhere in Melton Valley (Sledz and Huff 1981, as referenced in the HFIR SAR 1991, p. 2-352). Data obtained within SWSA 7 do not indicate a principal joint set parallel to bedding planes. However, field observations in SWSA 7 indicate that bedding-plane joints are present, but cannot be measured with certainty because of the difficulty in distinguishing them from bedding plane surfaces (Rothschild et al. 1984a, p. 29).

\section{Mesoscale folds and dislocations}

As discussed in the section on bedding orientation, various mesoscale folds and dislocations or minor faults occur in a band in the Maryville Limestone through the central portion of Melton Valley. Similar features have been observed in the same stratigraphic interval throughout Melton Valley. These superposed mesoscale folds and faults vary in size in two dimensions from a few inches to a few feet, but they are not traceable very far in the third dimension; thus, they are not mappable.

The orientation of these structures is consistent with the observed trend of geologic structure in the Valley and Ridge Province, supporting the contention that they formed at the time of regional deformation late in the Paleozoic era. It has been noted in other parts of Melton Valley that geologic structure plays a key role in groundwater 


\section{EQUAL AREA PROJECTION OF POLES TO JOINT PLANES}
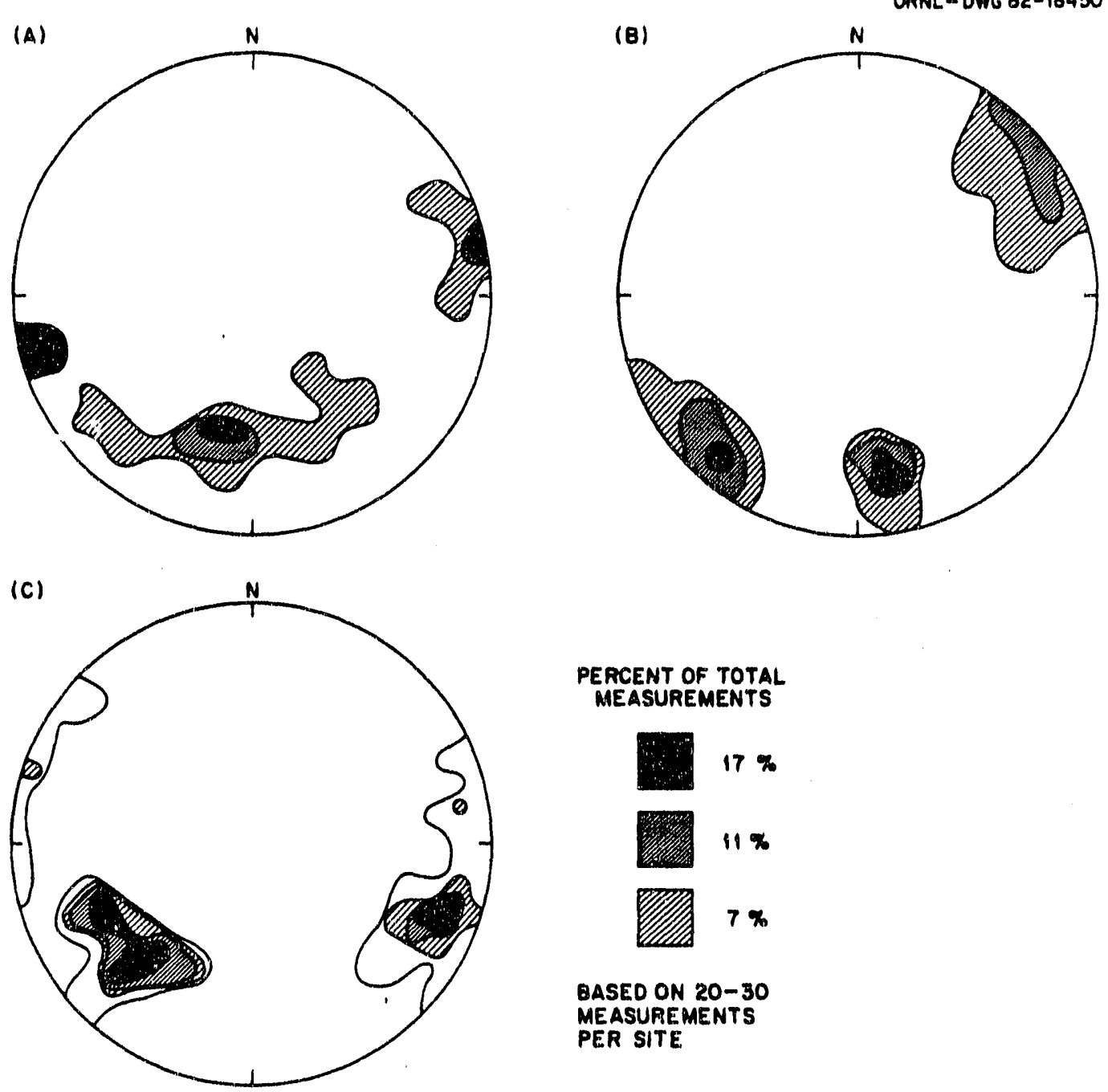

BASED ON 20-30

MEASUREMENTS

PER SITE

Fig. 25-15. Lower hemisphere equal area projections of poles to joint planes from measurements of joints at three separate sites within Solid Waste Storage Area 7, located approximately $610 \mathrm{~m}(2000 \mathrm{ft})$ along strike to the southwest of the ANS site. 
movement (Dreier and Toran 1989, p. XV), and based on the structural features evident in early site photographs, the same would be expected at the ANS site. Currently, the effects of geologic structure on groundwater movement at ANS cannot be adequately evaluated because a lack of data needed for the analysis.

\section{Weathering}

Rock at the ANS site weathers to a clayey residual soil derived from the underlying calcareous clay shale and interbedded limestone. According ro descriptions of soil samples and rock cores taken elsewhere in Melton Valley, the overburden consists of

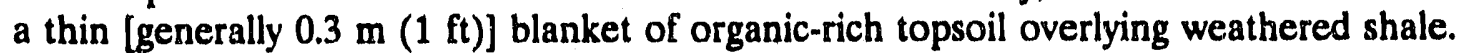
The weathered shale varies from a true clay (primarily $\mathrm{CL}$ and $\mathrm{CH}$ soils using the Unified Soil Classification System) at the top to a thick saprolitic zone-the commonly termed "rotten rock" -and finally grades into competent rock. Top-of-rock is generally defined as auger refusal during the site investigations.

\subsection{Soils}

This section discusses and described the various soils found on and around the proposed ANS site.

\subsubsection{Soils Mapped at the Proposed ANS Site}

This section presents a detailed soils map of the proposed ANS site along with supporting descriptive information pertaining to soil genesis, occurrence, soil profile characteristics, and geomorphic aspects of soil occurrence. Figure 2.5-16 is a soils map of the proposed ANS site. Soils have been classified and mapped on the basis of their parent materials, taxonomic classification, aspect of occurrence, and erosional condition. Table 2.5-3 presents the supporting key to nomenclature used on the map, and supporting detailed descriptions of the soils follows. Table 2.5-4 lists the soil identification codes applicable to soils at the proposed ANS Site with taxonomic classification and parent material. Materials presented have been excerpted from the mapping of D.A. Lietzke, (soil scientist, personal communication with R. H. Ketelle, ORNL, Jan. 28, 1992) and from descriptive text by D.A. Lietzke included in Hatcher et. al. (1991, pp 4-19-4-94).

\subsubsection{Conasauga Group}

\section{Pumpkin Valley Shale}

The No. 100 , No. 101, No. 102 , and No. 103 soils form a weathering sequence, from highly weathered to least weathered, respectively, on the lower member of this formation, which contains a high content of interbedded glauconitic fine-grained sandstone and siltstone. Of these rock, only the No. 102 soil occurs in the immediate vicinity of the proposed ANS site. These soils can be identified and easily mapped at a 1:1,200 to $1: 2,400$ scale, but only the soil of greatest extent (soil No. 102) was mapped at the 1:12,000 scale. The other soils of this sequence occur as inclusions. The degree of weathering and amount of soil development depends on whether water tends to flow off or infiltrate. Infiltration on these soils and their associated landforms depends not only on the slope gradient but also on the width of the side slope and the convexity, and also on the joint and fracture network of the underlying rock. While slope classes overlap for 


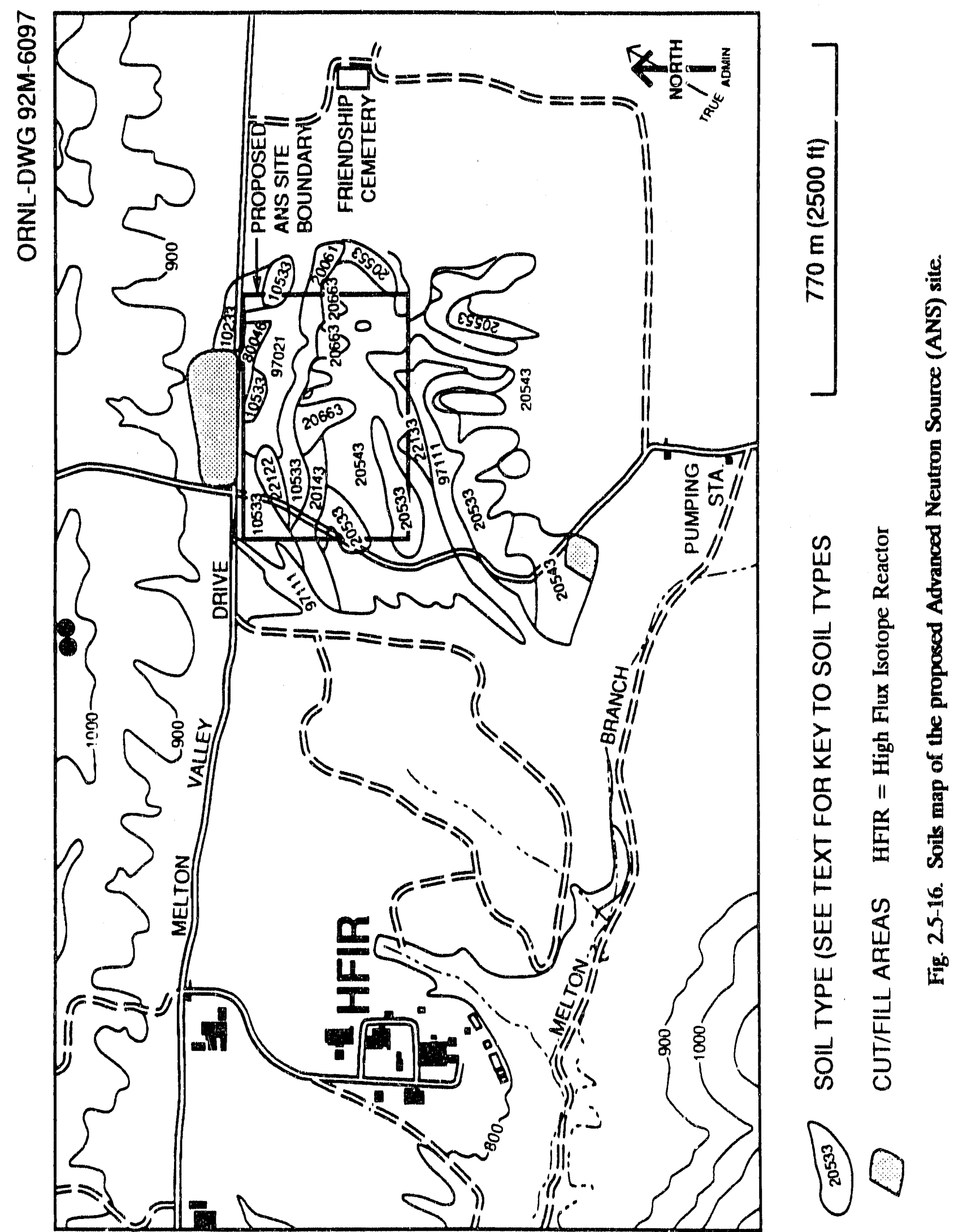


Table 25-3. Oak Ridge Reservation Soil Coding Systems as applicable to the proposed Advanced Neutron Source Site"

\section{EXAMPLE OF SOIL MAP CODE}

400434 is the geologic code (Knox Group),

${ }_{-}{ }_{-}$is the geomorphic code (Knox residuum)

- 0 is the individual soil code (Copper Ridge residuum)

$-\overline{4}$ is the slope code (12 to $25 \%$ slopes)

$\overline{3}$ is the erosion code (severe)

1st digit codes. _0000 Geologic formations

0

1

2

3

4

5

6

7

8

9

0

1

2

3

4

5

6

7

8

9

3rd Digit codes $00 \_00$ Individual soil identification numbers, 0 through 9.

\author{
Rome \\ Conasauga-Pumpkin Valley/Rutledge \\ Conasauga-Rogersville/Maryville \\ Conasauga-Nolichucky/Maynardville \\ Knox-Copper Ridge/Chepultepec/Longview/Kingsport/Mascot \\ Chickamauga [Lithic within $100 \mathrm{~cm}$ (40 in.)] \\ Chickamauga (deep and paralithic) \\ Silurian/Devonian/Mississippian \\ Altered Land. (cut, cut and fill, fill, burial trenches) \\ Alluvium
}

2nd Digit Codes. 0_000 Geomorphic codes.

residuum

Rome colluvium

Conasauga colluvium

Knox colluvium

Chickamauga colluvium

Silurian/Devonian, Mîssissippian colluvium

Rome alluvium

Conasauga alluvium

Knox/Chickamauga alluvium

Pleistocene-Tertiary alluvium

4th Digit codes. 000_0 Slope classes

1
2
3
4
5
6

0 to $2 \%$ slopes

2 to $5 \%$ slopes

5 to $12 \%$ slopes

12 to $25 \%$ slopes

25 to $45 \%$ siopes

$>45 \%$ slopes 
Table 25-3. (continued)

\begin{tabular}{ll}
\hline & 5th Digit codes. 0000 Past erosion classes and altered lands. \\
1 & none to slight accelerated erosion \\
2 & moderate accelerated erosion \\
3 & severe accelerated erosion \\
4 & very severe erosion with common to many gullies \\
5 & cut land \\
6 & fill land \\
7 & cut and fill land \\
8 & waste burial areas \\
\hline
\end{tabular}

a five digit number system was devised to code all important soil map information for easy computer sorting and manipulation in the soil survey.

The first digit codes the important geologic formations.

The second digit codes for residents, colluvium, and alluvium by major geologic formations, and Pleistocene alluvium.

The third digit codes for each individual soll.

The fourth digit codes each slope gradient class.

The fifth digit codes for soil erosion class or other soil or landform properties considered important for planning or utilizations.

The first three digits define each indtvidual member of the soil system in terms of the geology and geomorphology and are shown beneath. The residual and colluvial soils are organized according to geologic parent materials. The alluvial soils are grouped according to age, parent materials, and wetness. The mapping unit descriptions that follow are organized in the same sequence.

these soils, the landform width and convexity are different. Most areas of the No. 101 soils on E slopes are generally on 20 to $35 \%$ slopes, while most of the No. 102 soils that are on E slopes have slopes of 35 to $45 \%$. The No. 102 soils also occur on lower gradient landforms where interfluves are narrower and more convex. Most areas of the No. 103 soils are on slopes greater than 45 percent, but if areas are on less steep slopes, the landform, usually a spur ridge, is narrow and highly convex. The upper Pumpkin Valley Shale has a higher siltstone and shale content with less sandstone and has a high glauconite content that gives rise to a saprolite ranging from reds and violets to green. Because of the high content of less permeable shale, the upper Pumpkin Valley weathers differentially with more permeable strata more deeply weathered than less permeable strata. Soil No. 104 is mapped only over the upper part of the formation.

\section{Pumpkin Valley residuum}

As shown on the soil map key, there are several distinct soil types that develop as residuum of the Pumpkin Valley Shale. Only the description of the 102 type soil is included here. More detailed information is available in Hatcher et al. (1991, pp. 4-19-4-94). 
Table 25-4. Classification of soils mapped at the proposed Advanced Neutron Source site

\section{CONASAUGA GROUP}

\section{Pumpkin Valley residuum}

100 Typic Hapludults; clayey, mixed, thermic $>100 \mathrm{~cm}$ (40 in.) to the $\mathrm{Cr}$ soil horizon, or vertical stratification. [lower sandstone and siltstone facies]

101 Typic Hapludults; clayey, mixed, thermic $50-100 \mathrm{~cm}(20-40 \mathrm{in}$.) to the $\mathrm{Cr}$ soil horizon. [lower sandstone and siltstone facies]

102 Ochreptic Hapludults; clayey or fine-loamy, mixed, thermic. $>50 \mathrm{~cm}$ (20 in.) to the $\mathrm{Cr}$ soil horizon. [lower sandstone and siltstone facies] Soil of greatest extent.

103 Typic Dystrochrepts; loamy-skeletal, glauconitic, thermic, shallow. (lower sandstone and siltstone facies)

104 Ruptic-Ultic Dystrochrepts; clayey argillic and loamy-skeletal cambic), mixed, thermic. (violet micaceous and glauconitic facies of upper Pumpkin Valley)

\section{Rutledge residuum}

105 Ruptic-Ultic Dystrochrepts; clayey argillic and loamy-skeletal cambic, mixed, thermic. (calcareous siltstone and interbedded limestone member)

\section{Rogersville residuum}

Typic Dystrochrepts; loamy-skeletal, mixed, thermic, shallow. (steep slopes)

201 Ruptic-Uitic Dystrochrepts; clayey argillic and loamy-skeletal cambic, mixed, thermic. (moderate slopes)

202 Typic or Ochreptic Hapludults; clayey, mixed, thermic (slopes less than $6 \%$ )

\section{Maryville residuum}

Typic Hapludults; clayey, mixed, thermic. (slopes less than 6\%) fine-grained sandstone in Melton Valley SWSA-7 area) Ochreptic Hapludults or Ruptic-Ultic Dystrochrepts; clayey or loamy-skeletal, mixed, thermic. (moderate slopes)

Typic Dystrochrepts; loamy-skeletal, mixed, thermic, shallow. (steep slopes)

207 Typic Dystrochrepts loamy-skeletal, mi:zed, thermic. (deeply weathered saprolite on steep easterly facing aspects) 
Table 25-4. (continued)

\section{Nolichucky residuum}

300 Ruptic-Aquultic Dystrochrepts; clayey argillic and loamy-skeletal cambic, mixed, thermic. (lower sideslopes)

301 Ruptic-Ultic Dystrochrepts; clayey argillic and loamy-skeletal cambic, mixed, thermic. (moderate slopes)

302 Typic Hapludults; clayey, mixed, thermic. (slopes less than 6\%)

303 Typic and Ultic Hapludults-Eutrochrepts-Rock Ledge Complex.

Pumpkin Valley colluvium

120 Typic Hapludults; clayey or fine-loamy, mixed. [2.5YR hue (according to the Munsell color system) in the argillic horizon doubly convex toeslopes from landscape inversion]. (Pumpkin Valley and some Rome)

121 Typic Hapludults; fine-loamy, mixed, thermic. [7.5YR-5YR hue (according to the Munsell color system) in the argillic horizon] doubly concave footslopes. [Rome and Pumpkin Valley]

122 Typic Hapludults; fine-loamy or loamy-skeletal, mixed, thermic. (10YR hue, gravelly upper argillic with abundant Rome gravels. In drainageways, fans and low toeslopes.) [Rome and Pumpkin Valley]

123 Typic Hapludults; fine-loamy, mixed, thermic. [Pumpkin Valley alluvium-colluvium over No. 951 alluvium over Pumpkin Valley saprolite.] Soils of very small extent.

\section{Rogersville/Maryville/Nolichucky colluvium}

Aquic Hapludults; fine-loamy, mixed, thermic. (mostly Maryville colluvium)

221 Typic Hapludults; fine-loamy, mixed, thermic. (Rogersville, Maryville and some Nolichucky colluvium)

222 Typic Hapludults; fine-loamy, mixed, thermic (Gum Hollow alluvial fan with Rome fragments in Rogersville and Maryville colluvium)

223 Typic Hapludults; fine-loamy, mixed, thermic. (RogersvilleMaryville-Nolichucky colluvium over silty old alluvium over Conasauga residuum)

224 Typic Fragiudults; fine-loamy, mixed, thermic. (Maryville, Nolichucky, and old alluvium)

225 Typic Hapludults; clayey, mixed, thermic. (Rogersville and Maryville colluvium with topographic inversion) 
Table 25-4. (continued)

\begin{tabular}{ll} 
MODERN ALLUVIUM \\
Conasauga \\
970 & Typic and Aquic Udifluvents; coarse-silty, mixed, thermic \\
971 & Typic and Aeric Fluvaquents; coarse/fine-silty, mixed, thermic. \\
972 & Fluvaquents and Ochraqualfs; fine-silty and fine, mixed, thermic. \\
& [Bear Creek alluvium over a buried fine Typic Ochraqualf \\
& Maynardville soil at $>50$ to $90 \mathrm{~cm}(20$ to 36 in.)] \\
\hline
\end{tabular}

10241, 10251. These soils formed in interbedded glauconitic sandstone-siltstone of the lower Pumpkin Valley Shale, where they occupy narrower, steeper, or more convex landforms on the lower slopes of Pine and Haw Ridge. The argillic horizon contains welldeveloped structure and 5YR to 10YR hues, according to the Munsell color system. Depth to the $\mathrm{Cr}$ soil horizon is generally less than $50 \mathrm{~cm}$ (20 in.), but can range to about $80 \mathrm{~cm}$ (32 in.). Areas of these soils on E slopes have generally (1) shallower depth to paralithic materials which impedes both root penetration and proliferation, and (2) less downward water movement and more overland and subsurface lateral flow. Vegetation on these soils consists of mixed hardwoods with very few white oak and dogwood, or ground cover that requires higher natural fertility, an indication of low calcium carbonate content in deeper saprolite layers. These soils tend to generate more overland flow because of the greater convexity of the landform, although there is less clay plugging of the uppermost saprolite zone below.

\section{Rutledge Limestone}

Because of their topographic position, most areas of the Rutledge Limestone are buried by either alluvium or colluvium. Weathering of the high calcium carbonate sections of the formation results in collapse of the residue which is subsequently buried. The weatbering of the siltstone and shale sections, with lower calcium carbonate content, forms saprolite which has some surface exposure on low topographic highs. Rutledge soils have sporadic distribution, and indication of the highly variable nature of this formation in the area.

$10522,10523,10532,10533,10543$. These soils formed in yellowish, grayish, reddish, and olive shale-siltstone low glauconite saprolite, weathered from calcareous rocks. Saprolite from shale under these soils has low permeability. Water perches in the upper part of the paralithic materials and extends up into the lower subsoil, where drainage mottling is evidence for fluctuating water, while saprolite from siltstone is more permeable, and there is less perching of water. These soils are hydrologically important because they generate high overland flow rapidly during storms.

\section{Rogersville Shale}

The No. 200, No. 201, and the No. 202 soils form a weathering sequence on the Rogersville Formation, with the No. 200 soils in the least weathered class and the No. 202 
soils the most weathered. The No. 200 and the No. 201 soils occupy most of the surface area. The No. 202 soils have very limited extent due to lack of stable surfaces and lowgradient slopes.

\section{Rogersville residuum}

20051, 20061. These soils occur almost exclusively on steep north and northeast aspects below Dismal Gap ridgetops. The saprolite beneath the soil solum ranges from gray to pinkish siltstone and claystone and commonly contains glauconitic strata. These soils, because of the steep slopes on which they occur, generate overland water flow that removes surface soil material almost as fast as the underlying rock weathers to form soil. Thus, these soils are kept in a near steady state of youthfulness.

20121, 20142, 20143, 21051, 20161. These soils comprise the largest areal extent of the Rogersville Shale. They occur on summits and sideslope landforms. Severely eroded areas have lost most or all of their diagnostic features and have the morphology of shallow Typic Dystrochrepts (No. 200 soils), or very shallow Udorthents (soils without diagnostic subsurface pedogenic soil horizons). Because of the shallow soil solum, these soils do not have much water retaining capacity, so overland flow or near surface flow is common, especially on dip slopes. The rougher rock surface of obsequent or scarp slopes allows for longer water residence time and therefore more water tends to enter and move in the direction of dip along planar surfaces or gradually downward through joints and fractures.

20222, 20223. These soils formed in steeply dipping Rogersville Shales and siltstones. They have a continuous $\mathrm{Bt}$, soil horizon, or vertical stratification, but of variable thickness. The Bt horizon has a yellow-brown to strong brown color in 10YR and 7.5YR hues, in contrast to the 5YR and 2.5YR hues of Maryville Bt horizons. Depth to the $\mathrm{Cr}$ horizon is also highly variable, ranging from less than $50 \mathrm{~cm}(20 \mathrm{in}$.) to more than $100 \mathrm{~cm}(40 \mathrm{in}$.). These soils, of limited extent, occur only on gently sloping upland summits that were cultivated in the past.

\section{Maryville Limestone}

The No. 203, No. 205, and No. 206 soils form a weathering sequence on the interbedded shale, siltstones, and limestones of the Maryville Limestone. The No. 203 soils occupy gently sloping and stable landforms, are more highly weathered, have a deeper solum that has stronger horizonation, and a continuous clayey Bt horizon with a red 2.5YR hue, according to the Munsell color system. The moderately weathered No. 205 soils occur on steeper slopes or on landforms with more convexity. These soils have been periodically stripped of their upper soil horizons so that in an across the strike open trench sidewall, the $\mathrm{Bt}$ horizon is interrupted by either a cambic $\mathrm{Bw}$ horizon or by $\mathrm{C}$ or $\mathrm{Cr}$ horizon saprolite materials. The least weathered No. 206 soils occur on the steepest and most convex landforms. They have no $\mathrm{Bt}$ horizon except in a few deep pockets, and soil solum thickness is usually less than $50 \mathrm{~cm}(20$ in.) to as little as $10 \mathrm{~cm}(4 \mathrm{in}$.).

The No. 204 and No. 207 soils occur, to date, only in the SWSA-7 area of Melton Valley. These particular soils occur on saprolite with a higher siltstone content, and have a loamy Bt horizon in contrast to the clayey Bt horizon of the No. 203 soils. The No. 207 soils are similar in morphology to the No. 206 soils but are deeper to paralithic $\mathrm{Cr}$ horizons and occur only on northeast to east aspects where there has been deeper penetration of water resulting in more weathering. The Maryville Limestone contains 
more calcium carbonate than either the Pumpkin Valley, Rogersville, or Nolichucky Shales.

Of the several Maryville Limestone residual soil types observed on ORR, only those of the 205 and 206 soil types occur in the immediate vicinity of the proposed ANS site. Soil descriptions included here are restricted to the 205 and 206 soils. Additional information is available in Hatcher et al. (1991, pp 4-19-4-94).

20521, 20523, 20531, 20533, 20541, 20543, 20544, 20551. These soils occur on narrow summits and upper and middle sideslopes with considerable convexity, and are the most extensive soils underlain by the Maryville Limestone. They formed in less weathered but highly interbedded siltstone and claystone with thin strata of argillaceous limestone and very fine-grained sandstone saprolite of the Maryville Limestone. These strata have undergone differential weathering that increases soil variability, especially permeability in the upper saprolite. These soils have an intermittent clayey Bt horizon which has 2.5YR-5YR hue according to the Munsell color system. Siltstone and claystone fragments in the solum and upper saprolite have a 10YR-2.5Y hue according to the Munsell color system. Depth to paralithic ( $\mathrm{Cr}$ horizon) materials is highly variable ranging from less than $10 \mathrm{~cm}$ (4 in.) to more than $100 \mathrm{~cm}$ (40 in.) over very short distances.

20641, 20643, 20644, 20651, 20661. These soils occur on steep sideslopes of drainageways that are cutting headwardly through the Maryville Limestone or they are on highly convex shoulders and sideslopes of narrow spur ridges. Most areas of these soils are located on northwest, west, and southerly aspects. These soils have a thin solum, usually less than $50 \mathrm{~cm}$ (20 in.) thick above paralithic materials. The saprolite directly beneath the solum usually has a $2.5 \mathrm{Y}$ to $5 \mathrm{Y}$ hue, according to the Munseil color system, or if more weathered, has a 2.5Y-10YR Lue. Because of the shallow solum, these soils cannot retain much rainfall, resulting in the generation of considerable overland or near surface lateral flow during storms. Overland flow has removed soil particles from the surface almost as fast as soil is formed by the weathering of rock beneath. Consequently, these soils are kept in a near steady state of youthfulness.

\section{Nolichucky Shale}

The Nolichucky Shale can be readily identified by the oxidized brownish or pinkish brown color of the claystone and siltstone saprolite alternating with olive-colored saprolite from calcareous strata, and reddish-yellow clay seams that weathered from limestone. In contrast to the adjacent and evidently more permeable Maryville limestone geomorphic processes of erosion and denudation do not result in the formation of high hills and steep slopes in the less permeable Nolichucky Shale. The lower pirmeability of this unit may have allowed for high overland runoff and consequently for more equal denudation over the entire landform; and, perhaps, freeze-thaw cycles during the late Pleistocene were more effective in reducing hilltop elevations. The combination of landform configuration and saprolite colors were the primary distinguishing characteristics used to locate the surface boundary zone between the Maryville Limestone, and Nolichucky Shale. The lower Nolichucky is interbedded with the upper Maryville and the boundary zone is identified by interbedded olive-brown and strong-brown strata. The upper Nolichucky is also interbedded with the lower Maynardville where the number and thickness of argillaceous limestone strata gradually increase. 
Nolichucky residuum

30021, 30023. These soils are on lower sideslopes where overland and subsurface lateral waterflow from high areas keeps the lower part of the soil wet during winter and spring. The upper part of $\mathrm{Cr}$ horizon is usually plugged by gray clay. They have a limited extent because they are usually covered by No. 221 colluvium, except at the base of long slopes where colluvial materials have been deposited farther up slope.

30122, 30123, 30133, 30143. These soils occupy summits, upper, middle, and lower sideslopes. Because of favorable topography, they were cultivated $\mathrm{n}$ the past. Most areas, even on gentle slopes, were severely eroded. Because of the past erosion many borings of these soils have the morphologic characteristics of Typic Dystrochrepts, but the underlying saprolite contains abundant clay flows that had been translocated from a Bt horizon. These soils have an intermittent Bt horizon with 10YR and 7.5YR hues, according to the Munsell color system. Clay flows in the underlying saprolite have similar colors. Fragments in the less weathered saprolite are thickly coated with black manganese or red iron compounds. Due to the relatively impermeable nature of the saprolite, the upper soil layers become saturated readily, and, because of the high silt and clay content, tend to move down slope quite readily. The soils in these map units occupy the largest acreage in the area underlain by the Nolichucky Shale.

30222, 30223. These soils occur on very gentle slopes throughout the extent of the Nolichucky Shale, but they are most common in the upper portion of the Nolichucky Shale, which contains a high proportion of saprolite weathered from argillaceous limestone. These soils have a reddish-yellow Bt horizon. The saprolite beneath is soft, high weathered, and clay plugged in the upper part. Some of most areas of these soils were, at one time, covered by No. 995 alluvium and have been exhumed. A thin smear of alluvium, less than $50 \mathrm{~cm}(20 \mathrm{in}$.) thick, remains in some places where the elevation is less than $257 \mathrm{~m}(848 \mathrm{ft})$.

30343,30363 . The soils in these map units formed in interbedded shale-siltstone and limestone saprolite. They also contain few to many limestone ledges. These soils are mapped only in the Melton Hill area of the ORR where the upper Nolichucky Shale is better exposed.

\section{Conasauga colluvial soils}

\section{Rogersville-Maryville-Nolichucky colluvium}

Most colluvial soils could be easily separated according to their parent material origin. Rome and Pumpkin Valley colluvial soils have different rock fragment assemblages and low silt content. Most colluvium from the Rome and Pumpkin Valley Formations was intercepted by drainageways in the Rutledge topographic low and did not extend onto and through the Rogersville, Maryville, and Nolichucky with one exception: the No. 222 deltaic fan or fan terrace in the Bear Creek Low-Level Waste Disposal Development and Demonstration site that contains fragments and soil from the Rome and Pumpkin Valley. Soils that formed in Knox colluvium have a high chert content and are easily separated from the Rome, Rome-Pumpkin Valley, and colluvial soils derived from the Rogersville, Maryville and Nolichucky formations.

Colluvial soils derived from the Rogersville, Maryville and Nolichucky formations have similar morphologic characteristics, including shale and siltstone fragments, and high silt content. Therefore, they were grouped together in mapping. The only colluvial soil 
mapped in the immediate vicinity of the proposed ANS site are those of the No. 221 soil. Descriptions of Conasauga Group colluvial soil other than the No. 221 soil may be found in Hatcher et al. (1991, pp. 4-18-4-94).

22121, 22131, 22133, 22141, 22151. These soils are on toeslopes and fan terraces. They usually have one or more lithologic discontinuities, but there is little evidence of perched water at lithologic contacts unless the truncated remains of a clayey argillic horizon in the buried paleosol are present. Erosion during the Pleistocene epoch evidently stripped off most of the older soil before depusition of younger colluvium began. These soils are roughly equivalent to the Rome-Pumpkin Valley colluvial No. 121 soils in degree of soil development in the upper profile. Below the first lithologic-time discontinuity there is either an older colluvium or the truncated remains of a residual soil. These soils are most common on the Dismal Gap Formation, but they also occur on the Rogersville and Nolichucky formations. Most areas of these soils occur in first-order drainageways and sideslopes of these drainageways. Many areas have been partially covered by Modern Age colluvium and local slope-wash alluvium produced by cultivation of adjacent landforms. Included in mapping are small and scattered areas of a younger colluvium similar in age to the Pumpkin Valley No. 122 colluvial soils, but only about $50 \mathrm{~cm}$ (20 in.) thick. The Rogersville land upper Conasauga formations did not evidently generate as much colluvium as the higher and more dissected Pumpkin Valley and Rome formations during the neo-glacial episode. These soils have properties that permit intiltration and retention of rainfall, most which percolates downward or flows laterally and contributes to stream base flow.

\section{Modern alluvium}

Modern or recent alluvium is defined as alluvium of less than 300 years old, the result of anthropogenic accelerated erosion from the clearing and agricultural activities of european settlers. Recent alluvium is stratified close to or to the surface and lacks any diagnostic subsurface horizon within a depth or $50 \mathrm{~cm}$ below the surface. Several modern alluvial soils are recognized on the ORR. Only the Conasauga alluvium occurs in the immediate vicinity of the proposed ANS site. Information on the other soils may be found in Hatcher et al. (1991, pp 4-18-4-94).

\section{Conasauga allurvium}

97011, 97021. These soils formed in Recent alluvium and have a much higher silt content tnan the Rome and Pumpkin Valley alluvial soils. They are in narrow drainageways in areas of Rogersville, Dismal Gap, and Nolichucky soils. These well and moderately well drained soils are undifferentiated with respect to degree of wetness. Most areas of these soils have a well defined and entrenched channel. The largest areas of these soils occur on the floodplain and low terraces of Bear Creek. Nearly all areas of these soils have a buried soil between a depth of $50 \mathrm{~cm}$ and $100 \mathrm{~cm}(20$ and $40 \mathrm{in}$.).

97111. These somewhat poorly and poorly drained soils occur in nearly level drainageways within areas of Rogersville, Dismal Gap, and Nolichucky soils that contribute high silt-content sediments to drainageways. Most areas of these soils have a buried soil between a depth of 50 and $100 \mathrm{~cm}$ (20 and $40 \mathrm{in}$.). Most areas of these soils contain springs or seepage zones or do not have a defined channel and rernain wet most of the year. Present vegetation is hardwoods with a ground cover of water tolerant plants. 


\section{REGIONAL HISTORIC, ARCHITECTURAL, SCENIC, CULTURAL, AND NATURAL FEATURES}

This section discusses the historic, architectural, scenic, cultural, and natural features of the proposed ANS site.

\subsection{Recreation Near the Site}

The only potentially affected recreational activity on ORR is the annual deer hunt managed by the Tennessee Wildlife Resources Agency (TWRA). Deer hunting is not permitted on the proposed development site. The nearest permitted hunting area is the Park City Road area where archery hunting of deer is permitted once per year for a 2-d hunt. The area is considered a prime deer hunting area and is restricted to 100 hunters per year. However, access to this area would be maintained via the Health Physics Research Reactor Access Road. This road would be relocated, but this should not restrict access to the Park City Road hunting area. No other recreation takes place in this area.

\subsubsection{Cultural Resources}

Cultural resources have been assessed in DuVall 1991 (n.p.). A pedestrian reconnaissance failed to identify any archaeological or historical sites within the boundaries of the project. Based upon the reconnaissance, a search of the site files at the Tennessee Division of Archaeology, and a search of the National Register of Historic Places, the proposed ANS project should have no impact on any property included in or eligible for inclusion in the National Register of Historic Places pursuant to 36 CFR Pt. 60.4(d).

The contractors should be made aware of the present Tennessee burial law that protects both marked and unmarked, historic and prehistoric interments. In the event that human skeletal material is unearthed during construction activities, construction in the vicinity should cease and the Tennessee Division of Archaeology should be notified immediately.

The proposed site has no unique scenic features. Visual effects of the proposed reactor and supporting facilities would be consistent with existing developed areas on ORR. There is no public access to the proposed site other than during managed deer hunts. Therefore, the off-site public would not experience any visual effects during construction or operation.

\section{NOISE}

Noise emanating from the ANS site is, at present, limited to natural sounds, primarily from insects and wind effects. Over the course of a year, ambient noise levels are estimated to be between 35 and $45 \mathrm{~dB}(\mathrm{~A})$ (day-night level). Since the nearest potential human receptors are greater than $2.88 \mathrm{~km}$ (1.8 miles) away, and, since land masses are in the line-of-sight to those receptors, any natural noises created at the ANS site are not noticeable. In any case, similar levels are being experienced by persons on the south side of Melton Hill Lake (across from ORR) because of the similarity of natural noise sources. 


\section{RADIOLOGICAL AND CHEMICAL DOSE TO THE PUBLIC}

\subsection{Background Radiation Sources and Doses}

Natural sources of radiation are always present as a result of cosmic rays and radioactive elements occurring in the earth's soil. The intensity of the cosmic rays depends on factors such as altitude and local magnetic features. Naturally occurring radioisotopes vary in soil concentration depending on the geologic conditions. Within the environmental monitoring program at ORNL some of these background sources are regularly measured. Measurements taken at locaitions remote to ORNL represent background radiation, which is unaffected by operation of ORNL or the other ORR facilities. A small part of the background radiation results from the global distribution of fission pruducts released during atmospheric testing of weapons.

External gamma radiation measurements have been published by EPA (1987) for cities in the United States. Typical values are between 0.43 and $1.8 \mathrm{mSv} / \mathrm{year}$ (43 and $180 \mathrm{mrem} /$ year). The median value during 1987 was $0.81 \mathrm{mSv} / \mathrm{year}$ ( $81 \mathrm{mrem} / \mathrm{year}$ ) with $75 \%$ of the values between 0.66 and $1.3 \mathrm{mSv} /$ year (66 and $131 \mathrm{mrem} / \mathrm{year}$ ). An average of 12 locations in Tennessee yields $0.56 \mathrm{mSv} /$ year ( 56 mrem/year) $0.064 \mu \mathrm{G} / \mathrm{h}(6.4 \mu \mathrm{R} / \mathrm{h})$ (Myrick, Bervin, and Haywood 1981, p. 83).

An assessment of the average exposure of the U.S. population to ionizing radiation has recently been made by the National Council on Radiation Protection and Measurements (NCRP 1987). Six main radiation sources were considered: natural radiation and man-made sources including radiation, occupational activities (radiation workers), nuclear fuel production (power), consumer products, miscellaneous environmental sources, and medical uses.

The collective effective dose equivalent for each source category was obtained from the product of the average per capita effective dose equivalent received from that source and the estimated number of people exposed. Average effective dose equivalent for a member of the U.S. population was then calculated by dividing the collective effective dose equivalent value by the number of the U.S. population ( 230 million in 1980). The dose equivalent is the product of the absorbed dose, $D$, and the quality factor, $Q$, which accounts for differences in the relative biological effectiveness of different types of radiation. The effective dose equivalent relates the dose-equivalent to risk. For the case of partial body irradiation, the effective dose equivalent is the risk-weighted sum of the dose equivalents to the individually irradiated tissues.

Table 2.8-1 shows that three of the six radiation sources-radiation from occupational activities, nuclear power production (the fuel cycle), and miscellaneous environmental sources (including nuclear weapons testing fallout)-contribute only negligibly to the average effective dose equivalent, that is, less than $0.01 \mathrm{mSv} / \mathrm{year}$ (1 mrem/year).

A total average annual effective dose equivalent of $3.6 \mathrm{mSv} / \mathrm{year}$ ( $360 \mathrm{mrem} / \mathrm{year}$ ) to members of the U.S. population is contributed by the other three sources: naturally occurring radiation, medical uses of radiation, and radiation from consumer products. By far the largest contribution (82\%) is made by natural sources, two-thirds of which is caused by radon and its decay products. Environmental radon has only recently been recognized as the largest source of human exposure. Approximately equal contributions come from cosmic radiation, terrestrial radiation, and internally deposited radionuclides.

The remaining $18 \%$ of the average annual effective dose equivalent consists of radiation from medical procedures (X-ray diagnosis, $11 \%$; nuclear medicine, $4 \%$ ) and from consumer products $(3 \%)$. The average contribution by medical procedures is smaller than 
Table 28-1. Average annual effective dose equivalent of ionizing radiation to a member of the U.S. population

\begin{tabular}{|c|c|c|c|c|c|}
\hline \multirow[b]{2}{*}{ Source } & \multicolumn{2}{|c|}{ Dose equivalent ${ }^{\circ}$} & \multicolumn{3}{|c|}{$\begin{array}{c}\text { Effective dose } \\
\text { equivalent }\end{array}$} \\
\hline & $\mathrm{mSv}$ & mrem & $\mathrm{mSv}$ & mrem & $\%$ \\
\hline $\begin{array}{l}\text { Natural } \\
\text { Radon }^{b} \\
\text { Cosmic } \\
\text { Terrestrial } \\
\text { Internal } \\
\text { Total natural }\end{array}$ & $\begin{array}{c}24 \\
0.27 \\
0.28 \\
0.39 \\
-\end{array}$ & $\begin{array}{r}2400 \\
27 \\
28 \\
39 \\
-\end{array}$ & $\begin{array}{l}2.0 \\
0.27 \\
0.28 \\
0.39 \\
3.0\end{array}$ & $\begin{array}{l}200 \\
27 \\
28 \\
39 \\
300\end{array}$ & $\begin{array}{l}55 \\
8.0 \\
8.0 \\
11 \\
82\end{array}$ \\
\hline $\begin{array}{l}\text { Artificial } \\
\text { Medical } \\
\text { X-ray diagnosis } \\
\text { Nuclear medicine } \\
\text { Consumer products }\end{array}$ & $\begin{array}{l}0.39 \\
0.14 \\
0.10\end{array}$ & $\begin{array}{l}39 \\
14 \\
10\end{array}$ & $\begin{array}{l}0.39 \\
0.14 \\
0.10\end{array}$ & $\begin{array}{l}39 \\
14 \\
10\end{array}$ & $\begin{array}{l}11 \\
4.0 \\
3.0\end{array}$ \\
\hline $\begin{array}{l}\text { Other } \\
\text { Occupational } \\
\text { Nuclear fuel cycle } \\
\text { Fallout } \\
\text { Miscellaneous } \\
\text { Total artificial }\end{array}$ & $\begin{aligned} & 0.009 \\
< & 0.01 \\
< & 0.01 \\
< & 0.01 \\
- & -\end{aligned}$ & $\begin{aligned} & 0.9 \\
&<1.0 \\
&<1.0 \\
&<1.0 \\
&-\end{aligned}$ & $\begin{array}{r}<0.01 \\
<0.01 \\
<0.01 \\
<0.01 \\
0.63\end{array}$ & $\begin{array}{l}<1.0 \\
<1.0 \\
<1.0 \\
<1.0 \\
63\end{array}$ & $\begin{array}{l}<0.3 \\
<0.03 \\
<0.03 \\
<0.03 \\
18\end{array}$ \\
\hline Total natural and artificial & - & - & 3.6 & 360 & 100 \\
\hline
\end{tabular}

${ }^{a}$ To soft tissues.

${ }^{b}$ Dose equivalent to bronchi from radon daughter products. The assumed weighting factor for the effective dose equivalent relative to whole-body exposure is 0.08 .

'Department of Energy facilities, smelters, transportation, etc.

Source: National Council on Radiation Protection and Measurements 1987. lonizing Radiation Exposures of the Population of the United States, Report No. 93, Washirgton, D.C.

previously estimated. For consumer products, the chief contributor is radon in domestic water supplies, although building materials, mining, agricultural products, and coal burning also contribute. Smokers are additionally exposed to the natural radionuclide ${ }^{210} \mathrm{Po}$ in tobacco, resulting in the expusure of a small region of the bronchial epithelium to a relatively high dose [up to $200 \mathrm{mSv} / \mathrm{year}(20,000 \mathrm{mrem} / \mathrm{year})$ ] of radiation that may increase risk of lung cancer (NCRP 1984).

Uncertainties exist in the data in Table 2.8-1. Uncertainties for exposures from some consumer products are greater than those for exposures from cosmic and terrestrial radiation sources. Estimates for the most important exposure-lung tissue to radon and its decay products-have many associated uncertainties. Current knowledge of the average radon concentration, the distribution of radon indoors in the United States, and alpha- 
radon concentration, the distribution of radon indoors in the United States, and alphaparticle dosimetry in lung tissue is limited. In addition, knowledge of the actual effective dose equivalent is poorly quantified. Further uncertainties are caused by difficulties in combining data for exposure from different information sources.

\subsubsection{Historical Radiological Effluents}

The original mission of ORNL was to construct a nuclear fission reactor for the purpose of producing sufficient amounts of plutonium to support the research and development of plutonium-uranium separation. Results of experimentation at ORNL were to be used in the design and construction of the production reactors and separations facilities at the Hanford, Washington, facility. In addition to this primary mission, ORNL was given the task of producing various isotopes in support of other research facilities investigating the physical, chemical, and biological properties of these materials. After the early 1950s, the mission of ORNL became more diverse, encompassing a wide range of experimental programs and reactors.

Initial quantification of radioactive releases to the air and water was crude because instrumentation and methods for the measurement of radionuclides were new technologies. Much of the early data consists of gross measurements of, for example, total beta or total alpha activity. Because water samples could be taken with relative ease, compared with the difficulty of taking stack samples for airborne discharge, estimates of historic liquid releases are better recorded than gaseous releases. Table 2.8-2 contains historical data for liquid releases from ORNL. These occurred at the location of White Oak dam. Prior to the early 1960 s, airborne releases were evaluated by combinations of calculations and relatively crude sampling methods. Data for historic airborne effluents are presented in Table 2.8-3.

\subsection{Radiological Effluents for the Most Recent Year}

The gaseous emission point sources for ORNL consist of the following eight stacks located in Bethel and Melton Valleys:

Building 2026

Building 3020

Building 3039

Building 7911

Building 7025

Building 7830

Building 7512

Building 6010

\section{Description of major sources}

High Radiation Level Analytical Laboratory

Radiochemical Processing Plant

3500 and 4500 areas cells ventilation systems

Central off-gas and scrubber system

Isotope Solid State ventilation system

3025 and 3026 area cell ventilation system

Melton Valley complex (HFIR)

Radiochernical Engineering Development Center

\section{Description of minor sources}

Tritium Target Fabrication Facility

Melton Valley Storage Tank Facility

Molten Salt Reactor Facility Project

Electron Linear Accelerator Facility 
Table 28-2. Annual discharges of radionuclides from White Oak Creek to the Clinch River, 1944 to 1990

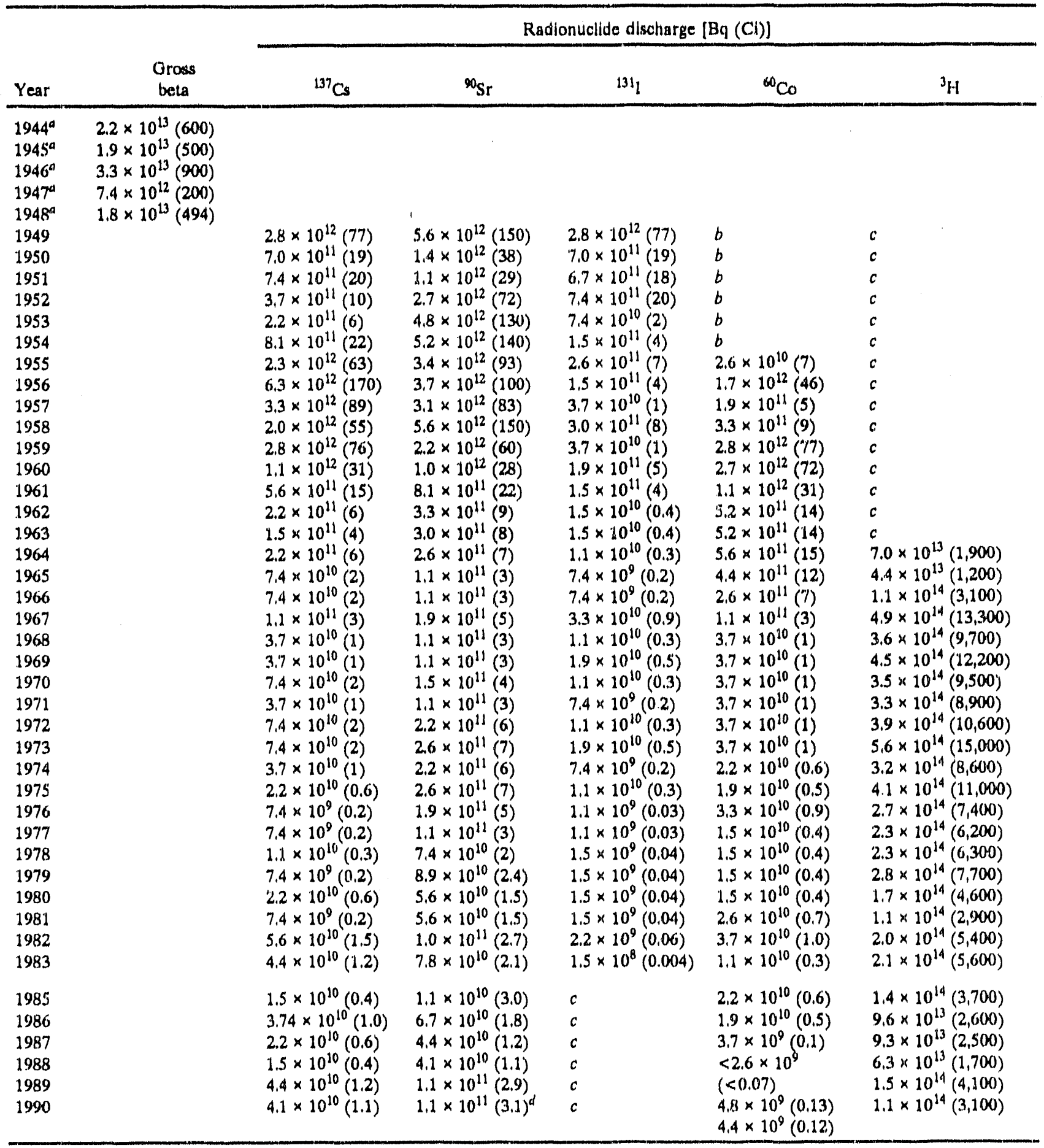

andividual radionuclide data nol avallable

bNo analysis performed.

'Not roported.

Total radlonctive $\mathrm{Sr}\left({ }^{89} \mathrm{Sr}+{ }^{90} \mathrm{Sr}\right)$.

Source: Ohnesorge, W. F, 1986. Historical Releases of Radioactivity to the Environmenil from ORNL, ORNLMM-135, Oak Ridge National Laboratory, Oak Ridge, Tenn., Kotnegay, F. C, of al. 1991. Oak Ridge Reserwation Environinential Report for 1990, Vol. 1, ORNLJES/ESH.18/VI, Oak RIIge National Laboralory, Oak Rudge, Teau. 
Table 2.8-3. Estimated atmospheric releases of radioactivity at Oak Ridge National Laboratory

\begin{tabular}{|c|c|c|c|c|c|}
\hline \multirow[b]{2}{*}{ Year } & \multicolumn{4}{|c|}{ Radionuclide discharge } & \multirow{2}{*}{$\begin{array}{l}\text { Unidontified } \\
\text { alpha }[\mathrm{Bq}(\mathrm{Ci})]\end{array}$} \\
\hline & ${ }^{131} 1$ & ${ }^{3} \mathrm{H}$ & ${ }^{w_{\mathrm{Kr}}}$ & ${ }^{201} \times \mathbf{X}$ & \\
\hline 1990 & $7.4 \times 10^{8}(0.02)$ & $7.4 \times 10^{14}(20,000)$ & $5.7 \times 10^{14}(15,300)$ & $2.8 \times 10^{15}(74,700)$ & \\
\hline 1989 & $1.1 \times 10^{9}(0.029)$ & $1.0 \times 10^{15}(28,000)$ & $5.9 \times 10^{14}(16,000)$ & $2.9 \times 10^{15}(79,000)$ & \\
\hline 1988 & $2.1 \times 10^{4}(0,056)$ & $7.8 \times 10^{14}(21,000)$ & $2.3 \times 10^{14}(6,300)$ & $1.1 \times 10^{15}(31,000)$ & \\
\hline 1987 & $7.0 \times 10^{8}(0.019)$ & $1.6 \times 10^{15}(44,000)$ & $1.7 \times 10^{14}(4,700)$ & $8.5 \times 10^{14}(23,000)$ & \\
\hline 1986 & $<1.3 \times 10^{9}(<0.035)$ & $1.1 \times 10^{15}(31,000)$ & $4.1 \times 10^{14}(11,000)$ & $1.9 \times 10^{15}(51,000)$ & \\
\hline 1985 & $3.2 \times 10^{9}(0.086)$ & $7.4 \times 10^{15}(20,000)$ & $2.4 \times 10^{14}(6,600)$ & $1.2 \times 10^{15}(32,000)$ & $3.6 \times 10^{3}\left(9.6 \times 10^{.8}\right)$ \\
\hline 1984 & $3.7 \times 10^{9}(0.10)$ & $1.2 \times 10^{15}\left(33,400^{\circ}\right)$ & $5.5 \times 10^{14}(14,900)$ & $2.7 \times 10^{15}(72,700)$ & $1.6 \times 10^{3}\left(4.3 \times 10^{-5}\right)$ \\
\hline 1983 & $1.9 \times 10^{9}(0.05)$ & $8.2 \times 10^{11}(22,200)$ & $4.4 \times 10^{14}(11,900)$ & $2.1 \times 10^{15}(57,700)$ & $1.0 \times 10^{5}\left(2.7 \times 10^{6}\right)$ \\
\hline 1982 & $4.8 \times 10^{9}(0.13)$ & $7.0 \times 10^{14}(19,000)$ & $4.3 \times 10^{14}(11,700)$ & $2.1 \times 10^{15}(57,100)$ & $2.9 \times 10^{3}\left(7.8 \times 10^{+8}\right)$ \\
\hline 1981 & $1.9 \times 10^{10}(0.50)$ & $4.2 \times 10^{14}(11,300)$ & $2.5 \times 10^{14}(6,700)$ & $1.2 \times 10^{15}(32,400)$ & $1.8 \times 10^{5}\left(4.9 \times 10^{-6}\right)$ \\
\hline 1980 & $8.1 \times 10^{9}(0.22)$ & $5.5 \times 10^{14}(14,800)$ & $3.3 \times 10^{14}(8,800)$ & $1.6 \times 10^{13}(42,800)$ & $1.8 \times 10^{5}\left(4.8 \times 10^{6}\right)$ \\
\hline 1979 & $1.1 \times 10^{10}(0.30)$ & $1.9 \times 10^{14}(5,109)$ & $3,9 \times 10^{14}(10,500)$ & $1.9 \times 10^{15}(51,190)$ & $1.5 \times 10^{5}\left(4.0 \times 10^{6}\right)$ \\
\hline 1978 & $6.3 \times 10^{10}(1.70)$ & $9.3 \times 10^{13}(2,500)$ & $4.4 \times 10^{14}(12,000)$ & $2.2 \times 10^{15}(59,000)$ & $1.5 \times 10^{5}\left(4.0 \times 10^{-6}\right)$ \\
\hline 1977 & $5.1 \times 10^{10}(1.37)$ & $9.3 \times 10^{13}(2,524)$ & $3.2 \times 10^{14}(8,606)$ & $1.6 \times 10^{15}(42,030)$ & $1.5 \times 10^{5}\left(4.0 \times 10^{-6}\right)$ \\
\hline 1976 & $4.6 \times 10^{10}(1.25)$ & $2.2 \times 10^{14}(6,019)$ & $4.3 \times 10^{14}(11,500)$ & $2.0 \times 10^{15}(54,0000)$ & $1.5 \times 10^{3}\left(4.0 \times 10^{-6}\right)$ \\
\hline 1975 & $7.8 \times 10^{10}(2.10)$ & $2.0 \times 10^{13}(534)$ & $6.5 \times 10^{14}(17,700)$ & $3.2 \times 10^{15}(87,500)$ & $1.5 \times 10^{5}\left(4.0 \times 10^{-6}\right)$ \\
\hline 1974 & $7.3 \times 10^{10}(1.97)$ & $2.0 \times 10^{13}(555)$ & $7.4 \times 10^{14}(20,000)$ & $3.7 \times 10^{15}(99,200)$ & $1.5 \times 10^{5}\left(4.0 \times 10^{-6}\right)$ \\
\hline 1973 & $8.1 \times 10^{10}(2.18)$ & $3.4 \times 10^{14}(9,100)$ & $5.2 \times 10^{14}(14,000)$ & $2.5 \times 10^{15}(68,600)$ & $1.5 \times 10^{5}\left(4.0 \times 10^{-6}\right)$ \\
\hline 1972 & $6.3 \times 10^{10}(1.70)$ & $6.7 \times 10^{13}(1,800)$ & $5.7 \times 10^{14}(15,400)$ & $2.4 \times 10^{15}(64,900)$ & $b$ \\
\hline 1971 & $1.3 \times 10^{11}(3.46)$ & $b$ & $5.6 \times 10^{14}(15,000)$ & $2.6 \times 10^{15}(71,000)$ & $b$ \\
\hline 1970 & $5.3 \times 10^{10}\left(1.43^{c}\right)$ & $b$ & $5.6 \times 10^{14}(15,000)$ & $2.8 \times 10^{15}(75,000)$ & $b$ \\
\hline 1969 & $6.1 \times 10^{11}(16.38)$ & $b$ & $b$ & $b$ & $b$ \\
\hline 1968 & $3.8 \times 10^{11}(10.38)$ & $b$ & $b$ & $b$ & $b$ \\
\hline 1967 & $8.3 \times 10^{11}(22.30)$ & $b$ & $b$ & $b$ & $b$ \\
\hline 1966 & $5.8 \times 10^{11}(15.7 / 9)$ & $b$ & $b$ & $b$ & $b$ \\
\hline 1965 & $6.8 \times 10^{11}(18.40)$ & $b$ & $b$ & $b$ & $b$ \\
\hline 1964 & $3.1 \times 10^{12}(84.50)$ & $b$ & $\boldsymbol{b}$ & $b$ & $b$ \\
\hline 1963 & $2.0 \times 10^{12}(54.00)$ & $b$ & $b$ & $b$ & $b$ \\
\hline 1962 & $4.5 \times 10^{12}\left(121.20^{d}\right)$ & $b$ & $b$ & $b$ & $b$ \\
\hline 1961 & $1.6 \times 10^{12}(42.00)$ & $b$ & $b$ & $b$ & \\
\hline
\end{tabular}

afirst tritium releave estimate developed from monitoring data rather than from a calculation based on radionuclide.

"No dala.

'First eatimate reflecting the effects of an upgraded charvoal filter nystem.

First catimate based on in-atack sampling information.

Source: Ohneworge, W. F. 1986. Historical Releases of Radioactivly to the Environment from ORNL; ORNLM-135, Oak Ridge National Laboratory, Oak Ridge, Tetın., Kornegay, F, C., et al. 1990. Oak Ridge Reservation Environnental Report for 1990, Vol 1, ORNL/ES/ESH-18N1, Oak Ridge National Laboratory, Oak Ridge, Tenn. 


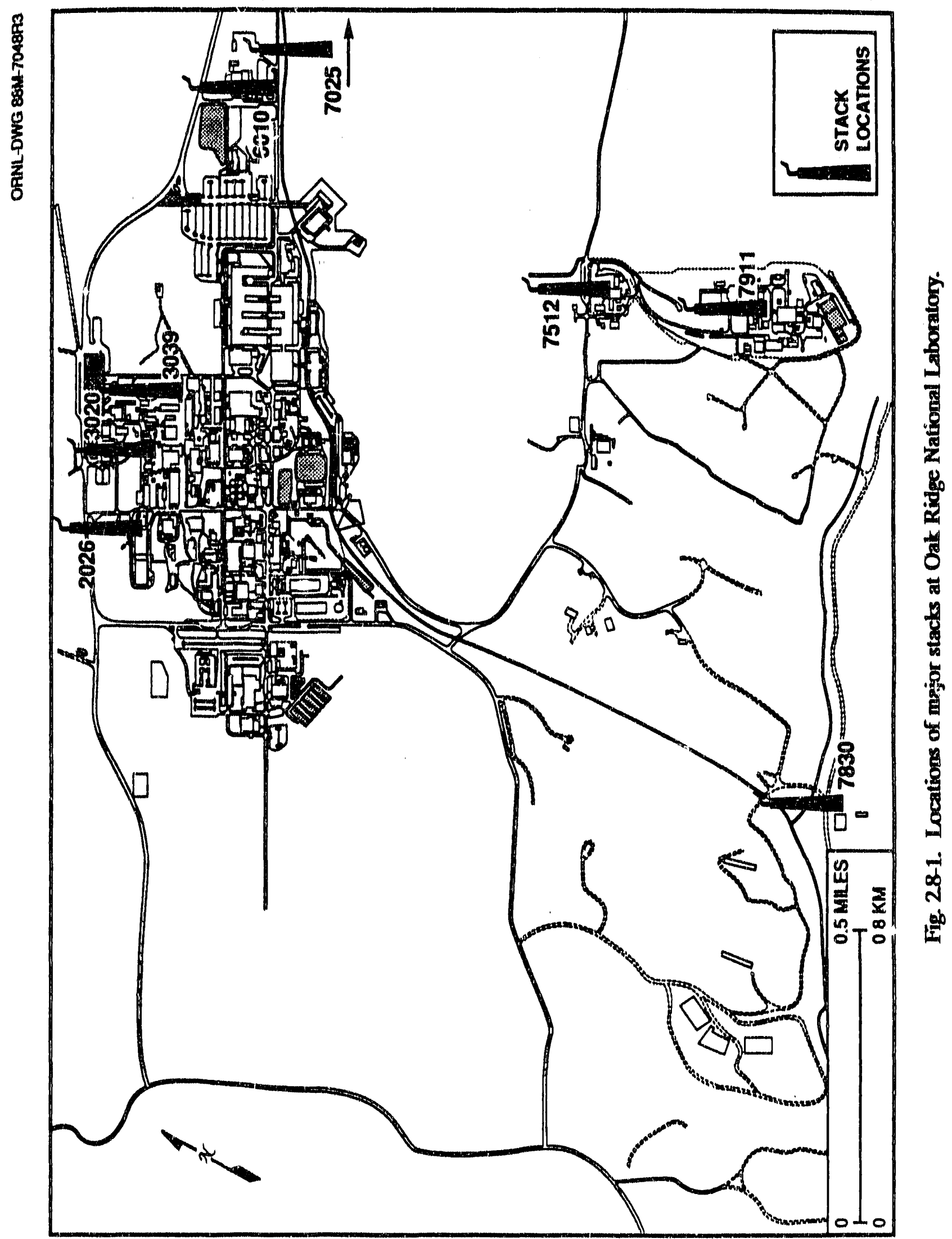


Discharges from each stack are unique because of the wide variety of research activities performed at ORNL. Radiological gaseous emissions from ORNL typically consist of solid particulates, adsorbable gases (e.g., lodine), tritium, and nonabsorbable gases. Typically, contaminated and potentially contaminated gaseous wastes are treated, then filtered with high-efficiency particulate air (HEPA) and charcoal filters before discharge to ensure that any radioactivity released is within acceptable levels.

\subsubsection{Airborne Emissions Sampling}

Each of the point sources identified in Fig. 2.8-1 has a variety of surveillance instrumentation, including radiation alarms, near-real-time monitors, and continuous sample collectors. Only data resulting from analysis of the continuous samples are used in this report. The other equipment does not provide data accurate enough to support the quantitation of emission source terms. The single exception is for noble gases, which must be evaluated with a monitoring chamber because those radionuclides cannot be quantitatively captured on a sampling medium.

Data are presented for all areas except the Electron Linear Accelerator Facility (Building 6010), where continuous sampling equipment is not currently installed. The Electron Linear Accelerator Facility exhibits extremely low concentrations of isotopes with very short half-lives. Consequently, this stack has virtually no impact on the radiation dose associated with the operation of ORNL.

Sampling systems generally consist of in-stack sampling probes, sample transport piping, a particulate filter, an activated charcoal canister, a silica-gel tritium trap, flow measurement and totalizing instruments, a sampling pump, and return piping to the stack. The sampling system for the Tritium Target Fabrication Facility is configured with a tritiun trap only. The sampling systems at Buildings 2026, 3020, and 7512 do not have tritium traps.

Data sources for the various isotopes identified in the 1990 airborne emission source term are shown in Table 2.8-4. Tritium data were generated by inventory for Building 3039 and by sampling for Buildings 7911 and 7025. Consequently, there is a double entry for tritium in the table. Other double entries are for isotopes that are captured by more than one sampling medium. The 1990 radioactive airborne ennissions data included 25 isotopes and 5 gross parameters captured from 5 data sources. Table 2.8-4 provides a listing of isotopes and gross parameters and the media from which they were captured. The charcoal filters, particulate filters, and silica-gel traps were collected weekly. During 1990, the weekly tritium samples were composited biweekly for analysis. Charcoal filters are a standard method for capturing and guantifying radioactive iodines in airborne emissions. Gamma spectrometric analysis of the charcoal traps identified nine additional noniodine isotopes, as shown in Table 2.8-4.

Particulate filters were held for $8 \mathrm{~d}$ prior to analysis to minimize the contribution from short-lived isotopes. A study conducted during 1989 and 1990 (Tardiff and Wolf 1991) showed the short-lived gross alpha and gross beta signature of the stacks to be primarily associated with ${ }^{220} \mathrm{Rn}$ and its daughter products. This decay series is quantified through measurements of ${ }^{212} \mathrm{~Pb}$ on the activated charcoal filter. If the short-lived gross alpha and beta were included, the emissions of ${ }^{220} \mathrm{Rn}$ and its daughters would be counted 
Table 28-4. Oak Ridge National Laboratory radioactive airborne emissions data sources, 1990

\begin{tabular}{|c|c|c|c|c|c|}
\hline Isotope & $\begin{array}{l}\text { Charcoal } \\
\text { filter }\end{array}$ & $\begin{array}{l}\text { Weekly } \\
\text { particulate } \\
\text { filter }\end{array}$ & $\begin{array}{l}\text { Particulate } \\
\text { composite }\end{array}$ & $\begin{array}{l}\text { Monitoring } \\
\text { or } \\
\text { iniventory }\end{array}$ & $\begin{array}{c}\text { Silica } \\
\text { gel }\end{array}$ \\
\hline${ }^{194} \mathrm{Au}$ & $X^{a}$ & & & & \\
\hline${ }^{7} \mathrm{Be}$ & & & $\mathbf{X}$ & & \\
\hline${ }^{82} \mathrm{Br}$ & $\mathrm{x}$ & & & & \\
\hline${ }^{60} \mathrm{Co}$ & $\mathrm{x}$ & & $\mathbf{X}$ & & \\
\hline${ }^{134} \mathrm{Cs}$ & & & $\mathrm{X}$ & & \\
\hline${ }^{137} \mathrm{Cs}$ & $\mathbf{X}$ & & $\mathrm{x}$ & & \\
\hline${ }^{154} \mathrm{Eu}$ & & & $\mathrm{X}$ & & \\
\hline${ }^{155} \mathrm{Eu}$ & & & $\mathrm{x}$ & & \\
\hline Gross alpha & & $\mathrm{X}$ & & & \\
\hline Gross beta & & $\mathrm{X}$ & & & \\
\hline${ }^{129} \mathrm{I}$ & $\mathbf{X}$ & & & & \\
\hline${ }^{131} I$ & $\mathrm{X}$ & & $\mathbf{X}$ & & \\
\hline${ }^{132} I$ & $\hat{\mathrm{x}}$ & & & & \\
\hline${ }^{133} \mathrm{I}$ & $\mathrm{X}$ & & & & \\
\hline${ }^{135} \mathrm{I}$ & $\mathrm{x}$ & & & & \\
\hline${ }^{140} \mathrm{La}$ & & & $\mathbf{x}$ & & \\
\hline${ }^{191} \mathrm{Os}$ & $\mathrm{X}$ & & $\mathrm{x}$ & & \\
\hline${ }^{212} \mathrm{~Pb}$ & $\mathrm{X}$ & & $\mathrm{x}$ & & \\
\hline${ }^{238} \mathrm{Pu}_{\mathrm{u}}$ & & & $\mathrm{x}$ & & \\
\hline${ }^{239} \mathrm{Pu}$ & & & $\mathrm{X}$ & & \\
\hline${ }^{106} \mathrm{Ru}$ & $\mathrm{x}$ & & $X$ & & \\
\hline${ }^{75} \mathrm{Se}$ & $\mathrm{X}$ & & & & \\
\hline Total Sr & & & $\mathbf{X}$ & & \\
\hline${ }^{132} \mathrm{Te}$ & $\mathbf{X}$ & & $\mathrm{x}$ & & \\
\hline${ }^{208} \mathrm{Th}$ & & & $\mathrm{x}$ & & \\
\hline${ }^{230} \mathrm{Th}$ & & & $\mathrm{X}$ & & \\
\hline${ }^{232} \mathrm{Th}$ & & & $\mathrm{X}$ & & \\
\hline Total & & & $\mathrm{X}$ & & \\
\hline Noble gas & & & & $x$ & \\
\hline Tritium & & & & $x$ & $\mathrm{X}$ \\
\hline
\end{tabular}

$\mathrm{X}=$ monitoring method.

Source: Kornegay, F. C., et al. 1991. Oak Ridge Reservation Environmental Report for 1990 , ORNL/ES/ESH-18/N1, Oak Ridge National Laboratory, Oak Ridge, Tenn., p. 26.

twice. These samples were analyzed for gross alpha and gross beta, because radioactive particulates are typically alpha and beta emitters. These data are not used in close calculations because an assumption about the contributing isotope would be necessary. Instead, the particulate filters are composited quarterly and analyzed for alpha and beta emitting isotopes, and these data are used for dose assessment. Compositing provides an opportunity to evaluate the lower specific activity radionuclides in the emissions. 
Identification and quantification of this group is initially confounded by the presence of short-lived isotopes.

Noble gas emissions from the stacks at Buildings 3039 and 7911 were derived from real-time monitoring data. Noble gases are chemically inert and, consequently, cannot be trapped on a collecting medium for analysis. Instead, after the monitoring system gas stream has passed through the particulate filter and charcoal trap, a part of the stream is pumped through a lead-shielded chamber equipped with a beta-gamma detecting monitor. The implicit assumption is that the upstream collecting media have removed all but the noble gases. Noble gas monitor data are accrued as 10-min and 1-h averages of counts per minute in the real-time monitoring system. Each of the chambers has been calibrated with ${ }^{85} \mathrm{Kr}$ at two concentrations. The calibration results can be used to convert counts per minute into noble gas activity as ${ }^{85} \mathrm{Kr}$. The 1990 noble gas emissions are based on the median counts-per-minute value for January through December 1990. The median counts per min we was then converted to an annual noble gas emission as ${ }^{85} \mathrm{Kr}$ by using the calibration data.

Data from silica-gel traps were used to calculate tritium emissions from the stacks at Buildings 7025 and 7911 . Tritium emissions from the 3039 stack area were based upon monthly inventory data of incoming and outgoing shipments and calculated net losses.

\subsubsection{Radioactive Airborne Emissions}

The total radioactive airborne emissions for ORNL during the calendar year 1990 are presented in Table 2.8-5. The table lists the total emission for each radionuclide and gross parameter and the percent of the total contributed by each stack. The percent values are based on summed emissions from each stack for the year. Sums for individual radionuclides were tested for statistical significance using laboratory counting uncertainties. If the $95 \%$ lower bound calculated from the variance of the sum is greater than zero, then the sum is determined to be significantly different from zero. The noble gas source term was assumed to be $83 \%{ }^{133} \mathrm{Xe}$ and $17 \%{ }^{85 m} \mathrm{Kr}$, based on data collected at HFIR. An assessment of the potential impacts of the emission source term to the public is presented in Sect. 2.8.5.

The tritium source term is lower than that of 1989 (Table 2.8-3). The increase of $2.6 \times 10^{14} \mathrm{~Bq}(7000 \mathrm{Ci})$ in 1989 over the 1988 level was within the error associated with estimating losses through inventory calculations at Stack 3039. This method of accounting has been revised to improve the estimates, and emissions at Stack 3039 for 1990 are lower by a factor of two from the 1989 value. In addition, tritium emissions from Stack 7025 were reduced as production work ended at the Tritium Target Fabrication Facility.

\subsubsection{Liquid Discharges}

Evaluation of health and environmental effects resulting from liquid radioactive discharges is made on the basis of concentrations of radinnuclides measured at the final point of discharge from ORNL in addition to samples coliected for radiological analyses at off-site locations and at background or reference locations. Treated water samples downstream of White Oak creek outfall are collected weekly at the Kingstor. and the K-25 Site (Gallaher) potable water treatment plants and are analyzed quarterly. In addition, flow-proportional samples are collected weekly at Melton Hill Dam and analyzed monthly. This sampling location, which is on the Clinch River, is above ORNL's discharge point to 


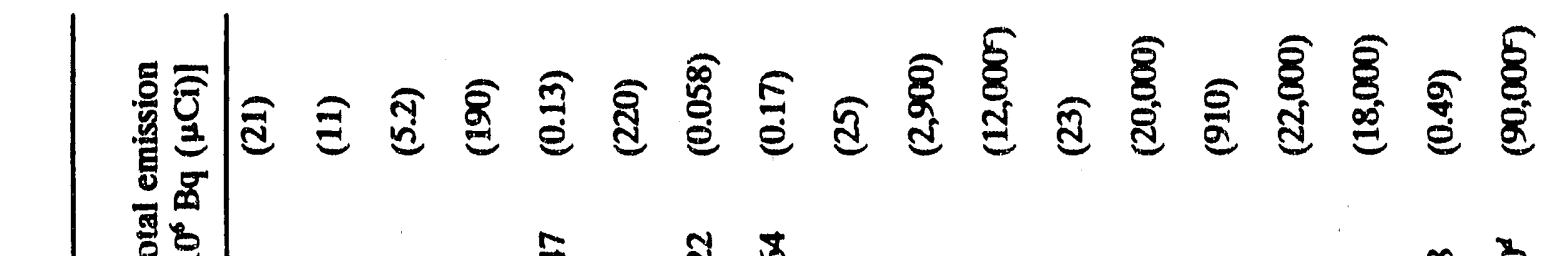

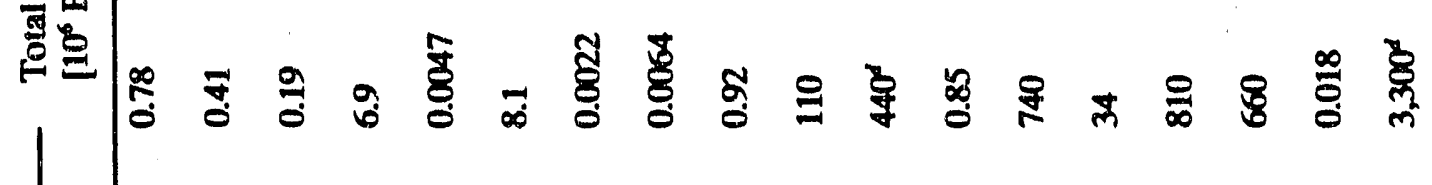

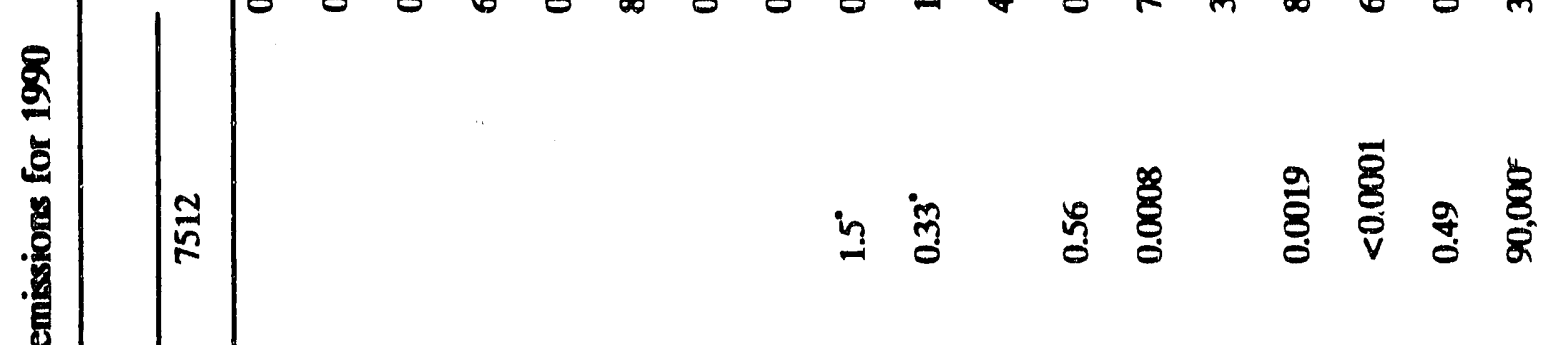

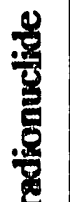

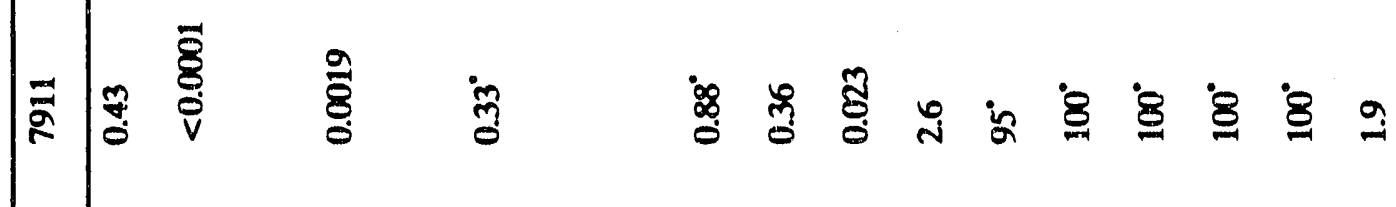

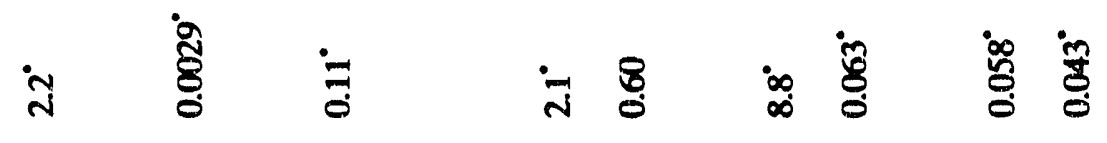

$$
\begin{aligned}
& \text { ₹ }
\end{aligned}
$$

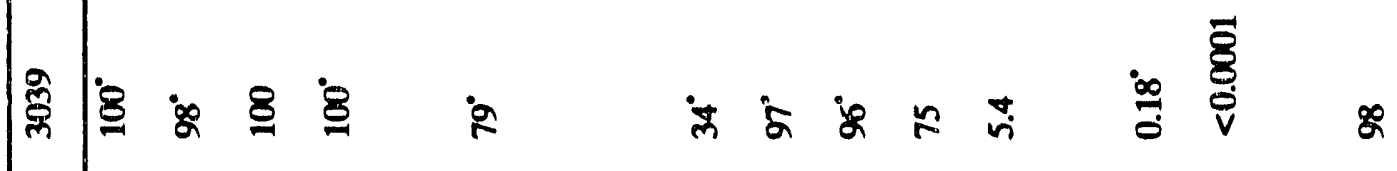

$$
\begin{aligned}
& \frac{1}{8}
\end{aligned}
$$

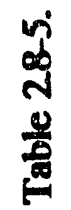

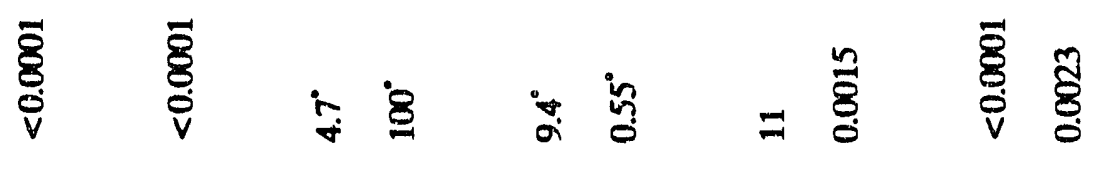

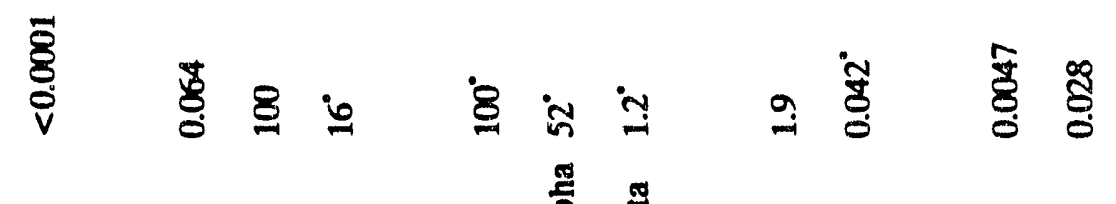

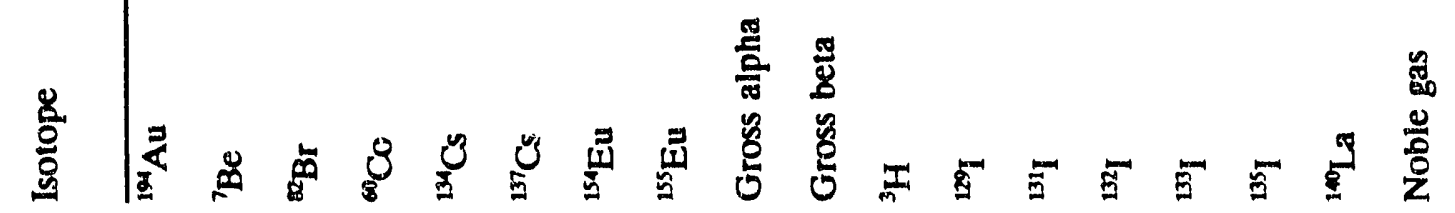




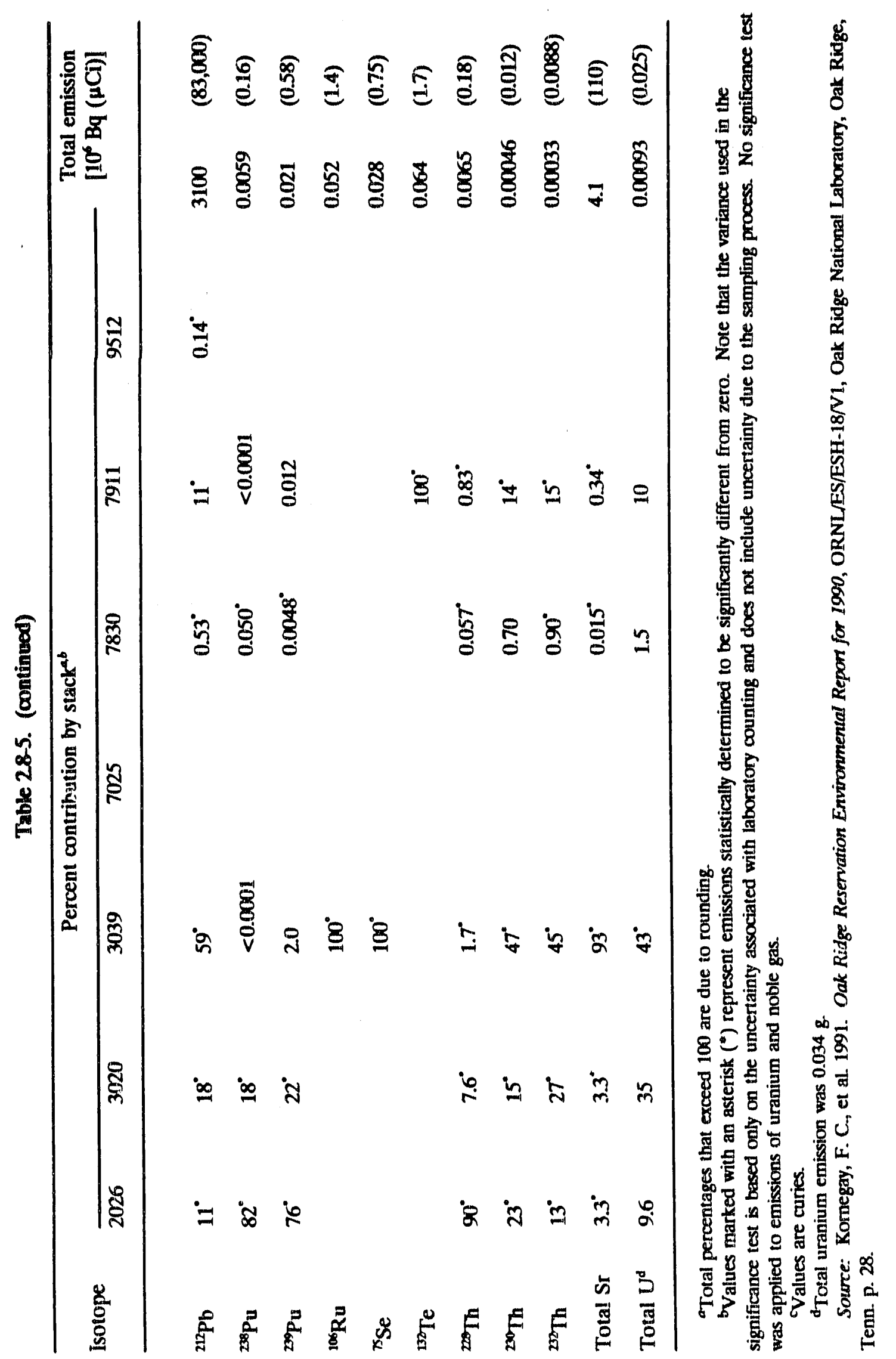


the Clinch River (with the exception of the cooling tower, roof, and parking lot runoff at the 7600 area) and serves as a local background or reference station. The complement of analyses performed on Melton Hill Dam (and White Oak Creek headwaters) samples was reduced to a gamma scan and gross alpha and beta determinations because of the historically low levels observed there. If certain gross alpha and beta thresholds are exceeded, specific isotopic analyses are performed.

Discharges of radioactivity at ORNL's final release point to the Clinch River, White Oak Dam, are summarized in Table 2.8-6. These discharges are calculated by multiplying the concentration for the period (month or week) by the flow volume. At White Oak Dam, weekly flow-proportional samples are analyzed. A flow-weighted concentration is calculated for each radionuclide. The discharge is calculated by multiplying flow-weighted concentration by the total annual flow.

Table 28-6. Oak Ridge National Laboratory liquid radioactive discharges measured at White Oak Dam for 1990

\begin{tabular}{ll}
\hline Radionuclide & Effluent [Bq (Ci)] \\
\hline${ }^{60} \mathrm{Co}$ & $4.4 \times 10^{9}(0.12)$ \\
${ }^{137} \mathrm{Cs}$ & $4.1 \times 10^{10}(1.1)$ \\
Gross alpha $^{a}$ & $2.9 \times 10^{9}(0.079)$ \\
Gross beta $^{b}$ & $2.5 \times 10^{11}(6.8)$ \\
${ }^{191} \mathrm{Os}$ & $5.2 \times 10^{8}(0.014)$ \\
Total Sre & $1.15 \times 10^{11}(3.1)$ \\
${ }^{3} \mathrm{H}$ & $1.15 \times 10^{14}(3100)$ \\
Total U & $460^{d}$ \\
${ }^{234} \mathrm{U}$ & $2.4 \times 10^{7}(0.00066)$ \\
${ }^{235} \mathrm{U}$ & $8.1 \times 10^{6}(0.00022)$ \\
${ }^{238} \mathrm{U}$ & $4.4 \times 10^{6}(0.00012)$ \\
\hline
\end{tabular}

"If gross alpha is greater than $1.0 \mathrm{~Bq} / \mathrm{L}(27 \mathrm{pCi} / \mathrm{L}$ ), then the contents are analyzed for $\mathrm{Am}, \mathrm{Cm}, \mathrm{Pu}, \mathrm{Th}$, and $\mathrm{U}$.

'If gross beta is greater than $30.0 \mathrm{~Bq} / \mathrm{L}(810 \mathrm{pCl} / \mathrm{L})$, the contents are analyzed for total radioactive strontium.

Total radiaactive $\mathrm{Sr}\left({ }^{*} \mathrm{Sr}+{ }^{*} \mathrm{Sr}\right)$.

Total U measured in grams.

Source: Kornegay, W. F., et al. 1991. Oak Ridge Reservation Environmental Report for 1990, ORNL/ES/ESH-18/V1, Oak Ridge National Laboratory, Oak Ridge, Tenn., p. 67.

\subsection{Euvironmental Monitoring Program}

While air and water are important pathways for human exposure to radiation, other pathways must also be monitored. Environmental surveillance programs also include biotic and additional abiotic media that may be affected by these releases or may provide pathways of exposure to people. Such media samples are taken to support the environmental surveillance of the entire ORR facilities. Only when specific radionuclides are uniquely associated with a specific ORR site (e.g., ORNL) can they be attributed to that site. 
28.4.1 Milk

One of the pathways of radioactivity to humans is ingestion. Radionuclides can be transferred from the environment to humans through food chains such as the grass-cowmilk pathway. Milk is a potentially significant source to humans of some radionuclides deposited from airborne emissions because of the relatively large surface area that can be grazed daily by the cow, the rapid transfer of milk from producer to consumer, and the importance of milk in the diet. The 1990 milk sampling program consisted of monthly grab samples collected from five locations in the vicinity of ORR. Figure 2.8-2 shows the locations of the stations.

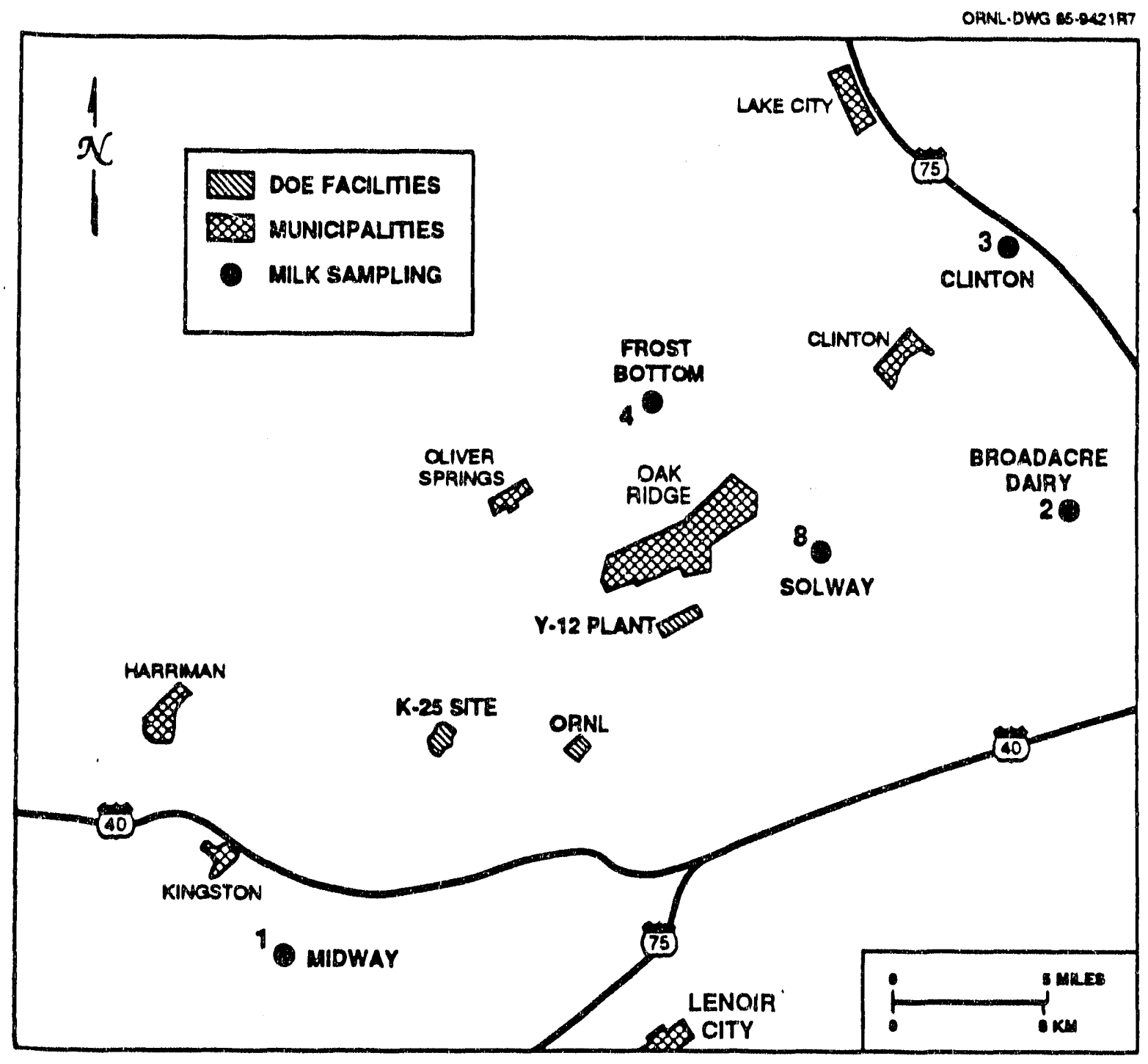

Fig. 28-2 Map showing milk-sampling stations. 
Milk samples are analyzed at ORNL for ${ }^{131}$ I by gamma spectrometry and for total radioactive strontium $\left({ }^{89} \mathrm{Sr}\right.$ and ${ }^{90} \mathrm{Sr}$ ) by chemical separation and by low background beta counting. These radioisotopes are likely to have their origins at ORNL. Concentrations of ${ }^{131}$ I and total radioactive strontium in milk are summarized for the 1990 data in Table 2.8-7. The average values from these samples were converted to effective dose equivalents and are presented later, in Sect. 2.8.5. Results of these samples are consistent with data from previous years. Additional location-specific data can be found in Vol. 2, Tables 5.1 and 5.2 of Kornegay et al. 1991 (p. 178).

Table 28-7. Radionuclide concentrations in raw mill in $1990^{\circ}$

\begin{tabular}{llllll}
\hline & & \multicolumn{4}{c}{$\begin{array}{c}\text { Concentration } \\
{[\mathrm{Bq} / \mathrm{L}(\mathrm{pCi} / \mathrm{L})]}\end{array}$} \\
\cline { 2 - 7 } Analysis & $\begin{array}{c}\text { Number of } \\
\text { samples }\end{array}$ & Maximum & Minimum & Average $^{b}$ & $\begin{array}{c}\text { Standard } \\
\text { error }\end{array}$ \\
\hline${ }^{131} \mathrm{I}$ & 56 & $0.1(2.7)$ & $0.089(-2.4)^{d}$ & $0.0048(-0.13)$ & $0.056(0.15)$ \\
Total Sre & 56 & $0.63(17)$ & $0.007(-0.19)$ & $0.10\left(2.7^{*}\right)$ & $0.013(0.35)$ \\
\hline
\end{tabular}

SSee Fig. 28-2.

${ }^{b}$ An asterisk $\left.{ }^{\circ}\right)$ indicates that the average is significantly greater than zero at $95 \%$ confidence level.

'Standard error of the mean.

Because of the intrinsic uncertainty associated with making radiation measurements, it is possible to subtract a background value from a sample result and get a negative number.

Total radioactive strontium $\left({ }^{80} \mathrm{Sr}+{ }^{80} \mathrm{Sr}\right)$.

\subsubsection{Fish}

Ingestion of fish is a pathway for contaminant uptake in humans. Prior to 1985, five types of fish (bluegill, catfish, bass, carp, and crappie) were measured for polychlorinated biphenyls (PCBs), mercury, and radionuclide concentrations. Carp exhibited the highest mercury and PCB concentrations, followed by bluegill. The highest concentrations of several radionuclides were found in bluegill. Because of this and because of the large number of available fish, bluegill (Lepomis macrochirus) were collected during 1990 for tissue analysis to estimate concentrations for dose assessment models. Additionally, bluegill are favored by sport fishermen in Tennessee and can be obtained in the large numbers required for tissue analysis.

Bluegill from three Clinch River locations were collected by ORNL twice during the year for muscle analyses for radionuclide, mercury, and PCB concentrations (Fig. 2.8-3; Table 2.8-8). Sampling locations include three Clinch River kilometer locations (CRKs). The first location is CRK 40.0 (river mile 24.8), which is above Melton Hill Dam and serves as a background location for the DOE facilities. The first sampling location is above all the Oak Ridge DOE facilities' outfalls with the exception of those from the ORNL 7600 area, the radioactive effluents from which are negligible. The second sampling location is CRK 33.3 (river mile 20.6), which is ORNL's discharge point from White Oak Creek to the Clinch River. The third location is CRK 8.0 (river mile 5), which is downstream from both ORNL and the K-25 Site. 


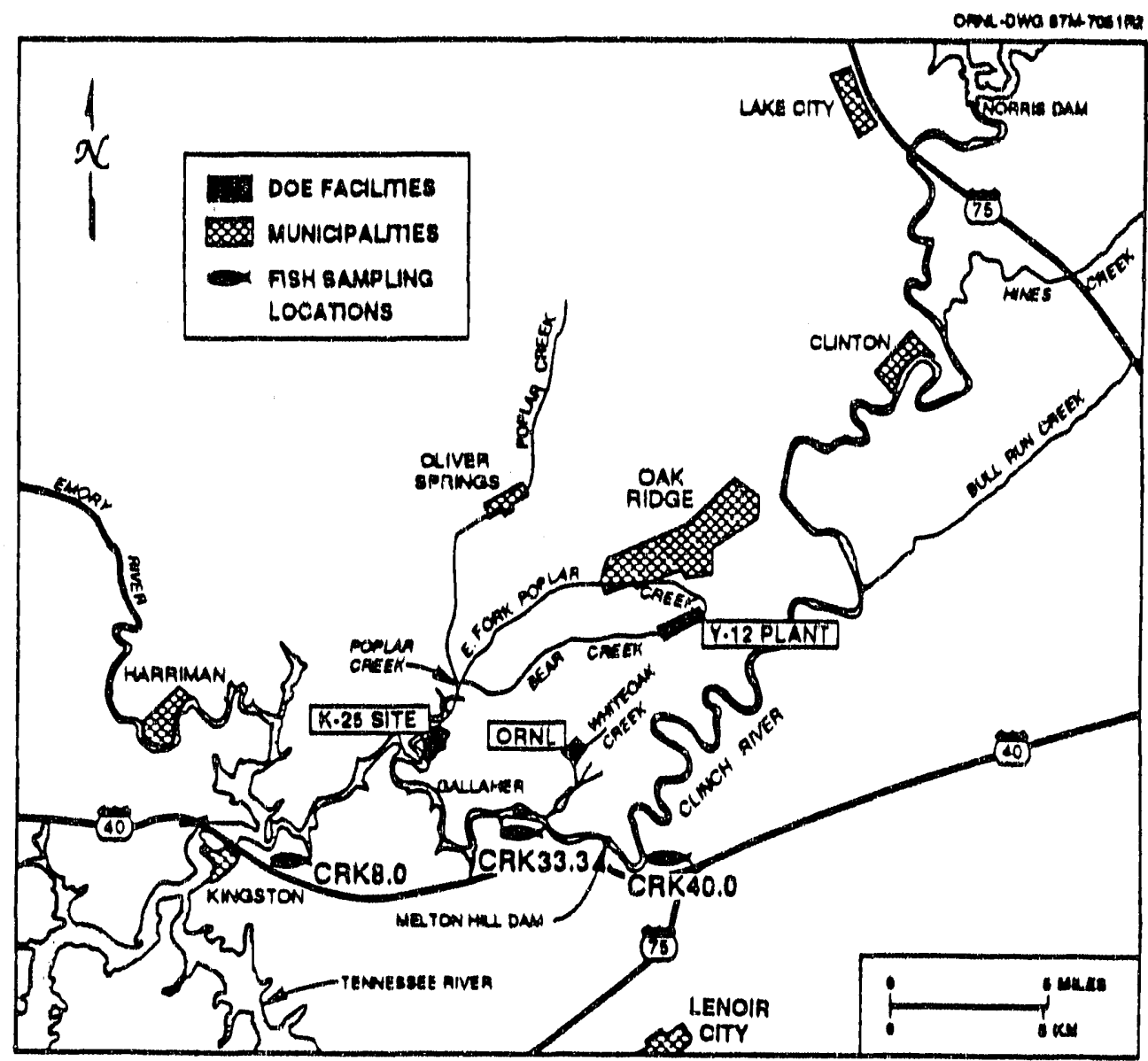

Fig. 2.8-3. Fish-sampling locations along the Clinch River.

Total radioactive strontium and ${ }^{137} \mathrm{Cs}$ are the primary radionuclides of concern at ORNL with regard to fish consumption. These two elements result in the highest dose to man from ingestion of fish. Radionuclide concentrations were determined on at least three composites of six to ten fish per sampling period. Mercury and PCB concentrations were also measured in six individual fish from each sampling location during each period. Each fish was filleted, and only the muscle tissue was used for analysis. Composite samples were ashed and analyzed by gamma spectrometry and radiochemical techniques for the radionuclides that contribute the majority of the potential radionuclide dose to humans. The ash typically constitutes $1 \%$ of the original sample. DOE Order 5400.1 requires that concentrations be reported in picoCuries per gram ash weight.

Concentrations of mercury, $\mathrm{PCBs},{ }^{60} \mathrm{Co},{ }^{137} \mathrm{Cs}$, and total radioactive strontium in bluegill collected in the Clinch River are given in Table 2.8-8, which provides a summary of the highest, lowest, and average concentrations of these parameters observed in bluegill from any of the three Clinch River locations. Information regarding potential health impacts associated with these data is provided in Sect. 2.8.5. 
Table 28-8. Tissue concentrations of Clinch River blucgill in $1990^{\circ}$

\begin{tabular}{|c|c|c|c|c|c|}
\hline \multirow[b]{2}{*}{ Analysis } & \multicolumn{5}{|c|}{ Concentration ${ }^{b}$} \\
\hline & $\begin{array}{c}\text { Number of } \\
\text { samples }\end{array}$ & Maximum & Minimum & Average & $\begin{array}{l}\text { Standard } \\
\text { orrord }\end{array}$ \\
\hline $\begin{array}{l}{ }^{60} \mathrm{Co}, \mathrm{Bq} / \mathrm{g}(\mathrm{pCl} / \mathrm{g}) \\
{ }^{137} \mathrm{Cs}, \mathrm{Bg} / \mathrm{g}(\mathrm{pCl} / \mathrm{g}) \\
\mathrm{Total} \mathrm{Sr} \mathrm{Bq} / \mathrm{g}(\mathrm{pCl} / \mathrm{g}) \\
\mathrm{Hg}_{\mathrm{g}} \\
\mathrm{PCB} \text { Aroclor } 1254 \\
\mathrm{PCB} \text { Aroclor } 1260\end{array}$ & $\begin{array}{l}18 \\
18 \\
18 \\
36 \\
36 \\
36\end{array}$ & $\begin{array}{l}0.02(0.54) \\
0.96(26) \\
0.2(5.4) \\
0.46 \\
<0.54 \\
<0.54\end{array}$ & $\begin{array}{l}0.004(-0.11)^{4} \\
0.015(0.41) \\
0.001(-0.027) \\
<0.025 \\
<0.010 \\
0.010\end{array}$ & $\begin{array}{l}0.005\left(0.13^{\circ}\right) \\
0.24\left(6.4^{\circ}\right) \\
0.036\left(0.97^{\circ}\right) \\
<0.13 \\
<0.15 \\
<0.16\end{array}$ & $\begin{array}{l}0.0014(0.038) \\
0.067(1.8) \\
0.0115(0.31) \\
0.014 \\
0.027 \\
0.026\end{array}$ \\
\hline $\begin{array}{l}\text { See Fig. 2.8-3. } \\
\text { bRadionuclides are in } \\
\text { weight. } \\
\text { 'For radionuclides, an } \\
\text { the 95\% confidence liml } \\
\text { dStandand error abou } \\
\text { "Becaule of the Intrin } \\
\text { background number from } \\
\text { Fotal radioactive stro } \\
\text { ipCB = polychlorina } \\
\text { Souunce: Komegay, F } \\
\text { Oak Ridge National Lab }\end{array}$ & $\begin{array}{l}\text { g/s }(p C L / B) \text { as } \\
\text { teriak (") ind } \\
\text { verage. } \\
\text { uncerialnty } \\
\text { sample result } \\
\text { lum ("Sr and } \\
\text { biphenyl. } \\
\text { et al, } 1991 \text {. } \\
\text { tory, Oak Rio }\end{array}$ & $\begin{array}{l}\text { t. Mercury an } \\
\text { hat the averag } \\
\text { ed wilh making } \\
\text { to negative ni } \\
\text { idge Rearvatio } \\
\text { an. }\end{array}$ & $\begin{array}{l}\text { polychlorinaled } \\
\text { slgnificantly } \\
\text { adlation measur } \\
\text { ber. }\end{array}$ & $\begin{array}{l}\text { myl (PCB) unit } \\
\text { than zera at } \\
\text { It, it is possible }\end{array}$ & $\begin{array}{l}\text { MQ/g wet } \\
\text { ubtract a }\end{array}$ \\
\hline
\end{tabular}

A test for analysis of variance compared contaminant concentrations in fish from the different sampling locations. Mercury concentrations were significantly higher in fish from CRK 8.0 (river mile 5) than in fish from CRK 33.3 (river mile 20.7) and CRK 40.0 (river mile 25). The highest concentration of mercury was measured at CRK 8.0 $(0.46 \mu \mathrm{g} / \mathrm{g}$ wet weight). This relationship among the locations is consistent with data from 1988 and 1989. PCB concentration data among the three sampling sites were not statistically different at a confidence level of $95 \%$. No statistically significant differences in ${ }^{60} \mathrm{Co}$ were detected in fish collected at the three locations. Total radioactive strontium levels for fish from CRK 33.3 were higher than the other two stations, but the difference was not statistically different at the $95 \%$ confidence limit. Concentrations of ${ }^{137} \mathrm{Cs}$ were significantly higher in fish collected at CRK 33.0 (river mile 20.7) than in fish from the other two locations. Concentrations of ${ }^{137} \mathrm{Cs}$ in fish from CRK 8.0 and CRK 40 were not significantly different.

\subsubsection{ORR Deer Population}

The sixth annual DOE-TWRA managed deer hunts were held during the final quarter of 1990. Basic conduct of the managed hunts for 1990 was similar to those of previous years; however, they consisted of one archery hunt (October 20-21) and two shotgun--muzzle-loader hunts (November 10-11 and December 8-9). During the archery hunt 151 deer were taken, and 291 were killed during the two gun hunts. From the total harvest of 442 animals, 239 (54\%) were bucks and 203 (46\%) were does. The 1990 harvest of 442 is similar to that of 1989 , when 440 deer were taken. The heaviest buck had 12 antler points and weighed $86.6 \mathrm{~kg}(191 \mathrm{lb})$. The greatest number of points (13) were found on two bucks that weighed $68.5 \mathrm{~kg}$ and $74.8 \mathrm{~kg}(151 \mathrm{lb}$ and $165 \mathrm{lb}$ ), respectively. The heaviest doe weighed $53.1 \mathrm{~kg}(117 \mathrm{lb})$. 
Soft tissue (liver or muscle) radioactivity concentrations of ${ }^{137} \mathrm{Cs}$ continued to be low and acceptable. Only two deer of the harvest exceeded $0.037 \mathrm{~Bq} / \mathrm{g}(1.0 \mathrm{pCi} / \mathrm{g})$ [confiscation limit is $0.74 \mathrm{~Bq} / \mathrm{g}(20 \mathrm{pCi} / \mathrm{g})$ ]. The maximum concentration of ${ }^{137} \mathrm{Cs}$ was $0.137 \mathrm{~Bq} / \mathrm{g}(3.7 \mathrm{pCi} / \mathrm{g})$. Concentrations of ${ }^{90} \mathrm{Sr}$ in bone exceeded $1.11 \mathrm{~Bq} / \mathrm{g}(30 \mathrm{pCl} / \mathrm{g})$ (confiscation limit) in 6 deer out of the 442 harvested $(1.3 \%)$. The maximum ${ }^{90} \mathrm{Sr}$ concentration was $8.03 \mathrm{Bg} / \mathrm{g}(217 \mathrm{pCi} / \mathrm{g})$.

\subsubsection{Vegetation}

Growing plants may be contaminated by absorbing materials from soil or deposition of materials from the atmosphere. Grass provides an early indication of fallout because of the relatively large surface area of the grass blades exposed to air. Grass was not sampled for radioactivity at ORNL in 1990. The grass program was given a low priority because grass samples from ORR do not represent a direct pathway to man. Contamination of grass used for agricultural grazing is monitored through the milk program.

\subsection{Potential Radiation Dose to the Public}

This section examines potential radiation doses to the public and includes a detailed presentation of all the potential pathways to humans followed by radiation dose estimates. Results are expressed in terms of maximum exposed individual, average exposed individual, and population doses.

\subsubsection{Radiation Dose to Humans}

Small quantities of radionuclides were released to the environment from operations at the ORR facilities during 1990. Those releases are quantified and characterized in the previous sections. This section presents estimates of the potential consequences of the releases and describes the methods used to make the estimates.

\section{Terminology}

Most consequences to humans associated with radionuclide releases to the environment are caused by the interaction between radiation emitted by the radionuclides and human tissue. This interaction involves the transfer of energy from radiation to tissue, a process that may damage the tissue. The radiation may come from radionuclides located outside the body (in or on environmental media or objects) or from radionuclides deposited inside the body (via inhalation, ingestion, and, in a few cases, absorption through the skin). Exposure to radiation from nuclides located outside the body is called external exposure; exposure to radiation from nuclides deposited inside the body is called internal exposure. External exposure occurs only when a person is near or in a radionuclide-containing medium; internal exposure continues as long as the radionuclides remain inside the person. External exposure may result in uniform irradiation of the entire body and all its components; internal exposure usually results in nonuniform irradiation of the body. (When ingested, most radionuclides deposit preferentially in specific organs or tissue and do not irradiate the body uniformly.)

A number of specialized units have been defined for characterizing exposure to lonizing radiation. Because the damage associated with such exposure is caused primarily by the deposition of radiant energy in tissue, the units are defined in terms of the amount 
of incident radiant energy absorbed by tissue and the biological consequences of the absorbed energy. Some of these units are as follows:

- Absorbed dose. A physical quantity that defines the amount of incident radiant energy absorbed per unit mass of an irradiated material; its unit of measure is the rad. The absorbed dose depends on the type and energy of the incident radiation and on the atomic number of the absorbing material.

- Dose equivalent. A quantity that expresses the biological effectiveness of an absorbed dose in a specified human organ or tissue; its unit of measure is the rem. The dose equivalent is numerically equal to the absorbed dose multiplied by modifying factors that relate the absorbed dose to biological effects. In this report, as in many others, the term "dose equivalent" ofiten is shortened to "dose."

- Effective dose equivalent (EDE). A risk-dose that can be used to estimate healtheffects risks to exposed persons; it is a weighted sum of dose equivalents to specified organs. The weighting factors and specific organs are described in Publications 26 and 30 of the International Commission on Radiological Protection (ICRP 1977, ICRP 1978).

- Committed (effective) dose equivalent. The total effective dose equivalent that will be received over a specific time period ( 50 years in this document) because of exposures to, and intakes of, radionuclides during the year of interest.

- Collective (committed) effective dose equivalent. The sum of (committed) effective dose equivalents to all individuals in an exposed population.

- Dose conversion factor $(D C F)$. The dose equivalent received from exposure to a unit quantity of a radionuclide via a specific exposure pathway. Two types of DCFs exdst. One type gives the committed dose equivalent (rem) resulting from intake (via inhalation and ingestion) of a unit activity of a radionuclide. The second gives the dose equivalent rate [Sv/year (mrem/year)] per unit activity $1.1 \mathrm{~kg}$ or $(\mu \mathrm{Ci})$ of a radionuclide in a unit $\left(\mathrm{cm}^{3}\right.$ or $\left.\mathrm{cm}^{2}\right)$ of an environmental compartment (air or ground surface). Table 7.1 in Vol. 2 of Kornegay et al. 1991 (p. 197) contains a listing of DCFs for inhalation añu ingestion of selected radionuclides released from ORR; Table 7.2 in Vol. 2 of Kornegay et al. 1991 (p. 198) contains a listing of DCFs for immersion in contaminated air and for exposure to a contarninated ground surface (Beres 1990). The radionuclides listed account essentially for all of the radiation doses from ORR.

\section{Methods for cvaluation of airborne radionuclides}

The radiological consequences of radionuclides released to the atmosphere from ORNL and the ORR operations during 1990 were characterized by calculating EDEs to the maximally exposed off-site individual and to the entire population residing within $80.5 \mathrm{~km}$ ( 50 miles) of the plants. The dose calculations were made using the CAP-88 package of computer codes (Beres 1990), which was developed under sponsorship of the EPA for use in demonstrating compliance with National Emission Standards for Hazardous Air Pollutants (NESHAP) Radionuclides, 10 CFR Pt. 61. This package contains the most recent, approved version of the AIRDOS-EPA and DARTAB codes and the ALILRAD88 radionuclide data file. The AIRDOS-EPA computer code implements a steady-state, Gaussian plume, atmospheric dispersion model to calculate concentrations of radionuclides in the air and on the ground and uses Regulatory Guide 1.109 food chain models to calculate radionuclide concentrations in foodstuffs (vegetables, meat, and milk) and subsequent intake by man. The concentrations and human intakes are used by the EPA's latest version of the DARTAB computer code to calculate EDEs 
to man from radionuclides released to the atmosphere. The dose calculations use the DCFs contained in the ALLRAD99 data file (Tables 7.1 and 7.2 in Vol. 2 of Kornegay et al. 1991, pp. 197.198).

Radionuclide release data werc collected or estimated for elght release points at ORNL. Table 2.8-5 lists the source parameters used in the calculations of the nuclides released, and the quantity ( $\mathrm{Bq}$ and $\mathrm{Ci}$ ) released from each release point. Other pertinent release information is provided in Table 2.8-9. Meteorological data used in the calculations consisted of joint frequency (STAR) distributions of wind direction, wind speed class, and atmospheric stability category that were prepared from data collected during 1990 at the $100-\mathrm{m}$ (308 ft) station on tower MT2 for ORNL. Rainfall in Oak Ridge during 1990 was $0.152 \mathrm{~m}(0.468 \mathrm{ft})$, the average air temperature was $15^{\circ} \mathrm{C}\left(59^{\circ} \mathrm{F}\right)$, and the average mixing layer height was $1000 \mathrm{~m}(3080 \mathrm{ft})$.

Table 2.8-9. Release point parameters and receptor locations used in the dose calculations

\begin{tabular}{|c|c|c|c|c|c|c|}
\hline $\begin{array}{l}\text { Source } \\
\text { name }\end{array}$ & Type & $\begin{array}{l}\text { Release } \\
\text { helght } \\
{[\mathrm{m}(\mathrm{ft})]}\end{array}$ & $\begin{array}{l}\text { Inner } \\
\text { diameter } \\
{[\mathrm{m}(\mathrm{ft})]}\end{array}$ & $\begin{array}{l}\text { Gas exit } \\
\text { volocity } \\
{[\mathrm{m} / \mathrm{s}(\mathrm{ft})]}\end{array}$ & $\begin{array}{l}\text { Cas exit } \\
\text { temperature }\end{array}$ & $\begin{array}{c}\text { Distance [m (ft)] } \\
\text { and direction } \\
\text { to maximally } \\
\text { exposed } \\
\text { individual }\end{array}$ \\
\hline 2026 & Point & $22.9(70.5)$ & $1.1(3.4)$ & $11.4(35.1)$ & Ambient & $5450(16,786) \mathrm{E}$ \\
\hline 3020 & Point & $61.0(188)$ & $1.5(4.6)$ & $11.5(35.4)$ & Amblent & $5450(16,786) \mathrm{E}$ \\
\hline 3039 & Point & $76.2(235)$ & $2.4(7.4)$ & $16.6(51,1)$ & Amblent & $54,50(16,786) \mathrm{E}$ \\
\hline 7025 & Point & $4.0(12.3)$ & $0.3(.92)$ & $14.0(43.1)$ & Amblent & $3500(10,780) E$ \\
\hline 7512 & Point & $30.5(93.9)$ & $0.9(2.8)$ & $7.3(22.5)$ & Ambiont & $4550(14,014)$ ENE \\
\hline 7911 & Point & $76.2(235)$ & $1.5(4.6)$ & $10.1(31.1)$ & Ambient & $4550(14,014)$ ENE \\
\hline 7830 & Point & $4.6(14.2)$ & $0.2(0.62)$ & $\% .1(21.9)$ & Ambient & $5810(17,896)$ ENE? \\
\hline Misc. & Point & $15.0(46)$ & 0 & 0 & Ambient & $4970(15,308) \mathrm{SW}$ \\
\hline
\end{tabular}

Source: Adopted from: Kornogay, F, C, et al, 1991. Oak Ridge Reservation Environmensal Report for 1990, ORNL/ES/ESH.18/V1, Oak RIdge National Laboratory, Oak Rldge, Tenn., p. 187.

The dose calculations assumed that each person remained, unprotected, at home (actually outside the house) during the entire year and obtained food according to the rural pattern defined in the NESHAP background documents (EPA 1989). This pattern specifies that $70 \%$ of the vegetables and produce, $44.2 \%$ of the meat, and $39.9 \%$ of the milk consumed by each person are produced in the local area (e.g., a home garden). The remaining portion of each food is assumed to be produced within $80.5 \mathrm{~km}$ (50 miles) of ORNL. Use of this pattern is more conservative (less likely to underestimate real dose) than the consumption patterns used in previous annual reports. For collective EDE estimates, production of beef, milk, and crops within $80 \mathrm{~km}$ (50 miles) of ORR were calculated using the state-specific production values provided with CAP-88.

The EDE received by the hypothetical individual maximally exposed to airborne effluents from ORNL was calculated to be $0.002 \mathrm{mSv}(0.2 \mathrm{mrem})$. This individual hypothetically is located $-5450 \mathrm{~m}$ ( 3.4 miles) east of the 3039 stack and $3500 \mathrm{~m}$ ( 2.2 miles) east of the 7025 stack. Approximately $91 \%$ of this dose is from ingestion and inhalation of ${ }^{3} \mathrm{H}$. The 50-year committed collective EDE to the $\sim 933,000$ persons residing within $80.5 \mathrm{~km}$ ( 50 miles) of ORNL was calculated to be -4 person Sv $(\sim 0.004$ person-rem). 
Waterborne radionuclides

Waterboine discharges of radionuclides from ORNL flow into White Oak Creek and through White Oak Lake, and discharge into the Clinch River. In Table 3.8 of Kornegay et al. (1991, p. 64), concentrations of radionuclides in water are given for samples taken at the Melton Hill Dam, the K-25 process water intake (Gallaher), and the Kingston water plant. Committed dose equivalents to persons drinking these waters were calculated using annual-average concentrations of radionuclides that are significantly different from zero and the assumption that a person drinks $2 \mathrm{~L}$ (2.1 quarts) of water per day [730 L/year (193 gal/year)]. The EDE estimated for consumption of water from Melton Hill Dam, $0.001 \mathrm{mSv}(0.1 \mathrm{mrem})$, represents an upstream (background) dose. Uranium isotopes are the major contributors to this dose. The inlet to the K.25 Site (Gallaher process water) is the closest nonpublic water supply downstream of ORNL discharges. The calculated EDE from drinking this water would be $0.001 \mathrm{mSv}(0.1 \mathrm{mrem})$ from ${ }^{90} \mathrm{Sr},{ }^{3} \mathrm{H},{ }^{238} \mathrm{Pu}$, and ${ }^{60} \mathrm{Co}$. The public water supply closest to the ORNL liquid outfall is located about $26 \mathrm{~km}$ (15.6 miles) downstream, at Kingston. Based on measured concentrations of ${ }^{90} \mathrm{Sr}$ and ${ }^{3} \mathrm{H}$ in river water from ORNL effluents, a person drinking water from the intake of the Kingston filtration plant could receive an annual EDE of $0.04 \mathrm{mSv}(0.0004 \mathrm{mrem})$; this could result in a collective committed effective dose of about 0.003 person Sv (0.3 person-rem) to the estimated 7500 persons who could drink this water.

Potential doses to individuals eating $21 \mathrm{~kg}$ (about $46 \mathrm{lb}$ ) of fish per year were calculated using measured concentrations of radionuclides in fish harvested at three locations. The highest potential EDE, $0.003 \mathrm{mSv}(0.3 \mathrm{mrem})$, could be received by persons eating fish from CRK 33.3, which is at the confluence of White Oak Creek and the Clinch River, ORNI's discharge point. Potential EDEs to persons eating fish caught upstream at Melton Hill Dam (CRK 40.0) and downstream at Kingston (CRK 8.0) are 0.0001 and $0.0005 \mathrm{mSv}(0.01$ and $0.05 \mathrm{mrem})$, respectively. The $0.0005 \mathrm{mSv}$ (0.05-inrem) EDE to an individual eating $21 \mathrm{~kg}(46 \mathrm{lb})$ of tish caught at Kingston could result in a population dose of about $4 \times 10^{.3}$ person-Sv (0.4 person-rem) if each of the inhabitants of Kingston caught and ingested $21 \mathrm{~kg}(46 \mathrm{lb})$ of fish. The primary contributors to the EDE are ${ }^{137} \mathrm{Cs}$ at Kingston; ${ }^{137} \mathrm{Cs}$, ${ }^{90} \mathrm{Sr}$, and ${ }^{60} \mathrm{Co}$ at $\mathrm{CRK} 33.3$; and ${ }^{90} \mathrm{Sr}$ and ${ }^{137} \mathrm{Cs}$ at Melton Hill Dam. To put these doses from waterborne radionuclides into perspective, the nearest population (Kingston) exposed to these radionuclides would receive an annual collective committed EDE of about $7 \times 10^{.3}$ person-Sv (0.7 person-rem) from drinking water and eating fish. This represents about $0.03 \%$ of the annual dose from background radiation 22.5 person Sv (2250 person.rem) to this population.

\section{Radionuclides in other environmental media}

One of the important pathways for movement of radionuclides from environmental media to man can be represented as follows: the atmosphere $\rightarrow$ pasture $\rightarrow$ cow $\rightarrow$ milk food chain. Strontiurn-90 and ${ }^{131} I$ are radionuclides that are especially important in this terrestrial food chain. The CAP 88 models calculated EDEs caused by consumption of milk containing airborne radionuclides released from ORR. Also, milk collected from area farms is sampled for radionuclides. Potential EDEs to an individual are based on the individual drinking $310 \mathrm{~L}$ ( 81.8 gal) of sampled milk per year. Measured, annual-average concentrations of total radioactive strontium (assuming $100 \%{ }^{90} \mathrm{Sr}$ ) and ${ }^{131} \mathrm{I}$ in milk taken from sampling stations near ORNL (see Fig. 2.8-2) were used to calculate the EDEs, 
which range from 0.0007 to $0.002 \mathrm{mSv}(0.07$ to $0.2 \mathrm{mrem})$ and average $0.001 \mathrm{mSv}$ (0.1 mrem).

\section{Direct radiation}

External radiation exposure rates have been measured at a number of locations on and off ORR; most of this exposure is caused by natural radioactivity in the ground. Table 2.8-10 gives postulated effective doses to unshielded individuals exposed to direct radiacion at sach monitoring station for $8760 \mathrm{~h} /$ year $(24 \mathrm{~h} / \mathrm{d}$, all year). Doses from background direct radiation over the staie of Tennessee range from about 0.3 to $1.0 \mathrm{mSv} / \mathrm{year}$ (30 to $100 \mathrm{mrem} / \mathrm{year}$ ) and average $0.56 \mathrm{mSv} / \mathrm{year}$ ( $56 \mathrm{mrem} / \mathrm{year}$ ) (Myrick et al. 1981). The latter elevated radiation levels are caused by air-scattered gamma radiation from an experimental ${ }^{137} \mathrm{Cs}$ field along the Clinch River at stations 64 through 67, located along the bank of the Clinch River between CRK 34 and 30. It is extremely unlikely that an individual would be exposed to this gamma radiation for an entire year $(8760 \mathrm{~h})$. However, a hypothetical maximally exposed individual might spend $5 \mathrm{~h} /$ week fishing along the shore. This individual could receive an effective dose equivalent of $0.06 \mathrm{mSv}(6 \mathrm{mrem})$ from a $250-\mathrm{h}$ exposure to the average of the measured exposure rates at stations 65 and 66 .

\subsubsection{Doses to Aquatic Biota}

DOE Order 5400.5, Chapter II, sets an absorbed dose rate limit of $0.01 \mathrm{~Sv} / \mathrm{d}$ ( $1 \mathrm{rad} / \mathrm{d})$ to native aquatic organisms. To demonstrate compliance with this limit, absorbed dose rates to aquatic invertebrates, fish, and muskrats were calculated by multiplying measured radionuclide concentrations in surface waters on and around ORNL with internationally recognized, organism-specific dose factors (National Research Council of Canada 1983). The results of these calculations, which are presented in Table 2.8-11, indicate that no aquatic biota should receive an absorbed dose at a rate greater than $3.0 \times 10^{-1}(0.03 \mathrm{rad} / \mathrm{d})$. The highest potential dose rates were $3.0 \times 10^{-4} \mathrm{~Sv} / \mathrm{d}(0.03 \mathrm{rad} / \mathrm{d})$ to muskrats, $1.0 \times 10^{-4} \mathrm{~Sv} / \mathrm{d}(0.01 \mathrm{rad} / \mathrm{d})$ to invertebrates, and $1.0 \times 10^{-5} \mathrm{~Sv} / \mathrm{d}(0.001 \mathrm{rad} / \mathrm{d})$ to fish at White Oak Dam.

\subsection{Chemical Dosc}

Varying amounts of chemicals were released to the environment from operations at ORNL during 1990. In this section, estimates of potential human exposure to these chemicals are made, and the exposures are compared with acceptable levels of exposure as defined by federal standards and regulations.

Chemicals enter the body by several routes, including inhalation of air and dust, ingestion of food and water, and dermal absorption. Analysis of potential exposure through inhalation is not possible because of lack of environmental monitoring data. Potential exposure through dermal contact is considered to be unlikely for members of the general public because the sites are restricted areas.

The environmental monitoring data on surface water allow the ingestion pathway via drinking water to be analyzed. Data on selected chemicals in fish allow exposure via ingestion of food to be analyzed. Therefore, exposures of humans to chemicals via drinking water and to selected chemicals via ingestion of food are provided. 
Table 28-10. Potential radiation dose equivalents from external exposures at locations on and near the Oak Ridge Reservation

\begin{tabular}{|c|c|}
\hline Station & $\begin{array}{l}\text { Effective dose equivalents } \\
\text { [mSv/year (mrem/year)] }\end{array}$ \\
\hline \multicolumn{2}{|c|}{ ORNL perimeter air monitors } \\
\hline 03 & $0.28(28)$ \\
\hline 07 & $0.50(50)$ \\
\hline 20 & $0.68(68)$ \\
\hline \multicolumn{2}{|c|}{ Clinch River stations } \\
\hline 60 & $0.52(52)$ \\
\hline 61 & $0.88(88)$ \\
\hline 64 & $1.6(160)$ \\
\hline 65 & $1.8(180)$ \\
\hline 66 & $2.1(210)$ \\
\hline 67 & $1.05(105)$ \\
\hline 68 & $0.88(88)$ \\
\hline 69 & $0.46(46)$ \\
\hline \multicolumn{2}{|c|}{ Backgrounc: } \\
\hline $\begin{array}{c}\text { Average of } 12 \text { locations in } \\
\text { Tennessee }\end{array}$ & $0.56(56)$ \\
\hline
\end{tabular}

"Assumes an exposure of 8760 h/year.

'Source: Rogers, J. G., et al. 1988. Environmental Surveillance of the U.S. Department of Energy Oak Ridge Reservalion and Surrounding Environs During 1987, ORNL/ES/ESH-4/V1, Oak Ridge National Laboratory, Oak Ridge, Tenn., April.

cSource: Myrick, T. E., B. A. Bervin, and F. F. Haywood, 1981. State Background Radiation Levels, ORNL/TM.7343, Oak Ridge National Laboratory, Tenn.

\section{Terminology}

Definitions of terms pertinent to the understanding of exposure are as follows:

- Acceptable Daily Intake $(A D I)$. Intake of a chemical, measured in $\mathrm{mg} /$ day, that is not anticipated to result in an adverse health effect over a lifetime of exposure. ADIs are calculated from several different federal standards and regulations.

- Calculated Daily Intake (CDI). Intake of a chemical, expressed in mg/day. For drinking water, it is assumed that adults drink $2 \mathrm{~L}$ of water per day. 
Table 28-11. Potential dose rates to aquatic biota

\begin{tabular}{lllllll}
\hline \multirow{2}{*}{ Location } & \multicolumn{5}{c}{ Absorbed dose rate } \\
\cline { 2 - 7 } & \multicolumn{2}{c}{ Invertebrates } & \multicolumn{2}{c}{ Fish } & \multicolumn{2}{c}{ Muskrats } \\
\cline { 2 - 7 } & $\mathrm{Sv} / \mathrm{d}$ & $\mathrm{rad} / \mathrm{d}$ & $\mathrm{Sv} / \mathrm{d}$ & $\mathrm{rad} / \mathrm{d}$ & $\mathrm{Sv} / \mathrm{d}$ & $\mathrm{rad} / \mathrm{d}$ \\
\hline $\begin{array}{l}\text { Melton Hill Dam } \\
\text { upstream }\end{array}$ & $4.0 \times 10^{-6}$ & 0.0004 & $1.0 \times 10^{-6}$ & 0.0001 & $4.0 \times 10^{-6}$ & 0.0004 \\
White Oak Creek & $8.0 \times 10^{-5}$ & 0.008 & $2.0 \times 10^{-5}$ & 0.002 & $2.0 \times 10^{-4}$ & 0.02 \\
White Oak Dam & $1.0 \times 10^{-4}$ & 0.01 & $1.0 \times 10^{-5}$ & 0.001 & $3.0 \times 10^{-4}$ & 0.03 \\
Gallaber (downstream) & $1.0 \times 10^{-5}$ & 0.001 & $1.0 \times 10^{-6}$ & 0.0001 & $1.0 \times 10^{-6}$ & 0.0001 \\
\hline
\end{tabular}

Source: Kornegay, F. C., et al. 1991. Oak Ridge Reservation Environmental Report for 1990, ORNL/ES/ESH-18/V1, Oak Ridge National Laboratory, Oak Ridge, Tenn., p. 191.

- Slope Factor $(S F)$. An estimate based on a lifetime probability that a chemical will cause cancer at a dose of $1 \mathrm{mg} \mathrm{kg}^{-1} \cdot \mathrm{d}^{-1}$.

- Maximum Contaminant Level (MCL). EPA National Interim Primary and National Primary Drinking Water Regulations that apply to all community or public water systems.

- Reference Dose (RfD). An estimate of the daily exposure to the human population, including sensitive individuals, that is likely to be without an appreciable risk of deleterious effects during a lifetime.

- Secondary Maximum Contaminant Level (SMCL). EPA National Secondary Drinking Water Regulations that apply to public water systems.

Airborne chemicals

The release of chemicals into the air at ORR facilities is discussed in an earlier section. Air permits issued by the Tennessee Department of Conservation allow release of permitted quantities of chemicals. Sampling or monitoring is required only at the ORNL steam plant. No air-monitoring data amenable to human exposure analysis were available.

\section{Waterborne chemicals}

EPA has set daily intake standards for chemicals in the form of oral REDs and SFs. These values are available from EPA's Integrated Risk Information System (IRIS). For noncarcinogenic chemicals, daily exposure to the $\mathrm{RfD}$, in $\mathrm{mg} / \mathrm{kg} / \mathrm{d}$, should result in no adverse effects over a lifetime. ADls in $\mathrm{mg} / \mathrm{d}$ were calculated from RfDs by multiplying by $70 \mathrm{~kg}$, the average human body weight. 
For carcinogens, ADIs were calculated from SFs using the formula

$$
\mathrm{ADI}=\frac{1 \times 10^{-5} \times \mathrm{BW}}{\mathrm{SF}}
$$

where $\mathrm{BW}=70 \mathrm{~kg}$ and $\mathrm{SF}=$ a slope factor of risk per unit dose (risk per $\mathrm{mg} / \mathrm{kg} /$ day). A 1 -in-100,000 $\left(1 \times 10^{-5}\right)$ lifetime risk of developing cancer was used in calculating the ADI.

For chemicals for which REDs and SFs were not available, national primary and secondary drinking water regulations, in milligrams per liter, were converted to $A D I$ values by multiplying by $2 \mathrm{~L}$, the adult average daily water intake.

Acceptable daily intakes for chemicals found in surface water at concentrations above detection limits are listed in Table 2.8-12. For RFDs and SFs, it is assumed that water ingestion is the only pathway of exposure. Average values of the sampling data (in $\mathrm{mg} / \mathrm{L}$ ) were multiplied by $2 \mathrm{~L}$ to estimate daily intake levels. Much of the sampling data for individual chemicals were reported as "less than" $(<)$ values indicating that concentrations were below the limits of detection of the instruments used. These data were used in the analysis only if one or more samples had values above the detection limit. Average sample concentrations were reported as < values, so the CDIs are also reported as < values. The CDIs were compared with the ADIs to establish whether the ingestion of $2 \mathrm{~L}$ of water would result in an exposure above the ADI. CDI-ADI ratios of $<1$ indicate an acceptable level of risk, while CDI-ADI ratios $>1$ indicate an unacceptable risk or the need for further study. Where CDIs are expressed as < values, CDI-ADI ratios are also expressed as < values, and the exposure cannot be fully quantified.

For the following reasons, all CDI-ADI ratios were $<1$ or could not be quantified. The high concentrations of aluminum are a reflection of the turbidity and high suspended solids (as much as $340 \mathrm{mg} / \mathrm{L}$ ) in the samples. The high concentration of phosphorus probably indicates the use of phosphate fertilizers in the area. Because analyses were for total phosphorus, a distinction between the potentially toxic element and phosphates could not be made, and phosphorus was not further considered.

Chemicals in water can be accumulated by aquatic organisms that may be eaten by humans. Mercury and PCB concentrations were measured in Clinch River bluegill sunfish (Table 2.8-8). The highest concentration of mercury in bluegill, $<0.19 \mathrm{mg} / \mathrm{kg}$ wet weight, was found at CRK 8.0. The majority of this mercury probably originated at the Y-12 facility. Assurning the average person eats $21 \mathrm{~kg}(46 \mathrm{lb}$ ) of fish per year $[0.058 \mathrm{~kg} / \mathrm{d}]$ $(0.13 \mathrm{lb} / \mathrm{d})$, the average daily intake of mercury would be $0.011 \mathrm{mg} / \mathrm{d}$, which results in a CDI-ADI (0.011-0.021) of 0.5. Calculated average intake by ingestion of both fish and water, at the highest concentrations measured, results in a CDI of $0.0144 \mathrm{mg} / \mathrm{d}$ $(0.011 \mathrm{mg} / \mathrm{d}+0.0034 \mathrm{mg} / \mathrm{d})$ and a CDI-ADI ratio of 0.68 , indicating an acceptable level of ingestion. All PCB concentrations in bluegill from three Clinch River sites were below the maximum limit of detection, and daily intakes could not be quantified.

In reality, surface-water monitoring stations are generally located within areas of DOE facilities that are not readily accessible to the general public. Thus, consumption of water from these points is unlikely. Furthermore, as pollutants move downstream and the volume of water increases, the concentration of pollutants decreases.

\section{Chemicals in other environmental media}

An important pathway of concern for human exposure to chemicals is through atmospheric deposition onto vegetation and subsequent transfer into beef and milk. 
Table 28-12 Acceptable daily intakes for chemicals found above detection limits at Oak Ridge Reservation facilities

\begin{tabular}{|c|c|c|}
\hline Chemical & $\mathrm{ADI}(\mathrm{mg} / \mathrm{d})$ & Reference \\
\hline Al & 0.1 & SMCLa \\
\hline Ammonia & 64 & $\mathrm{RfD}^{a}$ \\
\hline $\mathrm{Sb}$ & 0.028 & RED \\
\hline As & 0.07 & RfD \\
\hline $\mathrm{Ba}$ & 4.9 & RfD \\
\hline bis(2-ethylhexyl)phthalate & 0.05 & SF \\
\hline B & 6.3 & $\mathrm{RfD}$ \\
\hline $\mathrm{Cd}$ & 0.035 & RfD \\
\hline Chloroform & 0.1148 & SF \\
\hline $\mathrm{Cr}$ & 0.35 & $\mathrm{RfD}$ \\
\hline $\mathrm{Cu}$ & 2.6 & $\mathrm{MCL}^{a}$ \\
\hline Cyanide & 0.02 & $\mathrm{RfD}$ \\
\hline Fluoride & 4.2 & RfD \\
\hline $\mathrm{Fe}$ & 0.6 & SMCL \\
\hline $\mathrm{Pb}$ & 0.01 & $\mathrm{MCL}$ \\
\hline Mn & 7.0 & $\mathrm{RfD}$ \\
\hline $\mathrm{Hg}$ & 0.021 & RED \\
\hline Methylene chloride & 0.09 & $\mathrm{SF}^{\infty}$ \\
\hline Mo & 7.0 & RfD \\
\hline $\mathrm{Ni}$ & 1.4 & $\mathrm{RfD}$ \\
\hline Nitrate & 70 & $\mathbf{R f D}$ \\
\hline Phenol & 42 & RED \\
\hline P & 0.0014 & $\mathrm{RfD}$ \\
\hline $\mathrm{Se}$ & 0.21 & RfD \\
\hline Ag & 0.21 & RED \\
\hline Sulfate & 800 & $\mathrm{MCL}$ \\
\hline V & 0.49 & RfD \\
\hline $\mathrm{Zn}$ & 14 & RfD \\
\hline
\end{tabular}

-SMCLs = Secondary Maximum Containment Levels and apply to all public water systems. MCLs = Maximum Containment Levels and apply to all public water systems (copper, sulfate) or to community water systems (lead). $\mathrm{RID}=$ reference dose. $\mathrm{SF}=$ Slope.

Sounce: Kornegay, F. C., et al. 1991. Oak Ridge Reservation Envinonmental Report for 1990, ORNL/ES/ESH-18/V1, Oak Ridge National Laboratory, Oak Ridge, Tenn.

Direct measurements for concentrations of chemicals in vegetation, beef, or milk in the vicinity of ORR facilities have not been made. 


\section{Direct exposure}

Direct exposure to chemicals does not represent a likely pathway of exposure at the ORR facilities. For airborne releases, concentrations off-site are too small to be a problem through the dermal exposure pathway. For aquatic releases, outfalls are generally located within areas of DOE facilities that are not readily accessible to the general public. Although exposures for consumption of drinking water at the monitoring stations were calculated, public consumption of water from the outfalls or at the monitoring stations is highly unlikely.

\section{Current year summary}

Additional information on routes of exposure other than surface waters is needed to achieve a more complete chemical exposure analysis. In the present analysis on exposure to waterborne inorganic chemicals, the majority of CDI-ADI ratios on-site were $<1$, indicating that, for drinking water, most chemicais were below acceptable daily intake levels. Off-site exposures would be lower because of stream dilution. Most organic chemicals were below the limit of analytical detection and should pose no risk to the public.

\subsection{REFERENCES FOR SECTION 2}

AEC (Atomic Energy Commission) 1953. A Meteorological Survey of the Oak Ridge Area: Final Report Covering 1948-52, ORO-99, National Technical Information Service, Oak Ridge, Tenn.

AEC (Atomic Energy Commission) 1974. Safety Evaluation Report in the Matter of Tennessee Valley Authority, Bellefonte Nuclear Plant Units 1 and 2, U.S. Atomic Energy Commission Dockets 50-438 and 50-439.

American Nuclear Society 1983. An American National Standard for Estimating Tornado and Extreme Wind Characteristics at Nuclear Power Sites, La Grange Park, Ill.

Anderson, S. H., and H. H. Shugart, Jr. 1974. "Habitat Selection of Breeding Birds in an East Tennessee Deciduous Forest," Ecology 55, 828-837.

Anderson, S. H., L. K. Mann, and H. H. Shugart 1977. "The Effect of Transmission-Line Corridors on Bird Populations," Am. Midl. Nat. 97, 216-221.

Barclay, L. A. (U.S. Fish and Wildlife Service) 1990. Letter to R. Kroodsma, Oak Ridge National Laboratory, June 13.

Baxter, J. W., G. A. Desborough, and C. W. Shaw 1967. Areal Geology of the Illinois Fluorspar District, Part 3-Herod and Shetlerville Quadrangles, Illinois State Geological Survey Circular 413, Urbana, Ill.

Bay, R. T. (U.S. Fish and Wildlife Service) 1991. Letter to R. Kroodsma, Oak Ridge National Laboratory, March 7.

Bayer, K C. 1983. Generalized Structural, Lithologic, and Physiographic Provinces in the Fold and Thrust Belts of the United States, U.S. Geological Survey, Denver, Colo.

Beavers, J. E., W. E. Manrod, and C. W. Stoddart 1982. Recommended Seismic Hazard Levels for the Oak Ridge, Tennessee; Paducah, Kentucky; Fernald, Ohio; and Portsmouth, Ohio Department of Energy Reservations, K/BD-1025/R1, Oak Ridge National Laboratory, Oak Ridge, Tenn., December. 
Beres, D. A. 1990. The Clean Air Act Assessment Package-1988 (CAP-88), A Dose and Risk Assessment Methodology for Radionuclides Emissions to Air, Vols. 1-3, SC \& A, Inc., McLean, Va.

Binford, F. T., T. E. Cole, and E. N. Cramer, eds. 1968. The High-Flux Isotope Reactor $-A$ Functional Description, Vol. 1A, ORNL-3572, rev. 2, Oak Ridge National Laboratory, Oak Ridge, Tenn.

Bollinger, G. A. 1973. "Seismicity of the Southeastern United States," Bull. Seismol Soc. Am. 63(5), 1785-1808.

Bollinger, G. A., and R. L. Wheeler 1988. The Giles County, Vinginia, Seismic ZoneSeismological Results and Geological Interpretations, U.S. Geological Survey, Professional Paper 1335, Denver, Colo.

Bollinger, G. A, et al. 1976. "The Eastern Tennessee Earthquake Sequence of October Through December, 1973," Bull. Seismol. Am. 66(2), 525-547.

Bonilla, M. G. 1982. Evaluation of Potential Surface Faulting and Other Tectonic Deformation, NUREG/CR-2991, prepared by the U.S. Geological Survey for the U.S. Nuclear Regulatory Commission.

Boyle, J. W., et al. 1982. Environmental Analysis of the Operation of the Oak Ridge National Laboratory ( $X$-10 Site), ORNL-5870, Oak Ridge National Laboratory, Oak Ridge, Tenn.

Bradburn, D. M. 1977. Forest Management Plan, ERDA Oak Ridge Reservation: 1976-1980, ORNL/TM-5833, Oak Ridge National Laboratory, Oak Ridge, Tenn.

Braun, E. L. 1950. Deciduous Forests of Eastern North America, MacMillan, N.Y.

Cada, G. F. 1986. Characterization of Fish and Benthic Invertebrates of Melton Branch, Oak Ridge Reservation, Draft Report, Oak Ridge National Laboratory, Oak Ridge, Tenn.

Chance, W. W. 1986. Resource Management Plan for the Oak Ridge Reservation, ORNL/ESH-1/V22, Oak Ridge National Laboratory, Oak Ridge, Tenn., December.

Chance, W. W., and C. E. Fry 1989. Oak Ridge Reservation Site Development and Facilities Utilization Plan, DOE/OR-885, Oak Ridge National Laboratory, Oak Ridge, Tenn., July.

Changnon, S. A., Jr. 1972. "Examples of Economic Losses from Hail in the United States," J. Appl. Meteorol. 11(7), 1128-37.

Coats, D. W., and R. C. Murray 1985. Natural Phenomena Hazards Modeling Project: Extreme Wind/Tormado Hazard Models for Department of Enengy Sites, UCRL 53526, rev. 1, prepared for the U.S. Department of Energy by Lawrence Livermore National Laboratory, Livermore, Calif.

COE (U.S. Army Corps of Engineers) et al. 1989. Federal Manual for Identifying and Delineating Jurisdictional Wetlands, Washington.

Conant, R. 1958. A Field Guide to Reptiles and Amphibians, Houghton Mifflin, Boston.

Cook, R. E. 1969. "Variation in Species Density of North American Birds," Syst. Zool. 18, 63-84.

Cooper, W. T. 1981. Interactions Between Organic Solutes and Mineral Surfaces and Their Significance in Hydrogeology, Ph.D. dissertation, Indiana University, Bloomington.

Cox, W. C. 1991. "Site Description, Y-12 Plant Building 9215," pp. 1-226 in O.Wing Final Safety Analysis Report, Oak Ridge National Laboratory, Oak Ridge, Tenn., April.

Dahlman, R. C., J. T. Kitchings, and J. W. Elwood 1977. Land and Water Resources for Environmental Reseanch on the Oak Ridge Reservation, ORNL/TM-5352, Oak Ridge National Laboratory, Oak Ridge, Tenn. 
Daniels, K. L, et al. 1988. Environmental Surveillance of the U.S. Department of Energy Oak Ridge Reservation and Surrounding Enviroris During 1987; Volume 1: Narrative, Summary, and Conclusions, ES/ESH-4/V1, Environmental and Safety Activities, Oak Ridge National Laboratory, Oak Ridge, Tenn.

DOC (U.S. Department of Commerce) 1968. Climatic Atlas of the United States, Environmental Data Service.

DOC (U.S. Department of Commerce) 1977a. Local Climatological Data with Comparative Data, 1977, Knaxville, Tennessee, National Climatic Data Center, Asheville, N.C., pp. 1-4.

DOC (U.S. Department of Commerce) 1977b. Local Climatological Data with Comparative Data, 1977, Oak Ridge, Tennessee, National Climatic Data Center, Asheville, N.C., pp. 1-4.

DOC (U.S. Department of Commerce) 1977c. Local Climatological Data with Comparative Data, 1977, Chattanooga, Tennessee, National Climatic Data Center, Asheville, N.C., pp. $1-4$.

DOC (U.S. Department of Commerce) 1989a. Local Climatological Data with Comparative Data, 1989, Knaxville, Tennessee, National Climatic Data Center, Asheville, N.C., pp. 1-8.

DOC (U.S. Department of Commerce) 1989b. Lacal Climatological Data with Comparative Data, 1989, Oak Ridge, Tennessee, National Climatic Data Center, Asheville, N.C., pp. 1-8.

DOC (U.S. Department of Commerce) 1989c. Local Climatological Data with Comparative Data, 1989, Oak Ridge, Tennessee, National Climatic Data Center, Asheville, N.C., pp. $1-8$.

DOC (U.S. Department of Commerce) 1990. Bureau of the Census, 1990 Census of Population and Housing (computer database).

DOC (U.S. Department of Commerce) 1991. Bureau of the Census, Statistical Abstract of the US: 1991, 111th ed.

DOE (U.S. Department of Energy) 1989. Oak Ridge Reservation Site Development and Facilities Utilization Plan, DOE/OR-885, U.S. Department of Energy, Oak Ridge, Tenn., June.

DOE (U.S. Department of Energy) 1990. Guidance for Preparation of Safety Analysis Reports, DOE/OR-901, Oak Ridge Operations, Oak Ridge, Tenn.

Dreier, R. B., and L. E. Toran 1989. Hydrogeology of Melton Valley Determined from Hydraulic Head Measuring Station Data, ORNL/TM-11216, Oak Ridge National Laboratory, Oak Ridge, Tenn.

Dreier, R. B., et al. 1987. Summary of Geological Data in the Vicinity of the Hydrofracture Facilities, ORNL/RAP/LTR-87/26, Oak Ridge National Laboratory, Oak Ridge, Tenn.

DuVall, G. D. 1991. "An Archaeological Reconnaissance of the Advanced Neutron Source Project on the Oak Ridge Reservation in Anderson and Roane Counties, Tennessee," DuVall and Associates, Inc., Nashville, July.

Eagleman, J. R. 1985. Meteorology: The Atmosphere in Action, 2d ed., Wadsworth Publishing Co., Belmont, Calif.

Eardley, A. J. 1951. Structural Geology of North America, Harper, N.Y.

EPA (U.S. Environmental Protection Agency) 1987. Industrial Source Complex (ISC) Dispersion Model User's Guide, 2d ed., rev., EPA-450/4-88-002a and 002b (Vols. 1 and 2), Office of Air Quality Planning and Standards, Research Triangle Park, N.C. 
EPA (U.S. Environmental Protection Agency) 1989. Risk Assessments Methodology, Environmental Impact Statement, NESHAPS for Radionuclides, Baskground Information, Vol. 1, EPA/520/1-89-005.

EPRI (Electric Power Research Institute) 1988. Seismic Hazard Methodology for the Central and Eastern United States, EPRI Final Report NP-4726, Palo Alto, Calif.

Ervin. C. P., and L. D. McGinnis 1975. "Reelfoot Rift-Reactivated Precursor to the Mississippi Embayment," GeoL Soc. Am. Bull. 86, 1287-1295.

Evaldi, R. D., and J. G. Lewis 1986. Water-Quality Appraisal of NASQAN Stations Below Impoundments, Eastern Tennessee, Water-Resources Investigations Report 85-4171, Open-File Services Section, U.S. Geological Survey, Federal Center, Lakewood, Colo.

Exxon Nuclear Co., Inc. 1976. Nuclear Fuel Recovery and Recycling Center Preliminary Safety Analysis Report, Report XN FR-33, Docket No. 50-564, Richland, Wash.

Fitzpatrick, F. C. 1982. Oak Ridge National Laboratory Site Data for Safety Analysis Reports, ORNL/ENG/TM-19, Oak Ridge National Laboratory, Oak Ridge, Tenn.

Frezon, S. E., and T. M. Finn 1988. "Map of Sedimentary Basins in the Conterminous United States," U.S. Geological Survey, Oil And Gas Investigations Map OM-223, Denver, Colo.

Gale Research Company 1985. Climate of the States, 3d ed., Vol. 2, Detroit.

Geraghty, J., and D. Miller 1989. Draft Revised Hydrogeology of the Oak Ridge Gaseous Diffusion Plant, Geraghty and Miller Environmental Services, Inc., Reston, Va., Dec. 15.

Haase, C. S., E. C. Walls, and C. D. Farmer 1985. Stratigraphic and Structural Data for the Conasauga Group and the Rome Formation on the Copper Creek Fault Block near Oak Ridge, Tennessee: Preliminary Results from Test Borehole ORNL.JOY No. 2, ORNL/TM-9159, Oak Ridge National Laboratory, Oak Ridge, Tenn., June.

Hatcher, R. D., Jr. 1972. "Developmental Model of the Southern Appalachians," Geol. Soc. Am. Bull. 83, 2735-2760.

Hatcher, R. D., Jr., et al. 1989. "Alleghenian Orogen," pp. 233-318 in The AppalachianOuachita Orogen in the United States, eds. R. D. Hatcher, W. A. Thomas, and G. W. Viele, The Geology of North America, Vol. F-2, Geological Society of America, Boulder, Colo.

Hatcher, R. D., Jr., et al. 1991. Review Draft of Preliminary Summary of the Geology of the Oak Ridge Reservation, Oak Ridge National Laboratory, Oak Ridge, Tenn.

Hatcher, R. M. 1990. Help for Tennessee's Rare and Endangered Wildlife, Tennessee Wildlife Resources Agency, Nashville.

Holzworth, G. C. 1972. Mixing Heights, Wind Speeds, and Potential for Urban Air Pollution Throughout the Contiguous United States, AP-101 (NTIS No. PB 207-103), Research Triangle Park, N.C.

Hunt, C. B. 1967. Physiography of the United States, W. H. Freeman, San Francisco.

Johnson, R. M. 1964. The Herpetofauna of the Oak Ridge Area, ORNL-3653, Oak Ridge National Laboratory, Oak Ridge, Tenn.

Johnston, A. C., and L. R. Kanter 1990. "Earthquakes in Stable Continental Crust," Sci. Am., 68-75.

Keller, G. R., et al. 1983. "The Role of Rifting in the Tectonic Development of the Midcontinent, U.S.A.," Tectonophysics 94, 391-412.

Kelly, D. L., et al. 1978. "An Augmented Tornado Climatology," Mon. Weather Rev. $106(8), 1172-83$. 
Kennedy, R. P., et al. 1990. Design and Evaluation Guidelines for Department of Energy Facilitiles Subjected to Natural Phenomena Hazards, UCRL-15910, Lawrence Livermore National Laboratory, Livermore, Calif.

Kitchings, J. T., and J. D. Story 1984. Resource Management of Energy Oak Ridge Reservation, Vol 16: Appendix Q, Wildlife Management, ORNL-6026/V16, Oak Ridge National Laboratory, Oak Ridge, Tenn.

Kitchings, J. T., and L K. Mann 1976. A Description of the Terrestrial Ecology of the Oak Ridge Environmental Research Park, ORNL/TM-5073, Oak Ridge National Laboratory, Oak Ridge, Tenn.

Kornegay, F. C., et al. 1990. Oak Ridge Reservation Environmental Report for 1989, ORNL/ES/ESH-13 and 2, prepared for the U.S. Department of Energy by the Office of Environmental Compliance Documentation, Oak Ridge National Laboratory, Oak Ridge, Tenn., May.

Kornegay, F. C., et al. 1991. Oak Ridge Reservation Environmental Report for 1990 , ORIVL/ES/ESH-18/V1 and 2, Oak Ridge National Laboratory, Oak Ridge, Tenn., September.

Korshover, J. 1976. Climatology of Stagnating Anticyclones East of the Rocky Mountains, 1936-1975, NOAA Technical Memorandurn ERL ARL-55, U.S. Department of Commerce, National Oceanic and Atmospheric Administration.

Korshover, J., and J. K. Angell 1982. "A Review of Air-Stagnation Cases in the Eastern United States During 1981-Annual Summary," Mon. Weather Rev. 110(10), 1515-18.

Kroodsma, R. L. 1982. "Bird Population Ecology on Power-Line Corridors in East Tennessee," Biol. Conserv. 23, 79-94.

Kroodsma, R. L. 1984a. "Effect of Edge on Breeding Forest Bird Species," Wilson Bull. 96, 426-436.

Kroodsma, R. L. 1984b. "Ecological Factors Associaced with the Degree of Edge Effect in Breeding Birds," J. Wildl. Manage. 48, 418-425.

Kroodsma, R. L. 1985. Ecological Characterization of Terrestrial Biota of the Proposed Solid Waste Storage Area (SWSA) 7, unpublished report, Oak Ridge National Laboratory, Oak Ridge, Tenn.

Kroodsma, R. L. 1987. Resource Management Plan for the Oak Ridge Reservation, Vol. 24: Threatened and Endangered Animal Species, ORNL/ESH-1/V24, Oak Ridge National Laboratory, Oak Ridge, Tenn.

Lee, R. R., and R. H. Ketelle 1989. Geology of the West Bear Creek Valley Site, ORNL/TM-10887, Oak Ridge National Laboratory, Oak Ridge, Tenn., January.

LLNL (Lawrence Livermore National Laboratory) 1989. Seismic Hazard Characterizations of 69 Nuclear Plant Sites East of the Rocky Mountains, Vols. 1-r, NUREG/CR5250, prepared by Lawrence Livermore National Laboratory for the U.S. Nuclear Regulatory Commission.

Loar, J. M., et al. 1981. Ecological Studies of the Biotic Communities in the Vicinity of the Oak Ridge Gaseous Diffusion Plant, ORNIL/TM-6714, Oak Ridge National Laboratory, Oak Ridge, Tenn.

Loar, J. M., et al. 1987. First Annual Report on the ORNL Biological Monitoring and Abatement Program, Draft Report, ORNL/TM-10399, Oak Ridge National Laboratory, Oak Ridge, Tenn., pp. 1-354.

Loar, J. M. 1988. Second Annual Report on the ORNL Biological Monitoring and Abatement Program, Draft ORNL/TM Report, Oak Ridge National Laboratory, Oak Ridge, Tenn. 
Loar, J. M. 1989. Third Annual Report on the ORNL Biological Monitoring and Abatement Program, Draft ORNL/TM Report, Oak Ridge National Laboratory, Oak Ridge, T'enn.

Loar, J. M. 1990. Fourth Annual Report on the ORNL Biological Monitoring and Abatement Program, Draft ORNL/TM Report, Oak Ridge National Laboratory, Oak Ridge, Tenn.

Loar, J. M. 1991. Fifth Annual Report on the ORNL Biological Monitoring and Abatement Program, Draft ORNL/TM Report, Oak Ridge National Laboratory, Oak Ridge, Tenn.

Mann, L. K, and M. W. Biemer 1975. Oak Ridge, Tennessee, Flora: Habirats of the Vascular Plants-Revised Inventory, ORNL/TM-5056, Oak Ridge National Laboratory, Oak Ridge, Tenn.

McMaster, W. M. 1967. Hydrologic Data for the Oak Ridge Area, Tennessee, Water Supply Paper 1830-N, U.S. Geological Survey.

McMaster, W. M., und H. D. Waller 1965. Geology and Soils of White Oak Creek Basin, Tennessee, ORNL/TM-1108, Oak Ridge National Laboratory, Oak Ridge, Tenn.

Mitchell, B. J., et al, in press. "Seismotectonics of the Central United States," Decade of North American Geology Volume, Neotectonics of North America, eds., D. M. Slemmons, et al., Geological Society of America, Boulder, Colo.

Myrick, T. E., B. A. Bervin, and F. F. Haywood 1981. State Background Level, ORNL/TM-7343, Oak Ridge National Laboratory, Oak Ridge, Tenn.

NAS (National Academy of Sciences) 1973. Water Quality Criteria 1972-A Report of the Committee of Water Quality Criteria, PB-236-199, prepared for the U.S. Environmental Protection Agency, Washington.

NAS (National Academy of Sciences) 1972-Water Quality Criteria 1972. A Report of the Committee on Water Quality Criteria, National Academy of Sciences/National Academy of Engineering, Washington.

NCRP (National Council for Radiation Protection and Measurements) 1984. Education of Occupational and Environmental Exposures to Radon and Radon Daughters in the United States, Report No. 78, Bethesda, Md.

NCRP (National Council for Radiation Protection and Measurements) 1987. Ionizing Radiation Exposures of the Population of the United States, Report No. 93, Washington.

NPS (National Park Service) 1989. The National Park Service Statistical Abstract, 1989.

NRC (U.S. Nuclear Regulatory Commission) 1977. Final Environmental Impact Statement-Clinch River Breeder Reactor Plant, NUREG-0139.

NRC (U.S. Nuclear Regulatory Commission) 1983. Safety Evaluation Report related to the Construction of the Clinch River Breeder Reactor Plant, NUREG-0968.

NRCC (National Research Council of Canada) 1983. Radioactivity in the Canadian Aquatic Environment, Publication No. NRCC 19250, ISSN 0316-0114, Ottawa, Ontario.

Oak Ridge Chamber of Commerce 1990. Industrial Services Directory, Oak Ridge, Tenn.

Oakes, T. W., et al. 1987. Environmental Surveillance of the U.S. Department of Energy Oak Ridge Reservation and Surrounding Environs During 1986-Volume 1: Summary and Conclusions; and Volume 2; Data Presentation, ES/ESH-1/V1 and ES/ESH-1/N2, Environmental and Safety Activities, Oak Ridge National Laboratory, Oak Ridge, Tenn. 
Ohnesorge, W. F. 1986. Historical Releases of Radioactivity to the Environment from ORNL, ORNL/M-135, Oak Ridge National Laboratory, Oak Ridge, Tenn.

Oliver, J., and Isacks B. 1971. "Seismicity and Tectonics of the Eastern United Siates," Earthquake Notes 43, 30.

Olsen, C. R., et al. 1983. Chemical, Geological, and Hydrological Factors Governing Radionuclide Migration from a Formerly Used Seepage Trench: A Field Study ORNL/TM-8839, Oak Ridge National Laboratory, Oak Ridge, Tenn.

ORNL (Oak Ridge National Laboratory) 1986. Environmental Survelllance of the Oak Ridge Reservation and Surrounding Environs During 1985, ORNL-6271, Environment, Safety, and Health Division, Oak Ridge National Laboratory, Oak Ridge, Tenn.

ORNL (Oak Ridge National Laboratory) 1991. High Flux Isotope Reactor Safety Analysis Report, Integrated Analysis and Assessment Section, Energy Division, Oak Ridge National Laboratory, Oak Ridge, Tennessee, February.

Parr, P. D. 1984. Resource Management Plan for the Oak Ridge Reservation, Vol. 4: Appendix D, Endangered and Threatened Plant Species, ORNL-6026/V4, Oak Ridge National Laboratory, Oak Ridge, Tenn.

Pecora, W. T. 1978. Hydrologic Data for the Oak Ridge drea, Tennessee, Water Supply Paper 1839-N, U.S. Geological Survey.

Project Management Corporation 1975. Preliminary Safety Analysis Report, Clinch River Breeder Reactor, Oak Ridge, Tenn.

Project Management Corporation 1975. Clinch River Breeder Reactor Environmental Report, Vols. I-III, Docket No. 50-537.

Reed, P. R., Jr. 1988. National List of Plant Species that Occur in Wetlands: Southeast (Region 2), Biological Report 88(26.2), U.S. Department of Interior, Fish and Wildlife Service Research and Development.

Risk Eugineering, Inc. 1991. Seismic Hazard Evaluation for the High Flux Isotope Reactor (HFIR), Oak Ridge National Laboratory, Oak Ridge, Tennessee, Golden, Colo.

Rodgers, J. 1970. The Tectonics of the Appalachians, Wiley-Interscience, N.Y.

Rogers, J. G., et al. 1988. Environmental Surveillance of the U.S. Department of Energy Oak Ridge Reservation and Surrounding Environs During 1987, ORNL/ES/ESH4/V1 and 2, Oak Ridge National Laboratory, Oak Ridge, Tenn., April.

R.ogers, J. G., et al. 1989. Oak Ridge Reservation Environmenta! Report for 1988, ES/ESH-8/V1 and 2, Oak Ridge National Laboratory, Oak Ridge, Tenn., May.

Rothschild, E. R., et al. 1984a. Geohydrologic Characterization of Proposed Solid Waste Storage Area (SWSA) 7, ORNL/TM-9314, Oak Ridge National Laboratory, Oak Ridge, T'enn.

Russ, D. P. 1979. "Late Holocene Faulting and Earthquake Recurrence in the Reelfoot Lake Area, Northwestern Tennessee," Geol. Soc. Am. Bull. 90(1).

Seaber, P. R., J. V. Brahana, and E. F. Hollyday 1988. "Region 20, Appalachian Plateaus and Valley and Ridge," in The Geology of North America, Vol. O.2, Hydrogeology, Geological Society of America, Boulder, Colo.

Simpson, G. G. 1964. "Species Density of North American Recent Mammals," Syst. Zool. $7-9112,57-73$.

Spencer, E. W. 1977. Introduction to the Structure of the Earth, McGraw-Hill, New York. Stauder, W., et al. 1976. "Selsmic Characteristics of Southeast Missouri as Indicated by a Regional Telemetered Microearthquake Array," Seismol. Soc. Am. Bull. 66, 1953-64. 
Stover, C. W., ot al. 1979. "Solsmicity Map of the State of Ohio," U.S. Geological Survey Map MF-1142, Denver, Colo.

Stackdale, P. B. 1951. Geologic Conditions at the Oak Ridge National Laboratory (X-10) Area Relevant to the Disposal of Radioactive Waste, ORO.58, U.S. Department of Energy, Oak Ridge, Tenn.

Sutton, D. G. 1971. "Exploration Potential of the Rough Creek Fault System," pp. 391-412 in Proceedings' of the Symposium on Future Petroleum Potential of NPC Region 9 (Illinois Basin, Cincinnati Arch and Northern Part of Mississippl Embayment), Illinois State Geological Sunvey Petroleum Bulletin 95.

TDECD (Tennessee Department of Economic and Community Development) 1989. Tennessee Community Data, Kingston, Tenn., August.

TDHE (Tennessee Department of Health and Environment) 1989a. Licensed Hospitals and Ambulatory Sungical Treatment Centers in Tennessee, Board for Licensing Health Care Facilities, Nashville, September.

TDHE (Tennessee Department of Health and Environment) 1989b. Licensed Nursing Homes, Homes for the Aged and Residential Homes for Aged in Tennessee, Board for Licensing Health Care Facilities, Nashville, September.

TDHE (Tonnessee Department of Health and Environment) 1990. "Tennessee Radioactive Materials Licensees," computer data sheets, Nashville, December.

Thom, H. C. S. 1963. "Tornado Probabilities," Mon. Weather Rev. 91, 730-736.

Trifunac, M. D., and A. G. Brady 1975. "On the Correlation of Seismic Intensity Scales with the Peaks of Recorded Strong Ground Motion," Bull. Seismol. Soc. Am. 65(1), 139-162.

TSPO (Tennessee State Planning Office) 1991. Printout of 1990 Tennessee housing units, households, and population by county, city, and census designated places, Nashville, March 18.

TVA (Tennessce Valley Authority) 1959. Floods on Clinch River and East Fork Poplar Creek in the Vicinity of Oak Ridge, Tennessee, 0-5922, Division of Water Control Planning, Knoxville, Tenn.

TVA (Tennessee Valley Authority) 19.76. Watts Bar Nuclear Plant Unit Numbers 1 and 2 , Final Safety Analysis Report, Docket Numbers 50-390 and 50-391, Knoxville, Tenn.

TVA (Tennessee Valley Authority) 1977. Preliminary Safety Analysis Report, Clinch River Breeder Reactor Project, Knoxville, Tenn.

TWRC (Tennessee Wildlife Resources Commission) 1990. Wildlife in Need of Management, Tennessee Wildlife Resources Commission Proclamation Na. 86-29 as amended by Proc. No. 90-2, Feb. 1.

U.S. Army 1959. Glaze, Its Meteorology and Climatology, Geographical Distriburion and Economic Effects, Technical Report EP-105, Quartermaster Research and Engineering Center, Environmental Protection Research Division, U.S. Army, Natick Mass.

USGS (U.S. Geological Survey) 1988. "Oak Ridge Area, Oak Ridge, Tennessee, Topographic Map," Contour Interval 20 feet, National Geodetic Vertical Datum of 1929, Scale 1:24,000. S-16A, December, 1987, prepared by Mapping Services Branch, Tennessee Valley Authority, for U.S. Department of Energy, available from USGS, Reston, Va.

Webster, D. A. 1976. A Review of the Hydrologic and Geologic Conditions Related to the Radioactive Solid Waste Hurial Grounds at Oak Ridge National Laboratory, Tennessee, Open File Report 76-727, U.S. Geological Survey. 
Weiss, E. A. 1981. "Environmental Sedimentology of the Middle Ordovician and Paleoecology of a Portion of the Witten Formation at Solway, Tennessee," M.S. thesis, University of Tenneasee, Knoxville.

White, J. L. (ed.) 1990. Directory of Tennessee Manufacturers, M. L. Smith, Nashville. Zurawski, A. 1978. Summary Appraisals of the Nation's Croundwater Resources-Tennessee Region, Professional Paper 813.L, U. S. Geological Survey. 


\section{ITHE FACILITTY}

The Advanced Neutron Source (ANS), a new facility being designed at Oak Ridge National Laboratory (ORNL), would consist of a $3.30 . \mathrm{MW}(\mathrm{f})$, heavy water moderated reactor and extensive experiment and user support facilities. The primary purpose of the ANS would be to provide facillites for neutron scattering research in the United States. Studies and discussions have determined that a nuclear reactor would serve as the best steady state neutron source for the facility. The neutrons provided by the reactor will be thermalized to produce sources of hot, cold, and very cold neutrons usable at the experiment stations. Beams of cold neutrons would be directed into a large guide hall using neutron guide technology, greatly enhancing the number of research stations possible in the project. Fundamental and nuclear physics, materials analysis, and other research programs would share the neutron beam facilities, Laboratory and office space would be sufficient to create an effective user-oriented environment.

The design and arrangement of ANS facilities were guided by concerns for safety and function, resulting in a multilunction bullding arrangement. Consequently, ANS buildings incorporate design elements that would provide containment of airborne radioactive contamination; shielding from high-energy neutrons; security from vandalism, sabotage, or theft; a control room designed for ease of maintenance and operation; and well-eçulpped, flexible experiment operations. In addition, facility design would allow for segregation of the operations and experiment staff for security and health and safety purposes. Principal ANS structures would be the

- reactor bullding, which would provide shielding, containment of fission products during a possible accident, experiment support, and mechanical eq'ilpment support during normal operations;

- reactor support building, which would house the majority of the ANS mechanical equipment and a control room for the reactor; and the operations support building, which would provide office support for operations staff, maintenance facilities, an alternate control room, and a material recelving, storage, and inspection area;

- guide hall, which would contain additional experiments and the neutron guides from the reactor;

- the research support building, which would house the laboratories and experiment support activities;

- interface building, which would act as the main entrance and provide security and visitor control; it would also be the focus for the health and safety activities;

- oftice building, which would provide office support for visitors and experimenters; and

- other site facilities, such as the detritiation building, electrical substation, diesel generator building, and compressor building.

A conceptual site plan for the ANS is shown in Fig. 3.1-1, and principal features of the ANS reactor building and reactor support building are shown in Figs, 3.1-2 through 3.1-7. The conceptual design of the ANS is ongoing and significant changes can be expected. This section summarized the design as of January 1992.

\subsection{FUNCTIONAL DESCRIPTIONS}

This section describes the principal ANS facilities listed above. 


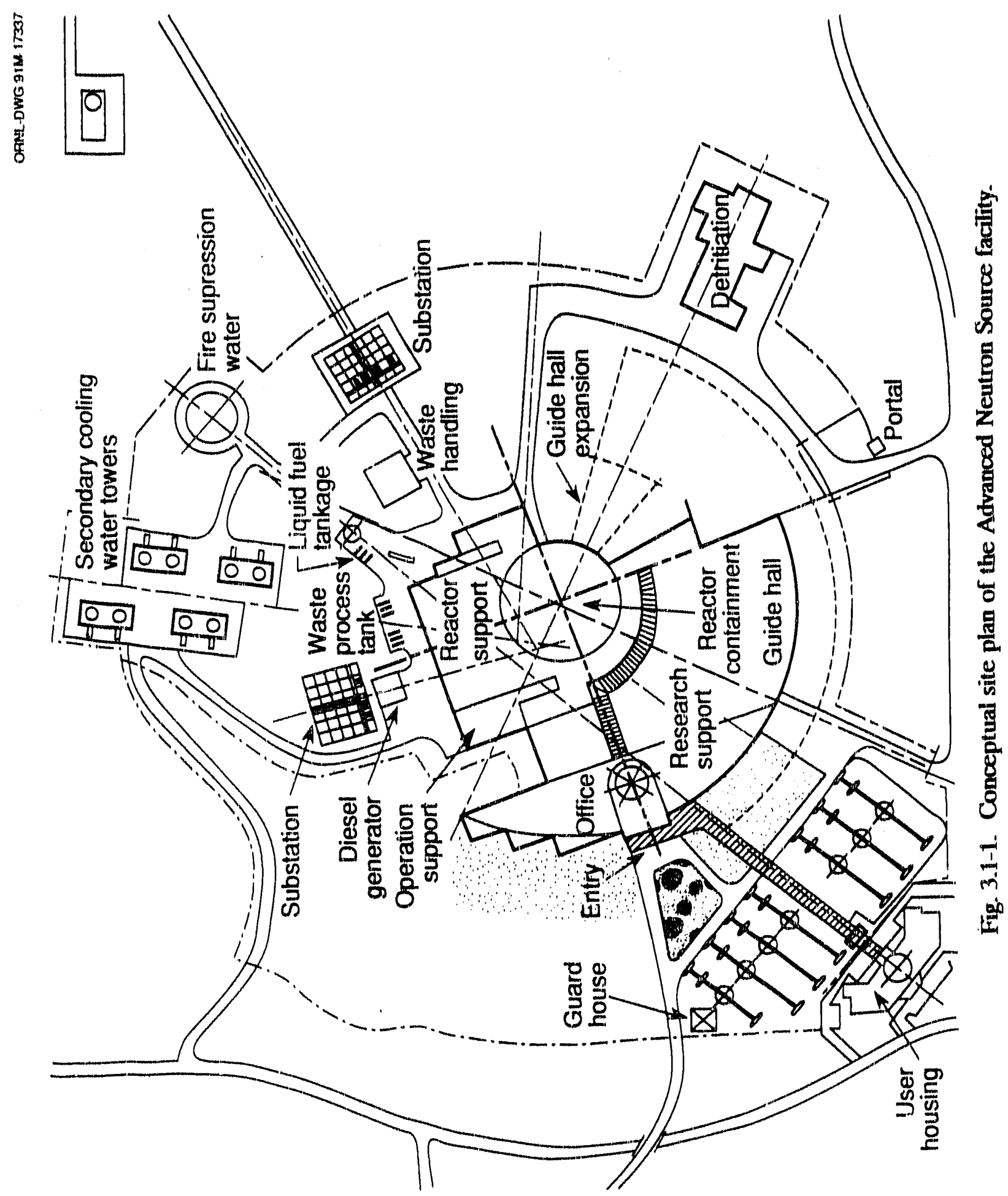




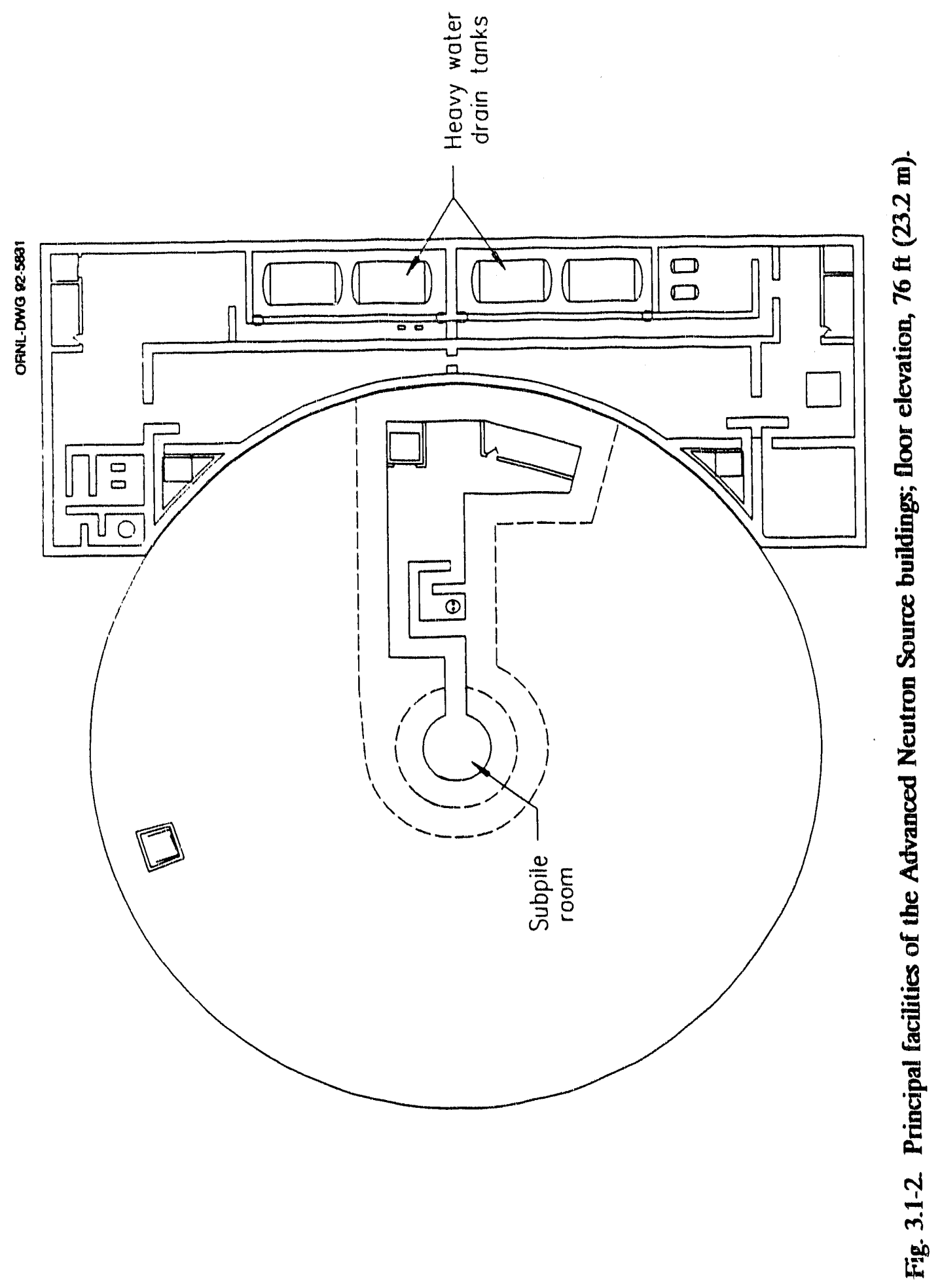




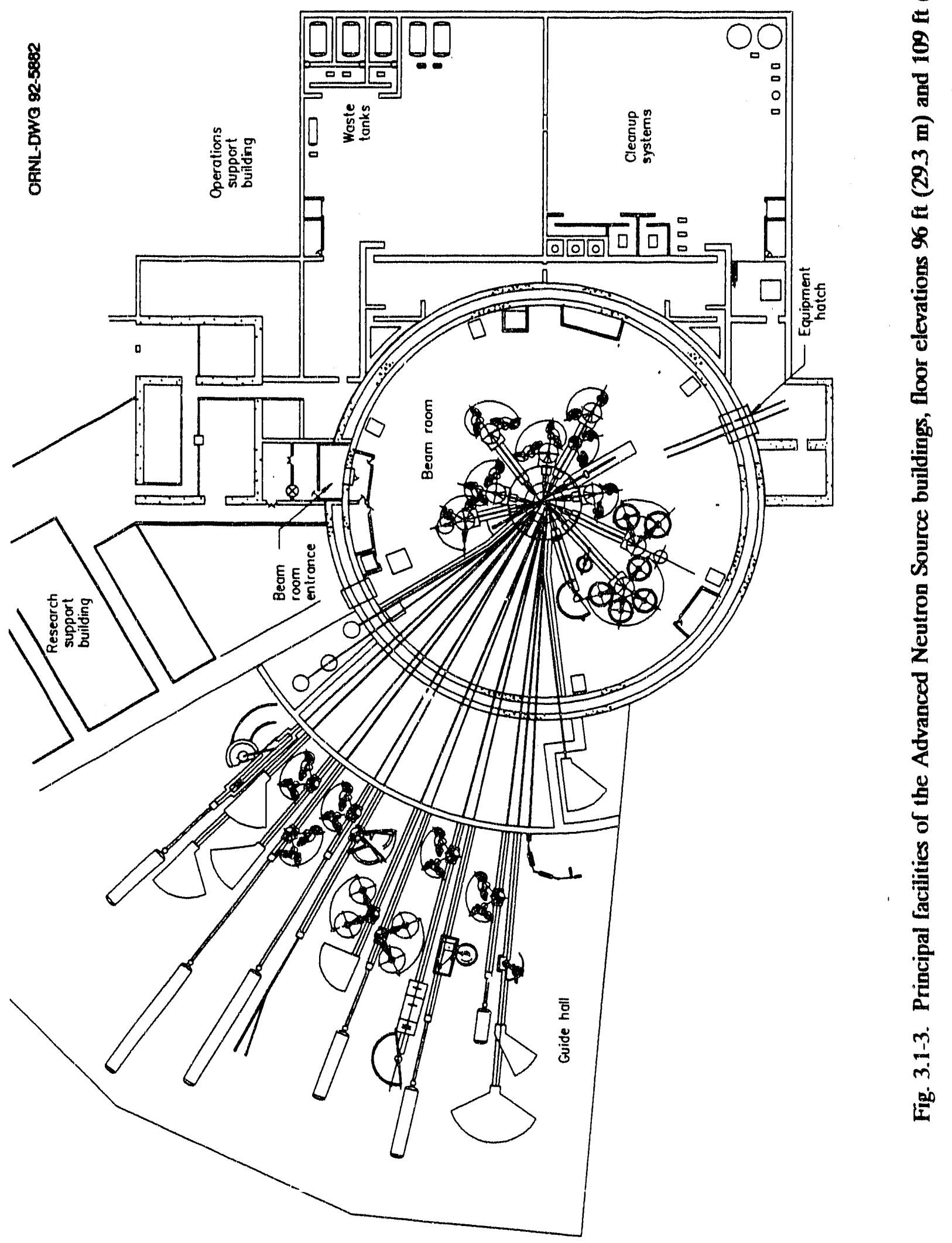




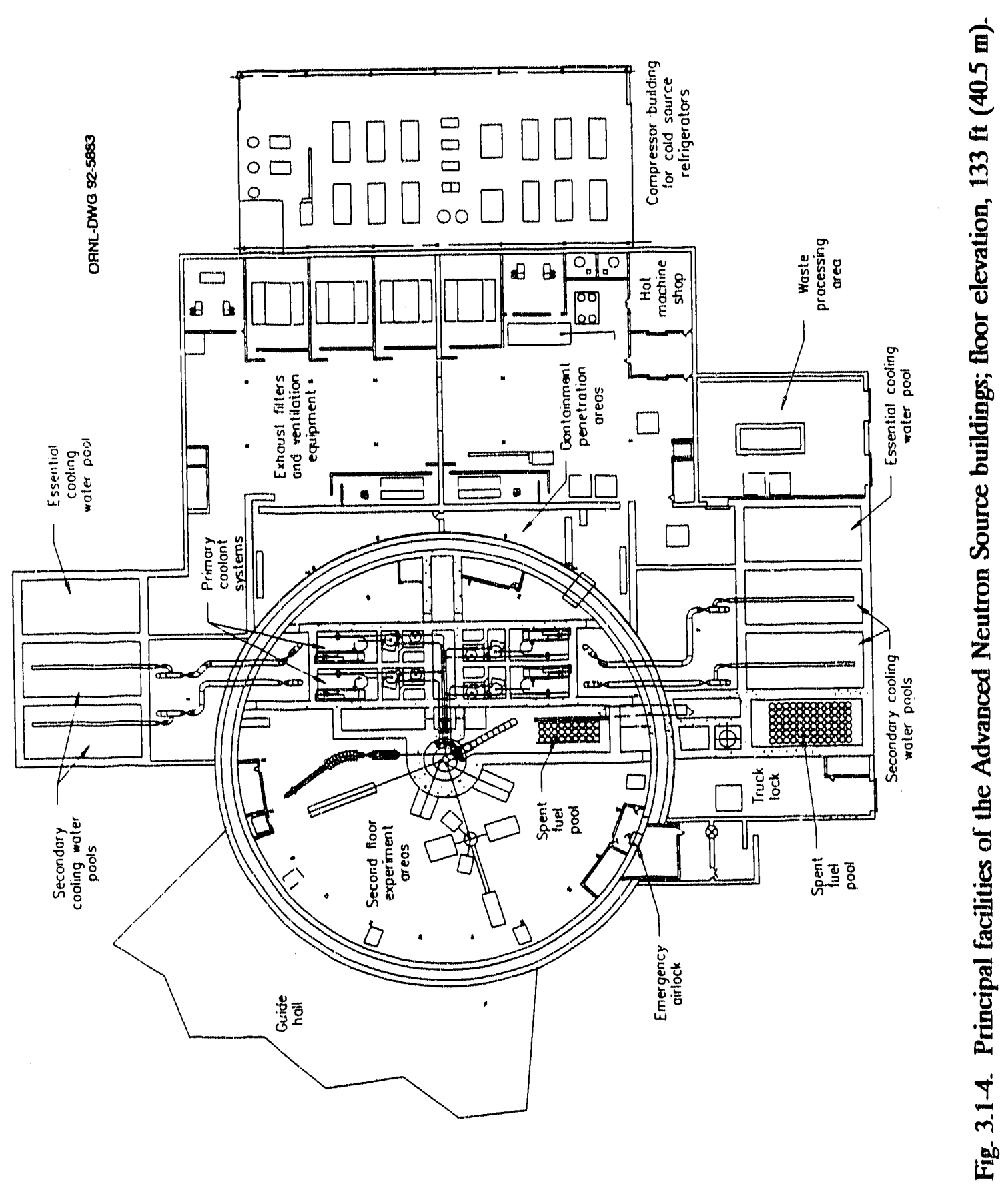




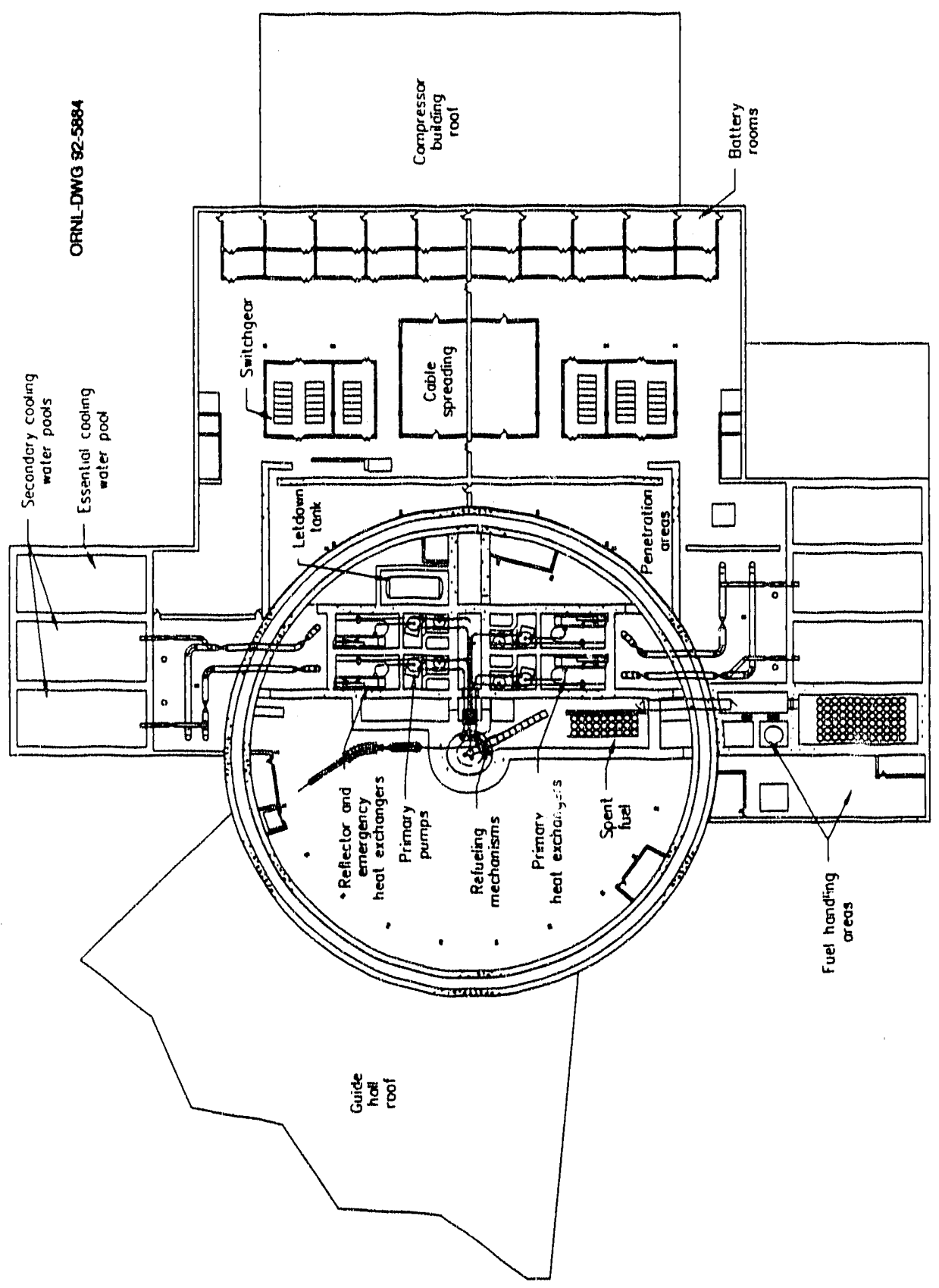

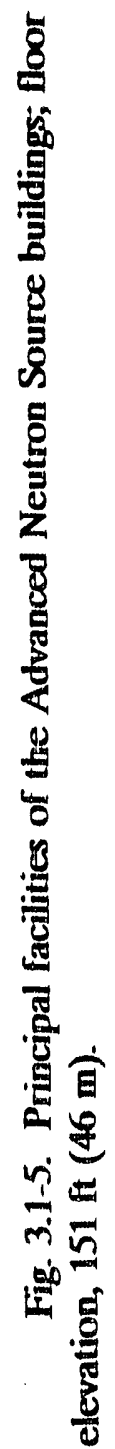




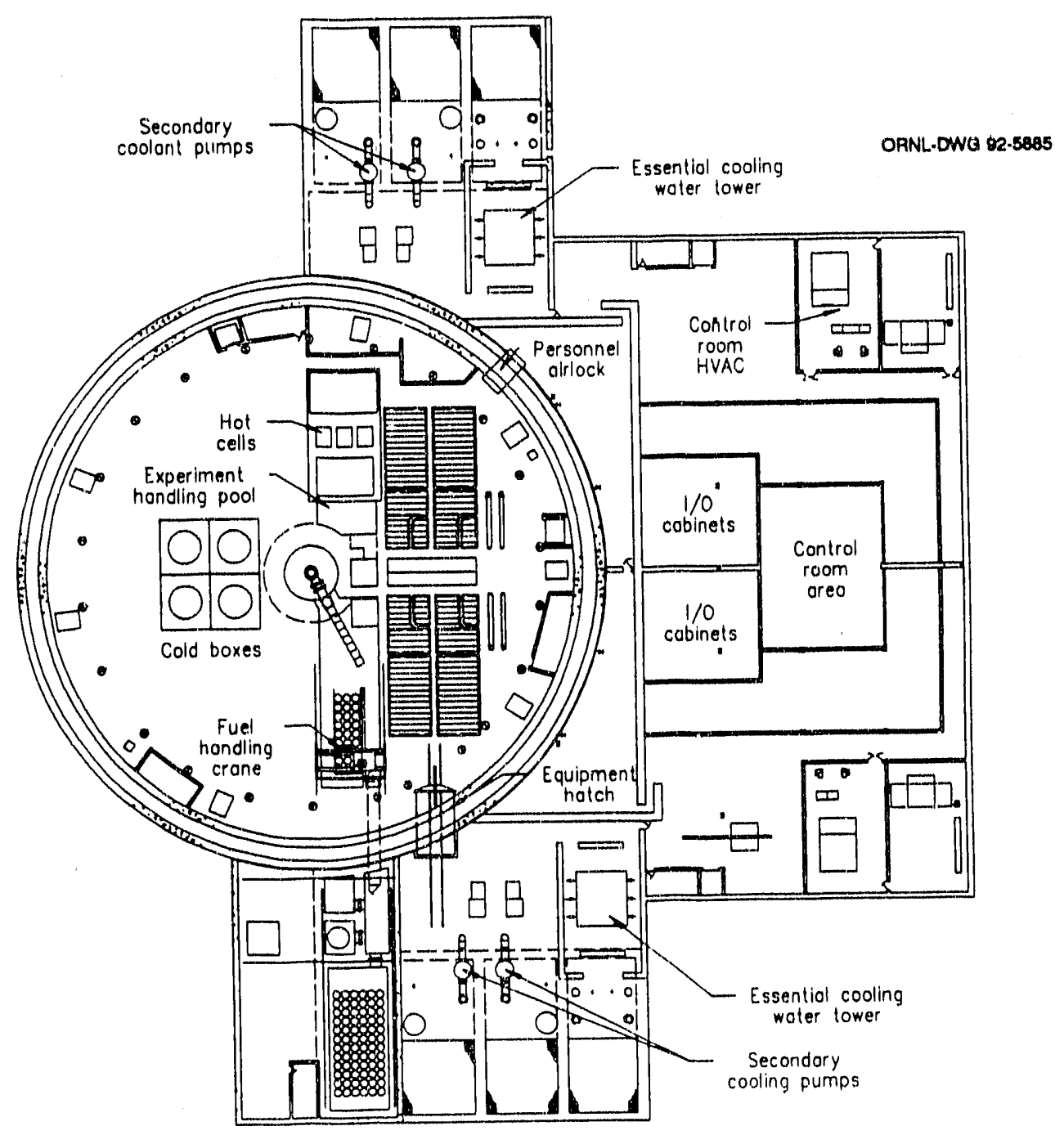

Fig. 3.1-6. Principal facilities of the Advanced Neutron Source buildings; floor elevation, $169 \mathrm{ft}(51.5 \mathrm{~m})$. 


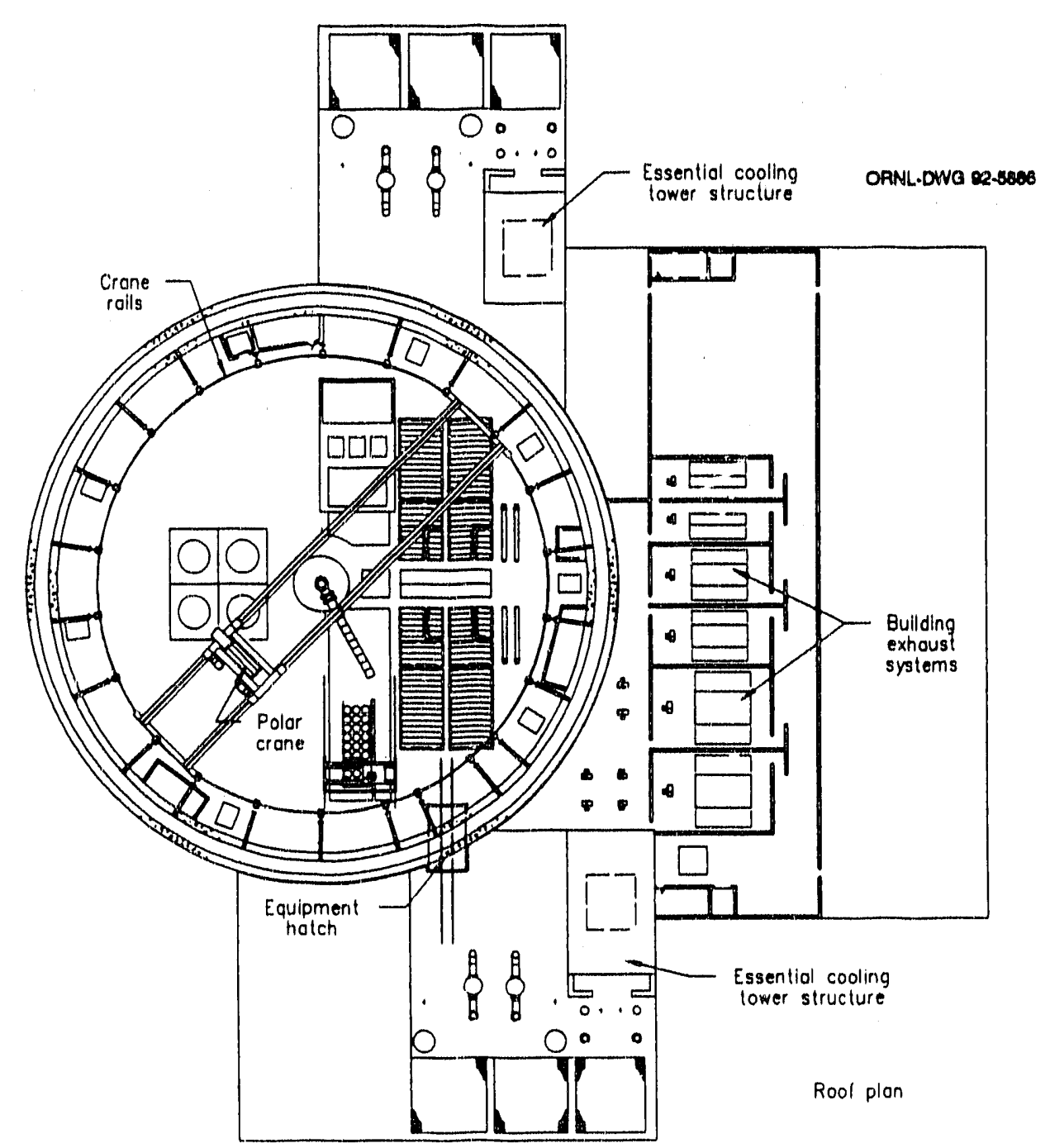

Fig. 3.1-7. Principal facilities of the Advanced Neutron Source buildings; roof elevation, $186 \mathrm{ft}(56.7 \mathrm{~m})$. 


\subsubsection{The Reactor Building}

The central structure would be the domed, cylindrical reactor building, the principle function of which is to house the reactor and experiment facilities. Other major functions of the reactor building structures would be radiation protection and containment. Radiation protection features would include biological shielding around the reactor (concrete horizontal shielding and light water vertical shielding), portable shielding around experiments, tritium control, and the use of limited volume cells for reactor safety. The reactor building would also be designed as a dual containment structure. The outer containment would be a load-bearing, 0.6- to 0.9 -m-thick (2- to 3-ft-thick) concrete structure that would also serve as the hardened structure protecting the reactor from the effects of natural phenomena. A second steel containment would be inside the concrete containment. The gap between the concrete (secondary) and steel (primary) containments would serve as a ventilated plenum for leakage control. Other measures incorporated into the containment features include designs for physical protection and venting containment outleakage through a stack with state-of-the-art filtration capabilities.

The center of the reactor building would contain the reactor pool, with fuel storage pools immediately adjacent to the reactor pool. A cross-section of the reactor building is shown in Fig. 3.1-8. The first floor would be open for beam research activities, with the exception of the quadrant through which the beam guides traverse into the guide hall. The remainder of the second tloor would also be dedicated to experimental purposes. The storage pool structures accessed from the third floor would occupy the remainder of the second tloor, along with heat exchangers, pumps, pressurizing system, and other reactor support equipment. The third (operating) floor, under the high bay, would be dedicated to reactor operations activities, and the cold box for providing liquid helium to the cold source. The reactor building third floor would also serve as a spent fuel storage location. Stored within containrnent, there may be up to about 34 fuel elements stored for 2 years. Longer-term storage (up to 5 years) would be in the reactor support building.

\subsubsection{Overall Building Structure}

This section gives an overview of the reactor building design criteria, foundations and major structures, and exterior features.

\section{Reactor building design criteria}

The reactor building would be designed to strict criteria for resistance to seismic, wind and other loadings, and to ensure containment integrity in response to a wide variety of incidents. It would protect safety-related equipment from both external and internal "missiles" that may be generated by natural phenomena or equipment failures. It would be designed to act as an effective barrier to intrusion.

The detailed design criteria for the reactor building would be developed by the architect-engineer as the conceptual design developed. Seismic design of the Reactor building will be in accordance with Department of Energy (DOE) Order 6430.1, and the design would conform to Nuclear Regulatory Commission (NRC) criteria to ensure that public exposure standards would also be met. In general, these criteria are similar to criteria used in the design of the Clinch River Breeder Reactor and in commercial reactors constructed in the region by the Tennessee Valley Authority (TVA). 


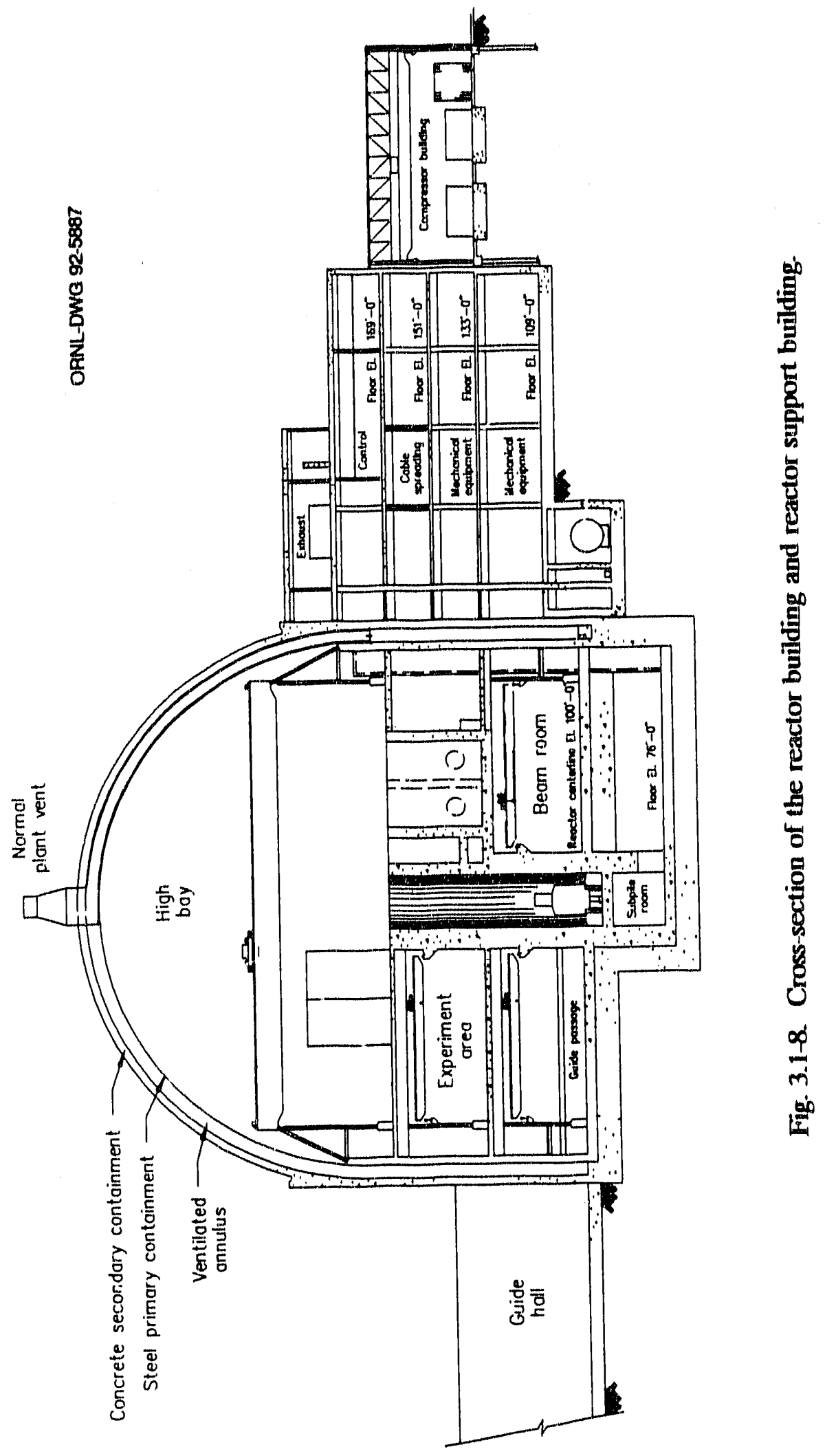


Foundations and major structures

Because it houses the reactor, the reactor building would be considered a Seismic Category 1 bullding capable of surviving a $0.3 \mathrm{mg}$ earthquake (the safe-shutdown earthquake). As a result, the reactor building would be a reinforced concrete structure, supported on the outside by the cylindrical concrete containment walls and on the inside by the massive shield walls for the reactor pool. The reactor building would be capped by a concrete dome that would provide the secondary containment. The outer cylindrical walls and dome would serve as the hardened protection barrier from external missiles for items inside the reactor building. The inner steel containment would be self-supporting and would be designed to withstand the rated pressure loads. The steel containment above the high bay would be free standing and also designed for design pressure.

\section{Exterior features}

The exterior view of the reactor building would be of a simple cylinder, capped by a hemispherical dome, with no windows, doors or other penetrations. The outer walls would be formed by the concrete secondary containment structure. Architectural treatments of the interior and exterior walls will be developed as the design progresses.

\section{Containment}

A primary function of the reactor dome is the containment of fission products that would be released during a potential accident. The ANS reactor is being designed in accordance with the defense-in-depth concept, in which succeeding layers of safety are built into the design and operations of the facility and excessive reliance upon any one element is avoided. The reactor containment system would provide the third level of this defense-in-depth concept. The containment systems would function to provide personnel protection for the ANS site population, the population of the Oak Ridge Reservation, and the general public against the effects of severe accidents. ANS site personnel include the operating and experimental personnel located within the containment building.

The reactor containment building (Fig. 3.1-9) would be a dual-containment structure consisting of an inner steel containment vessel, which would limit the leakage of any fission products that may be released into the internal containment atmosphere, and an outer concrete structure, which would provide for collection and subsequent treatment of fission products that leak trom the inner barrier. The concrete shell would also provide protection for the inner steel vessel against the external environment and would act as a radiation shield for any radioactivity between the inner and outer barriers that may be present during a severe accident. The barrier would also incorporate isolation valves installed on all penetrations through the steel vessel. The reactor containment building would also be divided into separate operating and experimental areas. The normal heating, ventilating, and air conditioning systems for these areas would be separated so that any radioactivity released into one area would not spread into the other, except in the most severe accident.

The fission product control system would provide a means to limit or delay the release of fission products in order to permit the safe evacuation of all on-site and off-site personnel. Fission product control inside the containment would be provided by the reactor fluid boundary and further enhanced locating the reactor primary fluid boundary in 


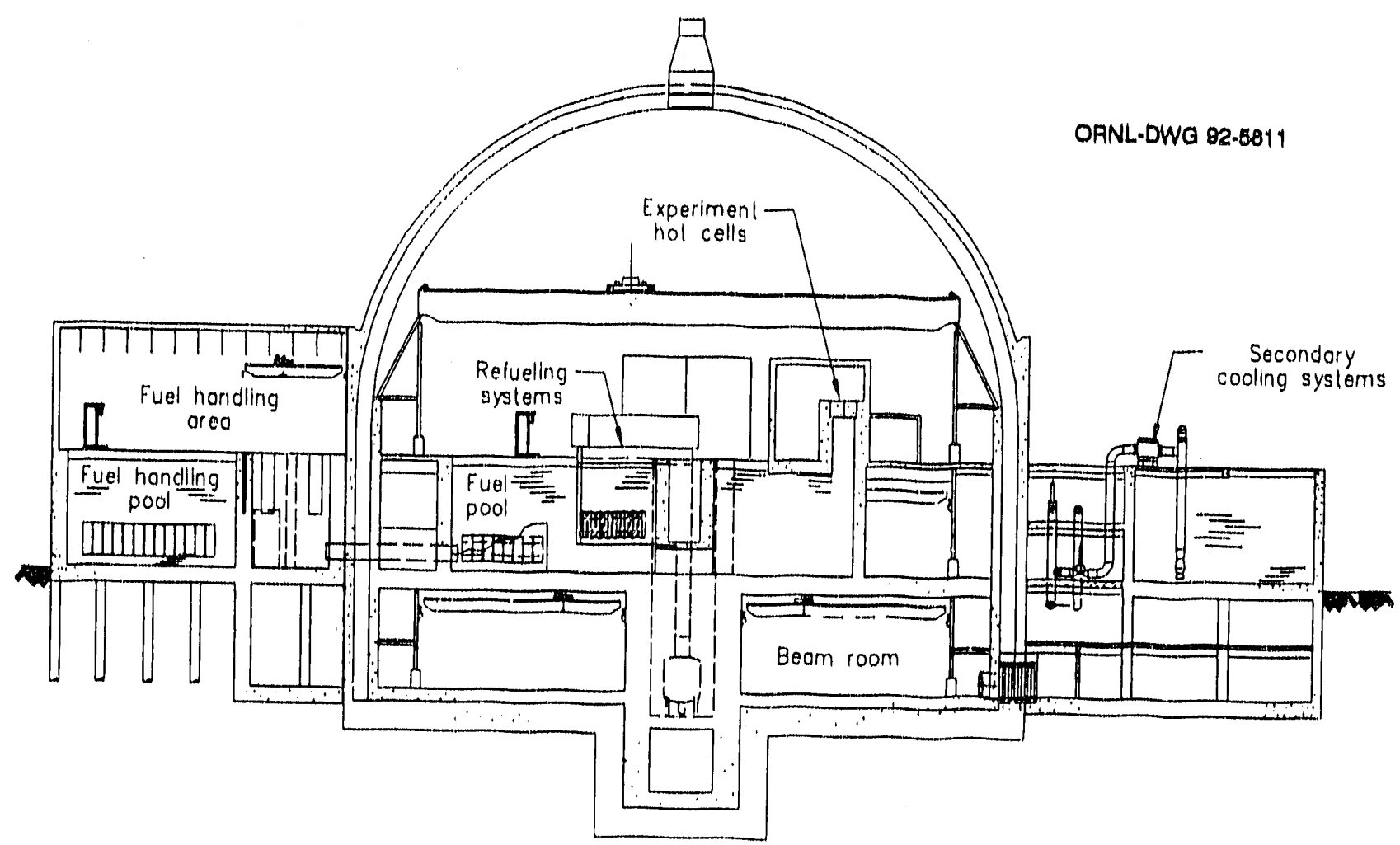

Fig. 3.1-9. Elevation view of the reactor building.

either water- or air-filled pools or celis and by isolation valves installed on all pool or cell wall penetrations. Fission product control would be provided by a fission product treatment system that would maintain a negative pressure relative to the outside air pressure in the annulus, the space between the inner steel containment vessel and the outer concrete structure, and would remove the fission products that would leak into the annulus during severe accidents. The combination of the inner primary containment leak rate, on the order of $0.5 \%$ volume per day, and the annulus fission product treatment system, having an iodine decontamination factor on the order of 400 , would satisfy the U.S. Environmental Protection Agency's (EPA) Protective Action Guidelines limits for the ANS boundaries. This would be true even for ground-level releases during severe accidents, including up to a $100 \%$ release of noble gases and iodine into the inner containment atmosphere.

Heat removal for severe accidents would be provided by the inherent containment building heat sinks and by passive heat transfer through the inner steel containment vessel and outer concrete wall. Inherent combustible gas control would be provided by the large containment volume that, with adequate mixing, would ensure that concentrations would be less than combustible limits.

\subsubsection{Central Reactor Pool, Shield, and Associated Structures}

The dominant interior feature of the reactor building would be the reactor pool and shield structure, along with the spent luel and equipment pools and the limited volume cells for valves and piping. At present, the function of these structures is being defined, and thus the dimensions assumed for the cells are likely to change significantly. 
The reactor pool and shield is currently conceived as a cyllindrical concrete structure with an inside radius of about $3 \mathrm{~m}$ (10 ft) and an outside radius of $5.5 \mathrm{~m}(18 \mathrm{ft}$ ). Thus, the concrete biological shleld is currently assumed to be about $2.5 \mathrm{~m}(8 \mathrm{ft})$ thick. From the standpoint of maximizing the neutron flux at the sample of an experiment, it is desirable for the outside radius of the shicld to be as small as possible while maintaining low radiation backgrounds in the experiment areas. The neutronic and gamma transport calculations on which the design of the shield would be based are continuing. The use of high-density concrete and other measures to improve the effectiveness of a given thickness of shield is anticipated in key areas. The possible need for a shield cooling system would also be considered as the design progresses. The interior of the reactor pool would be lined with stainless steel to facilitate decontamination and prevent leakage.

The auxillary pools would serve the needs of spent fuel handling target handling and shipping, and general reactor maintenance. Pools would be generally $10.6 \mathrm{~m} \mathrm{(35 \textrm {ft } )}$ deep, corresponding to the room height of the seound floor. Thus, they would eliminate sections of the second floor but would not interfere with the main beam room floor.

A potential overall arrangement of the auxiliary pools is shown in Fig. 3,1-6. In addition to the open pools shown, there would be a special heavy water pool covered by a shielded, inerted (or ultra-dry) cell for use in transferring spent fuel from reactor to storage locations, and for loading the reactor fresh fuel. The dimensions and arrangement of this pool have not yet been determined. The heavy water pool would be accessed via a refueling handling cell from the third floor of the reactor building.

The limited volume cells are also currently assumed to occupy a segment of the second floor area. The cells would likely be a sealed, limited volume, water-filled cell to help mitigate the consequences of a break in the primary piping; the sealed cells would limit the volume of heavy water that could leak from primary cooling in the event of a pipe break. The cells would carry the reactor primary coolant lines from the pool and also contain pumps and valves. Further specifications for the limited volume cells will be defined as the design progresses.

\subsubsection{First. Floor Features}

The first floor of the reactor building would be kept open to allow maximum use of space for experiments around the biological shield. The one exception would be the beam guide passage, a pie-shaped segment around the beam guide penetrations that would provide shielding around the guides as they pass from the reactor shield to the guide hall. This segment will be surrounded by concrete shield walls and covers. This shield, because it would not extend to the ceiling, would provide access to the guides in the pool, which would be obtained by lifting shield covers oft the top of the structure.

One or two polar-segment bridge cranes would be provided for handling of heavy experiment equipment. A review of experiments at other scattering facilities indicates a minimum hook height of $7 \mathrm{~m}(25 \mathrm{ft})$ is required. Local jib cranes and monorails would be provided as needed. Polished floor surfaces would be provided at some of the experiment positions, to allow the use of air pads on moving arms of the instruments. A large airlock into the beam room would be provided to allow equipment to be brought in from the reactor support building. A personnel airlock would be provided near the central entry of the complex to allow controlled access from a security control area in the interface area. Use of the large airlock may be restricted to periods when the reactor is not operating. (Because of the short operating cycle this may not pose excessive limitations on the experiment programs.) 


\subsubsection{Second Flocor Features}

The second tloor of the reactor bullding would be divided into two areas. One area would support the experiments on the second floor. The second would be the lower portion of the pools and tunnels that are accessed from the third floor. The main access to the experiment side of the second floor would be by stairway leading from the first floor adjacent to the first flocor personnel airlock. An alrlock on the opposite end of the second floor would be required for means ol personnel safety egress to allow rapid evacuation during an emergency. Access to the operational portion of the second floor would be through a stairwell leading from the third floor high bay.

The major use of the second floor would be to provide experimental areas by the scientific staff. Speciflc experiments are currently being defined for that area.

Because experiment facilities would be located on a portion of the second floor, ceiling space and crane requirements would be similar to those on the first floor. Polarsegment bridge cranes would be installed in the second floor to serve those experiment areas, Internal partitions of this flocor, tratfic patterns, and handling system requirements will be further detined as the design progresses.

The second portion of the second floor, housing the lower portion of the pools and tunnels, would normally be accessible by reactor operations personnel only, most likely from the third floor via stairwaly or elevator. A concrete wall separates the research and operation sides of the second floor. Emergency egress using alarmed doors may be required to allow operating personnel to evacuate through the experiment side.

\subsubsection{Third Floor Features}

The third floor of the reactor bulding would be the operating floor under the reactor building dome. This area would normally be accessible to reactor operations personnel only, not to visiting scientists, although permanently assigned and authorized scientists will operate limited number of experiments controlled from the third floor. The operating floor would be dedicated to those activities required for operating, refueling, and maintaining the reactor. It would also be used for installing, removing, and preparing for shipment all transuranic materials and isotopes irradiation targets and would have an operating area and counting room for the neutron activation and analysis facility (NAAF).

Generally, the operating floor would be characterized by the large, open area under the dome. At present, the major equipment inside the dome would be the refueling transfer cell and associated target handling cells, ventilation equipment for both containment cooling and hydrogen salety, and two helium cold boxes. An enclosure over the reactor pool would be considered il the design of hydrogen safety systems indicates the usefulness of such a structure. The high bay would be served by a polar crane; the size would be determined once the weight of the heaviest cask or equipment item to be handled is identified.

Access to the operating floor would be through a personnel airlock on the northeast side, passing into the high bay of the reactor support building. A hatch and transfer tube on the south side would be the path through which spent fuel and target casks would be handled and would also serve major maintenance aclivities. Because the operating floor would be serviced by reactor staff only, the smaller personnel airlock would be the normal means of access. This arrangement would enhance communication between the operating floor of the reactor building and the reactor support building, including the control room. The hatch would be used only during reactor outages when large equipment could be transported ir! or out of containment. 
Further definition of the operating floor features will evolve as the design progresses.

\subsubsection{Subpile Room Features}

A subpile room in the ANS would be required to house and provide access to the control drive assemblies. 'The general location of the subpile room is shown in Fig. 3.1-8. This area will be further defined as the systems to be located in it are designed.

Areas located under the reactor pool would offer the possibility of draining the pool if a major seal failure were to occur. Thus, provisions for flooding the subpile room would be considered. Options would range from controlling the volume of the subpile room and sealing the doors so that the total amount of water that can be lost from the pool would be acceptable, to simply operating the subpile room flooded at all times. A decision on this issue would be made when more design and safety analysis information is available. Figure 3.1-8 depicts a separate enclosure immediately under the reactor pool, operated dry but with a watertight door designed 10 withstand the static head of the pool.

\subsubsection{Major Issues and Options}

Most of the major options to the current concepts for the reactor building are associated with experiment facilities and the scope of reactor containment. Other issues generally deal with the optimal shape and dimensions of the building. Ceiling heights for the experiment floors will be confirmed as the design of experiments progresses.

\subsubsection{Reactor Support Building} section.

The principal characteristics of the reactor support building are described in this

\subsubsection{General Description}

The primary purpose of the reactor support building would be reactor operations support [i.e., mechanical equipment (electrical, waste, and cleanup), control room, fuel storage, and fuel transfer). The building would incorporate standards for limiting exposure to as low as reasonably achievable (ALARA) levels. For example, there would be shielding around contaminated equipment; and equipment cells with the potential to be contaminated would be ventilated. Backup power, both diesel and battery, would be available to key components during any power interruptions. The control room would be designed to be habitable during an accidenl (e.g., a separate ventilation system). Security at the reactor support building would allow access by operations personnel only.

\subsubsection{Exterior Features}

Generally, the exterior walls of the reactor support building would be smooth concrete, with no windows. Doors and loading docks would be located at appropriate points, with roadways leading to them as required. Runoff from the roofs would be collected and monitored for contamination. Archilectural treatments of the exterior walls will be developed as the design progresses. 


\subsubsection{Building Features}

Layouts of equipment in the reactor support building have not yet been developed. The areas under and adjacent to a cell bank would be dedicated to equipment directly supporting the systems in the cell bank. Compressors for the cryogenic refrigerators would be located in a separate structure along the east edge of the reactor support building in a separate compressor building. Heavy water collection tanks for draining the heavy water system would be located at a low elevation, below the level of the heavy water drains.

Although specific equipment locations are yet to be determined, a design philosophy applies when locating equipment. In general, tanks and low point drains would be in the basement or first floor of the building. Heavy mechanical equipment producing vibration-such as pumps, compressors, chillers, electrical generators-would either be located on the lower floors or in a separate building. Electrical and instrumentation facilities are located in the upper floors. A major feature included in the building is the reactor control room and its associated offices and maintenance facilities that will be required to operate the reactor. Included in the complex are all necessary emergency support facilities, habitability features, and hardware support areas required. The control room will likely be on the fourth or fifth floors. On the roof, or in a penthouse on the roof, are the ventilation fans that serve much of the building in areas that cannot become potentially contaminated. Other areas may be vented through the ANS stack.

Adjacent to the building in a covered structure is a compressor building. Providing support for the cold box located in the reactor building are a series of helium compressors that provide helium gas at high pressure. These components are located in a separate building since they produce a great deal of noise and vibration.

Electrical power is provided to the facility from either of two electrical substations, one served by a TVA high-voltage service line, the other from a low voltage line from ORNL. The primary electrical service entrance to the building will be located based on the location of the substation on the site and the location of the major equipment electrical loads within the building.

\subsubsection{Operations Support Building}

The operations support building would house the majority of the operations staff and provide a clean, radiation-free area for many of the general operations functions necessary to operate the facility. Contained in this building would be the remote shutdown control room, general operation offices, maintenance shops, training rooms, reactor simulator, etc. The building features will be defined as the design progresses.

\subsubsection{Guide Hall Building and Research Support Building}

This section describes the guide hall building and briefly covers the major issues and options regarding the building.

\subsubsection{General Building Description}

The guide hall building would be a single-floor structure of standard industrial construction. It would serve solely to house the beam guides and experiments along the guides. Portable shields around the guide tubes would reduce radiation levels from nonreflected neutrons and other spurious radiation. Containment nenetration isolation 
valves would be used on the guides so that the guide hall would not be part of containment.

The potential for expansion of the guide hall has been incorporated into the building design. An expansion guide hall has been incorporated into the site plan and facility layout.

The guide hall building would not contain radioactive materials (other than levels of induced activity in small samples) and would not be part of reactor containment. The building design criteria would thus be to provide the level of protection appropriate for the investment in beam facilities located inside the structure. At present, it is anticipated that the guide hall building would be designed to the requirements of DOE Order 6430.1A. Protection of the investment housed in the structure may dictate some additional criteria for resistance against natural phenomena, etc. Design criteria for the guide hall will be developed more fully in the future.

The guide hall would include a steel superstructure with concrete floor and foundation. The building would generally be a large, open structure shaped to accommodate the beam guides fanning out from the reactor; 14 of the 16 guides would be set in pairs. The guides of each pair would set $2^{\circ}$ apart, and the near guides of adjacent pairs would be set $6^{\circ}$ apart. A seventh guide on each cold source would be directed out of the main array by the use of a bender. The lengths of the guides and experiments on the guides and the appropriate distance from the sides and ends of the guides to the walls of the guide hall are still somewhat open. Thus, the outside dimensions of the structure hain mot yet been established. A shielded region would enclose the guides as they leave the reactor building. Unlike the pool and cell structures in the reactor and reactor support building, this shield structure would not be a load-bearing part of the overall structure.

The major features of the main floor of the guide hall building would be the guides, set on the angles described previously. The ceiling height inside the guide hall would be about $13 \mathrm{~m} \mathrm{(} 42 \mathrm{ft}$ ), and bridge cranes would serve the guides and instruments. The guide hall would also house industrialized computer workstations with desk space on the perimeter.

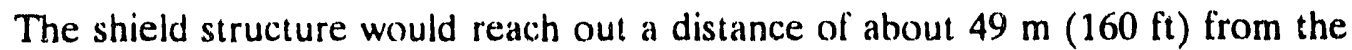
reactor axis and would have concrete walls of adequate thickness and depth to limit the backgrou'nd radiation in the guide hall to acceptable levels for both health physics and counting accuracy purposes. More specific criteria tor the shield will be developed later.

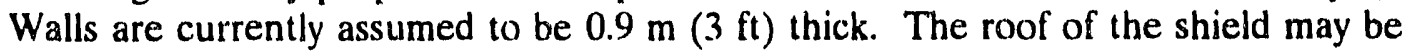
segmented to allow dismantling for the access to the guides.

A nuclear physics experiment would be located on the bent guide at the east end of the guide hall. This experiment uses $20 \mathrm{~L}(5.3 \mathrm{gal})$ of liquid hydrogen. The station would be designed into the shield structure so as to provide an explosion-proof wall between the experiment and the rest of the guide hall. The exterior wall would be designed to deflect a blast away from any part of the reactor complex.

The nature of the guides, with shielding covering the guide and instruments clutte. space around the guides, would be to impede movement across the guide hall. A passageway would be constructed above the guides, at the outer edge of the shield structure. 


\section{Research Support Building}

The research support building would house the laboratories and other related facilities required to support experiments and prepare samples for irradiation. Cryogenic, chemistry, and sample preparation laboratories are typical of those that would be found in the building. The building would also house NAAF-2 and possibly some of the health physics laboratories. The nature of the structure would be similar to that of the guide hall.

\subsubsection{Major Issues and Options}

Issues and options generally center around the layout of the beam guides, and on the number and size of experiments. If thermal guides are developed to the extent that thermal experiments could effectively be located in a guide hall, either a significantly larger guide hall or multiple halls may be desirable. If procedures for sealing guide penetrations in accident scenarios are not accepted, the entire guide hall could become part of reactor containment. Otherwise, most of the options deal with the dimensions of the guide hall and the degree of "hardening" appropriate for protection of the investment in experiments.

\subsubsection{Office Building and Interface Building}

The office building would provide sufficient space for ANS users. It would be laid out so that communication between outside users and permanent staff would be encouraged. The office building would provide all the necessary facilities, such as conference areas and an auditorium, for technical communication. It would also provide adequate services, including food services, for scientists who must remain at their stations for extended periods of time.

A survey of space requirements for beam instrument users and support personnel has recently been completed. This survey was based on staffing at a number of existing installations, and it indicates that an average of 6 persons per ANS instrument would be expected. It is estimated, therefore, that space must be available for 6 persons per instrument, or 246 people for the 41 instruments currently planned for an ANS. These numbers do not include space for management, secretarial support, user liaison, users of irradiation facilities, or the reactor operations staff. Thus, a total capacity of about 400 persons would likely be required at the ANS site.

The interface building would house security and health physics functions necessary for segregation of operations personnel from scientific staff. It would also serve as the main entrance to ANS.

The interface building would not contain any radioactive materials and would be isolated from reactor containment and ventilation systems. Design specifications $\mathrm{fc} i$ the building would conform to DOE Order 6430.1A.

Major issues and options center around the size of office building appropriate. A modular concept is anticipated for the offices so that the size of the facility could easily be adjusted as requirements are defined. Utilization of other existing buildings would also be considered. Design features and architectural requirement, will be developed as the design progresses. 


\subsubsection{Detritiation Building}

To reduce the tritium concentration that would accumulate over time in the heavy water and to upgrade the purity of the heavy water (from inleakage of light water), a detritiation process will be required on-site. The building would be separate from the main facility and would house the equipment for detritiation and upgrade of the heavy water. The liquid phase catalytic exchange (LPCE) (or vapor phase catalytic exchange) process followed by cryogenic distillation has been found the most reasonable process for detritiation in a plant of reasonable size. However, this process does involve handling a large inventory of deuterium gas and liquid, as well as a large tritium inventory. Thus, significant fire hazards and the potential for a large tritium release are present.

The detritiation plant at the Institut Laue-Langevin (ILL) Reactor in Grenoble, built in the early $1970 \mathrm{~s}$, is located in a structure away from the main reactor buildings. More recent plants being commissioned at Chalk River Nuclear Laboratories and at the Darlington power station, both in Ontario, have also been constructed in their own structures located away from the reactor buildings so that reactor safety would not be impacted if a fire or explosion were to occui. This separate building approach would be used for the ANS. The detritiation plant is located in the service area well inside the security fence.

The nature of the structure to house the detritiation plant would be dependent on the design of ventilation systems and on the approach towards fire safety and tritium containment. Canadian facilities stress tire safety first, then tritium containment to the extent practical. The building at Chalk River is disigned strictly for fire safety, with large "blowout" wall and rool sections …d a continuous iweep of air through and out the building. No attempt is made to recover tritium if it escapes the process enclosures. The Darlington plant is compartmentalized, with drier systems installed in the compartments. High-flow ventilation systems are used to exhaust deuterium (and tritium) if dangerous gas concentrations are detected. However, if flammable concentrations are not reached, the recombiner/drier systems are to be used to recover deuterium and tritium and limit releases from the plant. Fire safety is given priority over confinement of radioactive tritium-the contanment systems would be useless if building integrity is not maintained.

Requirements of DOE Order 6430.1 A would be reviewed in establishing firm design criteria for the detritiation building, including criteria for tritium facilities and for fire safety.

This description covers LPCE and Water Distillation (DW). ANS has recently changed to Combined Electrolysis Catalytic Exchange DW process. It involves similar technology, but does not require the large columns. Details will be available in updates to this document.

Secure facilities would be provided for the storage of tritium product (or waste). A vault may be necessary for this purpose. design.

Further descriptions of the detritiation building will evolve with the conceptual

\subsubsection{Other Structures}

Other major structures at the ANS facility are the reactor secondary cooling system cooling towers, the essential cooling water system cooling towers, the nonessential cooling water cooling towers, and the stack and filter pits. These are located as shown in Fig. 3.1-1. 


\subsubsection{Reactor Secondary Cooling System Cooling Towers}

Four multicell, mechanically induced draft cooling towers would be provided for rejection of reactor heat to the atmosphere for each primary cooling loop.

A water treatment building may also be constructed to house facilities for pretreating blowdown before it would be sent to the release point. Blowdown may be released at a common release point, sharing a National Pollutant Discharge Elimination System monitoring station in the reactor support building.

The Reactor Secondary Cooling System cooling towers would be sized to remove the heat removed by the reactor primary cooling system under summer conditions. Provisions for monitoring basin water for lission products, activation products, and tritium would be included in the design.

\subsubsection{Essential Cooling Water System Cooling Tower}

Two multicell, induced draft, cooling towers would be constructed to serve all other critical cooling needs for the ANS complex (aside from the reactor heat removed by the primary coolant loops) that are essential to operation or shutdown of the plant. Included would be (1) building loads such as the chillers for the control room and the ventilation systems for containment systems, (2) heat loads from reactor and spent fuel pools, and (3) core decay heat loads from the shutdown/isolation loop system and other systems as required. The exact sizing would be determined later in design after specific equipment heat loads have been cietermined but would be located in hardened enclosures on the roof of the reactor support building.

\subsubsection{Nonessential Cooling Water System Cooling Tower}

Other building heat loads that are classed as nonessential to operation or shutdown of the facility (such as air conditioning in the office building or guide hall, nonessential mechanical ventilation systems, and nonessential mechanical cooling water systems) would be served by the nonessential cooling tower. The cooling tower will be sized and located as the design develops.

\subsubsection{Stack and Filter Pits}

Filter pits and a reinforced concrete stack would serve the ANS facilities. The stack would serve the reactor containment systems (normal flow from occupied areas and the ventilated plenum and emergency flow from the ventilated plenum) as well as ventilation systems in other parts of the plant that contain radioactive materials. The stack would be located to optimize the various safety issues that govern its location, especially the distance from the site population (see Fig. 3.1-1).

Air flow rates, the number of parallel channels, and requirements for the filters would be developed as the design of the ventilation systems progresses. Space would be provided for roughing filters, successive high-efficiency particulate air (HEPA) filters, and charcoal filters used for iodine removal. Fans would be located downstream of the filters at the base of the stack. The design may include redundant fans and other fectures to provide reliability and availability to support top level plant goals. A tunnel would carry duct work from the reactor and reactor support buildings to the filter pit and remote release point. 


\subsection{REACTOR SYSTEMS}

This section addresses reactor hardware and systems. Principal components of the reactor systems are the reactor assembly and refueling systems.

\subsubsection{Overview}

The ANS would be based on a compact core, with a thermal output to the primary coolant of about $330 \mathrm{MW}(\mathrm{f})$. The reference core would be based on an involute fuel plate geometry, with two core segments split along the horizontal plane; the fuel would be uranium silicide $\left(\mathrm{U}_{3} \mathrm{Si}_{2}\right)$. The upper fuel element would have a larger diameter than the lower element, allowing separate parallel flow paths through each element (Fig. 3.2-1). The core would be cooled with heavy water $\left(\mathrm{D}_{2} \mathrm{O}\right)$, flowing up at high pressure and velocity through a core pressure boundary tube (CPBT) located immediately outside the fuel (Fig. 3.2-2). A small gap between the outer fuel surface and the inner wall of the CPBT would allow for cooling of the inner wall of the CPBT. The CPBT would be surrounded by a low-pressure heavy water reflector vessel that would surround the core with heavy water for at least $1.5 \mathrm{~m}(5 \mathrm{ft})$ in any direction. The reflector vessel would also serve as the major structural member of the reactor assembly (Fig. 3.2-3), and the reflector water system would remove most of the reactor thermal power not removed by the primary coolant. The reflector assembly would be submerged in a pool of light water.

The reactor would be controlled and shut down by three hafnium control rods located in the central hole of the core. Each of the control rods would be provided with an independent scram mechanism. A servo mechanism would be used to continually adjust the position of the control rods, maintaining a reactor constant power output. Much of the excess reactivity of a fresh core would be suppressed by the use of boron as a burnable poison.

A large additional shutdown margin would be provided by eight shutdown rods located in the reflector vessel, just outside the CPBT. These rods would have the greatest impact on the flux at the beam tubes and thus would not be used during reactor operation. The outer rods would also be provided with individual scram mechanisms. Core monitoring detectors would be positioned in the light water pool just outside the reflector. The electronics packages for the plant protection system and for the normal reactor control system would complete the reactor control package.

Reactor refueling would use a stack-and-tunnel concept, which would employ a stack filled with heavy water that would extend from the interface with the reactor system to a horizontal tunnel that would provide a passage to a transfer cell. For the stack-andtunnel concept, design estimates have shown that the required downtime for the refueling operation would be within the desired 4 days. The refueling system also provides facilities for handling the instrumented in-core irradiation sample assemblies. If a set of samples is to be irradiated for more than one fuel cycle, the instrument leads, which include gas cooling lines as well as electrical wires, could remain connected during the refueling operation.

Though a multipurpose reactor, the ANS would generally be optimized for beam research. As such, the fuel, geometry, coolant, and reflector have been chosen to produce as large a flux in the reflector as possible (in both magnitude and in usable volume).

Unlike power reactors, "efficiency" in the ANS would be defined as the number of neutrons entering the high-flux region of the reflector divided by the number of neutrons produced. Despite the focus on beam resenrch, effective fast and cpithcimal iñadiation positions would exist in the ANS core. Without significantly detracting from the 


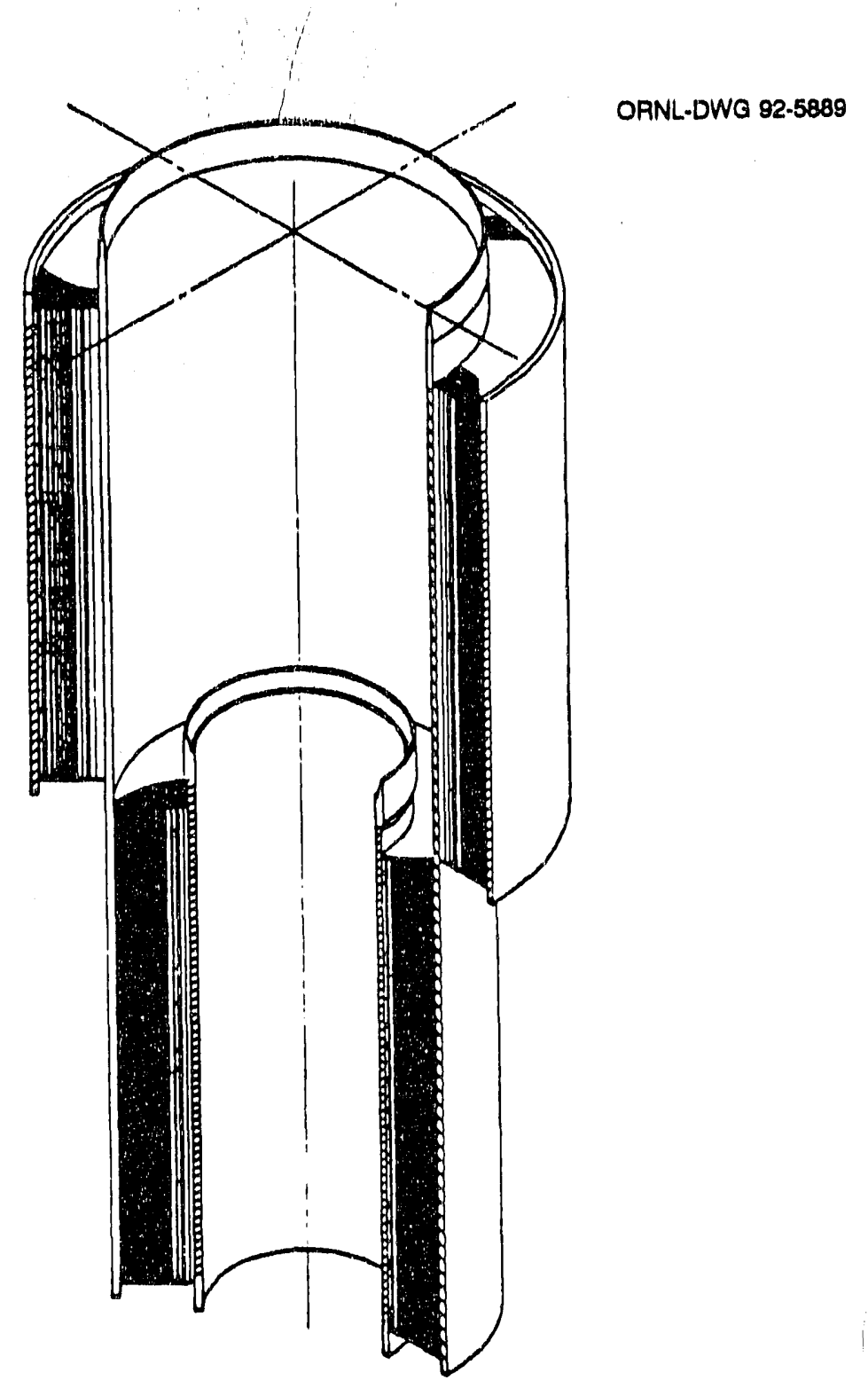

Fig. 32-1. Upper and lower fuel elements. 


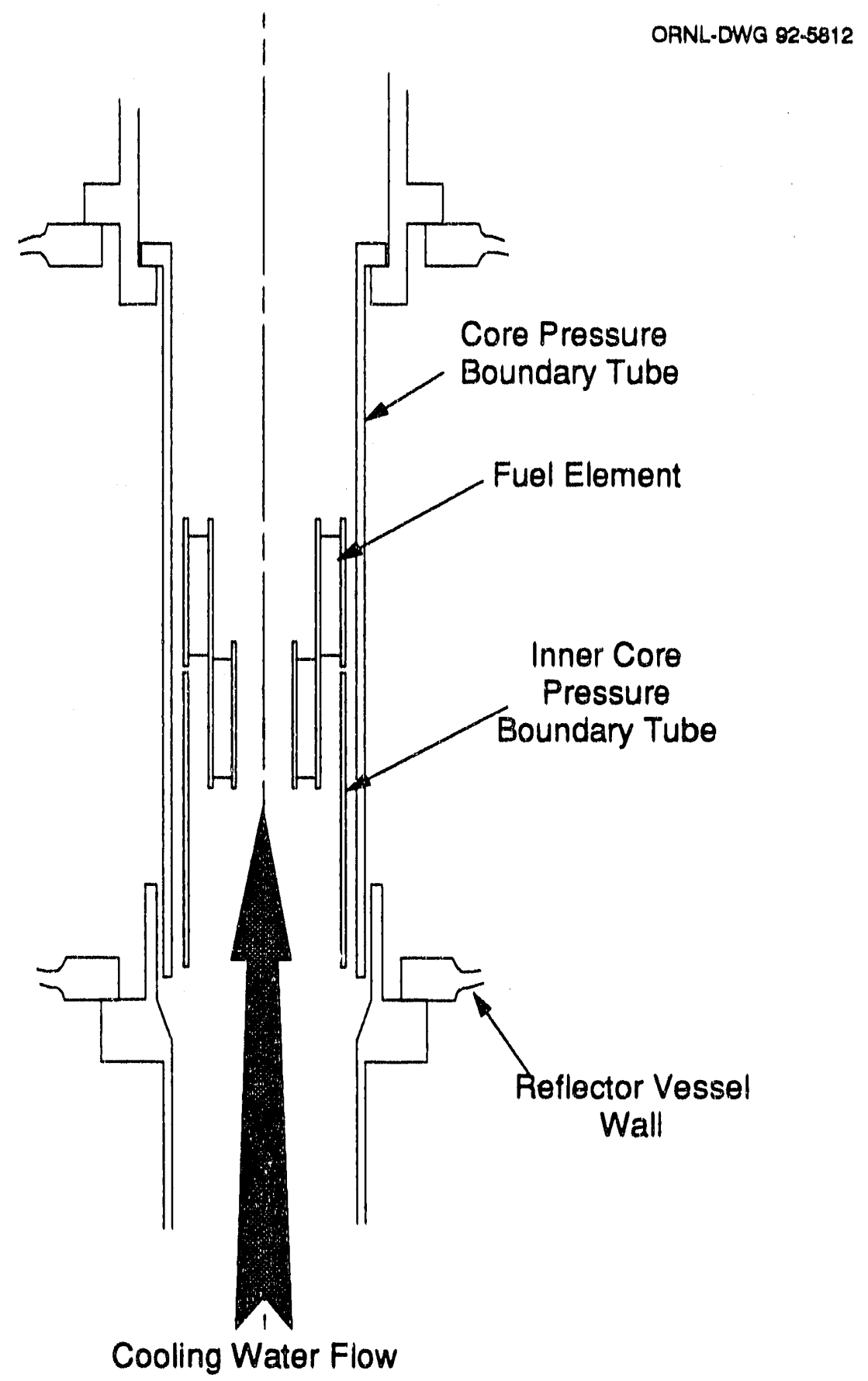

Fig. 3.2-2. The core pressure boundary tube. 


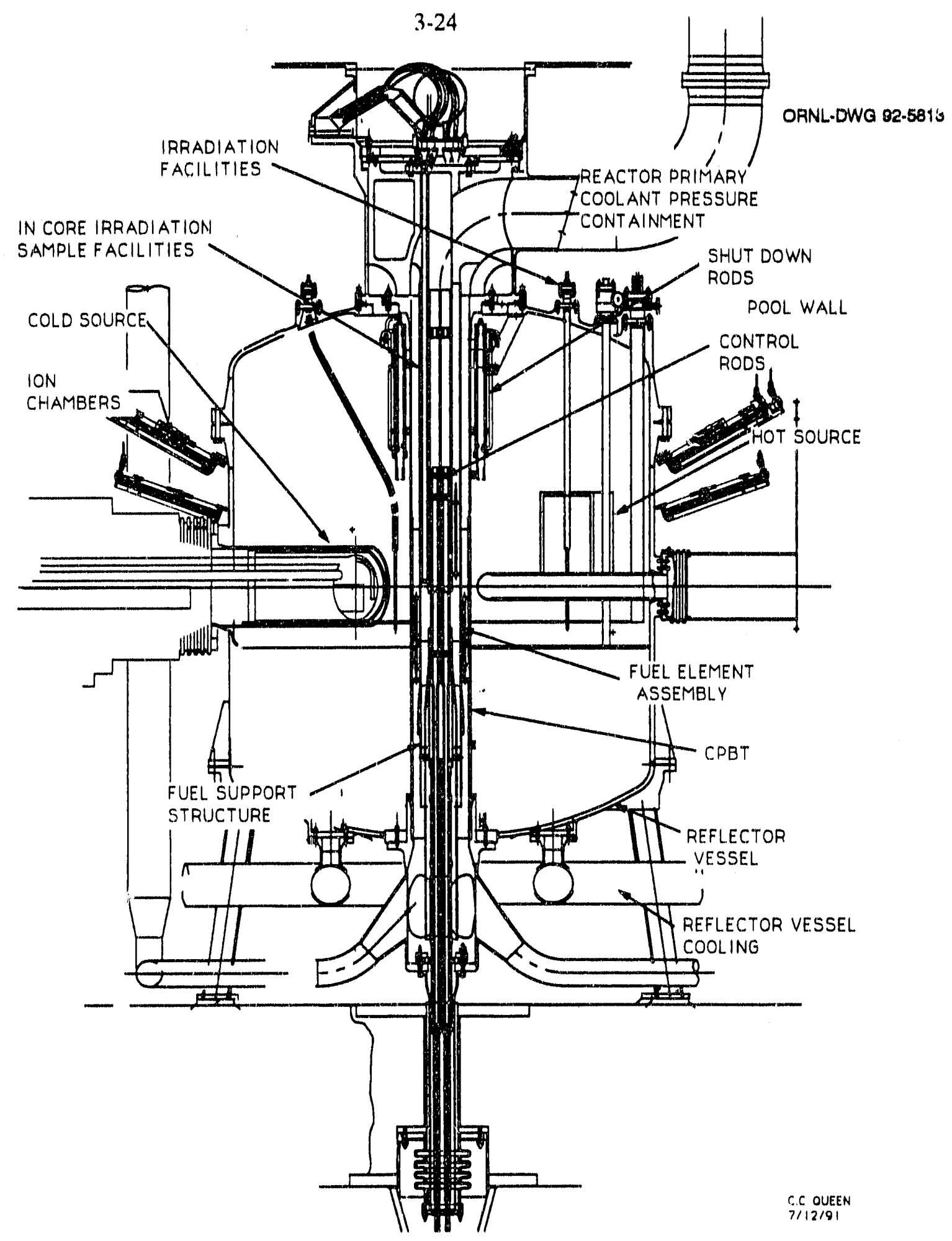

Fig. 3.2.3. Principal components of the Advanced Neutron Source reactor. 
efficiency, these positions have been expanded to support the requirements of materials irradiation and transplutonium production. General isotopes irradiation and activation analysis activities would require high thermal flux irradiation positions; thus, these activities could be performed readily in a reactor tailored for beam research.

\subsubsection{Reactor Assembly}

The reactor assembly would consist of the reactor enclosure, reflector vessel, beam tube and through tube thimbles, in-core irradiation and isotope production facilities, and internal support structures. Primary functions of the reactor assembly would be to provide

- a controlled, stable fission reaction, producing a source of neutrons;

- a coolant, moderator, and reflector that would maintain the fission chain reaction for generation of the thermal neutron source and for transmission of neutrons to special source facilities;

- a fuel form that would be mechanically and dimensionally stable, noncorrosive in the coolant environment, and effective in the retention of fission products and fuel material over all relevant normal and laulted operating conditions;

- the required flow, pressure, and temperature of coolant flowing past the reactor fuel assembly and other components inside the primary coolant boundary for all relevant normal and faulted operating conditions;

- the flow, pressure, and temperature of coolant surrounding all components of the reactor assembly located outside the primary coolant boundary for all relevant normal and faulted operating conditions; and

- the mechanical integrity of the reactor.

\subsubsection{Reactor Core Assembly}

The core assembly would be composed of the fuel elements, the fuel element support components, flow straightening vanes, and strainers at the inlet to the fuel element. The core assembly would (1) serve as the primary source of neutrons feeding all neutron sources, (2) provide the primary barrier to the release of fission products generated within the fuel element, (3) transfer heat from tissions and fission product decay from the fuel and other materials to the primary coolant, (4) provide space for movable neutron absorbers, (5) contain burnable absorbers, and (6) provide mechanical coupling of the core to the rest of the reactor assembly.

The ANS reference core would be a two-element offset core (Figs. 3.2-1 and 3.2-4) with upper and lower fuel elements separated both axially and radially. Heavy water coolant would tlow up through the elements, with parallel flow paths providing separate coolant streams for each element. The upper fuel element would contain 432 curved plates and the lower element 252 plates, extending between inner and outer cylindrical side plates.

The fuel plates would be curved to provide equal cooling gaps and thickness. For a compact core such as the ANS, the highest fuel density in the overall core region would be achieved with the cylindrical shapes (as opposed to an array of rectangular elements). The two geometrics that can provide a constant plate thickness and water gap in such elements are concentric cylinders and involutes. The involute shape has been chosen for the ANS core.

Structural integrity and support for the reference core would be provided by the side plates of the fuel elements and the concentric fuel support cylinder. The core would 


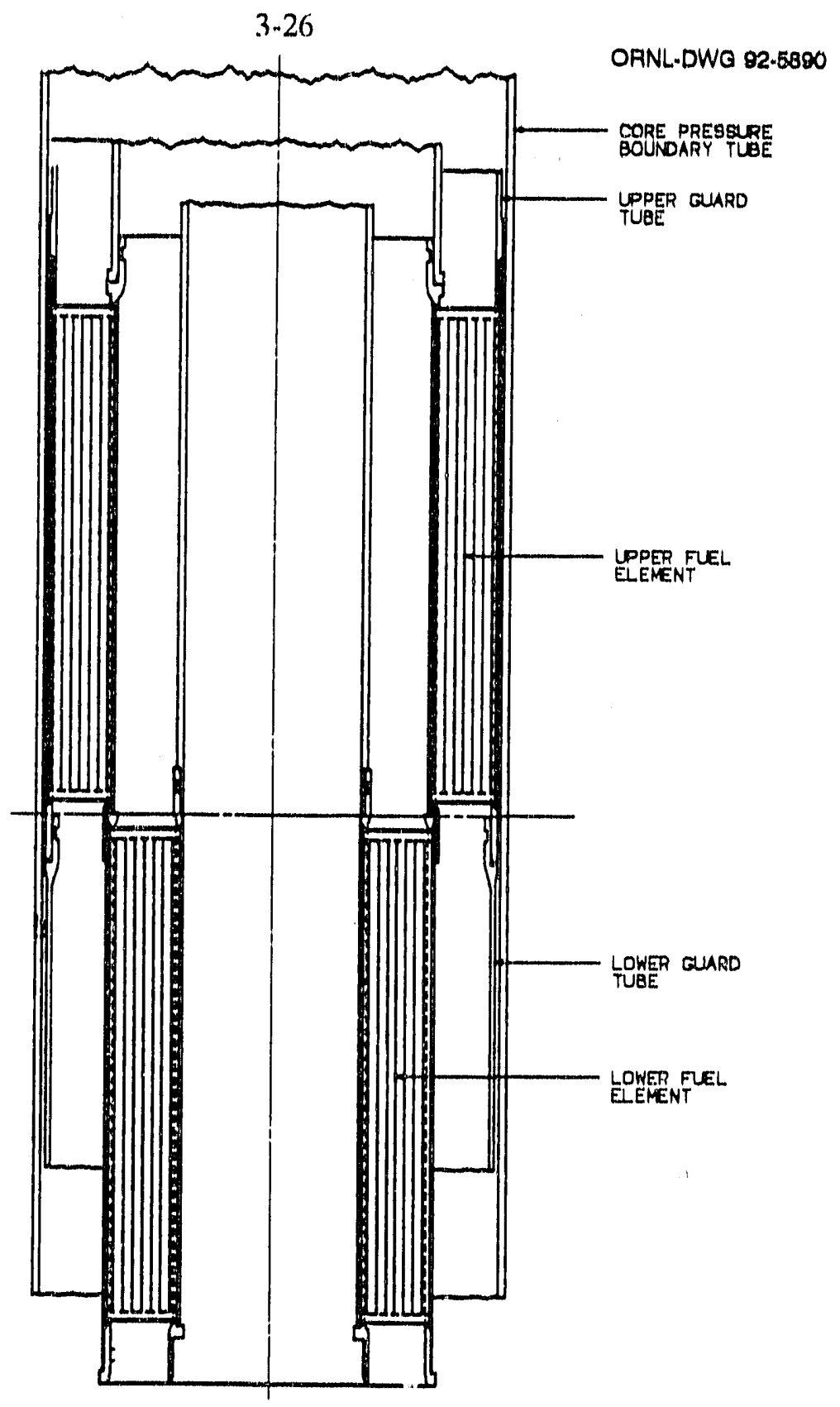

Fig. 3.2-4. The two-element offset core.

be a symmetrica، structure, with loads balanced in any horizontal plane. The side plates. would be attarised to each other by the fuel plates alone; but because of the large number of plates, the load on any individual plate would be small. Both elements would be fixed only at the central support post. Radial stresses would thus be relieved by minor rotation of the outer side plate of the upper element and the inner side plate of the lower element with respect to the central support post. Fuel plates would be welded into the side plates during the manufacture of the elements. Some axial stresses would develop because of differences in thermal expansion between the fuel plates and side plates. The high thermal conductivity of aluminum and effective thermal bonding at the welds would minimize these stresses. The coolant flow path through the reference core would be straightforward, with the fuel support cylinders channeling coolant directly into and out of the two elcments. 
The fuel selected for the ANS would be based on $\mathrm{U}_{3} \mathrm{Sl}_{2}$ in an aluminum matrix clad with Type 6061 aluminum. This fuel was developed for the Reduced Enrichment Research and Test Reactor program and allows high uranium densities in the fuel meat, if necessary, along with high thermal conductivity, high temperature capability, and resistance to swelling. A section of a fuel plate is shown in Fig. 3.2.5. The fuel meat, graded in thickness in both the radial and axial directions, would be placed in the center of the clad. Aluminum filler would be placed on top of the fuel to obtain a meat/filler zone of constant thickness. Burnable poison in the form of $\mathrm{B}_{4} \mathrm{C}$ would be mixed in with the aluminum filler at a constant concentration in bands at ends of the fuel plate. As noted earlier, the involute shape would provide fiuel plates that initially extend radially from the core and then bend in a curve that would provide a constant coolant gap width and constant plate thickness.

\subsubsection{Reactor Coolant Pressure Boundary System}

The reactor coolant pressure boundary system would include the removable and semipermanent portions of the primary coolant path into, through, and out of the reactor core. It would also include inlet and outlet piping to a point far enough away from the core to allow a transition to permanent facility piping. The function of the pressure containment would be to provide a (1) coolant path for core and other reactor components within the primary pressure containment boundary, (2) moderator for sustaining the fission chain reaction and transport of neutrons to targets and sources within the geometric boundaries of the primary containment boundary, (3) pressure boundary for primary coolant within the reactor assembly, and (4) secondary containment for fuel and fission prod: :..

The design pressure for the pressure boundary hardware would be determined initially by the thermal-hydraulic design of the core and would then be adjusted to account for a series of uncertainties, transients, and safety margins. The thermal and neutronic evaluations of the core would be based on a core inlet pressure of $3.2 \mathrm{MPa}$ (470 psi). At this pressure, incipient boiling was estimated to begin at the hot spot at a power of $330 \mathrm{MW}(\mathfrak{f})$. More detailed analyses of the system performance, including establishing the operating power, the lowest practical core inlet temperature, and realistic hot streak and hot spot factors for a graded and controlled core are being performed to fix the overall design pressure. The time required to detect and respond to pressure transients, either rapid transients or gradual drifts resulting from poor instrument calibration or other factors, must also be considered. Ultimately, detailed analysis of operating parameters would be considered in showing that the reactor would not have an unacceptable risk of exceeding the design pressure under all operating conditions.

A system operating pressure of 4.0 $\mathrm{MPa}(580 \mathrm{psi})$ would allow a peak pressure roughly $10 \%$ above the core inlet pressure. The design pressure for most of the pressure containment system, including primary system components and piping, would be about $10 \%$ above the peak operating pressure, or about $4.4 \mathrm{MPa}$ (640 psi). Because the thickness of the CPBT would have a substantial effect on the peak neutron flux, as well as the internal temperature of the pressure tube walls, considerable care would be exercised to ensure that the CPBT wall is not oversized.

With the CPBT concept, the pressure boundary walls near the reactor core would be subjected to high fluences of both fast and thermal neutrons and of gamma radiation. The resulting damage to the metal structure would require regular replacement of the CPBT. Initial evaluations of the anticipated material damage rates indicate that replacement every 6 months would be likely. The concept described here is designed for 


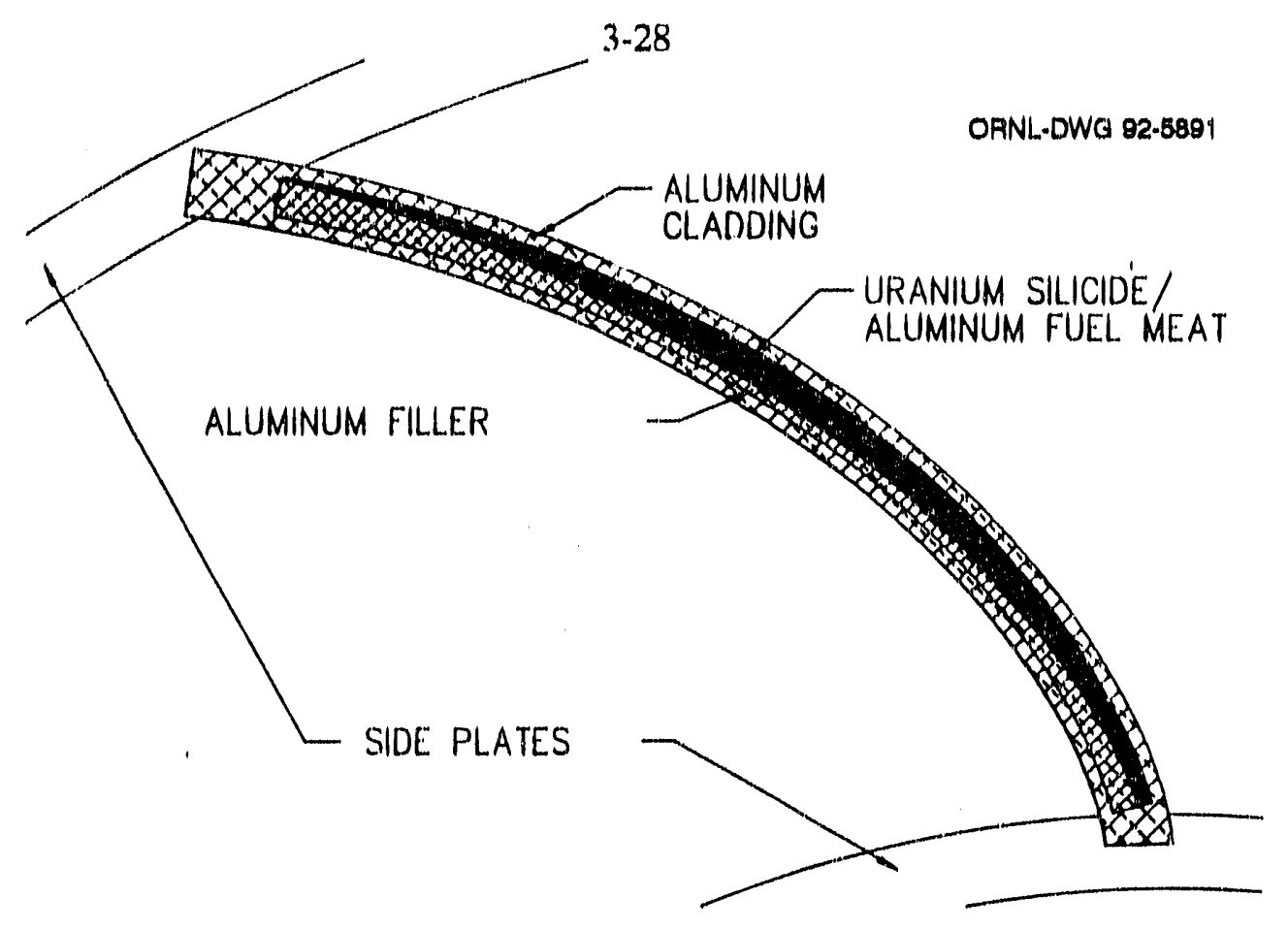

Fig. 3.2-5. Section of a fuel plate. (Width exaggerated to show details.)

removal of the CPBT up through the refueling port, using the refueling equipment. As a result, the lower connection of the CPBT must be able to pass through all obstructions around the core, such as outer control assemblies, beam tubes, and irradiation facilities.

Testing of the pressure boundary connections, in accordance with American Society of Mechanical Engineers (ASME) guidelines, would be a major consideration in the design of pressure boundary hardware. Inspection and testing of the connections would be required each time the CPBT is replaced.

The design of the pressure boundary hardware would be in accordance with the ASME Boiler and Pressure Vessel Code under Sect. III, Division 1, Subsection NB (Class 1 nuclear power plant components). Formal certification by the ASME is anticipated. Because the use of aluminum and the removable CPB'T concept are unique for codestamped reactor pressure boundary systems, special "codes cases" would be required for formal approval of the concept. Initial work on preparing a code case for the use of aluminum (which is currently listed as an acceptable material for Class 3 components but not Class 1 components) is under way. Code cases for either the design or the test and inspection procedures for the connections of the CPBT may also be required.

\section{Removable CPBT materials}

The selection of materials for the CPBT was determined by balancing requirements for strength, low neutron absorption, and effective dissipation of heat. The current reference concept is based on Type 6061 aluminum, which has been a common material in other research reactors; a considerable data base on its pruperties after irradiation is available. 


\section{Core supports}

The loads from the fuel element side plates would be transferred directly to a support cylinder. This support cylinder would be supported at the bottom and contains radial vanes; the vanes would serve to eliminate flow swirls. At the top, the support cylinder would be pressed down by the flow diverter assembly. The core support structures would be constructed of Type 6061 aluminum.

\subsubsection{Reflector Vessel Assembly}

The reactor vessel assembly woulu include the $3.5 \mathrm{~m}$-diam, 4.5-m-tall (11.5-ft-diam, 15-ft-tall) tank that would contain the reflector heavy water, the piping and flow channeling systems for circulation of the rellector water inside the vessel, and all penetration structures that enter the vessel and become an integral part of the reflestor water boundary. The reflector vessel system would (1) provide and contain the moderator/reflector to serve as the thermal neutron source, (2) provide and contain the moderator/reflector outside the primary pressure containment assemblies necessary to maintain criticality, (3) house the special neutron source moderator facilities, (4) serve as the main mechanical integrator of reactor and experiment facilities, (5) provide the mechanical support for the entire reactor assembly, and (6) provide the coolant path for all components located in the reflector vessel.

The reflector vessel is currently assumed to be constructed of Type 6061 aluminum. All the beam tubes, irradiation lubes, and other penetrations into the vessel would also be aluminum. Constructing the entire vessel of aluminum would minimize problems with the interface of dissimilar metals. The lid on the reflector vessel would be removable to allow access to the vessel internals for maintenance. All facilities penetrating the top lid would be flanged for removal. A water pressure of about $0.5 \mathrm{MPa}$ $(60 \mathrm{psi})$ is anticipated.

A flow rate of $0.120 \mathrm{Mg} / \mathrm{s}(160) \mathrm{gal} / \mathrm{min})$ would be required to transfer the heat deposited in the reflector vessel water and components to the reflector water system heat exchangers. With a flow of this magnitude, the interior of the reflector vessel could be swept out, and natural circulation need not be relied upon for bulk cooling of the vessel internals. Diversions of this tlow may also be led along the heam tubes and to any other components requiring higher coolant velocities than would be provided by the bulk flow through the reflector.

An additional function of the reflector vessel would be to collect radiolytic hydrogen and oxygen gases generated by irradiation of the water and to contain tritium produced by irradiation until it is removed in the detritiation plant. At present, it has not been determined whether a helium gas blanket would be provided at the top of the vessel for removal of radiolytic gases or if the outlet of the reflector water fluw would be designed to sweep the gases to a degasifier. Any gases released from heavy water should go to the let-down tank through a high point vent.

The many penetrations into the reflector vessel would contribute many interfaces between the reflector vessel and other systems and would add numerous components to the overall reflector vessel assembly. A large penetration at the top center of the lid would be closed by the upper pressure containment assembly. A similar penetration would be provided for the lower pressure containment assembly. Penetrations would also be provided for the reflector water inlet and outlet.

The next series of penetrations would be the beam tubes. Although subject to change as the design of beam tubes progresses, the portion of the beam tube reaching 
Inside the reflector vessel is currently considered part of the reflector vessel assembly. The external portion of the beam tube would be bolted onto a thange at the vessel surface.

Many irradiation facilities would enter the reflector vessel, including both static facilities and hydraulic and pneumatic tubes. These have yet to be designed. Interface philosophies would likely be similar to those for the beam tubes.

The reflector vessel assembly would serve as the main support structure for the various components of the reactor assembly. Not only would a structure be provided to support the reflector vessel from the pool floor but internal bracing may also be required to support beam tubes, irradiation facilities, control drives, coolant shrouds and baffles, etc. These structures would be seismically qualified and would also be designed to accommodate thermal expansion. The design of the supports must be compatible with disassembly and maintenance procedures.

A key interface would occur between the support systems for the reflector vessel and other reactor components and the large-diameter primary coolant piping and the permanent pressure boundary segments.

\subsubsection{In-Core Irradiation Facilities}

The in-core irradiation facilities would provide (1) a means of supporting five noninstrumented and five instrumented irradiation material samples in a region near the core, (2) closure of the primary pressure boundary, (3) guides for the reactor control rods, and (4) a location for transuranium production tacilities.

\subsubsection{Beam Tube Thimbles}

The beam tube thimbles are the portions of the beam tubes that would interface with the reflector vessel. The beam tube thimbles would (1) provide a nonmoderating, nonabsorbing path for neutrons leaving the optimal source location and being transmitted to experiment stations away from the reactor assembly and (2) complete the integrity of the reflector coolant boundary.

\subsubsection{Refueling System}

The refueling system would provide the necessary equipment and operating systems to safely remove spent fuel elements from the reactor and to replace them with new fuel elements within a time frame that allows the reactor to meet availability requirements. The refueling system facilities would also be used to remove and replace components other than the fuel elements from the reactor assembly. These components would be located inside the heavy water boundary of the reflector vessel and inside the primary pressure boundary of the reactor assembly. Characteristics of the refueling system would be as follows:

- The refueling system facilities must provide the ability to remove and replace key components within the reactor core area. These components would include the fuel element, the CPBT, the in-core irradiation facilities assembly, the transplutonium production rod assembly, control rod assemblies, and shutdown roci assemblies.

- Both the refueling system and the maintenance system must be designed to operate in a fail-safe manner so that any equipment failure would not increase the reactor or fuel element reactivity or increase the risk of injury to uperating or maintenance personnel. 
- Refueling system facilities must have the capacity to transfer the fuel elements from entry point in the reactor containment building to the installed position in the reactor assembly. This activity would include the necessary transition from atmospheric to heavy water environments.

- Refueling must allow rernoval and replacement of fuel elements within a 4-d period.

- Refueling system facilities must provide cooling of the fuel elements during removal and transport to the handling cell.

- A boundary between heavy water and light water interfaces must be maintained.

- Loose parts must not get into the reactor fuel element environment.

- Refueling and maintenance equipment must be designed to be maintained or replaced without impact on reactor operations.

- The fuel elements must be kept in a subcritical state during any movement or storage operations.

- The refueling system facilities must be able to handle removal and reinstallation of the primary pressure boundary closure, to disconnect control rod joints, and to disconnect and reconnect the CPBT interface.

- Lifting capabilities within the refueling system must include the capacity to lift primary pressure boundary closure elbows, in-core irradiation assembly, fuel assembly, transuranium production rod assembly, CPBT, and/or control rod elements.

- Alignment and positioning provisions for vertical and radial direction must be provided.

Several key factors would affect refueling component replacement, and general maintenance of the ANS reactor systems. Activation and contamination of equipment would result in the need for radiation protection measures for the operators. With a pool reactor concept, the pool could be used for shielding and control of airborne contamination. A further complication would result, however, from the fact that the pool would filled with light water and the reflector and coolant are both heavy water. Because small amounts of light water contamination in the heavy water systems would cause significant degradation of the neutronic properties of heavy water and because of the cost of lost heavy water, the separation of coolant and reflector water from pool water must be very carefully maintained. In addition, tritium in the heavy water must be prevented from contaminating the light water pool.

The ANS is expected to operate for $17 \mathrm{~d}$ and to be refueled and restarted within a 4-d shutdown. This schedule would allow an availability target of $80 \%$ excluding scheduled annual and unscheduled shutdowns. The cost of a heavy water fuel storage pool would be prohibitive; thus, the tuel must be stored in a light water pool. In heavy water reactors operating at lower power densities, the fuel is lifted out of the heavy water coolant, flushed with light water, and quickly discharged into the light water storage pool. With the decay heat densities of the ANS core, this operation could not be conducted without fuel damage. Fuel transfer equipment would be required to remove the spent fuel (and irradiation targets) from the reactor in a heavy water environment and transfer the assembly to a small heavy water handling pool. This pool would be enclosed by a manipulator cell, allowing dismantling of the fuel assembly and repackaging of irradiation targets for shipment to processing or analytical facilities. The spent fuel elements would be transferred from the pool into the long-term light water storage pool. The fuel would then be stored in the light water pool until it had decayed sufficiently for shipment to Savannah River. A storage time of at least 24 months is planned. The details of the refueling concept will be further defined as the design progresses. 
Transuranium targets would be located around the outside of the lower fuel element. These would usually be left in the core for many cycles /typical irradiation times approach 1 year in ORNL's High Flux Isotope Reactor (HFIR)]. Current concepts for these targets call for a target support ring to be locked to the lower core supports. In this case, the transplutonium target ring could be either left in the core for the next cycle or removed at the time of refueling.

\subsubsection{Reactor Control System}

The reactor control system would include the entire set of control rod assemblies. Core monitoring instruments would also be part of the reactor assembly hardware. Unlike the other elements of the reactor systems package, however, the scope of the reactor control system would extend beyond the reactor pool. All the data collection, transmission, analysis, and display systems that directly pertain to control of the nuclear reaction would be included in this scope up through the operator interface. This would include both the plant protection system (the safety system that initiates an automatic reactor scram if certain setpoints are exceeded) and the reactor control systems (used for normal control of the reactor by the operators). It would also include both the direct monitoring of the neutron and gamma flux generated by the reactor and the monitoring of key process variables used to ensure reactor safety and for normal control of the reactor.

In the current ANS concept, three control absorber positions would be located in the central hole. The absorbers would be constructed of hafnium. Each of the three control absorbers would have an independent scram mechanism with a separate magnet release, latch, and accelerating springs. The three inner absorbers would also be connected to a servo drive for continuous fine adjustment of reactivity. A set of eight outer rods, located in the retlector vessel, would serve only as a shutdown system for excess reactivity control. Again, independent scram springs would be provided to obtain fast action. The outer rods would not be used as shim rods, however, but would be in the fully withdrawn position during operation. These outer rods would be held withdrawn by the flow of heavy water; an interruption in flow would cause the rods to descend. They would be withdrawn out of the high-flux region, possibly behind some type of flux shield, to prevent burnout. The use of either hafnium or boron is currently being considered for the outer absorber. Boron would also be used as a burnable poison in the fuel plates, handling a large fraction of the total excess reactivity control. Fission chambers and boron-lined ion chambers would be used to monitor the neutron flux over various ranges of operation.

\subsubsection{Cold Source Assembly}

The ANS facility will have two liquid deuterium cold neutron sources located in separate reentrant reflector vessel thimbles. Each cold source will be an approximately spherical vessel with a nominal radius of $205 \mathrm{~mm}(8.1 \mathrm{in}$.), filled with liquid deuterium at about $25 \mathrm{~K}\left(-248^{\circ} \mathrm{C}\right)$. Mechanical pumps located behind the reactor pool wall will continuously circulate the deuterium through the cold source vessels to heat exchangers, as well as behind the shielding wall, where the energy absorbed in the deuterium from neutron and gamma heating will be transferred to cold helium gas at 5 to $8 \mathrm{~K}(-268$ to $-265^{\circ} \mathrm{C}$ ). The deuterium systems will he surrounded by a vacuum or a helium envelope-or both-to mitigate the possibility of air coming into contact with deuterium. The cold helium gas will be supplied by two independent refrigerators whose compressors will be located in a dedicated building next to the reactor support building. 


\subsubsection{Hot Source Assembly}

The hot source would essentially be a block of graphite, heated by radiation to a temperature of about $2000 \mathrm{~K}\left(1730^{\circ} \mathrm{C}\right)$. In the current ANS concept, the hot source would be located in an indentation in the side of the reflector vessel. Light water would be excluded from the gaps between the hot source and the reflector, as well as between the beam tubes and the hot source, to minimize loss of neutrons. Because the hot source would be located outside the reflector vessel, the consequences of accidentally flooding the 'white-hot graphite block with water would be minimized in terms of effects on the core and control systems. Safety would be further enhanced by successive barriers around the hot graphite block. The block itself would be kept in a helium environment to maintain a nonoxidizing atmosphere and to provide some measure of temperature control. A vacuum may further enclose the hot source, providing two layers of protection against inadvertent flooding.

\subsection{PLANT WATER SYSTEMS}

The plant water systems would include the various light water cooling and process water systems, sanitary waste, and potable water but exclude fire protection systems. For the engineering and design work on ANS, the reactor secondary cooling system is being considered a part of plant water systems; however, in this environmental report, the secondary cooling system is covered under heat dissipation systems (Sect. 3.4). This section gives an overview of the plant water systems; many specific parameters for the system, such as flow rates and pressures, are being designed and are not yet available. All makeup water for the ANS facility would be supplied by the water treatment plant at the Y-12 Plant, either by a new line that would be installed for ANS or by connecting to the existing ORNL distribution system. Radiological and nonradiological liquid discharges from the plant water systems are described in Sects. 3.5, 3.6, and 3.7. The environmental effects of these discharges are discussed in Sects. 5.3, 5.4, and 5.11.

\subsubsection{Essential Cooling Water System}

The essential cooling water system would provide cooling for spent fuel and for selected other components. The system would consist of two independent loops, each of which would use a separate circulating pump, forced draft cooling tower, and seismically qualified basin. Heat loads served by the system would include all spent-fuel-related cooling requirements and chillers for the control room and electrical equipment rooms. The system would normally function with forced circulation but would provide heat removal capability from the spent fuel pools and heat loads by means of natural circulation to the maximum extent feasible. The system would also provide containment isolation capability for portions of the system that penetrate containment.

\subsubsection{Demineralized Water System}

The demineralized water system would provide demineralized water to the various users in the ANS facility, including the light water pools and spent fuel pool. Demineralized water would also be furrished to experiment and production stations as required and to laburatories and analysis stations. The system would obtain process water from the process water system and condition it with cation and anion, or mixed-bed 
demineralizers that would remove essentially all impurities. Regenerant effluent would be sent to the ORNL liquid industrial waste collection system for treatment or for contract treatment and disposal.

\subsubsection{Cooling Tower Blowdown and Makeup System}

The cooling tower makeup and blowdown system would function to manage water quality and maintain water inventory in the reactor secondary system, the essential cooling water system, and the nonessential cooling water systems by providing continuous blowdown and makeup of tower water. The system would also direct blowdown water to the appropriate waste system for treatment before disposal. Long-term water makeup after $30 \mathrm{~d}$ following an emergency (if normal makeup is lost) would be provided by alternate methods, which may include trucking, tie-in to remaining functional systems, fire protection water, or on-site wells. The cooling tower makeup and blowdown system would be designed to prevent inadvertent drainage of the essential and reactor secondary cooling tower basins and the reactor secondary cooling system reservoirs during or following an emergency.

\subsubsection{Nonessential Cooling Water System}

The nonessential cooling water system would provide adequate coolant flow and pressure to remove heat from all nonsafety-related, water-cooled equipment located throughout the ANS facility. The system coolant would be circulated through the nonessential cooling tower to reject heat to the atmosphere. Water-cooled, nonsafetyrelated equipment served by the system would include air-conditioning unit condenser coils, water chillers, helium refrigerations systems, air compressors, vacuum equipment, experiment stations, and other equipment.

\subsubsection{Light Water Sampling System}

The light water sampling system would collect and analyze samples from various light water systems within the ANS facility, including cooling systems, chilled water systems, pools, storage tanks, and other water systems whose chemistry requires monitoring for $\mathrm{pH}$ and chemical content control. There would also be radiation detectors to identify leaks or system contamination.

\subsubsection{Chilled Water System}

The chilled water system would maintain adequate chilled water flow, temperature, and pressure to remove heat from air-handling units and other users of chilled water throughout the facility. The portion of the system serving the main control room, the control room electrical equipment rooms, and the control room air-conditioning mechanical equipment room would be safety related. A nonsafety-related, chilled water system would provide the same function for general plant areas of the reactor complex, experiment areas, offices, and other buildings.

\subsubsection{Building Heating System}

The building heating system would supply adequate water flow, temperature, and pressure to hot-water heating coils in air-handling units and in-unit heaters. The hot 
water may be provided by a dedicated hot water generator heated by steam from the ORNL Steam Plant or by other means. Containment penetrations for the heating water system would be safety-related.

\subsubsection{Biofouling Control System}

The biofouling control system would provide ozonated water to control biological growth in heat exchangers and cooling towers; it would consist of ozone generators, distribution piping, and controls.

\subsubsection{Process Water System}

The process water system would be a general-purpose, potable, water system with backflow preventers, that would provide water to various systems requiring a clean source of makeup or process water. The system would be supplied by the ORNL distribution mains serving the ANS facility and would consist of a storage tank and distribution piping. Systems served would include the open cooling systems, experiment and production stations, irrigation systems, washdown stations, and cooling tower makeup system.

\subsubsection{Light Water Pools and Spent Fuel Pool Cooling and Cleanup System}

The light water pools and spent fuel pool cooling and cleanup system would provide heat removal from the various heat exchanger cavities, reactor pool, guide tube pool, and spent fuel pools to the essential cooling water system. The system would include filtration and blowdown of water from the various pools to maintain optical clarity and cleanliness, and it would provide makeup from the demineralized water system to maintain design water levels. Radiation alarms would be provided in each pool blowdown to process waste.

\subsubsection{Sanitary Waste System}

The sanitary waste system would collect sanitary waste from fixtures served by the potable water system and floor drains in rest rooms and change rooms. The system would pump waste to the ORNL Sewage Treatment Plant for treatment and disposal (see Sect. 3.7.1).

\subsubsection{Potable Water System}

The potable water system would provide hot and cold potable water to all water fixtures in lunch rooms, change room showers, safety showers, drinking fountains, rest rooms, and other areas at the ANS site. The system would serve the reactor complex as well as support buildings.

Two new potable water mains would supply potable, process, and fire protection system water for the ANS facility. One main, the primary main, would also provide one of two sources of tire water for ine. ANS facility. The source of both water mains would be the ORNL water distribution system. The exact tie-in to the water system is to be determined. 


\subsection{REACTOR HEAT DISSIPATION SYSTEM}

The ANS reactor cooling system reference design (Fig. 3.4-1) would provide cooling heavy water flow up through the core using four separate and independent primary and secondary loops employing active and passive means to maintain coolant flow (natural circulation for decay heat removal), pressure (accumulators), and inventory (pools and flooded equipment cells) during emergency conditions. Three of the four loops would be required for full-power operation (one out for maintenance). A maximum of only one would be required for all emergency design-basis events.

Each primary loop would include, in series, a main heat exchanger, an emergency heat exchanger, a two-speed pump, and loop maintenance valves. The higher speed of the pumps would be used for normal operation and the lower speed (10\% of high speed) for shutdown conditions. Each pump would have an uninterruptible power supply for lowspeed operation, with a minimum mission time of at least 30 min. The heat exchangers would have the heavy water coolant on the shell side to facilitate tube inspection and maintenance activities. To enhance natural circulation, the heat exchangers would be elevated with , espect to the core; and the loops would be simple in shape, with only one high point and one low point. To obtain passive inventory control, all primary piping and equipment would be located in either tlooded or limited-volume cells (cells with a volume less than the capacity of the accumulators). All primary coolant system equipment would be located within the primary containment structure.

Each secondary system for the main heat exchangers would include a forced-draft cooling tower, cooling pools, pump, containment isolation valves, and tower bypass valve. The cooling pools, and the piping between the main heat exchangers and cooling pools that is required for natural circulation cooling would be designed for all design-basis events. Flow under normal conditiors would be by forced cirrulation; however, the cooling pools would be elevated with respect to the main heat cxchangers to enhance natural circulation for emergency conditions. Each cooling pool would have sufficient heat capacity to provide adequate shutdown cooling for $30 \mathrm{~d}$. Makeup water would then be required to replace evaporation losses.

The emergency heat exchangers would be located in flooded cells having sufficient heat capacity to provide adequate shutdown cooling for at least $72 \mathrm{~h}$. The secondary system would include the flooded cell water, piping, and maintenance valves, with flow provided by natural circulation.

The pressure control system would use a feed-and-bleed system coupled with passive accumulators (Fig. 3.4-1). The control parameter would be the reactor coolant outlet pressure. The letdown points would be through the high-point tanks on each loop to the letdown tank, while the makeup would be supplied by pumps to the hot leg from the letdown tank. An accumulator would be located in each primary pump suction leg to protect the core and the primary coolant pumps by maintaining higher core outlet and pump suction pressures during transient depressurization scenarios. The accumulators would also provide a sufficient amount of primary coolant inventory to flood any single limited-volume cell, in the event of a pipe break within that cell, and would provide diverse protection against core melt for total loss of power scenarios.

The ANS concept would provide two extra passive safety features: the first of these would be an independent shutdown cooling system; the second would be the integration of the piping and valving of the primary cooling systems with the boundary of the reactor pool. Failures of piping or equipment inside the pool boundary would not lead to a loss of coolant but rather to a mixing of primary heavy water with pool light water. As long as depressurization occurred sately, coolant flow to the core would be 


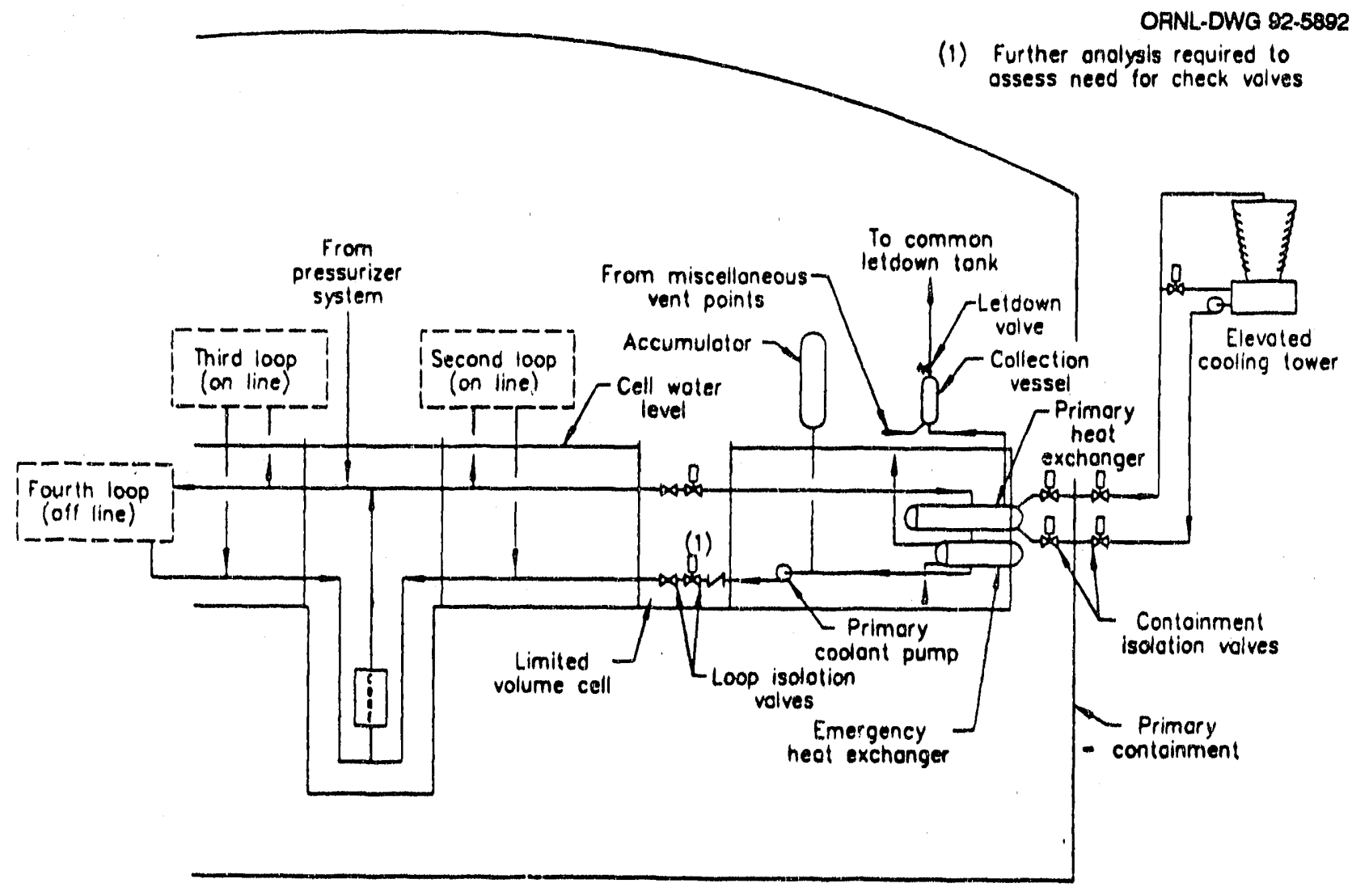

Fig. 3.4-1. Flowsheet of the reactor cooling system.

maintained. All nonredundant components and the first isolation valve to redundant circuits would be kept within the pool boundary.

\subsubsection{Heavy water management}

The use of heavy water for reactor coolant, moderator, and reflector would require a heavy water management plan for ANS. The plan must address how heavy water would be obtained, its storage, upgrade (to reverse the effects of gradual inleakage of light water), and removal of tritium produced by absorption of neutrons in coolant and reflector water.

An integrated approach would be used for handling heavy water at ANS. A single inventory of reactor-grade heavy water would serve all systems. Currently, "reactor grade" is assumed to be a hydrogen isotopic content of $>99.8 \%$ deuterium, with a maximum tritium content of $<185,000 \mathrm{MBq} / \mathrm{L}(5 \mathrm{Ci} / \mathrm{L})$. Although the detritiation process would be designed to maintain a $2 \mathrm{Ci} / \mathrm{L}$ tritium content, the analysis is based on a $5 \mathrm{Ci} / \mathrm{L}$ content. Heavy water would initially be obtained from an existing production plant, with supplies provided periodically to replace losses. This inventory would be kept at reactor-grade standards by use of an upgrade and detritiation plant on the ANS site, rather than by periodic replacement of the inventory with fresh heavy water from the production site. 
Heavy water would flow from areas of low degrading potential and low tritium production rates to systems with high production rates or potential for degradation.

retritiated heavy water will flow from storage to the pressure and inventory control s, stem, which will bleed heavy water to and from the reactor coolant system. There will also be a feed and bleed to the reflector system from the pressure and inventory control system to maintain a constant inventory and to provide for purification, since there is a designed leak between the primary and secondary systems through the core pressure boundary tube. Heavy water will be processed through the reflector/coolant purification system for removal of soluble radioactive ions. Heavy water will flow from the pressure and inventory control system to storage. Heavy water will tlow between storage and the upgrade and detritiation facility.

Detritiated heavy water will also be supplied as makeup to the refueling heavy water purification system, which supplies ion exchange purification to the refueling transfer cell (or tunnel). Downgraded heavy water will flow from the transfer cell (or tunnel) to heavy water storage, then between storage and the upgrading and detritiation facility.

\subsubsection{Primary Heavy Water Cooling System}

This section describes the high-pressure portion of the main primary cooling circuits, including letdown valves and pressurizer pumps. The primary circuit would begin and end at the removable CPBT. A single line would leave the top of the reactor assembly and slope upward through the flooded pipe tunnel until it entered the heat exchanger cell area in the reactor support building. Here the line would branch into four independent lines leading to the four sets of primary pumps and heat exchangers. Block valves would be provided at the point where the four lines would leave the pool; these block valves, although not capable of rapid action, may be remotely operated for operational flexibility or may be restricted to local use for blocking out individual exchangers (including the one of four not in service). Thus, the primary piping would be divided into a short nonredundant line that would be completely immersed in the pool and a set of redundant circuits that could be isolated if a leak is detected. Each of the four circuits would also include a tlow regulating valve on the core outlet side and a check valve on the core inlet side. Flow would proceed from the core to a horizontal U-tube heat exchanger and then to a centrifugal circulation pump. From the pump, flow would return to the core. The current concept for ANS calls for upflow through the core to enhance the transition to natural circulation for removal of decay heat, reducing the rime pumped systems would be required.

Basic parameters tor the primary coolant circuit are given in Table 3.4 $1_{\text {. }}$

Calculations for the core indicate that the core inlet and outlet pressures would fall to the range of 3.2 to $1.7 \mathrm{MPa}$ (464 to $245 \mathrm{psi}$ ) at conditions resulting in initiation of incipient boiling at $350 \mathrm{MW}$. A design pressure of $3.8 \mathrm{MPa}(550 \mathrm{psi}$ ) is being used for most of the primary system components. (For the CPBT, a thicker wall would lead to higher wall temperatures; thus designing to a higher pressure would not necessarily increase the margin of safety. The CPBT wall would be sized for a pressure of $3.2 \mathrm{MPa}$ ( $465 \mathrm{psi}$ ), with a $2-\mathrm{mm}(0.08$-in.) corrosion allowance. Flow rate data in Table 3.4 .1 are based on a $25-\mathrm{m} / \mathrm{s}(90-\mathrm{ft} / \mathrm{s})$ flow velocity past the fuel plates and a $6-\mathrm{m} / \mathrm{s}(20-\mathrm{ft} / \mathrm{s})$ velocity in the central hole and in the gap between the fuel and the CPBT. Temperatuic data are based on transfer of $300 \mathrm{MW}$ to the coolant. Both values are likely to overestimate realistic operating conditions for the system described here, but they provide conservative designs of the reactor hardware to allow for further advances in core cooling. 
Table 3.4-1. Primary and secondary coolant parameters

\begin{tabular}{|c|c|c|}
\hline Parameter & SI units & Alternate units \\
\hline Core inlet temperature & $45^{\circ} \mathrm{C}$ & $113^{\circ} \mathrm{F}$ \\
\hline Active core outlet temperature & $86.4^{\circ} \mathrm{C}$ & $187.5^{\circ} \mathrm{F}$ \\
\hline Hot leg return temperature & $81.5^{\circ} \mathrm{C}$ & $178.7^{\circ} \mathrm{F}$ \\
\hline \multicolumn{3}{|l|}{ Primary coolant flow rate: } \\
\hline Total (through pump) & $2.14 \mathrm{Mg} / \mathrm{s}$ & $30,80 \mathrm{gal} / \mathrm{min}$ \\
\hline Through active core (fuel) & $1.8 \mathrm{Mg} / \mathrm{s}$ & $25,700 \mathrm{gal} / \mathrm{min}$ \\
\hline Vessel gap and island (16\%) & $0.35 \mathrm{Mg} / \mathrm{s}$ & $5,100 \mathrm{gal} / \mathrm{min}$ \\
\hline Pump discharge pressure & $3.3 \mathrm{MPa}$ & 462 psia \\
\hline Cold leg outlet pressure & $3.4 \mathrm{MPa}$ & 476 psia \\
\hline \multicolumn{3}{|l|}{ Core inlet pressure (at inlet } \\
\hline $\begin{array}{l}\text { Core outlet pressure (at outlet } \\
\text { plenum downstream of fuel) }\end{array}$ & $1.9 \mathrm{MPa}$ & 266 psia \\
\hline Pump suction pressure & $1.7 \mathrm{MPa}$ & 238 psia \\
\hline \multicolumn{3}{|l|}{ Core pressure drops: } \\
\hline Total & $1.3 \mathrm{MPa}$ & 182 psia \\
\hline Due to friction & $1.2 \mathrm{MPa}$ & 168 psia \\
\hline \multicolumn{3}{|l|}{ Core power: } \\
\hline Fission & $330 \mathrm{MW}$ & $1.12 \times 10^{9} \mathrm{Btu} / \mathrm{h}$ \\
\hline Thermal power in active core & $308 \mathrm{MW}$ & $1.05 \times 10^{9} \mathrm{Btu} / \mathrm{h}$ \\
\hline Flow rate & $25 \mathrm{~m} / \mathrm{s}$ & $82 \mathrm{ft} / \mathrm{s}$ \\
\hline $\begin{array}{l}\text { Primary loop design } \\
\text { temperature }\end{array}$ & $100^{\circ} \mathrm{C}$ & $212^{\circ} \mathrm{F}$ \\
\hline Primary loop design pressure & $4.0 \mathrm{MPa}$ & $580 \mathrm{psi}$ \\
\hline Primary $\mathrm{pH}$ & $4.5-5$ & $4.5-5$ \\
\hline Primary resistivity & TBD & TBD \\
\hline $\begin{array}{l}\text { Primary maximum particle size } \\
\text { (filtration) }\end{array}$ & TBD & TBD \\
\hline $\begin{array}{l}\text { Maximum primary tritium } \\
\text { concentration }\end{array}$ & $185,000 \mathrm{MBq} / \mathrm{L}$ & $5 \mathrm{Ci} / \mathrm{L}$ \\
\hline $\begin{array}{l}\text { Maximum primary protium } \\
\text { concentration }\end{array}$ & 0.2 at. $\%$ & 0.2 at. $\%$ \\
\hline Secondary supply temperature & $29^{\circ} \mathrm{C}$ & $85^{\circ} \mathrm{F}$ \\
\hline Secondary return temperature & $46^{\circ} \mathrm{C}$ & $115^{\circ} \mathrm{F}$ \\
\hline Secondary coolant flow rate & $4.921 \mathrm{~m}^{3} / \mathrm{s}$ & $78,600 \mathrm{gal} / \mathrm{min}$ \\
\hline $\begin{array}{l}\text { Secondary design pressure, } \\
\text { maximum }\end{array}$ & $5.353 \mathrm{MPa}$ & $600 \mathrm{psi}$ \\
\hline
\end{tabular}


The total tlow handled by the primary circuit would be about $2.1 \mathrm{Mg} / \mathrm{s}$ $(30,800 \mathrm{gal} / \mathrm{min})$. As with HFIR, three of the four heat exchanger circuits would carry flow under normal operation, with the fourth in reserve. Thus, the large-diameter lines connecting to the CPBT would accommodate the full flow rate of $2.1 \mathrm{Mg} / \mathrm{s}$ $(30,800 \mathrm{gal} / \mathrm{min})$, while the heat exchanger loops would accommodate about $0.7 \mathrm{Mg} / \mathrm{s}$ $(10,300 \mathrm{gal} / \mathrm{min})$. All primary piping will be economically sized considering costs of pumping power, piping, and heavy water inventory and of the possibilicies of flow vibrations andl erosion. A flow diagram of the primary piping and major equipment is shown in Fig. 3.4-1 and Fig. 3.4-2.

No sizing of the primary pumps has been made to date. It is currently assurned that the same type of centrifugal pumps used in the HFIR would be used for ANS, with the design flow rate and pressure head revised to ANS conditions. Currently, each pump would be provided with an ac motor for normal operation and a battery-powered dc pony motor to maintain tlow for decay heat removal in the event of an ac power failure.

Block valves would be located at the boundary of the submerged pipe tunnel and the pump cells. Remotely operated actuators may be provided to allow closure of a set of valves if a leak is detected. Operation of all leak-prone items in a dry environment could allow rapid detection of any leakage by detection of escaping tritium and ${ }^{16} \mathrm{~N}$. The leaking leg could then be isolated before a significant quantity of inventory would be lost. This practice would also prevent the generation of large volumes of water slightly contaminated with tritium in the event of a valve or pump seal leak, which could go unnoticed for some time in a completely flooded system. The pump and valve stations could also be constructed so that only a limited amount of inventory would be lost before the piping and valves were submerged. Probabilistic techniques would be used to evaluate whether allowing the operator immediate access to the block valves would improve the likelihood of successful response to a loss-of-coolant accident or would create more possibilities for failure. In any case, the shutdown/emergency coolant loop would be totally submerged, without block valves. It would be impossible for the operator to close off all heat sinks by the action of a single primary system block valve.

Letdown valves located in each heat exchanger loop would establish the flow of primary coolant to the letdown tank. Flows have not yet been established but a value on the order of $26 \mathrm{~L} / \mathrm{s}(400 \mathrm{gal} / \mathrm{min})$ from the three active exchangers would appear likely based on HFIR experience. An equal flow would be returned to the primary system by either of the two $100 \%$ redundant pressurizer pumps.

\subsection{ANS RADIOACITVE WASTE SYSTEMS AND SOURCE TERMS}

This section describes the management of liquid, solid, and gaseous radioactive wastes at ORNL and provides a baseline for predicting how laboratory-wide radioactive waste management systems would be affected by the operation of ANS. It also describes ANS radioactive waste management systems and their interface with ORNL waste systems. Four principal radioactive waste types are generated during the operation of nuclear reactors. As defined by DOE and EPA, these are high-level radioactive waste (including spent fuel), transuranic (TRU) waste, low-level radioactive waste (LLW), and mixed (radioactive/hazardous) waste. For ANS, additional subcategories of concern include liquid low-level wastes (LLLW), liquid radiological process waste (PW), and tritium. 


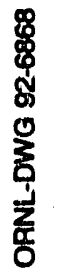
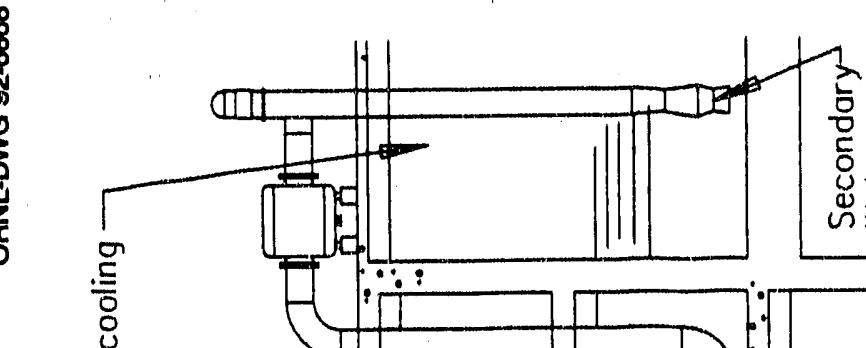

음

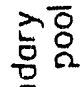

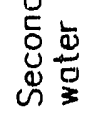

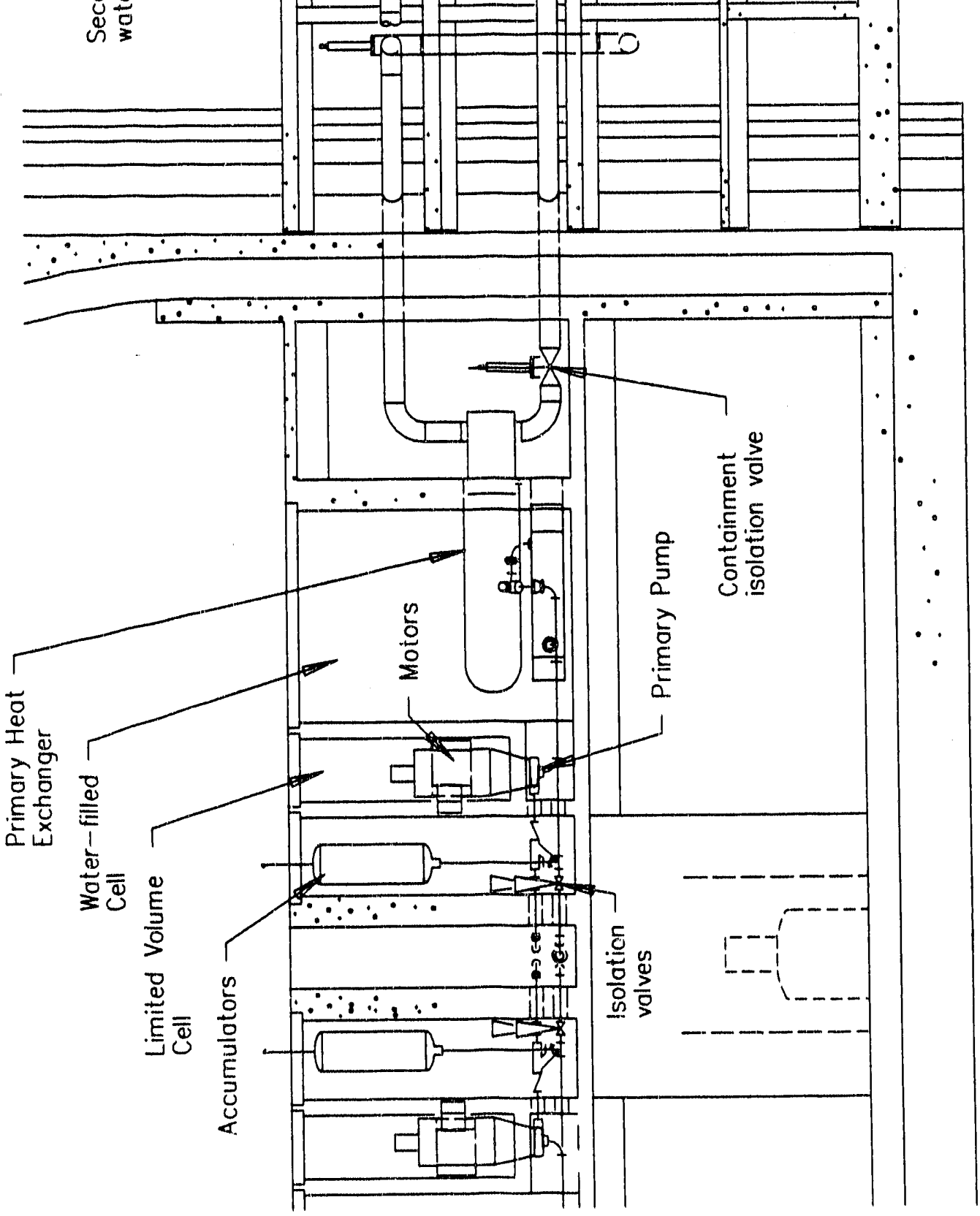




\subsubsection{Introduction}

This section examines ANS radioactive waste treatment systems and their capability to control, collect, process, handle, store, and dispose of liquid, solid, and gaseous radioactive wastes. It also describes the wastes to be produced by ANS. It is the goal of ANS designers to ensure that all waste management issues be identified at an early stage of design planning to minimize their impacts. This is consistent with DOE goals applied to research and production reactors. It is also consistent with NRC environmental permitting standards applied to the licensing of commercial nuclear power plants (DOE 1989a, p. 177; NRC 1976) (Fed. Regist. 46, 51100, 1976).

ANS radioactive wastes would be managed by the DOE waste management system (System Design Description 1991). Liquid and solid wastes would be segregated at the source and directed toward pretreatment steps at ANS. Following pretreatment, these wastes would be processed, stored, and disposed of at other DOE facilities, inciuding those located at ORNL and the nearby K-25 Site.

The future status of DOE waste facilities is uncertain. Some ORNL facilities currently available to waste generators may have become tilled to capacity by the time ANS is scheduled to come on-line. In addition, access to disposal facilities would be controlled partly through waste acceptance criteria developed through consultation between ORNL and its waste generators-including ANS. These criteria would require pretreatment, volume reduction, and proper labeling before disposal (Waste Acceptance Criteria 1991, p. 2).

In the future, it is also likely that waste management practices applied to the commercial nuclear industry would be applied to ANS (and to other DOE facilities). DOE has directed its generators to make every effort to ensure adequate storage space for radioactive wastes at DOE facilities-and to employ waste minimization practices whenever possible. These minimization practices include reducing the quantity of all solid waste generated, reducing the volume of solid LLW shipped for disposal, and dewatering and compacting liquid LLW (DOE 1989a, p. 177; Mezga 1988, pp. 17-21; Myrick, Scanlan, and Kendrick 1988, pp. 22-30; NRC 1976; Kornegay et al. 1991, p. 209) (Fed. Regist. 46, 5100 1976).

The analysis of ANS waste impacts will focus on the effects of waste on planned, as well as current, waste management facilities at the ORNL host site. Moreover, these impacts will be treated separately. Depiction of current waste management facilities will show that these systems are close to capacity and probably would not be able to handle ANS wastes (plans for current waste management facilities at ORNL did not anticipate ANS). Depiction of planned facilities will include assessment of future DOE capacity to manage ANS wastes.

The analysis will also examine current radioactive wastes transported from ORNL to off-site facilities as a baseline for comparison with ANS radioactive wastes expected to be transported off-site. Currently, spent nuclear fuel from the HFIR is shipped to the Savannah River Plant in South Carolina, as would be spent nuclear fuel from ANS. Under the requirements of DOE Order 5820.2A, TRU wastes from DOE operations (including the reprocessing of some ANS wastes) are to be disposed of at the Waste Isolation Pilot Plant (WIPP) near Carlsbad, New Mexico. 


\subsubsection{Methodology}

For each principal category of radioactive waste described in this section, the current ORNL waste management system designed to handle, process, and dispose of that waste will be described. With respect to those systems already in place, those associated with research reactors will be the focus of analysis. We will discriminate between reactor wastes and nonreactor wastes to show how the former are currently managed and the difficulties that would be posed by increases in research reactor waste streams. ANS would be a larger waste generator than HFIR-the reactor ANS would replace.

ANS waste management systems for each category of radioactive waste-and their projected interface with ORNL waste systems-are described. ANS plans for controlling, collecting, processing, and storing routine and nonroutine waste streams, and provisions for packaging and/or transporting waste are then depicted. Finally, planned ORNL waste management systems are described to predict likely impacts of ANS wastes. Because ANS would be a unique research facility, three additional methodologies have been employed to analyze the environmental impacts of its waste stream. These are described in the following sections.

\subsubsection{Comparison with HFIR Experience}

Experience gained from the HFIR has been employed to predict source terms from ANS as well as specific waste management impacts. Comparisons between ANS and HFIR serve to point up significant waste stream differences that make management of ANS wastes unique. They will also reveal existing demands placed on the ORNL waste management system and why current disposal space is likely to become exhausted.

Some types of ANS radioactive wastes are projected to be similar to those historically associated with HFIR (e.g., liquid and solid LLW). However, because ANS would be a larger reactor, the volumes of wastes it would produce may also be larger, putting a greater burden upon DOE waste management facilities (e.g., ANS would require higher water flow rates for coolant than does HFIR, which would generate greater pool water clean-up waste). The use of HFIR experience to predict source terms has guided much of the analysis in Sects. 3.5.3, 3.5.4, 3.5.5 and all of the analysis in Sect. 5.11.

\subsubsection{Tritium Management at DOE and non-DOE Reactors}

The use of heavy water for ANS means that, unlike HFIR, ANS would produce considerable quantities of tritium in liquid and gaseous form (System Design Description 1991). There is currently no laboratory-wide tritium management system at ORNL. The small amounts of tritium generated at ORNL are vented to the atmosphere. Tritiated solids have been packaged and sold at ORNL for a variety of applications.

To predict impacts from tritium management at ANS, therefore, the experience of other tritium-producing DOE and non-DOE reactors has been employed in the analysis. The former include the Savannah River Plant Production Reactors while the latter include the deuterium-moderated Canadian Deuterium Uranium (CANDU) reactors operated by Atomic Energy of Canada, Ltd. (e.g., the Darlington and Pickering Power Stations and the Chalk River Plant), and the Tritium Extraction Facility at ILL in Grenoble, France. These facilities' experience with tritium separation, packaging, and st )rage has been incorporated in the analyses in Sects. 3.5.7 and 5.11.4.1.

Ontario Hydro has had extensive experience with the treatment, handling, removal and transport of tritiated liquid and solid wastes (Krochmalnek, Krasznai, and Carney 
1987, p. 1-12; Reed 1991, pp. 40-50). The utility has constructed a Tritium Removal Facility at Darlington, designed to reduce tritium concentrations in moderator and heat exchanger systems to levels that ensure releases to the environment as well as occupational exposure are kept within ALARA guidelines (Spratt et al. 1985, p. 16; also, see Sect. 5.10). Moreover, tritiated liquid and solid waste generated by this facility is specially conditioned prior to storage and disposal (Krochmalnek, Krasznai, and Carney 1987, p. 1-12).

ILL has had considerable design experience addressing tritium control problems (Reed 1991, pp. 40-50). ANS staff are incorporating lessons from tritium management at these facilities in the areas of packaging and storing of tritiated wastes to reduce potentially adverse environmental impacts.

\subsubsection{Waste-Management Scenarios at the ORNL Host Site}

Institutional uncertainty surrounds the future of radioactive waste management at ORNL (Baldwin et al. 1989a, p. xix). This uncertainty has delayed construction and operation of new waste handling and disposal facilities, leading to an accumulation of waste inventories (Rivera et al. 1989, p. 9). Consequently, the analysis weighs impacts from radioactive wastes generated at ANS under two scenarios: (1) a preferred management scenario (in which new or updated waste management facilities become available at the ORNL host-site, ORR, or other DOE facilities); and (2) an interim storage scenario (in which older, existing facilities continue to be used until new ORNL facilities are available). Under the latter scenario, it is unlikely there will be sufficient capacity for managing ANS wastes. Under both scenarios, it is assumed that waste facilities are designed and operated in accordance with Waste Acceptance Criteria established by ORNL for the management of waste by its generators. These criteria require pretreatment, volume reduction, and waste minimization, as well as proper waste conditioning and labeling before disposal. The scenarios are depicted in Sect. 5.11.1.

\subsubsection{LLLW Management}

LLLW is any radioactive waste solution that is not classifiable as high-level waste (including spent nuclear fuel), TRU waste, or by-product material (e.g., uranium or thorium mine tailings) as defined in Sect. 11e (2) of the Atomic Energy Act of 1954. It must be specially processed before release to surface waters.

\subsubsection{Current ORNL Liquid Low-Level Radioactive Waste Management}

The principal sources of LLLW at ORNL are radioactive laboratory drains; radiochemical pilot plants, including the Radiochemical Engineering Development Center (REDC); and research reactors including HFIR. Laboratory-wide management of LLLW is depicted in Fig. 3.5-1. Because they comprise a special category of concern, liquid tritiated wastes are discussed separately in Sect. 3.5.7.

At ORNL, LLLW is directed to a series of area collection/surge tanks known as Monitoring and Control Stations (MCSs). These stations provide monitoring, $\mathrm{pH}$ adjustment, flow control, and emergency spill/leak diversion to the ORNL LLLW Piping Network-part of the laboratory-wide Collection and Transfer (CAT) System (System Design Description 1991, p. 2-17; Baldwin et al. 1989a). Following MCS holdup, LLLW is shipped via pipeline to the LLLW Evaporator Facility (Building 2531) through a Central 


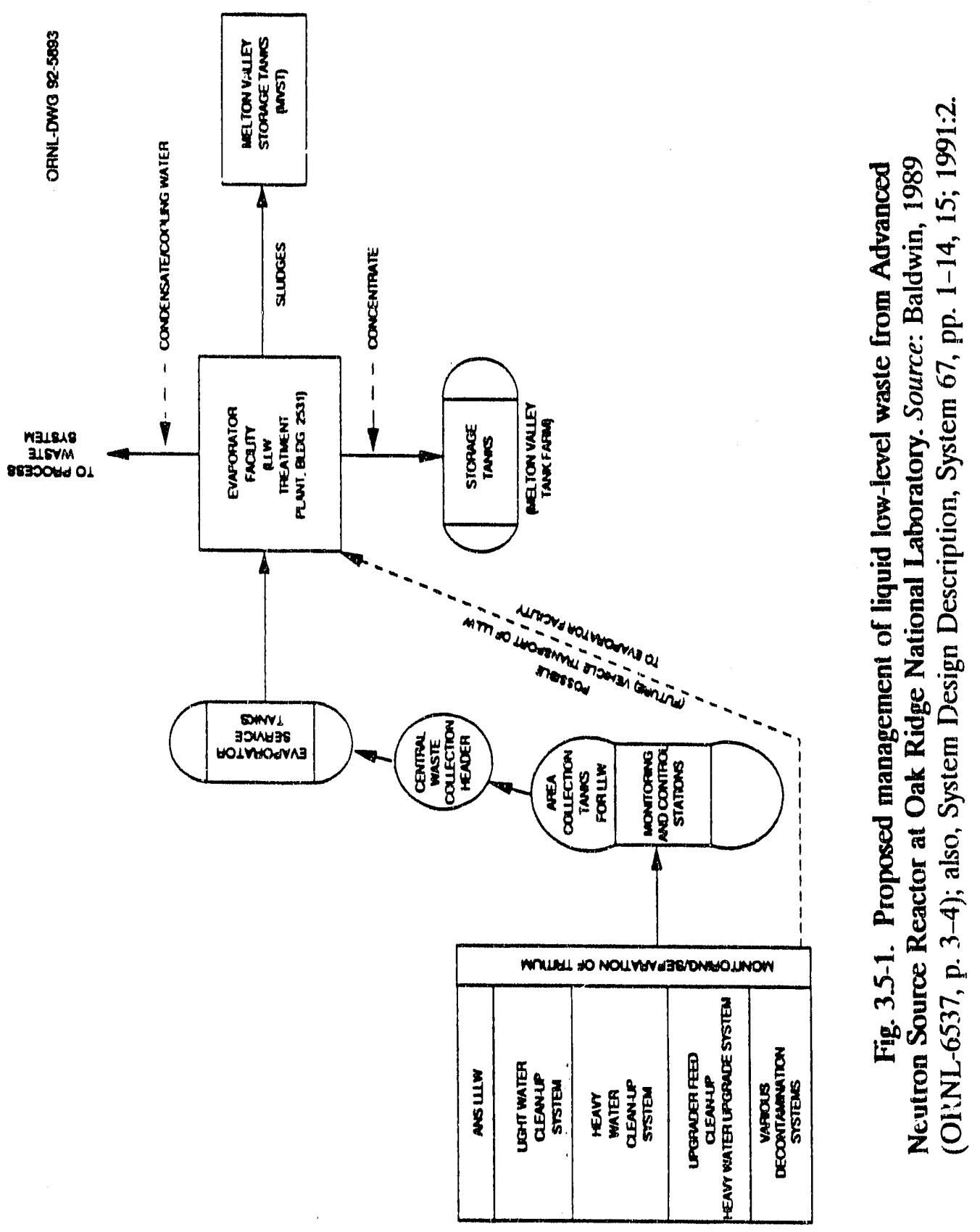


Waste Collection Header (see Fig. 3.5-1). The LLLW Evaporator Facility can process streams with radioactivity levels as high as $2 \times 10^{\prime \prime} \mathrm{Bq} / \mathrm{L}(5.3 \mathrm{Ci} / \mathrm{L})$.

After LLLW processing, the ORNL LLLW Treatment Plant discharges two principal wastes. Evaporator concentrate, produced at a ratio of 1:6 (concentrate vs dilute), is sent via a buried, double-walled stainless steel line to tank farms located behind the evaporator and in Melton Valley near an old hydrofracture site (previously used for transforming LLLW concentrate into cementious grout-a practice discontinued in August 1984). Condensate and cooling water from the evaporator facility, which contain minor amounts of radioactivity, are sent to the ORNL. Process Waste Treatment Plant (PWTP) for further cleanup before discharge to the White Oak Creek system. A third waste type-sludges-is stored in the Melton Valley Storage Tanks.

In Fiscal Year (FY) 1991, the ORNL LLLW system processed approximately $108 \mathrm{~m}^{3}\left(28,000\right.$ gal) of dilute LLW per month or $1,300 \mathrm{~m}^{3}(340,000$ gal $)$ annually. The total capacity of the ORNL LLLW storage system is $300 \mathrm{~m}^{3}(80,000$ gal), while the total available capacity of the concentrate storage system, minus one reserve tank for emergencies, is $410 \mathrm{~m}^{3}(104,100 \mathrm{gal})$. In FY 1991, this system produced $44 \mathrm{~m}^{3}$ (11,500 gal) of concentrate per month (Baldwin et al. 1989a, p. 3-7).

Historically, isotope production and the HFIR have accounted for the largest shares of LLLW generation at ORNL. The former accounted for $16 \%$ of the total laboratory-wide LLLW in 1988 , while the latter accounted for $12 \%$. However, by 1990 , with the HFIR restart, isotope production accounted for only $12 \%$ while HFIR accounted for $23 \%$ of total LLLW at ORNL (Baldwin et al. 1989a, p. 79; Robinson, DePaoli, and Walker 1991, p. 1-27).

\subsubsection{ANS LLLW and Its Management}

Principal sources of LLLW from ANS would be flushing fluids used to dewater spent resin and to flush out plugged filters. These fluids would result from the light water clean-up system, the Heavy Water Upgrading and Detritiation (HWUD) System (in particular, water from spent resin), and the decontamination systems installed for LLLW decontamination (System Design Description 1991, p. 1-14). Sources include backwashing of primary and pool demineralization systems, are fuel leakage, normal replacements of ANS components, corrosion and erosion that would result in "bursts" of radioactively contaminated solutions during start-up or unusual incidents, and LLLW from accident or decommissioning and decontamination activities (System Design Description 1991, p. 1-15).

After LLLW is detained for monitoring of deuterium oxide and tritium and for suparation of tritium (from the ANS primary coolant system, reflector/moderator, and heavy water fuel transfer pool), it will be directed by an elaborate network of piping and transfer lines from ANS to a series of area collection/surge tanks (the ANS MCS). Each tank would have a capacity of at least $3.8 \mathrm{~m}^{3}(1000$ gal) of LLLW. As with other ORNL facilities, ANS's MCS would provide monitoring, $\mathrm{pH}$ adjustment, flow control, and emergency spill/leak diversion to the ORNL. LLLW Piping Network (System Design Description 1991, p. 2-17; Baldwin et al. 1989a, p. 3-6).

ANS would be equipped with a doubly contained LLLW transfer line, as well as the capability to transport liquid LLW by tank truck (see Sect. 3.5.3.3) (System Design Description 1991, p. xiv). 


\subsubsection{Planned ORNL LLLW Management}

Plans for management of LLLW at ORNL include developing strategies for reducing laboratory-wide LLLW production, providing long-term treatment of LLLW to convert much of it to solid waste, upgrading the LLLW CAT and storage systems, and replacing both LLLW evaporators in Building 2531 (Baldwin et al. 1989a, p. 3-7).

At HFIR, plans are underway to dispose of loaded ion-exchange resins (similar to those to be produced at ANS) as solid LLW. If ANS enters operation, Waste Acceptance Criteria at ORNL would be expected to require similar conversion of ion exchange material to solid waste.

In addition, much of the current CAT system will be taken out of service when the Federal Facilities Agreement for the ORR goes into effect (Parrott et al. 1991, p. 2); thus, ANS may be required to dispose of much of its LLLW via bottling or tanker truck to an LLLW evaporator. If ANS enters operation, waste acceptance criteria expected to be in effect at the time would require liquid waste container contents to be of low specific activity because the liquid waste would be transported over ORNL roads (Parrott et al. 1991, p. 2).

Also, while both evaporators within the LILW Evaporator Facility (Building 2531) are currently functioning, ORNL Waste Management Operations is drawing up plans for their replacement (Office of Waste Management and Remedial Actions 1991). It is expected that this replacement process will be completed in time for ANS operation. However, if all other generators continue to produce LLLW at current rates when ANS enters operation (with the exception of HFIR, assumed to be closed), the capacity of the LLLW evaporator could be exceeded. Finally, evaporator concentrate tank farms behind the LLLW evaporator and in Melton Valley are also nearing capacity. DOE has prohibited the building of additional tanks. In order to retain the equivalent of one free tank for emergencies, ORNL Waste Management Operations has solidified some of this concentrate into solid LLW through grouting. Operation of ANS without adequate provision for converting ANS LLLW concentrate into solid waste could overload the capacity of these LLLW concentrate tanks.

\subsubsection{Liquid Radioactive PW Management}

Radioactive PW is liquid waste produced by laboratory or other "process" activities that use radioactive sources. It is classified as being in the waste water category of lowest radioactivity level that is treated at ORNL.

\subsubsection{Current ORNL Liquid Radioactive PW Management}

The principal sources of radioactive $P W$ at ORNL are remedial action program drywells, once-through cooling water systems, condensates from LLLW evaporators, spent resins that gradually accumulate in cleanup systems for contaminated water, and laboratory drain wastes from operations in Bethel and Melton Valley facilitirs, including research reactors such as HFIR (Parrott et al. 1991, p. 6). PW generally contains small quantities of radionuclides, anions, metals, and organic compounds. Laboratory-wide management of PW is depicted in Fig. 3.5-2.

At ORNL, following central collection of PW in holding tanks or basins, PW is diverted to a series of storage tanks in Bethel and Melton Valleys, pumped to an equalization basin (Pond 3524) and then routed to the ORNL PWTP for radionuclide removal (Fig. 3.5-2). 


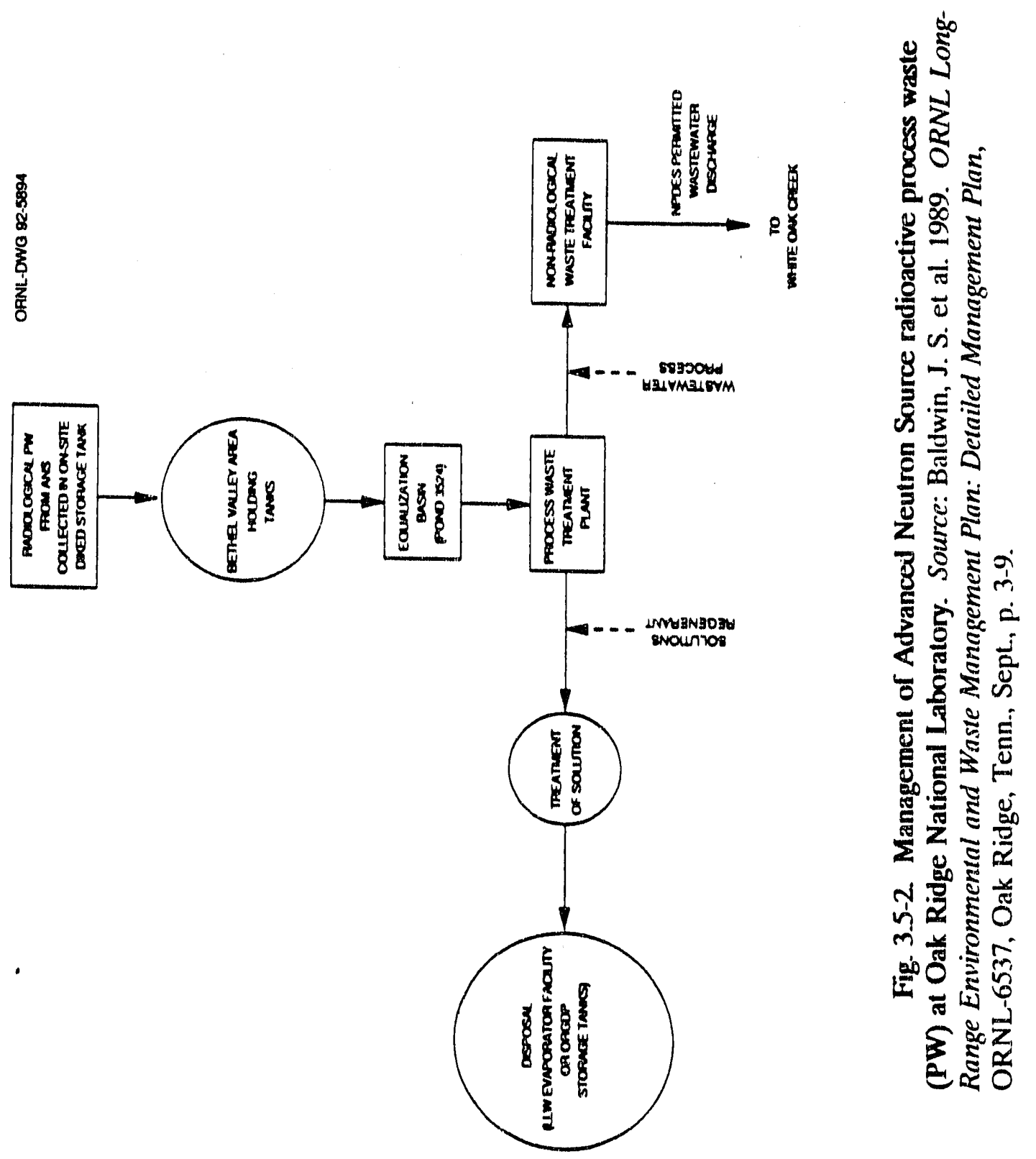


Each month, about $20,000 \mathrm{~m}^{3}(5,200,000 \mathrm{gal})$ of $\mathrm{PW}$ containing $1.22 \times 10^{3} \mathrm{~Bq} / \mathrm{L}$ $(33 \mathrm{nCi} / \mathrm{L})$ or more of gross beta activity is collected for treatment at ORNL. Regenerant solutions, removed from the process waste stream by ion exchange, produce sludges that . are passed through a filter press to reduce their liquid content for storage and to remove process wastewater (see Fig. 3.5-2). Sludges are stored in the LLLW evaporator building or packed in drums for solid LLW storage at the K-25 Site (Baldwin et al. 1989a, p. 3-7). Process wastewater are routed to the ORNL Nonradiological Waste Treatment Plant (NRWTP) for removal of suspended solids, heavy metals, and organic compounds and is then discharged to White Oak Creek. About $21,000 \mathrm{~m}^{3}(5,500,000$ gal) of treated wastewater are discharged to White Oak Creek monthly (Baldwin et al. 1989a). A portion of regenerant solution is sent to the ORNL LLLW Evaporator Facility for treatment.

\subsubsection{ANS Radioactive PWs and Their Management}

ANS would produce PW from water cleanup activities such as sampling the light water from reactor pool and filled cells, replacing plugged filters, and dewatering spent resin that gradually accumulates in both the light water (pool) and heavy water cleanup systems in the Reactor Support Building (System Design Description 1991, p. 1-13). In addition, the process of decontaminating LLLW in the ANS Plant Waste System (Sect. 3.5.3) would produce PW when resins and filters are replaced. Rinsing of used equipment and laboratory waste would produce small quantities of PW. Make-up for the ANS heavy water supply also may require a special cleanup process, depending on the heavy water source. This cleanup process would produce $P W$ ihrough the dewatering resin that is stripped of heavy water (System Design Description 1991, p. 1-14).

PW would be collected by several systems at ANS, with contaminated secondary cooling tower blowdown diverted to a special hold-up tank. Piping networks from the reactor building, detritiation facility, reactor and operations support facility, guide hall, and maintenance facilities would collect light water residues, laboratory waste, maintenance cleanup, and other PW sources (System Design Description 1991, pp. 2-14, 2-15).

Monitoring and sampling would be performed to determine the presence of tritium or other volatiles in PW streams (see Sect. 3.5.6.1). If these streams contained high levels of tritium, they would be solidified as a special case waste rather than being discharged to the PWTP - as required under laboratory-wide waste acceptance criteria (Parrott et al. 1991, p. 6). The Heavy Water Upgrade and Detritiation Building (HWUDB) would also process its own tritiated liquids for storage and disposal as a special case waste (System Design Description 1991, p. 1-14).

After collection at ANS, PW would be diverted to a diked waste collection tank on-site that is equipped with leak/spill diversion equipment and a means to adjust $\mathrm{pH}$. A transfer line trom ANS would be connected to an existing HFIR process waste transfer line, which would enable ANS PW to be discharged to the Bethel Valley Storage Tank Area (Tank F-1018). From this area, PW would be combined with that from other Bethel Valley generators and pumped to ORNL. PW treatment facilities.

\subsubsection{Planned ORNL Radioactive PW Management}

Conceptual planning has begun for a Sludge Volume Reduction Facility designed for the Process Waste Treatment Plant (PWTP). In addition, a projeci is also in place to increase the capacity of the PWTP evaporator facility to reduce the amount of LLLW concentrate requiring disposal (Baldwin et al. 1989a, p. 87). Finally, new waste acceptance criteria will impose maximum allowable concentrations of wastewater contaminants for 
discharge to the PWTP in the future (Table 3.5-1) (Parrott et al. 1991, p. 7). Contaminated wastewater in excess of these concentrations must be discharged to the LLLWW facility (Building 2531). For ANS, the net result of these improvements would be to ensure adequate waste management capacity for PW.

\subsubsection{Solid Radioactive Waste Management at ANS}

This section describes the management of solid radioactive wastes at ORNL and the proposed management of the principal solid LLW that would be generated by ANS. Under each waste category, current ORNL waste management systems are described, followed by a description of ANS waste sources and a discussion of planned waste management activities/facilities. Because they comprise a special category of concern, solid tritiated wastes are discussed separately in Sect. 3.5.7. Table 3.5-2 depicts major categories of solid radiological waste generated at ORNL in 1989.

\subsubsection{Overview of Current ORNL TRU Waste Management}

TRU waste is material that is contaminated with alpha-emitting radionuclides with atomic numbers greater than 92 , that has a half-life greater than 20 years, and that has a total assay concentration (sum of the concentration of all such radionuclides) greater than $3.7 \times 10^{3} \mathrm{~Bq} / \mathrm{L}(100 \mathrm{nCi} / \mathrm{g})$.

Three principal TRU wastes are found at ORNL-solid contact-handled (CH) TRU, with a surface dose rate of less than $2 \mathrm{mSv}(200 \mathrm{mrem} / \mathrm{h})$; solid remote-handled (RH) TRU, having a surface dose rate greater than $2 \mathrm{mSv}(200 \mathrm{mrem} / \mathrm{h})$, and TRU sludges. At ORNL, the latter are associated with residual heels from a gunite-hydrofracture disposal project completed in 1984. These wastes are stored in the Melton Valley Storage Tank complex, leaky gunite tanks and other active and inactive tanks, and are awaiting processing in the Waste Handling and Processing Plant for solidification, certification, and, ultimately, disposal as solid RH-TRU waste (Baldwin et al. 1989b, p. 31).

The management of newly generated TRU waste at ORNL (all TRU waste generated since July 1986), as well as contemplated management of ANS TRU waste, is depicted in Fig. 3.5-3. Current interim storage for $\mathrm{CH}$ and RH-TRU wastes are depicted in Table 3.5-3.

\section{Current ORNL CH-TRU management}

Most CH-TRU at ORNL originates from laboratory work associated with research reactors and consists of miscellaneous radioactive waste from glove box operations and from discarded HEPA filters and other equipment. Its dose rate is usually around $0.1 \mathrm{mSv}$ $(10 \mathrm{mrem} / \mathrm{h})($ Baldwin et al. 1989c, p. 4-12); thus, it can be handled with relatively minimal protection. More than half of the CH-TRU at ORNL is typically plastic; metals comprise $22 \%$ of annual generation, glass $20 \%$, cloth $5 \%$, rubber $2 \%$, and wood $1 \%$. Actinide separation at ORNL's REDC also produces CH-TRU waste.

Newly generated $\mathrm{CH}$-TRU wastes undergo neutron assay garnma scan at the Waste Examination Assay Facility (WEAF) located in the north area of Solid Waste Storage Area (SWSA) 5. WEAF determines which wastes contain CH-TRU and which are composed of solid LLW (SLLW). The latter are separated out and taken to SWSA 6, while the former are taken to a staging area (Building 7823 in the north area of SWSA 5) that has a storage area of $390 \mathrm{~m}^{2}\left(4200 \mathrm{ft}^{2}\right)$ and capacity of $850 \mathrm{~m}^{3}\left(30,000 \mathrm{ft}^{3}\right)$. This 
Table 3.5-1. Maximum allowable concentrations of specific wastewater contaminants for discharge to the process waste treatment plant

\begin{tabular}{|c|c|}
\hline Contaminant & Concentration \\
\hline \multicolumn{2}{|c|}{ Radionuclides } \\
\hline $\begin{array}{l}\text { Gross alpha } \\
\text { Gross beta } \\
{ }^{90} \mathrm{Sr} \\
{ }_{1.17} \mathrm{Cs} \\
{ }^{60} \mathrm{Co} \\
{ }^{152} \mathrm{Eu} \\
{ }^{155} \mathrm{Eu} \\
{ }^{106} \mathrm{Ru} \\
{ }^{95} \mathrm{ZrNb}\end{array}$ & $\begin{array}{r}175 \mathrm{~Bq} / \mathrm{L}\left(4.73 \times 10^{-9} \mathrm{Ci} / \mathrm{L}\right) \\
10,000 \mathrm{~Bq} / \mathrm{L}\left(2.703 \times 10^{-7} \mathrm{Ci} / \mathrm{L}\right) \\
10,000 \mathrm{~Bq} / \mathrm{L}\left(2.703 \times 10^{-7} \mathrm{Ci} / \mathrm{L}\right) \\
400 \mathrm{~Bq} / \mathrm{L}\left(1.09 \times 10^{-9} \mathrm{Ci} / \mathrm{L}\right) \\
185 \mathrm{~Bq} / \mathrm{L}^{a} \cdot\left(5 \times 10^{9} \mathrm{Ci} / \mathrm{L}\right) \\
740 \mathrm{~Bq} / \mathrm{L}^{a}\left(2 \times 10^{-8} \mathrm{Ci} / \mathrm{L}\right) \\
3,700 \mathrm{~Bq} / \mathrm{L}^{a}\left(1 \times 10^{-7} \mathrm{Ci} / \mathrm{L}\right) \\
222 \mathrm{~Bq} / \mathrm{L}^{a}\left(6 \times 10^{.9} \mathrm{Ci} / \mathrm{L}\right) \\
1,480 \mathrm{~Bq} / \mathrm{L}^{a}\left(4 \times 10^{-8} \mathrm{Ci} / \mathrm{L}\right)\end{array}$ \\
\hline \multicolumn{2}{|c|}{ Metals } \\
\hline $\begin{array}{l}\mathrm{Ag} \\
\mathrm{As} \\
\mathrm{B} \\
\mathrm{Ba} \\
\mathrm{Be} \\
\mathrm{Cd} \\
\mathrm{Cr} \\
\mathrm{Cu} \\
\mathrm{Fe} \\
\mathrm{Hg} \\
\mathrm{Ni} \\
\mathrm{Pb} \\
\mathrm{Sb} \\
\mathrm{Se} \\
\mathrm{Zn}\end{array}$ & $\begin{array}{c}0.4 \mathrm{mg} / \mathrm{L} \\
40.0 \mathrm{mg} / \mathrm{L} \\
40.0 \mathrm{mg} / \mathrm{L} \\
120.0 \mathrm{mg} / \mathrm{L} \\
0.2 \mathrm{mg} / \mathrm{L} \\
0.3 \mathrm{mg} / \mathrm{L} \\
7.5 \mathrm{mg} / \mathrm{L} \\
2.5 \mathrm{mg} / \mathrm{L} \\
500.0 \mathrm{mg} / \mathrm{L} \\
0.004 \mathrm{mg} / \mathrm{L} \\
65.0 \mathrm{mg} / \mathrm{L} \\
30.0 \mathrm{mg} / \mathrm{L} \\
65.0 \mathrm{mg} / \mathrm{L} \\
15.0 \mathrm{mg} / \mathrm{L} \\
60.0 \mathrm{mg} / \mathrm{L}\end{array}$ \\
\hline \multicolumn{2}{|c|}{ Others } \\
\hline $\begin{array}{l}\text { Chlorine } \\
\text { Cyanide } \\
\text { Nitrate } \\
\text { Oil and grease } \\
\text { pH } \\
\text { Phosphate } \\
\text { Sulfate } \\
\text { Total organic carbon } \\
\text { Total suspended solids } \\
\text { Total toxic organics }\end{array}$ & $\begin{array}{r}20.0 \mathrm{ppm} \\
0.2 \mathrm{ppm} \\
10.0 \mathrm{ppm} \\
100.0 \mathrm{ppm} \\
>6.0 \mathrm{ppm} \\
5.0 \mathrm{ppm} \\
3,000.0 \mathrm{ppm} \\
50.0 \mathrm{ppm} \\
1,000.0 \mathrm{ppm} \\
100.0 \mathrm{ppm}\end{array}$ \\
\hline
\end{tabular}

aDOE Order 5400.5 DCG values.

Source: Parrol, J. R. Jr., el al. 1991. Oak Ridge National Laboratory Liquid Waste Treatment Systems Wasti Acceptance C'riteria, WM-WMCO, 201 4, Oak Ridge National Laboratory, Oak Ridge, Tenn., July. 
Table 3.5-2. Solid radioactive waste generated at Oak Ridge National Laboratory in 1989: all sources

\begin{tabular}{cc}
\hline $\begin{array}{c}\text { Radioactive } \\
\text { waste type }\end{array}$ & $\begin{array}{c}\text { Quantity } \\
{\left[\mathrm{m}^{3}\left(\mathrm{ft}^{3}\right)\right]}\end{array}$ \\
\hline $\begin{array}{l}\text { Transuranic waste } \\
\text { Low-level waste }\end{array}$ & $50(1,750)$ \\
\hline
\end{tabular}

Source: Oak Ridge National Laboraton' Waste Management Plan for Department of Energy' Order 5820.2A, December 1989, ORNL/TM-11433, Oak Ridge National Laboratory, Oak Ricige. Tenn., p. $1 \cdot V$.

facility is principally used for drummed waste and temporary storage of boxed waste (e.g., TRU glove box wastes and 55-gal drums of LLW). From here, CH-TRU will be stored in Buildings 7826 and 7834 , which have a capacity of 1536 drums and 1920 drums, respectively (Baldwin et al. 1989a, p. 38).

Approximately $15 \mathrm{~m}^{3}\left(530 \mathrm{ft}^{3}\right)$ of $\mathrm{CH}-\mathrm{TRU}$ is generated annually at ORNL with an additional $2 \mathrm{~m}^{3}\left(600 \mathrm{ft}^{3}\right)$ resulting from decontamination and decommissioning activities (Baldwin et al. 1989b, p. 17-29; Baldwin et al. 1989c, p. 4-4). A total of $280 \mathrm{~m}^{3}(10,000$ $\mathrm{ft}^{3}$ ) of CH-TRU is currently in storage at ORNL (Baldwin et al. 1989c, p. 4-4). Under DOE order 5820.2A, all ORNL CH-TRU waste in retrievable storage is to be disposed of at the WIPP in Carlsbad, New Mexico (Baldwin et al. 1989a, p. xxii).

\section{ANS contact-handled TRU waste sources and their management}

CH-TRU from ANS experimental activities would be packed into polyethylene bags and placed into 55-gal stainless steel drums. From ANS, CH-TRU would undergo neutron assay gamma scan at the WEAF located in the north area of SWSA 5. CH-TRU would be stored on an interim, retrievable basis until WIPP becomes available. It is expected that the volume of CH-TRU wastes from ANS, processed by the REDC facility, would be comparable to that from HFIR.

\section{Planned ORNL contact-handled TRU waste management}

Building 7823 is expected to be phased out as a TRU waste staging facility in 1993 (Baldwin et al. 1989a, p. 38). A replacement facility (Building 7879) designed to store CH-TRU waste on an interim basis, has recently opened at SWSA 5. This facility is a butler-style building with a capacity for 700 drurns and 20 boxes, or 960 drums of CH-TRU waste (Baldwin et al. 1989a, p. 38). In addition, a new CH-TRU storage facility-also a butler-type structure-with a capacity for storing 3000 208-L (55-gal) drums, is planned for SWS.A 7 (Baldwin et al. 1989a, p. 38). Nevertheless, it is unlikely that these facilities alone will have sufticient storage space for ANS CH-TRU waste.

Both of these facilities are designed as interim storage facilities until WIPP becomes available some time after 1995 (Baldwin et al. 1989c, p. 4-5). Before CH-TRU wastes can be shipped to WIPP, they must be packaged for transport in a planned transuranic package transporter (TRUPACT) facility at ORNL. The expected disposal capacity for all DOE CH-TRU waste at WIPP is $176,000 \mathrm{~m}^{3}\left(6,195,200 \mathrm{ft}^{3}\right)$. 


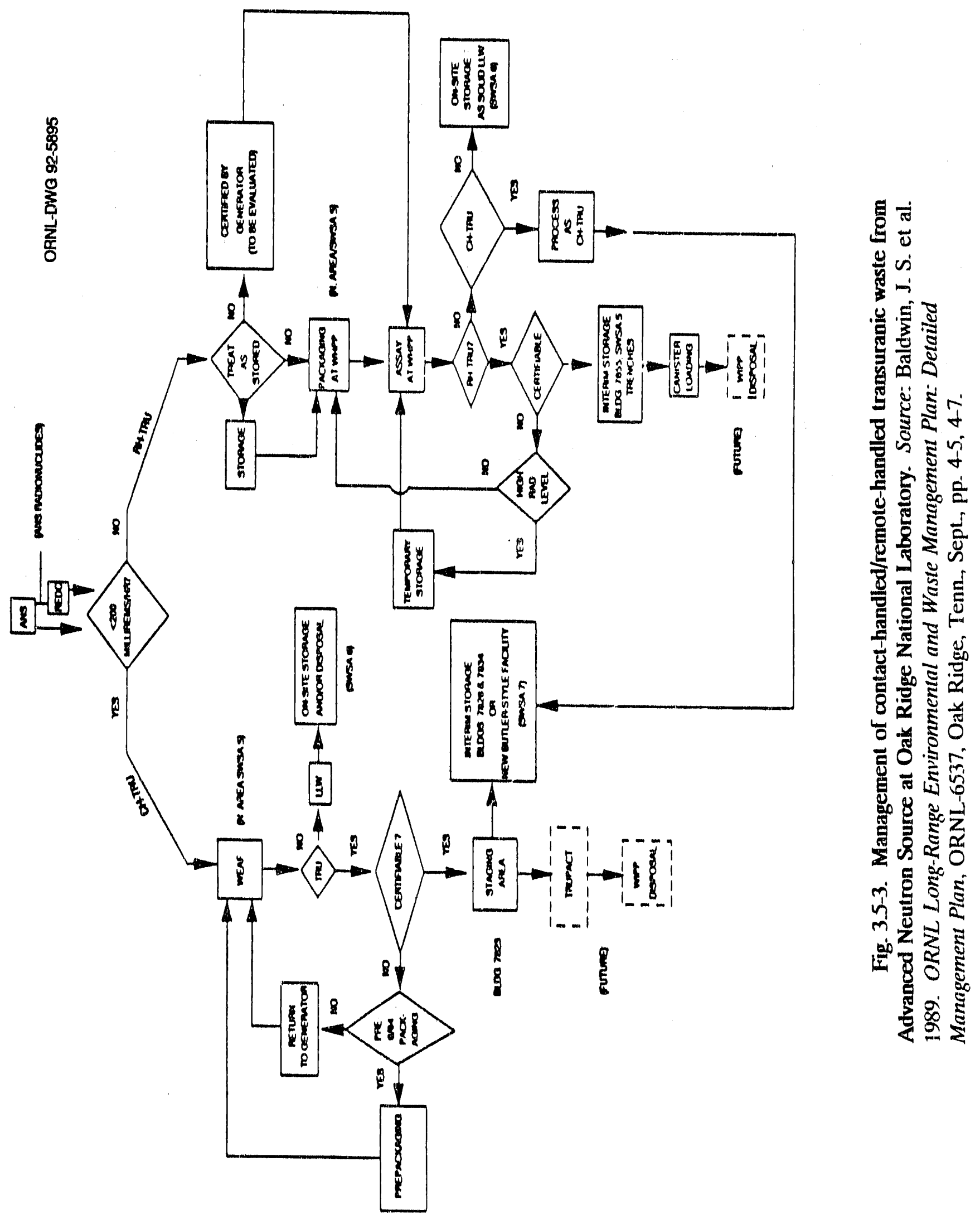




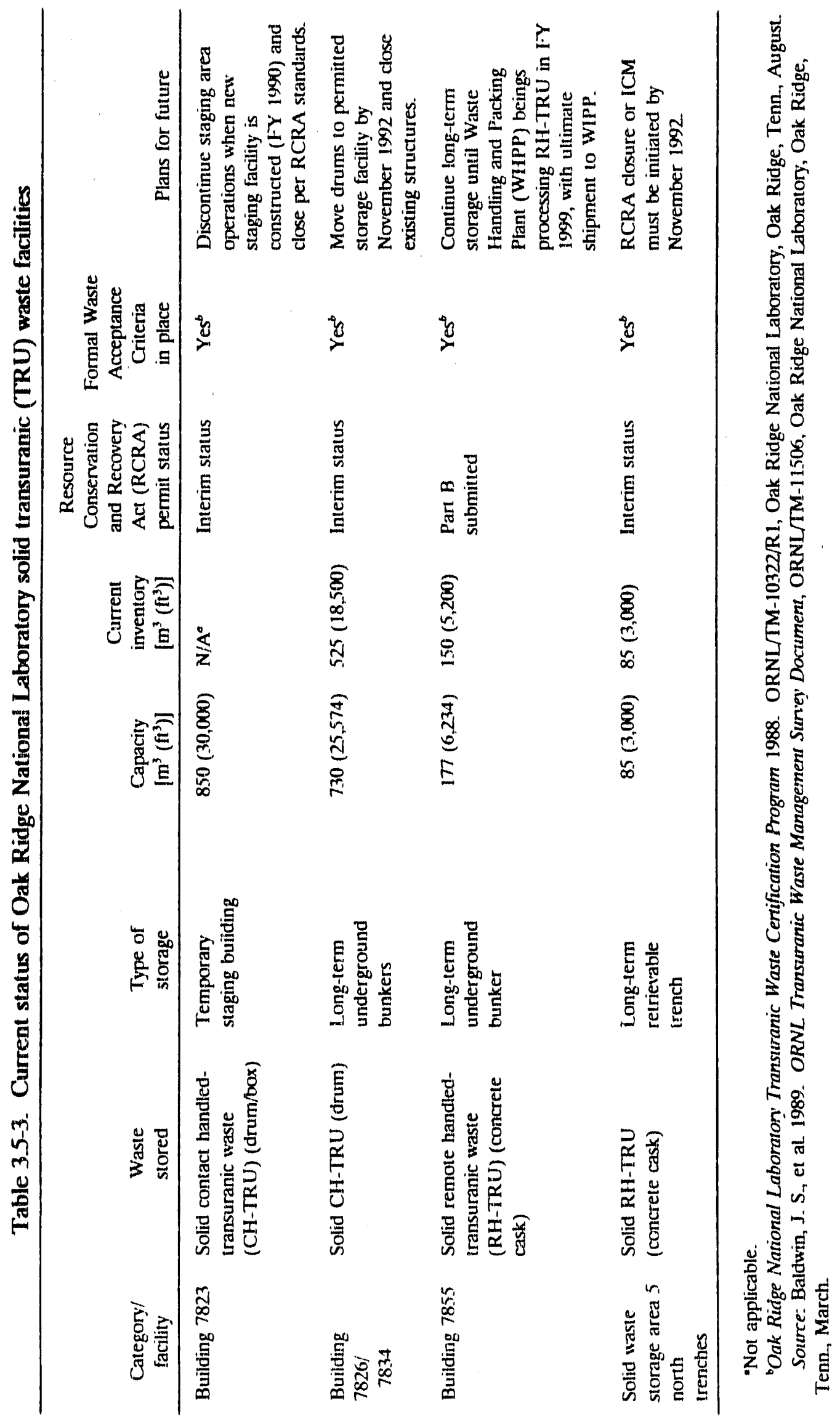




\section{Current ORNL RH-TRU waste management}

Most RH-TRU sources at ORNL consist primarily of miscellaneous cell waste, HEPA filters, discarded equipment, and leached target hulls from research reactors. Actinide separation at ORNL's REDC also produces RH-TRU waste.

RH-TRU cell waste (paper, glass, plastic tubing, show covers, and wipers), as well as HEPA filters and discarded contaminated equipment, are put into waste packages prior to placement in special concrete-filled casks (Baldwin et al. 1989b, p. 7). These casks are then stored in either Building 7855, which has a capacity of 108 casks divided among four bays, or in special trenches at SWSA 5. RH-TRU sources at ORNL emit between $1 \times 10^{.3}$ and $100 \mathrm{~Sv} / \mathrm{h}$ (between 0.1 and $10,000 \mathrm{rem} / \mathrm{h}$ ) when unshielded. In recent years, RH-TRU generation at ORNL has averaged between 4 and $5 \mathrm{~m}^{3}$ (140 and $\left.153 \mathrm{ft}^{3}\right)$ annually (Baldwin et al. 1989e, p. 4-5).

Approximately $130 \mathrm{~m}^{3}\left(4700 \mathrm{ft}^{3}\right)$ of RH-TRU is currently stored at ORNL. Most of this RH-TRU is stored in trenches at SWSA 5. However, some is buried in concrete casks in the north area of SWSA 5 (see following section) and is retrievable (Baldwin et al. $1989 b$ ).

\section{ANS RH-TRU and its management}

Targets from ANS, including TRU targets and associated equipment, will be transferred to the REDC, dissolved in a caustic solution, and put into waste packages prior to placement in special concrete-filled casks. Although targets are irradiated at ANS, waste is not physically generated until separations take place at REDC. At ANS, TRU target material will be stored for varying periods of time before shipment to REDC because ANS is farther trom REDC than is HFIR. After reprocessing, RH-TRU will probably be stored in new RH-TRU storage bunkers (Bunkers I and II), to be located at SWSA 5, until the WIPP in Carlsbad, New Mexico, is made available for permanen $九$ TRU waste disposal (Baldwin et al. 1989b, p. 7; 1989a, p. xxii). The volume of RH-TRU waste as a result of processing ANS targets varies. ANS will irradiate only those targets requested by the programs supporting REDC and TRU because of the greater number of targets planned for use in reactor experiment systems (estimated at more than the 30 currently used in HFIR).

\section{Planned ORNL RH-TRU management}

Long-term management of RH-TRU at ORNL hinges on the availability of a Waste Handling and Packaging Plant, an FY 1993 project (since indefinitely delayed) designed to (1) process stored, preexisting TRU sludges and (2) certify and package newly generated RH-TRU for disposal at WIPP (Baldwin et al, 1989b, p. xxiii). After certification and packaging, RH.TRU will probably be shipped to WIPP.

The new RH-TRU storage bunkers (Bunkers I and II), located at SWSA 5, are being built to provide additional interim storage for RH.'TRU until the Waste Isolation Pilot Plant (WIPP) in Carlsbad, New Mexico is made available for permanent TRU waste disposal (Baldwin et al. 1989a, p. 30). These bunkers have storage capacities of 108 and 162 casks, respectively. The eventual RH-TRU waste disposal capacity for WIPP will be $7,100 \mathrm{~m}^{3}\left(250,000 \mathrm{ft}^{3}\right)$. 


\subsubsection{Overview of High-Level Incidental Waste}

HLW is highly radioactive solid waste that must be handled and transported in shielded containers.

\section{Current ORNL HLW management}

HLW is generated at ORNL by alterations or major repairs on research reactors. It includes irradiated reactor parts removed for examination or replacement, plugged filter elements contaminated with radioactive cobalt, and discharged reactor fuel samples and irradiation test samples. Such wastes require special packaging, handling, and transport. A small quantity of this waste, termed Special Case, High-level Incidental, is currently stored in wells at SWSA 5.

\section{ANS HLW and its management}

ANS will not produce HLW from normal operations. HLW will only be produced as a result of major alterations and decommissioning and decontamination of the facility. At ANS, after case-by case analysis to ensure adequate shielding and packaging design, irradiated reactor parts and other HLW will be remotely-loaded underwater (or in special cells) into shielded containers for disposal when future facilities outside the Oak Ridge Reservation become available (System Design Description 1991).

\section{Planned ORNL HLW management}

Under the current ORNL radioactive waste management plan, high-level wastes are not suitable for disposal on the ORR. Discarded isotope sources and activated parts of reactors may eventually be disposed of in a planned Dry Cask Storage Facility, probably to be located at the Savannah River Plant in South Carolina. Configuration and planning for this facility have yet to be completed (Baldwin et al. 1989a, p. 69).

\subsubsection{Overview of Spent Fuel Management}

Spent fuel is produced when nuclear fuel is irradiated in a reactor. After removal, it is stored in racks placed in pools to isolate it from the environment and to allow cooling of fuel plates.

\section{Current ORNL spent fuel management}

After removal and temporary storage in pools, spent fuel from ORNL research reactors is shipped to the Receiving Basin for Offsite Fuels (RBOF) at the Savannah River Site (SRS) in South Carolina (DOE 1989b, p. 4; SAIC 1990, p. 19). There is currently no permanent system for disposal of spent fuel from DOE or commercial reactors.

HFIR annually transports an average of 12 spent fuel shipments from its spent fuel pool to RBOF. Historical shipments of DOE and university research reactor spent fuel-including shipments from ORNL-are depicted in Table 3.5.4. 
Table 3.5-4. Summary of Department of Energy and university research reactor spent fuel shipments, 1983-1989

\begin{tabular}{ccc}
\hline Year & $\begin{array}{c}\text { Number of } \\
\text { shipments }\end{array}$ & $\begin{array}{c}\text { Weight } \\
\text { (metric tons of uranium) }\end{array}$ \\
\hline 1983 & 24 & 0.444 \\
1984 & 43 & 2.2490 \\
1985 & 52 & 1.1607 \\
1986 & 53 & 13.5501 \\
1987 & 32 & 2.4837 \\
1988 & 5 & 0.1102 \\
1989 & 27 & 0.2956 \\
& & \\
Total & 236 & 20.293 \\
\hline
\end{tabular}

Source: Science Applications Internattional Corporation, 1990. Historical Overview of Domestic Spent Fuel Shipments-Update, prepared for Oak Ridge National Laboratory and the Office of Civilian Radioactive Waste Management Transportation Operations Office under subcontract no. 88-17B-997962/, Oak Ridge, Tenn.

\section{ANS spent fuel management}

Discharge of spent fuel (and replacement with fresh fuel) at ANS would occur 17 times annually (West 1989, pp. 96-101). Alter removal, the inventory of spent, enriched ${ }^{235} \mathrm{U}$, weighing approximately $15 \mathrm{~kg}(40 \mathrm{lb}$ ), would be stored in a pool on-site. Two scenarios for spent fuel storage are envisioned. In the first, following one year's accumulation. ANS spent fuel would be shipped to the RBOF (DOE 1989b, p. 4; SAIC 1990 , p. 19). At Savannah River, ANS spent fuel may be either reprocessed or stored until a permanent repository becomes available, sometime after 2010.

The second scenario is identical to the first, except that up to 5 years of resident storage space would be provided at ANS in case off-site storage space at RBOF (or elsewhere) were unavailable. However, only a 2-year supply of spent fuel would actually be stored at ANS prior to shipment to Savannah River.

\section{Planned ORNL spent fuel management}

After removal and temporary storage on-site, spent fuel from ORNL research reactors, including ANS, would continue to be shipped to the RBOF at the Savannah River Plant for storage (DOE 1989b, p. 17; SAIC 1990, p. 17). Interim storage will continue until a high-level waste repository becomes available after 2010 . 


\subsubsection{Overview of Greater-than-Class-C Waste Management}

Three categories of low-level radioactive waste (classes $A, B$, and $C$ ) distinguished by concentration of radionuclides are defined in $10 \mathrm{CFR} \mathrm{Pt} .61$. GTCC is defined as lowlevel waste in which radionuclide concentrations exceed those for regular low-level waste, and which therefore requires special packaging, handling, and transport (10 CFR Pt. 61). Because GTCC is often defined by reference to the class $C$ wastes whose radionuclide concentrations it exceeds, Table 3.5-5 depicts the most common examples of GTCC.

\section{Current ORNL management of greater-than-class-C waste}

Currently, ORNL classifies discarded isotope sources and activated parts of reactors as GTCC or, more precisely, as special case (SC) GTCC. At ORNL, SC-GTCC is treated as a subset of class L-IV low-level waste. Such wastes must be stored at SWSA 6 on an interim basis since no disposal of class IV waste is permitted on the Oak Ridge Reservation. Moreover, waste acceptance criteria explicitly forbid disposal of GTCC waste in waste containers also containing class $C$ or lower wastes. ORNL currently generates less than $140 \mathrm{~m}^{3}\left(5000 \mathrm{ft}^{3}\right)$ of class IV wastes annually, some of which is SC-GTCC waste (Baldwin et al. 1989a, p. 105).

\section{ANS greater-than-class-C waste management}

The principal source of GTCC is expected to be ${ }^{14} \mathrm{C}$, caused by radiation damage to spent primary cleanup resins. In addition, routine replacement of neutron damaged parts, major alteration and decontamination and decommissioning of ANS could produce some GTCC waste. GTCC from ANS that emits a surface rate dose of less than $0.5 \mathrm{mSv} / \mathrm{h}(50 \mathrm{mrem} / \mathrm{h})$ will be placed in interim storage at SWSA-6 or at the Y-12 Site until a licensed disposal facility is sited (see following section) (Baldwin et al. 1989a, p. 105).

\section{Planned ORNL management of GTCC waste}

Interim storage of GTCC is expected to continue until a licensed facility for GTCC waste is sited that provides maximum protection for the public as well as protection against accidental intrusion (Pub. L. 99-240) (Hutchison and Magleby 1990, pp. 617-619). Class L-III/IV Below Grade Storage facilities are planned for construction for GTCC waste by the mid-1990s (Office of Waste Management 1991, p. 180).

\subsubsection{Overview of Solid Low-Level Radioactive Waste Management at ORNL}

Solid Low-Level Radioactive Waste (SLLW) may be either $\mathrm{CH}$ [surface dose rate less than $2 \mathrm{mSv} / \mathrm{h}(200 \mathrm{mrcm} / \mathrm{h})$ ] or $\mathrm{RH}$ [surlace dose rate greater than $2 \mathrm{mSv} / \mathrm{h}$ $(200 \mathrm{mrem} / \mathrm{h})]$. The ORNL SLLW management system is depicted in Fig. 3.5-4.

The primary strategy for LLW management and disposal at ORNL is establishment of dose-based performance objectives that protect the public, minimize environmental releases, and reduce the need to undertake future remedial actions. An evolving classification system for LLW has come from this strategy, based on the specific isotopic composition and concentration in LLW (Kornegay et al. 1991, p. 206). As of September 1991, the classes were as follows: 
Table 3.5-5. Greater-than tiass-C radionuclides commonly found in solid radioartive waste

\begin{tabular}{ll}
\hline $\begin{array}{c}\text { Radionuclides exceeding class } \mathrm{C} \text { liquid low- } \\
\text { level waste limits }\end{array}$ & $\begin{array}{c}\text { Concentration limits } \\
{\left[\mathrm{Bq} / \mathrm{m}^{3}\left(\mathrm{Ci} / \mathrm{m}^{3}\right)\right]}\end{array}$ \\
\hline Long-lived radionuclides & \\
${ }^{14} \mathrm{C}$ & $2.96 \times 10^{11}(8)$ \\
${ }^{14} \mathrm{C}$ in activated metal & $2.96 \times 10^{12}(80)$ \\
${ }^{59} \mathrm{Ni}$ in activated metal & $8.14 \times 10^{12}(220)$ \\
${ }^{94} \mathrm{Nb}$ in activated metal & $7.4 \times 10^{9}(0.2)$ \\
${ }^{99} \mathrm{Tc}$ & $1.11 \times 10^{11}(3)$ \\
${ }^{129} \mathrm{I}$ & $2.96 \times 10^{9}(0.08)$ \\
${ }^{\mathrm{Short}-\text { lived radionuclides }}$ & \\
& \\
${ }^{63} \mathrm{Ni}$ & $2.59 \times 10^{13}(700)$ \\
${ }^{63} \mathrm{Ni}$ in activated metal & $2.59 \times 10^{14}(7000)$ \\
${ }^{90} \mathrm{Sr}$ & $2.59 \times 10^{14}(7000)$ \\
${ }^{137} \mathrm{Cs}$ & $1.7 \times 10^{14}(4600)$ \\
\hline
\end{tabular}

Source: Hutchison, D., and M. Magleby, Greater-Than-C.'lass-C. Low-Level Waste Characterization Technical Review Process, Nuclear Materials Management, 31st Annual Meeting Proceedings, Volume XIX, Los Angeles, July 15-18.

- below-regulatory-concern waste--LLW that is suitable for disposal in a sanitary/industrial landfill and that will not expose any member of the public to an effective dose equivalent of more than $0.04 \mathrm{mSv} / \mathrm{year}(4 \mathrm{mrem} / \mathrm{year})$ at the time of disposal,

- class L-I waste - LLW that is suitable for disposal using sanitary/industrial landfill disposal technology and that will not expose any member of the public to an effective dose equivalent of more than $0.1 \mathrm{mSv} / \mathrm{year}(10 \mathrm{mrem} / \mathrm{year})$ at the time of disposal,

- class L-II waste-LLW consisting of fission product radionuclides with half-lives of 30 year: or less that is suitable for disposal in engineered facilities designed to isolate the LLW from the environment and the public for a period sufficient to allow the decay of radionuclides to such a level that any member of the public will not be exposed to an effective dose equivalent of more than $0.1 \mathrm{mSv} / \mathrm{year}(10 \mathrm{mrem} / \mathrm{year})$,

- class L-III waste-LLW consisting of radionuclides that have long half-lives and will be disposed of in facilities having permanent intruder protection, and

- class L-IV waste-LLW that is not suitable for disposal on ORR and therefore requires either treatment to reduce the level of contamination to a level consistent with other classifications or shipment to an offsite disposal facility.

In addition, an environmental impact statement is being prepared to evaluate proposed sites for future solid waste disposal facilities. 


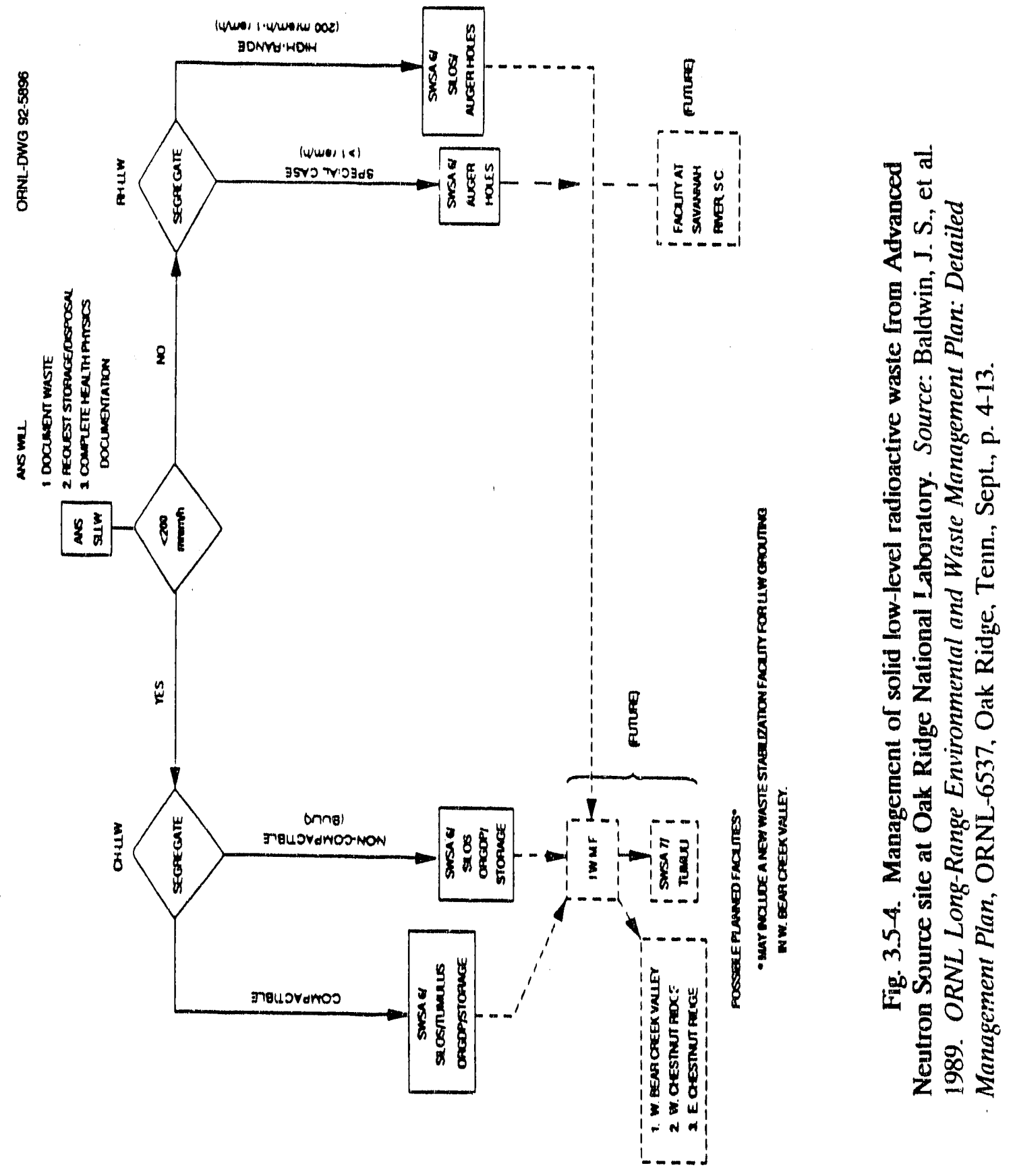




\section{Current ORNL CH-LLW management}

Principal sources of CH-LLW at ORNL include ion exchange resins and filters from research reactors, discarded clothing and maintenance items, and scrap wastes from irradiated experiments, as well as discarded reactor parts.

Currently, CH-LLW at ORNL is transported via a lead.lined pan to a below-grade concrete silo disposal unit at SWSA-6. Compactible wastes, such as paper, plastic, rubber, glass, light-gauge metals, and filters with a surface dose rate of less than $0.5 \mathrm{mSv} / \mathrm{h}$ (50 mrem/h), are first taken to a box compactor located in Building 7531 in SWSA 5. After compaction into $4 \times 4 \times 6 \mathrm{ft}$ metal boxes, the wastes are stored either at SWSA 6 or at the K-25 Site. Compactible wastes that cannot be processed in Building 7531 but can be packaged into 55-gal drums also are disposed of in below-grade concrete silos at SWSA 6.

Since 1986, ORNL has disposed of CH.LLW through greater confinement disposal (GCD) techniques. Two of these techniques-below-ground disposal in concrete silos and above-ground tumuli in SWSA 6-have been developed for compactible and noncompactible CH-LLW disposal (Baldwin et al. 1989a, p. 4-9).

A tumulus demonstration facility built at SWSA 6 in 1987 and designed for class II waste has a disposal capacity of $800 \mathrm{~m}^{3}\left(28,000 \mathrm{ft}^{3}\right)$ (Baldwin et al. 1989a, p. 4-12). This facility will be filled nearly to capacity by the time ANS enters operation and will not be available to dispose of ANS CH-LLW.

Approximately $1,400-2,300 \mathrm{~m}^{3}\left(50,000-80,000 \mathrm{ft}^{3}\right)$ of solid CH-LLW is routinely handled at ORNL annually (Baldwin et al. 1989a, p. 49). Most has a surface dose rate of less than $0.5 \mathrm{mSv} / \mathrm{h}(50 \mathrm{mrem} / \mathrm{h})$.

\section{ANS CH-LLW wastes and their management}

Principal sources of CH-LLW at ANS include (1) dewatered ion exchange resins and plugged filter cartridges from the cleanup cells of the light water system, heavy water system, and LLLW decontamination system drying operations; (2) discarded clothing, decontaminated materials, and maintenance and glovebox items; (3) tritium-contaminated wastewater and spent electrolyzer fluids solidified and prepared for disposal; (4) tritiated oils solidified for disposal; and (5) wastes from HEPA filters and maintenance craft activities (System Design Description 1991, p. 2-22).

Solid wastes resulting from nonreusable clothing and from the residue of demineralization and filtration activities in the cleanup of tritium will be collected, labeled, and delivered to a centralized monitoring and sorting area. Some of this waste will be dewatered with the liquids going to the ORNL Process Waste Treatment System (see Sect. 3.5.4). Glove box area wastes will be received in packages and sorted by ANS, according to $\mathrm{CH} / \mathrm{RH}$ criteria, for disposal.

\section{Planned ORNL CH-LLW management}

New LLW disposal facilities, as depicted in Fig 3.5-4, are expected to replace the GCD below-grade operations at SWSA 6, scheduled for phaseout by the end of 1993 (Baldwin et al. 1989a, p. 48; Butterworth 1988, pp. 36-38). These include an Interim Waste Management Facility (IWMF) located at the current SWSA 6 site, which is nearly ready to accept waste, and a series of tumuli at SWSA 7 for the permanent disposai of Class II wastes, if approved by DOE and if the DOE Environmental Impact Statement for 
waste management recommends their use. The IWMF is expected to be filled to capacity by 1996; thus, it will not be available for ANS waste unless expanded.

Projected plans for expanding on-site disposal capacity of SLLW at ORNL include construction at one of several Oak Ridge Reservation sites. Likely sites include SWSA-6 (for an expanded IWMF) and SWSA-7-a possible site for a new Class II solid waste tumulus facility. Other sites under consideration include West Chestnut Ridge and East Chestnut Ridge for Class I wastes, with the former being the preferred site. However, these latter two sites would likely not be available if Complex 21 is built on the Oak Ridge Reservation. Siting and scheduling new waste facilities is complicated by the needs of new waste programs. Capacities and status of these sites are depicted in Table 3.5-6. A site in West Bear Creek Valley that had been under consideration for Class II wastes has been taken out of consideration (Baldwin et al. 1989a, p. 66; Rivera et al. 1989, p. 9).

A new Class I disposal facility is not expected to be on line until 2000. A new Class II disposal site was expected to be available by the end of 1996 but will likely be delayed.

\section{Current ORNL RH-LLW managemeet}

Current RH-LLW at ORNL includes reactor and hot cell debris, such as various equipment components contaminated with radioactive materials or activation products and sludges. RH-LLW must be transported in special shielded containers (Baldwin et al. 1989a, p. 51). RH-LLW is composed of wastes that have an especially high radionuclide concentration and thus high activity (e.g., activated ${ }^{154} \mathrm{Eu}$ and ${ }^{155} \mathrm{Eu},{ }^{237} \mathrm{Th}, \mathrm{Np},{ }^{241} \mathrm{Am}$, radioactive $B k$ and $C$, and ${ }^{\text {(k) }} \mathrm{TC}$ ).

Since 1986, RH-LLW at ORNL has been transported via 0.5-m-diam. (20-in.-diam.) lead-shielded casks to either a below-grade silo or below-grade auger holes at SWSA 6. The waste is handled by remote means throughout the operation (Baldwin et al. 1989a, p. 51). The preferred method for R.H-LLW disposal is through auger holes and silos located at SWSA 6.

\section{ANS RH-LLW wastes and their managemerit}

RH-LLW from ANS will be composed of (1) scraps from irradiated experiments and from discarded control and safety rods, (2) analytical chemistry wastes, and (3) heat exchanger replacement wastes. When removed from ANS, these wastes will be packaged in special shielded containers for disposal. Much of these wastes will be generated during fuel changeouts that will occur 17 times annually or intermittently in the case of heat exchanger changeouts.

\section{Planned ORNL RH-LLW management}

Solid RH-LLW from ORNL with high radionuclide concentrations and a very long half-life (Class III/IV waste) is expected to be disposed of at an off-site facility, possibly at SRS in South Carolina. In the interim, a retrievable Class III/IV storage facility has been proposed at ORNL to provide interim storage capacity for approximately 10 years until off-site disposal becomes practicable (Baldwin et al. 1989a, p. 4-12; Office of Waste Management 1991, p. 61). This facility would be located in SWSA 7 and would initially consist of 32 wells. Design of this facility is on hold pending NEPA documentation. 
Table 3.5-6. Preliminary on-site disposal capacity scenarios for Oak Ridge National Laboratory (ORNL) wastes

\begin{tabular}{|c|c|c|c|c|}
\hline Site & Status & $\begin{array}{l}\text { Projected disposal } \\
\text { capacity }\left[\mathrm{m}^{3}\left(\mathrm{ft}^{3}\right)\right]\end{array}$ & $\begin{array}{l}\text { Disposal } \\
\text { technology }\end{array}$ & $\begin{array}{c}\text { Waste } \\
\text { stream/category }\end{array}$ \\
\hline $\begin{array}{l}\text { SWSA-6 } \\
\text { (ORNL) }\end{array}$ & Current & $\begin{array}{l}51,200(551,005) \\
6.30(6,742)\end{array}$ & $\begin{array}{l}\text { Below-grade silo } \\
\text { Below-grade wella } \\
\text { Above-grade } \\
\text { lumulus }\end{array}$ & $\bar{z}$ \\
\hline $\begin{array}{l}\text { SWSA-7 } \\
\text { (ORNL) }\end{array}$ & Planned & $\begin{array}{l}6,400(68,749) \\
400(4,312) \\
230,000(2,4.35,479)\end{array}$ & $\begin{array}{l}\text { Below-grade silo } \\
\text { Below-grade well } \\
\text { Below-grade } \\
\text { lumulus }\end{array}$ & Class I \\
\hline $\begin{array}{l}\text { West } \\
\text { Chestnut } \\
\text { Ridge }^{b}\end{array}$ & Planned & $\begin{array}{l}483,000)(5,195,175) \\
200,000)(2,149,362) \\
175,000(1,880,334)\end{array}$ & $\begin{array}{l}\text { Below-grade trench } \\
\text { (Area A) } \\
\text { Below-grade trench } \\
\text { (Area B) } \\
\text { Below-grade trench } \\
\text { (Area } 5 \text { ) }\end{array}$ & Class I \\
\hline $\begin{array}{l}\text { East } \\
\text { Chestnut } \\
\text { Ridge }^{c}\end{array}$ & Planned & $1,650,000(17,767,296)$ & $\begin{array}{l}\text { Below-grade hill-cut } \\
\text { trench }\end{array}$ & $\begin{array}{l}\text { Below regulatory } \\
\text { concern/sanitary/ } \\
\text { industrial } \\
\text { Class I }\end{array}$ \\
\hline
\end{tabular}

aProbably not viable under Department of Energy Order $5 \$ 20.2 \mathrm{~A}$.

This site has subsequently been downsized.

This site may be taken out of consideration.

Source: Lockwood Greene Engineers, Inc. 1987. Oak Ridgi Reservation Low-Level Waste Storage and Disposal Capacity Evaluation, Oak Ridge, Tenn., reproduced in Rivera, A. L., et al. March 1989. LLWDDD Program Waste Management Data System Status Report for the Period October-December 1988, ORNL/CF-89/14, Oak Ridge National Laboratory, Oak Ridge, Tenn.

\subsubsection{Overview of Radioactive Gaseous Waste Management}

Gaseous radioactive wastes are composed of vapors from radioactive liquids and other emissions from radioactive environments at ORNL.

\subsubsection{Current ORNL Radioactive Gaseous Waste Management}

The principal radioactive gaseous wastes at ORNL are (1) process off-gas streams, characterized as low-volume, high activity gas streams from pressure vessels or other systems where release of radioactivity is routine and of relatively high concentration; (2) cell ventilation (CV) streams, which are high-volume, low-activity gas streams from enclosed areas such as hot cells; and (3) laboratory hoods and individual vents. The management of radioactive and nonradioactive gaseous emissions at ORNL is depicted in Fig. 3.5-5. 


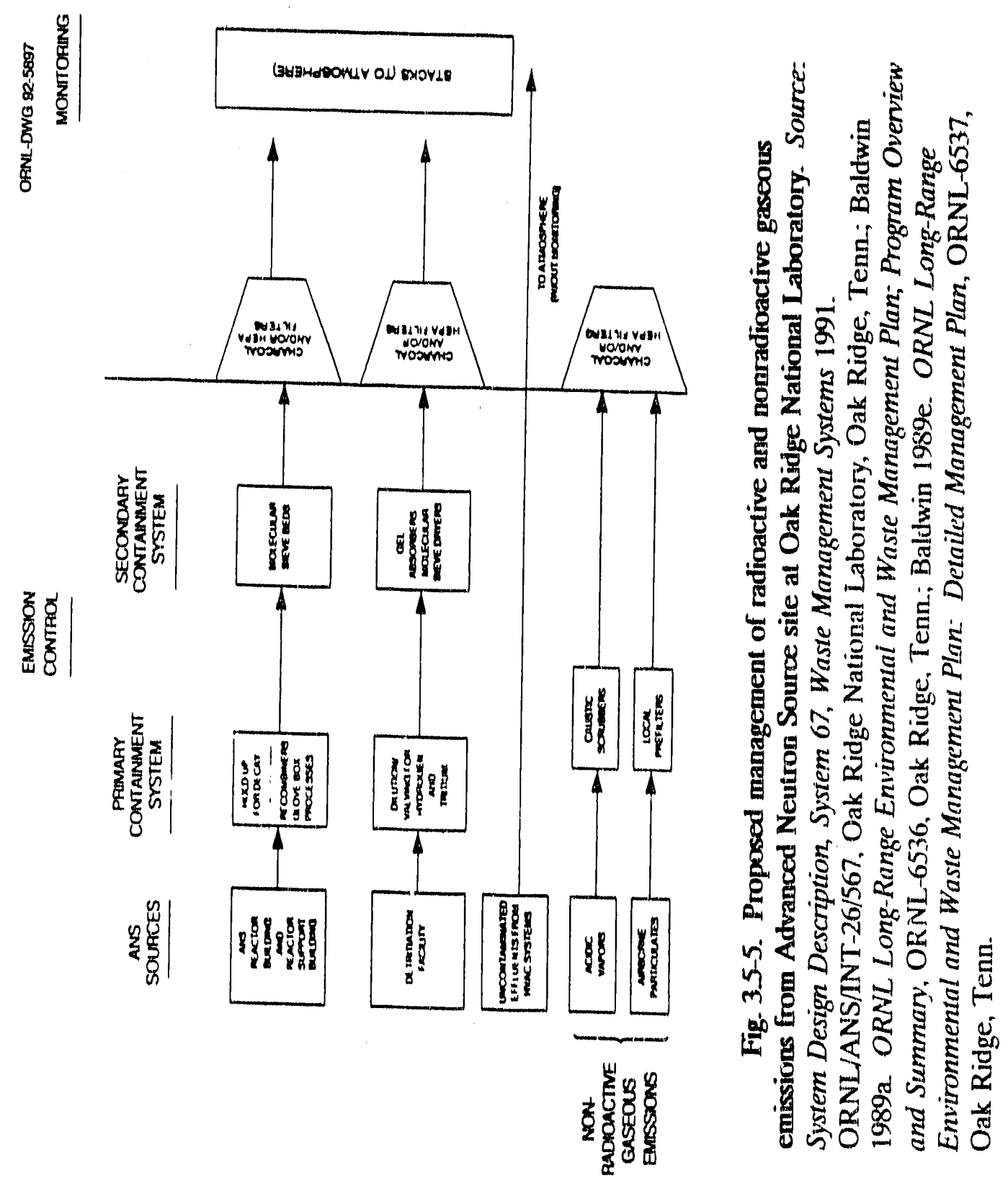


At ORNL, gaseous radiological wastes are currently discharged through seven stacks located at various points around the laboratory. These stacks serve isotope areas, HFIR and REDC, and other R\&D facilities (Baldwin et al, 1989b, p. 2-3-2.4). Each is equipped with a variety of caustic scrubbers and HEPA and charcoal filters and several are equipped with compliance monitors for tritium. ORNL also has an extensive atmospheric emissions program which includes an Otf-Gas and Cell Ventilation System providing negative pressure in laboratory structures and processes.

\subsubsection{ANS Gaseous Radioactive Wastes and Their Management}

ANS would have a gas collection system. The principal sources of gaseous radiological wastes from ANS would include deaerator or let-down tank discharge through the stack, hydrogen discharges from the region over the reactor pool, and cryogenic liquid releases or gas leaks in the HWUDB (which are expected to be vented to the environment) (see Sect. 3.5.5.1). Other sources include laboratory hoods and hot cells; the latter will be equipped with their own cleanup systerns. The principal gaseous radioactive waste management systems for ANS are depicted in Table 3.5.7.

All gaseous radiological wastes from ANS will be collected in one of three systems and cross-connected to an emergency clean-up system (System Design Description 1991, pp. 2-6-2-8). Atmospheric releases will be emitted from an ANS stack on the reactor building, adjacent experimental and service buildings, and from the HWUDB.

Radiological gaseous wastes will be stored in primary containment systems for short periods, treated and processed in secondary containment systems with molecular sieve beds and gel absorbers, and filtered through charcoal and/or HEPA filters before discharge to the environment. Secondary containment will also serve to collect leaks from primary containment. If specific siluation warrant, process ventilation systems with hold-up delays (activated charcoal beds) will permil short.lived isotopes to decay (System Design Description 1991, p. 1-2). Stack discharges will he monitored.

\subsubsection{Planned ORNL Radioactive Gaseous Waste Management}

While incremental upgrades to the laboratory-wide gaseous radiological waste management system will occur, these would not directly affect ANS. ANS would be equipped with its own gaseous radiological waste system (see Sect. 3.5.6.2). ANS gaseous waste emissions would eventually be affected by plans that call for further ALARA studies to find ways to reduce gaseous emissions and by more stringent laboratory-wide evaluation of regulatory compliance (Baldwin et al. 1989a, p. 110).

\subsubsection{Tritium}

Tritium is the heaviest isotope of the element hydrogen and a beta emitter (Spratt et al. 1985, p. 43). Because heavy water and liquid deuterium are used in the primary coolant and reflector and the cold sources in the ANS system, considerable quantities of tritium will be produced in liquid and gaseous form in these components. (System Design Description 1991, p. 1-10).

\subsubsection{Current Tritium Management at ORNL}

Because there is no major single tritium source al ORNL, there is currently no laboratory-wide tritium management system. In the past, ORNL, isotope facilities 
Table 3.5-7. Principal gaseous waste management systems for the proposed Advanced Neutron Source and their leatures

\begin{tabular}{|c|c|}
\hline System & Equipment \\
\hline \multicolumn{2}{|c|}{ Reactor building and reactor support building } \\
\hline $\begin{array}{l}\text { Primary containment } \\
\text { system }\end{array}$ & $\begin{array}{l}\text { Neutralizing or dilution } \\
\text { equiprnent, hold-up } \\
\text { vessels, and recombiners } \\
\text { (LLLW, tritium) }\end{array}$ \\
\hline $\begin{array}{l}\text { Secondary containment } \\
\text { system }\end{array}$ & $\begin{array}{l}\text { Molecular sieve beds, } \\
\text { regeneration systems for } \\
\text { beds (gaseous } \\
\text { radiological wastes) }\end{array}$ \\
\hline $\begin{array}{l}\text { Emergency gas treatment } \\
\text { system }\end{array}$ & $\begin{array}{l}\text { Dilution and valving } \\
\text { equipment (llammability } \\
\text { detection of hydrogen } \\
\text { gas, tritium detection and } \\
\text { isolation) }\end{array}$ \\
\hline \multicolumn{2}{|c|}{ Heavy water upgrading and detritiation building } \\
\hline Primary containment system & $\begin{array}{l}\text { Dilution equipment to } \\
\text { prevent explosions } \\
\text { (hydrogen gas) }\end{array}$ \\
\hline Secondary containment system & $\begin{array}{l}\text { Dilution and valving } \\
\text { equipment for } \\
\text { flammability detection, } \\
\text { tritium detection and } \\
\text { isolation (hydrogen gas } \\
\text { and tritium) }\end{array}$ \\
\hline $\begin{array}{l}\text { Emergency gas treatment } \\
\text { system }\end{array}$ & $\begin{array}{l}\text { Dilution and valving } \\
\text { equipment for } \\
\text { flammability detection, } \\
\text { tritium detection and } \\
\text { isolation (hydrogen gas } \\
\text { and tritium) }\end{array}$ \\
\hline
\end{tabular}

Source: System Design Description, System 67, Wosile Manageinent Systeins 1991. ORNL/ANS/INT-26/S67, draft reporl, Oak Ridge Nallonal Laboratory, Oak Ridge, Tenn, February 27. 
processed tritium for various commercial uses, and a Tritium Target Fabrication Facility, no longer in operation, continues to hold tritium for decay and directly vent.it to the atmosphere by way of stack 7025 (Olfice of Waste Management 1991: 68, 97). Also, between 2500 and $2900 \mathrm{Cl}\left(92.5 \times 10^{12}\right.$ and $\left.107.3 \times 10^{12} \mathrm{~Bq}\right)$ of tritlum are annually discharged into Melion Hill Lake from SWSA-5 remediation activities (Personal Communication with John Trabalka, Environmental Science Division, ORNL, to D. L. Feldman, January 17, 1991). Emissions comply with current standards for tritium dose commitments. The small amounts of tritium generated at research tacilities at ORNL are held for decay and vented to the atmosphere. Emission levels comply with current ambient standards for tritium concentrations.

\subsubsection{ANS Tritium Sources and Their Management}

The principal source of tritium release to the environment at ANS would be the Heavy Water upgrading and Detritiation Facility (HWUDF or detritiation building) (System Design Description 1991, p. 1-10). To lessen tritium concentrations and therefore reduce worker exposure, this lacility functions 10 remove the tritium produced in the heavy water in the ANS reaclor. The HWUDF includes a receiving, storage and transfer system to aid in heavy water accountability. The HWUDF will collect and concentrate tritium in two specific subsystems: 1) a feed preparation, upgrade and detritiation, and recovery system and 2) a tritium removal and packaging system. Operation of the detritiation facility would result in the generation of routine solid wastes including spent filters, ion exchange resin, activated charcoal, gloves, shoe covers, and PVC airline suits contaminated with tritium. In addition, some tritluin-contaminated waste that could potentially be released within the reactor facility would be contained within the primary coolant cleanup system.

The feed preparation, upgrade and detritiation, and recovery systems function to remove tritium and protium from reactor-grade heavy water and downgraded heavy water, and to remove tritium from limited quantities of light water wastes. The tritium removal and packaging system would fix tritium or uranium metal encapsulated in stainless steel. This provides a container for on-site storage and if required, off'-site shipment. Routine solid wastes from the operation of this facillity-including paper, plastic, neoprene rubber, and cotton fiber-would be tritium contaminated and would require special packaging prior to their removal.

Detritiation and upgrade would be performed by the combined electrolysis and catalytic exchange process, followed by cryogenic distillation. Tritium would be in many forms in the HWUDF, including the elemental, oxide and organic chemical forms, and physical forms such as solidified aqueous wastes, soliditied oily wastes that may be absorbed by vermiculite, and bound water in spent resins, or gaseous wastes vented to the environment. The detritiation tacillity would be designed 10 monitor for tritium and to separate it where possible. Hold-ups may be provided in sumps, in heavy water cleanup cells where headers and tankers may be used to collect LL.LW, and in high integrity containers. Sumps and waste headers would then direct the LLLW to an ANS location for ion exchange decontamination followed by transfer to an appropriate waste treatment facility-the PWTP or Nonradiological Waste Treatment Plant (NRWTP). Oily tritiated wastes from ANS may be sent to the K-25 Toxic Substances Control Act (TSCA) incinerator for disposal. ANS designers have anticipated the contingency.

Small amounts of tritiated water may gather on external surfaces and parking lots and may be washed into surlace waters. Consequently. ANS would be equipped with a rainwater collection system that would be segregated from other rainwater basins at 
ORNL and specially monitored (System Design Description 1991, p. 1-6), Contaminated water from this basin would require dilution to reduce the concentration below acceptable limits.

\subsubsection{Planned Tritium Management at ORNL}

Plans for tritium management at ORNL will be based on ANS plans as discussed in previous sections. To predict impacts trom tritium management at future ANS operations, information gained trom the experience of other DOE and non-DOE high-volume, tritlum-producing reactors is being incorporated into the ANS design.

\subsubsection{Mixed Waste}

Mixed waste contains both radioactive and chemically hazardous components as defined under the Resource Conservation and Recovery Act (RCRA) and the Atomic Energy Act, as amended.

\subsubsection{Current Liquid Mixed Waste Management at ORNL}

Current liquid mixed wastes generated at ORNL include cleaning fluids and oils from systems in radioactive environments, and some scintillation wastes containing radioactive contaminants. In the past, the latter have been treated commercially through off-site incineration (Baldwin et al, 1989, p. 4-20), but off-site treatment of mixed wastes has been terminated. No other off-site treatment of mixed wastes is currently performed. The management of liquid mixed waste at ORNL is depicted in Fig. 3.5-6.

ORNL's liquid mixed wastes are stored on-site. Bulk storage of mixed waste oils is provided by two tanks in Buildings 7075 and $7830 \mathrm{~A}$, which have a total capacity of $35 \mathrm{~m}^{3}$ $(9,200 \mathrm{gal})$ (Baldwin et al. $1989 \mathrm{~b}, \mathrm{p}, 147)$. Near-term use of storage space at the K-25 Site is being explored until these wastes are disposed of by the Oak Ridge Mixed Waste Incinerator (ORMWl) at the K-25 site.

\subsubsection{Current Solid Mixed Waste Management at ORNL}

Although most mixed wastes are in liquid form, the Environmental Protection Agency, which is partly responsible for regulating mixed waste, defines "containerized" liquid mixed waste as a solid (Baldwin et al. 1989a, p. 147). The primary sources of mixed solid waste at ORNL are liquid wastes placed into drums or other containers, including $R \& D$ wastes such as polychlorinated biphenyls (PCBs), corrosives, poisons, and other flammables that are containerized before removal trom a facility. After dewatering, ion exchange resins trom nuclear reactors are also considered solid mixed wastes. Approximately $10 \%$ of all CH-TRU waste drums at ORNL contain mixed waste (Baldwin et al. 1989 b, p. 11). The management of solid mixed waste at ORNL is depicted in Fig, 3.5-6.

ORNL generates about 10055 -gal drums of solid mixed waste annually (Baldwin et al. 1989a, p. 151). In FY 1991, this volume equaled approximately $16,790 \mathrm{~kg}(45,000 \mathrm{lb}$.) This waste is currently stored in Building 7654, Building $7507 \mathrm{~W}$, and Building 7823 . Building 7654 is filled to capacity. Building $7507 \mathrm{~W}$, which has a capacity of 40055 -gal drums or approximately $84 \mathrm{~m}^{3}(22,000$ gal), is nearing capacity. Building 7823, in SWSA-5, has a capacity for 110055 -gal drums or approximately $230 \mathrm{~m}^{3}$ $(60,500 \mathrm{gal})$. However, this facility also stores nonmixed process wastes and oils. 


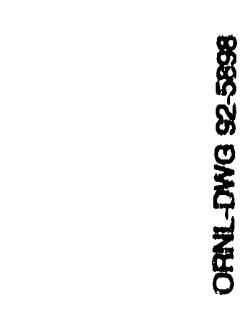

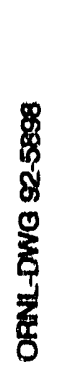

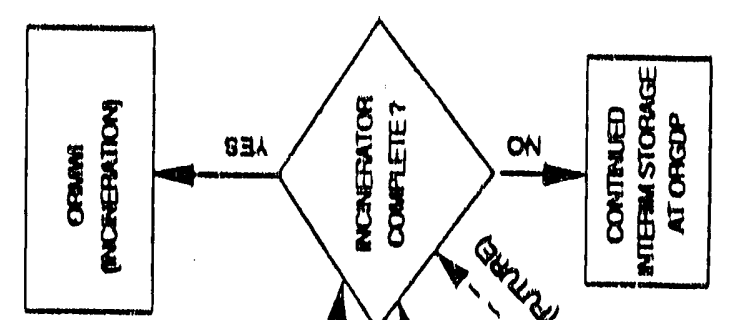

8

$\bullet$

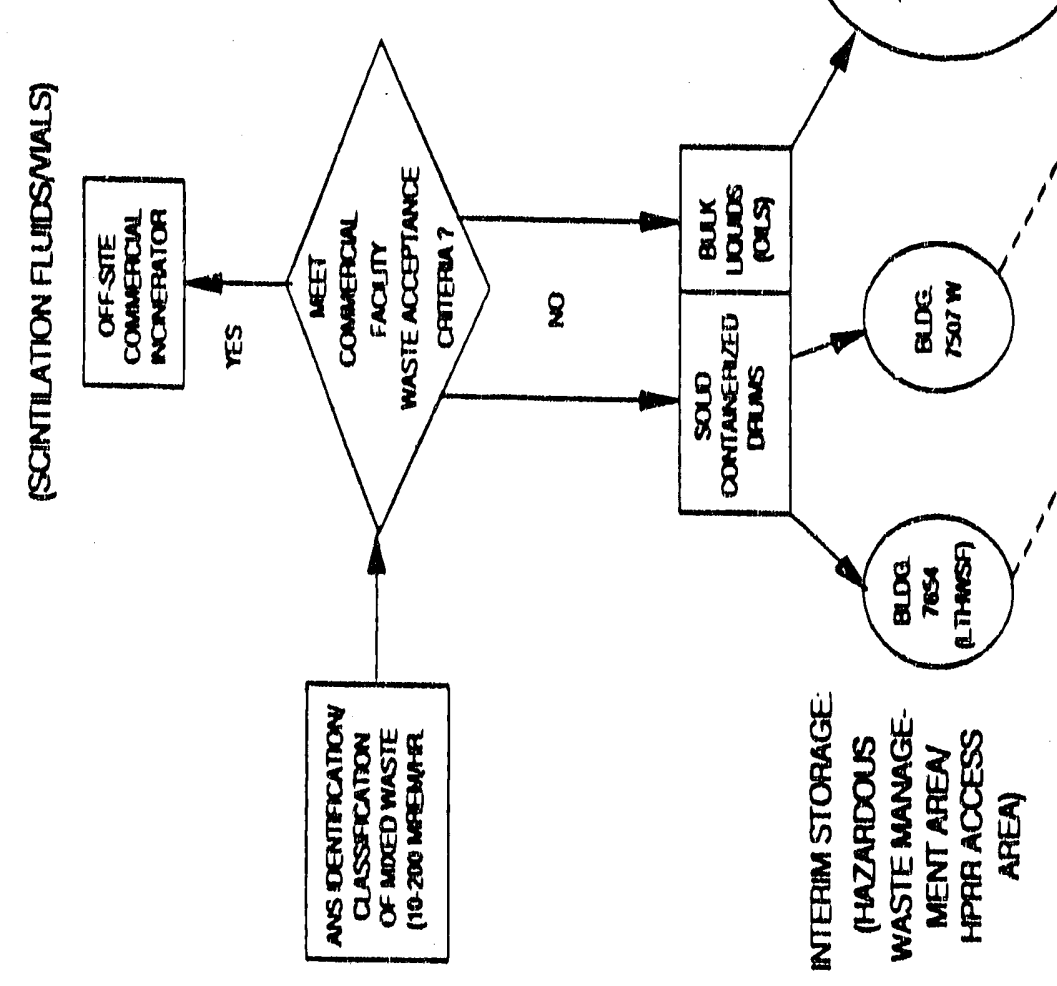




\subsubsection{ANS Liquid and Solid Mixed Wastes}

The primary source of liquid mixed wastes at ANS would be contaminated oils from the reactor area and detritiation facility. These are expected to be drummed (after immobilization with vermiculite) and thus treated as solid mixed wastes. They will eventually be incinerated.

\subsubsection{Planned Liquid and Solid Mixed Waste Management at ORNL}

Because bulk storage space for mixed waste oils is nearing exhaustion (Baldwin et al. 1989a, p. 151), two new mixed waste storage facilities of unknown storage capacity, are in the planning stage awaiting approval of NEPA documentation (Baldwin et al. 1989 a, p. 152). Storage space at the K-25 Site may have to be used in the interim until these facilities are completed. The Central Waste Management Division is also evaluating the need for a mixed waste disposal facility on the Oak Ridge Reservation. In addition, laboratory-wide mixed waste management plans emphasize growing reliance on treatment technologies for mixed waste management as opposed to storage (Baldwin et al. 1989d, p. 4.20). It is expected that all mixed waste oils will be disposed of in the ORMWI at the K.25 Site.

DOE is currently working with EPA to develop appropriate regulatory requirements for liquid mixed waste treatment at all of its facilities, including $O R N L$ (DOE 1989a, p. 177). Disposal of waste which is not separable into its radioactive and hazardous constituents shall comply with both hazardous and radioactive waste requirements (DOE 1989a, p. 177).

\subsection{CHEMICAL AND BIOCIDE WASTES}

Most ANS liquid discharges would be treated at existing facilities before release. For example, nonradiological process wastewaters will be treated by the ORNL PWTP before discharge to White Oak Creek (Sect. 3.7.5). ANS laundry and sanitary wastewaters will be treated by the ORNL. Sanitary Waste Treatment Facility (Sect. 3.7.2). The only nonradiological liquid eftluents that are expected to be discharged to surtace waters without extensive treatment are stormwater runcuff from the ANS site and cooling tower blowdown.

Stormwater runoff from the ANS site could contain suspended sediments, small quantities of oils and greases from parking lots, and contaminants washed from building roofs and other structures. Present plans call for the collection of stormwater runoff in two detention basins: one on the north side of the site with a discharge to Friendship Creek (a tributary of Bearden Creek and the Clinch River) and another to collect runoff from the south side of the plant before discharge to upper Melton Branch. Collection of runoff in these basins would allow suspended sediments to settle out and would allow monitoring for radiological and other contaminants. Collected runoff would be monitored before release into the creeks and would be contained and treated if necessary.

Treatment may require that runotl' be translerred to the PWTP.

Cooling tower blowdown would conlain the same water quality constituents as the influent potable water, except that these constituents would be concentrated approximately 3.5 times by the recycling of cooling water. Blowdown would also contain some particulate matter as a result of capturing airborne dust. The potable/process water that would be used for cooling tower makeup contains chlorine at a typical concentration 
of about $1.7 \mathrm{mg} / \mathrm{L}$. The ORNL National Pollutant Discharge Elimination System (NPDES) permit allows concentrations of up to $0.2 \mathrm{mg} / \mathrm{L}$ of total residual chlorine in the discharge of cooling tower blowdown. However, because chlorine is a major toxicant in discharges to ORNL streams, the ORNL Environmental and Compliance Section has called for the abatement of existing discharges of highly chlorinated waters to surface streams (Rohwer 1989, p. 1-2). Because the installation of additional new chiorinatedwater discharge sources is not consistent with this plan (Rohwer 1989, p. 1-2), it is expected that the ANS would be required to dechlorinate its cooling tower blowdown before discharge.

Cooling tower blowdown also contains chemicals that have been added to control bacterial slimes and scaling. Two chemical additives are used at existing cooling towers at ORNL: a $15 \%$ sodium hypochlorite solution as a biocide and Endcor 4529 to control scaling (G. Irby, JRNL Plant and Equipment Division, personal communication to G. Cada, October 9, 1991). Endcor 4529 is a corrosive liquid composed of approximately $50 \%$ sulfuric acid and $3 \%$ phosphoric acid. Both additives are used as needed; amount and frequency of use depend on such factors as time of the year and the number of times cooling water is cycled through the tower before blowdown. Both total residual chlorine concentrations and $\mathrm{pH}$ are monitored to ensure that releases of these chemicals are within NPDES permit limits.

\subsection{ANS SANITARY AND OTHER WASTE SYSTEMS}

This section describes the management of sanitary, conventional, and hazardous wastes at ORNL and provides a baseline for predicting how laboratory-wide sanitary and other waste management systems would be affected by the operation of the ANS. It also describes ANS sanitary, conventional, and hazardous waste management systems and their interface with ORNL waste systems.

Principal wastes of concern include routine solid, liquid, and gaseous wastes-disposed of as trash, refuse, sewage, or atmospheric emissions at ANS-as well as hazardous wastes, including solvents, oils, and acids.

\subsubsection{Current ORNL Sanitary Waste Management}

At ORNL, nonradiologically contaminated wastewater is collected at each facility and directed to the ORNL Sanitary Waste Treatment Plant (SWTP) (Building 2521), where it is treated and discharged to the White Oak Creek systen. The sanitary waste treatment system accepts biodegradable sanitary wastes, laundry wastewater, ethylene glycol solutions, and nonhazardous biodegradable waste. The SWTP has a treatment capacity of $1142 \mathrm{~m}^{3} / \mathrm{d}(300,000 \mathrm{gal} / \mathrm{d})$ or $417,000 \mathrm{~m}^{3}(109,000,000 \mathrm{gal})$ annually.

Figure 3.7-1 depicts the management of sanitary wastes at ORNL.

\subsubsection{ANS Sanitary Wastes}

At ANS, sanitary sewage wastes would be collected and treated separately from all other wastes. Prior to discharge, they would be held up for radiological monitoring. Under new waste acceptance criteria at ORNL, waste containing trace radiological contamination [less than five times the Derived Concentration Guide (DCG) value for radionuclides] can be treated in the ORNL SWTP, Building 2521. Waste containing five 


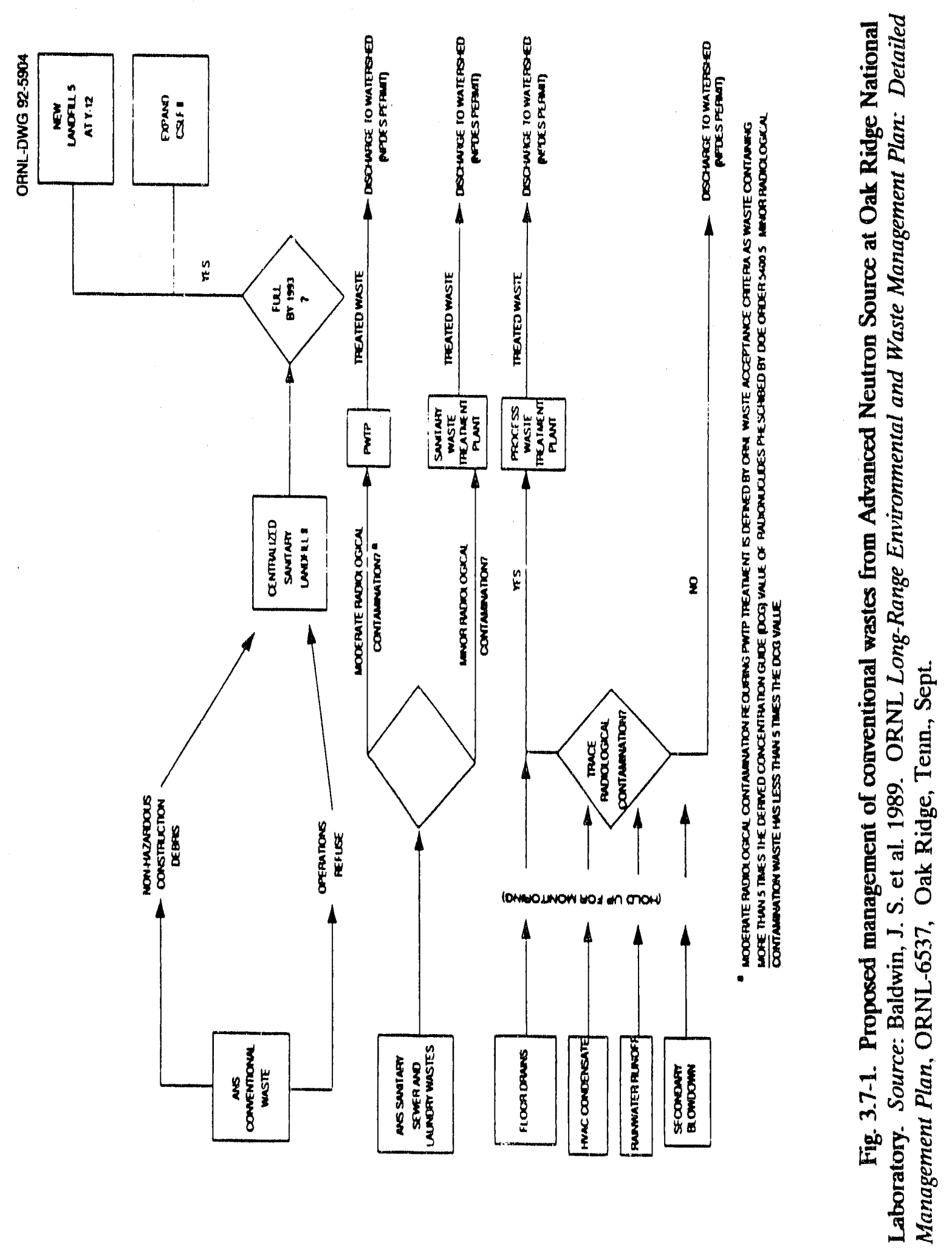


times or greater of the DCG value would be directed to the PWTP (Building 3544) for treatment before discharge to the White Oak Creek watershed.

\subsubsection{Future ORNL Sanitary Waste Management}

It is expected that the ORNL SWTP would continue to receive sanitary and laundry waste streams. Some of these streams are expected to be recycled. It would be the responsibility of future generators, including ANS, to ensure that laundry and sanitary wastewater radionuclide concentrations, averaged monthly, are less than five times the DCG value before directing these wastes to the SWTP (Parrott 1991, p. 15).

\subsubsection{Current ORNL Conventional Liquid Waste (Effluents) Management}

At ORNL, conventional liquid wastes, such as stormwater runoff, as well as minor liquid waste streams, such as air conditioner condensate, are discharged to White Oak Creek via a storm sewer system. Effluents that may be accepted by the ORNL storm sewer system include rainwater runoff from parking lots, grassy areas, and roof drains. Figure 3.7-1 depicts the management of conventional liquid wastes from ANS at ORNL.

\subsubsection{ANS Conventional Liquid Waste Management}

At ANS, stormwater runoff from a $312,000-\mathrm{m}^{2}$ (77-acre) area, including the reactor building, support facility, guide hall, and laboratory buildings, as well as sprinkler discharges and heating, ventilating, and air conditioning cooling condensate, are likely to display trace quantities of radioactive contamination above background-including tritium. Effluents will be held up and monitored for deuterium oxide and tritium, with separation of tritium whenever possible.

Treatment of the remaining decontaminated effluents will take place at the ORNL PWTP before discharge to the White Oak Creek watershed under a NPDES permit.

\subsubsection{Planned ORNL Conventional Liquid Waste (Effluents) Management}

Conventional liquid wastes with small amounts of radioactive contamination would continue to be accepted by the storm sewer discharge system. All outfalls, including those from ANS, would have to be separately accounted for under the ORNL NPDES permit.

\subsubsection{Current ORNL Conventional Solid Waste Management}

ORNL solid conventional wastes are regulated by the state of Tennessee via the Tennessee Solid Waste Disposal Act. The ORNL conventional solid waste management system is depicted in Fig. 3.7-1.

Solid conventional waste generated at ORNL amounts to nearly $46 \mathrm{~m}^{3}\left(1600 \mathrm{ft}^{3}\right)$ per regular workday, or $12,200 \mathrm{~m}^{3}\left(430,000 \mathrm{ft}^{3}\right)$ annually. The majority of this waste is directed to the Centralized Sanitary Landfill II (CSLF II) located on Chestnut Ridge, 6 miles east of ORNL. The daily general refuse volume at ORNL is about $28 \mathrm{~m}^{3} / \mathrm{d}$ $\left(985 \mathrm{ft}^{3} / \mathrm{d}\right.$ ), while bulky material (e.g., cardboard boxes) adds approximately $18 \mathrm{~m}^{3} / \mathrm{d}$ $\left(630 \mathrm{ft}^{3} / \mathrm{d}\right)$ (Baldwin et al. 1989b, p. 4-27). The current CSLF II is nearing capacity and would not be available for disposal of ANS general refuse. 


\subsubsection{ANS Conventional Solid Wastes}

ANS would produce sewage sludge, nonhazardous construction debris, water treatment wastes (sludges and high saline streams whose residues are disposed of as solids), and general refuse collected in trash cans and dumpsters. Sewage sludge residues would be packaged for disposal while general refuse would be loaded into two dumpsters with a capacity of approximately $70 \mathrm{~m}^{3}\left(250 \mathrm{ft}^{3}\right)$ each.

\subsubsection{Planned ORNL Conventional Solid Waste Management}

The CSLF II located on Chestnut Ridge is expected to reach capacity in FY 1992. After this date, the current facility will be expanded or replaced by a new facility, Landfill 5, which would be located at the Y-12 Plant (Fig. 3.5-7). No final decision on either option has been made.

\subsubsection{Current Conventional Gaseous Waste Management at ORNL}

Sources of gaseous conventional wastes at ORNL include paint spray booths, fuel storage tanks, oil burners, ovens, and some shop operations. Control of these nonradioactive pollutants at ORNL is conducted in accordance with federal and Tennessee regulations. Over 100 separate permits have been issued for point source gaseous emissions at ORNL.

\subsubsection{ANS Conventional Gaseous Wastes}

ANS gaseous emissions that would require air quality permits could include acidic vapors from laboratory work, airborne particulates, and volatile organic compounds. These gaseous wastes would be comparable to those from HFIR. There may also be airborne emissions that normally do not require special treatment, nor a special permit, before atmospheric discharge. All gaseous emissions with potential radiological contamination would be filtered through charcoal and HEPA filters before discharge, as depicted in Fig. 3.5-5. They would be filtered through the ANS stack system (see Sect. 3.5.6.2.). ANS would secure a discharge permit from the state of Tennessee for regulated conventional gaseous waste discharges.

\subsubsection{Planned Conventional Gaseous Waste Management at ORNL}

While incremental upgrades to the laboratory-wide conventional gaseous waste management systern will occur, these would not affect ANS. ANS would be equipped with its own conventional gaseous waste management system (see Sect. 3.5.6.2).

\subsubsection{Current Hazardous Liquid Waste Management at ORNL}

Hazardous liquid wastes encompass a wide range of substances that are toxic, ignitable, corrosive, reactive, or explosive. There are over 400 substances that are classified by the EPA, under RCRA, as hazardous (40 CFR 261.24, pt. D).

At ORNL, hazardous liquid waste associated with construction would include waste adhesives, solvents, oils, cleaning fluids, solvents, and coatings. In facility operation, hazardous liquids of concern include solvents, oils, and acids from laboratory operations.

Such materials are managed in two ways. Those which can be packaged are disposed of in special RCRA-approved facilities, as depicted in Fig. 3.7-2. Those hazardous liquid wastes 
emanating from nonradiological process wastewaters are diverted to a special Nonradiological Wastewater Treatment Plant (NRWTP). NRWTP sources include drainage from laboratory-operations, once-through cooling water, and other aqueous contaminated streams from laboratory and reactor operations containing heavy metals (measured in parts per million or less) and various organics (at parts per billion or less) (Parrott et al. 1991).

\subsubsection{ANS Hazardous Liquid Wastes}

The principal hazardous liquid wastes from ANS would include (1) lubricant oil from fan gearboxes, diesel generators, pumps, compressors, and cranes; as well as insulating fluids from transformers (non-PCB based), and hydraulic fluids from elevators; (2) neutron scattering laboratory oils; and (3) chemical laboratory solvent wastes including acetone, benzene, trichloroethylene, and various cleaning acids (J. Devore, personal communication to R. Saylor, Energ' Division, Oak Ridge National Laboratory, Oak Ridge, Tenn., July 1991). These would be packaged and disposed of in RCRA-approved facilities.

In addition, ANS cooling water blowdown would remove hazardous impurities from the cooling tower water system. Blowdown would contain trace quantities of iron, copper, and aluminum in both free and oxide form, as well as dirt and grime, chlorine, and corrosion control chemicals including molyboate and polyacrylate (J. West, ANS Project, personal correspondence to R. Saylor, Energy Division, ORNL, Oak Ridge, Tenn., July 1991). ANS would pretreat blowdown and makeup water in a special treatment plant integrated with the ANS pump house building prior to their release to the White Oak watershed. Finally, organic and heavy metal-contaminated liquid wastes meeting the criteria in Table 3.5-1 above would be discharged to the NRWTP.

\subsubsection{Planned Hazardous Liquid Waste Management at ORNL}

The principal RCPA-permitted hazardous waste storage facility at ORNL, Building 7652, is scheduled for closure in 1992 and would not be available for ANS hazardous waste. Building 7651 , a waste oil storage pad, will be used as an interim storage facility prior to off-site disposal of waste oils.

ORNL's Hazardous Waste Management Program (Baldwin et al. 1989b, p. 4-22) outlines a long-term strategy for storing, treating, and disposing of major liquid hazardous waste streams. Plans emphasize off-site commercial incineration of nonradioactive oils, poisons, and solvents; neutralization of bulk acids; and commercial treatment and disposal of miscellaneous bulk chemicals and water-reactive chemicals.

\subsubsection{Current Hazardous Solid Waste Management at ORNL}

Hazardous solid wastes encompass a wide-ranging set of substances that are toxic, ignitable, corrosive, reactive, or explosive (40 CFR 261.24, pt. D). At ORNL, disposal of nonradioactive hazardous solid wastes must comply with guidelines established under the RCRA. RCRA requires EPA and states to establish a permit system for disposal of these wastes in licensed landfills.

Hazardous solid waste generation has been declining at ORNL. In 1988, ORNL generators produced a total of $161,420 \mathrm{~kg}(433,000 \mathrm{lb})$ of hazardous waste. While over $56 \%$ was routine generated waste, the remainder $(44 \%)$ was nonroutine cleanout, 

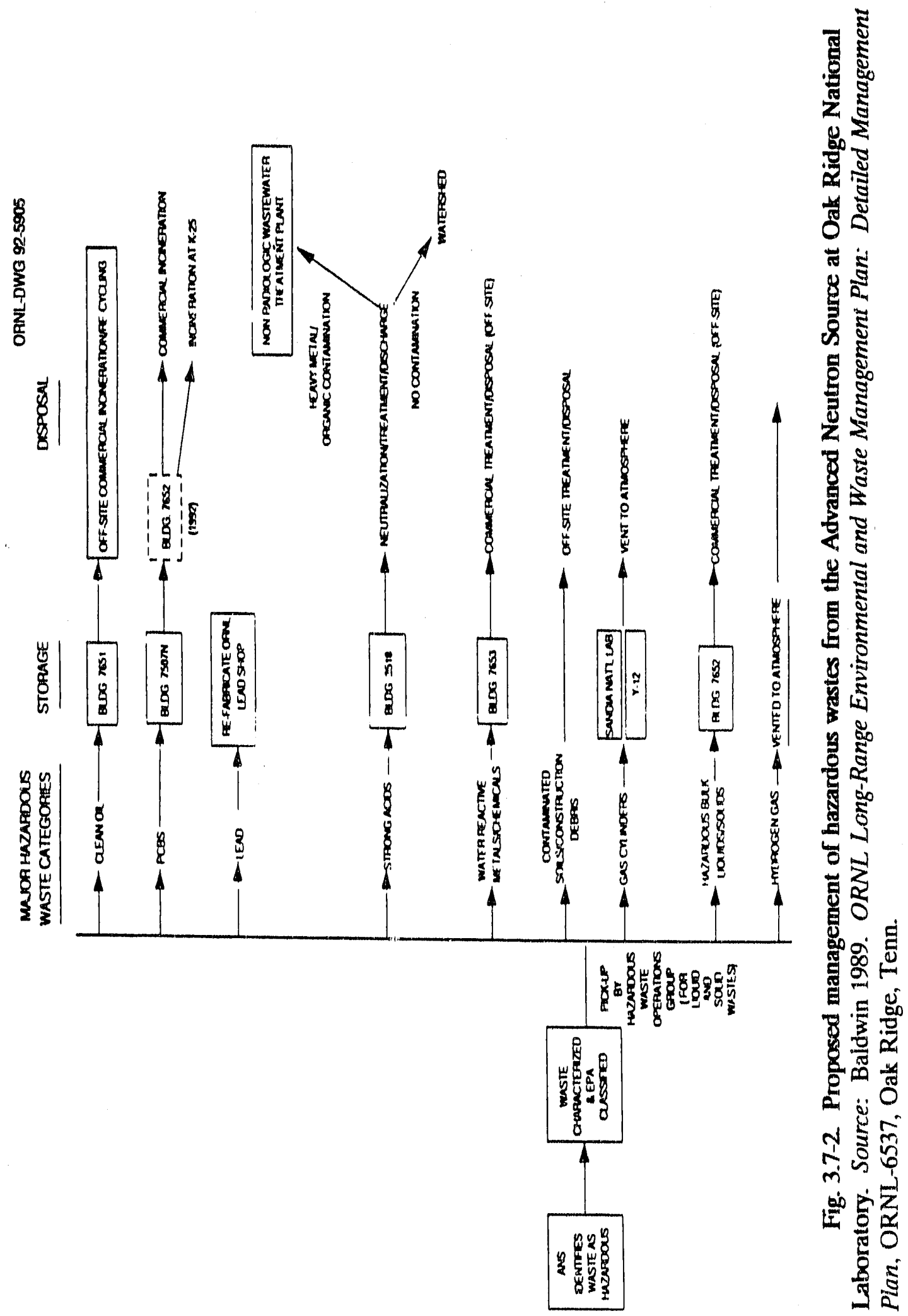
construction, and spill residue waste (Baldwin et al. 1989a, p. XXV). In 1990, this figure had fallen to $71,000 \mathrm{~kg}(190,000 \mathrm{lb})$ (Kornegay et al. 1991, p. 213).

\subsubsection{ANS Hazardous Solid Wastes}

Hazardous solid wastes generated by ANS would fall into two principal categories: construction wastes and routine operation wastes. The former include solls and other construction debris contaminated with the hazardous materials listed above. Operations-related hazardous solid wastes encompass trace quantities of biological waste from ANS experiment systems.

Construction-related solld wastes from ANS would be routed to holding ponds until chemical runoff became suitable for discharge to nearby surface waters. After dewatering, construction-related hazardous solid wastes from ANS would be taken off-site and commercially disposed of, as would operations-related hazardous solids, as depicted in Fig. 3.7-2.

\subsubsection{Planned Hazardous Solid Waste Management at ORNL}

ORNL's Hazardous Waste Management Program (Baldwin et al. 1989b, p. 4-21) recommends a long-term strategy for storing, treating, and disposing of major solid hazardous waste streams. It is expected that all hazardous solid wastes will be disposed of in the ORMWI at the K-25 site.

\subsubsection{Current Management of Hazardous Gases at ORNL}

At $\mathrm{ORNL}$, hazardous gaseous emissions are managed separately from radioactive gaseous emissions. Included in the category of potentially hazardous gases are $\mathrm{CO}, \mathrm{SO}_{2}$, $\mathrm{Pb}, \mathrm{O}_{3}$, and fluorides. These gases are managed in accordance with Clean Air Act guidelines and/or the requirements of the Tennessee Department of Health and Environment Air Pollution Control Division. In addition, research reactors such as HFIR routinely store compressed gaseous wastes on-site (Sect. 5.10.4).

\subsubsection{ANS Hazardous Gases}

ANS would be expected to generate some emissions that are toxic, ignitable, corrosive, reactive, or explosive. In the reactor coolant system, elemental deuterium $\left({ }^{2} \mathrm{H}_{2}\right)$ will be generated by radiolysis. This deuterium, which appears in the gases in the accumulators and in the letdown tank, will be recombined and returned to the coolant. In addition, hydrogen ( ${ }^{\prime} \mathrm{H}_{2}$ ) will be discharged as an effluent from the detritiation facility since we have adopted the CECE process. ANS is also expected to store some compressed gasses on-site for experimental purposes, particularly oxygen.

\subsubsection{Planned Management of Hazardous Gases at ORNL.}

Long-term plans for hazardous gas management at ORNL include treatment of nonradiological gas cylinders, minimization of hazardous waste emissions at their source, and venting wastes to the environment, as appropriate. 


\subsection{REPORTING OF RADIOACTIVE MATERIAL MOVEMENT}

\subsubsection{Current Reporting of Radioactive Material Movement}

The major source of spent nuclear fuel at ORNL is HFIR. After removal from the reactor core, spent nuclear fuel is stored on site in a fuel storage pool before shipment to the RBOF at the Savannah River Plant in South Carolina. Between 198.3 and 1989, HFIR shipped 84 specially designed spent fiuel storage casks from Oak Ridge, Tennessee, to the Savannah River Plant in South Carolina (an average of 12 shipments per year). Each cask weighed 0.03 । (0.03 tons) (SAIC 1990, p. 21),

Between 1983 and 1989, there were 93 spent tuel shipments from HFIR, 84 of which were in special "HFIR casks," which are no longer in use, and 9 of which were in the GE-700 cask during the years 1988 and 1989 (SAIC 1990, p. 19). The total weight of the 84 HFIR casks was 2.67 MTU (2.4 tons of uranium) 1983-1989 while the total weight of the 9 GE-700 casks was 0.0558 MTU (0.051 tons of uranium) (SAIC 1990, p. 19).

\subsubsection{ANS Radioactive Material Movement Reporting}

After a 1-10 2-year supply of spent fuel had accumulated at ANS, it would be shipped by truck to the RBOF at the Savannah River Plant in South Carolina. Similarly, TRU wastes from ANS are expected to be packaged and shipped to the WIPP in New Mexico. Expected annual waste volumes generated by ANS are given in Table 3.8-1.

Measures will be undertaken by DOE to minimize occupational and population exposure to all forms of radiological waste. These measures will include use of strong, tight packaging able to withstand normal and severe accident conditions; placarding and package labeling; rigorous training; and prior notification of transport corridor states before shipments of spent fuel and TRU wastes (DOE 1990, pp. 1\%18).

\subsubsection{Planned Radioactive Material Movement Reporting}

The measures delineated in the previous paragraph will continue to be undertaken by the DOE research reactor community. It is likely that, with the opening of WIPP for shipments of TRU wastes from ANS and other facilities, route selection and inspection procedures will be subject to negotiation between communities and DOE (Channell, Rodgers, and Neill 1986; Gallegos and Channell 1989). Dissemination of radioactive material movements to the media, public, and interested local officials during shipments of waste is likely to continue to be important for purposes of emergency planning and response (Ball et al. 1990; SAIC 1990).

\subsubsection{Transportation Risk Assessment for the ANS Reactor}

This section describes the analysis of transportation risk associated with the transport of radioactive materials $t o$ and from ANS. The methodology of the risk assessment will be presented along with an analysis of the transportation routes, characterization of the radioactive materials, a description of the RADTRAN iV computer code used to perform the risk assessment, and a summary of the transportation risks.

Fresh fuel would be shipped from the Baboock and Wilcox (B\&W) fuel fabrication plant near Lynchburg, Virginia, to the Y-12 Site near Oak Ridge, Tennessee, for temporary storage and inspection and then to the ANS site for refueling. Spent fuel 
Table 3.8-1. Annual ANS waste volumes

Waste category

Annual generation

I. Liquild radioactive wastes

a. Liquid low-level radiaactive waste (LLLW)

$480 \mathrm{~m}^{3}(126,100 \mathrm{gal})$

b. Radiological process wastes

$27,550 \mathrm{~m}^{3}(7,248,500 \mathrm{gal})$

II. Solid radioactive waste

a. Transuranic waste (TRU)

1. Contact-handled (CH) TRU

2. Remote-handled (RH) TRU

Comparable to High Flux lsotope Reactor

Comparable to High Flux Isotope Reactor

b. High-level incidental waste

To be determined

c. Spent tuel

17 fuel bundles/95 $\mathrm{m}^{2}\left(1,024 \mathrm{ft}^{2}\right)$

d. Greater-than-class-C waste

$<1 \mathrm{~m}^{3}\left(35.2 \mathrm{ft}^{3}\right)$

e. Solid LLW
1. CH-LLW
$115 \mathrm{~m}^{3}\left(3,900 \mathrm{ft}^{3}\right)$
2. RH-LLWa
$10 \mathrm{~m}^{3}\left(352 \mathrm{ft}^{3}\right)$

III. Radioactive gaseous wastes (by radionuclide)
${ }^{\infty} \mathrm{Co}$
${ }^{85} \mathrm{Kr}$
${ }^{90 S r}$
${ }^{132} \mathrm{Te}$
${ }^{129} \mathrm{I}$
${ }^{131}$
${ }^{132} \mathrm{I}$
${ }^{135} 1$
${ }^{133} \mathrm{Xe}$
${ }^{137} \mathrm{Cs}$
${ }^{237 m} \mathrm{Ba}$
${ }^{140} \mathrm{La}$
${ }^{194} \mathrm{Au}$
${ }^{212} \mathrm{~Pb}$
${ }^{28} \mathrm{Th}$
${ }^{230} \mathrm{Th}$
${ }^{232} \mathrm{Th}$
${ }^{234} \mathrm{U}$
${ }^{239} \mathrm{Pu}$
${ }^{3} \mathrm{H}$

$2.15 \times 10^{-6} \mathrm{Cl}\left(8.0 \times 10^{2} \mathrm{~Bq}\right)$

$1.75 \times 10^{3} \mathrm{Cl}\left(6.5 \times 10^{13} \mathrm{~Bq}\right)$

$2.24 \times 10^{6} \mathrm{Cl}\left(8.3 \times 10^{4} \mathrm{~Bq}\right)$

$1.04 \times 10^{.5} \mathrm{Cl}\left(3.8 \times 10^{5} \mathrm{~Bq}\right)$

$3.65 \times 10^{-6} \mathrm{Cl}\left(1.4 \times 10^{5} \mathrm{~Bq}\right)$

$1.13 \times 10^{-1} \mathrm{Cl}\left(4.2 \times 10^{9} \mathrm{~Bq}\right)$

$5.44 \times 10^{.3} \mathrm{Cl}\left(2.0 \times 10^{8} \mathrm{~Bq}\right)$

$1.31 \times 10^{-1} \mathrm{Cl}\left(4.8 \times 10^{9} \mathrm{~Bq}\right)$

$1.08 \times 10^{-1} \mathrm{Ci}\left(4.0 \times 10^{10} \mathrm{~Bq}\right)$

$8.52 \times 10^{3} \mathrm{Cl}\left(3.2 \times 10^{14} \mathrm{~Bq}\right)$

$4.40 \times 10^{-6} \mathrm{Cl}\left(1.6 \times 10^{5} \mathrm{~Bq}\right)$

$4.40 \times 10^{-6} \mathrm{Cl}\left(1.6 \times 10^{5} \mathrm{~Bq}\right)$

$2.95 \times 10^{-6} \mathrm{Cl}\left(1.1 \times 10^{5} \mathrm{~Bq}\right)$

$5.40 \times 10^{.7} \mathrm{Ci}\left(2.0 \times 10^{4} \mathrm{~Bq}\right)$

$5.68 \times 10^{.2} \mathrm{Ci}\left(2.1 \times 10^{9} \mathrm{~Bq}\right)$

$8.76 \times 10^{-9} \mathrm{Cl}\left(3.2 \times 10^{2} \mathrm{~Bq}\right)$

$1.06 \times 10^{-8} \mathrm{Cl}\left(3.9 \times 10^{2} \mathrm{~Bq}\right)$

$7.76 \times 10^{9} \mathrm{Cl}\left(2.9 \times 10^{2} \mathrm{~Bq}\right)$

$1.56 \times 10^{-8} \mathrm{Cl}\left(5.8 \times 10^{2} \mathrm{~Bq}\right)$

$4.28 \times 10^{-10} \mathrm{Cl}(1.6 \times 10 \mathrm{~Bq})$

$7.19 \times 10^{3} \mathrm{Cl}\left(2.7 \times 10^{14} \mathrm{~Bq}\right)$ 
Table 3.8-1. (continued)

Waste category

IV. Liquid/solid tritium

V. Mixed waste

a. Liquid mixed waste

b. Solid mixed waste

VI. Nonradiological wastes

a. Sanitary waste

b. Conventional laundry waste

c. Conventional liquild wastes (effluents)

d. Conventional solid wastes

e. Conventional gaseous waste

f. Hazardous wastes

1. Liquids

2. Solids

3. Gases
Annual generation

$1.12 \times 10^{6} \mathrm{Cl}\left(4.1 \times 10^{16} \mathrm{~Bq}\right)$

not applicable

$1.2 \mathrm{~m}^{3}$ (330 gal)

Isotopic composition of RH-LLW: ${ }^{31} \mathrm{Si},{ }^{20} \mathrm{Mg},{ }^{64} \mathrm{Cu},{ }^{67} \mathrm{Cu},{ }^{60} \mathrm{Ni},{ }^{65} \mathrm{Ni},{ }^{60} \mathrm{Ni},{ }^{60} \mathrm{Co},{ }^{61} \mathrm{Co},{ }^{32} \mathrm{Mn},{ }^{43} \mathrm{Mn},{ }^{54} \mathrm{Mn}$,

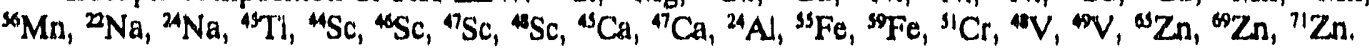

from the ANS would be shipped to SRS near Aiken, South Carolina. All fuel shipments will be performed using NRC-approved Type B packages.

Fresh and irradiated targets would also be shipped in Type B packages such as the General Electric (GE) model 1500 shielded container or other approved package to and from the ANS to REDC at HFIR located just west of the ANS site.

Depending upon what options are chosen for LLLW handling, the LLLW may be shipped by tanker truck to treatment facilities at HFIR. Treatment of primary cleanup water and ion exchange resins would generate solid CH-LLW that would also require onsite shipment. Limits on the actual radioactive inventory of the Type B waste packages will meet all applicable Department of Transportation regulations, NRC package certificate requirements, and the waste acceptance criteria limits for each facility.

\subsubsection{Transportation Routes}

Three transportation scenarios will be considered: (1) fresh fuel shipments from the B\&W fuel fabrication plant to the ANS, (2) spent fuel shipments from the ANS to SRS, and (3) on-site shipments of fresh and irradiated targets, LLLW, and solid CH-LLW from the ANS to HFIR. 
The route for the first scenarto, involving shipments of tresh fuel to ANS, leaves the B\&W fuel fabrication plant near Lynchburg, Virginla and proceeds on State Route (SR) 726 to $3 R 460$ which is followed west through Bedford to Iriterstate 581 in Roanoke. Interstate 581 is taken to Interstate 81 . The longest leg of the trip then proceeds nouthwest on Interstate 81 for $351 \mathrm{~km}$ (218 miles) through Virginia to Interstate 40 at Dandridge, Tennessee. Interstate 40 is followed west, making use of Interstate 640 to bypass Knoxville, to State Route 95 which proceeds to Lagoon Road where local roads are used to gain access to the $Y^{\prime}-12$. Site for inspection and storage before movement to the ANS site. This travel route is $549 \mathrm{~km}$ (.341 miles) long.

The route for the second scenario, involving shipments of ANS spent fuel to SRS, leaves the ANS site near Oak Ridge, Tennessee, and proceeds on local roads to State Route 95, then south on State Route 95 to Interstate 40 near Lenoir City. A brief run east on Interstate 40 is followed by the longest segment of the trip on south Interstate 75 to Atlanta, Georgla. Interstate 285 is used to bypass Allanta and then the route continues east on Interstate 20 through Georgia and 1 mile $(1.61 \mathrm{~km})$ into South Carolina to State Route 230. SR 230 proceeds to SR 125 which is taken to Interstate 278. Interstate 278 is followed until it rejoins SR 125 near Beech Island, South Carolina. SR 125 continues to the SRS boundary where local ronds are then taken to the spent fuel receiving area. This travel route is $613 \mathrm{~km}$ ( $381 \mathrm{~m}$ lles) long.

The route for the third scenario would Involve on-site shipments of ANS targets, LLLW, and solid CH-LLW between the ANS and various processing facilities at the HFIR located about a mile west of the ANS site. The route, which is $2.1 \mathrm{~km}$ (1.3 miles) long, proceeds along local roads.

The HIGHWAY computer conde model (Joy and Johnson 1983) was used to select and analyze each transportation scenario. The selection of preferred routes assumes that each shipment consists of highway route controlled quantities of radioactive materials. Travel time is optimized based on maximum utilization of the interstate highway system with preference given to bypasses around major cities except where alternate routes have been designated by state or local officials.

The total travel distance and the fraction of travel in each population density zone are needed inputs to the RADTRAN IV program and are given in Table 3.8-2. The routing data from the HIGHWAY model, which makes use of 12 population density zones, has been collapsed into 3 zones for use in RADTRAN. The 3 zones (i.e., rural, suburban, and urban) are further divided into freeway (interstate) or non-freeway road types. Non-freeway designates a U.S., state, or local road. Factors such as population density, accident rates, and vehicle velocity can vary for difterent zones. Each population zone, along with an associated road type, make up a RADTRAN IV "LINKS" category. The mileage for each link in the route is shown in Table 3.8.2.

\subsubsection{Characterization of Radioactive Materials}

The fresh fuel for the ANS is composed of $\mathrm{U}_{3} \mathrm{Si}_{2}$ dispersed in an aluminum matrix. Each core load consists of approximately $15 \mathrm{~kg}(33.3 \mathrm{lb})$ of heavy metal (93\% enriched ${ }^{235} \mathrm{U}$ ). The level of radioactivity in the tresh fuel is quite small in comparison to the spent fuel activity and thus the calculated transportation risks for fresh fuel are also quite low. After a fuel cycle of about $17 \mathrm{~d}$, the spent fuel will be removed from the core and allowed to cool on site for 16 to 24 months. The spent fuel will then be shipped to SRS for reprocessing. The ORIGEN2 (Croff' 1980) computer code was used to determine the radiological characteristics and isolopic inventory of ANS spent fuel after discharge from the reactor and after the 2-year cooling time before fuel shipment. 
Table 3.8-2. Transportation route analysis from HIGHWAY model"

\begin{tabular}{|c|c|c|c|c|c|}
\hline $\begin{array}{c}\text { Population } \\
\text { density } \\
\text { zone }\end{array}$ & $\begin{array}{l}\text { Population } \\
\text { density range } \\
\text { (people/mile })\end{array}$ & & $\begin{array}{c}\text { Babcock \& } \\
\text { Wilcox (B\&W) } \\
\text { to Advanced } \\
\text { Neutron Source } \\
\text { (ANS) } \\
\text { (mile) }\end{array}$ & $\begin{array}{l}\text { ANS to } \\
\text { Savannah } \\
\text { River Site } \\
\text { (SRS) } \\
\text { (mile) }\end{array}$ & $\begin{array}{l}\text { ANS to } \\
\text { High-Flux } \\
\text { Isotope } \\
\text { Reactor } \\
\text { (HFIR) } \\
\text { (mile) }\end{array}$ \\
\hline Rural & $0-139$ & & 196 & 229 & 1.3 \\
\hline Suburban & $139-3,326$ & & 143 & 149 & 0 \\
\hline \multirow[t]{2}{*}{ Urban } & $3,326-10,000-1$ & & 2.1 & 2.7 & 0 \\
\hline & & Total: & 341.1 & 380.7 & 1.3 \\
\hline \multicolumn{3}{|c|}{ RADTRAN IV "LINKS" category } & $\begin{array}{c}\text { B\&W to ANS } \\
(\mathrm{km})\end{array}$ & $\begin{array}{l}\text { ANS to } \\
\text { SRS } \\
(\mathrm{km}) \\
\end{array}$ & $\begin{array}{l}\text { ANS to } \\
\text { HFIR } \\
(\mathrm{km})\end{array}$ \\
\hline \multicolumn{3}{|l|}{ Rural treeway } & 222 & 308 & 0 \\
\hline \multicolumn{3}{|c|}{ Rural non-freeway } & 9.3 & 61 & 2.1 \\
\hline \multicolumn{3}{|c|}{ Suburban freeway } & 230 & 240 & 0 \\
\hline \multicolumn{3}{|l|}{ Urban freeway } & 3.4 & 4.3 & 0 \\
\hline & & Total: & 548.4 & 613.3 & 2.1 \\
\hline
\end{tabular}

"HIGHWAY is shown in unils of miles and the RAD'TRAN IV input must be given in kilometers.

"Fuel from B\&W stops at the Y.12 Silte for temporary storage and inspection before golng to ANS.

For this analysis, it will be assumed that ANS targets will be similar in composition to targets used at HFIR. Since specific intiormation on ANS target design was not available, information on typical HFIR targets was used to model the transportation risks. A typical HFIR tresh target contains up $1010 \mathrm{~g} \mathrm{of}{ }^{242} \mathrm{Pu},{ }^{24.3} \mathrm{Am}$, or ${ }^{244} \mathrm{Cm}$, or any combination of the above, including equilibrium amounts of heavier isotopes, for a total of about $10 \mathrm{~g}$ of heavy metal (Bigelow et al. 1981, p. 5). An irradiated target may contain several transplutonium isotopes as well as a number of lission products, depending on the composition of the tresh targel. The average composition of multiple irradiated HFIR targets was used to model the ANS targets. (Bigelow et al. 1981, p. 14., King, Bigelow, and Collins 1981, p. 137).

The quantities and isotopic compositions of the LLLW and CH-LLW generated at ANS were estimated based on scaled-up models trom the HFIR waste production history (Reed 1991, p. 4-8). It is estimated that $4.773 \times 10^{5} \mathrm{~L},(126,100$ gal) of LLLW will be generated each year at the ANS. If necessary, this waste may be shipped by truck to on. site treatment facilities and, therefore, a RADTRAN analysis was performed. LLLW may very well be piped trom the ANS site to the HFIR site, in which case no LLLW truck 
shipments would be required. Approximately $57 \mathrm{~m}^{3}\left(2,000 \mathrm{ft}^{3}\right)$ of CH-LLW, consisting primarily of ion-exchange resins and other solids generated from the ANS primary water cleanup system, will be generated each year. The isotopic composition of this solid CH. LLW is sirnilar to the LLLW composition (Reed 1991, p. 8).

\subsubsection{Transportation Risk Assessment}

During the ANS transportation risk assessment, the following three scenarios were analyzed: (1) fresh fuel shipments from the B\&W fuel fabrication plant to the ANS via $Y \cdot 12$, (2) spent fuel shipments from the ANS to SRS, and (3) on-site shipments of fresh and irradiated targets, LLLW, and solid CH.LLW from the ANS to HFIR. The third scenario consists of three RADTRAN runs to model the on-site shipments of fresh and irradiated targets, LLLW, and solid CH-LLW.

RADTRAN IV models both the incident-free radiological exposure and the consequences of radiological releases due to severe accidents. The incident-free risks are dependent on the radiation dose rate from the shipment, number of shipments, package dimensions, route distance, vehicle velocity, and population densities along the travel routes. The accident risks are dependent on the radiological inventory, accident severity, probability of occurrence for each accident category, and the amount of inventory released, aerosolized, and inhaled, as well as the dispersibility of the waste form. The primary RADTRAN assumptions used for the AN'S transportation risk assessment are shown in Table 3.8-3.

Incident-tree radiological exposure was determined by calculating a total body dose for the transport crew and the general population from the radiation dose rate at 1 meter from the package surface. Both pointusource and line-source approximations were used based upon the distance between the exposed individuals and the radiation source. Each shipment was modeled as a single "effective" package with a homogeneous distribution of the radiological inventory throughout the package. The characteristic dimension, known in RADTRAN as the variable PKGSIZ, is the largest linear dimension of the configuration and is used in the line-source approximation to calculate total dose. The source term was conservatively ansumed to consist entirely of gamma radiation.

The dispersibility category is used to characterize the relative dispersibility of the radiological inventory based upon the chemical and physical properties of the material. RADTRAN uses the dispersibility category to determine the tractions of the total inventory that are aerosolized and respirable. RADTRAN contains default values for aerosolized and respirable fractions of the total inventory based on the assignment of dispersibility category. The user assigns a dispersibility category to each material and chooses release fractions based on the type of package as a function of accident severity.

\subsubsection{Summary of Transportation Risks from Incident-Free Transport}

An analysis of the three transportation scenarios was performed using the RADTRAN IV risk assessment code (Neuhauser and Reardon 1989) to determine the radiological impacts associated with the transport of radioactive materials to and from ANS. The radiological impacts considered were health effects associated with both normal transport (incident-free) and with low-probability accidents severe enough to release some or all of the radioactive material. Incident-free risk results trom exposure of the surrounding population to radiation emitted by the waste packages during normal transport. 


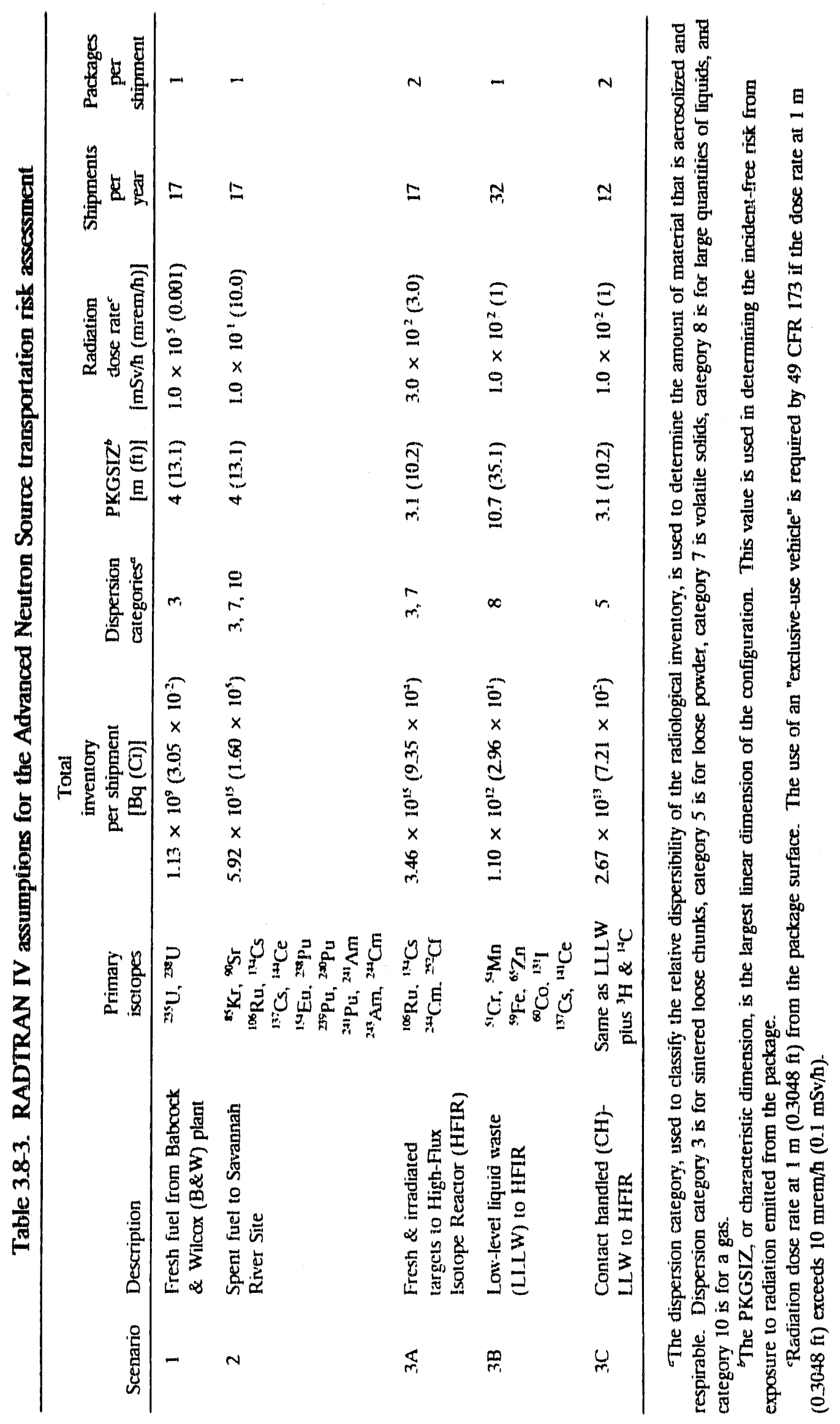


Table 3.8-4 lists the risk of latent cancer fatalities (LCFs) expected to result from radiation exposure during incident-free transportation. Table 3.8-5 lists the LCF risks that might be expected to result from accidents during transporation. Radiation doses to the general population and the truck crew were converted to estimates of LCFs usinf the upper limit risk coefficient $\left(2.0 \times 10^{-4} \mathrm{LCFs}\right.$ per person-rem) suggested by the National Academy of Sciences (Wilmot 1983, p. 35).

The analysis indicates that the radiological risks of transporting radioactive materials to and from the ANS is quite low. The number of latent cancer fatalities (LCFs) statistically expected to occur from the calculated exposures did not exceed $4.32 \times 10^{-5} \mathrm{LCFs}$ for the truck crew ( 2 crew members) or $2.81 \times 10^{-4}$ LCFs for members of the general public (excluding crew) exposed during incident-free transportation. The maximally exposed individual would receive $5.86 \times 10^{-8} \mathrm{~Sv}\left(5.86 \times 10^{-6} \mathrm{rem}\right)$ which is less than $0.0029 \%$ of the $2-\mathrm{mSv}(200-\mathrm{mrem})$ average annual effective dose received from natural background radiation sources. 


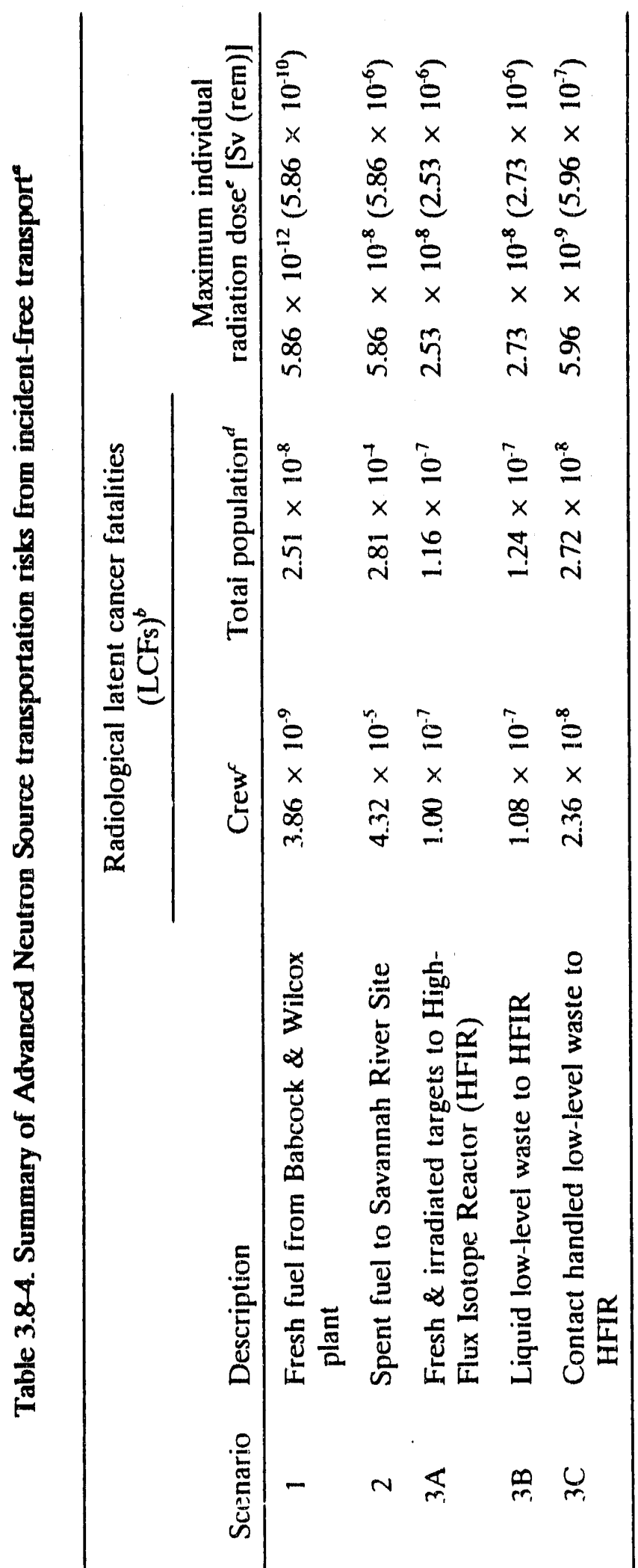

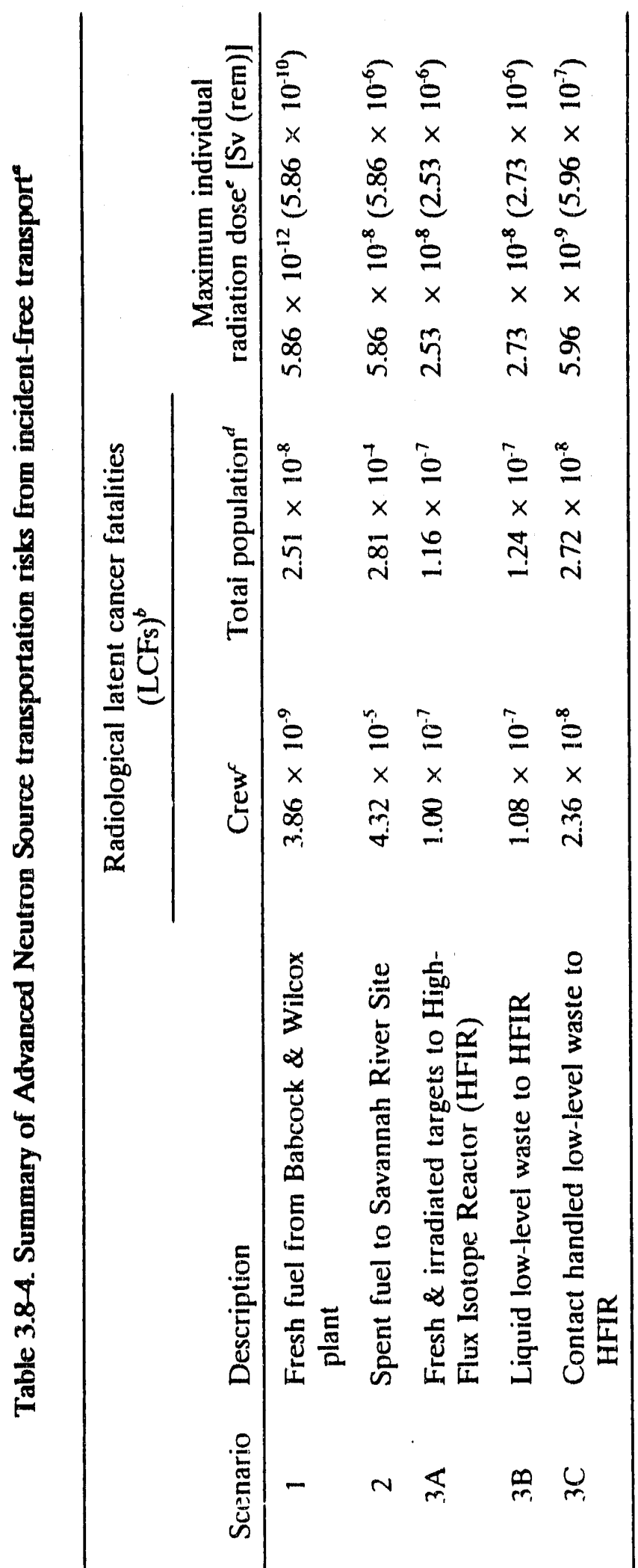

乌

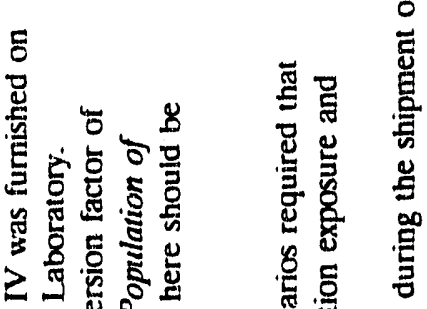

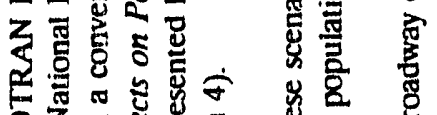

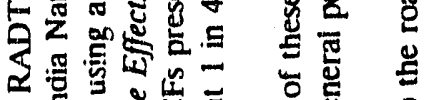

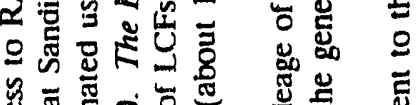

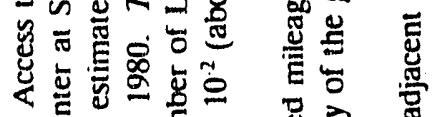

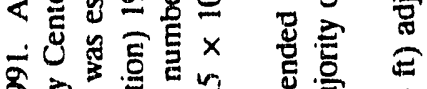

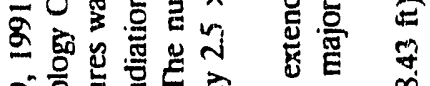

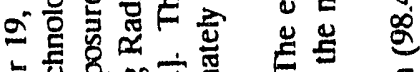

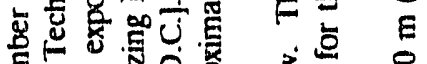

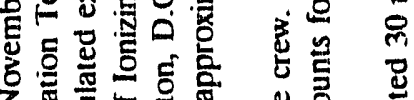

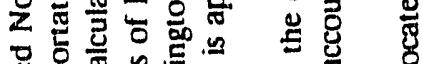

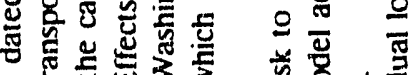

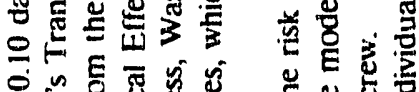

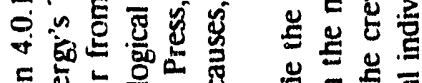

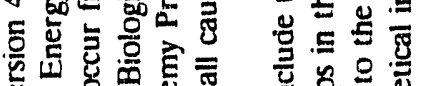

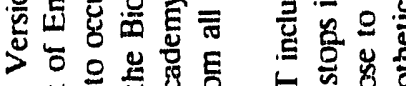

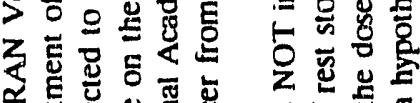

튼

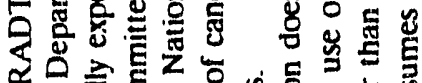

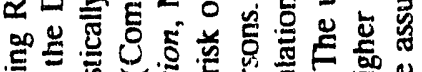

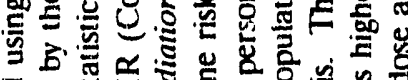

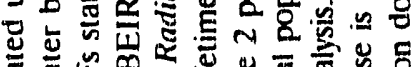

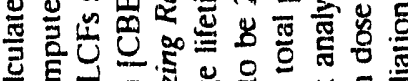

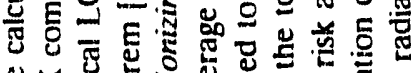

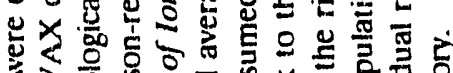

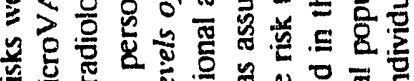

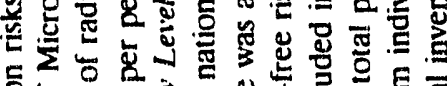

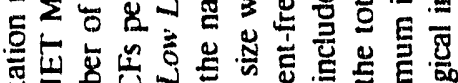

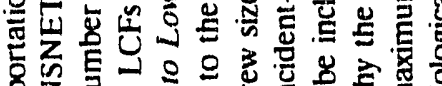

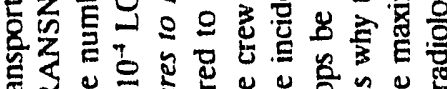

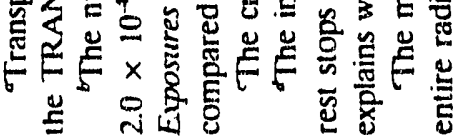




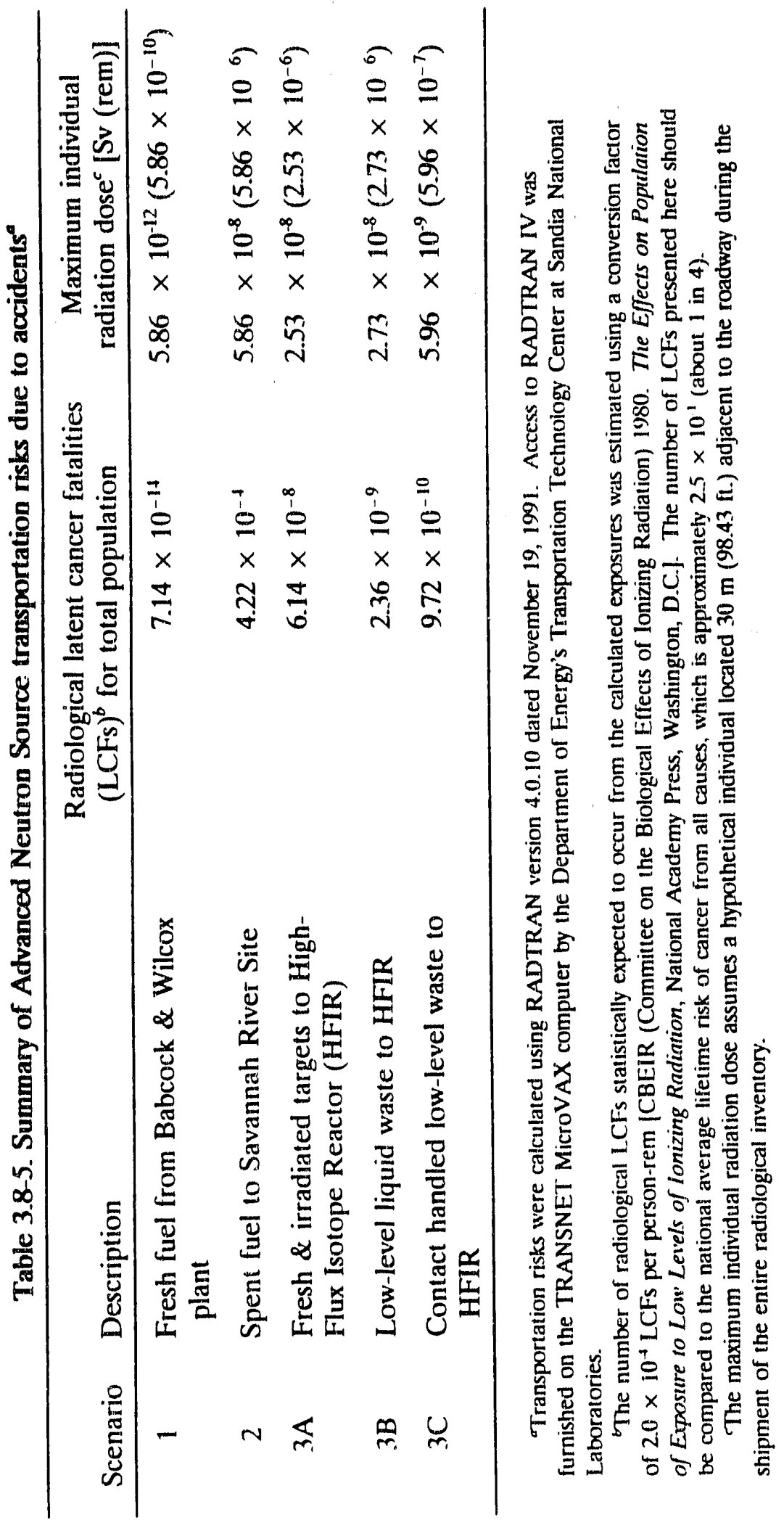




\subsection{REFERENCES FOR SECTION 3}

Baldwin, J. S. et al. 1989a. ORNL Long-Range Environmental and Waste Management Plan: Detailed Management Plan, ORNL-6537, Oak Ridge National Laboratory, Oak Ridge, Tenn., Sept.

Baldwin, J. S., et al. 1989b. Oak Ridge National Laboratory Implementation Plan for DOE Order 5820.2A, ORNL/TM-11166, Oak Ridge National Laboratory, Oak Ridge, Tenn., April

Baldwin, J. S., et al. 1989c. Oak Ridge National Laboratory Transuranic Waste Management Strategy Document, ORNL/TM-11506, Oak Ridge National Laboratory, Oak Ridge, Tenn., March.

Baldwin, J. S, J. D. Sease, and D. L. Jones 1989. Oak Ridge National Laboratory Waste Management Plan for Department of Enengy Order 5820.2A, ORNL/TM-11433, Oak Ridge National Laboratory, Oak Ridge, Tenn., Dec.

Baldwin, J. S., et al. 1989d. ORNL. Long-Range Environmental and Waste Management Plain: Program Overview and Summary, ORNL-6536, Oak Ridge National Laboratory, Oak Ridge, Tenn., Sept.

Ball, L. J., et al. 1990. TMI-2 Core Shipping Preparations, unpublished manuscript, supported by U. S. Department of Energy, Assistant Secretary for Nuclear Energy, Office of LWR Safety and Technology under DOE contract no. DE-ACO7-76ID01570.

Bigelow, J. E., et al. 1981. "Production of Transplutonium Elements in the High-Flux Isotope Reactor," Transplutonium Elements-Production and Recovery, American Chemical Society.

Butterworth, G. 1988. "Low-Level Waste Disposal, Development, and Demonstration Program," Oak Ridge National Laboratory Review 21(4).

CBEIR (Committee on the Biological Effects of Ionizing Radiation) 1980. The Effects on Population of Exposures to Low Levels of Ionizing Radiation, National Academy Press, Washington, D.C.

Channell, J. K., J. C. Rodgers, and R. H. Neill 1986. Adequacy of TRUPACT-I Design for Transporting Contact-Handled Transuranic Wastes to WIPP, EEG-33/DOE/AL-10752-33. Santa Fe, New Mexico: Environmental Evaluation Group, Environmental Improvement Division, Health and Environment Department, State of New Mexico, July.

Croff, A. G. 1980. ORIGEN2 - A Revised and Updated Version of the Oak Ridge Isotope Generation and Depletion Code, ORNL-5621, Oak Ridge National Laboratory, Oak Ridge, Tenn.

DOE (U. S. Department of Energy) 1989a. Environmental Restoration and Waste Management: Five-Year Plan, DOE/S-0070.

DOE (U. S. Department of Energy) November 1989b. Integrated Data Base for 1989: Spent Fuel and Radioactive Waste Inventories, Projections, and Characteristics, DOE/RW-0006, rev. 5, Assistant Secretary for Nuclear Energy, Assistant Secretary for Defense Programs, Office of Civilian Radioactive Waste Management, prepared by Oak Ridge National Laboratory, Oak Ridge, Tenn.

DOE (U. S. Department of Energy) 1990. Shipment of Radioactive Material by the U.S. Department of Energy, DOE/DP-0065, Transportation Management Division, DP-21. 
Gallegos, A. F. and J. K. Channell 1989. Risk Analysis of the Transport of Cortact Handled Transuranic (CH-TRU) Wastes to WIPP Along Selected Highway Routes in New Mexico Using Radtran IV, EEG-46/DOE/AL/58309-46, Environmental Evaluation Group, Albuquerque, N.M.

Hutchison, D., and M. Magleby 1990. Greater-Than-Class-C Low-Level Waste Characterization Technical Review Process. Nuclear Materials Management, 31st Annual Meeting Proceedings, Vol. XIX, Los Angeles, July 15-18.

Joy, D. S., and P. E. Johnson 1983. HIGHWAY, A Transportation Routing Model: Program Description and Revised User's Manual, ORNL/TM-8759, Oak Ridge National Laboratory, Oak Ridge, Tenn.

King, L. J., J. E. Bigelow, and E. D. Collins 1981. "Experience in the Separation and Purification of Transplutonium Elements in the Transuranium Processing Plant at Oak Ridge National Laboratory," Transplutonium Elements - Production and Recovery, American Chemical Society.

Kornegay, F. C., et al. 1991. Oak Ridge Resen'ation Environmental Report for 1990, Volume 1: Narrative, Summary, and Conclusions, Environmental, Safety, and Health Compliance and Environmental Management Staff, ORNL, Y-12, K-25, Martin Marietta Energy Systems, Inc., Oak Ridge, Tennessee, Sept.

Krochmalnek, L. S., J. P. Krasznai, M. Carney 1987. "Conditioning and Handling of Tritiated Wastes at Canadian Nuclear Power Facilities," American Chemical Society Proceedings, Denver, April.

Mezga, L. 1988. "The Energy Systems Approach," Oak Ridge National Laboratory Review 21 (4), Oak Ridge National Laboratory, Oak Ridge, Tenn.

Myrick, T., T. Scanlan, and C. Kendrick 1988. "Improving Waste Management Operations," Oak Ridge National Laboratory Review 21 (4).

Neuhauser, K. S., and P. C. Reardon, 1989. RADTRAN 4.0 - Advanced Computer Code for Transportation Risk Assessment, PATRAM89, The 9th International Symposium on the Packaging and Transportation of Radioactive Materials, Washington, D.C., June.

NRC (U.S. Nuclear Regulatory Commission) 1976. Preparation of Environmental Reports for Nuclear Power Stations, Regulatory Guide 4.2, Rev. 2, NUREG-0099.

NRC (U.S. Nuclear Regulatory Commission) 1989. Occupational Radiation Exposure at Commercial Nuclear Power Reactors and Other Facilities 1986, NUREG-0713, U. S. Nuclear Regulatory Commission, Volume 8.

Office of Waste Management and Remedial Actions 1991. Oak Ridge National Laboratory Waste Management Plan, ORNL/TM-11433/R1, prepared for Office of Environmental Restoration and Waste Management, Oak Ridge, Tenn., Dec.

Parrott, J. R., et al. 1991. Oak Ridge National Laboratory Liquid Waste Treatment Systems Waste Acceptance Criteria. WM-WMCO-201. Office of Waste Management and Remedial Actions, Waste Management Operations, Waste Management Coordination Office, Oak Ridge National Laboratory Oak Ridge, Tenn., July.

Reed, W. R. 1991. Information about Wastes from ANS, draft internal memo, Oak Ridge National Laboratory, Oak Ridge, Tenn., September 25.

Rohwer, P. S. 1989. Environmental Monitoring and Compliance (EMC) Section Position on the Discharge of Chlorinated Water to ORNL Surface Streams, memorandum to environmental protection officers, Oak Ridge National Laboratory, Oak Ridge, Tenn.

Rivera, A. L., et al. 1989. LLWDDD Program Waste Monagement Data System Status Report for the Period October-December 1988. ORNL/CF-89/14, Oak Ridge National Laboratory, Oak Ridge, Tenn., Miarch. 
Robinson, S. M., S. M. DePaoli, and A. B. Walker 1991. Federal Facility Compliance Agreement Contingency, Upgrade, and Replacement Plans for the ORNL Active Low-Level Radioactive Waste Tank System. Prepared for the Office of Environmental Restoration and Waste Management. ORNL/TM-11795. Oak Ridge National Laboratory, Oak Ridge, Tenn., June.

SAIC (Science Applications International Corporation, Inc.) 1990. Historical Overview of Domestic Spent Fuel Shipments-Update. Prepared for Oak Ridge National Laboratory and the Office of Civilian Radioactive Waste Management Transportation Operations Office under subcontract no. 88-17B-997962V/1, Oak Ridge, Tenn., July.

Spratt, P., et al. 1985. Final Report of the Tritium Issues Working Group, Vol. 2 Appendices. P. J. Spratt and Associates, Toronto, Sept.

System Design Description, System 67, Waste Management Systems 1991. ORNL/ANS/INT-26/S67 SDD-67, draft, Oak Ridge National Laboratory, Oak Ridge, Tenn., July.

Waste Acceptance Criteria for Radionctive Solid Waste Disposal at SWSA-6 1991. WM-WMCO-203, Waste Management Coordination Office, Waste Management Operations Section, Oak Ridge National Laboratory, Oak Ridge, Tenn.

West, C. 1989. "The Advanced Neutron Source: An Update," Oak Ridge National Laboratory Review 22 (4).

Wilmot, E. L. 1983. A Preliminary Analysis of the Cost and Risk of Transporting Nuclear Waste to Potential Candidate Commercial Repository Sites, SAND83-0867, Sandia National Laboratory, Albuquerque, N.M.

"Wrap-up (LLRW)" 1991. The Radioactive Exchange 10(10), Apr. 30. 


\section{ENVIRONMENTAL EFFECTS OF SITE PREPARATION AND FACILITY CONSIRUCTION}

\subsection{SITE PREPARATION AND FACILITY CONSTRUCTION}

This section discusses the effects of site preparation and facility construction on terrestrial and aquatic biota, and water and air quality.

\subsubsection{Effects on Terrestrial Biota}

This section discusses the effects of site preparation and facility construction on vegetation, wildlife (including threatened and endangered species), and wetlands. Mitigative measures to minimize effects on terrestrial biota are also discussed.

\subsubsection{Vegetation}

Construction of the Advanced Neutron Source (ANS) facility, support facilities, and construction laydown facilities would result in the loss of 25-35 ha (60-.90 acres) of second-growth hardwood forest. In addition, the construction of power lines would require the clearing of 6-10 ha (15-25 acres) of predominantly hardwood forest, as discussed in Sect. 4.2. These losses represent about $0.8 \%$ of the roughly 5,800 ha (14,300 acres) of hardwood forest on the Oak Ridge Reservation (ORR). However, the locations of offsite construction laydown areas, which might require about 8 ha (20 acres) of the acreage previously mentioned, have not been finalized. No rare or unique plant communities are known to be present in the areas that would be affected by proposed facilities, including laydown areas that might be located near the ANS site. Second-growth hardwood forests, such as those that would be affected by the proposed action, are extensive on ORR.

\subsubsection{Wildlife}

The hardwood forests on ORR are inhabited by many wildlife species, as discussed in Sect. 2.2.1. The loss of forest would result in a corresponding reduction of forest wildlife populations. Although some relatively mobile wildlife may move to unaffected areas, such areas are already inhabited and would generally not support greater population levels. Therefore, it must be assumed that the reduction in wildlife populations would, at a minimum, be directly proportional (1:1) to the amount of habitat lost (Kroodsma 1985, p. 85). For some species, forest fragmentation effects could cause population reductions to be greater than directly proportional. The wildlife species that would be affected are all relatively common species; thus, their populations on ORR would be reduced by only a small fraction.

\subsubsection{Wetlands}

Low-lying, often wet-forested habitats along ephemeral streams occur in several places on the ANS site. These habitats may be jurisdictional wetlands subject to permitting by the Corps of Engineers (COE) in accordance with Sect. 404 of the Clean Water Act (CWA) (33 U.S.C. 1344). Approximately 5.7 ha (14 acres) of these habitats would be directly affected by construction of ANS, its support facilities, and construction laydown areas. A site inspection is being scheduled for COE staff to determine which of these wet areas, if any, are jurisdictional wetlands, whether a Sect. 404 permit is required, and whether or not any additional surveys are required (e.g., surveys of hydrology, soils, and vegetation).

Construction of facilities would result in the loss of about 5.7 ha (14 acres) of young to mature hardwood forest on these wet areas and decreases in the populations of 
wetland wildlife. The only wetland wildlife that have been identifted on the ANS site are the burrowing crayfish and raccoon. Wildlife species more characteristic of marshes or swamps (e.g, herons, ducks, beaver) do not use the ANS site and would not be affected.

Construction of facilities would have negative impact on certain wetland functions, including groundwater recharge and maintenance of water quality.

\subsubsection{Threatened and Endangered Species}

No rare, threatened, or endangered plant species is known to occur on the site. Ginseng, listed as threatened by the state of Tennessee, occurs along a stream northeast of the site and near the top of a stream divide at the east boundary of the site (Fig. 2.2-2). Neither of the two locations is expected to be impacted by construction of ANS facilities; however, additional assessment of the potential for impact will be provided as the site layout continues to evolve.

No threatened or endangered animal species is known to inhabit the site, and none would be expected to occur regularly on the site except for the state-listed Cooper's hawk. Cooper's hawks are not belleved to nest on the site but probably visit the site occasionally when searching for prey. Because the Cooper's hawk forages primarily within forests, the clearing of forest for the proposed project would represent a habitat loss for this species. If the proposed project were to cause the loss of a nest site, a permit would be required from the Tennessee Wildlife Resources Agency. Cooper's hawk populations in the United States have apparently recovered significantly since dichlorodiphenyltrichloromethane (DDT) was banned.

The black vulture, which is listed by the state as "in need of management," is fairly common on ORR and probably flies over the site often. However, the site is likely not important to the vulture because nesting habitat (large trees with cavities, rock ledges, caves, abandoned buildings) is absent and because the vulture finds carrion in open areas as well as in forests. Therefore, the proposed project should have no impact on the black vulture.

\subsubsection{Mitigation}

Mitigative measures to minimize impacts on terrestrial biota would be accomplished primarily by the use of standard erosion control methods. Also, consideration is being given to minimizing the area in which clearing of hardwood forest would be necessary. Clearing could be minimized, for example, by using already disturbed areas or designated expansion areas for construction laydown, using one corridor for the two power lines rather than two corridors, and using a compact or tight siting of facilities rather than a loose or dispersed siting.

\subsubsection{Effects on Water Quality and Aquatic Biota}

The proposed ANS facility is located within the watersheds of Melton Branch and Friendship Creek, both of which are tributaries to the Clinch River. Additional areas that would be disturbed during construction (e.g., materials laydown areas and parking lots) are also expected to be within these watersheds.

Site clearing and construction of access roads, buildings, materials laydown and storage areas, fences, and parking lots would result in soil ercsion. Because ANS would be constructed in an area of steep slopes, the potential for erosion is high. If uncontrolled, eroded soil would subsequently increase turbidity and sedimentation in Friendship Creek and the Melton Branch-White Oak Creek-White Oak Lake system. Mitigative measures to control erosion and sedimentation would be based on Best Management Practices (BMPs) developed for construction activities at Oak Ridge National Laboratory (ORNL); such measures could include construction of berms, maintenance of vegetated filter strips along the creek banks, silt curtains, and settling basins to collect sediment-laden runoff. 
Spills of chemicals used in construction could also contaminate surface water bodies if not properly contained. The types of mitigative measures previously listed should also be effective in controlling spills. Solls excavated in the area of the ANS site and materials storage and laydown areas would need to be monitored for contamination; if existing contamination were found, special measures might need to be taken to prevent leaching of contaminants into surface waters. Only uncontaminated fill materials would be brought in from other areas.

Site disturbance associated with construction of ANS will be subject to CWA regulations and various permits, for example the Sect. 404 dredge and fill permit and aquatic alteration permit (Sect. 12.3). It is expected that the employment of mitigative measures would adequately control soil erosion and spills during construction of ANS, so that impacts to water quality and aquatic biota would be negligible.

\subsubsection{Effects on Air Quality}

Temporary and localized increases in atmospheric concentrations of carbon monoxide, nitrogen dioxide, volatile organic compounds, and particulate matter would result from exhaust emissions of heavy construction vehicles, diesel generators, and other construction equipment. These emissions would not add appreciably to those already in the area and would have negligible impacts on ambient air quality.

Fugitive dust would result from excavation and earthwork. The potential impacts of this dust were modeled under the assumption that excavation and earthwork activities would occur simultaneously throughout the construction area, which was assumed to be 20 ha (50 acres). It was further assumed that no dust suppression measures (e.g., sprinkling) would be used, even under the dustiest conditions. An average emission factor for total suspended particulate matter of 2.2 metric tons/ha ( 1.2 tons/acre) per month (EPA 1988, p. 22) was used, and $30 \%$ of that amount was conservatively assumed to be inhalable matter (particles less than 10 microns in diameter, abbreviated $\mathrm{PM}_{10}$ ).

The air dispersion model recommended by the U.S. Environmental Protection Agency, Industrial Source Complex, Short Term Model (EPA 1987, pp. 1-293), was used to predict fugitive dust concentrations resulting from construction activities. One year (1989) of hourly meteorological data from Tower 4 was used as input. Flat terrain was assumed for this analysis of ground-level dust emissions.

Assuming that excavation and earthwork at the scale described above continued for 6 months, the predicted increase in average annual $\mathrm{PM}_{10}$ concentrations would be 12. $\mu \mathrm{g} / \mathrm{m}^{3}$ at the nearest site boundary and less than $5 \mu \mathrm{g} / \mathrm{m}^{3}$ at the nearest residence in the direction of a prevailing wind. Such increases would not lead to any of the standards being exceeded (Table 2.3-12), even though the annual average at the nearest site boundary would be close in this highly conservative simulation. The highest 24 -h average concentration at the nearest site boundary was simulated to increase by $140 \mu \mathrm{g} / \mathrm{m}^{3}$, which would exceed regulatory standards if the assumed construction practices actually occurred under flat terrain and no dust suppression measures were used. However, with dust suppression measures such as sprinkling, the maximum 24-h concentration increase would probably be less than $70 \mu \mathrm{g} / \mathrm{m}^{3}$ so that the simulated increases-when added to the background concentrations given in Table 2.3-13-would probably not exceed any ambient air quality standard. At the nearest residence in the direction of a prevailing wind (most affected nearby residence) the greatest simulated 24-h average increase in $\mathrm{PM}_{10}$ concentration was $80 \mu \mathrm{g} / \mathrm{m}^{3}$, which could exceed the standard by a small percentage, depending on the background value at the time. Note that it is unlikely that 20 ha (50 acres) would be excavated simultaneously for 6 months, and dust suppression measures would considerably reduce $\mathrm{PM}_{10}$ concentration. Because the excavation and earthwork activities would be temporary, no long-term deterioration of air quality would result from these activities.

Currently, the total area that is expected to be disturbed will be approximately 40 ha (100 acres). The hypothetical modeling was done for 20 ha (50 acres). At the scales and distances involved, a doubling of the surface area to be disturbed would 
increase the particulate matter concentration in the air at the nearest site boundary by a factor of 1.6. (The doubled emission amount is initially spread out over a doubled area, which increases dispersion and thus leads to an increase in the dust concentration of less than a factor of 2). Thus, if 40 ha (100 acres) is all disturbed at once and no dustsuppression measures are used, the highest 24-h average $\mathrm{PM}_{10}$ concentration at the nearest site boundary could increase from $140 \mu \mathrm{g} / \mathrm{m}^{3}$ as previously calculated to about $225 \mu / \mathrm{m}^{3}$. If this were to happen, dust suppression measures would have to be sufficient to reduce fugitive dust by a factor of 3 in order to remain within the ambient air quality standards at the nearest site boundary. Options for dust suppression include ensuring that appropriate sprinkling (watering) is used when needed, disturbing less than about 10 to 15 ha (25 to 47 acres) at any stage of construction, or a combination disturbing no more than 15 to 30 ha (37 to 74 acres) at any one time and sprinkling as needed.

\subsection{UTILITY CORRIDOR CONSTRUCTION}

The construction of $161-\mathrm{kV}$ power lines would require the clearing of 6 to 10 ha (15 to 25 acres) of predominantly second-growth hardwood forest. After clearing the forest, the corridor would be allowed to revegetate naturally or grass would be planted. Then, the corridor would be cut periodically (e.g., every 3 or 4 years) to prevent vegetation from growing tall enough to interfere with operation of the lines. Some species of forest wildlife would be reduced by the clearing, others might be relatively unaffected (e.g., wide-ranging herbivores and predators), while relatively few species (e.g., small, brush-inhabiting bird species) might benefit from the clearing. Literature on the impacts of power-line corridors on wildlife is extensively reviewed by the Nuclear Regulatory Commission (NRC) (1991, p. 4-60) and indicates that impacts have been neither significantly positive nor negative. The operation of power lines, even lines of much higher voltage than those planned for ANS, has not been shown to have significant electromagnetic impact on biota (NRC 1991, p. 4.60).

\subsection{RESOURCES COMMITTED}

Materials of construction, except those that can be salvaged or recycled, are irreversibly committed. Radioactively contaminated components from AlNS would become waste requiring permanent disposal. Construction would also result in a loss of land for the life of the project. The extent to which this land might become irretrievaliy or irreversibly lost would depend on proposed uses. As part of a national laboratory, it is likely that land occupied by ANS could be used for other comparable research facilities or for waste disposal. Because alternate sites exist for both purposes, irretrievable loss of land occupied by ANS would not pose long-term adverse impacts.

Construction of the ANS and associated facilities would eliminate small amounts of intermittent stream habitat in the headwaters of Melton Branch and Friendship Creek. These habitats may support amphibians and communities of aquatic invertebrates that are adapted to highly variable flows and desiccation. No fish are known to occupy the stream reaches that would be eliminated by ANS construction. If loss of downstream aquatic habitat were avoided by careful attention to controlling soil erosion, sedimentation, and spills of construction materials, no other irretrievable and irreversible commitments of aquatic resources would be expected.

\subsection{RADIOACTIVITY}

ANS would occup; land that was previously undisturbed with respect to operations of ORNL facilities; thus, there is little likelihood of hazardous materials being on the surface or below the surface at the ANS site as a result of prior activity. The potential 
exists for transport of materials through the environment from a facility, such as a burial ground, to the site; however, this possibility is precluded because of the locations of the burial grounds and waste disposal areas with respect to the ANS site. Descriptions of groundwater flow presented in Sect. 2 demonstrate that seepage from any of the burial grounds within the X-10 Site will be toward White Oak Creek, away from the ANS site. Consequently, no adverse impacts to workers would be expected as a result of exposure to radioactive or hazardous chemicals resulting from other previous or ongoing activities at ORNL. Some areas which may be used for laydown may require monitoring because they were previously disturbed or they are in the groundwater pathway of areas which may have been contaminated.

\subsection{CONSTRUCTION IMPACT CONTROL PROGRAM}

Construction-related impacts to water quality and aquatic blota will stem primarily from soll erosion, sedimentation, and chemical spills. These impacts are regulated under the CWA (Sect. 12.3.2), especially through Sect. 404 dredge and fill permits (issued by the COE), Aquatic Resources Alteration Permits, and NPDES permits for storm water runoff (both issued by the Tennessee Department of Environmental Control). Measures to control erosion and sedimentation will be based on BMPs already used for construction activities at ORNL. Details of the ANS BMPs will be developed and finalized as the design proceeds, but will likely include the construction of berms, maintenance of vegetated filter strips along creek banks, spraying to control dust, and the construction of silt curtains and settling basins to collect sediment-laden storm water runoff from cleared areas. Spills of oils and other construction chemicals will be controlled by the employment of the ORNL Spill Prevention Control and Countermeasures Plan (Sect. 12.7.5.2).

\subsubsection{Dust Suppression Measures}

Specifications of practices for reducing fugitive dust are often a part of the planning of construction activities to prevent construction-related violations of the ambient air quality standards for particulate matter. Reductions of fugitive dust can often be accomplished by scheduling construction activities so that excavation and earth-moving activities are minimized on days when the wind is unfavorable $[\mathrm{e} . \mathrm{g} .,<2 \mathrm{~m} / \mathrm{s}(3 \mathrm{mph})$ or $>7 \mathrm{~m} / \mathrm{s}(16 \mathrm{mph})]$ and no precipitation has occurred for more than a specified period (e.g., 2 or $3 \mathrm{~d}$ ). If such a procedure is unacceptable from a scheduling viewpoint, then the ground can be sprinkled with water, which greatly reduces fugitive dust. Finally, construction activities can be staged so that no more than about 10 ha ( 25 acres) would be disturbed by earth moving and excavation on any single day. Examples of tactics for reducing fugitive dust are as follows:

- Excavation or earth-moving operations shall be restricted to periods when surface wind speed is $>1.3 \mathrm{~m} / \mathrm{s}(3 \mathrm{mph})$ and from a direction which will not carry smoke or fugitive dust over any city; town; residential, recreational, commercial, or industrial area; navigable water; public road; or landing strip within $5 \mathrm{~km}$ ( 3.1 miles) of the site unless the soil has been wetted by natural precipitation or sprinkling machinery to the point where no fugitive dust is visible at the construction site.

- Excavation or earth-moving operations will not be conducted during periods of reduced visibility ( $<1$ mile) caused by blowing dust.

- Fixcavation or earth-moving operations shall not be initiated until at least $0.5 \mathrm{~h}$ after sunrise and will be concluded by at least $0.5 \mathrm{~h}$ before sunset.

- Excavation or earth-moving operations will not be conducted during any lowaltitude inversion condition.

- Earth-moving or excavation operations will not be conducted during periods of local air quality advisories/alerts. 


\subsection{REFERENCES FOR SECTION 4}

DOE (U.S. Department of Energy) 1990. The Spill Prevention, Control, Courtermeasures', and Contingericy Plans for the Oak Ridge National Laboratory, ORNL/M-1032, Oak Ridge National Laboratory, Oak Ridge, Tenn., January.

EPA (U.S. Environmental Protection Agenoy) 1987. Industrial Source Complex (ISC) Dispersion Model User's Guide-2d ed., rev., EPA-450/4-88-002a and 002b (Vols. 1 and 2), EPA Office of Air Quality Planning and Standards, Research Triangle Park, Ruloigh, N.C.

EPA (U.S. Environmental Protection Agency) 1988. Gap Filling for PM-10 Emission Factors for Selected Open Area Dust Sources, EPA-450/4-88-003, Research Triangle Park, Raleigh, N.C.

Kroodsma, R. L. 1985. Ecological Characterization of Terrestrial Biota of the Proposed Solid Waste Storage Area (SWSA) 7, unpublished report, Oak Ridge National Laboratory, Oak Ridge, Tenn.

NRC (U.S. Nuclear Regulatory Commission) 1991. Generic Environmental Impact Statement for License Renewal of Nuclear Plants, NUREG.1437. 


\section{ENVIRONMENTAL EFFECTS OF FACILITY OPERATION}

\subsection{EFFECTS OF TYIE HEAT DISSIPATION SYSTEM}

\subsubsection{Effluent Limitations and Water Quality Standards}

Liquid effluents from Dak Ridge National Laboratory (ORNL) are regulated under the Clean Water Act (Sect. 12.3.1). The Tennessee Department of Environmental Control (TDEC) is authorized to implement the Ternessee Watcr Quality Control Act of 19\%7, which establishes a state policy to maintain reasonable standards of water quality (Sect. 12.3.2). General Tennessee water quality critoria call for a maximum water temperature of $30.5^{\circ} \mathrm{C}\left(86.9^{\circ} \mathrm{F}\right)$ and a maximum temperature change of $3^{\circ} \mathrm{C}\left(37.4^{\circ} \mathrm{F}\right)$ or less relative to an upstream control point. Speciffe effluent limitations, monitoring requirements, and other conditions are determined by 'TDEC for ORNL and are described in the ORNL National Pollutant Discharge Elimination System (NPDES) permit. This permit authorizes ORNL facilities to discharge liquid effluents to receiving waters of White Oak Creek, Melton Branch, and other tributaries in the White Oak Creek watershed.

The ORNL NPDES permit (TN0002941) expired on March 31, 1991, but because a permit renewal application has been filed, ORNL is qualified to operate under the guidelines of the old permit until the regulatory agency acts on the new application (Borders et al. 1991, p. 31). December 1991, Tennessee Water Quality Standards state that receiving streams (i.e. White Oak Creek and Melton Branch) ternperatures should not exceed $3^{\circ} \mathrm{C}\left(37.4^{\circ} \mathrm{F}\right)$ relative to an upstream control point. Temperattre of the stream shall not exceed $30.5^{\circ} \mathrm{C}\left(86.9^{\circ} \mathrm{F}\right)$.

The NPDES permit under which ORNL presently operates allows cooling tower blowdown to be discharged at a daily maximum temperature of $38^{\circ} \mathrm{C}\left(100^{\circ} \mathrm{F}\right)$ and a daily average temperature of $35^{\circ} \mathrm{C}\left(95^{\circ} \mathrm{F}\right)$. Residual chlorine is allowed at a daily maximum concentration of $0.2 \mathrm{mg} / \mathrm{L}$. However, discharge temperature limitations for cooling tower discharges are expected to be lower in the new ORNL NPDES permit, perhaps with maximum temperatures as low as $30.5^{\circ} \mathrm{C}\left(86.9^{\circ} \mathrm{F}\right.$ ) (C. K. Valentine, Environmental Compliance Section, ORNL, Oak Ridge, Tennessee, personal communication to G. F. Cada, ORNL, Oak Ridge, Tennessee, Oct. 9, 1991). Also, it is the position of the ORNL Environmental and Compliance Section that all new sources of aqueous discharges be dechlorinated before discharge to levels that are not toxic to aquatic organisins. Therefore, it is assumed for the purpose of this analysis that Advanced Neutron Source (ANS) cooling tower blowdown would be dechlorinated and discharged at a maximum temperature of $30.5^{\circ} \mathrm{C}\left(86.9^{\circ} \mathrm{F}\right)$.

Concentrations of water quality constituents in upper Melton Branch, ORNL potable water, and in the ANS cooling tower blowdown are given in Table 5.1-1. Biological effects of these discharges are discussed in Sect. 5.1.3.

\subsubsection{Physical Effects on Surface Water}

This section discusses increased temperatures in the east fork of Melton Branch that would be caused by the discharge of cooling tower blowdown from ANS. Cumulative temperature increases in Melton Branch caused by blowdown from both ANS and the High Flux Isotope Reactor (HFIR) are also summarized. The headwaters of Melton 
Table 5.1-1. Concentrations of water quality constituents of upper Melton Branch, Oak Ridge National Laboratory (ORNL) potable water, and projected Advanced Neutron Source (ANS) cooling tower blowdown

\begin{tabular}{|c|c|c|c|}
\hline & $\begin{array}{c}\text { Upper } \\
\text { Melton } \\
\text { Branch } \\
\text { (Site MEK 1.8) }\end{array}$ & $\begin{array}{l}\text { Potable } \\
\text { water }^{b}\end{array}$ & $\begin{array}{l}\text { ANS } \\
\text { cooling } \\
\text { tower } \\
\text { blowdownc }\end{array}$ \\
\hline \multicolumn{4}{|c|}{ Conventional parameters ( $m g / L)$} \\
\hline $\begin{array}{l}\text { Ammonia nitrogen } \\
\text { Biochemical oxygen demand, 5-day } \\
\text { Chlorine, total residual } \\
\text { Conductivity }(\mu \mathrm{S} / \mathrm{cm}) \\
\text { Dissolved solids } \\
\text { Fluoride } \\
\text { Nitrate } \\
\text { Oil and grease } \\
\text { pH } \\
\text { Phosphorus } \\
\text { Sulfate } \\
\text { Suspended solids } \\
\text { Turbidity }\end{array}$ & $\begin{array}{l}<0.2(\text { all }<0.2) \\
<5(\text { all }<5) \\
0 \\
231(118-262) \\
158(118-266) \\
0.1(0.0-0.2) \\
0.04(<0.005-1.1) \\
<2(\text { all }<2) \\
7.9(7.5-8.1) \\
0.012(0.003-0.152) \\
12.1(6.8-16.4) \\
8(<5-159) \\
6.4(2.5-32)\end{array}$ & $\begin{array}{l}\cdot \\
1.51 \\
310 \\
154 \\
- \\
0.365 \\
- \\
7.2 \\
0.291 \\
18.0 \\
<2 \\
-\end{array}$ & $\begin{array}{c}- \\
0 \\
1085 \\
539 \\
. \\
1.278 \\
-\overline{-} \\
6-9 \\
1.019 \\
63.0 \\
<7 \\
-\end{array}$ \\
\hline \multicolumn{4}{|c|}{ Metals and organics $(\mu g / L)$} \\
\hline $\begin{array}{l}\mathrm{Al} \\
\mathrm{Cd} \\
\mathrm{Cr} \\
\mathrm{Cu} \\
\mathrm{Fe} \\
\mathrm{Pb} \\
\mathrm{Mn} \\
\mathrm{Hg} \\
\mathrm{Ni} \\
\mathrm{Zn}\end{array}$ & $\begin{array}{l}39 \\
0.05(0.01-0.59) \\
0.41(0.17-1.5) \\
0.82(0.30-2.1) \\
97(47-578) \\
0.70(0.2-5.7) \\
12 \\
0.003(<0.001-1.19) \\
3.1(0.1-16) \\
0.52(0.19-56)\end{array}$ & $\begin{array}{r}<100 \\
<2 \\
<20 \\
20 \\
120 \\
<2 \\
<10 \\
<1 \\
144\end{array}$ & $\begin{array}{r}<350 \\
<7 \\
<70 \\
70 \\
420 \\
<7 \\
<35 \\
<4 \\
- \\
504\end{array}$ \\
\hline Polychlorinated biphenyls & $<0.5$ (all $<0.5)$ & - & - \\
\hline
\end{tabular}

"Source: Loar, J. M. (ed.) 1991. Fifth Annual Report on the ORNL Biological Monitoring and Abatement Program, Oak Ridge National Laboratory, Oak Ridge, Tenn.

Source: Health and Environmental Analysis Report for ORNL potable water, sample date 4/2/90. Personal communication from C. K. Valentine, ORNL, Oak Ridge, Tenn., to G. F. Cada, ORNL, Oak Ridge, Tonn., October 11, 1991.

Values in this column represent potable water concentrations multiplied by 3.5 to reflect concentration of these constituents by evaporation in the ANS cooling towers. 
Branch are displayed in Fig. 5.1-1 (also see Fig. 2.2-3). Four tributaries coalesce to form the main channel of Melton Branch. These tributaries are denoted in Fig. 5.1-1 as the east, central, and west forks. The U.S. Geological Survey (USGS) has installed a gaging station on the fourth tributary that is denoted as the USGS fork in Fig. 5.1-1. ANS is located on the east fork of Melton Branch. HFIR is located further downstream on Melton Branch proper. Both facilities would discharge heated blowdown into the Melton Branch watershed, which would cause increased water temperatures.

Cooling tower blowdown would be discharged from ANS into the east fork of Melton Branch at a rate of approximately $33 \mathrm{~L} / \mathrm{s}$ ( $525 \mathrm{gal} / \mathrm{min}$ ) (Sect. 5.1.3), having a maximum effluent temperature of $30.5^{\circ} \mathrm{C}\left(86.9^{\circ} \mathrm{F}\right)$ [future expected NPDES permit limitation (Sect. 5.1.1)]. Measured discharge rates and temperatures can be used to estimate the thermal effects of ANS blowdown on the Melton Branch watershed. Table 5.1-2 summarizes the mean monthly discharges and daily temperatures that have been measured in the head'vaters of Melton Branch. The period of record for the discharge data is approximately 3 years. All four sets of recorded temperatures are displayed in Tahle 5.1-2. The average mean monthly discharge in the east fork of Melton Branch was $12.7 \mathrm{~L} / \mathrm{s}$ (202 $\mathrm{gal} / \mathrm{min})$. The mean monthly discharge ranged from a minimum of $0.28 \mathrm{~L} / \mathrm{s}(4.5 \mathrm{gal} / \mathrm{min})$ to a maximum of $55.6 \mathrm{~L} / \mathrm{s}(882 \mathrm{gal} / \mathrm{min})$. The water temperature varied from 8.6 to $20.4^{\circ} \mathrm{C}\left(47.5\right.$ to $\left.68.7^{\circ} \mathrm{F}\right)$. Similar measurements reported for the remaining three Melton Branch tributaries appear in Table 5.1-2.

Table 5.1-3 contains water temperatures that would be realized in the east fork of Melton Branch caused by the increased heat load imposed by ANS cooling tower blowdown. During the winter and spring, the natural flow in the east fork of Melton Branch would reduce the temperature of the ANS cooling tower blowdown by 2.8 to $13.7^{\circ} \mathrm{C}\left(5.0\right.$ to $\left.24.7^{\circ} \mathrm{F}\right)$. However, during the summer and fall, when the flow is sustained by groundwater discharge (e.g., base flow), the blowdown temperature would not be reduced. The maximum water temperature that would then occur in the east fork of Meiton Branch would be the NPDES permit limit for ANS cooling tower blowdown, which is $30.5^{\circ} \mathrm{C}\left(86.9^{\circ} \mathrm{F}\right)$.

The water temperatures calculated in Table 5.1-2 and the remainder of this section were calculated using a steady flow energy balance that assumes complete mixing. Evaporation and evaporative cooling, which are secondary effects, have been neglected. The predicted temperatures are slightly higher than would actually occur. Alterations to the natural steam-flow hydrograph (discharge versus time history) caused by urbanization (installation of parking lots, storm sewers, gutters, drainage ditches, etc.) have not been considered. These alterations to the hydrograph would manifest themselves as increased peak flows during precipitation events. These peak flows would be reduced by the installation of a storm water retention basin which would control the rate at which rainwater entered the Melton Branch watershed from ANS.

Additional cooling takes place downstream from ANS as Melton Branch forms from its tributaries (see Fig. 5.1-1). Water temperatures that would occur below the confluence of the four tributaries and ANS, but above HFIR, are contained in Table 5.1-4. During minimum flow conditions, additional water temperature reductions (the difference between the temperatures in Tables 5.1-3 and 5.1-4) would be less than $1^{\circ} \mathrm{C}\left(1.8^{\circ} \mathrm{F}\right)$. Increased temperature reductions ranging from 3 to $8^{\circ} \mathrm{C}\left(5\right.$ to $\left.14^{\circ} \mathrm{F}\right)$ occur on the average, slightly smaller temperature reductions occur during storms because of the relatively large cooling of ANS blowdown that has already occurred in the east fork of Mífelion Bianch bcforc its conflicence with the remaining three tributaries.

Water temperatures in Melton Branch below HFIR are listed in Table 5.1-5 which account for the blowdown from both ANS and HFIR. Blowdown from HFIR is 


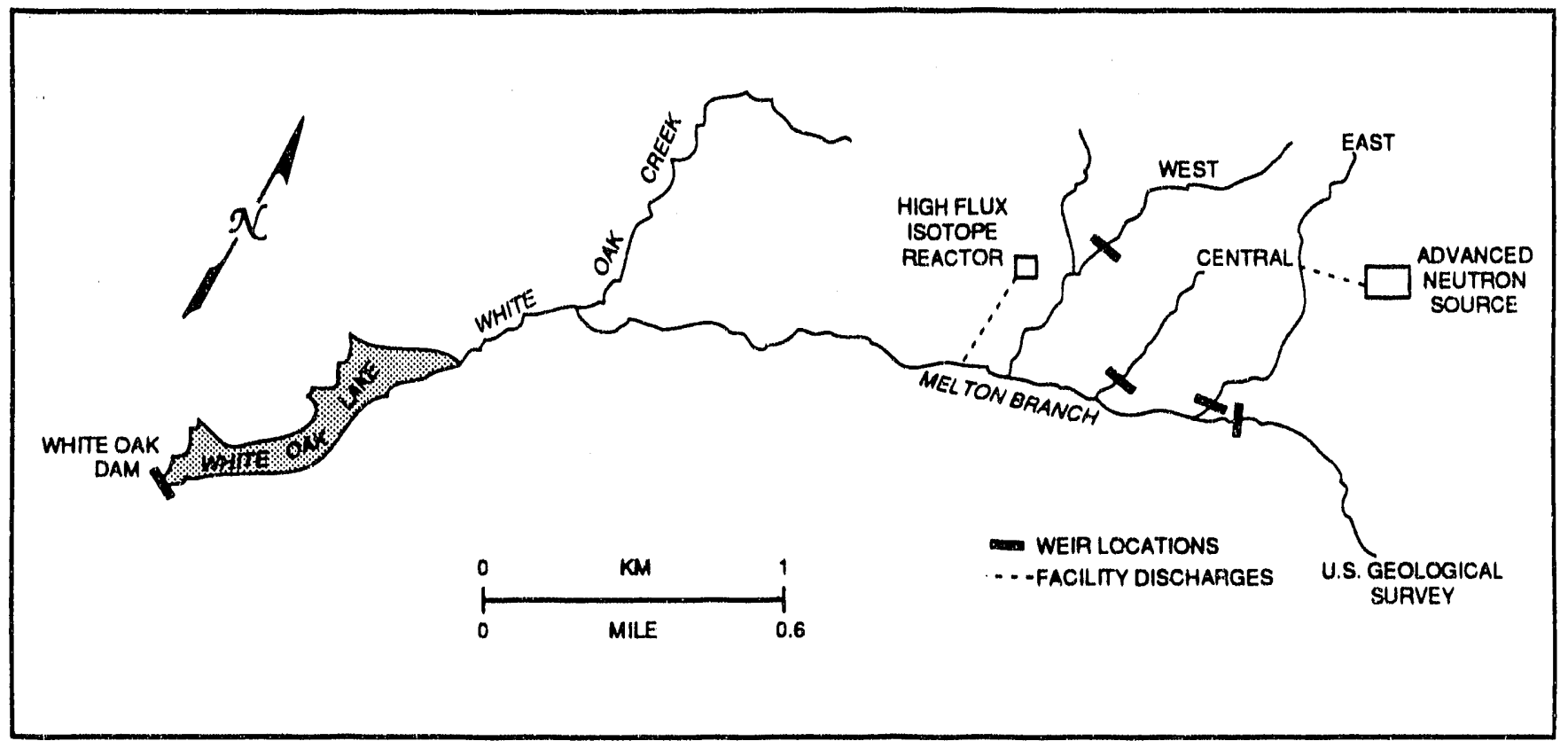

Fig. 5.1-1. The four tributaries of Melton Branch in relation to the Advanced Neutron Source and the High Flux Isotope Reactor. 


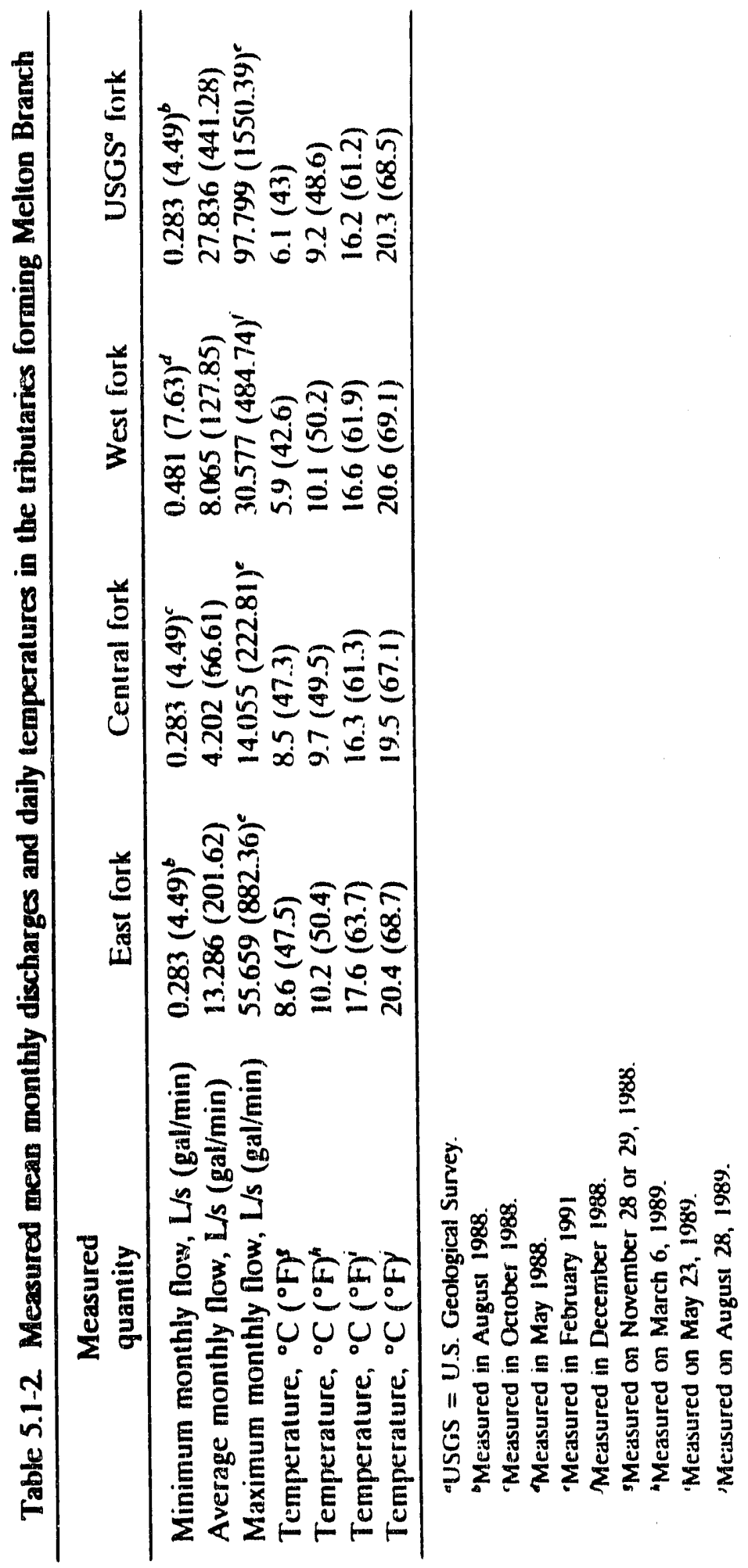


Table 5.1-3. Calculated water temperatures in the east fork of Melton Branch downstream from the Advanced Neutron Source (ANS) that consider effects from the cooling tower blowdown heat load and flow"

\begin{tabular}{|c|c|c|c|}
\hline \multirow{2}{*}{$\begin{array}{c}\text { East fork of } \\
\text { Melton } \\
\text { Branch } \\
\text { temperature } \\
{\left[{ }^{\circ} \mathrm{C}\left({ }^{\circ} \mathrm{F}\right)\right]}\end{array}$} & \multicolumn{3}{|c|}{$\begin{array}{l}\text { Water temperature as a function of the East } \\
\text { fork of Melton Branch discharge } \\
\left.\qquad{ }^{b} \mathrm{C}\left({ }^{\circ} \mathrm{F}\right)\right]\end{array}$} \\
\hline & $\begin{array}{l}\text { Minimum } \\
\text { discharge }^{c}\end{array}$ & $\begin{array}{c}\text { Mean } \\
\text { discharge }^{d}\end{array}$ & $\begin{array}{l}\text { Maximum } \\
\text { discharge }^{t}\end{array}$ \\
\hline 8.6 & $.31(86.5$ & $24.42(7$ & 10.1 \\
\hline $10.2(50.4)$ & 30.33 (86.59) & $24.87(76.77)$ & $17.77(63.99)$ \\
\hline $17.6(63.7)$ & $30.39(86.70)$ & $26.92(80.46)$ & $22.41(72.34)$ \\
\hline $20.4(68.7)$ & $30.41(86.74)$ & $27.70(81.86)$ & $24.17(75.51)$ \\
\hline
\end{tabular}

aCooling tower blowdown flow rate and temperature are $33.117 \mathrm{~L} / \mathrm{s}(525$ $\mathrm{gal} / \mathrm{min}$ ) and $30.5^{\circ} \mathrm{C}\left(86.9^{\circ} \mathrm{F}\right.$ ) (maximum allowable), respectively.

Total flow $=$ East fork of Melton Branch discharge + ANS blowdown.

Water temperature calculated using a steady flow energy balance.

Minimum discharge $=0.283 \mathrm{~L} / \mathrm{s}(4.49 \mathrm{ga} / \mathrm{min})$.

Mean discharge $=13.286 \mathrm{~L} / \mathrm{s}(201.62 \mathrm{gal} / \mathrm{min})$.

Maximum discharge $=55.659 \mathrm{~L} / \mathrm{s}(882.36 \mathrm{gal} / \mathrm{min})$.

Table 5.1-4. Calculated water temperatures in the main channel of Melton Branch, upstream from the High Flux Isotope Reactor

\begin{tabular}{|c|c|c|c|}
\hline \multirow[b]{2}{*}{ Future date } & \multicolumn{3}{|c|}{$\begin{array}{l}\text { Water temperature as a function of Melton } \\
\text { Branch discharge } \\
{\left[{ }^{\circ} \mathrm{C}\left({ }^{\circ} \mathrm{F}\right)\right]}\end{array}$} \\
\hline & $\begin{array}{l}\text { Minimum } \\
\text { discharge }^{b}\end{array}$ & $\begin{array}{c}\text { Mean } \\
\text { discharge }^{c}\end{array}$ & $\begin{array}{l}\text { Maximum } \\
\text { discharge }^{d}\end{array}$ \\
\hline Nov. 28 or 29 & $29.59(85.26)$ & $15.97(60.75)$ & $10.32(50.58)$ \\
\hline March 6 & $29.70(85.46)$ & $17.67(6.81)$ & $12.64(54.75)$ \\
\hline May 23 & $29.97(85.95)$ & $21.96(71.53)$ & $18.64(65.55)$ \\
\hline Aug. 28 & $30.10(86.18)$ & $24.23(75.61)$ & $21.78(71.20)$ \\
\hline
\end{tabular}

Includes blowdown flow and heat load from the Advanced Neutron Source. Water temperature calculated using a steady flow energy balance.

'Minimum discharge $=34.448 \mathrm{~L} / \mathrm{s}(546.10 \mathrm{gal} / \mathrm{min})$.

${ }^{c}$ Mean discharge $=85.938 \mathrm{~L} / \mathrm{s}(1362.36 \mathrm{gal} / \mathrm{min})$.

Maximum discharge $=231.207 \mathrm{~L} / \mathrm{s}(3665.30 \mathrm{gal} / \mathrm{min})$. 


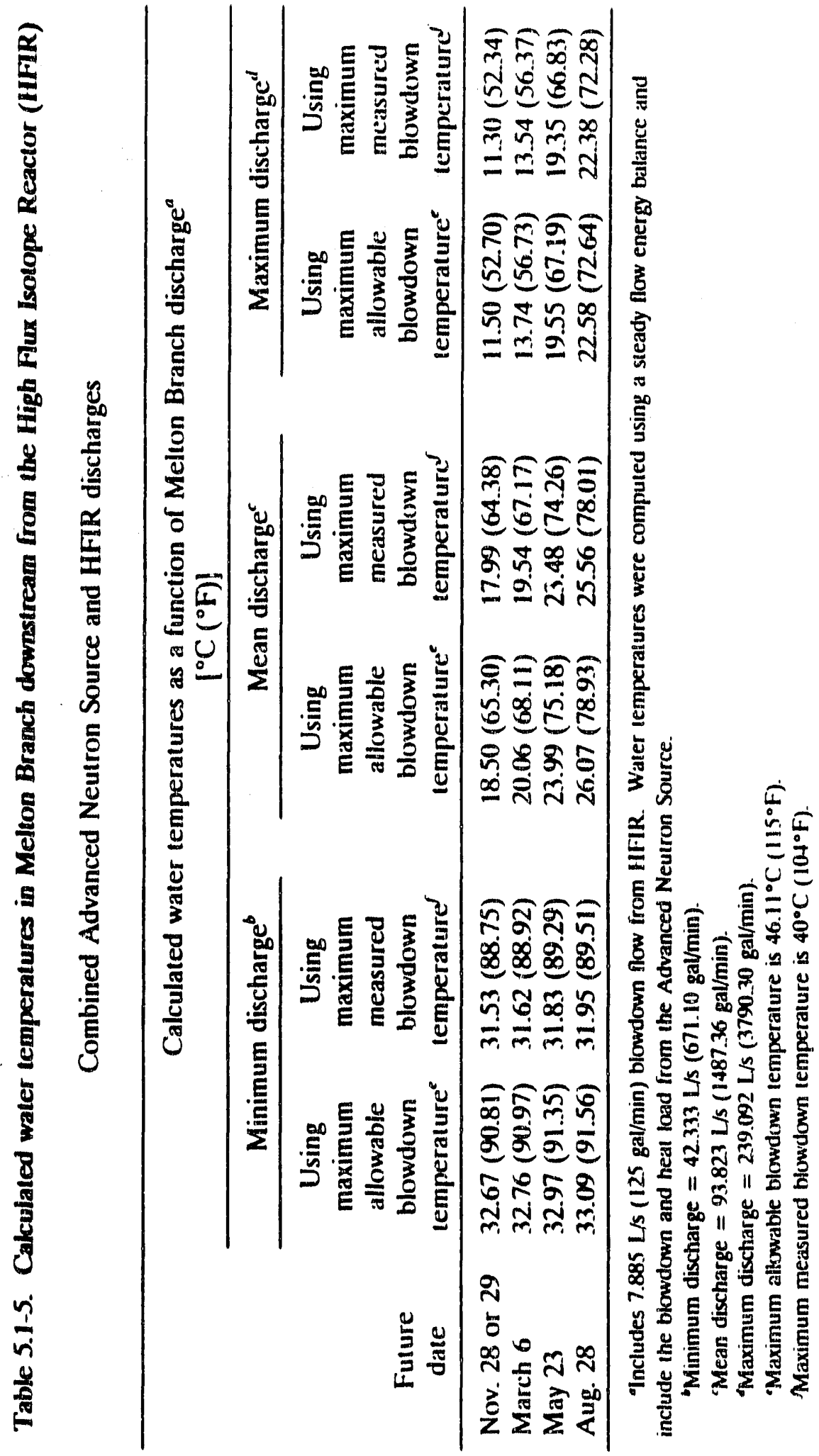


discharged at a rate of $7.9 \mathrm{~L} / \mathrm{s}(125 \mathrm{gal} / \mathrm{min})$ having a maximum allowable temperature of $46.1^{\circ} \mathrm{C}\left(115^{\circ} \mathrm{F}\right)$. Maximum recorded HFIR blowdown temperatures are generally less, being approximately $40^{\circ} \mathrm{C}\left(104^{\circ} \mathrm{F}\right)$, because of evaporative cooling that occurs between the discharge outfall and the actual location where the blowdown enters Melton Branch. During normal and stormy conditions, the increased heat load on Melton Branch from HFIR would not cause the $30.5^{\circ} \mathrm{C}\left(86.9^{\circ} \mathrm{F}\right)$ future expected NPDES permit limitation to be exceeded. However, the permit limitation would be exceeded by as much as $2.5^{\circ} \mathrm{C}$ $\left(36.5^{\circ} \mathrm{F}\right)$ during low-flow conditions, based on the maximum allowable blowdown temperature.

\subsubsection{Biological Effects}

An estimated $150 \mathrm{~L} / \mathrm{s}(2500 \mathrm{gal} / \mathrm{min})$ of potable water would be used by the ANS cooling towers. This figure represents a $22 \%$ increase in the rate of water withdrawal from the Clinch River by the U.S. Department of Energy (DOE) Water Treatment Plant, which supplies all ORNL potable water (Kasten 1986, p. 2). The additional water use would be well within the capability of the treatment plant, which operates at about $55 \%$ capacity. Although fish entrainment and impingement have not been studied at this facility, significant entrainment effects on fish populations from the increased water withdrawals are not anticipated. Even with the additional ANS cooling tower needs, total withdrawals at the DOE Water Treatment Plant would be approximately $830 \mathrm{~L} / \mathrm{s}$ $(13,200 \mathrm{gal} / \mathrm{min})$. This water withdrawal rate is larger than those of other public water supply systems in the vicinity (Kasten 1986, p. 11), but much smaller than those of nearby Tennessee Valley Authority (TVA) steam-electric power plants (Kasten 1986, p. 12). For example, TVA's Bull Run Steam Plant is located on the Clinch River $10.4 \mathrm{~km}$ (6.5 miles) upstream of the DOE Water Treatment Plant and withdraws an average of $25,000 \mathrm{~L} / \mathrm{s}$ (396,300 gal/min). Similarly, the Kingston Steam Plant, $62.9 \mathrm{~km}$ (39.1 miles) downstream, withdraws an average of $61,300 \mathrm{~L} / \mathrm{s}(971,700 \mathrm{gal} / \mathrm{min})$. It is not likely that entrainment rates of aquatic organisms at intakes with water withdrawal rates as small as the DOE Water Treatment Plant are low, and incremental entrainment from the additional withdrawal of water to supply ANS cooling towers is not expected to be significant. Also, because of the low overall water withdrawal rate, impingement of fish from the Clinch River is not expected to be a significant problem. Additional water withdrawals for ANS should not affect aquatic biota or habitat in the Clinch River.

Discharge of blowdown from the ANS heat dissipation system could affect aquatic communities. Owing to evaporation and drift, the discharge rate of blowdown would be smaller than the withdrawal rate; blowdown is expected to be discharged at a rate of approximately $33 \mathrm{~L} / \mathrm{s}(525 \mathrm{gal} / \mathrm{min})$. The temperature of the blowdown would be elevated above ambient stream temperatures, and dissolved water quality constituents would be concentrated as a result of cycling within the cooling towers (Sect. 5.1.1). Further, chemicals would be added to control biofouling and corrosion that would be discharged in the blowdown (Sect. 3.6).

A maximum blowdown discharge temperature of $30.5^{\circ} \mathrm{C}\left(86.9^{\circ} \mathrm{F}\right)$ would not exceed the upper lethal temperature limit of the most common fish that inhabits the upper reaches of Melton Branch, the creek chub (Semotilus atromaculatus). The upper lethal temperature for this species is around $31.5^{\circ} \mathrm{C}\left(88.7^{\circ} \mathrm{F}\right.$ ) (NAS 1972 , pp. $\left.4-10-19\right)$. Creek chub would be able to tolerate water temperatures in upper Melton Branch, even under low-natural stream flows when ANS discharges dominate (Sect. 5.1.2). Cada (1986) recorded the highest density and standing crop of creek chubs in Melton Branch at a site influenced by the heated HFIR discharge; temperature at that site was $30.5^{\circ} \mathrm{C}\left(86.9^{\circ} \mathrm{F}\right)$. 
On the other hand, a maximum blowdown discharge temperature of $30.5^{\circ} \mathrm{C}\left(86.9^{\circ} \mathrm{F}\right)$ would be greater than the upper lethal temperature limit of blacknose dace (Rhinichthys atratulus), estimated to be $29.3^{\circ} \mathrm{C}\left(84.7^{\circ} \mathrm{F}\right)$ (NAS 1972, pp. 4-10-19). As a result, populations of this minnow species might be limited in the immediate vicinity of the ANS cooling tower discharge. Sublethal elevated temperatures could inhibit the growth or reproduction of these species (NAS 1972). Warmer temperatures might eliminate or reduce the numbers of cool-water benthic invertebrates such as stoneflies in currently unimpacted areas of Melton Branch. Other taxa (e.g., some dipteran genera) might be similarly affected. Reduction in taxonomic richness among the benthic invertebrate communities could reduce the food base for the two minnow species in Melton Branch.

The combined heated discharges from ANS and HFIR could elevate temperatures to $32^{\circ} \mathrm{C}\left(90^{\circ} \mathrm{F}\right)$ or more in the middle reach of Melton Branch under conditions of low natural flow (Sect. 5.1.2), which would exceed the Tennessee Water Quality Standard for temperature. These temperatures would be greater than those tolerated by both creek chub and blacknose dace, as well as by many benthic invertebrates. Populations of these organisms would be reduced downstream from the confluence of these two heated discharges until cooling and dilution lowered water temperatures to tolerable levels.

Concentrations of most chemicals in the ANS blowdown (Table 5.1-1) should not exceed the tolerances of fish and many benthic invertebrates in Melton Branch. Chlorine has often been the most common chemical toxicant in ORNL discharges. As noted in Sect. 2.2.2.2, chlorine is a major cause of toxicity in White Oak Creek, which receives cooling tower blowdown from the main ORNL site. Toxic effects of chlorine on aquatic biota in Melton Branch could be avoided if ANS discharges were to be dechlorinated in order to comply with the ORNL Environmental and Compliance Section's position on discharge of chlorinated water to ORNL surface streams (Rohwer 1989, p. 1-2). Although the conductivity and total dissolved solids levels (Table 5.1-1) in the ANS cooling tower blowndown are not expected to adversely affect aquatic biota, concentrations of particular consitutents (e.g., copper and nickel) may exceed toxicity values for freshwater organisms or federal water quality criteria (EPA 1986).

As noted in Sect. 2.2.2.1, populations of the two species of minnows in upper Melton Branch are probably limited by low flows. A continuous discharge of ANS blowdown would provide more reliable flows in Melton Branch and, as a result, could provide more habitat and enhance fish populations, assuming water temperatures and water quality are not limiting. Composition of the benthic invertebrate community might be altered to favor those species whose life cycles require relatively constant flows. However, if blowdown were to be discharged on an intermittent basis or cease for extended periods (e.g., during temporary facility shutdowns), stream flow in Melton Branch would return to pre-ANS levels. Fish and benthic invertebrate habitat would also return to pre-ANS levels. The additional fish normally supported by ANS discharges could be displaced downstream to areas of Melton Branch with constant stream flows, but benthic invertebrates in areas of upper Melten Branch subject to periodic drying would be lost.

Discharge of ANS blowdown to Friendship Creek would have similar impacts to those in upper Melton Branch. No fish were found in the survey of this small tributary to the Clinch River, but salamander larvae and a relatively diverse benthic invertebrate community were observed (Sect. 2.2.2.1). Assuming that discharge temperatures do not exceed upper lethal limits, and that the discharge has been dechlorinated to reduce toxicity, continuous discharges into Friendship Creek could provide more habitat for aquatic organisms whose life cycles require more constant stream flows. ANS blowdown 
would be quickly diluted in the Clinch River; thus, no effects on water quality and aquatic habitat in this river are expected.

\subsubsection{Potential Influence of the Proposed ANS Facility on Local Meteorology}

The influence of the proposed ANS facility on local meteorology would be small. Clearing of land and replacing trees with buildings and other structures can alter the local albedo (reflectivity of solar radiation), surface roughness, and evaporation in various ways, depending on exact locations. Because of the small size of the proposed facility, the usual "urbanization" effects (reduced evaporation, increased temperature, and decreased relative humidity) are expected to be minor.

The proposed cooling towers would be a local source of atmospheric water vapor and heat from convection over the warm water and from recondensation of water vapor as warm, moist air exiting the tower mixed with cooler, ambient air. Recondensation occurs quickly, forming a plume of small liquid water droplets that eventually re-evaporate and continue in the hydrologic cycle. The plume of water droplets can be thought of as a cloud and may have any of several effects, including shading to reduce locally the amount of solar radiation. The plume could extend to ground level and impair visibility or, in subfreezing temperatures, cause icing on exposed surfaces. Because no roads (except access roads) or highways are located near the proposed ANS site, effects of the cooling tower would not pose a safety hazard to the public.

\subsubsection{Impacts on Terrestrial Biota}

Salts in drift emissions from cooling towers have the potential to damage vegetation, including native plants and agricultural crops; hence, the impacts of cooling tower operation on vegetation have been extensively reviewed by the Nuclear Regulatory Commission (NRC) (1991, pp. 4-22-4-42). The review addresses the impacts of natural-draft and mechanical-draft cooling towers at nuclear plants. Such large cooling tower facilities have greater potential for significant impact than the small cooling towers that would be used at ANS. The review includes the scientific literature as well as annual environmental monitoring reports prepared by power companies for nuclear plant operation.

Cooling tower operation has not had significant impact on native vegetation or agricultural crops at nuclear plants. In one rare case, however, trees near mechanical-draft towers experienced severe damage, apparently during a period of unique meteorological conditions when the cooling towers were not operating properly. After corrective actions, such impacts no longer occurred. At several other nuclear plant sites, minor damage to nearby vegetation was noted. Apparently, there are no known instances of significant chronic impact on terrestrial biota caused by the operation of any type of cooling tower. Therefore, normal operation of the small ANS cooling towers would not be expected to have any significant impact on terrestrial biota, although vegetation in the immediate vicinity of the towers could be slightly damaged.

\subsection{RADIATION DOSE TO THE PUBLIC FROM ROUTINE OPERATIONS}

Operation of ANS would result in controlled releases of measured amounts of radioactive materials to the environment. Small fractions of this material would eventually

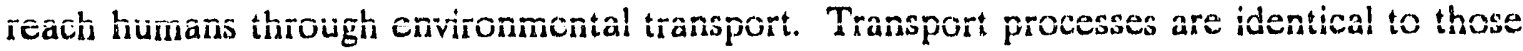




\section{$5-11$}

described in Sect. 2.8 which focuses on current radioactive releases and consequent doses from operations of the entire ORNL facility.

\subsubsection{Exposure Pathways}

Potential exposure pathways for effluents from the ANS facility are the same as from the presently operating ORNL site. However, under normal operating conditions the ANS facility would not actively discharge radioactive materials to surface waters. All liquids would be processed through the central liquid waste processing facility; consequently, the direct liquid pathway to the environment under normal operating conditions would be precluded. For this analysis, potential pathways are those that can follow atmospheric release plus direct radiation. Pathways, starting with release to the atmosphere, include: transport of radioactive materiais through the atmosphere; deposition into water and on soil; direct uptake through drinking water; exposure to dust; uptake by animal and plant life forms and subsequent exposure of humans through dermal absorption and ingestion; and finally direct exposure from materials deposited on the ground, radioactive gases in the air, or from "skyshine." Skyshine could occur, for example, if neutrons or gamma rays were to penetrate the reactor structure vertically, and these radiations werc subsequently scattered by air particles to people on the ground. Because of the remote location of ANS, any skyshine would likely be limited to on-site personnel.

Exposure pathways for normal operation of ANS are modeled exactly the same as for other sources at ORNL, which were described in Sect. 2.8. However, for clarity, selected calculational parameters and assumptions are described in the following paragraphs.

\subsubsection{Calculational Parameters and Assumptions}

Radiation doses were calculated using the CAP. 88 computer code required by the U.S. Environmental Protection Agency (EPA) for demonstration of compliance with federal law (10 CFR Pt. 61). Doses were calculated for a hypothetical maximally exposed person off-site and for persons living within $80 \mathrm{~km}$ (50 miles) of the ANS facility. A number of factors and assumptions were required and some of the major ones are as follows:

- Exposure time was assumed to be 1 year.

- For the maximally exposed off-site individual, the annual exposure time to the plume and to soil contamination was 0.7 years based on Regulatory Guide 1.109 (NRC 1977).

- For both the maximally exposed individual and for population exposures, an infinite Gaussian plume model was used for air immersion doses. Other pathways evaluated were direct exposure from deposition onto the ground, inhalation, ingestion of food crops, and ingestion of animal productr. Some specific assumptions are that each person remains unprotected at home (outside the house) during the entire year and obtains food according to the rural pattern as defined in the National Emission Standards for Hazardous Air Pollutants (NESHAPS) (EPA 1989). The rural pattern specifies that $70 \%$ of the meat, and $39.9 \%$ of the milk consumed by each person are produced locally (e.g., home garden). The remaining portion of each food is assumed to be produced within 80-km (50-miles) of ANS. Production of beef, milk, and crons 
within the $80-\mathrm{km}$ (50-mile) radius of ANS were calculated using the state-specific production values provided with CAP-88.

- A stack height of $15 \mathrm{~m}(50 \mathrm{lt})$ was used with an assumed exit velocity of $5 \mathrm{~m} / \mathrm{s}(16$ $\mathrm{ft} / \mathrm{s}$ ). Meteorology was based on 1989 data from the A-30 tower (see Sect. 2.3). Doses were calculated on the basis of 50-year dose commitments per 1 year of intake.

- Resuspension of particulates was not considered because this pathway is negligible compared with other pathways.

\subsection{Health Effects Calculations}

Doses calculated by CAP-88 were used to estimate health effects according to risk models recommended by the Biological Effects of Ionizing Radiation V committee (NAS 1990). The upper limit incremental cancer fatalities in a population due to radiation exposure were estimated by multiplying the collective effective dose equivalent by $5 \times 10^{-4}$ fatal cancers per person-rem. The lower limit of this range is zero because there may be biological mechanisms that can repair damage caused by radiation at low doses or dose rates (NAS 1990). Excess herenlitary effects have an upper limit of 0.01 person-Sv $\left(1 \times 10^{-4}\right.$ person-rem) (lower limit of zero) using the collective dose equivalent to the gonads. Radiation-induced effects of this type have not been observed in any human populations, in contrast to excess malignancies that have been identified among populations receiving instantaneous and near-uniform exposures above $0.1 \mathrm{~Sv}$ (10 rem).

Health risk coefficients are applied only to collective doses because they were derived from populations of individuals and because the National Academy of Sciences (NAS) risk coefficients are for linear dose-response models.

\subsection{Source Terms}

Estimated source terms for atmospheric releases during normal operations of the ANS facility are presented in Tables 3.8-1, 5.11-4, and 5.11-5. Along with the amounts released, Table 5.11-4 presents solubility classes.

\subsubsection{Results of Dose Calculations}

The CAP- 88 computer code was used to estimate exposures to both the highest exposed individual and to the population. [Stack meteorological parameters used are: temperature $15^{\circ} \mathrm{C}\left(59^{\circ} \mathrm{F}\right)$, rainfall $152 \mathrm{~cm} /$ year $(59.8 \mathrm{in}$./year), mixing height $1000 \mathrm{~m}$ $(3281 \mathrm{ft})$, stack height $15 \mathrm{~m}(50 \mathrm{ft})$, stack diameter $2 \mathrm{~m}(6.6 \mathrm{ft})$, and exit velocity $5 \mathrm{~m} / \mathrm{s}$ $(16 \mathrm{ft} / \mathrm{s})$. It is anticipated that stack height may change as ANS undergoes design maturation. A higher stack will reduce the dose to the maximum exposed individual.] Because of meteorological conditions, the closest individual, assumed to be at Shoreline Estates, $2.8 \mathrm{~km}$ (1.7 miles) southeast of the site, is estimated to receive $0.0017 \mathrm{mSv} / \mathrm{year}$ ( $0.17 \mathrm{mrem} /$ year) whereas an individual at Gallaher Bend, $2.9 \mathrm{~km}$ (1.8 miles) eastnortheast of the site, could receive the greatest radiation dose of $0.0128 \mathrm{mSv} / \mathrm{year}$ (1.28 mrem/year). Of this $0.0128 \mathrm{mSv} /$ year ( $1.28 \mathrm{mrem} / \mathrm{year})$, ingestion provides $76 \%$ and tritium contributes $98 \%$ of the ingestion dose. Over all pathways, tritium contributes $93.7 \%$ of the dose and ${ }^{133} \mathrm{Xe}$ contributes $4.6 \%$. The maximum individual doses calculated are below applicable federal law specified in $10 \mathrm{CFR} \mathrm{Pt}$. 61 as $0.1 \mathrm{mSv} / \mathrm{year}$ (10 mrem/year). Currently, the Oak Ridge Reservation (ORR) releases of radioactive 
materials to the atmosphere that annually result in 50-year committed effective dose equivalent (EDE) of $0.02 \mathrm{mSV}(2 \mathrm{mrem})$ to maximally exposed individuals. This hypothetical individual is near the Y-12 Plant. Alrborne releases from operation of the ANS facility would result in a radiation dose less than the present EDE of $0.02 \mathrm{mSv} / \mathrm{year}$ ( 2 mrem/year) to any individual as now occurs from overall operation of ORR. As a consequence, the ANS facility should have negligible impact on compliance with respect to the NESHAPS for Radionuclides (10 CFR Pt. 61).

Estimates of population dose were also obtained using the CAP.88 code. For persons residing within $80 \mathrm{~km}$ (50 miles) of the ANS site, the annual International Commission on Radiological Protection (ICRP) collective effective dose equivalent is 431 person-Sv (4.31 person-rem). In addition, the collective dose equivalent to the gonads is 429 person-Sv (4.29 person-rem). Among the pathways, ingestion contributes $54 \%$ of the estimated dose, inhalation contributes $29 \%$, and air immersion $17 \%$. Tritium accounts for $88 \%$ of dose from all pathways and ${ }^{133} \mathrm{Xe}$ accounts for $12 \%$. Health effects resulting from the collective dose are estimated to be $2.2 \times 10^{.3}$ excess fatal cancers and $4.3 \times 10^{-4}$ excess heritable effects. These effect levels are extremely small and may be compared with spontaneous effects. In the year 2020 , approximately 3000 people will die annually from a fatal cancer and approximately 160 dominant genetic disorders may be observed annually in the at-risk population of 1.1 million persons projected to be located within $80 \mathrm{~km}$ (50 miles) of ANS (NAS 1990, pp. 70 and 176).

From the previous analysis, operation of the ANS facility should have insignificant and nondetectable impacts on the off-site population. Releases of tritium over White Oak Dam into the Clinch River are currently uncertain, but the maximum anticipated level would be about $1.1 \times 10^{14} \mathrm{~Bq}(3000 \mathrm{Ci})$. This level of tritium is currently being discharged over White Oak Dam. On the basis of measurements of radioactive materials in the nearest source of drinking water, Kornegay et al. (1991, pp. 188-189) concluded that the maximally exposed individual from tritium discharge would receive about $0.001 \mathrm{mSv} /$ year (0.1 mrem/year).

\subsection{EFFECIS OF CHEMICAL AND BIOCIDE DISCHARGES}

ANS could routinely discharge biocides and other nonradiological chemical contaminants to surface waters through four routes: (1) laundry and sanitary wastewaters, which would be treated by the ORNL Sewage Treatment Plant (STP) and discharged to White Oak Creek; (2) process wastewater, which would be treated by the ORNL Nonradiological Wastewater Treatment Facility (NRWTF) and discharged to White Oak Creek; (3) storm water runoff, which would be collected by storm water detention basins and discharged to Melton Hill Reservoir and upper Melton Branch; and (4) cooling tower blowdown, which would be discharged to either upper Melton Branch or Bearden Creek (Sect. 5.1.1).

Effects of sanitary waste discharges on aquatic communities in White Oak Creek are considered in Sect. 5.4.

Nonradiological process wastewaters would be piped to NRWTF for treatment before discharge to White Oak Creek. The estimated flow rate of process wastewater from ANS will be $1.8 \mathrm{~L} / \mathrm{s}(28.5 \mathrm{gal} / \mathrm{min})$, which would increase the present estimated

\footnotetext{
These include 40 clinically severe and 120 clinically mild autosomal dominant disorders (NAS 1990), using a birth rate of 15 per 1000 population.
} 
discharge of NRWTF of $22 \mathrm{~L} / \mathrm{s}$ (349 gal/min) (Loar 1991, pp, 2-11) by $8.2 \%$. Recent toxicity tests showed that the effluent from NRWTF was nontoxic to both fathead minnow (Pimephales promelas) larvae and the zooplankter Ceriodaphnia (Loar 1991, pp. 3-4). The chemical composition of process wastewaters from ANS has not been determined. However, assuming that these wastes could be treated adequately, the NRWTF effluent would continue to be nontoxic, and any impacts would be the result of increased flows in White Oak Creek. The combined discharge of treated NRWTF effluents of $23.8 \mathrm{~L} / \mathrm{s}$ [( $377 \mathrm{gal} / \mathrm{min})$ including the projected ANS contributions] represents $13 \%$ of the 1990 mean flow rate in White Oak Creek below the NRWTF outfall (site WCK 3.9 in Loar 1991, pp. 2-7). This increase in flow is small compared to seasonal and annual variations, and would not be expected to significantly alter aquatic communities in White Oak. Creek.

Storm water runoff from the ANS site could contain suspended sediments, small quantities of oils and greases from parking lots, and contaminants washed from building roofs and other structures. Plans presently call for the collection of storm water runoff in two detention basins: one on the north side of the site with a discharge to Friendship Creek (a tributary to the Clinch River) and another to collect runoff from the south side of the plant before discharge to upper Melton Branch. Collection of runotf in these basins would allow suspended sediments to settle out and would allow for monitoring for radiological and other contaminants. Collected runoff would be monitored before release into the creeks and contained and treated if necessary. Treatment might require that runoff be transferred to the Process Waste Treatment Plant (PWTP) (Sect. 5.11). Discharge of collected runoff from the detention basins would need to be controlled in order to minimize alteration of thermal regimes and hydrographs of the receiving streams. Effects of cooling tower blowdown on aquatic communities in Melton Branch are considered in Sect. 5.1.3.

There are no domestic water supplies within the Melton Branch and White Oak Creek watersheds. As a result, no effects on domestic water supplies are expected from the routine discharge of biocides and other chemicals from ANS. Collection of storm water runoff by detention ponds before discharge into Melton Hill Reservoir and Melton Branch would minimize the chance of any contamination reaching domestic water supplies from this source.

\subsection{EFFECTS OF SANITARY WASTE DISCHARGES}

Laundry and sanitary wastewaters are expected to be generated during construction and operation at a rate of $0.03 \mathrm{~L} / \mathrm{s}(0.5 \mathrm{gal} / \mathrm{min})$ and $3.1 \mathrm{~L} / \mathrm{s}(50 \mathrm{gal} / \mathrm{min})$, respectively. Both types of wastewaters would be piped to the Sewage Treatment Plant (STP) for treatment bsfore discharge to White Oak Creek. The combined wastewater flow of $3.1 \mathrm{~L} / \mathrm{s}(50 \mathrm{gal} / \mathrm{min})$ from these ANS sources would increase the STP discharge [present average discharge rate of $10.1 \mathrm{~L} / \mathrm{s}(160 \mathrm{gal} / \mathrm{min}) ; \mathrm{Loar} 1991, \mathrm{p} .2-11$ ] by $31 \%$. Recent toxicity tests (Loar 1991, p. 3-4) indicated that the treated STP effluent was usually nontoxic to fathead minnow larvae but sometimes moderately toxic to the zooplankter Ceriodaphnia. Conductivity, hardness, and alkalinity of the STP effluent were quite stable and well within the tolerance ranges for both minnows and Ceriodaphnia. Because laundry and sanitary wastewaters from ANS are not expected to be different in composition from those already treated by STP, additional impacts to aquatic biota in White Dak Creek would result only frorn the increased flows of treated effluents. A total discharge from STP of $13.2 \mathrm{~L} / \mathrm{s}(210 \mathrm{gal} / \mathrm{min}$ ) (including ANS contributions) represents $4 \%$ of the 1990 mean flow rate in White Oak Creek below the STP outfall (site WCK 3.54 in 
Loar 1991, p. 2-7). This increase is small compared to seasonal and annual variations in stream flows, and would not be expected to alter aquatic communities.

There are no domestic water supplies within the White Oak Creek watershed. As a result, no effects on domestic water supplies are expected from the increased discharge of treated STP effluent that would result from operation of ANS.

\subsection{EFFECTS OF OPERATION AND MAINTENANCE OF UTUITY CORRIDORS}

The effects of power line maintenance, corridor maintenance, and electromagnetic fields produced by power lines have been extensively reviewed by NRC (1991, pp. 4-50-72). Resources that might be impacted include air quality, land use, human health, surface water quality, aquatic ecology, terrestrial ecology, floodplains, wetlands, and cultural or historic resources.

Power line operation would cause the production of ozone and nitrogen oxides in small amounts that would have no significant impact on air quality. No existing land uses are present in the proposed corridor, so none would be affected. Electromagnetic fields from the $161 \mathrm{kV}$ power lines would not be strong enough to have any adverse effects on human health, vegetation, or wildlife. There is some controversy, however, as to whether electromagnetic fields affect human health.

No aquatic habitats would be directly affected by power line and corridor maintenance, although surface runoff and erosion from a dirt maintenance road on the corridor could increase turbidity and sedimentation in nearby streams. Vegetation and wildlife would be affected by periodic cutting of vegetation on the corridor. The wildlife community is not significantly impacted by such cutting, however, because the early successional vegetation on the corridor provides useful habitat. Wildlife impacts are minimized if cutting is not done during the bird nesting season. No wetlands, floodplains, or historic or cultural resources should be significantly affected by power line or corridor maintenance.

\subsection{OTHER EFFECTS}

\subsubsection{Noise}

The principal source of noise from operation of the ANS facility is cooling tower operation. Other occasional noise sources not expected during normal operation (such as loudspeakers used during construction) may be present, but will be less intense than cooling towers. Both natural-draft and meshanical-draft cooling towers emit noise of a broadband nature. Because of the broadband character of the cooling tower noise, it is inherently less obtrusive than, for example, loudspeaker noise. ANS would be a 330. MW( $f$ ) facility, thus requiring more than four times the cooling capacity of HFIR. The associated power output of noise would also be greater.

As mentioned in Sect. 2.8 and presented in map form in Sect. 2.1, the nearest human receptors to noise intrusion are approximately $2.8 \mathrm{~km}(1.7$ miles) SE away from the main ANS site. Further, most potential locations of the cooling towers will be such that intervening land masses would be between receptors and sources. Consequently, effects of noise generated at the ANS site during operation would be negligible. 


\subsubsection{Dispersion Estimates for Routine Operations}

Because the stack parameters and emissions are not yet specifled, a generic calculation was made for $1 \mathrm{~g} / \mathrm{s}$ of emissions from a $15 \cdot \mathrm{m}$ (50 ft) stack located on top of the

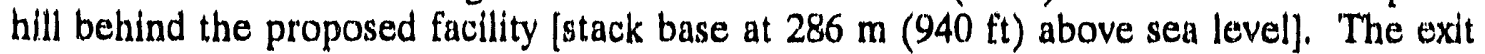
temperature was conservatively assumed to be $293 \mathrm{~K}$, the stack exit velocity was assumed to be $5 \mathrm{~m} / \mathrm{s}$, and the inside top diameter of the stack was assumed to be $2 \mathrm{~m}(7 \mathrm{ft}$ ). Meteorological data for 1989 from Tower 4 at $30 \mathrm{~m}$ (98 ft) were used in the calculations. Stability was calculated using the standard deviation of wind direction (sigma theta). Three different types of terrain were assumed. In the first case, complex terrain was modeled using the EPA-approved model VALLEY (EPA 1977, pp. 1-90). In the second case, terrain was input to another EPA-approved model, Industrial Source Complex, Short Term (ISCST), which models all terrain at elevations less than stack height and sets all higher terrain equal to stack height (i.e., a "chopped-terrain" model). In the third case, a flat-terrain version of ISCST was used. In all cases, a radial grid was used with rings at $500-\mathrm{m}(1641-\mathrm{ft})$ intervals. For the simulations including terrain, the receptor rings extended to $3,500 \mathrm{~m}(11,484 \mathrm{ft})$. In the ISCST flat-terrain simulation, rings of receptors extended to $10,000 \mathrm{~m}(32,810 \mathrm{ft})$.

At 3,500 $\mathrm{m}(11,484 \mathrm{ft})$, the ISCST flat-terrain model provided the most conservative results in general. For the annual average concentrations, ISCST with flat terrain provided the highest concentrations at $3,500 \mathrm{~m}(11,484 \mathrm{ft})$ in 12 of the 16 directions, and ISCST with chopped terrain provided the highest estimated average annual concentrations at $3,500 \mathrm{~m}(11,484 \mathrm{ft})$ the remaining 4 directions (i.e., VALLEY never provided the highest average annual concentrations at distances that far from the source). For the highest $24 \mathrm{hh}$ average, VALLEY provided the highest concentrations at $3,500 \mathrm{~m}(11,484 \mathrm{ft})$ in nine directions, and ISCST with flat terrain provided the highest concentrations in the remaining seven directions. The highest $24-\mathrm{h}$ concentrations, regardless of direction, were provided by ISCST with flat terrain.

The nearest site boundary is $2.1 \mathrm{~km}$ ( 1.3 miles) northeast of the proposed ANS site. The ISCST flat terrain model provided the highest annual and $24-\mathrm{h}$ averaged concentrations at the receptor located closest to the nearest site boundary, $2 \mathrm{~km}$ (1.2 miles) to the northeast. These annual and $24-\mathrm{h}$ average concentrations are summarized in Table 5.6-1.

The nearest significantly populated areas are $5.2 \mathrm{~km}$ ( 3.25 miles) to the northnorthwest, in the direction of Oak. Ridge, and $4.6 \mathrm{~km}$ ( 2.86 miles) to the east-southeast, near the intersection of Diggs Road and Lovelace Drive in west Knox County. The elevations of both locations are approximately the height of the stack base [ $286 \mathrm{~m}$ $(940 \mathrm{ft})]$. The ISCST model with flat terrain provided the highest annual average results at $3,500 \mathrm{~m}(11,484 \mathrm{ft})$ in the directions of the nearest populated areas. The VALLEY results at $3,500 \mathrm{~m}(11,484 \mathrm{ft})$ in both of these directions were about $0.02 \mu \mathrm{g} / \mathrm{m}^{3}$, or about half the amounts obtained at $5000 \mathrm{~m}(16,405 \mathrm{ft})$ (approximate distance to the nearest populated areas) in the same directions with the ISCST flat-terrain model. The ISCST flat-terrain model results for those directions at $5000 \mathrm{~m}(16,405 \mathrm{ft})$ are presented in Table 5.6-1 as the modeled annual average concentrations for the nearest populated areas.

The VALLEY model provided the highest $24-\mathrm{h}$ concentrations at $3,500 \mathrm{~m}$ $(11,484 \mathrm{ft})$ in the directions of the nearest populated areas. Another VALLEY simulation was therefore run with recep ors at $700-\mathrm{m}(2297-\mathrm{ft})$ intervals, to $4900 \mathrm{~m}(16,077 \mathrm{ft})$ (approximate distance to the populated areas) in these directions. The simulated concentrations at $4900 \mathrm{~m}(16,077 \mathrm{ft})$ in these directions werc still higher than ISCST flatterrain results at about the same distance $[5000 \mathrm{~m}(16,405)]$, so the VALLEY results for 
Table 5.6-1. Simulated concentrations of a neutrally buoyant pollutant ${ }^{a}$ at selected receptors on a radial grid centered at the proposed Advanced Neutron Source site

\begin{tabular}{lcccc}
\hline Averaging time & $\begin{array}{c}\text { Concentration } \\
\left(\mu \mathrm{g} / \mathrm{m}^{3}\right)\end{array}$ & Direction $^{b}$ & $\begin{array}{c}\text { Distance } \\
{[\mathrm{m}(\mathrm{ft})]}\end{array}$ & Model $^{c}$ \\
\hline & \multicolumn{2}{c}{ Receptor closest to the nearest site boundary } & \\
Annual & 1.33 & $\mathrm{NE}$ & $2000(6,562)$ & ISCST FT \\
$24 \mathrm{~h}$ & 9.64 & $\mathrm{NE}$ & $2000(6,562)$ & ISCST FT \\
& Receptors closest to nearest significantly populated areas & \\
Annual & 0.05 & ESE & $5000(16,405)$ & ISCST FT \\
Annual & 0.04 & NNW & $5000(16,405)$ & ISCST FT \\
$24 \mathrm{~h}$ & 2.73 & ESE & $4900(16,077)$ & VALLEY \\
$24 \mathrm{~h}$ & 2.94 & NNW & $4900(16,077)$ & VALLEY \\
$24 \mathrm{~h}$ & 1.05 & ESE & $5000(16,405)$ & ISCST FT \\
$24 \mathrm{~h}$ & 1.51 & NNW & $5000(16,405)$ & ISCST FT \\
\hline
\end{tabular}

Emitted at a rate of $1 \mathrm{~g} / \mathrm{s}$ from a $15-\mathrm{m}(50 \mathrm{ft})$ stack with inside top diameter $=2 \mathrm{~m}(7 \mathrm{ft})$, exit velocity $=5 \mathrm{~m} / \mathrm{s}$, and exit temperature $=293 \mathrm{~K}$.

${ }^{b} \mathrm{NE}=$ northeast, $\mathrm{ESE}=$ east-southeast, $\mathrm{NNW}=$ north-northwest.

FT indicates the flat-terrain version of Industrial Source Complex, Short Term (ISCST).

24-h concentrations are presented for the nearest populated areas. The ISCST flat-terrain results at $5,000 \mathrm{~m}(16,405 \mathrm{ft})$ in the same directions are also shown for comparison.

\subsection{RESOURCES COMMTTTED}

Operation of ANS would result in generation of large quantities of solid radioactive and nonradioactive waste that would require permanent disposal. Land devoted to this purpose would probably be irreversibly and irretrievably committed. Lowlevel radioactive waste (LLW) facilities might remain contaminated for up to 500 years. The highly-enriched depleted uranium fuel used by ANS would be irretrievable. If DOE were to decide to reprocess this depleted fuel, plutonium and other transuranic elements might be retrievable for other purposes.

Operation of the ANS cooling towers would result in an evaporative loss of approximately $117 \mathrm{~L} / \mathrm{s}(1875 \mathrm{gal} / \mathrm{min}$ ) of potable water (Sect. 5.1.3). Potable water is withdrawn from the Clinch River at the DOE Water Treatment Plant. The consumptive water use of $117 \mathrm{~L} / \mathrm{s}(1875 \mathrm{gal} / \mathrm{min})$ represents $17 \%$ of the present water withdrawals by the DOE Water Treatment Plant, and $0.1 \%$ of the mean annual flow of the Clinch River at Melton Hill Dam near ORNL (Sect. 2.4.1.1). Consumptive water use by ANS would not significantly decrease the amount of aquatic habitat in the Clinch River, but discharge 
of treated wastewater (primarily cooling tower blowdown) might provide additional aquatic habitat in presently intermittent reaches of Melton Branch and Friendship Creek.

Properly treated wastewater discharges are not expected to significantly degrade water quality or to have toxic effects on aquatic organisms in Friendship Creek, Melton Branch, and White Oak Creek.

Operation of ANS would result in the use of about $7,000 \mathrm{~kg}(16,000 \mathrm{lb})$ of highly enriched uranium fuel over the 25 -year life of the facility. About $17 \mathrm{~kg}(37 \mathrm{lb})$ of $95 \%$ enriched uranium fuel is used each time the reactor is refueled. Spent fuel contains only about $10.3 \mathrm{~kg}(22.7 \mathrm{lb})$ of ${ }^{235} \mathrm{U}$. Spent fuel is expected to be reprocessed, so the amount of ${ }^{235} \mathrm{U}$ consumed over the life of the ANS would be about $2200 \mathrm{~kg}(4800 \mathrm{lb})$.

Reprocessing the spent fuel would produce substantial quantities of high- and low-level radioactive wastes that would need permanent disposal. The amounts of these wastes produced in reprocessing are not known at this time, but they would be generated at the Savanah River Site, where the reprocessing would take place.

ANS would also consume substantial quantities of electricity, natural gas, and steam from the ORNL steam plant. Over the life of the facility, ANS would consume about $6 \times 10^{16} \mathrm{~J}\left(6 \times 10^{13} \mathrm{Btu}\right)$ of primary energy in various forms.

\subsection{DECOMMISSIONING AND DISMANTLING}

ANS facilities will be designed for eventual decommissioning as required by DOE Order 5820.2A (Radioactive Waste Management) and DOE Order 6430.1A (General Design Criteria). No facility similar to ANS has been decommissioned so the impacts of decommissioning cannot be extrapolated from other experiences. Phase 2 of this ER will address the expected impacts of decommissioning based on the details of the design and design features intended to facilitate decommissioning.

\subsection{THE URANIUM FUEL CYCLE}

The uranium fuel cycle is the cycle of production, use, and disposal of uranium fuel. The cycle begins with mining uranium ore, proceeds through various refining steps followed by enrichment and fabrication of fuel elements. After use in a reactor, it includes disposal or reprocessing. The U.S. Nuclear Regulatory Commission has documented the effects of the uranium fuel cycle for nuclear power plants in $10 \mathrm{CFR}$ Pt. 51. Because of the highly enriched fuel to be used, the fuel cycle for ANS would be somewhat different and may need to be assessed. If judged appropriate by DOE, the uranium fuel cycle for ANS could be assessed in the Phase 2 ER.

\subsection{WORKER HEALTH AND SAFETY}

Because the design of ANS is currently only conceptual, the occupational radiation doses cannot be predicted with certainty. However, experience frc: $n$ other reactors with similar features can be used to provide a perspective on what might be expected. In addition, ORNL has a well developed program designed to minimize occupational radiatior xposures. This program has proved effective in past operations and is expected to continue to do so in the future. No reactor in operation is exactly like ANS; however, certain reactors have similarities. These are reviewed in Sect. 5.10.1. 


\subsubsection{Experience at Other Facilities}

\subsubsection{High Flux Isotope Reactor at Oak Ridge National Laboratory}

HFIR is a research reactor at ORNL that will be used as an analog for ANS in many areas. However, the fact that HFIR is a light-water reactor makes comparisons of occupational doses to permanent staff and visiting researchers more difficult. The majority of dose from heavy water reactors is generally due to tritium, which is not the case for HFIR; therefore, the two facilities should be compared carefully.

There are nine research instrument facilities set up on four beam lines at HFIR for use by the permanent ORNL staff and outside users. The neutron scattering facilities available at HFIR are described in H. A. Mook and R. M. Nicklow 1990. A permanent staff of 10 people conduct neutron scattering experiments of which approximately onethird are strictly in-house, one-third are close collaborations between ORNL staff and visitors, and one-third are conducted by the outside users. The experiments mostly involve small angle neutron scattering on four horizontal beams with two instruments per line. Over the course of a year, the number of outside users will average about 150 so that the research instruments are generally in full use. The dose received by experimenters from this type of work is due to scattering of the beam. Personnel are monitored for dose and are limited to a daily maximum of $0.2 \mathrm{mSv}(20 \mathrm{mrem})$. It has been rare for a researcher to receive more than $0.02-0.03 \mathrm{mSv} / \mathrm{d}(2-3 \mathrm{mrem} / \mathrm{d})$. Full-time staff average $3-4 \mathrm{mSv} / \mathrm{year}$ (300-400 mrem/year) above background.

According to DOE regulations, ... yone receiving (Iver $1 \mathrm{mSv} / \mathrm{year}$ (100 mrem/year) must be classified as a radiation worker and receive special training. At ORNL the number of radiation workers varies in the range of 500 to 600 . Because HFIR was in the shutdown mode in 1989, the total number of people classified as radiation workers during that year at that facility was greatly reduced. In fact, for Solid State Division (SSD), there were no people classified as radiation workers in 1989. In calendar year (CY) 1991 the Research Reactor Division (RRD) had 53 radiation workers, 19 of whom have not received any measurable dose, even though still classified. Through the third quarter of CY 1991, RRD at HFIR had ouly 11 people with greater than $1 \mathrm{mSv}$ (100 mrem). Extrapolating this rate for all of CY 1991 yields 15 ptople with $1 \mathrm{mSv}(100 \mathrm{mrem})$ for the year. In contrast, out of SSD's 19 people, only 9 have had any exposure through the third quarter of CY 1991 and only 1 person has exceeded $1 \mathrm{mSv}(100 \mathrm{mrem})$. All the other exposures are less than $0.58 \mathrm{mSv}(58 \mathrm{mrem}$ ) (J. A. Setaro, Environmental and Health Protection, ORNL, Oak Ridge, Tenn., personal communication to D. R. James, Health and Safety Research Division, ORNL, Oak Ridge, Tennessee, Nov. 20, 1991).

Further cumulative data on occupational exposures are available on HFIR for the last 3 calendar years and is given in Table 5.10-1. Because HFIR was in a shutdown mode in CY 1989, the doses were much lower than for the next 2 years when the facility was returning to normal operations. The data for CY 1991 should be the most representative of typical exposures.

ANS would have up to 50 instruments, which is an increase by a factor of 3 or 4 over HFIR. This level of research would require an anticipated 100 permanent staff for as many as 1000 outside users per year (R. M. Moon, Solid State Division, ORNL, personal communication to D. R. James, ORNL, Oak Ridge, Tennessee, Nov. 20, 1991). 
Table 5.10-1. Cumulative doses at the High Flux Isotope Reactor

\begin{tabular}{lccc} 
& & & 1989 \\
\multicolumn{1}{c}{ Division } & {$[\mathrm{mSv}(\mathrm{mrem})]$} & $\begin{array}{c}1990 \\
{[\mathrm{mSv}(\mathrm{mrem})]}\end{array}$ & $\begin{array}{c}\text { (first 3 quarters) } \\
{[\mathrm{mSv} \text { (mrem)] }}\end{array}$ \\
\hline $\begin{array}{l}\text { Research Reactor } \\
\text { Solid State }\end{array}$ & $13.8(1380)$ & $26.9(2691)$ & $27.1(2707)$ \\
\hline
\end{tabular}

"Half of this was received by a single individual.

Source: J. A Setaro, Environmental and Health Protection, ORINL, Oak Ridge, Tenn., personal communication to D. R. James, Health and Safety Research Division, ORNL, Oak Ridge, Tenn, Nov. 20, 1991.

\subsubsection{Experience from the Savannah River Plant}

The Savannah River K reactor is a heavy water production reactor [2700 MW(t)] that has been shut down for the last 3 years. It is currently in the last stages of being restarted. Being a heavy water reactor, its dose experience has relevance to the proposed ANS even though ANS is much smaller [approximately $330 \mathrm{MW}(\mathrm{f})$ ] and has a much different design. A major occupational dose problem for heavy water reactors is the formation of tritium. When tritium is formed from neutron bombardment of heavy water, tritium remains dissolved in the water. A leak or break in the water lines can then allow tritiated water to escape. Because this tritiated water behaves the same chemically as regular water, it can be readily assimilated by the body upon dermal contact with liquid or vapor or upon respiration of vapor.

After 3 years of shutdown, the level of tritium dissolved in the cooling water at Savannah River is approximately $3.3 \times 10^{11} \mathrm{~Bq} / \mathrm{L}(9 \mathrm{Ci} / \mathrm{L})$. Under normal operating conditions this level from previous experience was $4.4-4.8 \times 10^{11} \mathrm{~Bq} / \mathrm{L}(12-13 \mathrm{Ci} / \mathrm{L})$. This amount would be substantially reduced for ANS, which would operate at much lower tritium concentrations, about $7.4 \times 10^{10} \mathrm{~Bq} / \mathrm{L}(2 \mathrm{Ci} / \mathrm{L})^{*}$ (D. McClain, Savannah River Plant, personal communication to D. R. James, ORNL, Oak Ridge, Tennessee, Nov. 18, 1991).

\subsubsection{Institut Laue Langevin, Grenoble, France}

The high flux reactor of the Institut Laue Langevin (ILL) is a heavy water research reactor located in Grenobie, France; this reactor also has a detritiation plant. ILL may be a good analog for ANS. The annual dose for experimenters who work on beam lines at ILL is less than $0.01 \mathrm{mSv}(1 \mathrm{mrem})$. For permanent staff working on the reactor itself the dose is summarized in Table 5.10-2. The amount of tritium in the cooling heavy water is reported to be $7.4-11.1 \times 10^{10} \mathrm{~Bq} / \mathrm{L}(2-3 \mathrm{Ci} / \mathrm{L})$.

\subsubsection{National Institute of Standards and Technology Reactor}

The collective dose equivalents for the years 1985-1989 range from a high of about 0.39 person-Sv ( 39 person-rem) in 1985 to a low of 0.13 person-Sv ( 13 person-rem) in 1986. Generally, a small proportion of people receive greater than $5 \mathrm{mSv}$ (500 mrem),

This is a probable operating level of tritium; design level is $5 \mathrm{Cl} / \mathrm{L}$. 
Table 5.10-2. Occupational doses at the Institut Laue-Langevin Research Reactor, Grenoble, France

\begin{tabular}{cc}
\hline $\begin{array}{c}\text { Annual dose range } \\
{[\mathrm{mSv}(\mathrm{mrem})]}\end{array}$ & $\begin{array}{c}\text { Number of } \\
\text { workers }\end{array}$ \\
\hline 0 & 55 \\
$0.01-0.5(1-50)$ & 12 \\
$0.51-2.0(51-200)$ & 12 \\
$2.01-5.0(201-500)$ & 6 \\
$5.01-10(501-1000)$ & 4 \\
above 10 (above 1000) & 0 \\
\hline
\end{tabular}

Source: Veyrat, J. F., Institut Laue Langevin, Grenoble, France, personal communication to D. R. James, Oak Ridge National Laboratory, Oak Ridge, Tenn., Nov. 21, 1991.

and the average dose for the NIST reactor workers is less than half of the current average of about $3 \mathrm{mSv}$ ( $300 \mathrm{mrem}$ ) for nuclear power plant workers. Detailed exposures are given in Tables 5.10-3 and 5.10-4.

\subsubsection{Canadian Heavy Water Reactors}

The Canadian nuclear power program uses the Canadian Deuterium Uranium Reactor (CANDU) design. This design is a pressurized heavy water reactor using natural uranium oxide as fuel. The reactor consists of pressure tubes containing the fuel constructed. Their operation has provided a considerable data base for tritium surrounded by a tank containing the heavy water moderator. Experience has been accrued in tritium management at CANDU facilities since operation of the Nuclear Power Demonstration Rolphton Gas Sulfide facility began in 1962. Since that time, many larger facilities have been managed. Generally, the tritium in the coolants has been approximately $7.4 \times 10^{10} \mathrm{~Bq} / \mathrm{L}(2 \mathrm{Ci} / \mathrm{L})$ and tritium levels in the moderators have been approximately $9.3 \times 10^{11} \mathrm{~Bq} / \mathrm{L}(25 \mathrm{Ci} / \mathrm{L})$.

Occupational doses due to tritium have been between 15 and $45 \%$ of total occupational radiation doses. And, as a rule, personnel at the newer reactors experience both lower tritium dose and lower total dose. Annual tritium doses to workers at selected CANDU facilities are presented in Table 5.10-5.

\subsubsection{Occupational Doses Anticipated at ANS}

Having reviewed experiences at reactors with some similarities to ANS, a few conclusions are apparent: occupational radiation doses at reactor facilities of all types 


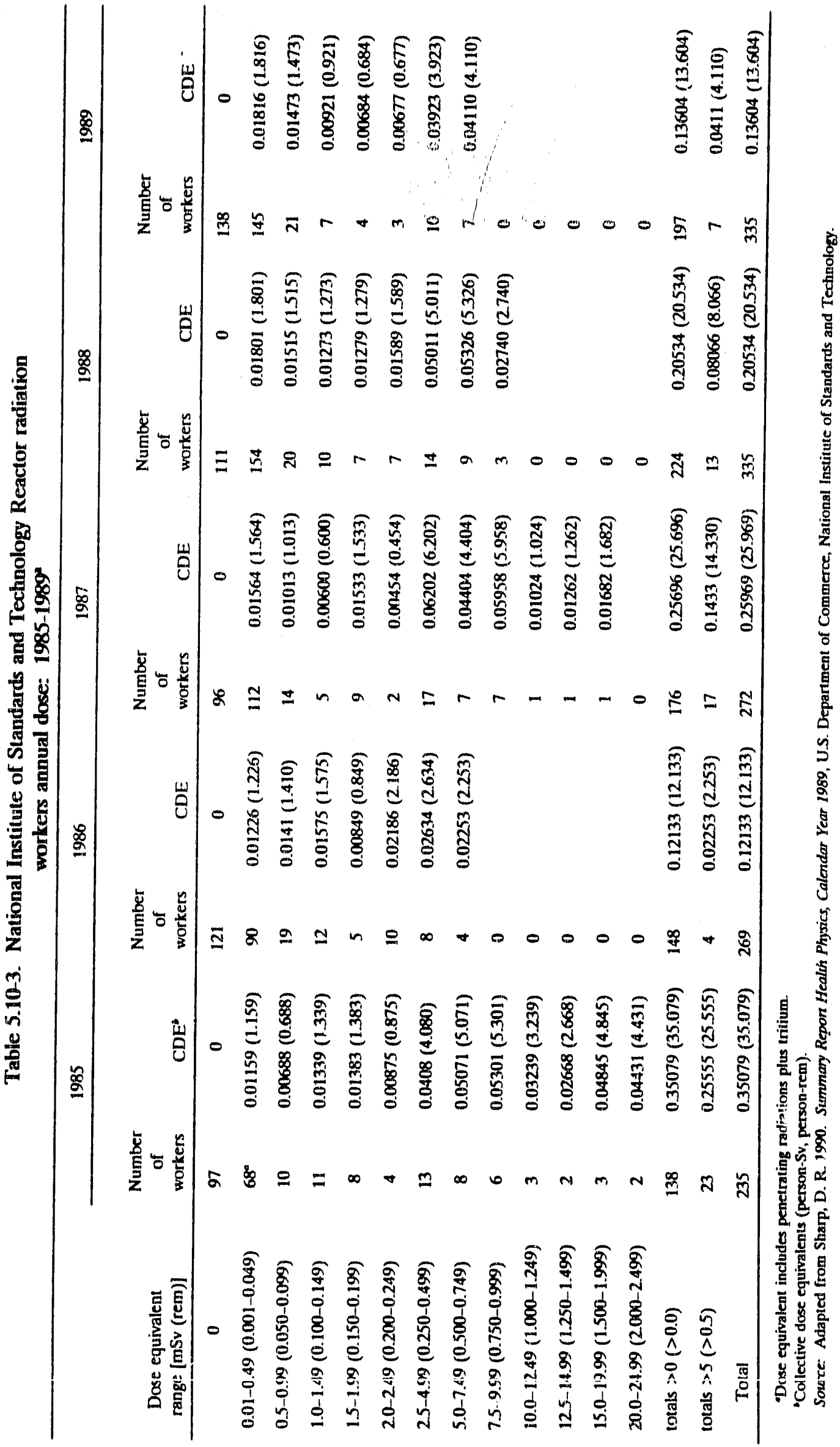


Table 5.10-4. National Institute of Standards and Technology person-codes and licenewe work areas for radiation workers, assigned dose equivalents $\geq 0.005 \mathrm{~Sv}$ ( $\geq 0.5 \mathrm{rem}$ ) for $1985-1989$

\begin{tabular}{|c|c|c|c|c|c|c|}
\hline \multirow[b]{2}{*}{$\begin{array}{l}\text { Reactor license } \\
\text { work }\end{array}$} & \multirow[b]{2}{*}{$\begin{array}{l}\text { Person } \\
\text { code }\end{array}$} & \multicolumn{5}{|c|}{$\begin{array}{c}\text { Year of dose equtvalent assignment } \\
\text { Sv (rem) }\end{array}$} \\
\hline & & 1985 & 1986 & 1987 & 1988 & 1989 \\
\hline \multirow[t]{18}{*}{ Operations } & $\mathrm{A} 2$ & $0.01408(1.408)$ & & $0.01682(1.682)$ & $0.00509(0.509)$ & \\
\hline & $\mathrm{B2}$ & $0.00927(0.927)$ & & & & \\
\hline & $\mathrm{C} 2$ & $0.01815(1.815)$ & & $0.00886(0.886)$ & & $0.00709(0.709)$ \\
\hline & $\mathrm{D} 2$ & $0.00596(0.596)$ & & $0.00704(0.704)$ & $0.00543(0.543)$ & \\
\hline & E2 & $0.02403(2.403)$ & $0.00500(0.500)$ & $0.01262(1.262)$ & $0.00592(0.592)$ & $0.00513(0.513)$ \\
\hline & $F 2$ & $0.01260(1.260)$ & & $0.00991(0.991)$ & & \\
\hline & G2 & $0.01169(1.169)$ & & $0.00599(0.599)$ & & \\
\hline & $\mathrm{H} 2$ & $0.01067(1.067)$ & $\cdot$ & & & \\
\hline & 12 & $0.00915(0.915)$ & & & $0.00935(0.935)$ & \\
\hline & $\mathrm{J} 2$ & $0.00615(0.615)$ & & & $0.00703(0.703)$ & \\
\hline & $\mathrm{K} 2$ & $0.01524(1.524)$ & & $0.00638(0.638)$ & $0.00657(0.657)$ & $0.00691(0.691)$ \\
\hline & L2 & $0.00875(0.875)$ & & & & \\
\hline & M2 & $0.02028(2.028)$ & & $0.00890(0.890)$ & $0.00714(0.714)$ & $0.00522(0.522)$ \\
\hline & N2 & $0.00996(0.996)$ & & & & \\
\hline & $\mathrm{O} 2$ & $0.01506(1.506)$ & & $0.00790(0.790)$ & $0.00880(0.880)$ & \\
\hline & $\mathbf{P} 2$ & & & $0.00820(0.820)$ & & \\
\hline & Q2 & & & $0.00609(0.609)$ & $0.00531(0.531)$ & $0.00598(0.598)$ \\
\hline & R2 & & & $0.00793(0.793)$ & $0.00529(0.529)$ & $0.00509(0.509)$ \\
\hline \multirow[t]{3}{*}{$\begin{array}{l}\text { Engineering } \\
\text { Support }\end{array}$} & $A 3$ & $0.00726(0.726)$ & & & & \\
\hline & B3 & $0.00719(0.719)$ & & & & \\
\hline & $\mathrm{C} 3$ & & & & $0.00548(0.548)$ & \\
\hline \multirow[t]{12}{*}{ Experimenters } & A4 & $0.00715(0.715)$ & & & & \\
\hline & B4 & & & $0.00605(0.605)$ & & \\
\hline & $\mathrm{CA}$ & $0.00573(0.573)$ & & & & \\
\hline & D4 & $0.00834(0.834)$ & & $0.00788(0.788)$ & & \\
\hline & EA & $0.01003(1.003)$ & $0.00570(0.570)$ & & & \\
\hline & F4 & $0.00754(0.754)$ & & & & \\
\hline & G4 & $0.00558(0.558)$ & $0.00641(0.641)$ & & & \\
\hline & $\mathrm{H}_{4}$ & & $0.00542(0.542)$ & & & \\
\hline & 14 & & & $0.00745(0.745)$ & & \\
\hline & 34 & & & $0.01024(1.024)$ & & \\
\hline & K4 & & & $0.00504(0.504)$ & & \\
\hline & LA & & & & $0.00925(0.925)$ & \\
\hline \multirow[t]{2}{*}{ Health Ptrysics } & AS & & & & $0.00899(0.899)$ & \\
\hline & B5 & & & & & $0.00568(0.568)$ \\
\hline
\end{tabular}

Source: Adapted fnsm Sharp, D. R. 1990. Summary Repors Health Phosics, Calendar Year 1989, U.S. Depanment of Commerce, National institute of Sutudards and Technolong. 


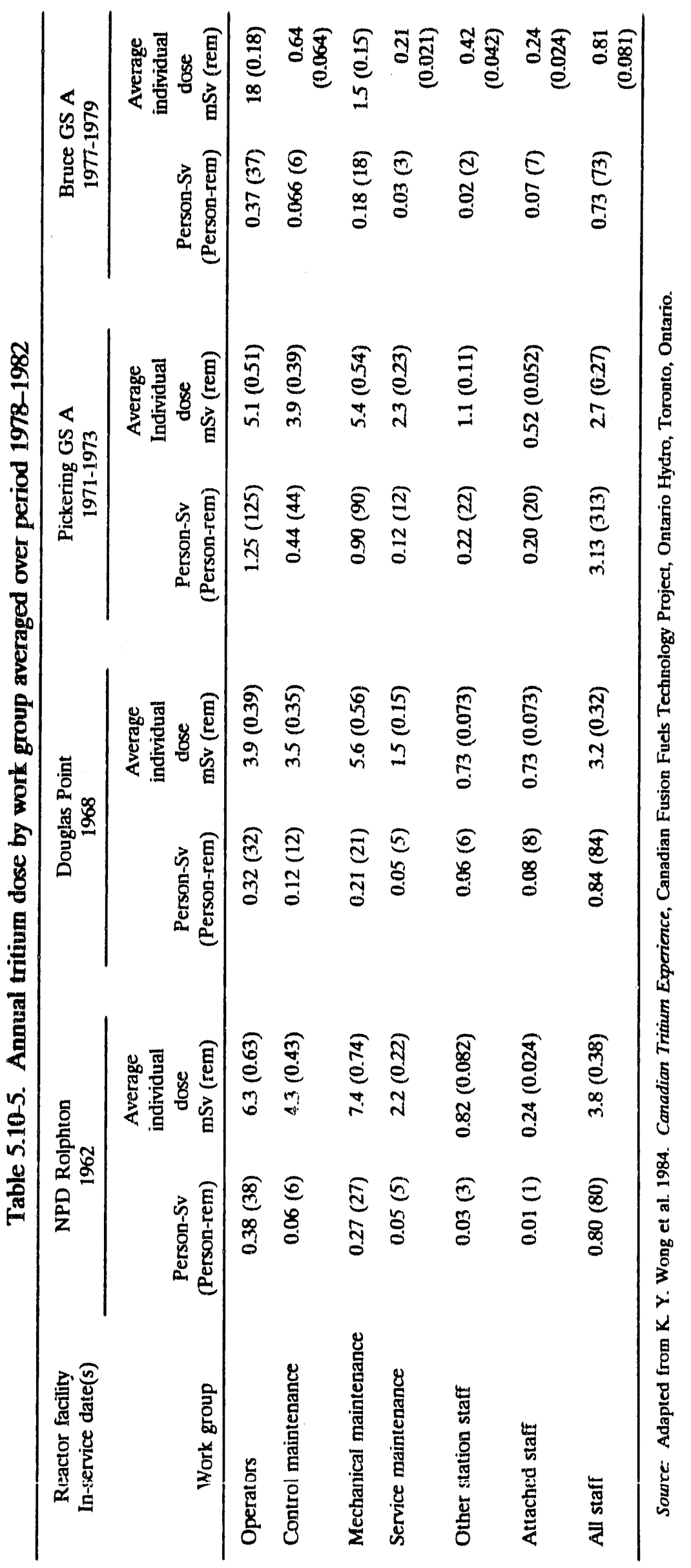


have steadily declined over the past several decades; few people receive greater than $0.01 \mathrm{~Sv}(1 \mathrm{rem})$ in any year; and, at most reactor locations, the average occupational radiation dose tends to be less than $5 \mathrm{~Sv} / \mathrm{year}(500 \mathrm{mrem} / \mathrm{year})$. These same observations are present at commercial power production facilities (Munson, et al. 1988). Expectations are that typical ANS occupational doses would be less than $5 \mathrm{mSv} / \mathrm{year}$ ( 500 mrem/year), average doses would probably be less than $2.5 \mathrm{mSv} / \mathrm{year}(250 \mathrm{mrem} / \mathrm{year})$, but a few individuals, reactor operators as well as experimentalist., might experience near $10 \mathrm{mSv} /$ year (1 rem/year). Not evaluated as a possible source of occupational exposure is skyshine. While this source is not expected to be significant, it remains currently unevaluated.

\subsubsection{The Biological Effectiveness of Neutrons}

Because of the unique nature of ANS and the fact that some occupational and experimental dose might result from neutrons, a review of the pertinent radiological issues related to neutrons is presented. This review is intended to provide a perspective on whether significant changes are expected in the scientific understanding of the radiobiological effectiveness of neutrons between the present and the mid-life of the ANS facility. The concept of relative biological effectiveness (RBE) is used to compare and quantify the effectiveness of different kinds of radiation in producing a given level of biological damage. The reference radiation for making comparisons is usually $\mathrm{X}$-rays. The RBE of a particular type of radiation, such as neutrons, in producing a given biological end point is then defined as the inverse ratio of the $X$-ray dose $D_{x}$ and neutron dose $D_{n}$ needed to produce the end point:

$$
R B E=\frac{D_{x}}{D_{n}} .
$$

In an experiment that measures RBE for the two radiations, all physical and biological parameters, such as dose rate and the particular biological effect and level of damage, are to be kept as nearly the same as possible. Neutron RBE values vary greatly, depending on all of these factors.

An extensive, authoritative review and compilation of RBE data, particularly as they pertain to personnel radiation protection, has been published recently by the National Council on Radiation Protection and Measurements (NCRP) in their Report No. 104 (NCR.P 1990). The term RBE $\mathrm{M}_{\mathrm{M}}$ is defined in ICRP-ICRU63 to indicate the RBE value obtained from the initial, low-dose portions of dose-response curves, regarded as linear (the ratio of the $\alpha$ terms). $R B E_{M}$ is assumed to represent the maximum $R B E$ value. $A$ summary of $R_{B} E_{M}$ values for fission neutrons relative to gamma rays (NCRP 1990, $p$. 169 ) is given in Table 5.10-6.

Another quantitative index of the biological effectiveness of neutrons is provided by values of the neutron quality factors, Q, recommended by NCRP (NCRP 1987, p. 11). Quality factors are used for radiation protection to weight the contributions of different kinds of radiation for administrative control purposes. For $X$ and $\gamma$ rays, $Q=1$, the smallest value that a quality factor is assigned. For neutrons, the recommended values of $Q$ range up to 20 , depending on the neutron energy. In radiation protection, the quality factor plays a role akin to RBE, though in the entirely different context of administrative surveillance of long-term, low-level, chronic exposures to radiation. 
Table 5.10-6. Estimated values of relative biological effectiveness $\left(\mathrm{RBE}_{\mathrm{M}}\right)^{\text {a }}$ for fission neutrons relative to gamma rays

for several biological end points

\begin{tabular}{lc}
\hline \multicolumn{1}{c}{ Biological end point } & End point range of $\mathrm{RBE}_{\mathrm{M}}$ \\
\hline $\begin{array}{l}\text { Cytogenetic studies, human lymphocytes in } \\
\text { culture }\end{array}$ & $34-53$ \\
Transformation & $3-80$ \\
Genetic end points in mammalian systems & $5-70$ \\
Genetic end points in plant systems & $2-100$ \\
Life shortening, mouse & $10-46$ \\
Tumor induction & $16-59$ \\
\hline
\end{tabular}

anternational Commission on Radiological Protection-International Commission on Radiation Units and Measurements 63, 1963. "Report of the RBE Committee of the International Commission on Radiological Protection and The International Commission on Radiation Units and Measurements," Health Physics 9 , $35 \%$.

Source: NCRP (National Council on Radiation Protection) 1990. The Relarive Biological Effectiveness of Radiation of Different Quality, NCRP Report no. 104, NCRP, Bethesda, Md.

Quality factors have long been defined in terms of an empirical relationship between $Q$ and the linear energy transfer (LET) of radiation or the secondary charged particles that radiation produces in water. Values are defined so that $Q$ is in the range $1 \leq \mathrm{Q} \leq 20$ for any kind for radiation. In its latest recommendations, NCRP

(1987, p. 11) also recommends the use of effective quality factors, $\bar{Q}$, which do not underestimate actual values of $Q$. For neutrons, NCRP simply recommends the values $\bar{Q}=5$ for thermal neutrons and $\bar{Q}=20$ for all other neutrons (NCRP 1987, p. 13). In its latest recommendations, ICRP (ICRP 1990) has somewhat modified the explicit relationship between $Q$ and LET and has also introduced the concept of radiation weighting factor, $w_{R}$, to be used in place of $Q$. ICRP recommends the values for neutroms shown in Table 5.10-7 and states, "The value of the radiation weighting factor for a specified type and energy of radiation has been selected by the Commission to be representative of values of RBE of that radiation in inducing stochastic effects at low doses" (ICRP 1990, p. 5) Current publications of the NCRP and ICRP thus recommend values of neutron quality factors or radiation weighting factors of up to 20 .

A joint task group of ICRP and the International Commission on Radiation Units and Measurements (ICRU) conducted an extensive review of RBE data, especially at low doses, up to the end of 1984 (ICRP-ICRU 1986). Their attention was focused mainly on neutrons as high-LET radiation and on biological end points having a bearing on carcinogenesis or mutagenesis. (The revision in the Hiroshima neutron dosimetry was documented by this time.) Their analysis also includes discussions of quality factor defined in terms of the microdosimetric lineal energy as an alternative to its definition in terms of LET. When the energy is not well known, they suggest an approximate average quality factor $\bar{Q}=25$ for neutrons. 
Table 5.10-7. Radiation weighting factors, $W_{R}$, recommended by the International Comrnission on Radiological Protection

\begin{tabular}{cc}
\hline $\begin{array}{c}\text { Neutron energy } \mathrm{E} \\
(\mathrm{MeV})\end{array}$ & $\mathrm{W}_{\mathrm{R}}$ \\
\hline$<0.010$ & 5 \\
$0.010 \leq \mathrm{E} \leq 0.100$ & 10 \\
$0.100<\mathrm{E} \leq 2.0$ & 20 \\
$2.0<\mathrm{E} \leq 20.0$ & 10 \\
$>20.0$ & 5 \\
\hline
\end{tabular}

Source: International Commission on Radiological Protection 1990. Recommendations of the International Commission on Radiological Protection, International Commission on Radiation Units and Measurements Report Number 60, International Commission on Radiation Units and Measurements, Bethesda, Md.

The neutron quality factors specified for use at ORNL in DOE Order 5480.11 are indicated in Table 5.10-8. The values of $Q$ as a function of neutron energy increase from 2 for thermal neutrons to a maximum of 11 for veutrons in the energy range from $0.5 \mathrm{MeV}$ to $1.0 \mathrm{MeV}$ (Table 5.10-9). At higher energies, $\mathrm{Q}$ generally decreases to a value of 3.5 at $400 \mathrm{MeV}$. When fis spectral data are insufficient to determine neutron energies, an average quality factor $Q=3$ is used for neutrons with energies $\leq 10 \mathrm{keV}$ and $\mathrm{Q}=10$ is used for energies $>10 \mathrm{keV}$. Thesc values, specified in DOE 5480.11, are generally consistent with the recommendations of NCRP, ICRP, and ICRU. As a consequence, there is no indication at this time that radical changes in the understanding of the radiobiological effectiveness of neutrons are taking place to iniluence future operation of ANS.

\subsubsection{ORNL As Low As Reasonably Achievable Program}

Experience at HFIR, other radiological hazards at ORNL, and that gained by the health physics community around the world, points to the likelihood that radiation doses that would occur at the ANS facility can be maintained at acceptably low levels. ORNI. maintains an active program to ensure the safe operation of every facility. The ORNL As Low as Reasonably Achievable (ALARA) Program functions to maintain occupational doses as low as reasonably achievable and while doses at ANS cannot be predicted at this point, established procedures would ensure their minimization. The smallest organizational unit consists of the ALARA Program manager and staff, who are divided into Radiological ALARA and Hazardous Materials ALARA subgroups. The ALARA Program manager reports to the head of the Office of Radiation Protection, who in turn reports to the Director of the Environmental, Safety, and Health Compliance Directorate. The ORNL ALARA Program is formally chartered.

In addition to the formal ALARA Program staff, there are several other personnel at ORNL who have formal responsibility for implementing DOE ALARA requirements. The Radiation Protection Surveillance Section, whose head reports to the head of the 
Table 5.10-8. Neutron quality factors

\begin{tabular}{lc}
\hline \multicolumn{1}{c}{ Radiation type } & $\begin{array}{c}\text { Quality factor } \\
(\mathrm{Q})^{a}\end{array}$ \\
\hline $\begin{array}{l}\text { X rays, gamma rays, positrons, electrons (including tritium } \\
\text { beta particles) }\end{array}$ & 1 \\
Neutrons, $\leq 10 \mathrm{keV}$ & 3 \\
Neutrons, $>10 \mathrm{keV}$ & 10 \\
$\begin{array}{l}\text { Protons and single-charges particles of unknown energy } \\
\text { with rest mass greater than one atomic mass unit }\end{array}$ & 10 \\
$\begin{array}{l}\text { Alpha particles and multiple-charged particles (and } \\
\text { particles of unknown charge) of unknown energy }\end{array}$ & 20 \\
\hline
\end{tabular}

If spectral data are sufficient to Identify the energy of the neutrons, the $Q$ values in Table 5.10.9 may be used.

Source: Department of Energy Order DOE 5480.11 (12-21-88).

Table 5.10-9. Quality factor as a function of neutron energy

\begin{tabular}{lcc}
\hline $\begin{array}{c}\text { Neutron energy } \\
(\mathrm{MeV})\end{array}$ & $Q$ & $\begin{array}{c}\text { Neutron flux density } \\
\left(\mathrm{cm}^{-2} / \mathrm{s}^{-1}\right)\end{array}$ \\
\hline $2.5 \times 10^{-8}$ (thermal) & 2 & 680 \\
$1 \times 10^{-7}$ & 2 & 680 \\
$1 \times 10^{-6}$ & 2 & 560 \\
$1 \times 10^{-5}$ & 2 & 560 \\
$1 \times 10^{-4}$ & 2 & 580 \\
$1 \times 10^{-3}$ & 2 & 680 \\
$1 \times 10^{-2}$ & 2.5 & 700 \\
$1 \times 10^{-1}$ & 7.5 & 115 \\
$5 \times 10^{-1}$ & 11 & 27 \\
1 & 11 & 19 \\
2.5 & 9 & 20 \\
5 & 8 & 16 \\
7 & 7 & 17 \\
10 & 6.5 & 17 \\
14 & 7.5 & 12 \\
20 & 8 & 11 \\
40 & 7 & 10 \\
60 & 5.5 & 11 \\
$1 \times 10^{2}$ & 4 & 14 \\
$2 \times 10^{2}$ & 3.5 & 13 \\
$3 \times 10^{2}$ & 3.5 & 11 \\
$4 \times 10^{2}$ & 3.5 & 10 \\
\hline
\end{tabular}

"Mean quality factors, $Q$ (maximum value of $Q$ in a $30-\mathrm{cm}$ dosimetry phantom), and values of neutron flux density that, in $40 \mathrm{~h}$, result in a maximum dose equivalent of i mSiv (iố mrem). Source: Department of Energy Order DOE 5480.11 (12-21-88). 
Office of Radiation Protection, includes all of the health physics staff. In the course of providing radiation protection coverage, they include ALARA considerations in their operations. The ALARA Working Committee is chaired by the ALARA Program manager and consists of a representative from each division that does radiation work, including RRD, and the Radiation Protection Surveillance Section. It is a working group that meets monthly and discusses problems in radiation protection, hears presentations on radiation topics, and makes recommendations (including ALARA goals) to the ALARA Steering Committoe. The ALARA Steering Committee is chaired by the assistant to the Director of the Environmental, Safety, and Health Compliance Directorate and consists of the ALARA Program manager and the heads of all divisions that do radiation work. It is a policy committee that meets quarterly and hears presentations on radiation topics, approves ORNL ALARA goals and proposed actions, and makes recommendations to upper management.

Major DOE Orders stating requirements for ALARA implementation in dose control, particularly in design, are as follows: DOE Order 5400.5, Radiation Protection of the Public and the Environment; DOE Order 5480.11, Radiation Protection for Occupational Workers; and 6430.1A, General Design Criteria. Note that, although DOE Order 6430.1A states that it applies to nonnuclear facilities, DOE Order 5480.6, Safety of Department-of-Energy-Owned Nuclear Reactors, states that the specific guidance of $6430.1 \mathrm{~A}$ is to be followed in the design of new reactor facilities and in the modification of existing facilities where applicable.

DOE Order 5480.11 refers to PNL-6577, "Health Physics Manual of Good Practices for Reducing Radiation Exposure to Levels that are As Low As Reasonably Achievable (ALARA)" (Munson et al., June 1988), for more detailed guidance on what constitutes an acceptable ALARA program. Also, "DOE Implementation Guide (for an) Acceptable Program and Philosophy for Maintaining Occupational Radiation Doses As Low As Reasonably Achievable (ALARA)," Draft Implementation Guide ("Draft ALARA IG"), August 1991, gives similar guidance. The specifications of PNL-6577 have served as a guide since 1989, when the formal ORNL ALARA Program first began, and the Draft ALARA IG is being studied by the ALARA Program group for comment and implementation.

\section{Policy and Management Commitment}

The charters of the ALARA Program (group), the ALARA Working Committee, and the ALARA Steering Committee were signed by the Laboratory Director in 1990. A draft policy statement was sent to ORNL upper managernent in 1990, but has not yet been approved. ALARA review requirements for Radiation Work Permits have been approved when proposed.

\section{Organization and Responsibilities}

The organization of the ALARA Program at ORNL has jeen previously described. Responsibilities of the ALARA Program Manager and the two ALARA committees are given in their respective charters. In addition, the responsibilities of various other functional groups (e.g., operations, health physics) are delineated in procedures in the Health Physics Manual. 
3. Administrative Control Levels

Administrative control levels well below regulatory limits are set in the Health Physics Manual. Ad hoc or nperation-specific levels may be recommended and implemented by the AlLARA Program or the Health Physics (HP) groups. Reporting and investigation levels have been established in conjunction with the administrative levels. Radiation workers are trained regarding the contral levels.

\section{Radiological Goals}

The members of the ALARA Working Committee bring to their fall meetings information regarding work that is expected to be done in the following calendar year. From discussions at these meetings the ORNL ALARA goals are formulated by the ALARA Program manager, recommended by the ALARA Working Committee to the ALARA Steering Committee, and formally approved by the ALARA Steering Committee. Each division also produces divisional ALARA goals where appropriate.

In addition, for operations in which doses may be high or for which uncertainties exist, dose and other radiological goals may be proposed by the ALARA Program Manager, the Health Physics staff, the division itself, or a contractor who is to perform the operation.

\section{ALARA Training}

All occupational workers at ORNL, receive a general orientation to ORNL that includes a discussion of radiological hazards that they may encounter. When appropriate for their jobs and locatiqus, they may receive more specific training regarding such hazards (e.g., for researchers and technicians).

Radiation workers include those satisfying the definition in DOE Order 5480.11 and perhaps others. They receive training in accordance with DOE Order 5480.11, including retraining. Radiation protection technicians also receive training in accordance with the applicable provisions of DOE Order 5480.11. Design and operations engineers are being trained (as time permits) in the appropriate principles of ALARA, ALARA reviews, and optimization.

ALARA training for managers and supervisors and, as needed, for other distinct groups is planned for the future.

ANS design staff, except for some contractors who do not go into any radiological areas unescorted, all receive the general training and some have received the training for engineers. As radiation sources begin to be present on site (e.g., for testing and calibration of radiation monitors and experimental instruments), other appropriate training as previously described is expected to be added.

\section{Plans and Procedures}

An ALARA Program Plan is being prepared and will be submitted for formal approval. It will delineate the organization, responsibilities, and methods of operation of the ORNL ALARA Program. In addition, it is expected that in the year before ANS goes into operation, a facility-specific ALARA Plan will be prepared for it. 


\section{Internal Audits}

The ALARA Program is to be audited as part of the triennial audit of radiation protection programs. In addition, the ALARA Steering Committee is, according to its charter, supposed to exercise an audit function within the program. Efforts are being made to have an external audit of the ALARA Program in order to identify and correct any weaknesses not identified by internal audits.

\section{Optimization and Cost-Benefit Methodology}

Procedures for performing optirnization analyses are currently in preparation. A presentation of monetary values for radiation detriment ("dollars per person-rem") is to be made to the ALARA Steering Committee by the beginning of 1992, with the expectation of having a recommendation of such value(s) approved in 1992.

\section{Radiological Design Review}

While the Draft ALARA IG states, "DOE has an approved system of radiological design criteria," it is evident that DOE recognizes that there is not a single comprehensive document embodying such a system. ("These approved practices are specified in several rules, orders, and standards.") At ORNL, participation in the design process by a radiological engineer or health physicist, while not completely formalized, has increased. Several projects have had project-specification design criteria written for them (based on DOE and other authoritative guidance). ANS has had substantial input from the ALARA and HP groups, and drawings and other design documents are circulated to them for review and comment as appropriate. Formal ALARA design reviews are expected to be held at appropriate times during the design and construction phases.

\section{Radiological Work and Experiment Planning}

The Health Physics Manual gives requirements for job and experiment reviews, including those for Radiation Work Permits. Review of jobs and operations is expected to be further proceduralized to provide better documentation. ANS will most likely have facility-specific experiment review procedures, although the job and operations reviews would be the same as the general ORNL reviews.

\section{Records}

Records of ALARA Program work and associated HP activities are kept for all categories mentioned in the Draft ALARA IG, including dose authorization forms, incident investigations, goals, training records, and ALARA Steering and Working Committee minutes.

Because it is desired to design and operate ANS according to the applicable licensing standards of NRC, compliance must be demonstrated not only with state, federal, and DOE regulations, but also, so far as is practicable, with NRC regulations and with recommendations of the Institute of Nuclear Power Operations and the Electric Power Research Institute. DOE's radiation protection standards are to be consistent with EPA guidance to federal agencies [i.e., "Radiation Protection Guidance to the Federal Agencies for Occupational Exposure," Fed. Regist. 52 (Pt. 17) (1987), according to DOE Order 5480.11] and the recommendations of authoritative professional and scientific 
organizations, specifically NCRP and ICRP. Note that the ORNL Health Physics Manual has the status of an ORNL Standard Operating Procedure.

The major nonquantitative goals for the ORNL ALARA Program are as follows (these follow ICRP and other guidance):

- Individual radiation doses (both external and internal) to workers or the public sliould not only be kept below regulatory and operational limits, but should also be minimized.

- Collective radiation dose (both external and internal) to a work group or population should be minimized.

- Action taken to reduce radiation risks to workers or the public should not result in a significantly higher risk from other nonradioactive hazards.

- Action taken to reduce occupational doses should not result in significantly higher doses or risk to the public and vice versa.

- Contamination of personnel, areas, equipment, and the environment should be minimized.

- The generation of radioactive waste, both during operation and at the end of plant life, should be minimized.

\subsubsection{Hazardous Chemicals at ANS}

Another aspect of occupational health and safety relates to exposure to chemicals in the workplace. Identification of such materials for ANS must audit considerably more design work. Control of worker exposure to chemicals is assisted by industrial hygiene personnel who monitor the workplace to minimize exposure to hazardous chemicals. In addition, ongoing programs attempt to minimize the presence of unneeded chemicals. A picture of what the chemical environment at ANS might be like can be obtained by examining the chemical stores at HFIR. A compilation of hazardous chemicals stored at the HFIR site (7900 Complex) that are the responsibility of RRD has been made and is given in Table 5.10-10 (A. Lewis, RRD, ORNL, Oak Ridge, Tennessee, personal communication to D. R. James, Health and Safety Research Division, ORNL, Oak Ridge, Tennessee, November 1991). This list has been compiled in order to comply with EPA regulations and is contained in the ORNL Hazardous Chemicals data base maintained by Environmental Safety and Health Division (Y. Horton, Environmental Safety and Health Division, ORNL, personal communication to D. R. James, ORNL, Oak Ridge, Tennessee, November 1991). A significant amount of the chemicals is used for cleaning and maintaining the quality of the cooling water. For example, the Calgon listed is a corrosion inhibitor and water softener composed of $72 \%$ sodium nitrice and $20 \%$ borax pentahydrate. A number of compressed gas cylinders are listed, including 25 tanks of oxygen.

Because HFIR is a research reactor, there are several other divisions at ORNL that routinely use the facility. These divisions also have their own stockpile of chemicals and a list is kept by Allen Lewis. Instrumentation and Controls Division has only small amounts of chemicals [less than $3.8 \mathrm{~L}$ (1 gal) each] for general laboratory use and will not be listed here. These include mostly solvents and greases. Analytical Chemistry Division has on the order of 185 different chemicals also in small quantities. Two liters $(0.5$ gal) each of hydrochloric acid and hydrofluoric acid are stored, which is typical of laboratory scale usage. Plant and Equipment Division has approximately $950 \mathrm{~L}$ ( 250 gal) of paint and enamel stored at HFIR along with about $190 \mathrm{~L}$ (50 gal) of paint thinner, other 
Table 5.10-10. Hazardous chemicals inventory for the High Flux Isotope Reactor

\begin{tabular}{|c|c|c|c|}
\hline $\begin{array}{c}\text { Chemical/trade } \\
\text { name }\end{array}$ & $\begin{array}{l}\text { Average daily } \\
\text { amount stored }\end{array}$ & $\begin{array}{l}\text { Physical } \\
\text { state }\end{array}$ & $\begin{array}{l}\text { Maximum daily } \\
\text { amount stored }\end{array}$ \\
\hline Sulfuric acid & $5,223.3 \mathrm{~L}(1,380 \mathrm{gal})$ & Liquid & $18,925 \mathrm{~L}(5,000 \mathrm{gal})$ \\
\hline Calgon & $15,897 \mathrm{~L}(4,200 \mathrm{gal})$ & Liquid & $15,972.7 \mathrm{~L}(4,220$ gal $)$ \\
\hline Endcore & $283.9 \mathrm{~L}$ (75 gal) & Liquid & $416.4 \mathrm{~L}(110 \mathrm{gal})$ \\
\hline Sodium hypochlorite & $624.5 \mathrm{~L}$ (165 gal) & Liquid & Not available \\
\hline Nitric acid & $4,568.5 \mathrm{~L}(1,207 \mathrm{gal})$ & Liquid & $10,215.7$ L $(2,699 \mathrm{gal})$ \\
\hline Sodium hydroxide & $4,394.4 \mathrm{~L}(1,161 \mathrm{gal})$ & Liquid & $12,324 \mathrm{~L}(3,256 \mathrm{gal})$ \\
\hline Diesel fuel & $13,035.5$ L (3,444 gal) & Liquid & $14,882.6 \mathrm{~L}(3,932 \mathrm{gal})$ \\
\hline Cadmium nitrate & $416.4 \mathrm{~L}(110 \mathrm{gal})$ & Liquid & $567.8 \mathrm{~L}(150 \mathrm{gal})$ \\
\hline Hydrochloric acid $0.2 \mathrm{M}$ & $2.84 \mathrm{~L}(0.75 \mathrm{gal})$ & Liquid & $2.84 \mathrm{~L}(0.75 \mathrm{gal})$ \\
\hline Sodium thiosulfate $\mathrm{N} / 10$ & $180 \mathrm{~mL}$ & Liquid & $180 \mathrm{~mL}$ \\
\hline Beryllium sulfate & $120 \mathrm{~mL}$ & Liquid & $120 \mathrm{~mL}$ \\
\hline $\begin{array}{l}\text { Sulfuric acid } \\
\text { Code } 542\end{array}$ & $710 \mathrm{~mL}(24 \mathrm{oz})$. & Liquid & $710 \mathrm{~mL}(24 \mathrm{oz})$. \\
\hline $\begin{array}{l}\text { Sulfuric acid } \\
\text { Code } 541\end{array}$ & $3.79 \mathrm{~L}$ (1 gal) & Liquid & $3.79 \mathrm{~L}$ (1 gal) \\
\hline Methyl purple indicator & $1.89 \mathrm{~L}$ (0.5 gal) & Liquid & $1.89 \mathrm{~L}(0.5 \mathrm{gal})$ \\
\hline Glycerine & $473 \mathrm{~mL}(16 \mathrm{oz})$. & Liquid & $473 \mathrm{~mL}(16 \mathrm{oz})$. \\
\hline Calcium indicator & $551 \mathrm{~cm}^{3}(16 \mathrm{oz})$ & Solid & $551 \mathrm{~cm}^{3}(16 \mathrm{oz})$. \\
\hline Organic phosphorus reagent $\mathrm{C}$ & $180 \mathrm{~mL}$ & Liquid & $180 \mathrm{~mL}$ \\
\hline Organic phosphorus reagent $\mathbf{A}$ & $240 \mathrm{~mL}$ & Liquid & $240 \mathrm{~mL}$ \\
\hline Organic phosphorus reagent $D$ & $660 \mathrm{~mL}$ & Liquid & $660 \mathrm{~mL}$ \\
\hline Beryllium sulfate solutions & $240 \mathrm{~mL}$ & Liquid & $240 \mathrm{~mL}$ \\
\hline Organic phosphorus reagent B & $100 \mathrm{~g}$ & Solid & $100 \mathrm{~g}$ \\
\hline Cadmium nitrate, 4-hydrate & $6 \mathrm{~kg}(13.2 \mathrm{lb})$ & Solid & $6 \mathrm{~kg}(13.2 \mathrm{lb})$ \\
\hline $\begin{array}{l}\text { EDTA standard titrating } \\
\text { solution }\end{array}$ & $4 \mathrm{~L}(1.06 \mathrm{gal})$ & Liquid & $4 \mathrm{~L}(1.06 \mathrm{gal})$ \\
\hline Xylenol orange indicator & $340 \mathrm{~g}(12 \mathrm{oz})$. & Solid & $340 \mathrm{~g}(12$ oz. $)$ \\
\hline Citric acid & $90.7 \mathrm{~kg}(200 \mathrm{lb})$ & Liquid & $90.7 \mathrm{~kg}(200 \mathrm{lb})$ \\
\hline Diesel oil & $0.95 \mathrm{~L}(0.25 \mathrm{gal})$ & Liquid & Not applicable \\
\hline Araldite 502 & $56.8 \mathrm{~L}(15 \mathrm{gal})$ & Liquid & $56.8 \mathrm{~L}(15 \mathrm{gal})$ \\
\hline Cimstar 52 & $75.7 \mathrm{~L}(20 \mathrm{gal})$ & Liquid & $75.7 \mathrm{~L}$ (20 gal) \\
\hline Sikadur 42 & $118.4 \mathrm{~kg}(261 \mathrm{lb})$ & Solid & $118.4 \mathrm{~kg}(261 \mathrm{lb})$ \\
\hline Sikadur 42 & $9,000 \mathrm{~cm}^{3}$ (2 gal) & Solid & $9,000 \mathrm{~cm}^{3}(2 \mathrm{gal})$ \\
\hline Activated carbon & $0.48 \mathrm{~m}^{3}(110 \mathrm{gal})$ & Solid & $0.48 \mathrm{~m}^{3}(110 \mathrm{gal})$ \\
\hline Amberlite IRA 400 & $2.9 \mathrm{~m}^{3}(660 \mathrm{gal})$ & Solid & $2.9 \mathrm{~m}^{3}(660 \mathrm{gal})$ \\
\hline $3 \mathrm{M}$ fire barrier CP $25 \mathrm{~N} / \mathrm{S}$ & $18.9 \mathrm{~L}(5 \mathrm{gal})$ & Liquid & $18.9 \mathrm{~L}(5 \mathrm{gal})$ \\
\hline Wedjrok concrete & $18.9 \mathrm{~L}(5 \mathrm{gal})$ & Liquid & $18.9 \mathrm{~L}(5 \mathrm{gal})$ \\
\hline Beryllium & $771.1 \mathrm{~kg}(1,700 \mathrm{lb})$ & Solid & $771.1 \mathrm{~kg}(1,700 \mathrm{lb})$ \\
\hline Cadmium & $9.1 \mathrm{~kg}(20 \mathrm{lb})$ & Solid & $9.1 \mathrm{~kg}(20 \mathrm{lb})$ \\
\hline
\end{tabular}

This amount is the maximum quancity ordered for use at the facility and is therefore the largest quantity of chemical that would be present at any one time.

Source: A. Lewis, Reactor Research Division, ORNL, Oak Ridge, Tenn., personal communication to D. R. James, Health and Safety Research Division, ORNL, Oak Ridge, Tenn., November 1991. 
solvents, lubricants, and sealers. SSD has small quantities of about 80 different chemicals for use in their research on the beam lines.

\subsection{WASTE MANAGEMENT IMPACTS OF ADVANCED NEUTRON SOURCE}

This section describes the principal impacts of ANS wastes to the ORNL waste management system. Impacts will be identified and evaluated to ascertain their significance. The impacts of radioactive, mixed, hazardous, and conventional wastes to existing and planned waste management facilities at ORNL are discussed. Impacts of wastes to worker health and safety and ecological resources are discussed elsewhere.

\subsubsection{Scenario-Driven Impact Analysis}

This section discusses the methodology for impact analysis of ANS waste management under two scenarios: (1) a preferred management scenario (in which new or updated facilities become available at the ORNL host-site, ORR, or other DOE facilities); and (2) an interim storage scenario (in which older, existing facilities at the ORNL host site continue to be used). Under both scenarios, waste facilities would be operated in accordance with Waste Acceptance Criteria established by ORNL for the management of waste by its generators. These criteria require pretreatment, volume reduction, waste minimization, and proper waste conditioning and labelling before disposal.

\section{Scenario 1: ANS Radioactive Waste Management Preferred Alternative}

- Liquid low-level waste (LILW) and radiological process wastes would be disposed of through improved waste management systems. Efforts to reduce LLLW would become more widely adopted through increased use of local ion-exchange treatment of wastewater and waste solidification.

- Transuranic (TRU) wastes would be disposed in the Waste Isolation Pilot Plant (WIPP), near Carlsbad, New Mexico, after interim storage at ORNL.

- High-level waste and spent fuel would be removed from ANS and temporary storage at the reactor and would then be shipped to the Receiving Basin for Offsite Fuels (RBOF) at the Savannah River Plant, South Carolina, for interim away-from reactor storage. Permanent disposal might be at the Yucca Mountain High-Level Waste (HLW) repository. Other high-level wastes from decontamination and decommissioning (D\&D) activities would be disposed of in special facilities.

- Greater-than-class-C (GTCC) disposal plans are still unknown; however, DOE is developing an inventory of all GTCC sources and is considering possible disposal sites and alternative disposal technologies (OTA 1989, p. 85; Hutchison and Magleby 1990, pp. 617-19). Future waste acceptance criteria will emphasize reduced GTCC generation.

- Contact-handled and remotely handled low-level waste (CH- and RH-LLW): New ORR facilities are being planned to replace existing solid LLW (SLLW) facilities nearing capacity. New LLW disposal facilities will replace the Greater Confinement Disposal below-grade operations at Solid Waste Storage Area (SWSA) 6, which are scheduled for eventual phase-out (Butterworth 1988; pp. 36-38, Baldwin et al. 1989b). 
- Gaseous radiological wastes would be processed and disposed through existing methods, although greater use of molecular-sieve type dehumidifiers is expected. ALARA guidelines governing these wastes are likely to become more stringent than those used today.

- Mixed waste would be disposed either on ORR or off-site.

- Tritium would be collected in the ANS Heavy Water Upgrading and Detritiation Facility. After processing in a Tritium Removal Unit, tritides would be stored on-site until sold or otherwise disposed. Tritiated solid waste may also be incinerated.

\section{Scenario 2: ANS Radioactive Waste Management Interim Management Plans}

- LLLW and radiological process wastes would be disposed through existing waste management systems that should undergo only limited upgrade.

- TRU waste interim storage at SWSA 5 and SWSA 7 (for CH-TRU), and SWSA 5 bunkers (for RH-TRU) would continue indefinitely due to unavailability of WIPP.

- High-level waste and spent fuel would be removed from ANS and temporary storage at-reactor and would then be shipped to RBOF for interim storage. Because eventual disposal at Yucca Mountain or a similar repository is uncertain, prolonged interim storage at RBOF is likely. HLWs from D\&D activities would be stored on an interim basis at ORNL.

- GTCC: In lieu of long-term disposal plans, interim storage at ORNL host site, or at ANS, might be necessary.

- CH and RH-LLW: Until new ORR facilities being planned to replace existing SLLW sites are completed, interim storage at various ORR sites would continue.

- Gaseous radiological wastes would be processed and disposed through existing methods.

- Mixed waste would continue to be stored in interim storage facilities at ORNL.

- Tritium would be collected in the ANS Heavy Water Upgrading and Detritiation Facility. After processing in a Tritium Removal Unit, tritides would be stored on site.

\subsubsection{Impacts of Liquid Low-Level Radioactive Wastes}

ANS would generate approximately $480 \mathrm{~m}^{3}(126,100$ gal) of LLLW annually. The principal sources of LLLW at ANS would be: (1) the reactor facility and adjacent buildings, and (2) the detritiation facility designed to separate tritium from deuterium coolant. Because it comprises a special category of concern, the impacts of liquid tritiated wastes will be discussed in Sect. 5.11.5. Applying the LLLW system's current concentrate to liquid waste ratio of 1:6 means that ANS liquid wastes would annually produce $80 \mathrm{~m}^{3}$ (21,000 gal) of concentrate. Impacts of LLLW are depicted in Table 5.11-1.

Within the reactor facility, contaminated floor drains would comprise the largest single source of LLLW, comprising $286 \mathrm{~m}^{3}$ (75,000 gal) or nearly $60 \%$ of projected annual totals. Projected volumes of LLLW from the ANS detritiation facility, comprising $145 \mathrm{~m}^{3}$ $(38,000 \mathrm{gal})$ or $30 \%$ of annual volume, assume decontamination to a liquid radiological process waste through ion exchange. Such pretreatment could eventually eliminate LLLW generation at ANS. Table 5.11-1 depicts the sources of LLLW at the proposed ANS. 
Table 5.11-1. Predicted generation of liquid low-level waste from the Advanced Neutron Source

\begin{tabular}{|c|c|}
\hline Source & $\begin{array}{c}\text { Volume } \\
{\left[\mathrm{m}^{3} / \text { year (gal/year)] }\right.}\end{array}$ \\
\hline \multicolumn{2}{|c|}{ Reactor facility and adjacent buildings } \\
\hline Primary liquid waste (cleanup resin using ion exchange) & $38.0(10,000)$ \\
\hline $\begin{array}{l}\text { Pool liquid waste (spent resin and water removal from } \\
\text { pool cleanup using ion exchange) }\end{array}$ & $8.0(2,000)$ \\
\hline Primary filters liquid waste & $3.8(1,000)$ \\
\hline Pool filter liquid waste & $0.38(100)$ \\
\hline Contaminated floor drains-reactor area & $280.0(75,000)$ \\
\hline Subtotal & $330.0(88,100)$ \\
\hline \multicolumn{2}{|l|}{ Detritiation facility } \\
\hline Liquid waste from detritiation and upgrade wastewater & $150.0(38,000)$ \\
\hline Total-_all systems & $480.0(126,100)^{a}$ \\
\hline \multicolumn{2}{|c|}{$\begin{array}{l}\text { "Assumes that there will be no pretreatment through ion exchange of liquid low-level waste (LLLW) } \\
\text { from the detritation facility and that a line from Advanced Neutron Source (ANS) to the LLW treatment } \\
\text { system will be required. } \\
\text { Source: Reed, W. R. 1991. "Summary of Information about ANS Wastes," September } 26,1991 \text {, version } \\
\text { update. This table is based upon the assumption that an LLW line will be discharged from ANS, and that } \\
\text { LLLW is not pretreated through dewatering by a small ion exchange system a ANS. For accompanying } \\
\text { tritium contamination, see Table } 5.11-4 \text {. }\end{array}$} \\
\hline
\end{tabular}

\section{Impacts Under Scenario 1}

If the future ORNL LLLW system is upgraded and given a comparable capacity for storing, neutralizing, concentrating, and processing LLLW as that in operation today, the $480 \mathrm{~m}^{3}(126,100 \mathrm{gal})$ of projected ANS LLLW would utilize almost $40 \%$ of the ORNL LLLW system's annual capacity, compared with HFIR's utilization rate of between 12 and $23 \%$ of the LILLW system's capacity in recent years (Robinson, DePaoli, and Walker 1991, p. 15; Office of Waste Management 1991, p. 69). Moreover, this additional loading would occupy $20 \%$ of the LLLW concentrate tank storage component unless additional tank storage were provided and/or conversion to SLLW undertaken. Assuming efforts to decontaminate LLLW through ion exchange are undertaken in the detritiation facility, LLLW from this source could be eliminated.

Because much of the current LLLW Collection and Transfer (CAT) system will be taken out of service when the Federal Facilities Agreement for ORR becomes effective, ANS LLLW would probably be transported to an evaporator facility via truck, causing more frequent usage of laboratory road systems for the shipment of LLLW than is presently the case (Parrott et al. 1991, p. 2). 


\section{Impacts Under Scenario 2}

If the future ORNL LLLW system reaches capacity without significant upgrade, the LLLW evaporators are not replaced, and projected ANS LLLW is not reduced, ANS LLLW would exceed the system's capacity for treatment and disposal.

\subsubsection{Impacts of Radioactive Process Waste}

ANS would generate approximately $751,900 \mathrm{~m}^{3}(29,488,000$ gal) of liquid radioactive process waste (PW) annually. The principal sources of $\mathrm{PW}$ at ANS would be: (1) the reactor facility and adjacent buildings, which would account for almost $98 \%$ of total PW, and (2) the Detritiation Facility designed to separate tritium from deuterium coolant, which would produce the remaining $2 \%$. Table 5.11-2 depicts the sources of PW at ANS. Impacts from ANS radioactive PW would be to future PW processing, storage, and disposal facilities including the PW equalization basin (Pond 3524) (or Bethel Valley Storage Tanks F-2101 and F-2102) and special PWTP. PW from ANS would require approximately $47 \%$ of radioactive process waste treatment capacity at $\mathrm{ORNL}$, a ratio that is 16 times larger than that of HFIR.

\section{Impacts Under Scenario 1}

If $\mathrm{PW}$ facilities are upgraded and their capacity increased beyond their current $240,000 \mathrm{~m}^{3}(62,400,000$ gal $)$ annual capacity, the impacts of ANS PW to the ORNL PW system should be minor. ANS PW would use $47 \%$ of the system's capacity. The ORNL PW system should be able to absorb ANS's loading.

\section{Impacts Under Scenario 2}

If PW facilities are not upgraded and their capacity not increased beyond their current $240,000 \mathrm{~m}^{3}(62,400,000$ gal $)$ annual capacity, ANS PW should require approximately $47 \%$ of the ORNL PW system's capacity. The ORNL PW system might not be able to absorb ANS's additional loading without upgrade.

\subsubsection{Impacts of Solid Radioactive Wastes}

This section describes impacts of TRU waste, high level incidental, spent fuel, GTCC, and radioactive SLLW to off-site TSD facilities such as WIPP and existing and planned ORNL waste treatment facilities. Because it comprises a special category of concern, the impacts of solid tritiated wastes will be discussed in Sect. 5.11-5.

\subsubsection{Transuranic Waste Impacts}

ANS would generate miscellaneous CH-TRU wastes comparable to those associated with HFIR. In addition, RH-TRU wastes from experimental systems processed in the Radiochemical Engineering Development Center (REDC) should be comparable to those from HFIR. It is expected that impacts from this TRU waste would be to ORNL staging facilities and WIPP, as shown in the following paragraphs. 
Table 5.11-2. Predicted generation of liquid radiological process waste (PW) from the Advanced Neutron Source (ANS)

\begin{tabular}{|c|c|}
\hline Source & $\begin{array}{c}\text { Volume } \\
{\left[\mathrm{m}^{3} / \text { year (gal/year) }\right]}\end{array}$ \\
\hline \multicolumn{2}{|l|}{ Reactor facility and adjacent buildings } \\
\hline Primary cleanup resin using ion exchange & $38(10,000)$ \\
\hline $\begin{array}{l}\text { Spent resin and water removal from pool cleanup } \\
\text { using ion exchange }\end{array}$ & $8(2,000)^{a}$ \\
\hline $\begin{array}{l}\text { Primary cleanup filters and water cleanup using } \\
\text { pre-treatment to reduce radiological content }\end{array}$ & $4(1,000)$ \\
\hline Reactor contaminated floor drain waste & $300(75,000)$ \\
\hline Pool filter cleanup & $13,000(3,400,000)$ \\
\hline Subtotal & $13,300(3,488,000)$ \\
\hline \multicolumn{2}{|l|}{ Detritiation facility } \\
\hline $\begin{array}{l}\text { PW from processing cooling tower blowdown, contaminated } \\
\text { condensate, and from miscellaneous organic liquid } \\
\text { wastes, decon solutions, and ion exchange resins }\end{array}$ & $738,000(26,000,000)$ \\
\hline Total-all systems & $751,300(29,488,000)^{b}$ \\
\hline $\begin{array}{l}\text { This waste may be greater-than-class C due to its }{ }^{14} \text { content (see } S \\
\text { "Estimate is a "worst case" assumption based upon: (1) assumption } \\
\text { of cooling water blowdown (contaminated with ethylene glycol and other conta } \\
\text { Process Waste Treatment Plant (PWTP) annually; (2) 790,400 L (208,000 gal } \\
\text { contaminated condensate will be discharged to the PWIP; and (3) up to appr } \\
\text { could be discharged through other floor drain by unplanned discharges. } \\
\text { Source: Reed, W. R. 1991. "Summary of Information about ANS } \\
\text { J. R. Devore, ORNL, Oak Ridge, Tennessee, Memorandum to R. A. Brown, } \\
\text { January 30, 1992. }\end{array}$ & $\begin{array}{l}5.11 .3 .4) \\
\text { about } 79,000 \mathrm{~L} \text { ( }(20,810 \mathrm{gal}) \\
\text { ants) will be dischiarged to the } \\
\text { pproximately) of sitnilarly } \\
\text { nately } 654,000 \mathrm{~L},(172,000 \mathrm{gal}) \\
\text { tes," September } 23: 17 \text {. } \\
\text { NL, Oak Ridge, Ternnessee, }\end{array}$ \\
\hline
\end{tabular}

\section{Impacts Under Scenario 1}

ANS CH- and RH-TRU wastes would ultimately be disposed of ir WIPP if the Waste Handling and Packaging Plant is made available. The former facility is expected to become available for ORNL TRU wastes sometime after 2007 (Baldwin et al. 1989c, p. 28). The expected disposal capacity for CH-TRU waste at WIPP is $176,000 \mathrm{~m}^{3}$ $\left(6,195,200 \mathrm{ft}^{3}\right)$. The expected RH-TRU waste capacity for WIPP is expected to be $7100 \mathrm{~m}^{3}\left(250,000 \mathrm{ft}^{3}\right)$. If $\mathrm{CH}$ - and RH-TRU generated from ANS were to be comparable to that from HFIR (via REDC processing), as expected, it would comprise a small proportion of WIPP's total capacity. 


\section{Impacts Under Scenario 2}

If WIPP does not become available, impacts from ANS CH- and RH-TRU wastes would be to interim storage facilities at ORNL. Total CH-TRU interim storage at ORNL is expected to be between 775 and $1000 \mathrm{~m}^{3}\left(27,000\right.$ to $35,000 \mathrm{ft}^{3}$ ) (Baldwin, Sease, and Jones 1989 , p. 39). Interim facilities for RH-TRU wastes (Bunkers I and II) will have a total storage capacity of 270 casks. Without additional interim storage, TRU waste capacity at ORNL would be exceeded by the addition of ANS.

\subsubsection{High-Level Incidental Waste Impacts}

The amount of high-level incidental waste generated by ANS cannot be predicted. With the exception of spent nuclear fuel (Sect. 5.11.3), ANS would not produce high-level waste from normal operations. It would only produce high-level waste as a result of major alterations and $D \& D$ of the facility.

Impacts from high-level waste due to these activities would include generation of discarded isotope sources and activated parts of reactors. Under the current laboratory-wide radioactive waste management plan, these wastes cannot be disposed of on ORR. It is expected that they would be disposed of in a Dry Cask Storage Facility whose configuration and planning have yet to be identified (Baldwin, Sease and Jones 1989; p. 108; Office of Waste Management 1991, p. 61-2).

\subsubsection{Spent Fuel Impacts}

ANS would annually discharge 17 fuel bundles. These bundles would be placed into special carriers that, in turn, would be placed into an on-site storage pool. After onsite storage for between 1 to 2 years, the spent fuel would be transferred to special shipping casks still under design and shipped by truck to RBOF.

In order to assess the impacts of spent fuel from ANS to ORNL pool storage facilities and off-site storage facilities, the following method was employed. It is assumed that spent fuel bundles from ANS would be stored in special carriers $1.4 \mathrm{~m}(4.6 \mathrm{ft})$ diameter and $4 \mathrm{~m}(13.1 \mathrm{ft})$ tall. These carriers will be stored erect. Each removed spent fuel bundle in its special carrier would thus use $1.96 \mathrm{~m}^{2}\left(21.09 \mathrm{ft}^{2}\right)$ of pool area. Seventeen annual spent fuel replacements-combined with a 1-year on-site spent fuel accumulation before shipment-would utilize $33.3 \mathrm{~m}^{2}\left(359 \mathrm{ft}^{2}\right)$ of pool storage area at ANS.

Impacts to RBOF have been assessed as follows. The total useable spent fuel storage area at $\mathrm{RBOF}$ is $1700 \mathrm{~m}^{2}\left(47,252 \mathrm{ft}^{2}\right)$ (NPR 1991, p. 2). If ANS were the sole user of RBOF, it would exhaust this total spent fuel storage capacity in 131.6 years. In actuality, much of the basin space at RBOF is currently being taken up by the Savannah River Plant's N-Reactor spent fuel. It is believed that this spent fuel will be discharged by the time ANS enters operation (NPR 1991, p. 2).

\section{Impacts Under Scenario 1}

A permanent deep-geologic storage facility for spent nuclear fuel is not expected to become available until after the year 2010. Plans for this permanent spent fuel repository envision a facility with a capacity of 70,000 metric tons ( 77,000 tons). The impacts from ANS spent fuel to this permanent repository would be small. 


\section{Impacts Urider Scenario 2}

If a permanent spent fuel repository were not available, impacts from ANS spent fuel would be to RBOF. There is sufficient spent fuel storage space for ANS spent fuel for 131.6 y yars.

\subsubsection{Greater-than-Class-C Waste Impacts}

ANS would generate small amounts, for example, $<1 \mathrm{~m}^{3}\left(35 \mathrm{ft}^{3}\right)$ of GTCC annually. The principal source of GTCC would be Carbon-14, generated by radiation damage to spent primary cleanup resins. This waste would be stored at ANS in a High Integrity Container until off-site storage or disposal space could be located. GTCC generated by major alteration and D\&D of ANS also could produce some GTCC waste.

\section{Impacts Under Scenario 1}

Impacts from small amounts of GTCC at ANS would be to future GTCC disposal facilities that provide maximum protection for the public as well as protection against accidental intrusion (U.S. OTA 1989, p. 85; Hutchison and Magleby 1990, p. 618). Such facilities might be located at the Savannah River Plant, South Carolina, or they might include new class L-III/TV below grade storage facilities planned for construction for GTCC waste by the mid-1990s (Office of Waste Management 1991, p. 180).

\section{Impacts Under Scenario 2}

In lieu of a permanent disposal facility identified by DOE for disposal of ANS GTCC, impacts from GTCC from ANS would be to interim storage facilities at the K-25 Site or ORNL (Baldwin, Sease and Jones 1989; p. 105). Because the small amount [ $\left.<1 \mathrm{~m}^{3}\left(35 \mathrm{ft}^{3}\right)\right]$ of GTCC waste generated by ANS would comprise a fraction of the total annual generation of class IV wastes at ORNL, impacts should be small. Special caseGTCC disposal is not permitted on ORR (Office of Waste Management 1991, p. 61).

\subsubsection{Solid Low-Level Radioactive Waste Impacts}

ANS would generate approximately $124 \mathrm{~m}^{3}\left(4300 \mathrm{ft}^{3}\right)$ of CH-SLLW annually. The primary source of CH-SLLW from ANS would be the reactor facility and adjacent buildings. Primary cleanup resins, water removal from pool cleanup, removal and replacement of pool filter cartridges and high-efficiency particulate air (HEPA) filters, and miscellaneous engineering and crafts wastes (including discarded clothing and maintenance items) would generate almost $100 \mathrm{~m}^{3}\left(3232 \mathrm{ft}^{3}\right)$, or $82 \%$ of all CH-SLLW at ANS.

Feed preparation resins and miscellaneous solid low activity wastes from the detritiation facility would account for $14 \%$ of CH-LLW, while ANS LLLW treatment facilities would generate the remaining $3 \%$. Table 5.11-3 depicts the sources of CH-SLLW from ANS.

Impacts from SLLW at ANS would be to future solid waste disposal facilities at ORNL. Most CH-LLW from ANS would be class I waste, as is that for HFIR.

ANS will generate approximately $10 \mathrm{~m}^{3}\left(350 \mathrm{ft}^{3}\right)$ of $\mathrm{RH}$-LLW annually from experimental systems and material irradiation facilities. 
Table 5.11-3. Predicted generation of solid contact and remote-handled low-level radioactive waste (CH- and RH-LLW) from the

Advanced Neutron Source (ANS)

\begin{tabular}{cc}
\hline & $\begin{array}{c}\text { Volume } \\
\text { Source }\end{array} \mathrm{m}^{3} /$ year $\left(\mathrm{ft}^{3} /\right.$ year $\left.)\right]$ \\
\hline
\end{tabular}

Reactor facility and adjacent buildings

\section{RH-LLWa}

Material irradiation facilities waste

(ANS experimental systems)

Analytical chemistry experimental wastes

Heat exchangers ${ }^{c}$

Subtotal

\section{CH-LLW}

Primary cleanup resin:

Dry primary resin to high-integrity container

Dry secondary resin [from decontamination process for liquid LLW (LLLW)]

Spent resin and water removal from pool cleanup:

Dry resin or "cemented" secondary water

Secondary resin from decontamination process for LLLW

Primary cleanup filters

4 (140)

Pool water cleanup

$0.9(30)$

High efficiency particulate air filters

$8(283)^{d}$

Crafts and electrical systems waste

$2(75)$

Engineering, mechanical pumps, assorted boxed metal

$7(261)$

wastes

Instrumentation and Controls engineering

94 (3232)

Subtotal 
Table 5.11-3. (continued)

\begin{tabular}{|c|c|}
\hline Source & $\begin{array}{c}\text { Volume } \\
{\left[\mathrm{m}^{3} / \text { year }\left(\mathrm{ft}^{3} / \text { year }\right)\right]}\end{array}$ \\
\hline \multicolumn{2}{|l|}{ Detritiation facility } \\
\hline \multicolumn{2}{|l|}{ CH-LLW } \\
\hline $\begin{array}{l}\text { Heavy water detritiation and upgrade feed } \\
\text { preparation resin }\end{array}$ & $3(94)$ \\
\hline Miscellaneous solid processed low-activity waste & $26.4(930)$ \\
\hline Medium-activity waste & $0.08(3)$ \\
\hline High-activity waste & $0.26(9)$ \\
\hline Sub-total & $29.7(1036)$ \\
\hline \multicolumn{2}{|l|}{ ANS LLLW treatment facilities } \\
\hline CH-LLW & $0.34(12)^{e}$ \\
\hline Total RH-LLW & $10(352)$ \\
\hline Total CH-LLW & $124(4280)$ \\
\hline
\end{tabular}

Isotopic composition of RH-ILW: ${ }^{31} \mathrm{Si},{ }^{24} \mathrm{Mg},{ }^{40} \mathrm{Cu},{ }^{6} \mathrm{Cu},{ }^{63} \mathrm{Ni},{ }^{65} \mathrm{Ni},{ }^{6} \mathrm{Ni},{ }^{60} \mathrm{Co},{ }^{61} \mathrm{Co}_{3},{ }^{32} \mathrm{Mn},{ }^{33} \mathrm{Mn}$,

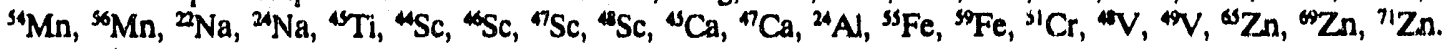

Instrumented and uninstrumented experiment capsules, spent charcoal from gas cleanup, replacement of molecular sieve dryer material, cable and thermocouple leads. This waste is removable only during fuel outages, which occur 17 times per year.

'During the estimated 40-year life of ANS, heat exchanger replacement will generate $300 \mathrm{~m}^{3}(10,480$ $\mathrm{ft}^{3}$ ) of CH-LLW or $7.4 \mathrm{~m}^{3}\left(262 \mathrm{ft}^{3}\right)$, if annualized. HEPA filters.

HEPA filters are generally replaced at 5-year intervals; this figure assumes a total installment of 15

The ANS LLLW treatment facility will dewater resin and treat reactor LLLW.

Source: Reed, W. R. 1991. "Summary of Information About ANS Wastes," September 23, 1991, version and September 26, 1991, version update.

\section{Impacts Under Scenario 1}

Impacts from SLLW generated by ANS would be to new LLW disposal facilities at ORNL. Assuming the most likely candidate disposal sites for class I and II wastes would be available at the time ANS would enter operation (SWSA 7 for class II and West Chestnut Ridge for class I waste), as depicted in Table 3.5-3, impacts from ANS solid wastes would be to these sites.

Total planned class I disposal space at West Chestnut Ridge is $262,000 \mathrm{~m}^{3}$ $\left(9,224,871 \mathrm{ft}^{3}\right)$. Total planned class II disposal space in SWSA 7 is $71,000 \mathrm{~m}^{3}$ $\left(2,508,540 \mathrm{ft}^{3}\right.$ ) (Rivera et al. 1989, p. 20). This space, if available, should be adequate for 
ANS SLLW. Space availability in a possibly expanded Interim Waste Management Facility at SWSA 6 for class II wastes is less certain, however.

SLLW from ANS falling into class III or IV categories that has high radionuclide concentrations and a long half-life would likely be shipped to a yet-to-be built, specially-engineered facility at the Savannah River Plant, South Carolina. Such a facility probably will not be available until after the year 2000 (Office of Waste Management 1991, p. 61). In the interim, a new class III or IV storage facility, which has been proposed to provide interim storage capacity for approximately 10 years until off-site disposal becomes practicable (Baldwin, Sease and Jones; 1989, p. 105), should be available.

\section{Inpacts Under Scenario 2}

If a new class $T$ disposal facility does not come on-line in the year 2000 , and if SWSA 6 closure begins as expected (in December 1993, Office of Waste Management 1991, p. 58), a significant shortage in class I disposal capacity will result (Baldwin, Sease, Jones 1989; p. 66). Likewise, if a new class II disposal site also is delayed, and ANS enters operation, interim stcrage of ANS class II wastes would likely be necessary.

Under this scenario, ANS solid wastes would have to be stored at various ORR sites. Some SLLW might be subject to interim storage at ORNL, while some might undergo interim storage at the K-25 Site. Finally, interim storage of class II and IV wastes from ANS at the planned storage facility at ORNL's SWSA 7 would continue until capacity is reached.

\subsubsection{Gaseous Radioactive Waste Impacts and Tritium Vapor Impacts}

Following holdup for decay and filtration, several radioactive gases would be discharged into the atmosphere through a single on-site stack at the proposed facility. As depicted in Table 5.11-4, trace emissions of several radioactive gases are likely. However, the single largest radionuclide emission would be $2.7 \times 10^{14} \mathrm{~Bq}(7200 \mathrm{Ci})$ of tritium released from the reactor and detritiation facility annually. The latter would account for nearly $70 \%$ of all atmospheric tritium discharges. Some radioactive gases will be locally treated in glove box cleanup systems. Dehumidification will be employed to minimize losses of tritiated water vapor.

The impacts of ANS gaseous radiological wastes to existing and planned improvements to the laboratorywide stack-discharge system should be minor because ANS would provide its own stack system for removal of tritium.

Since HEPA filters are ineffective for tritium retention, it will have to be collected and monitored (Office of Waste Management 1991, pp. 97 and 107). The $2.7 \times 10^{14} \mathrm{~Bq}$ $(7200 \mathrm{Ci})$ of tritium anticipated to be released through the stack system should not pose a significant impact to total allowable dose commitments at ORNL (see Sect. 5.7.5).

Other gaseous radioactive emissions would have an impact on the ORNL SLLW management system, however. ANS staff estimate that pre-filters, bag filters, charcoal filters, and high efficiency particulate air filters installed in the ANS atmospheric emissions stack system would have to be replaced every 5 years, resulting in the disposal of approximately $40 \mathrm{~m}^{3}\left(1450 \mathrm{ft}^{3}\right)$ of solid CH-LLW. Broken down annually, this would amount to $8 \mathrm{~m}^{3}\left(290 \mathrm{ft}^{3}\right)$ of CH-LLW for disposal. 
Table 5.11-4. Predicted gaseous radiological emissions from the Advanced Neutron Source reactor facility and adjacent buildings

\begin{tabular}{|c|c|c|}
\hline Element & $\begin{array}{l}\text { Solubility } \\
\text { class }^{b}\end{array}$ & $\begin{array}{c}\text { Radionuclides } \\
\text { [Bq/year (Ci/year)] }\end{array}$ \\
\hline${ }^{3} \mathrm{H}$ & G & $2.661 \times 10^{14}\left(7.193 \times 10^{3}\right)$ \\
\hline${ }^{60} \mathrm{Co}$ & $\mathrm{Y}$ & $7.96 \times 10^{2}\left(2.15 \times 10^{-8}\right)$ \\
\hline${ }^{85} \mathrm{Kr}$ & G & $6.48 \times 10^{13}\left(1.75 \times 10^{3}\right)$ \\
\hline${ }^{90} \mathrm{Sr}$ & $\mathrm{D}$ & $8.29 \times 10^{4}\left(2.24 \times 10^{-6}\right)$ \\
\hline${ }^{132} \mathrm{Te}$ & W & $3.85 \times 10^{5}\left(1.04 \times 10^{-5}\right)$ \\
\hline${ }^{129} \mathrm{I}$ & $D$ & $1.35 \times 10^{5}\left(3.65 \times 10^{-6}\right)$ \\
\hline${ }^{131} I$ & D & $4.18 \times 10^{9}\left(1.13 \times 10^{-1}\right)$ \\
\hline${ }^{132} I$ & $D$ & $2.01 \times 10^{8}\left(5.44 \times 10^{-3}\right)$ \\
\hline${ }^{133} I$ & D & $4.85 \times 10^{9}\left(1.31 \times 10^{-1}\right)$ \\
\hline${ }^{135} \mathrm{I}$ & D & $4 \times 10^{9}\left(1.08 \times 10^{-1}\right)$ \\
\hline${ }^{133} \mathrm{Xe}$ & $\mathrm{D}$ & $3.15 \times 10^{14}\left(8.52 \times 10^{3}\right)$ \\
\hline${ }^{137} \mathrm{Cs}$ & $\mathrm{D}$ & $1.63 \times 10^{5}\left(4.40 \times 10^{-6}\right)$ \\
\hline${ }^{137 \mathrm{~m}} \mathrm{Ba}$ & $\mathrm{D}$ & $1.63 \times 10^{5}\left(4.40 \times 10^{-6}\right)$ \\
\hline${ }^{140} \mathrm{La}$ & W & $1.09 \times 10^{5}\left(2.95 \times 10^{-6}\right)$ \\
\hline${ }^{194} \mathrm{Au}$ & -- & $2 \times 10^{4}\left(5.40 \times 10^{-7}\right)$ \\
\hline${ }^{212} \mathrm{~Pb}$ & $\mathrm{D}$ & $2.10 \times 10^{9}\left(5.68 \times 10^{-2}\right)$ \\
\hline${ }^{228} \mathrm{Th}$ & $\mathbf{Y}$ & $3.24 \times 10^{2}\left(8.76 \times 10^{-9}\right)$ \\
\hline${ }^{230} \mathrm{Th}$ & $\mathbf{Y}$ & $3.92 \times 10^{2}\left(1.06 \times 10^{-8}\right)$ \\
\hline${ }^{232} \mathrm{Th}$ & $\mathbf{Y}$ & $2.87 \times 10^{2}\left(7.75 \times 10^{-9}\right)$ \\
\hline${ }^{234} \mathrm{U}$ & $\mathbf{Y}$ & $5.77 \times 10^{2}\left(1.56 \times 10^{-8}\right)$ \\
\hline${ }^{239} \mathrm{Pu}$ & $\mathbf{Y}$ & $1.58 \times 10^{1}\left(4.28 \times 10^{-10}\right)$ \\
\hline
\end{tabular}

"Of the $2661 \times 10^{14} \mathrm{~Bq} /$ year (7193 Ci/year) of tritium from the Advanced Neutron Source (ANS), $1.85 \times 10^{14} \mathrm{~Bq}(5000 \mathrm{Ci})$ would come from the detritiation facility.

This $1.85 \times 10^{14} \mathrm{~Bq}(5000 \mathrm{Ci})$ would be accompanied by nitrogen, argon, helium-3 and -4 , and hydrogen.

${ }^{b} \mathrm{G}=$ gas, $\mathrm{W}=$ moderately soluble, $\mathrm{Y}=$ insoluble, $\mathrm{D}=$ soluble.

Source: Reed, W. R. 1991. "Summary of Information About ANS Wastes," September 23-26. 


\subsubsection{Impacts of Tritiated Liquids and Solids}

While tritium would be discharged into the atmosphere as a gas following holdup and decay, as discussed in Sect. 5.11.4, ANS would also be equipped to segregate and remove gross amounts of tritium from liquid and solid waste streams and store it on-site in embedded tritides. As shown in Table 5.11-5, $4.14 \times 10^{16} \mathrm{~Bq}(1.12$ million $\mathrm{Ci})$ of tritium would be removed through the detritiation process. Removal would mostly take place in the tritium removal sub system (Sect. 3.5.7). After removal, it would be packaged in the form of metal tritides (probably zirconium or uranium in order to immobilize tritium by-products), and stored on a retrievable basis. The exact location and space requirements for this on-site storage have not yet been determined.

Despite this program of deliberate segregation of tritium, nominal amounts of tritium from the reactor and Heavy Water Upgrade and Detritiation facility would accompany LLLW and SLLW destined for disposal. The impacts of these nominal amounts would be to the laboratory-wide liquid and solid waste systems.

Annually, $8.88 \times 10^{13} \mathrm{~Bq}(2400 \mathrm{Ci})$ of tritium would accompany liquid reactor facility wastes from the primary liquid waste cleanup system, spent resins from the reactor pool, pool water cleanup, and primary pool filtration system. Tritium associated with the reactor liquid waste management systern may be discharged to the laboratory-wide LLLW system and/or radiological process waste system. Because these systems do not have the ability to remove this tritium, it would then be discharged to the White Oak Creek system where between $9.25 \times 10^{13}$ to $1.07 \times 10^{14} \mathrm{~Bq}(2500$ to $2900 \mathrm{Ci})$ of tritium are already annually discharged into White Oak Lake from SWSA-5 remediation activities (Personal communication from J. Trabalka, Environmental Science Division, ORNL, to D. L. Feldman, Energy Division, ORNL, January 17, 1992).

Alternatively, this $8.88 \times 10^{13} \mathrm{~Bq}(2400 \mathrm{Ci})$ of tritium may be disposed as $\mathrm{CH}$ LLW in the form of solidified dry resins, primary filter debris, and solid processed LLW such as paper, plastic, neoprene rubber, and clothing. It is expected that most of this CHLLW will be packaged into high-density polyethylene containers and disposed at ORNL facilities. Because the exact location and space requirements for this on-site storage have yet to be determined, incineration of solid tritiated wastes, separation of tritium vapors at ANS and discharge through the stack system where it would not pose significant impacts (Sect. 5.11.4), as well as other methods of disposal, will continue to be explored.

\subsubsection{Mixed Waste Impacts}

ANS would generate approximately $1.2 \mathrm{~m}^{3}$ (330 gal) of mixed waste annually. Mixed waste would consist of contaminated oils from the reactor area and detritiation facility. The impacts of ANS mixed waste would be to interim liquid mixed waste storage facilities at ORNL and the K-25 Site or to future treatment and disposal facilities on ORR or DOE sites.

In order to estimate the impacts of ANS mixed waste to future treatment, disposal, or storage facilities, the following assumptions were made. It is assumed that annual mixed waste generation at ORNL will be comparable to that at present. It is anticipated then, that projected mixed waste from ANS would account for $6 \%$ of the $20 \mathrm{~m}^{3}$ laboratorywide mixed waste requiring treatment, disposal, or storage (see Table 5.11-6). 


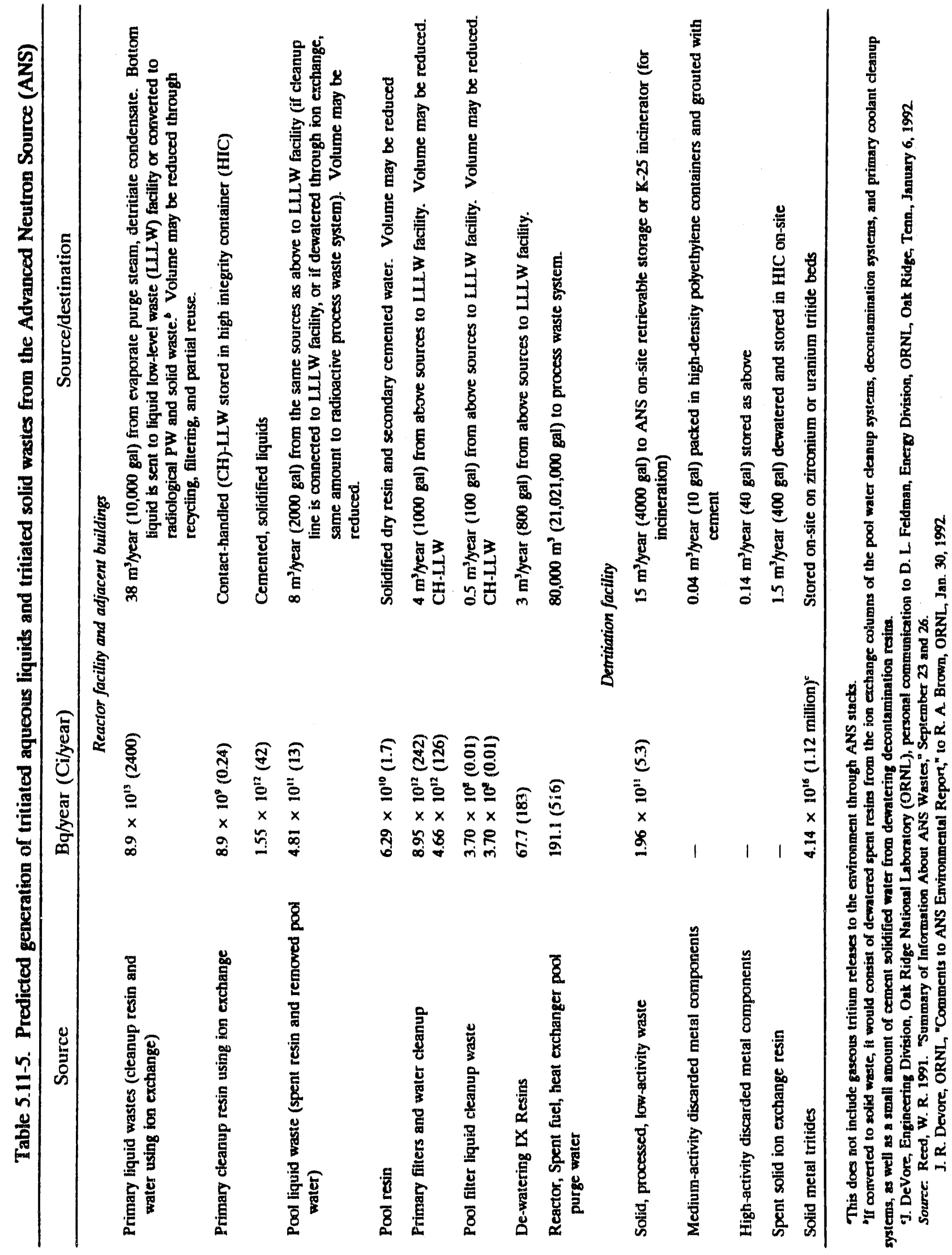


Table 5.11-6. Predicted hazardous and mixed waste generation at the Advanced Neutron Source (ANS) ${ }^{a}$

Volume

Categories $\left[\mathrm{m}^{3} /\right.$ year (gal/year)]

\section{Hazardous liquids}

Uncontaminated oils-transformers, fuels and lubricants,

cooling tower gearboxes and fans ${ }^{b}$

Oil from vacuum pump-Neutron Scattering System

Subtotal-oil

Chemical laboratory wastes ${ }^{c}$

Subtotal-all liquids

Hazardous solids

Biological waste

\section{Mixed Waste}

Contaminated oil from reactor area

Oil contaminated with tritium (Detritiation facility)

Subtotal-mixed wastes

$1.2(329)$

"Source: Reed, W. R. "Summary of Information About ANS Wastes," September 26, 1991, version information provided with assistance of George McNutt and Jeff Cleveland.

Transformers, capacitors, and ballasts will not be filled with polychlorinated biphenyl.

'Principally acetone, benzene, alcohol, trichloroethylene, and various acids used for cleaning equipment as well as sotvent wipes and chemical solids. It is important to note that at High Flux Isotope Reactor, while comparable amounts of laboratory wastes are annually generated, they are stored on-site, in conjunction with hazardous chemicals from other research divisions (see Table 5.10-10).

\section{Impacts Under Scenario 1}

Impacts from ANS liquid mixed wastes would be to the Oak Ridge Mixed Waste Incinerator (ORMWI) at the K-25 Site-which is expected to accept liquid mixed waste when ANS enters operation. ANS mixed waste would account for $6 \%$ of total ORNL mixed waste for treatment or disposal.

\section{Impacts Under Scenario 2}

In the event that ORMWI or other ORR treatment or disposal facilities are not available for treatment or disposal of ANS mixed wastes, or additional characterization and evaluation determines that ANS mixed wastes are unsuitable for treatment at the ORMWI, impacts of mixed wastes would be to new mixed waste storage facilities presently in the planning stages (Office of Waste Management 1991, p. 125). 
As in Scenario 1, it is expected that ANS would account for $6 \%$ of the total annual mixed waste at ORNL requiring interim storage at these new facilities.

\subsubsection{Sanitary Waste Impacts}

ANS would generate approximately $16,900 \mathrm{~m}^{3}(4,440,000 \mathrm{gal})$ of human sanitary wastes annually. In addition, ANS would generate $1040 \mathrm{~m}^{3}$ (273,000 gal) of laundry wastewater annually. Impacts of this waste would be to the ORNL Sanitary Waste Treatment Plant located in Building 2521 at the west end of ORNL. The total ANS sanitary waste generation of $17,960 \mathrm{~m}^{3}(4,700,000$ gal) would require about $4 \%$ of total ORNL Sanitary Waste Treatment system capacity. Sanitary waste from ANS would probably be pumped directly to the southwest corner of the ORNL Sanitary Waste Treatment Plant. This is in contrast to HFIR which currently trucks its sanitary waste to this facility.

\subsubsection{Conventional Waste Impacts}

This section describes impacts from ANS conventional wastes, floor drains, rainwater runoff, and other nonhazardous waste sources to ORNL conventional waste management facilities.

\subsubsection{Conventional Liquid Waste (Effluent) Impacts}

Effluents from ANS that would impact the ORNL storm sewer system include rainwater runoff from parking lots, grassy areas, and roof drains. Storm water runoff from areas surrounding the reactor building, support facility, guide hall, and laboratory buildings, as well as sprinkler discharges and heating, ventilating, and air conditioning cooling condensate would occasionally contain trace quantities of radiological contamination above background-including cesium, strontium, cobalt, and tritium. Before release of these effluents to the White Oak Creek system, effluents would be held up and monitored for deuterium oxide and tritium, with separation of tritium whenever possible.

Treatment of contaminated effluents would take place at ORNL PWTP before discharge to the White Oak Creek watershed as permitted under an NPDES permit. Uncontaminated effluents would be directly discharged to the White Oak Creek watershed under the requirements of an NPDES permit.

\subsubsection{Conventional Solid Waste Impacts}

ANS would generate a total of $1330 \mathrm{~m}^{3}\left(47,000 \mathrm{ft}^{3}\right)$ of conventional solid waste annually. As shown in Table 5.11-7, most of this waste would be refuse, while the remainder would be miscellaneous glass and scrap metal. In addition, about $620 \mathrm{~m}^{3}$ $\left(22,000 \mathrm{ft}^{3}\right)$ of solid waste from ANS support areas, likely to be taken over from HFIR, will be generated annually. Impacts from these nonhazardous conventional wastes would be either to an expanded Centralized Sanitary Landfill II located on Chestnut Ridge, $10 \mathrm{~km}$ (6 miles) east of ORNL, or to Landfill 5-a planned acility to be located at the Y-12. Plant (Fig. 3.7-1).

\footnotetext{
Based on an estimate of $7000 \mathrm{gal} / \mathrm{d}$ shift of 250 workers; $1500 \mathrm{gal} / \mathrm{d}$ for 100 visitors $120 \mathrm{~d} / \mathrm{year}$, and up to 100 people per shift on 16 weekends, evenings, and night shifts. It is estimated that each person will use about 35 gal of water per shift.
} 
Table 5.11-7 Predicted conventional waste generation at the Advanced Neutron Source (ANS)

\begin{tabular}{|c|c|}
\hline Waste categories & Volumes \\
\hline \multicolumn{2}{|c|}{$\begin{array}{c}\text { Conventional liquid waste } \\
{\left[\mathrm{m}^{3} / \text { year (gal/year)] }\right.}\end{array}$} \\
\hline Laundry wastewater & $1040(273,000)$ \\
\hline Noncontaminated floor drains & $57,000(15,000,000)$ \\
\hline Sanitary waste & $16,900(4,440,000)$ \\
\hline \multicolumn{2}{|c|}{$\begin{array}{l}\text { Conventional solid waste } \\
{\left[\mathrm{m}^{3} / \text { year }\left(\mathrm{ft}^{3} / \text { year }\right)\right]}\end{array}$} \\
\hline Refuse & $1220(43,000)^{a}$ \\
\hline Miscellaneous nonhazardous scrap metal & $114(4000)$ \\
\hline Subtotal & $1334(47,000)$ \\
\hline $\begin{array}{l}\text { ANS support area/former High Flux Isotope } \\
\text { Reactor area conventional waste }\end{array}$ & $620(22,000)$ \\
\hline
\end{tabular}

Includes, as major constituents, conventional Instrumentation and Control wastes, electrical engineering wastes, shipping waste from furniture, ANS lunch room, office waste baskets, and similar sources. 18.

Source: Reed, W. R. 1991. "Summary of Information About ANS Wastes," September 23, pp. 10 and

\subsubsection{Conventional Gaseous Waste Impacts}

It is expected that ANS would generate routine nonhazardous gaseous emissions, including suspended particulates, carbon monoxide and carbon dioxide, ozone, nitrogen oxides, volatile organic compounds, and fluorides from laboratory work. These would be regulated by air quality permit, as required, and no changes from conventional gas impacts associated with HFIR are expected.

\subsubsection{Hazardous Waste Impacts}

This section describes impacts of ANS hazardous wastes to the hazardous waste management facilities at ORNL (see Table 5.11-6).

\subsubsection{Impacts of Hazardous Liquids}

ANS would generate approximately $23 \mathrm{~m}^{3}$ (3000 gal) of hazardous liquids annually, divided almost evenly between waste oils and chemical laboratory wastes. Impacts of these wastes would be to on-site storage facilities and to off-site, EPA-permitted treatment and disposal facilities. 
Contaminated floor drain runoff from ANS, estimated to be $57,000 \mathrm{~m}^{3}$ $(15,000,000$ gal) annually, would impact the NRWTF. After treatment, these wastes would be discharged to the White Oak Creek system.

Contaminated blowdown from ANS would impact a special ANS treatment plant integrated with the ANS pump house building and further treated in the LLLW Evaporator Facility or PWTP. Treated blowdown would also be released to the White Oak Creek watershed.

\subsubsection{Impacts of Hazardous Solids}

Small amounts $\left[<1 \mathrm{~m}^{3}\left(<35 \mathrm{ft}^{3}\right)\right]$ of hazardous biological wastes (e.g., animal brain extract used in experiments) would be produced annually at ANS. Within the ANS biological laboratory, tissues would be exposed to aqueous solutions of detergent and methanol compounds. After preparation in this laboratory, these tissue samples would be irradiated by neutron scattering and eventually discarded. They should have no impact to the hazardous waste system at ORNL.

Impacts of hazardous materials (e.g., solvents) generated by construction of ANS would be on off-site commercial disposal facilities or to ORMWI at the K-25 Site.

\subsubsection{Impacts of Hazardous Gases}

The ANS reactor pool would generate small amounts of explosive, flammable hydrogen gas. As depicted in Fig 3.7-2, hydrogen would be vented to the atmosphere to reduce its explosive concentration in reactor containment. It is expected that ANS would also use compressed gas cylinders, such as oxygen tanks, for various purposes. These should be comparable to those stored at HFIR (see Table 5.11-3).

\subsection{REFERENCES FOR SECTION 5}

Baldwin, J. S., J. D. Sease, and D. L. Jones 1989. Oak Ridge National Laboratory Implementation Plan for DOE Order 5820.2A, ORNL/TM-11166, Oak Ridge National Laboratory, Oak Ridge, Tennessee, April.

Baldwin, J. S., et al. 1989a. ORNL Long-Range Environmental and Waste Management Plan: Detailed Management Plan, ORNL-6537, Oak Ridge National Laboratory, Oak Ridge, Tenn., September.

Baldwin, J. S., et al. 1989b. ORNL Long-Range Environmental and Waste Management Plan: Program Overview and Summary, ORNL-6536, Oak Ridge National Laboratory, Oak Ridge, Tenn., September.

Baldwin, J. S., et al. 1989c. Oak Ridge National Laboratory Transuranic Waste Management Strategy Document, ORNL/TM-11506, Oak Ridge National Laboratory, Oak Ridge, Tenn., March.

Borders, D. M., et al. 1991. Annual Hydrologic Data Summary for the White Oak Creek Watershed: Water Year 1990 (October 1989-September 1990), ORNL/ER-55, Oak Ridge National Laboratory, Oak Ridge, Tenn.

Butterworth, G. 1988. "Low-Level Waste Disposal, Development, and Demonstration Program," Oak Ridge National Laboratory Review 21 (4), pp. 36-38.

Cada, G. F. 1986. Characterization of Fish and Benthic Invertebrates of Melton Branch, Oak Ridge Reservation, Oak Ridge National laboratory, Oak Ridge, Tenn. 
EPA (U.S. Environmental Protection Agency) 1977. Valley Model User's Guide, WPA450/2-77-018, U.S. Environmental Protection Agency, Office of Air Quality Planning and Standards, Research Triangle Park, Raleigh, N.C.

EPA (U.S. Environmental Protection Agency) 1989. Risk Assessments Methodology, Environmental Impact Statement, NESHAPS for Radionuclides, Background Information, Vol 1, EPA/5201/1-89-005, EPA, Research Triangle Park, Raleigh, N.C.

Hinson, C. S., and F. J. Congel 1990. LWR Occupational Dose Data for 1989, Nuclear Regulatory Commission Staff Report, U.S. Nuclear Regulatory Commission Washington, D.C., June 28.

Hutchison, D., and M. Magleby 1990. "Greater-Than-Class-C Low-Level Waste Characterization Technical Review Process," Nuclear Materials Management, 31st Annual Meeting Proceedings, Vol. XIX, Los Angeles.

ICRP and ICRU (International Commission on Radiological Protection and International Commission on Radiation Units) 1963. "Report of the RBE Committee of the International Commission on Radiological Protection and the International Commission on Radiation Units and Measurements," Health Physics 9, 357.

ICRP and ICRU (International Commission on Radiological Protection and International Commission on Radiation Units) 1986. The Quality Factor in Radiation Protection, ICRU Report Number 40, International Commission on Radiation Units and Measurements, Bethesda, Md.

ICRP (International Commission on Radiological Protection) 1990. Recommendations of the International Commission on Radiological Protection, ICRP Publication 60, Annals of the ICRP 21 (1-3), Oxford, UK.

Kasten, J. L. 1986. Water Conservation Plan for the Oak Ridge Reservation, Vol. 21 in Resource Management Plan for the Oak Ridge Reservation, ORNL/ESH-1/N21, Oak Ridge National Laboratory, Oak Ridge, Tenn.

Kornegay, F. C., et al. 1991. Oak Ridge Reservation Environmental Report for 1990, ORNL/ES/ESH-18/V1 and 2, Oak Ridge National Laboratory, Oak Ridge, Tenn., September.

Loar, J. M. (ed.) 1991. Fifth Annual Report on the ORNL Biological Monitoring and Abatement Program, ORNL/TM, Oak Ridge National Laboratory, Oak Ridge, Tenn.

Mook, H. A., and R. M. Nicklow 1990. "Neutron Scattering at the High Flux Isotope Reactor," Solid State Division, Oak Ridge National Laboratory, Oak Ridge, Tenn., December.

Munson L. H., et al. 1988. Health Physics Manual of Good Practices for Reducing Radiation Exposure to Levels that Are as Low as Reasonably Achievable, PNL-6577, Pacific Northwest Laboratory, Richland, Wash.

NAS (National Academy of Sciences) 1972. Water Quality Criteria 1972, a report of the Committee on Water Quality Criteria, National Academy of Sciences/National Academy of Engineering, Washington, D.C.

NAS (National Academy of Sciences) 1990. Health Effects of Exposure to Low Levels of Ionizing Radiation, National Research Council, Advisory Committee on the Biological Effects of Ionizing Radiation BEIR V, Washington, D.C.

NCRP (National Council on Radiation Protection) 1987. Recommendations on Limits for Exposure to Ionizing Radiation, Report No. 91, Bethesda, MD.

NCRP (National Council on Radiation Protection) 1990. The Relative Biological Effectiveness of Radiations of Different Quality, NCRP Report No. 104, Bethesda, MD. 
NPR (New Production Reactor) 1991. Long-Term Storage of NPR Spent Fuel in SRS Disassembly Basins and at Hanford, Memorandum, Westinghouse Savannah River Company, Aiken, S.C.

NRC (U.S. Nuclear Regulatory Commission) 1977. Calculation of Annual Doses to Man from Routine Releases of Reactor Effluents for the Purpose of Evaluating Compliance with 10 CFR Pt. 50, Appendix 1, Regulatory Guide 1.109, Office of Standards Development.

NRC (U.S. Nuclear Regulatory Commission) 1991. Occupational Rudiaticn Exposure at Commercial Nuclear Power Reactors and Other Facilities 1988, NUREG-0713, Vol 10.

Office of Waste Management and Remedial Actions 1991. Oak Ridge National Laboratory Waste Management Plan, ORNL/TM-11433/R1, prepared for the Office of Environmental Restoration and Waste Management, Oak Ridge National Laboratory, Oak Ridge, Tenn.

Parrott, J. R., et al. 1991. Oak Ridge National Laboratory Liquid Waste Treatment Systems Waste Acceptance Criteria, WM-WIMCO-201, Office of Waste Management and Remedial Actions, Waste Management Operations, Waste Management Coordination Office, Oak Ridge National Laboratory, Oak Ridge, Tenn., July.

Rivera, A. L., et al. 1989. LLWDDD Program Waste Management Data System Status Report for the Period October-December 1988, ORNL/CF-89/14, Oak Ridge National Laboratory, Oak Ridge, Tenn., March.

Robinson, S. M., S. M. DePaoli, and A. B. Walker 1991. Federal Facility Compliance Agreement Contingency, Upgrade, and Replacement Plans for the ORNL Active Low-Level Radioactive Waste Tank System, ORNL/TM-11795, prepared for the Office of Environmental Restoration and Waste Management, Oak Ridge National Laboratory, Oak Ridge, Tenn., June.

Rohwer, P. S. 1989. Environmental Monitoring and Compliance (EMC) Section Position on the Discharge of Chlorinated Water to ORNL Surface Streams, memorandum to Environmental Protection Officers, Oak Ridge National Laboratory, Oak Ridge, Tenn.

Sharp, D. R. 1990. Summary Report, Health Physics 1989 Calendar Year, U.S. Department of Commerce, National Institute of Standards and Technology.

OTA (U. S. Office of Technology Assessment) 1989. Partnerships Under Pressure: Managing Commercial Low-Level Radioactive Waste, OTA-O-426, U.S. Congress. 


\section{EFFLUENT AND ENVIRONMENTAL MEASUREMENTS AND MONTTORING PROGRAMS}

\subsection{PREOPERATIONAL MONITORING PROGRAM}

This section provides an overview of effluent and environmental monitoring programs on the Oak Ridge Reservation (ORR), the proposed site for the Advanced Neutron Source (ANS) facility. Most of the information in this section is summarized from Kornegay et al. (1991, Vol. 1, pp. 1-283 and Vol. 2, pp. 1-279), which provides a comprehensive description of sampling, monitoring, and regulatory compliance activities at the three major ORR installations. The monitoring programs for the ORR are reviewed and enhanced frequently in response to various considerations [e.g., U.S. Department of Energy (DOE) Orders and revisions to environmental regulations]; as a result, the monitoring described in this section (which uses 1990 information) may differ in some respects from current activities. However, the purpose of this section is to give an overview of the types of monitoring programs in place for ORR, not to offer specific descriptions of those programs. Current descriptions of ORR monitoring programs are available in the Environmental Monitoring Plan maintained by Oak Ridge National Laboratory's (ORNL's) Office of Environmental Compliance, which is continuously updated to reflect changes in monitoring activities. The discussion that follows emphasizes the ORNL area, where ANS would be located, and provides more summary information for the K-25 Site and Y-12 areas.

\subsubsection{Nonradiological Monitoring}

This section describes nonradiological monitoring on the ORR; radiological monitoring is discussed in Sect 6.1.2.

\subsubsection{Surface Water}

Field measurements and sample collections for surface water monitoring are carried out at various effluent sources and receiving streams on the ORR. Additional sampling is done at the nearest off-site municipal water intake location (at Kingston, Tennessee). Water samples are collected and analyzed at various intervals (weekly, monthly, etc.). Concentrations of contaminants in the streams and creeks on or around the ORR are compared with Tennessee's in-stream water quality criteria, which are based on stream classification and recommendations made by the Tennessee Department of Conservation (TDC) to the DOE-Oak Ridge Operations. In many cases, allowable effluent concentrations are dictated by discharge permits, which are issued by TDC. Water quality at the intake for the K-25 Site Water Treatment Plant is compared with Tennessee water quality criteria for domestic water supplies.

\section{Physical and chemical properties}

Surface water monitoring for nonradiological parameters on the ORR includes the National Pollutant Discharge Elimination System (NPDES) monitoring, non-NPDES monitoring, and stream sediment sampling. 
NPDES monitoring program. Under the requirements of the Clean Water Act, an NPDES permit has been issued to each of the three major ORR facilities. ORNL NPDES discharge outfalls and effluent parameters are given in Table 6.1-1. The permit for each plant outlines specific outfalls and sampling locations, parameters, and frequencies for analysis for all nonradiological parameters. In addition, each plant has developed a radiological sampling plan specific to its needs (see Sect. 6.1.2). Other components of the permit include requirements for a toxicity control and monitoring program, a biological monitoring and abatement program (BMAP), a mercury assessment plan, and a polychlorinated biphenyl (PCB) sampling plan for aquatic pathways.

At ORNL, discharges to White Oak Creek from the ORNL Sewage Treatment Plant and the Nonradiological Wastewater Treatment Facility (which would treat ANS nonradiological wastewater) are monitored in compliance with the ORNL NPDES permit. Water quality monitoring is conducted in Melton Branch for the purpose of the BMAP (Loar 1988, pp. 1-475; Loar 1989, pp. 1-436; Loar 1990, pp. 1-371; Loar 1991; Loar et al. 1987, pp. 1-354). Also, hydrologic and water quality data are compiled for the White Oak Creek watershed in support of the ORNL Environmental Restoration Program (Borders et al. 1991, pp. 1-243). No monitoring of stream flows or water quality in Friendship Creek (tributary to Bearden Creek and the Clinch River) is being done.

Monitoring not required by an NPDES permit. At ORNL, monthly surface water samples are collected at two sampling locations for the purpose of determining background concentration levels before the influence of ORNL: (1) Melton Hill Dam above ORNL's discharge point into the Clinch River (with the exception of the cooling tower, roof, and parking lot runoff at the Building 7600 area) and (2) White Oak Creek Headwaters above the point where ORNL discharges to White Oak Creek (Fig. 6.1-1). The samples are analyzed for several organic compounds, inorganic elements, and other water quality parameters: $\mathrm{Al}, \mathrm{Sb}, \mathrm{As}, \mathrm{Ba}, \mathrm{Be}, \mathrm{B}, \mathrm{Cd}, \mathrm{Ca}, \mathrm{Cr}, \mathrm{Co}, \mathrm{Cu}$, total dissolved solids, fluoride, $\mathrm{Fe}, \mathrm{Pb}, \mathrm{Li}, \mathrm{Mg}, \mathrm{Mn}, \mathrm{Mo}, \mathrm{Ni}$, nitrate, oil and grease, total organic carbon, $\mathrm{P}, \mathrm{Se}$, $\mathrm{Si}, \mathrm{Ag}, \mathrm{Na}, \mathrm{Sr}$, sulfate as $\mathrm{SO}_{4}$, total suspended solids, $\mathrm{Sn}, \mathrm{Ti}, \mathrm{V}, \mathrm{Zn}, \mathrm{Zr}$, conductivity, dissolved oxygen, temperature, turbidity, and pH. The results of these analyses help to assess surface water quality independent of impacts from ORNL.

At the Y-12 Plant, nonradiological parameters are also monitored at four nonNPDES sites: Upper Bear Creek [at kilometer 12.4 (mile 7.7) and at kilometer 11.97 (mile 7.44)], Station 17, and the two sanitary sewer lines that discharge to the City of Oak Ridge sanitary sewer. Parameters measured are similar to those for ORNL. At the K-25 Site, samples are taken at seven locations: the Clinch River (Brashaer Island), West Fork Poplar Creek, Building K-716, Building K-1513, Building K-1710, Building K-1770, and Mitchell Branch. K-25 Site non-NPDES monitoring includes analyses for more organic compounds than are included in the ORNL or Y-12 Plant studies.

Sediment monitoring. Stream sediment sampling occurs at six Poplar Creek locations and two Clinch River locations. Samples are collected in summer and analyzed for concentrations of $\mathrm{Hg}, \mathrm{Pb}, \mathrm{Ni}, \mathrm{Cu}, \mathrm{Zn}, \mathrm{Cr}, \mathrm{Mn}, \mathrm{Al}, \mathrm{Th}, \mathrm{Cd}$, and $\mathrm{U}$. The details of sediment sampling (locations and analytical techniques) are described in Kornegay et al. (1991, pp. 175-182).

\section{Aquatic ecology}

Considerable biological monitoring of Melton Branch and White Oak Creek is taking place as part of the ORNL BMAP. These studies fall into six major areas: 
Table 6.1-1. 1990 National Pollutant Dischargo Elimination System permit (TN 0002941) points and effluent parameters at Oak Ridge National Laboratory

\begin{tabular}{|c|c|}
\hline Discharge point & Effluent parameters \\
\hline X01 (Sewage Treatment Plant) & $\begin{array}{l}\text { Biochemical oxygen demand (BOD), total } \\
\text { suspended solids (TSS), ammonia (as N), oil and } \\
\text { grease, dissolved oxygen, pH, residual chlorine, } \\
\text { and fecal coliform }\end{array}$ \\
\hline $\begin{array}{l}\text { X02 (Coal Yard Runoff Treatment } \\
\text { Facility) }\end{array}$ & $\begin{array}{l}\text { Temperature, TSS, oil and grease, } \mathrm{Cr}, \mathrm{Cu}, \mathrm{Fe}, \mathrm{pH} \text {, } \\
\text { and } \mathrm{Zn}\end{array}$ \\
\hline $\begin{array}{l}\text { X06A (Bldgs. } 1500 \text { and } 2000 \text { areas } \\
\text { and Bldgs. } 3539 \text { and } 3540 \text { ponds) }\end{array}$ & $\mathrm{pH}$ \\
\hline $\begin{array}{l}\text { X07 (Process Waste Treatment } \\
\text { Plant) }\end{array}$ & $\mathrm{pH}$ \\
\hline X09A (REDC/HFIR ponds) ${ }^{a}$ & $\mathrm{pH}$ \\
\hline X11 (Acid Neutralization Facility) & $\mathrm{pH}$ \\
\hline $\begin{array}{l}\text { X12 (Nonradiological Wastewater } \\
\text { Treatment Facility) }\end{array}$ & $\begin{array}{l}\text { Temperature, TSS, oil and grease, total toxic } \\
\text { organics, total cyanide, total } \mathrm{Cd} \text {, total } \mathrm{Cr} \text {, total } \\
\mathrm{Cu} \text {, total } \mathrm{Pb} \text {, total } \mathrm{Ni}, \mathrm{pH} \text {, total } \mathrm{Ag} \text {, and total } \mathrm{Zn}\end{array}$ \\
\hline X13 (Melton Branch) & $\mathrm{pH}$ \\
\hline X14 (White Oak Creek) & $\mathrm{pH}$ \\
\hline X15 (White Oak Dam) & $\mathrm{pH}$ \\
\hline Category I (storm drains) & Oil and grease, $\mathrm{pH}$, and TSS \\
\hline $\begin{array}{l}\text { Category II (parking lot and storage } \\
\text { area drains, once-through cooling } \\
\text { water, blowdown, condensate) }\end{array}$ & Oil and grease, $\mathrm{pH}$, and TSS \\
\hline $\begin{array}{l}\text { Category III (process and/or } \\
\text { laboratory drains) }\end{array}$ & $\mathrm{pH}$ \\
\hline Steam Plant & $\mathrm{pH}$ and temperature \\
\hline Vehicle cleaning facility & $\begin{array}{l}\text { BOD, fecal coliform, oil and grease, } \mathrm{pH} \text {, phenols, } \\
\text { and TSS }\end{array}$ \\
\hline Equipment Maintenance Facility & Oil and grease and $\mathrm{pH}$ \\
\hline Cooling systems & $\mathrm{Cl}, \mathrm{Cr}, \mathrm{Cu}$, temperature, $\mathrm{Zn}$, and $\mathrm{pH}$ \\
\hline
\end{tabular}

${ }^{\circ}$ REDC $=$ Radiochemical Engineering Development Center; HFIR = High Flux Isotope Reactor. Source: modified from Kornegay, F. C. et al., Oak Ridge Reservation Environmental Report for 1990, Volume 1, Narrative, Summary and Conclusions, ES/ESH-18/V1, Oak Ridge National Laboratory, Oak Ridge, Tenn., Sept. 1991, pp. 81-83. 


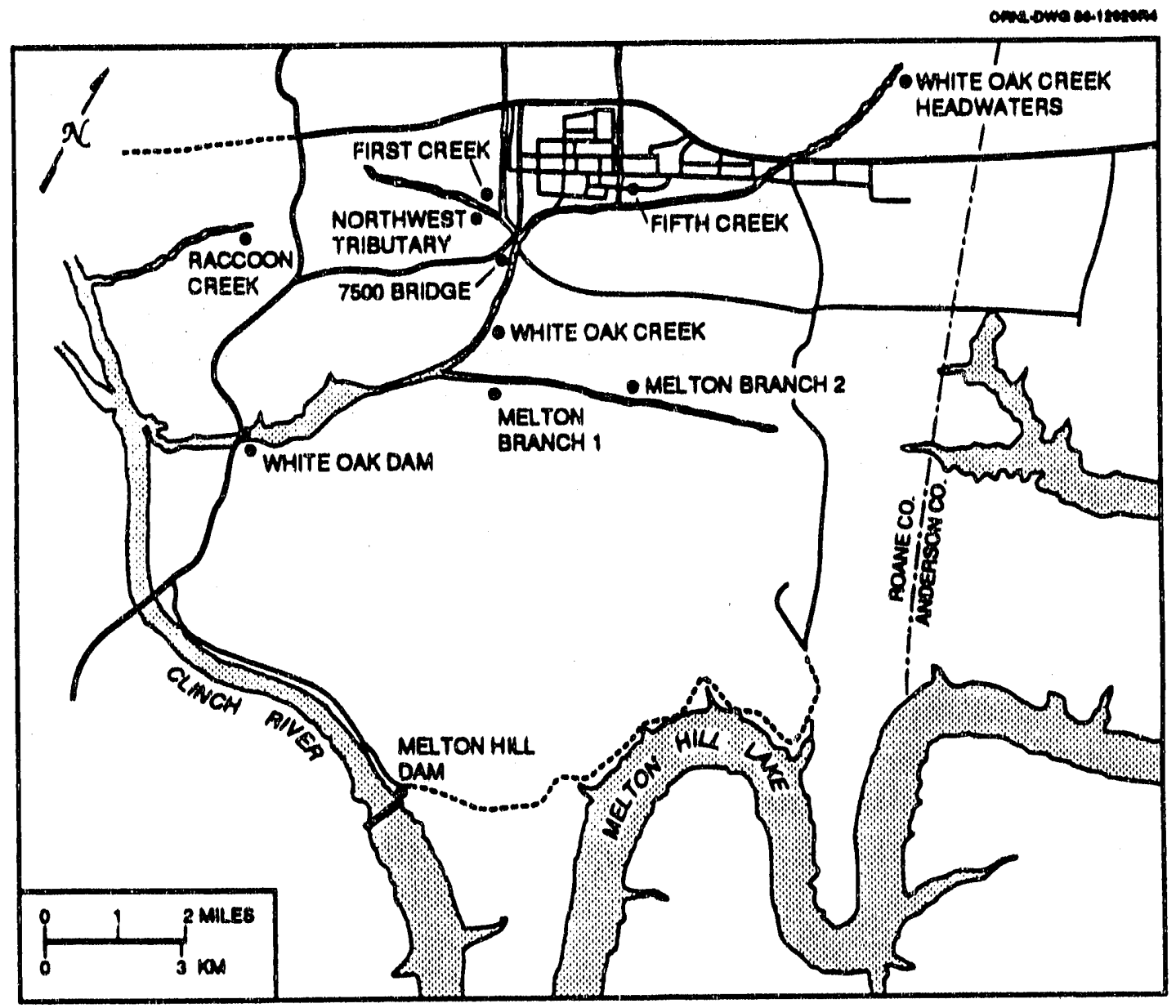

Fig. 6.1-1. Oak Ridge National Laboratory surface water and reference sampling locations. Source: Kornegay, F. C. et al., Oak Ridge Reservation Environmental Report for 1990, Volume 1, Narrative, Summary and Conclusions, ES/ESH-18/V1, Oak Ridge National Laboratory, Oak Ridge, Tenn., Sept. 1991, p. 65. 
(1) toxicity monitoring, (2) bioaccumulation monitoring of nonradiological contaminants in aquatic biota, (3) biological indicator studies, (4) in-stream ecological monitoring, (5) assessment of contaminants in the terrestrial environment, and (6) radioecology of White Oak Creek and White Oak Lake. These studies provide much of the basis for description of the existing aquatic ecology in Sect. 2.2.2. Assuming that these studies continue into the ANS construction phase, they will provide long-term base-line information about aquatic communities in Melton Branch and White Oak Creek, which could be used to detect impacts of construction activities on these water bodies.

Because ingestion of fish is a possible pathway for contaminant uptake by man, bluegill are collected from three Clinch River locations twice per year and are analyzed for mercury, PCBs, and radionuclides. Six fish from each location were analyzed in 1990; only muscle tissue is used for analysis.

Aside from the 1989 survey of Friendship Creek (Sect. 2.2.2.1), there has been no biological monitoring of this tributary to the Clinch River. Monitoring during the preconstruction period would be needed to establish a base line for detecting impacts of construction and operational discharges of ANS.

\subsubsection{Groundwater}

The ORR has more than 1000 groundwater monitoring wells that provide an enormous volume of monitoring data regarding groundwater quality. Parameters monitored for compliance with applicable standards are shown in Table 6.1-2; these parameters are not necessarily the only parameters monitored at the facilities.

The groundwater monitoring program at ORNL consists of a network of wells of two basic types and functions: (1) water quality monitoring wells built to Resource Conservation and Recovery Act (RCRA) specifications and used for site characterization and compliance purposes and (2) piezometer wells used to characterize groundwater flow conditions. ORNL has established an Environmental Restoration Program to provide comprehensive management of areas where past and current research, development, and waste management activities may have resulted in residual contamination of facilities or the environment. Because of the large number of remedial action sites at ORNL located close to one another and the proven hydrologic interconnections among many of these units, individual monitoring and assessment was shown to be impractical. Therefore, the concept of waste area groupings (WAGs) was developed to evaluate potential sources of releases to the environment.

At ORNL, 20 WAGs were identified by the RCRA Facilities Assessment. Eleven of these have been identified as potential sources of groundwater contamination, and there are a few areas where potential remedial action sites are located outside the major WAGs. Table 6.1-3 lists the 20 ORNL, WAG's and the number of potential remedial action sites within each WAG, and Fig. 6.1-2 shows the location of the 20 WAGs. Water quality monitoring wells are being established around the perimeter of the WAGs determined to have a potential for the release of contaminants. Similar groundwater monitoring programs are conducted at the Y-12 Plant and K-25 Site.

\section{Off-site monitoring}

Twenty-one monitoring wells have been selected on the basis of their proximity to the ORR and a representative distribution of sources from different geologic formations in the area. The wells were sampled once during 1990 . Analytical parameters used for 
Table 6.1-2 Groundwater monitoring parameters for the Oak Ridge Reservation

Primary drinking water parameters monitored during 1990

As; $\mathrm{Ba}$; $\mathrm{Cd}$; $\mathrm{Cr} ; \mathrm{F} ; \mathrm{Pb}$; nitrate; $\mathrm{Hg}$; $\mathrm{Se}$; $\mathrm{Ag}$; endrin; lindane; methoxychlor; toxaphene; 2,4-D; 2,4,5-TP silvex; ${ }^{226} \mathrm{Ra}$ and ${ }^{228} \mathrm{Ra}$; gross alpha; gross beta; coliform bacteria

Parameters establishing groundwater quality monitored during 1990

Chloride, Fe, Mn, phenols, Na, sulfate

Indicator parameters monitored semiannually in 1990

Total organic carbon, total organic halogen, specific conductance, $\mathrm{pH}$

Typical inductively coupled argon plasma metals scan

$\mathrm{Al}, \mathrm{Sb}, \mathrm{Ba}, \mathrm{Be}, \mathrm{B}, \mathrm{Cd}, \mathrm{Ca}, \mathrm{Cr}, \mathrm{Co}, \mathrm{Cu}, \mathrm{Pb}, \mathrm{Li}, \mathrm{Mg}, \mathrm{Mn}, \mathrm{Mo}, \mathrm{Ni}, \mathrm{Nb}, \mathrm{P}, \mathrm{K}, \mathrm{Si}, \mathrm{Ag}, \mathrm{Na}$, $\mathrm{Sr}, \mathrm{Th}, \mathrm{Ti}, \mathrm{V}, \mathrm{Zn}, \mathrm{Zr}$

Typical metals sought by atomic absorption spectroscopy

$\mathrm{Sb}, \mathrm{As}, \mathrm{Ba}, \mathrm{Be}, \mathrm{Cd}, \mathrm{Cr}, \mathrm{Cu}, \mathrm{Pb}, \mathrm{Hg}, \mathrm{Ni}, \mathrm{Se}, \mathrm{Ag}, \mathrm{Tl}, \mathrm{Zn}$

Typical anions

Chloride, fluoride, nitrate, nitrite, phosphate, sulfate

Volatile onganics (hazardous substance list)

Chloromethane; bromomethane; vinyl chloride; chloroethane; methylene chloride; acetone; carbon disulfide; 1,1-dichloroethene; 1,1-dichloroethane; 1,2-dichloroethene (total); chloroform; 1,2-dichloroethane; 2-butanone; 1,1,1-trichloroethane; carbon tetrachloride; vinyl acetate; bromodichloromethane; 1,1,2,2-tetrachloroethane; 1,2dichloropropane; cis-1,3-dichloropropene; trichloroethene; dibromochloromethane; 1,1,2-trichloroethane; benzene; trans-1,3-dichloropropene; bromoform; 2-hexanone; 4methyl-2-pentanone; tetrachloroethene; toluene; chlorobenzene; ethyl benzene; styrene; xylenes (total)

Pesticides and polychlorinated biphenyls (hazardous substance list)

Alpha-BHC; beta-BHC; delta-BHC; gamma-BHC; heptachlor; aldrin; heptachlor epoxide; endrin; dieldrin; 4,4'-DDE; endosulfan I; endosulfan II; 4,4'-DDD; endosulfan sulfate; 4,4'-DDT; endrin ketone; methoxychlor; alpha-chlordane; gamma-chlordane; toxaphene; aroclor-1016, -1221, -1232, -1242, -1248, -1254, -1260

Base/neutrallacid extractable onganics (hazardous substance list)

Phenol; bis(2-chloroethyl) ether; 2-chlorophenol; 1,3-dichlorobenzene; 1,4dichlorobenzene; benzyl alcohol; 1,2-dichlorobenzene; 2-methylphenol; bis (2chloroisopropyl) ether; 4-methylphenol; $N$-nitroso-di- $n$-propylamine; hexachloroethane; nitrobenzene; isophorone; 2-nitrophenol; 2,4-dimethylphenol; benzoic acid; bis(2chloroethoxy) methane; 2,4-dichlorophenol; 1,2,4-trichlorobenzene; naphthalene; 
Table 6.1-2 (continued)

\section{Base/neutral/acid extractable organics (continued)}

4-chloroaniline; hexachlorobutadiene; 4-chlor 0-3-methylphenol; 2-methylnaphthalene; hexachlorocyclopentadiene; 2,4,6-trichlorophenol; 2,4,5-trichlorophenol; 2chloronaphthalene; 2-nitroaniline; dimethyl phthalate; acenaphthylene; 2,6dinitrotoluene; 3-nitroaniline; acenaphthene; 2,4-dinitrophenol; 4-nitrophenol; dibenzofuran; 2,4-dinitrotoluene; diethylphthalate; 4-chlorophenyl phenyl ether; fluorene; 4-nitroaniline; 4,6-dinitro-2-methylphenol; N-nitrosodiphenylamine; 4bromophenyl phenyl ether; hexachlorobenzene; pentachlorophenol; phenanthrene; anthracene; di-n-butylphthalate; fluoranthene; pyrene; butyl benzyl phthalate; 3,3'dichlorobenzidene; benzo[ $a$ ]anthracene; chrysene; bis(2-ethylhexyl)phthalate; di-noctyl phthalate; benzo[b]fluoranthene; benzo[ $k]$ fluoranthene; benzo[ $a]$ pyrene; indeno( $1,2,3-c d)$ pyrene; dibenz $[a, h]$ anthracene; benzo $[g, h, i]$ perylene

\section{Radionuclides and radioactive metals}

Gross alpha, gross beta, gross gamma, ${ }^{226} \mathrm{Ra}$ and ${ }^{228} \mathrm{Ra},{ }^{137} \mathrm{Cs},{ }^{89} \mathrm{Sr},{ }^{90} \mathrm{Sr},{ }^{60} \mathrm{Co},{ }^{3} \mathrm{H},{ }^{99} \mathrm{Tc}$, ${ }^{239} \mathrm{Pu},{ }^{234} \mathrm{U},{ }^{235} \mathrm{U},{ }^{238} \mathrm{U}$, total uranium

\section{Other typical parameters that may be included in groundwater studies}

Alkalinity $\left(\mathrm{CO}_{3}\right)$; alkalinity $\left(\mathrm{HCO}_{3}\right)$; total phosphorus; solids (total, suspended, dissolved); turbidity; total Kjeldahl nitrogen; ammonia (as $\mathrm{N}$ ); chemical oxygen demand

Source: modified from Kornegay, F. C. et al., Oak Ridge Reservation Environmental Report for 1990, Volume 2, Data Presentation, ES/ESH-18/V2, Oak Ridge National Laboratory, Oak Ridge, Tenn., Sept. 1991, pp. 133-141.

monitoring include volatile organics; selected atomic absorption metals ( $\mathrm{As}, \mathrm{Hg}, \mathrm{Pb}$, and $\mathrm{Se}$ ); inductively coupled argon plasma metals; anions (fluoride, chloride, sulfate, nitrate, and nitrite); total fluorometric uranium; and the radioactivity parameters gross alpha, gross beta, total radioactive $\mathrm{Sr},{ }^{99} \mathrm{Tc},{ }^{3} \mathrm{H}$, and radionuclides observed in a gamma scan.

\subsubsection{Air}

This section summarizes the three types of air monitoring activities on the ORR: airborne discharges, ambient air monitoring, and meteorological monitoring.

\section{Airborne discharges}

Each major ORR facility has an air pollution control and monitoring program to (1) ensure that airborne discharges meet regulatory requirements, (2) meet DOE objectives for as low as reasonably achievable radiological emissions, and (3) ensure that ambient air quality is not adversely affected. Also, each installation has developed a stack monitoring program to measure pollutants that are not removed by the air pollution control equipment. 
Table 6.1-3. Oak Ridge National Laboratory waste area groupings, 1990

\begin{tabular}{|c|c|c|}
\hline $\begin{array}{l}\text { Waste } \\
\text { area } \\
\text { group }\end{array}$ & Description ${ }^{a}$ & $\begin{array}{l}\text { Potential } \\
\text { remedial } \\
\text { action } \\
\text { sites }\end{array}$ \\
\hline 1 & Main plant area & 99 \\
\hline 2 & White Oak Creek/White Oak Lake & 2 \\
\hline 3 & Solid Waste Storage Area 3 & 3 \\
\hline 4 & Solid Waste Storage Area 4 & 3 \\
\hline 5 & Solid Waste Storage Area 5 & 25 \\
\hline 6 & Solid Waste Storage Area 6 & 3 \\
\hline 7 & LLW pits and trenches area & 15 \\
\hline 8 & Melton Valley area & 20 \\
\hline 9 & Homogeneous reactor experiment area & 6 \\
\hline 10 & Hydrofracture injection wells and grout sheets & $4^{b}$ \\
\hline 11 & White Wing scrapyard & 1 \\
\hline 12 & Closed contractors' landfill & 1 \\
\hline 13 & Environmental research areas & 2 \\
\hline 14 & Tower Shielding Facility & 2 \\
\hline 15 & ORNL facilities at $Y-12$ Plant & 5 \\
\hline 16 & Health Physics Research Reactor area & 5 \\
\hline 17 & ORNL services area & 10 \\
\hline 18 & Consolidated fuel reprocessing area & 9 \\
\hline 19 & Hazardous waste treatment and storage facility & 7 \\
\hline 20 & Oak Ridge land farm & 1 \\
\hline \multicolumn{3}{|c|}{ Additional sites } \\
\hline c & Surplus-contaminated facilities & 29 \\
\hline
\end{tabular}

LLW = low-level waste, ORNL = Oak Ridge National Laboratory.

-Principal sites located underground beneath Waste Area Grouping 5.

Not applicable.

Source: modified from Kornegay, F. C. et al., Oak Ridge Reservation Environmental Report for 1990, Volume 1, Narrative, Summary and Conclusions, ES/ESH-18/V1, Oak Ridge National Laboratory, Oak Ridge, Tenn., Sept. 1991, p. 150.

At ORNL, 107 mostly nonradioactive sources are permitted with the TDC Air Pollution Control Board. All gaseous emissions are treated and filtered before discharge to the atmosphere. Total particulate and chemical emissions from any one emission point at ORNL are very low, except for the Steam Plant. Therefore, the air permits issued by TDC do not require sampling or monitoring at any of the permitted emission points except the Steam Plant, which monitors for particulate matter, $\mathrm{SO}_{x} \mathrm{CO}$, and $\mathrm{NO}_{x}$ These pollutants are also monitored at the Y-12 Plant and K-25 Site steam plants. 


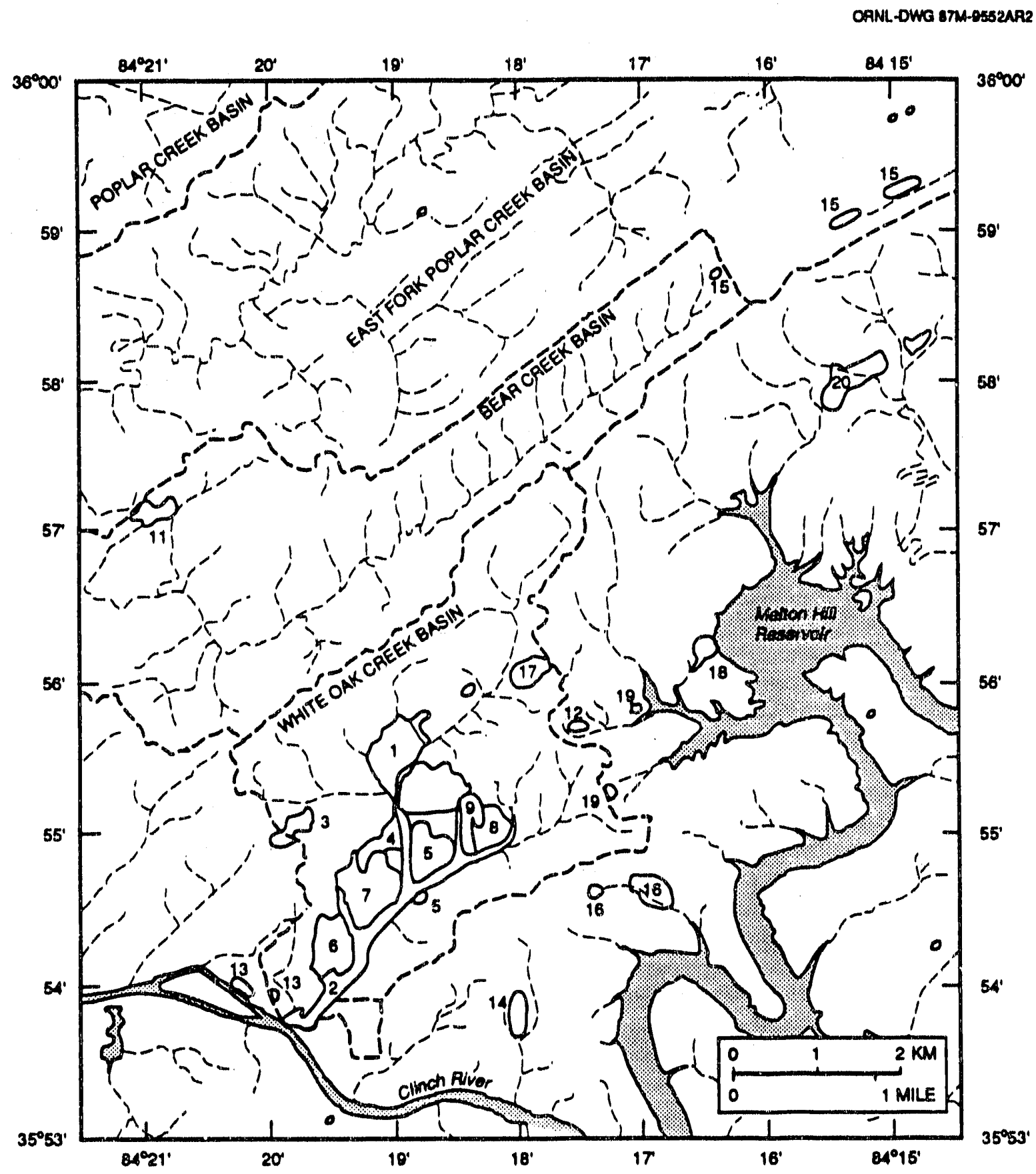

Fig. 6.1-2. Oak Ridge National Laboratory waste area groupings. Source: Kornegay, F. C. et al., Oak Ridge Reservation Environmental Report for 1990, Volume 1, Narrative, Summary and Conclusions, ES/ESH-18/V1, Oak Ridge National Laboratory, Oak Ridge, Tenn., Sept. 1991, p. 151. 
6-10
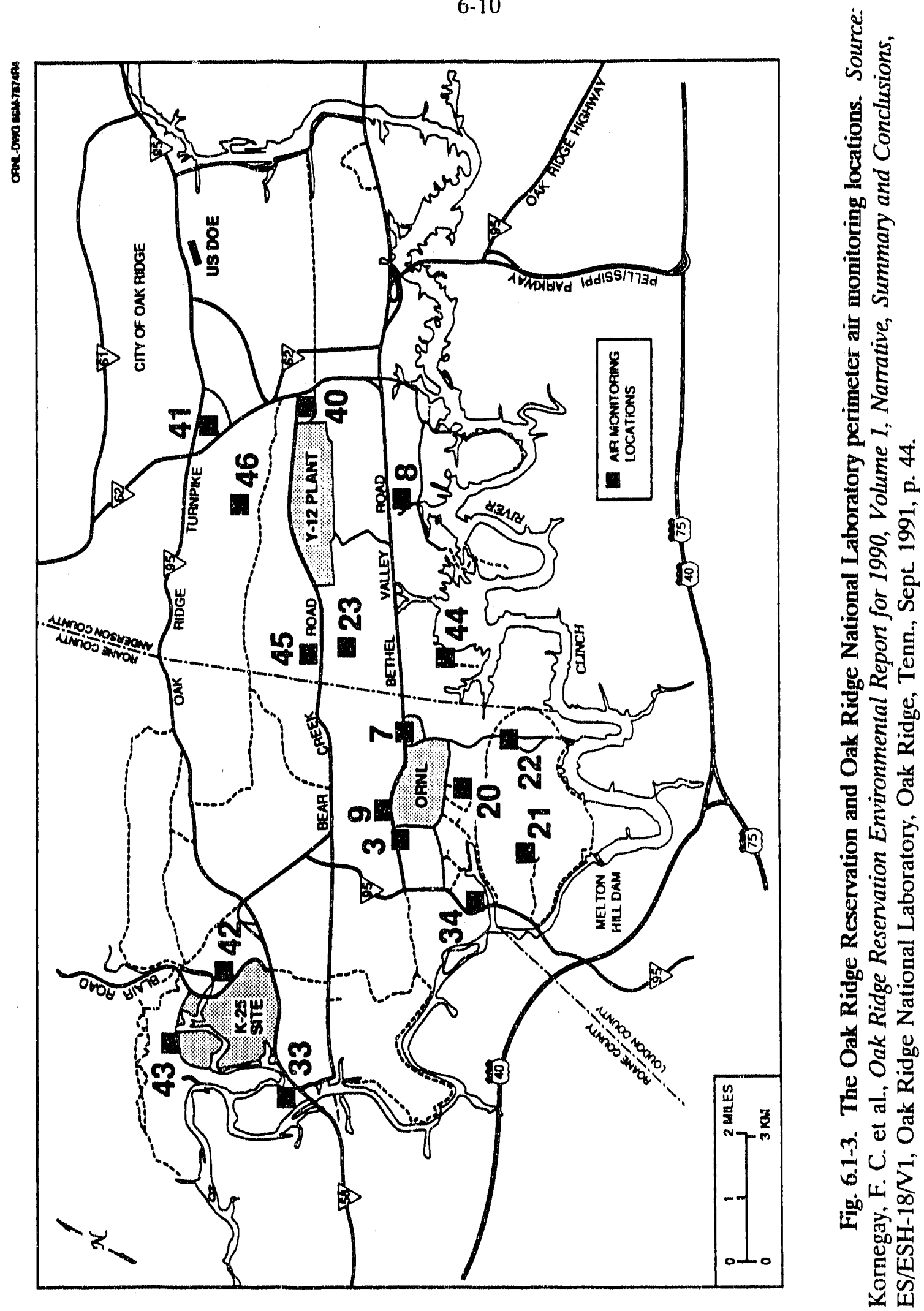


\section{Ambient air monitoring}

The ambient air monitoring network at ORNL (Fig. 6.1-3) includes the 6 ORNL perimeter monitoring stations, 11 DOE ORR perimeter monitoring stations, and the 2 remote monitoring stations (not shown on figure). The monitoring at these stations is primarily for radionuclides (Sect. 6.1.2.3). The Y-12 Plant operates 12 ambient air monitoring stations to measure suspended uranium particulates (at all 12 stations) and fluorides (11 stations). Two additional stations monitor total suspended particulates (TSP), and two stations were operated through August 1990 to monitor ambient sulfur dioxide concentrations. In 1990, particulate matter samplers were also placed in service at the same locations as the TSP monitors. The K-25 Site has five ambient air monitoring stations; the parameters analyzed are $\mathrm{U}, \mathrm{Ni}, \mathrm{Pb}, \mathrm{Cr}$, and $\mathrm{TSP}$.

\section{Meteorological monitoring}

A network of meteorological observation towers provides data on the meteorological conditions and the transport and diffusion qualities of the atmosphere on the ORR. The meteorological monitoring network (Fig. 6.1-4) consists of one $60-\mathrm{m}$ (196.9-ft) tower at the K-25 Site (MT1), one 100-m (328-ft) tower (MT2) and two 30-m (98.4-ft) towers (MT3 and MT4) at ORNL, and one 100-m (328-ft) tower (MT5) and one 60-m (196.9-ft) tower (MT6) at the Y-12 Plant. Data are collected at different levels to determine the vertical structure of the atmosphere and the possible effects of vertical variations on releases from the facilities; these data are collected by a dedicated control computer at each site. Fifteen-minute and hourly values are stored at each site for a $24-\mathrm{h}$ period. Only hourly data are routinely stored beyond $24 \mathrm{~h}$. Tower instruments are calibrated quarterly.

\subsubsection{Land}

\section{Soils}

Nonradiological soil samples are collected at the ORNL and Y-12 perimeter air monitoring stations. ORNL air stations 3, 7, 9, 20 and 21 and ORR air stations 40, 45 and 46 are monitored for 30 metals: $\mathrm{Ag}, \mathrm{Al}, \mathrm{As}, \mathrm{B}, \mathrm{Ba}, \mathrm{Be}, \mathrm{Ca}, \mathrm{Cd}, \mathrm{Co}, \mathrm{Cr}, \mathrm{Cu}, \mathrm{Fe}, \mathrm{Hg}, \mathrm{Li}, \mathrm{Mg}, \mathrm{Mn}, \mathrm{Mo}$, $\mathrm{Na}, \mathrm{Ni}, \mathrm{P}, \mathrm{Pb}, \mathrm{Sb}, \mathrm{Se}, \mathrm{Si}, \mathrm{Sn}, \mathrm{Sr}, \mathrm{Ti}, \mathrm{V}, \mathrm{Zn}$, and $\mathrm{Zr}$. Each of the stations was sampled once during 1990, the latest year for which results have been published. Three samples are collected at each station. The three samples are randomly selected from the four cardinal directions at each of the stations, and each sample is a composite of ten aliquots taken from two $1-\mathrm{m}^{2}\left(10.8-\mathrm{ft}^{2}\right)$ plots. Each aliquot is $8 \mathrm{~cm}(3.7 \mathrm{in}$.) in diameter by $2 \mathrm{~cm}(0.8 \mathrm{in}$.) deep. All samples are dried and pulverized before analysis. Starting in 1990 , the metals analysis was conducted by inductively coupled plasma arc emission spectrometry.

Soil is also monitored at 14 sites around the K-25 Site. These sites are monitored for $\mathrm{U}$, $\mathrm{Hg}, \mathrm{Pb}, \mathrm{Ni}, \mathrm{Cr}, \mathrm{Al}$, and fluoride concentrations.

\section{Terrestrial ecology}

Grass near the K-25 Site is analyzed routinely for fluorides because of its importance as pasture for dairy herds and its year-round availability. 
6-12
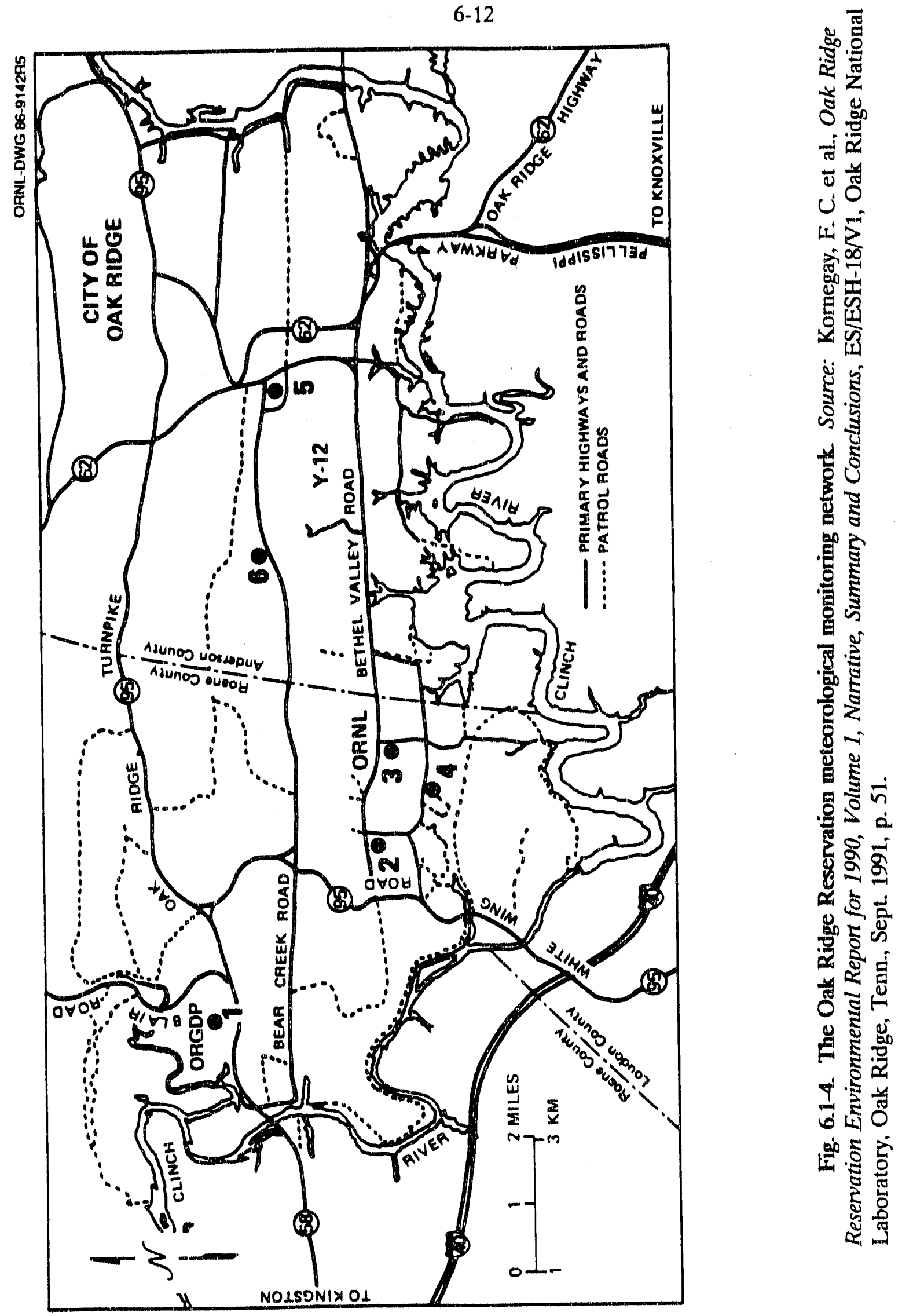


\subsubsection{Radiological Monitoring}

This section describes radiological monitoring on the ORR.

\subsubsection{Surface Water}

Surface water monitoring for radiological parameters on ORR includes NPDES monitoring and non-NPDES monitoring. Section 6.1.1.1 briefly describes surface water sample collections and locations. There is no radiological sediment sampling on ORR; however, chemical monitoring on ORR does include analyses for uranium and thorium (Sect. 6.1.1.1).

\section{Physical and chemical properties}

NPDES monitoring program. ORNL's radiological sampling plan calls for monitoring many of the same locations as required in the permit for nonradiological monitoring. Outfalls $\mathrm{X06A}, \mathrm{X07}, \mathrm{X09A}$, and X11 were eliminated during the first quarter of 1990 as part of the implementation of the Nonradiological Wastewater Treatment Facility at ORNL. Table 6.1-4 lists the NPDES radiological sampling locations and the parameters analyzed.

Monitoring not required by an NPDES permit. ORNL collects samples for radiological analyses at off-site locations, at background or reference locations, in streams at the ORNL site, from process discharge point sources, and from various other outfalls. Parameters that are monitored in the samples are ${ }^{3} \mathrm{H}$, total $\mathrm{Sr}$, gamma scan, gross alpha, gross beta, total $\mathrm{U},{ }^{238} \mathrm{Pu}$, ${ }^{239} \mathrm{Pu},{ }^{60} \mathrm{Co},{ }^{137} \mathrm{Cs},{ }^{234} \mathrm{U},{ }^{235} \mathrm{U}$, and ${ }^{238} \mathrm{U}$. Monitoring at the K-25 Site measures concentrations of ${ }^{237} \mathrm{~Np},{ }^{239240} \mathrm{Pu},{ }^{280} \mathrm{Pu},{ }^{99} \mathrm{Tc},{ }^{137} \mathrm{Cs}$, uranium, ${ }^{238} \mathrm{Pu}$, and ${ }^{239} \mathrm{Pu}$. The Y-12 Plant surface water monitoring program parameters include ${ }^{241} \mathrm{Am},{ }^{237} \mathrm{~Np},{ }^{238} \mathrm{Pu},{ }^{239240} \mathrm{Pu},{ }^{99} \mathrm{Tc},{ }^{235} \mathrm{U}$, total uranium, alpha, beta, and gamma.

\section{Aquatic ecology}

Radiological monitoring of aquatic ecosystems in Melton Branch and White Oak Creek is taking place as part of the ORNL BMAP. One of the six major areas in the BMAP is radioecology of White Oak Creek and White Oak Lake. These studies provide much of the basis for description of the existing aquatic ecology in Sect. 2.2.2. Complete descriptions of BMAP activities are available in the annual reports for the program (e.g., Loar 1990, pp. 1-371).

Because ingestion of fish is a possible pathway for radioactive contaminant uptake by man, bluegill are collected from three Clinch River locations twice per year and analyzed for mercury, $\mathrm{PCBs},{ }^{60} \mathrm{Co},{ }^{137} \mathrm{Cs},{ }^{89} \mathrm{Sr}$, and ${ }^{90} \mathrm{Sr}$; only muscle is used for analysis.

\subsubsection{Groundwater}

The groundwater monitoring wells on the ORR provide data regarding the presence of radionuclides in the groundwater (Sect. 6.1.1.1). Samples from the wells are tested for the radionuclides and radioactive material listed in Table 6.1-2. At the Y-12 Plant, radionuclide analyses also include total radium, uranium, ${ }^{237} \mathrm{Th},{ }^{230} \mathrm{Th},{ }^{232} \mathrm{Th},{ }^{241} \mathrm{Am},{ }^{237} \mathrm{~Np},{ }^{239} \mathrm{Pu},{ }^{144} \mathrm{Ce},{ }^{134} \mathrm{Cs}$, ${ }^{137} \mathrm{Cs},{ }^{125} \mathrm{I},{ }^{129} \mathrm{I}, \mathrm{Pa},{ }^{228} \mathrm{Ra},{ }^{89} \mathrm{Sr},{ }^{90} \mathrm{Sr},{ }^{99} \mathrm{Tc},{ }^{231} \mathrm{Th},{ }^{234} \mathrm{Th},{ }^{106} \mathrm{Ru},{ }^{95} \mathrm{Zr}$, 
Table 6.1-4. National Pollutant Discharge Elimination System outfalls at Oak Ridge National Laboratory and radionuclide parameters monitored

\begin{tabular}{ll}
\hline \multicolumn{1}{c}{ Outfall } & \multicolumn{1}{c}{ Parameter } \\
\hline Sewage Treatment Plant (X01) & ${ }^{60} \mathrm{Co},{ }^{137} \mathrm{Cs}$, gross beta, total $\mathrm{Sr}$ \\
Nonradiological Wastewater & ${ }^{60} \mathrm{Co},{ }^{137} \mathrm{Cs}$, gross alpha, gross beta, total \\
Treatment Facility (X12) & $\mathrm{Sr},{ }^{3} \mathrm{H}$ \\
Melton Branch (X13) & ${ }^{60} \mathrm{Co},{ }^{137} \mathrm{Cs}$, total Sr, ${ }^{3} \mathrm{H}$ \\
White Oak Creek (X14) & ${ }^{60} \mathrm{Co},{ }^{137} \mathrm{Cs}$, total Sr, ${ }^{3} \mathrm{H}$ \\
White Oak Dam (X15) & ${ }^{60} \mathrm{Co},{ }^{137} \mathrm{Cs}$, gross alpha, gross beta, total \\
& $\mathrm{Sr}_{1}^{191} \mathrm{Os},{ }^{238} \mathrm{Pu},{ }^{239} \mathrm{Pu}$, total U, ${ }^{3} \mathrm{H},{ }^{234} \mathrm{U}$, \\
\hline
\end{tabular}

Source: modified from Kornegay, F. C. et al., Oak Ridge Reservation Environmental Report for 1990, Volume 2, Data Presentation, ES/ESH-18/V2, Oak Ridge National Laboratory, Oak Ridge, Tenn., Sept. 1991, pp. 70-71.

and ${ }^{3} \mathrm{H}$. The 21 off-site wells are used to monitor for gross alpha, gross beta, total radioactive strontium, ${ }^{9} \mathrm{Tc},{ }^{3} \mathrm{H}$, and radionuclides observed in a gamma scan.

\subsubsection{Air}

This section describes radiological monitoring of airborne discharges and ambient air on the ORR. Meteorological monitoring (Sect. 6.1.1.3) does not include radiological parameters.

\section{Airborne discharges}

The major sources of radionuclide emissions to the air at ORNL consist of the following eight stacks:

- Building 2026, High Radiation Level Analytical Lahoratory,;

- Building 3020, Radiochemical Process Plant;

- Buildings 3039,3500 , and 4500 , area cell ventilation system, central off-gas and scrubber system, and isotope solid state ventilation system;

- Building 7025, Tritium Target Fabrication Facility;

- Building 7830, Melton Valley Storage Tank Facility;

- Building 7911, Melton Valley complex (High Flux Isotope Reactor, Radiochemical Engineering Development Center);

- Building 7512, Molten Salt Reactor Facility project; and

- Building 6010, Electron Linear Accelerator.

Radiological gaseous emission from ORNL typically consist of solid particulates, adsorbable gases (e.g., iodine), tritium, and nonabsorbable gases. All gaseous emission are treated and filtered before discharge to the atmosphere. Also, each of the eight major point sources is provided with 
a variety of surveillance instrumentation. The sampling systems generally consist of in-stack sampling probes, sample transport piping, a particulate filter, an activated charcoal canister, a silica-gel tritium trap, flow measurement and totalizing instruments, a sampling pump, and return piping to the stack. Monitoring parameters include 27 isotopes and 4 gross parameters: ${ }^{194} \mathrm{Au}$, ${ }^{3} \mathrm{Be},{ }^{82} \mathrm{Br},{ }^{60} \mathrm{Co},{ }^{134} \mathrm{Cs},{ }^{137} \mathrm{Cs}$, ${ }^{154} \mathrm{Eu},{ }^{155} \mathrm{Eu}$, gross alpha, gross beta, ${ }^{3} \mathrm{H},{ }^{129} \mathrm{I},{ }^{131} \mathrm{I},{ }^{132} \mathrm{I},{ }^{133} \mathrm{I},{ }^{135} \mathrm{I},{ }^{140} \mathrm{La}$, noble gas, ${ }^{14} \mathrm{C},{ }^{191} \mathrm{Os},{ }^{212} \mathrm{~Pb},{ }^{238} \mathrm{Pu},{ }^{239} \mathrm{Pu},{ }^{106} \mathrm{Ru},{ }^{75} \mathrm{Se}$, total $\mathrm{Sr},{ }^{132} \mathrm{Te},{ }^{228} \mathrm{Th},{ }^{230} \mathrm{Th},{ }^{232} \mathrm{Th}$, and total $\mathrm{U}$.

At the K-25 Site, the major components of the radioactive emission sources are ${ }^{238} \mathrm{U},{ }^{235} \mathrm{U}$, and ${ }^{99} \mathrm{Tc}$. Also, monitoring of the Toxic Substances Control Act Incinerator measures emissions of uranium, technetium, ${ }^{137} \mathrm{Cs},{ }^{277} \mathrm{~Np},{ }^{234} \mathrm{~Pa},{ }^{238} \mathrm{Pu},{ }^{239} \mathrm{Pu},{ }^{228} \mathrm{Th},{ }^{230} \mathrm{Th},{ }^{232} \mathrm{Th}$, and ${ }^{234} \mathrm{Th}$. At the Y-12 Plant, primary monitoring is for uranium emissions.

\section{Ambient air}

Airborne radioactive particulates at $\mathrm{ORNL}$ are sampled biweekly by continuously pumping ambient air through a 47-mm-diam (1.8-in.-diam) paper filter. Monitoring station locations are shown in Fig. 6.1-3. Airborne adsorbable gases are collected biweekly using a cartridge packed with activated charcoal that is in line and downstream of the particulate filter. Annual composites of particulate air filters from the ORNL perimeter stations $(3,7,9,20,21$, and 22), ORR perimeter stations $(23,33,42,43$, and 44$)$, remote stations (52 and 58), and some individual stations $(34,40,41,45$, and 46$)$ are analyzed for specific radionuclides. Monitoring parameters for the ambient air stations include gross alpha, gross beta, ${ }^{3} \mathrm{H},{ }^{131} \mathrm{I},{ }^{60} \mathrm{Co},{ }^{137} \mathrm{Cs},{ }^{238} \mathrm{Pu},{ }^{239} \mathrm{Pu}$, ${ }^{228} \mathrm{Th}$, ${ }^{230} \mathrm{Th},{ }^{232} \mathrm{Th}$, total $\mathrm{Sr},{ }^{234} \mathrm{U},{ }^{235} \mathrm{U}$, and ${ }^{278} \mathrm{U}$. Monitoring for radionuclides in ambient air at the Y-12 Plant and the K-25 Site is for uranium.

\subsubsection{I and}

ORR radiological monitoring includes analyses of soil and terrestrial ecology.

\section{Soils}

Radiological soil samples are collected at the same air stations and in the same manner as nonradiological samples (Sect. 6.1.1.4). Radiological monitoring includes gross alpha, gross beta, ${ }^{60} \mathrm{Co},{ }^{137} \mathrm{Cs}$, ${ }^{40} \mathrm{~K}$, total radioactive strontium ${ }^{89} \mathrm{Sr}$ plus ${ }^{90} \mathrm{Sr}$ ), ${ }^{238} \mathrm{Pu},{ }^{239} \mathrm{Pu},{ }^{228} \mathrm{Th},{ }^{230} \mathrm{Th},{ }^{232} \mathrm{Th},{ }^{234} \mathrm{U}$, ${ }^{235} \mathrm{U}$, and ${ }^{238} \mathrm{U}$.

\section{Terrestrial ecology}

Milk ingestion is a potentially significant route to humans of radioactive lodine and strontium deposited from airborne emissions. The 1990 milk sampling program consisted of monthly grab samples collected from five locations in the vicinity of ORR. The locations of the stations are given in Kornegay et al. (1991, vol. 1, p. 166). Milk samples are analyzed for ${ }^{131}$ I by gamma spectrometry and for total radioactive strontium by chemical separation and lowbackground counting.

Annual DOE-Tennessee Wildlife Resources Agency deer hunts are held in the fourth quarter of each year. Each deer killed during the hunt is sampled for radioactivity. Liver or muscle is sampled for ${ }^{137} \mathrm{Cs}$; bone is sampled for ${ }^{90} \mathrm{Sr}$.

No vegetation sampling is conducted at ORNL because vegetation from the ORR is not a direct pathway to man. Grass samples from 15 locations and pine needle samples from 6 locations were collected around the K-25 Site in 1991. Sampling locations and analytical procedures are described in Kornegay el al. (1991, p. 169). 


\subsection{PROPOSED MONITORING PROGRAMS}

ANS operational monitoring programs have not yet been developed. Descriptions of these programs will be included in the Phase II Environmental Report. However, some preliminary comments about wastes and surface water monitoring are given in this section.

Wastes. The staff of the proposed ANS would monitor (1) low-level liquid waste (LLLW) collection and transfer system components for leakage to the environment and radiological contamination, (2) solid wastes resulting from nonreusable clothing and the residue of demineralization and filtration activities in the reactor and detritiation facility, (3) sanitary wastes for radiological contamination, (4) storm water runoff from parking lots and building surfaces for tritium contamination, and (5) gaseous emissions from the ANS stack system for as low as reasonably achievable compliance.

LLLW would be monitored twice. First, LLLW discharges would be held and monitored for deuterium oxide and tritium before discharge to area collection tanks (see Sect. 3.5.3.2). Second, before transfer to the ORNL LLLW treatment system, LLLW temporarily stored in area collection tanks for ANS would be monitored for leaks and spills.

Monitoring for tritium in solidified aqueous wastes, oily wastes absorbed by vermiculite, or as bound water in spent resins would occur in the ANS detritiation facility. Before discharge, ANS sanitary sewage wastes would also be monitored. Wastes containing trace radiological contamination would be treated in the ORNL Sanitary Waste Treatment Facility. Wastes containing high levels of contamination would be directed to the Process Waste Treatment Plant before discharge to White Oak Creek.

ANS storm water runoff from the resctor building, support facility, guide hall, and laboratory buildings would be segregated from other rainwater basins at ORNL and specially monitored for trace quantities of radioactive contamination-including tritium (see Sect. 3.7.2). Following treatment, processing, and filtration, ANS radiological gaseous wastes would be discharged through a single stack system that would be monitored (see Sect. 5.11.4).

Surface Water. The existing ORNL NPDES permit would need to be modified to account for increased discharges from the Sewage Treatment Plant and the Nonradiological Wastewater Treatment Facility associated with operation of ANS, although these modifications are unlikely to require additional monitoring. The ANS blowdown discharge point would likely be added as a new outfall on the NPDES permit, which would likely require additional sampling. Existing ORNL, blowdown discharges are monitored for flow rates, temperature, $\mathrm{pH}, \mathrm{Cu}, \mathrm{Zr}, \mathrm{Cr}$, and residual chlorine levels; total suspended solids may also have to be monitored.

Storm water discharges from ANS would be monitored to comply with recent amendments to the Clean Water Act (Sect. 12). The U.S. Environmental Protection Agency and Tennessee Department of Environment and Conservation (TDEC) storm water monitoring regulations require the DOE to submit storm water permit applications for new and previously unpermitted storm water outfalls associated with industrial activity (Borders et al. 1991, p. 32). To comply with these new regulations, a Storm Water Monitoring Compliance Plan has been developed at ORNL that will involve sampling storm water at approximately 35 sites. Monitoring of storm water runoff during construction and operation of ANS would need to be consistent with the new TDEC regulations.

Sampling of aquatic communities in Melton Branch and White Oak Creek as part of the ORNL BMAP could continue during ANS operation to detect impacts to these streams. A biological monitoring station in Friendship Creek should also be considered. The monitoring frequency of these sampling stations might have to be increased during the construction period. 


\subsection{REFERENCES FOR SECTION 6}

Borders, D. M. et al. 1991. Annual Hydrologic Data Summary for the White Oak Creek Watershed: Water Year 1990 (October 1989-September 1990), ORNL/ER-55, Oak Ridge National Laboratory, Oak Ridge, Tenn.

Kornegay et al., Oak Ridge Reservation Environmental Report for 1990, Volume 1, Narrative, Summary and Conclusions and Volume 2, Data Presentation, ES/ESH-18/V1\&2, Oak Ridge National Laboratory, Oak Ridge, Tenn., Sept. 1991.

Loar, J. M. et al. 1987. First Annual Report on the ORNL Biological Monitoring and Abatement Program, ORNL/TM-10399, Oak Ridge National Laboratory, Oak Ridge, Tenn.

Loar, J. M. (ed.) 1988. Second Annual Report on the ORNL Biological Monitoring and Abatement Program, Oak Ridge National Laboratory, Oak Ridge, Tenn.

Loar, J. M. (ed.) 1989. Third Annual Report on the ORNL Biological Monitoring and Abatement Program, Oak Ridge National Laboratory, Oak Ridge, Tenn.

Loar, J. M. (ed.) 1990. Fourth Annual Report on the ORNL Biological Monitoring and Abatement Program, Oak Ridge National Laboratory, Oak Ridge, Tenn.

Loar, J. M. (ed.) 1991. Fifth Annual Report on the ORNL Biological Monitoring and Abatement Program, Oak Ridge National Laboratory, Oak Ridge, Tenn. 


\section{ENVIRONMENTAL EFFECTS OF ACCIDENTS}

\subsection{FACILTYY ACCIDENTS INVOLVING RADIOACTIVITY}

\subsubsection{Source Terms and Radiological Consequences from Reactor Severe Accidents}

This section deals with accidents that compromise the integrity of the reactor fuel and therefore have the potential to release significant portions of the radioactive material held within the core. The calculations reported in the following paragraphs assume that a severe accident has occurred and that the core debris has reached the bottorn of the reactor pool or the subpile room. The MELCOR code (Version 1.80) (Summers et al., 1991 ) is used to predict the transport of the fission product nuclides and their release from containment; thereafter, the MELCOR Accident Consequence Code System (MACCS) (Version 1.5) (Chanin et al. 1990, p. 1-260) is used to determine subsequent atmospheric dispersion and radiation exposures.

This section also reports the results of analyzing worst-case severe accidents using only the most conservative assumptions regarding accident sequences and containment features. For example, all calculations assume early containment failure via a $0.5 \mathrm{~m}(20 \mathrm{in}$.) hole through which fission products are released from primary containment directly to the environment. However, this failure mode would be unlikely and is beyond the design basis of the reactor. A range of accident scenarios based on more realistic assumptions and frequencies is planned and will be reported later in the preliminary safety analysis report.

The single most important factor in determining severe accident source terms is water. The Advanced Neutron Source (ANS) reactor is located at the bottom of a $600-\mathrm{m}^{3}$ $\left(21,190-\mathrm{ft}^{3}\right)$ pool of light water, and the primary coolant system has another $150 \mathrm{~m}^{3}$ $\left(5300 \mathrm{ft}^{3}\right)$ of heavy water. Figure 7.1-1 illustrates the sequence of events between severe accident initiation and various states of debris cooling. Independent factors, such as core irradiation time and core power level at the time of the accident, determine the event tree path for any given severe accident. The event tree in Fig. 7.1-1 shows six end states, three of which (end states 1,3, and 4) involve well-cooled debris under a large quantity of water. Due to their low potential risk, these end states are not addressed initially. Because end states 2 and 5 involve debris that is dispersed and cooled in $100 \mathrm{~m}^{3}\left(3500 \mathrm{ft}^{3}\right)$ of water, they are considered together and provide the initial state for the MELCOR code in scenario 1 described in Sect. 7.1.1.1. End state 6 is the MELCOR initialization point for the calculations of scenario 2 in Sect. 7.1.1.1. For end state 6 to occur, the molten core debris would have to melt through the primary coolant pressure boundary and drop into the subpile room, leaving the heavy water contained in the primary coolant system (possibly because debris or solidified molten metal plugs the breach through which debris has been ejected to the subpile room floor).

The ANS containment system is being designed to allow no more than $0.5 \%$ loss per day from the primary containment and no more than $10 \%$ loss per day from the secondary containment which is held at negative pressure by blowers exhausting through absolute and charcoal air filters. The containment isolation system automatically initiates the closing signals for isolation valves on lines that penetrate primary containment (i.e., normal ventilation lines).

The most likely containment failure modes (not the ones assumed here) involve excess leakage from the primary containment to the secondary containment (e.g., due to failure of electrical or mechanical penetrations). This type of failure would be relatively 


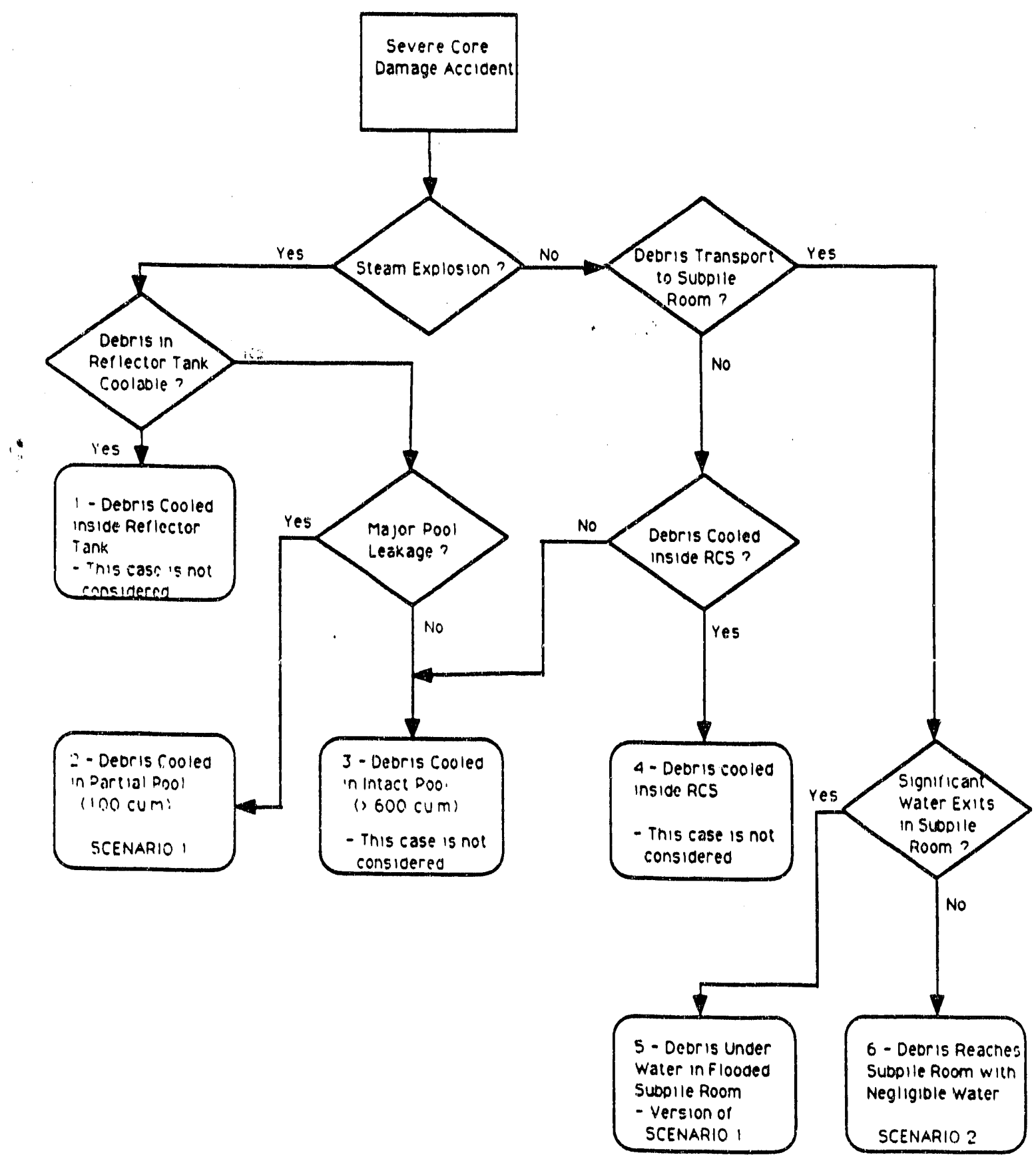

Fig. 7.1-1. Partial core-melt progression event tree for environmental report studies. 
mild because the uncompromised secondary containment air treatment system would still function to remove airborne radionuclides (excluding noble gases) before release to the environment. Other failure modes involve components of the secondary containment system such as the air treatment and blower system, but their impact would also be relatively small without simultaneous failure of primary containment. Severe accident phenomena can lead to containment failure under extreme conditions, but for ANS this possibility is being minimized by design. That is, severe-accident-related loads are included in the design basis of the ANS containment. For example, containment design pressure will be set to withstand static pressures generated from severe accidents such as core-concrete interactions. There is a possibility that a severe-accident-initiated explosion (e.g., a steam explosion) could generate energetic missiles or shock waves. However, containment failure would occur for only the most energetic loads under current design criteria. For example, a missile generated from a steam explosion in the core region would have to rise through the $20 \mathrm{~m}(65.6 \mathrm{ft})$ of water above the reactor to the top of the high bay and then penetrate both the 25 -mm-thick (1-in.-thick) steel primary containment and the 0.8 -m-thick (30-in.-thick) reinforced concrete secondary containment wall. Several such scenarios are being examined for their damage potential and will be addressed at a later time.

The worst containment failure mode would involve a failure of primary containment in a manner that would allow leakage directly to the environment. A credible scenario would be for a containment ventilation line to fail to isolate upon demand. As a conservative standard, this containment failure mode has been selected for all calculations reported in this section. Because these lines are isolated by at least two valves in a series, the probability of this failure mode is low, on the order of $10^{-4}$ per demand.

The MACCS calculations reported in Sect. 7.1.1.2 show that significant radiation exposures are associated with the conservative source terms posed for this report. To quantify the risks associated with the calculated radiation exposures, it is necessary to consider accident and equipment failure probabilities.

Level 2 and level 3 probabilistic risk assessments have not yet been completed for ANS, but approximate probability levels have been estimated [M. Harrington, Oak Ridge National Laboratory (ORNL), personal communication to R. Taleyarkhan, Engineering Technology Division, ORNL, November 1991] from design goals and scoping probabilistic risk assessment studies that have been completed. For example, the ANS design goal for limiting the risk of severe core damage is $10^{-5} /$ year, and preliminary probabilistic risk assessment studies indicate that this goal is realistic. Another safety-related design goal is for the probability of containment failure to be less than $10^{-2}$ per accident-initiated demand. From these considerations, it is evident that the frequency of severe accidents with containment failure is expected to be approximately $10^{-7}$ per year.

Using the preliminary core-melt progression event tree (Fig. 7.1-1), our best engineering judgement is that scenario 1 outcome represents perhaps as much as $25 \%$ and scenario 2 outcome, a little more than $5 \%$ of core-melt progression sequences. The remaining $70 \%$ of possible melt progression outcomes is less serious and not further considered. These estimates will be refined as more effective means of estimating are developed. Probability levels of $2.5 \times 10^{-8}$ per year for scenario 1 and $1 \times 10^{-8}$ per year for scenario 2 were used to estimate the health risks reported in Sect. 7.1.1.2. Lower consequence, higher probability severe accidents will add to the overall ANS severe accident risk. The work to estimate these risks is planned, and the results will be reported in the ANS Preliminary Safety Analysis Report. 


\subsubsection{Source Terms}

This section describes the postulated severe accident scenarios, methodology for analysis, modeling assumptions, modeling of several severe accident phenomena, and the resulting source terms.

\section{Severe accident scenarios}

Due to the preliminary stage of severe accident technology development for ANS, it has not been possible to develop mechanistic tools for capturing core-melt progression phenomena. As previously explained, two severe accident scenarios are postulated with a view towards evaluating conservatively estimated source terms. The first scenario evaluates maximum possible steaming loads and associated radionuclide transport. The second scenario is geared towards evaluating maximal containment loads from releases of radionuclide vapors and aerosols with associated generation of combustible gases. Specific aspects of explosive conditions have not been modeled mechanistically, but primary containment failure caused by missiles or shock waves generated from steam-induced or other explosive processes and a resulting 0.5-m-diam (20-in.-diam) leak path directly to the environment has a low probability of occurrence.

Scenario 1: severe accident steaming event. The evaluation of loads from steaming events during severe accidents for this ANS Environmental Report (ER) is modeled along the lines of the Nuclear Regulatory Commission's (NRC's) guidance for power reactors (AEC 1963), and will be referred to as scenario 1. The core debris for this case is assumed to be confined within a $100 \mathrm{~m}^{3}\left(3500 \mathrm{ft}^{3}\right)$ volume of water. At the beginning of the MELCOR calculations, it is assumed that a partitioning of fission products has occurred. All of the noble gases and $50 \%$ of the halogen inventory are assumed to escape from the water and move directly into the atmosphere of the primary containment high bay area. The balance of the radionuclides would remain behind and cause the water to boil. This prescription would be characterized as conservative because it assumes no time span allowance for core material degradation, relocation, fission product release, and possible retention. Also, the prescription does not take into account iodine removal due to scrubbing as it passes through the large reactor pool in ANS. However, it does represent a conservative guide for the evaluation of source terms in the absence of mechanistic melt progression analyses, and has a long history of similar usage for the power reactor licensing process.

Scenario 2: molten-core-concrete-interaction (MCCI) event. Based upon more than a decade of research [first postulated in the Reactor Safety Study, WASH-1400] on severe accidents for power reactors it is now well known that the study of MCCls represents an important phase of any hypothetical severe accident that results in core debris becoming relocated outside of the primary system onto a concrete surface. MCCI events can release large amounts of combustible gases $\left(\mathrm{CO}\right.$ and $\left.\mathrm{H}_{2}\right)$ as well as considerable quantities of radionuclides in the form of vapors and aerosols. Due to the relatively high power density of the ANS fuel debris it is postulated that during a core-meltdown accident, core debris could ablate penetration seals or other structures and fall onto the concrete floor of the subpile room. Thereafter, the core debris would spread and an MCCI event would begin. Details of a preliminary study conducted for ANS on MCCI are reported elsewhere (Hyman and Taleyarkhan 1991, pp. 1-62). The scenario postulated for the current study conservatively assumes that the core debris would relocate 
instantaneously (i.e., after insertion of control rods) onto a dry concrete floor in the subpile room. Thereafter, the containment capacity will be challenged from the resulting loads arising from combustible gas deflagration and released radionuclides, in addition to other gases produced from MCCl. Additional conservatism is factored into the scenario through the assumption that none of the more than $100 \mathrm{~m}^{3}$ (3532 $\left.\mathrm{ft}^{3}\right)$ of heavy water from the primary coolant system would relocate through the same breach (as the core debris) into the subpile room.

\section{ANS containment modeling}

ANS containment modeling was conducted using the MELCOR (Version 1.80) severe accident analysis code. MELCOR is a fully integrated computer code that has been developed primarily for power reactor severe accident analysis. MELCOR incorporates models for core-melt progression (specific to power reactors), generalized containment response evaluations including radionuclide transport, and engineered safety features. It has been developed by $\mathrm{NRC}$ as a second generation plant risk assessment tool. MELCOR is a control volume code that models transport of various materials between volumes via flow paths. Extensive capability is ayailable for fairly detailed representation of complex heat-absorbing structures and flow paths for various materials and radionuclides (both as vapors and aerosols).

However, being general in nature, MELCOR does not have the capability to model specific ANS core-melt progression phenomena associated with radically different fuel-types, power densities, materials, and geometries. Hence, the two scenarios are modeled without taking into consideration the salient aspects of core-melt progression. The ANS MELCOR containment representation developed for the current study is shown in Fig. 7.1-2. Additional coding was done to develop control functions that enable the definition or control of various aspects of the simulation such as opening and closing of valves; specification of pump characteristics; specification of heat structure boundary conditions; and control of plot, edit, and restart frequencies. As seen in Fig. 7.1-2, all of the major components of the ANS containment have been represented along with associated flow paths. The model consists of 11 control volumes; 15 flow paths; and 21 heat structures (which represent structural components such as walls, ceilings, shells, and miscellaneous materials) of various shapes. A fan model has also been included to account for flow through the large annulus gap between the steel shell and concrete outer containment structure. Leakage into the annulus is modeled assuming an allowance of $0.5 \%$ leak amount per day (i.e., of high-bay volume) at a design pressure of $171 \mathrm{kPa}$ (24.7 psi). Details regarding control logic, elevations, geometry, and plant layout have been documented elsewhere with quality assurance checks in place. This preliminary representation of ANS is based upon the best available information regarding the containment and was developed to fulfill the needs of this ER.

For scenario 1 source term evaluations, 50\% of the iodine inventory and $100 \%$ of the noble gases are assumed to be in the high bay volume (i.e., CV 240) along with the associated decay energy. The remaining radionuclides are evenly distributed in the reactor pool water (CV 202). The reactor coolant system boundary piping and reflector tank are not taken into consideration.

For scenario 2 source term evaluations, the whole core inventory of fission products and the fuel plate structural materials are assumed to relocate onto the subpile room concrete floor where the $\mathrm{MCCI}$ event then occurs. This assumption is conservative because at least some of the noble gases and halogen inventory would have been released before ablation and relocation to the subpile room. With $100 \%$ of the core debris and its 


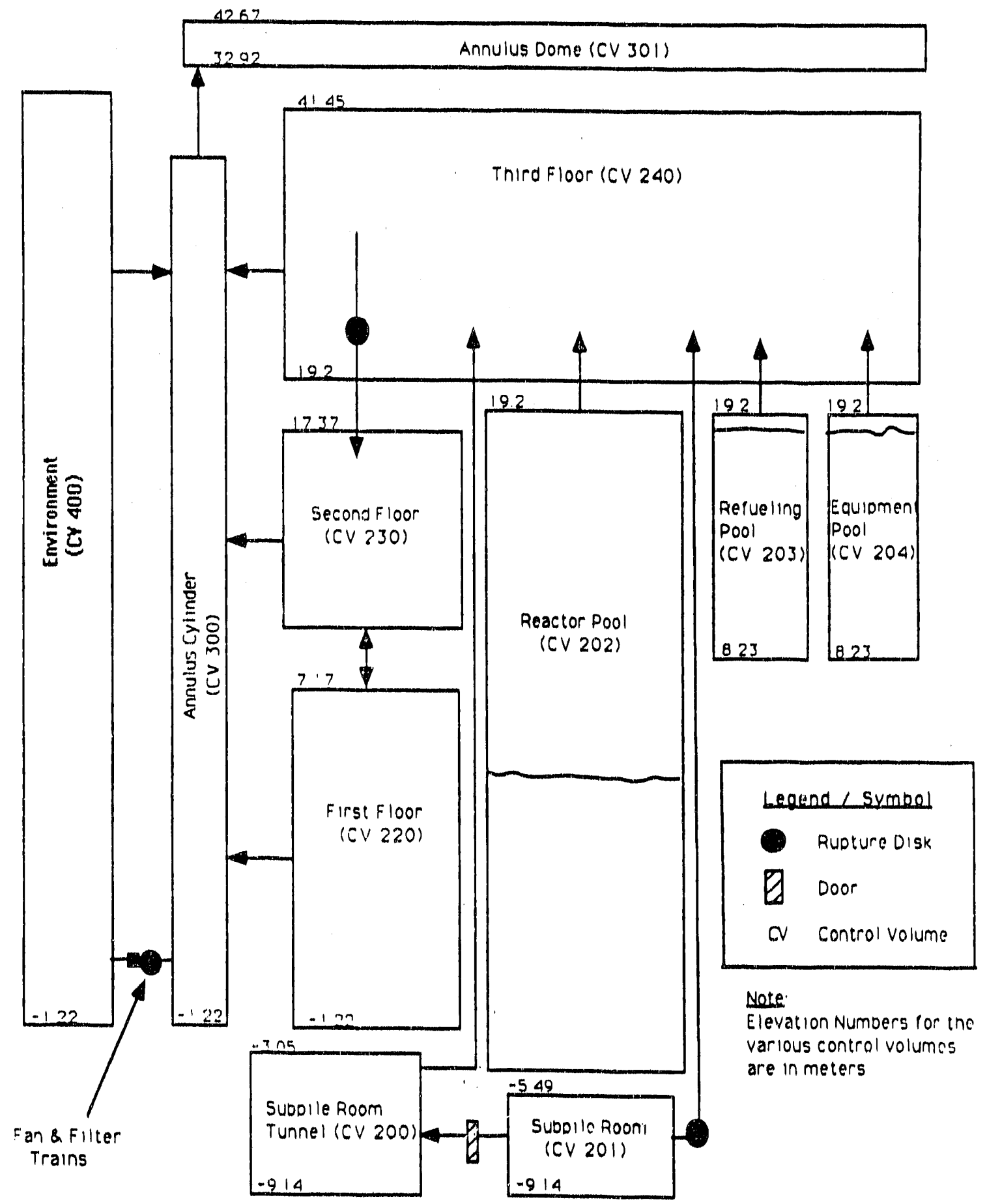

Fig. 7.1-2 Advanced Neutron Source containment (MELCOR) representation for environmental report. 
fission products initialized on the subpile room floor, we model gas generation from $\mathrm{MCCI}$ which results from $50 \%$ of core debris power contributing to core-concrete interaction. This is reasonable because at the limestone-common-sand-concrete ablation temperature of $1500 \mathrm{~K}$, most of the volatile fission products (contributing about $50 \%$ of the debris decay power) will escape the silicide fuel debris into the subpile room atmosphere (Saito et al. 1989). Once again, the various aspects of the core-melt progression and associated timing of such events leading up to this stage are not taken into account these aspects have not been modeled in the interests of conservatism, and because a core-melt progression capability has yet to be developed.

The various modeling assumptions that have been implemented for conducting source-term calculations are given in the following section.

\section{Modeling assumptions}

The modeling assumptions made for conducting evaluations with MELCOR are discussed below:

1. Average ANS core end-of-cycle (EOC) radionuclide inventory are computed using the ORIGEN2 code assuming a 17-d fuel cycle at an operating power level of $330 \mathrm{MW}$. Results are summarized in Table 7.1-1 and 7.1-2.

2. Radionuclide decay of parent to daughter isotopes during the containment transport stage is negligible.

3. For scenario 1, all the noble gases and $50 \%$ of iodine inventory (in vapor form) are assumed to be in the high bay volume at the start of MELCOR evaluations for radionuclide transport. The remaining radionuclide inventory is in the reactor pool water. Upon heatup of pool water to saturation, cesium and tellurium are released in quantities proportional to the steaming rate. Cesium is released in hydroxide form (i.e., $\mathrm{CsOH}$ ), and release of the remaining iodine (i.e., the $50 \%$ not previously released) is modeled mechanistically. Aerosol formation, deposition, and transport is allowed.

4. For scenario 1 it is assumed that, due to some event (e.g., beam-tube rupture), the reactor pool water is depleted up to the level of the beam tubes, which results in a pool-water volume of $100 \mathrm{~m}^{3}\left(3500 \mathrm{ft}^{3}\right)$. It is assumed that cooling equipment (for all pools in the high bay area) fails to function.

5. For scenario 2, all of the volatile fission products are in the subpile room at the start of evaluations for radionuclide transport. Iodine is assumed to be in vapor form, cesium and tellurium, in aerosol form. The nonvolatile species contribute to the continuation of $\mathrm{MCCI}$.

6. Decay power generation in the refueling pool occurs at a constant level of $0.62 \mathrm{MW}$.

7. ANS target elements with their transplutonium inventory remain intact. Associated radioactivity is not released into the atmosphere.

8. Core-melt progression phenomena and their associated time histories in-vessel are not modeled.

9. Neither normal nor emergency ventilation flow paths for ANS containment are accounted for as being potential radionuclide release pathways. However, the postulated 0.5 -m-diam (20-in.-diam) containment leak path directly from the primary containment to the environment is based upon the assumed failure-to-isolate of one normal containment ventilation line. 
Table 7.1-1. Radionuclide mass inventory predicted by ORIGEN2 for Advanced Neutron Source core (end-of-cycle)

\begin{tabular}{cll}
\hline Class (MELCOR) & \multicolumn{1}{c}{ Elements } & \multicolumn{1}{c}{ Mass [kg (lb)] } \\
\hline 1 & $\mathrm{Kr}, \mathrm{Xe}$ & $1.0112(2.23)$ \\
2 & $\mathrm{Na}, \mathrm{Rb}, \mathrm{Cs}$ & $0.40142(0.88)$ \\
3 & $\mathrm{Sr}, \mathrm{Ba}$ & $0.680(1.49)$ \\
4 & $\mathrm{Br}, \mathrm{I}$ & $0.09667(0.21)$ \\
5 & $\mathrm{Se}, \mathrm{Te}$ & $0.11537(0.25)$ \\
6 & $\mathrm{Ru}, \mathrm{Rh}$ & $0.38511(0.85)$ \\
7 & $\mathrm{Mn}, \mathrm{Nb}, \mathrm{Mo}, \mathrm{Tc}$ & $0.65289(1.44)$ \\
8 & $\mathrm{Zr}, \mathrm{Ce}, \mathrm{Np}$ & $1.4386(3.17)$ \\
9 & $\mathrm{Al}, \mathrm{Y}, \mathrm{La}, \mathrm{Pr}, \mathrm{Nd}$ & $87.042(191.89)$ \\
10 & $\mathrm{U}$ & $10.68(23.55)$ \\
11 & $\mathrm{As}, \mathrm{Sb}$ & $0.004156(0.0092)$ \\
12 & $\mathrm{Ge}, \mathrm{In}, \mathrm{Sn}$ & $0.0068828(0.0152)$ \\
\hline
\end{tabular}

10. Natural circulation phenomena that may occur between interconnecting volumes are not modeled explicitly.

11. Gas, vapor, and stratification phenomena are not modeled. All control volumes are assumed to exhibit perfect mixing.

12. Containment cooling features such as fan and pool coolers are assumed to be inoperable.

13. The subpile room is modeled based on functioning igniters, so that if oxygen is available, any hydrogen and carbon monoxide gas are allowed to deflagrate (but not detonate). The composition of the subpile room basemat is assumed to be limestone-common-sand concrete.

14. Highly energetic events such as steam explosions, recriticality, and detonation of combustible gases are not modeled explicitly. Nevertheless, the rapid draining of the reactor pool assumed for scenario 1 (see assumption 4 ) could only occur as a result of such an energetic event.

15. Upon occurrence of a severe accident, a 0.5 -m-diam (20-in.-diam) opening in the high bay volume is assumed to release radionuclides directly to the environment without filtration. This release path is $1 \mathrm{~m}(3.28 \mathrm{ft})$ above the lowest level of the high bay area (essentially a ground level release). Such a pathway, although based directly on failure-to-isolate of a ventilation duct (see assumption 9), should also simulate early containment failure from the possible effects of explosive or external events.

16. Any steam condensation run off from the vertical structures in the high bay area is assumed to collect in a basin and is not allowed to drain back into the reactor pool. 
Table 7.1-2. Activity levels of important radionuclides at end-of-cycle for Advanced Neutron Sounce core

\begin{tabular}{|c|c|c|c|}
\hline Nuclide & Activity [Bq (Cl)] & Nuclido & Acttvity [Bq (Cl)] \\
\hline${ }^{56} \mathrm{Mn}$ & $1.77 \times 10^{16}\left(4.79 \times 10^{5}\right)$ & ${ }^{132} \mathrm{Te}$ & $4.18 \times 10^{17}\left(1.13 \times 10^{7}\right)$ \\
\hline${ }^{*} \mathrm{Co}$ & 0 & ${ }^{132} I$ & $4.26 \times 10^{17}\left(1.15 \times 10^{7}\right)$ \\
\hline${ }^{60} \mathrm{Co}$ & 0 & ${ }^{13} \mathrm{Te}$ & $3.53 \times 10^{17}\left(9.53 \times 10^{6}\right)$ \\
\hline${ }^{3} \mathrm{Br}$ & $4.83 \times 10^{16}\left(1.30 \times 10^{6}\right)$ & $13 \mathrm{bm} \mathrm{Te}$ & $2.64 \times 10^{17}\left(7.14 \times 10^{6}\right)$ \\
\hline$m+m^{m}$ & $4.84 \times 10^{16}\left(1.30 \times 10^{6}\right)$ & ${ }^{133} I$ & $6.40 \times 10^{17}\left(1.73 \times 10^{7}\right)$ \\
\hline${ }^{4} \mathrm{Br}$ & $9.07 \times 10^{16}\left(2.45 \times 10^{6}\right)$ & ${ }^{133} \mathrm{Xe}$ & $5.07 \times 10^{17}\left(1.36 \times 10^{7}\right)$ \\
\hline${ }^{85} \mathrm{Kr}$ & $8.17 \times 10^{13}\left(2.21 \times 10^{3}\right)$ & ${ }^{13 x+1 \times e}$ & $1.99 \times 10^{16}\left(5.37 \times 10^{5}\right)$ \\
\hline $\sin \mathrm{Kr} r$ & $1.14 \times 10^{17}\left(3.08 \times 10^{6}\right)$ & ${ }^{134} \mathrm{Te}$ & $6.05 \times 10^{17}\left(1.63 \times 10^{7}\right)$ \\
\hline${ }^{\sigma / K r}$ & $2.29 \times 10^{17}\left(6.19 \times 10^{6}\right)$ & ${ }^{134} \mathrm{Cs}$ & $4.24 \times 10^{14}\left(1.14 \times 10^{4}\right)$ \\
\hline${ }^{m} \mathrm{Kr}$ & $3.27 \times 10^{17}\left(8.85 \times 10^{6}\right)$ & $134 I$ & $6.90 \times 10^{17}\left(1.86 \times 10^{7}\right)$ \\
\hline${ }^{16} \mathrm{Rb}$ & $1.65 \times 10^{14}\left(4.46 \times 10^{3}\right)$ & ${ }^{133} I$ & $5.73 \times 10^{17}\left(1.54 \times 10^{7}\right)$ \\
\hline$m_{R b}$ & $3.31 \times 10^{17}\left(8.94 \times 10^{6}\right)$ & ${ }^{13 s} \mathrm{Xe}$ & $2.00 \times 10^{16}\left(5.40 \times 10^{5}\right)$ \\
\hline${ }^{\circ} \mathrm{Rb}$ & $4.28 \times 10^{17}\left(1.15 \times 10^{7}\right)$ & $\operatorname{lism} \times \mathrm{e}$ & $1.04 \times 10^{17}\left(2.82 \times 10^{6}\right)$ \\
\hline${ }^{*} \mathrm{Sr}$ & $1.00 \times 10^{17}\left(2.73 \times 10^{6}\right)$ & ${ }^{136} \mathrm{Cs}$ & $1.03 \times 10^{15}\left(2.81 \times 10^{4}\right)$ \\
\hline${ }^{\circ} \mathrm{Sr}$ & $8.22 \times 10^{14}\left(2.22 \times 10^{4}\right)$ & ${ }^{137} \mathrm{Cs}$ & $6.70 \times 10^{14}\left(1.81 \times 10^{4}\right)$ \\
\hline${ }^{91} \mathrm{Sr}$ & $5.26 \times 10^{17}\left(1.42 \times 10^{7}\right)$ & $10 \times e$ & $5.63 \times 10^{17}\left(1.52 \times 10^{7}\right)$ \\
\hline $90 Y$ & $6.37 \times 10^{14}\left(1.72 \times 10^{4}\right)$ & ${ }^{134} \mathrm{Cs}$ & $6.08 \times 10^{17}\left(1.64 \times 10^{7}\right)$ \\
\hline${ }^{91} \mathrm{Y}$ & $1.06 \times 10^{17}\left(2.87 \times 10^{6}\right)$ & ${ }^{1.90} \mathrm{Cs}$ & $5.76 \times 10^{17}\left(1.55 \times 10^{7}\right)$ \\
\hline $9 \ln Y$ & $3.05 \times 10^{17}\left(8.24 \times 10^{6}\right)$ & ${ }^{139} \mathrm{Ba}$ & $5.83 \times 10^{17}\left(1.57 \times 10^{7}\right)$ \\
\hline $2 \mathrm{Sr}$ & $5.38 \times 10^{17}\left(1.45 \times 10^{7}\right)$ & ${ }^{140} \mathrm{Ba}$ & $3.77 \times 10^{17}\left(1.02 \times 10^{7}\right)$ \\
\hline $9 Y$ & $5.41 \times 10^{17}\left(1.46 \times 10^{7}\right)$ & $140 \%$ & $3.56 \times 10^{18}\left(9.62 \times 10^{7}\right)$ \\
\hline${ }^{9} \mathrm{Sr}$ & $5.71 \times 10^{17}\left(1.54 \times 10^{7}\right)$ & ${ }^{14} \mathrm{Ba}$ & $5.36 \times 10^{17}\left(1.44 \times 10^{7}\right)$ \\
\hline PY & $5.81 \times 10^{17}\left(1.57 \times 10^{7}\right)$ & $\mid 14 \mathrm{La}$ & $5.41 \times 10^{17}\left(1.46 \times 10^{7}\right)$ \\
\hline MY & $5.61 \times 10^{17}\left(1.51 \times 10^{7}\right)$ & ${ }^{|1|} \mathrm{Ce}$ & $1.76 \times 10^{17}\left(4.76 \times 10^{6}\right)$ \\
\hline 9s $\mathrm{Y}$ & $5.75 \times 10^{17}\left(1.55 \times 10^{7}\right)$ & ${ }^{142} \mathrm{Ba}$ & $5.21 \times 10^{17}\left(1.40 \times 10^{7}\right)$ \\
\hline s'Zr & $1.09 \times 10^{17}\left(2.95 \times 10^{6}\right)$ & ${ }^{142} \mathrm{La}$ & $5.31 \times 10^{17}\left(1.43 \times 10^{7}\right)$ \\
\hline${ }^{9} \mathrm{Nb}$ & $1.68 \times 10^{16}\left(4.57 \times 10^{5}\right)$ & ${ }^{143} \mathrm{La}$ & $5.30 \times 10^{17}\left(1.43 \times 10^{7}\right)$ \\
\hline$r_{\mathrm{Zr}}$ & $5.56 \times 10^{17}\left(1.50 \times 10^{7}\right)$ & ${ }^{143} \mathrm{Ce}$ & $5.71 \times 10^{17}\left(1.4 \times 10^{7}\right)$ \\
\hline${ }^{97} \mathrm{Nb}$ & $5.58 \times 10^{17}\left(1.50 \times 10^{7}\right)$ & ${ }^{143} \mathrm{Pr}$ & $2.89 \times 10^{17}\left(7.82 \times 10^{6}\right)$ \\
\hline $\lim _{\mathrm{Nb}}$ & $5.27 \times 10^{17}\left(1.42 \times 10^{7}\right)$ & ${ }^{14} \mathrm{Ce}$ & $2.24 \times 10^{16}\left(6.06 \times 10^{5}\right)$ \\
\hline
\end{tabular}


Table 7.1-2. (continued)

\begin{tabular}{|c|c|c|c|}
\hline Nuclide & Acttuity $[\mathrm{Bq}(\mathrm{Cl})]$ & Nuclide & Aotivity [Bq (Cl)] \\
\hline${ }^{9} \mathrm{Mo}$ & $5.89 \times 10^{17}\left(1.592 \times 10^{7}\right)$ & ${ }^{14} \mathrm{pr}$ & $1.23 \times 10^{17}\left(3.32 \times 10^{6}\right)$ \\
\hline sem $T \mathrm{c}$ & $5.30 \times 10^{17}\left(1.43 \times 10^{7}\right)$ & ${ }^{1 \omega s} \mathrm{Pr}$ & $3.54 \times 10^{17}\left(9.57 \times 10^{6}\right)$ \\
\hline${ }^{101} \mathrm{Mo}$ & $4.63 \times 10^{17}\left(1.25 \times 10^{7}\right)$ & ${ }^{146} \mathrm{Ce}$ & $2.68 \times 10^{17}\left(7.24 \times 10^{6}\right)$ \\
\hline${ }^{101} \mathrm{Tc}$ & $4.63 \times 10^{17}\left(1.25 \times 10^{7}\right)$ & ${ }^{140} \mathrm{Pr}$ & $2.69 \times 10^{17}\left(7.26 \times 10^{6}\right)$ \\
\hline${ }^{1 m} \mathrm{Mo}$ & $3.86 \times 10^{17}\left(1.04 \times 10^{7}\right)$ & ${ }^{147} \mathrm{Pr}$ & $2.06 \times 10^{17}\left(5.57 \times 10^{6}\right)$ \\
\hline${ }^{102} \mathrm{Tc}$ & $3.86 \times 10^{17}\left(1.04 \times 10^{7}\right)$ & ${ }^{147} \mathrm{Nd}$ & $1.26 \times 10^{17}\left(3.43 \times 10^{6}\right)$ \\
\hline${ }^{100} R u$ & $8.18 \times 10^{16}\left(2.21 \times 10^{6}\right)$ & ${ }^{149} \mathrm{Nd}$ & $1.03 \times 10^{17}\left(2.79 \times 10^{6}\right)$ \\
\hline $100 \mathrm{~m} R \mathrm{Rh}$ & $7.38 \times 10^{16}\left(1.99 \times 10^{6}\right)$ & ${ }^{149} \mathrm{Pm}$ & $1.14 \times 10^{17}\left(3.09 \times 10^{6}\right)$ \\
\hline${ }^{104} \mathrm{Tc}$ & $1.77 \times 10^{17}\left(4.79 \times 10^{6}\right)$ & ${ }^{150} \mathrm{Pm}$ & $5.26 \times 10^{16}\left(1.42 \times 10^{6}\right)$ \\
\hline${ }^{105} \mathrm{Ru}$ & $1.01 \times 10^{17}\left(2.74 \times 10^{6}\right)$ & $|s| \mathrm{Pm}$ & $2.39 \times 10^{16}\left(6.4^{7} 7 \times 10^{5}\right)$ \\
\hline${ }^{105} \mathrm{Rh}$ & $1.78 \times 10^{16}\left(4.83 \times 10^{5}\right)$ & ${ }^{133} \mathrm{Sm}$ & $6.50 \times 10^{16}\left(1.75 \times 10^{6}\right)$ \\
\hline${ }^{105 m} \mathrm{Rh}$ & $2.84 \times 10^{16}\left(7.68 \times 10^{5}\right)$ & ${ }^{217} \mathrm{U}$ & $1.78 \times 10^{17}\left(4.81 \times 10^{6}\right)$ \\
\hline${ }^{106} \mathrm{Ru}$ & $1.42 \times 10^{15}\left(3.86 \times 10^{4}\right)$ & ${ }^{20} \mathrm{Pu}$ & $1.34 \times 10^{12}\left(3.63 \times 10^{1}\right)$ \\
\hline${ }^{106 m \mathrm{Rh}}$ & $2.75 \times 10^{16}\left(7.43 \times 10^{5}\right)$ & ${ }^{2 M} \mathrm{~Np}$ & $1.78 \times 10^{16}\left(4.83 \times 10^{5}\right)$ \\
\hline${ }^{127} \mathrm{Sb}$ & $1.55 \times 10^{16}\left(4.20 \times 10^{5}\right)$ & $200 \mathrm{U}$ & $2.21 \times 10^{17}\left(5.98 \times 10^{6}\right)$ \\
\hline${ }^{12} \mathrm{Te}$ & $1.41 \times 10^{16}\left(3.82 \times 10^{5}\right)$ & ${ }^{200} \mathrm{~Np}$ & $2.01 \times 10^{17}\left(5.42 \times 10^{6}\right)$ \\
\hline${ }_{18 m}^{16} \mathrm{Te}$ & $1.62 \times 10^{14}\left(4.37 \times 10^{4}\right)$ & ${ }^{200} \mathrm{Pu}$ & $6.01 \times 10^{10}(1.62)$ \\
\hline $2_{\mathrm{Sn}}$ & $3.39 \times 10^{16}\left(9.17 \times 10^{5}\right)$ & ${ }^{240} \mathrm{~Np}$ & $1.13 \times 10^{16}\left(3.07 \times 10^{5}\right)$ \\
\hline $122 m \mathrm{Sb}$ & $3.51 \times 10^{16}\left(9.49 \times 10^{5}\right)$ & ${ }^{200 m} \mathrm{~Np}$ & $2.87 \times 10^{15}\left(7.76 \times 10^{4}\right)$ \\
\hline${ }^{120} \mathrm{Sb}$ & $6.33 \times 10^{16}\left(1.71 \times 10^{6}\right)$ & ${ }^{240} \mathrm{Pu}$ & $1.06 \times 10^{11}(2.87)$ \\
\hline${ }^{129} \mathrm{Te}$ & $5.85 \times 10^{16}\left(1.58 \times 10^{6}\right)$ & ${ }^{240} \mathrm{U}$ & $2.84 \times 10^{13}\left(7.66 \times 10^{2}\right)$ \\
\hline${ }^{120 u r T e}$ & $3.05 \times 10^{15}\left(8.24 \times 10^{4}\right)$ & ${ }^{241} \mathrm{Am}$ & $2.82 \times 10^{8}\left(7.62 \times 10^{3}\right)$ \\
\hline${ }^{131} \mathrm{Sb}$ & $2.33 \times 10^{17}\left(6.30 \times 10^{6}\right)$ & ${ }^{241} \mathrm{Pu}$ & $2.17 \times 10^{13}\left(5.86 \times 10^{2}\right)$ \\
\hline${ }^{13} \mathrm{Te}$ & $2.36 \times 10^{17}\left(6.39 \times 10^{6}\right)$ & ${ }^{212} \mathrm{Cm}$ & $8.63 \times 10^{10}(2.33)$ \\
\hline IstumTe & $3.56 \times 10^{16}\left(9.63 \times 10^{5}\right)$ & ${ }^{24 s} \mathrm{Pu}$ & $1.74 \times 10^{15}\left(4.72 \times 10^{4}\right)$ \\
\hline$|3| y$ & $2.23 \times 10^{17}\left(6.02 \times 10^{6}\right)$ & ${ }^{244} \mathrm{Cm}$ & $9.35 \times 10^{10}(2.53)$ \\
\hline
\end{tabular}

Source: ORIGEN2 computer code. 
17. Rupture disks are provided to allow passage of materials between the subpile room and the high bay area, and between the high bay area and the first and second floors, respectively. These rupture disks opens if a pressure differential of $14 \mathrm{kPa}$ (2 psi) or greater is imposed. The doorway in the subpile room leading to the access tunnel fails to open if a pressure differential of $34 \mathrm{kPa}(5 \mathrm{psi})$ or greater is imposed.

\section{Severe accident response and source term estimates}

A summary of the severe accident response behavior (including source-term estimates) of the ANS containment is provided in this section for scenarios 1 and 2 . For reference purposes, the decay power history obtained from the ORIGEN2 computer code is shown in Fig. 7.1.3.

Scenario 1. The key results in this case are graphically represented in Figs. 7.1-4 through 7.1-13. As noted in Fig. 7.1-4, a mild pressurization results in the various control volumes, with the plotted differences in pressure due primarily to density heads. The pressure in the high bay area does not exceed $115 \mathrm{kPa}(16.7 \mathrm{psi})$; consequently, the first and second floor volumes are not avallable to receive radionuclide vapors or aerosols. The variation in water mass for the reactor pool is shown in Fig. 7.1.5. As illustrated, the water becomes saturated in about $2.5 \mathrm{~h}$; the water begins to steam, thereafter, resulting in the loss of approximately $55,000 \mathrm{~kg}(121,250 \mathrm{lb})$ of water in $70 \mathrm{~h}$.

The radionuclide vapor and aerosol masses in the atmosphere of the high bay area and environment are shown in Figs. 7.1-6 and 7.1-7. At the onset of stearning, there is a sharp increase in aerosol and vapor mass release to the environment, followed by characteristic leveling-off behavior. This leveling-off behavior is due to pressure gradients between the volume in the high-bay and the environment approaching zero. The amount of radionuclide mass deposition on heat structures is shown in Fig. 7.1-8. Figures 7.1-9 through 7.1-11 provide the time history of the various radionuclide masses trapped in the reactor pool. Note the fractional reduction of the cesium and tellurium species in the water due to the steaming process. Figure 7.1-10 highlights an important factor in source-term evaluation: when the reactor pool water reaches saturation, almost all of the halogen inventory is released to the atmosphere. As expected, all of the nonvolatile species elements stay in the reactor pool.

Figures $7.1-12$ and $7.1-13$ provide the transient variation of the radionuclides leaving the containment (i.e., the source-term) and entering the environment. Figure 7.1-12 provides the integrated masses of the various volatile radionuclides being released into the environment, whereas in Fig. 7.1-13 fractional release amounts are given. As seen from these figures for the steaming-pool case with early containment failure, approximately $26 \%$ of the noble gases, about $8.3 \%$ of the halogen inventory, and approximately $0.8 \%$ of the cesium and tellurium inventories get released into the environment. The balance of the radionuclides, based on assumptions made for the present model, remains within the containment.

Scenario 2. Key points of interest for scenario 2 are given in Figs. 7.1.14 through 7.1-23. Due to the intensity of the MCCI (Fig. 7.1-14) the subpile room pressure rises rapidly causing the rupture disk to open and allow passage of radionuclides to the high bay area. The pressure in the subpile room does not rise high enough to cause failure of the door leading to the subpile room tunnel; however, the existence of a direct pathway from the high bay area to the subpile room tunnel causes the pressure there to rise 


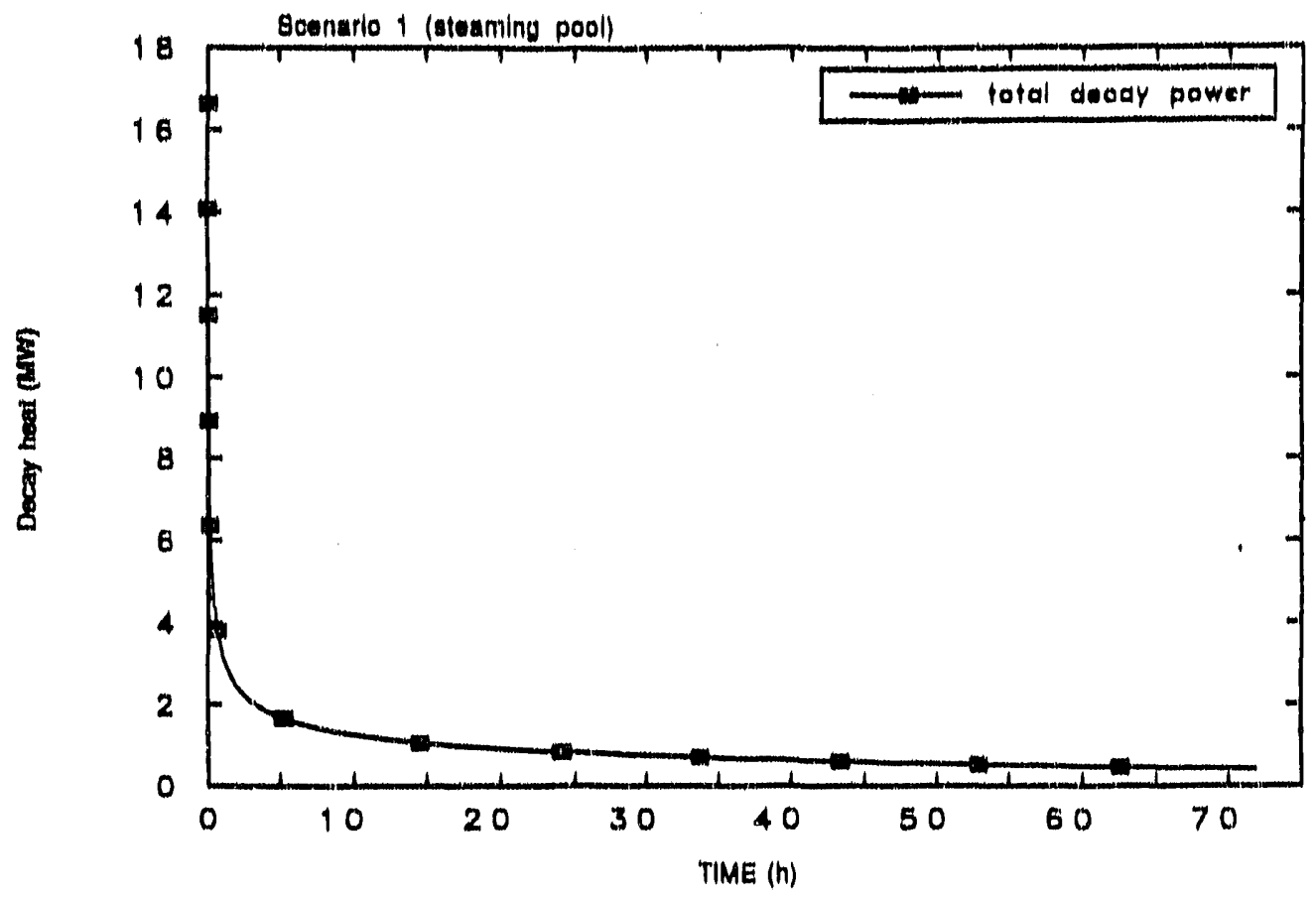

Fig. 7.1-3. Total decay power variation with time for Advunced Neutron Sourco core (14-d operation at $362 \mathrm{MW}$ ).

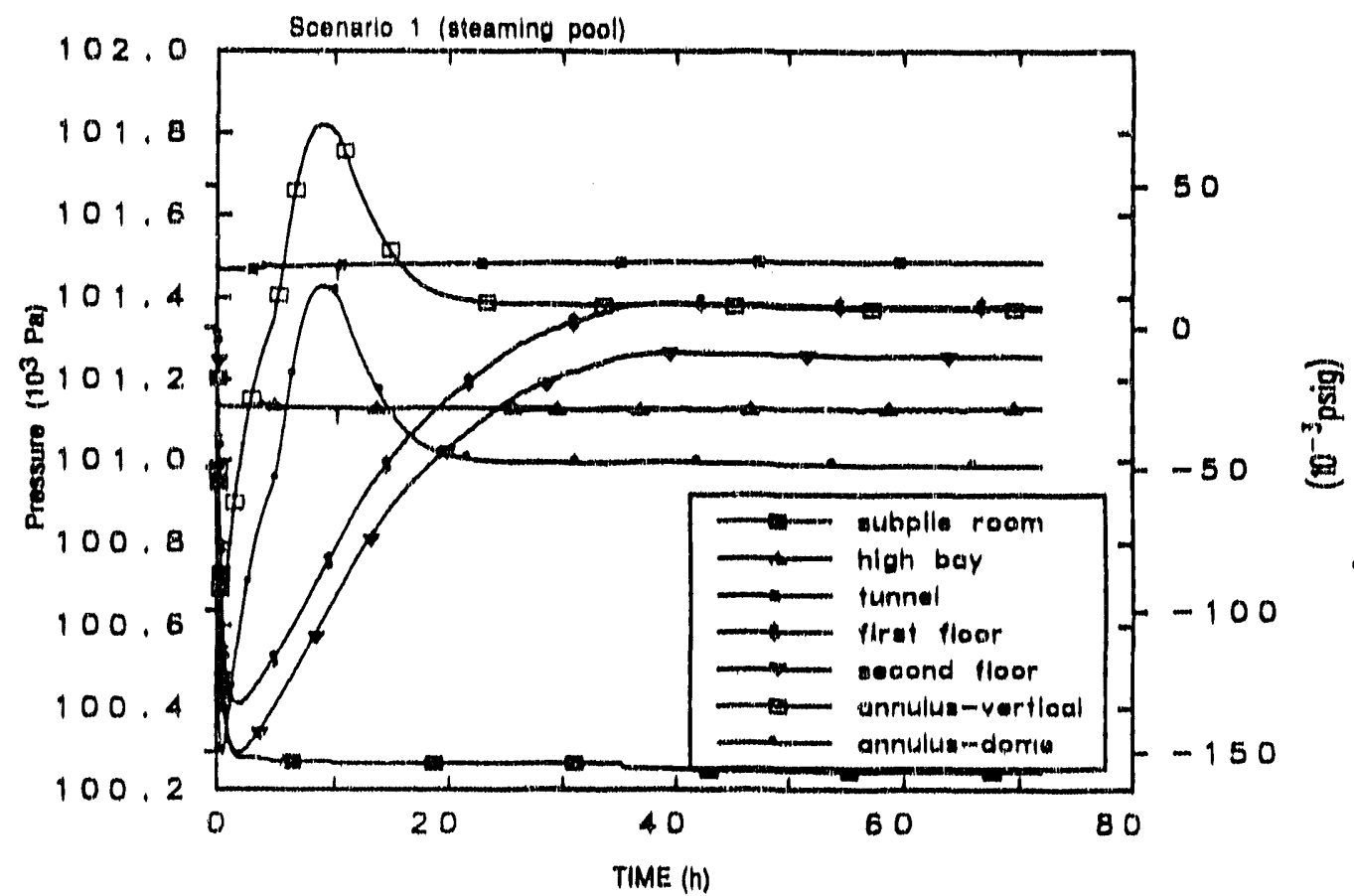

Fig. 7.1-4. Variation of control volume pressures with time (stearning pool case-scenario 1 ). 


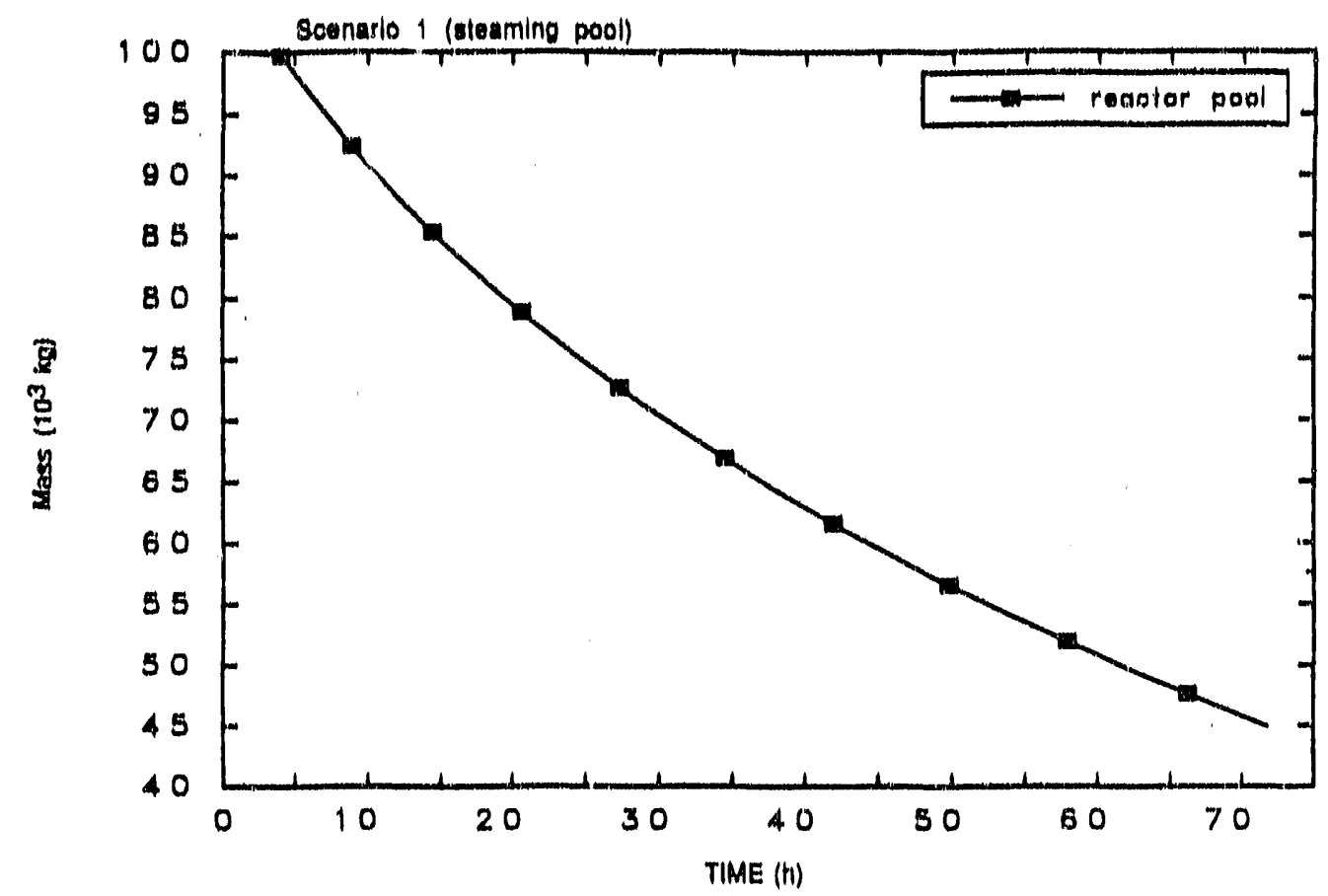

Fig. 7.1-5. Variation of reactor pool water inventory with time (steaming pool case-scenario 1).

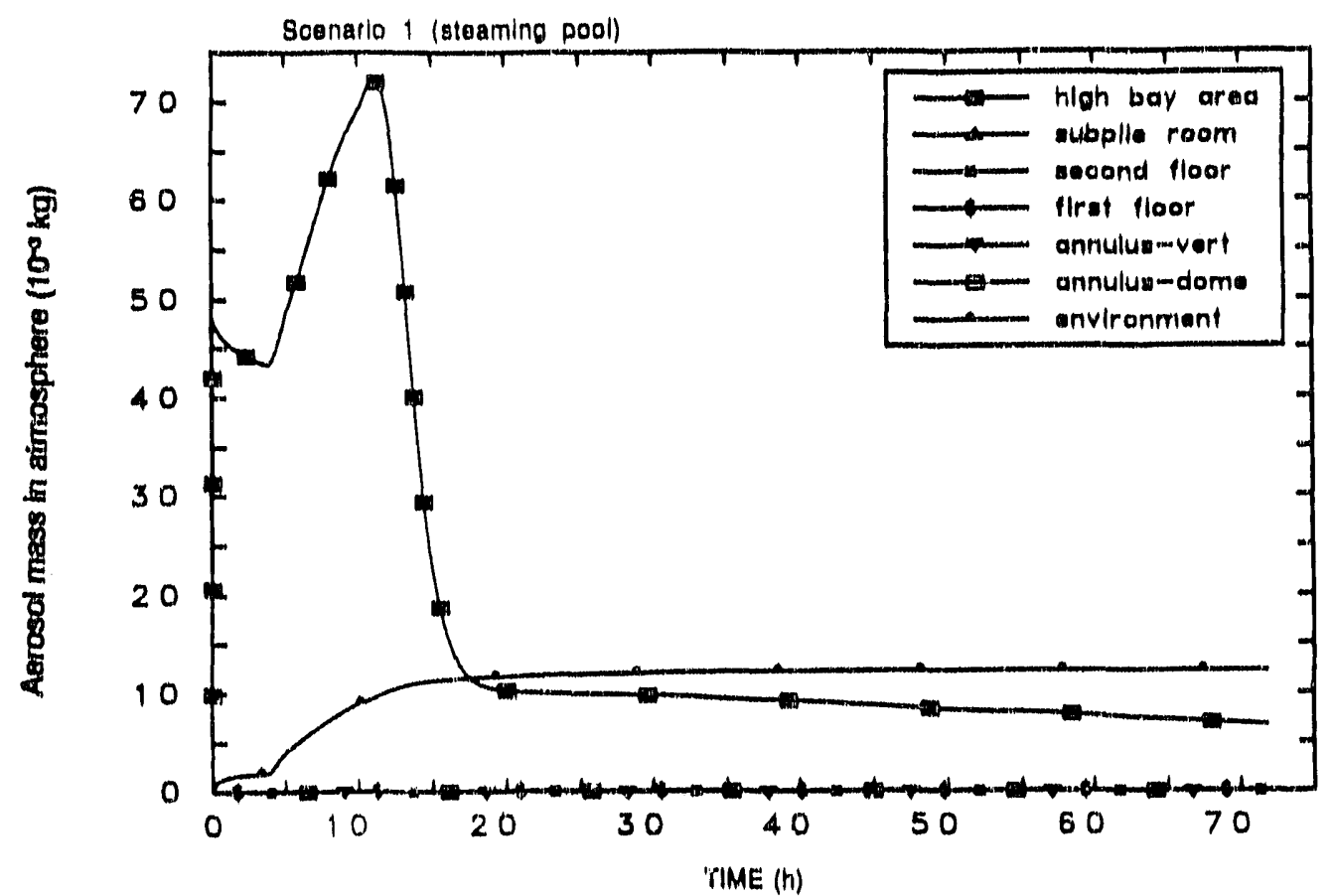

Fig. 7.1-6. Distribution of aerosol masses in various control volumes with time (steaming pool case-scenario 1). 


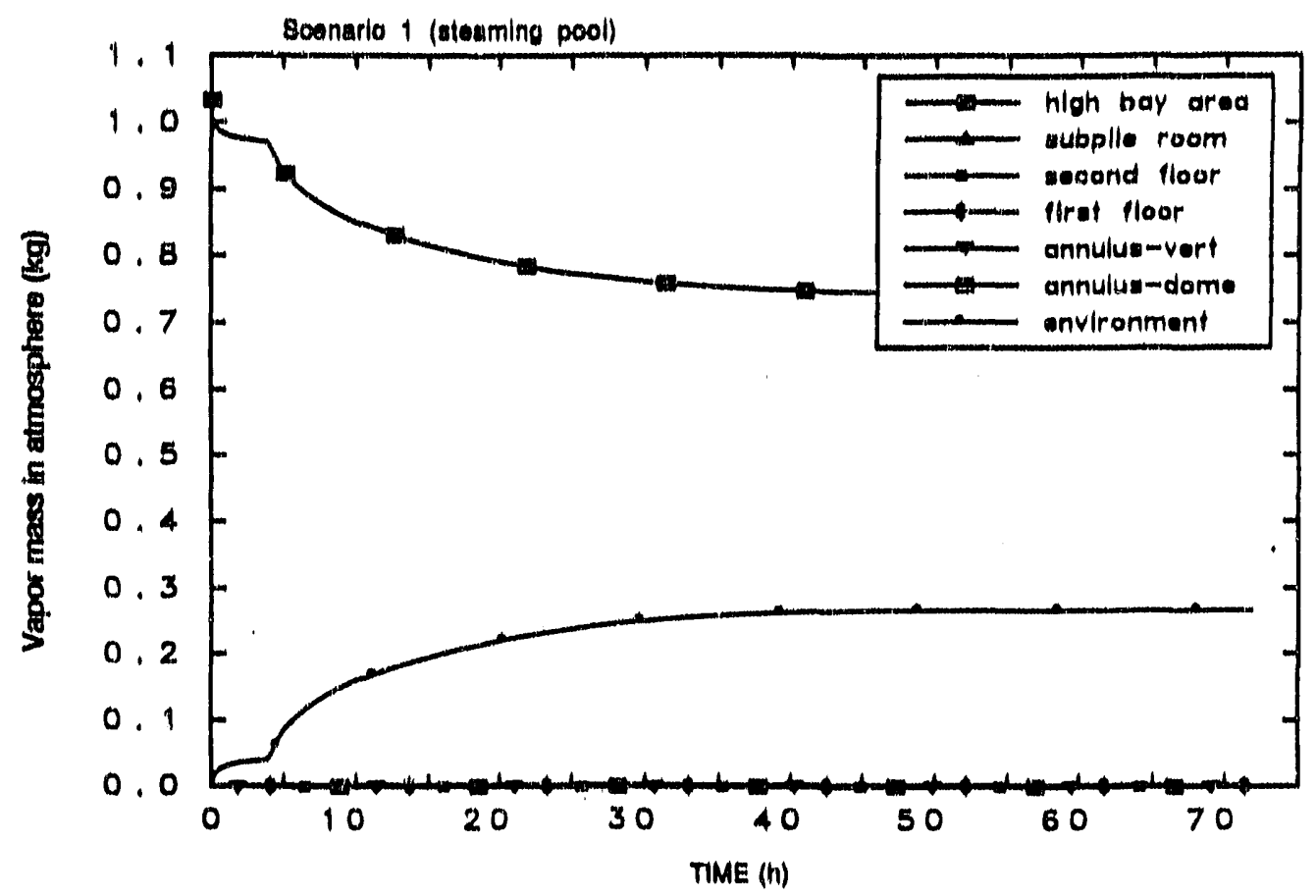

Fig. 7.1-7. Distribution of vapors (noble gases anc halogens) in various control volumes with time (steaming pool case-scenario 1).

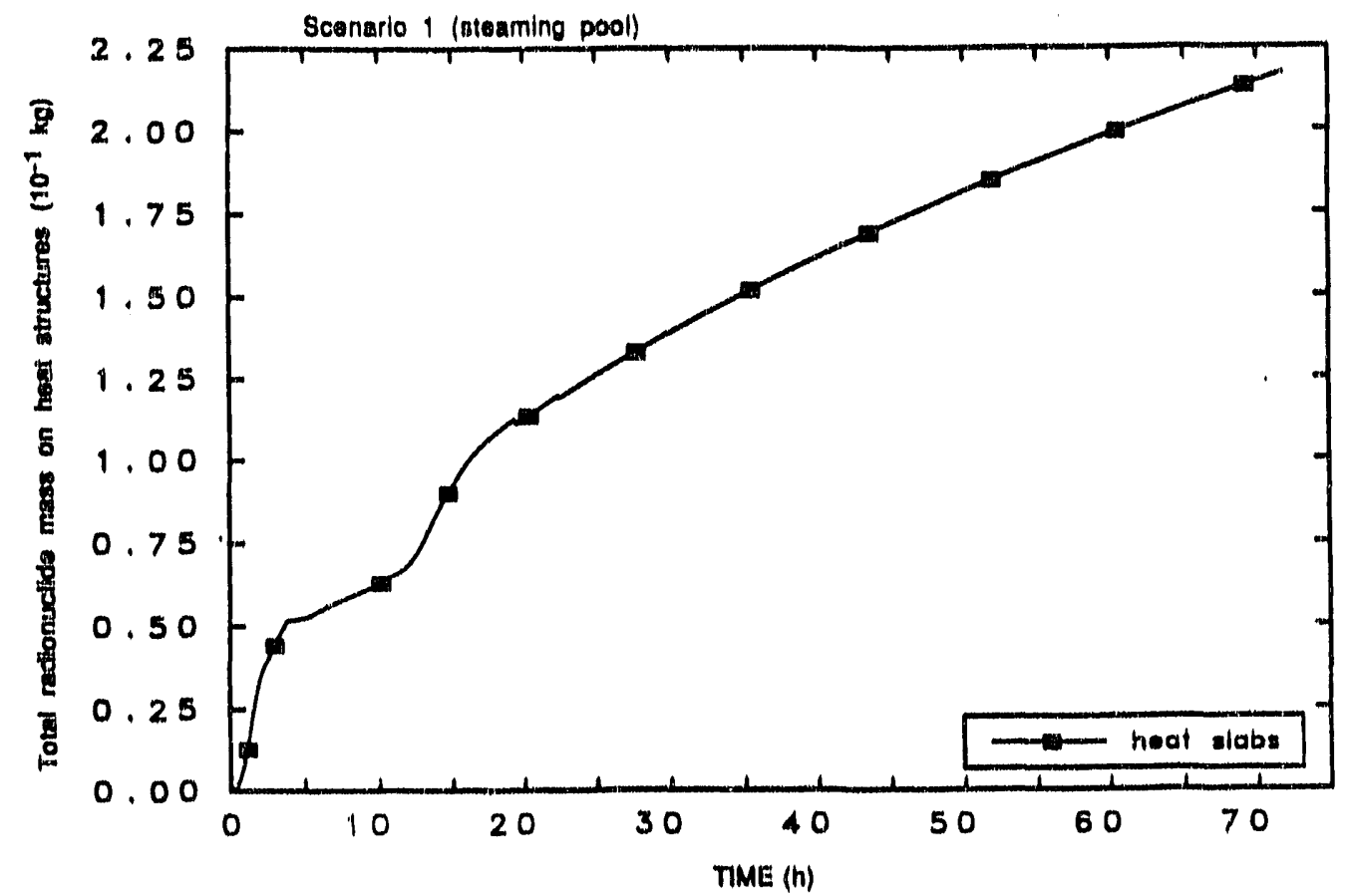

Fig. 7.1-8. Radionuclide deposition on heal structures with time (steaming pool case-scenario 1). 


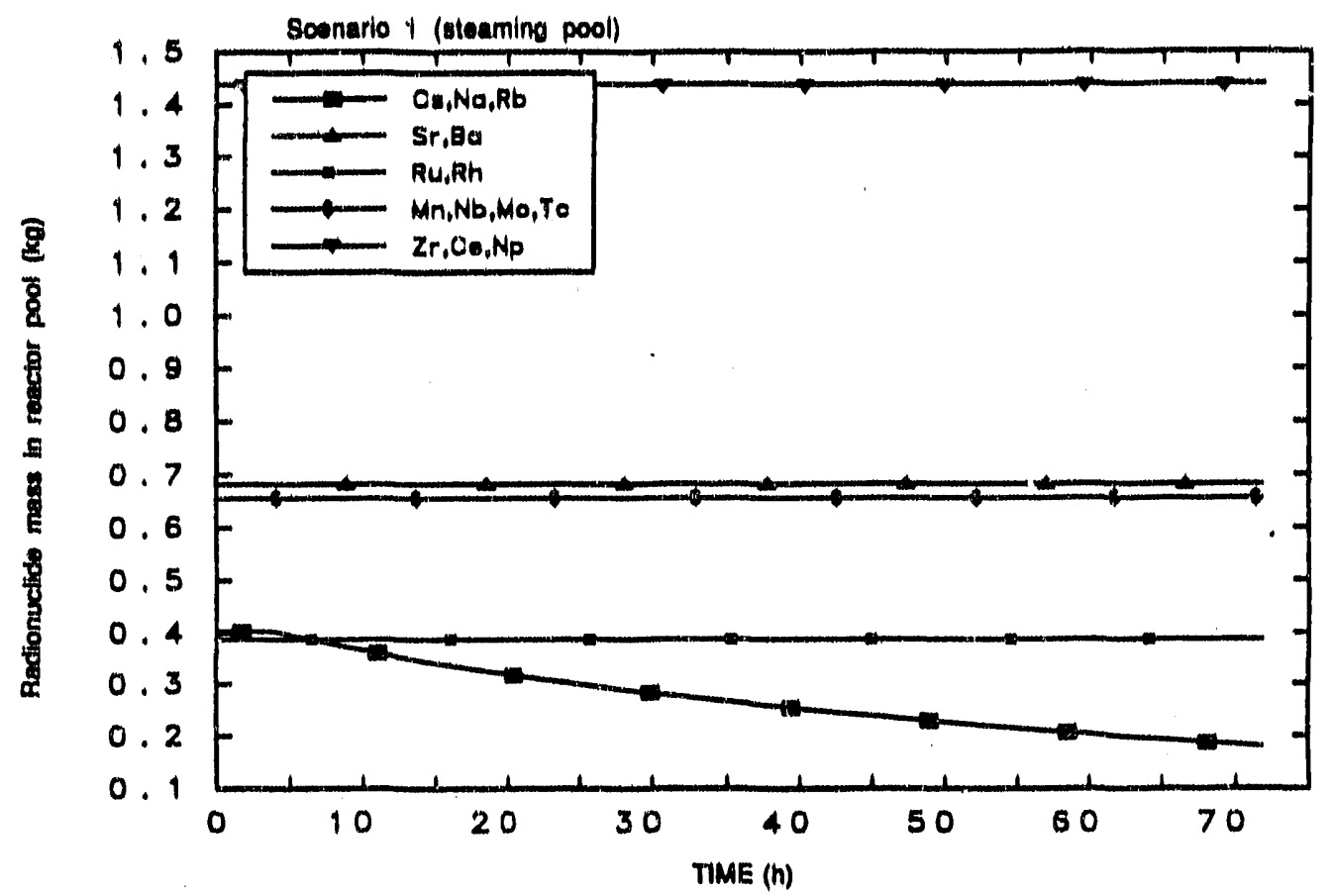

Fig. 7.1.9. Variation of radionuclide masses in reactor pad with time (steaming pool case-scenario 1).

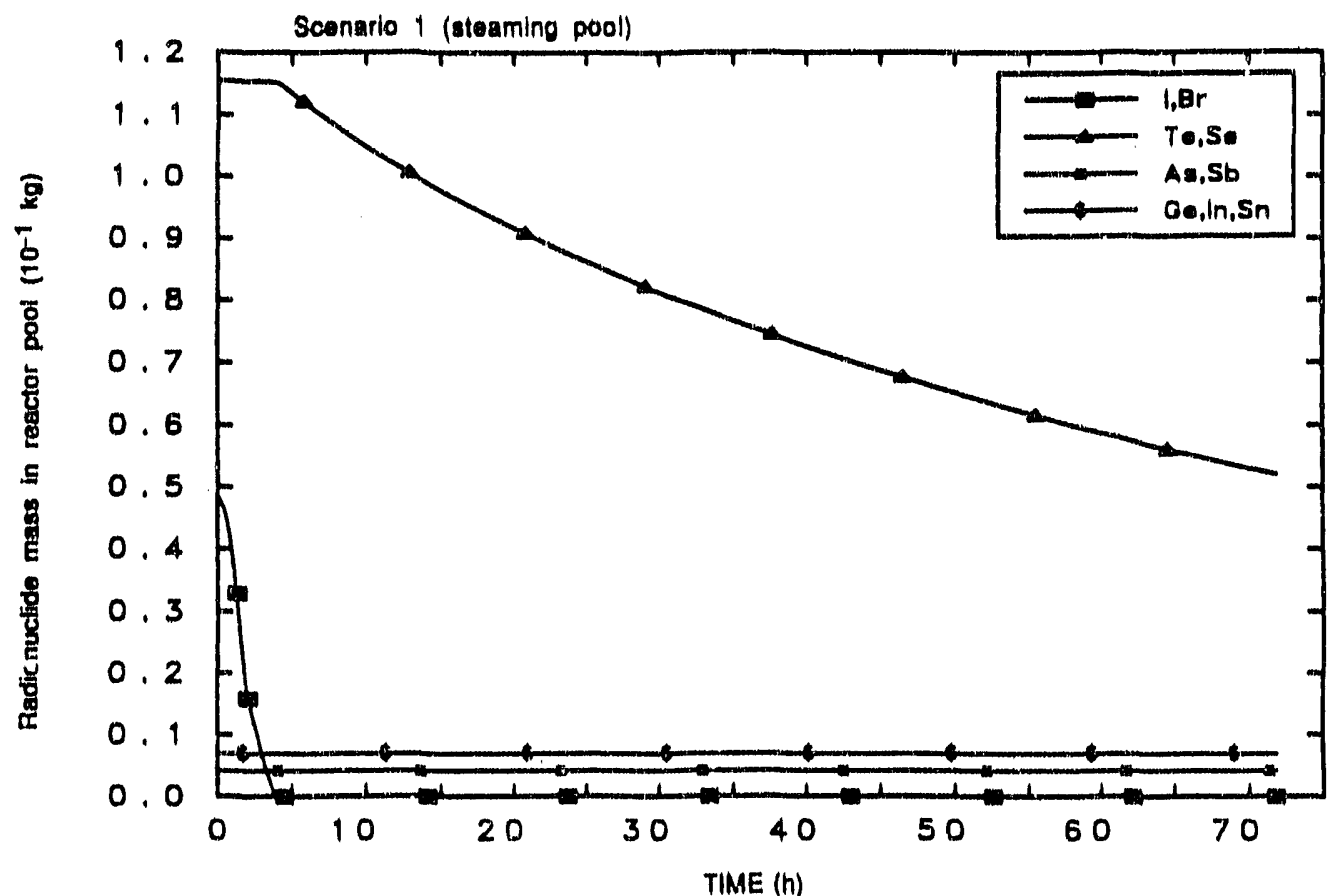

Fig. 7.1-10. Variation of radionuclide masses in reactor pool with time (steaming pool case-scenario 1). 


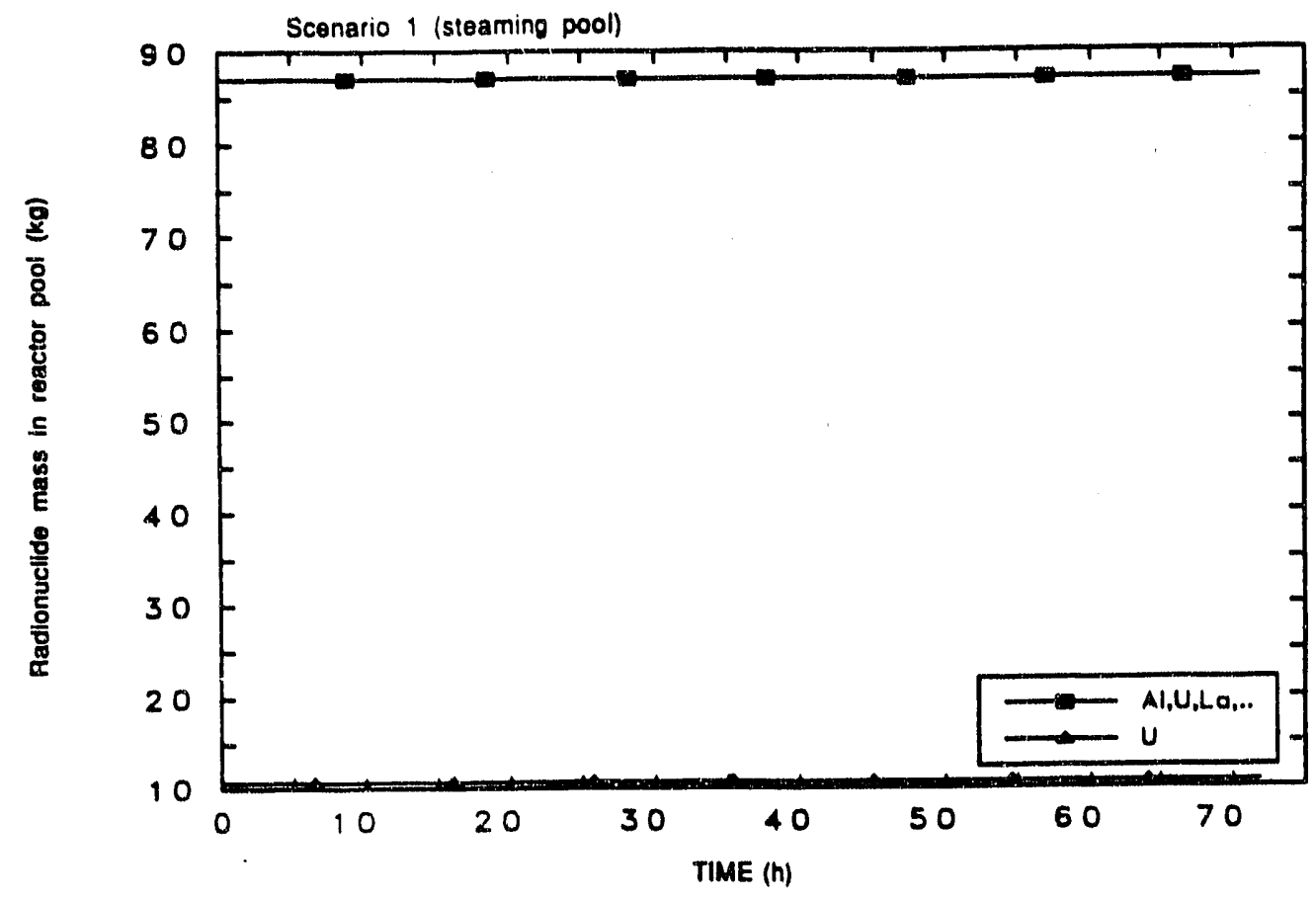

Fig. 7.1-11. Variation of radionuclide masses in reactor pool with time (steaming pool case-scenario 1).

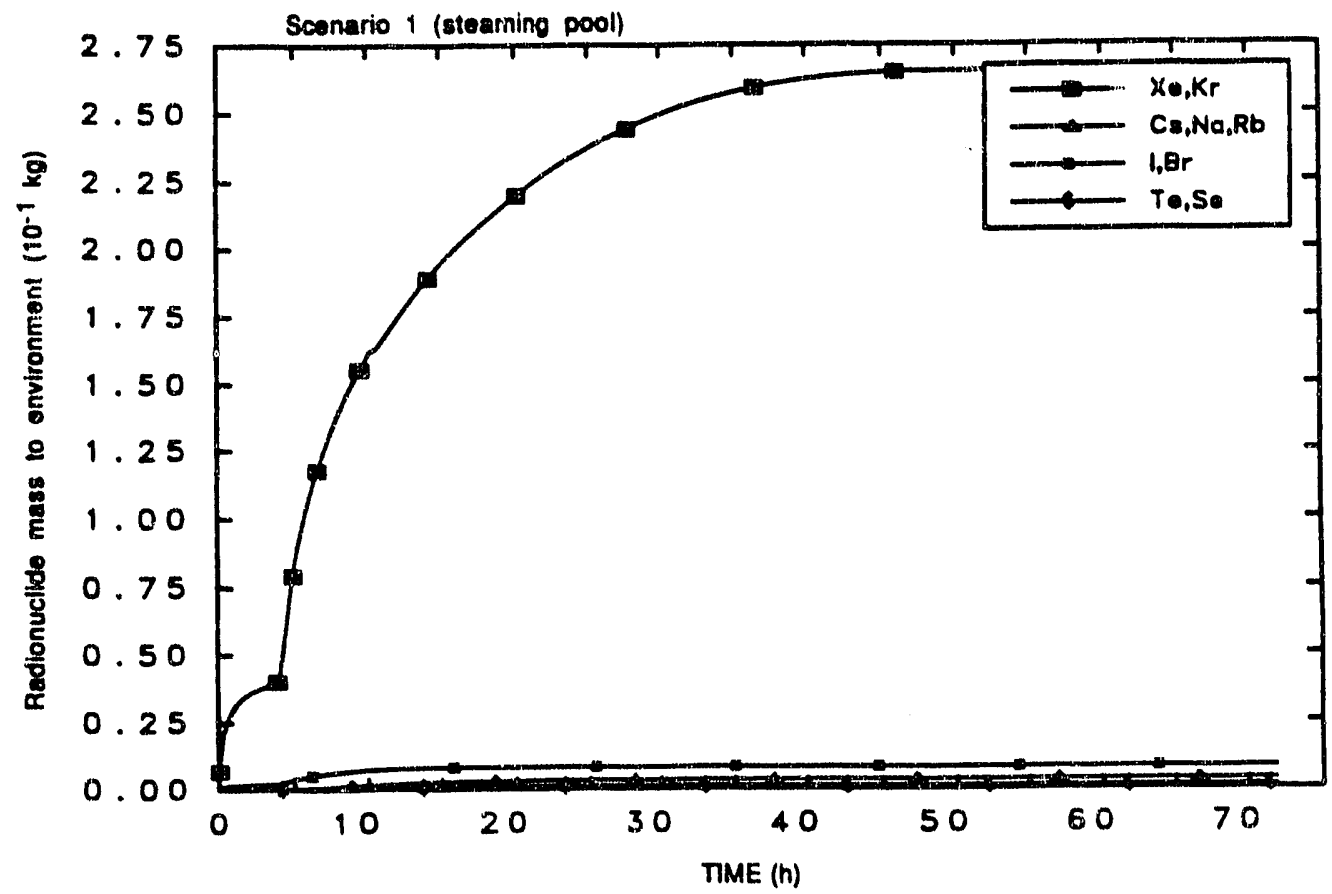

Fig. 7.1-12. Radionuclide masses entering environment with time (steaming pool case-scenario 1). 


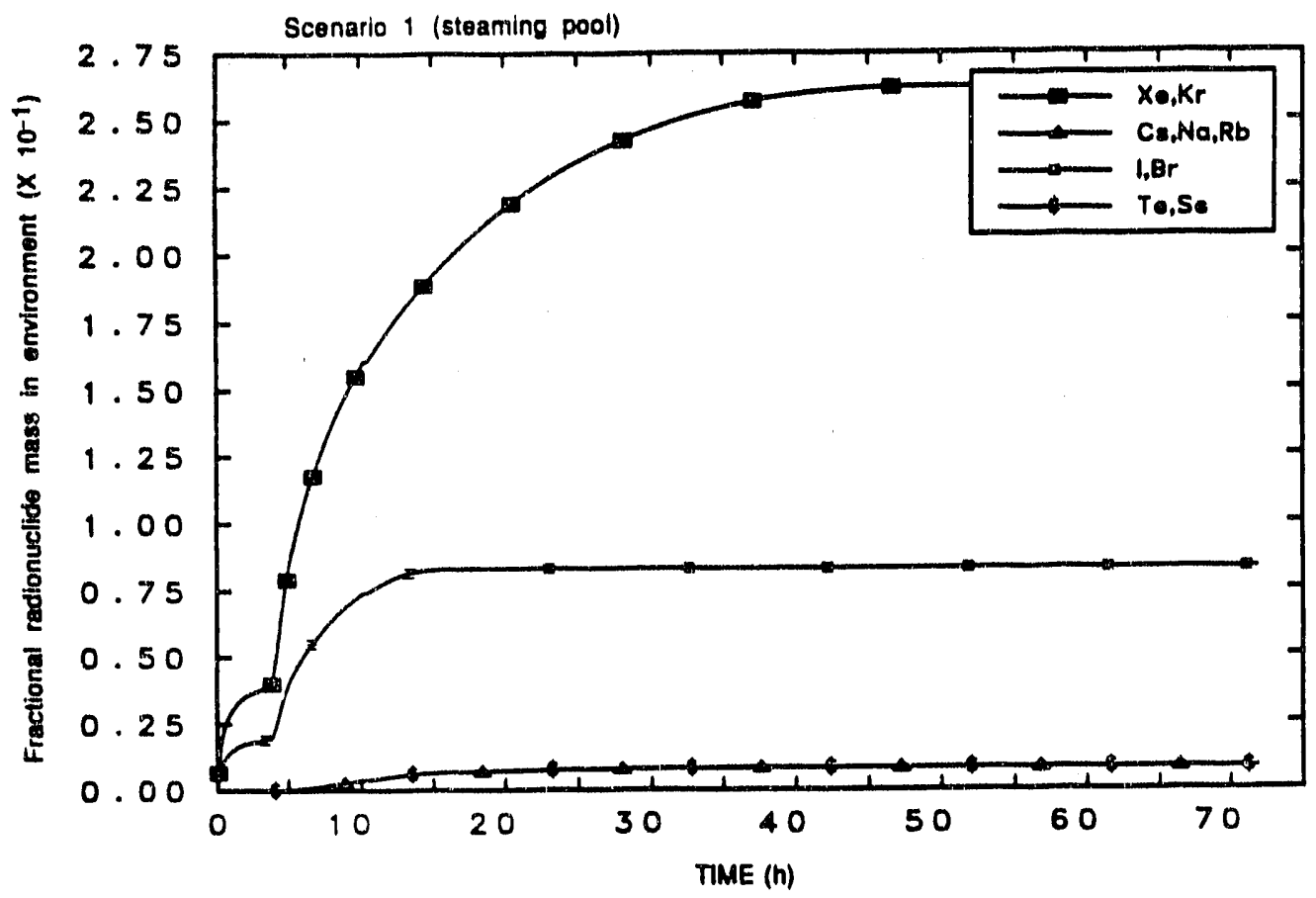

Fig. 7.1-13. Variation of core radionuclide inventory entering environment with time (steaming pool case-scenario 1).

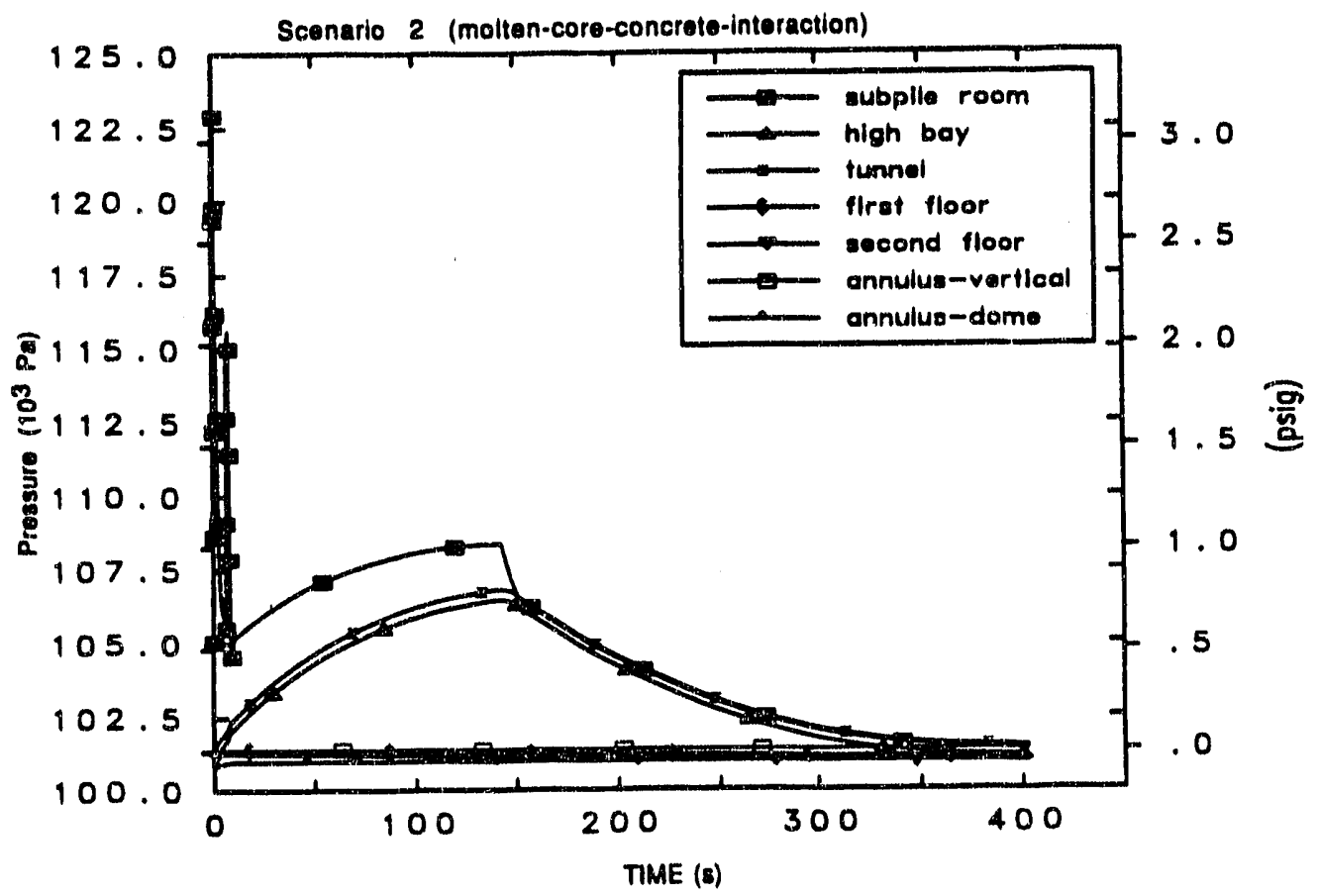

Fig. 7.1-14. Variation of control volume pressures with time (case of molten-core-concrete-interaction in subpile room-scenario 2). 
concomitantly. Pressure in the high bay area does not exceed $115 \mathrm{kPa}$ ( $2 \mathrm{psig}$ ); hence, the first and second floor volumes do not become available for pressurization and radionuclide transport. The short spike in the subpile room pressure lasts only a matter of seconds and is due in part to hydrogen and carbon monoxide deflagration, after which the oxygen content is completely depleted. Because no ventilation flow path is available (via modeling) to bring in a fresh supply of oxygen, hydrogen combustion stops. The traces of atmospheric temperature variations are shown in Fig. 7.1-15. These traces indicate cooling of the air in the subpile room due to the release of heat-producing radionuclides to the high bay area, and also due to energy absorption of structural materials. Note the decline in pressure traces about $2 \mathrm{~min}$ into the transient. This is attributed to the significant drop in the rate of $\mathrm{MCCI}$ gas generation (especially hydrogen due to completion of oxidation of aluminum).

The variation of hydrogen mole fractions in the various system volumes is shown in Fig. 7.1-16. Even though relatively high hydrogen and carbon monoxide mole fractions exist in the subpile room, it is not possible for combustion to occur due to the unavailability of oxygen as depicted graphically in Fig. 7.1-17. The mole fraction of hydrogen in other system components is close to zero.

Figures 7.1-18 and 7.1-19 show the transient variation of aerosol and vapor mass distributions within the high bay and the environment. As in scenario 1 , the amounts released to the environment level-off rapidly as driving pressure gradients approach zero.

Figure 7.1-20 shows the variation over time of the radionuclide vapor and aerosol deposition on heat structures. Note that a considerable amount of the radionuclides are likely to deposit on relatively cold structures.

Figures 7.1-21 through 7.1-23 provide the transient variation and distribution of radionuclides within the various control volumes (including the environment which constitutes the source term). About $10.5 \%$ of the noble gas inventory, $10.2 \%$ of the halogen inventory, $8.6 \%$ of the cesium class inventory, and about $8.6 \%$ of the tellurium class inventory will enter the environment over $70 \mathrm{~h}$. No radionuclides enter the first and second floor volumes. The balance of the radionuclides, based on assumptions made in the present model, remains within the containment.

\subsubsection{Off-Site Consequences}

This section describes the methodology, assumptions, modeling of various features related to radiation exposure, and health consequences resulting from source terms calculated in Sect. 7.1.1.1.

\section{Modeling Methodology Overview}

A schematic of the consequence assessment approach is presented in Fig. 7.1-24. The MACCS (Version 1.5) (Chanin et al. 1990) was used for evaluating radiological impacts. The MACCS was developed to replace the Calculation of Reactor Accident Consequences (CRAC2) Code (Ritchie et al. 1984), which was developed to estimate the consequences of severe reactor accidents for NRC's reactor safety study (NRC 1975).

The MACCS code system consists of a sequence of mathematical and statistical models that represent the radioactivity material immediately after release from containment, the movement of the material as it disperses downwind of the plant, the deposition of the radioactive material onto the ground, and the effects of the airborne and deposited material on people and their environment. The consequences estimated by 


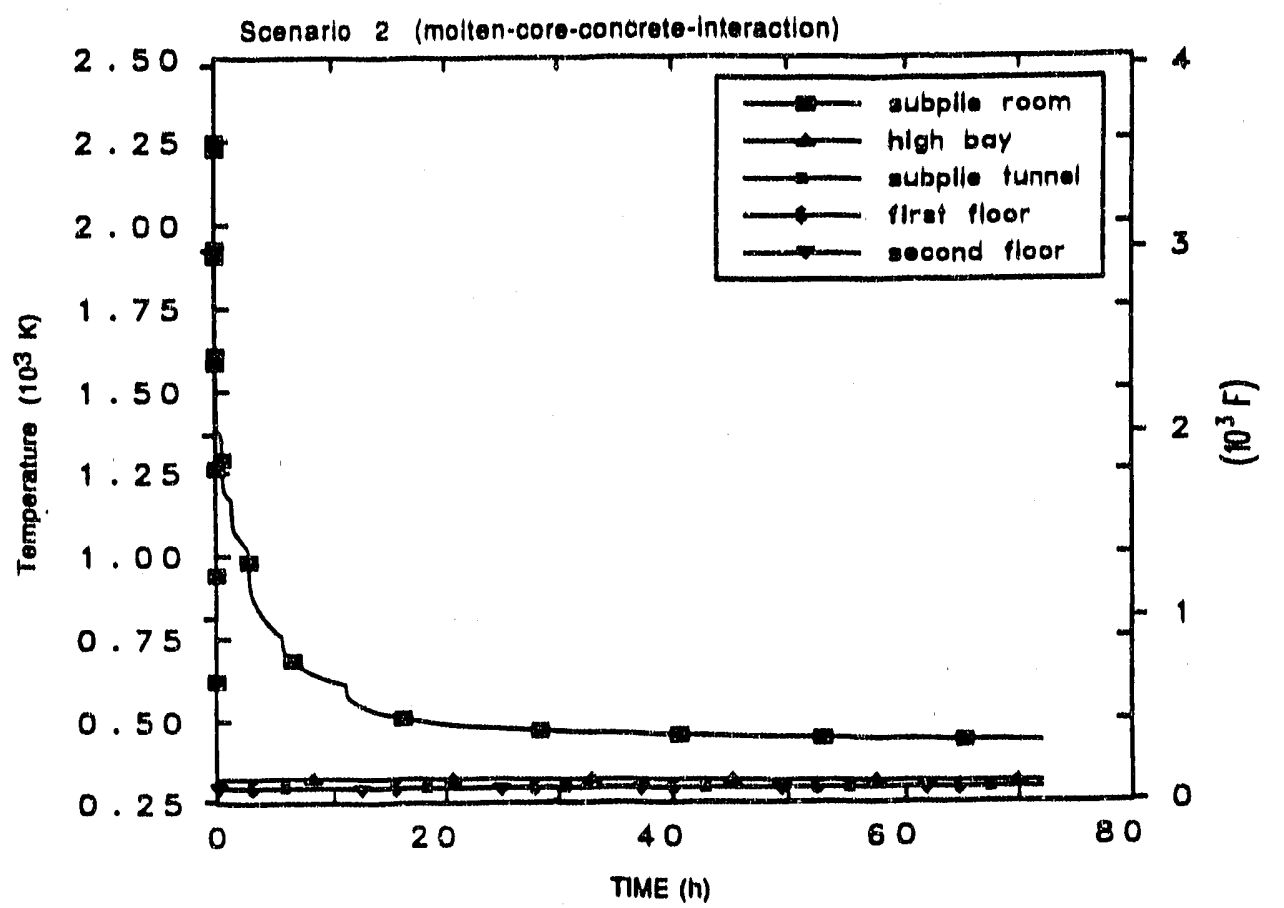

Fig. 7.1-15. Variation of control volume temperatures with time (case of molten-core-concrete-interaction in subpile room-scenario 2).

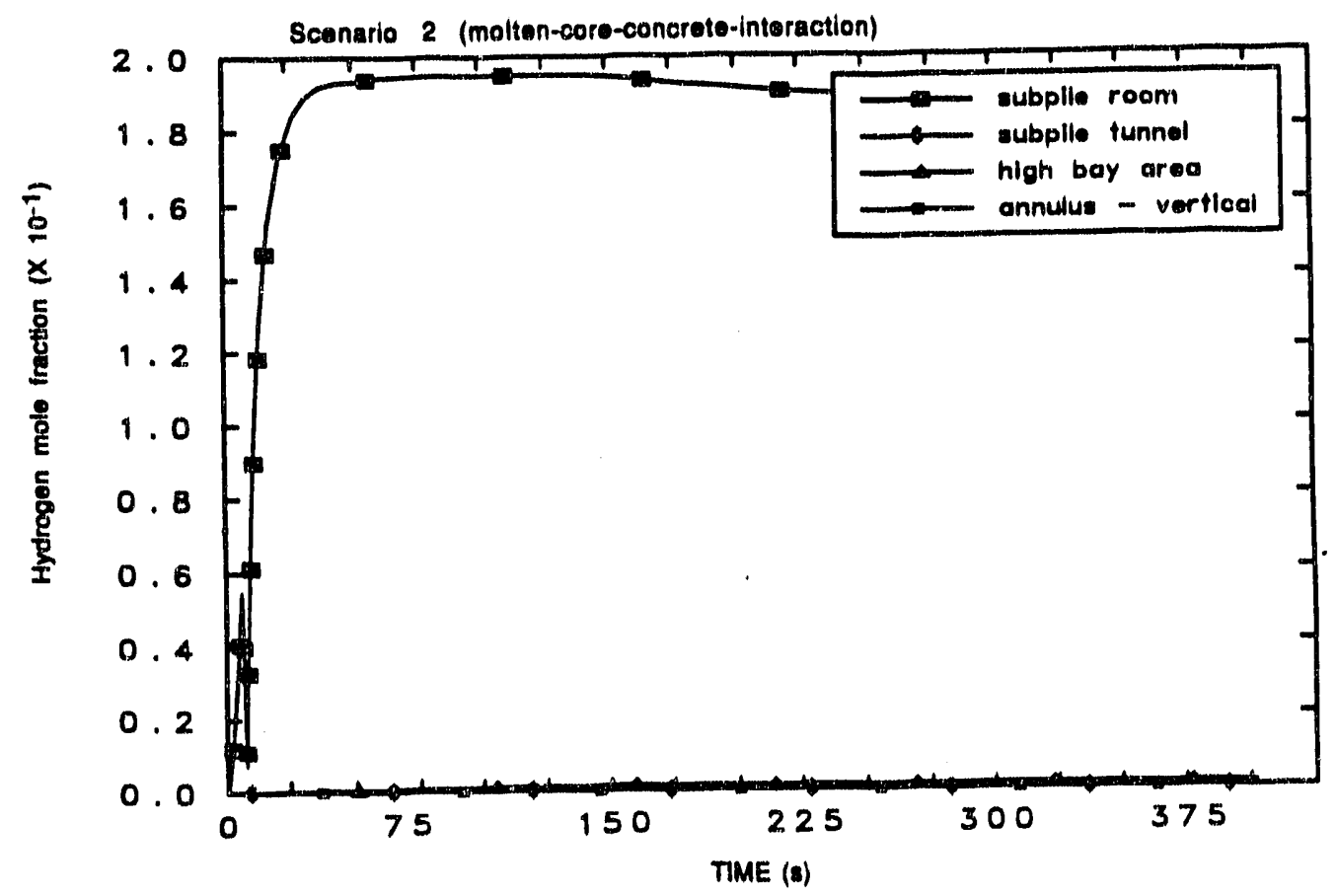

Fig. 7.1-16. Variation of hydrogen mole fractions in various control volumes (case of molten-core-concrete-interaction in subpile room-scenario 2). 


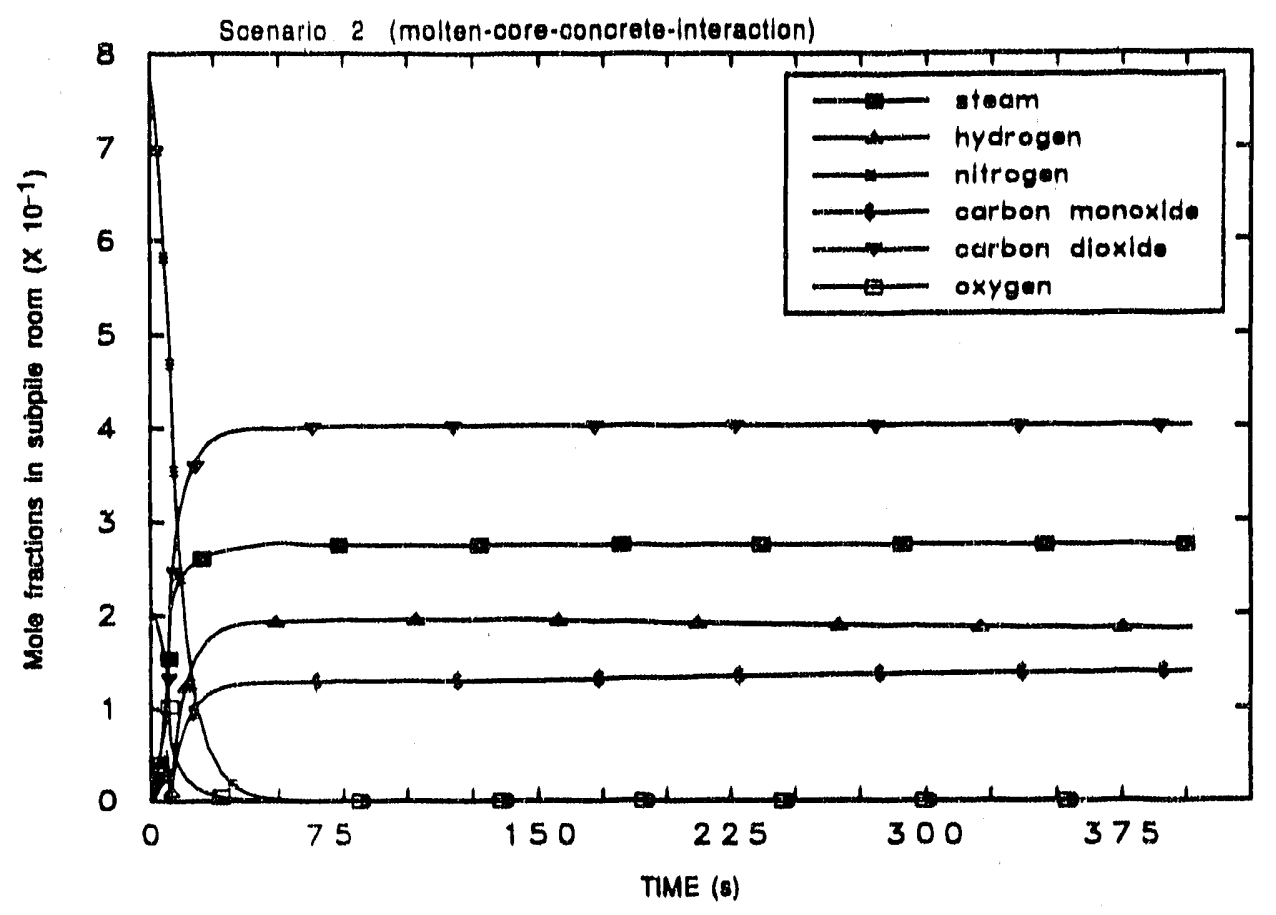

Fig. 7.1-17. Variation of various gas mole fractions in subpile room (case of molten-core-concrete-interaction in subpile room-scenario 2).

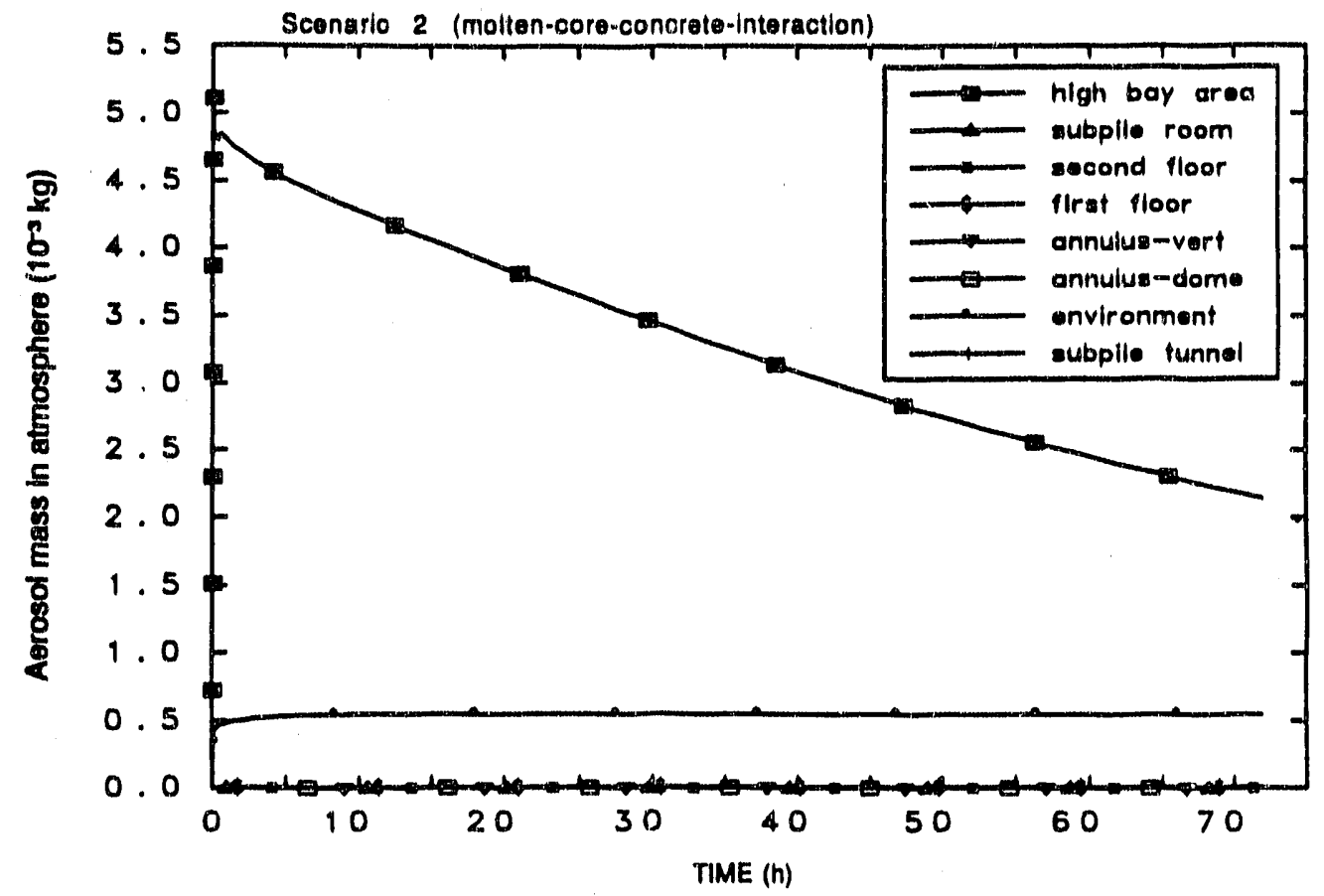

Fig. 7.1-18. Variation of total radionuclide aerosol mass in control volume atmospheres with time (case of molten-core-concrete-interaction in subpile room-scenario 2 ). 


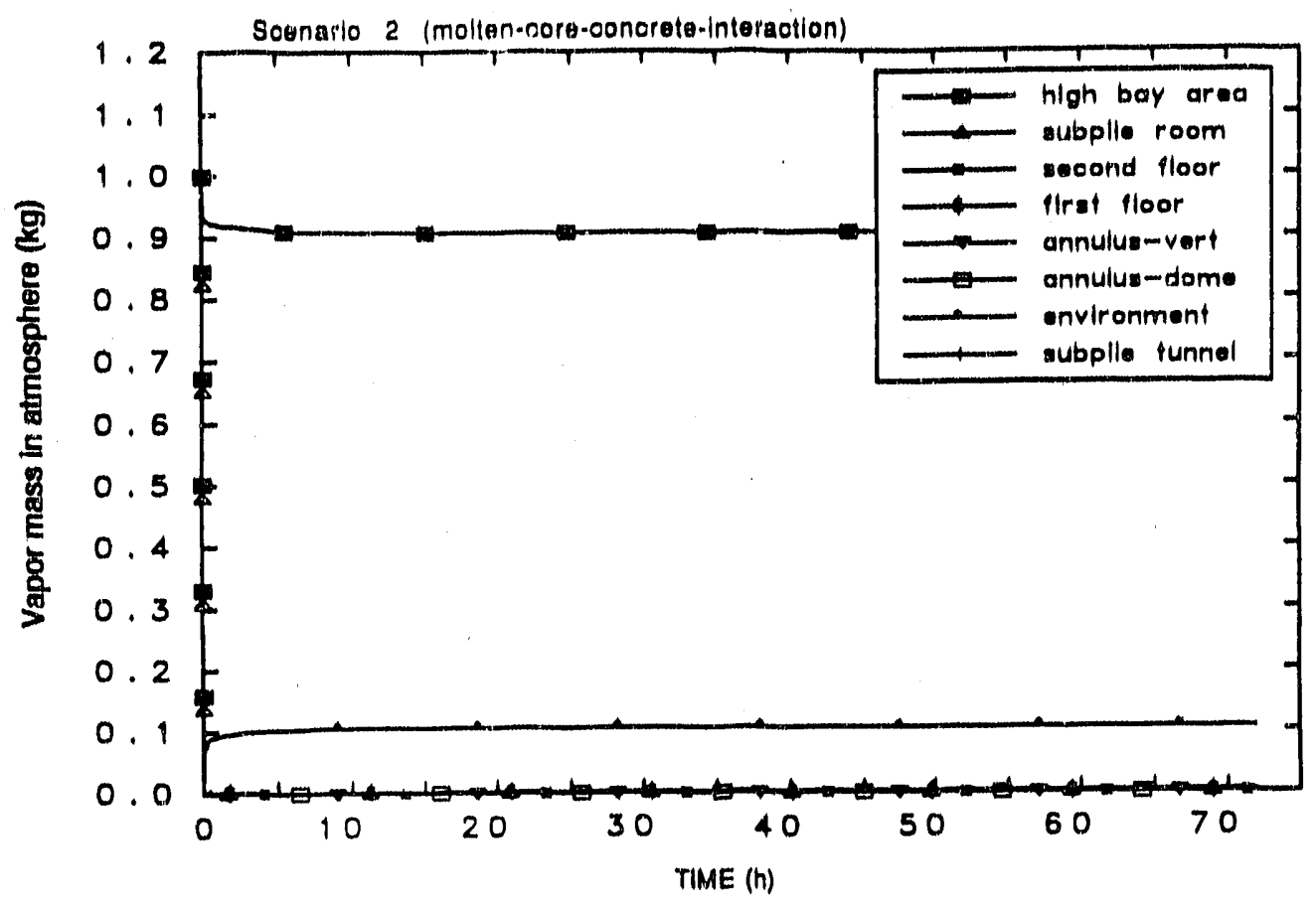

Fig. 7.1-19. Variation of total radionuclide vapor mass in control volume atmospheres with time (case of molten-core-concrete-interaction in subpile room-scenario 2).

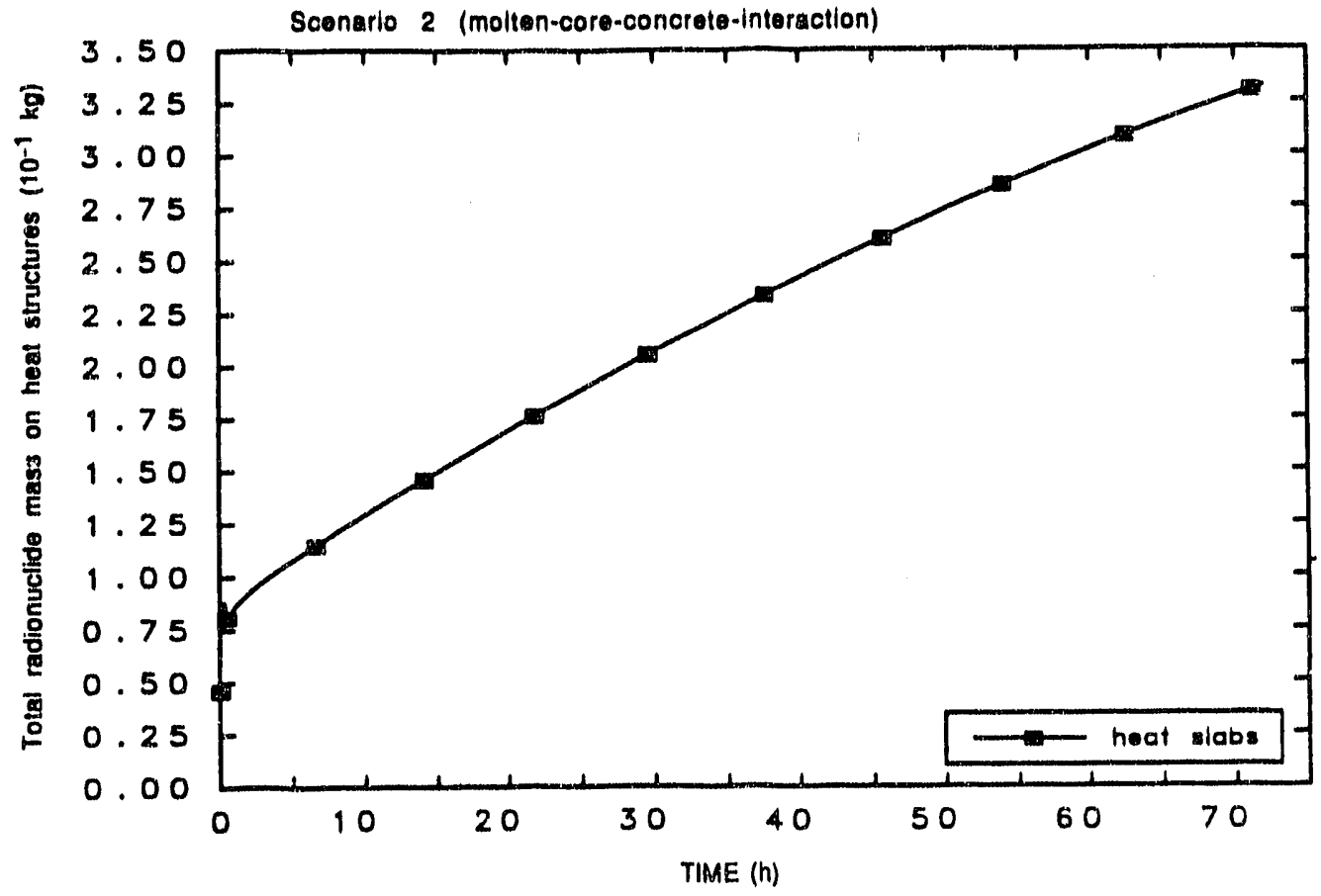

Fig. 7.1-20. Variation of total radionuclide mass deposited on heat structures with time (case of molten-core-concrete-interaction in subpile room-scenario 2). 


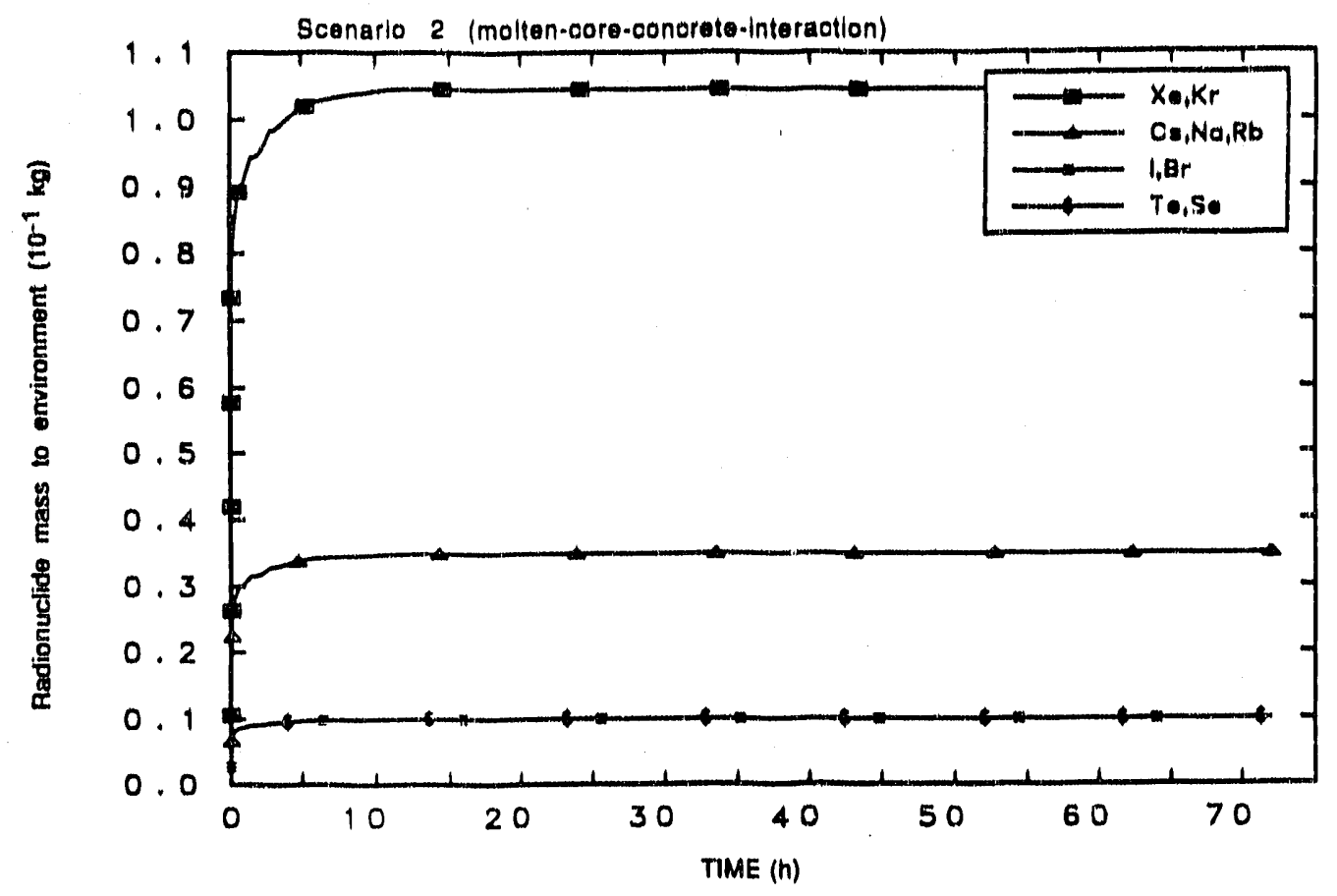

Fig. 7.1-21. Radionuclide masses entering environment with time (case of molten-core-concrete-interaction in subpile room-scenario 2).

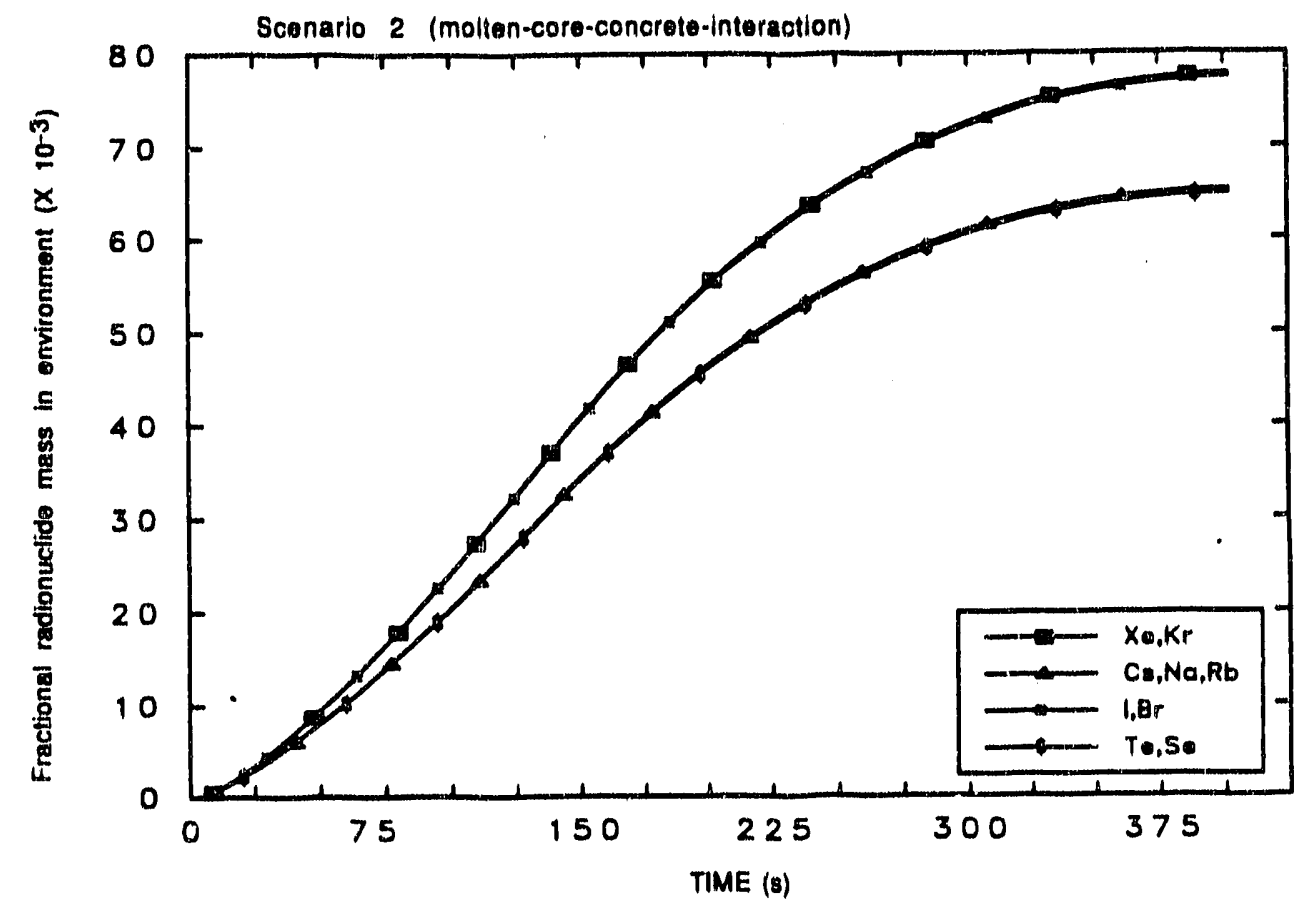

Fig. 7.1-22. Variation of fraction of core radionuclide inventory entering the environment with time over $4(1) \mathrm{s}$ (case of molten-core-concrete-interaction in subpile room-scenario 2). 


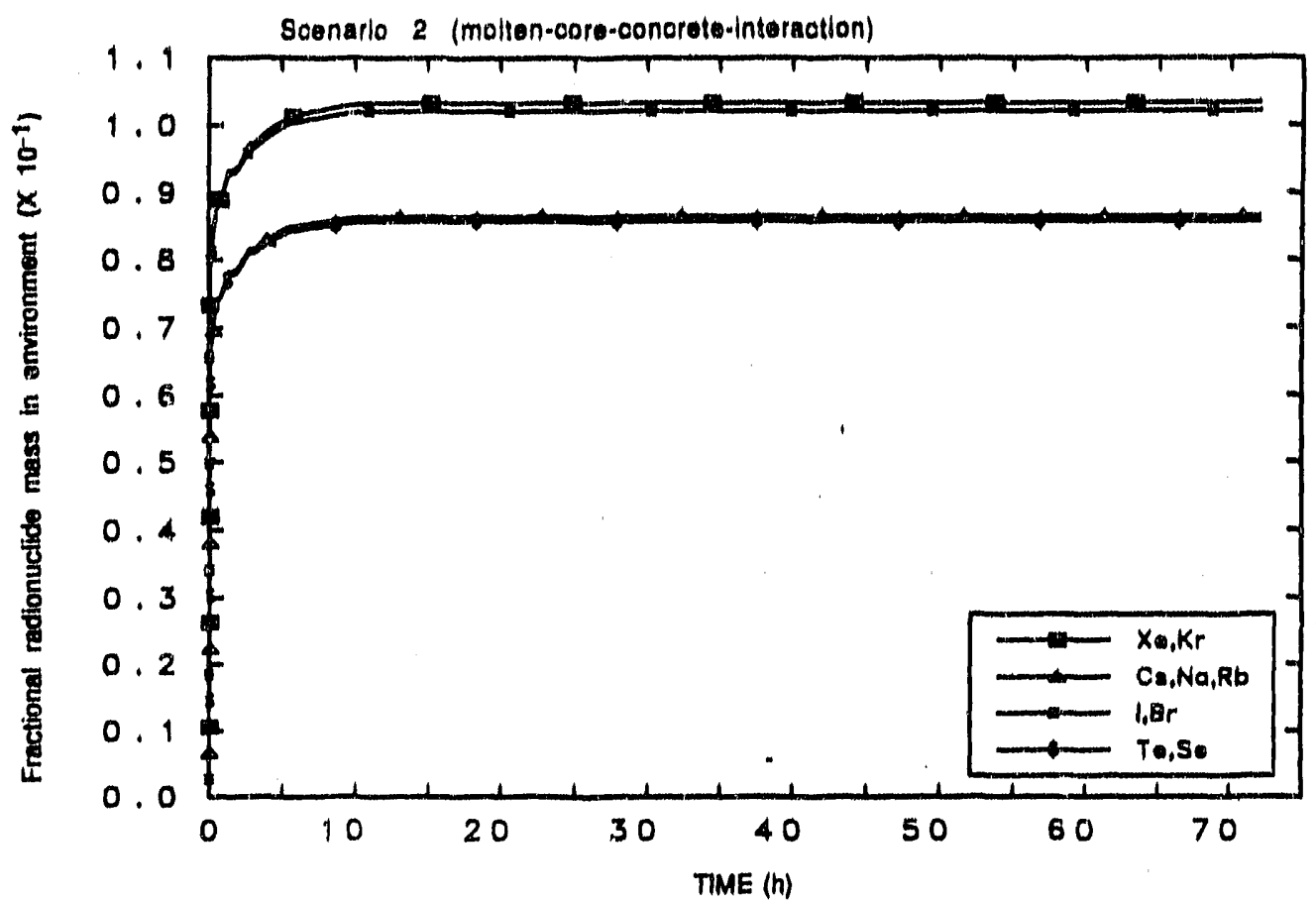

Fig. 7.1-23. Variation of fraction of core radionuclide inventory entering the environment with time over $72 \mathrm{~h}$ (case of molten-core-concrete-interaction in subpile room-scenario 2).

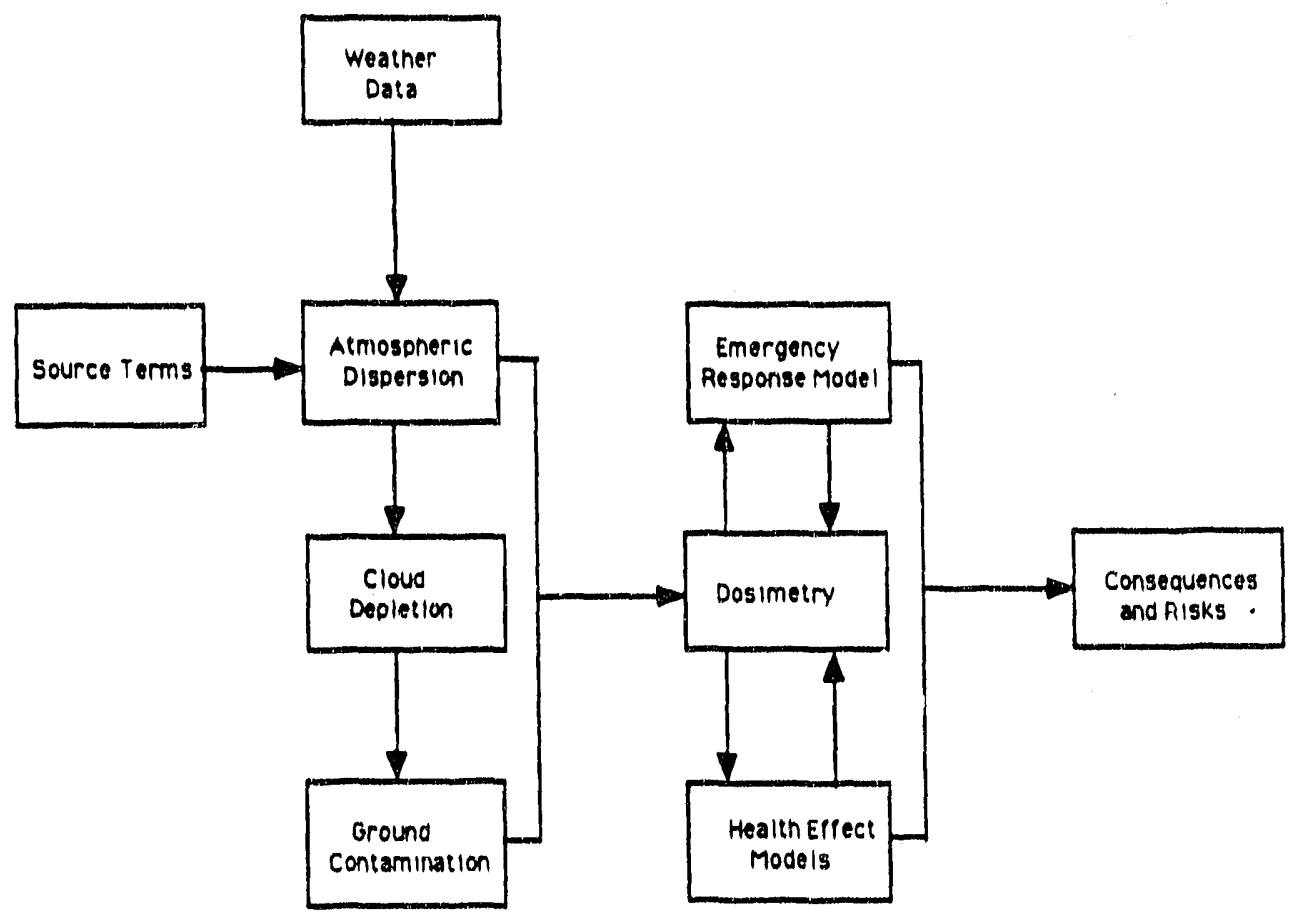

Fig. 7.1-24. Schematic representation for radiological consequence calculations. 
MACCS are: early health effects, chronic (i.e., latent) health effects, and economilc impacts.

The ANS ER will make use of the source terms presented in Sect. 7.1.1.1, and model the dispersion and deposition of radionuclides released from the reactor containment to the atmosphere will be modeled with a straight-line Gaussian plume model in MACCS. Plume rise and dry and wet deposition will be taken into account. Downwind concentrations of radionuclides up to a distance of $80 \mathrm{~km}$ ( 50 miles) will be calculated for each directional sector around ANS. Radiation doses to on-site and off-site populations will be calculated using the concentration of radionuclides predicted by the dispersion models. Exposure pathways to be considered for evaluating early consequences are (1) direct radiation from the passing plume and (2) from radioactive material deposited on the ground, and inhalation of resuspended ground contamination. Alr pathway exposures are known to be dominant contributors to the effects of a severe accident, typically more so than liquid pathways. Again, reactor coolant system (RCS) response has not been modeled for deriving source terms. Also, the severe accident scenarios postulated already embody a significant measure of conservatism. As in the modeling done for the two accident scenarios described in Sect. 7.1.1.1, RCS liquid pathways would not lead to radionuclide transport to the environment and subsequently to people. Hence, radiological consequences arising from RCS liquid pathways have not been explicitly modeled. For assessing the long-term impact of water pathways in general (i.e., from rain, rivers, lakes), the MACCS clefiault values (generated for NUREG-1150) have been suitably modified to represent the environment around ANS.

In evaluating porential radiation doses, emergency response actions play an important role. Short- and long-term actions such as evacuation, sheltering, and relocation need to be considered. A description of the overall modeling approach is given in the following section, and emergency response modeling in particular is described in assumptions 10 through 12 .

\section{MACCS Model and Assumptions}

The proposed ANS site was chosen as the center of a polar grid. The grid was divided into 16 equally spaced sectors, with the outermost radius extending to $80 \mathrm{~km}$ (50 miles). Population data for the various sectors were also developed. A summary of population data around the ANS site is given in Table 7.1-3. A straight-line Gaussian plume model was used, and several modeling assumptions were made as follows:

1. The ANS site and its surroundings are adequately represented by a polar grid consisting of 16 sectors (a fixed value built into MACCS). Each sector is further divided into 13 elements to account for the site-specific population distribution. ANS is located at the center of the system, and each element assumes average conditions (i.e., for population, rainfall, wind speed and direction, radionuclide concentration, etc.) in that spatial region.

2. To ensure conservatism, shielding effects of the ANS containment and buildings are not accounted for. All individuals at the ANS site and within the first four rings receive no shelter unless they relocate to the sheltering zone at ORNL. However, for the first ring, it is assumed that all the individuals (on the ANS site) are uniformly distributed over the 16 elements of the first ring, and not consciously positioned in the most unfavorable direction. While this approach may sound nonconservative, the effect is partially nullified through random sampling of the actual weather pattern over the course of 1 year. 
Table 7.1-3. Population distribution around the Advanced Neutron Source

\begin{tabular}{|c|c|c|c|}
\hline Ring & $\begin{array}{c}\text { Distance } \\
{[\mathrm{km} \text { (miles) }]}\end{array}$ & Population & Notes \\
\hline 1 & $0.0-0.177(0.0-0.11)$ & 240 & $\begin{array}{l}\text { Advanced } \\
\text { Neutron Source } \\
\text { site boundary } \\
\text { fence }\end{array}$ \\
\hline 2 & $0.177-1.0(0.11-0.62)$ & 0 & $\begin{array}{l}\text { Exclusion Area } \\
\text { Boundary to } \\
1.6 \mathrm{~km} \text { (1 mile) } \\
\text { (includes High } \\
\text { Flux Isotope } \\
\text { Reactor) }\end{array}$ \\
\hline 3 & $1.0-1.6(0.62-1.0)$ & 285 & \\
\hline 4 & $1.6-2.0(1.0-1.25)$ & 200 & $\begin{array}{l}\text { Low Population } \\
\text { Zone to } 2 \mathrm{~km} \\
\text { (1.25 miles) }\end{array}$ \\
\hline 5 & $2.0-3.22(1.25-2.0)$ & 4,413 & $\begin{array}{l}\text { Immediate } \\
\text { Notification Zone } \\
\text { to } 3.22 \mathrm{~km} \\
(2 \text { miles); Oak } \\
\text { Ridge National } \\
\text { Laboratory }\end{array}$ \\
\hline 6 & $3.22-4.82(2.0-3.0)$ & 249 & \\
\hline 7 & $4.82-6.44(3.0-4.0)$ & 960 & \\
\hline 8 & $6.44-8.05(4.0-5.0)$ & 3,108 & $\begin{array}{l}\text { Emergency } \\
\text { Planning Zone to } \\
8.05 \mathrm{~km} \text { ( } 5 \text { miles) }\end{array}$ \\
\hline 9 & $8.05-16.09(5.0-10.0)$ & 68,024 & \\
\hline 10 & $16.09-32.19(10.0-20.0)$ & 214,968 & \\
\hline 11 & $32.19-48.28(20.0-30.0)$ & 320,844 & \\
\hline 12 & $48.28-64.37(30.0-40.0)$ & $164,37 \%$ & \\
\hline \multirow[t]{2}{*}{13} & $64.37-80.47(40.0-50.0)$ & 160,832 & \\
\hline & Total population & 938,500 & \\
\hline
\end{tabular}

Source: Personal communication from S. Cotter, Office of Environmental and Health Protection, ORNL, to R. Taleyarkhan, ORNL, Oct. 29, 1991. 
3. Source terms used for MACCS calculations are derived from the previously mentioned ORIGEN2 and MELCOR evaluations. ORIGEN2 calculations for EOC inventory of radionuclides are used (l.e., for conservatism because fission product buildup is greatest at EOC conditions) in conjunction with source term information for varlous scenarios. In addition, MELCOR calculations are also used to specify the energy content of the generated plumes.

4. Source terms from various accident scenarios are released at ground level. Such a prescription provides for the maximum possible contact with the radioactive cloud before dispersion begins and, as such, stipulates conservative initial conditions that might exist for certain accident scenarios.

5. Building wake effects are taken into account. Reactor bullding dimensions are specifled to have a width of $65.84 \mathrm{~m} \cdot(220 \mathrm{ft})$ and height of $15.85 \mathrm{~m}(52 \mathrm{ft})$ above ground level.

6. Due to a limitation of MACCS, no credit is taken for ridges and hills surrounding the ANS site that might block motion of the plume to off-site populated areas. Ridges and hills can also cause greater deposition of aerosol particulates; therefore, assuming a flat terrain is conservative. However, it should be noted that the meteorological data used for dispersion calculations have the effect of surrounding terrain implicitly built into them.

7. Weather data (hourly wind speed, wind direction, and atmospheric stability) taken at the High Flux Isotope Reactor (HFIR) site tower at 30-m (100-ft) elevation are assumed to be representative for the ANS site. This assumption is considered reasonable because the ANS site is located in the general vicinity of HFIR, with no intervening hills or ridges. The best available data for rainfall and mixing height are used. Rainfall data for the ANS site are assumed to be the same as that for Oak Ridge. Mixing height data (for morning and afternoon) recommended by the National Climatic Center in Asheville, North Carolina, are considered representative for the ANS site and surrounding terrain. A weather file consisting of 24 samples per day for $365 \mathrm{~d}$ of meteorological information is considered adequate, in conjunction with stratified random sampling of four samples per day (therefore, $365 \times 4=1460$ samples that are evaluated for atmospheric dispersion calculations).

8. Beyond $16 \mathrm{~km}$ (10 miles) of the ANS reactor, boundary weather conditions are applied such that the mixing height is conservatively specified as being at the lowest level from the yearly meteorological database information supplied by the National Climatic Center in Asheville, North Carolina. Because actual data are not available for locations beyond $16 \mathrm{~km}$ (10 miles), we have conservatively assumed neutral stability conditions combined with the specification of no precipitation and a low constant wind speed of $0.5 \mathrm{~m} / \mathrm{s}(1.12 \mathrm{mph})$.

9. The plume is defined as consisting of multiple sections (i.e., in time) based upon guidance received from the source term transient variation predicted from MELCOR calculations.

10. An evacuation alarm is assumed to sound 10 min after occurrence of a severe accident. Individuals within the first four rings of each sector [i.e., within $2 \mathrm{~km}$ (1.25 miles)] are assumed to start evacuating after a 35 -min delay time. The 35-min time frame consists of two components. The first component of $30 \mathrm{~min}$ represents the mean time associated with general emergency conditions, warning of the employees, and visitor evacuation. This assumption is a standard that has been used previously for similar studies in support of the New Production Reactor (NPR) draft Environmental Impact Statement (EIS) (DOE 1991, p. 15). The 
second 5 min component represents a reasonable delay time between warnings to evacuate, and the time people actually start to evacuate.

11. Individuals evacuating from the first four rings of the grid move at a rate of $10 \mathrm{~m} / \mathrm{s}$ $(23 \mathrm{mph})$ to the $X_{1} 10$ Site for sheltering. Upon reaching the $X^{\prime} 10$ Site, evacuees are assumed to take an additional $5 \mathrm{~min}$ to take shelter. They remain sheltered for at least $1 \mathrm{~h}$. Upon passage of the plume, these shelterees return to their original locations at the end of the emergency phase, which is assurned to last for $7 \mathrm{~d}$. Again, this assumption is a standard that has been used for similar studies in support of the NPR draft EIS (DOE 1991, p. 15).

12. Relocation of individuals residing outside of the Immediate Notification Zone is allowed in one of two ways, hot spot relocation and normal relocation. Hot spot relocation occurs if the effective whole-body dose equivalent to an individual exceeds $0.5 \mathrm{~Sv}$ (50 rem) in the 1-week emergency phase. Thereafter, individuals in that ring are relocated $30 \mathrm{~min}$ after arrival of the first pluine. Relocated individuals receive no further dosage during the emergency phase. Normal relocation is activated if the effective whole-body dose equivalent exceeds $0.25 \mathrm{~Sv}$ (25 rem) in the 1 week emergency phase. Thereafter, individuals in that ring are relocated $1 \mathrm{~h}$ after the arrival of the first plume at that distance. Individuals relocated receive no further dosage during the emergency phase. These assumptions are based upon guidance given from default values suggested in MACCS (which were also utilized for the NUREG-1150 studies).

13. The breathing rate of individuals is conservatively assumed to be constant and equal to the MACCS default value of $2.66 \times 10^{-4} \mathrm{~m}^{1} / \mathrm{s}\left(9.4 \times 10^{-3} \mathrm{ft}^{3} / \mathrm{s}\right)$, which is an averaged value close to the upper limit of $3.1 \times 10^{-4} \mathrm{~m}^{3} / \mathrm{s}\left(1.1 \times 10^{2} \mathrm{ft}^{3} / \mathrm{s}\right)$, as suggested by NRC Regulatory Guides.

14. Other parameters that enter the calculational process, such as protection factors for inhalation or skin exposure, resuspension, cloud and other shielding factors, and specific input required for deriving chronic (l.e., latent) effects are assumed to be the default values recommended in the MACCS User's Guide (Chanin 1990, pp. 1-260).

\section{Radiological Consequence Results}

The radiological consequences arising from source terms described earlier in Sect. 7.1.1.1 for scenarios 1 and 2 are presented in this section. Tables 7.1-4 through 7.1-7 summarize key results of mean value estimates in various categories. Results are also presented conventionally as Complementary Cumulative Distribution Functions (CCDFs). CCDFs sl.ow the probability that the severity of the event will be greater than any given value of Severity Index (X). These values are shown in Figs. 7.1-25 through 7.1-30.

Table 7.1-4 presents mean cumulative values for prompt and latent cancer fatality . estimates as a function of distance from the ANS site. As can be seen, the values for prompt fatality estimates are a small fraction of the total number of individuals expected to be on-site, even for the $\mathrm{MCCI}$ case (scenario 2), considering that 240 individuals are assumed to be within the ANS site boundary [i.e., within a radius of $0.17 \mathrm{~km}(0.11$ miles)]. This can be attributed to the weather patterns at the ANS site, and to the fact that it is unlikely that all 240 individuals would be directly in the pathway of the plume. As noted, the MCCI case provides for greater fatalities than the steaming pool case (scenario 1). In scenario 1, no prompt fatalities are predicted. For scenario 1, several hours would elapse before the release of any significant amounts of radioactivity to the environment, leaving 
Table 7.1-4. Mean values for estimates of prompt fatalities and latent cancer fatalities and injuries

\begin{tabular}{cccc}
\hline $\begin{array}{c}\text { Distance } \\
{[\mathrm{km} \text { (miles) }]}\end{array}$ & Prompt fatalities & Cancer fatalities & Cancer injuries" \\
\hline $0-1.0(0-0.62)$ & 0.00 & 1.24 & \\
$0-2.0(0-1.25)$ & 0.00 & 1.31 & 6.26 \\
$0-3.2(0-2)$ & 0.00 & 1.42 & 6.54 \\
$0-8.0(0-5)$ & 0.00 & 1.61 & 6.89 \\
$0-80.0(0-50)$ & 0.00 & 8.92 & 7.99 \\
& & 5 & 62.70 \\
$0-1.0(0-0.62)$ & 5.16 & 16.10 & \\
$0-2.0(0-1.25)$ & 5.16 & 16.90 & 89.70 \\
$0-3.2(0-2)$ & 5.16 & 17.40 & 94.40 \\
$0-8.0(0-5)$ & 5.16 & 17.90 & 96.80 \\
$0-80.0(0-50)$ & 5.16 & 40.00 & 98.80 \\
\hline
\end{tabular}

"Cancer injuries imply cancer of the stomach, lungs, thyroid, and skin.

sufficient time for evacuation and sheltering of all individuals on the ANS site and within the three neighboring rings. Cancer deaths and injuries would also be much smaller for scenario 1.

Table 7.1.5 presents a summary of the total number of individuals expected to receive radiation doses in excess of various levels, and Table 7.1-6 gives a breakdown of the total and individual doses to various body organs for the two scenarios. As expected, scenario 2 has the potential to cause greater damage than scenario 1. Individual doses to the thyroid and whole body would be expected to exceed annual permissible exposure limits for employees close to the ANS site.

Table 7.1-7 presents a summary of average individual risk (prompt and latent) from the two scenarios, assuming $100 \%$ frequency of occurrence (i.e., MACCS-evaluated risk values for scenarios 1 and 2 ) and accounting for the frequency of occurrence of the two scenarios (i.e., effective fatality risk) for various rings in the polar grid. In MACCS, risk for individuals in a sector is evaluated as a function of health consequences (as reported in Table 7.1-4) and the fraction of that population that is susceptible to radionuclide exposiue. Average individual risk over a certain distance (as in Table 7.1-7) is the individual risk averaged over all 16 sectors in that region. As expected, scenario 2 dominates risk of prompt and latent cancer fatalities (LCFs). 


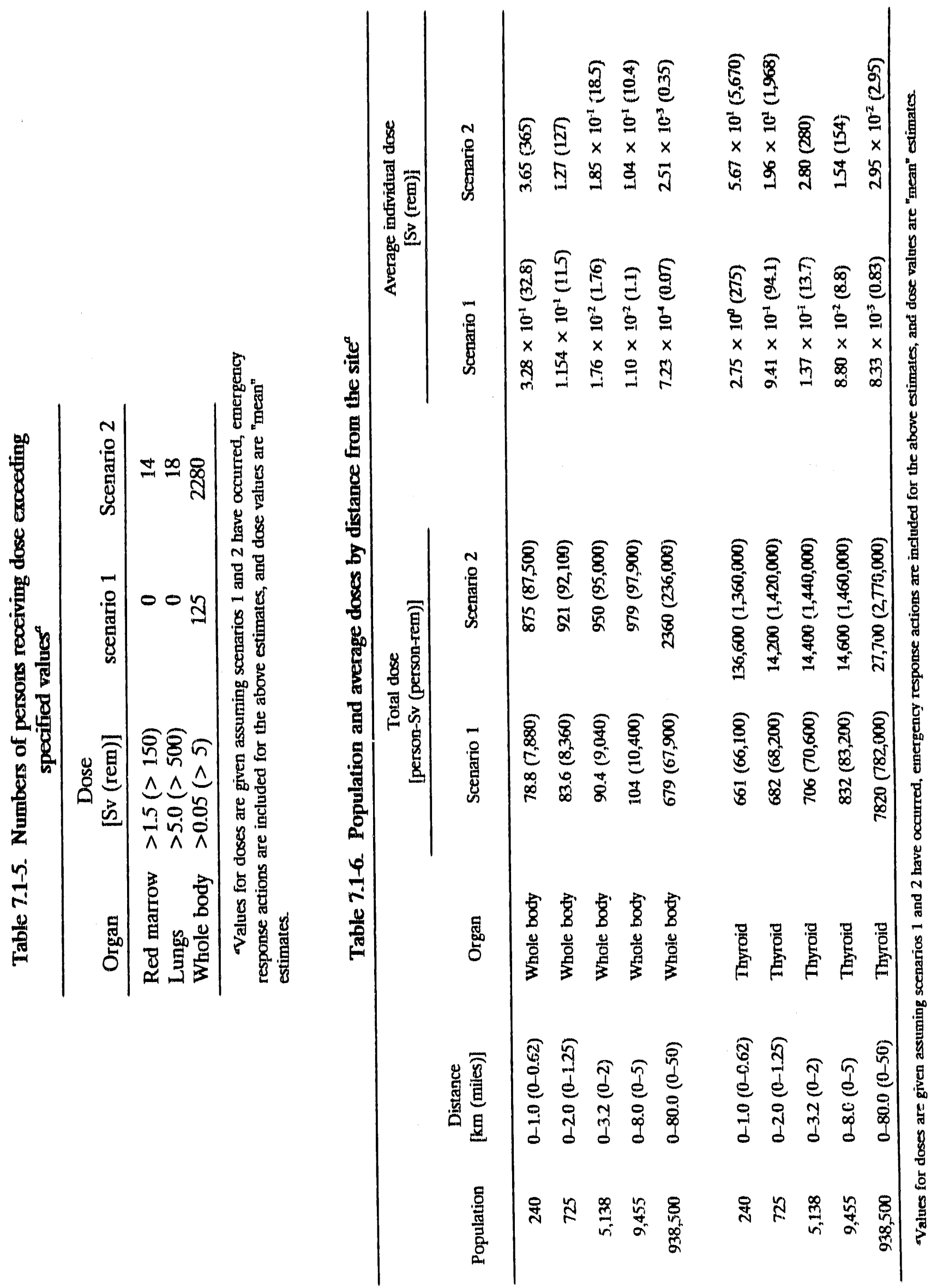




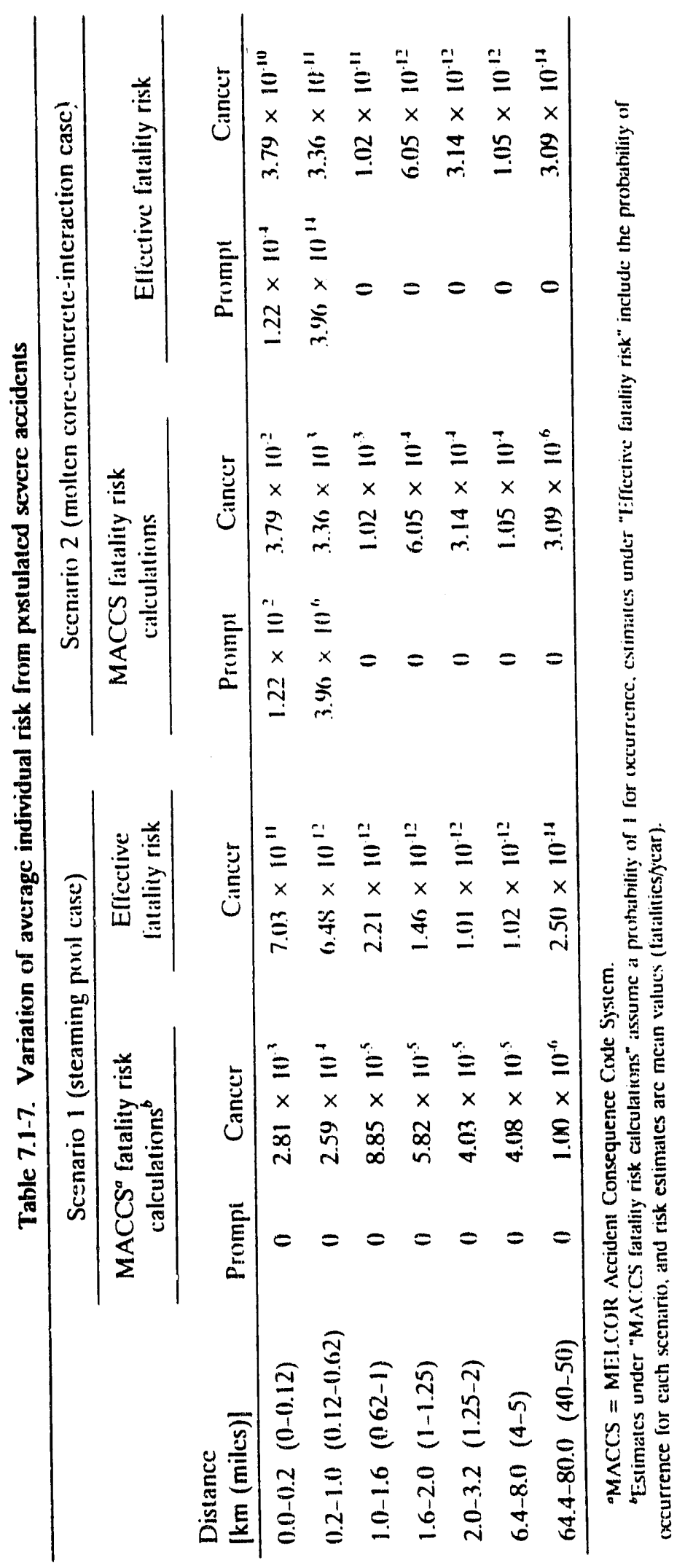




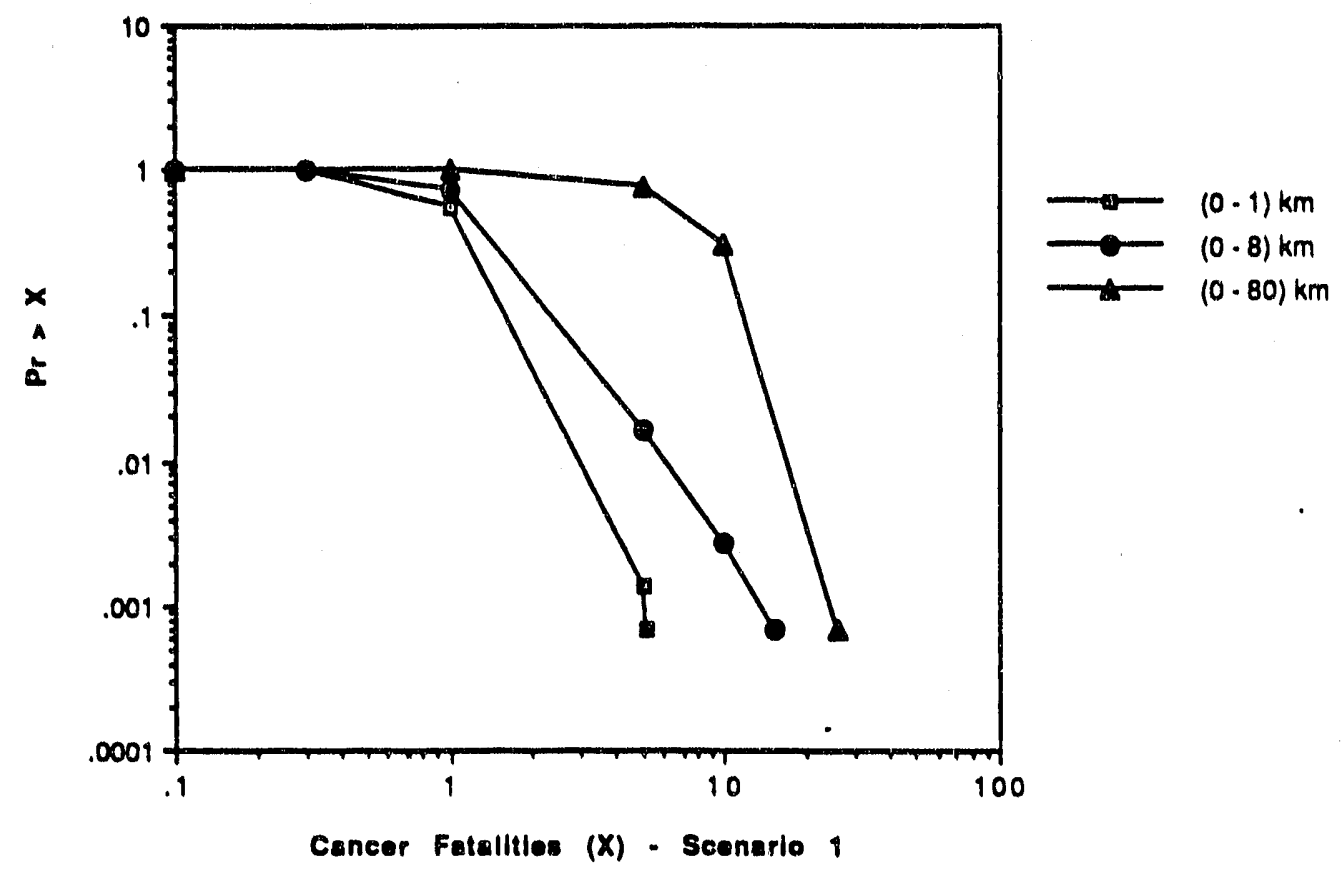

Fig. 7.1-25. Cumulative complementary distribution functions for cancer fatality estimates from scenario 1.

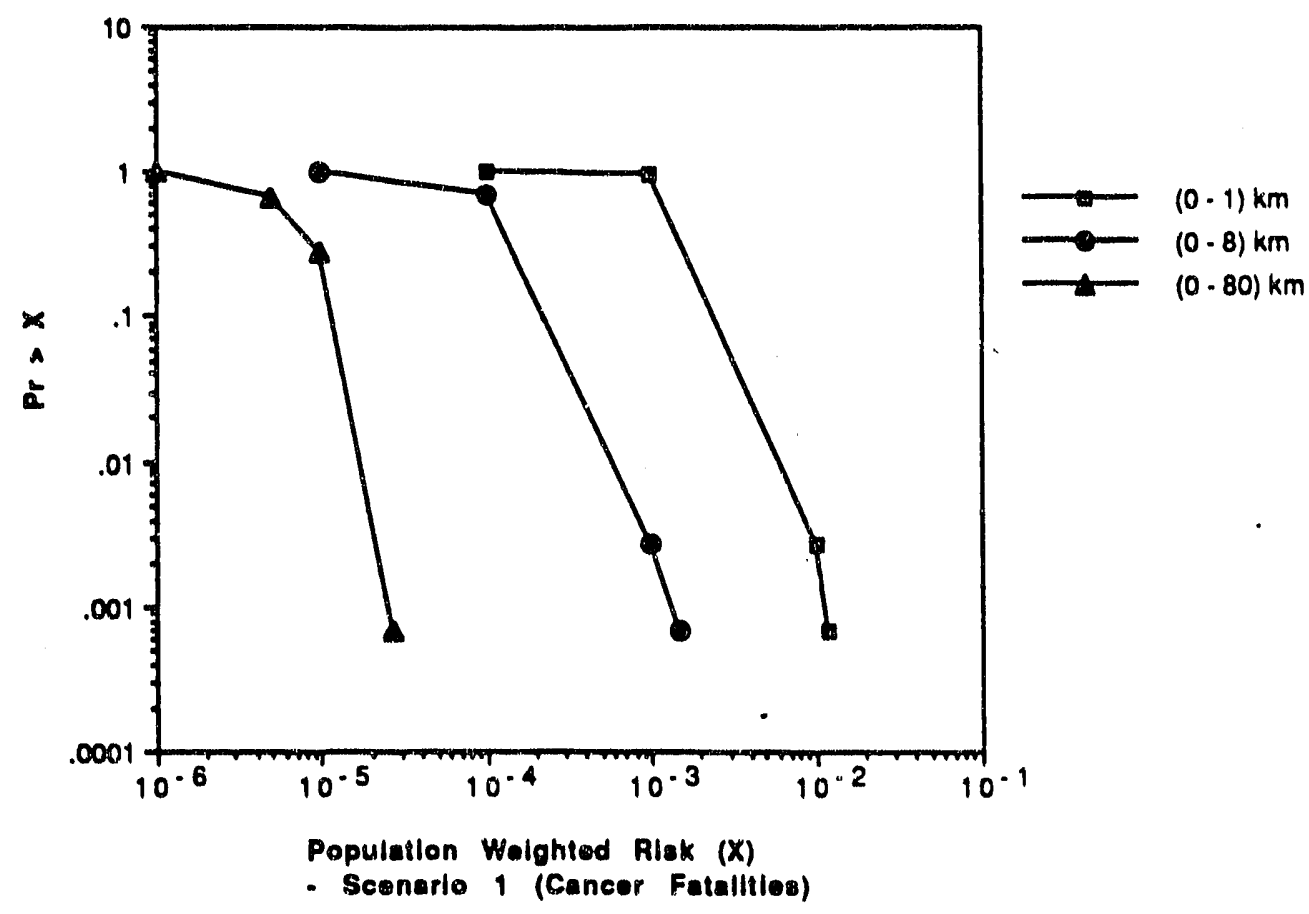

Fig. 7.1-26. Cumulative complementary distribution functions of populationweighted risk for cancer fatality estimates from scenario 1 (MELCOR Accident Conseguence Code System calculations). 


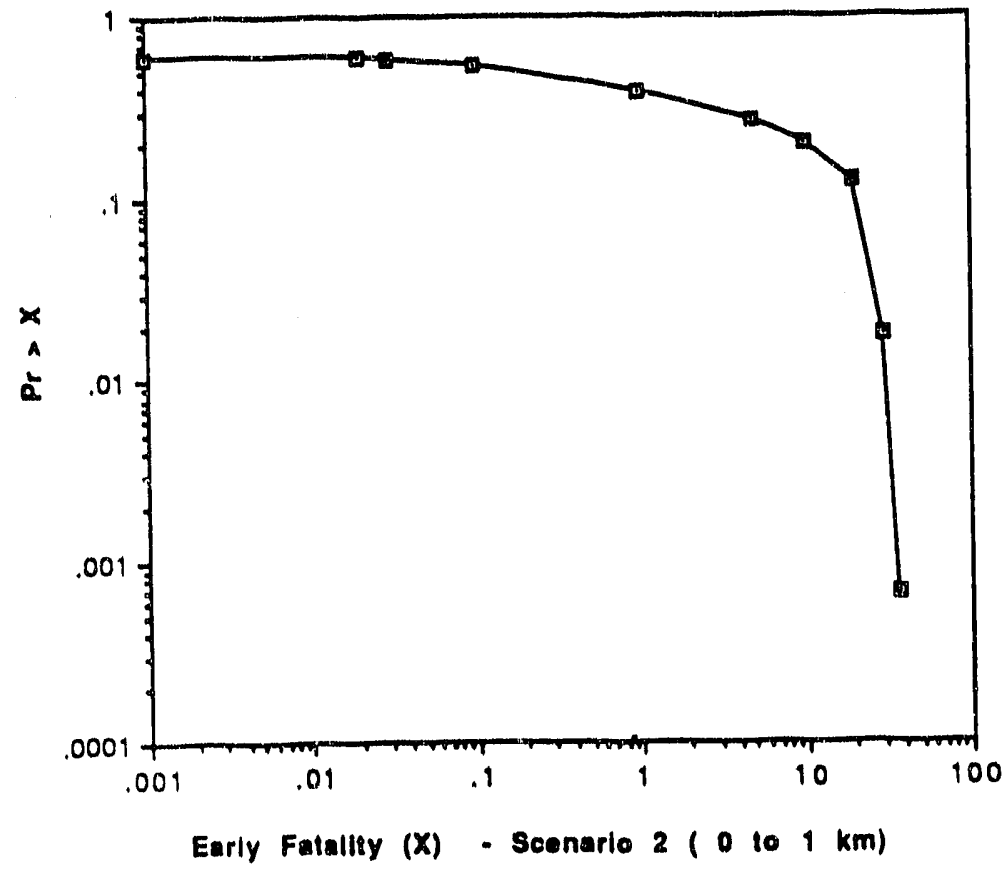

Fig. 7.1-27. Cumulative complementary distribution functions for early fatality estimates from scenario 2

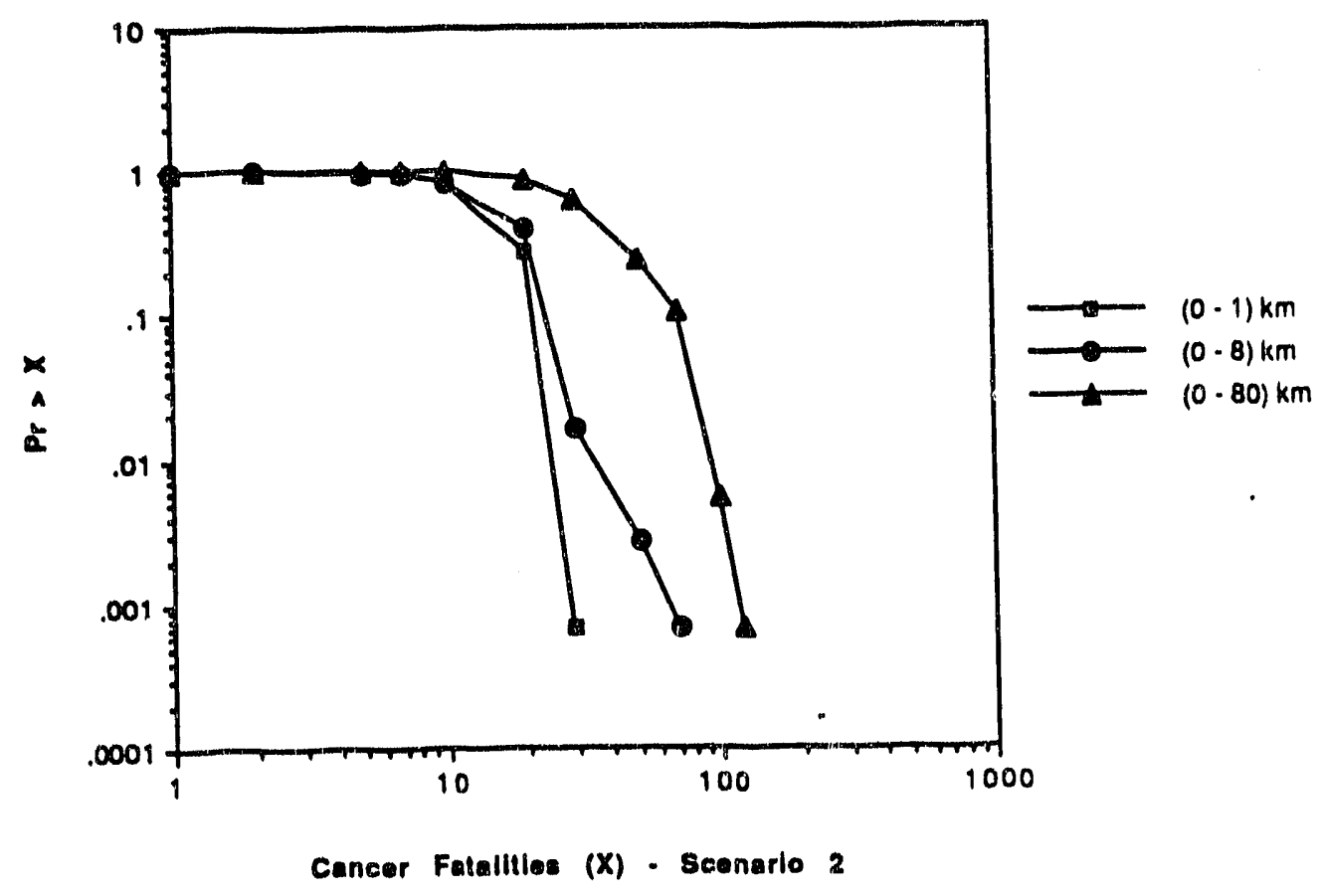

Fig. 7.1-28. Cumulative complementary distribution functions for cancer fatality estimates from scenario 2. 


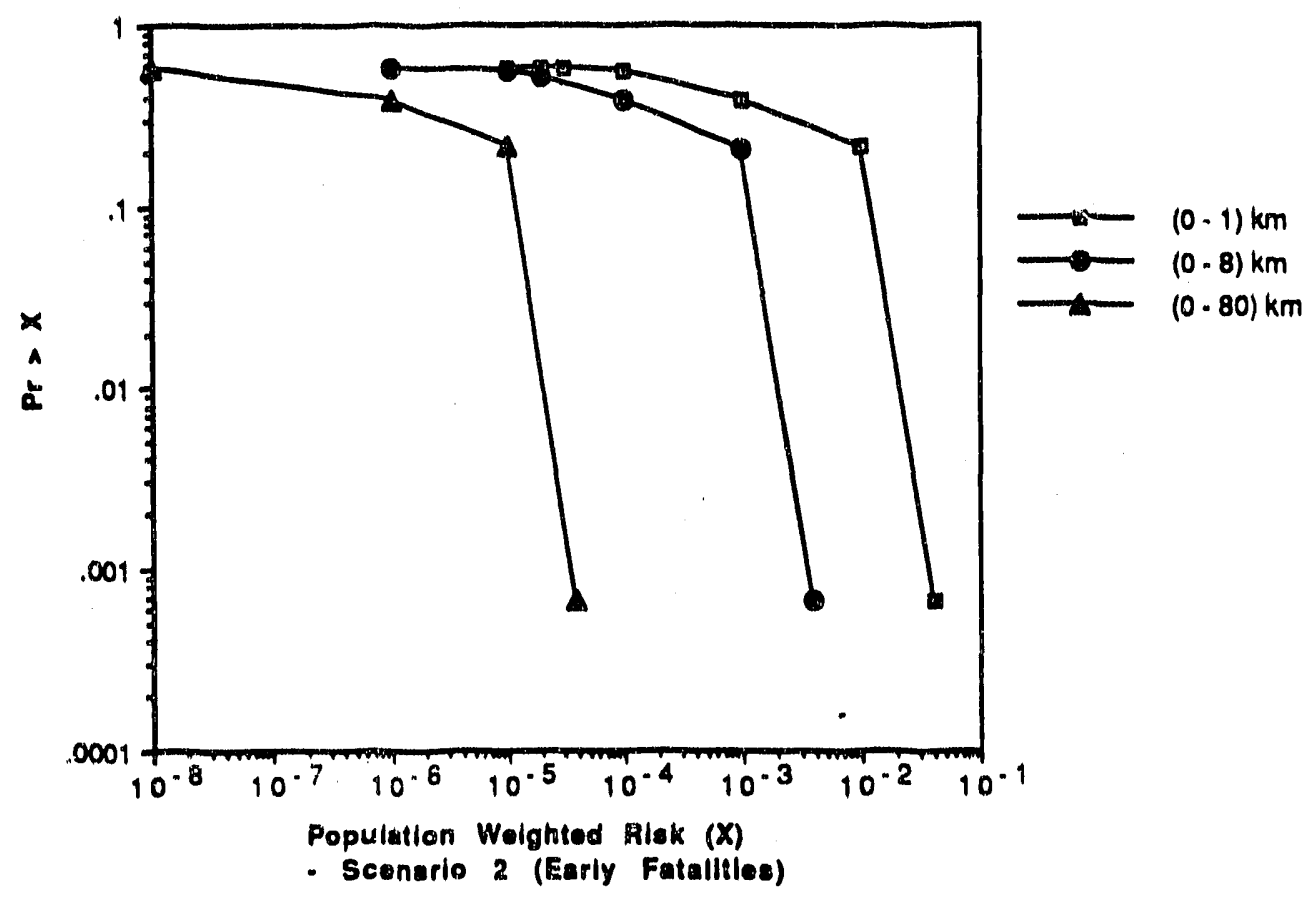

Fig. 7.1-29. Cumulative complementary distribution functions of population weighted risk for early fatality estimates from scenario 2 (MELCOR Accident Consequence Code System calculations).

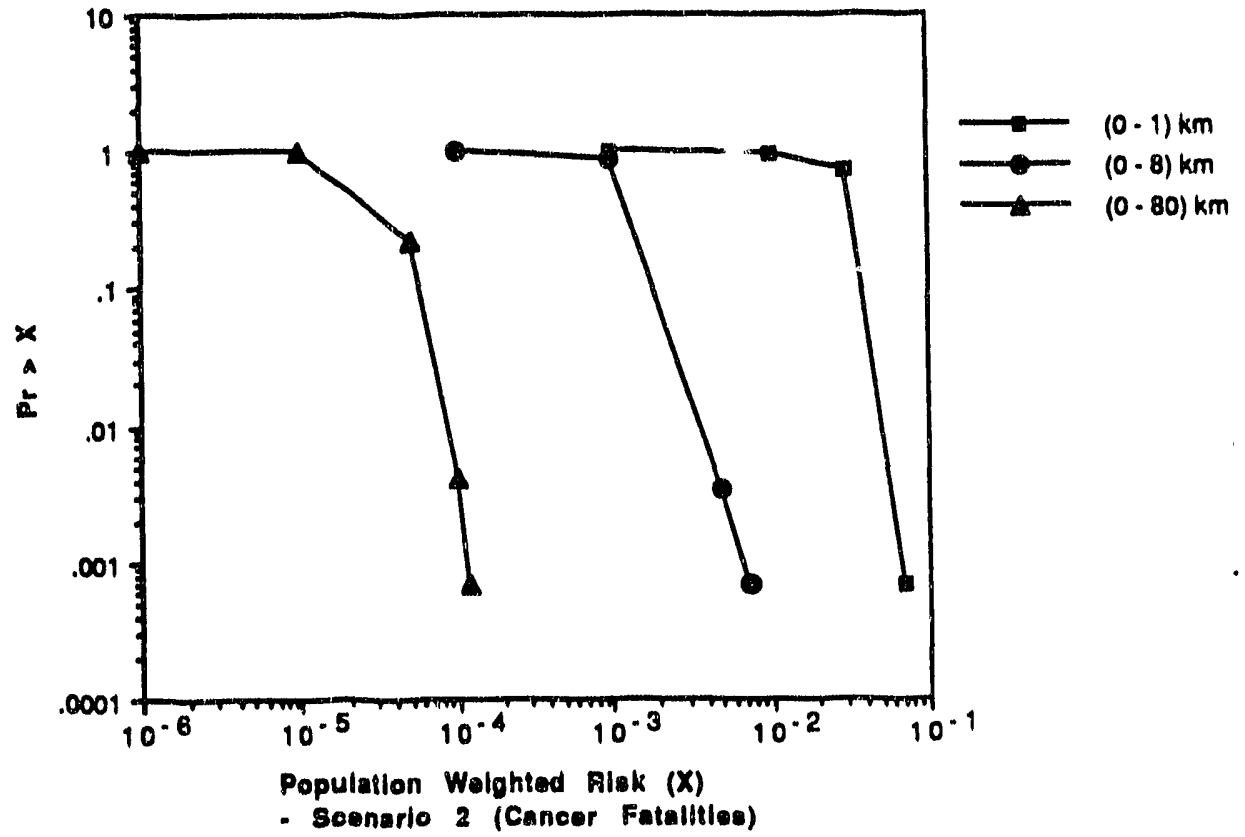

Fig. 7.1-30. Cumulative complementary distribution functions of population weighted risk for cancer fatality estimates from scenario 2 (MELCOR Accident Consequence Code System Calculations). 
It should be noted that the MACCS-calculated risk values presented in Table 7.1-7 are not the effective measures of actual risk. As mentioned in Sect. 7.1.1, fatality risk estimates for the accident scenarios representing early containment failure should be multiplied by $2.5 \times 10^{-6}$ for scenario 1 and $10^{-8}$ for scenario 2 to obtain estimates of effective risk. The columns under the heading "Effective Fatality Risk" reflect these values.

As the project evolves, improved risk assessment methodologies and a greater understanding of ANS design features should provide more accurate (i.e., less conservative) values that will reduce source terms and yield lower fatality estimates. The results shown in Table 7.1-7 and Figs. 7.1-25 through 7.1-30, indicate that the ANS risk goals in individual categories shown in Table 7.1-8 are met with a wide margin for the two severe accident scenarios under consideration. Obviously, overall risk will have to consider several severe accidents in various release categories; however, the risk from the other accidents is expected to be lower than the ones highlighted in Table 7.1-7 and the CCDFs.

The wide margin of safety (in relation to ANS risk goals) that has been evaluated at this stage of development arises from the assumptions of low risks from core damage (i.e., ANS core damage frequency goal of less than $10^{-5}$ occurrences per year) and containment failure (i.e., ANS containment failure design goal of less than $10^{-2}$ per occurrence of a severe accident). Nevertheless, the prompt and latent fatality estimates for scenario 2 are clearly undesirable and should be reduced or eliminated whenever possible. Efforts currently in place include (1) use of the best-estimate evaluation of coremelt progression and fission product release and transport, (2) the introduction of severe accident mitigative features (such as the use of alumina concrete coupled with a flooding strategy to eliminate or minimize the potential for $\mathrm{MCCI}$ ) and (3) the introduction of strategically positioned missile shields to absorb loads from generated shocks and missiles with the potential for causing containment failure. Such measures, when adopted, (1) would prevent a direct path for release of radionuclides to the environment (2) would significantly reduce (by up to $90 \%$ ) the release of combustible gases; and, most importantly, (3) could lower the possibility of core debris relocation out of the RCS or considerably increase the amount of time required for core debris to relocate onto the subpile room floor (thereby allowing sufficient time for evacuation). Consideration of these measures should indicate that the proposed facility would be safe (i.e., would have, from probabilistic and deterministic standpoints, negligibly low values for risk and for fatalities and injuries in the event of a severe accident).

\subsubsection{Nonsevere Accidents}

This section deals with accidents that either do not compromise the integrity of the reactor fuel or do not present a realistic potential for large scale release of the core fission product inventory to the environment. The consequences of nonsevere accidents must be considered in order to characterize completely the overall risk profile of a plant. Nonsevere accident frequencies range from about $5(10)^{-1} /$ year down to $10^{-3}$ /year or less. Most of the accidents involve the reactor, but the detritiation facility (a support facility to be located on the reactor site) has a significant accident potential that is also addressed near the end of this section.

The nonsevere accidents are listed in accordance with the format followed by Appendix I of NRC's Regulatory Guide 4.2, Preparation of Environmental Reports for Nuclear Power Stations (1976), except where underlying plant physical features and characteristics are not applicable. For example, power reactors use pin-type fuel rods that have a gâp tetwecin the $\mathrm{UO}_{2}$ fuel pellets and the zirconium cladding, but research reactors 
Table 7.1-8. Radiological accident risk limitation goals for the Advanced Neutron Source (ANS)

\begin{tabular}{lcc}
\multicolumn{1}{c}{ Population } & Risk mode & Risk to average individual \\
\hline $\begin{array}{l}\text { Off-site residents within } \\
1.6 \mathrm{~km}(1 \text { mile) of } \\
\text { reservation boundary }\end{array}$ & Early & $4 \times 10^{-7} /$ year \\
$\begin{array}{l}\text { On-site workers and } \\
\text { visitors within } 1.6 \mathrm{~km} \\
(1 \text { mile) of the ANS facility }\end{array}$ & Early & $1 \times 10^{-6} / \mathrm{year}$ \\
security fence & & \\
$\begin{array}{l}\text { Off-site residents within } \\
16 \mathrm{~km}(10 \text { miles) of the } \\
\text { reservation boundary, and } \\
\text { on-site workers and guests }\end{array}$ & Latent & $2 \times 10^{-6} /$ year \\
\hline
\end{tabular}

Source: Advanced Neutron Source Plant Design Requirements 1991, ORNL/TM-11625, Oak Ridge National Laboratory, Oak Ridge, Tenn.

use plate type fuel in which the cermet fuel material is bonded to the aluminum cladding. Thus, the nrescriptions for the release of the radioactivity held in the gap do not apply. Therefore, similarly conservative assumptions (with regard to physical differences) are made concerning the possible release of fission products from the ANS reactor fuel.

The source terms for nonsevere accidents are derived from the distinct inventories of radioactivity in the plant: fission product nuclides in the reactor fuel, activated corrosion products, and fission products and tritium in the coolant. The fuel contains far greater levels of radioactivity than any other component in the reactor, but during normal operation and during most nonsevere accidents, it is not released. The whole-core inventory of halogens and noble gas fission products at EOC (17 full-power days) for immediately after shutdown and $24 \mathrm{~h}$ after shutdown is listed in Table 7.1-9.

Activation products in the coolant, including tritium, determine the source term for several important nonsevere accidents. The ANS coolant radionuclide activity concentrations are listed in Table 7.1-10. The assessment of radioactivity content of the primary coolant is based on measurements of the HFIR coolant made in 1985 (F. F. Dyer, Analytical Chemistry Division, ORNL, personal communication to M. Harrington, ORNL, Oak Ridge, Tenn., December 29, 1985). It is a safe assumption that the ANS purification system will maintain comparable chemical concentrations of impurities in the primary coolant. But the higher flux of ANS (by design, higher than other high-flux reactors by a factor of five) can be expected to lead to higher activation rates. Therefore, the HFIR concentrations have been increased by a factor of five for application to ANS.

Because HFIR uses a light water coolant and ANS uses heavy water, HFIR data on tritium concentration are not applicable to ANS. ANS will continuously produce tritium during normal operation, typically by absorption of a single neutron to convert a heavy water molecule to a tritiated heavy water molecule. The production rate of tritium is estimated at more than $3.7 \times 10^{16} \mathrm{~Bq} / \mathrm{year}(1$ million Ci/year). A heavy water upgrade 
Table 7.1-9. Reactor core end-of-cycle inventory of noble gas and halogen fission products

\begin{tabular}{lccc}
\hline \multicolumn{1}{c}{ Nuclide } & Half-life & $\begin{array}{c}\text { Inventory at } \\
\text { shutdown } \\
{[\mathrm{Bq}(\mathrm{Ci})]}\end{array}$ & $\begin{array}{c}\text { Inventory } 24 \mathrm{~h} \\
\text { after shutdown } \\
{[\mathrm{Bq}(\mathrm{Ci})]}\end{array}$ \\
\hline${ }^{83} \mathrm{Br}$ & $2.39 \mathrm{~h}$ & $4.77 \times 10^{16}\left(1.29 \times 10^{6}\right)$ & $4.82 \times 10^{16}\left(1.33 \times 10^{13}\right)$ \\
${ }^{83 m} \mathrm{Kr}$ & $1.83 \mathrm{~h}$ & $4.81 \times 10^{16}\left(1.3 \times 10^{6}\right)$ & $1.90 \times 10^{16}\left(5.15 \times 10^{14}\right)$ \\
${ }^{84} \mathrm{Br}$ & $0.56 \mathrm{~h}$ & $9.06 \times 10^{16}\left(2.45 \times 10^{6}\right)$ & 0 \\
${ }^{85} \mathrm{Kr}$ & 10.7 years & $8.18 \times 10^{12}\left(2.21 \times 10^{3}\right)$ & $8.29 \times 10^{16}\left(2.24 \times 10^{13}\right)$ \\
${ }^{85} \mathrm{Kr}$ & $4.48 \mathrm{~h}$ & $1.14 \times 10^{17}\left(3.08 \times 10^{6}\right)$ & $2.82 \times 10^{15}\left(7.62 \times 10^{4}\right)$ \\
${ }^{87} \mathrm{Kr}$ & $1.27 \mathrm{~h}$ & $2.29 \times 10^{17}\left(6.19 \times 10^{6}\right)$ & $4.81 \times 10^{11}\left(1.30 \times 10^{1}\right)$ \\
${ }^{88} \mathrm{Kr}$ & $2.84 \mathrm{~h}$ & $3.27 \times 10^{17}\left(8.85 \times 10^{6}\right)$ & $9.36 \times 10^{14}\left(2.53 \times 10^{4}\right)$ \\
${ }^{131} \mathrm{I}$ & $193.0 \mathrm{~h}$ & $2.23 \times 10^{17}\left(6.02 \times 10^{6}\right)$ & $2.08 \times 10^{17}\left(5.61 \times 10^{6}\right)$ \\
${ }^{132} \mathrm{I}$ & $2.3 \mathrm{~h}$ & $4.26 \times 10^{17}\left(1.15 \times 10^{7}\right)$ & $3.48 \times 10^{17}\left(9.41 \times 10^{6}\right)$ \\
${ }^{133} \mathrm{I}$ & $20.8 \mathrm{~h}$ & $6.40 \times 10^{17}\left(1.73 \times 10^{7}\right)$ & $2.95 \times 10^{17}\left(7.97 \times 10^{6}\right)$ \\
${ }^{133} \mathrm{Xe}$ & $126.0 \mathrm{~h}$ & $5.03 \times 10^{17}\left(1.36 \times 10^{7}\right)$ & $5.00 \times 10^{17}\left(1.35 \times 10^{7}\right)$ \\
${ }^{133 m} \mathrm{Xe}$ & $53.0 \mathrm{~h}$ & $1.99 \times 10^{16}\left(5.37 \times 10^{5}\right)$ & $1.79 \times 10^{16}\left(4.84 \times 10^{5}\right)$ \\
${ }^{134} \mathrm{I}$ & $0.88 \mathrm{~h}$ & $6.88 \times 10^{17}\left(1.86 \times 10^{7}\right)$ & $1.73 \times 10^{10}\left(4.68 \times 10^{-1}\right)$ \\
${ }^{135} \mathrm{I}$ & $6.61 \mathrm{~h}$ & $5.70 \times 10^{17}\left(1.54 \times 10^{7}\right)$ & $4.62 \times 10^{16}\left(1.25 \times 10^{6}\right)$ \\
${ }^{135} \mathrm{Xe}$ & $9.08 \mathrm{~h}$ & $2.00 \times 10^{16}\left(5.4 \times 10^{5}\right)$ & $1.26 \times 10^{17}\left(3.4 \times 10^{6}\right)$ \\
${ }^{135 m} \mathrm{Xe}$ & $0.26 \mathrm{~h}$ & $1.04 \times 10^{17}\left(2.82 \times 10^{6}\right)$ & $7.40 \times 10^{15}\left(2 \times 10^{5}\right)$ \\
${ }^{138} \mathrm{Xe}$ & $0.24 \mathrm{~h}$ & $5.62 \times 10^{17}\left(1.52 \times 10^{7}\right)$ & 0 \\
\hline
\end{tabular}

facility is provided to remove this tritium: the detritiation facility is designed to enable primary coolant tritium concentration to be maintained below a technical specification limit of $1.85 \times 10^{11} \mathrm{~Bq} / \mathrm{L}(5 \mathrm{Ci} / \mathrm{L})$. In actual operation, the detritiation facility should enable the tritium concentration to be maintained below $7.4 \times 10^{10} \mathrm{~Bq} / \mathrm{L}(2 \mathrm{Ci} / \mathrm{L})$.

\subsubsection{Radioactive Waste System Failures}

The ANS reactor uses ion exchange to control the radioactivity of primary coolant, reflector coolant, and pool coolant. The process takes radioactive ions from the coolant and deposits them on the surface of the ion exchange resin. Most of the radioactivity in the radioactive waste system is bound in the ion exchange resin and, therefore, not readily releasable.

When the ion exchange resins are saturated and will adsorb no more ions, they are dewatered in the ANS service building, and shipped to another facility for further packaging and disposal. Approximately $1900 \mathrm{~L}$ (500 gal) of contaminated light water are left over each time a batch of resin is prepared for shipment (W. R. Reed, ORNL, personal communication to M. Harrington, ORNL, Oak Ridge, Tenn., October 21, 1991). This volume of contaminated water is circulated through an ion-exchange bed and then pumped to the ORNL Low-Level Liquid Waste (LLLW) Treatment plant.

As a limiting radioactive waste system accident, it is postulated that a break occurs in the transfer line somewhere between ANS and the ORNL waste treatment plant and that all $1900 \mathrm{~L}(500 \mathrm{gal})$ of contaminated light water is pumped into the ground. Most of 
Table 7.1-10. High Flux Isotope Reactor (HFIR) and Advanced Neutron Source (ANS) coolant activity concentrations

\begin{tabular}{lccr}
\hline & & $\begin{array}{c}\text { ANS } \\
\text { concentration }\end{array}$ & $\begin{array}{c}\text { HFIR } \\
\text { concentration } \\
{[\mathrm{Bq} / \mathrm{mL}(\mu \mathrm{Ci} / \mathrm{mL})]}\end{array}$ \\
Nuclide & Half-life & {$\left[\mathrm{Bq} / \mathrm{mL}\left(\mu \mathrm{Ci} / \mathrm{mL}^{a}\right)\right]$} & -0 \\
\hline${ }^{3} \mathrm{H}$ & 12.3 years & $1.85 \times 10^{8}\left(5 \times 10^{3}\right)$ & $\left.-10^{-1}\right)$ \\
${ }^{24} \mathrm{Na}$ & $15.0 \mathrm{~b}$ & $29600\left(8.00 \times 10^{-1}\right)$ & $5920\left(1.60 \times 10^{-3}\right)$ \\
${ }^{36} \mathrm{Cl}$ & $37.2 \mathrm{~min}$ & $185\left(5.00 \times 10^{-3}\right)$ & $37\left(1.00 \times 10^{-3}\right)$ \\
${ }^{46} \mathrm{Sc}$ & $83.8 \mathrm{~d}$ & $0.55\left(1.50 \times 10^{-5}\right)$ & $0.11\left(3.00 \times 10^{-6}\right)$ \\
${ }^{51} \mathrm{Cr}$ & $27.7 \mathrm{~d}$ & $159\left(4.30 \times 10^{-3}\right)$ & $32\left(8.60 \times 10^{-4}\right)$ \\
${ }^{54} \mathrm{Mn}$ & $312.5 \mathrm{~d}$ & $0.26\left(7.00 \times 10^{-6}\right)$ & $0.05\left(1.40 \times 10^{-6}\right)$ \\
${ }^{56} \mathrm{Mn}$ & $2.6 \mathrm{~h}$ & $3145\left(8.50 \times 10^{-2}\right)$ & $629\left(1.70 \times 10^{-2}\right)$ \\
${ }^{59} \mathrm{Fe}$ & $44.6 \mathrm{~d}$ & $0.26\left(7.00 \times 10^{-6}\right)$ & $0.05\left(1.40 \times 10^{-6}\right)$ \\
${ }^{60} \mathrm{Co}$ & 5.27 years & $5.18\left(1.40 \times 10^{-4}\right)$ & $1.04\left(2.80 \times 10^{-5}\right)$ \\
${ }^{65} \mathrm{Zn}$ & $243.8 \mathrm{~d}$ & $0.28\left(7.50 \times 10^{-6}\right)$ & $0.055\left(1.50 \times 10^{-6}\right)$ \\
${ }^{95} \mathrm{Zr}$ & $64.0 \mathrm{~d}$ & $0.05\left(1.35 \times 10^{-6}\right)$ & $0.01\left(2.70 \times 10^{-7}\right)$ \\
${ }^{95} \mathrm{Nb}$ & $35.1 \mathrm{~d}$ & $0.026\left(7.00 \times 10^{-7}\right)$ & $0.005\left(1.40 \times 10^{-7}\right)$ \\
${ }^{103} \mathrm{Ru}$ & $39.4 \mathrm{~d}$ & $0.15\left(4.05 \times 10^{-6}\right)$ & $0.03\left(8.10 \times 10^{-7}\right)$ \\
${ }^{131} \mathrm{Sb}$ & $23.0 \mathrm{~min}$ & $18.5\left(5.00 \times 10^{-4}\right)$ & $3.7\left(1.00 \times 10^{-4}\right)$ \\
${ }^{133 m} \mathrm{Te}$ & $55.4 \mathrm{~min}$ & $37\left(1.00 \times 10^{-3}\right)$ & $7.4\left(2.00 \times 10^{-4}\right)$ \\
${ }^{134} \mathrm{Te}$ & $42.0 \mathrm{~min}$ & $37\left(1.00 \times 10^{-3}\right)$ & $7.4\left(2.00 \times 10^{-4}\right)$ \\
${ }^{131} \mathrm{I}$ & $8.0 \mathrm{~d}$ & $2.8\left(7.50 \times 10^{-5}\right)$ & $0.55\left(1.50 \times 10^{-5}\right)$ \\
${ }^{132} \mathrm{I}$ & $2.3 \mathrm{~h}$ & $7.4\left(2.00 \times 10^{-4}\right)$ & $1.5\left(4.00 \times 10^{-5}\right)$ \\
${ }^{133} \mathrm{I}$ & $20.8 \mathrm{~h}$ & $18.5\left(5.00 \times 10^{-4}\right)$ & $3.7\left(1.00 \times 10^{-4}\right)$ \\
${ }^{134} \mathrm{I}$ & $52.6 \mathrm{~min}$ & $74\left(2.00 \times 10^{-3}\right)$ & $15\left(4.00 \times 10^{-4}\right)$ \\
${ }^{135} \mathrm{I}$ & $6.6 \mathrm{~h}$ & $18.5\left(5.00 \times 10^{-4}\right)$ & $3.7\left(1.00 \times 10^{-4}\right)$ \\
${ }^{137} \mathrm{Cs}$ & $30.1 \mathrm{years}$ & $0.01\left(2.55 \times 10^{-7}\right)$ & $0.002\left(5.10 \times 10^{-8}\right)$ \\
${ }^{140} \mathrm{Ba}$ & $12.8 \mathrm{~d}$ & $2.03\left(5.50 \times 10^{-5}\right)$ & $0.41\left(1.10 \times 10^{-5}\right)$ \\
${ }^{140} \mathrm{La}$ & $40.2 \mathrm{~h}$ & $1.85\left(5.00 \times 10^{-5}\right)$ & $0.37\left(1.00 \times 10^{-5}\right)$ \\
${ }^{141} \mathrm{Ce}$ & $32.5 \mathrm{~d}$ & $0.3\left(8.00 \times 10^{-6}\right)$ & $0.06\left(1.60 \times 10^{-6}\right)$ \\
${ }^{181} \mathrm{~W}$ & $121.0 \mathrm{~d}$ & $925\left(2.50 \times 10^{-2}\right)$ & $185\left(5.00 \times 10^{-3}\right)$ \\
${ }^{187} \mathrm{~W}$ & $23.9 \mathrm{~b}$ & $203\left(5.50 \times 10^{-3}\right)$ & $41\left(1.10 \times 10^{-3}\right)$ \\
\hline
\end{tabular}

aAN nuclide concentrations are assumed to be five times typical HFIR concentrations. 
the nuclides would be held up in the clay soil typical of Oak Ridge Reservation (ORR), but the tritiated water would most likely find its way into a creek and eventual release from White Oak Lake. The net result of this accident would be a volume of contaminated earth around the pipe and a release of tritium that would have occurred anyway. That is, the tritium-contaminated waste water would have been released from the main ORNL waste treatment facility after processing for removal of the residual radioactive contamination. Sufficient information does not exist to quantify the source term for this incident, but it seems likely that the consequences, at least in terms of exposure to individual employees or the public, would be minor. The frequency of a radioactive waste line breaking is low ( $<1$ every 50 years). Leaks would occur at a higher frequency of about once every 10 years. Because the tritium release component of this accident would have occurred in the normal case, without the accident occurring, the consequences of this accident are included in normal releases (see Sect. 5.2).

\subsubsection{Fission Products to Primary and Secondary Systems}

The recommendation of Regulatory Guide 4.2, Appendix I, to assume a continuous primary-to-secondary coolant leak of $75 \mathrm{~L} / \mathrm{d}(20 \mathrm{gal} / \mathrm{d})$ is neither realistic nor reasonable for application to ANS, primarily because of the value of heavy water. Aside from any other considerations, it would not be cost effective to operate for any appreciable time with a leak that would cost approximately $\$ 30,000 / \mathrm{d}$ (at $\$ 400 / \mathrm{L}$ ) in lost heavy water. Detection of a tube leak would initiate shutdown of the affected loop, which would not be used again until the leaking tube had been plugged. Because leaks, even based upon the unfortunate experience with HFIR's main heat exchangers, can be expected to occur at an average frequency of no more than once every 2 years and last only for a few hours. The probability of another accident and a tube leak occurring simultaneously is negligibly small.

Similarly, the Regulatory Guide's assumption of a pre-accident coolant radioactivity level based on $0.5 \%$ fuel damage is not applicable to ANS. As previously discussed, research reactor fuel has no gap activity, so release formulas based on gap activity do not translate to ANS.

\section{Heat Exchanger Tube Leaks}

The source term for this accident is summarized by Table 7.1-11. Major assumptions used to characterize the release include the following:

1. Leaking loop detected and isolated after $2 \mathrm{~h}$ of $3.78 \mathrm{~L} / \mathrm{min}(1 \mathrm{gal} / \mathrm{min})$ leakage (twice the Regulatory Guide 1.45 minimum requirement). Different leak rates would take proportionally shorter or longer periods to detect, based on sensing loss of heavy water, e.g. a $1.89 \mathrm{~L} / \mathrm{min}(0.5 \mathrm{gal} / \mathrm{min})$ leak would be detected in $4 \mathrm{~h}$ instead of $2 \mathrm{~h}$, but the total leakage volume would be the same. More sensitive leak detection methods based on heavy water or tritium sensing would be used in ANS, but since design parameters are not currently available, the inventory-based leakage volume of $454 \mathrm{~L}$ (120 gal) will be used for now.

2. The affected loop is returned to service after the tube leak is plugged.

3. Secondary coolant volume is $1100 \mathrm{~m}^{3}$ (290,700 gal) per loop [1020 $\mathrm{m}^{3}$ (269,500 gal) in the basin]. 
Table 7.1-11. Source term calculation sheet for heat exchanger tube leak ${ }^{a}$

\begin{tabular}{lcl}
\hline & \multicolumn{2}{c}{ Environmental release to } \\
\cline { 2 - 4 } Nuclide $^{b}$ & $\begin{array}{c}\text { Air } \\
{[\mathrm{Bq}(\mathrm{Ci})]}\end{array}$ & $\begin{array}{c}\text { Water } \\
{[\mathrm{Bq}(\mathrm{Ci})]}\end{array}$ \\
\hline${ }^{3} \mathrm{H}$ & $6.29 \times 10^{13}\left(1.7025 \times 10^{3}\right)$ & $2.09 \times 10^{13}\left(5.675 \times 10^{2}\right)$ \\
${ }^{24} \mathrm{Na}$ & 0 & $1.34 \times 10^{10}\left(3.632 \times 10^{-1}\right)$ \\
${ }^{46} \mathrm{Sc}$ & 0 & $2.59 \times 10\left(7.0 \times 10^{-6}\right)$ \\
${ }^{51} \mathrm{Cr}$ & 0 & $7.22 \times 10\left(1.952 \times 10^{-3}\right)$ \\
${ }^{54} \mathrm{Mn}$ & 0 & $1.11 \times 10^{5}\left(3.0 \times 10^{-6}\right)$ \\
${ }^{56} \mathrm{Mn}$ & 0 & $1.43 \times 10^{9}\left(3.859 \times 10^{-2}\right)$ \\
${ }^{59} \mathrm{Fe}$ & 0 & $1.11 \times 10^{5}\left(3.0 \times 10^{-6}\right)$ \\
${ }^{60} \mathrm{Co}$ & 0 & $2.33 \times 10^{6}\left(6.3 \times 10^{-5}\right)$ \\
${ }^{65} \mathrm{Zn}$ & 0 & $1.11 \times 10^{5}\left(3.0 \times 10^{-6}\right)$ \\
${ }^{95} \mathrm{Zr}$ & 0 & $2.26 \times 10^{4}\left(6.10 \times 10^{-7}\right)$ \\
${ }^{95} \mathrm{Nb}$ & 0 & $1.17 \times 10^{4}\left(3.17 \times 10^{-7}\right)$ \\
${ }^{103} \mathrm{Ru}$ & 0 & $7.4 \times 10^{4}\left(2.0 \times 10^{-6}\right)$ \\
${ }^{131} \mathrm{I}$ & $1.26 \times 10^{6}\left(3.40 \times 10^{-5}\right)$ & 0 \\
${ }^{137} \mathrm{Cs}$ & 0 & $4.29 \times 10^{3}\left(1.16 \times 10^{-7}\right)$ \\
${ }^{140} \mathrm{Ba}$ & 0 & $1.11 \times 10^{6}\left(3.0 \times 10^{-5}\right)$ \\
${ }^{141} \mathrm{Ce}$ & 0 & $1.48 \times 10^{5}\left(4.0 \times 10^{-6}\right)$ \\
${ }^{181} \mathrm{~W}$ & 0 & $4.18 \times 10^{8}\left(1.13 \times 10^{-2}\right)$ \\
${ }^{187} \mathrm{~W}$ & 0 & $9.25 \times 10^{7}\left(2.500 \times 10^{-3}\right)$ \\
\hline
\end{tabular}

Source term calculations assume the following: (1) event frequency, $0.5 /$ year; (2) release duration, $6 \mathrm{~h}$; (3) primary coolant leaks into secondary coolant until secondary coolant isolation; heat exchanger returned to service after the leaky tube is plugged during a subsequent refueling outage; therefore, most of the release occurs 1-3 weeks after the initial leak; (4) volume of coolant spilled or released, $454 \mathrm{~L} ;(5)$ amount vaporized, $75 \%$ (evaporates in cooling tower; the remainder is carried off with the blowdown); and (6) for ${ }^{3} \mathrm{H}, 75 \%$ of the release is to air and $25 \%$ to water; for ${ }^{131} \mathrm{I}, 100 \%$ of the release is to air; and for all other nuclides, $100 \%$ of the release is to water.

"Half-lives and coolant activity concentrations for these nuclides are given in Table 7.1-9.

4. Secondary coolant per loop make-up rate is $2.93 \mathrm{~m} 3 / \mathrm{min}$ ( $773 \mathrm{gal} / \mathrm{min}): 75 \%$ of this is to replace secondary coolant evaporated in the cooling tower and the other $-25 \%$ is blowdown (a waste stream, necessary to maintain secondary coolant calcium concentration sufficiently low). This ratio is based on HFIR operating parameters and determines which part of the tritium release would be airborne and which part would be released via a water pathway.

5. Based on the $2.93-\mathrm{m}^{3} / \mathrm{min}(773-\mathrm{gal} / \mathrm{min})$ secondary coolant make-up rate and the $1100-\mathrm{m}^{3}(290,700-\mathrm{gal})$ inventory, it is apparent that the entire inventory is replenished every $6 \mathrm{~h}$. Most of the environmental release will occur over this 6 -h period. For radiation exposure evaluations, the entire radioactivity release will be conservatively assumed to be completed within $6 \mathrm{~h}$. The reader should note that, per assumption 1 , the first $2 \mathrm{~h}$ of the release would occur before positive identification of the leak and 
isolation of the offending loop. The remaining $4 \mathrm{~h}$ of release would occur several weeks (or even months) later, after the leaking tube had been plugged and the affected loop restarted. During the intervening time, the radioactivity concentration in the affected secondary coolant loop would be analyzed in order to allow consideration on a case-by-case basis of the most desirable option for restart.

\section{Heat Exchanger Tube Ruptures}

The source term for this accident is summarized by Table 7.1-12. The assumptions for this accident are identical to those for the tube leak, except for the following:

1. The ruptured tube leak rate $=12.6 \mathrm{~L} / \mathrm{s}(200 \mathrm{gpm})$, based on the tube diameter and primary-to-secondary pressure difference.

2. Although ANS is equipped with automatic leakage detection and secondary coolant isolation, it is assumed that, under transient conditions, that more leakage would be required to actuate the protective circuitry, consistent with a finite delay time of 1 min required for detection and automatic loop isolation.

3. The amount leaked into the secondary coolant system is $756 \mathrm{~L}$ (200 gal).

After a tube rupture accident, the offending heat exchanger would be isolated from primary and secondary coolant systems by isolation valves. Part of the accident recovery procedure would be to drain the primary and secondary coolant into separate receptacles, preferably without causing any further loss of heavy water into the secondary coolant or mixing of secondary coolant into the heavy water. To accomplish the draining with a minimum of mixing would involve draining both the primary and secondary coolant sides of the heat exchanger at the same time so that there is no pressure difference would develop and permit interchange of primary and secondary coolant. The separate inventories of recovered primary and secondary coolant would then be assayed and either sent back to the appropriate coolant systems, sent to the heavy water upgrade (detritiation) facility, or pumped to the liquid waste disposal system. The loss of an additional $1 \%$ of the primary coolant inventory into the secondary coolant during the mixing operation would represent the loss of an additional $150 \mathrm{~L}$ (39.7 gal) of heavy water, which would either be recycled or pumped to the ORNL LLLW treatment plant, depending on radioactivity concentration. The treatment plant would, in turn, discharge into White Oak Lake. This pathway represents possible environmental release not included in the Table 7.1-12.

\section{Off-design transients that induce fuel failure above those expected and steam generator} leak

As previously explained, the assumption of a heat exchanger leak coincident with an occurrence that would release fission products to the primary coolant system is not applicable to the heavy-water-cooled ANS. The Regulatory Guide's prescription for this accident is for $0.02 \%$ of the core inventory of noble gases and halogens to be released into the reactor coolant. For ANS, this amount represents about $13 \%$ of the fission product inventory in a single fuel plate (666 fuel plates in the entire core). Possible causes would include the failure to detect a flaw introduced during the manufacturing process. In the following analysis we assume that the fuel damage and subsequent release does not occur until the end of the core irradiation, when fission product inventories would be at a maximum. Such a release would involve a significant amount of 
Table 7.1-12. Source term calculation sheet for heat exchanger tube rupture ${ }^{a}$

\begin{tabular}{lcc}
\hline & \multicolumn{2}{c}{ Environmental release to } \\
\cline { 2 - 3 } $\mathrm{Nuclide}^{b}$ & $\begin{array}{c}\text { Air } \\
{[\mathrm{Bq}(\mathrm{Ci})]}\end{array}$ & \multicolumn{1}{c}{$\begin{array}{c}\text { Water } \\
{[\mathrm{Bq}(\mathrm{Cl})]}\end{array}$} \\
\hline${ }^{3} \mathrm{H}$ & $1.05 \times 10^{14}\left(2.835 \times 10^{3}\right)$ & $3.50 \times 10^{13}\left(9.45 \times 10^{2}\right)$ \\
${ }^{24} \mathrm{Na}$ & 0 & $2.24 \times 10^{10}\left(6.048 \times 10^{-1}\right)$ \\
${ }^{46} \mathrm{Sc}$ & 0 & $4.07 \times 10^{5}\left(1.1 \times 10^{-5}\right)$ \\
${ }^{51} \mathrm{Cr}$ & 0 & $1.30 \times 10^{8}\left(3.520 \times 10^{-3}\right)$ \\
${ }^{54} \mathrm{Mn}$ & 0 & $1.85 \times 10^{5}\left(5 \times 10^{-6}\right)$ \\
${ }^{56} \mathrm{Mn}$ & 0 & $2.38 \times 10^{9}\left(6.426 \times 10^{-2}\right)$ \\
${ }^{59} \mathrm{Fe}$ & 0 & $1.85 \times 10^{5}\left(5 \times 10^{-6}\right)$ \\
${ }^{60} \mathrm{Co}$ & 0 & $3.89 \times 10^{6}\left(1.05 \times 10^{-4}\right)$ \\
${ }^{65} \mathrm{Zn}$ & 0 & $1.88 \times 10^{5} \mathrm{~Bq}\left(5 \times 10^{-6}\right)$ \\
${ }^{95} \mathrm{Zr}$ & 0 & $3.7 \times 10^{4}\left(1 \times 10^{-6}\right)$ \\
${ }^{95} \mathrm{Nb}$ & 0 & 0 \\
${ }^{103} \mathrm{Ru}$ & 0 & $1.11 \times 10^{5} \mathrm{~Bq}\left(3 \times 10^{-6}\right)$ \\
${ }^{131} \mathrm{I}$ & $2.09 \times 10^{6}\left(5.67 \times 10^{-5}\right)$ & 0 \\
${ }^{137} \mathrm{Cs}$ & 0 & 0 \\
${ }^{140} \mathrm{Ba}$ & 0 & $1.52 \times 10^{6}\left(4.1 \times 10^{-5}\right)$ \\
${ }^{141} \mathrm{Ce}$ & 0 & $2.22 \times 10^{5}\left(6 \times 10^{-6}\right)$ \\
${ }^{181} \mathrm{~W}$ & 0 & $6.99 \times 10^{8}\left(1.89 \times 10^{-2}\right)$ \\
${ }^{187} \mathrm{~W}$ & 0 & $1.54 \times 10^{8}\left(4.158 \times 10^{-3}\right)$ \\
\hline
\end{tabular}

Source term calculations assume the following: (1) event frequency, 0.1/year; (2) release duration, $6 \mathrm{~h}$; (3) primary coolant leaks into secondary coolant until secondary coolant tsolation; heat exchanger returned to service after the leaky tube is plugged during a subsequent refueling outage; therefore, most of the release occurs 1-3 weeks after the Inittal leak; (4) volume of coolant spilled or released, $756 \mathrm{Li}$ (5) amount vaporized, $75 \%$ (evaporates in cooling tower; the remainder is carried off with the blowdown); and (6) for ${ }^{3} \mathrm{HI}, 75 \%$ of the release is to air and $25 \%$ to water; for ${ }^{13} I, 100 \%$ of the release is to air; and for all other nuclides, $100 \%$ of the release is to water.

Half-lives and coolant activity concentrations for these nuclides are given in Table 7.1-9.

radioactivity (e.g., $0.02 \%$ of the core EOC inventory of ${ }^{131} \mathrm{I}$ immediately after shutdown would come to $4.45 \times 10^{13} \mathrm{~Bq}(1204 \mathrm{Ci})$. For such an incident to occur, there would have to be a major breakdown in the fuel manufacturing and quality control processes. Such an incident is, therefore, considered to be a limiting, once-in-a-lifetime accident. There has never been such a fuel-damage incident at HFIR.

The path for release to the environment would not be immediate because the integrity of the primary coolant system would not be compromised. However, as coolant is cycled through the purification system, noble gases and halogens would be released from the primary coolant in the deaerator, which vents to the building hot off-gas system and then to the environment through absolute and charcoal filters. The Regulatory 
Guide prescription for air ejector release is $100 \%$ of the noble gases and $0.1 \%$ of the halogens; charcoal filter efficiency for retaining the released halogens is $99 \%$. For ANS analysis, we must adjust the air ejector release upward to $10 \%$ to bound the possible conversion of I' to $\mathrm{I}_{2}$ (C. Weber, Chemical Technology Division, ORNL, personal communication to M. Harrington, ORNL, Oak Ridge, Tenn., November 13, 1991). It is assumed that all iodine in the $\mathrm{I}_{2}$ form is vaporized and flows into the off-gas.

Consideration of the original $4.45 \times 10^{13} \mathrm{~Bq}(1204 \mathrm{Ci})$ of ${ }^{131} \mathrm{I}$ postulated to be released provides an apt example of how the halogen transport factors determine the ultimate release to the environment. Of the $4.45 \times 10^{13} \mathrm{~Bq}(1204 \mathrm{Cl})$ of ${ }^{131} \mathrm{I}$ released to the primary coolant, $4.44 \times 10^{12} \mathrm{~Bq}(120 \mathrm{Ci})$ would be vaporized and escape to the hot off-gas duct-work, but the charcoal filters would allow only $4.44 \times 10^{10} \mathrm{~Bq}(1.2 \mathrm{Ci})$ to be released to the environment.

The duration of release for this event is determined by the $-1 \% / \mathrm{min}$ rate of circulation of primary coolant into the purification system. At this rate $100 \%$ of the primary coolant volume would be circulated through the purification system in $100 \mathrm{~min}$; considering mixing, it would take at least two residence times (i.e., $>200 \mathrm{~min}$ ) for all of the volatile fission products to be released from the primary coolant. The duration of release for this event is, therefore, listed as $3 \mathrm{~h}$.

The source term for this accident is summarized by Table 7.1-13.

\subsubsection{Refueling Accidents}

\section{Fuel bundle drop}

The source term for this event follows guidance of Appendix I of Regulatory Guide 4.2 in a general sense, but the basic accident is a drop of one fuel element (two elements per core) instead of one fuel bundle (e.g. about 200 per core for a pressurized-water reactor). Other particulars of the accident that must be revised to fit ANS are as follows:

- During refueling of ANS, the fuel is vulnerable to more than just mechanical damage. Cooling is also a consideration because the relatively high power density and narrow cooling channels make it necessary to maintain free circulation through the element for several days after shutdown. For this reason, instead of the lightwater reactor mechanical damage-based formula prescribing release of the gap activity of one row of pins, it must be assumed for ANS that the fuel element is dropped in such a manner that decay heat removal is crippled. The under-cooled element is assumed to overheat, and the entire noble gas and halogen inventory of one element is released to the heavy water surrounding the fuel element.

- Instead of 1 week of cooling time before fuel removal, the ANS refueling plans call for a $1 \mathrm{~d}$ cooling time before fuel removal begins.

The other assumptions of the Regulatory Guide are applicable, including the iodine decontamination factor in water of 500 . The requirement that, "A realistic fraction of the containment volume shall be assumed to leak to the atmosphere before isolating the containment" is satisfied by assuming that $1 \%$ of the inventory of fission products released to the atmosphere is released before isolation. This amount is a guess because sufficient information to allow a quantitative estimate is not currently available; however, a low percentage is realistic in this case for two reasons. First, there is no direct path for release from the damaged fuel to the containment atmosphere above the pool; therefore, 
Table 7.1-13. Source term calculation sheet for end-of-cycle off-design event inducing $0.02 \%$ fuel failure,

\begin{tabular}{|c|c|}
\hline Nuclide $^{c}$ & $\begin{array}{l}\text { Environmental release to air } \\
\qquad[\mathrm{Bq}(\mathrm{Cl})]\end{array}$ \\
\hline${ }^{83} \mathrm{Br}$ & $9.55 \times 10^{9}\left(2.58 \times 10^{-1}\right)$ \\
\hline${ }^{83 m} \mathrm{Kr}$ & $9.62 \times 10^{13}\left(2.60 \times 10^{3}\right)$ \\
\hline${ }^{84} \mathrm{Br}$ & $1.81 \times 10^{10}\left(4.9 \times 10^{-1}\right)$ \\
\hline${ }^{85} K_{M r}$ & $1.64 \times 10^{10}\left(4.42 \times 10^{-1}\right)$ \\
\hline${ }^{85} \mathrm{sin} \mathrm{Kr}$ & $2.28 \times 10^{13}\left(6.16 \times 10^{2}\right)$ \\
\hline${ }^{87} \mathrm{Kr}$ & $4.58 \times 10^{13}\left(1.238 \times 10^{3}\right)$ \\
\hline${ }^{88} \mathrm{Kr}$ & $6.55 \times 10^{13}\left(1.770 \times 10^{3}\right)$ \\
\hline${ }^{131} \mathrm{I}$ & $4.54 \times 10^{10}(1.204)$ \\
\hline${ }^{132} I$ & $8.5 \times 10^{10}(2.3)$ \\
\hline${ }^{133} I$ & $1.28 \times 10^{11}(3.46)$ \\
\hline${ }^{133} \mathrm{Xe}$ & $1.01 \times 10^{14}\left(2.720 \times 10^{3}\right)$ \\
\hline${ }^{133 m} \mathrm{Xe}$ & $3.97 \times 10^{12}\left(1.074 \times 10^{2}\right)$ \\
\hline${ }^{134} I$ & $1.38 \times 10^{11}(3.72)$ \\
\hline${ }^{135} \mathrm{I}$ & $1.14 \times 10^{11}(3.08)$ \\
\hline${ }^{135} \mathrm{Xe}$ & $3.99 \times 10^{12}\left(1.08 \times 10^{2}\right)$ \\
\hline${ }^{13 \sin } \mathrm{Xe}$ & $2.09 \times 10^{11}(5.64)$ \\
\hline${ }^{138} \mathrm{Xe}$ & $1.12 \times 10^{12}\left(3.04 \times 10^{1}\right)$ \\
\hline
\end{tabular}

"Source term calculations assume the following: (1) event frequency, 0.02 /year; (2) release duration, $3 \mathrm{~h} ;(3)$ fuel damage fraction is 0.0002 , filter efficiency is 0.99 , other retention factor is $10(1=$ no retention); (4) $100 \%$ of the release is to air for all nuclides; (5) release path, deaerator off-gas.

Nonnoble gas and nonhaiogen radionuclides not released per direction of Regulatory Guide 4.2, Appendix I.

Half-Itves and in-fuel inventory for these nuclides are given in Table 7.1-9. 
it would take a significant amount of time for released fission products to reach the containment atmosphere. Secondly, the containment isolation actuation instrumentation would be sensitive to a high radiation level in the containment atmosphere. A more quantitative estimate of the pre-isolation release will be made when more detailed design information becomes available.

There is no reason to assume for this event that the pool cooling is lost, so there would be no pressure build-up to drive leakage from containment. Nevertheless, it has been assumed that the containment leaks at the design-leak rate for $30 \mathrm{~d}$ following containment isolation. This extended containment leakage is included in the environmental release on Table 7.1-14.

A probabilistic risk assessment for this accident has not yet been undertaken, but the frequency can be judged to be low based on other considerations. The consequences of this accident would be severe in terms of extended facility shutdown for clean-up, repair, and obtaining restart approval. Therefore, design features will be incorporated as necessary to reduce the estimated frequency to a value that indicates a low probability of occurrence over the 50-year life of the facility. A frequency of 1/500 years would yield approximately a $10 \%$ chance of occurrence over 50 years.

The source term for this accident is summarized in Table 7.1-13. Most of the release would occur with the containment isolated and leaking only a small amount each day. The duration of the release is assumed to be $30 \mathrm{~d}$.

\section{Heavy object drop onto fuel in the core}

This event is not considered explicitly in this report because of its similarity to the previously mentioned fuel element drop accident. ANS fuel is susceptible to damage by any dropped objeci that strikes the core in such a manner as to decrease the effective width of the cooling channels between the fuel plates or to actually tear the cladding off the fuel plates. The probability of such an event may be greater than a catastrophic fuel element drop, but the consequences would be correspondingly smaller because dropping something onto a fuel element would cause localized damage (as opposed to the previously mentioned generalized damage postulated for the element drop). The ANS refueling system desizn has not proceeded to the point that would allow a detailed consideration of this event.

\subsubsection{Spent Fuel Handling Accident}

Sufficient design information does not presently exist to allow detailed consideration of this category of accident. In any case, the consequences of these accidents would be bounded by the consequences of refueling accidents, Sect. 7.1.2.3.

\subsubsection{Accident Initiation Events Considered in Design Basis Evaluation in the Safety Analysis Report-Loss of Coolant Accidents}

Small pipe break

The assumptions for this event generally follow those of Regulatory Guide 4.2, with one significant exception: the ANS analysis does not follow the Regulatory Guide prescription to assume $0.5 \%$ faiied fuei in effect before the accident. As discussed previously in this section, the $0.5 \%$ prescription is not applicable to ANS. Therefore, the 
Table 7.1-14. Source term calculation sheet for refueling accident with $100 \%$ damage to one element ${ }^{a}$

\begin{tabular}{ll}
\hline Nuclide & $\begin{array}{c}\text { Environmental release } \\
\text { to air }[\mathrm{Bq}(\mathrm{Ci})]\end{array}$ \\
\hline${ }^{83} \mathrm{Br}$ & $1.12 \times 10^{9}\left(2.03729 \times 10^{-2}\right)$ \\
${ }^{84} \mathrm{Br}$ & 0 \\
${ }^{85} \mathrm{Kr}$ & $8.83 \times 10^{12}\left(2.386944 \times 10^{2}\right)$ \\
${ }^{85 m} \mathrm{Kr}$ & $3.00 \times 10^{14}\left(8.119872 \times 10^{3}\right)$ \\
${ }^{87} \mathrm{Kr}$ & $5.13 \times 10^{10}(1.38528)$ \\
${ }^{88} \mathrm{Kr}$ & $9.98 \times 10^{13}\left(2.695968 \times 10^{3}\right)$ \\
${ }^{131} \mathrm{I}$ & $3.18 \times 10^{12}\left(8.593398 \times 10^{1}\right)$ \\
${ }^{132} \mathrm{I}$ & $5.33 \times 10^{12}\left(1.4414238 \times 10^{2}\right)$ \\
${ }^{133} \mathrm{I}$ & $4.52 \times 10^{12}\left(1.2208446 \times 10^{2}\right)$ \\
${ }^{133} \mathrm{Xe}$ & $5.32 \times 10^{10}\left(1.438560 \times 10^{6}\right)$ \\
${ }^{133 m} \mathrm{Xe}$ & $1.91 \times 10^{15}\left(5.157504 \times 10^{4}\right)$ \\
${ }^{134} \mathrm{I}$ & $2.66 \times 10^{17}\left(7.2 \times 10^{6}\right)$ \\
${ }^{135} \mathrm{I}$ & $7.08 \times 10^{11}\left(1.91475 \times 10^{1}\right)$ \\
${ }^{135} \mathrm{Xe}$ & $1.34 \times 10^{16}\left(3.62304 \times 10^{5}\right)$ \\
${ }^{135 m} \mathrm{Xe}$ & $7.89 \times 10^{14}\left(2.1312 \times 10^{4}\right)$ \\
${ }^{138} \mathrm{Xe}$ & \\
\hline${ }^{13}$ & 0 \\
\hline
\end{tabular}

"Source term calculations assume the following: (1) event frequency, $1 / 1000$ years; (2) release duration, $30 \mathrm{~d}$ (hegins 24 h after shutdown); (3) the nobles and halogens escape from the heavy water via leakage paths and/or via refueling water system; (4) fuel damage fraction is 0.666 ;

(5) containment fractional release before isolntion is 0.01 ;

(6) containment leak rate (fraction per day) is 0.005 ; (7) filter efficiency is 0.99 ; $(8)$ other retention factor is $500(1=$ no retention $)$.

"Half-lives and in-fuel inventory for these nuclides are given in Table 7.1-9. 
environmental releases for this accident are determined by the fraction of the primary coolant radioactivity inventory (see Table 7.1-9) that can escape as a result of a small pipe break.

The design of ANS's primary coolant system must be taken into account in order to model this accident. The most important ANS design feature in this regard is that most of the primary coolant system would be located under pools of water within the primary containment. Those parts of the coolant system not in pools of water would be in air cells of sufficiently limited volume to ensure submersion of the major coolant pipes after an accident. Smaller piping would typically connect to the primary coolant system's major piping in an air cell. Therefore, it is assumed that the break would occur in an air cell, allowing the leak to spray out into the chamber in such a manner as to maximize the chance for contamination to reach the containment atmosphere. Although the occurrence of a small break in an immersed portion of the primary coolant system would allow an environmental release, it would be less severe than a release triggered by a similar occurrence in an air cell.

The primary coolant leakage volume is $15 \mathrm{~m}^{3}$ (3960 gal) because the leak would not, in all likelihood, be isolable and the entire heavy water contents of the accumulators would discharge before the primary coolant system could reach ambient pressure.

As the airborne radionuclides reach the containment atmosphere, it is possible that the increased radiation level might be sufficient to trigger an automatic containment isolation, thereby preventing essentially all of the release. However, sufficient design information is not now available to allow determination of the likelihood of containment isolation. Therefore, the present analysis assumes that any airborne radioactivity reaching the containment atmosphere would be releas $u$ to the environment.

The source term for this event is summarized on Table 7.1-15. The release duration of $2 \mathrm{~h}$ is based on the normal ventilation rate of primary containment.

\section{Large pipe break}

The assumptions for this event follow the Regulatory Guide 4.2 prescriptions with two significant exceptions: (1) for previously discussed reasons there is no pre-existing fuel damage, and (2) fuel damage during the event is $1 \%$ instead of $2 \%$ because the acceptance criterion for the ANS emergency core cooling system for very infrequent events is $1 \%$. To maximize radioactivity release, the large pipe break is assumed to occur in a limited-volume air cell. The complete depressurization following a large pipe break would spill the entire $15-\mathrm{m}^{3}(3960 \mathrm{gal}) \mathrm{D}_{2} \mathrm{O}$ inventory of the accumulators to a limitedvolume air cell. This would be about $10 \%$ of the primary coolant inventory, so $10 \%$ of the fission products released by the fuel damage would be subject to rapid release to the containment atmosphere. Isolation of primary containment is assumed to occur before the escape of more than $1 \%$ of the containment air volume (see discussion under "Fuel bundle drop").

The source term for this event is summarized on Table 7.1-16. In calculating the initial release assumed to occur before containment isolation the immediate postshutdown fission product inventory is used; the long-term (30-d) release is estimated using the fission product inventory $24 \mathrm{~h}$ after shutdown (see Table 7.1-9). The preisolation release is important because charcoal and absolute air filtration is not initiated until isolation occurs. For example, about $42 \%$ of the total ${ }^{131}$ I hypothetical release takes place before isolation. The $1 / 1000$ years frequency listed for this event was chosen to represent conservatively a range of pipe failures that would severely challenge the ANS emergency core-cooling system. 
Table 7.1-15. Source term calculation sheet for small pipe break into limited volume celf ${ }^{a}$

\begin{tabular}{lc}
\hline & $\begin{array}{c}\text { Environmental release to air } \\
\text { Nuclide }{ }^{b, c}\end{array}$ \\
\hline${ }^{3} \mathrm{H}$ & $2.58 \times 10^{4}\left(6.975 \times 10^{3}\right)$ \\
${ }^{131} \mathrm{I}$ & $4.18 \times 10^{20}\left(1.13 \times 10^{-3}\right)$ \\
${ }^{132} \mathrm{I}$ & $1.11 \times 10^{8}\left(3.0 \times 10^{-3}\right)$ \\
${ }^{133} \mathrm{I}$ & $2.77 \times 10^{8}\left(7.5 \times 10^{-3}\right)$ \\
${ }^{134} \mathrm{I}$ & $1.11 \times 10^{9}\left(3.0 \times 10^{-2}\right)$ \\
${ }^{135} \mathrm{I}$ & $2.77 \times 10^{8}\left(7.5 \times 10^{-3}\right)$ \\
\hline
\end{tabular}

"Source term calculations assume the following:

(1) event frequency, 0.02 /year; (2) release duration, $2 \mathrm{n}$;

(3) volume of coolant spilled or released is $15,000 \mathrm{~L}$ (3970

gal) to limited volume air cell; (4) fraction vaporized, 0.093

[bounding calculation based on $82^{\circ} \mathrm{C}\left(180^{\circ} \mathrm{F}\right)$ initial coolant

temperature and $25^{\circ} \mathrm{C}\left(77^{\circ} \mathrm{F}\right)$ final temperature];

(5) lodine release fraction, 1.

'Half-lives and ccolant activity cons for these

nuclides are given in Table 7.1-10.

'Nonvolatile nuclides in coolant have been omitted.

\subsubsection{Detritiation Facility Accidents}

The detritiation facility is a support facility located in a separate building on the ANS site. The need to detritiate is unique to heavy water reactors, so Regulatory Guide 4.2 has no guidance for detritiation facility accidents. It is possible, however, to characterize conservatively the potential environmental releases with a series of four events (J. Devore, Engineering Div., ORNL, to M. Harrington, Central Management, ORNL, October 23, 1991). The first two events involve the cryogenic processing equipment, and the last two involve the storage of heavy water and deuterium tritium oxygen (DTO) in aqueous form.

(1) Discharge of $D_{2}$ from the cryogenic system to the building atmosphere, followed by detonation. This is a limiting event and its probability will have to be kept low by design features because an explosion would threaten worker health. A frequency of 1/500 years is assigned for an event of the severity assumed here.

(2) Accidental discharge of tritium into the off-gas treatment system by operator error during removal of tritium from the high tritium column. This event is represented as moderately frequent ( $1 / 10$ years).

(3) Discharge of heavy water from all tanks into the surface runoff to White Oak Creek (i.e. due to beyond-design-basis earthquake). This is the limiting event for exvironmenta! release of tritiated heawy water from this facility. The frequency of this event would be lower than the design basis earthquake frequency for the 
Table 7.1-16. Source term calculation sheet for large pipe break accident with $1 \%$ fuel damage ${ }^{a, b}$

\begin{tabular}{ll}
\hline $\mathrm{Nuclide}$ & \multicolumn{1}{c}{$\begin{array}{c}\text { Environmental release } \\
\text { to air }[\mathrm{Bq}(\mathrm{Ci})]\end{array}$} \\
\hline${ }^{83} \mathrm{Br}$ & $4.77 \times 10^{10}(1.29)$ \\
${ }^{84} \mathrm{Br}$ & $9.06 \times 10^{10}(2.45)$ \\
${ }^{85} \mathrm{Kr}$ & $1.32 \times 10^{11}(3.58)$ \\
${ }^{85 m} \mathrm{Kr}$ & $5.36 \times 10^{12}\left(1.45 \times 10^{2}\right)$ \\
${ }^{87} \mathrm{Kr}$ & $2.24 \times 10^{12}\left(6.19 \times 10^{1}\right)$ \\
${ }^{88} \mathrm{Kr}$ & $4.66 \times 10^{12}\left(1.26 \times 10^{2}\right)$ \\
${ }^{131} \mathrm{I}$ & $5.32 \times 10^{11}\left(1.44 \times 10^{1}\right)$ \\
${ }^{132} \mathrm{I}$ & $1.08 \times 10^{12}\left(2.56 \times 10^{1}\right)$ \\
${ }^{133} \mathrm{I}$ & $1.08 \times 10^{12}\left(2.92 \times 10^{1}\right)$ \\
${ }^{133} \mathrm{Xe}$ & $7.54 \times 10^{14}\left(2.0386 \times 10^{4}\right)$ \\
${ }^{133 m} \mathrm{Xe}$ & $2.70 \times 10^{3}\left(7.31 \times 10^{2}\right)$ \\
${ }^{134} \mathrm{I}$ & $6.88 \times 10^{11}\left(1.86 \times 10^{1}\right)$ \\
${ }^{135} \mathrm{I}$ & $6.40 \times 10^{11}\left(1.73 \times 10^{1}\right)$ \\
${ }^{135} \mathrm{Xe}$ & $1.88 \times 10^{14}\left(5.105 \times 10^{3}\right)$ \\
${ }^{135 m} \mathrm{Xe}$ & $1.21 \times 10^{13}\left(3.28 \times 10^{2}\right)$ \\
${ }^{138} \mathrm{Xe}$ & $5.62 \times 10^{12}\left(1.52 \times 10^{2}\right)$ \\
\hline
\end{tabular}

Source term calculations assume the following: (1) environmental release due to loss of coolant: negligible in comparison to fuel damage release; (2) fraction vaporized, 0.093 [bounding calculation based on $82^{\circ} \mathrm{C}\left(180^{\circ} \mathrm{F}\right)$ initial coolant temperature and $25^{\circ} \mathrm{C}\left(77^{\circ} \mathrm{F}\right)$ final temperatu:-1; (3) the nobles and halogens are assumed to escape through broken primary coolant pipe; (4) fuel damage fraction, 0.01 ; (5) containment fractional release before isolation, 0.01 ; (6) containment leak rate (fraction per day), 0.005 ; (7) filter efficiency, 0.99 ; (8) other retention factor, 10 ( 1 = no retention).

"Nuclide activities at $24 \mathrm{~h}$ used to evaluate the $30-\mathrm{d}$ leakages. For estimate of nuclides released with coolant, see Table 7.1-15.

'Half-lves and in-fuel inventory for these nuclides are given in Table 7.1.9. 
detritiation facility, which has not been chosen yet. Therefore, a trequency of $1 / 500$ years is assigned and will be updated if the chosen design basis earthquake has a frequency greater than $1 / 500$ year.

Discharge of heavy water from one tank into the low-level waste (LLW) system by operator error. This event is represerated as moderately frequent (1/10 years).

The environmental release for the itst vent would be $1.16 \times 10^{16} \mathrm{~Bq}$ $(314,000 \mathrm{Ci})$ in the form of tritiated water vapor; based on design inventories of a similar system designed and operated by Atomic Energy of Canada Limited. It is assumed that the explosion vents work, and that the tritium is discharged from the roof about $7 \mathrm{~m}$ $(23 \mathrm{ft})$ above ground level.

The initial release for the second event would be $1.16 \times 10^{15} \mathrm{~Bq}(31,400 \mathrm{Ci})$. Because the off-gas treatment system (catalytic oxidation and absorption) is designed for normal operations, it could be swamped with such a sudden infusion and remove only about $10 \%$. Therefore, the environmental release for the second event would be $1.03 \times 10^{15} \mathrm{~Bq}(28,000 \mathrm{Ci})$, released from the central stack. Due to low temperature oxidation, some $10 \%$ of the $1.03 \times 10^{15} \mathrm{~Bq}(28,000 \mathrm{Ci})$ would be in the chemical form tritiated water (HTO) or DTO, but the other $90 \%$ would be released in the form hydrogen tritium.

The environmental release for the third event, based on the $1.85 \times 10^{11} \mathrm{~Bq} / \mathrm{L}$ $(5 \mathrm{Ci} / \mathrm{L}$ ) design operational limit for ANS primary and/or reflector coolant, would be $6.73 \times 10^{14} \mathrm{~Bq}(18,200 \mathrm{Ci})$ as HTO or DTO into White Oak Creek, which discharges to the Clinch River below Melton Hill Dam.

The environmental release for the fourth event, based on the largest single, $1440-\mathrm{L}$ (381-gal) tank, and the $1.85 \times 10^{11} \mathrm{~Bq} / \mathrm{L}(5 \mathrm{Ci} / \mathrm{L})$ design operational limit on reactor coolant, would be $2.66 \times 10^{14} \mathrm{~Bq}(7200 \mathrm{Ci})$ of HTO or DTO released to the liquid waste system (and eventually, therefore, into White Oak Lake).

\subsubsection{Radiological Impacts of Postulated Nonsevere Accidents}

Accidents involving release of radioactivity can result in exposure of people in the same ways as normal releases (see Sect. 2.8). Thus, potential pathways include direct exposure from the plume, inhalation of airborne material, ingestion of dust carrying radioactive particles, ingestion of foods that have radioactive materials deposited on the surface or metabolically incorporated, and drinking water. Of all these possible routes of exposure, the direct atmospheric pathway is the most rapid. Atmospheric transport to the nearest residents can take place in less than $1 \mathrm{~h}$. Planned evacuation could be effected, if necessary, for the time when the plume passes over the residents. In the case of an accidental release involving greater amounts of radionuclides than normal operation, there is the opportunity to intervene a food supply if needed, because of the time $\mathrm{d}$ / lay between release of material and transport through the food chain to people. Due to this fact, for most of the accident scenarios described in the previous section, only direct irradiation from the plume and inhalation are considered as pathways for exposure to accidental releases to the atmosphere. For cases involving direct losses of radioactivity to waterbodies, the drinking water pathway is evaluated (although this pathway can easily be interdicted).

Radiation dose calculations for nonsevere accidents involving atmospheric releases have been made using the GENII computer code described in Napier et al. 1988. For purposes of this analysis, the atmospheric plume was assumed to be transported toward the nearest residents in Shore Line Estates $2800 \mathrm{~m} \mathrm{SE}$ of the ANS site. Further, the 
atmospheric stability was $F$ and the wind speed $1.2 \mathrm{~m} / \mathrm{s}(3.66 \mathrm{ft} / \mathrm{s})$. In the cases involving up to $6 \mathrm{~h}$, the wind was assumed to blow continuously toward the nearest residents. In the cases involving 30-d releases, the wind was assumed to blow in the direction of the nearest residents $10 \%$ of the time. The previous assumptions are conservative in that there is essentially no likelihood that actual meterorological conditions could result in greater radiation doses (Fig. 2.3-9 contains data that indicate that wind will blow in the SE direction less than $4 \%$ of the time).

In the scenario involving the large pipe break, $42 \%$ of the halogens (iodines are the important halogens in this situation) are assumed to be lost before isolation of the primary containment takes place. All of the initial release $(42 \%)$ is assumed to is assumed to be transported to the nearest receptor. The remainder of the source term escapes over a $30-\mathrm{d}$ period and, as previously noted, it is assumed that $10 \%$ of the $30-\mathrm{d}$ period has wind directed at the nearest receptor. Again, this assumption is conservative (see Sect. 2.3.3). The refueling accident with $100 \%$ damage to one fuel element also involves a $30-\mathrm{d}$ release. However, in this case, the entire release is assumed to take place uniformly over the 30-d period. The entire release for this case is subject to the assumption that the wind blows $10 \%$ of the time toward the nearest resident.

Results of the dose evaluations for the seven accident scenarios are presented in Table 7.1-16. Except for the detritiation facility accident, doses are all below $0.01 \mathrm{~Sv}$ (1 rem), whether for effective whole body or organ (thyroid). The detritiation facility accident is estimated to result in a dose of $0.013 \mathrm{~Sv}(1.3 \mathrm{rem})$. All other postulated nonsevere accidents for the ANS thus fall below the 0.01 Sv (1 rem) level at which EPA has recommended protective actions. For the case of the $0.013 \mathrm{~Sv}(1.3 \mathrm{rem})$ estimate, the recommended actions are, to seek shelter as a minimum, consider evacuation, or evacuate unless constraints make it impractical (EPA 1990).

In order to provide a perspective on the liquid pathway, the accident scenarios involving liquid discharges are evaluated for the drinking water pathway. The heat exchanger tube leak scinario and the heat exchanger tube rupture scenario involve relatively small amountis of radioactive discharges. Both of these scenarios contain smaller activities than are normally discharged annually from ORNL over White Oak Dam. The dose consequences to the maximum exposed individual will be less than the $0.001 \mathrm{mSv}$ (0.1 mrem) calculated for normal releases from ORNL (see Sect. 2.8). In the case of the detritiation facility acciclents, one scenario involves release of $6.73 \times 10^{14} \mathrm{~Bq}(18,200 \mathrm{Ci})$ of tritium that are assumed to pass over White Oak Dam. Because environmental transport cannot be predicted with accuracy, several conservative assumptiors were made. First, all $6.73 \times 10^{14} \mathrm{Bd}(18,200 \mathrm{Ci})$ are assumed to enter the Clinch River in a month's time. Second, the Clinich River is assumed to be at a low flow $\left[2 \times 10^{11} \mathrm{~L} / \mathrm{month}\right.$ $\left.\left(5.28 \times 10^{10} \mathrm{gal} / \mathrm{month}\right)\right]$. Third, a person is assumed to consume $100 \mathrm{~L}(26.4 \mathrm{gal})$ of this water. On this basis a dose of $8.2 \times 10^{-6} \mathrm{~Sv}\left(8.2 \times 10^{-4} \mathrm{rem}\right.$ ) is estirnated. This is equivalent to about $1 \%$ of the annual natural external background radiation dose in Tennessee.

\subsection{TRANSPOR YATION ACCIDENTS INVOLVING RADIOACTIVITY}

\subsubsection{Transportation R/sk Assessment}

During the ANS transportation risk assessment, the following three scenarios were analyzed: (1) fresh fuel shipments from the Babcock and Wilcox fuel fabrication plant to ANS, (2) spentit fuel shipmeñts from ANYS to SRS, and (3) oñ-site shipments of fresh and 


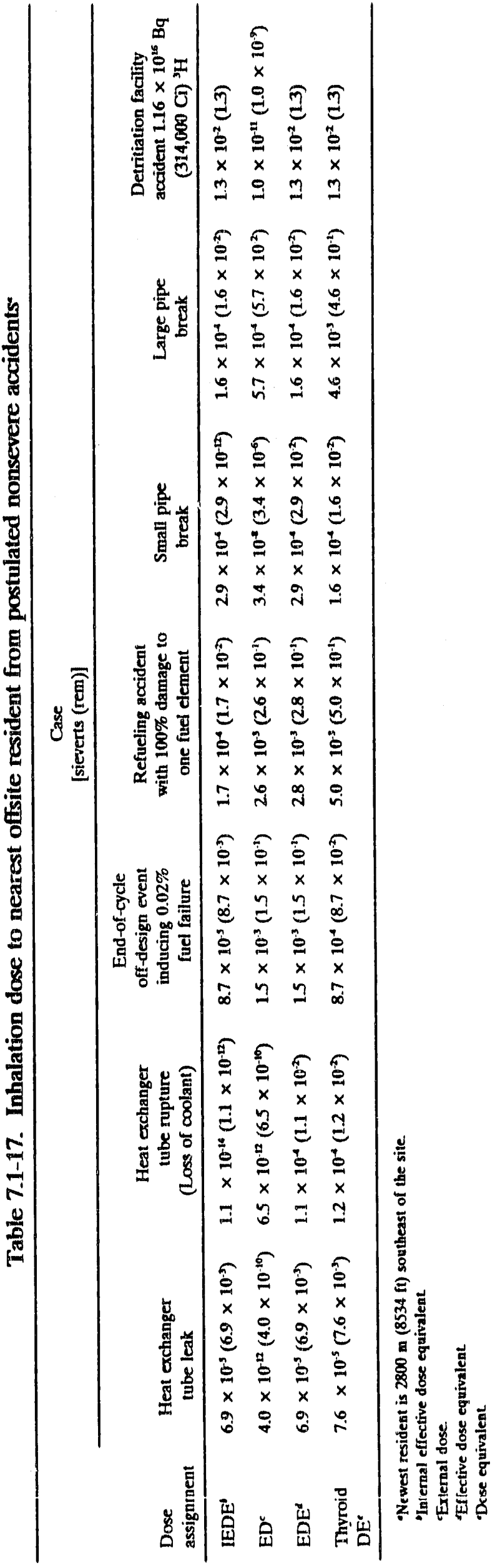


irradiated targets, LLLW, and CH-SLLW from ANS to HFIR. The third scenario consists of three RADTRAN runs to model the on-site shipments of fresh and irradiated targets, LLLW, and CH.SLLW.

RADTRAN IV models both the incident-free radiological exposure and the consequences of radiological releases due to severe accidents. The incident-free risks are dependent on the radiation dose rate from the shipment, number of shipments, package dimensions, route distance, vehicle velocity, and population denrities along the transportation routes. The accident risks are dependent on the radiological inventory, accident severity, probability of occurrence for each accident category, and the amount of inventory released, aerosolized, and inhaled, as well as the dispersibility of the waste form. The primary RADTRAN assumptions used for the ANS transportation risk assessment are given in Table 3.8.2. More detailed information on the transportation risk assessment, including the calculation of incident-free risk, can be found in Sect. 3.8.1.

\subsection{Summary of Transportation Risks from Accidents}

An analysis of the three transportation scenarios was performed using the RADTRAN IV risk assessment code (Neuhauser et al. 1984, Neuhauser and Reardon 1989, pp. 1074-1080), to determine the radiological impacts associated with the transport of radioactive materials to and from ANS. The radiological impacts considered were health effects associated with normal (incident-free) transport and with transport involving low-probability accidents severe enough to release some or all of the radioactive material.

Accident risks encompass both acute fatalities and LCFs (chronic) to both present and future generations due to accidents. The accident risk (expected value of dose from accidents) is the summation of the products of estimated dose for each accident-severity category and the associated probability of occurrence for the category. Incident-free risk results from exposure of the surrounding population to radiation emitted by the waste packages during normal transport.

Table 3.8.4 lists the risk of LCFs expected to result from radiation exposure from postulated accidents. Radiation doses to the general population were converted to estimates of LCFs using the upper limit risk coefficient $2.0 \times 10^{-4}$ LCFs per 0.01 person-Sv (1 person-rem) suggested by the National Academy of Sciences (CBEIR 1980 , pp. 1-524). No acute radiation fatalities are projected as a result of releases of radioactive material from any postulated accidents. Thus, only LCFs and the maximum individual radiation dose have been included in Table 3.8.4.

The analysis indicates that the radiological risks of transporting radioactive materials to and from ANS would be quite low. The number of LCFs statistically expected to occur from the calculated exposures does not exceed $4.22 \times 10^{-4}$ LCFis for any postulated accident. The maximally exposed individual would receive $5.86 \times 10^{-8} \mathrm{mSv}\left(5.86 \times 10^{-6} \mathrm{rem}\right)$, which is less than $0.0029 \%$ of the $2 \times 10^{-3} \mathrm{mSv}$ $(200$-mrem) average annual effective dose received from natural background radiation sources.

\subsection{REFERENCES FOR SECTION 7}

AEC (U.S. Atomic Energy Commission) 1963. Technical Information Document, DIDTID-14844, Washington, D.C. 
CBEIR (Committee on the Biological Effects of Ionizing Radiation) 1980. The Effects on Population of Exposures to Low Levels of Ionizing Radiation, National Academy Press, Washington, D.C.

Chanin et al. 1990. MELCOR Accident Consequency Code System, NUREG/CR-4691, Washington, D.C.

DOE (U.S. Department of Energy) 1991. Draft Environmental Impact Statement for the Siting, Construction, and Operation of New Production Reactor Capacity, Vol. 1, DOE/EIS-01440, April.

EPA (Environmental Protection Agency) 1990. Manual of Protective Actions for Nuclear Incidents, Office of Radiation Programs, U.S. EPA, EPA 520-001A, Washington, D.C.

Hyman, C. R. and R. B. Taleyarkhan 1991. Characterization of Coal Debris/Concrete Interactions for the Advanced Neutron Source, ORNL/TM-11761, Oak Ridge National Laboratory, Oak Ridge, Tenn.

Napier, B. A., et al., 1988. GENII-the Hanford Environmental Radiation Dosimetry Software System, Pacific Northwest Laboratory, PNL-6584, Richland, Wash.

Neuhauser, K. S., et al. 1984. A Preliminary Cost and Risk Analysis for Transporting Spent Fuel and High-Level Wastes to Candidate Repository Sites, SAND84-1795, Sandia National Laboratories, Sandia, N.M., October.

NRC (U.S. Nuclear Regulatory Commission) 1975. Reactor Safety Study, NUREG/75-0114, Washington, D.C.

NR.C (U.S. Nuclear Regulatory Commission) 1976. Preparation of Environmental Reports for Nuclear Power Stations, Regulatory Guide 4.2, rev. 2, NUREG-0099.

Saito et al. 1989. Further Data of Silicide Fuel for the LEU Conversion JMTR, Proceedings of International Symposium Research Reactor Safety Operations and Modifications, IAEA-SM-310/59P, Vienna.

Summers et al. 1991. MELCOR 1.8.0: A Computer Code for Nuclear Reactor Severe Accident Source Term and Risk Assessment Analyses, NUREG/CR-5531, Washington, D.C. 


\section{SOCIOECONOMIC EFFECTS}

Socioeconomic effects of the Advanced Neutron Source (ANS) facility would primarily be characterized by changes in local employment and income. These may be examined by projecting the potential employment and income changes associated with the ANS facility's construction and operation and then evaluating the impact of these changes on the existing local economic and social structure. A key indicator of potential socioeconomic effects is population change. Changes in population precipitate changes in requirements for public and private services; therefore, the project's economic impact will be examined to determine how it might affect population and ultimately public and private services in the local area.

The region of influence (ROI) is defined as a five-county area comprised of Anderson, Knox, Loudon, Morgan, and Roane counties. This determination was based on the Department of Energy (DOE) payroll per capita in these counties as indicated in Table 8-1. The DOE payroll per capita was used to determine the ROI because it indicates the locations of the residences of employees who work at the federally funded facilities and projects in and near Oak Ridge. Of these counties. Anderson and Roane are by far the counties with the largest per capita impacts. Although not as large on a per capita basis, the total DOE payroll is quite large in Knox County, which has a much larger population than other impacted counties. Within the ROI, Table 8.2 indicates the numbers (by location) of Oak Ridge National Laboratory (ORNL) employees living within incorporated areas.

In 1990, the ROI had a combined population of 497,831 (see Table 8-3). About two-thirds of the ROI population resides in Knox County. In 1990, the overall unemployment rate of $4.6 \%$ in the ROI was low compared with Tennessee $(5.2 \%)$ and U.S. (5.5\%) averages. As indicated by personal income per capita, the ROI is typical of Tennessee. However, within the ROI, Morgan County, which has only $4 \%$ of the ROI's population, suffers from a depressed economy as indicated by its $8.9 \%$ unemploymen: rate.

The existing DOE opera: :. "s are extremely critical to the economy of the ROI. The 1990 annual payroll for DOE's Oak Ridge facilitics (ORNL, Y-12 Plant, and K-25 Site) was $\$ 597$ million with $\$ 226$ million going to employees of ORNL. Significant additional payroll is generated as the result of the local subcontractors that support DOE's Oak Ridge Operations. Regular employment at the DOE Oak Ridge facilities included 15,025 employees in December of 1990. In September 1991, regular employment at ORNL was 5132 or 7810 including part-time employees and guests (ORNL Workforce Report 1991).

Another measure of the economic impact of DOE on the local area is indicated by the DOE payroll per capita (Table 8-1) compared with the personal income per capita (Table 8-3). By this measure, Anderson and Roane counties and the city of Oak Ridge are extremely dependent on DOE expenditures, with DOE payroll representing over $10 \%$ of the personal income. Even this figure somewhat understates the economic significance of DOE activities because it does not include purchases of equipment and material from local businesses and the secondary income that is generated as employees expend their payroll income on local goods and services. 
Table 8-1. Department of Energy (DOE) local payroll distribution

\begin{tabular}{lccc}
\hline \multicolumn{1}{c}{ Municipality } & $\begin{array}{c}\text { DOE payroll } \\
(\$ 1,000)\end{array}$ & $\begin{array}{c}\text { Total payroll } \\
(\%)\end{array}$ & $\begin{array}{c}\text { DOE payroll } \\
\text { per capita }\end{array}$ \\
\hline City of Oak Ridge & 155,018 & 28.1 & 5,676 \\
Anderson County & 207,031 & 37.5 & 3,033 \\
(including Oak Ridge) & & & \\
Blount County & 8,575 & 1.6 & 100 \\
Campbell County & 7,975 & 1.4 & 227 \\
Cumberland County & 2,128 & 0.4 & 61 \\
Knox County & 185,947 & 34.1 & 554 \\
Loudon County & 28,756 & 5.2 & 920 \\
McMinn County & 1,195 & 0.2 & 28 \\
Monroe County & 3,427 & 0.6 & 112 \\
Morgan County & 8,337 & 1.5 & 482 \\
Roane County (including Oak Ridge) & 87,547 & 15.9 & 1,852 \\
\hline
\end{tabular}

Source: Chance, W. W. and C. E. Frye 1989. Oak Ridge Reservation Site Development and Facilities Utilization Plan, DOE/OR-88.5, prepared by Martin Marietta Energy Systems, Inc., for the

U.S. Department of Energy, pp. 2-8.

\subsection{EMPLOYMENT AND INCOME}

The employment and income associated with the construction and operation of ANS can be classified into primary and secondary components. The employment and income that would be generated directly by ANS salary and wages paid to local residents and by purchases from local businesses is the primary component. The secondary component is additional employment and income that can be attributed to ANS as the primary income is spent in the local economy.

For purposes of analysis, the estimate of employment and income generated by ANS has been based on several categories. Employment categories have been broken down into craft employment, which is associated with construction, and noncraft employment, which is associated with design, management, and operation. Other categories comprise the expenditures for equipment and material associated with construction and operation.

This section assumed project approval in FY 1993 and design started accordingly. Current project plans are that the project will be approved, at the carliest, FY 1994. This 1-year project delay will defer the impacts resulting from this analysis one year. 
$8-3$

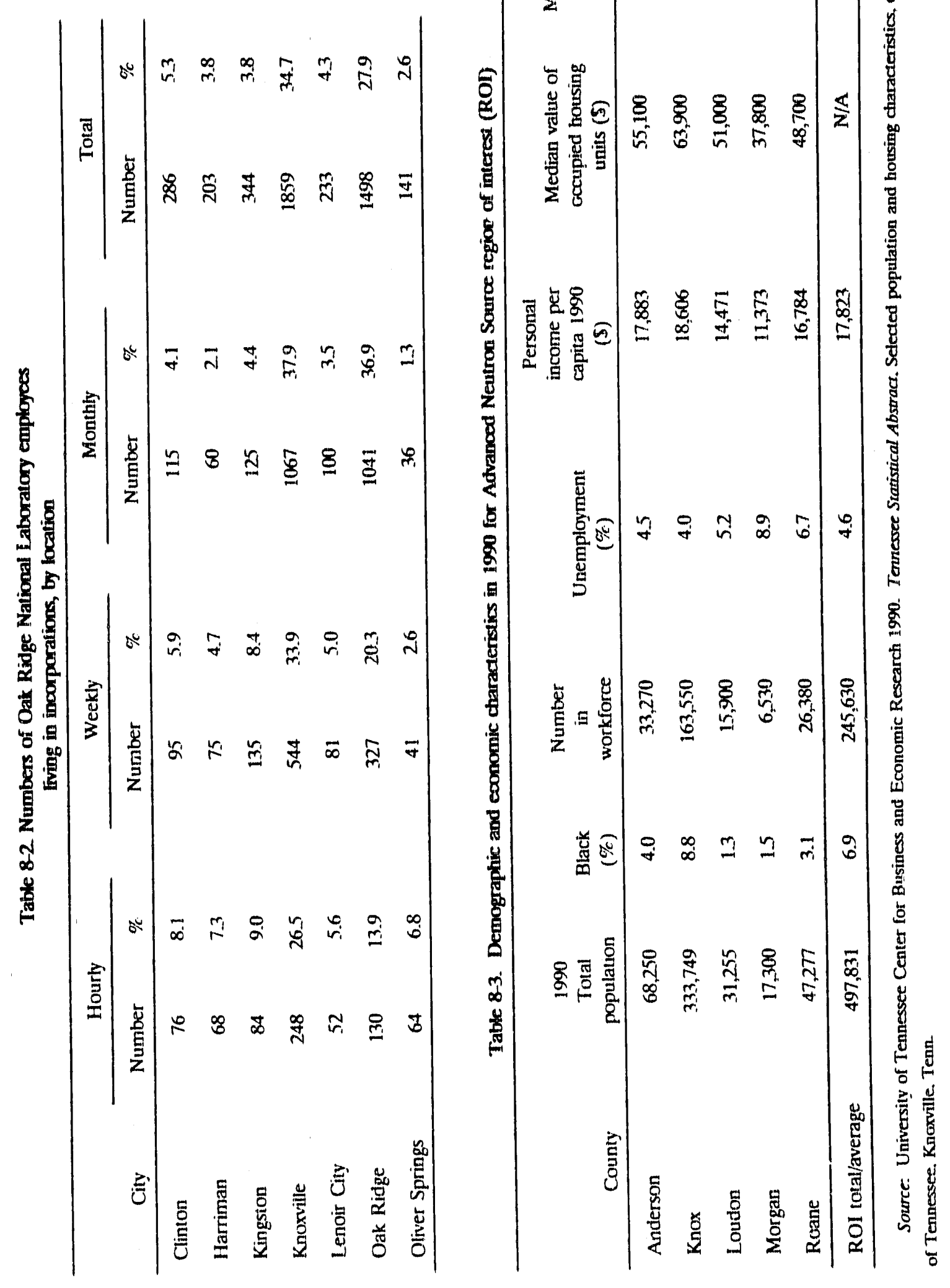


The classification of employment and income facilitates analysis of the economic changes that could induce population changes. For example, because primary emaployment generated by ANS requires concentrations of specifle skills that may not be avallable in the local area, it might actually require more workers trom outside the area than would the secondary employment generated by the facility. Secondary employment usually involves employment in services and retail trade for which the necessary work force is Incally available.

Projected budget data has been used in conjunction with assumptions about employment expenditures per full-time equivalent and labor costs per hour. Tables 8.1-1 and 8.1-2 present an estimated ANS budget for local expenditures and direct employment. Noncraft employment will peak at slightly more than 300 people in 1995 and provide an operating work force of 200 , starting in 2004. The construction work force is expected to peak in 1999 at about 540. The combined craft and noncraft work forces are also expected to peak in 1999 at slightly less than 800 . Table 8.1-3 allocates the projected direct employment to the live counties in the ROI in the same proportion as indicated by payroll distribution in Table $8-1$.

The noncraft employment necessary during construction and operation of ANS will be composed of engineers, managers, scientists, and their support staff. Much of this employment will be drawn from the existing pool of employees at ORNL. The most prominent source of new employment is engineering and management personnel associated with the design and supervision of the project. However, these activities would peak in 1994 and 1995 and therefore would not add to the peak direct employment projected for 1999 in Table 8.1-2. Some of the 200 operational workers would be transferred from the existing High Flux Isotope Reactor (HFIR) work force and thus would not represent new workers in the employment ligures.

Table 8.1-4 lists the distribution of craft requirements over the project schedule. Pipefitters would be the most heavily utilized craft, peaking at 187 in 1999; therefore, they have been considered an indicator of the potential for immigration due to labor demand that cannot be satisfied within the local area through daily commuting. Local 102 Plumbers and Pipefitters Union covers 19 East Tennessee counties including all the counties in the RO1. Currently, 207 active journeymen are available from this local. Additional journeymen could be made available through the apprentice program, which currently includes 40 apprentices. If sufficient work becarne available, approximately 40 journeymen could return from pipefitting jobs outside the area. Other available members are currently unemployed, underemployed, or working in other types of jobs until work becomes available. If other projects (now unforeseen) develop requiring additional labor, the union could respond through increasing the apprentice program and/or calling on other locals in Chattanooga. Nashville, and Johnson City (G. Jones, Business Agent, Knoxville Local 102. Plumbers and Steamfitters, October 10, 1991 personal communication with J. W. Van Dyke, Oak Ridge National Laboratory, Oak Ridge, Tenn.).

It appears that sufficient pipefitters would be available from Local 102 so that there would be no need for other pipefitters 10 relocate. If additional projects materialized that exceeded local availability, then pipefitters from nearby locals would most likely commute on a weekly basis, renting motel rooms at weekly rates or living in trailer homes through the week and returning to their permanent homes during weekends and holidays. It is unlikely that there would be any relocation of families to the ROI (G. Jones, Business Agent, Knoxville Local 102 Plumbers and Steamfitters, October 10, 1991 personal communication with J. W. Van Dyke, Oak Ridge National Laboratory, Oak Ridge, Tenn.,). Thus, it appears that the labor supply of pipefitters would be 


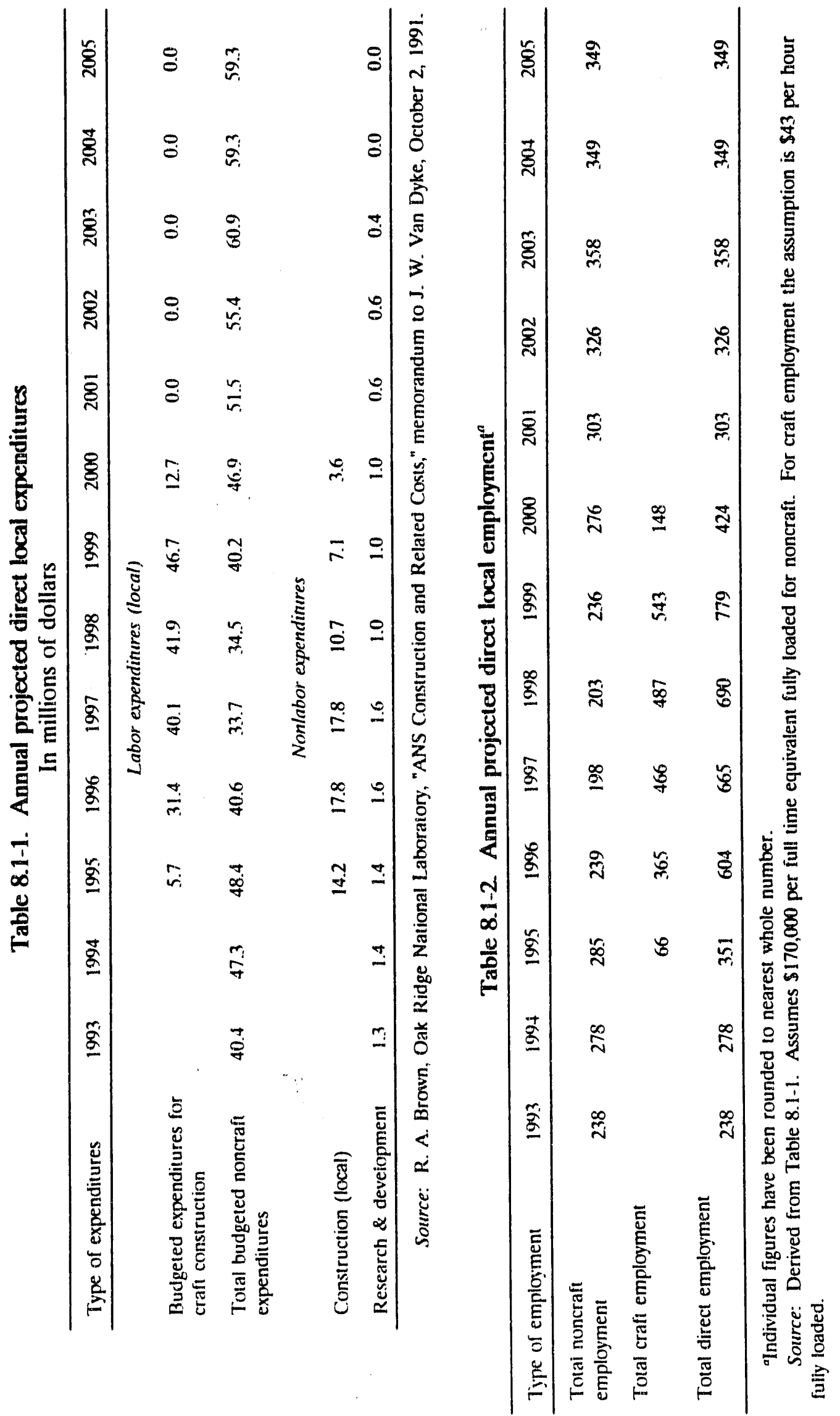




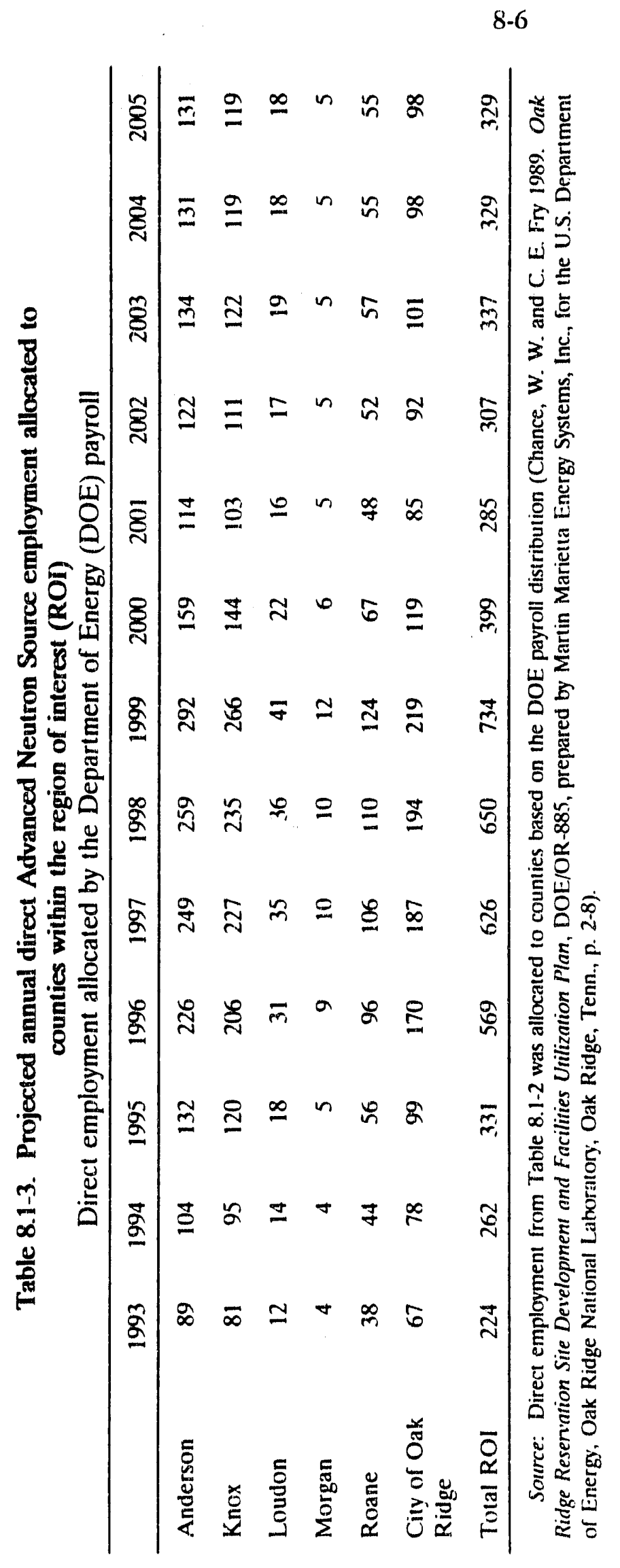


Table 8.1-4. Projected craft employment by year during construction of Advanced Neutron Source ${ }^{a}$

\begin{tabular}{lcccccc}
\hline $\begin{array}{c}\text { Construction } \\
\text { employment }\end{array}$ & 1995 & 1996 & 1997 & 1998 & 1999 & 2000 \\
\hline Boilermaker & 2 & 14 & 13 & 20 & 13 & 2 \\
Carpenter & 13 & 60 & 71 & 57 & 56 & 8 \\
Laborer & 16 & 74 & 87 & 70 & 46 & 21 \\
Electrician & 5 & 37 & 52 & 104 & 115 & 31 \\
Pipefitter & 8 & 60 & 113 & 141 & 187 & 51 \\
Ironworker & 10 & 46 & 54 & 33 & 43 & 13 \\
Operating engineer & 6 & 28 & 33 & 20 & 26 & 8 \\
Miscellaneous & 7 & 46 & 43 & 44 & 57 & 13 \\
$\quad$ Total craft & 66 & 365 & 466 & 487 & 543 & 148 \\
$\quad$ employment & & & & & & \\
\hline
\end{tabular}

"Individual figures have been rounded to nearest whole number.

Sources: Projected craft labor distribution in "ANS Project Economic Information 19-Sep-91" (C. F. Weiss, Gilbert/Commonwealth, communication craft distribution) and projected craft labor expenditures in Tables 8.1-1 and 8.1-2.

sufficient to meet project requirements with few if any inmovers into the area. It seems reasonable to conclude that the other crafts would also be able to provide adequate labor without immigration from outside the area.

\section{Income, Employment, and the Effect on Local Economic Structure}

Project expenditures are summarized in Tables 8.1-1 and 8.1-2; however, total budgeted expenditures are not necessarily indicative of total economic effects of the project on local income and employment. The budgeted amount (for noncraft labor only) has been reduced by $10 \%$ to account for various internal taxes that support other research activities. This adjusted figure was then reduced by $25 \%$ to account for taxes. Of this amount it was assumed that $70 \%$ (average propensity for local consumption) would be spent in the local economy. The calculation is $1 \times 0.9 \times 0.75 \times 0.7=0.4725$. This figure is used to adjust the projected budget for noncraft labor, excluding equipment and materials, to project local economic effects. An adjustment of $1 \times 0.75 \times 0.7=0.525$ was used for craft labor. Nonlabor expenditures were not adjusted.

Table 8.1-5 uses Regional Industrial Multiplier System (RIMS) II multipliers (DOC 1986, p. 114) to estimate the total economic effect of ANS on the local economy. Tables 8.1-6 and 8.1-7 have allocated the estimated increases in earnings and employment, including secondary effects, to the ROI counties proportional to the DOE payroll presented in Table 8-1. The relative effects would be largest in Anderson and Roane counties and the city of Oak Ridge. In Anderson County, the largest total employment effect is projected to be in 1997 with 735 . This would be about $1.6 \%$ of the projected 
$8-8$

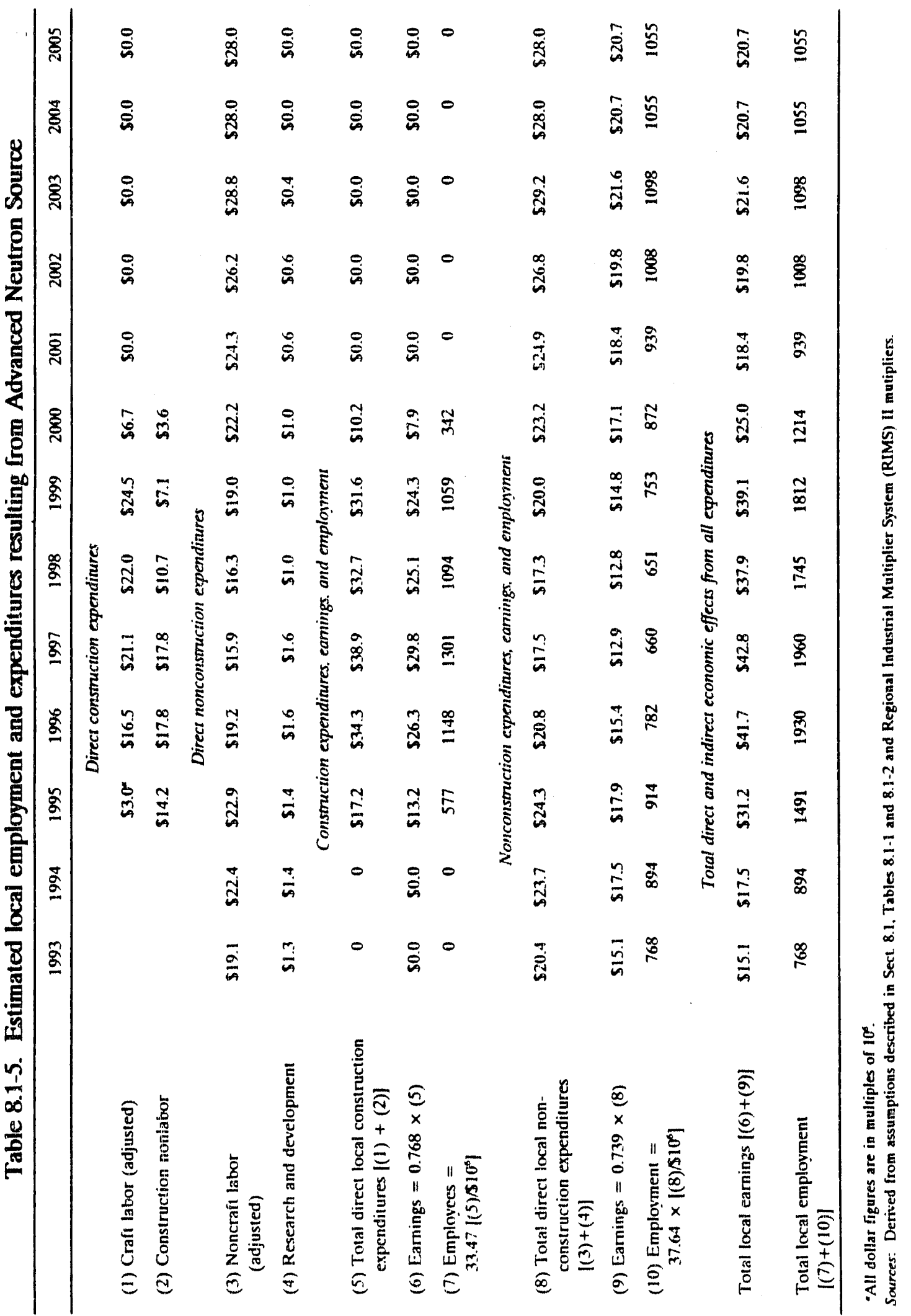




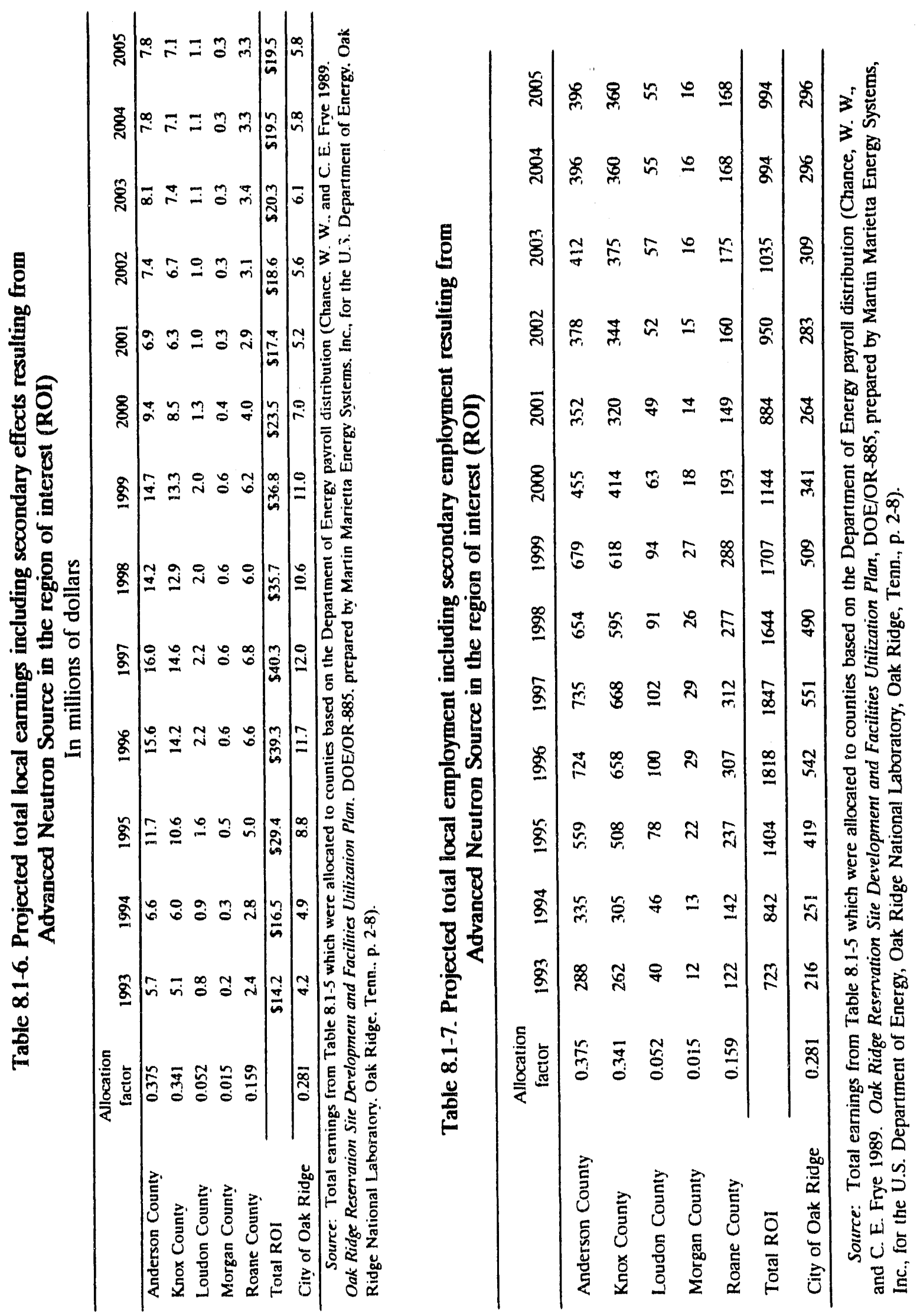


total employment for that year. The effect in Roane County in 1997 would be 312, or $1.1 \%$ of the total projected employment. In 1997 the projected total employment effect in Oak Ridge would be 551 or $4.1 \%$ of total estimated employment.

The net economic effect of the ANS project, including secondary employment and income, would be decidedly positive. This positive effect would be greatest from 1995 through 1999 while the proposed facility was under construction. Total local employment would reach about 2000 before declining to about 1000 after facility operations began. While these numbers are large, they are less than $1 \%$ of the ROI labor force and would not cause a significant change in the local economy.

With the exception of specialized scientific and managerial positions, the primary and secondary employment associated with ANS would be supplied with local labor. Therefore, little immigration would be associated with construction and operation of the proposed facility.

\subsection{POPULATION}

Table 8-3 presents selected population and housing characteristics for the counties within the ROI. The analysis of labor and supply requirements indicates that most of the incremental employment required for ANS would be tilled by local residents; therefore, the proposed facility would induce very little population change. Assuming that half of the noncraft employees came from outside the area, about 140 workers would relocate within the ROI during 1995, the peak year for noncraft employment (see Table 8.1-2). Assuming that each worker moving into the area brings two additional family members, the population would increase by about 420 . This increase would be distributed across the ROI, and it is unlikely that it would have a noticeable effect on any one community. For example, existing DOE operations (see Table 8-1) have by far the largest per capita effect on the city of Oak Ridge. Assuming that inmoving pof "llation was distributed in the same proportion in Oak Ridge as are DOE payroll expenditures (Table 8-1), the Oak Ridge population would increase by about 120 residents. This would be one-half of $1 \%$ of the existing Oak Ridge population of about 27,000 . Part of this population change would be temporary because noncraft employment would fall to a permanent level of 350 during operations (see Table 8.1-2). This would result in a permanent population increase in the city of Oak Ridge of less than 100 or about four-tenths of $1 \%$ of the existing Oak. Ridge population during the facility's operation. According to the comprehensive plan of the city of Oak Ridge (City of Oak Ridge 1989, p. 21), one broad objective of the city is "to gradually and consistently increase the city's population." Therefore, a modest increase could be considered beneficial.

\subsection{HOUSING AND PURLIC SERVICES}

For the most part, necessary on-site services for ANS would be provided for by extending or enhancing the existing ORNL infrastructure; therefore, little if any strain on existing services would be associated with the on-site construction and operation of ANS. The major utilities serving the Oak Ridge Reservation (ORR) are raw and treated water, natural gas, telecommunications, steam from an on-site coal plant, and electric power (Chance and Frye 1989, p. 3-32). Electricity would be provided through three feeders, two independent $13.8-\mathrm{kV}$ feeders from the main ORNL substations, and a third from a $161-\mathrm{kV}$ line that extends from Ft. Loudon Dam to the Y-12 Plant. The two feeders from 
the existing ORNL distribution system, are supplied by the Tennessee Valley Authority (ORNL 1991, p. 29).

Water would be supplied by a 16 in. main for potable, fire protection, and process needs. This main would access sanitary water from two storage tanks on Pine Ridge with a combined capacity of $15,141 \mathrm{~kL}$ ( 4 million gal). These water tanks are owned by DOE but also provide water to the Oak Ridge city industrial area. The on-site system provides for two independent water supplies: the ORNL potable water/fire protection system and a minimum on-grade storage tank [1,135,500 L $(300,000$ gal $)]$. Sanitary sewage would be supplied through corridors to the ORNL sewage treatment plant. Currently a need for natural gas is not anticipated. (Chance and Frye 1989, p. 3-36; ORNL Site and Facilities Planning 1991, p. 29)

The requirement for additional public services should be closely correlated with population effects. Because population changes assessed in Sect. 8.2 are insignificant relative to existing population, requirements for additional public services associated with these changes are assumed to be negligible. Support for this assessment is provided in a study of refurbishment of seven nuclear power plants and the potential impacts on housing and public services of 1810 additional refurbishment workers (NRC 1991, pp. 3-5 to 3-25). This analysis found that, in general, only where refurbishment of nuclear power plants took place in relatively sparsely populated areas was there the potential for any significant impacts on public services. For ANS workers, the peak demand for services is projected to come in 1999 (see Table 8.1-2). The number of ANS workers is well below the projected work force of about 1800 assumed in the Nuclear Regulatory Commission (NRC) study of refurbishment. Using the NRC study's criteria, the ANS site would be classified as a high population area where potential effects on public services from the projected work force would tend to be insignificant.

Aside from the ROI, the population within $32 \mathrm{~km}$ ( 20 miles) of the proposed ANS facility is over 300,000 , and within $80.5 \mathrm{~km}$ ( 50 miles) the population is over 900,000 (ORNL 1991, p. 2-15) This exceeds the population criteria that were used to classify high-population sites in the NRC study of refurbishment. Projected impacts for all the high-population reactor sites were evaluated as insignificant except for traffic effects at one of the sites. The categories of projected impacts included the following: housing, education, transportation, public safety, social services, public utilities, and tourism and recreation. The potential impact of ANS traftic is evaluated in Sect. 8.6. Given the similarities between ANS and the NRC sites in terms of size of population and development level of public and private infrastructures, there is no reason to believe that ANS impacts on other public services would be significant.

\subsection{FISCAL AND TAX EFFECTS}

The fiscal and tax effects of ANS would be due to tax revenues generated by the project, requirements for additional services associated with increased population, and the increased income base in the local area. The LOE facilities paid about $\$ 1.3$ million in sales tax to Roane County in 1988. Although materials purchased in the construction and operation of the ANS facility would be subject to local and state sales tax, the real estate and personal property value of the ANS facility would not contribute any property tax or in-lieu-of-tax payments to local governments because ANS will be federally owned (J. Fowler, Asst. Chief Counsel, DOE Oak Ridge Operations, October 3, 1991 personal communication with J. W. Van Dyke, Oak Ridge National Laboratory, Oak Ridge, Tenn.). 
However, even though the facility would not contribute directly to the property tax base, as Sect. 8.3 indicates, public infrastructure would not be required for the facility.

The additional ANS employment and the income associated with ANS would tend to raise residential property values and increase the number of taxable expenditures throughout the area. This would provide additional tax revenue that would tend to corr late with residential location and expenditure patterns of ANS employees (see Sect. 8.2). The magnitude of potential sales tax revenues is indicated by Table 8.4-1.

Overall, there should be a favorable effect on the fiscal ability of local governments to generate tax revenue. Employees at ANS during the construction and operating phases would tend to make above average incomes for the local area. The income generated through ANS would result in maintaining or enlarging the existing tax base through increased residential property values and sales tax collections. However, because there are relatively small changes projected for local populations (see Sect. 8.2) the associated fiscal and tax effects would tend to be small relative to local government budgets (Table $8.4-1$ ).

\subsection{LAND USE}

The ANS facility would be located on the DOE ORR in an undeveloped expanse that is classified as a natural area. Within ORR there are many other land-use classifications, related to various types of activities, that support DOE's programmatic requirements. Table 8.5-1 presents the distribution of ORR's land use by area. The ANS facility would require 46 ha ( 115 acres), which is $0.3 \%$ of the total land encompassed by ORR. The land used for ANS would accommodate the reactor building and a complex of support buildings and other facilities with footprint of 4-5 ha (10-12 acres). In addition, roads and parking areas will cover $6-8$ ha (15-20 acres). The buildings and support facilities would reduce the existing land on ORR classified as natural by $0.5 \%$ and increase the land used for research and development by $1.6 \%$. Although the existing land use of the proposed site would be altered, the development of this area for the ANS facility is consistent with the general programmatic requirements for which ORR is currently used. The changes in land use necessary for the proposed ANS facility would have no effects outside ORR.

\subsection{TRANSPORTATION}

Access to the new ANS facility would be through two interstate highways, 140 and 1-75, and U.S. Highways $11,25 \mathrm{~W}$, and 70 . State highways that lead to the area include 58 , $61,62,95$, and 162. These highways lead to Bethel Valley Road, which is the last public road leading to the site (Fig. 8.6-1). State Routes (SRs) 95 and 62 intersect. Bethel Valley Road on the west and east ends, respectively. The major access road to the site is Melion Valley Road, which intersects Bethel Valley Road approximately $3.7 \mathrm{~km}(2.3$ miles) east of the SR-95 intersection and $8.9 \mathrm{~km}$ (5.5 miles) west of the SR-62 intersection. The ANS facility would be located at the intersection of Melton Valley Road, Melion Valley Drive, and Ramsey Drive (Fig. 8.6-2). These are private roads and therefore will not be included in this discussion. The major public access roads examined for potential adverse effects on traffic due to the construction and operation of the ANS facility are Berhel Valley Road, SR-95, and SR-62. These routes were evaluated for changes in traffic flcws and level of 


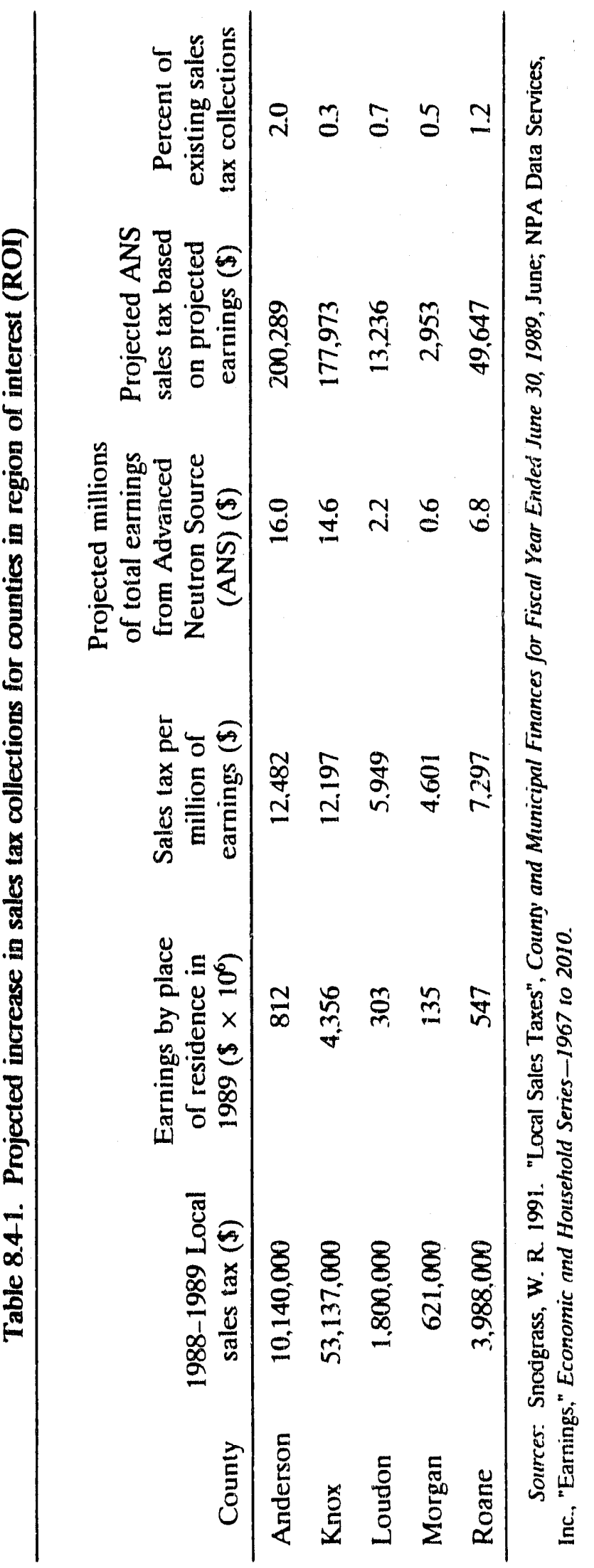




\section{8-14}

Table 8.5-1. Distribution of land use by area and percentage

\begin{tabular}{|lrrr}
\hline \multicolumn{1}{c}{ Classification } & \multicolumn{2}{c}{$\begin{array}{c}\text { Area } \\
\text { [ha (acres)] }\end{array}$} & $\begin{array}{c}\text { Percent of } \\
\text { total }\end{array}$ \\
\hline Administration/technical services & 49 & $(120)$ & 0.3 \\
Research and development & 2,470 & $(6,100)$ & 17.3 \\
Production & 180 & $(445)$ & 1.3 \\
Support & 1,721 & $(4,250)$ & 12.1 \\
Waste & 304 & $(750)$ & 2.1 \\
Public & 320 & $(790)$ & 2.2 \\
Natural & 8,735 & $(21,577)$ & 61.2 \\
Buffer & 494 & $(1,220)$ & 3.5 \\
$\quad$ Total & 14,272 & $(35,252)$ & 100.0 \\
\hline
\end{tabular}

Source: Chance, W. W., and C. E. Frye 1989. Oak Ridge Reservation Site Development and Facilities Utilization Plan, DOE/OR-885, prepared by Martin Marietta Energy Systems, Inc., for the U.S. Department of Energy, Table 5.1, June.

service (LOS). LOS is a qualitative measure describing operational conditions of a traffic stream and human perception of those conditions (TRB 1985).

For the analysis, the roads were divided into five segments:

- Bethel Valley Road East, from Melton Valley Road eastward to SR-62;

- Bethel Valley Road West, from Melton Valley Road westward to SR-95;

- SR-95 North, from Bethel Valley Road northward to SR-58;

- SR-95 South, from Bethel Valley Road southward to I-40; and

- SR-62, from Bethel Valley Road southward to the Pellissippi Parkway (toward Knoxville).

All of these road segments are classified as two-lane rural highways except SR-62, which is a four-lane rural highway.

The impact of construction and operation of the ANS facility on traffic was evaluated using the year with the greatest increase in number of workers as a reference. It is anticipated that the number of new workers will peak at 779 in 1999 . Two future traffic scenarios were evaluated for the increase in work force: (1) driving alone (one new worker per car) and (2) carpooling (two new workers per car). In both cases, the number of workers using each access road was assumed to be proportional to the present distribution of traffic flow on these roads (TN DOT 1990). In addition, it was assumed that each new worker would travel to and from work on the same route. Therefore, there will be twice as many vehicles per day as there are new employees (under the driving alone scenario). The 1990 average daily traffic flows and the estimated average daily flows under the two future scenarios are presented in Table 8.6-1. 


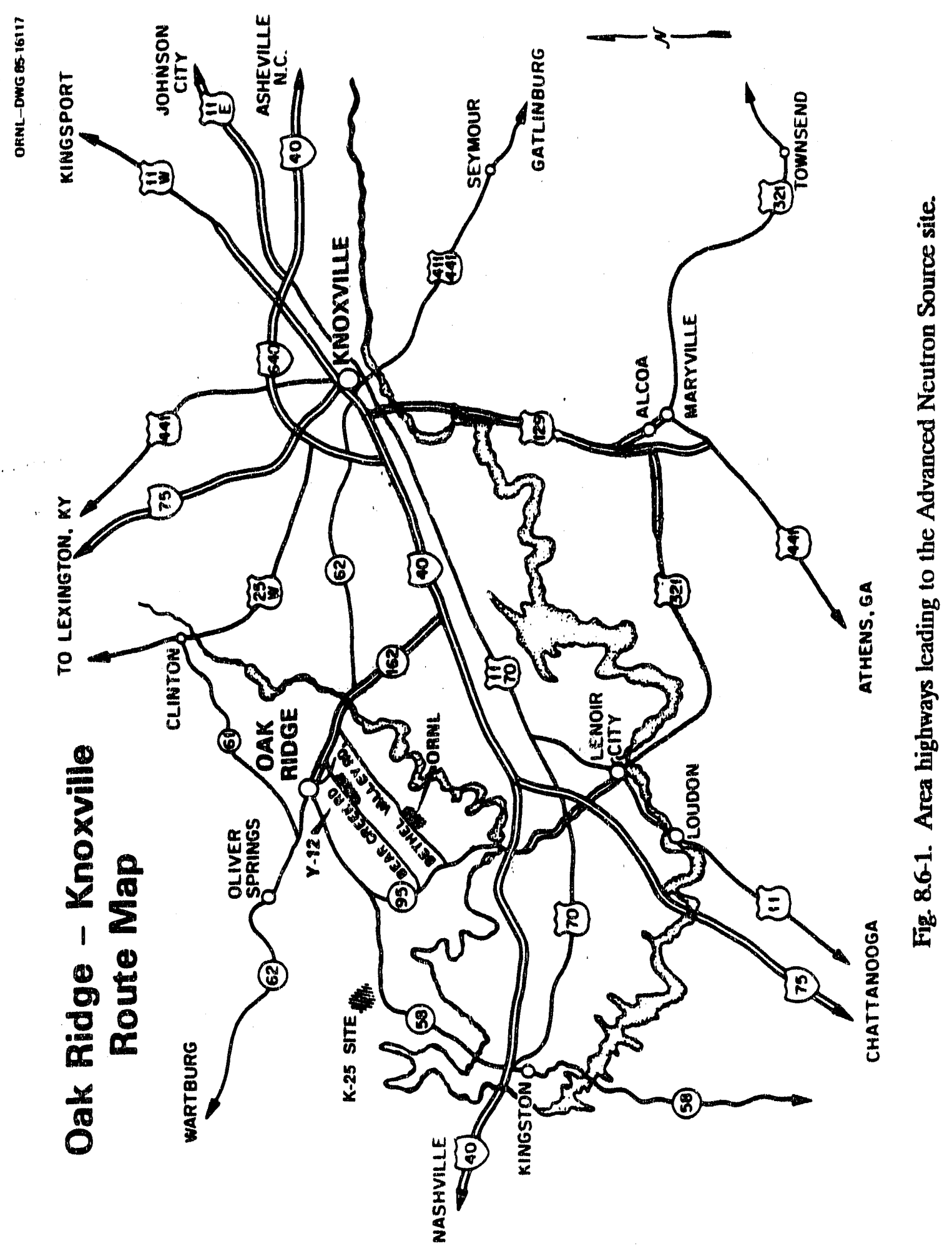




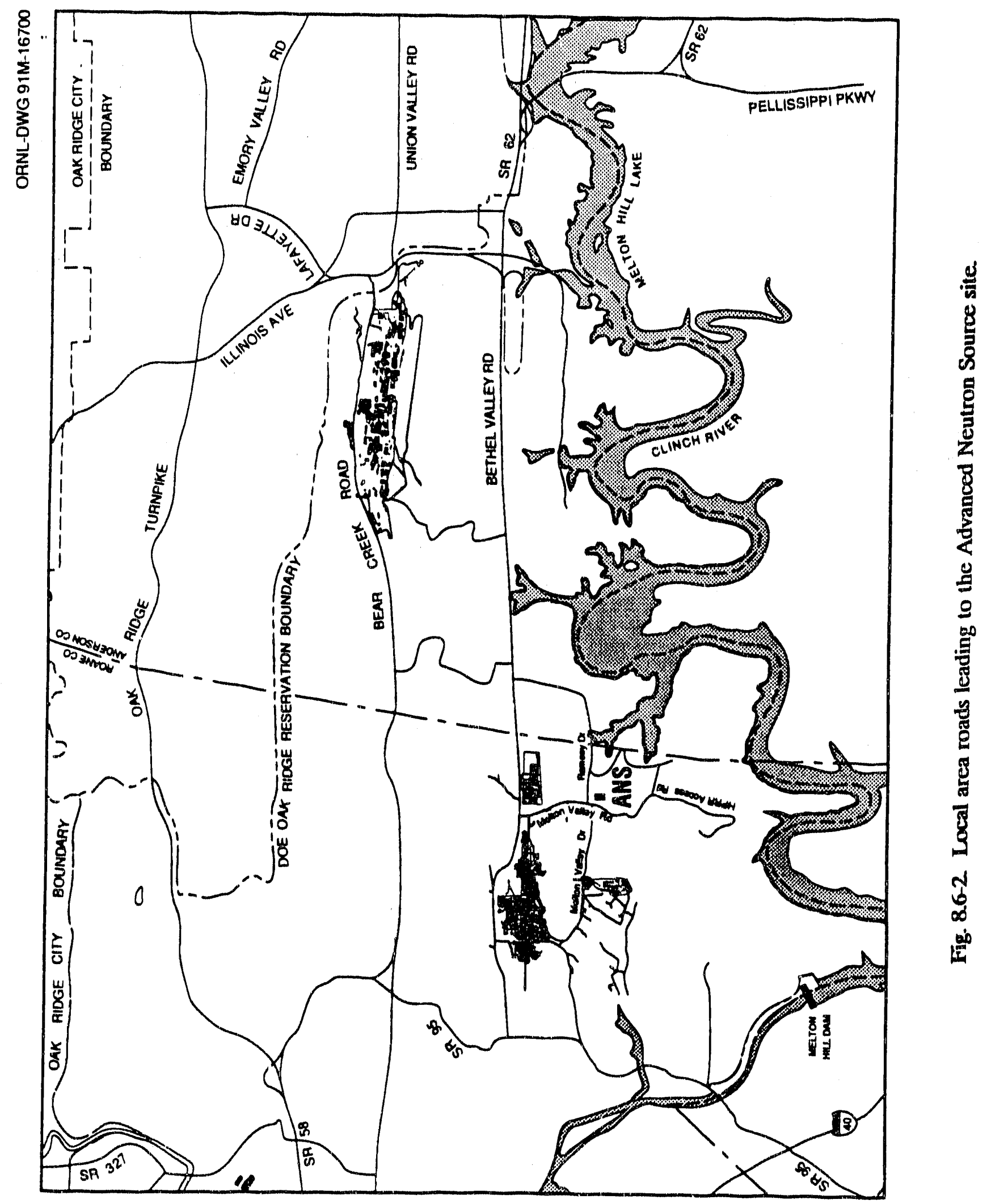


Because all new employees (craft and noncraft) would work the same schedule as workers at existing facilities in the area (R. Weiss, Gilbert/Commonwealth, October 16, 1991 personal communication with M. L. Socolof, Oak Ridge National Laboratory, Oak Ridge Tenn.), the peak hours of traffic flow (approximately 7:30-8:30 am and $3: 30-4: 30 \mathrm{pm})$ are of greatest concern. It was assumed that the peak hourly flow is $10 \%$ of the average daily flow (provided in Table 8.6-1) (S. Byrd, Oak Ridge City Engineer, Oak Ridge, Tenn., October 18, 1991 personal communication with M. L. Socolof, Oak Ridge National Laboratory, Oak Ridge, Tenn.).

Furthermore, it was assumed that the estimated peak hourly flow represents both the morning and afternoon rush hours. Peak hour factors, which account for 15-min peaks within the peak rush hour, were used to determine the LOS. Therefore, the LOS will represent the 15-min peak during rush hours. For Bethel Valley Road East, this factor was derived from raw data. Default values were used for the other roads where data were not available (TRB 1985, pp. 8-1-8-27).

LOS for the rush hour peaks for each roadway, under both present and future conditions, is presented in Table 8.6-2. The data and/or assumptions used to generate these data are listed in Table 8.6? The increases in traffic resulting from the ANS facility would not affect the LOS of SR-95 North or South. SR-95 would remain constant at level $\mathrm{D}$ (bordering on unstable flow).

The increases in traffic flows would cause LOS during rush hour peaks to change on Bethel Valley Road East and West and on SR-62. On Bethel Valley Road East, LOS would change from $D$ (bordering on unstable flow) to $E$ (quite unstable flow) (TRB 1985, pp. 1-3-1-4) under both the driving alone and the carpooling scenarios. On the west end of Bethel Valley Road, the driving alone situation would cause LOS to change from $B$ (stable flow, good level of comfort) to C (stable flow, moderate level of comfort); however, if carpooling is implemented, LOS would remain at B. LOS on SR-62 would change under both future scenarios from the present level of $\mathrm{D}$ to $\mathrm{E}$.

A second analysis was conducted to determine whether the adverse impacts on Bethel Valley Road and SR-62 could be mitigated. It was hypothesized that if the craft and noncraft workers report to work at different times, there would be a reduction in the adverse effects on traffic flow during rush hours. In this analysis, only the peak number of noncraft workers (285 in 1995) was added to the rush hour traffic flows. The results showed that in both future scenarios (driving alone and carpooling) there were no changes in LOS on Bethel Valley Road and SR-62. Therefore, changing the work schedule of the craft workers to non-rush-hour times would mitigate the negative traffic impacts expected if all new ANS employees work the same schedule. The above analyses assumed that all other factors remained constant between 1991) and 1999, except the increase in workers due to the construction and operation of the ANS facility. For example, no new public roads would be constructed, and the distribution of use would remain the same. Additionally, this analysis assumed that there would be no transferring of personnel from other facilities in the area. If some of the 779 workers were already working at other area facilities (e.g., HFIR), the impact on traffic would be reduced.

In the event that the craft workers and all other workers did not travel to and from work at the same time, the peak hour effects presented would also be reduced. On the other hand, additional truck traffic from the transport of construction materials to the site would tend to decrease LOS to comfortable conditions. In this case, the traffic impacts may be increased. 
Table 8.6-1. Present and projected average daily traffic flows (vehicles/day)

\begin{tabular}{lccc}
\hline \multicolumn{1}{c}{ Road } & $\begin{array}{c}\text { 1990 Average } \\
\text { daily flow }^{a}\end{array}$ & $\begin{array}{c}\text { 1999 Driving } \\
\text { alone scenario }^{b}\end{array}$ & $\begin{array}{c}\text { 1999 Carpooling } \\
\text { scenario }^{c}\end{array}$ \\
\hline Bethel Valley (East) & 7,400 & 8,397 & 7,899 \\
Bethel Valley (West) & 4,200 & 4,761 & 4,480 \\
State Route (SR) 95 (North) & 6,660 & 7,034 & 6,847 \\
SR-95 (South) & 6,660 & 6,847 & 6,753 \\
SR-62 (South) & 29,940 & 30,532 & 30,236 \\
\hline
\end{tabular}

Tennessee Department of Transportation, 1990. Average Traffic Daily Volume Count Book, Nashville, Tenn.

This 1999 projected daily traffic flow is determined by adding the expected increase in flow in 1999 (resulting from the increase in the Advanced Neutron Source workforce) to the 1990 average daily flows. For each road, the expected flow increase is the number of new workers in 1999, multiplied by the fraction of workers that are expected to travel on that roid, multiplied by two 10 account for the two commutes traveled per day per car (or worker). This assumes that each car travels on the same route to and from work. The driving alone scenario assumes that all new workers travel alone in their own cars. The future flow is calculated as follows:

(1990 average daily flow) $+[($ number of new employees in 1949$) \times$ (fraction of new employees using road) $\times(2$ commutes per day $)]=$ (future flow $)$.

For example, for Bethel Valley Road East:

$(7400$ vehicles/day in 1990) $+[(779$ new workers in 1999$) \times 0.64 \times 2]=8407$ vehicles/day in 1999.

This 1999 projected daily traffic flow was calculated the same as above, except "carpooling" assumes that there are two new workers per car traveling to work; therefore, the increase in flow is half that of the driving alone scenario. The future flow is calculated as follows:

(1990 average daily flow $)+1$ (number of new employees in 1999) $\times$ (fraction of new employees using road) $\times(2$ commutes per day $) /(2$ workers per car $)]$

For example, for Bethel Valley Road East:

$(7400$ vehicles/day in 1990$)+(779 \times 0.64 \times 2 \div 2)=7904$ vehicles/day in 1999. 
Table 8.6-2. Present and future levels of service ${ }^{a, b}$

\begin{tabular}{lccc}
\hline Road & Present & $\begin{array}{c}\text { Driving } \\
\text { alone }\end{array}$ & Carpooling \\
\hline Bethel Valley (East) & D & E & E \\
Bethel Valley (West) & B & C & B \\
State Rciute (SR)-95 & D & D & D \\
(North) & & & \\
SR-95 (South) & D & D & D \\
SR-62 (South) & D & E & E \\
\hline
\end{tabular}

'Calculations based on: TRB (Transportation Research Board) 1985. Highway Capacity Manual, Special Report 209, Washington, D.C.

${ }^{b}$ Level of service: B - stable flow, presence of others noticeable, good level of comfort.

C. - stable flow, presence of others affects driver, moderate level of comfort.

D - high-density, stable flow, speed and freedom to maneuver severely restricted, poor level of comforl and convenience.

$E$ - at or near capacity level, all speeds reduced to a low but relatively uniform value, maneuverability extremely difficult, extremely poor level of comfort and cunvenience. 
Table 8.6-3. Data/assumptions for level-of-service calculations

\begin{tabular}{cll}
\hline Route & $\begin{array}{l}\text { Data/ } \\
\text { assumptions }\end{array}$ & Source \\
\hline
\end{tabular}

Fethel Valley East

\begin{tabular}{|c|c|c|}
\hline$\%$ use & $64 \%$ & Tennessee Department of Transportation (TN DOT) ${ }^{a}$ \\
\hline$\%$ no passing & $20 \%$ & Observation ${ }^{b}$ \\
\hline terrain & level & Observation \\
\hline direction distance & $50-50$ & $\mathrm{BPJ}^{\mathrm{c}}$ \\
\hline peak hour factors & 0.41 & Observation \\
\hline (PHFs) & & Department of Energy/Oak Ridge (DOE/OR) ${ }^{d}$ \\
\hline lane width & $12 \mathrm{ft}(3.7 \mathrm{~m})$ & Observation \\
\hline shoulder width & $2 \mathrm{ft}(0.6 \mathrm{~m})$ & DOE/OR, Observation \\
\hline$\%$ trucks & $1 \%$ & Observation \\
\hline$\%$ buses & $0 \%$ & Observation \\
\hline$\%$ recreational vehicles & $0 \%$ & Observation \\
\hline
\end{tabular}

Bethel Valley West

\% use
$\%$ no passing
terrain
direction distanc
PHF
lane width.
shoulder width
$\%$ trucks
$\%$ buses
$\%$ RVs

$\begin{array}{ll}36 \% & \text { TN DOT } \\ 87 \% & \text { Observation } \\ \text { level } & \text { Observation } \\ 50-50 & \text { BPJ } \\ \text { default } & \text { TRB'; Table } 8-3 \\ 12 \mathrm{ft}(3.7 \mathrm{~m}) & \text { DOE/OR, Observation } \\ 2 \mathrm{ft}(0.6 \mathrm{~m}) & \text { DOE/OR, Observation } \\ 1 \% & \text { Observation } \\ 0 \% & \text { Observation } \\ 0 \% & \text { Observation }\end{array}$

State Route (SR)-95 North

\% use
$\%$ no passing
terrain
direction distance
PHF
lane width
shoulder width
\% trucks
\% buses
$\%$ RVs

$\begin{array}{ll}24 \% & \text { BPJ } \\ 100 \% & \text { Observ'tion } \\ \text { rolling } & \text { Observation } \\ 60-40 & \text { BPJ } \\ \text { default } & \text { TRB, Table } 8-3 \\ 9 \mathrm{ft}(2.7 \mathrm{~m}) & \text { DOE/OR, Observation } \\ 4 \mathrm{ft}(1.2 \mathrm{~m}) & \text { DOE/OR, Observation } \\ 5 \% & \text { BPJ } \\ 1 \% & \text { BPJ } \\ 0 \% & \text { BPJ }\end{array}$


Table 8.6-3. (continued)

\begin{tabular}{lll}
\hline \multicolumn{1}{c}{ Route } & \multicolumn{1}{c}{$\begin{array}{c}\text { Data/ } \\
\text { assumptions }\end{array}$} \\
\hline SR-95 South & & Source \\
\% use & $12 \%$ & BPJ \\
$\%$ no passing & $35 \%$ & Observation \\
terrain & rolling & Observation \\
direction distance & $60-40$ & BPJ \\
PHF & default & TRB, Table $8-3$ \\
lane width & $9 \mathrm{ft}(2.7 \mathrm{~m})$ & DOE/OR, Observation \\
shoulder width & $4 \mathrm{ft}(1.2 \mathrm{~m})$ & DOE/OR, Observation \\
$\%$ trucks & $5 \%$ & BPJ \\
$\%$ buses & $1 \%$ & BPJ \\
$\%$ RVs & $0 \%$ & BPJ \\
SR-62 South & & \\
$\%$ use & & \\
PHF & $38 \%$ & TN DOT \\
design speed & 1 & TRB \\
travel speed & $60 \mathrm{mph}$ & BPJ \\
lane width & $50 \mathrm{mph}$ & BPJ \\
distance from pavement & $12 \mathrm{ft}(3.7 \mathrm{~m})$ & DOE/OR, Observation \\
obstruction & $6 \mathrm{ft}(1.8 \mathrm{~m})$ & DOE/OR, Observation \\
driver population & none & BPJ \\
$\%$ trucks & regular & BPJ \\
$\%$ buses & $5 \%$ & BPJ \\
$\%$ RVs & $3 \%$ & BPJ \\
\hline
\end{tabular}

"Tennessee Department of Transporialion 1\%90. Average Traffic Daily' Volume Coum Book, Nashville, Tenn., (\% use = the percent of new workers thal would use roadwaly estimalled from the proportion of present traffic volume).

"Observation by M.L. Socolol, Oak Ridge Nalional Laboratory, Oak Ridge, Tenn., October 18, 1991.

${ }^{\mathrm{C}} \mathrm{BPJ}=$ best professional judgement.

${ }^{\circ C}$ Chance, W. W., and C. E. Frye 1989. Oak Ridge Reservation Site Development and Facilities Utilization Plan, DOE/OR-885, June.

TRB (Transportation Research Board) 1985. Highway Capacity Manual, Special Reporn 209, Washington, D.C.

\subsection{EMERGENCY PREPAREDNESS}

The ANS tacility is very important to ORR emergency preparedness considerations because it is a nuclear reactor with approximately four times the thermal power of HFIR, the largest existing research reactor at ORNL. The main concern is radiological hazards resulting from radioactive fission products that under hypothetical severe accident conditions could be released as an airborne cloud. An important safety feature reducing and mitigating the potential effects of severe accidents is that the ANS reactor is to be housed in a containment building that can be isolated to prevent the uncontrolled release of radioactivity. The following assessment of the effect of the proposed ANS facility on 
emergency preparedness considers emergency preparedness plans as they would relate to a Maximum Credible Accident (MCA) at the ANS facility. The analysis considers an MCA within the context of existing emergency planning, warning systems, and appropriate response.

There are several existing planning documents that outline emergency preparedness procedures for ORNL facilities and the DOE complex at Oak Ridge. These include the X-10 Site Emergency Plan (ORNL 1991) and documents for Anderson, Knox, Loudon, and Roane counties called Hazardous Materials Events at U.S. Department of Energy-Oak Ridge Operations (DOE-ORO) Facilities. The county documents are appendices to the State of Tennessee Emergency Plan Working Document (Tennessee 1989). A 5-year readiness assurance plan that will provide the primary documentation for the readiness of the emergency preparedness program at ORNL will be completed in 1992.

Emergency planning at ORNL for facilities such as HFIR and the proposed ANS facility is based on emergency planning zones that are defined by various criteria including population, control, and maximum potential exposure. The zones for ANS include the following: (1) the ANS Site, (2) the Exclusion Area, (3) the Low Population Zone, and (4) the Immediate Notification Zone (IMZ).

The various emergency planning zones can be characterized by their corresponding population, facilities, personnel control, and notification systems. They can also be characterized by the potential dose impacts to personnel within the zones. Table 8.7-1 presents the various zones and potential impacts associated with the proposed ANS facility.

An assessment of potential credible emergencies is the planning basis for emergency preparedness. Hazard analysis and consequence assessments have been used to designate the Emergency Planning Zones previously indicated (ORNL 1991, Chap. 4, p. 1). Hazardous or potentially hazardous events are classified and reported based on considerations of nature and severity. The following are the designations from least to most serious events: Alert, Site Area Emergency, and General Emergency.

After events have been reported, the emergency response depends on the type and classification of the event. The responses depend in part on the environmental pathways, exposures, and affected populations. Major types of protective action such as shelteringin-place or evacuation can be communicated to on-site ORNL populations through siren warning and public address systems (MMES 1991). Emergency preparedness is most relevant for the on-site populations, including the ORNL employees closest to the releases of potential hazards. Because most of the ORNL facilities are separated from public areas by considerable distances, the public off the DOE reservation has a much lower probability of being affected in any direct way during an emergency event. However, emergency planning for areas off the DOE reservation and beyond the 2-mile IMZs has been provided for through Five-Mile Emergency Planning Sectors.

Provisions have been made for notifying local and state emergency planning organizations in case of an emergency that would potentially affect the public outside the ORR boundaries. The Tennessee Emergency Management Agency would be contacted for any emergency. The other local areas that are included for priority notification include the counties of Anderson, Knox, Loudon, and Roane and the city of Oak Ridge. These local governments would be contacted with the priority based on (1) immediate need to know and (2) time permitted. 
Table 8.7-1. Advanced Neutron Source (ANS) emergency zone characteristics and planning criteria for dose impacts under hypothetical maximum credible severe accident conditions

\begin{tabular}{|c|c|c|c|}
\hline Zone & Definition & Characteristics & Dose impacts \\
\hline ANS Site & $\begin{array}{l}\text { Areas within ANS } \\
\text { site boundary fence }\end{array}$ & $\begin{array}{l}\text { Occupied by the ANS } \\
\text { research and } \\
\text { operations staffs }\end{array}$ & $\begin{array}{l}\text { Dose impacts cannot } \\
\text { be calculated using } \\
\text { simple, "worst case" } \\
\text { models }\end{array}$ \\
\hline ANS Exclusion area & $\begin{array}{l}\text { From ANS site } \\
\text { boundary to an outer } \\
\text { boundary at a circle } \\
\text { centered at the } \\
\text { release point with a } \\
\text { radius of } 1(K)(\mathrm{m} \\
(3281 \mathrm{ft})\end{array}$ & $\begin{array}{l}\text { Occupied by a few } \\
\text { minor Oak Ridge } \\
\text { National Laboratory } \\
\text { (ORNL) facilities. } \\
\text { Covered by an early } \\
\text { notification system, } \\
\text { easily controlled }\end{array}$ & $\begin{array}{l}\text { If evacuated within } \\
1 \mathrm{~h} \text {, doses will not } \\
\text { exceed twice the } \\
\text { upper Protective } \\
\text { Action Guide (PAG) } \\
{[0.1 \mathrm{~Sv}(10 \mathrm{rem})} \\
\text { whole body, } 0.5 \mathrm{~Sv} \\
(50 \text { rem) thyroid]; } \\
\text { well under } 10 \mathrm{CFR} \\
\text { Pt. } 100 \text { limits }\end{array}$ \\
\hline $\begin{array}{l}\text { ANS Low population } \\
\text { zone }\end{array}$ & $\begin{array}{l}\text { From outer Exclusion } \\
\text { Area houndary to } \\
2000-m(6562-f 1) \\
\text { radius from the } \\
\text { release point }\end{array}$ & $\begin{array}{l}\text { Occupied by } \\
\text { significanı ORNL } \\
\text { facilities. Most of the } \\
\text { zone is covered hy } \\
\text { alarms and public } \\
\text { address systems. } \\
\text { There are nn } \\
\text { residences, schools, } \\
\text { or farms located in } \\
\text { these zones }\end{array}$ & $\begin{array}{l}\text { Plans to evacuate in } \\
\text { under } 2 \mathrm{~h} \text { are } \\
\text { recommended. } \\
\text { Upper PAGs are not } \\
\text { exceeded if evacuated } \\
\text { in less than } 4 \mathrm{~h}\end{array}$ \\
\hline $\begin{array}{l}\text { ANS Immediate } \\
\text { notification zone } \\
\text { [Subsel of ORNL } \\
\text { immediate } \\
\text { notification zone } \\
\text { (INZ)] }\end{array}$ & $\begin{array}{l}\text { From outer Low } \\
\text { Population Zone } \\
\text { boundary } 10.3 .2 \cdot \mathrm{km} \\
\text { (2-mile) radius from } \\
\text { the release point }\end{array}$ & $\begin{array}{l}\text { Includes most of the } \\
\text { ORNL complex. } \\
\text { Most of zone is } \\
\text { covered by alarms, } \\
\text { public address } \\
\text { systems, and security } \\
\text { patrols. There are no } \\
\text { schools or farms and } \\
\text { very few residences } \\
\text { located in these zones }\end{array}$ & $\begin{array}{l}\text { Upper PAGs are not } \\
\text { exceeded even if no } \\
\text { action is taken. } \\
\text { Lower PAGs would } \\
\text { not be exceeded with } \\
\text { evacuation in less } \\
\text { than } 24 \mathrm{~h}\end{array}$ \\
\hline $\begin{array}{l}\text { ANS 5-mile } \\
\text { emergency planning } \\
\text { zone [subset of } \\
\text { ORNL emergency } \\
\text { protection zone } \\
(E P Z)]\end{array}$ & $\begin{array}{l}\text { This area includes } \\
\text { public areas off the } \\
\text { Oak Ridge } \\
\text { Reservation out to } \\
8.05 \mathrm{~km}(5 \text { miles) } \\
\text { from the main ORNL } \\
\text { X-10) site }\end{array}$ & $\begin{array}{l}\text { If an emergency } \\
\text { requires sheltering-in- } \\
\text { place or evacuation, } \\
\text { instructions would be } \\
\text { given through local } \\
\text { radio or television } \\
\text { slations }\end{array}$ & \\
\hline
\end{tabular}


The effect of ANS on emergency planning would be related to potential accident scenarios resulting in release of radioactivity to the environment. The ANS design must meet DOE requirements for potential radioactivity exposure resulting from damage to the reactor core (melting). Protective Action Guides (PAGs) are criteria used to develop emergency plans for nuclear facilities. They define radiation dose exposure levels at which actions to protect the public should be taken. These levels range from 0.01 to $0.05 \mathrm{~Sv}$ ( 1 to $5 \mathrm{rem}$ ) whole body dose and 0.05 to $0.25 \mathrm{~Sv}$ ( 5 to $25 \mathrm{rem}$ ) thyroid dose (Peretz 1991). These define the potential exposure levels that require emergency planning for warning systems, emergency drills, and protective actions such as evacuation, sheltering-inplace, and other measures.

The potential effect of ANS facilities on emergency planning can be placed in context by comparing ANS accident calculations to those performed for the HFIR facility. The ANS facility would be located within $1.3 \mathrm{~km}(0.81$ mile) of the existing HIFR facility. Assuming successful containment isolation and design containment performance for ANS that includes a $0.5 \% / \mathrm{d}$ maximum primary containment leak rate, the maximum credible severe accident with $95 \%$ meteorology would result in a 30 -d whole body dose of $0.0072 \mathrm{~Sv}(0.72 \mathrm{rem})$ of radiation at $2.2 \mathrm{~km}$ (1.36 miles). This level of exposure is reached after about $24 \mathrm{~h}$ and increases very little thereafter (Selby, Harrington, and Peretz 1987, p. 66). This compares with a whole body 30 -d cumulative exposure of $0.036 \mathrm{~Sv}$ (3.6 rem) for the HIFR facility under MCA conditions at $2.2 \mathrm{~km}$ (1.36 miles)" (Craddick and Cook 1988, p. 43). The maximum hypothetical accident accumulated thyroid dose at 2.2 $\mathrm{km}(1.36$ miles) would be $0.037 \mathrm{~Sv}(3.7 \mathrm{rem})$ of radiation (Selby, Harrington, and Peretz 1987, p. 67) compared to 0.039 Sv (3.9 rem) for HFIR (Craddick and Cook 1988, p. 43). These are both well under the lower PAGs for thyroid exposures.

The above dose/distance estimates have been extrapolated from the original estimates to make them comparable. Dose/distance estimates can, to a first approximation, be adjusted by the ratio of the distances from the release raised to the 1.5 power. For instance, based on the $2.2-\mathrm{km}(1.36-\mathrm{mile})$ distance, the ANS design containment for the MCA at $5 \mathrm{~km}\left(3.10\right.$ miles) would be $(2.2 / 5)^{1.5} \times 0.72 \mathrm{rem}=$ $0.0021 \mathrm{~Sv}(0.21 \mathrm{rem})$ of cumulative radiation. At $1 \mathrm{~km}(0.62 \mathrm{mile})$ the ANS design containment would be $(2.2 / 1)^{1.5} \times 0.72 \mathrm{rem}=0.0235 \mathrm{~Sv}(2.35 \mathrm{rem})$ of cumulative radiation for more than $24 \mathrm{~h}$.

The ANS comparison with HFIR indicates that under design basis MCA conditions the ANS facility would give lower whole body doses than would HFIR, but would give about the same thyroid doses. Both HFIR and the design basis for ANS would result in doses for an MCA that are lower than the upper dose values in the PAGs, and the design basis MCA for ANS would also result in doses lower than the lower dose values in the PAGs.

In summary, the planning objectives for selecting the design and site of the ANS facility would provide for public safety in case of a design basis accident because they would exceed existing DOE and NRC regulations. In addition, they would also be consistent with the existing ORNL emergency preparedness planning procedures, including warning systems. The ANS facility would not increase the demands on the existing emergency preparedness systems.

\footnotetext{
The $95 \%$ meteorology conditions are calculated as the condilions, that would result in a lower level of exposure $95 \%$ of the tirne with a higher level of exposure $5 \%$ of the time.

"Craddock and Cook reported $2.5 \mathrm{rem}$ at $2.8 \mathrm{~km}$ and this was Iranslated to $2.2 \mathrm{~km}$ using the approximation that dose is proportional to distance to the 1.5 power.
} 


\subsection{REFERENCES FOR SECTION 8}

Chance, W. W., and C. E. Frye 1989. Oak Ridge Reservation Site Development and Facilities Utilization Plan, DOE/OR-885, prepared by Martin Marietta Energy Systems, Inc., for the U.S. Department of Energy, Oak Ridge National Laboratory, Oak Ridge, Tenn., June.

City of Oak Ridge 1989. Oak Ridge Comprehensive Plan Including 1988 Update, prepared by Comprehensive Plan Update Team, City of Oak Ridge, Tennessee, May.

Craddick, W. G., and D. H. Cook 1988. An Assessment of the Risk of HFIR Operation from Internal Events, ORNL/RRD/INT-35, Martin Marietta Energy Systems, Inc., Oak Ridge National Laboratory, May.

DOC (U.S. Department of Commerce) 1986. Regional Multipliers: A User Handbook for the Regional Input-Output Modeling System (RIMS II), Bureau of Economic Analysis, May.

MMES (Martin Marietta Energy Systems, Inc.) 1991. What to Do If the Sirens Sound: ORNL Public Warnings Sirens Brochure, Oak Ridge National Laboratory, Oak Ridge, Tenn., September.

NRC (Nuclear Regulatory Commission) 1991. Generic Environmental Impact Statement for License Renewal of Nuclear Plants, (Draft Report for Comment), NUREG1437, Vol. 1, Division of Safety Issue Resolution, Office of Nuclear Regulatory Research.

ORNL (Oak Ridge National Laboratory) 1991. X-10 Site Emergency Plan (Revision 1), ORNL/CF-91/71/R1, Oak Ridge National Laboratory, Oak Ridge, Tenn., September.

ORNL Workforce Report 1991. Oak Ridge National Laboratory, Oak Ridge, Tenn.

Peretz, F. J. 1991. ANS Reactor Containment: Potential Use of Confinement System, Containment Design Basis, presented at the Reactor Containment Systems Performance, Operability and Maintainability Workshop, Oak Ridge National Laboratory, Oak Ridge, Tenn., October.

Selby, D. L., R. M. Harrington, and F. J. Peretz 1987. ORNL Contributions to the Advanced Neutron Source (ANS) Project for October 1986-March 1987, ORNL/TM-10579, Oak Ridge National Laboratory, Oak Ridge, Tenn., November.

Tennessee 1989. State of Tennessee Emengency Plan Working Document, "Knoxville-Knox County Appendix," in Hazardous Materials Events at U.S. Department of EnergyOak Ridge Operations (DOE-ORO) Facilities, Oak Ridge National Laboratory, Oak Ridge, Tenn., June.

TN DOT (Tennessee Department of Transportation) 1990. Average Traffic Daily Volume Count Book, Nashville.

TRB (Transportation Research Board) 1985. Highway Capacity Manual, Special Report 209, Washington, D.C. 


\section{TECHNOLOGIES AND SITES}

Alternate technologies, which may be used instead of ANS, and alternate sites for locating ANS have not been identified at this time. These issues have therefore been initially designated for address in the Phase II Environmental Report. 


\section{FACILITY DESIGN ALTERNATTVES}

Facility design alternatives, dealing with areas such as circulator and intake systems, are not issues assessed in a DOE EIS. Design alternatives for major ANS systems may, however, be assessed in the Phase II Environmental Report. 


\section{SUMMARY OF IMPACTS}

According to NRC Regulatory Guide 4.2, Chap. 11 of the environmental report (ER) should present a cost-benefit analysis of building and operating the proposed facility. The U.S. Department of Energy (DOE) does not prepare cost-benefit analyses of its facilities for environmental impact statements. For this reason, this section summarizes the environmental effects of building and operating the Advanced Neutron Source (ANS) as described in Chapters $4,5,7$, and 8 but does not attempt to compare costs and benefits. Comparison of costs and benefits will be performed for Phase 2 of the ER.

\subsection{CONSTRUCTION IMPACTS}

\subsubsection{Terrestrial Biota}

Construction of ANS would require clearing 25-35 ha (60-90 acres) of secondgrowth hardwood forests for facilities and laydown areas. In addition, 6-10 ha (15-25 acres) of forest would be cleared for power line right-of-ways. These clearings would benefit animal species that thrive in cleared areas and adversely affect animal species that are dependent on relatively undisturbed forest conditions.

A number of areas that may be wetlands are found on the ANS site (Fig. 2.2-2). About 4 ha (10 acres) of these would be destroyed or damaged by construction of ANS. The exact extent and legal status of these areas is being pursued but is not yet clear. The site has been surveyed for threatened or endangered plant and animal species. The only threatened or endangered plant or animal found on the site is ginseng, but it is located in an area that would not be disturbed by ANS as currently planned.

\subsubsection{Water Quality and Aquatic Biota}

Construction of ANS could adversely affect water quality and aquatic biota in Friendship Creek and in the Melton Branch-White Oak Creek system. Standard mitigative techniques should be adequate to prevent significant adverse effects on water quality and aquatic biota.

\subsubsection{Air Quality}

Exhaust from construction equipment would increase local levels of carbon monoxide, nitrogen oxides, volatile organic compounds, and particulate matter. These emissions would not have appreciable effects on regional ambient air quality. Excavation and earthwork could appreciably increase local concentrations of inhalable particulate matter with a diameter of less than 10 microns. To avoid violations of national air quality standards during the construction period, a combination of limiting the amount of area disturbed at one time and using diligent dust suppression measures may be required.

\subsection{RESOURCES COMMITTED}

Construction of ANS would involve irretrievable commitment of land, energy, and material resources in the construction of the facilities. The $30-45$ ha ( $75-115$ acres) of 
land committed to the facilities and the power lines would not likely be available for other uses in the foreseeable future. The material and energy used in construction of the ANS facilities (estimates for which are not available at present) would be essentially unavailable for any future uses.

Operation of ANS would result in the use of about $7,200 \mathrm{~kg}(16,000 \mathrm{lb})$ of highly enriched uranium fuel over the 25 -year life of the facility. About $17 \mathrm{~kg}(37 \mathrm{lb})$ of $95 \%$ enriched uranium fuel is used each time the reactor is refueled. Spent fuel contains only about $10.3 \mathrm{~kg}(22.7 \mathrm{lb})$ of ${ }^{235} \mathrm{U}$. Spent fuel is expected to be reprocessed, so the amount of ${ }^{235} \mathrm{U}$ consumed over the life of ANS would be about $2200 \mathrm{~kg}(4800 \mathrm{lb})$. Reprocessing the spent fuel would produce substantial quantities of high-and low-level radioactive wastes that would need permanent disposal. The amounts of these wastes produced in reprocessing are not known at this time, but they would be generated at the Savannah River Site where the reprocessing would take place.

ANS would also consume substantial quantities of electricity, natural gas, and steam from the Oak Ridge National Laboratory (ORNL) Steam Plant. Over the life of the facility, ANS would consume about $6 \times 10^{16} \mathrm{~J}\left(6 \times 10^{13} \mathrm{Btu}\right)$ of primary energy in various forms.

\subsection{HEAT DISSIPATION SYSTEM EFFECTS}

Blowdown from the cooling towers would be discharged to upper Melton Branch. Depending on the way blowdown is released, these discharges could change the flow regime in upper Melton Branch from intermittent to perennial. The temperature of the blowdown will increase the temperature of the water in much of the upper reaches of Melton Branch during most of the year. This increased flow will support warm-watertolerant aquatic life where little aquatic life is currently found and discourage aquatic life that prefers colder water and more variable stream flows.

The plume from the cooling towers may cause fog and icing during certain weather conditions. Because no roads (except access roads) are located near the ANS site, fog and icing would not cause a public safety hazard. Normal operation of the ANS cooling towers would not be expected to have any significant effects on terrestrial biota, although vegetation in the immediate vicinity could be slightly damaged.

\subsection{OTHER EFFECTS OF OPERATION}

\subsubsection{Sanitary, Chemical, and Biocide Discharges}

Sanitary wastewaters would be piped to the ORNL Sewage Treatment Plant. After treatment, this wastewater would be dischargen to White Oak Creek, where it would increase the annual average flow in White Oak Creek by about $1 \%$ but would not significantly alter the aquatic communities in the creek.

Process water would be piped to the Nonradiological Wastewater Treatment Facility, where it would be treated and discharged to White Oak Creek a short distance upstream of the Sewage Treatment Plant outfall. The chemical composition of process waters from ANS has not yet been determined but would be nontoxic after treatment. 
Process water from ANS would increase mean annual flows in White Oak Creek by about $1 \%$, which is not expected to significantly affect aquatic communities.

Storm water runoff from the ANS site would be collected in detention basins and monitored before being released to Friendship Creek and Upper Melton Branch. If treatment were necessary, storm water could be piped to the Process Waste Treatment Plant. Discharge of collected runoff from the detention basins would need to be controlled to minimize alteration of the receiving streams.

\subsubsection{Noise}

During operation, the principal noise from the ANS site would be from the mechanical-draft cooling towers. Because the nearest is about $2.4 \mathrm{~km}$ (1.5 miles) away and would be separated from the nearest humans by intervening hills, there would be no significant noise impacts to humans.

\subsection{RADIATION DOSE TO THE PUBLIC}

This section discusses radiation dose to the public from routine operations, routine transportation of radioactive materials, nonsevere accidents, severe accidents, and transportation accidents.

\subsubsection{Routine Operations}

Because of meteorological conditions, the closest individual, assumed to be at Shoreline Estates, $2.8 \mathrm{~km}$ (1.7 miles) southeast of the site, is estimated to receive $1.7 \mu \mathrm{Sv} /$ year $(0.17 \mathrm{mrem} / \mathrm{year})$, while an individual at Gallaher Bend, $2.9 \mathrm{~km}$ (1.8 miles) east-northeast of the site, would receive the greatest radiation dose of $12.4 \mu \mathrm{Sv} / \mathrm{year}$ (1.24 mrem/year). For this maximally exposed individual, tritium contributes $97 \%$ of the dose and ${ }^{133} \mathrm{Xe}$ contributes $2.7 \%$. The above individual doses are below the applicable federal limit of $100 \mu \mathrm{Sv} / \mathrm{year}(10 \mathrm{mrem} / \mathrm{year}$ ) specified in $10 \mathrm{CFR} \mathrm{Pt}$. 16. Current Oak Ridge Reservation (ORR) radioactive material releases to the atmosphere result in a 50-year committed effective dose of $20 \mu \mathrm{Sv}(2 \mathrm{mrem})$ to the hypothetical maximally exposed individual (near the Y-12 Plant). Releases from ANS would contribute to a negligibly small increase in this maximally exposed individual's dose.

Operation of ANS is estimated to result in a collective effective dose to persons within $80 \mathrm{~km}$ (50 miles) of ANS of 0.0418 person-Sv/year (4.18 person-rem/year) and a collective effective dose to the gonads of 0.0416 person-Sv/year ( 4.16 person-rem/year). Tritium accounts for $91 \%$ of this dose and ${ }^{133} \mathrm{Xe}$ accounts for $8.7 \%$. These doses are small compared with natural doses. They would increase the population-wide chance of fatal cancer by less than one in one million and the chance of birth defects by less than three in one million.

\subsubsection{Routine Transportation of Radioactive Materials}

Transport of spent fuel to the Savannah River Site would be the dominant source of radiation exposure to the public, but the dose from that activity would result in less than a 3-in-10,000 chance per year of inducing a latent cancer facility. Other transportation activities would carry less than one-thousandth the risk of inducing cancer fatalities. 


\subsubsection{Nonsevere Accidents}

Radiation dose calculations for atmospheric pathways (the most rapid pathway) of the seven nonsevere accident scenarios were evaluated using computer-assisted modeling. The evaluation indicates that all doses are below $0.01 \mathrm{~Sv}(1 \mathrm{rem})$, whether for effective whole body or organ (thyroid), except for the detritiation facility accident. A dose of $0.013 \mathrm{~Sv}(1.3 \mathrm{rem})$ would result from the detritiation facility accident. Doses from postulated accidents other than the detritiation facility accident are below the $0.01 \mathrm{~Sv}$ (1 rem) level at which the U.S. Environmental Protection Agency (EPA) has recommended protective actions. In the case of the $0.013 \mathrm{~Sv}(1.3 \mathrm{rem})$ estimate, the recommended actions are to at least seek shelter, consider evacuation, or evacuate, unless constraints make it impractical.

For nonsevere accidents with liquid pathways, a maximum dose of $8.2 \times 10^{-6} \mathrm{~Sv}$ $\left(8.2 \times 10^{-4} \mathrm{rem}\right)$ is estimated to result from drinking contaminated water; this dose is equivalent to about $1 \%$ of natural annual external background radiation dose in Tennessee.

\subsubsection{Severe Accidents}

ANS is being designed to ensure that severe accidents are very unlikely. ANS is being designed to a 1-in-100,000 per year probability of a core damage accident and a containment failure design goal of less than 1-in-100 per core damage accident. However, in the unlikely event of a severe accident the consequences could be severe.

Two potential severe accidents were examined using pessimistic assumptions. For the more severe of the two, an estimated five on-site workers would be expected to die within a few weeks of radiation exposure. Another 17 would be expected to die of radiation-induced cancers. About another 33 persons within $80 \mathrm{~km}$ ( 50 miles) would be expected to die of radiation induced-cancer due to the accident.

\subsubsection{Transportation Accidents}

Radiological risks of transporting radioactive materials to and from ANS would be very low. The chance of inducing a latent cancer fatality for any postulated accident are estimated to be less than 5 in 10,000. For any postulated accident, the expected dose to a maximally exposed individual would be less than $0.06 \mu \mathrm{Sv}(6 \mu \mathrm{rem})$.

\subsection{WORKER HEALTH AND SAFETY}

Because the design of ANS is currently conceptual, occupational radiation doses cannot be predicted with any certainty. However, experience from other reactors with similar features and trom ORNL's program to minimize occupational exposure suggest that typical doses will be less than $5 \mathrm{mSv} / \mathrm{year}$ ( $500 \mathrm{mrem} / \mathrm{year}$ ). A few operators and experimentalists might experience up to $1 \mathrm{mSv} /$ year $(1 \mathrm{rem} / \mathrm{year}$ ). (While not expected to be significant, the possible contributions from skyshine have not been evaluated.) 


\subsection{WASTE MANAGEMENT}

Waste management procedures and techniques are being upgraded on ORR and throughout DOE. Many types of waste are being stored on-site while permanent storage disposal facilities are being developed. The analysis of waste management impacts considers two scenarios: (1) permanent waste disposal and improved waste treatment facilities will be available by the time ANS becomes operational, and (2) permanent disposal and improved waste treatment facilities will not be available by the time ANS becomes operational, so most wastes will continue to go to interim storage on ORR.

The potential impacts of ANS wastes on the ORR waste management system are summarized below.

- Without upgrades, liquid low-level radioactive wastes (LLLW) from ANS would exceed the capacity of the ORNL LLLW system.

- Without upgrades, the ORNL radioactive process waste (PW) system may not be able to accommodate additional PW from ANS.

- If the Waste Isolation Pilot Plant becomes operational in 2007, as planned, transuranic wastes from ANS could be easily accommodated; if not, interim transuranic waste storage facilities will need to be constructed on ORR.

- High-level incidental radioactive wastes would not be generated during normal ANS operations.

- Spent fuel from ANS could be accommodated by either the proposed deepgeologic storage facility or the Receiving Basin for Offsite Fuels at the Savannah River Site.

- DOE has responsibility for developing disposal facilities for greater-than-class-C (GTCC) low-level radioactive waste. Until such facilities are develuped, ANS GTCC wastes will be stored on ORR. Because the volume of GTCC waste that would be generated by ANS is small, it could be accommodated by interim storage facilities at ORNL or the K-25 Site until permanent disposal facilities (on or off ORK) become available.

- If planned and proposed solid low-level waste disposal facilities (on and off ORR) do not become available, additional interim storage capacity on ORR would be needed.

- About $2.7 \times 10^{14} \mathrm{~Bq} /$ year $(7200 \mathrm{Ci} /$ year) of tritium would be released to the atmosphere; these releases are not expected to cause any serious problems. Tritium would permeate most solid and liquid radioactive wastes generated by ANS. There is concern in the waste management organization that additional tritium releases to White Oak Creek may not be acceptable because of the $9 \times 10^{13}$ to $11 \times 10^{13} \mathrm{~Bq} /$ year $(2500$ to $2900 \mathrm{Ci} /$ year) currently leaking into White Oak Creek from Solid Waste Storage Area 5.

- Mixed wastes from ANS could be readily accommodated by the Oak Ridge Mixed Waste Incinerator.

- Sanitary wastes from ANS could be readily accommodated by the ORNL Sanitary Waste Treatment System.

- Disposal of conventional solid, liquid, or gaseous wastes would not cause any particular problems; however, waste water discharges to upper Melton Branch or Friendship Creek would require modification of the ORR National Pollutant. Discharge Elimination System permit.

- Nonradiuactive hazardous wastes generated at ANS would be disposed of off-site at EPA-permitted treatment and disposal facilities. 


\subsection{SOCIOECONOMIC EFFECTS}

The net economic effect of ANS would be positive; however, since it would involve less than $1 \%$ of the labor force in the region of influence (ROI), it would not induce significant changes in the local economy. Immigration would modestly increase populations of the communities in the ROI, with the largest effect in Oak Ridge at about 100 persons or $0.3 \%$ of the current population. Public services and housing in the surrounding communities are expected to be able to easily support the additional people who come to the community because of ANS. ANS would have small but beneficial fiscal and tax effects on local communities. ANS would increase the fraction of ORR committed to facilities by about $0.5 \%$ but would have no appreciable effect outside ORR. Additional workers traveling on Bethel Valley Road and State Road 62 could reduce the level of service (LOS) from D to E during rush hour periods; however, staggering work hours would allow these roads to accommodate the ANS workers without reducing LOS on these highways. ANS design objectives would protect public safety to the extent that it would not increase demands on the existing emergency preparedness systems. 


\section{ENVIRONMENTAL, HEALTH, AND SAFETY REGULATORY REQUIREMENTS}

This section identifies the major environmental and health and safety statutes, regulations, Executive Orders, and Department of Energy (DOE) Orders that are applicable to the proposed construction and operation of the Advanced Neutron Source (ANS) facility. In particular, this section addresses the various federal statutes that impose environmental, health, and safety protection and compliance requirements upon DOE, as well as the applicable state statutes and compliance requirements. Table 12.1-1 lists the environmental permit and notification requirements that would apply to the ANS candidate site, and Table 12.1-2 lists consultation requirements.

\subsection{GENERAL REQUIREMENTS}

Under the National Environmental Policy Act (NEPA) of 1969, as amended, federal agencies are required to prepare an environmental impact statement (EIS) for proposed major federal actions that may significantly affect the quality of the human environment (42 U.S.C. Sect. $4321 \mathrm{et}$ seq.). DOE has determined that the proposed siting, construction, and operation of the ANS facility is such an action. Therefore, an EIS will be prepared in accordance with the Council on Environmental Quality Regulations (40 CFR Pts. 1500-1508) implementing the NEPA and DOE Guidelines for Compliance with NEPA (10 CFR Pt. 1021).

The DOE Organization Act (42 U.S.C. Sect. 7101 et seq.) and the Atomic Energy Act of 1954, as amended, (42 U.S.C. Sect. 2011-2259) provide for, among other issues, the protection of the health and safety of the public and the environment in the conduct of the department's programs. Pursuant to the Energy Reorganization Act of 1974, as amended (42 U.S.C. Sect. 5801 et seq.), DOE is authorized to control all types of nuclear materials at sites under its jurisdiction and is exempt from the Nuclear Regulatory Commission (NRC) licensing and regulatory requirements.

DOE is not completely exempt from other federal agency rules and regulations. For example, Executive Order 12088 [Fed. Regist. 43, 47707 (1978) as amended], Federal Compliance with Pollution Control Standards, requires federal agencies, including DOE, to comply with applicable administrative and procedural pollution control standards established by, but not limited to, the Clean Air Act (CAA), the Noise Control Act, the Clean Water Act (CWA), the Safe Drinking Water Act (SDWA), the Toxic Substances Control Act, and the Resource Conservation and Recovery Act (RCRA). It is also statutorily mandated that DOE comply to environmental laws, such as the CAA, and to applicable standards. The DOE is also required to adhere to applicable state and local rules and regulations.

DOE establishes orders that impose additional requirements upon DOE facilities and contractors. The Price-Anderson Amendments Act of 1988 (Pub. L. 100-408), which arnends the Atomic Energy Act, affected the legal significance of certain DOE orders by subjecting DOE contractors and their subcontractors to civil and criminal penalties for violations of "any applicable rule, regulation or order related to nuclear safety." It is also DOE's policy to adopt and implement standards that are generally consistent with those of the NRC and with other federal agencies but that may not be legally required. 







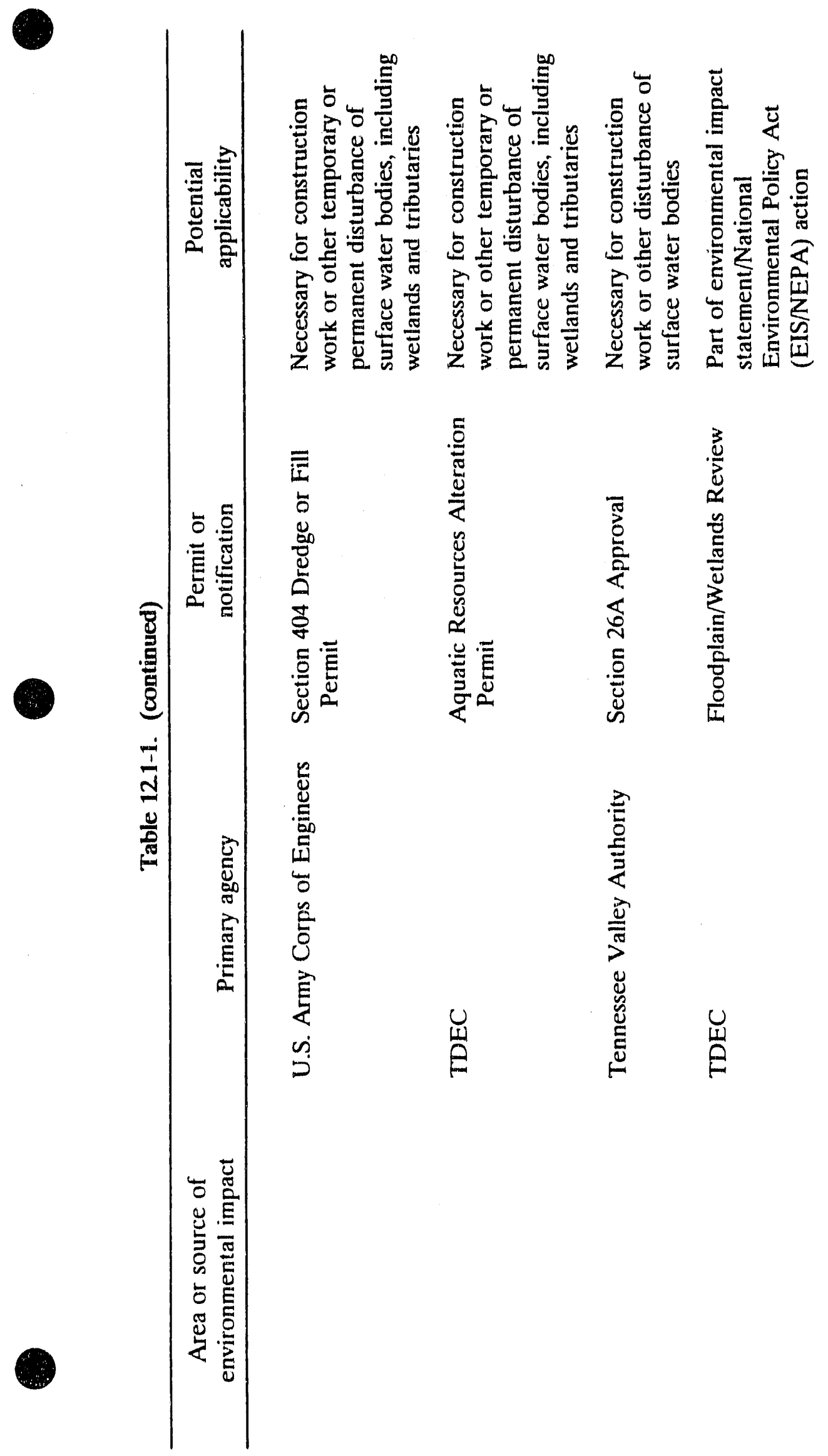




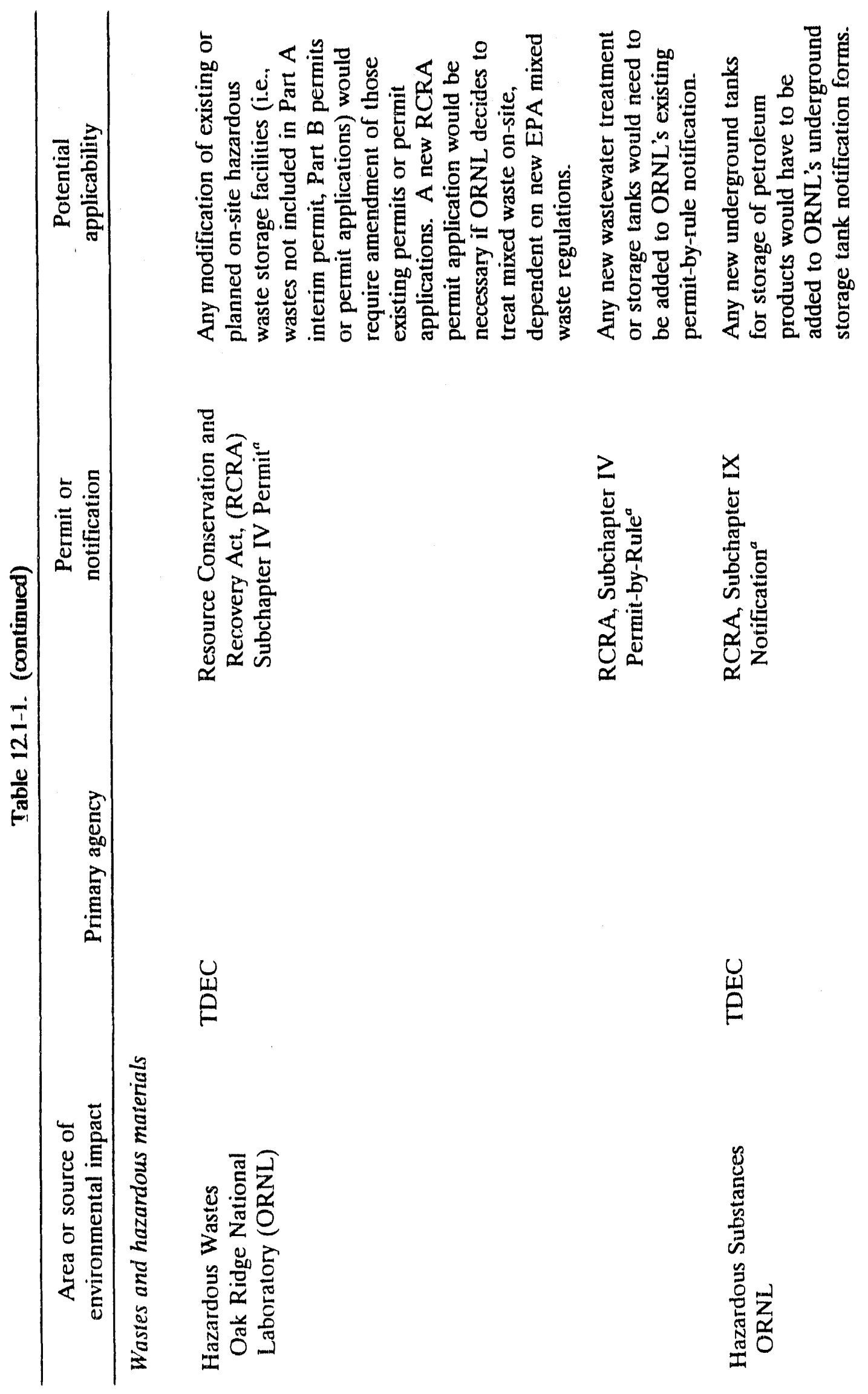




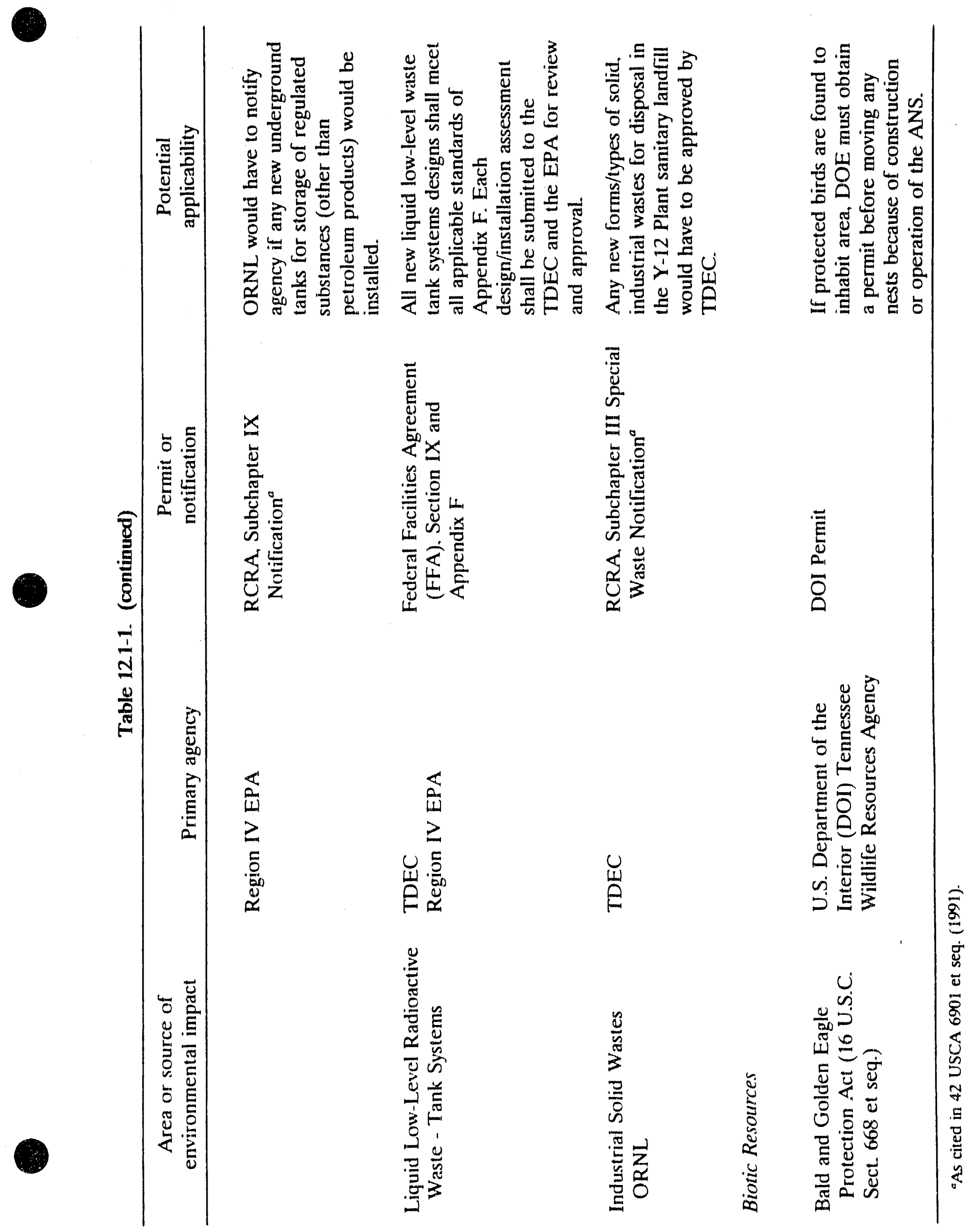




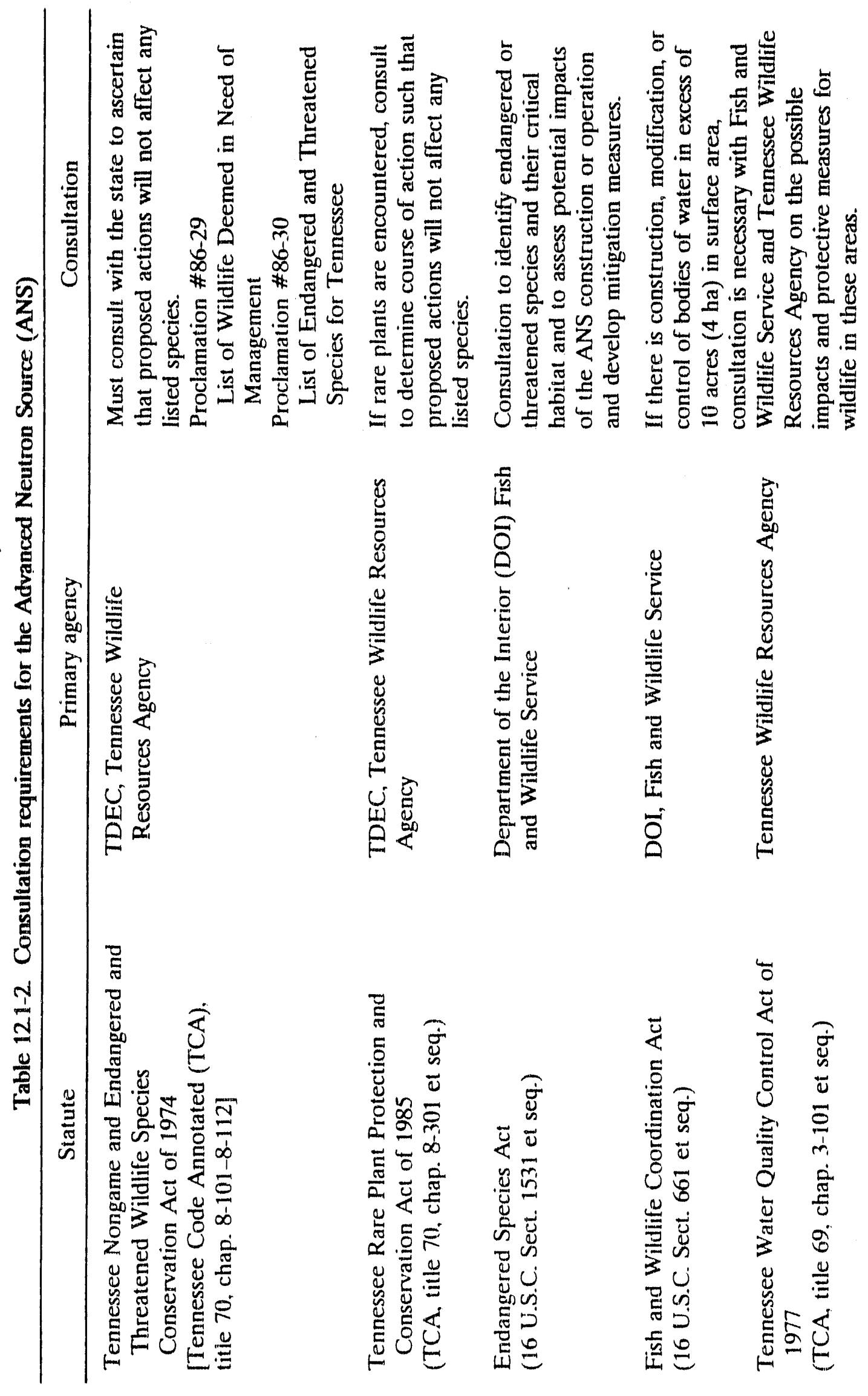


○

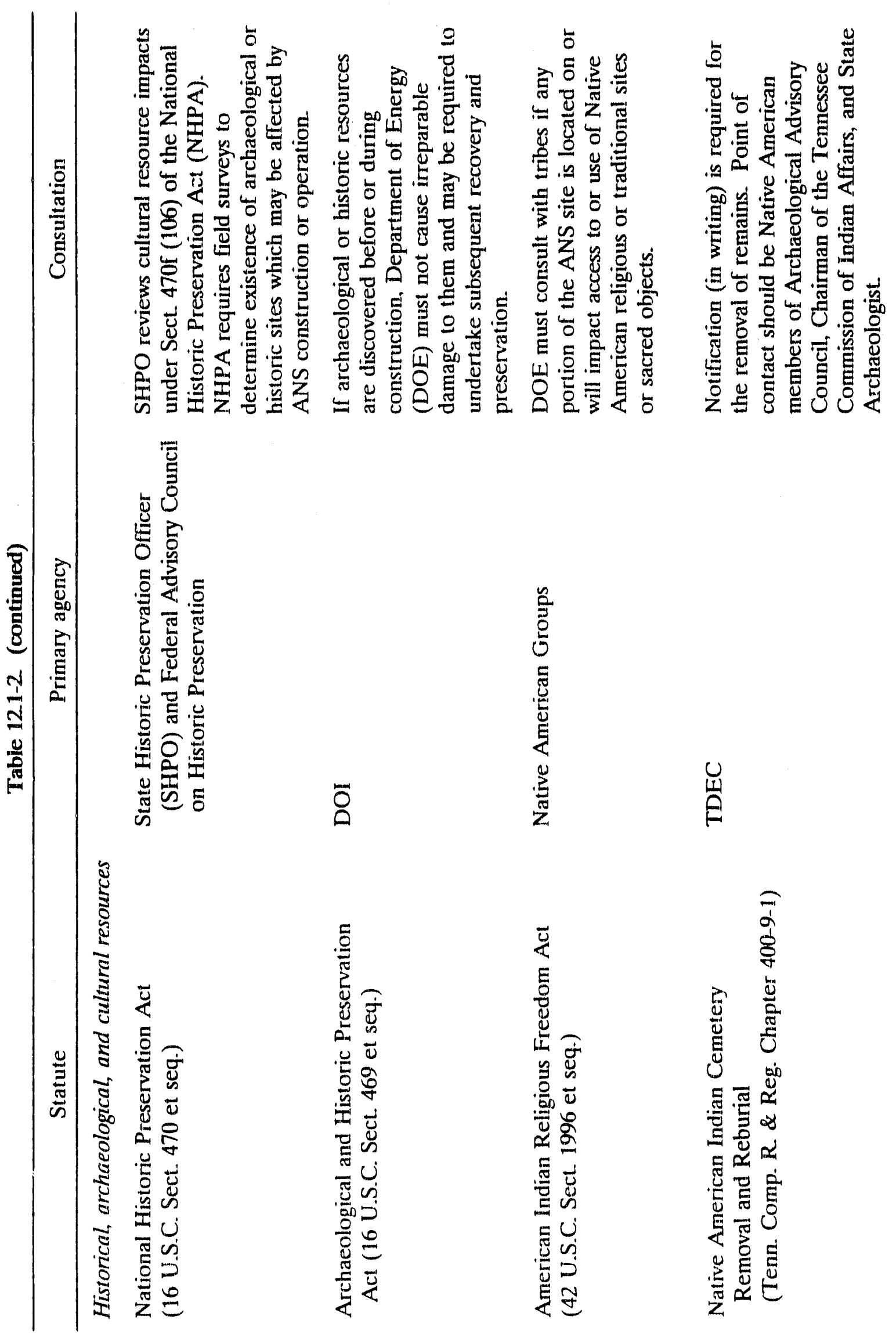




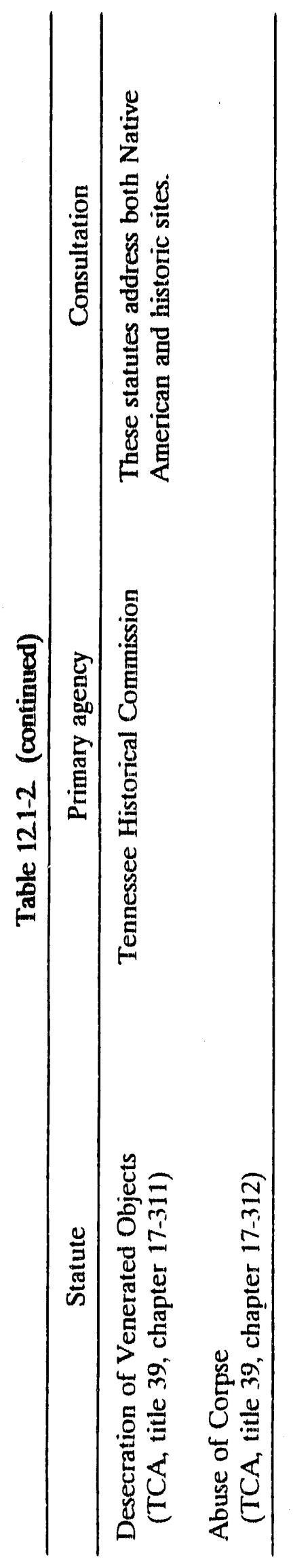




\subsection{AIR QUALITY REQUIREMENTS}

\subsection{Clean Air Act}

The CAA (42 U.S.C. Sect. 7401 et seq.) requires the EPA to establish national primary and secondary ambient air quality standards as necessary to protect public health, with an adequate margin of safety, from any known or anticipated adverse effects of a regulated pollutant (42 U.S.C. Sect. 7409). The CAA also requires establishment of (1) national standards of performance for new stationary sources of atmospheric pollutants; (2) emissions limitations for any new or modiffed building, structure, facility, or installation that emits or may emit an air pollutant (42 U.S.C. Sect. 7411); and (3) standards for emission of hazardous air pollutants (42 U.S.C. Sect. 7412).

EPA, as mandated by the CAA, issued the following: (1) Primary and Secondary National Ambient Air Quality Standards (NAAQSs), including standards for emissions of $\mathrm{SO}_{2}, \mathrm{NO}_{x} \mathrm{CO}$, particulate matter with a diameter of $<10$ microns $\left(\mathrm{PM}_{10}\right)$, ozone $\left(\mathrm{O}_{3}\right)$, and lead (Pb) (40 CFR Pt. 50); (2) the Standards of Performance for New Stationary Source within specific source categories enumerated in 40 CFR Pt. 60.16, including electric steam generating units (Subpart $D_{a}$ ), industrial-commercial-insticutional steam generating units, (Subpart $D_{t}$ and $D_{t}$ ) and stationary gas turbines (Subpart $G G$ ); (3) the National Emission Standards for Hazardous Air Pollutants (NESHAPs), including radionuclides (40 CFR Pt. 61); and (4) the Prevention of Significant Deterioration (PSD) of Air Quality review regulations (40 CFR Pt. 52.21).

Tennessee was delegated authority [Fed. Regist. 37, 10840 (1972)] under the CAA to maintain the NAAQS (40 CFR Pt. 52, Subpart RR), to issue permits under PSD (40 CFR Pt. 52.2233), and to enforce performance standards for new stationary sources (40 CFR Pt. 60.4). As of fall 1991, Tennessee does not have authority under NESHAPs to regulate emissions of radionuclides.

\subsubsection{Impact of Clean Air Act Amendments}

Under the CAA Amendments of 199), new standards will be developed, and states will submit new statc implementation plans to address these new requirements. As of February 1992, regulations pursuant to the CAA Amendments have not yet been promulgated by the EPA; therefore, it is not certain how the amendments will affect new major construction such as the ANS. The significant new regulations that may impact the ANS facility include use of chlorofluorocarbons (CFCs), permitting requirements, and the emission of certain "hazardous" materials.

Pursuant to CAA Amendments (Pt. 601 et seq.), Title Vl, Stratospheric Ozone Protection, upcoming regulations will prohibit the use of ozone depleting materials. CFCs have been identified as ozone depleting materials, and the CAA Amendments will phase out the use of these material by prohibiting their manulacture. Therefore, development of the ANS should consider alternatives to CFCs in cooling (or other) systems.

Current permitting procedures will be changed because of the new CAA Amendments. It is not known what information or data or how much time will be required to obtain an air permit under the anticipated permitting requirements and procedures.

Of the various new provisions in the amendments, those regulating hazardous air pollutants could have the greatest impact on environmental compliance at the ANS site. The amendments substantially amended CAA Pt.112(b). The amendments establish a list of 189 hazardous air pollutants, including radionuclides and all other NESHAPs governed 
contaminants. Within 1 year of enactment of the amendments, EPA is to establish a list of categories and subcategories of sources that emit the listed hazardous air pollutants (based on similar industry, facility, or operation). For each category of sources, EPA must issue standards for applicable maximum achievable control technology by source and pollutant.

To comply with provisions of the amendments, DOE will monitor the development of new regulations. Once additional CAA requirements are determined, DOE will develop and implement a compliance strategy for meeting those requirements and file the necessary permit applications according to the final determination of the EPA and the state of Tennessee. As these amendments are implemented, the compliance processes described in this section may change.

\subsubsection{Regulation of Radionuclide Emissions Under NESHAP}

The ANS is subject to NESHAPs regulations listed in 40 CFR Pt. 61, Subpart H. These regulations require that a new facility with the "potential" to discharge radionuclides that could result in an effective dose equivalent in excess of $1 \%$ of the standard $1 \times 10^{4} \mathrm{~Sv} /$ year (40 mrem/year) (10 CFR PL. 61.92) to the nearest resident must first apply for and receive approval from the EPA to construct. "Potential" is defined as the radionuclide emission rate that would result if there were no emission control devices.

As of fall 1991. Tennessee does not have authority under NESHAPs to regulate radionuclide enissions. The ANS will likely require a permit to construct from the EPA. This process should be initiated well in advance of the planned construction date in order to provide sufficient time to address comments and concerns from the EPA. This procedure should be initiated approximately a year before construction. In addition, radionuclide emission monitoring and annual reporting of radionuclide emissions will be required.

\subsubsection{Air Quality Requirements for Tennessee}

Tennessee was delegated authority under the CAA [Fed. Regist. 37, 10840 (1972)] to develop its own ambienı air quality standards. The Tennessee Air Quality Act (TCA Titie 68, Chap. 25-101 et seq.) authorizes TDEC to develop ambient air quality standards. The rules of the TDEC, Division of Air Pollution Control, define the air quality standards and regulations that limit emissions of air contaminants (Tenn. Comp. R. \& Regs., Title 1200, Chap. 3-3 et seq.).

New construction is subject to TDEC air permitting requirements (Tenn. Comp. $R$ \& Regs., Title 1200, Chap. 3.9 et seq.). All nonradioactive sources of emissions-criteria pollutants and other hazardous air pollutants must be evaluated for permit requirements under the TDEC rules (see Tenn. Comp. R. \& Regs., Title 1200, Chap. 3-9 et seq.). Unless the process is specilically exempt, an air permit must be obtained. This will include ANS process emissions and support facilities. Permit applications must be delivered to the TDEC 90 days prior to construction. Therefore, depending on the complexity of the process which requires a permit, this procedure should be initiated approximately a year prior to construction.

PSD Air Quality Standards may apply to ANS construction if any emission source discharges pollutants in "significant" quantities, as defined in Tenn. Comp. R. \& Regs., 
Title 1200, Chap. 3-9.01(4). A source impact analysis must be completed and public hearings are required before a construction permit can be obtained for the source.

Fugitive dust emissions during construction of the facility would be limited pursuant to Tenn. Comp. R. \& Regs., Title 1200, Chap. 3-8. These rules require that reasonable precautions be made to prevent particulate from becoming airborne.

\subsection{WATER QUALITY AND WATER RESOURCE REQUIREMENTS}

The ANS facility would use water for sanitary and domestic purposes, reactor cooling, manufacture and processing of targets and fuel, environmental control of site and facilities, and emergency and safety systems. However, the area encompassing Oak Ridge Reservation (ORR) has no rivers or streams classified as scenic rivers (DOE-OR 1980 pp. 7-9); therefore, requirements pursuant to the Wild and Scenic Rivers Act (16 U.S.C. Sect. 1271 et seq.) would not be relevant to ANS facility construction and operation. Water quality and water resource requirements to which the ANS facility and activities would be subject are discussed in this section.

\subsubsection{Clean Water Act}

The federal CWA (33 U.S.C. Sect. 1251 et seq.) makes it illegal to discharge pollutants from a point source into navigable waters of the United States except in compliance with a National Pollutant Discharge Elimination System (NPDES) permit. Through administrative and judicial interpretation, the navigable waters of the United States are considered to encompass any body of water the use, degradation, or destruction of which would affect or could affect interstate or foreign commerce. This definition includes, but is not limited to, interstate and intrastate lakes, rivers, streams, wetlands, playa lakes, prairie potholes, mudtlats, intermittent streams, and wet meadows.

The NPDES program is administered by the Water Management Division of EPA pursuant to regulations promulgated by the agency and codified in $40 \mathrm{CFR}$ Pt. 122 et seq. Shortly after NPDES permit requirements were issued in 1986, Tennessee was delegated NPDES permitting authority by the EPA. Thus, DOE would file with TDEC, for an NPDES permit for any ANS activities at ORNL subject to these requirements. It is anticipated that the existing NPDES permit would be amended to incorporate discharges from the ANS facility.

Section 402(p) of the CWA requires that EPA establish regulations for issuing permits for stormwater discharges associated with industrial activity. As of November 16, 1990, when the EPA rule requiring stormwater permits were promulgated, any stormwater discharge associated with industrial activity requires an NPDES permit application [40 CFR Pt. 122.26(a)(1)(ii)].

Under Sect. 404 of the CWA (3.3 U.S.C. Sect. 1344), dredged or fill material may not be discharged into waters of the United States, including rivers, streams, wetlands, and playa lakes, by, or on behalf, of, any federal agency, other than the U.S. Army Corps of Engineers, without a permit issued pursuant to Corps rules and regulations (33 CFR Pts. 320-328). Those regulations prescribe special policies, practices, and procedures to be followed by the Corps in reviewing applications for permits to authorize such discharges (33 CFR. Pts. 320, 323, and 325). In issuing such permits, the Corps must consider the impact that such activity would have on tloodplains and wetlands in accordance with Executive Orders 11988 and 11990 (See Sect. 12.3.5). 


\subsubsection{Clean Water Act Requirements for Tennessee}

The Tennessee Water Quality Control Act of 1977, as amended (TCA. Title 69, Chap. 3-101 et seq.) establishes a state policy to maintain reasonable standards of water quality. The Act authorizes TDEC to develop regulations to implement this policy and to adopt water quality standards. The TDEC Division of Water Quality Control water quality standards and regulations are delineated in Tenn. Comp. R. \& Regs., Title 1200, Chap. 4. The TDEC implements and enforces its delegated authority to issue NPDES permits. However, EPA Region IV acts as a review agency for permit applications. The Tennessee NPDES Permit Regulations include discharge requirements, application and filing procedures, terms and conditions of permits, duration of permits, and record keeping responsibilities of dischargers.

TDEC is adopting the EPA rule that requires an NPDES permit application for any stormwater discharge associated with an industrial activity (Draft Tenn. Comp. R. \& Regs., Title 1 1 1 J, Chap. 4-10). A new NPDES permit may be required for construction site stormwater runoff discharges if the ANS construction site is 2.02 ha ( 5 acres) or more and for the post-construction ANS facility itself, or (2) from the discharge of cooling water from new ANS outfall structures constructed in White Oak Creek watershed on the Clinch River. The existing sitewide NPDES permit would have to be modified for discharge of additional sanitary wastewater, cooling tower blowdown, boiler blowdown, laboratory wastewater, process wastewater, effluent streams from the treatment facilities, and for the additional discharge of cooling water through new or existing on-site surface drainage systems. Also, for any construction in wetland areas or projects involving dredge and fill activities, a U.S. Army Corps of Engineers permit would have to be applied for under Sect. 404 of the CWA, as well as a TDEC permit under Draft Tenn. Comp. R. \& Regs., Title 1200, Chap. 4-7, and approval under the Tennessee Valley Authority (TVA) Act, Section 26A. In addition to the monitoring requirements of the NPDES permit, the discharge monitoring will have to comply with DOE Order 5400.1, and discharges will have to meet the requirements of DOE Order 5400.5 .

In addition, the TDEC applies a permitting system, the Aquatic Resources Alteration Permit, for dredge and fill projects that is similar to that of the U.S. Army Corps of Engineers (33 CFR Pts. 320, 323, and 325). The TDEC Rule is Tenn. Comp. R. \& Regs., title 1200, chap. 4-7, "National Resources Development." The TVA must also be consulted for dredge/fill activities under Sect. 26A of the TVA Act of 1933 (16 U.S.C. Sect. 831 et seq.), as amended.

\subsection{Rivers and Harbors Appropriations Act}

Section 10 of the Rivers and Harbors Appropriations Act of 1899, as amended (33 U.S.C. Sect. 401 et seq.) prohibits the unauthorized obstruction or alteration of any navigable water of the United States. The construction of any structure in or over navigable water, the excavation from or depositing of material in such waters, or the accomplishment of any such work affecting the course, location, condition, or capacity of such waters is unlawful uniess the work has been recommended by the U.S. Army Corps of Engineers and authorized by the Secretary of the Army.

For structures or work affecting navigable waters pursuant to regulations cited in 33 CFR Pts. 320, 322, and 325, permits may be required. Application for a permit under Sect. 10 of this act can be submitted to the Corps in conjunction with any application for a permit for the discharge of dredged or fill materials under Sect. 404 of the CWA. [33 CFR Pt. 325.1(d)(2)]. Pursuant to Corps regulations, consultation with the 
Tennessee Wildlife Resources Agency, which is responsible for fish and wildlife, must take place before a Sect. 10 permit is issued. It is expected that the primary impact from ANS operations will be to Friendship Creek and/or Melton Branch, which should not obstruct or alter navigable waters. However, if new cooling water intake structures were constructed for the ANS facility or if construction for additional cooling water discharges were to impact navigable waters (e.g., the Clinch River) DOE would consult with the Corps to determine which requirements might apply under the Rivers and Harbors Appropriations Act and 33 CFR Pt. 320 et seq.

\subsubsection{Safe Drinking Water Act}

The primary objective of the SDWA [42 U.S.C. Sect. 300(f) et seq.] is to protect the quality of public water supplies, water supply and distribution systems, and all sources of drinking water. Sections of the act address public water systems, protection of underground sources of drinking water, emergency powers, general provisions, and additional requirements to regulate underground injection wells. The National Primary Drinking Water Regulations administered by EPA, establish standards applicable to public water systems (40 CFR Pt. 141 et seq.). The regulations set forth maximum contaminant levels, including those for radioactivity in community water systems. No new public water supply system is anticipated to be constructed at ORNL.

No other injection wells are contemplated at any site. Furthermore, no site is located over a sole source aquifer or wellhead protection area as designated by the state under the SDWA (42 U.S.C. Sect. 1421). Therefore, this act does not apply to the construction or operation of the ANS facility except as set forth above.

\subsubsection{Executive Order 11988, Floodplain Management Executive Order 11990, Protection of Wetlands}

There are many small floodplains and swampy areas throughout the ORR (ORR pp. 3-1-3-4, 4-3 1991). Portions of ORNL are located in the 100- and 500-year Clinch. River floodplain (Pat Scofield, Research Associate, ORNL, Oak Ridge, Tenn., personal communication with Ed Bright, Computing and Telecommunications Division, ORNL, Oak Ridge, Tenn., Nov. 13, 1991). A preliminary study of wetlands areas on the ORR has been recently completed (Cunningham and Pounds 1991, pp. 1-44). If construction and operation of the ANS facility were to impact tloodplains or wetlands areas, compliance with the Executive Orders 11988 [Fed. Regist. 42, 26951 (1977)] and 11990 [Fed. Regist. 42,26961 (1977)] and the DOE floodplain/wetlands environmental review requirements would be required (10 CFR Pt. 1022).

Executive Order 11988 requires federal agencies to establish procedures to ensure that the potential effects of flood hazards and floodplain management are considered for any action undertaken in a floodplain and that tloodplain impacts be avoided to the extent practicable. Executive Order 11990 requires all federal agencies to consider protection of wetlands in decision making for a proposed action.

DOE has established procedures (10 CFR Pt. 1022, Compliance with Floodplain/Wetlands Environmental Review Requirements) for compliance with these executive orders. These regulations require DOE to assess the effects of a proposed action on the survival, quality, and natural or beneficial values of wetlands and to avoid impacts to floodplains to the extent practicable. Pursuant to the regulations and concurrent with DOE's review of a proposed action. DOE shall prepare a floodplain/ wetlands assessment which would be prepared currently with, and included in the NEPA 
document [10 CFR Pt. 1022.12(b)] and included in the Notice of Intent to satisfy the early public review requirement [10 CFR Pt. 1022.14 (a)]. For actions that would take place in a floodplain, DOE must publish a statement of findings which may be incorporated into the Finding of No Significant Impact or final EIS (10 CFR Pt. 1022.15). The findings must include a brief description of the proposed action, an explanation indicating why the action is proposed to be located in the floodplain, a list of alternatives considered, a statement that the action conforms to applicable state and local floodplain protection standards, and a brief description of steps to be taken to minimize potential harm to or within the floodplain.

\subsection{BIOTIC RESOURCES}

\subsubsection{Endangered Species Act of 1973}

The Endangered Species Act of 1973 (16 U.S.C. Sect. 1531 et seq.), as amended, is intended to prevent the further decline of endangered and threatened species of animals and plants and to restore these species and their critical habitats. The act is jointly administered by the U.S. Department of Commerce (marine species and their habitats under 50 CFR Pts. 222.23 and 227.4) and DOI (all other plant and animal species and their habitats under 50 CFR parts 17.11 and 17.12). DOE is required to consult with the U.S. Fish and Wildlife Service (FWS), DOI, and/or the National Marine Fisheries Services of the U.S. Department of Commerce, to determine if endangered and threatened species and their critical habitats are found in the vicinity of the proposed site (16 U.S.C. Sect. 1536). The FWS list of endangered and threatened species and their critical habitats is found in 50 CFR Pt. 17. Federal and state rare, threatened, or endangered animal or plant species known to occur on or near ORR are listed in the Resource Management Plan for ORR, Vol. 24 (Kroodsma 1987, pp. 10-15; Parr and Pounds 1987, pp. 37-47; ORR 1991, pp. 3-6, 3-10). Updated information on threatened or endangered animal or rare plants on or near ORR are available through the Oak Ridge National Environmental Research Park.

If, during site construction or operation, investigations reveal the presence of any rare, threatened, or endangered animals or plants at the ANS site, requirements pursuant to the Endangered Species Act, the Tennessee Nongame and Endangered or Threatened Wildlife Species Act of 1974, (TCA, title 70, chap. 8-101-112) and the Tennessee Rare Plant Protection and Conservation Act of 1985 (TCA, title 70, chap. 8-301 et seq.) would be implemented (see Table 12.2). DOE must consult with the Tennessee Wildlife Resources Agency (TWRA), DOI, and FWS, to assess potential impacts and develop mitigation measures. In addition, habitat modification impacting any species designated by the state as "in need of managernent" (Proclamation \#86-29) may also trigger the state requirements (Etnier 1991, p. 40).

\subsubsection{Bald and Golden Eagle Protection Act}

The Bald and Golden Eagle Protection Act (16 U.S.C. Sect. 668-668dd) makes it unlawful to take, pursue, molest, or disturb bald and golden eagles, their nests, or their eggs anywhere in the United States. No permits or approval procedures are required unless a nest interferes with resource development. In that case, a permit must be obtained from DOI to relocate the nest. The Southern Bald Eagle has been sighted on the ORR, but is not known to nest in the ORR area (Kroodsma 1987, p. 10). If a bald 
eagle nest were found in the vicinity of the ANS construction and operation activities, DOE will consult with DOI and TWRA.

Bald and golden eagles and their habitats are also protected under the federal Endangered Species Act as well as the State of Tennessee Nongame and Endangered and Threatened Wildlife Species Conservation Act of 1974.

\subsubsection{Fish and Wildlife Coordination Act}

The Fish and Wildlife Coordination Act (FWCA) (16 U.S.C. Sect. 661 et seq.) is intended to ensure that wildlite conservation receives equal consideration and is coordinated with other features of water resource development programs through effective and harmonious planning, development, maintenance, and coordination of wildlife conservation and rehabilitation. The act applies whenever the waters of any stream or other body of water greater than or equal to 10 acres ( $4 \mathrm{ha}$ ) in surface area are proposed or authorized to be controlled or modified for any purpose whatever by any department or agency of the United States or by any public or private agency under federal permit or license. Friendship Creek and Melton Branch may be impacted by the ANS facility. It is not expected that these streams would be modified such that the FWCA would be triggered. If ANS construction or operation requires modification of a stream or river, DOE will consult with FWS and TWRA to develop protective measures for affected wildlife.

\section{HISTORICAL, ARCHAEOLOGICAL, AND CULTURAL RESOURCE REQUTREMENTS}

\subsubsection{National Historic Preservation Act}

Section 470f of the National Historic Preservation Act (NHPA) of 1966, as amended (16 U.S.C. Sect. 470 et seq.; commonly known as Section 106 [Pub L, 89-665, 1966]) requires federal agencies to take into account the effects of their operations on properties included in, or eligible for, the National Register of Historic Places (NRHP). The Advisory Council of Historic Preservation regulations specify a number of criteria to be used in determining whether a given federal or federally supported action will result in adverse effects to historic properties (36 CFR Pt. 8(0).9).

If a proposed action might impact an historic property resource, consultation with the State Historic Preservation Officer (SHPO) and the Advisory Council on Historic Preservation is required (36 CFR Pt. 800). Such consultation can result in execution of a Memorandum of Agreement that includes stipulations that must be followed to minimize adverse impacts.

In Tennessee, the deputy SHPO, Herbert Harper, is the Executive Director of the Tennessee Historical Commission (Pat Scofield, Research Associate, ORNL, Oak Ridge, Tenn., personal communication with Kevin Smith, Federal Program Archaeologist, Tennessee Department Environment and Conservation, Nashville, Tenn., November 1991). The Tennessee Historical Commission reviews cultural resources impacts pursuant to Sect. 106 of the NHPA.

The NRHP lists 80 sites in the five-county area (Roane, Anderson, Knox, Loudon, and Morgan) surrounding ORR, but only one, the Graphite Reactor, is located at ORNL (NRHP 1989, pp. 666-78). Though not listed in the NRHP, several cemeteries are located on the ORNL site (Etnier 1991, p. 38). Cemeteries are protected by Tennessee state laws 
[e.g., TCA, Title 39, Chap. 17-311 (Desecration of Venerated Object) and TCA. Title 39, Chap. 17.312 (Abuse of Corpse)] (Fielder 1990). A court order would be required to remove cemetery remains (TCA, Title 46, Chapter 101-104).

\subsubsection{Archaeological and Historic Preservation Act}

The Archaeological and Historic Preservation Act of 1974 (16 U.S.C. Sect. 469 et seq.), as amended, is directed at the preservation of historic and archaeological data that would otherwise be lost as a result of federal construction or other federaliy licensed or assisted activities. It authorizes DOI to undertake recovery, protection, and preservation of archaeological and historic data. If a federal agency determines that a proposed action might cause irreparable damage to archaeological resources, that agency is required to notify DOI in writing. The agency involved may then undertake recovery and preservation or may request that DOI undertake preservation measures.

In a study conducted in 1974, sites of aboriginal occupations on the ORR were located and evaluated (Fielder 1974). Of the sites examined, the majority were distributed along the drainage system of the Clinch River (Fielder 1974, p. 79). A recent archaeological survey has been completed that indicates that the expected ANS site should not impact archaeological sites (Pat Scofield, Research Associate, ORNL, Oak Ridge, Tenn., personal communication with M. C. Weist, Health, Safety, and Environment, Y-12 Plant, Oak Ridge, Tenn., Nov. 11, 1991). If any ANS activities might result in irreparable damage to historic or archaeological resources, DOE would be required to notify DOI.

\subsubsection{American Indian Religious Freedom Act}

The purpose of the American Indian Religious Freedom Act (42 U.S.C. Sect. 1996 et seq.) is to protect and preserve for Native Americans their inherent right of freedom to believe, express, and protect the traditional religions, including, but not limited to, access to religious or traditional sites, use and possession of sacred objects, and freedom to worship through ceremonies and traditional rites. DOE will cooperate with Native Americans in expressing their religious beliefs on DOE-controlled sites that are also traditional Native American religious sites.

In Tennessee, the protection of Native American burial sites and religious objects is covered by two sections of the criminal code that deal with cemeteries and grave robbing [TCA, title 39, chap. 17-311 (Desecration of Venerated Object) and TCA, title 39, chap. 17-312 (Abuse of Corpse)]. Legislative intent includes Native American and burial sites and religious objects and historic sites (Pat Scofield, Research Associate, ORNL, Oak Ridge, Tenn., personal communication with Kevin Smith, Federal Program Archaeologist, Tennessee Department Environment and Conservation, Nashville, Tenn., November 1991). New rules have been issued pertaining to Native American Indian Cemetery removal and reburial (Tenn. Comp. R \& Reg. Chapter 400-9-1). Written notification of the removal of remains must be submitted to the Native American members of the Archaeological Advisory Council, Chairman of the Tennessee Commission of Indian Affairs, and the State Archaeologist. 


\subsubsection{Executive Order 11593}

Executive Order 11593, Protection and Enhancement of the Cultural Environment [Fed. Regist. 36, 8921 (May 13, 1971)], requires federal agencies to locate, inventory, and nominate qualifying properties under their jurisdiction or control to the NRHP. This process requires DOE to provide the opportunity for the Advisory Council on Historic Preservation to comment on the possible impacts of the proposed action on any potential eligible or listed resources.

\subsection{HEALTH AND SAFETY}

Under the authority of the Atomic Energy Act, DOE has the responsibility to establish a comprehensive health and safety and environmental program for its facilities. The regulatory mechanism through which DOE manages its facilities is the issuance of DOE orders. DOE is in the process of codifying certain orders into regulations, such as DOE Order 5480.11, Radiation Protection for Occupational Workers, which may be superseded by 10 CFR Pt. 835, and DOE Order 5400.5, Radiation Protection for the Public and Environment, which may be superseded by 10 CFR Pt. 834.

It is the objective of DOE and ORNL to operate its facilities and conduct its activities so that the health and safety of workers and members of the public are maintained within the limits specified in DOE orders. It is also a DOE and ORNL objective to limit radiation exposures to workers and members of the general public to levels that are as low as reasonably achievable (ALARA).

It is the policy of DOE to implement legally applicable occupational health, safety and radiation protection standards. Such standards are referenced in DOE Orders and many of them are prescribed. Also it is DOE's policy to adopt and implement standards that are generally consistent with those of NRC for its facilities and activities not subject to NRC's licensing authority.

\subsubsection{Worker Health and Safety}

Occupational worker radiation protection standards and program requirements for DOE and DOE contractors are given in DOE Order 5480.11, Radiation Protection for Occupational Workers. It has been proposed that this order will be codified in 10 CFR Pt. 835. The ALARA process for the limitation of occupational exposures for DOE operations would also be addressed in 10 CFR Pt. 835 (see Sect. 5.10.3 concerning ORNL's ALARA program).

As a matter of DOE policy, it is required that ORNL comply with the following occupational safety standards: 29 CFR Pt. 1910, Occupational Safety and Health Standards; 29 CFR Pt. 1926, Safety and Health Regulations for Construction; and 29 CFR Pt. 1928, Safety and Health Standards for Agriculture. DOE policy also requires compliance to other applicable standards, such as, ANSI Z.117.1, "Safety Requirements for Working in Tanks and Other Confined Spaces" and ANSI Z88.2, "Standard for Respiratory Protection" (current version).

Examples of DOE orders applicable to the protection of health and safety of workers are listed below: 
DOE Order 5483.1A

DOE Order 5480.1B

DOE Order 5480.4

DOE Order 5480.9

DOE Order 5484.1

DOE Order 5482.1B

DOE Order 5480.6

DOE Order 5480.5

DOE Order 5480.10

DOE Order 5480.20
Occupational Safety and Health Program for DOE

Contractor Employees at Government-Owned ContractorOperated Facilities

Environmental Safety and Health Program for DOE Operations

Environmental Protection, Safety, and Health Protection

Standards

Construction Safety and Health Program

Environmental Protection, Safety, and Health Protection

Information Reporting Requirements

Environmental Safety and Health Appraisal Program

Safety of DOE-Owned Nuclear Reactors

Safety of Nuclear Facilities

Contractor Industrial Hygiene Program

Personnel Selection Qualification, Training, and Staffing

Requirements at DOE Reactors and Nonreactor Nuclear

Facilities

Other DOE Orders that may be applicable to occupational health protection are listed in Table 12.6-1.

\subsubsection{General Public Health and Safety}

DOE is proposing to promulgate in 10 CFR Pt. 834 its primary standard for Radiation Protection of the Public and Environment, which was originally issued as DOE Order 5400.5. This proposed radiation protection standard is generally consistent with the recent radiation protection rulemakings by the NRC and EPA. The following list provides examples of DOE orders that also address general public health and protection:

DOE Order 5400.1

DOE Order 5480.4

DOE Order 5484.1

DOE Order 5482.1B

DOE Order $5000.3 \mathrm{~A}$
General Environmental Protection Program

Environmental Protection, Safety, and Health Protection Standards

Environmental Protection, Safety, and Health Protection Information Reporting Requirements

Environmental Safety, and Health Appraisal Program

Occurrence Reporting and Processing of Operations Information

Other DOE Orders that may be applicable to public health protection are listed in Table 12.6-1.

DOE has prepared two documents, entitled, Environmental Regulatory Guide for Radiological Effluent Monitoring and Environmental Surveillance, and DOE Guidance on the procedures in applying the ALARA process for compliance with DOE 5400.5 which provides DOE Order 5400 series compliance guidance, which would be applicable to ANS facility operations.

EPA also has general public protection regulations that must be considered for DOE facilities (Etnier 1991, p. 28); these are listed in Table 12.6-2.

In addition, DOE and the state of Tennessee have entered into an agreement, the TN/DOE Oversight Agreement, whereby the state has site access to conduct independent monitoring and environmental oversight at ORNL. These activities are designed to ensure 
Table 12.6-1. Department of Energy Orders applicable to the Advanced Neutron Source project

\begin{tabular}{|c|c|}
\hline Order & Subject \\
\hline 1540.2 & Hazardous Material Packaging for Transport-Administrative Procedures \\
\hline 1540.3 & Base Technology for Radioactive Material Transportation Packaging Systems \\
\hline 1540.4 & Physical Protection of Unclassified Irradiated Reactor Fuel in Tansit \\
\hline 4700.1 & Project Management System \\
\hline $5000.3 \mathrm{~A}$ & Unusual Occurrence Reporting System \\
\hline 5400.1 & General Environmental Protection Program \\
\hline $5400.2 \mathrm{~A}$ & Environmental Compliance Issue Coordination \\
\hline 5400.3 & Hazardous and Radioactive Mixed Waste Program \\
\hline 5400.4 & $\begin{array}{l}\text { Comprehensive Environmental Response, Compensation, and Liability Act } \\
\text { Requirements }\end{array}$ \\
\hline 5400.5 & Radiation Protection of the Public and the Environment (10 CFR Pt. 834) \\
\hline $5440.1 \mathrm{D}$ & National Environmental Policy Act \\
\hline $5480.1 \mathrm{~B}$ & Environmental, Safety, and Health Program for DOE Operations \\
\hline 5480.3 & $\begin{array}{l}\text { Satety Requirements for the Packing and Transporation of Hazardous } \\
\text { Materials Hazardous Substances and Hazardous Waste }\end{array}$ \\
\hline 5480.4 & Environmental Protection, Safety, and Health Protection Standards \\
\hline 5480.5 & Safety of Nuclear Facilities \\
\hline 5480.6 & Safety of DOE-Owned Nuclear Reactors \\
\hline 5480.7 & Fire Protection \\
\hline 5480.9 & Construction Safety and Health Program \\
\hline 5480.11 & Radiation Protection for Occupational Workers (10 CFR Pt. 835) \\
\hline $5481.1 \mathrm{~B}$ & Safety Analysis and Review System \\
\hline $5482.1 \mathrm{~B}$ & Environmental Protection, Safety, and Health Protection Appraisal Program \\
\hline $5483.1 \mathrm{~A}$ & $\begin{array}{l}\text { Occupational Safety and Health Program for DOE Contractor Employees at } \\
\text { Government-Owned Contractor-Operated Facilities }\end{array}$ \\
\hline 5484.1 & $\begin{array}{l}\text { Environmental Protection, Safety, and Health Protection Information } \\
\text { Reporting Requirements }\end{array}$ \\
\hline $5500.1 \mathrm{~A}$ & Emergency Management System \\
\hline 5500.3 & $\begin{array}{l}\text { Reactor and Nonreactor Nuclear Facility Emergency Planning, Preparedness, } \\
\text { and Response Program for DOE Operations }\end{array}$ \\
\hline 5630.11 & Safeguards and Security Program \\
\hline
\end{tabular}


Table 12.6-1. (continued)

\begin{tabular}{ll}
\hline Order & \multicolumn{1}{c}{ Subject } \\
\hline 5630.12 & Safeguards and Security Inspection and Evaluation Program \\
$5700.6 \mathrm{~B}$ & Quality Assurance \\
$5820.2 \mathrm{~A}$ & Radioactive Waste Management \\
$6430.1 \mathrm{~A}$ & General Design Criteria \\
\hline
\end{tabular}

Table 12.6-2. U.S. Environmental Protection Agency public protection regulations applicable to the Advanced Neutron Source project

\begin{tabular}{lll}
\hline \multicolumn{1}{c}{ Regulation } & \multicolumn{1}{c}{ Applicability } & \multicolumn{1}{c}{ Exposure conditions } \\
\hline 40 CFR Pt. 61 & $\begin{array}{l}\text { NESHAP for DOE } \\
\text { facilities }\end{array}$ & Airborne emissions \\
40 CFR Pt. 141 & $\begin{array}{l}\text { Drinking water } \\
\text { maximum containment levels }\end{array}$ & $\begin{array}{l}\text { Community water } \\
\text { systems }\end{array}$ \\
40 CFR Pt. 190 & $\begin{array}{l}\text { Nuclear Power Operations } \\
\text { 40 CFR Pt. 191 }\end{array}$ & All sources \\
& $\begin{array}{l}\text { Spent nuclear fuel } \\
\text { high level and transuranic } \\
\text { wastes }\end{array}$ & All sources \\
40 CFR Pts. 264.90-264.101 & $\begin{array}{l}\text { Releases from Solid } \\
\text { Waste Management Units }\end{array}$ & All sources \\
\hline
\end{tabular}

that the facility is in compliance with state, federal, and local laws and regulations as well as assuring the citizens of the state that their health, safety, and environment are being protected. The Tennessee Oversight Division will be involved in environmental compliance, radiological monitoring, waste management, and environmental restoration.

\subsection{MANAGEMENT OF WASTES AND HAZARDOUS MATERIALS} in Sect. 3.

Generation and management of wastes from proposed ANS activities are described

\subsubsection{Resource Conservation and Recovery Act of 1976}

The treatment, storage, or disposal of solid waste, both nonhazardous and hazardous, is regulated by EPA following guidelines established by Congress under the Solid Waste Disposal Act of 1965, as amended by RCRA (42 U.S.C. Sect. 6901 et seq.), 
the Solid Waste Disposal Act Amendments of 1980, and the Hazardous and Solid Waste Amendments (HSWA) of 1984. Although EPA promulgates the regulations (see title 40 CFR Pt. 240 et seq.) governing solid and hazardous waste, the states can establish their own regulations and receive EPA authorization to administer and enforce a hazardous waste program pursuant to RCRA. State programs must be at least as stringent as the federal regulations, but may be more stringent than the EPA's regulations. Before EPA's enactment of HSWA, changes in the federal regulations were not enforced in an authorized state until the state's program was appropriately modified and approved by EPA. However, all regulations enacted under HSWA are enforced by EPA until the authorized state receives approval under $\operatorname{Sect} 3006(\mathrm{~g})$. As a result, a regulated facility in an authorized state operates under a dual state-federal regulatory system. ORNL operates under this dual system.

The Tennessee regulations are patterned closely after the federal regulations promulgated by EPA, but by necessity lag behind EPA rulemaking because of the frequency of EPA rulemaking changes. In a few instances, the state requirements are deliberately different (more stringent) from EPA's regulations. As of October 1991, Tennessee did not have authorized hazardous waste regulations that incorporated all of EPA's latest HSWA amendments to the RCRA regulations.

\subsubsection{Tennessee RCRA Program}

TDEC is responsible for implementing rules and regulations mandated by the Tennessee Solid Waste Disposal Act (enacted by Tennessee Public Acts of 1969, as amended) (TCA, Title 68, Chap. 31-101 et seq.) and the Tennessee Hazardous Waste Management Act (THWMA) of 1975, as amended (TCA. Title 68, Chap. 46-101 et seq.). Those acts provide for the protection of human health and the environment from the effects of improper or unsate management of solid and hazardous wastes. THWMA also promotes recycling of hazardous waste and minimization of hazardous waste generation and also establishes a tracking or manifesting system for these wastes. Both the solid and hazardous waste acts establish requirements for the design, construction, and permitting of treatment, storage, or disposal facilities, and they also provide for issuing fines and penalties against violators. TDEC, Division of Solid Waste Management, promulgates the solid waste regulations under Tenn. Comp. R. \& Regs., 'Title 1200, Chap. 1-7 and the hazardous waste regulations under Tenn. Comp. R. \& Regs., Title 1200, Chap. 1-11, and enforces those regulations. Typically, those regulations mirror the federal regulations. Only a few portions of the state's hazardous waste regulations are more restrictive than the federal regulations. Tennessee has EPA authorization to implement the solid waste program under Subchapter III of RCRA and the hazardous waste program (including mixed wastes) under Subchapter IV of RCRA.

The ANS facility is expected to generate solid, hazardous, radioactive, and mixed waste as a part of construction or operation. ORNL does not operate an on-site solid waste landfill. Currently, ORNL uses the Y.12 Plant Sanitary Landfill II for nonradioactive, nonhazardous solid wastes. The Y-12 Plant's acceptance of ORNL's solid wastes is largely governed by waste acceptance criteria in the Y-12 Plant operating permit for the landfill. That landfill is nearing capacity and the opening and permitting of a new landfill is planned. It appears likely that any solid waste generated at the ANS facility should meet the Y-12. Plant waste acceptance criteria for both the existing and planned landfill. If special types of solid wastes are generated by ANS, ORNL and the Y-12 Plant may request permission from TDEC to dispose of those wastes at the Y-12 Plant landfill. 
ORNL's existing facilities may not be adequate to accommodate all of the hazardous or mixed waste that would be generated by the ANS facility. ORNL plans to construct additional hazardous waste storage facilities and one treatment facillty for mixed waste. However, most of the new facilities are for transuranic mixed wastes. Capacity for hazardous and low-level mixed waste is limited. Additional waste-handling capacity may be needed to accommodate the ANS.generated radioactive hazardous or mixed waste. Any modification of existing or planned on-site hazardous waste storage facilities (including wastes not identified in the Part A interim permit, Part B permits or permit applications) or wastewater treatment facilities (regulated under Permil-by-Rule [Tenn. Comp. R. \& Regs., title 1200, chap. 1-11-.07(1)(c)|) would require amendment of those existing permits or permit applications for those facilities." A new permit application would have to be submitted for ORNL to treat mixed waste on-site ${ }^{c}$

For any hazardous or mixed wastes generated by the ANS activities, ORNL and DOE would have to comply with the EPA and state hazardous waste regulations (see 40 CFR Pt. 260 et seq. and Tenn. Comp. R. \& Regs., Title 1200, Chap. 1-11, respectively). Those regulations govern the identification of hazardous waste regulations; the handling of wastes by generators and transporters; and treatment, storage, and disposal facilities. Those regulations include requirements for container management (labeling, marking, handling, etc.), preparedness and prevention, contingency planning, reporting, and record keeping. For the construction of new or modified treatment, storage, or disposal facilities, ORNL and DOE would have to comply with the permitting requirements and regulations applicable to owners and operators of hazardous waste facilities.

Subchapter IX of RCRA requires regulation of underground storage tanks (USTs) containing petroleum products and any substance defined as hazardous under the Comprehensive Environmental Response, Compensation, and Liability Act (CERCLA) of 1980. (Subchapter IX does not regulate tanks storing hazardous wastes as detined by RCRA.) Any new USTs installed for the ANS facility must meet EPA or state standards for environmental protection. The TDEC, Division of Underground Storage Tanks, regulates USTs storing petroleum products, but EPA regulates USTs containing the remaining regulated substances. In general, these regulations (40 CFR Pt, 280 and Tenn. Comp. R. \& Regs., title 1200 chap. 1-15) govern the design, installation, and operation of USTs. ORNL. would have to notify either EPA or the TDEC (as appropriate) if any new Subchapter IX USTs are installed at the ANS facility. Once the USTs are installed, DOE and ORNL would have to comply with the requirements for operating those USTs.

\subsubsection{Comprehensive Environmental Response, Compeusation, and Liability Act}

CERCLA (42 U.S.C. Sect. 9601 et seq.), as amended by the Superfund Amendments and Reauthorization Act of 1986 (Pub. L. 99.499), provides liability, compensation, cleanup, and emergency response by the federal government for hazardous substances released into the environment and for the cleanup of inactive hazardous waste disposal sites. ORR was placed on the National Priorities List for remedial action under CERCLA in November 1989.

Pursuant to the authority of Sect. 120 of CERCLA, an FFA has been negotiated between EPA-Region IV, TDEC, and the DOE Oak Ridge Field Office. The FFA

\footnotetext{
'Permit applications for existing and planncd stornge fucilities are to the submited to the TDEC by May 1922.

The RCRA Part B permit applicalion for llie Waste Hindling and Packiging Planl, " trentment facillity for transuranic wastes, should be submilled in CY 1094 or CY I(4)
} 
outlines the mechanisms for the expeditious completion by DOE of all necessary remedial actions required by CERCLA as well as those of RCRA Sects, 3004 (u) and (v).

DOE must also observe the reporting requirements if a release of a hazardous substance or raclionuclide (Table 302.4 and Appendix A and B) occurs that exceeds established Reportable Quantitles (RQ)(40 CFR Pt. 302.6). If a release occurs that is equal to or exceeds the $R Q$, the person in charge of the facility must immediately notify the National Response Center.

Therefore, in performing such remedial actions, or in the case of a release of a reportable substance, DOE must observe the reporting, response, removal, and remediation provisions of CERCLA, in compliance with the National Oil and Hazardous Substances Pollution Contingency Plan 140 CFR Pt. 300 et seq; Fed. Regist, 55, 666 (Mar, 8, 1990)], FFA, and DOE Order 5401).4, Comprehensive Environmental Response, Compensation, and Liability Act Requirements.

\subsubsection{Radioactive Waste}

The Atomic Energy Act of 1954 (42 U.S.C. Sects. 2011-2259) and its amendments delegated authority for control of nuclear energy to DOE, NR.C, and EPA. DOE is authorized to control all types of nuclear materials at sites under its jurisdiction and is exempt from the NRC licensing and regulatory requirements. DOE regulations for handling of radioactive materials are outlined in a series of internal DOE Orders that are legally binding to DOE contractors.

The following are examples of DOE orders applicable to transport, handling, and disposal of radioactive waste:

DOE Order $5480.1 \mathrm{~B}$

DOE Order 5400.1

DOE Order $5820.2 \mathrm{~A}$

DOE Order 5400.3

DOE Order 5480.3

DOE Order 1540.2

DOE Order 1540.3

DOE Order 1540.4

DOE Order 5480.4
Environmental, Safety, and Health Program for DOE Operations

General Environmental Protection Program Requirements

Radioactive Waste Management

Hazardous and Radioactive Mixed Waste Program

Safety Requirements for the Packaging and

Transportation of Hazardous Materials, Hazardous

Substances, and Hazardous Wastes

Hazardous Material Packaging for Transport .

Administrative Procedures

Base Technology for Radioactive Material Transportation

Packaging Systems

Physical Protection of Unclassified Irradiated Reactor

Fuel in Transil

Environmental Protection, Safety, and Health Protection

Standards

Interim storage of radioactive wastes and residues are guided by $\mathrm{DOE}$

Order 5400.5 (Draft 10 CFR Pt. 834), and DOE Order 5820.2A. Long-term management of radioactive waste is also guided by the aforementioned DOE Orders and

$40 \mathrm{CFR}$ Pt. 191. These EPA regulations pertain to management, storage, and disposal of spent nuclear fuel, high-level wastes, and transuranic wastes. Applicable Department of Transportation regulations include 49 CFR Pts, 100-180 and Pts, 211-236.

In addition to the remedial action requirements defined in the FFA, low-level radioactive waste tank system requirements are also specifled. All new liquild low-level 
radioactive waste tank system designs must meet all applicable standards of Appendix $F$ of

the FFA. Furthermore, each design/installation assessment must be submitted to EPA and TDEC for review and approval.

The TN/DOE Oversight Agreement allows the state to have site access to conduct independent monitoring and environmental oversight at ORNL. The Tennessee Oversight Division will be evaluating ORNL waste management operations. These activities are designed to ensure that the facility is in compliance with state, federal, and local laws and regulations as well as assuring the citizens of the state that their health, safety, and environment are being protected.

\subsubsection{Emergency and Spill Prevention Control Planning}

Under the Emergency Planning and Community Right to Know Act of 1986 (42 U.S.C. Sect, 11001 et seq.), industrial facilities are required to provide information, such as inventories of speciflc chemicals used or stored, to the appropriate State Emergency Response Commission and Local Emergency Planning Committee to ensure that emergency plans are sufficient to respond to accidental releases of hazardous substances. This act does not apply to federal agencies. However, the DOE will voluntarily comply with respect to the ANS tacility activities.

\subsubsection{National Oil and Hazardous Substances Pollution Contingency Plan}

The National Oil and Hazardous Substances Pollution Contingency Plan ( 40 CFR Pt. 300) applies to all federal agencies and is in effect for discharges or potential threats of discharges of oil and hazardous substances into the environenent. The plan provides for efficient, coordinated, and effective response to discharges by providing for the division and specification of responsibilities among federal, state, and local governments. It establishes requirements for federal, regional, and local contingency plans.

\subsubsection{Spill Prevention, Control, and Countermeasures Plan}

Under Sect. 311 of the federal CWA, as codified in 40 CFR Pt. 112, a spill prevention control and countermeasures (SPCC) plan is required for all facilities that could be reasonably expected to discharge oil in harmful quantities (as defined in $40 \mathrm{CFR}$ Pt. 110) into or upon the navigable waters of the United States or adjoining shorelines and which store oil in excess of specified storage volumes. There are no analogous state of Tennessee regulations on oil pollution prevention.

ORNL is considered to be a "facility" for the purpose of this regulation. ORNL uses oil in quantities which require an SPCC plan to be developed, and it has an SPCC plan. The ANS facility would be incorporated into the ORNL SPCC plan by amendment.

In addition to the requirement to have a written SPCC plan, 40 CFR Pt. 112 contains certain engineering requirements to prevert oil spillage from reaching waters of the United States, and also contains certain inspection, training, security, and record keeping requirements. The SPCC engineering requirements will be incorporated into the ANS facility design. The inspection, training, and record keeping requirements for the ANS will be incorporated into the ongoing ORNL, environmental compliance program. The security requirements will be more than adequately covered by the existing ORNL security program. 


\section{REFERENCES FOR SECTION 12}

Cunningham, M., and L. Pounds 1991 Draft Resource Management Plan for Oak Ridge Reservation, Volume 28: Wetlands on the Oak Ridge Reservation, ORNL/NERP-5, Oak Ridge National Laboratory, Oak Ridge, Tenn.

DOE-ORO (Department of Energy-Oak Ridge Operations) 1980. Oak Ridge Reservation Land-Use Plan, pp. 7-9, DOE/ORO-748, Oak Ridge National Laboratory, Oak Ridge, Tenn., March.

Etnier, E. L., and R. S. Weaver 1991. Applicable or Relevunt and Appropriate Requirements (ARARS) for Remedial Actions at the Oak Ridge Reservation, A Compendium of Major Environmental Laws, ES/ER/TM-1, O.jk Ridge National Laboratory, Oak Ridge, Temn., July.

Fielder, G. F., Jr., 1974. Archaeological Survey with Emphasis on Historic Sites of the Oak Ridge Reservation, Oak Ridge, Tennessee, p. 79, ORNL/TM-4694, Oak Ridge National Laboratory, Oak Ridge, Tenn., October.

Fielder, N. 1990. New Cemetery Laws, Memorandum, Tennessee Department of Environment and Conservation, Nashville, Tenn., January 19.

Kroodsma, R. L., 1987. Resource Management Plan for the ORR, Volume 24: Threatened and Endangered Animal Species, pp. 10-15, ORNL/ESH-V. 24, Oak Ridge Natic ral Laboratory, Oak Ridge, Tenn., January.

NRHP (National Register of Historic Places) 1989. National Conference of State Historic Preservation Officers, National Register of Historic Places 1966-1988, pp. 666-78, American Association for State and Local History, Nashville, Tennessee.

ORR (Oak Ridge Reservation) 1991. Department of Energy - Martin Marietta Energy Systems, Oak Ridge Reservation, Site Development and Facilities Utilization Plan, 1990 Update, pp. 3-1-3-4, 3-6, 3-10, DOE/OR-885/RI, Oak Ridge National Laboratory, Oak Ridge, Tenn., June.

Parr, P. D., and L. R. Pounds 1987. Resource Management Plan for the Oak Ridge Reservation, Vol. 23: Oak Ridge National Environmental Research Park, Research Sites, and State Natural Areas, pp. 37-47, ORNL/ESH-1/V 23, Oak Ridge National Laboratory, Oak Ridge, Tenn., May. 


\section{INTERNAL DISTRIBUTION}

$\begin{array}{ll}1 . & \text { T. J. Blasing } \\ 2 . & \text { W. W. Bowman } \\ 3-7 . & \text { R. A. Brown (5) } \\ 8 . & \text { G. F. Cada } \\ 9-13 . & \text { J. H. Campbell (5) } \\ 14 . & \text { J. B. Cannon } \\ 15 . & \text { B. L. Corbett } \\ 16 . & \text { C. Easterly } \\ 17 . & \text { D. L. Feldman } \\ 18 . & \text { M. L. Gildner } \\ 19 . & \text { P. S. Gillis } \\ 20-24 . & \text { C. W. Hagan (5) } \\ 25 . & \text { R. M. Harrington } \\ 26 . & \text { J. B. Hayter } \\ 27 . & \text { R. L. Johnson } \\ 28 . & \text { R. O. Johnson } \\ 29 . & \text { R. H. Ketelle } \\ 30 . & \text { R. L. Kroodsma } \\ 31-35 . & \text { L. N. McCold (5) } \\ 36 . & \text { R. B. McLean }\end{array}$

$\begin{array}{ll}37 . & \text { G. R. McNutt } \\ 38 . & \text { F. J. Peretz } \\ 39 . & \text { C. C. Queen } \\ 40 . & \text { R. M. Reed } \\ 41 . & \text { W. R. Reed } \\ 42 . & \text { W. J. Reich } \\ 43 . & \text { P. A. Scofield } \\ 44 . & \text { D. L. Selby } \\ 45 . & \text { M. L. Socolof } \\ 46 . & \text { J. N. Stone } \\ 47 . & \text { R. P. Taleyarkhan } \\ 48 . & \text { P. B. Thompson } \\ 49 . & \text { J. W. Van Dyke } \\ 50 . & \text { C. D. West } \\ 51 . & \text { J. L. Westbrook } \\ 52 . & \text { K. Williams III } \\ 53 . & \text { Central Research Library } \\ 54 . & \text { Document Reference Section } \\ 55-57 . & \text { Laboratory Records (3) } \\ 58 . & \text { Laboratory Records (Record Copy) }\end{array}$

\section{EXTERNAL DISTRIBUTION}

59. R. Awan, U.S. Department of Energy, NE-473, Washington, DC 20585.

60. B. G. Buchanan, Computer Science Department, University of Pittsburgh, 206 Mineral Industries Building, Pittsburgh, PA 15260.

61. A. W. Campbell, U.S. Department of Energy, Oak Ridge Office, SE-311, Building 2714-J, Oak Ridge, TN 37831.

62. A. Hirsch, Midwest Research Institute, 5109 Leesburg Pike, Suite 414, Falls Church, VA 22041.

63. R. A. Hunter, Nuclear Energy Division, U.S. Department of Energy, NE-47, Washington, DC 20585.

64. L. C. Ianniello, Office of Energy Research, U.S. Department of Energy, ER-10, Washington, DC 20585.

65. H. M. Ingram, Udall Center for Studies in Public Policy, The University of Arizona, 803/811 East First Street, Tucson, AZ 85719.

66. C. D. Mac.Cracken, Calmac Manufacturing Corporation, 101 West Sheffield Avenue, P.O. Box 710, Englewood, NJ 07631.

67. W. F. Manning, U.S. Department of Energy, Oak Ridge Field Office, FEDC, MS 8218, P.O. Box 2009. Oak Ridge, TN 37831-8218.

68-69. W. E. Meek, Gilbert/Commonwealth, Inc., P.O. Box 1498, Reading, PA 19603.

70. W. T. Oosterhuis, Office of Energy Research, U.S. Department of Energy, ER132, Washington DC 20585.

71-80. OSTI, U.S. Department of Energy, P.O. Box 62, Oak Ridge, TN 37831.

81. J. B. Shrago, Office of Technology Transfer, 405 Kirkland Hall, Vanderbilt University, Nashville, TN 37240. 
82. I. Thomas, Office of Energy Research, U.S. Department of Energy, ER-13, Washington, DC 20585.

83-107. D. K. Wilfert, U.S. Department of Energy, Oak Ridge Field Office, FEDC, MS 8218, P.O. Box 2009, Oak Ridge, TN 37831-8218.

108. M. Williams, Department of Economics, Northern Illinois University, DeKalb, IL 60115.

109. Assistant Manager of Energy Research and Development, P.O. Box 2008, Oak Ridge, TN 37831-6269. 

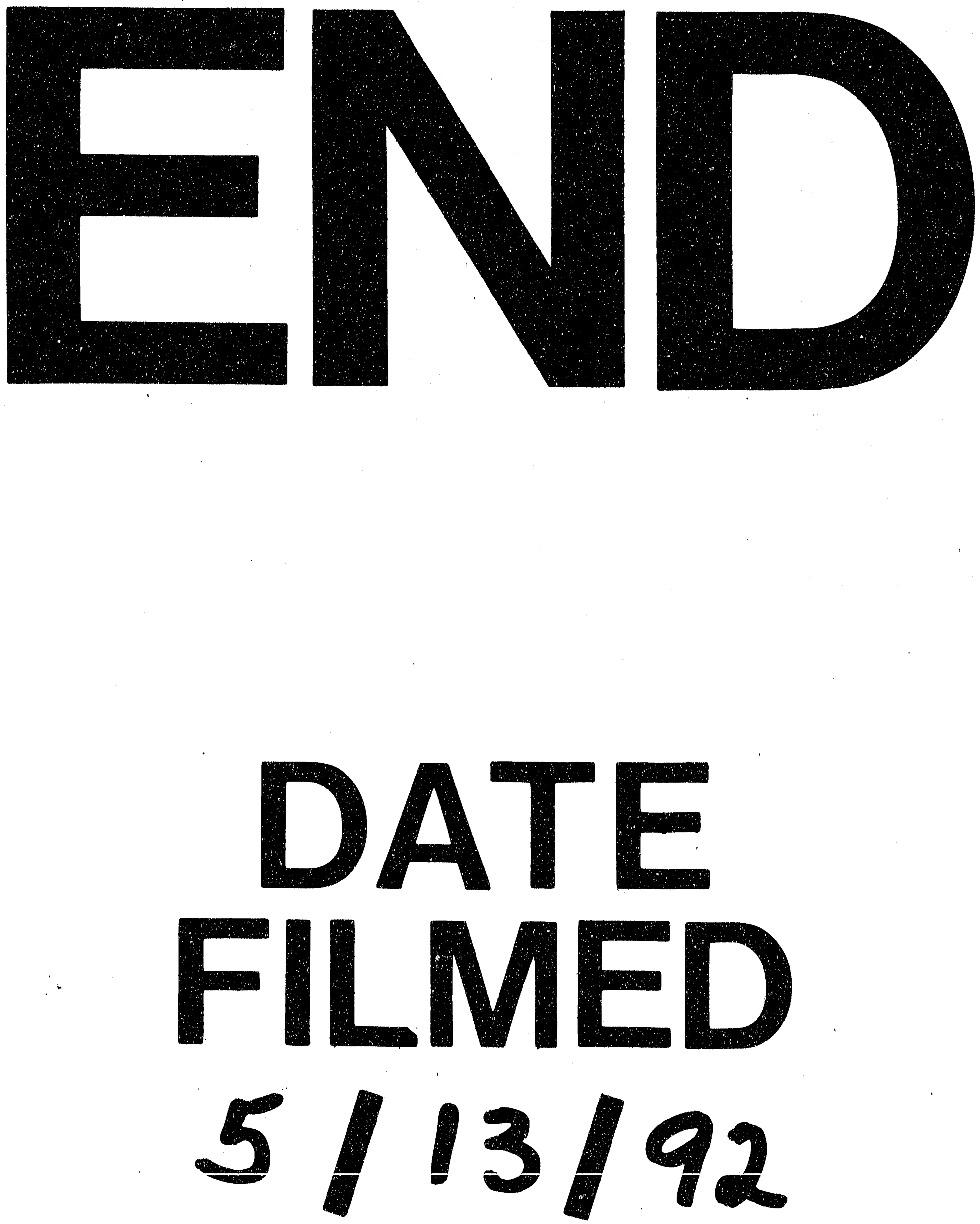
